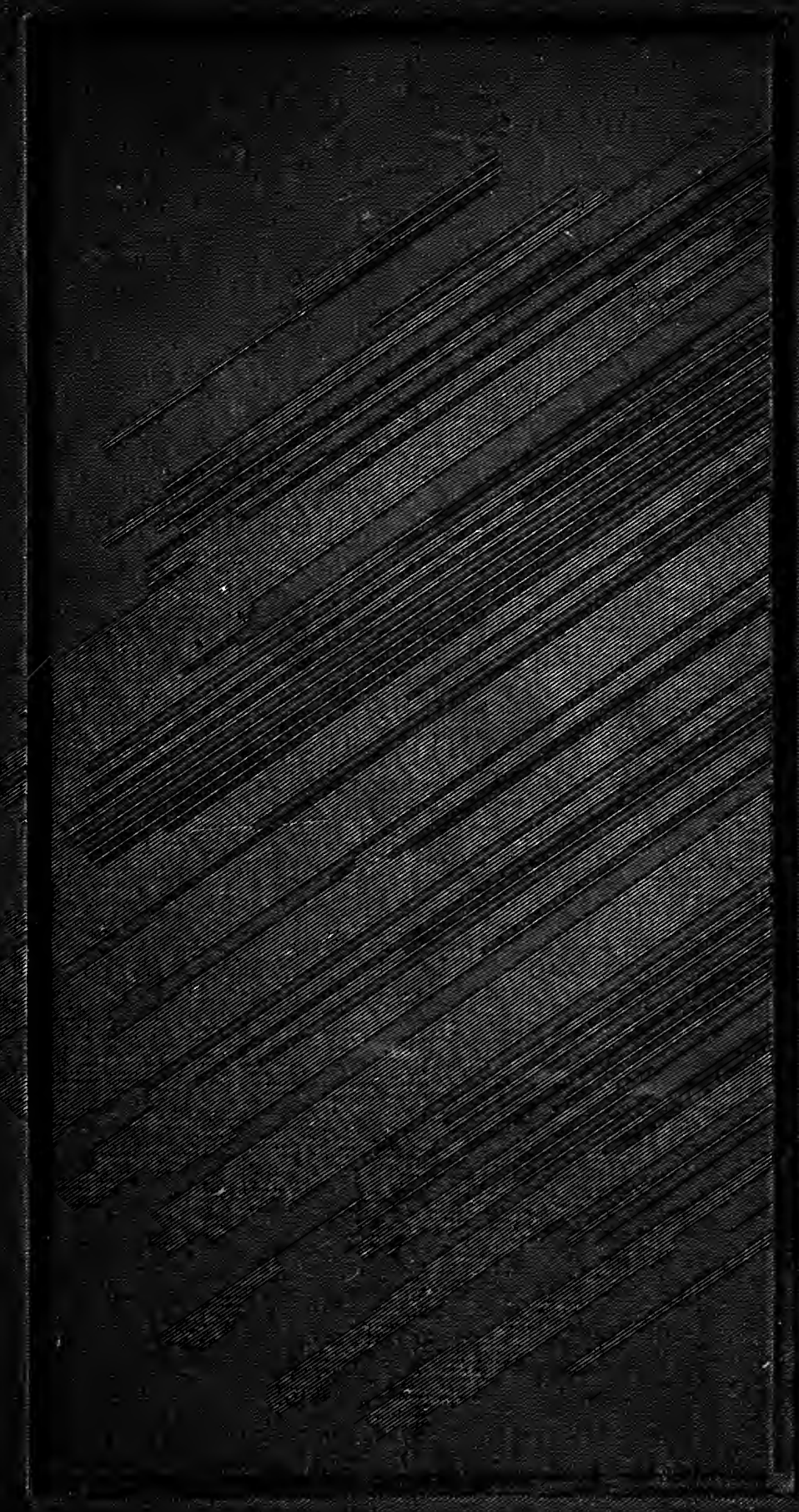




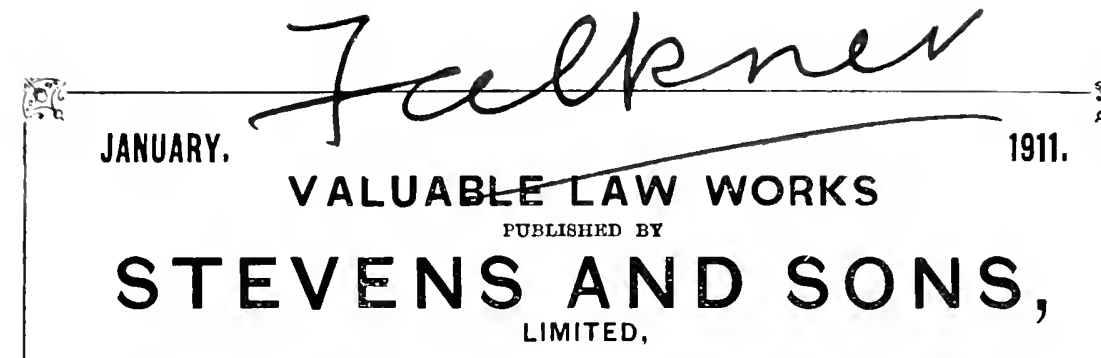

$119 \&$ 120, CHANCERY LANE, LONDON, W.C.

Prideaux's Forms and Precedents in Conveyancing.

(neorporati

Notes. Thu

BEDHAT

In this

particularl:

A chapt

ancing, and

other a

complete se

The Dis

practice poi

Short F,

space have

Addison's 1

Edition. B

Royal ser.

Browne anc

Fineth firli

CONACHE]

Fry's Treati

-Fy the Rt

K.C. Iringu

Knowles' E

relating to 1

Traction. ]

Traction. I

2). 2.s. cluth

Mannooch's

students. I

Pollock's P

Sir FIEEIV

11. 8.. eloth.

Sebastian's
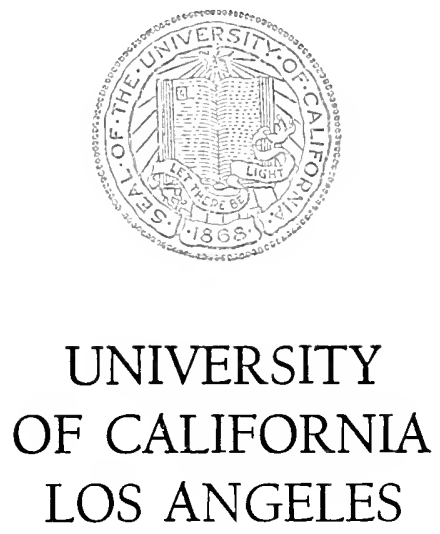

SCHOOL OF LAW

LIBRARY

anil matters HARTS finjul sio. I911. I'rice 1\%. 12.. cloth

Wharton's Law Lexicon.-Forming an Epitome of the Law of England, as existing in Statute Iaw and Fecided Cases, aul containing full explanations of the Technient Terms and Phrasts thereof, hoth ancient, modern and commereial, with selecterl Titles from the Civil, Scots and Indian Law. Elcrenth Erlitun. By W. HANBURY AG(ris, Barrister-at-Law. Cruper-royml sro. 1911. I'ree 1\%. 1sis. cluth.

Williamson's Law of Licensing.--Intoxicating Liquors, Theatres, Mnsic Halls, and ('inematograplus. incluling the Licensing (Consolidation) Act, 1!16, all relevaut Provisions of the Finance (190!-10) Act, 1:190, and a full Appendix of statutes. Rules and Forms. Fonth Lideture BY JOHN BRUCE

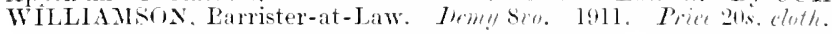

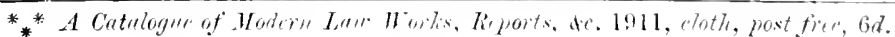


Annual Practice (The), 1911.-Edited by B. FosserT Lock, Barrister-at-Law; RICHARD WIIITE, a Master of the Supreme Court; and F. A. STRINGER, of the Central Office. Two Tols. 8to. irice, net, 25s, cloth.

*** A Thin Paper Edition in One Iol., mice, net, 25s., or an Indiu Paper, 3s. 6al. extra.

A, B, C (The) Guide to the Practice of the Supreme Court, 1911. -By F. R. P. STRINGER, of the Central Office. lioyal 12mo. Price, net, 5 s. eloth.

Annual County Courts Practice, 1911.-By His Honour JUDGE SMYLY, K.C., and W. J. BROOKS, Barrister-at-Law. Two Tols. Demy sio. Price 25s. cloth.

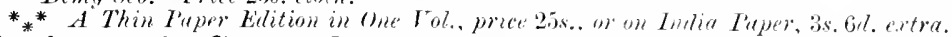

Magistrate's General Practice, 1911 (The).-By ('Harles MILNER ATKINSON, Stipendiary Magistratr for Leeds. Tem! seo. 1911. Price 20 s. cloth.

$$
\text { ** A Thin l'uper Eilition men! le luni ut the sume price. }
$$

Greenwood's Law relating to Trade Unions.-BY JoHN H. GREENWOOD, Barrister-at-Law, Author of "Amomt of Compensation and Review of Weekly Payments under the Workmen's Compensition Act, 1906." Demy 8\%o. 19l1. Price 10s. cloth.

Harman's Finance Act, 1894, and subsequent legislation as to the Death Duties, and partieularly to Estatr. Duty and Settlement Estate Duty, and the Finance (1909-10. Act, 1910, as to Ineroment Value buty, especially as to its payment on the occasion of Death. Third Elition. By J. E. HAliMAN, Barrister-at Law. Trmm bio. 1910. Pine 7s. (id. ch/h.

Napier's New Land Taxes and their Practical Application,-Being an Examination and Explamition, from a Legal Point of View, of the Land Cianses of the Finance (190m-10) Act, 19l0. With Ardendum containing Rules, Regulations and Forms. By T. B. N.PIER, LL.T., Barrister-at-Law.

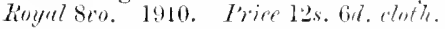

Aggs' Finance (1909-10) Act, 1910. With Full Notes, an Introduction and Inkex. Secoul Exldin. With linles, Regutations and Forms.

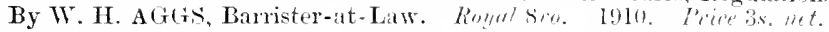

Marsden's Treatise on the Law of Collisions at Sea.By REGISALD G. MARSIEx, Barrister-at-Law. sisth fiditin. By E. s. ROSCOE, Registrar, Adminalty cout, and H. M. ROBERT-ON, Barister-at-

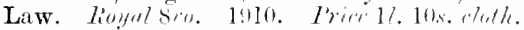

Goddard's Treatise on the Law of Easements. - Seventh

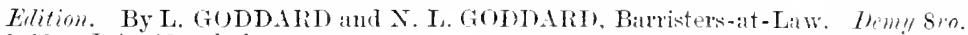
1!10. Iricie is. cloth.

Beverley's Digest of Cases under the Workmen's Com-

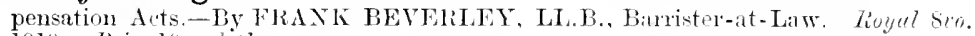
1910. Price 10s. alith.

Palmer's Company Law. - A Practical Handbook for Lawyers and Business Men. With an Appendix containing the Companies (Consolidation) Aet, $190 \mathrm{k}$, and Rules. Eighth Erlition. By Nir FRANCIS BEAUFORT PALMER, Bencher of the Inner T'emple. Ronal sio. 1910. I'rié 12s. 6i. cloth

Palmer's Company Precedents.-For nse in relation to

Companies subject to the Companies Acts.

PART I.: GENERAL Forms Tinth Editin. Iy Sil' FRANCIS BEAUFORT

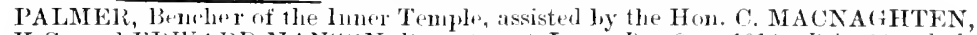
K.C., and EIU ARD MANSON, Barreter-at-Law. Roy. Sio. 1910. lrice 3ss. cloth.

PART II. : WINDING-UP FORMS AND PRACTICE. Tinth Edition. By Sil FRANeIS

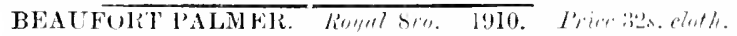

I'ART III. : DEBENTURES AND DEBENTURE STOCK. Tinth fiditum. 13y Sir litANi IS

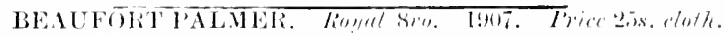

Fuller's taw relating to Friendly Societies and Indus-

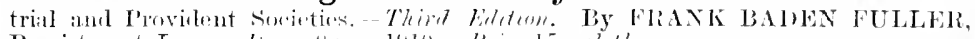

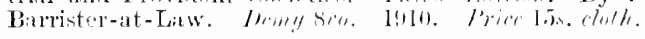

WHERE to LOOK for YOUR LAW. as set out in the Latest Legal Text-books. 1s. net. 


\section{ELETETTH EDITIOY 1311. doth, 38s. WHARTON'S LAW LEXICON, FORMIING}

AN EPITOME OF THE LAW OF ENGLAND AS EXISTING IN STATUTE LAW AND DECIDED CASES,

And containing Full Explanations of Technical Terms and Phrases both Ancient, Modern and Commercial.

WITH

SELECTED TITLES FKOII THE CIIIL. SCOTS AND INDIAN LAW.

ELEVENTH EDITION.

By W. HANBURY AGGS, BARISTER-AT-LAW.

The character of this Edition has been considerably altered and its scope much enlarged so as (it is hoped) to render it the most convenient book of Legal Reference ever published. Far more numerous references are made to decided cases.

This Edition fulfils the functions of a Concise Legal Encyclopædia, and will be found indispensable for reference as to the latest Act and Case on any subject.

STEVENS \& SONS, Ltd., $119 \& 120$. Chancery Lane, London. 


\title{
PRINCIPLES OF CONTRACT:
}

A TREATISE ON THE

GENERAL PRINCIPLES CONCERNING THE VALIDITY

OF AGREEMIENTS IN THE LAW OF ENGLAND.

\author{
EIGHTH EDITION.
}


BY TII: NAUE AITHOIS.

TIIE LAW OF TOR'TS:

A TREATISE ON THE IRINOIPLES OF OBLIGATIONS ARISING FROM GIVIL WHONGS

IN THE COMMON IAW.

EIGHTH EDITION, 1908. Price 25s.

A IOT(BEST OF THE IAW OF

PARTNERSHII,

WITH FORNS.

NINTH EDITION, 1909. Price 10s.

THE EXPANSION (OF THE COMLUON LAW.

1904. Price 6s. 


\section{Princtples of CONT'RaCT:}

A TREATISE ON THE

GENERAL PRINCIPLES CONCERNING THE VALIDITY

OF AGREEMENTS IN THE LAW OF ENGLAND.

\section{EIGHTH EDITION}

BY

Sir FREDERICK POLLOCK, Bart., D.C.L.,

OF LINCOLN'S INN, BARRISTER-AT-LAW ;

CORRESPONDEXT OF THE INSTITUTE OF FRANCE; PIST FELLWW AF TRINITY COLLEFE,

CAMBRIDGE; HOSORARY FELLOW OF CURPLS AIIISTI COLLEGE, OXFURD;

HONORARY DOCTOR OF LAWS IX THE TNIVERSITIES OF

EIINBLRGH, DUBLIN AND H.ARVARD.

"This notion of Contract is fart of men's common stock even tutsile the tieltl nf legal science, and to men of law so familiar and necussary in its varions apllications that we might expect a settled and just apprehension of it to pevail ererywhere. Nevertheless we are yet far short of this."-SAvignY, System des leutigen römischen Rechts, $\$ 140$.

LONDON :

STEVENS AND SONS, LIMITED, $119 \& 120$, CHANCERY LANE.

7Laum 争uhlisbers.

TORONTO :

CANADA IAW BOOK COMPANY, LIMITEI).

1911. 
$1+1$
$1+2=$
1 
UEDICATED TO

MY MASTER IN THE LAW.

TIIE RIGIT HONOUPADLE

NATHANIEL LORD LINDLEY 



\section{( vii )}

\section{PREFACE}

TO THE SEVENTH EDITION.

Twenty-five years have passed since the first edition of this book was publisherl. At that time the concurrent administration of equity and common law under the Judicature Acts was quite new; modern company law was in its infancy, and so was the revived study of Roman law in this country ; colonial, Indian, American, and foreign laws and legislation were little known and sometimes, especially as regards our own colonies, really difficult of access in England.

A young writer might well be excused at that time for setting forth with some pains, if not always in the most appropriate places, things of which he had not been able to find an orderly account (at any rate in his own language) anywhere else. Now there las been great change in all these matters. English students may read books in English ou Roman law which they can safely trust, and we lave an English Society of Comparative Legislation which publishes an excellent journal. I have endeavoured to bear this in mind in preparing the present edition, and have omitted or abridged much diseussion which seemed to be no longer useful.

The space thus set free has been claimed partly by new authorities, partly by the results of historical research, and partly by the consideration 
due to the recent arguments on principle of learned writers, both here and in America. But I have also borne in mind that exploded errors may remain a necessary part of the history of the law, and cannot be ignored even by purely practical text-writers so long as any ingenious advocate may by possibility attempt to revive them.

The most considerable alterations will be found in the earlier chapters. Besides other additions and amendments in detail, what is said of the doctrine of corporations in general has been recast and condensed, and the historical account of Consideration has been wholly rewritten. An excursus on the Roman and medieval law of contracts has been transferred, with some revision, from the text of Chapter III. to the Appendix. In Chapter VII. the rules as to contracts in restraint of trade have been reduced to a much simpler form in consequence of the leading decision of the Honse of Lords in Nordentelt's écuse.

$$
\text { F. P. }
$$

Lincolin's Ins,

Hilary Term, 190): 


\title{
( ix )
}

\section{ADVERTISEMENT}

\author{
TO THE EIGHTH EDITION.
}

In this edition cases have been noted down to November, 1910. Few recent decisions have affected any point of principle. Perhaps the most remarkable are those known as the roronation cases (p. 440). They strengthen my belief that "Impossible Agreements" is really not a legal category at all. If I could now rewrite the whole book, I should break up the contents of the chapter so named, and assign them partly to the head of Duties under Contract, and partly to a new chapter on Conditional Agreements.

I have now ventured (p. 191) to deny plainly that there is any logical reason, or any other reason than convenience, for holding mutual promises to be good consideration for one another. At first sight this may look novel; but the contrary proposition, unless I am greatly mistaken, can be defended only by arguments which, if they were sound, would lead to far stranger consequences.

F. P.

13 Old Square, Iincoln's Inn, Mirhutmas Term, 1910. 



\section{TABLE OF CONTENTS.}

\section{CHAP'TER I.}

agrement, Proposal, and acceptance.

Nature of contract

PAGE

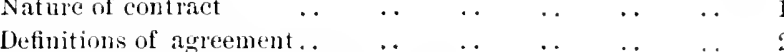

Ways of leclaring eonsent .. ...

Plomise $\quad$.

$\begin{array}{lllllllllll}\text { Contract } & \ldots & \ldots & \ldots & \ldots & \ldots & \ldots & \ldots & \ldots & 8\end{array}$

$\begin{array}{lllllllll}\text { Void agrecments } & \ldots & \ldots & \ldots & \ldots & \ldots & \ldots & \ldots & \vdots\end{array}$

$\begin{array}{llllllll}\text { Voidable contracts } & \ldots & \ldots & \ldots & \ldots & \ldots & \ldots & 9\end{array}$

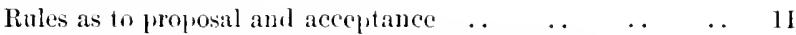

Express and tacit contracts, and quasi-contracts $\quad . \quad$. . 11

Proposals to mascertained persons (contracts by offer of $\begin{array}{lllllllll}\text { reward, de. }) & \ldots & \ldots & \ldots & \ldots & \ldots & \ldots & \ldots & \text { I. }\end{array}$

$\begin{array}{lllllllll}\text { Discussion of cases } & \ldots & \ldots & \ldots & \ldots & \ldots & \ldots & 17\end{array}$

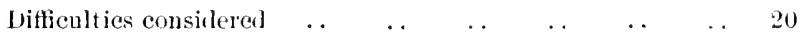

Theory of floating obligation inalmissil,le $\quad \ldots \quad$.

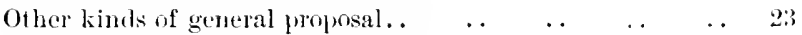

Acceptance ly act when eomplete $\quad \ldots \quad$.

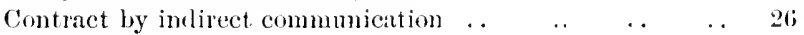

$\begin{array}{llllllll}\text { Revocation of uffer } & \ldots & \ldots & \ldots & \ldots & \ldots & \ldots & 27\end{array}$

$\begin{array}{llllllll}\text { Determination of offer } & \ldots & \ldots & \ldots & \ldots & \ldots & \ldots & 2 !\end{array}$

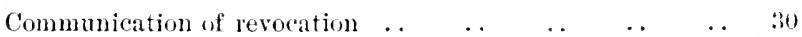

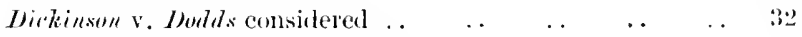

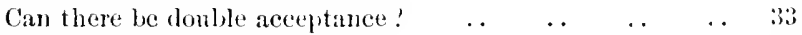

C'ommunication of aceeptance $\ldots$.

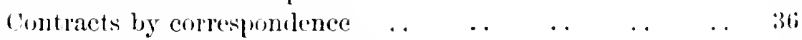

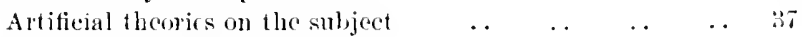

State of English authority $\quad \ldots \quad$.

Eiffeet of leat bo proposer $\quad$.

Certainty of acceptance .. $\quad \ldots \quad$.

Agreements in terms where consent not linal. . $\quad . . \quad \ldots \quad$ t5

Certainty of tems of agreement $\quad \ldots \quad$.

Illusory promises .. $\quad \ldots \quad$.

Construction of tacit aceeptancess $\quad \ldots \quad$.

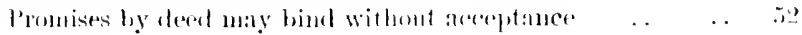


CHAPTER II.

\section{CAPACITY OF PARTIEs.}

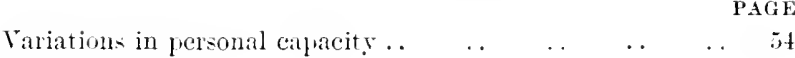

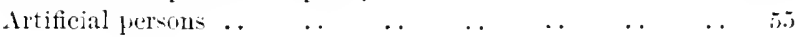

$\begin{array}{lllllll}\text { Limitations of capacity } & \ldots & \ldots & \ldots & \ldots & \ldots & \text { in }\end{array}$

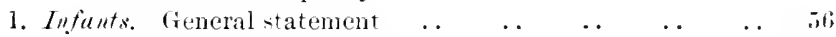

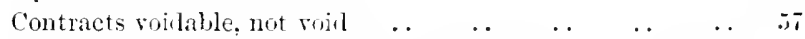

supposed distinction between void and rodable now exploded is

Aroilance of infant is contract $\ldots \quad$.

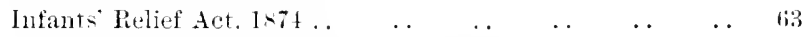

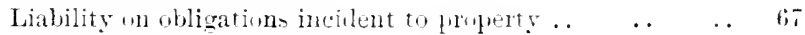

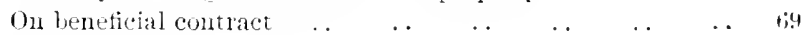

$\begin{array}{llllllllll}\text { For necessaries } & \ldots & \ldots & \ldots & \ldots & \ldots & \ldots & \ldots & \text { il }\end{array}$

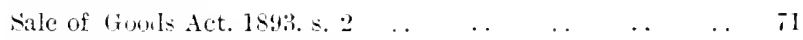

$\begin{array}{llllllll}\text { What are necessaries } & \ldots & \ldots & \ldots & \ldots & \ldots & \ldots & i 2\end{array}$

Certain contracts of infants binling ly enstom $\quad \ldots \quad \ldots$

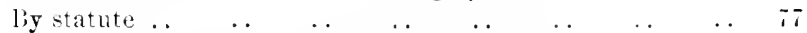

Liability of infants on wrongs collateral to contraet.. . . is

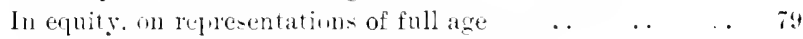

subseruent contract after full age prevails $\ldots \begin{array}{llll}\ldots & \ldots & \ldots & \end{array}$

2. Merried Women. Can contrate only an to selarate property s:3

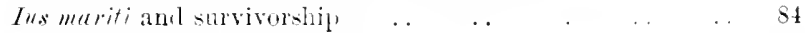

Cannot revive barresl debt by acknowledement . . A

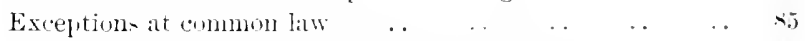

Costom of bomlon as to married woman tralling aloue .. she

Agreement-for aparation between lusband and wafe alone $s$;

Statutury exception: julicial separation, cke. . . os

$\begin{array}{lllllllll}\text { Equitable cloctrine of separate estate } & \ldots & \ldots & \ldots & & \ldots & 89\end{array}$

Marriel Women's Property Act, 1852 . . . . . . 90 90

3. Lunation and Drunken Persens. Old law . . . . . . 9.

Modern law : cuntract not void but voidable.. . . 9i

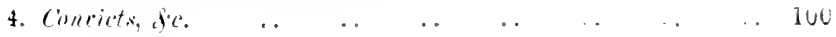

Estension of capacity . . . . . . . . 100

3. Agency ..

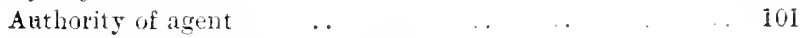

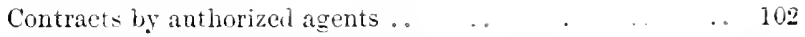

When agent known to be such, there is contract with principal 103

If princilal namer. mima fucie no contract with agent .. 103

If principal not named. prima fucie there is contract with

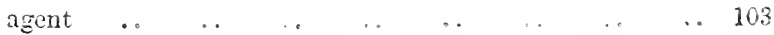

These rults subject to evidence of cortrary intention _. 103 
When agent not known to be such, there is generaily contract

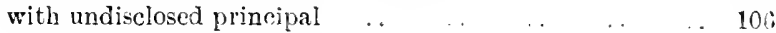

Exceptions to and limits of the rule . . 106

Rights of other contracting party $\quad \ldots \quad 108$

Professed agent not having authority eannot sue on the contract if a responsible principal has been named . . . $\quad 110$

$\begin{array}{llllllll}\text { Nor be sued on it . . } & \ldots & \ldots & \ldots & \ldots & \ldots & & \\ 112\end{array}$

But may be sued on implied warranty of authority . . . . 112

Where no principal named, or one who could not be respion-

sible, professed agent is treated as principal _. . 113

2. Artificial Persoms.

$\begin{array}{llllllll}\text { Nature of artificial persous } & \ldots & \ldots & \ldots & \ldots & \ldots & 117\end{array}$

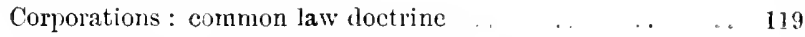

Capacities of corporations in themselves $\quad \ldots \quad \ldots \quad . \quad \ldots \quad 121$

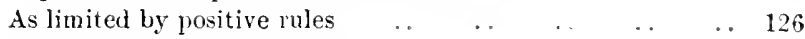

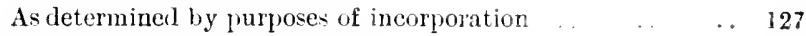

$\begin{array}{lllllll}\text { Application of partnership law } \ldots & \ldots & \ldots & \ldots & \ldots & 12 .\end{array}$

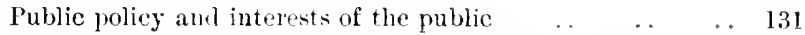

Decision of House of Lords on Companies Aet. 1862.. . . 131

Corporations eannot bind themselves by negotiable instru-

ments : explanations of this ..

$\begin{array}{lllllllllll}\text { Exceptions . . } & \ldots & \ldots & \ldots & \ldots & \ldots & \ldots & \ldots & 136\end{array}$

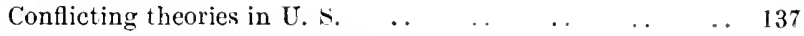

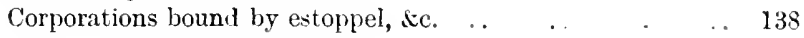

\section{('HAPTER III.}

\section{Fory of CONTRACT.}

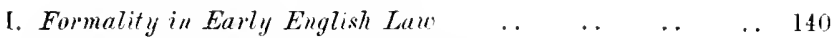

Hodern principles as to requirements of form. . $\quad \ldots \quad \ldots \quad \ldots 140$

Position of informal contracts in ancient law.. $\quad \ldots \quad \ldots \quad \ldots 141$

Formal and informal contracts in Roman law $\quad . . \quad \ldots \quad 142$

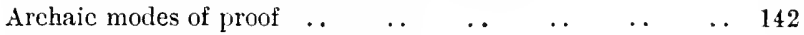

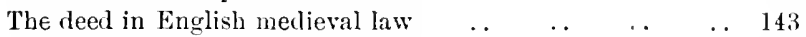

Remedies on contracts : debt on covenant or simple contract 144

$\begin{array}{llllllll}\text { Action of covenant } & \ldots & \ldots & \ldots & \ldots & \ldots & \ldots & 145\end{array}$

$\begin{array}{lllllllll}\text { Aetion of account . } & \ldots & \ldots & \ldots & \ldots & \ldots & \ldots & 146\end{array}$

II. The Artion of Assmmpsit.. $\quad$.

Intruduction of assumpsit to supply remedy on executory

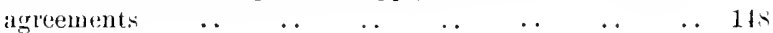


111. Motern liequirements of Form

Inolern law : requirements of form exceptional $\quad \ldots \quad$.. 151

$\begin{array}{llllllll}\text { Contracts of record } & \ldots & \ldots & \ldots & \ldots & \ldots & \ldots & 152\end{array}$

$\begin{array}{lllllll}\text { Contracts subject to special forms } & \ldots & \ldots & \ldots & \ldots & 152\end{array}$

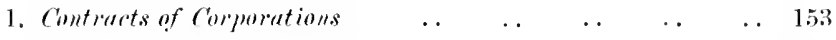

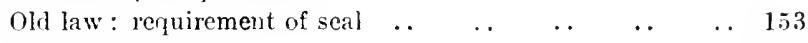

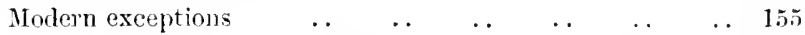

Trading corporations : contracts in course of business . 156

Non-traling corporations : contracts neessary and incidental

$\begin{array}{llllllll}\text { to corporate purposes } & \ldots & \ldots & \ldots & \ldots & \ldots & \ldots & 158\end{array}$

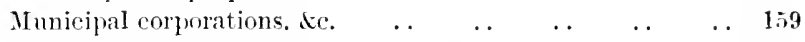

$\begin{array}{llllllll}\text { Appointments of officers . } & \ldots & \ldots & \ldots & \ldots & \ldots & 159\end{array}$

Exeeuter contracts with corporatiom $\ldots \begin{array}{llllll} & \ldots & \ldots & \ldots & \ldots & 162\end{array}$

Statutory forms of contract $\quad \ldots \quad$.

$\begin{array}{lllllllllll}\text { summary } & \ldots & \ldots & \ldots & \ldots & \ldots & \ldots & \ldots & \ldots & 163\end{array}$

2. Nequtiable Instruments $\quad \ldots \quad$.

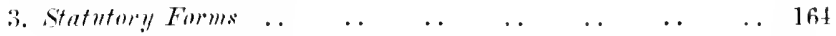

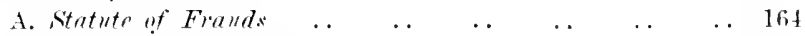

$\begin{array}{llllllllll}\text { Guarantees .. } & \ldots & \ldots & \ldots & \ldots & \ldots & \ldots & \ldots & 165\end{array}$

Agreements upon consideration of marriage $\ldots$.

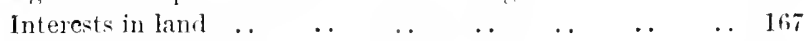

Agreements not to be performel within a year $\quad$. $\quad$.. 169

$\begin{array}{lllllllll}\text { Sale of goruls } & \ldots & \ldots & \ldots & \ldots & \ldots & \ldots & \ldots & 169\end{array}$

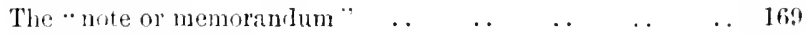

$\begin{array}{lllllllll}\text { Bills of sale Acts } & . & \ldots & \ldots & \ldots & \ldots & \ldots & \ldots & 172\end{array}$

$\begin{array}{lllllll}\text { Transfers of ships and copyright } & \ldots & \ldots & \ldots & \ldots & 172\end{array}$

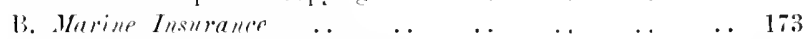

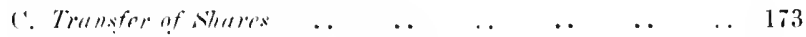

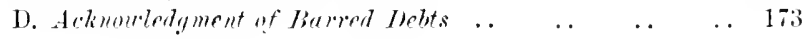

CHAPTER 11 .

CONSIDERATION.

Ileaning of the term $\quad \ldots \quad$.

$\begin{array}{lllllllll}\text { Gratuitous promises } & \ldots & . & \ldots & \ldots & \ldots & \ldots & 176\end{array}$

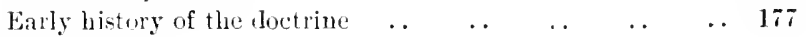

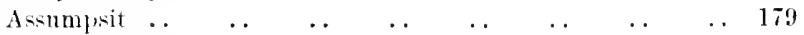

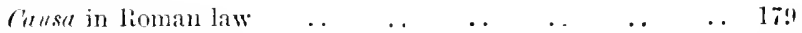

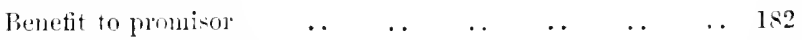

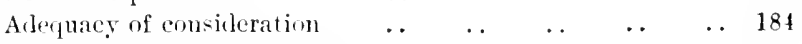

Past consideration ineffectual $\ldots \begin{array}{lllllll} & \ldots & \ldots & \ldots & \ldots & \ldots & 189\end{array}$

Acknowledgment of barred debt: $\quad \ldots \quad$. 
$\begin{array}{llllllllll}\text { Mntual promises } & \ldots & \ldots & \ldots & \ldots & \ldots & \ldots & \ldots & 191\end{array}$

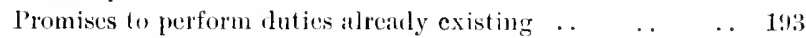

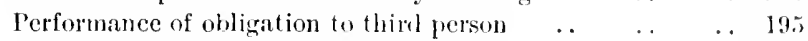

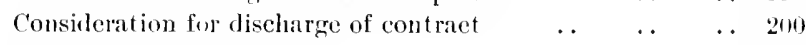

$\begin{array}{llllllll}\text { For variation of contract. } & \ldots & \ldots & \ldots & \ldots & \ldots & 201\end{array}$

$\begin{array}{lllllllll}\text { Forbearance to sue } & \ldots & \ldots & \ldots & \ldots & \ldots & \ldots & 202\end{array}$

$\begin{array}{lllllllll}\text { Compromises } & \ldots & \ldots & \ldots & \ldots & \ldots & \ldots & \ldots & 203\end{array}$

Treatment of gratnitous contracts under seal in equity $\quad$. 20.5

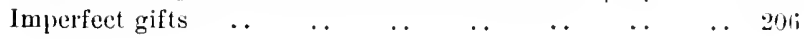

('IIAP'TEIS $\mathrm{V}$.

P'ERSONA AFFECTED BY CONTRACT.

$\begin{array}{llllllllll}\text { Preliminary } & \ldots & \ldots & \ldots & \ldots & \ldots & \ldots & \ldots & 20 \Omega\end{array}$

$\begin{array}{llllllll}\text { Definitions anıl rules } & \ldots & \ldots & \ldots & \ldots & \ldots & \ldots & 2(19\end{array}$

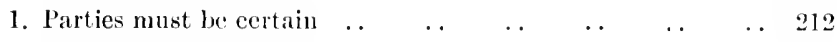

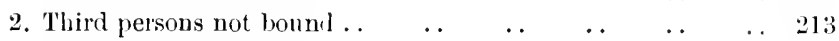

$\begin{array}{llllllll}\text { Apparent exceptions } & \ldots & \ldots & \ldots & \ldots & \ldots & \ldots & 214\end{array}$

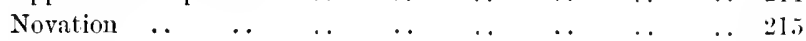

3. Third persons not entitled by the contract itself $\quad \ldots \quad \ldots \quad 217$

$\begin{array}{lllllllll}\text { Apparent execptions } & \ldots & \ldots & \ldots & \ldots & \ldots & \ldots & 217\end{array}$

$\begin{array}{llllllllll}\text { Trusts } & \ldots & \ldots & \ldots & \ldots & \ldots & \ldots & \ldots & \ldots & 219\end{array}$

Exception of certain provisions for chiluren $\ldots$.

$\begin{array}{lllllllll}\text { Statutory exceptions } & \ldots & \ldots & \ldots & \ldots & \ldots & \ldots & 221\end{array}$

Contract for benefit of third prerson gives him no right of $\begin{array}{lllllllll}\text { action at law } & \ldots & \ldots & \ldots & \ldots & \ldots & \ldots & \ldots & 223\end{array}$ $\begin{array}{lllllllll}\text { A uthorities in equity } & \ldots & \ldots & \ldots & \ldots & \ldots & \ldots & 221\end{array}$

Third person camnot be empowerel to suc for convenience of $\begin{array}{llllllllll}\text { parties } & \ldots & \ldots & \ldots & \ldots & \ldots & \ldots & \ldots & \ldots & 227\end{array}$

Negotiable instruments payable to holder of oflice $\quad \ldots \quad$. $\quad 228$

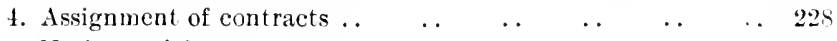

$\begin{array}{llllllllll}\text { Notice to debtor } & \ldots & \ldots & \ldots & \ldots & \ldots & \ldots & & . & 232\end{array}$

Assignment "subject to equities " $\quad$.

Assignment free from ecfuities by agreement of partics:

$\begin{array}{lllllll}\text { transferable lebentures } & \ldots & \ldots & \ldots & \ldots & \ldots & 231 ;\end{array}$

$\begin{array}{lllllllll}\text { Transferable debentures } & . & & \ldots & \ldots & \ldots & \ldots & \ldots & 237\end{array}$

$\begin{array}{lllllllll}\text { Negotialble instruments } & \ldots & \ldots & \ldots & \ldots & \ldots & \ldots & 240\end{array}$

$\begin{array}{llllllll}\text { Rights of lomer fide holder } & \ldots & \ldots & \ldots & \ldots & \ldots & 211\end{array}$

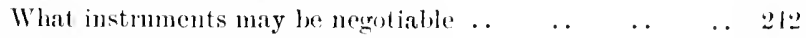

$\begin{array}{lllllllll}\text { Negotiability ly estoppel. . } & \ldots & \ldots & \ldots & \ldots & \ldots & 24\end{array}$

Ifow instruments may cease to be negotiable. $\quad \ldots \quad \ldots \quad \ldots 11$ 
PAGE

$\begin{array}{lllllllll}\text { Tran } & & & & & & & & \end{array}$

Obligations attached to preperty $\quad \ldots \quad \ldots \quad$.. 247

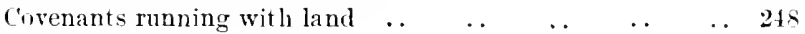

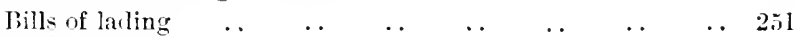

Conflict between common law anıl equity as to burden of

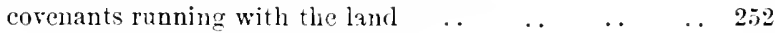

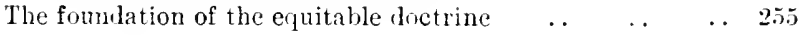

\section{CHAPTEli Vl.}

DCTIES UXDER CONTRACT.

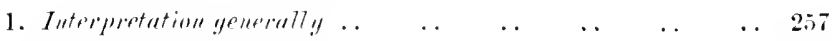

$\begin{array}{lllllll}\text { Necensity of interpretation } & \ldots & \ldots & \ldots & \ldots & \ldots & 257\end{array}$

Agreements in writing: rule against prarol variations _. 260

$\begin{array}{llllllll}\text { Alparent excepitions } & . & \ldots & \ldots & \ldots & \ldots & \ldots & 262\end{array}$

$\begin{array}{lllllllll}\text { Extrinsic evidence } & \ldots & \ldots & \ldots & \ldots & \ldots & \ldots & 264\end{array}$

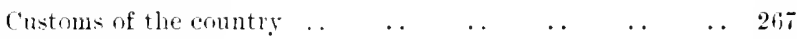

$\begin{array}{lllllllll}\text { Trarle usages. \&c. .. } & \ldots & \ldots & \ldots & \ldots & \ldots & \ldots & 267\end{array}$

Construction : preference of general intention $\quad \ldots \quad \ldots \quad 268$

Special rules of construction $\quad \ldots \quad$.

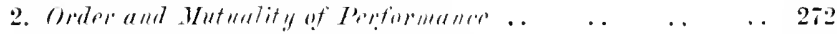

Order of performance in executory contracts . $\quad \ldots \quad \ldots \quad$. $\quad 272$

Iorlen authorities look to general intention of erntract . 273

$\begin{array}{llllllllll}\text { Effect of lefault } & \ldots & \ldots & \ldots & \ldots & \ldots & \ldots & \ldots & 276\end{array}$

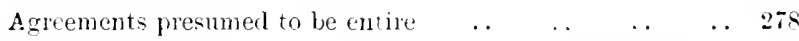

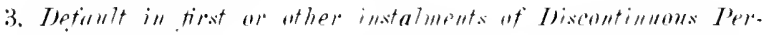

$\begin{array}{llllllllll}\text { formulure } & \ldots & \ldots & \ldots & \ldots & \ldots & \ldots & \ldots & \ldots & 280\end{array}$

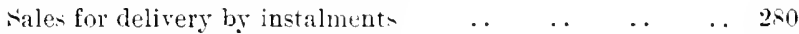

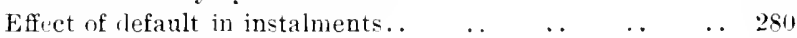

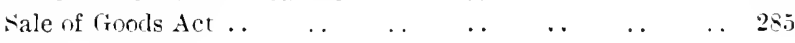

CHAPTER VII,

VNLAWFUL AFREEMEXTS.

Of unlawful agreements in general. and their elassification. . 287

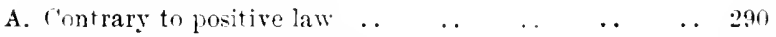

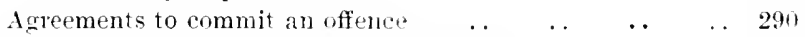

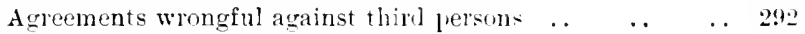
$\begin{array}{llllllll}\text { Fraul on creditors } & \ldots & \ldots & \ldots & \ldots & \ldots & \ldots & 293\end{array}$ 
PATi:

Dealings between creditor and principal debtor to prejulice

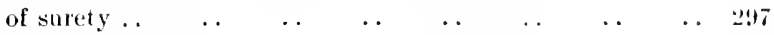

Dealings by agent, executor, de., agaiust his duty $\quad$. $\quad$. $\quad 2$ 2!4

Settlements in fraul of marital right $\ldots \begin{array}{llllll} & \ldots & \ldots & \ldots & 303\end{array}$

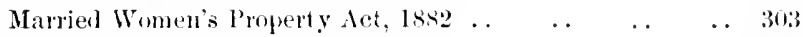

Marriages within prohibited degrees $\ldots \begin{array}{llllll} & \ldots & \ldots & \ldots & 301\end{array}$

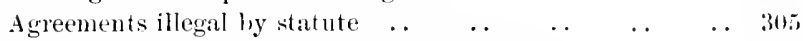

Rules for construction of prohibitory statutes.. $\quad \ldots \quad$. . 306

When agrcements may be not void though forbidien, or voil

$\begin{array}{llllllll}\text { without being illegal } & \ldots & \ldots & \ldots & \ldots & \ldots & \ldots & 312\end{array}$

$\begin{array}{llllllllll}\text { Wagers } & \ldots & \ldots & \ldots & \ldots & \ldots & \ldots & \ldots & \ldots & 313\end{array}$

B. Agreenents contrary to morals or good manners .. 316

Agreements in eonsideration of illicit cohabitation . . . . 317

Validity of separation deeds $\quad \ldots \quad$.

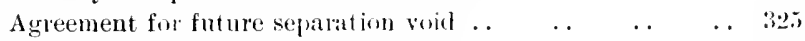

Publication of immoral or seditions works is not merely

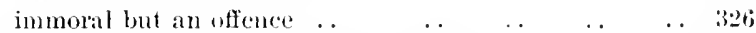

C. Agreements contary to prublic policy $\quad \ldots \quad$.

Connection of the roctrine with the common law as to wagers $32 \mathrm{~s}$

Modern extent of the dectrine: Lifferton v. Brownlow .. 830

Public policy as to external relations of the state $\quad . \quad \ldots \quad 333$

$\begin{array}{llllllll}\text { Trading with enemies } & \ldots & \ldots & \ldots & \ldots & \ldots & \ldots & 333\end{array}$

Effect of war on subsisting cont raets $\ldots \begin{array}{llllll} & \ldots & \ldots & \ldots & \ldots & 334\end{array}$

Negotiable instruments between Englind amd hostile comt ry 336;

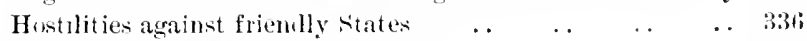

Trade with belligerents not unlawful $\ldots \begin{array}{llllll} & \ldots & \ldots & \ldots & & \mathbf{3} 37\end{array}$

$\begin{array}{lllllllll}\text { Foreign revenue laws } & \ldots & \ldots & \ldots & \ldots & \ldots & \ldots & 337\end{array}$

Foreign laws as to stamps $\quad$.

Public policy as to internal govermment : at tempts to intluence

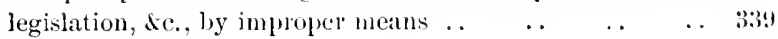

$\begin{array}{lllllllll}\text { Sille of offices, de. . } & \ldots & \ldots & \ldots & \ldots & \ldots & \ldots & 343\end{array}$

$\begin{array}{lllllllll}\text { Assignment of salaries } & \ldots & \ldots & \ldots & \ldots & \ldots & \ldots & 343\end{array}$

"stifling prosecutions" and compoumling offences . . . 34

Compromise of election petition $\quad \ldots \quad$.

Secret agreement as to eondnet of winding-np $\quad \ldots \quad \ldots \quad$; 317

Agreements for referenee to arbitration: extent of their

validity at common law, and by the Arbitration Act . 31 is

$\begin{array}{llllllll}\text { Maintenance ancl champerty } & \ldots & \ldots & \ldots & \ldots & \ldots & 3511\end{array}$

$\begin{array}{llllllllll}\text { liules as to champerty } & \ldots & \ldots & \ldots & \ldots & \ldots & \ldots & 952\end{array}$

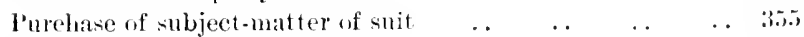

statute of llenry VIII. against buying pretended titles . . 3.5

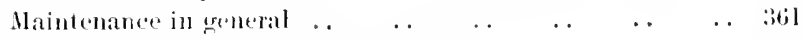

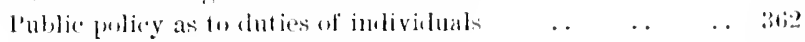

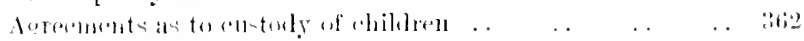

l'. 


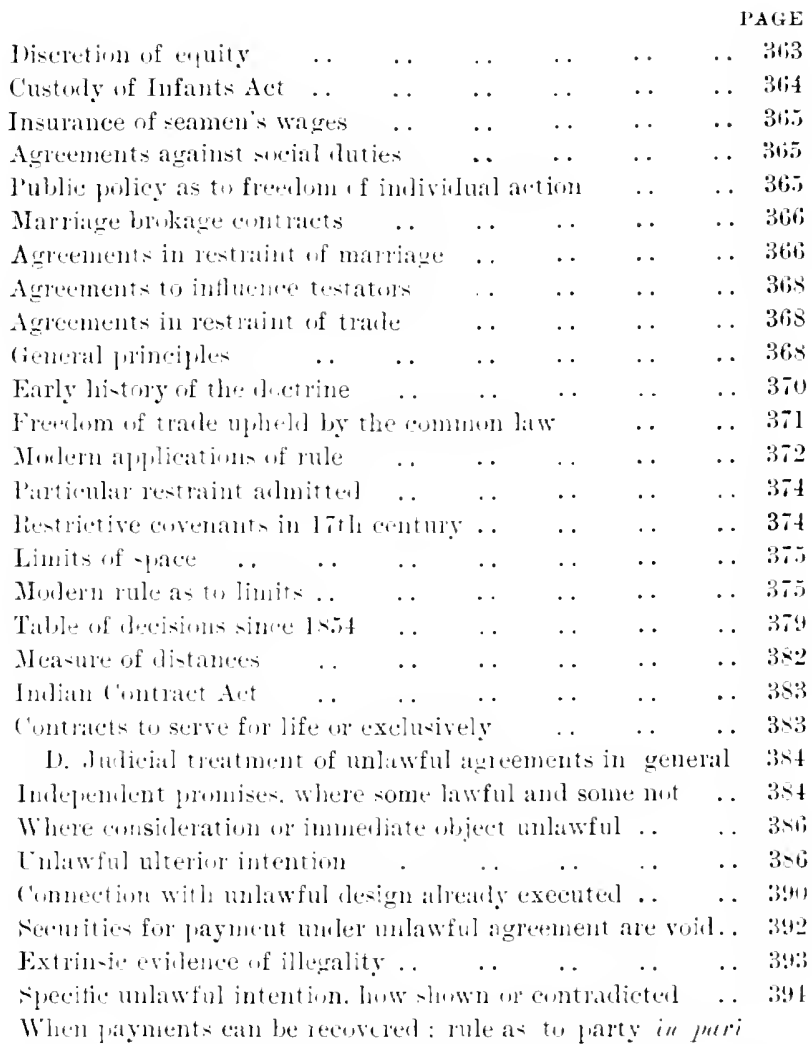

$\begin{array}{llllllllll}\text { derlicte } & \text {. } & \ldots & \ldots & \ldots & \ldots & \ldots & \ldots & \ldots & 397\end{array}$

Exceptions: duty of agents to frineipal maffected . . . 399

Ioney recorerable where agreement not executed . . . $\quad$ \&01

Where the payment was compulary $\quad \ldots \quad$.

In erpuity where circum-tances of framl. Ne., as between the

$\begin{array}{llllllllll}\text { parties } & . & \ldots & \ldots & \ldots & \ldots & \ldots & \ldots & \ldots & 404\end{array}$

Final statement of the rule and publitication. . . . . . to.;

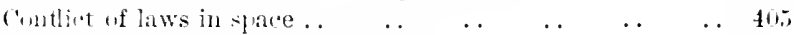

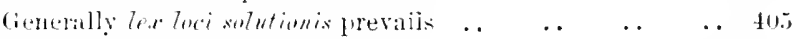

bxeeptions-when a polibitory mucipal law is not merely $\begin{array}{lllllllllllll}l<k a l & \ldots & \ldots & \ldots & \ldots & \ldots & \ldots & \ldots & \ldots & 406\end{array}$

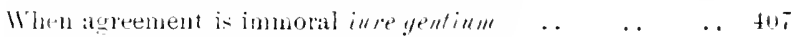

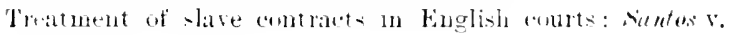

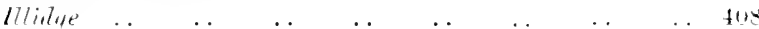


Other instanees of conlliet of laws as to valility of agree-

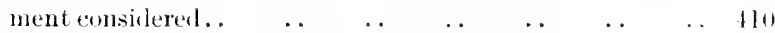
Agreements against interests of the liseal sovereign . . . . 11: Conflict of laws in time: subseguent illegality dissolves con-

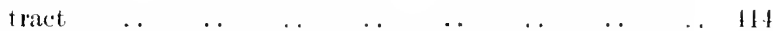

Otherwise validity determined by law at diate of agrement flit

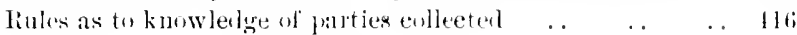

\section{CHAPTLIS VIII.}

IMPOKSLLE ATREEMENTS.

Performance of arreement may be inpmosible in itself. ly law, or in fatet (i.e., by reason of particular state uf fiacts) fls

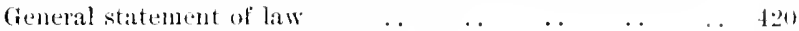

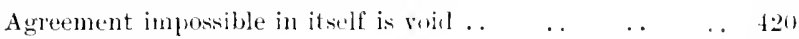
P'ractieal impossibility $\quad \ldots \quad$. $\begin{array}{llllllll}\text { Logical improssibility } & \ldots & \ldots & \ldots & \ldots & \ldots & \ldots & 42: 3\end{array}$ Improssibility merely relative to promisor mo excuse.. . . 1:21 Agreements imposibile in law $\begin{array}{lllllll} & \ldots & \ldots & \ldots & \ldots & \ldots & 4: .5\end{array}$

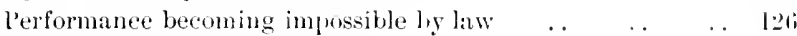
liuying one's own property $\quad \ldots \quad$. Impossibility in fact no excuse where contract absulute . . t26

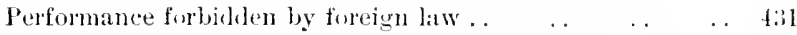

Obligation to pay rent when premises aceidentally destroyed t32 Exceptions in eases of events mit contemplated by the $\begin{array}{lllllllll}\text { contraet } \ldots & \ldots & \ldots & \ldots & \ldots & \ldots & \ldots & \ldots\end{array}$

Performance depentent on speedife thing existing: Taylor $r$.

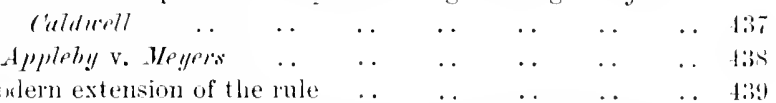

Impossibility at date of eontract from existingstate of things not kmown to the parties $\quad \ldots \quad$.

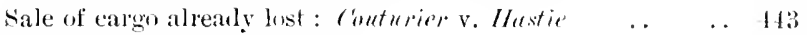
Civenants to work mines, de. $\begin{array}{lllllll} & \ldots & \ldots & \ldots & \ldots & \text { tht }\end{array}$ clifford v. llatts $\quad \ldots \quad$.

Construction of express exceptions in certain contrants . . Hti l'erformane depentent on life or lealth of prominor . . Hij

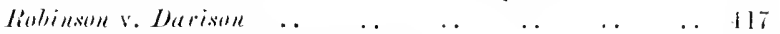

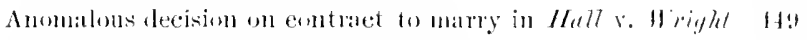

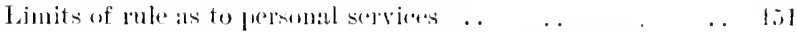

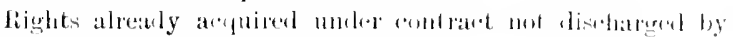

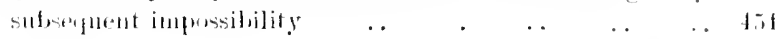


P.trit:

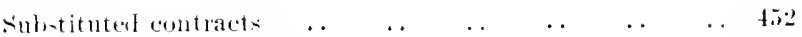

Impessibility by alefault of either party: such default of promisor is equivalent to breach of contract $\quad \ldots \quad \ldots 4.2$

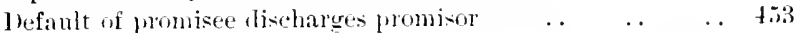

Alternative contracts where whe altematise is or becomes

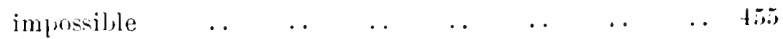

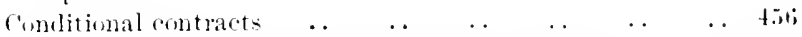

Impossible comotitions in londs: peculiar treatment of then tho

Indian Contract Act on impossible agreements . . . . the

\section{fHAPTELI IX.}

\section{MISTAKE.}

\section{PAR'T I.-Of Mistake in Cipneral.}

clasification of conditions affecting validity of consent in agreement: Mintake. Framl. de. . . $\quad \ldots \quad \ldots \quad \ldots t 63$

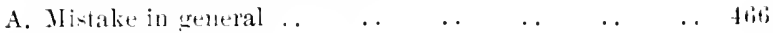
(ienerally it is in itself inmerative eithel to avoid civil liabilities

(Fxcept in certain special cases. and except on far as in the ease wi purchave for value withut notice. ignorance is a

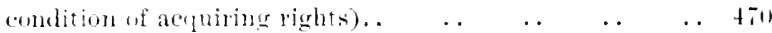

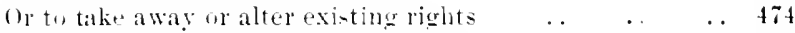

Or to alter comstruction of contract $\ldots \quad \ldots \ldots \ldots$. . . ti;

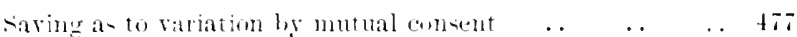

fiecial eases where mistalit important $\ldots \quad \ldots \quad \ldots$ tis

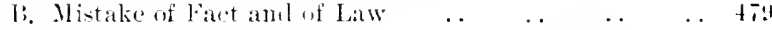

Limits of the tistinction: Where certainly or probably not $\begin{array}{llllllllll}\text { a) } & \text { Hitible } & \ldots & \ldots & \ldots & \ldots & \ldots & \ldots & \ldots & 47 !\end{array}$

Common mistake and rectitication of instrument; .. . . 4No

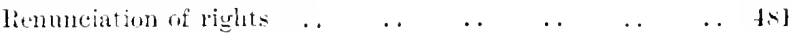

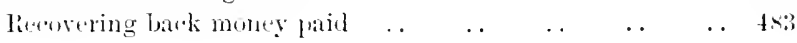

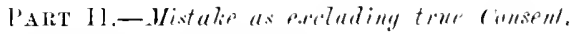

livision of easer under this head $\quad \ldots \quad$.

A. Frror as to nature of transaction.. $\quad \ldots \quad \ldots \quad \ldots$ the

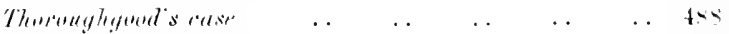

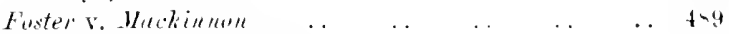

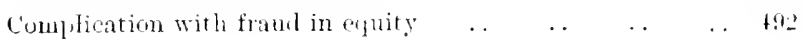


PAC;E

Total and partial misapprehension distinguished $\ldots$. . 1922

Error as to legal chatacter of transaction $\quad \ldots \quad \ldots \quad \ldots \quad \ldots \quad$ [!'

B. Frror as te the person of the other party $\quad \ldots \quad \ldots \quad$. 15,5

Analogous doetrines: application to deerls . . . . . . . 197

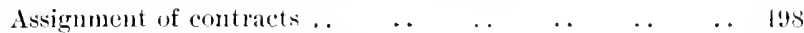

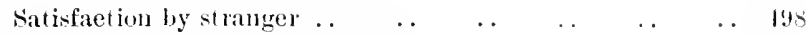

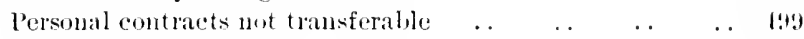

$\begin{array}{llllllllll}\text { Agency } & \ldots & \ldots & \ldots & \ldots & \ldots & \ldots & \ldots & \ldots & \text { inl }\end{array}$

C. Error as to the subject-matter $\quad \ldots \quad \ldots \quad \ldots \quad \ldots \quad \ldots 2$

With regard to irlentity of specific thing $\quad \ldots \quad \ldots \quad \ldots$ inlt

Inelusion of parcels ly mistake on sale of land $\ldots \ldots$. . inj

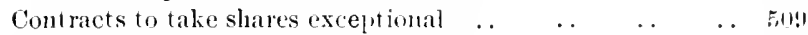

Error with regard to kinkl, yuantity, \&e. . . . . . . 5to

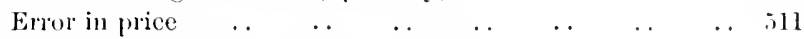

Error as to quality incprerative muless material and enmmon

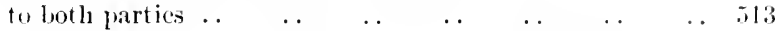

Even if error of one party known to, but not cansent hy, the

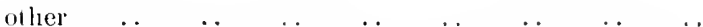

Cases distinguisher where misteseription of estate on ale

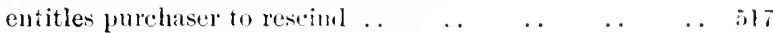

Error as to existence of subjeet-matter $\quad \ldots \quad \ldots \quad \ldots \quad \ldots$ ils

Purchase or lease of one's own property $\quad \ldots \quad \ldots \ldots$

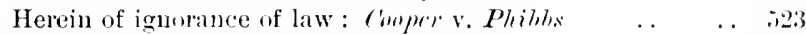

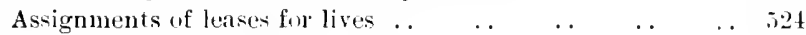

Where only one party is ignorant of the nuiterial lact . 525

Where fundamental error produced by framl or misepresen$\begin{array}{lllllllllll}\text { tation } & \ldots & \ldots & \ldots & \ldots & \ldots & \ldots & \ldots & \ldots & 526 ;\end{array}$

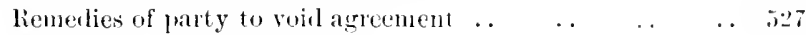

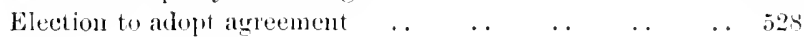

\section{PART 111.- Mistale in erpresting true rousent.}

Correction of mistake in expressing intention $\quad \ldots \quad \ldots \quad \ldots \quad 529$

1. Rules of constunction common to law and cupity . . . 5. 530

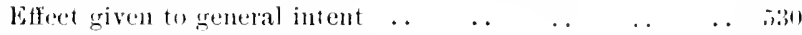

2. l'econliar rules of construetion in entrity . . . . .3.

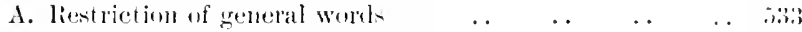

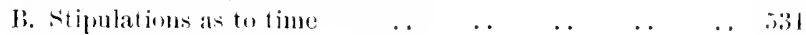
Where tume of essence of comtract . . . . $\quad \ldots \quad \ldots 36$ Indian Contract Act thereon. . $\quad \ldots \quad \ldots \quad \ldots \quad \ldots \quad \ldots 37$

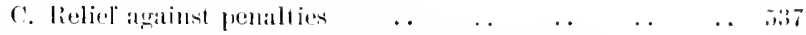

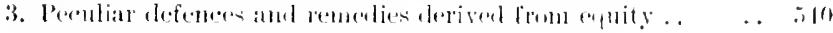

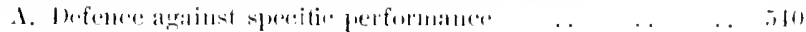

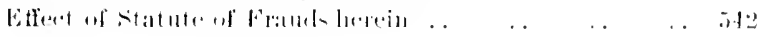




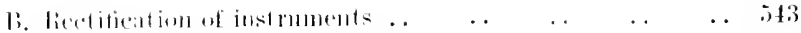

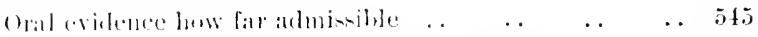

lical intention must $h$ distimetly proved. and common to all pallit.

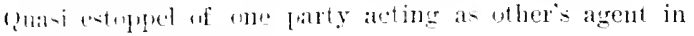

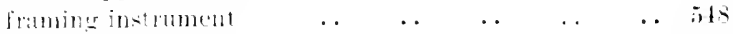

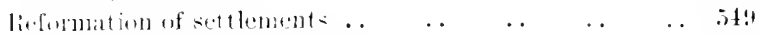

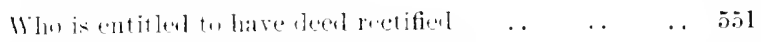

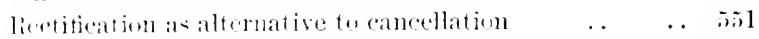

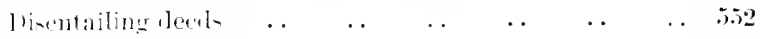

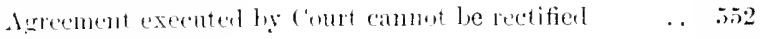

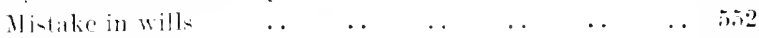

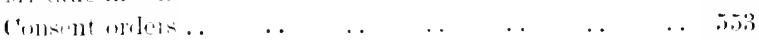

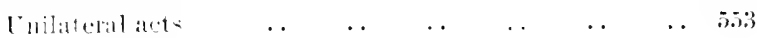

C'IIATEli X.

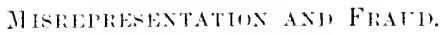

l'AIT 1.- Gimminlly.

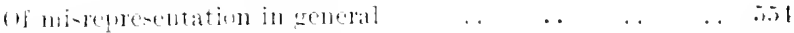

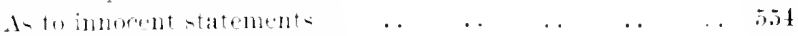

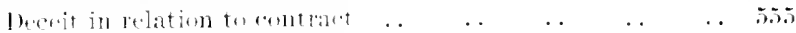

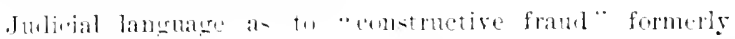

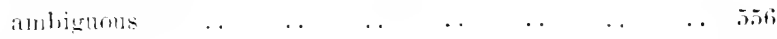

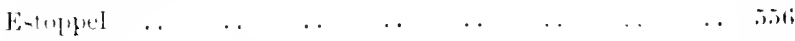

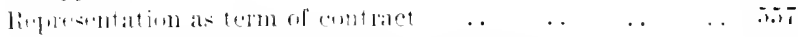

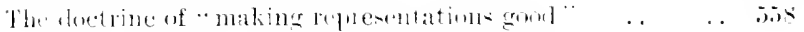

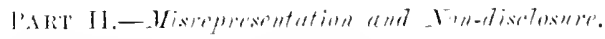

Xu general puritive duty of diselosme . . . . . . . . .5!

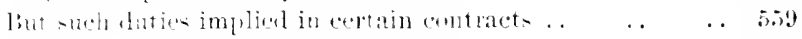

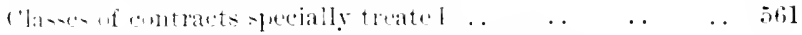

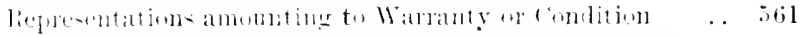

flistinden- between warranty ame comdition on sale of

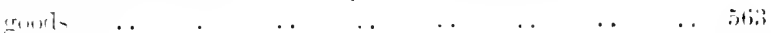

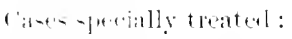

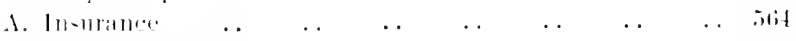

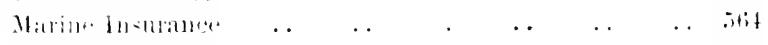

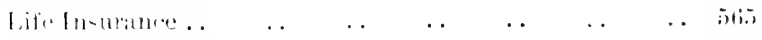

firr Insumate

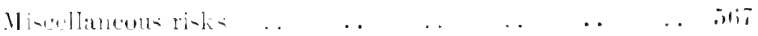




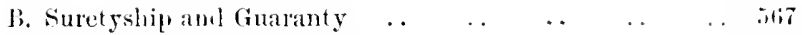

Extent of creditor's duty to surety . . . . . . . . ilis

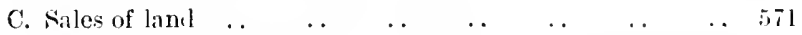

specific performance and compensition : three classes of

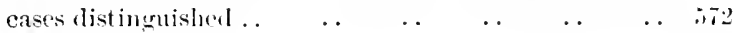

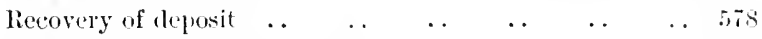

General duty of vemulor to describe property correctly . . 5is

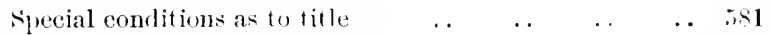

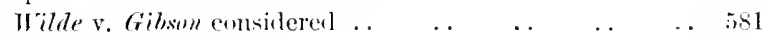

D. Family Settlements $\quad \ldots \quad$.

E. lartnership, eontracts to take shanes in eomplanies, and

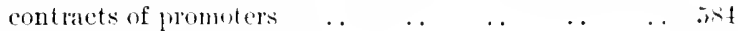
The Companies Aet. 1 !nos $\quad \ldots \quad \ldots \quad \ldots \quad \ldots \quad \ldots \quad$. . . Contrict to marry not exceplional .. $\quad \ldots \quad \ldots \quad \ldots$. . . . $\begin{array}{lllllllll}\text { Voluntary gifta. . } & \ldots & \ldots & \ldots & \ldots & \ldots & \ldots & \text {.x.4 }\end{array}$

\section{l'ART III.-Frend or' Dirit.}

Fraul generally but not always includes misceperentation asy $\begin{array}{lllllllll}\text { Right of rescission } & \ldots & \ldots & \ldots & \ldots & \ldots & \ldots & \text { i2: }\end{array}$ Frandulent representation or concealment $\ldots \quad \ldots \quad \ldots \quad \ldots 92$

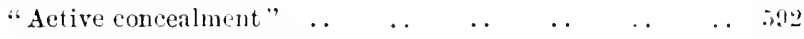

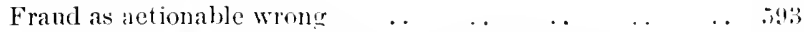
Reckless ignoranee equivalent to knowlerlge of untruth _. itt Pepresentation of expectation as present fact . . . . . . . 595

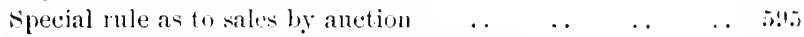

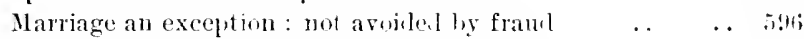
But knowledge of nature of ceremony esential _. . . isti Cousent of thiml person proemed by framl is voirable . . ist

\section{CllAp'TEL XI.}

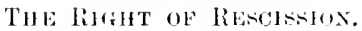

General rules as to rescision for misepresentation or laaul ons The representation relied on must be of fact . . . . . . . 5.t?

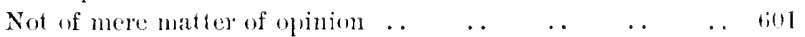

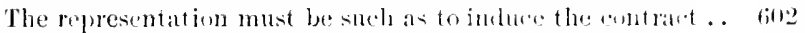

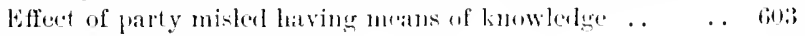

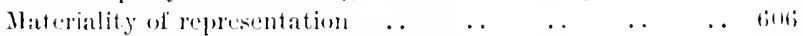

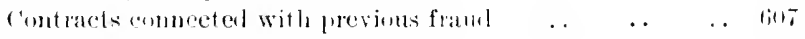

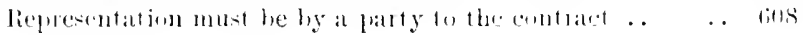


PAfiE

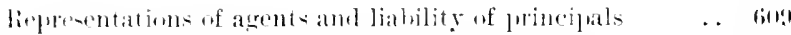

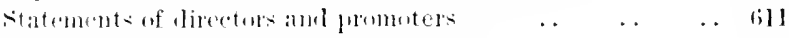

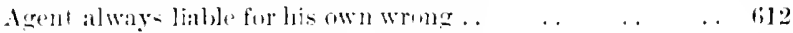

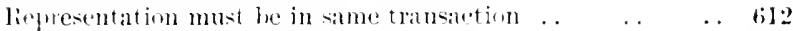

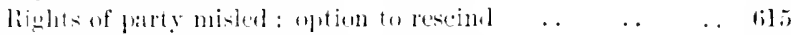

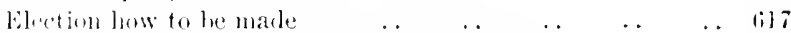

light extreiveable by and arainst representative $\ldots$. . ti2l

Nu moissom where the fommer state of things cannot be

$\begin{array}{llllllllll}\text { resturel } & \ldots & \ldots & \ldots & \ldots & \ldots & \ldots & \ldots & \ldots & 1822\end{array}$

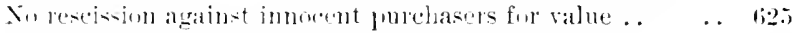

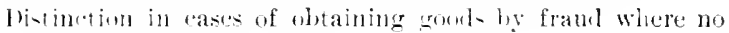

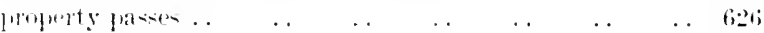

liepuliation of slater $\quad \ldots \quad$.

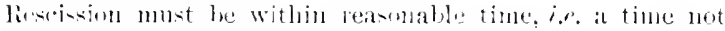

-

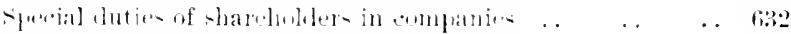

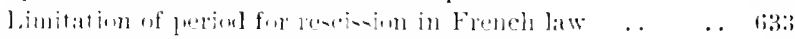

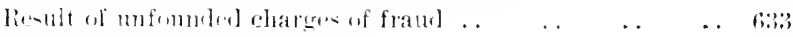

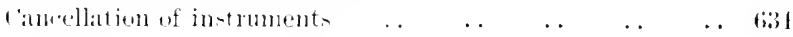

('HAI'TER XII.

DURES AND TYHE IXFLEATE.

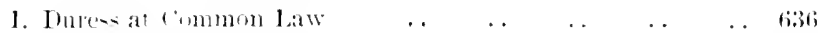

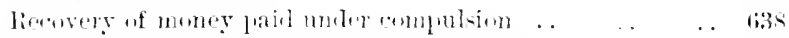

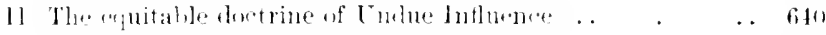

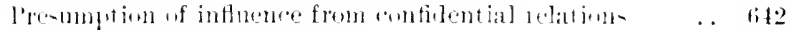

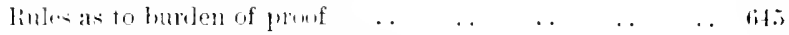

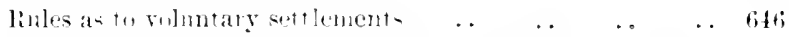

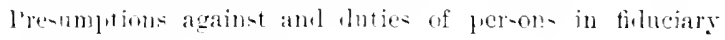
relations $\quad$.

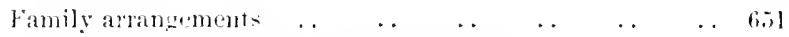

l'articular cases where inthence presumed:

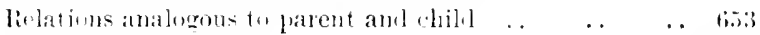

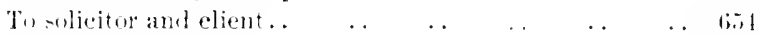

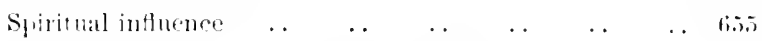

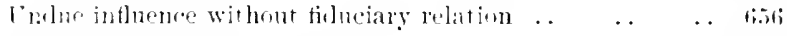

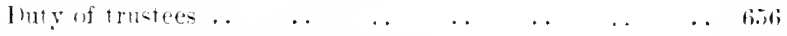

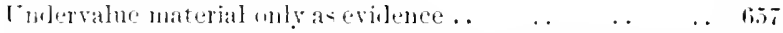

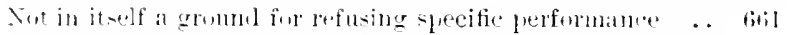

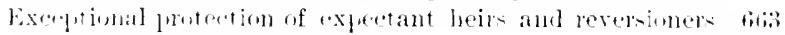

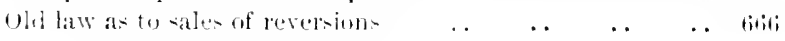


Aet of $\ln 67 \quad$.

liules of equity as to "eatching bargains" wut affecter . . litiz

What me " catching hargains" $\quad \ldots \quad \ldots \quad \ldots \quad \ldots$ ofis)

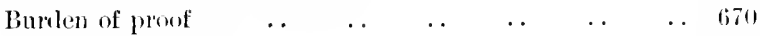

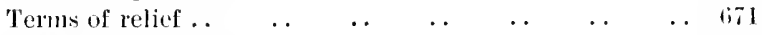

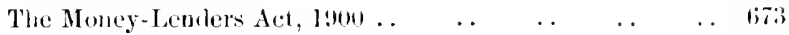

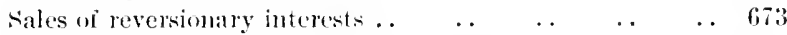

"simprise" and "improvidence" not sulstantive gromul of

reilef against contracts, hut only evidence of fraud, de. . 6izj

light of rescission for modue inlluence $\quad \ldots \quad \ldots \quad \ldots \quad \ldots \quad 677$

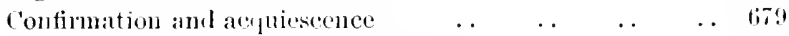

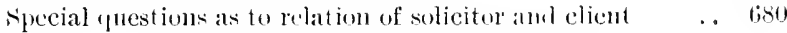

\section{IHAT'TEL XII]}

\section{AGREEMENTS GF IMPREECT OHLIGATIMN.}

Nature of Imperfect Obligations: Right without remerly . . lise

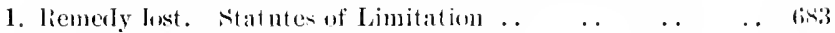

lights of creditor notwithstanding loss of remedy hy action bis.

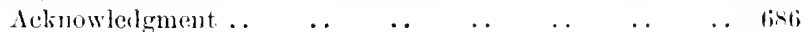

What is sufficient acknowledgment $\ldots \quad \ldots \quad \ldots \quad \ldots$ list

Statutes of limitation belong to ler forri $\quad \ldots \quad \ldots \quad \ldots$ bisi

2. Cunditions precedent to remedy not satisticed.

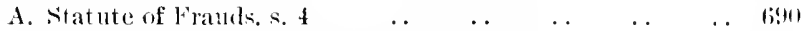

A law of procerlure omly, not of substance . . . . . . $\quad 693$

Riesults of informal agrement :

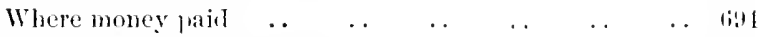

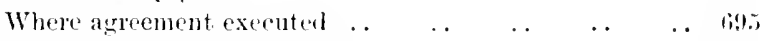

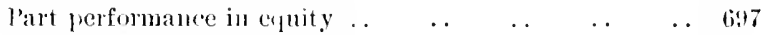

Informal ante-muptial agreements, and comtimation by

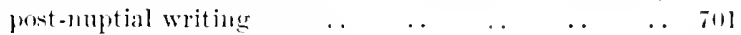

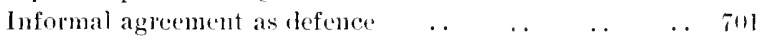

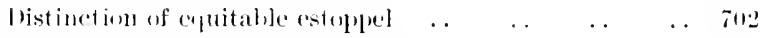

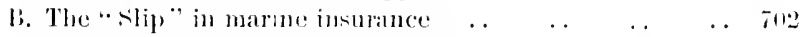

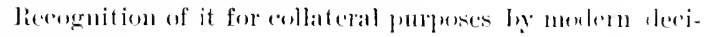

$\begin{array}{llllllllll}\sin & \ldots & \ldots & \ldots & \ldots & \ldots & \ldots & \ldots & \ldots & 703\end{array}$

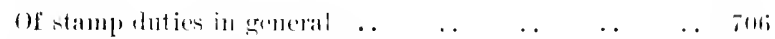

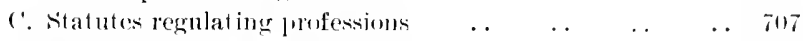

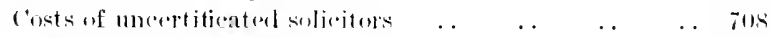

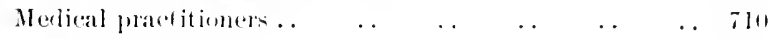

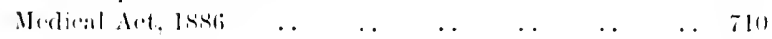

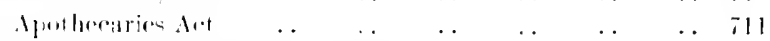

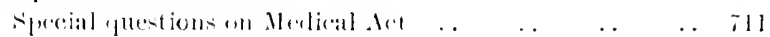


i. Nommaly all all. PArE

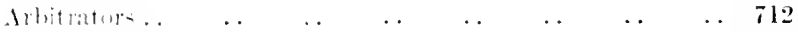

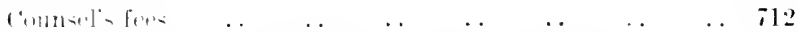

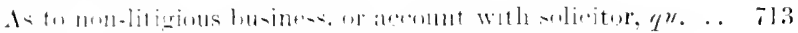

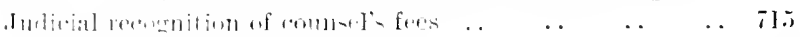

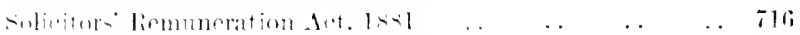

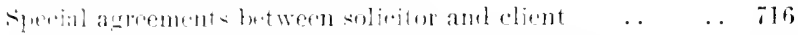

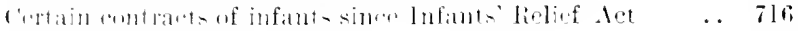

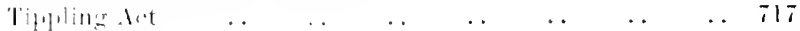

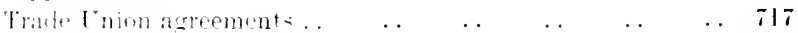

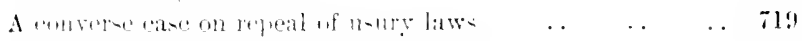

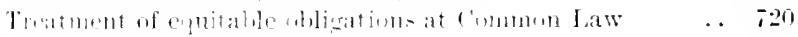

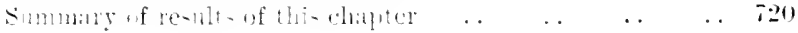

\section{I'I'ENHIX}

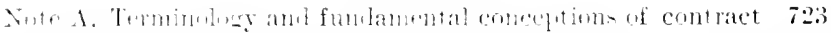

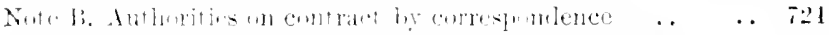

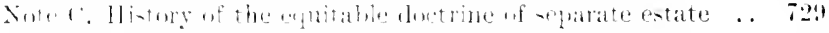

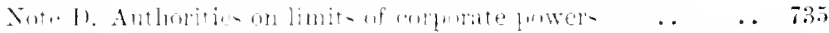

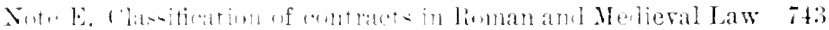

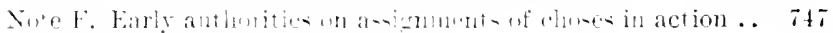

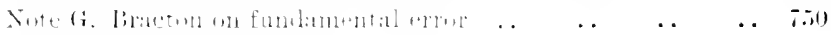

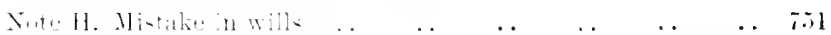

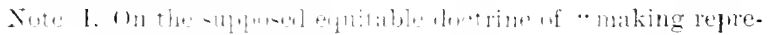

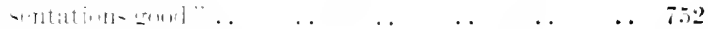

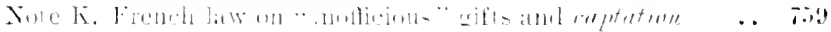




\section{( xxvii )}

\section{TABLE OF ('ASES.}

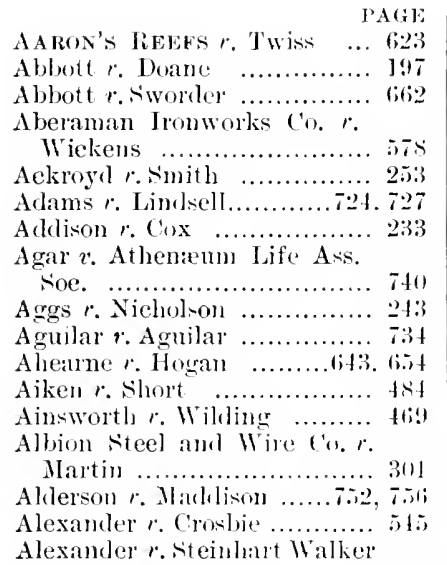
sco.

Alger $r$. Thacker.

Alison, E.r parte... 334

Alleard $r$, skimel ...6ill, 64t4, 64.5, 6.5.), 6i:9, tis 1

Allearl $r$ Walker ............... ts

Alleock $r$ Monmoure............ 2 $4: 9$

Allen $r$. Allen ................... $5: !$

Allen $r$. liaker ................ fis

Alliance liank $r$. liroon ...... 2403

Alliance Bank of Nimla $r$.

Carey ........................ bis?

Allkins r. Iure .................. $39 \%$

Allsoply r. Wheatrof of ......... $3 \mathrm{SI}$

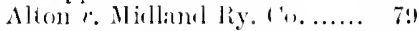

Alranley $r$ linnairl........... तns

Alvarez de la lioxa r. l'licto... T11

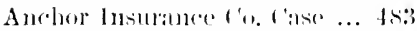

Amelersul's dise ................. tis

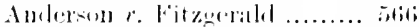

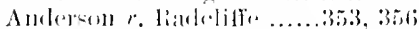

Andrewn, fir ................... 360
Pars

Andlews r. Belfield ........... t!

Andrews r. Mockforl............ (i]

Andrews $r$. sialt ................. : 363

Angell. Rir ...................... 71.

Angell r. Duke ...16i-264.433, T.5

Anglo- Egyptian Navgation

Co. r. liennie ................ + II

Antoine r. Morslueanl ............. 336

Alpleby $r$. Johnoon ............ 43

Appleby $r$. Meyer's ........4.8s, 43:

Arbutlinot $r$. Norton ............. 341

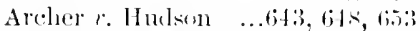

Ardenlasie $r$. Mtuschamp ........ biti.

Arlinasas fmelting (cor r. Jicl-

den Co.

Amotronger. Arm-trong ..... $3: 44$

Armstrong $r$. lewis ............

Arm-trong $r$. Stokes .....104, 109?

Armstromer $r$ 'Joler .........38

Arnolel $r$. Arnoled .............. $5 \pi$ is

Amolel r. Nayor of I'oole... J.53, lis!

Arthur $:$ Wymue .............. 1:1

Arumelel so caice.................. 1:2l

Aslibury Ry. larringe ('o. r.

liche...125, 132, ]34, 582.7 f1, 742

Ashley's Case ................... 6il?

Ashlingr $r$. Boon ................... Th

Asiatic lanking ('orporation,

LE purto ................23, 237

Aspelen $r$. Serlefon ............... 2.0

Athensem life As-surance

sire. r. P'ooley ................. 239

Atherfold r. beard .............. 32s

Atkinson $r$ bersloy ...........40.3, 6i3:4

Atkinson r. litchic ......... 411 , 42!

Atlee $r$. liackloome.............. 8.37

Attonborougle $r$. St. KathitJine's llock ('i) .............. 1507

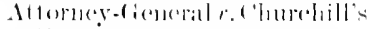

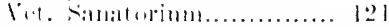

Attorueyefiencral r. Ai. k. liy. (') 


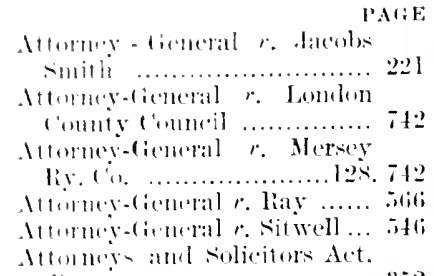
li. 352

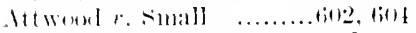

Au-terferey r. forporation of (1) 1h:1m ..................2.20, 251

dution r. licthnal fireen

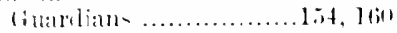

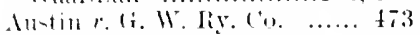

Auntalian boyal Mail, se. (1). . In

Anstrial (Emperes off) 1. liay

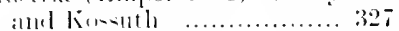

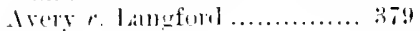

Axforid r. licid ...............

lrere r. Sonth An-tralian Jialking ('o................

dretet r. Jukin ...31s, 31!1, 320, $34,39 ! 1$

Arle r. Cox ..................... הis

Aileforel ( Earl of ) 1 lorris. litis.

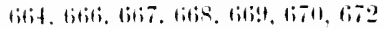

Ayr llathur Trustes $r$.

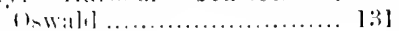

Arimal r. (a-ella........... ilt, iro

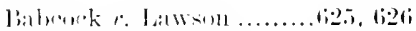
litelle I. Jibllinghatm .......... 3.00 bialinelue Anilin. Ne. Falnik $r$ $\therefore+1+11$ 379

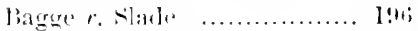

liagnall r. carlton ............ siti

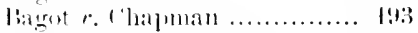

bag-latw r. Seymour ......... blt

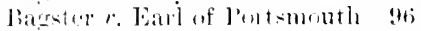

babial and sall Francisen biy.

('o.. lí, $2: 3 ! !$

lially r. llarris ............... 312

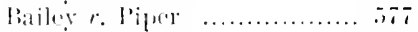

lat y r.

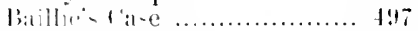

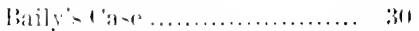

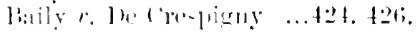

tis.

Hain r. Fllergil] ............. तit

bainhindee r. Firm-tulle ..... ls.

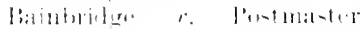

litherial

120
PAFE

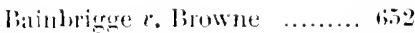

baines $r$ (ieary ................. 378

bines $r$. Wemifall ............. to

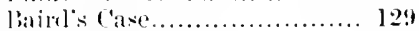

balier r. liradley................ 652

baker r. Cartwight .......... sst

laker $x$. Herlgecoek .......... 37s

liaker $r$ Londer ................. lii.t

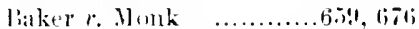

bilker $r$. liearl .................

bialfour r. Ernest .....243, 737, 73s

ball $r$. Sturie .................. itt itti

liamfielal $r$ lioger ........5s!. 64.

liankatt $r$. lowers ..........2 274

liank of Am-tralasia $r$. Beillat $12 ! 1$,

38.5

liauk of Australa-ia r. l'almer 26 ti3

liank of columbia $r$. Patternon lis.

156

Bank of Eneranil $r$. Amiter-

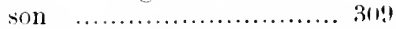

bink of Hindustan $r$ Alison... 520

jimk of Ireland $r$ Evans ('harities ................. 13s. 1:1

bank of New Kealand r. Simpsill ......................... 26 is

bauk of [niter States $r$. Ditniel ..................4. 484

bink of l'niterl states $r$. Owent ....................... 309

liank=r. Cromblambl............ 1i94

liamer $r$. bohnton .......... 219

liamerman r. Il hite ......islt, ili. 56il. 5is

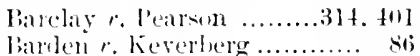

birker r. ('ux ..................

barlier r. Howg-n ........t14, t3l

liakwortler. Foung .....tis, 700

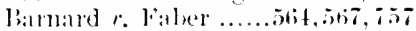

barnardo $x$. Ml.Hugh ........... 34 th

birnes r. Jine ............... 73

barnett, E.r purto ............. 497

billnett $r$. Jlowall ............?4), !t

barrett $r$ Iartley ............... tibir

batron r. Willis ........... lisen, lisu

Bitrmen r. I-ilates................ tis

Patry r. l'mkey ............ bis

bartlett $r$. Ireils................

liarton r. Mnir ................ 307

biatom r. Pigent ............ 311

liawick e. linglish hoint storek

lianli ....................... bill

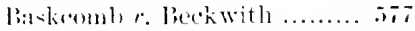

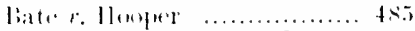

batemian rocountess of lion... si 
I'A (iE:

Bateman $r$ Faber ........... y. I bateman r. Mind-llales liy. Co............................. 1:37

Bateman $\ell$. P'inler .............. bist;

Bates, E.r parte ............... \$2

Bateson $r$. (iosling .............. 298

Bath ( Earl of ) and Muntarnes C'ase iiti

latson $r$. Newmin.............. 313

Batty $r$. Chester ............... 31!

Baudains 1 . Richaroton........ titt

Baxendale $r$. seale ............. 508

baxter $r$ Earl ..................

Beachey $x$. Brown .......t17. 5.8

Beale $r$. Kyte ..............507, 52

Beanland $r$. Brabley .......... (i.r2

Beard $r .17 \mathrm{eb}$................ s

Beattie $r$. Lond Ebury ...1]2, s99

lieauchan], (Earl) $r$. Winn ... thiti

lieammont $r$. Dukes ........... tis

Beaunont $r$. Reeve ........... 31s

Beavan $\left.r . \mathrm{I}^{6} ;\right)_{0}$ nnell ........... 98

Bechervaje $r$. Iewis ........... 29.9

Hechuanaland Exploration ('o.

r. Lombon T'rablius liank ... l:3is, $238.24: 3$

Beek $x$. l'ieree .................. 9.;

Beekhatm $r$. Drake ...l11, 1116, 107

Bedford r. Bagshaw ......... $64 t$

Berlforl (Duke of) $r$. Trustces of British Musemm .......... 256

Beeston $r$. Beenton ............... 35 .

Beglie $r$ Phompate Fewage Co.

398

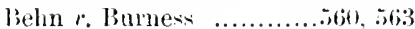

Bell $r$. Kalls .................. 170

Bell $r$. Reid ...................... $3: 33$

Bellair's $x$. 'Jueker ..............

Bellamy $x$. Debenham ....... i is.

Bellaniy $r$. Sabine ............. bist

Belshaw $r$ B Buh ............... 49s

Bence $r$. Shearman............ 238

Pennett (Joe d.) $x$. Hale ..... TI:3

Benwley r. bignoll ............. 30.

Bentley r. Mackay...ti

ci79

Bentley $r$. Vilmomt............ 62ti

Benwe]l r. luns ............... 37 s

Benyon $r$. Nettlefold ........31k, 319

berise $r$. Mawoll .............. liz!

lierea cullege r. Kenturky ... 11 s

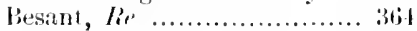

liesant $r .11$ aml ................ $3: 22$

litewiek r. swimlells .....tist, lil.

ettini dige ....................
PAGE

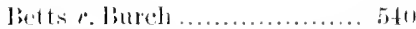

lints-dleldell ('u, r. strats ... 217

lieverley's ('ase ................ 9i

Peverley $r$ lincoln (xas 1 ' )... 1.57

beynon r. Cook ....titit. bitis, bit,

bij:

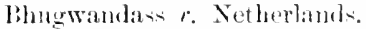

de. Insurance (u. .......... $2: \%$

Bickerton $r$. liurell...111, 111, 112,

116

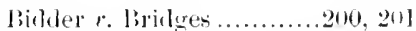

liffin $\because$. Bignell ................. tias

Biggar r. liock Life As. ('o... slili

Riggerstalf $r$. Rowatt Whatr... Tis

Iillage $r$. Southee ........titt. tirt

bimlley $r$ Mulloney ........... 326;

Bingluam r. Binglaim ...... 4 s1, .,21.

Bird's Trust .................... $26 \%$

Birkmyr $r$ lotrnell ........ 16ti. liq9

Hirmingham and llistrict land

Co. $r$ Alklay ............... 254

birrell $r$ bryer ...........25, ziti

Piscoe $r$ kennedy ............ 7 .

liachforl $r$. I'reston ............ $34: 3$

Placklume $r$. ITatlan........... isti.

Blackburn $r$. Sinith .......... (i2t

blacklmun $r$. Vigors ........... itis

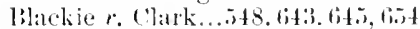

blaeklock $r$. Wobje .............. 24.)

Blacksmith's Cave. The ........ 371

blackwool r. Lombor Char-

tered Bank of Australia..... $t 70$

blade $r$. Free ................ 42,102

blaiberg $r$ leves.............. itg

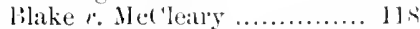

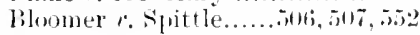

liloxam r. Mletrup. liy. Co. ...3.j.

Blyth \& Co.'s Care ............. For Fi

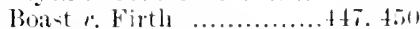

lioblett $r$. I'inkett ............. 242

Pold r. Hutehinson............. nith

Bolitlue (iinler................

boltun (Duke of) $r$. Willianu... $7: 30$, $7: 31$

biolton $r$. lambert ...........ti, lote

Bolton 2 . Maublen .............. ] si;

liolton $r$ stalmon .............. 2y

Fumar r. Macedunali .......... 297

bone $r$. Fklexw.................. Jil]

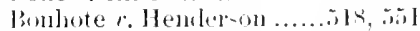

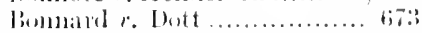

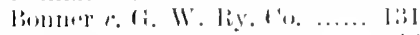

linutewell n. Jenkin-......... tis

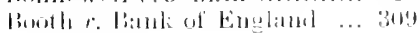


Finrie r. Imprerial ottuman bimk ......................... J18 liondutuet r. Mray............. 72011 Bu-tock $\ell$. I. staffurd hire liv. ('o........................... 181

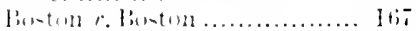

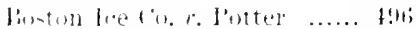

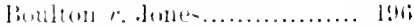

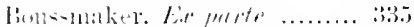

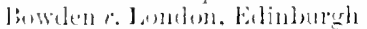

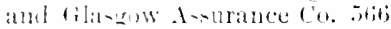

liower $t$. (imper ................. 24!

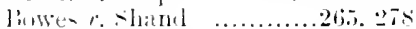

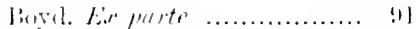

biver. Rirmberough.... 4lit. 6it2.

(i)t

Hratowell r. Williams ....... 2014

biatforal r. lammer ..........

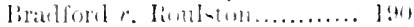

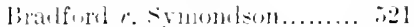

liadford $r$. Villiams........... $: 74$

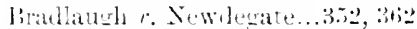

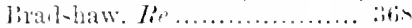

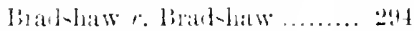

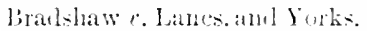

liy. $(10 . \ldots \ldots \ldots \ldots \ldots \ldots \ldots . .21]$

lirater $r$ stamel..............

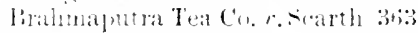

Jiranah $\therefore$. lobert

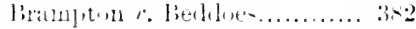

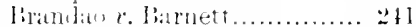

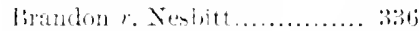

linult's roms diver. Lumber

liubler (o. .................. $2: 1$

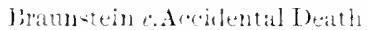
Iusurance $1: \ldots . . \ldots \ldots \ldots \ldots . .4$

biay-haw $\therefore$. Eitun........... is

bleton $\therefore$. Winllien .......... 2017

lirett. Eir pute .............. is

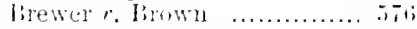

Jirilger r. -atage ............ flu

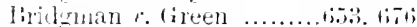

Jiriges. E.r pute............... hili

briegs r. livitn ...............

Jiriglit $\because$ Legerton............. 1330

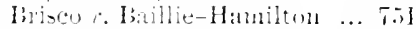

Iiristow r. singueville ........ 3.3.t

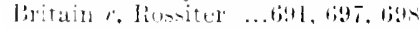

lintintl and Anerican Felesraph Co. r. Colson ..... T24, .27

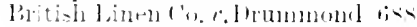
liritioh $\therefore$ Alrica $1 \%$ i. De

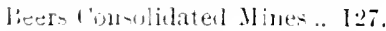

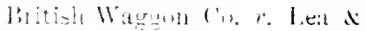
41.5

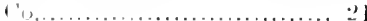

PAGE

linoul $r$. hllye ................. 37 ;

liroad r. Mniton ............. Es

lirockwell r. Jinlleck..........

Hresglen r. Mermp. lig. ('o....36. tri

Bromley $e$. Smith ............ 672 Bromley $r$ Sinith ([l909) 2

K. R. 235). 71

lirock r. Brook ...............3014. 305

Bronkman's Trust, lie ....... Btic

lironnte r. -iveak............... 49

lirotherhod's Case............ itl

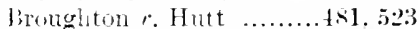

liroughton $r$. Manchester

Waterworks ('0............ 13.5

bonn r. Kennedy ............ हो

liown $i$. Brine..............34t, 654

lirown $t$. lipers ................ 136

limwn $r$. bile................ 126

brown $\therefore$. bimbleby...........9, 94

bromn r. Gualaintee Trust

(1)........................ 2st

Frown r. Mla gor of Loniton ... +27.

tiil

linwn r. liveal In-uance co. to9.

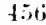

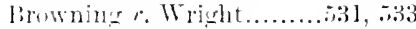

brownlie r. Campisell ......s.s. 759

firuntul, ("laim.............. 239

liryan (Dine d.) r. lianclis..... is

lirynt and barninghan's iontrart. lir ................ inl

byant $r$ Flight................ th

liryant $r$. Helbert ............. $1+4$

Bucklam] 2 . liucklan? ....... 91

linlkky, . IV ilf

bult $r$. If net .................. list

linrobell $r$ ( lark ............ 2ti!

liurge $r$. Ashler and sinith ... 411

buren's ('ase................ big

bimeses $r$. Eve ................ 294

limphant $\therefore$ Hall.............. it

liurke r. . E. Riy. Co. ....... i]

liurland $\therefore$ Earle............... 737

burn $\therefore$ Carrahn, ............ 2329

liumard $r$ Hagris............

burjell. E.r parte...........294. $6(4)$

bumbligher $r$ Bayne........... Ith

linuw $r$. sammell ...........

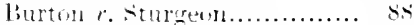

bute (Jariuis of $r$ Thompsill........................ 44

butler amd Baker's Cane ..... 53

butler \& butler ................ 94

liwleh-y-llwm letal llining (i) r. baynes ................ bly

ligrue $\therefore$. Van Tienhoren ..... 31 
PAGE

('aballelo $r$. Henty............ 57!)

Cahill r. Cahill ................ हis

Caird $r$. Moss ................... 5..2

Cadlecott, E.e pute.........3t6, 398

Calder r. Dobell .....101, 102, $10: 3$

Calverley $r$. Williams ........

Camberwell and $\$$. Ionion

Puilding Society $e$. Holloway 5\%.

Cambriclge ( 11 ayor of $r$.

Dennis .................... 297

Cameron and Wells, he ..... 22l

Campanari $r$. Woollourn ..... t2

Campbell's Case ...........73s, 74I

Campluell, E.r purte ......... 5. 50

Camplell $v$. Flenting ........... tils

Campbell $r$. French .......... 551

Canlan $r$. Barry ...... 424,425 , int

Cannam r. Farmer............ 8.3

Camnan $r$ Bryce................ $38 \pi$

Guning 1. Farduluar ........21, 46

Cargill $r$ llower .................. till

Cargo e.t Argus ................ 306 ;

Carington (Jorl) $r$. Wyeombe liy. Co.

Carlill r. Carbolie simoke ball

Co. ................15, 20, 22, 3.)

Carlisle r. Salt ................

Carmarthen (Mayor of) $r$.

Lewis ..................... 161

Carney r. l'limmer.............. 314

('arr $\ddot{c}$.Jaekson..............105, 111;

Can $v$. Lymeh .................. 170

Carrington $r$. Koots ........... (i9:2

Carrol r. Blencow .............. sit

Carter 8 . MeLatren ............. 46.

Cartwright $r$. Cartwright ..... : :

Cartwight r. Hately........... , ol

Casborne $r$. liursham.......... (its

Castle $r$. Wilkinsun .......... irt

Catling $r$. King ................ 170

Cato $r$. Thompin ............. 262

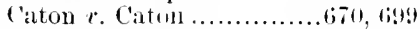

Catt $r$ Tourle ..................... B

Caudell $\ell$. Shatw .............. 87

lavendish $r$ lieares ........... 236;

C'entral liy. Co. of Vencznelit r. Kisch.......585, 586, 1304, 13:32

('haclwick r. Mamminer ........ 7.

('hatlis's l'ase ................. हnt?

('baurberlain r. Williamsoll ... 1,00

Chambers $r$. Maldehester amb Millume liy. Cir.

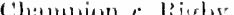

(1)ampion tive

ilather r. Hopkins ........... sti:

l'houter r. lawa................
PACL

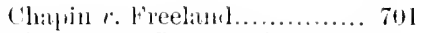

(Miapleo $v$. Brunswick linihling fociety ................ Tt1

('hipmann r. ('ole ............. 49.

Chuman $r$. C'ounty of Douglas 313

Clapman $v$. Nichaclson........ 673

Clapman r. Smethurst ....... 10.5

('happle r. Conper ...........75, 7i;

Charlesworth $v$. Holt............ 321

Clarter r. Charter .............. 7 .

chater r. T'revelyam...390, ti21, (;30)

Chasemute $t$. Turmer .......... is

C'batwasse, Er parte ........... 333

C'luale $\therefore$ Kenwall............. lsi;

('homin de fer du Dauphini $r$.

clet ......................... 4.t

('lerty r. Colmial Bank of

Australatia ................... I12

cherry $r$ Heming.......... lis, 172

chestertiuld r. Jasissen ...titi3, 66t.

titi.;

Chetti $r$ C'hetti ............... 30.5

Chijergo ancl (r. k. liy. ('i. r.

Jatie ....................... 187

chilton r. Corpuration of Jom-

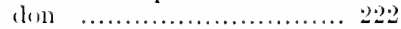

Chimnock r. Matchioness af

Ely ....................... tis

cholmondeley r. clinton...3339.360

Chorley, Er purte .............. 23:)

church $r$. luperial Gaslight.

de. (o. ................. 1,

fitizens Jiank of Loulsiana $\bullet$.

First National Bank of New

Orleans ................ 71, 7.,

('ity Bank, Lir parte..136, 1:37, 23:

City of $\mathrm{Itemphis} r$. Brown ... 3!) 1

l'ity of Sin Jnan $r$. St. John's

Gas ('o.................... 2010

('ivil service co-operative

Society r. (ienemal Sitean

Navigation $1 \% . \quad . . . . . . . . . . .440$

(lick $r$. Hollanil ............. 2:3;

('lare $r$ litmb................... tst

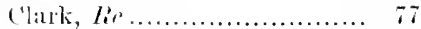

('lark r. Glark.................. 32.2

Clark r. (airdwor] ............. 549

(lark r. Malpas ................. 6.is!

Garke $r$. Birley ................. 29s

Clarke r. (obley.............. sin

clarke r. Curktield Uninn ... 1.s

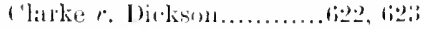

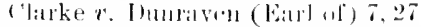

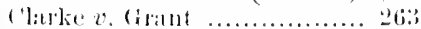

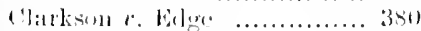

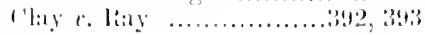




\begin{tabular}{|c|c|}
\hline PAlit: & PAGE \\
\hline ('latytone r. Alatuls & C'noke $r$. Vorley \\
\hline ('licytum e. Costoy & ('onmbse $v$. Wiliees \\
\hline ('leiger r cleura.... & Croper $r$ Evans .. \\
\hline Clements r. I. A $x$. W. liy. & rooper $r$. Jcel. \\
\hline ('o.... & ('onper $\therefore$. kemlall \\
\hline 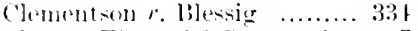 & Cooper $\therefore$ Phibbs......4titi. 481. 484. \\
\hline ("leve r. Financial Corpuration $1 \mathrm{~T}$ & 52 \\
\hline 'litford $r$ Watts $\ldots \ldots+12,+19,+4 t$ & Cinger r. simmons \\
\hline 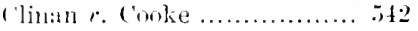 & Cooper $x$. Veser..... \\
\hline ('linch $r$ Financial corpura- & Cope $x$. liowlands \\
\hline $\operatorname{tion} \ldots \ldots \ldots \ldots \ldots \ldots$ & Cope $r$. Thames Haven, \&e. \\
\hline Close r. Close ........................ & (opper Miners of \\
\hline & \\
\hline
\end{tabular}

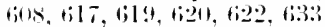

Clowes i. Higginsull..261, 517, it2

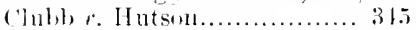

('lugas r. lenaluna .......... 338

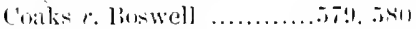

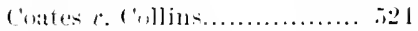

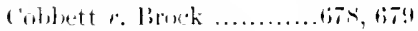

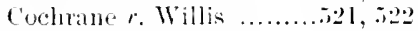

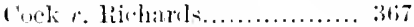

Cockedl r. Taylor ............. ti.s8

cinclier's case ................. olti

(o)king e. Ward............... figt;

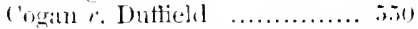

colsen $\therefore$ Kittell ................ fin

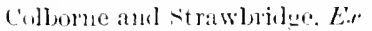

mete......................

(olleot r. llill ................ 53.3

(oble r. Giblums ................. bitit

Coler. (ijlson ................... Briti

Cinles $t$. l'ilkingtom ........ 17i. 7...

roles r. l'yecothick.............. biti2

Coles and litven-hear, $R f^{\prime} . . . .4 .469$

collen r. Wriglit ..........112. 113

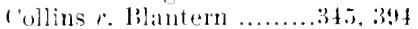

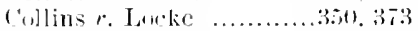

Collyer e. Fallon ............ 343

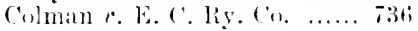

Colyear r. Ilulgrate .......... 204

Coinfort $r$ lietts............... 29on

(ommisioners of tewers r.

lieg. ...................... 437

Commonwealtin 4 . Lalle ..... 3044

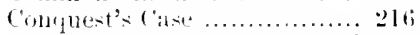

Consolictater Explomation and

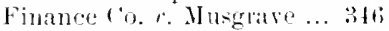

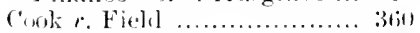

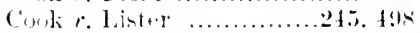

crobe r. Cooke (4 H. .J. S. T114) 3601

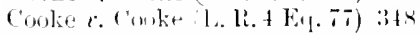

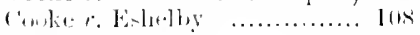

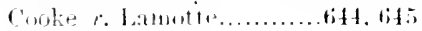

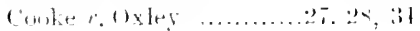

Coppock $r$. linwer................

Cordingley $r$. Cheesebrough ... $59: 3$

Curk and lanton liy. Co. $r$.

Cazenove ................... fis

cirk ancl Youghal liy. Co.

lite............................ 308

Cinley r. Loml stafford ...302, 5t!

(inn $r$. Mattliews ............ in

('ornfout $r$. Fowke .............. oo!

Comforl $i$ Carlton bank..... 123

Giry $r$ Gerteken................ su

Cory r. l'atton.................. 704

cory d ton r. llarrison........ 382

Custa licea liy. Cor r. Forwool ............................ 30

Cinte. Ix purte................. tit

cottage street chureh $r$. Kendall ........................ 17

county Lite Assurance Co., lie '................................ 738

county of (ikucester Bankr.

Rutry Merthyr, die. Co...... 738

Courtenay $r$ Williams ......... bx.

(Coutts r. Acworth ............... 67s

Conturied $r$. Hastie ...4t3, S19. 751

Coverdate r. Eastwood ........

Cowan r. Mlilbonm ...28s, 327, 388,

389

Cuwan $r . O^{\prime}$ Comnor............. 3.

('warl and Adam"s l'urehase. lif .......................... s!

('ward r. Hughes .......... tht. litis

currely r. bay ................. s.3.

coweri r. Truetitt, 1.tu....... 20!)

Cox r. l'rentice ................ \$l

Coxhearl $r$. Ilullis ............... lit

('ragoe r. Juntes ................ 2!k

('ramptum r. libley ......... 7l:

Cramptom r. Varna liy. Co... 160

('rears r. Honter................ 203

l'reel r. Hentlerom. R'́ Mut.

(iml........................... 


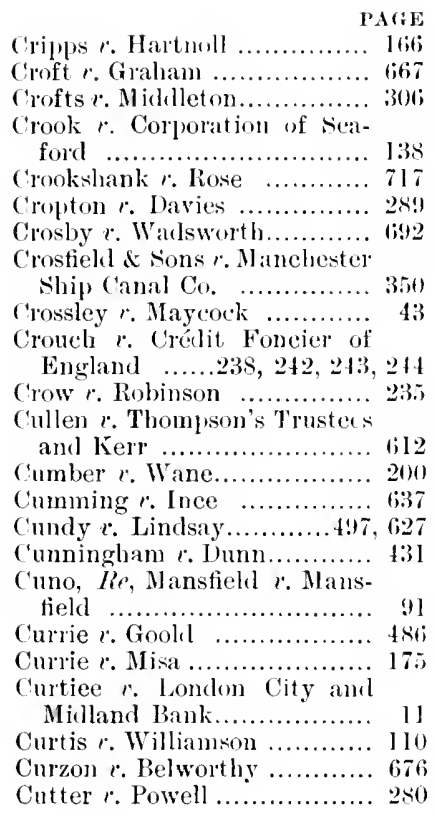

D. C. r. Gallaher. 270

Dabowski $\imath$. Goldstein ......... 380

Da Costa $r$. Inaris .............. 453

Da Costa $r$. Jones .............. 3332

Dacre $r$ Gorges ................

Dagenham Dock Co., Mr ...... 539

Dale $r$ Hamilton .............. 6998

Dally $r$. Wouham ............... (ji) 1

Dalton $r$. Angus .................... 253

Dalton $r$ (Gib .................. it

Dalton $r$. Midlaud liy. 1 'o. $\ldots$. 81

Daniell $r$. Sinclair ......... I ind, Is

Daniel's Setlement ........... 24i9

Inarell $r$. Tibbitts..............

Dathwoud $r$. Jermyn ........... 75.5

Tlaubuz $r$. Morshearl ........... 3306

Dauglish $r$. Tennent ............ 294

bavenport $r$. Bishopl $\ldots . . . .224$

Iavenprort $r$. Reg. ............... 5

lavey $r$. Shaumon ........l6h, 360

Davies r. Davies (9 Frp.)...... li2, lil

Davies $r$. lowies ( 36 ( hh. Jliv.) $37 s$

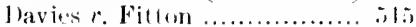

bavies $r$. Jenkius ................
Daties r. Iandon and l'rovin-

cial Marine losurance (o.... stis

lavies 1. Makmma ........7li", 7II

Davis $x$. Duke of Harllwomeh 311

lavis r. I'homats................. 8394

l)awes r. llamess .............. (ils

Dawsem r. Ellis .................. big

Dawsm r. Fitggerahl.......... 3iso

lhawson r. (i. N. and ('ity liy.

('o. .........................30, 3.57

beacon $r$. Gricley ............... 199

Dearle $r$. IIall .................... 23:

Dr licil r. 'Thomson ..........36

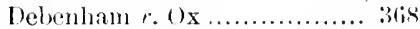

lebtor. $1, l_{1}$...................... fi:

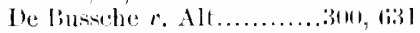

De Franceseo $r$. Barnum ..... त"

De Hoghton $r$. Anoney ...2li, 3.5, $35 \mathrm{~s}$

De la liere $r$. l'earson ........ J 5.5

De Lassalle r. Guildford...J67, 26il,

433,758

De La Tonche's Settlement,

lie .............................. 5.

De Mlattos $r$. Gibson ............ $2 \cdot 7$

Dendy $\boldsymbol{r}$. Hemlerson ............. 37!

De Nicholls $v$. Sammlers ..... t?99

Denn $r$ Wilford ............... $53: 2$

Dennet $r$. Atherton ............. 25;

Denny $r$. Hancoek ............... , ins

Dent $r$. liennet t.....6i3.3, 6il4, 615,

(65) 4 , 6 .5.5

Denton $r$ G. X. Riy. Co. ...17, 20,

21,24

I)enton $r$ Peters................ 212

Deposit Life Assurance Co.".

Ayscongh ...................... 61!)

Derry $r$. Duchess of Mazarine st;

Derry $r$. leek ….....5.5, 585. 59.;

Devonshire's (Earl of) Case ... 146 ;

Dew $r$ l'arsols..............ti3!t, fitt)

Le Wahl $r$. liame ........siti, 100

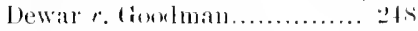

De Wiitz r. Hentriclss ......... $\$ 337$

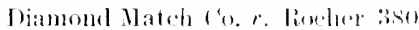

Diblins $r$. Jibhins.............. 102

bickinson $r$ burrell ........... 357

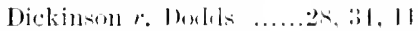

Dickinson $r$. Valyy ............... 136;

Diekson r. Riruteris lirlegram

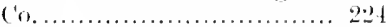

liekson r. Swanseat Val, liy.

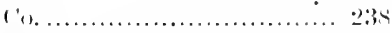

Digerle r. IJigers.............311, J01

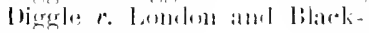

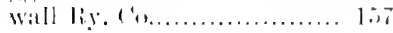




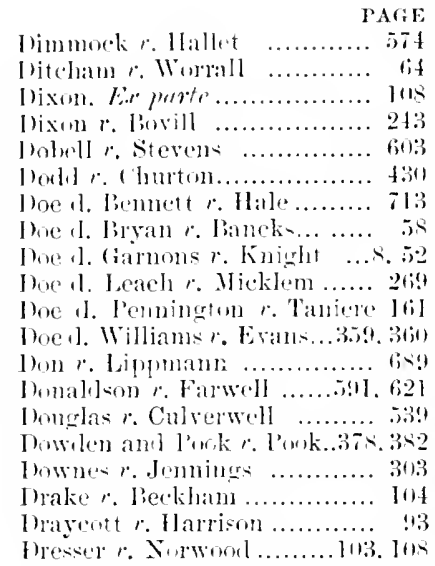

Dew $r$ xum .....t2, 4\%. 94. 102

Driefontein Consolishated forkl

Nines r. Janson ........333. 334

Druffe $r$. bord l'arker......2ti2, itt,

itti

Drummond $x$. Van Ingen .....

Lublin and Wicklow Ry. (o. $r$ Black

68

Duckett r. (iofer................

Durlgern $e$ l'embroke ......... 3s9

Dugilate $r$ kovering ........... 13

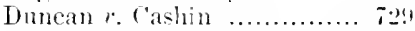

Dunean $r$. Vixon ..............te , fit

Duncan r. Tuphann............ 720 ;

Duncan. Fox \& C.. r. X. S S.

Wales Bank

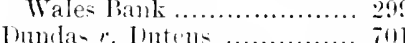

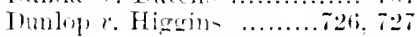

Dummere (Countess of) $r$.

Alexander...................... i2.5

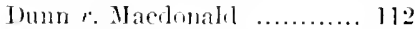

Dunnage $r$. White ................ dis

bumer English ............... 802

Jum-tom r. Juperial laas Light

(1)............................... Jiti

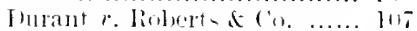

Jurlatm $r$ flurlam .......... !"i

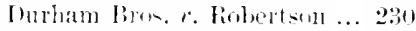

Dorlam ( Earl of ) r. Teegarl... 517.

$5 \pi$ it

Dutton r. Mar.h ............... 213

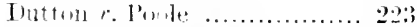

Jutton $r$. Thompon ............ titi

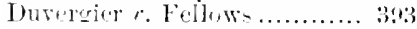

Dyer r. Hargrave ...5i2. 57. 60103 ,
Dyer's ('aze The PAFE

Dyson $r$. Forster..................... 24

kaste Insurance Co, Er parte 758

Earrlesfielel $r$ Marpuis of

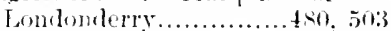

Ealle $r$. IIopworl ............... 3.5

Earle $r$. Oliver ............... Is?

East Eonlon Waterworlis Co.

$r$. Bailey ..................... 15\%

Eastern Comnties Ry. Co. $r$.

Hawkes..................... $7 \$ 2$

Eastwool $r$. Kenton ....... Itid, 189

Eaton r. liasker ................. 143

Elbw Vale C'o. Crave ........ 158

Ebsworth and Tidy's Con-

tract ............................ $8 \pi 9$

Eeclesiatical Commissioners $r$.

Merral ..................... 16I

Edelstein $r$. schner \& Co. $^{\circ} 135$.

238,243

Eilen $r$. Rislitales, se. Co...... 641

Edgcomb $r$. Lee ...... Itt. 14s, bis

Edgington $x$. Fitzmaurice..... biol

Edgware Highway Board $r$.

Harrow (ras (o, ........175, 395

Eilmonison $r$. Render ......... i2s

Elmund r. Bushell ........... Iot

Elmund $r$. Merchants" De-

spatch 'lransport C'o. ...t97. (;27

Erwarkls. Iir .................. 3ite

Edward $r$ Aheraym. se. sodety .......................... 350

Elwarls $r$. Hrown ............. 4!

Edwards r. linrt .................. G 672

Elwarls $r$ ('arter ............61. 6i2

Edwark $x$. Jerrick ........... 6.I

Egan r. Guardians of lien. sineton [nion............... TI3

Eecrton $x$. Earl of Frownlow... 3.28, $329,8330,332$

Ehrman $r$ Barthulomew ..... $3<2$

Elhinger tetien-fievell-chaft

$r$ Clare........................ 104

Eley 2 Poritive A-umance ('o. I6!

2.20

Eliason $r$. Ilenthaw ........... 30

Ellen r. Topl ................... 4.;4

Elliman. She of fo.r. Carring-

ton

Elliot $r$ lnee .....................

Elliott $r$. crutchley ............ $f f 11$

Elliot $r$. lichardion ......36 


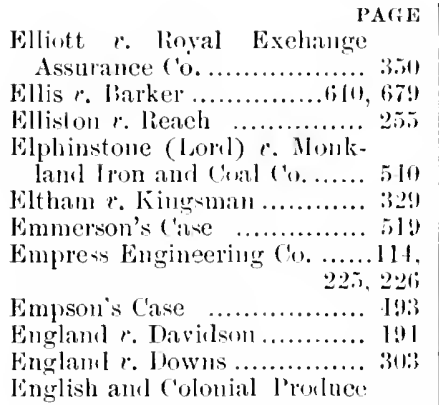

Co.'s Case................... bios

English and Foreign creslit Co. $r$. Arduin ................. 4i

Hno $r$. Inum .................. 326

Equitable Fire and Accilent Olfice $r$. The Ching Wo Hong t.5

Entuitable Insurance $C^{\circ} \circ, r$ Hearne ........................ nts

Erlanger $\boldsymbol{c}$. New Sombrero

Phosphate Co. ...........58ti, 587,

(53:3,, $8+1$

Ermest $r$. Nicholls .............. 739

Erskine $r$. Adeane ...167, 264, 423,

Espey $r$. Lake .................. 653

Esposito r. Bowden ...334, 335, +14

Evans $r$. Bicknell ...............

Evans r. Brembridge............. 570

Evane 1. Carrington...323, 321, .28,

-5!, 590

Evans $r$. Edmon 1 , ...5:10, 593, 584

Evans $r$. Hoare ................. 170

Fvans $r$. Llewellyn ........655, 678

Evans $v$. l'rothero ............. 70 t

Evalls $"$. smalleombe.......... 7 f

Evanturel $x$. Evanturel......... 331

Evelyn $r$. Chichester ........... is

Everet $x$. Williams .............. 290

Everitt $r$. Everitt ................ difl;

Exton $r$ steott................. ;2

Fairhurst r. Liverpol Aelphi

Laall Asociation

lairlie $r$. Fentem ............. $10 \%$

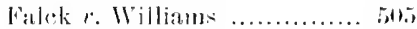

Falele r. liray ................. bitiz

Fane r. lane ................... हs

Harewell r. Coker .............. in
PAre

Firrar v. Chuchill............. bo:

Fantrow $r$. Wilsm ..........21], 1.17

Faviel r. E. C. liy G........ In!

Faweet and Holmes, lir ..... in

Fisweett $e$. Whitehou-e........ is.

Fearom $r$. Warl of $A$ ylesforl ... :221

Fellowes r. In) I Givydyr ... 11 I

Felthonse e. Binulley ........29, II

Feltmakers (co. of $)$ n. Itavis... 22:3

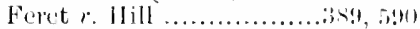

l'erguson r. (A)rington ...5!m, (i)

Fergussou r. Norman........... :

Fertand $r$. Bivehotf-heim ...... 107

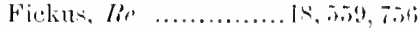

Fichl $r$. 11 ore................... bi

Field $r$. Lelean ................. 2 ti7

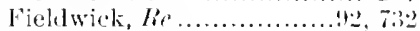

Fife $r$ Clayton ................. il:

Filby $r$. lloumsell ...........11. 171

Finaneial Corporation's claim z:3

Findon $x$. l'arker.................. : $; i^{2}$

Finlay r. Bristol and Exeter

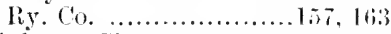

Finlay $r$. Chimey .......2 $[1$, fing

Firtl $r$. Mirland Ry. (o...... t52

Fischer $r$. Kamala Niticker ... 360

Fisher \& co. $r$ A Apollinaris

Co. ............................. $3 \mathrm{ti}$

Fisher $r$ Bridges......3:1, 3:12, 394

Fisher r. Liverpon Marine In-

surance Co. ….......... 8113,701

Fishmongers" Co. $r$. lubert. son ......................... 161

Fitch $r$. Jones ........313.314, 42:3

Fitz $r$. Iles ....................... 36.

Fitzgeralel $r$, Chapman ......... B.

ritzoy r. cave ................... 35

Fivaz $r$. Nicholls .............. :3!!!

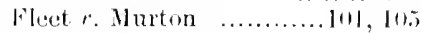

Flect $r$ Perrins ................ st

Fleetwod $r$. Hull .............. 21

Fleming $r$. biank of Now Kea.

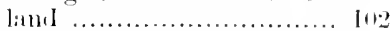

Fleteher $r$. Fleteles ...........

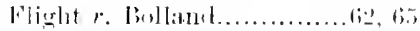

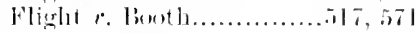

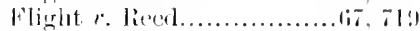

Flint $r$. Womlin .................. sini

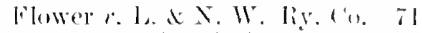

Flurean $r$. Thurulitl ............ ה

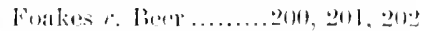

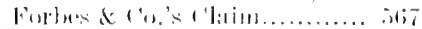

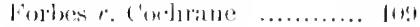

finthes $r$ Watt ................. Ira

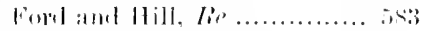

find $i$ licesh ................... 


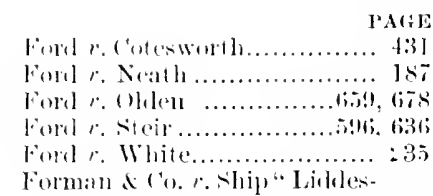

dal. " ....................... 43 !

Formann $r$. Wright ........tist, titio

Formly r. Parker .............. 25t

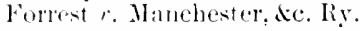

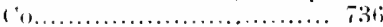

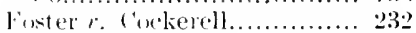

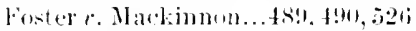

Fuster r. Romlgrare.............

Fuster $r$. Wheeler ................ 5n

Fonthes r. Dretro. Dint. Iiv. Co. tra

Fountaine r. carmathen Ry.

Co........................... 737

Fowkes $r$. llanchester and

Iomdon Assunanee Astoc. ... 25:9

Fuwler r. Fuwler ............. $54 \mathrm{i}$

Fowler r. Hollins .............. fis

Fowler r. Nommonthane Canal ('o...................... Tos

Fox r. Nott ...................... 2.:2

Franklin $\bullet$. Viller ................ 277

Franks, E.t pute ............... sit

Fravet $r$. Hill .................... $3: 4$

"Freelom," The............... 252

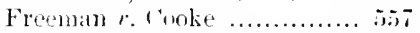

Freeman $r$. Jeffries ........... (i2.

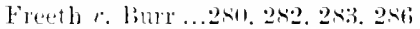

Freml $r$. lemett ............. 16i2

Freblitield Trusts, he ......... 23:

Fuest $r$ Knight ................. 21

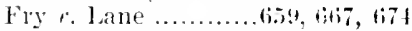

Fuentes r. Iontis ................

Fullaluve $r$ l'arker .............

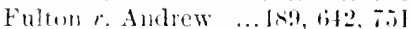

Fumival r. 'immles ........... 115

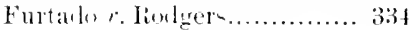

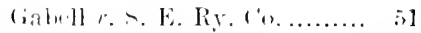

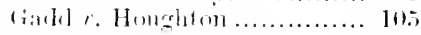

biale re diale........................ $2: 1$

Galloway r. Hayou of Lomelon jol

tiandy $r$. Iacanlay ........... 534

Giardurer $r$. cazenuve ........... s3s

diatand r. ('artisle.............. the

(iamum ( Dote d.) r. Jinight...8. 5.

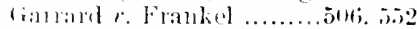

dian light and coke (oor. $r$.

rumer
General liill Posting (o. $r$. Alkinson ................278, 369

General cumneil of the Bar $r$.

Inlaud Revenue Commis.

sioners ......................... it.

Geere $r$. Mare................... 392

Geipel $r$. smith ...........335, fin

(ieorge $r$. Clagett .............. 107

Gerhard $r$. Jates................ 614

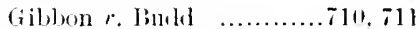

Giblons $r$. X. E. Metropolitan

Asylum bistrict .............. It

(iibbons $r$. Protor............... 2.2

Gibbs $r$. Harkling ................ 323

(iibun r. D'Este ...........581, 582

Gilkm $r$. East India Co. ..... 180

Gibson r. Jeyes .....64t2, 643. 6its

Gibson $r$. Kirk................. 162

didller $r$ Lord ralmerston ... 10:

Gieve, Re ......................... 315

liibert $v$. Lewis ................ b3t

diilhert $r$ sykes .................. 329

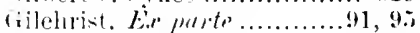

(iiles $r$. Edwards................. 453

rilkes $\therefore$. Leonino .............. 27

(ilasspole $r$. Toung ............ t69

(iloncester Comnty Bank $r$.

liuiry IIerthyr i Co. ...... 738

(ilubl, Re .................589, 645

Goddarl $r$ obrien ............ 200

Godlari $r$. snow ............... 303

Gulwin $r$. Franeis .............. 1]2

(ioman r. Salisbury ........... 26I

(iooch's Case....................6\% tio, ti

fioud $r$. Chees man ............ 201

Good r. Ellicitt ................. 328

(trodle $\because$. Harrison ............... 60

(roolman $r$. Harres ............. 242

Goolman $x$. Sarers.............. 485

(iootion r. Griterson ........... 2413

(inodwin r. Robarts........243, 244

fiordon $r$. Gorden .............. 584

(fordon $r$. street ...........5us, bit

Gore $r$. Gibson ................ 97

Gorgier $r$. Mieville............... 24

(iviett $r$. Risehmond ............ 215

(iozney r. Fristol Trade and

Provident soedety ........... 373

Græeme $r$. Wroughton ........ 392

Graham $r$. Johnstul...236. 238. 239

Grain's Case …..........216, 217

(irant's case ....................40, 302

Grant $r$. जold Exploration.

di. Svmolieate of British

Colombia ..................... 30

(irast $x$. Maddos ............... 2tit 


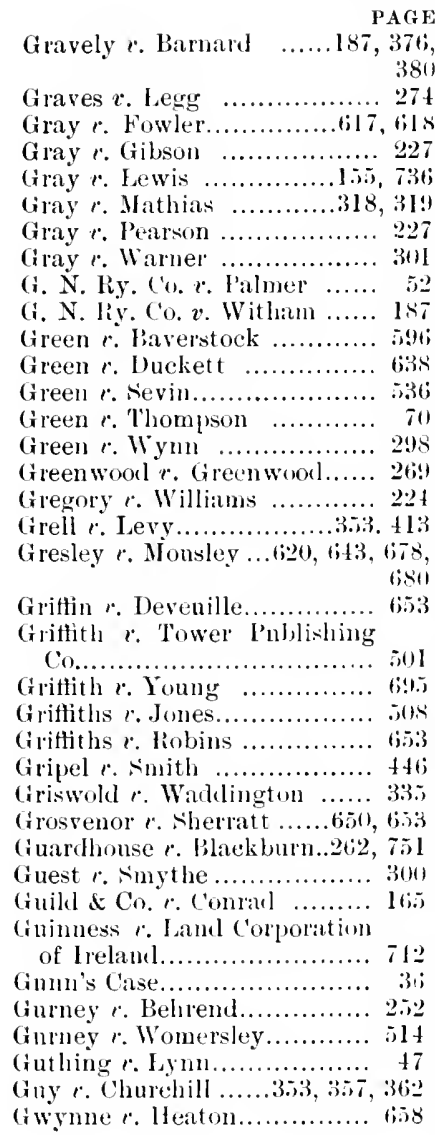

H. r. W. 325

llack $r$ london P'ovident

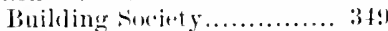

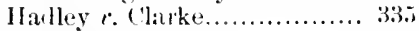

llaighi $r$ Brokst................. 155

Haigh $r$. North Bierley Union 15s

Hlaines $r$. busk ................ 39\%

Ilalbot $r$ Lens.................... 113

llalford r. Cameron's conl-

browe, dr. (co.

213

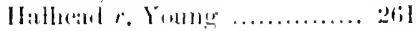

P'Alie

Halifax Union Guardians r.

Wheelwright ................ $f$ !n

Hall, he ......................... th

Hall $c$. Bainbridge ............... 2:

Hall r. Cazenove................ 421

Hall $r$. Comter.................... त15

Hall $r$. Ityson .................. 29!5

Hall $r$. Ewin...............251, 25it

Hall $r$. Hall (L. li, I L'. \& l).

4s.2) ........................... bits

Hall $x$. Hall (1. li. stio, 130) 617

Hall $r$. Hayor of swatisea..... 16\%

Hall $r$ old Talargoch leat

Mining Co. ................... ti2s

Hall r. Palmer ................., 319

Hall $r$. Warren .................

Hall $r$. Wright ........... $36 i, 446$,

$f(9,4 i 5$

Hall-Dare $r$. Hall-Dare........ ind

Hallows it Fernie .............. 60.?

Halsey $d$ Grant ................... si:

Hamilton e. Giainger ......... 311

Hamiltou r. Hector ........... 3 isis

Hamilton $r$. Vaughan-sherrin

\& Co..........................

Hamilton $r$ Watson..........its, stig

Hamlin r. Great Norberu Ry. ('o.

Hamlynd ('o. r. Talisker Histillery $.3+5,4115$

Hammersley $t$. Baron de beil.a36s, $752,753.754,755$

Hammonel r. Messenger ..... 22:

Hamplen $x$. Walsh............. fol

Hananer $r$. Loane .........38., 34:

Haneock $r$. Hancuek........... !l

Hancock r. Peaty .............. 9 ;

Hanington $r$. 1) Chastel ...... 313

IIanley $x$. l'earson ............. 550

Hanson $r$. Waller ................. this

Harben $r$. Plillips ............. $73 \overline{7}$

Irarburg India Fubber ('omb)

(o. c. Martin .................. 16.

Harling, in the ciomts of ...... 8.

Hatdman $r$. looth ........4!r, li:7

Harly $r$. Metropolitan Land

ami Finance Co................

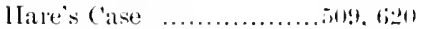

llatruan's Case ................ 207

Harms r. Yarsoms .............. 3sen

Harrington $r$. lonk..........35;3, 3.5

Harris" ('ase................... 7027

Harris r. Brisco .................. 39.

llaris e. (i. W. Ry.t'o........ il

Ilarris $r$. Nickelson ............ 17 . 1!

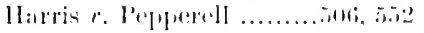




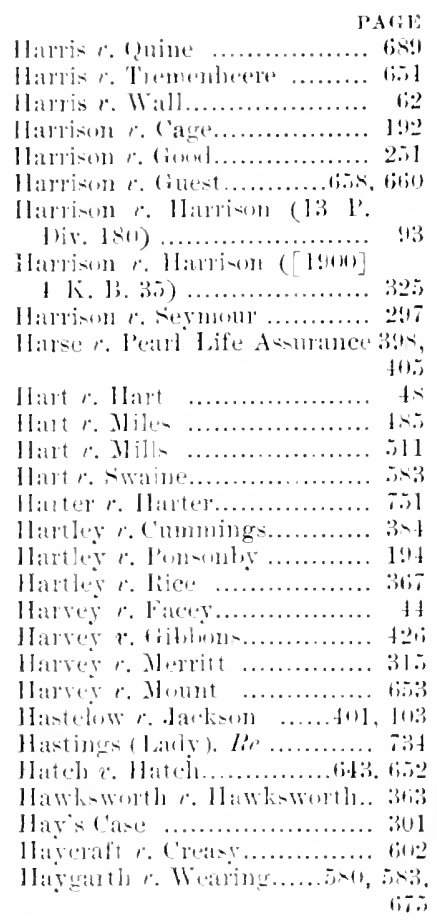

Haynes r. Demma.........37s, 381

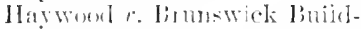
ing suctety................5. 25t

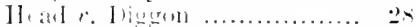

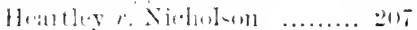

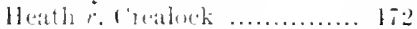

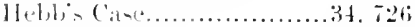

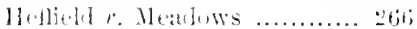

"11.+leu," the .................. 8387

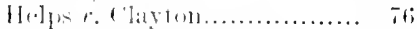

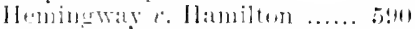

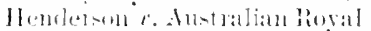
Mail, de. (i) (1)................ 15

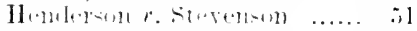

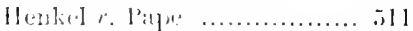

llonkle re lesal kxibh. Awce.

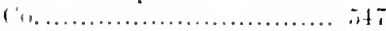

Henty r. Armetrong ............ bits

Hentjun r. Fraser...,31.:31.33,35.

Iferefored and some Wales 3०, 111 Wageon and Enginering (i)... lir
PAGE

Heruan $v$. Jeuchner ......346, 366,

Hermano $r$. Mildred ........... lot

Herue liay steamboat co. $v$.

Huttum ....................... H H

Herse r. Ntevenron.............. 532

Herworl $r$. Mallalieu .........

Heywortle $c$. Hutchinson ...... sti2

llick r. liaymond .............. 4:31

Hickman $v$. Berens............. 510

II

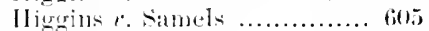

Higrins $x$. scott ............... bist

Higrins $t$. tenior .............. I03

lligrimon $r$. Clowes.............sos, it?

lligginson $r$. simpson ........ 3919

Higre r. Northern Assam Tea

(i) ............................. 239

Hill r. Bople .................... 357

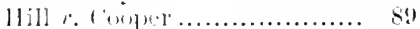

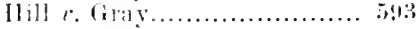

Ilill $r$ Tuiver ..............25:2, 25t

Hill $r$. Walker ..................... bis

Hill $r$. IVilsem .............261, 4!t

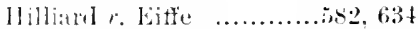

Jlill r. liowland................ 519

llills $r$. sinell ................... $4 ! 5$

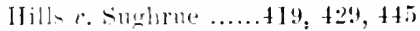

Hilton $r$ Eckersley ........... 372

llimbley s (atre.................... 30

Himlley r. Maryuis of West-

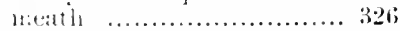

Himlen 8 Wetherill........... bitt

Hipewed $r$ knight ................ s.3t;

Hirchtield r. London, Rrigh-

ton and south Coast lig. (1). .5y!

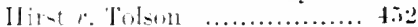

II inley r. Leckie ................... 2.it

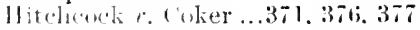

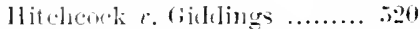

Hoatly r. Mclaine............... 1699

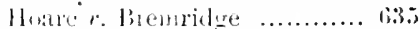

Hoare $r$ liennie...2\$0, $281,282,2<3$

Ifobat ${ }^{2}$ lintler ........... $12, \pi 13$

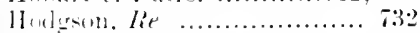

Howlons settlement. Lit ..... bi2

Hexinn $r$. Henlamel ........... bis!

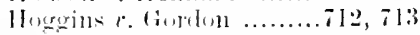

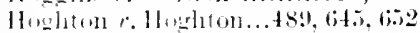

Heghton $r$. Hentey ................. 383

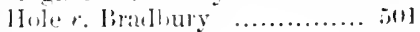

Hollinul. Rit....................... in

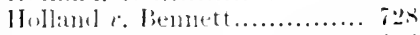

Hollamel r. Hall .................. 34th

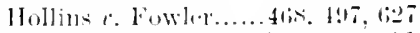

Holleway lime r. Hill ........ 2:1 
PAGE

Holman r. Johnson .........33s, 398

Holman $x$. Loynes..643, 6i17,651,679

Holne $x$. Brunskill.............. 297

Holme $r$. Gulpy ............... \$5

Holmes $r$. Blogg ................. 6i3

Holnes $r$. Jalfues .............. 228

Homersham $r$. Wolverhamp-

ton Watelworks ('o. ........ 157

Jonck $\bullet$. Miiller ................. 281

Honeyman $r$. Marryat ........ \$3

Jfood of Avalon (Liuly) $r$. Mackinnon .................... tit

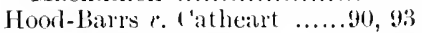

Hood-Barrs $x$. lleriot ........98, 94

Hoole r. G. W. Iiy. ('o......... 736

Hope $r$. Hope .........8:3, 347, 412

Hopkins $r$. I'rescott .......... 343

Hopkinson $r$. Foster .......... 7333

Horne's C'ase .................. 250

Horrocks r. Righy .............. .777

Horsfall r. Fauntleroy ........ 109

Horsfall $r$ 'Thomas.............. tiot;

Hort's Case ...............216, 217

Hotson r. Browne .............. 261

Hongin $r$. Manzanos .......... 10.

IIouldsworth $r$. ('ity of Giasgow biunk...................6 613

Honldsworth r. Evans ........ $7+1$

Houseliold fire lnsurance 1 ' $v$. (r)ant .................39, 727

Howald $r$. Browulill........... 720

Howared r. Harris .............. iss

Howard i. l'atent l vory Manu-

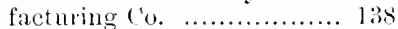

Howarth $r$. Breatrley ........... 711

Howatson $v$. Webl,... is!1, 490, 492,

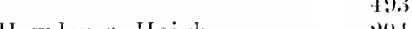

Howiten $r$. Haigh ............ 294

Howden (Liml) $r$ s simpon ... 394

IIowes $r$. Bishop ............... 64.3

Howell $r$. Compland $\ldots \ldots \ldots \ldots$. 442

Howke $r$. li. Hulton \& 1 's.... 12 t

Howley $r$ Kuight ............. 121

Ilovle, lir....................... I6t;

lluber $r$. Steiner ...........tis?, 698

Hurberstield Banking ('o. $r$. Lister .....................2.2, 5.,3

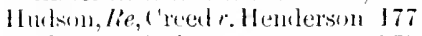

Hudson $r$ rook ................ 57.

Hughur, lid .....................? $73: 2$

llughes 9 . lhone ................. 717

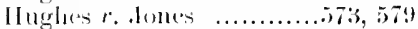

Hugheser. J'ump, Houne Hotel $2: 30$

llaguenin r. Batseley ......6it, bit,

(i.)

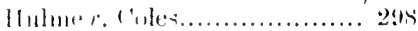

PAGE

Itulme $r$. Tenant............... 729

Hulse, bo pate ................ 5.38

Humble $x$. Hunter ......... 16i, t96;

Hume $v$. l'ocock ................. 100.5

Humliey $r$. Irale ........... 10.5, $21 ; 7$

Humphreys $r$ (rreen ........... 6997

Hunphries r. Humplaries ..... (i9l

Humplitys r. Polak .......... :361

Hunt, lin the Grodis of ........ $4 ! 1$

Hunt $r$. Hunt ...317, 321, 32.2, 32:3,

Hunt $x$. lionsmaniere's Ad-

ministrators ..............4.4. 517

Hunt $r$ silk.................... (i2)

Hunt $r$ Wimbleton local

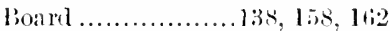

Huntel $\because$. Atkins.................

Hunter $\bullet$ Ditniel ...........3.3.8, 3.5

Hunter r. Waltets ... 190, 49., 493 ,

$19 \%$

llussey $r$. Horne-liane ......43, ti;

IIutcheson $\&$. Eaton .......... 1(1)

Hutchinson $r$. Tatham......101, 10.5

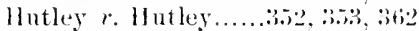

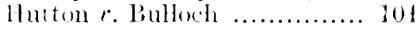

Hutton $r$. Warren ............. 267

Hyams $x$. stuart King ....... 31.

Hybart $r$. Parker ............. 2.27

Hyde r. llycle s Woodmansee fos

Jyde $r$. Wreneh ................ 311

IIfrlautie Engineering C'o. $r$.

Methattie ................... 537

Imperial liank of ('anarla $r$.

Bank of Hasniltom .......... trg

Imperial Loan ('o. r. S̈tone ... 9. 9,

$97,9 ! 9$

Ind's l'ase..................... of

Ind, Cooped ('o. r. Emmerson 172

Inman $r$. Inminn ............... s.

Ionides $r$. Pacitic Insmance

('o............................ 701 lomirles $r$ l'ender................... lpswieh 'Taifors' ( 'asc........... 37 I

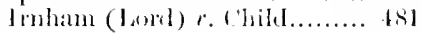
lrvine $r$. Watson............... 10!! llwin r. Williar ................ Islergr. Bowten .............. 107

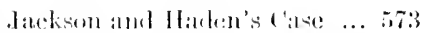

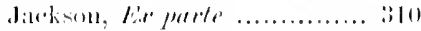




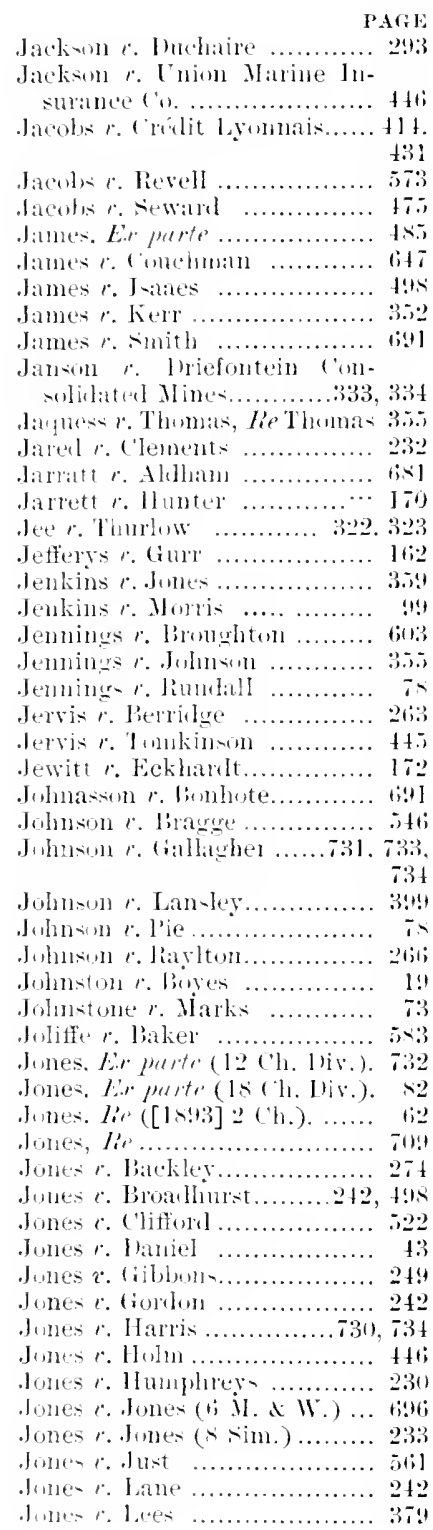

Jones $r$. Merionethshire Building society .................. 346 Jones $r$. North .............373. 417 Jones $i$. licketts ............. 667 Jones $r$. limmer................. 580 Jones $x$. Robin Jones r. St. John's College, Oxford ......................... 430 Jones $r$ Victoria Graving [wek ........................ Ji] lones 2 . Waite ... J85, 194, 324,386; Jordeu $\therefore$. Ione y .....695, 753, 754,

Joseyhis c. J'ebrer .............. 240 Joyete $r$ siwann ................. t4

Karhwry Ciase .............214, 58 latufuals $r$. Gersull .........34t, fog K:ty r. smih .................. 653 Kearley $r$ Thumson ........... to? Kearni $r$. Pearson ............. 429 Kearsley $\ell$ Cole ................. 29s Keaten 2 . Earl C'alligan... 883,593 Keates $r$ Iyon ..............25], 2.54 Kedar Yath Bhattacharji $\iota$.

Gorie Mahomed ............. 17 Keeeh $r$ siuddford ................ 3ul Keenan $r$. Handley ............. 204 Keighley. Maxsted it Co. $r$. lurrant ..................... 107 Keir $r$. Leeman ................... 34: liekewich $r$. Manning ......... 20: Felly $r$. Solari ................. 479 helier $r$. Baxter ...........114. 115 Kemp, r. Paerstman ........... 230 Kemp e. Falk ................. tit Kempsu $\because$ A habee ........653, 680 Kennerly r. Limun ... kennerly $r$. direen ............. 492

kennerly $v$. lee ................... $2 \mathrm{~s}$ kennedy $r$. Lyell ................ 359 Kennety $r$. l'anama. de. Mail (i) .................502. 513, 514 lient $r$. Freehold Land (o. ... 50: 620 Kepuell $r$. Bailey...........2.54, 250 Ker-haw $r$ Kelsey............. 334 Kettle $x$. Ehrot..................... is Kibule. Ex porte .............. Bt Kidulerminster (Mayor of) $x$. Hardwick ............ 1it. 1.5. I is king r. llamlet .................. 6ir 


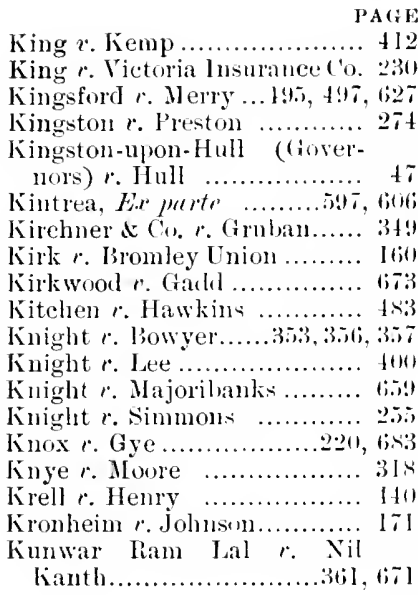

Iacey, kir pute $3(10)$

Lachlan r. Heynohts ........... $\pi 7$ !

Lagunas 1 Nitrate Co. $r$. lagunas symbieate ........ ist

laidlaw $r$. Org:m .............. .s.t

Lake, Re .................... 2:32

lakeman $r$. Mountsteplen ... lis

lamare $r$. Dixon .............. Th, 75s

Lamb's Case ................ 425. 46il

I ampet is ciase................. 2.2!

Lampleigh $r$. liraithwaite.... 14,

$17(i, 1) 10$

Lamprell $r$. Billericay [ninu.. 1.s

Lane $r$. Hortock ................ lifiz

Langrish $r$. Watts ............. list

liastence $r$. Tiemey ............ (i99)

Laughter's Case...............5.5, 460

Laver $r$. Demett ..............

I a very $r$. Pursel $\}$.............. $11 ; i$

Lavery $r$. Turtey................ 1i!l6;

Lawes $r$. Purser ................ 1s

Lawford $r$. liblericay linat ('ouncil ....................... l.s

lawrance $r$. Nomeys ........... (ii3.

Lawlence $r$. Smitli ............. 328

Lazarus r. Cowie............... 2li

learh (boe d.) r. Mieklem ... 2lis

leach $r$. Mullett ................ तl

lakk $r$. Hiflield ............... $9: 3$

latoyel $r$. lipouk ............... dis

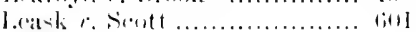

Leather Cloth Co. I. Ilieroni-

mus ....................... I 1

Leatler (')oth (0. r. Jorsont... 374

$37 \%, 3 \times 10$

lebel $r$. Tucker ................ 21:2

Le Brassemr and Oakley, lie... Tl.;

Le Bret 1. I'apillon............. 101

Lee, H.r pute ................. $3: 34$

dee $\bullet$. Bule, de. liy. (1) ..... 307

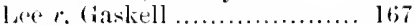

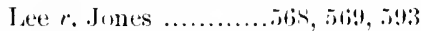

leeds $r$. Cheetham ........432, f33

Leerls and Hanley 'l'heatres of Varieties ENT

Leetham \& fons $r$. Juhnstune

White ...................374, 389

Legue $r$ Croker ................ is:

Lepgutt r. (i. . .. Riy. ('o. ...... 211

Lehigh hine and $\operatorname{lron}(0 . r$.

liamford ..................... int

leticter $r$. liose................. $2: 4$

Leifelililis case ................ 200;

Lenan $r$. Fleteleer .............. 711

Leman r. Honseley ........311, ill

Lempriere r. Lange .......... so

Jeng 6 Co. $r$. Anilyews ... 71), 3.2

fentuard $r$. Robinsom .......... lo.

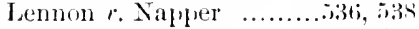

Leroux $r$. Brown ..........6.6!2, 6!93

Leslie r. Fitzpatriek ........ s!t, ro

letchforit, Le .................. $\tau_{7}$

Lever $r$. Kottler ............... 170

Lery r. Greell .................. il

Lewis $r$. Alleyne................ fir

lewis $r$. lirass ..................... 17

Lewis r. Irright .............. 31!

Lewis $x$. Browning ............. 41

I.twis $x$. Jomes.................. 5!t!

lew is $r$. Nicholson ............. 1l:

Leyland $r$. llingworth ..507, ,7.3

leyland r. Stewart............. li.

bichtield $r$. Baker .............. 4s.

life Association of seotlinul $r$.

vild $l_{i 1}$..................... (i;i)

Liles $x$. Tery .................. bly

Limentn college C'ase ......... is

lindo $r$ l.melo ................ 53:3

timdsaly $r$ c'muly .............. Jit

limbar Ietroleum $(\because 1$. lluril .....................tiond. ti3l

finclus r. Bradwell............ 101

lishmatu r. Nolthern ilati-

time lusurance (o.......... 70)

Lister r. Holgson ............. 万is

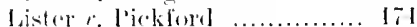

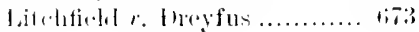




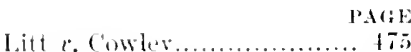

Livingston r. lialli ............. 3ts

Llamelly liy and lock (or r.

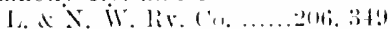

Jloyel r. Attwoul ............. ti3n

livel r. lianlis ................ 2333

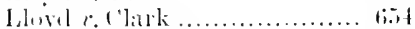

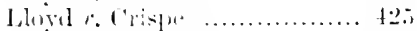

Llugid $r$ dinibert ............... 270

luyd $r$. Niwell................. 4:3

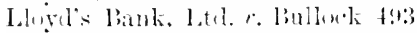

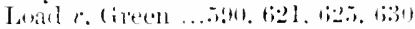

Lanlge $r$. Nationai Union ..... tia

Lufft $r$. Jennis.........432. 133, 4.34

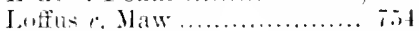

Lohre $\theta$ Aitrlibin ............ 27:

Jondon anl Sorthern bink. I.?

Lunlom and X. II. lis. Co. 8

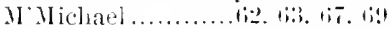

I.moluand l'mpincial ln-ur-

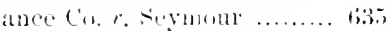

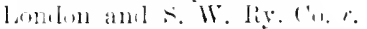

Blackmone ...................3

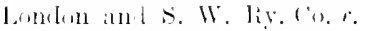

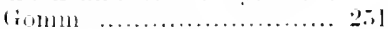

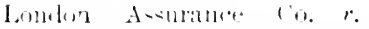

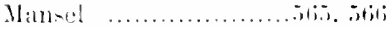

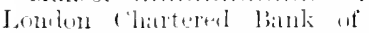

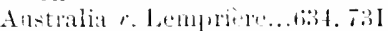

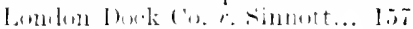

lanton Joint stack liank $r$.

Nayol of lamelum .......... I:3

lomdine Juint stenck liank $r$.

simmon. ...................

london Land co. r. Harric ... (i3.)

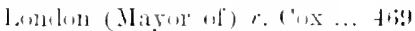

donerman $\therefore$ liath Electric

Tramway -................. I!10

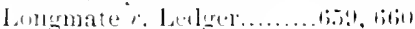

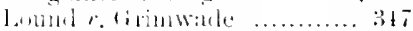

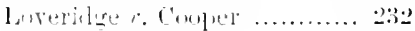

luvesy rmith ............... it!

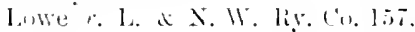

Iti]

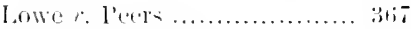

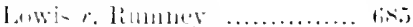

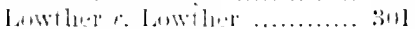

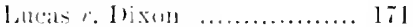

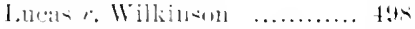

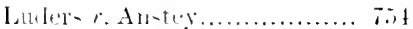

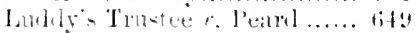

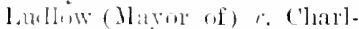

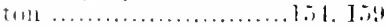

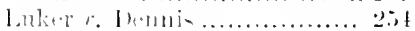

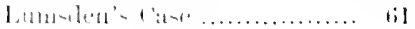

PA $;: E$

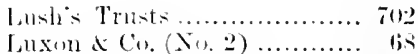

1.yall $\because$. Eilwarts ............. 53:

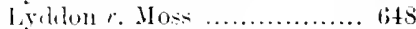

Linch. Er purte ............ \$2

lymle $r$ Anglo-Italian Hemp

vinning (o. ................

Lyon $r$. Haynes ................ 247

lion $r$. Home .............tisis, 7isy

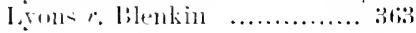

Marleath $r$. Haldimand ...... low;

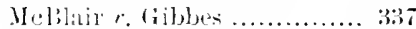

Marbryle $r$. Weekit ......... 3.37

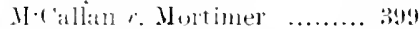

Maclean - Trusts................34t

I't'tean r. 'lylesdalte liank-

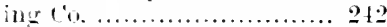

Herlean $\because$. Kennari ............. 47

Hecomell r. llector ............ 3:3;

Macentel r. 0-borne .......... bis

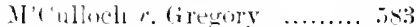

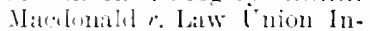

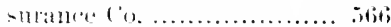

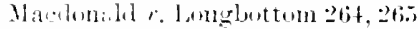

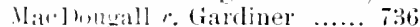

Mlaremerer $r$. bover and theal

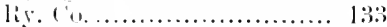

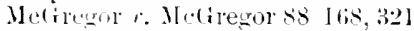

Ilecirntlel r. l'ilcher........... 24

1]rlemy r. Intiex ......... T38. 734

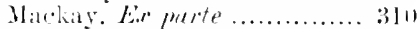

Inatiar $r$. (ommercial liank of New lirumswick........... bli

Mackay r. Diek ............... tit

Macken\%er rombon.......... its

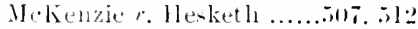

Mckewan r. Simlerson ...293, 29.;

Ue.Janun r. Bitrk ............ 20

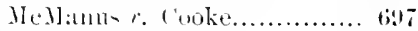

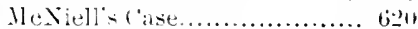

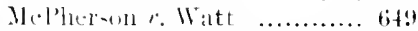

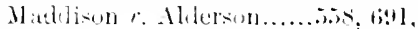
$6942,1947.71 \% 2.75$

Millon $r$ White. (i) bi)

Madhub ('hamder l'uramanick

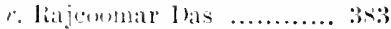

"Mallais." The ............... 4B.

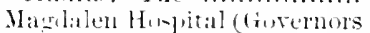
uf ) $r$ Knutt

Magerer. latridl ............... ifll

Malumy $r$ bast Holyluril

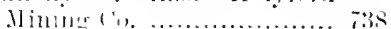


Mainprice $i$. Westley........... 19

Maitland $r$. Backhouse ........ (i79

Maitland $r$. Irving ........64i, isis

Malius $r$. Freeman (1 ling. N. C. 395)

Malins $r$. Freeman (2 líen, 25)...........................

Mallalien $r$. Holgson ....... 1!13, 2!)4

Mallett $r$ Bateman .......... lib;

Manby $r$. Seot t .............. $7: 31$

Manchester (Mayor of) r. W'illiams..................... 12:3

Manchester Brewery (o. $r$. Coombs.

230

Mangles $r$. Dixon .............. 23.

Mamn r. Stephens .............. 2.it

Manstielıl $r$. Ilamstielel. L' Cumo ......................... !1

Marehant $r$. Morton ............ 230

Margrett, E.r fiarte, Iee toltykoff

Marlow $r$. Yittield $7 i$

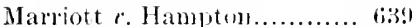

Marsh and Earl $r$. Granville... is

Marsh $r$. Rainsford............ 1!)

Marsh r. Whitmore .......... 301$\}$

Marsliall $r$. Baltimone and Ohio Railoan ( $0, \ldots . . . . .118,3+0$

Marshall $r$. lierrilge .......... 47

Marshall $r$. Collett ............... 473

Marshall $r$ Green .............. lis

Marshall $\therefore$ Marshall .......... 322

Marshall $r$. Finton............. st

Martin's Claim ................ 万人i

Martin $r$. Gale..................

Martin r. L. C. d 1). liv. ('1... ?li

Martin $r$. Pycroft.............

Mat tiulale $r$. Faulknel ...201, 47!

Matingell, E.r fletel........... $20: 3$

Masom $r$. Harris ................ 737

Massey 1. Mavies................ $3011^{2}$

Mather $r$. Loml Maidstont. ... 2010

Matheson $r$. lioss ............ 7116

Matthews r. baxter .......... as

Matthews r. Wallwyll ........ 2l!

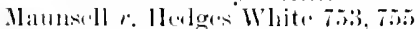

Maw r. Topham ................

Mawson $r$. Fleteher ......... ni:

Maxim-Nomlenfelt ('o. r. Nordenfelt ..............376, 37 $37,3 \pi$

May $r .0$ Nitll..................

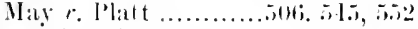

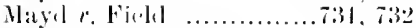

Maylurw r. frickitt. ..........

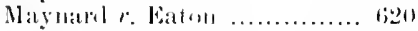

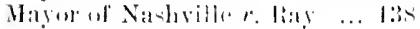

PAl:

Meal $r$. Yomm ............... ti:

Mearing $r$. Helling ........... for

Measures limos. Me. M-ures ... 3tial

Meguire r. Corwine ........... 34:2

Melbomrut lianking timprat-

time $r$. Bongham .......... 1:3

IIchramle $r$. Jorto Alegre liy. (o..............................

Hamplis (City of ) $r$. Brown.. $3: 1$

Menier $x$. Hoxsurs Tolegraple Worlis $7: 37$

Mereantile Bank if Ionslone. Evall .........................

Merchant Banking (') of

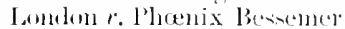

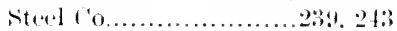

Merchants of the sianler. Rank of Englaumel ........... 1:3

Mereicr $x$. Campledl ........... 16i

Iersey sterel aml liom (i) r.

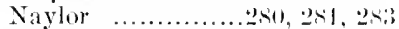

Metcalfe's Tru-ts ........... bizs

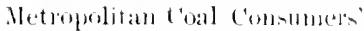

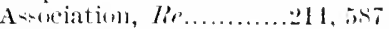
Meycrhoff $e$ Friblich ....... bis $\vec{b}$ Midileton r. Hown ........... Mligley r. Mitlgley ........... lis.

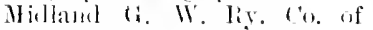
Ireland $r$. Johnsoni ........... tre ti

Midlaml liy. Co. r. Pye........ st

Miles $e$ N. \%. Alforil Estate ('o.......................... 2013

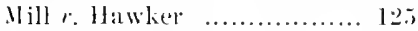

Milla r. (raig................... ont

dliller \& Aldworth r. Shath ... list

Miller.

Miller e. look ................... libis

dlikls r. Jumhan ......37s, 37!, :

Nill: e. Fuwles ............... lis.;

Milli $r$ Fox ..................... Titi

Mill= r. Seut t ................... 2.2

Millwalel r. Littlewerl ... 11:3, 2:2.2.

:31, :311,

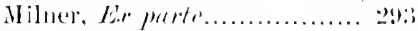

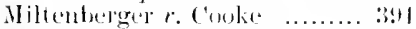

Mineral Watre lintle is. $r$

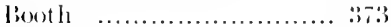

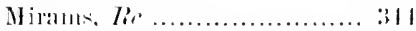

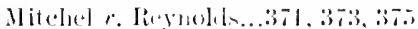

Mitehell's claim ................ list

lliteholl r. llomllat ........... tist

Mitrhell r. Laturathint alul

Yorkshige liy. ('1). ........... 17

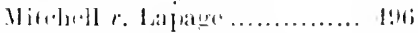

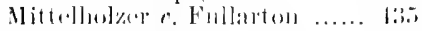

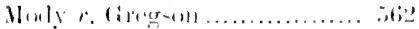




\begin{tabular}{|c|c|}
\hline PAGE & PAGE \\
\hline Mugnl s.s Cor r Meciregur, & 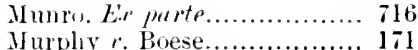 \\
\hline 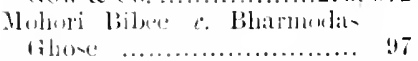 & 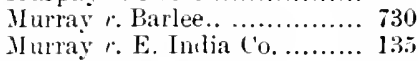 \\
\hline Mollett $r$ Robins-on a......... 300 & Murray $\because$ Flavell ... \\
\hline 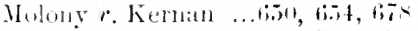 & Nurray $x$. Parlier \\
\hline 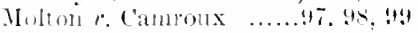 & Ituray $r$. Pinkett $\ldots \ldots \ldots \ldots \ldots . .235$ \\
\hline rnemx $r$ Satal Lamu, de. & Myers $\theta$. Nal.. \\
\hline ('il) & \\
\hline
\end{tabular}

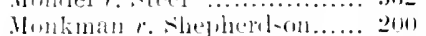

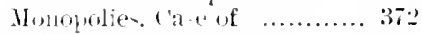

Montigne r. Furworl ........ los

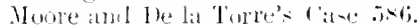
iilt

None r. Juhnern ............. it

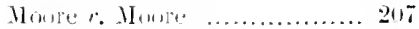

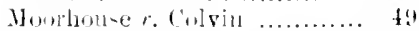

Moran r. l'itt ................. 173

Mortan $r$. Grittith ...16i . 264. 433,

Morsan $r$ Malleon …...... 20.

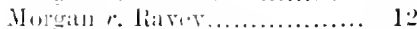

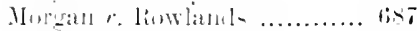

Merioun $r$ Thomp -ont.......... 302

Morley r. Lumginam ............. tiog

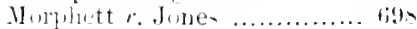

Itorell $t$ tenwall .............. 732

Worell $r$. Norrell .................

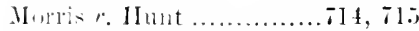

Jorrion $r$. Chiveral Marine

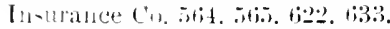

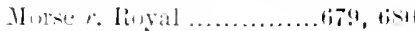

Montara $r$ llall .................. it

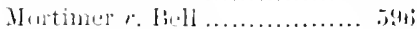

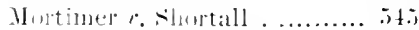

Mortlock $r$. Buller ............... तis

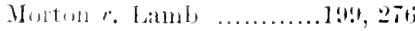

II

In 1 . sulth .................. 42:3

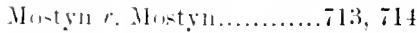

Mortyn r. Went Mustyn Cial

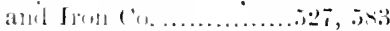

Wuntlet $\therefore$ C Cule ................. 350

Monlis $r$ Owen ................... 11:

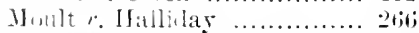

Itsmitstephen r. Larkemin ... Itis

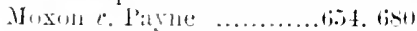

Moyee $r$. Newington ............ 6 int

Mrizley $r$ Tinkler ............... is

Nuller $\bullet$. Trattord ............... 24s

Mulliner r. llilland Jy. c'u.... 13I

Mumford $\therefore$ diething ............ $38: !$

Mlunicilatl linilding suciety $r$. kitut
$: 349$
Narlen, tir parte................. 320

Sante- $r$ Corrock ............... 730

Nash r. Hodgsun................. 685

Nil-li $r$ Iuman .................. $\pi$, it

Na-hville (Maror of) r. Ray... 138

Sational Phonograph co. $r$. Elimon bell (o. .............. 214

Tational Provincial lauk of Englami. Eic parte........... 546

National Provincial Bauk of England r. Jack-on ........ 493

Teale $r$. Gordon Lennox ...... 510

Neale $:$ Turton .................. 136

Neili $\because$. Duke of Devomshire... 271

Neilsun. Er parte .............. 30s

Nelion r. Stocker .............. sI

Nelthorpe $x$. Holgate............ 573

Nenbitt $r$. Berridge................ bit

Sevill $\therefore$ Sutelling ...669. $670,6 \pi 1$.

672

Jewbigging $r$ Adam .....598, 621

New lirm-wiek. ate. (o. r. conybeare ................605, 611

New liruntwiek. de. ('o. $r$. II ngereridue .................... isti

New combrero Phos phate co. $r$ Erlanger ..............30I, 586

tew York Life lus. ('o. $c$. Statham ..................... 33.;

Sew Zealand Banking Corporation, E.r parte ............... 238

Sew Zealand Land (o. $r$.

$W_{\text {it }}$ solt .......................... 104

Newburgh $e$. Newburgh ...... 751

Seweomb $z$. We Roos............

Newell $r$. Radford .............. 169

Newry and Enni-killen Ry.

co.r. ('oombe ..............tiz. 68

Nichol $r$ Gublts ................... 061

Nichols $r$. Marsland ............ 43i

Niehols $r$. liagubred .......... 191

Ficholson $x$. Frarlfield Uniun... 1.8

Nickoll r. Ashtoin ............... 141
Nickalls $r$. Merry ............... 268 
TABLE OF CANES. XlV

PAriE

Nieol r. Nieol 324

Niell $v$. Morley ................ 97

Nisbet and lotts, Fir: $250,253,25.5$

Noakes \& ('o. v. licee........... 5:3

Noble $r$. Ward .........2(il, 701, 707

Nordenfelt $r$. Maxim-Norden.

felt, אe. ('o. ..........369, 37 i, 381

Norrington $r$. Wright .....275, 2x:3

Nortl $\bullet$. Percival .............. 44

North British Insuranee ( $o$. Isloyd 5(is, 5409

Northampton (Marjuess of) $r$. Pollock

Sorthumberland Avenue Hotel ('o., R.' 538

Norton r. Relly 114

Norwich (Mayor of) $r$. Norfolk Ry. Co. (ii).

Norwood 133,290

Read .............2 213

Tottidge $r$. Prince ............

Sottingliam Firick $\sigma^{\circ} \mathrm{O}$. Pintler. 2.4. 56

Nugent r. Smith................ 43i;

Nomm r. Fabian .................

Nutt r. Easton ................. (i)

Nuttall r. Bracewell .......... 2.is

Oakilen r. Pike isit

Oakeley $r$. Pasheller ........... 298

Oakes $r$. Turquant...t(it, iog, (ill;, (i)7. 1832

Oakley $r$. Port of l'outsmoutl anrl Ryle Steam Packet ('o. 436 Odessa Tramways Co. r. Mendel 385

Offord $r$. Mavies..............29, 187

Ogilvie $r$. leaffiexon ........... 492

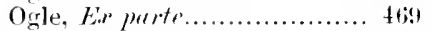

Oglenby $r$. Vlesias .......... 10;

Oldershaw $r$. King ............. 208

Oliver, E.r parte............... 29t

oliver $r$. Bank of lingland ... 1 13

Oliver $r$. IJmting ............. 17J

olley $r$. Fisher................... 516

Onerod $r$. Hardmall ........... 26il

Onward Buileling cocicty $r$.

smithson .........250, 4910, 493

Orient Insurance ('o. r. 1)aggr 118

Oriental Bank ('orporation $r$.

leleming ..................492, $19 \%$

Oriental Financial ('orporation

r. Overent, Gumey \& 1 in... 295

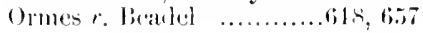

PAris

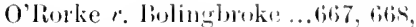

(i7)

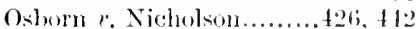

O-bentue $r$ Amalgamated

Soe. of Ry. Siervalle ....... I:

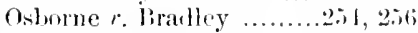

Osborne $r$ liogers ............. II

Osborne $r$. Williams........343, 101

Oscauyan r. Arus ('u. ........ 107

O'sullivan $r$. Thumas........... 101

Oswakl r. Mayor of Rirrwick-

on-Tweed ................... 29,7

()verton $r$. lianister .......... si

Owen r. Wavies ................

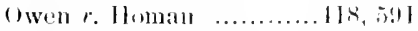

()wens r. Dickensoll ...........

Oxforl ( Mayor of) $r$ ( 1 row $\ldots$...

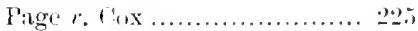

Pagret r. Marsliall .............. inti

l'aice $r$. Walker ........... 10;, 10;

laine $r$. Strand Inion ........ lis

Pakenham's ('ase ............ 2;0

l'almer $r$. Johnson ........575, 583

Palyart $r$. Leckie ............ 102

Parama and $\$$. I'acific 'T'ele-

graph ('o. r. Jurlia Riulber

('o............................ 30.3

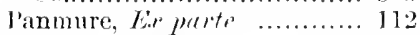

l'aquin $r$. Beanclerk .........., y

l'aradine $r$. Jane ......432, 433, 431

Patitt r. Lawless ............ bit:

Paris Slkating link ('o., lie'... 357

l'arker $r$. Butcher .............. tibit

l'arker $\therefore$ (

Parker $\bullet$. Mckenna .........3(1) l, li3t

Parker $r$. s. E. liy. ( o........ bl

larkes $r$. White ................. 730

l'arkin $\bullet$. Thoroli ........ 5.3.5, sist,

l'arry r. Liverpoul Malt ('o... :it!

J'artimenton $r$. Att.-fren......... st

l'artrifge $r$. Strange ........... 3.89

l'atman $r$. Halland ........... 2.n

l'atrick $r$. Bowmin ........... $: 32$

l'atrick $r$. lliller..................3t;

l'attle $r$. Hornibrok ........... 26i:

fauling $\therefore$. I. \& N. W. liy. ('o. I.:T

l'awle's Case .................. (i:

l'awley $r . l^{\prime}$ awley .............

layne's tase ...................

layne $d$ ('are ................... 1i;

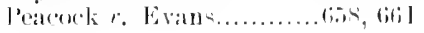




\begin{tabular}{|c|c|}
\hline $\begin{array}{l}\text { Piti: } \\
\text { P.t. }\end{array}$ & PAGE \\
\hline 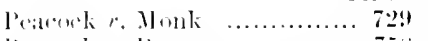 & l'ickering $"$ llf racmbe Ry.' o. 235. \\
\hline$\therefore$ l'en-m. & \\
\hline 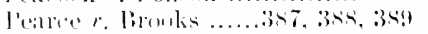 & Pirkeriun $r$ stephenson \\
\hline we dioldher ............ & Prilenels r. Bishonl ...... \\
\hline 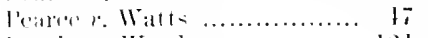 & l'serey r. Yomner....... \\
\hline 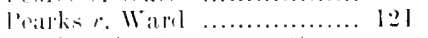 & l'ingute $r$ Stration \\
\hline 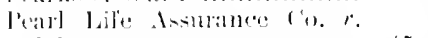 & ligot sc rase .......... \\
\hline & Thenrpess \\
\hline r. Laintr................. fiss & l'ike $r$ lit $z$ gibbon... \\
\hline ........ $1 i 2 t ;$ & $10 . ;$ \\
\hline sell $\because$. Wat & lileher r. Rawlings \\
\hline 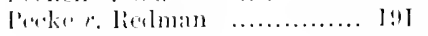 & l'ilkington $r$ s.entt... \\
\hline 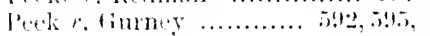 & C. Van Miern! \\
\hline (il: & $.118,213$ \\
\hline (1) & ......235 \\
\hline 17 & $\ldots 210$ \\
\hline $.23 x$ & ibbraltar... 644! \\
\hline Hos. r. Jarriom $\ldots . . . \quad 43$ & $\ldots \ldots \ldots \ldots \ldots \ldots+5$ \\
\hline $11 \ldots \ldots \ldots \ldots \ldots+63 \mathrm{I}$ & \\
\hline 73.5 & liarson ... 36i2 \\
\hline 1.) $\because$ Taniere liil & \\
\hline ….......... $2: 31$ & ['la \\
\hline 17 & .224 \\
\hline l............ & \\
\hline .509 & .318 \\
\hline 100 & \\
\hline cial & 138 \\
\hline 216 & \\
\hline $3+i 1$ & 2,2 \\
\hline o.. lir & $2 \pi i$ \\
\hline lix & C'ase \\
\hline & \\
\hline ... I & $i 26$ \\
\hline & \\
\hline 2.27 & $1 \ldots+4$ \\
\hline $2: 34$ & \\
\hline$\therefore 2 !$ & 2.56 \\
\hline talleleugh. & 7. 6its \\
\hline & \\
\hline .533 & $69 !$ \\
\hline $2 !$ & $12 \mathrm{I}$ \\
\hline$a y$ & 6.54 \\
\hline$r$ llull Alhambra & $(0.54$ \\
\hline & 351 \\
\hline & $\therefore 10$ \\
\hline (ilis & tit \\
\hline$\ldots 171,172$ & mington \\
\hline $3: 0$ & $26 i 1$ \\
\hline 汀 & 2.25 \\
\hline 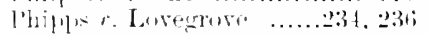 & $-s$ \\
\hline & \\
\hline . $3: 7.3$ & \\
\hline (n.......... & .729 .732 \\
\hline aml lenunty & \\
\hline & \\
\hline icteringrs $=1$ laim & Irince $i$. Iaworth \\
\hline
\end{tabular}




\section{PAGE}

Jrinec of Wales Assece. Co. 1 .

Hardingr .................... Tt0

Printing anl Numerical linesis-

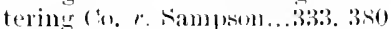

Pritchatel $r$. Merehamts' I,ife

Insuranee society i21

l'roale r. Fo:mly 7.51

l'rossey r. Elmonds...3.s I, 3.3. 3.7.

35

Proulfoot $r$. Montefine ..... btis

Prugnell $r$. Gosse .............. 37 .

l'yse $r$. l'ryse.................... 3tin

l'ucket and smith's ('mtract 57

lublbrook $r$. Latwe .............. (69)

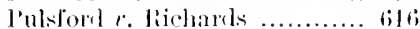

J'meell r. Maenamira ....... 6.i.

lybus r. (xibb .................. 2!97

like, Ed pute ................. 31.

lym r. Campled ............ 20

Quarier r. Colston ........111, 412 Queen-Empress r. Nantlam

Jas Murirám 314

Quineey r. Sharpe ............ bis

Quinn $\bullet$. leathem ............ 293

liadenhmist $r$. liates

liaflles $r$. Vichelhaus....

$226 ;$

liagrett $r$. lishop, .11

..... 11

liaggett $r$. Musgrave ........... 718

liailton $r$. Mat thew's .........

Rainbow $r$. Hawkins............ 1!

liajah Mokham Singlı r. liajah liup singl

liam Comma Coomblon r. chunder Canto Mookeriee ......... $3: \vdots]$

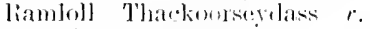
Simjumnull 1)Hmimul].....

liamsilen re lineirley

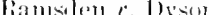

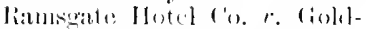
siliil

Riansgate Holed ro. r. Montefiore

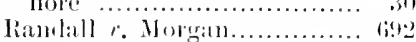

liamelegerer r. Ilolumes...........

Ramlell, Saumlers d $(\because), \%$

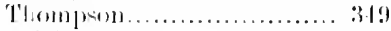

lamellr. Jinum
PArit:

Jaukin $r$. lotted................ 41 !

lianu $r$. Hugles .............. lsio

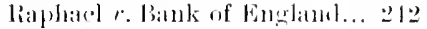

liasblall r. Ford ............... b! b!

Rawley $r$. liat ley ... . .......

liawlins r. Wiekham ......t!2, sol,

(i) 1 ;

Risymonel r. Minton ........... tis

liagner r. limbe ...........111, 116

liciul $r$. Anlersen ............. 400

lieald $r$ ldegard ...............

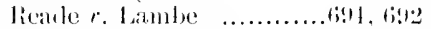

liefferu $r$ lingnimer .......... 26is

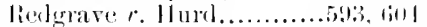

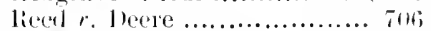

liees $r$. lle liennaty ......3ist. dizi

liees $r$. Williams.............. 716

liees liver silver Mining ('o.

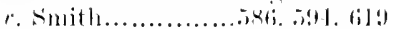

liceve $r$. Jemnings ............. I Iis

R. $r$. Asliwell ................... 4!

- r. Aspinall ................... $: 93$

- r. Cumberlamil (.lustices of ) liou

- $r$. Demers .................. 1s7

- r. Doutre..................... 711

- r. kssex (commissinners of Siewers for ) ............... 13.i

- r. A. N. of Eng. Ry. Co. .. 12:3.

I:1

- r. Holmes .................. 728

-r. Lorl .....................

- r. Mayor of stamford ..... Jili

- r. McDonadel ................. bi

- r. Midilleton .................. 19.

- r. I'orter ...................... 3ti

- r. I'rinee .................... tiz

- r. Ramsey and Foote ..... $3: 27$

- r. liowlands .............. 293

- v. Warburtom................. 2!y

lieid $v$. liekelstaff............... $2: 1$

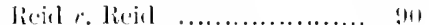

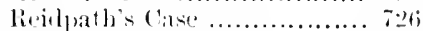

lienals $r$. (owlinhaw .....25t, 25.

lienss r. lickled ............ 1711

licuter r. Electric Telentiph $(1, \ldots \ldots \ldots \ldots \ldots \ldots \ldots \ldots \ldots \ldots, 1.17$

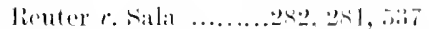

licymant r. Almolel............. b:

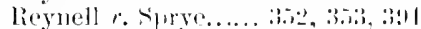

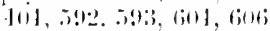

liholes, fir ..................... libules r. biate............. diti, biil,

(ixil

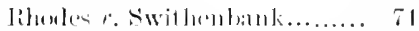

like $r$ romblom ..............

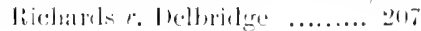


PACiE

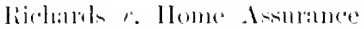
l-melation ................... 36

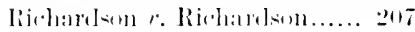

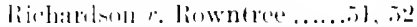

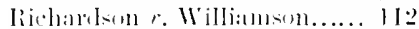

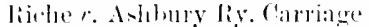

( $11 . .1212,132,131,532.7+11,7+2$

licketts r. Enfiehl church-

watrlems n....................

lideway r. snegl ............ 111

lideway $r$ Whatom.......... 16;

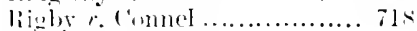

litelise . Smith............... 311

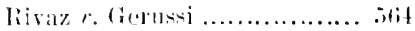

liver llea) ('ommensinntels $r$.

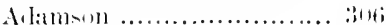

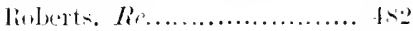

liobertse e. Berry................ isti

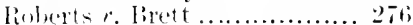

lioberts $\therefore$ lingry limmissimers ..................... 4.33

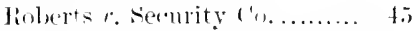

Roberts $r$. smith.............. 4s, 4 th

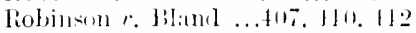

liobinson r. Wavisull..21!. 147. J!k

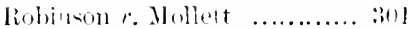

liobinson r. Xesbitt ............ 2.:

Rolinson 1. Ommanney ...... Bit

liobinsm $\therefore$ l'se . ............ gli]

Rohinson r. I'ickering.....7311. 73:2

Robinsm d ('u., Jtıl. r. Heuer :3) liobinson. Kined ('u, r, l,yes !2

Robsen $\because$ l Hollis............... i.sti

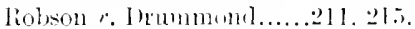
$1 ! 11 ;$

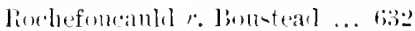
Roullam r. lluley .......tist. dis

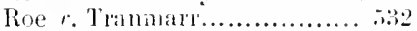
liogeds $r$. Ilatlley ............ 21 19.3

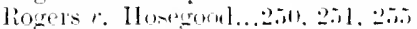
liogers r. Ingham...... . . . I I I 3. tho

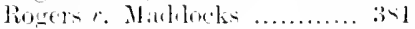
liogrers $r$ l'ary ................. Polfe r. Flower ................ 2li; Fomford ( 'anal $(1, \ldots \ldots \ldots \ldots \ldots$ T3. Porke $r$. Lawsin.............. I! looke r. Lorl Kenington....is?.

Hoper $r$. Donraster ........ .31. 732 Roper r. Holland ............ $7: 011$ Rosenrla $r$. Thrma-............. 1s!

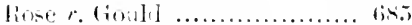

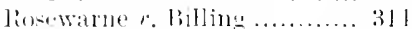
limhere r. Williams ........ l!3. bitil

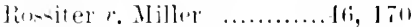
linsiter r. Walsh i.i.t
Ristherham Nlum ande'hemical

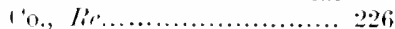

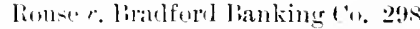
Romillon $r$. Jinnsillon.......380. 3.5l linwley r. liowley .............. se liownim, If ............. 3!15, tis. lioval fritish liank $r$ Turquand................ 15ti, 735. 740

lioyal Exchange Assurance Corporation r. Sjorforsakrings Alitiebulaget Vega ... 3s.j kulen r. Great Fingall ('onmilitated 133

liuckmabore r. Lulloobhoy ... tis limel $x$. Lascelles .............. lindge $r$. linwman ...........

Finfles r. Mliton............... 32.;

limmball $r$. Metropolitan Bank 24:3

liussell $r$. Amalgamaterl soc. of carpenters and Joiners... 373

linsell $r$. Ita liandema ........ 4.2

linstell $r$. Rinssedl................ 34!9

lin-ell $r$. 'hoolbres ........... ostg

linsiell $\because$ Thornton............. 34

lia-sell $\because$. Wakefiehl Water. wurks 1 o..................... T36

Riall $r$. Rowles .................... 344

ligler r. Wombwell .....

\section{Sinckille-llent r. Yiseount}

Holmerlale .................. isin

st. Alban r. Ilatrling........... bitiz

st. lieorge . Wake............. 3013

st. John r. st. John ......... 32.2

st. Leonarils, shorediteh (Guarlians of) r. Franklin 124 salter r. Burkina............. bit salton r. New liexton (ycle

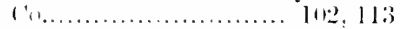
Salve-eu of (o. v. heleri Aktieblatget Xord-tjernan..... 11:3 simuel 8 . Newlulkl............. 673

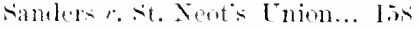
sambersun r. Aston .........297. 29!9 samlerson r. liraves........6.tit, 707 Sin Iuan (City of ) r. St. lohn s

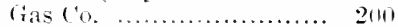

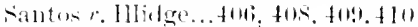
.Satanita." The ............. 7.27

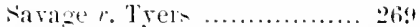
savery $r$. King........tits. 6i.2. 6iz! savin r. Ifoylate liy. Co...... 3lij 
PAGE

Saxby $r$. Fulton

. 12

Saxon Life Assurance Soeiety, Re 482,483

Sayers $x$. Collyer................ 25t

Sicaltock $r$. Hartson ........... 249

Searf $r$. Jardine ................6. 633

Scarpellini $\therefore$ Ateheson ........ 6334

Sichmalt $z r$. Avery .......115, 116

Scholefield $r$. Templer......6;2:, 6:31

Scholey $r$. Central Riy. Co. of

Venezuela.................... $6 ; 17$

Schott, In the Goods of ....... 7 is

Seotson $v$. Pegg ...........196, 197

Seott $x$. Avery .................. 350

Seott $x$. Corp. of Liverpool ... 350

seott $r$. Coulson ................ 521

Seott $r$. Ebury (Jorl) ........ 114

Sicott $x$. Gillmore............... 71 i

Neott $x$. Littledale ............. 507

Ścott $r$. Pilkmgton ............. 24

Seott $v$. Seabright $\ldots \ldots \ldots . .588,630 ;$

ficott $r$. Tyler .................. 400

Ficottish Petrolem Co., Re... 5s6.

$620,7.77$

Seager $\imath$. Aston ................. 685;

Featon $r$. Bmmand ...564, 567, 569,

Seaton $r$. Graut

736

Seaton $r$. Heath .....56t, sti7, 571

S'eaton $r$. Seaton ............... 77

Seddon r. North Eastern Sialt

Co......................... 5 $8: 3$

Seear $v$. Lawson ...........353, 3i 7

Religmann r. Le Boutillier ... 34s

Selsey (Lord) $r$. lihoades ..... 6.55

seton $r$. slade .................. $\$ 36$

Sewell $x$. Burlick ........... 2.2

Sewell $v$. Foyal Exchange $A$ ssurance Co. .................. 39.

Sewers (Commis. of ) $c$. Rer.... $\$ 36$

Seymour $r$. Bridge ............. 4to

shadwell $r$. Shadwell........... 196;

Shand $x$. Du Buisson ........... 733

Shardlow $v$. Cotterell.......... 170

Sharingtom $r$. strotton ........ 181

Sliarman $x$. Blandt ........116,300

Sharp $x$. Leaeh ............... 653

wharp $\varepsilon$. Taylor ........... 32!, 39.;

Sharpe $r$. Foy 702

Sinirpley $r$. Louth and East Coast Ry. Co. 617

Shat toek $i$. Shattock .....730, 733

Shaw's Claim ................... 316

Sliaw $r$. Foster ................. 220

shaw $r$. Jeffery

296
PAGE

Shaw r. Woorleock ........fis9, 69t

Shetichl, sc. Building Society,

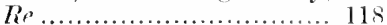

Sheftield Nickel Co. r. Unwin b-1

Sheffield (Earl of ) r. Jomlon

Joint stuck liank ........... 244

Sheppard $r$. Oxenford ....... 40\%

shillito $r$. llobson ............. 206

Ship's Case ..................... not?

shoolbred $r$. Roberts ........... Inl

Shrewshmy (Earl of) $r$. $\mathrm{N}$.

Stafforlshire Ry. (10........ 312

Shuey $x$. Ciniter states .....23, 25

s'hulter"s ('ise ................. the

sirlenham $r$. Worliuston ..... 190

Silber Light ' 0. . Silbes...... 737

sillem $x$. Thornton ............. isti

Silliman $r$. United Sitates..... (i:3

Simnomels, Ea pate .......... t85

Simons r. (i. W. Ry. (a........ 4!1

simons $r$. l'atchett ............. 112

simpson $x$. ('rippin .......2 $2 \times 1,282$

Simpsin $r$. Denison .......... 73.5

Simpson $r$. Egginton ........... 4!s

Simpson $r$. Lamb ...........3.3.3, 35t;

simpison 1. Lord Howden 318,342

simes $r$. Homl ................. 107

Sismey $\bullet$. Ely .................... 31!

skeate $r$. lieale ................ 6337

slieet $r$. I.

skidnore r. Bridfor l ........ 7.4

skilbeck $r$. Hilton ...........34, fizt

skillett $r$. Fletcher............. 297

Skottowe $r$. Williams.......... 63:2

Alyyring $r$. (ireenwoor ........ 4tst

Sla le's Case .................... 1511

Slator $x$. Pirarly...............5s,, 2

Slator $r$ 'Trimble...............

Sloman $r$. Walter .............

Smart r. West Ham Lnion ... J60

smethurst $r$. Mitchell ........ 11:4

Smith 5.) 1 , (;i) , 612

Smith's Cave (I. R. \& ( h. (i11) 70:3

smith r. bromley ............ do:

Simith $v$. lirown ................ bit

Smith $x$. Cartwight ............ 160

Smith $r$ Chadwick ...6(t)2, 6010, bit)7

smith $r$. llatke ............... isti

smith $r$ ('nff .................. 41,3

simith $r$ Eggington ........... 2$\}$

suith $r$. Foll coast amel

Aslanti Explopers .......... 16.

smith r. Hughes....2.2. 4st, in $516,205,254$, (id)

smith $r$ Iliffe ................ 5in 
PAFE

Smitle r. Kay . .602, foot, fitl dit?.

(ii, f (iis

smith r. King ................. ti.5

sunith $r$. Limd and Ilonse l'ro-

perty Corporation ............

smitl $r$ l.ind, ............... 312

simith r. Luras .............(i), 269

smith $r$. Mawlyoor ................3 $3 \mathrm{I}_{2}$

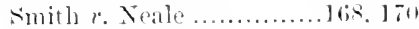

snith r. Webuter ............ 44

simith r. Wheatcroft ........... 4.t.

smitl $r$. White ................. Bises

smith r. Wilson ................ 2tit

smont $r .11$ bery ................ 113

smutlowate 2 . Wilkins ..... 25.

smyther. Girithin ............. Bs

society of lractical linum

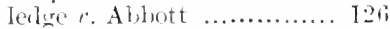

sultykutf, Rir. Eir purte Margrett

-

soler r. Arnold ................. 36.

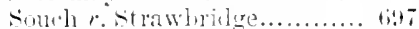

somth Africa lineweries $r$ King ...................... 116;

Sorth Hetton roal ('o. r. Haswe]l firal tis.

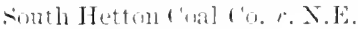
News dereiation .......... 123

fouth of Irelarul ('ulliers ("i). r. Hathle .................. 1.56

South Yorkbire. de. ('o.

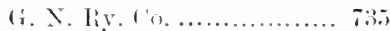

suthall r. liber ...........tst. lib

sist hamptom (ford) r. Jirown 10t,

Southorn Develofment $\left({ }^{\circ}, \mathrm{r}\right.$. ril ra .......................... 819

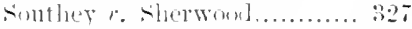

soutliwell $r$. Rowlitch ........ bo

Sfrackman r. Erank......... Tto, TH

sinenburgh r. liamnatye ... 38ti

sparling 1. brereton .......... 70?

sivears r. Hartly ............. 6.5.

Spelling $\&$ Serell............. 112

spencer. chombick ......... 131

spencel's r'ase .............2ti, $24 \mathrm{~s}$

spencer $r$. Harding............. 1!

spicer r. Martin ...........s. 25.

- flilier t. laris skatiug Rink ro.

114

spliclt r. bow les ................ 247

-jiange r. Lee................... 94

syott r. lnited states ...387. 34.9

- prye r. Porter...35 I. 353, 354, 35.5
PAGE

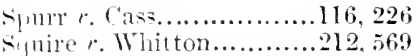

stafforel (.lator of) $r$. Till $\ldots .166$

stahlschmidt $r$. Lett ...........6.6.5

Stanley r. Dow leswell ........ 44

ctanley $r$. Jones................ 353

stantin i. Tattersall .....517, 5.8

Starkey r. Bank of England.. 112,

113

stedman r. Hart............... 96

stead r. ('alley ................ 6.5.3

steele $\because$ Hamer................. 136

steete $r$. Williams ............. 639

steph+ns r. Indbridge Iron-

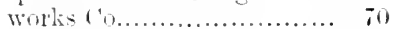

stephen-r. Venalles........... 23i

sterly $\therefore$. C'lifton................ 343

steven r. Beming .......211, 501

stevens r. Biller................ 108

sterens r. Gimley.............311

fiteverson $r$. Melian ...2s, 31,3f

Stevenson $r$. Tewnliam........ 620;

stewart's 'ase (Agriculturists'

Cattle Ins. ( o.) 741

ctewat's lanse (Riussian Vyk-

sounsliy Ironworks (o.)..... sog

stewart $r$. Alliston.............. 50s

stewall r. laser................ J90

stewat $r$ Erlilowes........ 171, 529

stewat r. Kenmely ........... 47

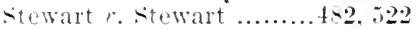

stewat $r$. Wroming Ranelse

(10. ......................... 51,13

stikeman $r .1$ ) $w$ son ............ 81

stilwell $\ell$ Wilkins............. (i.)

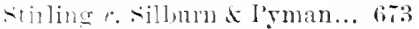

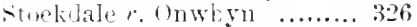

streker. Dibsin .............. 233

stoglom r. Lee .............92, 73]

stoner ('its and County Bank 6i2

stune $r$ roulfrey............... 482

Sturer s Trusts ................ 91

stopey r. 16aulle......25, 552, 63.5

strange r. Brennan.........353. 35.5

stray r. linseell ................. 425

siteet r. Blay ................... 504

street $r$ kighy ................ 34s

stribley $\bullet$ Imperial Marine

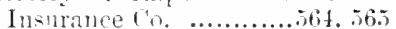

strickland $r$ Turner .......... 521

stuart r. Diplnek ............. 380

stuble r. Holywell Ry. Co. ... tis

stulus r. Watson ............... 17t

stump r. Galy ................ 679

sturge r. siar ................ 609

sturee $x$ sturge .................. bis 


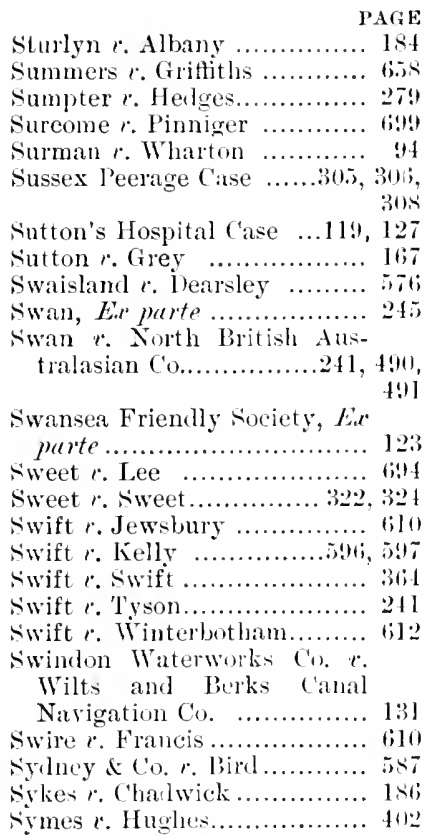

Tadly \& Co. r. Sterions d Co. 247 Taite $r$ Gowling ..................., Talbot $r$. Staniforth .......... 6.\%

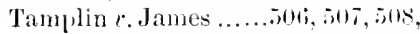
il:

Tancred r. Delagoa biay amb Fa-t Africa Railway (ir, ... 2:30 Tappenten r. Fiamlali ........ 412 Tasker $r$. Small ................ 215

Tatam r. lieeve..............314, 40)

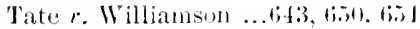
Tayloe $r$. Dereluants Fire

jusurance ('o............... 727

Taylor, E.r pulte............... (ii)

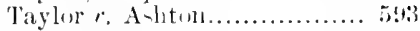

laylor $r$ licmers.............. I112

laylur $\therefore$. lirewer................ th

'aylor r. Calolwell ... l:31, 1:3, l:37, $439,417,451,4(3), 460$

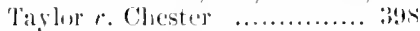

'laylor r. Chichenter amel Mirlliurst liy. ('o.
PAGE

Taylor r. Crowland fas Co... 311

Taýlor r. G. E. liy. Co. ........ 691

Tarlor $x$. Johnston............., , ti.;.3

'livlor r. Jones ............... ige

Taylor $r$. Manners ............. lsi;

Taylor $e$. Mearls ................ $7: 9$

'Taylor r. P'arry ................ 215

Thylor $r$. Portington ........... As

Taylor $r$. Pngh ............... 303

Taylor r. St. Helens (Corpmora.

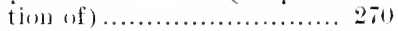

Taylor r. Sinith ............... li!

'Tenant r. Elliott............... 3999

Temllent r. City of Gilanow

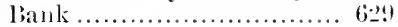

Tement r. lennent $=\ldots . . . \ldots$. bis

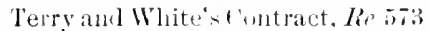

" Teintmia." 'The ................ +4t;

Texa; r. Wlite ............... 3337

Thanes Haven, de. ('o. r. Ilall ..................... 1, 1, 1601

Thiolman $r$ Golil-chmilt..... 242

Thiis r. livers .................. 129

Thomas, Re, Jaques, $r$.

Thoma: ....................... 35.

Thomas r. lirown ............. ti!lt

Thomas $r$. Davis............... 33.3

'1'homa , $r$. Thomas ........17;, 1;3

'l'bulupson $r$. Arlams ..........

'Thomp-on $\bullet$. Hicknan ....... if.

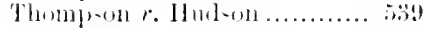

'Tlompon r. Puwles .......... 337

Thumpsom r. Eniversal sillvage 6 (1) .................... 136

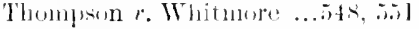

Thom-on r. Darenjolt ........ 101\%

Thomsin $r$. Eantwouk ........ 13.34

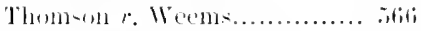

Thome $r$. Mayor of Lomblom ... \$30

'Thoruborow $r$. Whitace ..... 421

'Tleruton $r$. Kempeter ....... 511

'Thormghgoml's ('a-e......... fis'

Thurshy $r$ l'lant.............. 248

Thurstan r. Nettingham l'ermanent bentit dinilding

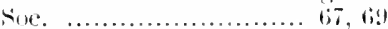

Thwates $r$. Culthwalte ..... 39.5 ,

Tichener, Re ................. 2:31

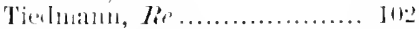

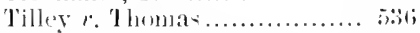

Tiker r. Tuke r................... lits

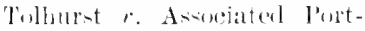

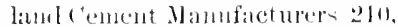
2:30, 1!Hi, 1993

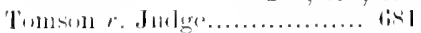




\begin{tabular}{|c|c|}
\hline 18 & I \\
\hline Topham r. Moreeraft.. & Valentine $r$. Canali.. \\
\hline dingtun $r$. Magree... & Vallance $r$. Blagden \\
\hline$r$ Bultom ...5lz, ils, sit & Van l'raagh $r$. Ereridge. \\
\hline 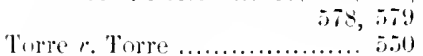 & Vansittart $r$ Vansittart... $87, \underset{322,}{3633}$ \\
\hline Tortenham $r$. Emmett & Varley $x$. Whipl \\
\hline 1...678. 672,679 & derstegen...90, 729 \\
\hline 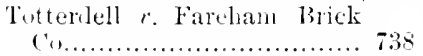 & $\begin{array}{l}\text { Veitch } r \text {. Fussell... } \\
\text { Vermon } r \text {. Kess.... }\end{array}$ \\
\hline Tonclie $r$.tie & Viditz $c$. O Hagan \\
\hline , $\ldots \ldots \ldots \ldots 226$ & \\
\hline & 310 \\
\hline innsente che & Vorley $r$ cuoke $\ldots \ldots \ldots \ldots \ldots \ldots$. 492 \\
\hline
\end{tabular}

Traill $r$. Stangrom on

Triegere r. Lavalise ................. 204

Trimble $r .11$ ill ..................31t, $f(1)$

Trist r. chilhl ................... 342

Trueman $r$ Luler ............ log

Trumenter r. Trumper ............ 301

Tru-tees $\theta$ Thacker ........... 2.,

Tucker $r$ Bemett .............. it!

Tueker r. Linger.................. 20;

Tucker $r$ vowle, ................. 2it

'Tulk $r$. Muxhay ................. 25t

Tullett $\therefore$ Am-trong ............ 731

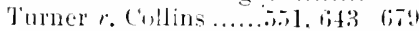

Tumer $r$ fioidsmith ........... 141

Turner r. lirent................

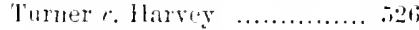

lurner r. lieynall ............. 711

Turnock r. Sartoris.............. 340

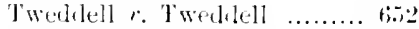

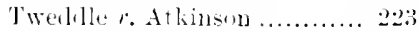

Twistletrm $r$ diritlith............

Jwo sicilies (King of ) $\therefore$ Wil-

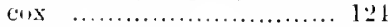

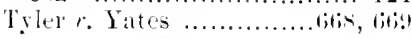

Litell $r$ Atherton .............. $:$ s]

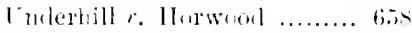

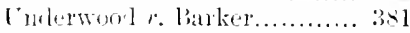

Fnderwond Enderwond...... 26!

longley r. l'ngley............tils, tisls

Inity l'ank. Err perte ........ \& 8

Inivelsil life Assurance Co..

E.r prate ........................ 239

Eniveral stock Exchange strachan ...............315, 411

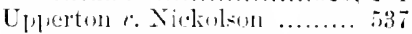

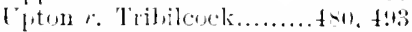

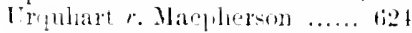

Cermelile $\therefore$ Xornent ........ tis

W. $r$. B....................... 404

Wace $r$. Allen ................... 262

Waldell $r$. Hlockey.............. $4: 4$

Wain $r$. Warlters ............. 169

Waite $x$. Morland .............. \$9

Wake $r$. Harrop ................. 20 20.2

Wakefield $r$. Newbon........... 438

Wally e. Giay ............... 172

Walker, Rir .................... 95

Walker $r$. Armstrong.............. its

Walker' $r$ J'erkins ................ 31 s

Walker $x$. smith............... bitt

Walkers Winser d Hamm and

shaw. son d Co............... 267

Wall's Case ........................ 727

Wallaces case.................. 21

Wallace $x$. Gibson .............. 16,

Wallace $r$. Wallace............... $65 \%$

Wallis e. Day ................37 $38,3 \times 3$

Wallis 2 . Smith.............272. stu

Walter $r$ Everard ….........75, 7

Warel 2 . Bank of New Zealand 2og

Warl $r$. luncombe ........232. 234

IIarden $r$. Iones................ T(1)

Warring's Case.................... 219

Warlow $x$. Ilamison...18, 19, 20, 21

Warne $r$. liontledge........... 732

Warner $r$. Texas and l'acilic ky. .......................... lis

Warier $r$. Willington........... 50

Warrender $r$. Warrender ...... 32:

Warriner $c$ lingers............... 207

Warwick $r$ Bruce................ \&s, 61

Warwiek $x$. lichardson......... $: 293$

Wasateh Mining Co. $x$. Cres-

eent Mining Co. ............... nosi

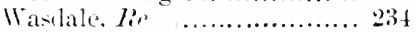

Wison $r$. Wareing ................. 4 st

Watcrluuse $x$. Jamiesm........ 62. 


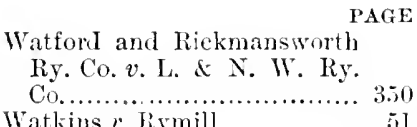

Watkins $x$. Fymill ............. 51
Watkins $x$. Nash................ 263

Watson, Ed parte ............. 82

Watson r. Alleock .............. 2!!

Watson $r$. Eal of Charlemont $\mathbf{6}(\mathbf{6}$ Watson $r$. Marston .........5t1, 66l

Watson $r$. Mid-Wales Lí. Co. 236

Watteau $r$. Fenwick ........... lot;

Watts $v$. Porter ................. 23.;

Waugh $r$. Morris ...........3! $35,41 j$

Way $\ell$. East....................... 35\%

Way $r$. Hearn .............5i 1,614

Weymell $r$. Reel............... 33s

Webb e. Herme Bay Commis-

sioners.............13s, 237, 241)

Webb $r$. Hewitt ................ 29s

Webb $r$ Hughes................. 537

Webb $x$. Whitin ................ 24i;

Webster's Case ................. ,0!)

Webster $r$. Cecil ................. ils

Webster $r$. Cook................. 66!

Webster $r$. De Tastet........... 3ri5

Weeks $t$. Propert................. 112

Weidner $r$. Hoggett ........... 106

Weir r. liarnett ................ 6ill

Weir $r$. Bell ..................... bis

Wellon r. Winslow .......... ol

Wells r. Kingston-upon-Hull.. 159,

Wells $r$. Mallon

Welman $r$. Welman ........... 546

Wenlock (Baroness) r. River Dee (co. .................127, 12s

Wennall $r$. Adney ............... 189

West Iomolon Commercial Bank $r$. Kitson ............11. 599

Western Bank of Footlaml $r$. Aldie (i) $10,613,623$

Western Fububan, sc. (o. $r$.

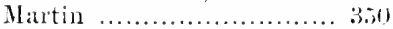

Western Wagon anl l'roperty (o.r. Mest $2: 31$

Westlake $r$. Alamts............. list

Westmeatl $r$. Nalisbury...324, 32.5.

Westmeatl (Maripuis of) $r$.

Malehioness of $W^{r}$ (est meatlo.. 320 , $\$ 22,32 \%$

Weston r. Metropulitan $A s y-$

lum Histrict................. ; 10

Whatron $r$. Matekemzit ....... $7:$

Whatman r. (iilson .......... 25l

Wheatley r. Lane
PAGE

Wheatley $r$ slade .............. 577

Wheeler, Re...................

Wheelton $r$. Hardisty ........ 69.5 , 609

Whelan $r$. Palmer ............. 263

Whelpdale's Case ........... 6.36

Whicheote $r$. Lawrence........ 300

Whineup $r$. Hetghes .......... 4.2

Whitconb $r$. Whiting ....... bsi

White $r$. Bluett ................ I98

White $r$. Cullon................ is

White $r$. (iamlen ..........5.50, $1 ; 20$

White $r$. White ............... 5.33

Whitechuch, Ltil. rava-

nagh ........................ $\pi .54$

Whitehead $r$. Anderson.......... t75

Whiteman $r$. Saller .......... 673 .

Whiteley's C'ase ..........586, 620

Whiteley r. Elwards ........... 90

Whiting s settlement.......... 36\%

Whittaker, Er moto .......... igl

Whittaker $r$. Kershaw........41, 93

Whittemore $r$. Whittemore ... 5r6;

Whittington r. Seale Hayne... (i2l

Wilgery $r$ Tepper............. it

Wirglesworth $r$. Inalison ..... 267

Wiby $x$. Elgee.......203, 204, ist

Wild $e$. Hatris................. 113

Wille r. Gibson ...........s 1,582

IVildes $r$. Duklow .............. lob

Willing $r$. samelerson ......t7 5 , 5.53

Wilkinson $r$. Clements ....... 27 !

Wilkinson $r$. Gilsson ........... si

Will-inson $r$. Loudonsack ...... 116

Willan $r$. Willan................. 530

Willé $r$. st. John ............. 25t

Willesford $r$. Watson .....34s, 34!

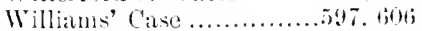

Williams, E.r parte..............311

Williams r. bayley ...345, tito, (i.s)

Williams r. Byrnes..........25, 16!

Williams $r$. ('arwarline ..... 15, 22

Williams (Due d.) $r$. Evaus ... 359,

360

Willians $\ell$ (ilenton ........... Bat;

Williams $\bullet$. Iathaway ......... I1.;

IViiliams $x$. Hedley.............. 40:3

Williams $r$. Jordan............. 16!!

llillians $x$. Moor ............. i:

Williams 1 . Owen ............... 339

Williams $\&$. Protheroe ........ 3.s.

Williams 1 . Wentworth....... 9t

Williams, app.. Wheeler, resp. t593

Williams $r$ Williams .......... (i.)

Williamson $r$ lihon ........... Bit;

Willingale $r$ Mathland ........ 2.2.2

Williuon r. liattexom ........... 3.30 


\begin{tabular}{|c|c|}
\hline PAGE & $9 G E$ \\
\hline t $r . B_{i}$ & Wright $r$. Leonard ... \\
\hline illom $r$ lowe $\ldots \ldots \ldots \ldots \ldots$. sto & right $r$. IIonarch Invest- \\
\hline ilson $r$. Carnley ............... 30. & ment Builuling Society ...... 349 \\
\hline ilson r. Ilart & right $r$. Promel ....... \\
\hline son $r$. Llowel & -p \\
\hline Vilson r. liankin & $\ldots \ldots \ldots \ldots \ldots, 326$ \\
\hline Vilom $t$. liay & $321,6+8$, \\
\hline ilson r. iVest & \\
\hline 135 & \\
\hline Wilson $r$. Wilson $\ldots . . .24$ & a...... \\
\hline ..... 7109 & $\therefore$ Domning. \\
\hline Lueal hoard $r$. Vint 345 & ... \\
\hline ................ & $I$ \\
\hline $6,5.5$ & Wynn $r$ Shropshire Enion, \\
\hline$\ldots$ & $\begin{array}{l}\text { kc. } \\
\text { Wrthes } r \text { Labouchere........t9. }\end{array}$ \\
\hline & \\
\hline
\end{tabular}

Wolverhanptun banking ('o., Eir pute ........................ 34 it

Wool r. Abrey ..........tis, 6;is, titan Woul r. Barker ................. 2:4t

Wood $r$. Downes.....353, 35.5. 356, 361

Woul r. Fenwick...............5:4, 69

Wool $r$. tiriffith ................

Woul $r$. scarth............. 508 , itl

Wonl $r$. Tate ................. lib

Wualall $r$ clifton ................ 24s

Woolf $r$. Wuole ................. so

Woulfe $r$. Horne ................ lot

Worrall $r$. Jacob................. ;:202

Worthing Corporation $r$.

Heather .................... 333

Worthingron $r$. ' 'urtis ........ f(u)

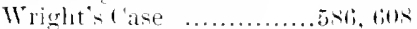
Wright $r$. Carter................... tits

Wright $r$ chard ................ 334

Xenos $r$ Wickham........8, 52, 703

Yarborongh $r$. Bank of England ......................... 162 Yeomans $r$. William $=\ldots \ldots \ldots \ldots . . .602$ Young d (o. r. Mayor of Leamingtrm .................. 169 Yonge $r$. Toynbee .............. 113 Yzquardo $i$. Clylebank Engineering co. ............... 227

Zourll $r$ l'arsoms................ 59 


\section{REFERENCES AND ABBREVIA'TIONS.}

Benjamin on Sale. Fifth edition, 1906.

Finch Sel. Ca. A Selection of Cases on the English law of contract by Gerard Brown Finch. Seeont edition, 189t.

Harvard Law Review. Cambrilge, Mass., 18si-. ('ited by volume and page.

I. C. A. means the Intian ('ontract Aet (IX. of 1872); ed. Pollock \& Mulla, 2d. ed., 1909, and in Dr. Whitley Stokes's Anglo-Indian codes.

L. Q. R. Law Quarterly Review. Lonlon, 1885-. Cited by rolume and page.

Langdell. A Summary of the Law of Contraets, by (C. C. L. Second edition. loston, Mass., 1881.

Law Jomrnal. Always eited by the number of the rol. in the New Series.

Law Reports (1875-90). The Scoteh Alpreals to the House of Lords and appeals to the Judicial Committee of the l'rivy Conncil reporterl in the Appeal Cases series, if not expressly mentioned to be such in the context, are distinguished hy the adhlitions (Ac.) aml (J. ('.) respectively. Cases in the Comrt of Appeal are distinguisherl hy the abbreviation of "Inivision " in the form " Div."

The current series of Law lieprerts, $1891--$, is cited thus: Imprrial Lmen Co. v. Stone $[1892] 1$ Q. B. 59:1, C. A.

Lindley on lartnership, 7th ed., 1905; Lindley on Companies, 6th ed., 1902.

R. I. The Revised Reports.

Saunders' Reports, notes to, by the late Serjeant William: (Wms.

Saund.). Ed. 1si1. Cited by the paging of that elition.

Sarigny, System des hentigen Jömischen Rechts (Sayigny, or Sav. Syst.). Berlin, $1840-1849$.

Savigny, Das Obligationenrecht (Sav. Obl.). Berlin, 18.51-3

sm. I. C'. Smith's Leading Cases. Eleventh edition, 1903. 



\section{( lvii )}

\section{YEAR BOOKS CITED.}

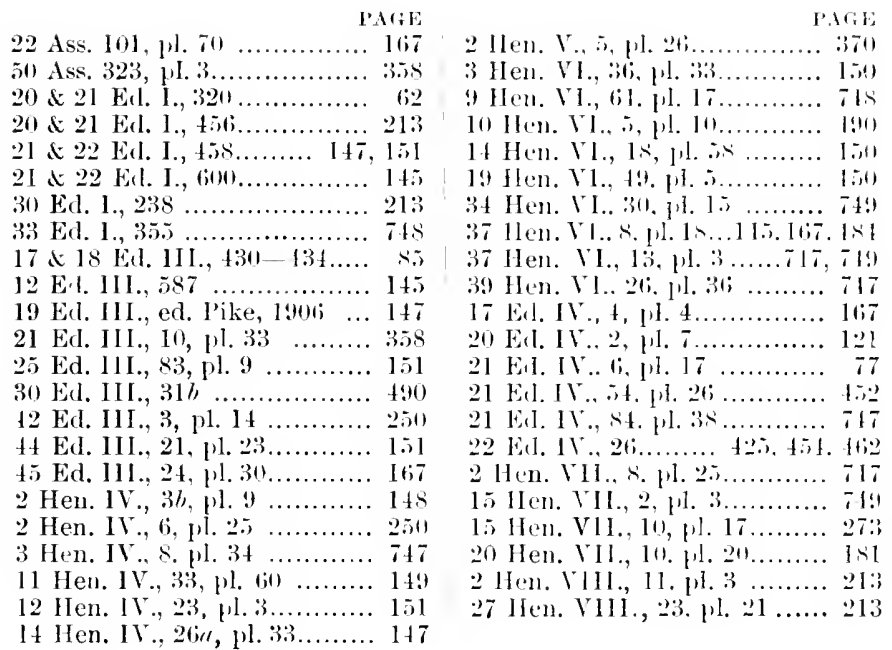




\section{( lviii )}

\section{ADDENDUM.}

Pp. 488-494. The doctrine of Thoroughgood's case and Foster v. Muclimnon was very lately considered by the Court of Appeal in Carlisle and Cumberlond Banking Co. v. Bru!q, Dec. 7, 1910. Here a guaranty was frambulently producer to the defendant, and signed by him, as being an insurance proposal. The person who so obtained his signature forged an attestation and handed the docmment to his bankers, the plaintiff company. The Court held that the defendant's signature was inoperative, and that he ras moler no duty to the bank (this not being the case of a negotiable instrument) and therefore was not estopped from denying that he signed a guaranty. It was pointed out that no question of estoppel can arise unless the issue of non est factum is decided in the defendant's favour, and then some special duty towards the plaintiff, under the law merchant or otherwise, must be shown to raise an estoppel. Cases of this kind are not confined to the blind and illiterate, see especially $\%$ Brciler, L. J. The result is to confirm the authority of Foster v. Mackinnon as against any supposed weakening of it by Howatson v. Webb. 


\section{PRINCIPLES OF CONTRACT.}

\section{CHAPTER I.}

Agrement, Proposal, and Acchptarel.

The law of Contract may be described as the endeavour of the State, a more or less imperfect one by the nature of the case, to establish a positive sanction for the expectation of good faith which has grown up in the mutual dealings of men of average right-mindedness. Accordingly the most popular description of a contract that can be given is also the most exact one, namely that it is a promise or set of promises which the law will enforce. The specific mark of contract is the creation of a right, not to a thing, but to another man's conduct in the future. He who has given the promise is bound to him who accepts it, not merely because he had or expressed a certain intention, hut because he so expressed himself as to entitle the other party to rely on his acting in a certain way. This is apt to be obscured in common cases, but is easily seen to be true. Suppose that $A$. agrees to sell to $B$. a thing of which not he but $C$. is the true owner. C. gives the thing to B. Here, though B. has got the thing he wanted, and on better terms than he expected, A. has not kept his promise; and, if the other requisites of a lawful contract were present as betweren himself and J), he has broken his eontract. 'The primaly questions, then, of the law of contract are first, what is a promise? and next, what promises are enforceable? 
The importance and difficulty of the first of these questions depend on the fact that men can justly rely on one another's intentions, and courts of justice hold them bound to their fulfilment, only when they have heen expressed in a manner that would convey to an indifferent person, reasonable and reasonably competent in the matter in hand, the sense in which the expression is relied on hy the party claiming satisfaction. Judges and juries stand in the place of this supposed indifferent persm, and have to be convinced that the dealings in the particular case contained or amounted to the promise alleged to have been made and relied upon.

Our first business must therefore he to separate and analyse the elements which, generally spealing, must concur in the formation of a contract. A series of statements in the form of definitions, though necessarily imperfect, may help to clear the way.

Contract. $\quad$ 1. Every agreement and promise enforceable by law is a contract.

Agreement. $\quad 2$. An agreement is an act in the law whereby two or more persons declare their consent as to any act or thing to be done or forborne by some or one of those persons for the use of the others or other of them $(a)$.

Expression of consent.

Fromise and offer.
3. Such declaration may take place by

(a) the concurrence of the parties in a spoken or written form of words as expressing their common intention, or

(b) an offer made by some or one of them, and accepted by the others or other of them.

4. The declaration of any party to an agreement, so far as relates to anything to be done or forborne on his

(1) This -tiztement was adopter by kokewich I. Fister v. Whefley.

(1887) $3 t^{\circ}$ C'h. D. $695,695,57$ L. J. Ch. 149. 
part, is called a promise. The expression of a person's willingness to become, according to the terms expressed, a party to an agreement, is called an offer or proposal. An offer may become a promise by acceptance, but is not a promise unless and until it is accepted $(b)$.

5. An agreement which has no legal effect is said to be void. An agreement which ceases to have legal effect Vois agreement. is said to become void or to be discharged.

6. An agreement is said to be a voidable contract if it is enforceable by law at the option of one or more of the parties thereto but not at the option of the other or others.

We proceed to develop and explain these statements, so far as appears convenient at the outset of the work.

1. Definition of Ayreement. - The first and most essential element of an agreement is the consent of the parties. There must be the meeting of two minds in one and the same intention. But in order that their consent may make an agreement of which the law can take notice, other conditions must be fulfilled. The agreement must be, in our old English phrase, an act in the law: that is, it must on the face of the matter be capable of having legal effects. It must be concerned with duties and rights which can be dealt with by a court of justice. And it must be the intention of the parties that the matter in hand shall, if necessary, be so dealt with, or at least they must not have the contrary intention. An appointment between two friends to go out for a walk or to read a book together is not an agreement in the legal sense: for it is not meant to produce, nor does it produce, any new legal duty or right, or any change

(b) This does not imply that every offer is revocable until acceptance. How far that is so is a quention not of definition bat of substantive law. "Offer" and "proposal" are symmymous terms: "uroposil" is often convenient as allowing "proposer" to be used ats at correlative term rather than the legitinate but clumsy "offeror."
Voliable contract.

Nature and scope of consent. 
in existing ones (c). Again, there must not only be an act in the law, but an act which determines duties and rights of the parties. A consent or declaration of several persons is not an agreement if it affects only other people's rights, or even if it affects rights or duties of the persons whose consent is expressed without creating any obligation between them. The verdict of a jury or the judgment of a full Court is a concurrent declaration of sercral persons affecting legal rights; but it is not an agreement, since the rights affected are not those of the judges or jurymen. If a fund is held by the trustees of a will to he paid over to the testator"s daughter on her mirriage with their consent, and they gire their consent to her marrying $J$. S., this declaration of consent affects the duties of the trustees themselves, for it is one of the elements determining their duty to pay over the fund. Still it is not an agreement, for it concerns no duty to be performed by any one of the trustees towards any other of them. There is a common

obligation. duty to the beneficiary, but no mutual obligation. By obligation we mean the relation that exists between two persons of whom one has a private and peculiar right (that is, not a merely public or official right, or a right incident to ownership or a permanent family relation)

(a) Nothing but the abence of intention seems to urevent a comtract from aringe in many ease's of this kind. A. asks Is, to dimner. Here is propusal of something to be dome by li. at A.'s request, namely. coming at A.'s house at the approinted time. If $\mathrm{B}$. accepts, there is in form a contract by nutual promises. If aeceptance is not required. the tronble and expense of eoming to $A$.'s house are ample encideration for A.'s promise to provide a limer. Why is $A$. not legally bount to have meat and drink ready for li.. so that if $A$. har forgotten his invitation and cone elsewhere $\mathrm{B}$. shoull have it right of action? Only beeause no legal bond was intended by the parties. It might possibly be sairl that these are really cases of contract. and that only soeial usage and the trifling amount of preeuniary interest involved keep them out of courts of justice. But 1 think Savigny's view, which is here arlopted. is the better one. - There is not a contract which it would he ridiculous to enforce, but the original proposal is not the proposal of a contract. One or two nowlern writers think it enongh to say $D^{\prime}$ minimis mon curet lex. But linrely honorary engagenents are olten of great importance. 
to control the other's actions by calling upon him to do or forbear some partieular thing $(d)$. An agreement might be defined, indeed, as purporting to ereate an obligation; and the mark which distinguishes an obligation so created from any other kind of obligation is that its contents are wholly determined hy the will of the parties $(e)$. But for the purposes of English law we prefer to say (what is in effect the same) that an agreement contemplates something to be done or forborne by one or more of the parties for the use of the others or other. The word use (representing the Latin opus through an Anglo-French form oeps, not usus) is familiar in English law-borkis from early times in such a connexion as this.

The common intention of the parties to an agreement is a fact, or inference of fact, which, like any ofluer fact, l'roof of consent. has to be proved according to the general rules of evidence. When it is said, therefore, that the true intent of the parties must govern the decision of all matter's of contract, this means such an intent as a cont of justice can take notice of. If A., being a capable person, so bears himself towards B. that a reasonable man in B.'s place would naturally understand $A$. to make a promise, and B. does take A.'s words or conduct as a promise, no further question can be male about what was passing in A.'s mind. "Mental acts or acts of the will," it has been well said, "are not the materials out of which promises are made" ( $f$ ). Under such ciremmstances, as well as in certain other more special cases, the law does not allow a party to show that his intention was not in truth such as he made or suffered it to appear. But in the common and regular course of things the consent to which the law gives effect is real as well as apparent.

(d) Savigny, Syst. i. 338-9: Obl. i. 4, sert.

$(\rho)$ That is, their will as ascertained by the proper rules of inter pretation, not necessarily a will completely expresised on the fatce of the traissation.

(f) Langrlell. Summary \$ 1 su. 
l'roposal and acceptance.
Is the analysis universally applicable?

2. Ways of declaring Consent.-Two distinct modes of the formation of an agreement are here specified. It is possible, however, to analyse and define agreement as constituted in every case by the acceptance of a proposal. In fact this is clone in the Indian Contract Act. And it is appropriate to most of the contracts which occur in daily life, buying and selling, letting and hiring, in short all transactions which involve striking a bargain. One party proposes his terms; the other accepts, jejects, or meets them with a counter-proposal: and thus they go on till there is a inal refusal and breaking off, or till one of them names terms which the other can accept as they stand. The analysis is presented in a striking form by the solemn question and answer of the Roman Stipulation, where the one party asked (rpecifying fully the matter to be contracted for): That you will do so and so, do you covenant? and the other answered with the same operative word: I corenant $(g)$. Yet the importance of proposal and acceptance as elements of contract has, until of late years, been much more distinctly brought out in the Common Law than by writers on the modein civil law.

It seems overstrained to apply this analysis to a case in which the consent of the parties is declared in a set form, as where they both execute a deed or sign a written agreement. Some say that, although there is no proposal or acceptance in the final transaction, the terms of the document must hare been settled by a process reducible to the acceptance of a proposal; but this hardly suffices: for the formal instrument has a force apart from and beyond that of the negotiation which fixed its terms. And it may well be, and some-

(a) Nodoubt the formula sipundes: sponder, originally the only binding one, and almost eertainly of religious origin. was in early times -upposerl to have a kind of magical effect. But it was necessary that the stipulatur shonld hear the promisor's answer. ('p. Palgrave. Commonwealtl of ringland, 2, exxxvii, exli. 
times is the case, that the parties intend not to be legally bound to anything until their consent is formally declared. In such a case it camnot be said that the proposal and acceptance constitute the final and iegal agreement. Take the common case of a lease. There is generally an enforceable agreement, constituted by letters or memorandum, before the lease is executed. But the lease itself is (besiles its effect as a transfer of property) a new contract or series of contracts. In this who is the proposer and who the acceptor? Are we to say that the lessor is the proposer because in the common course he executes the lease before the lessee executes the counterpart? Or are we to take the corenants severally, and say that in each one the party with whom it is made is the proposer, and the pretty bound is the acceptor? What, again, if two parties ale cliscussing the terms of a contract and camnot agree, and a third indifferent person suggests terms which they both accept? Shall we say that he who accepts them first. thereby proposes them to the other? And what if they accept at the same moment? The case of competitor's in a race who, by accepting rules laid down by the managing committee, become bound to one another to observe those rules $(h)$, is even stronger. The fruth is, as I venture to think, that the exclusive pursuit of the analytical method in dealing with legal conceptions always leads into some strait of this kind, and it the pursuit be obstinate, lands us in sheer fietions.

3. Promise. - Except in the case of simultancous declaration just mentioned, a promise is regularly either the acceptance of an offer or an offer aceepted. Where the promise is embodied in a deed, there is an apparent anomaly; for the deed is irrevocable and binding on the

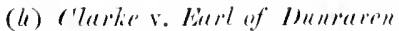

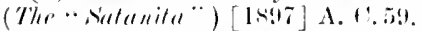
fiti $\mathrm{I}$, J. I'. I. Hore we ale thiven to say that every farty is both at proposer and an accoptor. ('p. p. $2 \pi$, h.
Effect of iteed in makimg simple fritrmise uprerative. 
promisor from the moment of its delivery by him, even before any acceptance by the promisee $(i)$. But this depends on the peculiar nature of a deed in our law. The party who seals and delivers a deed witnessing his promise does not, strictly speaking, thereby create an obligation, but rather declares himself actually bound, and that declaration is conclusive, as against himself, under normal conditions. In fact it is only in modern times that special defences, on the ground of fraud and the like, have been allowed to arail a man against his own deed. Thus the questions of consent and acceptance are not open, as ordinary questions of fact, to any discussion. The party has recorded his own promise in solemn form, and cannot require proof that any other positive condition was satisfied. As matter of history, the very olject of the Anglo-Norman writing under seal was to dispense with any other kind of proof, and to substitute the authenticated will of the parties themsetves for an appoal to the hazards of oath, ordeal, or judicial combat. It is not that an anomalous liability is created; the contracting party is estopped (special and (xceptional causes excepted) from disputing that he is liable. Not the promise, but the deed itself, is irrerocable and operative withont need of external confirmation. Whether it is convenient, on the whole, for the purpuses of modern law to retain the deed with its ancient qualities is a question beyond our present limits $(j)$.

Riestriction of contruit to enfineeables agreements.

4. Definition of Contract.-The term contract is here confined to agreements enforceable by law. This restriction, suggested perhaps by the Roman distinction between contractus and pactum, is believed to have been

(i) Tomes v. Hickliam (18si) I. li. 2 H. L. 296, 323: Dow d. Giarmes is knight (1-20) is li. d ('. bit, 2!) R. R. 3is. and see
I'ref. to 29 R. R. $\mathrm{y}-\mathrm{ix}$.

(j) The old law has been altered in varions ways in many Ameriean States. 
first introduced in English by the Indian Contract Act. It seems a manifest improvement, and free from the usual drawbacks of innovations in terminology, as it makes the legal meaning of the words more precise use.

5. Void Agreements.-The distinction botween roid without any violent interference with their accustomed and voidable transactions is a fundamental one, though it is often obscured by carelessness of linguage. An Void agreement ; distinction of inid and rividable. agreement or other act which is roid hats from the beginning no legal effect at all, save in so far as any party to it incurs penal consequences, as maty happen where a special prohibitive law both makes the act roid and inposes a penalty. Otherwise no person's rights, whether he be a party or a stranger, are affected. A roidable act, on the contrary, takes its full and proper legal effect unless and until it is disputed and set aside by some person entitled so to do. The definitions of the Indian Contract Act on this head are simpler in form than those given above: but certain peculiarities of English law prevent us from adopting the whole of them as they stand. It is not correct as an universal proposition in England that "an agreement not enforceable by law is said to be void," for we have agreements that camnot be sued upon, and yet are recognized by law for other purposes and have legal effect in other ways $(k)$.

6. Voidable Contracts.-The definition here given is from the Indian Contract Act. The idea is not an easy Toidable (e)lltiact. one to express in terms free from objection. Perhajs it would be better to say that a voidable contract is an agreement such that one of the parties is entitled at his option to treat it as never having been binding on him. The Anglo-Indian definition certainly covers rather more than the ordinary use of the terms. Cases vecur 
in English law where, by the effect of peculiar enactments, there is a contract enforceable by one party alone, and yet we should not naturally call it a roidable contract. An example is an agreement required by the Statute of Frauds to be in writing, which has been signed by one party and not by the other. Here the party who has signed is bound and the other is free. "Voidable contract" seems not exactly the appropriate name for such a state of things. And it may even be said that a contract which has been completely performed on one side is literally "enforceable by law at the option of one of the parties " only. But the definition as it stands camnot pratetically mislead $(l)$.

Considera. tion.

Consideration is sometimes treated as if it were among the necessary elements of an agreement $(m)$. But the conception, in the generality with which we use it, combined with its restriction within the limits of exchangeable value of some lind, is peculiar to the Common Law. It does not exist in the jurisprudence of the Continent or of Scotland. In our law we require, for the validity of an informal contract, not merely agreement or deliberate intention, but bargain; a gratuitous pomise is not enforceable unless included in the higher ohligation of a deed. The rules as to proposal and acceptance cannot be fully understond without bearing this in mind ; still the requirement of consideration is a condition imposed by positive law and has nothing universal or necessary about it. Hereafter a fuller discussion will be given: for the present it may serve to describe consideration as an act or forbearance, or the

(l) There is a similar hint slighter difficulty about the use of the word void. i contract when it is fully performed ceases to have lewal effeet; it is discharyed. but there is something harsh in saying that it beeomes void. a lerm singrestive of inteficacy lather thin of completed effect. Hence in the fifth definition I have introdned the word discharyed as an alternative.

(m) Thus it is refined in the interprelation clause of the Indian (intraet Act. 
promise thereof, which is offered by one party to an agreement, and accepted by the other, as an inducement to that other's act or promise.

Proposal and acceptance, though not strictly necessary parts of the general conception of Contract, are in practice the normal and most important elements. When agreement has reached the stage of being embodied in a form of words adopted by both parties, the contents of the document and the consent of the parties are generally simple and easily proved facts: and the only remaining question (assuming the other requirements of a valid contract to he satisfied) is what the words mean. The acceptance of a proprosal might seem at first sight an equally simple fact. But the complexity of human affairs, the lonseness of commom speech, the mutalility of circumstances and of men's intentions, and the exchange of emmunications between parties at a distance, raise questions which have to be provided for in detail.

We may have to consider separately whother the offer of a contract was made; what the terms of that offer were; whether there was any aceeptance of it; and whether the acceptor was a person to whom the offer was made.

\section{Communications in general.}

The proposal or acceptance of an agreement may be communicated by words or by conduct, or partly by the one and partly by the other. In so far as a proposal or acceptance is conveyed by works, it is said to he express. In so far as it is conveyed by conduct, it is salid to be tacit $(n)$.

(11) We shall see that commmnication of an acceptance noty be dispensed with in -onte calces. liut the law knows nothing of eornstructive communicatim. A derolment lying mexamined in at letter.
Sipecial rules governing fropusal and acepitince. l'monsal and aceeptanceExpresis or tacit. box is mot yet commmicatid, even if the omission to take it out ant

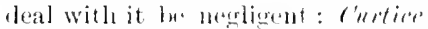

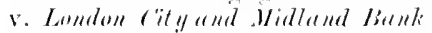
[1:4k] 1 K. I. 243.76 1..... K. I:. $311,1 . \Lambda$. 
Distinction of tacit from fictitions Iromises.
It would be as difficult as it is needless to adduce distinct authority for this statement. Cases are of constant occurrence, and naturally in small matters rather than in great ones, where the proposal, or the acceptance, or both, are signified not by words but by acts. For example, the passenger who steps into a ferry-boat thereby requests the ferryman to take him over for the usual fare, and the ferryman accepts this proposal by putting off. In the case of ohtaining a chattel from an automatic machine (where putting in our coin is the acceptance of a standing offer made by the owner of the machine) there is no possibility of accepting in words.

A promise made in this way is often said to be implied: but this tends to obscure the distinction of the real though tacit promise in these cases from the fictitious promise "implied by law," as we shall immediately see, in certain cases where there is no real contract at all, but an obligation quasi ex contractu, and in others where definite duties are annexed by rules of law to special linds of contracts or to relations arising out of them. Sometimes it may be difficult to draw the line. "Where a relation exists between two parties which involves the performance of certain duties by one of them, and the payment of reward to him by the other, the law will imply [fictitious contract] or the jury may infer [true contract] a promise by each party to do what is to be done by him " $(o)$. It was held in the case cited that an innkeeper promises in this sense to keep his guests' goods safely. The case of a carrier is analogous. So where A. does at B.'s request something not apparently illegal or wrongful, but which in fact exposes $A$. to an action at the suit of a third person, it seems to be not a proposition of law, but an inference of

(b) Per Cur. Morgan v. liarey (1861) is H. \& X. 265, 30 L. J. Ex. 131. 
fact which a jury may reasonably find, that $B$. must be taken to have promised to indemnify A. $(p)$.

If A. with B.'s knowledge, but without any express request, does work for $B$. such as people as a rule expect to be paid for, if $B$. accepts the work or its result, and if there are no special circumstances to show that $A$. meant to do the work for nothing or that B. honestly believed that such was his intention, there is no difficulty in inferring a promise by B. to pay what A.'s labour is worth. And this is a pure inference of fact, the question being whether B.'s conduct has been such that a reasonable man in A.'s position would understand from it that B. meant to treat the work as if done to his express order. The doing of the work with B.'s knowledge is the proposal of a contract, and B. 's conduct is the acceptance. The like inference cannot be made if the work is done without B.'s knowledge. For by the hypothesis the doing of the work is not a proposal, not being communicated at the time: $B$. has no opportunity of approving or countermanding it, and cannot be bound to pay for it when he becomes aware of the facts, although he may have deriver some benefit from the work; it may be impossible to restore or reject that benefit without giring up his own property $(q)$. If $\mathrm{A}$. of his own motion sendis goods to B. on approval, this is an offer which $B$. accepts by dealing with the goods as owner. If he does not choose to take them, he is not bound to return them; nor indeed is he bound to take any active care of them till $\mathrm{A}$. reclaims them $(r)$.

But it does not follow that because there is no true contract, there may not be cases falling within this

(p) Dngtale r. Lurering (1si.j) I. R. IO C. I'. 196\%. H L. J. ('. I'. 197.

(4) ('p. dirfa of I'ollock 1'.l. :-2; J..J. Ex. at 1). 332. The effeet of a subseruent expres promine to pay for work already clone comes under the dretrine of Consideration.

(r) It is prulent, however, to inform the semter that the cromls sent without requent are at his disprosal and ri-k.
Juties quasi e.r contractu in English law. 
Inclian Con. tract Act deals with them separately.

Pelformance of conditions de. as acceptance. general description in which it is just and expedient that an obligation analogous to contract should be imposed upon the person receiving the benefit. In fact there are such cases: and as the forms of our common law did not recognize obligations quasi ex contractu in any distinct manner, these cases were dealt with by the fiction of an implied previous request, which often had to be supplemented (as in the action for money had and received) by an equally fictitions promise. The promise, actual or fictitious, was then supposed to relate back to the fictitious request, so that the transaction which was the real foundation of the matter was treated as forming the consideration in a fictitious contract of the regular type. Here, as in many other instances, the law was content to rest in a compromise between the forms of pleading and the convenience of mankind. These fictions have long ceased to appear on the face of our pleadings, but they have become so established in legal language that it is still necessary to understand them $(s)$. The Indian Act provides for matters of this lind more simply in form and more comprehensively in substance than our present law, by a separate chapter, entitled "Of certain Relations resembling those created by Contract" (ss. 68-72, cp. s. 73). The ter'm constructice contract might properly be applied to these obligations; it would be exactly analogous to "constructive possession " and "constructive notice." It is adopted, we helieve for the first time, in the comprehensive work on the Laws of England which bears Lord Halsbury's name. The term Quasi-Contract is now generally recognized.

A corollary from the general principle of tacit acceptance, which in some classes of cases is of considerable

(*) For detail see notes to Lamy. leigh" r. Brutheruit in $1 \mathrm{Sm}$. L. C..,

and Oxberne v. Rogers. 1 Wms raunel. $33 \%$. 
importance, is thus expressed by the Indian Contract Act (s. 8):-

"Performance of the conditions of " proposal, or the acceptance of any consideration for a reciprocal promise which may be offered with a proposal, is an acceptance of the proposal."

This rule, though it might have heen more aptly worded, substantially contains the true legal theory of offers of reward made by public advertisement for the procuring of information, the restoration of lost property, and the like. On such offers actions have many times been brought with success by persons who had done the things required as the condition of ohtaining the reward.

It appears to have been once held that even after performance an offer thus male did not become a binding promise, because " it was not averred nor declared to whom the promise was made" $(t)$. But the established modern doctrine is that there is a contract with any person who performs the condition mentioned in the advertisement (u). That is, the advertisement is a proposal which is accepted by performance of the conditions. It is an offer to become liable to any person who happens to fulfil the contract of which it is the offer $(v)$. Until some person has done this, it is a proposal and no more. It ripens into a promise only when its conditions are fully satisfied. As Sir IV. Anson has well put it, "an offer need not be made to an ascertained person, but no contract can arise until it has been accepted by an ascertained person " $(x)$.

(t) Noy, $11 ; 1$ liolle Ab. fi M. pl. 1.

(i) Il illiams v. rarurdine (1833) + li. a Acl. 6:21, 38 R. Ii. 328.

(r) lear Willes.J. Sigemere v. Hurd-

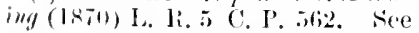

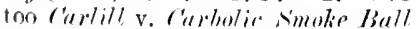
(iv. [189.3] I (3. B. 2.;6, per Lind]ey 1..J. at 1. 262, per bowen L..J. at
Offers by alvertisement. 
In the same manner each bidding at a sale by auction is a proposal; and when a particular bid is aecepted by the fall of the hammer (but not before), there is a complete contract with the particular bidder to whom the lot is knocked down $(y)$.

I)ifticulties in working ont the
principle.

The principle is sufficiently clear, but its application is not wholly free from difficulties. These are partly reducible to questions of fact or of interpretation, but partly arise from decisions which appear to give some countenance to a fallacious theory.

Distinetion between offer and invita. tion of offers.

First, we have to consider in particular cases whether some act or announcement of one of the parties is really the proposal of a contract, or only an invitation to other persons to make proposals for his consideration (z). This depends on the intention of the parties as collected from their language and the nature of the transaction, and the question is one either of pure fact or of construction. Evidently it may be an important one, but due weight has not always been given to it.

The proposal of a definite service to be done for reward, which is in fact a request (in the sense of the ordinary English law of contract) for that particular service, though not addressed to any one individually, is quite different in its nature from a declaration to all whom it may concern that one is willing to do business with them in a particular manner. The person who publishes such an invitation does indeed contemplate that people who choose to act on it will do whatever is necessary to put themselves in a position to arail themselves of it. But acts so done are merely incidental to the real object; they are not elements of a contract but preliminaries. It does not seem reasonable to construe

(y) P'eyne v. r'are (17*9) 3 T. R. 14s, 1 li. li. 6is. Prof. Ianglell (Summary. \$ 1!) thomght it would have been better to hold that every biul constitutes ". an actual sale, subject to the condition that no one else shall bid higher."

(i) In German this is Aufforderung ill Anträgen as opposed to Antrag. 
such preliminaries into the consideration for a contract which the parties had no intention of making. Yet there are some modern decisions which seem to disregard the distinction between mere invitations or declarations of intention and binding contracts (a). We shall now examine these cases.

In Denton v. G. N. Railway Co. (b), the facts were shortly these: The plaintiff had come from London to Peterborough, had done his business there, and wanted to go on to Hull the same night. He had made his arrangements on the faith of the company's current time-tables, and presented himself in due time at the Peterborough station, applied for a ticket to Hull by a train advertised in those tables as running to Hull at 7.20 p.m., and offered to pay the proper fare. The defendant company's clerk refused to issue such a ticket, for the reason that the 7.20 train no longer went to Hull. The fact was that beyond Milford Junction the line to Hull belonged to the North Eastern Railway Company, who formerly ran a train corresponding with the Great Northern train, for which the Great Northern Railway Company issued through tickets by arrangement between the two companies. This corresponding train had now been taken off by the N. E. R. Co., but the G. N. R. time - table had not been altered. The plaintiff was unable to go further than Milford . Junction that night, and so missed an appointment at IFull and sustained damage. The cause was removed from a County Court into the Queen's Bench, and the question was whether on the facts as stated in a case for tho opinion of the Court the plaintiff could recover $(c)$.

(a) Compare the jutgments in Hurris v. Nirletrom (1si:?) 1. li. 8 Q. 1., 2466, 1.2 I., J. Q. 1:. 171 .

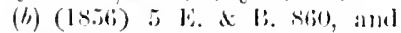
better in 2: 1. I. (2. 18. 124). wher: the cave stated is given at length: loi) R. li. 33is. (c) As torthe measure of damages, which bere was not in dispute, see Ilamlın v. C. I. IR. Co. (1sit) 1 II. \& $\mathrm{x}, 40 \mathrm{~s}, 26$ 1, J. Ex. 20. 10.i li. li. fitg (where a ticket Ja ving been taken there was an mupustimathle comblatet).
Examination of cases: lentoul. (i. N. Ii. Co. 
It was held by Lord Campbell C.J. and Wightman J. that when anyone offered to take a ticket to any of the places to which the train was advertised to carry passengers the company contracted with him to receive him as a passenger to that place according to the advertisement. Lord Camplell treated the statement in the time-table as a conditional promise which on the condition being performed became absolute. This proposition, reduced to exact language, amounts to saying that the time-table is a proposal, or part of a proposal, addressed to all intending passengers and sufficiently accepted by tender of the fare at the station in time for the advertised train. Crompton J. $(d)$ did not accept this view, nor was it necessary to the actual decision: for the Court had only to say whether on the given facts the plaintiff could succeed in any form of action, and they were unanimously of opinion that there was a good cause of action in tort for a false representation; an opinion itself questionable, but not in this place $(c)$.

Warlum $r$. II:irisun.

In Marlow r. Harrison ( $f$ ), a sale by auction was amnounced as without reserve, the name of the owner not being disclosed. The lot was put up, but in fact bought in by the owner. The plaintiff, who was the highest real hidcler, sued the anctioneer as on a contract to complete the sale as the owner's agent. The Court of Queen's Bench held that this was wrong; the Court of Exchequer Chamber affirmed the judgment on the pleadings as they stood, but thought the facts did show another cause of action. Watson and Martin BB. and Byles J. considered that the anctioneer contracted with the highest bona fide bidler that the sale should be without reserve. They said they could not distinguish the case from that of a rewarl offered by advertisement,

(d) The fuller regunt of his julge-

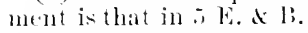

(a) Siere l'ellocels on Torts, sth ed. 245. But and preface to 105 li. li.

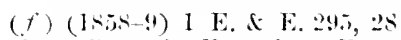
I. I. O. l, ls, in Ex. ('h. I E. E L. 309, 24 L. J. Q. 1. 14; 117 Ii. 1..2.21!. 
or of a statement in a time-table, thus holding in effect (contrary to the general rule as to sales by auction) that where the sale is without reserve the contract is completed not by the acceptance of a bidding, but by the bidding itself, subject to the condition that no higher bona fide bidder appears. In other words, every bich is in such a case not a mere proposal but a conditional acceptance. Willes J. and Bramwell 33. preferred to say that the auctioneer by his announcement warranted that he had authority to sell without reserve, and might be sued for a breach of such warranty. The result was that leave was given to the plaintiff to amend and proceed to a new trial, which, however, was not done (y). The opinions expressed by the judges, therefore, are not equivalent to the actual judgment of a Court of Error, and have been in fact regarded with some doubt in a later case where the Court of Queen's Bench decided that at all events an auctioneer whose principal is disclosed by the conditions of sale does not contract personally that the sale shall be without reserve $(h)$. Luter, again, the same Court held that when an auctioneer in good faith advertises a sale of certain goods, he does not by that advertisement alone enter into any contract. or warranty with those who attend the sale that the goods shall be actually sold (i). In an analogons case $(k)$ it was decided that a simple offer of stock in

(y) The parties aureed to a strt prorssus: see note in lhe l. J. report.

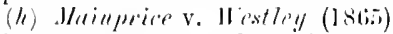

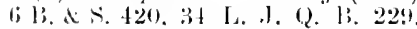
(See further linimber v, Howlins [1!\%) 2 K. 13.322. 83 L. I. K. R. ibl. Which adts nothine on the point before ns.) But in .lohtenston v. Royes [18!9] 2 e th. 7.3, tis 1..J. ('li. 12:5, Corens-Hawly J. Was prefared to hold on the atuthority ol

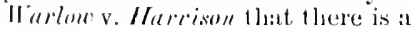
centratel by the ventor with the highest bidker that he shall be the pureliaser, distinet from the ronltract of sale. 'lite platintifl fatilet (min anther point.

(i) Marris v. Vinkerson (1sis:

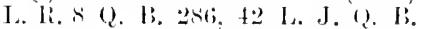
171.

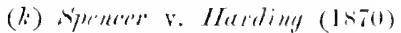

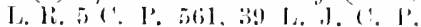
332. In each of these cases we tave the manimous derision of at

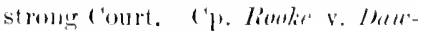
soru [1s:5)] 1 ('h. 150.
Doct rine subsequently doubted and not extenderl. 
trade for sale by tender does not amount to a contract to sell to the person who makes the highest tender.

Difficulties of Dinton $i$. G. N. li. Co. and II arlow e. Harrisou.
Camminger Farquhiar.

The doctrine of these cases, though capable, as we have seen, of being expressed in a manner conformable to the normal analysis of contract, goes to the utmost limit warranted by sound principle, and is not likely to be extended. If a man advertises that he has goods to sell at a certain price, does he contract with any one who comes and offers to buy those goods that until further notice communicated to the intending buyer he will sell them at the adrertised price? $(l)$. Again, does the manager of a theatre contract with every one who comes to the theatre and is rearly to pay for a place that the piece amounced shall be performed ? or do directors or committee-men who summon a meeting contract with all who come that the meeting shall he held? Offers to negotiate, in other worde expressions of willingness to consider offers, must not he confounded with offers to be bound $(m)$.

The distinction hetween the proposal of a contract and the mere preliminaries is clearly brought ont by a later decision of the Court of Appeal. A "proposal " in the usual form was made to a life assurance society; the actuary wrote a letter stating that the proposal had been accepted at a certain freminm, but adding this note: "No assulance can take platee until the first premium is paid." Afterwards, and before the time limited for that payment, an acejlent happened to the assured which affected his health, and the society, being informed of this, refused the premium when tendered. It was held that they were entitled to do so. The letter of acceptance did not conclude a contract, first, because the amount of premium was then first specified, and

(7) See per ( rompton J. in Ilen-

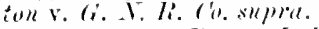

('il) Soe per Browen Is..t. ravlill

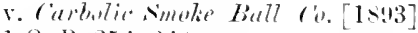
1 Q. R. 2.6t, 24s. 
the assured had therefore not consented to that material term of the agreement; next, hecaluse of the express declaration of contrary intention $(n)$.

Another matter for remark is the effect of notice of revocation. Suppose the traveller in Denton's case har seen and read a new and correct edition of the timetable in the booking-office immediately before he offered to take his ticket. This would clearly have been a revocation of the proposal of the company held out in the incorrect time-table, and accorlingly no contract comld arise. Similarly if on putting up a particular lot the auctioneer expressly retracterl as to that lot the statement of the sale being without reserve, there could be no such contract with the highest bona fide bidder as supposed in Warlow v. Harrison (o) : yet the traveller"s or bidder's grievance would be the same.

There is also difficulty in dotermining what are the contents of the contract supposed to be made. In the case of the time-tahle, for example, we have a contract said to he conchuded by the mese demand of a ticket and tender of the fare, a contract not to cary the passenger: but to issue a ticket. So in the case of the anction we have a contract alleger to be eomplete not on the aceeptance but on thr making of a bicl.

Another difficulty (though for English lawyers hardly a serious one) is laised by the suggestion that in these cases the first offer or annomeement is not a mere proposal, but constitutes at once a kind of floating contrat with the unascertained person, if any, who shall fulfil

Hifticulty of fixing the silpowised contract. (n) Firming v. Fiarqular (18si) 16 Q. 13. Liv. 727 . 5i I. .1. 9. B.

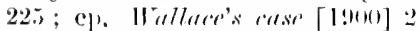
('h. 67. 69) I., J. Ch. $77 \%$ application for shates muler an amaleramation agresment liy a sharehoriber in the old complany).

(o) The (outinental luetrine lhat the revoration must be so communi- cater as to amount to reasmable motice is not arlmisible in our law ; sec note to Frost v. Kniglet (1870) L. Ji.5 Ex.at 1..3337, and ip. 27-"?!, betow. As to the sumewhat analowells sllgegestom marle in that cast, sees, e. in Ex. (1, I, li. 7 lix. at p. 117 .
Munt there le a real acceptance?

Theory of thating obligation. 
the prescribed condition. Sarigny quite justly held that on this theory the right of action could not be supported: there cannot he a rinculum iuris with one end loose; but he strangely missed the true explanation $(p)$. To a certain extent, however, this notion of a floating obligation is countenanced by the language of the judges in the cases above discussed, and also in the much earlier case of IVilliums r. Curutine $(q)$. There a reward had bern offered by the defendant for information which should lead to the discovery of a murder. A statement which had that offect was made by the plaintiff, but not (as the jury found) with a view to obtaining the reward; it does not appear to whom it was made, or whether with any knowledge that a reward had heen offered. The Court held, nevertheless, that the plaintiff hat a good cause of action, because "there was a contract with any peron who performed the condition mentioned in the adrertirement," and the motive with which the information was given was immaterial: but on this it must be observed that the question is not of motive but of intention. The decision seems to set up a contract without any privity between the parties. Such a doctrine cannot now be received $(r)$, thongh the decision may have been right on the facts. There cannot be an acceptance constituting a contract without any communication of the proposal to the acceptor. The question may arise whether the party claiming the reward has in fact performed the required condition according to the terms of the advertisement. In Carlill r. Carbolic Smoke Bull Co. (s), it arose in a curious

(p) Ol). 2. (n. Vet within a few pages he does grite the true analysis for the not li-similar case of a sale by auction.

(q) $(1+33)+$ R, \& A,l. li21. A. C.

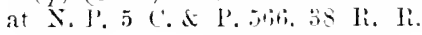
$32 \mathrm{~s}$. (r) ('f. Langilell. \$ 3. The solitary molern ease of Gibbons $x$. Irostor (1891) bt L. T. 5!4, is clearly nol law as reported.

(*) $[1593] 1$ (2. 1,. 2.5ti, 62 L. J. Q. 1.. 2.7, C.A. 
manner. The advertisement of a reunedy for influenzal and similar diseases offered a sum of money to any ono who should contract such disease "after wsing " the remedy according to the directions supplied with it, and for a certain time. A buyer who used the remely as directed, and caught influenza while still using it, was held entitled to the sum offered, notwithstanding the argument strenuously wrged for the defondant that the offer was ton vague to bo taken seriously, and the porformance could not be rerified.

The Supreme Court of the linited Nitates has hold that a general proposal made hy public annomnermont may" Revomition of iffer by be effectually revolied by an annomneomont of roual ment. publieity, such as an alvertisement in the samo nowspaper, even as against a person who afterwards acts on the proposal not knowing that it has been revoked. For "he should have known," it is said, "that it could bo" revolied in the manner in which it was marle" $(t)$. In other words, the proposal is treated as subject to a tacit condition that it may be revoked by an announcement made by the same means. This may be a convenient rule, and may perhaps be supported as a fair inforence of fact from the habits of the newspaper-reading part of mankind: yet it seems a rather strong piece of judicial legislation.

Other kinds of general proposals have also been dealt with as capable of acceptance hy any one to whose liands they might come.

In Ex parte Asiatic Bankiny Corporation (u), thr following letter of credit had been givon hy Igra and Masterman's Bank to J)ickson, 'Tatham and Co.

Other general tropiosals. (f) Shury v. Inited situtes (1) !2 U. S. 73 .

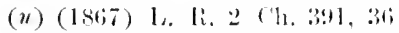

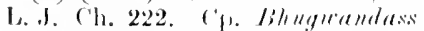

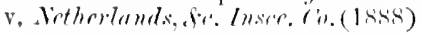

11 Alp. Ca. (J. (․) 83. decisled on the grommet that the "onen coser" was a propreal of insurance aul. dressed to any one laving insmable interest in the cargr. 
"No. 394. You are hereby anthorized to draw mon this bank at six

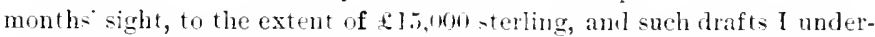
take duly to bonour on presentation. This crelit will remain in force for twelve months from this dite. and parties negotiating bills under it are requested to indore prarticulars on the back hereof. The bills must speeify that they are drawn muler cretit No. 394, of the 33st of October. $1855 . "$

The Asiatic Banking Corporation held for ralue bills drawn on the Agrat and Materman's Bank under this letter; the Bank stroped payment before the bills were presented for acceptance, and 1)ickson, Tatham and Co. were indebted to the Bank in an amount exceeding what was due on the bills: but the Corporation claimed nevertheless to prore in the winding-up for the amount, one of the grounds being "that the letter shown to the person adrancing money constituted, when money was advanced on the faith of it, a contract by the Bank to accept the hills." Cairns L.J. adopted this view, holding that the letter did amount to "a general invitation " to take bills drawn hy Dickson, Tatham and Co. on the Agra and Masterman's Bank, on the assurance that the Agra and Mis-terman's Bank would accept such bills on presentation; and that the acceptance of the offer in this letter by the Asiatic Banking Corporation constituted a binding legal contract against the Agra and This care free Masterman's Bank $(x)$. The difficulties abore discussed from the difficulty in Dentrin: (i. N. li. Co. do not seem to exist in this case. From an open letter of credit (containing too in this instance an express

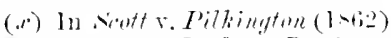
2 H. . . 511 . 31 I. J. (2. B. B. in the wher hand. an action was bromght on a julgment of the cupreme Court of New York, on a very similar state of filcts. The decisin of the English courts was that the law alplicalle to the cance was the law of New Sork and that the judgment having been griren by a coml of competent jurisdiction in a case to which the lucal jaw was froper!y anplicable. there was mo rom to question its correctne.. in an English court. So far as any opinion was expressed by the court as to what shnld have been the decision on the same facts in a case enverned by the law of Englant. it was against any right of action at law being actuirel by the bill-holders. This howerer was hy the way aml as a encession to the iefendants. and is therefore no pusitive authority. 
request to persons negotiating bills under it to indorse particulars) there may be inferred without any violence either to law or to common reason a proposal or request by the author of the letter to the mercantile public to advance money on the faith of the undertaking expressed in the letter. This undertaking must then he treated as addressed to any one who shall so advance money: the thing to be performed by way of consideration for the undertaking is definite and substantial, and is in fact the main object of the transaction. If any question arose as to a revocation of the proposal, it would be decided by the rules which apply to the revocation of proposals made by letter in general $(y)$.

The hearing of the Statute of Frauds on these contracts made hy advertisements or general offers was discussed incidentally in a case brought before the Judicial Committee of the Privy Council on appeal from the Supreme Court of New South Wales $(z)$. It is settled that the requirements of the statute in the cases where it applies are generally not satisfied unless the written evidence of the contract shows who hoth the contracting parties are. But it was suggested in the Colonial Court that in the case of a proposal made by advertisement, where the nature of the contract (e.y., a guaranty) was such as to hring it within the statute, the advertisement itself might be a sufficient memorandum, the other party being indicated as far as the nature of the transaction would arlmit (a). The Judicial Committee, however, showed a strong inclination to think that this view is not tenable, and that in such a case the evidence required hy the statute would not be complete without some further writing to show who in particular had accepted the proposal. It was observed

(y) See however sthury v. Inited States, 11. 23, above.

(z) Il illiams v. Byrues (1s6;3) 1
Moo. P. ('. N. S. 1:4. 15.4 .
Sialute of Frauels and contracts by alvertisement : dictu in Williams $r$. Byrnes. 
Aceeptance hy art when complete.
Fulmation of contract by indilexet erimmunication,

that as a matter of fact the cases on advertisements had been of such a kind that the statute did not apply to them, and it was a mere circumstance that the advertisement was in writing $(b)$. We are not aware of the point having arisen in any later case.

The speculative question has lately been asked at what point of time acceptance by an act is complete, and it is suggested that $A$. may request $B$. to do something, say to move a piece of furniture, for reward which $A$. names, that 13. may do a substantial part of the work, and A. may rerolis his offer any time before the work is complete, leaving $B$. without remedy or at least any remedy on a contract. But surely the acceptance is complete as soom as P. has made an unequirocal heginning of the performance requested, a "commencement d'exécution," to use the term familiar in French law. Whether anything is payable before the whole of the work is done depends on the terms express or implied of A.'s offer on which B. acts. As a matter of fact $A . '$ s offer will almost always be a conditional offer, and will become, on acceptance, a promise conditional on the work being done within a reasonable time and otherwise competently. Such a conditional promise is still a prounise, and wholly different from a revocable offer $(c)$.

It is possible for a contract to be formed without any direct communication between the parties or any per-

(b) See I Xim. I'. C. X. S. at 1. 1:2. The language of the headnote is mistemling : there is nu suggestion in the jurlgment of any -uch loposition of law as that the statute of Frauls is not applicable to contracts made in this manner.

(r) Clarence D. Ashley, in Harv. Law Rev. xxiis. 1.9. "()ffers calling for a consileration other than a counter pomise" a sury ingenious exercise in leral sophistry. The learned author assumes that the act which is sufficient to constitute acceptance must be co-extensive with the whole performance requesterl; ". until the entire consideration is furnished there is nothing but an offer." Now aceeptance is one thing and consileration quite another. A more plausible query is whether the beginning of performance in acceptance of a request implies any fromise to complete the performance (p. 16I). But here note that an action lies for misfeasance in a voluntary undertaking whether there is a contract or not. 
sons who in an orlinary sense are their agents. Where competitors enter for a club race unter express rules prescribed or adopted by the managing committee, and those rules declare that any competitor breaking them shall be liable for dimages arising therefrom, this is sufficient to create a mutual contract hetween the competitors to be liahle for and discharge any such damages $(d)$. Here the secrotary of the club who receives the entries may be regarded as an agent to receive, as between the enmpetitors, the offer of every competitor to be bound by the rules, and the aceptance of every other competitor ; and his anthority to do so is implied in the nature of the transaction. There may be cases of this lind in which it woukt be hard, if the question were raised, to determine whother the parties intended to ereate a logal or a merely bonorary obligation.

\section{Revocation.}

An offer may be revoked at any tine hefore aceptance, but not afterwards.

lierncation of offer.

For before acceptance there is mo agreement, and therefore the proposer cannot be bound to anything $(e)$. So that even if he purports to give a definite time for acceptance, he is free to withdraw his proposal before that time has elapsed. He is not bound to keep it open unless there is a distinct contract to that effect, founded on a distinct consideration. If in the morning $A$. offers goods to B. for sale at a cortain price, and gives B. till Cinker. four o'clock in the afternoon to make up his mind, yet A. may sell the goods to $\mathrm{C}$. at any time before four

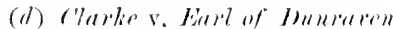

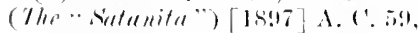
fiti T... I. H. The only question serionsly argued in the H. L. was on the contruction of the rules. It would seem the contracts must all be referrerl to th: date when the entries are empleted. Cp. 1). T. above.

(e) The same rule applies to a propesal to vary an existing atgree-

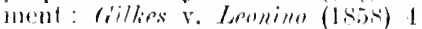
('. I. N. S. 45\%. 
o'clock, so long as B. has not accepted his offer $(f)$. But if B. were to say to A.: "At present I do not know, but the refusal of your offer for a definite time is worth something to me: I will give you so much to keep it open till four o'clock, " and A. were to agree to this, then A. would be bound to keep his offer open, not by the offer itsclf, but by the subsequent indepennickinun dent contract (. 1$)$. If $A$. on Wednesday hands to B. a r. Ioulis. memorandum offering to sell a house at a certain price, with a postscript stating that the offer is to be "left over" till nine o'clock on Friday morning, A. may nevertheless sell the house to $C$. at any time before the offer is accelted hy $B$. If $B$., with notice of $A$.'s dealing with C., tenders a formal acceptance to $A$., this is inoperative $(h)$. It is different in modern Roman law. There a promise to keep a proposal open for a definite time is treated as binding, as incleed there appears no reason why it should not he in a system to which the doctrine of consideration is foreign: nay, there is held

$(f)$ Aclunitted in (inlere r. (1), toy

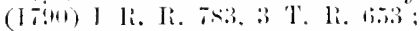
atfl. in lix. (he see note: Finch sel. (a. 2nel al. s.). The decision grese farther, an i has leen the subject of mieh eritici-m. For the conflicting views see lienjamin on sale. ith cil. bi. M7. and lang-

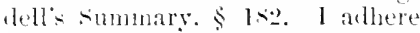
to Langell"s view that it cannot les -lupurted in any sense. If the lefembats offer had been revoked b. fore th" paratiff's aceeptance, it was for the defendant to jeard and yore it. The decision wuml hare been right if the action has been on a promine to ketp the wffer open. ac seems to be supposed by

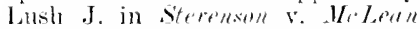

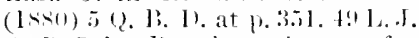
Q. P. 7ul. lint the action was for nut clelivering goods. as on a complete bargain and sale: and this was insisted upon in the argument. The Court may pussibly have sup- posed that arceptance of an offer mate any appreeiable time before was not eomplete without a fresh sign of consent from the proposer. ('i. Kennedy r. Lee (IS17) 3 Mer. 4t1, 17 R. K. 110; Head v. Diggon (1528) 3 II. \& R. 97, showing that this fallacr was current much later.

(g) $1 \mathrm{~W}$ ' find something like this in early Germanic law. where earnest on a sale was not payment on account of a completed cont ract, but the price of the seller"s forlearance to sell to any other frerson for a limiter time. Hlensler. Inst. des I), I'. li. ii. 2.it, ep. (ilanr. x. 14. showing the law to be then still doubtful in England.

(h) Divkinsmen v. Hodds (1876) 2 ('h. liv. 463. 45 L. J. ('h. 77. The case sugtrests. but does not deeirle. amother question. which will be present ly considered. (int ra Langlell. Summary, p. 24f; and on prineiple perhaps rightly. 
in effect to be in every proposal an implied promise to keep it open for a reasonable time (i). In our own law the effect of naming a definite time in the proposal is simply negative and for the proposer"s henefit; that is, it operates as a warning that an acceptance will not be received after the lapse of the time named, not as an undertaking that if given sooner it shall be $(j)$. In fact, the proposal so limited comes to an end of itself at the end of that time, and there is nothing for the other party to accept. This leads us to the next rule, namely:-

\section{Conditions of Offer.}

The proposer may prescribe a certain time within Determinawhich the proposal is to be accepted, and the manner and form in which it is to be accepted. If no time is prescribed, the acceptance must be communicated to him within a reasonable time. In neither case is the acceptor answerable for any delay which is the comsequence of the proposer's own default. If no manner of form is prescribed, the acceptance may be communicated in any reasonable or usual manner or form.

This is almost self-evident, standing alone; we shall see the importance of not losing sight of it in dealing with the difficulties to be presently considered. Notre, however, that though the proposer mat prescribe a form or time of acceptance, le cannot preseribe a form ar time of refusal, so as to fix a contract on the othere party if he does not refuse in some particular way or within some particular time $(k)$.

Among other conditions, the preponal may prescribe a particular place for acceptance, and if it does so, an

(i) See 1. 1.. : 1 Kx. $337, n$.

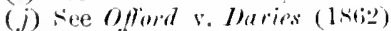
12 C. B. N.'s. 71 s, finch sel. ('a. 87. where the only anduable artistion was whether the defemlant's guaranty limited in time was it (ontrat. on only a stamling offer sis linited.

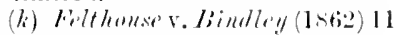

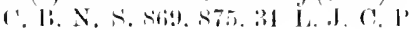
201. tion of offec by lapke of b)escriber 11 reasomable time. 
acceptance elsewhere will not do $(l)$. The question in cases of this kind is whether the condition as to time, place, or manner of acceptance was in fact part of the terms of the proposal.

There is direct authority for the statement that the proposal must at all events be taken as limited to a reasonable time $(\mathrm{m})$; nor has it ever been openly disputed. The rule is obviously required by convenience and justice. It may be that the proposer has no means of making a revocation known (e.g., if the other party changes his address without notice to him, or goes on a long journey), and he cannot be expected to wait for an unlimited time. Words of present obligation (but not capable of operating to that effect) have been held to constitute an offer with limit of time $(n)$.

\section{Limits of Rerocation.}

Rerocation of proposal must bes communicated beforte itceptance.

A proposal is revoked by communication to the other party of the proposer's intention to revoke it, and the revocation can take effect only when that communication is made before acceptance.

The communication ma be either express or tacit, and notice received in fart, whether from the proposer or from any one in his behalf or otherwise, is a sufficient (o)mmunication.

A person who has mate an offer must be considered as continuously making it until he has hrought to the knowledge of the person to whom it was made that it is withdrawn (o). But that person's refusal or counteroffer puts an end to the original offer $(p)$.

(7) Eliasun r. Henshulle (181!) (Sup. ('t. C. S.) 4 Wheat. 2:s. langiell. siel. ('a. on ront. ts. Finch stel. ('a. iti.

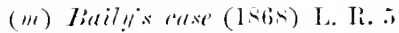
E. 42R. I. k., 3 (h. 5!92, 3 L. J.

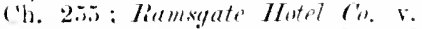
Hontefiore; same lo. vo Goldsmid (I titi) L. R. l Ex. lon. 35 L. .J.
Fix. $\$(1)$

(11) Itindleys case $[1896] 2 \mathrm{Ch}$. 121, (is) L. J. ('h. 5!1, C, A.

(a) Lond Hersehell. Itentharn s. Frreser [1s:12] 2 Ch. 27, 31, til L. J. ('h. 373. iti l. T. 439.

(1') Hyde s. IIrench (1st(1) 3 Bear. 334.22 R. R. 144. 
The first point under this head is that an express revocation communicated after aceeptance, though determined upon before the date of the acceptance, is too late. This was decided in 1880 in two distinet cases (q). It will suffice to give shortly the facts of the carlier one $(r)$. The defendants at Cardiff wrote to the plaintiffs at New York on the 1st of October, 1879, oflering for sale 1000 boxes of tinplates on certain terms. Their letter was received on the 11th, and on the same day the plaintiffs accepted the offer by telegraph, confirming this by a letter sent on the 15th. Meanwhile the defendants on the 8th of October had posted a letter withdrawing their offer of the 1st: this reached the plaintiffs on the 20th. The plaintiffs insisted on completion of the contract; the defendants maintained that there was no contract, the offer having been, in their view, withdrawn before the acceptance was either received or despatched. Lindley J. stated as follows the questions to be considered: "1. Whether" a withdrowal of an offer" has any effect until it is commminicaterl to the person to whom the offer has been sent? 2. Whether posting a letter of withdrawal is a communication to the person to whom the letter is sent?" The first he answered in the negative, on the principle "that a state of mind not notified cammot be regarded in dealings betweren man and man, and that an meommunicated revoeation is for all practical purposes and in point of law no revocation at all." The second he likewise answered in the negative, on grounds of both principle and convenience, and notwithstanding an apparent, hut only apparent, inconsistency with the rule as to accoptances hy letter which will he presently considered. This doetrine hats been

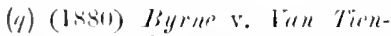

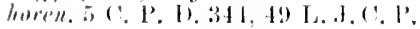

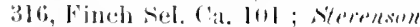

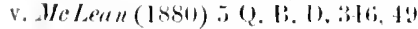

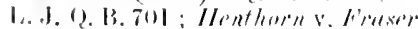

lievocation after acreptance tor late.

byrne r. Van T'ienhoven. 
As to tacit reveation.

accepted hy the Supreme Court of the United States (s).

It seems impossible to find any reason in principle why the necessity for communication should be less in the case of a revocation which is made not by words but by conduct, as by disposing to some one else of a thing offered for sale. Nor does it seem practicable in the face of the decisions just cited, though they do not actually cover such a case, to say that any such difference is recognized by the law of England. The authority most in point, Dickinson v. Dodds $(t)$, is not of itself decisive. The facts were these. A. offered in writing to sell certain houses to $B$., adding a statement that the offer was to be "left over" until a time named; which statement, as we have already seen, could have no legal effect unless to warn B. that an acceptance would not be received at any later time. B. made up his mind the next morning to accept, but delayed communicating his acceptance to A. In the course of the day he heard from a person who was acting as his agent in the matter that $A$. had meanwhile offered or agreed to sell the property to C. Early on the following day (and within the time limited by $A$.'s memorandum) B. sought out A. and handed a formal acceptance to him: but $A$. answered, "You are ton late. I have soll the property." It was held in the first instance by Bacon V.C. that A. had made to $B$. an offer which up to the time of acceptance he had not reroked, and that consequently there was a binding contract between $A$. and $B$. But in the Comrt of Apreal it was said that, although no "express and actual withdrawal of the offer" had reached B., yet by his own showing $B$., when he tendered his acceptance to $A$., well knew that $A$. had done what was incon-

(*) Putrick r. Butemen (1893) 149 C.... 411,424 .

(t) (187ti) 2 (h. lis. this. 4is
I. J. Ch. 77\%. One or two immaterial details are omitted in stating the facts. 
sistent with a continued intention of contracting with B. Knowing this, B. could not by a formal acceptance force a contract on A. (u). It does not appear that the knowledge which $B$. in fact had was conveyed to him or his agent by or through A., or any one intending to communicate it on A.'s behalf. Yet the Comt held that knowledge in point of fact of the proposer's changed intention, however it reaches the other party, will make the proposer's conduct a sufficient revocation. But what if $B$. had communicated his acceptance to $A$. without knowing anything of A.'s dealings with C.? This question remains open, and must be considered on principle.

Suppose that A. offers to sell one hundred tons of iron to B., not designating any specific lot of iron, and that $B$. desires time to consider, and $A$. assents. Then A. meets with C., they talk of the price of iron, and C. offers A. a better price than he has asked from B., and they strike a bargain for a hundred tons. Then $B$. returns, and in ignorance of $\mathrm{A}$.'s dealings with $\mathrm{C}$. accepts A.'s offer formerly made to him. Here are manifestly two good contracts. A. is bonnd to delivel 100 tons of iron to B. at one price, and 100 tons to C $C$ at another. And if A. has in fact only 100 tons, and was thinking only of those humderl tons, it makes no difference. He would be equally bound to B. and (?. if he had none. He must deliver them iron of the quantity and quality contracted for, or pay damages. How then will the case stand if, other ciremustances being the same, the dealing is for specific goods, or for a house? Here it is impossible that A. Hould perform his agree-

(11) The hendnote sayk: " semble. that the sale of the forperty 10 it third person woukd of itself anomit to a withluawal of the offer, even although the persin to whism the offer was tijet mark hanl no knowlerge of the sale." bat his seem- unwarranted by the julgments. See the remarks of James I... at p. 172, and of Mellish L.J. at 1. tis. and per Lord Herwhell,

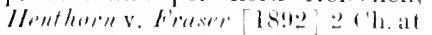
1. . : 3.
Pussibility of double acceptance. 
ment with both B. and C., and therefore they cannot both make him perform it; but that is no reason why he should not be answerable to both of them. The one who does not get performance may have damages. It remains to ask which of them shall have the option of claiming performance, if the contract is otherwise such that its performance can be specifically enforced. The most convenient solution would seem to be that he whose acceptance is first in point of time should have the priority: for the preference must be given to some one, and the first acceptance makes the first complete contract. There is no reason for making the contract relate back for this purpose to the date of the proposal. This is consistent with everything that was really decided in Dickinson $v$. Dodds $(v)$. The reasons given for that decision cannot, it is submitted, be relied on.

It is right to add that Cooke v. Oxley $(w)$ may be so read as to support the opinion that a tacit revocation need not be communicated at all. But the apparent inference to this effect is expressly rejected in Sterenson v. IIcLean $(x)$. If Cooke r. Oxley be still iuthority for anything, it is not authority for that.

Limits of Acceptance or of its Rerocation.

('ommunication w a areptance :

liniliteral amd bilateral :10reements.

'L'here is a material distinction, though it is not fully recognized in the language of our atuthorities, between the acceptance of an offer which askis lor a promise, and of an offer which asks for an act, as the condition of the offer becoming a promise. Where the acceptance is to consist of a promise, it must be communicated to the proposer $(y)$. But where the acceptance is to consist

(r) 2 ('h, Llix, tij3, t5 I. J. ('h, 7it. Note that the suit was fon specitic perfurmance. ambl cp. langdell, Summary, 245-6, and Anson. 4-2-t. There was alon a claim for dimatges. but alparently nothing wits said : blust it.

(w) $(173+4) \mid$ Ii. li. $7 \times 3,3 \mathrm{~T} . \mathrm{li}$. 633.

(x) $(18>0) 5$ Q. B. D. at p. 3is. 4! 1. J. Q. B. 701.

(y) Mosley v. Tinkler (1835) 1 C. II. A R. 1992. to R. R. 16.5: Russell v. Thorntom $(1859)$ + H. a N. iss.

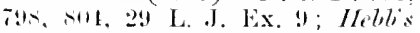
arse (lntio) L. R. 4 Ein. 9. 
of an act - as despatching goods ordered by post - it seems that no further communication of the aceeptance is necessary than the performance of the proposed at, or at any rate the proposer may dispense with express communication, and an intention to dispense with it may be somewhat readily inferred from the nature of the transaction $(z)$. In the former case the proposed contract is called bilateral, in the latter milateral, these terms have long been current in America lout are little used in England. In America the presumption in the case of an unilateral contract is against any communication being needed beyond the performance of the act requested.

Further, even when the acceptance consists of a promise, and therefore must be communicated, any reasonable means of communication prescribed or contemplated by the proposer are deemed sufficient as between the acceptor and himself.

If an acceptance by means wholly or partly beyond the sender's control, such as the publice post or tolegraph $(a)$, is contemplated by the parties, then an acceptance so despatched is complete as against the proposer from the time of its despatch out of the sender's control; and, what is more, is eflectual notwithstanding any miscalriage or delay in its fansmis sion happening alter such despateh.

the parties are presimed to eontemplate aleceptancer hy post or telegraph whenever the eiremmstances ane such as to make such acceptance reasonable in the usual course of business (b).

It should seem obvious that an uncommunicated mental assent, since it is neither the communication of

Means

anthorized by propuser.

Post of tele. grath.

(ieneral rule of commmuncation.

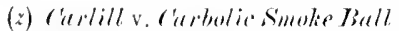

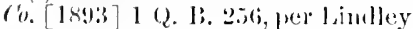
1. I, at 19. 26.2-3, liwwen 1..J at 1). 26 ì.

(a) As to the felegrath leing on the same fonting as letter post, l'meall r. O'( 1). 6411, 57 I. .1. 1). 1), 101.

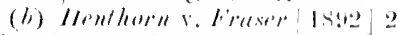
('h. 27 . 1il 1. . . (1). 37:3. 
a promise nor an overt act of performance, cannot make a contract in any class of cases; though so late as 1875 it was found needful to reassert this principle in the House of Lords (c). At the same time a proposer who prescribes a particular manner of communication may prechule himself from afterwards showing that it was not in fact sufficient. In Lord Blackburn's words, "when an offer is made to another party, and in that offer there is a request express or implied that he must signify his acceptance by doing some particular thing, then as soon as he does that thing there is a complete contract." The most important application of this exception will come before us immediately. But it is not true "that a simple acceptance in your own mind, without any intimation to the other party, and expressed by a mere private act, such as putting a letter into a drawer," will, as a rule, serve to conclude a contract $(d)$.

Difficulties as to contraets by corresjondence.

We now come to the special rules which, after much uncertainty, have been settled by our Courts as to contracts entered into by correspondence between persons at a distance. Before dealing with authorities it may be useful to show the general nature of the difficulties that arise. We start with the principle that the proposer is bound from the date of acceptance. Then we have to consider what is for this purpose the date of aeceptance, a question of some perplexity, and much vexed in the books. It appears just and expedient, as

(c) Breydens, Metropulitun Iiy. (a. (1875) 2 App. (a. at p. tisis (Lord Selborne), at p. 691 (lomel Blackburn), and at p. 697 (look (iojdon). The jurlgments in the Court below which gave rise to these remarks are not reported.

(d) As to a different rule formerly supposed to have been introduced in the case of agreements to take shares unler the companies Act. 1862 . see Ciuntis case' (1867) L. li.
3 ('h. 41).37 l. J. ('h. to. There need not be formal notice of allotment ; aeting towarks the applicant on the footing that he has got the shares, $e . f$ appointing him 11 an office under the company for which the shares are a necessary qualitication. is enough. This of course is yuite in accordance with general prineiples. Ridlards v. Home As-

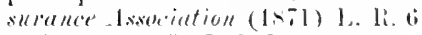
('. I'. 341 . 41 L. J. ('. 1'. 2940. 
concerning the accepting party's rights, that the aceeptance should date from the time when he has done all he can to accept, by putting his affirmative answer in a determinate course of transmission to the proposer. From that time he must be free to act on the contract as valid, and disregard any revocation that reaches him afterwards. Hence the conclusion is suggested that at this point the contract is irrevocable and absolute. But are we to hold it absolute for all purposes? Shall the proposer be hound, though, without any default of his own, the acceptance never reach him? Shall the acceptor remain hound, though he should afterwards despatch a revocation which arrives with or even before the acceptance? The first question is answered hy our Courts in the affirmative; the second is still open. On principle a negative answer to both would seem the more reasonable. The proposer cannot, at all events, act on the contract before the acceptance is communicated to him; as against him, therefore, a revocation should be in time if it reaches him together with or before the original acceptance, whatever the relative times of their despatch. On the other hand, it seems not reasonable that he should be bound by an acceptance that he never receives. He has no means of making sure whether or when his proposal has been received $(e)$, or whether it is accepted or not, for the other party need not answer at all. The acceptor might more reasonably be loft to take the more avoidable risk of his acceptance miscarrying.

In the judicial treatment of these questions, however, Theories considerations of a different kind have prevailed. It has been assumed that there must be some one moment at propinsed in English cascs. which the consent of the parties is to be deemed com-

( $\rho$ ) It is possible to obtain an oflicial acknowledgment of the lue delivery of a registerel letter ; but this does nut prove that the contents have actually come to the knowlerlge of the addressee. 
plete, and the contract absolute as against both of them and for all purposes; and further, a peculiar character has been attributed to the post-office as a medium of communication. In some of the cases it is said that the acceptance of a proposal by post completes the contract as soon as the letter is despatched, because the postoffice is the common agent of both parties. This may be so as regards the property in the letter, but the promise expressed by the words written on the paper is not a subject of bailment. But the reason has been put in a different way ; namely, that a man who requests or authorizes an acceptance of his offer to be sent in a particular way must take the risks of the mode of transmission which he has anthorized, and that in the common course of affairs the sending of a written offer by post amounts to an authority to send the answer in the same manner; and more lately $(f)$ it has been put on the broader ground that persons who are not in the immerlate neighbourhood contemplate the post-office as the ordinary and reasonable means of communication. But if the proposer of a contract by letter does not really choose the post as a means of communication any more than the acceptor, it in not easy to see why the risk of miscarriage should be thrown on him by preference.

Revocation arriving before acceltance.
Much of the language that has been used suggests, though it only suggests, the consequence that even a revocation despatched after the acceptance and arriving before it rould he inoperative. If the contract is absolutely bound hy posting a letter of acceptance, a telegram revoking it would be too late; and this even if the letter never arrived at all, so that the revocation were the only notice received by the proposer that there ever had been an acceptance.

This is a startling consequence at first sight, but the hardship is less than it seems, for a party wishing to (f) Henthern v, Fraser [1892] 2 Ch. 27, 61 L. J. Ch. 3 i3. 
reserve his freedom of action as long as possible will still have two ways of doing so: he may make his acceptance in writing expressly subject to revocation by telegraph, or he may abstain from answering l,y letter at all, and only telegraph his final decision. English Courts may now be bound to hold that an unqualified acceptance, once posted, cannot be reroked even by a telegram or special messenger outstripping its arrival.

Turning to the authorities, we need not dwell much on the earlier cases, of which an account is given in the Appendix $(g)$. They established that an acceptance by Eitrlier canes on eontraets h: currepost, despatcher in due time as far as the acceptor is concerned, concludes the contract notwithstanding delay in the despatch by the proposer's fault (as if the offer' is mis-directed), or accidental delay in the delivery : and that the contract, as against the proposer, dates from the posting, so that he cannot revoke his offer after the acceptance is despatched. Until 1879 it was uncertain whether a letter of acceptance that miscarried altogether was binding on the proposer. In that year the point came before the Court of Appeal $(h)$. An application for shares in the plaintiff company, whose office was in London, was handed by the defendant to a country agent for the company. A letter of allotment, duly addressed to the defendant, was posted from the London office, but never reached him. The company went into liquidation, and the liquidator sued for the amount due on the shares. It was held by Thesiger and Baggallay I..J.I. that "if an offer is made hy letter, which expressly or" impliedly authorizes the sending of an acceptance of such offer by post, and a letter of acceptance is posted

(g) See Note l?. For Continental opinions see Irof. J. Kohler. Vertrag unter Abswesenden, in Archiv fiir biirgerl. Rerht, March, 1ss:?; Valery, Des Contrats par corre- spondance, Paris, 1895 .

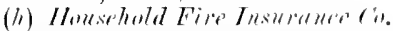
v. Grout $(1 \times 89)+$ kx. liv. 216 . I [.. J. Ex. 377, Fineh sel. ('a. 133. 
in clue time, a complete contract is made at the time when the letter of acceptance is posted, though there may be delay in its delivery " (i) ; that, on the grounds and reasoning of the authorities, this extends to the case of a letter wholly failing to reach its address; that in the case in hand the defendant must under the circumstances be taken to have anthorized the sending by post of a letter of allotment; and that in the result he was bound. They were disposed to limit the rule "to cases in which, by reaton of general usage, or of the relations between the parties to any particular transactions, or of the terms in which the offer is made, the acceptance of such offer by a letter through the post is expressly or impliedly authorized " $(k)$. Cases outside these limits, howercr, are not likely to be frequent; and now, in Henthorn r. Fraser (l), it is decided that an offer delivered by hand may anthorize, or, in the terms preferred by the Court, contemplate, an acceptance by post $(m)$. In Grant's case Bramwell L.J. delivered a vigorous dissenting judgment, in which he pointed out among other things the absurdity of treating a revocation which overtakes the acceptance as ineffectual, but relied mainly on the broad ground that a letter not. delivered at all is not a communication $(n)$. In Henthorn v. Fraser, Kay L.J. did not conceal his dissatisfaction with the reasoning of the anthorities by which the Court was bound. It may perhaps not be too presumptuous, but it seems useless, to regret that these views could not prevail. It will be seen hy reference to the Appendix that the decisions of the Court of Appeal confirm that sense in which a previous decision of the

(i) Baggallay L..J. + Ex. Dir. at 1. 224 .

(k) Baggallay L.J. + Ex. Div. at 1. 228 ; the same limitation seems admitted by Thesiger I.J. at P. 218. 373. (m) Delivery to a postman who is not authrized to receive letters for the post is not equivalent to posting: Dit Landon and Sorthern Bank [1900] 1 Ch. 220, 69 L. J. Ch. 24. (II) 4 Ex. Dir. at p. 234 . 
House of Lords was generally understont. The practical conclusion seems to be that every prudent man who makes an offer of any importance by letter should expressly make it conditional on his actual receipt of an acceptance within some definite time. It would be impossible to contend that a man so doing conld be bound by an acceptance which either wholly miscarried or arrived later than the specified time (o).

We have seen that in general the contract dates from the acceptance; and though the acceptance be in form an acknowledgment of an existing agreement, yet this will not make the contract relate back to the date of the proposal, at all events not so as to affect the rights of third persons $(p)$.

There is helieved to be one positive exception in our law to the rule that the revocation of a proposal takes effect only when it is communicated to the other party. This exception is in the case of the proposer dying before the proposal is accepted. This erent is in itself a revocation, as it makes the proposed agreement impossible by removing one of the persons whose consent would make it $(q)$. There is no distinct authority to show whether notice to the other party is material or not; but in the analogous case of agency the death of the principal in our law, though not in Roman law, puts an end ipso facto to the agent's authority, without regard to the time when it becomes linown either to the

(a) Siee per 'Thesiger H.I. 1 Fx. liv. at p. 223, and per framwell L.J. at \%. 238. Helel ace, in Massachusetts (where, hrwever, the general doetrine that an acceptance by prist eonelurles the contract from the rate of posting is not received) ; lewis v. Bromming (1850) 130 Mass. 173. There is now a tendency to hold that even in one-sider com-
Aceepitance will nut relate back though retrospeetive in form.

leath of proposer : semble, an absulute revocation though not known to otber party. munications by letter the rights of parties are fixedat the date of posting: see theramler v. Ntrinluadt

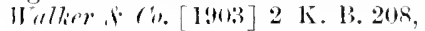
7: 1... K. Ii. 1!).

(j) Folfhurse v. Bimble'y (Istiz)

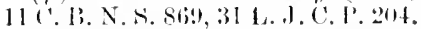

(y) Per Mellish I..J in Dirlinisun r. Homlds (1876)2 Ch. Div, at 1). 475, 45 L. J. ( เ. 777. 
Insanity no revocation.

Accelitance must be un'pulified. agent or to third parties $(r)$. It would probably be impossible not to follow the analogy of this doctrine. The Indian Contract Act makes the knowledge of the other party before acceptance a condition of the proposal being revoked by the proposer's death. As for insanity, which is treated in the same way by the Indian Act, that would not in general operate as a rerocation by the law of England, for we shall see that the contract of a lunatic (not so found by inquisition) is only voidable even if his state of mind is known to the other party. But it has been said that "if a man becomes so far" insane as to have no mind, perhaps he ought to be deemed dead for the purpose of contracting " $(s)$.

\section{Certainty of Acceptance.}

The next rule is in principle an exceedingly simple one. It is that

"In order to convert a proposal into a promise the acceptance must be absolute and unqualified " $(t)$.

For unless and until there is such an acceptance on the one part of terms proposed on the other part, there is no expression of one and the same common intention of the parties, but at most expressions of the more or less different intentions of each party separately - in other words, proposals and counter-proposals. Simple and obvious as the rule is in itself, the application to a given set of facts is not always obvious, inasmuch as contracting parties often use loose and inexact language, even when their communications are in writing and on important matters. It will be seen that the question whether the language used on a particular occasion

(r) Blades v. Frep (1829) : B. \& rule.

C. 167,32 R. R. 6211; Campanari v. Woendhurn (1854) 15C. B. 400. 24 L. I. ('. I'. 13, 2 Kent Comm. 646, D. 4li, 3, de solut. et liberat. 32. The Indjan Contraet Act, 8. 208 , illust. (c), adopts the Roman

(s) Dramwell I.J. Drefe v. Tunn $(1579)+$ Q. B. Div. at p. 669, ts I. J. Q. 13. 591 .

(t) Indian Contract Act. s. 7 , sub-s. 1 . 
does or does not amount to an acceptance is wholly a question of constrution, and generally though not necessarily the construction of a written instrument. The cases in which such questions have been decided are numerous (u), and we shall here give by way of illustration only a selection of morlern ones $(x)$.

In Honmyman v. Marryut (y), before the llomse of Joris, a proposal, for a sale was accepted "subject to the terms of a contract being aranged" between the vendor"s and purchaser's solicitors: this was lustances of insutlicient aceptiance. clearly no contract. Comprare with this IInswy v. Iturur-Inyne $(\because)$, from which it seems that the acceptance of an uffer to soll land "subject to the title being approvel by wn solicitors" is mot a qualified or conditional acceptanee, but means only that the title must he investigated in the nsual way ; in other works, it expresses the conclitions amexed by law to contracts of this class, that a gowel title shall he shown by the vendor.

In Applehy v. Tolmson(a), the plaintiff wrote to the defendant, a ealieo-printer, and offerel his services as salesman on certain terms, among which was this: "a list of the merchants 10 be regularly callet on by me to be male." The lefendant wrote in answer: "Yours of yesterday embolies the sulstance of our conversation and terms. If we ean define some of the terms a little elearer, it might prevent mistakes: but I think we are suite agreed on all. We shall therefore expleet you on Monday. (Signerb) J. Appleby.-J.A.-I have mate a list of eustomers which we can conmiler torether." It was held that on the whole, and especially hoving regand to the postscript, which left an important term open to disenssin, there was no emulete contraet.

In remsstey v. Wayfock (b), an offer to buy ecrtain land was accepted, but with reference to special conditions of sile not before known to the intending furchaser. IJehl ouly a enditional aceptance.

In Lloyd s. Inuell (c), an agrenent "subject to the preparation by my solicitor and completion of a formal "untract" was hele (1) to exchute the formation of a binding arreenent: (2) not to be a comblition

(u) For collecterl inthorities, see (inter alia) Fry on sipecitir l'erformance, c. 2 .

(.r) (1) alow the French case in the comrt of cassation given in Iangdell's select ('ases on (intract, Jis.

(y) $(1 \times .7)$; $11.1 .1 .(\div, 112,20$;

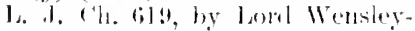
dale, The ease was not alyued, no one appearing for the appellant.
() $(1 \times 39)+\Lambda \mu .(2.31], 322$ is h. J. ('h. Stri.

(a) $(1 \times 74)$ J. I. :) C. L', Jis, $131 . .1 \% 1.1 \%$.

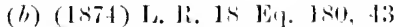
L. .l. ('h. 37!), followed in .Jenes v.

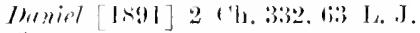
(1) 5iz.

(a) $[1,95] 2(\mathrm{ch} .711 .6 \mathrm{ll}$ L. J. (h. it). 
Instances of sufficient acceptance.

which the ventar conlul waise as leing only for his benefit. Put in vorth v. Preciral (d), the words ". heat of agreement . . subject to approval of conditions and form of agrement by jurchaser's solicitor", were held hy Kekewirh J. annistenl with a eomplete contract.

In Fill!! v. Homnsell $(d d)$ an seceptance by a purchaser "subject to contract "s agred," i.f. a form set out on the vendor's own conditions of sale, was held without dithelilty to be absolute.

In stanley $x$. Intramell ('), an answer in this form : " I have decidat

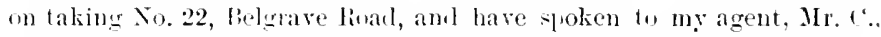
who will arrange matters with you." was hell insufieient to make a contract, as not being complete and unpualified, assuming (which was doubtful) that the letter of which it was fart dicl otherwise sutficiently refer to the terms of the prinosil.

A. telegraphs to H.: "Will grom sell us Whiteacre? Telegraph lowest cash price. answer pail." li. telegraphs in reply: "Lowest price for Whiteacre. (mon)." This is an anwer only to the secont question asket, and dues not amomut 10 an offer 10 sell, but only to a statement that an (nffer below 9041 . will nut be considered, and therefore a telegram from A. purporting to agree to the purchase at $9 m \%$. is itself only an offer $(f)$.

Where a seller undertouk tw aceept the highest net money tender male ly either of two empetitor for the purehase. and one of them offered such sum as would exceed hy 2007. the sum (unknown) which might be offered by the other: this was hell no arecptance of the seller's terms, and incapable of constituting a cont ract ( $(y)$.

On the other hanl. the following in-tances will show that the rule must be cautiously applict. An acceptance may be complete thongh it expresses dissatisfaction at sume of the terms, if the dissatisfaction stops short of disisut, su, that the whole thing may be describcr as a "grumbling assent" ( $(1)$.

Again, an aceptanee is of curse not made conditional by adding words that in truth make no difference: as where the arblition is simply immaterial (i), or a mere formal memorandmm is enclosed for signature. but not shown to contain any new term $(k)$. Anc further, if the person answering an unambiguous prolosal accepts it with the aldition of

(a) $[$ ls.tx] 2 (h. 12s, 67 L. J. ('h. 321 .

(dil) $[1 \times ! 6] 2($ 'b. $737,6.5$ L. J. Ch. sis:

(f) (litt) I. R. 10) (. l'. 1112 . Cp. simith r. Welster (187i) 3 ('h. Div. 49. 4; L. J. Ch. ids.

(f) Llarmy v. Farey (J. ('.) [18:43] A. C. 5.2, 62 I. J. P. ('. 127. It woukl not be safe to rely on this case except in closely similar circumstances. (g) Sinth IIetton rial rit. v.

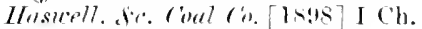
fiis, fi. L. J. Ch. 23s. C. A.

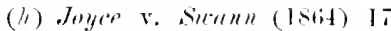
('. B. X.s. st; ch. per Lold st. Leonarls, 6 H. L. C. 27-s (in a dissenting julgment).

(i) ('7im v. Bcolumont $(1+47) 1$ le G. A $5.397,75$ li. li. 1 t4.

(k) Giblins v. I. E. Wetrop. Asylum Jistrict (1847) 11 Beav. I. (.) Ii, li. 111. 
anbiguous words, which ale capalle of being eonstrucd consistently with the rest of the rocument amb so as to leave the acceptance absolute, they will if possible be su comstruel $(l)$.

Again, the unconditional acceptanee of a proposal is not deprivel of its effect by the existence of a misunderstanting between the parties in the eonstruction of collateral terms which are not part of the argeement itself $(m)$.

An aeceptanee on condition may be absolute il expressed in a manner which estops the aceeptor from denying that the eondition has been performed, or that he has waived its performance(u). A formal acceptance of an alleged proposit may estop the acceptor from denying that any snch proposal was in fact male, at any rate if he las taken any benefit moder the expresserl agreement (")).

One further caution is needed. All rules albout the formation and interpretation of contracts are subject to the implied proviso, "unless a contrary intention of the parties appears." And it may happen that though the parties are in fact agreed mpon the terms - in other words, though there has heen a proposal sufficiently accepted to satisfy the general ruf-yet they do not mean the agreement to be binding in law till it is put into writing or into a formal writing. If such be the understanding between them, they are not to be sooner bound against both their wills. "If to a proposal or" offer an assent be giren subject to a provision as to a contract, then the stipulation as to the contract is a term of the assent, and there is no agreement independent of that stipulation "( $(1)$. Whether such is in truth the understanting is a fuestion which depends on the circumstances of each particular case; if the evidence of an agreement consists of writan documents, it is a

(l) Emalish and finerigu revelit (i). r. Arduin (1850-1) l. li. i 11. L. 64, per Joml Westbury, at 1).79, 101, 1. . .x. 10k.

(iil) limilles v. 16 ind fill (18.5!) di

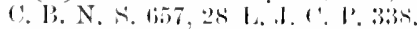
The facts unfortmately do not allnit of abritlentenl.

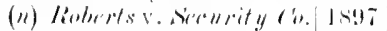

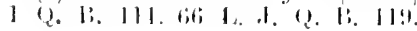

Partics may poslpone conclusion of contract, though agreed on the terms, till embulied in nore formal instiument.
(‥ A., but $q u$. as to the actual lexision there, see Eiquituble Five

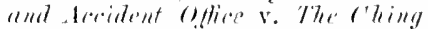
Ho llomg $[19077$ A. C. !16, 101. Tij L. A. 1'. 1. 31.

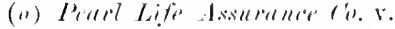

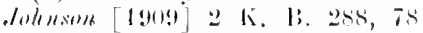
I. I. K. I: . 777 .

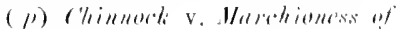

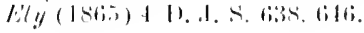


question of construction (not subject to any fixed rule or presumption) whether the expressed agreement is final $(q)$. For this purpose the whole of a continuous correspondence must be looked at, although part of it, standing alone, might appear to constitute a complete contract $(r)$.

It is not to be supposed, "because persons wish to have a formal agreement drawn up, that therefore they cannot be bound by a previous agreement, if it is clear that such an agreement has been made; but the circumstance that the parties do intend a subsequent agreement to be made is strong evidence to show that they did not intend the previous negotiations to amount to an agreement" $(s)$. Still more is this the case if the first record of the terms agreed upon is in so many words expressed to be "subject to the preparation and ap. proval of a formal contract", $(t)$ : or where a certain act, such as payment of the first premium of insurance, is expressly mentioned to fix the commencement of the contract $(u)$. But again: "it is settled law that a contract may be made by letter's, and that the mere reference in them to a future formal contract will not prevent their constituting a binding bargain " $(x)$. And in Brogden r. Metropolitan Ry. Co. (y), it was held by the House of Lords that the conduct of the parties, who in fact dralt for some time on the terms of a draft agleement which had nerer been formally executed, was inexplicable on any other supposition than that of an actual though informal consent to a contract upon those terms.

(4) Rossiter v. Mill'r (1-is) 3 29. Alu. (a. 1124. 1152,4 L. J. ('b. 11).

(1) Hussey v. Hornel'ayne (1879) t All. Ca. 311. to L. J. Ch. Sti.

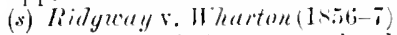
6 H. L. ( .23\%. 2tit. 26s. per Lord Cranworth ('.. and see per Lord IV ensleydile at 1,. 30.5-ti. 27 L. J. ('h. th.

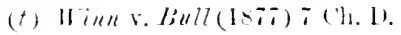

(u) Canning F. Firquhar (1880) Iii Q. I?. Liv. 72 - 55 L. J. Q. B. 2.2.).

(,r) James L.J. in Bonnerell $v$. Jenkina (1sis) \& Ch. Div. To. i3, ti 1.J.Ch. 75s: Balton $x$ Lambert (1s:s!) 41 (h. Dir. 295. 305.

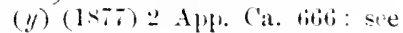
Lorit litirns opintoll. 
The tendency of recent authorities is to discourage all attempts to lay down any fixed rule or canon as governing these cases. The question may, however, be made clearer by putting it in this way-whether there is in the particular case a final consent of the parties such that no new term or variation can be introduced in the formal document to be prepared $(z)$.

\section{Certuinty of Terms.}

An agreement is not a contract unless its terms are certain or capable of being made certain.

Agreement must be

For the Court cannot enforce an agreement without knowing what the agreement is. Such knowledge can be derived only from the manner in which the parties have expressed their intention. It is their business to find such expressions as will convey their meaning with reasonable certainty to a reasonable man conversant with affairs of the kind in which the contract is made. The question then is whether such certainty be present in the particular case. One or two instances will serve as well as many. A promise by the buyer of a horse that if the horse is lucky to him, he will give $5 l$. more, or the buying of another horse, is "much too loose and vague to be considered in a court of law." "The buying of another horse" is a term to which the Court cannot assign any definite meaning (1). An agreement to soll an estate, reserving "the necessiary land for making a railway," is too vague $(b)$. An agreement to take a house "if put into thorough repair," and if the drawing-rooms were "handsomely decorated according to the present style," has been dismissed as too uncertain to

(:) Lord Hlackburn, 3 Apr. ('at. at 1 . 1151. In addition to cases alrearly cited see lowis v. Siruss

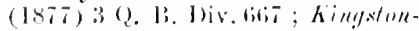

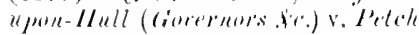

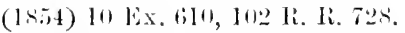

(a) Couthing v. Lymen (1831) $21 \%$.

(c) Al, 23:2.

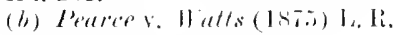

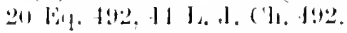


Illusory promises.

be specifically enforced $(c)$. A statement by a parent to his daughter's future husband that she will have "a share " of his property cannot be construed as a promise of an equal share $(d)$. On the other hand an agreement to execute a deed of separation containing "usual covenants" is not too vague to be enforced $(e)$.

To this head those cases are perhaps best referred in which the promise is illusory, being dependent on a condition which in fact reserves an unlimited option to the promisor. "Nulla promissio potest consistere, quae ex voluntate promittentis statum capit" $(f)$. Thus where a committee had resolved that for certain services "such remuneration be made as shall be deemed right," this gave no right of action to the person who had performed the services; for the committee alone were to judge whether any or what recompense was right (a). Moreover a promise of this kind, though it creates no enforceable contract, is so far effectual as to exclude the promisee from falling back on any contract to pay a reasonable remuneration which wonld be inferred from the transation if there were no express agreement at all. In Roberts r. Smith (h) there was an agreement between A. and $B$. that B. should perform certain services, and that in one event $A$. should pay B. a certain salary, but that in another erent A. should pay B. whatever A. might think reastinable. That other event having halpened, the c'ont held there was no contract which B. could onfores. Services had indeed been rendered, and of the sort for which people usually are paid and expect to be paid; so that in the absence of express

(c) Theylor v. Purtiugton (195i) 7 D. M. dir. 328,109 li. R. $1+\bar{r}$. This of course did not decide that an action for dianages woukl not lie.

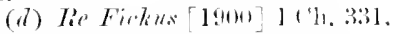
69 1.... ('h. 161.

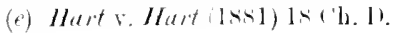

Biol, bist. 50 L. J. Ch. 199.

(f) I) 45. ?. de verb, obl. 10. $\$ 1$.

(g) Tughterv. Breceer (1813) I M. d $5.290,21$ R. Li. 831.

(h) $(15.59)$ + H. . N.315. 28 L.J. Ex. lit. 11: li. R. this. 
agreement there would have been a good cause of action for reasonable reward. But here 3 . had expressly assented to take whatever $A$. should think reasonable (which might be nothing), and had thus precluded himself from elaiming to have whatever a jury should think reasonable. It would not be safe, however, to infer from this case that under no circumstances whatever can a promise to give what the promisor shall think reasonable amount to a promise to give a reasonable te. ward, or at all events something which can be found as a fact not to be illusory. The circumstances of each case (or in a written instrument the context) must he looked to for the real meaning of the parties; and "I leave it to you " may well mean in particular circum stances (as in various small matters it notorionsly does), "I expect what is reasonable and usual, and I leave it to you to find out what that is," or", "I expect what is reasonable, and am content to take your estimate (assuming that it will be made in good faith and not illusory) as that of a reasonable man" (i). Again, there may be a good promise conditional on the promisor being satisfied with the work done for him, or with the proof of a fact. This is not an arbitrary power but a diseretion to be exercised in good faith $(k)$.

Another somewhat curious case of an illusory promise (though mixed up to some extent with other doctrines) is Moorhouse v. Colvin $(l)$. 'There a testator', having made a will by which he left a considerable legaey to his

(i) Such a case (if it ran be supporterl, see the remarks on it in Rolerts v. simith, and per Puckley 1..J. in Bromme v. Sperelk [1903] 1 ('h. is6, 599) was Brygent v. Flight (1839) 5. II. \& W. 11 i, where the majority of the court helel that it was for the jury to ascertain bow mnch the defendant, acting bona fide, would or ought to have

P. awartel.

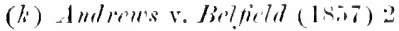

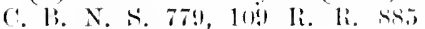
(goosls); Erannstoin v. dicidental Derath Insief. Co. (1N61) 1 13. \& s. 7.82 (proof of elaim).

(l.) (1Ki) 15 Reav. 311, 31h, alffl. by I..J.J. 21 I. J. Ch. 742, 92 R. Ii, 152, 15. 
daughter, wrote a letter in which he said, after mentioning her other expectations, " this is not all: she is and shall be noticed in my will, but to what further amount I cannot precisely say." The legacy was afterwards revoked. It was contended on behalf of the daughter's husband, to whom the letter had with the testator's authority been communicated before the marriage, that there was a contract binding the testator's estate to the extent of the legacy given by the will as it stood at the date of the letter. But it was held that the testator's language expressed nothing more than a rague intention, although it would have been binding had it referred to the specific sum then standing in the will, so as to fix that sum as a minimum to be expected at all events.

Promise to make contract with thind perion.
Tacit acceptance of contract mu-t be unambigunus.

Case- of special conditions on tickets.
A promise to enter into a certain kind of agreement with a third person is obriously dependent for its performance on the will of that person, but is not thereby rendered so uncertain as not to afford a cause of action as between the parties to it. The consent of a third person is not nore uncertain than many other things which parties may and do take on themselves to warrant $(m)$.

\section{Acceptance by Conduct.}

Conduct which is relied on as constituting the acceptance of a contract must (no less than words relied on for the same purpose) be unambiguous and unconditional $(n)$.

Where the proposal itself is not express, then it must also be shown that the conduct relied on as conreying the proposal was such as to amount to a communication to the other party of the proposer's intention. Difficult questions may arise on this point, and in particular have

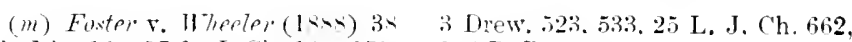
Ch. Inv. 130, 57 L. J. Ch. 14!, sit. (n) Harner v. Willington $(1-56)$ 
arisen in cases where public companies entering into contracts for the carriage or custody of goods have sought to limit their liability by special conditions printed on a ticket delivered to the passenger or depositor at the time of making the contract. The tendency of the earlier cases on the subject is to hold that (apart from the statutory restrictions of the Railway and Canal Traffic Act, 1854, which do not apply to contracts with steamship companies, nor to contracts with railway companies for the mere custody as distinguished from the carriage of goods) such conditions are binding. A strong opposite tendency is shown in Henderson $v$. Stevenson (o), where the House of Lords decided that in the case of a passenger travelling by sea with his luggage an indorsement on his ticket stating that the shipowners will not be liable for loss does not prevent him from recovering for loss caused by their negligence, unless it appears either that he knew and assented to the special terms, or at any rate that he knew there were some special terms and was content to accept them without examination $(p)$. Since this there have been reported cases arising out of the deposit of goods, for safe custory or otherwise, in exchange for a ticket on which were indorsed conditions limiting the amount of the receiver's liability $(q)$. The result appears to be that it is a question of fact whether the notice given in

(ii) (1875) 1, li. 2 Sic. \& I) 170. loret ('helmoford's and Lord Hatherley's dista (11) 177, 179) go farth.r. and suregest that the eontract is complete before the ticket is elelivered al all, so that some other erommunication of the speeial terms would have to be shown. lint the later cases have not alopted this view.

(p) Followed in Rirbardsone of "o. v. Rimentier [1891] A. (\%. 217, (i.) I. . J. Q. B. 2. $2 \times 3$.

q) Harrisv. (i. II.R. (o. (1876)
1 Q. B. D. 515, 45 1. .J. Q. B. 729 ; Prurler v. S. E. R. ("i. (1Si6) : Gabell v. S. E. R. ('). (1877) $2($. I'. Iliv. 416,46 I. I. C. I'. 768 , reversing in lorkers sose the jurlument of the C. P. I)iv. 1 C. I'. 1). (118. th 1..J. C. I'. 768; Watkins v. Rymill (1483) Jo Q. 13. 1). 17s, 52 L. J. Q. B. 121, where the former cases are fully reviewed by stephen J. Compare Burlie r. S. E. R. CW. (1879) 5 C. P. I. 1, 19 L. J. C. I'. 107. 
As to promiseexpressed in deerls. each case was reasonably sufficient to inform the party receiving it at the time of making the contract that the party giving it intended to contract only on special terms. A prison who, knowing this $(r)$, enters into the contract. is then deemed to assent to the special terms; but this, again, is probably subject to an implied condition that the troms are relevant and reasonable.

It has alrearly been pointed out that the ordinary rules of proposal and acceptance do not apply to promises embodied in a deed. It is established by a series of authorities which appear to be confirmed by the rutio decidendi of Xenos v. Wickham (s), in the House of Lords, that a promise so made is at once operative without any question of acceptance; and this because it derives its force not from anything passing between the

(i) Kinowletse that there ate succial comlitions mut he foumel as a fart. lt may be inferred from reasmable mean of knowlerlere; in clectiling whether the means offered are reasmable all the circum-tances. sileh as the class of yersins to whom the notice is abliresed. are proberly

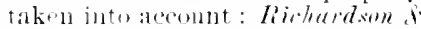

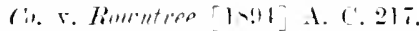
(i) I. .1. 1!. 13. 2-3. Compre Clpians remalks on a fairly analogons ease. I), 14. 3, de inst. act. 11. \$ 2, 3. It fuo lalan. proseriffim fucrit, ne cum en contrabatur. is pratpositi loeo nou lialetur. . . . Proscribere palam sic acejpimu-: claris loteris, unde le plane recte legi possit, ante tabernam seilicet. vel ante emm

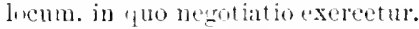
nom in lico remoto. seal in evidenti ... C'erte a quis dicat innorase se litteras. rel non ubservasse quod propositum erat. cum mult i legerent. eumque palam enset propositmm. non aurlietur. Formerly the conditions pinted by railway eompanies on their tickets, and the corresponding notices txhibited by them, were not of ten, they are still not alwars. " claris litteris. unde de plano recte leri possit." or " in loco evilenti." As to conditions on paswenger tickets see pel Wills and Wlight J.J. in $G ., T . R$. G. Pulmer [1S95] \& Q. B. sfiz. fit L. .J. (2. 13.316, where the point whether there was sufficient notice of the comlition was not open.

(.) (Isfiti) I. Ii. 2 H. L. 2!!6. The previous cases were Doe d.

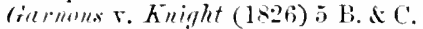
6i.l. 29 li. R. 35.; (a mortgage): E.roten v. Scott (I.333) ti Sim. 31,35 Li. li, 72 (the like) : Hall v. Palmer (l-tt) 3 Hare, .32 .13 L. J. Ch. 3.5, tit R. R. Bit? (bond to secule ammity after (ubligurs ateath): Flotelie, r. Fletulier (1-itt) \& Hare. Bi. 1 t L. J. C'h. bit, lit li, Ii. i (covenant for settlement to be marle by exeeutors). Jenus r. Wiekhaim might have been deculed on the grouml that the company"s execution of the policy was the acctitance of the plaintiffs' proposal. and the plaintiff:" broker was their agent to receive communication of the acceptance. But that ground is distinctly not relied upon in the opinions of the Lnrds: see L. R. 2 H. L. at pp. $320,323$. 
parties, but from the promisor's-or, in the regular language of conveyancing, covenantor's-solemn admission that he is bound. Thus an obligation is created which whenever it comes to the other party's knowledge affords a cause of action without any other signification of his assent, and in the meanwhile is irrevocable. But if the promisee refuses his assent when the promise comes to his knowledge the contract is a voided.

"If A. make an obligation to B., and teliver it to C. to the use of B., this is the deed of A. presently; hut if $\mathrm{C}$. offers it to B., then B. may refuse it in pais." (i.e., without formality) "and thereby the obligation will lose its force" $(t)$.

(t) Butler and Baker's rast. 3 ('o. Rep. 26, qnoted by Blackburm J. L. R. 2 H. L. at p. 312. *Obligation" here, as always in our

older books. means the special form of deed otherwise. and now exclurively, ealled a bund. 
Capacity of Parties.

Variations in personal capacity.

Disabilities of natural persuns: Infancy.

Cuverture.

Insanity. ke.
Alu statements about legal capacities and duties are taken, unless the contrary be expressed, to be made with reference to "lawful men," citizens, that is, who are not in any manner unqualified or disqualified for the full exercise of a citizen's normal rights. There are several ways in which persons may be or become incapable, wholly or partially, of doing acts in the law, and among other things of becoming parties to a binding contract. All persons must attain a certain age before they are admitted to full freedom of action and disposition of their property. This is but a necessary recognition of the actual conditions of man's life. The age of majority, however, has to be fixed at some point of time by positive law. By English law it is fixed at twentyone years; and every one under that age is called an infant (Co. Lit. 171 b).

Every woman who marries has to sustain, as incident to her new status, technically called coverture, a loss of legal capacity in varions respects ; a loss expressed, and once supposed to be sufficiently explained, by the fiction that husband and wife are one person.

Both men and women may lose their legal capacity, permanently or for a time, by an actual loss of reason. This we call insanity when it is the result of established mental disease, intoxication when it is the transient effect of drink or nareotics. Similar consequences, again, may be attached by provisions of positive law to 
conviction for criminal offences. Deprivation of civil rights also may be, and has been in England in some particular cases, a substantive penalty; but it is not thus used in any part of our law now in practical operation.

On the other hand, the capacity of the "lawful man" receives a vast extension in its application, while it remains unaltered in kind, by the institution of agency. One man may empower another to perform acts in the law for him and aequire rights and duties on his behalf. By agency the individual's legal personality is multiplied in space, as by succession it is continued in time. The thing is now so familiar that it is not easy to realize its importance, or the magnitude of the step taken by legal theory and practice in its full recognition. We may be helped to this if we remember that in the classical Roman system there is no law of agency as we understand it. The slave, who did much of what is now done by free servants and agents, was regarded as a mere instrument of acquisition for his owner, except in the special classes of cases in which either slaves or freemen might be in a position analogous, but not fully equivalent, to that of a modern agent. As between the principal and his agent, agency is a special kind of contract. But it differs trom other kinds of contract in that its legal consequences are not exhausted by performance. Its object is not merely the doing of specified things, but the creation of new and active legal relations between the principal and third persons. Hence it may fitly have its place among the conditions of contract in general, though the mutual duties of principal and agent belong rather to the ireatment of agency as a species of contract.

While the individual citizen's powers arte thas ex- aritivial tended hy agency, a great increase of legal seoper and leisons. 
safety is given to the conjoint action of many by their association in a corporate hody or artificial person. The development of corporate action presupposes a developed law of agency, since a corporation can execute its intentions only through natural persons generally or specially authorized to act on its behalf. And as a corporation, in virtue of its perpetual succession and freedom from all or most of the disabilities which may in fact or in law affect natural persons, has powers exceeding those of a natural person, so those powers have to be defined and limited by sundry rules of law, partly for the protection of the individual members of the corporation, partly in the interest of the public.

We proced to deal with these topics in the order indicaterl: and first of the exceptions to the capacity of natural persons to bind themselves by contract.

\section{PART 1.}

\section{Infants.}

Infants(ieneral statement of lie law.
An infant is not abcolutely incapable of binding himself, lout is, generally speaking. incapable of absolutely binding himself by contract $(a)$. His acts and contracts are voidable at his option, subject to certain statutory and other exceptions.

By the common law a contract made by an infant is generally voidable at the infiant's option, such option to be exercised either before $(b)$ his attaining his majority or within a reasonable time afterwards.

Where the obligation is incident to an interest (or at all events to a beneficial interest) in property, it cannot be aroided while that interest is retained.

Some agreements are, exceptionally, not roidable but roid.

(a) Stated in this form by Hayes J. 14 Ir. 1. L. Rep. at 1 . 3.iti. (b) Is to this ate p. tiz. beluw. 
By the Infants' Relief Act, 1874, loans of money to infants, contracts for the sale to them of goods other than necessaries, and accounts stated with them are absolutely void; and no action can be brought on a ratification of any contract made during infancy.

On the other hand an infant is bound to pay a reasonable price for necessaries sold and delivered to him; where "necessaries" mean goods suitable to his condition in life and his actual requirements at the time (c).

An infant's express contract may be valid if it appears to the Court to be beneficial to the infant.

In certain other cases infants are enabled to make binding contracts by custom or statute.

An infant is not liable for a wrong arising out of or immediately connected with his contract, such as a fraudulent representation at the time of making the contract that he is of full age. But an infant who has represented himself as of full age is bound by payments made and acts done at his request and on the faith of such representations, and is liable to restore any advantage he has obtained by such representations to the person from whom lie has obtained it.

1. Of the contracts of infants in general at common law, and as affected by the Act of 1874 .

It was once commonly said that an agreement made by an infant, if such that it cannot be for his benefit, is not merely voidable, but absolutely void; though in general his contracts are only voidable at his option $(d)$.

(r) Siale of loods Aet, 18:93, s. 2. This confirms the opinion that ‘u infant's obligation to pay lor necessaries is not created by agreement but imposed by law ; iin other words, that there is not a true contraret but a quasi-cond racet. fee line observations of the lomels
Justives in Kash v. Inmon [19ms 2 K. li. 1, 77 L. J. K. R. 6i26, and note thereon in I. Q. R. xxiv. 2:35. (d) An infant's deed is generally voilable, Litl. s. 259, but it is salial that il it is mot sueh as to take effert "hy dhe delivery of his own haml," it is roill: lectk. 12, shepe. l'omeh.
Of infauts' contractsin creneral: and as to supposed distinction thiat somer alr. wholly voirl. 
This distinetion unsup. porterl by authority.

Contract of selvice.

But this distinction is in itself unreasonable, and is really unsupported by anthority, while there is considerable authority against it. The use of the word roid proves nothing, for it is to be found in cases where there has never been any doubt that the contract is only voidable. And as applied to other subject matters it has been held to mean only roidable in formal instruments (e) and even in Acts of Parliament $(f)$.

Actual decision is the only safe guide; and as early as 1813 it was clearly laid down in the Exchequer Chamber, as the general rule of law, that the contract of an infant may be aroider or not at his own option. The Court refused to recognize any rariation of the rule as generally applicable to trading contracts $(g)$.

There is nothing to set against this in any reported case of co-ordinate authority. Dicta in cases of inferior authority to the effect that trade contracts of infants are roid (as distinct from roidable) could not prevail against a decision of the Exchequer Chamber even if they were necessary to the judgments in which they occur. Fxamination shows that they were superfluous in every case cited for the formerly current loctrine; but it seems needless to repeat what was sail in earlier editions, as that doctrine is now, I believe, abandoned everywhere.

In a modern case, indeed, the following opinion was given by the Court of Queen's Bench on the conviction

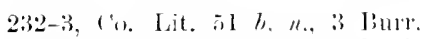
leis. 2 lor. 2 II. 3li. It is assumed in molern pratice that an infant s sale or gift of personal chattels with atual delively is

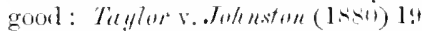
Ch. D. (i)is, tisk. Areoreling te the old louks it would seem to le voilable.

(e) Linceln (nlliges rase (15yj)

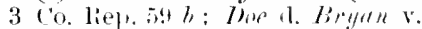
Buncks (1-2) + li. A All, to1, 2:?

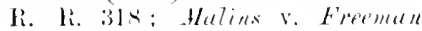

$(1 \times 3 \times)+$ bine. X. 1'.345, 44 R. Ji. ก.).

$(t)$ ('omplare harepent v. liey. (18\%) (.J. ('. from Queensland) 3 Aly. ta. at J. Jas, t7 L. J. I. e'. $\therefore$ with rovernors of Maydulen Ilwspital v. Knotts (is-9) 4 App. (a. 321, to L. J. Ch. 579 , in which case this latitule has at last been restrained.

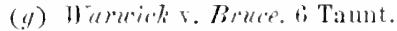

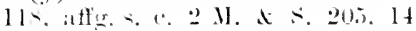
li. li, lisis. 


\section{of a servant for unlawfully absenting himself from his master's employment:-}

"Among many oljections onc appears to us clearly fatal. He was an infant at the time of entering into the agreement, which authorizes the master to stop his wages when the steam engine is stopled working for any eause. An agreement to serve for wages may be for the infant's benefit (h); but an agreenent which compels hin to serve at ali times during the term but leaves the master free to stop his work and his wages whenever he ehooses to do so canmot be econsidered an beneficial to the servant. It is inequitable and wholly voil. The convirtion must be quasbed " (i).

But this is mere laxity of language. The Court decided only that the agreement was not enforceable against the infant. It cannot have meant to say that if the master had arbitrarily refused to pay wages for the work actually done the infant could not have sued him on the agreement. Again, it is said that a lease made by teases. an infant, without reservation of any rent (or even not reserving the best rent), is absolutely void. But this opinion was disapproved by Lord Mansfield, whose judgment Lord st. Leonards adopted as good law, though the actual decision was not on this particular point in either case $(k)$. And in a modern Irish case $(l)$ it was expressly decided that at all "vents a lease made by an infant reserving a substantial rent, whether the

(h) It setms that prime for.ir it is so, even if it colltains (bluses inlposing penalties. ol giving a fow ('] uf dismissal, in certain erents:

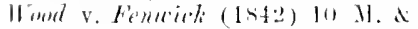

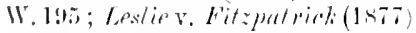

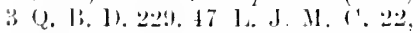
distinguiding liey. r. Jand (noxt irote).

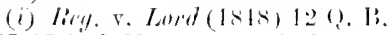

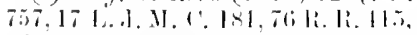
whene the leatume lightly says "voisl agreinst the infunt"; $\overline{6}$; R. IR. 11 ,

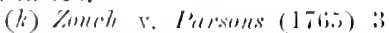
liurl. 179t (where the derision was that the recomveyanes of a nutertgagree infant licir, tloe moldenge

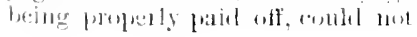

be avoiled by his entry lefore full

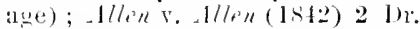

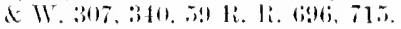

(l) N/ator v lirad (1siis) $14 \mathrm{l}$. ('. I. licp. 6il. Thie cinut inalined to think that sune act of motoricty by the lessor wombl be repuiped. weh as entering, bringing ejectment, ar desnamaling ponsession (uote that a frechold estate for the lile of the Jessur al twenty-one years hate passed by the original lease) ; howerer there was another retison, liamely, that the secombl lease might be eonstrued as only creating at future interest to talie cifert on the droternination of the tirst. 
sale, se., of land.

Partnership and shareholding.

best rent or not, is not void but voidable; and further that it is not well avoided by the infant granting another lease of the same property to another person after attaining his full age. There is good English authority for the proposition that if a lease made by an infant is beneficial to him he cannot aroid it at all $(m)$. It appears to be agreed that the sale, purchase $(n)$, or exchange (o) of land by an infant is both as to the contract and as to the conveyance only roidable at his option.

Again, there is no doubt that an infant may be a partner or shareholder (though in the latter case the company may refuse to accept him) ( $p)$; and though he cannot be made liablo for partnership debts during his infancy, he is bound hy the partnership accounts as between himself and his partners and cannot claim to share profits without contributing to losses. And if on coming of age he does not expressly disaffirm the partnership he is considered to affirm it, or at any rate to hold himself out as a partner, and is thereby liable for the debts of the firm contracted since his majority $(q)$.

The liability of an infant shareholder who does not repudiate his shares to pay calls on them rests, as far as existing authorities go, on a somewhat different form of the same principle (of which afterwards). As to contribution in the winding $u p$ of a company, Lord Lindley (r) " is not aware of any case in which an infant lias been put on the list of contributories. Upon principle, howerer, there does not appear to be any

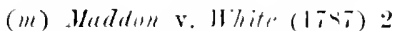

T. li. 15:4, 1 Ii. li. 4.33.

(n) Co. I.it. 2 b, like. Ah. Infamey, 1. 3 $(1,36010)$.

(ii) Co. Lit. $51 \%$.

(l) lint the company annot dispute the validity of a transter (1) an infant after the infant hats transferted wer to a persom

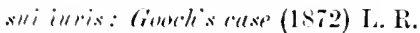
it th. 26it. 4: L. J. Ch. 3st. And see finlley. s-st.

(1) Linilley on Companies. ith el. sll. s2s; Goule v. Harrism (1521) ; I?. \& Ald. 14;. 24 R. R. $30 \%$.

(r) (1) ('mnpanies. Sus. 
reason why he should not, if it be for his benefit; and this, if there are surplus assets, might be the ease." Otherwise he cannot be deprived of his right to repudiate the shares, unless perhaps by fraud; but in any case if he "does not repudiate his shares, either while he is an infant or within a reasonable time after he attains twenty-one, he will be a contributory," and still more so if after that time he does anything showing an election to keep the shares. On the whole it is clear on the authorities (notwithstanding a few expressions to the contrary), that both the transfer of shares to an infant and the obligations incident to his holding the shares are not void but only roidable $(s)$.

Marriage is on a different footing from ordinary con- Marriage. tracts $(t)$, and it is hardly needful to say that the possibility of a minor contracting a valirl marriage has never been doubted in our Courts $(u)$.

As to promises to marry and marriage settlements, it has long been familial law that just as in the case of his other voidable contracts an infant may sue for a l'romines to marry and marriage settlements breach of promise of marriage, though not liable to be sued $(x)$. An infant's marriage settlement is not binding on the infant unless made under the statute (see post, pl. 76, 77), and the Court of Chancery has no power to make it hinding in the case of a ward $(y)$. Particular covenants in an infant's settlement may be valid $(a)$. In any case the settlement is not void but

(s) Lumsalonis cose (1sios) Loli.

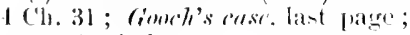
cp. H. lifi, infm.

(r) continental writer have wasterl mueh ingenuity in debating with which class of contracts it should be reckonerl. Siav. Syst. $\$ 1+1(3.317) ; 0$ )rtul un on Inst. 2 . io.

(u) For details see Eneycl. Laws of Englantl, s.r. Marriage.
(, Bacon. Abr. Infancy and Ige, 1. $t$ (4. 370). Per Lard Ellen-

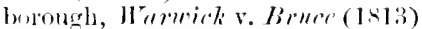
2 II. A S. 205,14 R. R. ti31.

(y) Finld v. 1forme (18-5) 7 D. 11. (i. 691, 710, 25 I. J. ('t. ti6.

(a) Simith vo Luras (18si) 1 is (ch. 1). .331, not overruled on this point by Edwards v. (ititor. [1893] A. C. 36io. (5.3 L. J. ('h. 100). 
only roidable; it may be confirmed by the subsequent sonduct of the party when of full age and sui iuris (b), and can be repudiated only within a reasonable time

Negotiable instruments.

Accounts stated.

Infant cannot have specitic performance.

At what time he may aroid lis contracts. after attaining full age $(c)$. Again an infant's contract on a hill of exchange or promissory note was once supposed to be wholly roid, but is now treated as only voidable $(d)$. The same holds of an account stated $(e)$. There is one exception to the rule that an infant may enforce his voidable contracts against the other party during his infancy, or rather there is one way in which he canmot enforce them. Specific performance is not allowed at the suit of an infant, because the remerly is not mutual, the infant not being bound $(f)$.

An infant may avoid his voidable contracts (with practically few or no exceptions) either before or within a reasonable time after coming of age: the rule is that "matters in fait [i.e., not of recorl] he shall avoid either within age or at full age," but matters of record only within age (Co. Lit. 380 b) (g). Subject to the general rule, established for the benefit of innocent third persons, that roidable transactions are not invalic until ratified but valis until rescinded $(h)$, an infant

(b) Dariess. Juaries (1871) L. R. ! E.t. this, 3!! L. I. Ch. 343 . This is mot affected hy the Infants Iielief

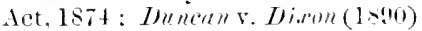
t4 Ch. D. 211. 5. I. .J. ('h. 437. A woman marriel under age in not disabled by the coverture from contirmine an ante-nuptial settlement after she is of age: Rr Imolwin: sittlement [1R日4] 2 Ch. I2I, 6 is I. J. ('h. grig.

(r) Without regard (1) the date at which any particular interest affected may fall into possession :

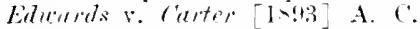
360. 193 L. J. ('h. 16n), with which Re Jones [1043 2 Ch. til. (i2 L.J. Ch.996. dnes not seem reconcileable. And election must be marle once for all. not separate elections for each aerpusition-see Tiditz $r$.
O'Ilagull [189!1 2 Ch.pp. 569, 576. (d) Endi-puted in Hawis v. 11 all (18ti) 1 Ex. 122. 1t L. J. Ex. 27u. foll. In ie IIodsones Sittlement [18:4] 2 Ch. 421. 63 L. .J. Ch. t609.

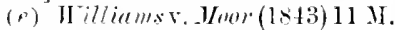
(E W. 25ti.264.266.12 L. J. Ex. 233. ( $f^{*}$ Flight v. Bolland (1828) I

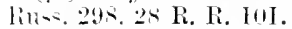

(y) See per Parke B. Nenry und

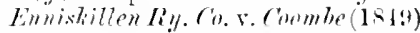
3 Ex. 56i. I L. J. Ex. 325: per (uv. L. I. I. W. R. v. M.Michearl (15.51) 5 Ex. 114. 20 L. J. Ex. 97.

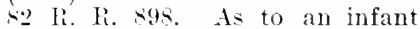
heing bounl when he comes of age by an acknowlergment made in a Court of Record. see Y. B. 211 \& 21 Er1. 1. p. 320.

(i) Per Lord Colonsay, L R. 2 H. L. 375. 
cannot deprive himself of the right to elect at full ag", and only then can his election be conchusively determined $(i)$. If an infant pays a sum of money under a contract, in consideration of which the contract is wholly or partly performed by the other party, he can acquire no right to recover the money back by rescinding the contract when he comes of age. Such is the case of a premium paid for a lease $(k)$, or of the price of goors (not being necessaries) sold and delivered to an infant and paid for by him: and so if an infant enters into a partnership and pays a premium, he cannot either before or after his full age recover it back, nor therefore prove for it in the bankruptey of his partners $(l)$.

We must now consider the Act of 1874 (37\& 38 Vict. c. 62), which enacts as follows:-

Money pairl under a voided eontraet, when unt. recoverable.

I. All contracts whether by speeialty or by simple eontract henceforth entered into by infants for the repayment of money lent or to be lent. or for gouds supplied or to lie supplier (other than contracts for necessaries), and all accounts stated with infants, shall be absolutely void: provided always that this enactment shall not invalislate any eontrace into which an infant may by any existing or future statute or by the rules of common law or equity enter, exeept such as now hy law are roidable.

2. No action shall be bronght whereby to eharge any person upon any promise matle after full age to pay any debt contracted luring intancy, or upon any ratification marle after full age of any promise or contract mate during infaney, whether there thall or shall not be any new consideration for such promise w ratifiation after full age.

3. This Act may be cited as The hnfants' lielief Act, 187.

The 2nd section ( $m$ ) forbicls an action to be brought on any promise or ratification of a contract made rluring

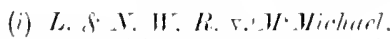
sumere note (a) : Nlentor v. Trimble (1s(i) 11 fr. C.. L. Lep. 312.

(k) Ilolmes v. Blu!t!l (1817) \&

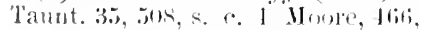

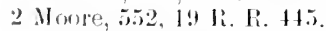

(l) Ear parto Taylur (1<isg) \& 1 . M. (i. 2.5.,2.s. But if the infant has rereiver un ansideration at all he can reeover: Hamilton $v$. langhan-stherrin, for. Co. [189.1]

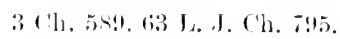

(Iii) 'l'he Act of $18 \pi t$ supersed the ith section of borrl Tenterdents Act (: tien. l. c. 14), by which no ratification of such a contract conlel be s'sul unon wuless in writing and signed by the party to b. ehargerl, since expressly repeated by the statute law hevision Ad, lat. (3x s $39 \mathrm{vict}$ e. 66 ).
Ratification still operative for some imposes. 
infancy, and it applies to a ratification since the Act of a promise made in infancy before the passing of the Act $(n)$, whether the agreement is or is not one of those included in s. $1(\mathrm{o})$. It probahly also prevents the ratification from being available by way of set-off $(p)$. This, however, is a different thing from depriving the ratification of all effect. For it may have other effects than giving a right of action or set-off, and these are not touched. While the matter was governed by Lord Tenterden's Act ( $(1, \prime)$ there were many cases where a contract made during infancy might be adopted or confirmed without any ratification in writing so as to produce important results. Thus in the case of a marriage settlement the married persons are bound not so much by liability to be sued (though in some cases and for some purposes the hushand's covenants are of importance) as by inability to interfere with the disposition of the property once made and the execution of the trusts once constituted: and so far as concerns this an infant's marriage settlement may, as we have seen, be sufficiently confirmed by his or her conduct after full age $(q)$. Again an infant partner who does not aroid the partnership at his full age is, as between himself and his partners, completely bound by the terms on which he entered it without any formal ratification; and in taking the partnership accounts the Court woukd

(ii) Fin merte Kible (387i) L. li. 10 ('h. 373. 4t L. .J. Bk. 1i3.

(ii) Cinclement v. Mullis (18-8) is ('. P. D. 43!) 47 I. J. (\%. I'. 761. It is held, however, that in a case which would before the Act have been one of ratification it maty be left to the jury to say whether the combluet of the prarties amounts to a new promise: Ditsham v. Wirmall $(18 \times 0) ;$ C. P. D. 410,49 L.J. ('. I'. 6ss, by Lindley and Demman JJ., dis. Lord Colerialge C.J.

(1) Rucley v. Rueley (1876) I
Q. P. Div. 460, 45 L. J. Q. B. $6 \pi 5$.

( $\left({ }^{\prime \prime}\right)$ ) See note (m). p. (i3.

(1) Darios v. Daries (1siil) L. R. $9 \mathrm{Eq}$. 4ts. 39 I. J. (h. 343. supre. 1. ti:. In Duncan v. Dixom (1890) 4 (h. D. 211. 59 L. J. Ch. 437 . an attempt was made to bring an infant's marriage settlement within s. 1. on the gromm that it must be read as including all contracts whatever. The Act is not quite so ill-drawn as to admit this construction. 
apply the same rule to the time of his minority as to the time after his full age. Again an infant shareholder who does not disclaim may after his full age, at any rate, be made liable for calls without any express ratification ; on the contrary, the burden of proof is on him to show that he repudiated the shares within a reasonable time $(r)$.

And as Lord T'enterden's Act did not formerly stand in the way of these consequences of the affirmation or non-repudiation of an infant's contract, so the Act of 1874 will not stand in the way of the same or like consequences in the future. In fact the operation of the present Act seems to be to reduce all voidable contracts of infants ratified at full age, whether the ratification be formal or not, to the position of agreements of imperfect obligation, that is, which cannot be directly enforced but are valid for all other purposes. Other examples of such agreements and of thcir legal effect will be found in the chapter specially assigned to that subject.

A collateral result of this enactment appears to be that one who has marle a contract during his infancy is not now able to obtain specific performance of it after his full age, for the same reason that he cannot and formerly could not do so sooner $(s)$.

The proviso as to new consileration meets such cases as that of an attempt to set up as a new contract the compromise of an action brought on the original promise $(t)$. It is reinforced by s. 5 of the Betting and Loans (Infants) Act, 1892, which ahsolutely avoids all agreemonts and instruments (even negotiable ones) made for the payment of money ropresenting or connected with a loan advancerl during infancy $(u)$.

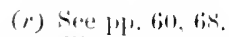

(ii) Flight ve Buildtul (152t) t

liuss. 295,21 li. li. tol, w. liz, supue.

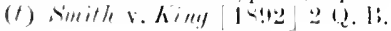

1 . i13, 137 1. T. T.21\%.

(ii) is Vict. 6. 1. The rest of Ho. A.t is arminat. semble, no specific performance for either party of any contract male during infancy.

Effect of proviso as to new consideration. 
Of \&. 1, making cer tain contracts vind.

In the first section of the principal Act, the words concerning the purchase of goods are not free from obscurity. If we might construe the Act as if it said "for payment for gools supplied," \&c., it would be clear enough: but it is not so clear what is the precise operation of an enactment that contracts "for goods supplied or to he supplied," other than necessaries, shall be void. It seems to follow that no property will pass to the infant by the attempted contract of sale, and that if he pays the price or any part of it before delivery of the goods he may recover it back; as indeed he might have done before the Act, for the contract was voidable, and he was free to rescind it within reasonable time. But it does not follow that if the goods are delivered no property passes or that if they are paid for the money may be recovered back. At all erents an infant who has paid for goods and received and used them cannot recover the money back (l). The contrary construction would be unreasonable, and is not required by the policy of the statute, which in to protect infants from running into debt, not to disable them from making purchases for realy money. It is certain that when a particular class of contracts is simply declared to be unlawful, this does not prevent property from passing by an act competent of itself to paiss it, though done in pursuance or execution of the forbiriden contract $(u)$. Moreover it has been hele that an infant may be guilty of lar. ceny an a balce though the gonds were delivered to him on an agreement void under the Aut $(x)$. On the whole it seems that the contract is voidable, but that goods actually delivered can he rotumed, and the price recovered back, only so far and so long as complete restitution is possible.

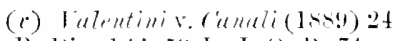
Q. B. Liv. liti, .S? L. J. Q. R. Tt.

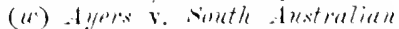
Bunkinif ('o. (1Ni1) L. R. 3 I'. ('. its. .5. 40 I. J. C. P. 22.

(x) R. v. Ho Lomald (18s.i) I5 Q. B. I. 323. 32 L. T. 583 . 
It has been suggested that the exception of "contracts for necessaries" may include loans of money advanced and in fact used for the purpose of buying necessaries. The point is not known to have heen judicially considered. It was an old rule in equity that a person so advancing money was entitled to stand in the legal ereditor's place to the extent of what was actually spent on necessaries (y).

It is doubtful whether a bond, bill of exchange, $01^{\circ}$ note given by a man of full age, for which the cunsideration was in fact the supply of goods not neecessaries during his infancy, would be void under s. 1(z). But s. 2 (which indeed seems altogether more useful than s. 1) woukl no doubt effectually prevent it from being enforced as between the immediate parties, though perhaps the words are not the most apt for that purpose.

The Building Societies Act, 187t, mables an infant to be a member, but this does not imply any exemption from the disability to mortgage his real estate created by the Infants' Relief Aet: for that is not the sole purpose or a necessary purpose of membership (a).

2. Of the liability of infants on obliyations incident to interests in permanent property.

In an old case reported under various names in various books $(b)$, it was decided that an infant lessee who continues to occupy till he comes of full age is a fiter his full age liable for arrears of rent incurred during his infancy. In like manner a copyholder who was al-

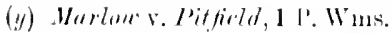
sise, and see Lrwis v. Hlleyur

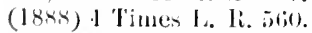

(z) Co. Flight r. Refd (I S6i3) 1 H. . ( . .703, 32 5. J. Ex. 26ii.

(a) Thurstan v. lottingluam, for. Building sire. [1902] I i h. 1, , I I.J. ('h. 83, [1903] A. C.6. (b) Eittle v. Eliot (16ils) liolle Ab. 1, 731, K., ('ro. Jale. : :i20, Brownlow, I:20, 2 bulst. (i9). Siee the jurlgnent of the court of Exchequer in L. \&. I. II. I'y. ('i. v. W Michael (1850) is Ex. 111,20

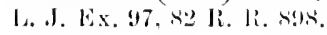

Liability on ubligations incident to property, and especially as to railway thares. 
mitted during his minority and has not disclaimed is bound to pay the fine $(c)$. The same principle is applied to the case of infant shareholders in railway companies. An infant is not incapable of being a shareholder $(d)$, and as such is prima facie liable when he comes of age to be sued for calls on his shares. He can aroid the liability (which, though regulated by statute, has the general incidents of contract) only by showing that he repuliated the shares either before attaining his full age $(e)$, or in a reasonable time afterwards $(f)$. A railway shareholder is not a mere contractor, but a purchaser of an interest in a subject of a permanent nature with certain obligations attached to it; and those obligations he is bound to discharge, though they arose while he was a minor, unless he has renounced the interest. A mere absence of ratification is no sufficient defence, even if coupled with the allegation that the defendant has derived no profit from the shares. For if the property is unprofitable or burdensome, it is the holder's business to disclaim it on attaining his full age, if not before; and perhaps he could not exonerate himself even during his minority by showing that the interest was not at the time beneficial, moness he actually disclaimed it (y). Comparing the analogous case of a

(a) Eirlyn r. ('hichestes (17isi)

3 linire 17 it.

(d) lle can subscribe a nemo-

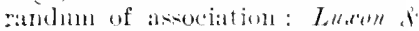

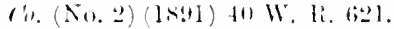

(P) Lenry dinnisknlen Ry. l'i.

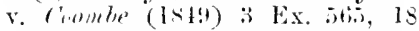
L. J. Ex. 325.

(f) A plea which merely allerel repuliation after full age was therefore held bad in thblin of Hiaklone

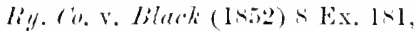
22 L. J. Ex. 94,91 li. li. 40.2 . At one time it seems to have been thought that even an infant share. hohler was made alsolutely liable by the gemeral lom of the enate nient in the companies clanses (omolidation Aet detining the liability of sharebohlers. see jer Lord lienman C.J.and l'attesm J.

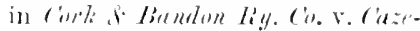
nere (18ti) ]0 Q. B. 935. This vitw w:L afterwards abantoned as inconsistent with the established mule that gencral works in statutes are not to be construed so as tu deprive infants. Inuatics. sc.. of the protection given to them by the common law.

(g) It is submitted that in sueh a ease the diselinimer if made would conch-ively determine his interest and not merely suspent it. 
lease, the Court said:- "We think the more reasonable view of the case is that the infant, even in the case of a lease which is disadvantageous to him, cannot protrect himself if he has taken possession, and if he has not disclaimed, at all events unless he still be a minor " $(h)$. Similarly an infant member of a building society who has purchased land hy means of an advance from the society cannot claim to hold the property free from the society's charge for the money advaneed $(i)$. In all the decided cases the party appears to have been of full age at the time of the action being brought, but thepe is nothing to show that (exerpt possibly in the case of a disadvantageous contract) he might not as well be surel during his minority.

The same results, except perhaps as to suing the shareholder while still a minor, would follow from the general principles of the law of partnership even if the company in which the shares were held had not any permanent property.

3. Of the liability of an infant when the contract is for his benefit, and especially for necessuries.

It has been laid down in general terms that if an agreement be for the benefit of an infant at the time, it shall bind him $(j)$, or even that the contract is binding unless manifestly to the infant's prejudice $(k)$. An infant's contract of apprenticeship (l), or an orlinary contract to work for wages, will, if it he reasomahle, be considered binding on the infant, so that he may no less than an adult incur the statutory penalties for unlaw-

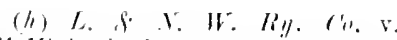

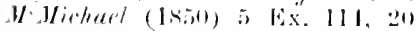
I. .J. Ex, $97,101, x 2$ Ii. Ii,,$! ! ! !$.

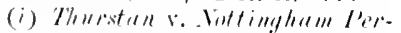
manent beruefit linilitimg sine. [190): A. ( 1,6 .

(j) Malden v.t. White:(1757) 2
T'. R. 1.i!. 1 li. li, ti:?.

(li) (inemer v. ximmons ( 1 sisiz) 7 11. A 5.707 .721 ; per Wille 18. Not sis strongly put in lle 1. J. repurt. 31 1... . M. 1. 138. 111.

(l) 11 ind v. Fomwirl (1512) 10 M. \& W.1195.
Liability on heneficial contract. ",$\prime$. extent of the rule? 
fully absenting himself from his master's employment $(m)$. An infant entered the service of a railway company and, as a condition of the service, became a member of an insurance society established by the company: the funds were augmented by the company to the extent of five-sixths of the premiums payable by the members. The rules provided for compensation in all cases of accident not due to the member's own wilful act or gross negligence, and hound the members to accept the benefits of the society in lieu of any claims under the Employer's Liability Act. The Court of Appeal held that the infant wat hound by this agreement as being on the whole for his benefit $(n)$. But an action will not lie against an infant on a covenant in apprenticeship indentures $(0)$ : and if the terms are not reasonable the agreement is roid for all purposes, so that an action will not lie against a stranger for enticing away the apprentice $(p)$. Agtin there are many conceivable cases in which it might be for an infant's bene-

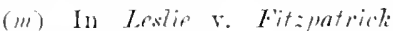
(1.7T) 3 U. I. 1). 204. 47 L. J. .l. C'. 2.2. a case of summary proceelings umber the Eumloyers and Work. men Act. 1sis, it ina be collerted llat the farts were of the same kiml. thones the employer"s plaint was in telms for a bueach of rom-

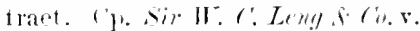

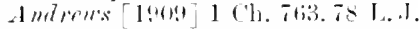
('h. -1). 1. A.. where howcrer the restrietive covemant in question was luld unenforceable apart from infaley. As to infant apuentiees in I,miton. ace 1\% 7\%. below.

(11) $6 \%$ ments r. J. o. I. II. Ry.

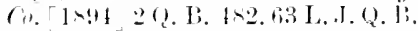
837. It scems. though it was not nece-ary to decile the point, that the principle of an infant"s contract beine valid when the count is satisfied that it was for his benefit is mot coutined (as was aroned for the haintiff) to contlacts of alpuenticeship or labuur: se especially the julgment of Kay L.J. Sote as to the Workmen's Compensation Act that there is nothing in it to make a statutory agreement for eompensation binding on an infant if not for his benefit: Stephens r. Thulbrilue Tramewris (o. [1904] 2 K. I. 225.73 L. J. K. B. 73!4. A. C. (a) Joe Francesco v. Barmum (Xo, 1) (1<, 43 Ch. D, I L. J. ("ll. 1.j.

(l) Dir Framesen v. Barnum (Xo.2) (18.90) 45 ('h. L. 430.63 L. T. A3s. A clause enabling the master to suspend the apprentices wages in an event which may be the to the master"s own act. say a luck-ont. is not reasonable: rim v. Wuttlems [1-93]1 Q. B. 310,62 L. J. II. C. Ail. C. A.. dist. Green ․ Jhompson [189!t] 2 Q. B. 1.68 L. J. Q. B. 719. where the exception was of days when the business shoukl be at a standsill by aceidents beyom the contrul of the master. 
fit, or at least not manifestly to his prejudice, to enter into trading contracts, or to buy goods other than necessaries: one can hardly say for example that it would be manifestly to the disadrantage of a minor of years of discretion to buy goods on credit for re-sale in a rising market; yet there is no donbt whatever that such a contract would at common law be voidable at his option. A contract whereby an infant agrees with a railway company, in consideration of being allowed to make a certain habitual journey to and fro on special terms, to waive all claims for accident to himself or his property, is detrimental to the infant and not binding on $\operatorname{him}(q)$. Nor has it ever been suggested that an infant partner or shareholder is at liberty to disclaim at full age only in case the adventure has been unprofitable $\mathrm{OP}^{\circ}$ is obviously likely to become so. However, inammoh as since the Infants' Relief Act, 187t, an infant 's contract, if not binding on him from the first, can nerer. be enforced against him at all, it seems quite possible that the Courts may in future be disposed to extend rather than to narrow the description of contracts which are considered binding because for the infant's benefit $(r)$. A contract may be for an infant's benefit as a whole though particular terms are bad as heing in excessive restraint of frade or the like $(s)$.

3a. Contracts for necessuries.

By the Sale of Croods Act, 1893, s. 2-

Lialility for necessaries.

... "Where necessaries are sold and deliverel to an infant . . or to a person who by reason of mental

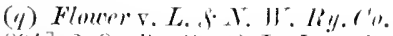
[18:4] 2 Q. B. 155. 4i3 L. J. (). B. 517. $1 . \mathrm{A}$.

(r) In an action brought by an infant, an ludertaking eiven by the infant's next frient is mot binding if the circumstauces ane such that it cannot be for the infint's benetit : Rhendes v. Sirithen-

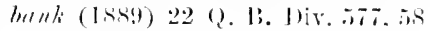
I. I. (2. 1., 2. i.

(s) Bromley v. ximith [1!0!9]2 K. I. $235, \pi$, I. I. K. I. T1. 
incapacity or drunkenness is incompetent to contract, he must pay a reasonable price therefor.

" Necessaries' in this section mean goods suitable to the condition in life of such infant.. . or other person, and to his actual requirements at the time of the sale and delivery."

This enactment is a legislative declatation of the law as settled hy a series of authorities, of which the judgment of the Exchequer ('hamber in Pyder v. Wombuell is the chief :-

"The ceneral rule of law is clearly e-tabli-berl, and is that an infant is senerally incapable of binding himelf by a contract. To this rute there is an exception intrubued, not for the benefit of the tradesman who may trust the infant. but for that of the infant himself. This "sception is that be may make a contraet for necssaries, and is accurately

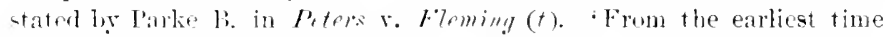
down tw the present the worl necesaries is not confined in its striet sense to such articles as were necessary to the support of life. but estender to articles fit to maintain the paticular person in the state. degree and -tation in life in which he is: and therefore we must not take the word necesarjes in its muluafied sense, but with the qualification abrve pointed ont ${ }^{\cdots}$ (u).

What are necessiries : a question of mixed fact and law.

What in any particular case may fairly be called necessary in this extended sense, is what is called a question of mixed fact and law: that is, a question for a jury, subject to the Court being of opinion that there is evidence on which the jury may not unreasonably find for the plaintiff.

The station and circumstances of the defendant and the particulars of the claim heing first ascertained, it is then for the Court to say whether the things supplied are prima facie such as a jury may reasonably find to be necessaries for a person in the defendant's circumstances, or "whether the case is such as to cast on the plaintiff the onus of proving that the articles are within

(t) $(18+11)$ is M. . W W. at 1'. 46.

(ii) (1k68) L. R. 4 Fx, 32.35: in the Conrt helow L. F. 3 Ex. 90. 3 L. J. Ex. S. 
the exception [i.e., are necessinies], and then whether there is any sufficient eridence to satisfy that onus." In the latter case the plaintiff must show that although the articles would generally not be necessary for a person in the defendant's position, yet there exist in the case before the Court spocial circumstances that make them necessary. Thus articles of diet which are prima facie mere luxuries maly heconte necessaries if proscribed by medical advice $(r)$. It is said that in gemrral the test of necessity is usefulness, and that nothing can be a necessary which cannot possibly be useful: but the converse does not hold, for a useful thing may bo of unreasonably costly fashion or material. It is to be borne in mind that the question is not whether the things are such that a person of the defendant's means may reasonably buy and pay for them, but whether they can be reasonably said to he so necessary for him that, though an infant, he must obtain them on credit rather than go without. For the purpose of deciding this question the Court will take judicial notice of the ordinary customs and usages of society $(w)$.

If the Court does not hold that there is no evidence on which the supplies in question may reasonahty be treated as necessaries, then it is for the jury to say whether they were in fact necessaries for the defendant under all the circumstances of the case.

The Act has laid down, in accordance with the weight of authority $(x)$, that the huyer's actual requirements must be considered. If the goods supplied

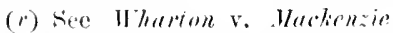

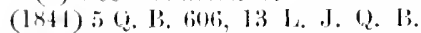
li30, dil R. R. ist. and per Brantwetl P., I. Ri. 3 Fx. at p. !hi.

(ii) I. li. + lix, at l. Io.

(x) Bragsham v. Eutom (1539) 5 Bing. N. G. 231, 7 Sicott, 183, ,

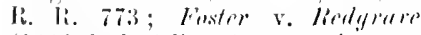

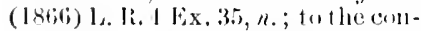
trary, $l$ gydor v. 11 omblectl (Isiss)
I. IR. 3 lix. !10, 3 I. I. Fx. \& (the penint was left open in Fx. ('h.e i. li. + Ex. (2); but this was dis-

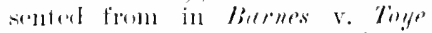
(Jist) $1: 3$ \%. H. I). HIt. alme (by memlerse of the ('. A. sittiong ats a loivisional ('omet) Johnstomer v.

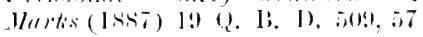
1. I. (?. I). 6 , 
are necessiry, the tradesman will not be the less entitled to recover because he made no inquiries as to the infant's existing supplies; but if the infant is already so well supplied that these goods are in truth not necessary, the tradesman's ignorance of that fact will not make them necessary, and he cannot recover. There is no rule of law casting on him a positive duty to make inquiries, but he omits to do so at his peril, and the burden of proof is on him to show that the infant was not sufficiently supplied (y). But the defendant having an income out of which he might keep himself supplied with necessaries for rearly money is not equiralent to his being actually supplied, and does not prevent him from contracting for necessaries on credit $(z)$. Since the Act, at all events, the infant buyer can be liable only for the reasonable price of the goods, and it seems that this was always the law, though before the Infants' Relief Act he could at full age ratify a contract for an agreed price, whether for necessaries or $\operatorname{not}(a)$.

Apparent means of buyer not material.

It would be natural for juries, if not warned against it, to fall into a way of testing the necessary character of supplies, not so much by what the means and position of the buyer actually were, as by what they appeared to be to the seller, aud such a view was not altogether without countenance from authority $(b)$. It is conceived, however, that the knowledge or helief of the tradesman has nothing to do with the question whether the goods

(4) Vask v. Imman [1908] $2 \mathrm{~K} . \mathrm{B}$.

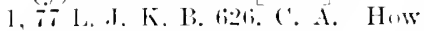
the plaintiff is to obtain this information does not aplear.

(z) Jingyhait r. Ihall (1S3:1) $4 \mathrm{M}$.

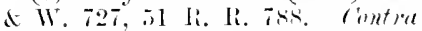

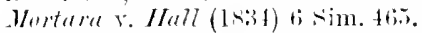
The dectrine there laid down seems superthous. for the supplies there claimed for (such as zos prairs of gloves in half a year) conkmot have heen reasonably fount necessary in any case.

(a) Julgment of Fleteher Mourton L..J. [190k] 2 K. B. at p. 8 .

(b) In Dalton v. Gib (1839) 5

ling. $x$. C. 128, 50 R. li. 75s, and l'reface: $;$ scott. 117, mueh weight is given to the "plumernt rank and circumstances of the party. This annmes to supposing that an infant may be liable, by a kind of lolding out, for gools which are not necessary in faet. 
are necessary or not. It may be said that the question for the Court will, as a rule, be whether articles of the general class or description were prima facie necrssaries for the defendant, and the question for the jury will be whether, being of a general class or description allowed by the Court as necessary, the particular items were of a kind and quality necessiry for the defendant, having regard to his station and circumstances. For instance, it would be for the Court to say whether it was proper for the defendant to buy a watch on credit, and for the jury to say whother the particular watch was such a one as he could resandibly afford. But this will not hold in extreme cases. In Ryder v. Wombwell (c) the Court of Exchequer Chamber held, reversing the judgment of the majority below on this point, that because a young man must fasten his wristbands somehow it does not follow that a jury are at liberty to find a pair of jewelled solitaires at the price of $25 l$. to be necessaries even for a young man of good fortune.

Hitherto we have spoken of a tradesman supplying goods, this being by far the most common case. But the range of possible contracts for " necossaries" is a much What the term "neces. sitries" includes. wider" one. "It is clearly agreed by all the books that speak of this matter that an infant may bind himself to pay for his necessary meat, drink, apparel, physic [including, of course, fees for medical attendance, \&c., as well as the mere price of medicines], and such other necessaries and likewise for his good teaching and instruction, whereby he may profit himself afterwards" (d). Thus loming a trate may be necessary,

(a) (18is) 1. 12. 1 Lix. 32. 33 I. J. Ex.s.

(d) Bace dir. lufaury ant den. I.

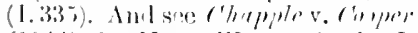
(1814) 13 M. \& W.2.2, 13 1. J.
Rx. 2sti. di R. R. 万S6. As to instruetion in trater se. Wallor.

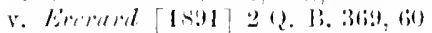

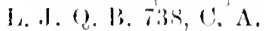


and on that principle an infant is indenture of apprenticeship has been said to be binding on him (e). The preparation of a settlement containing proper provisions for her benefit has been held a necessary for which a minor about to be married may make a valid contract, apart from any question as to the validity of the settlement itself $(f)$.

A more remarkable extension of the definition of necessaries is to be found in the case of Chapple r. Cooper (!), where an infunt widow was sued for her hushand's funeral expenses. The Court held that decent hurial may he considered a necessary for every man, and husband and wife being in law the same person, the decent hurial of a deceased husband is therefore a necesisary for his widow. It would perlapss have been better to adopt the hroader ground that a contract entered into for the purpose of performing a moral and social, if not legal, duty, which it would have been scandalous to omit, is of as necessary a character as any contract for personal service or purchase of goods for personal use.

The liability is on simple contraet only.

The supply of necessaries to an infant creates only a liability as on simple contract, and it cannot he made the ground of any different lind of liability. Coke says: "If he bind himself in an olligation or other writing with a penalty for the payment of any of these, that obligation shall not hind him" $(h)$. Similarly his negotiable instruments are voidable eren if given to pay for necessaries ( $i$ ). A fortiori, a deed given by an infant to secure the repayment of money adranced to buy

(e) (muper v. Simmoms (1ntia) H. $\mathrm{x}$ ․ $70 \%, 31$ L. J. II. (‥ 139, per llartin li. siee, however, 1. 70, supra.

(f) Helpss. claytom (Istit) It

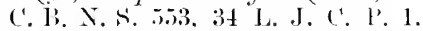
see the plearlings, and the julgment of the Court ad, tin. (g) $(1 \times 44) 13$ 11. A W. 252. 1.3

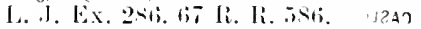

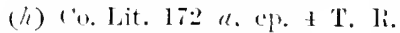
:3iis.

(i) Mr sistyke!t, E.r parte Margrett [1:5!1] I Q. B. 413, 60 J. J. Q. 1.33!. C. A. 
necessaries is voidable $(j)$. But in these and similar cases the infant's liability on simple contract, or rather quasi-contract, is not affected $(k)$.

There are some particular contracts of infants valid by custom. By custom incident to the tenure of gavelkind an infant may sell his land of that tenure at the age of fifteen, but the conveyance must he by feoffment, and is subject to other restrictions $(l)$. 'This, however, is not really a capacity of contracting, for there is no reason to suppose that an action could be brought against the infant for a breach of the contract for sale, or specific performance of it enforced.

"Also by the custom of London an infant unmarried and above the age of fourteen, though under twenty-one, may bind himself applentice to a freeman of London by indenture with proper covenants; which covenants by the custom of London shall be as binding as if he were of full age," and may be sued upon in the superior courts as well as in the city courts $(m)$.

Infants, or their guarlians in their names, are emWhat contracts an infant can make by custom: powered by statute (11 Geo. $4 \& 1 \mathrm{Wm} .4$, c. 65, ss. 16, 17) to grant renewals of leases, and make leases meler the direction of the Count of Chancery, and in like manner to surrender leases and aceept new leases (s. 12) (n). And by a later Aet (18 \& 19 Viet. e. -13) (o), infants may with the sancetion of the Court malie valid marriage set tements of hoth real and personal property.

(i) Martin b. Virle (1siti) I ('h. 1). $128,46 \mathrm{I}, \mathrm{J} .1$ h. 31 .

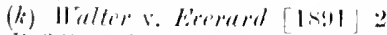

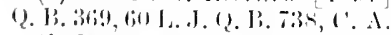

(l) liobinon in ciavelkind, i!l.

(iii) Bacon, Mия. Intiuney, li. 1.

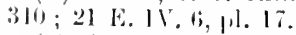

(1i) Sice Dau. ('l, I'r. 2. 1917 ;

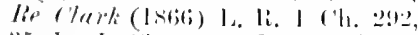

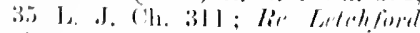
(1sti) $2(1) .11 .719,45$ I. .1. 1 h.

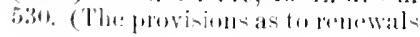

of leases exteml alio to marriol womin'll.)

(a) This Aet does not affect covertare or asy disiblitity other than inlancy : Sortom v. Serelon

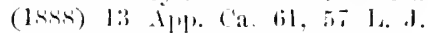
rle. citil. Surl qu. whetleer it a]plies to post-muthial sottlements. 10 ders apply to covellant- to settle

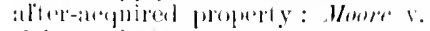

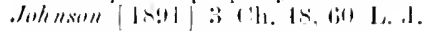
('11. 119!). 
linfant not liable for wrong where the claim is in sulsstance ex contractu. liut liable for wrong apart from contract, though touching llie subject-matter of a contract.

4. Of an infant's immunity as to wrongs connected with contract.

An infant is generally no less liable than an adult for wrongs committed by him, subject only to bis being in fact of such age and discretion that he can have a wrongful intention, where such intention is material; but he cannot be sued for a wrong, when the cause of action is in substance ex contractu, or is so directly connected with the contract that the action would be an indirect way of enforcing the contract - which, as in the analogous case of married women $(p)$, the law does not allow. Thus it was long ago held that an infant innkeeper conld not be marle liable in an action on the case for the loss of his guest is goods $(q)$. There is another old case reported in divers books $(r)$, where it was decided that an action of deceit will not lie upon an assertion by a minor that he is of full age. It was said that if such actions were allowed all the infants in England would be ruinerl, for though not bound by their contracts, they would be mate liable as for tort; and it appears in Kohle's report that an infant had already been held not liable for representing a false jewel not belonging to him as a diamond and his own. The modern case usually cited for this rule is Jennings v. Rundall (s), where it was sought to recover damages from an infant for orerriding a hired mare. But if an infant's wrongful act, though concerned with the subject-matter of a contract, and such that but for the contract there would have been no opportunity of

(p) Sec 1. \$3. infir

(q) Iiolle Ab. 1. 2, Action sur Case. I. :3.

(r) . Johlusoll v. I'ie (16itis) risl. 25. I Lev. 1199, 1 Keb, 413. fully cited by kuight Pruce Y.('. in stikemun r. Jumsan (1847) 1 lede d Sm. 113, 16 I. J. Ch. 205, 75 li. li. 4i: and see other canes collected it. at p. 110, where "the ease mentioned in lieble " is that which, as stated in the text, oeeurs in his report of Johneren s. Pie.

(.) $s$ T. R. 335. t li. li, 680. It is also reeognizel in Price $v$. Hereett (1-i2) \& Ex. Hi (not a deeision on the point). 
committing it, is nevertheless independent of the contract in the sense of not being an act of the kind contemplated by it, then the infant is liable. The distinction is established and well marked by a modern case where an infant hat hired a horse for riding, but not for jumping, the plaintiff refusing to let it for that purpose; the defendant allowed his companion to use the horse for jumping, whereby it was injured and ultimately died. It was held that using the horse in this manner, being a manner positively forbidden by the contract, was a mere trespass, for which the defendant was liable $(t)$.

It is doubtful whether an infant can be made liable quasi ex contractu (as for money received), when the real cause of action is a wrong independent of contract; but since the Judicature Acts have abolished the old forms of action, the question seems of little importance $(u)$.

5. Liability in equity on representation of full aye.

When an infant has inducerl persons to deal with him by falsely representing himself as of full age, he incurs an obligation in equity, which, howerer, in the case of a contract is not an obligation to perform the contract, and must be carefully distinguished from it $(x)$. Indeed

(t) Burnam v. Huggis (lsti3) It C. 13. N. S. 45, 32 1. J. C. I. 18\%. A bailment at will would liave been determined, ats where a bailee commits theft at common law by "breaking bulk."

(u) The liability is affimed by Leake (p. tro). and disputed by Mr. Hicey (on l'arties, 2xt), who is supported by a dictum of Willes.l. assuming that infancy would be a good plea to an action for money received, though substantially foundert on a wrong. Altom r. Widlend liy. ('o. (18isi) 19 ('. R. N. S. at 1. 211,34 L. J. ('. l' at
1. 295 (a deceision of doubtful authority, see bolluck on lourts, Stloel. itt).

(x) Arre liatlett v. Wolls (186i2) 1 I. A. A. 83ti. 31 L. J. Q. I: 57. lecelaration for goods sold. Se. llea. infancy. Equitable replica. tion, that the cont ract was induced by chemulant's framblutent representation that he was of age. The replication wats held bad, ats not meeting the defence, but only showing a disinct equitable riglit collateral to the cause of action sued upkus.
(1). whether liable on contracl implied in law.

in equity liable and birund by his arets, sce.. if he represent. linuself as of full age : but (mily to the extent of any alvantage thereby gainerl. 
it is not a contractual obligation at all. It is limited to the extent we have stated above (p. 57), and the principle on which it is founder is often expressed in the form: "An infant shall not take advantage of his own fraud." A review of the principal cases will clearly show the correct doctrine. In Clarke v. Cobley $(y)$ the defendant being a minor had given his bond to the plaintiff for the amount of two promissory notes made by the defendant's wife hefore the marriage, which notes the plaintiff delivered up. The plaintiff, on discovering the truth, and after the defendant came of age, filed his bill praying that the defendant might either execute a new bond, pay the money, or deliver back the notes. The Court ordered the defendant to give back the notes, and that he should not plead to any action brought on them the Statute of Limitation or any other plea which he could not have pleaded when the bond was given; but refused to decree payment of the money, holding that it could do no more than talie care that the parties were restored to the same situation in which they were at the date of the bond. In Lemprière v. Lange, a quite modern case, it was held that an infant who had obtained the lease of a furnished house by representing himself of full age could not he made liable for use and vecupation, although the lease could be set aside and the infant ordered to pay the costs of the action $(z)$. Cory r. Ferteken (a) shows that when an infant by falcely representing himself to be of full age has induced trusters to pay over a fund to him, neither he nor his representatives can afterwards charge the trustees with a breach of trust and make them pay again.

(4) 1789$) 2 \cos 173.2$ li. R. 25. It must lue taken, thongh it is not clear by the repunt that the defendant falsely reputented himself as of full age.

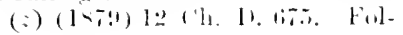

luwed on the question of costs,

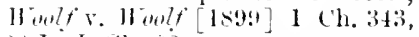
bis J.. I. Ch. S2. (ii) (loli) 2 Math. to. 17 R. Ji. $1 \times 0$. 
Overton v. Banister (b) confirms this: it was there held, however, that the release of an infant cestui que trust in such a case is binding on him only to the extent of the sum actually received by him. The later case of Wright v. Snowe (c) seems not to agree with this, though Overton v. Banister was cited, and apparently no dissent expressed. There a legatee had given a releaso to the executrix, representing himself to her solicitor as of full age; afterwards he sued for an account, alleging that he was an infant at the date of the release. The infancy was not sufficiently proverl, and the Court would not direct an inquiry, considering that in any event the release could not be disturbed. This appears to go the length of holding the doctrine of estoppel applicable to the class of representations in question, and if that be the effect of the decision its correctness may perhaps be doubted. In Stikeman v. Dawson ( $d$ ) the subject of infant's liability for wrongs in general is discussed in an interesting judgment by Knight Bruce V.-C. and the important point is decided that in order to establish this equitable liability it must be shown that the infant actually represented himself to be of full age; it is not enough that the other party did not know of his minority. And as there must be an actual false representation, so it has been more lately held that no claim for restitution can be sustained unless the representation actually misled the person to whom it was made. No relief can be given if the party was not in fact deceived, but knew the truth at the time; and it makes no difference where the husiness was actually conducted by a solicitor or agent who did not know $(e)$.

(b) $(1811): 311 \mathrm{a} .513$.

(a) (1818) 2 be (1. \& sim 321 .

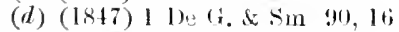

L. J. Ch. 205,75 R. R. 47 ,

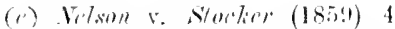
be (i.d. I. 458, 24 1. J. (h. 751. As to a marriesl woman's similat fratul, see f. 83, helow.
There mu-t be a positive representation, not mere dissimulation, and the other party must be in fict misled. 
Proof in bankruptey.

But subsequent valisl contract after full age prevails.

A minor cannot be adjudicated a bankrupt in the absence of an express representation to the creditor that he was of full age. The mere fact of trading cannot be taken as a constructive representation $(f)$. But if a minor has held himself out as an adult, and so traded and been made bankrupt, he cannot have the bankruptcy annulled on the ground of his infancy $(q)$; and a loan obtained on the faith of an express representation that he is of full age is a claim provable in bankruptey $(h)$.

A transaction of this kind cannot stand in the way of a subsequent valid contract with another person made by the infant after he has come of age; and the person who first dealt with him on the strength of his representing himself as of age acquires no right to interfere with the performance of the subsequent contract $(i)$. This is another proof that the infant's false representation gives no additional force to the transaction as a contract.

It was also held in the case referred to that, assuming the first agreement to have been only roidable, it was clearly aroided by the act of the party in making another contract inconsistent with it after attaining his full age. But it has been decided in Ireland (as we have seen) that this is not so in the case of a lease granted by an infant; the making of another lease of the same property to another lessee after the lessor has attained full ago in not enough to aroid the first lease $(k)$. The fact that an interest in property and a right of possession has passed by the first lease, though voidable, explains the distinction.

(f) Ex parte Jont's (1841) 18 ('h. Div. 109, 50 L. J. Ch. 183. overruling E.r purte Lynch (185i) 2 Ch. D. 227,45 L. J. Bk. 48.

(9) Eir parte Watson (18is9) 16 Ves. 265 ; E.r purte Butes (18+1) 2 Iont. 1). \& D. 337.

(h) E.r parte Enity Bank (1858)
3 De G. \& J. 63, 2 - L. J. Bk. 33 : see observations of Jessel M.R. thereon, 1 s Ch. D. at p. 121.

(i) Inmen v. Inman (1873) L. R. 15 Eq. 260.

(k) Slator v. Brady (1863) 14 Ir. C. I. Rep. 61, supra. p. 59. 


\section{Married Womes.}

A married woman is capable of binding herself by a contract only "in respect of and to the extent of her separate property" $(I)$. This limited capacity is created by a statute founder on the practice of the Court of Chancery, which for more than a century had protected married women's separate interests in the manner to be presently mentioned. Except as to separate property the old common law rule still exists, though with greatly diminished importance. That rule is that a married woman cannot bind herself by contract at all.

If she attempts to do so "it is altogether voirl, and no action will lie against her husband or herself for the breach of it $"(m)$. And the same consequence follows as in the case of infants, namely, that although it married woman is answerable for wrongs committed by her during the coverture, including frauds, and may be sued for them jointly with her hushand, or separately if she survives him, yet she cannot be sued for a fraud where it is directly connected with a contract with her, and is the means of effecting it and parcel of the same. transaction, e./\%, where the wife has ohtained ardvances from the plaintiff for a third party hy means of her guranty, falsely representing herself as sole $(m)$; but it is doubtful whether this extends to all cases of false representation by which credit is obtained (n). For the same reason - that the law will not allow the contract to be indirectly enforced - a married woman is not estopped from pleading coverture hy laving deseribed herwelf as sui iuris (o).

The fact that a married woman is living and trading

(l) Married Wemen is l'mperty Act, $1 \times 6,2,15 \& 46$ Vict. c. 75, s. 1 .

(iil) l'er cur. Fiairhurst v. Lirme-

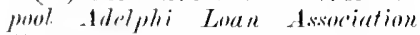
(18.51) 9 Ex. 122, 129, 23 L. J. Ex. I 64.
Married women can contract only as to separate property.

Old common law disability 
apart from her husband does not enable her at common law to contract so as to give a right of action against herself alone $(p)$. Nor does it make any difference if she is living separate from her husband under an express agreement for separation, as no agreement hetween hushand and wife can change their legal capacities and characters $(q)$.

lint may aculuire com. traetual rights: for her husliand"s henefit if he exercise them luring the coverture : otherwise for hel own. if she survive.

But " a married woman, though incapable of making a contract, is capable of having a chose in action conferred upon her, which will survive to her on the death of the husband, unless he shall have interfered by doing some act to reduce it into possession ": thus she might, hefore the Married Women's Property Act, buy railway stock, and hecome entitled to sne for dividends jointly with her hushand $(r)$. When a third person assents to hold a sum of money at the wife's disposal, but does not pay it over, this is conferring on her a chose in action within the meaning of the rule $(s)$.

During the joint lives of the husband and wife the hushand is entitled iure mariti to receive any sum thus due; "but if the wife dies hefore the hushand has received it, the lusband, althongh his beneficial right remains the same, must in order to receire the money take out administration to his wife; and if he dies without haring done $s o$, it is necessary that letters of administration should he taken out to the wife's estate (for such is still the legal character of the money), but the wife's administrator is only a trustee for the representative of the husband " $(t)$. Accordingly the Court

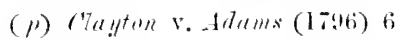
T. H. 60.5.

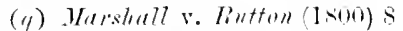
T. li. itis. is R. R. 14.

(r) l'er Cur. Mrettan vo Midland Riy. (‥ (18.3) 1:3 ('. li. tit. 22 L.. J. C. l'. 17\%. Anl see 1 Wms. Saund. 22.2. 22:3. On the duestion what amounts to recluetion into 10session. see Williams on Execu. tors, tifl stry. (10th ed. $1 !(1) 5)$. "Iidfory v. Tepper (18Ti) S ('h. D. ilti. i ch. Div. 423,47 L. J. Ch. isil.

(s) Fleet $x$ Perrins (1sis) l. R. 3 Q. B. .3 3i, + Q. B. 5no. 3r L. J. Q. B. 2.7.

(t) Per Lord Westbury, Partingtan v. Att.-Gen. (1869) L. R. 't H. L. $100,119$. 
of Probate cannot dispense with the double administration, even where the same person is the proper reprrsentative of both husband and wife, and is also beneficially entitled $(u)$.

Inasmuch as according to the view established by modern decisions a promise to pay a debt barred by the Statute of Limitation operates not by way of pustdating the original contract so as to "draw down the promise" then made, but as a new contract founderl on the subsisting consiteration, a married woman's general incapacity to contract prevents such a promise, if made by her, from being effectual ; and where before the marriage she became a joint debtor with another person, that person's acknowledgment after the malriage is also ineffectual, since to bind one's joint dehtor an acknowledgment must be such as would have bound him if made by himself $(v)$.

The rules of law concerning a wife's power to bind her husband by contract, either as his actual or ostensible agent $(w)$ or, in some speeial circumstancess, by al peculiar authority independent of ageney, do not fall within the province of this work.

Exceptions at common law.- The wife of the ling of England maly sue and be surd ats a feme sole (c'o. Litt. 133 a). This was settled ats eally as the forrternth century $(x)$.

The wife of a person civilly dead may sue and be sued alone $(I b .132 b, 133 a)$. T'he cases dwelt on by Coke are such as practically cannot occur at this day, and it, seems that the only persons who can now be regarded

(u) In the tronds of Ilatrding (1572) L. R. 2 P. . I 1). 394.

(c) Pittum v. Fister (1503) 1

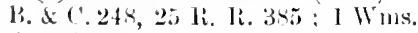
Saund, 172.

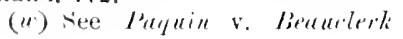

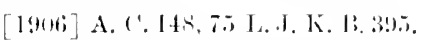
(r) Y. L. 17 it is Eil. III., ed. Pike, 430 134. Where Qunen lhiliplat sued the Abbot of cirrisceseter and anther in a quares imperdit.
Cannot during coverture renew debt barred by stat. of Limitation.
Exceptions: Queen ('unsort.
IVife of person civilly dead. 
as civilly dead are persons convicted of felony, and not lawfully at large under any licence $(y)$. An alien enemy, though disabled from suing, is not civilly dead, and his wife cannot sue alone on a contract made with her either before or during corerture; so that while he is an alien enemy neither of them can maintain an action on the contract $(z)$. This decision does not expressly overrule any earlier authority (and there is such authority) (a) for the proposition that she may be sued alone. But it is conceived that such must be the result.

Of alien not r. sident in the kinglom.

C'ustom of hombon as to married woman trading alone.

It appears to be the result of the authorities that the wife of an alien husband who has nerer been or at least never resided in England may bind herself by contract if she purports to contract its a feme sole (b).

"By the custom of London, if a feme corert. the wife of a freeman, trades by herself in a trade with which her husband does not intermeddle, she may sue and be sued as a feme sole, and the hushand shall be named

(y) Transportation wat consilfered at an abjuration of the realin. Which eerulil be letermined only by an actual return after tho sentence lat explired: (armel $v$

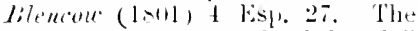
analugy to loke . Ciril l beath"

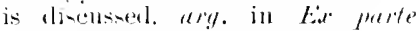

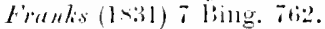

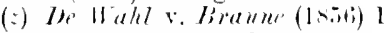
11. \& N. 17s, 2; L. J. Ex. 34:3. lt is llere surmised that the nferation of the statute of Linitation is not suspended cluring liontilities: hut this is mot eren a positive dietum. and the sinprene Comrt of the Unitul stides has repeatcelly held otherwist: see 1. 1). li. $\mathrm{xx}$. 168. 169. l'erhaps it may le cioulsted whether ".ivil teath" was ever leally appopriate as a term of art in linglish conts except "when a man entereth into religinn [i.e. a religious orler in England and is professed ": in that case he eould make a will and aploint exeeutors (who might be stied as sueh for his telets. F. N. li. 121. ()), annl if he dial not. his gonls rould be: administered (Litt. s. 230. (i) litt. 1:3l li). liractur. hwwevel. spealis of outlawry $(4: 6 ; b$ as well at religions profession (301 b) as mors cicilis. A person muler the penalties of profmunise. which include being put out of the king spotection, would. I suppose, be in the same plight as an omt law. The Joman more ricilis was a pure lesal fiction. introlued not to cleate disabilities, but to olviate the incmbenient results of disabilities otherwise created. Sav. $\therefore y-t .2$. 11it.

(11) Mrrry v. Huchessut Mazurille (1697) 1 Lil. Raym. 147 .

(b) Barden $\therefore$. Ke'erbery (15:3i) 2 H. \& W. i], i L. I. Ex. liti. liut the guestion is now of little interest. 
only for conformity; and if judgment be given against them, she only shall be taken in execution." (Bacon, Abr. Customs of London, I).) This custom applies only to the city courts (c), and even there the formal joinder of the husband is indispensable. But if acted upon in those corrts it may be pladed as matter of defence in the superior courts $(d)$, though they do not otherwise notice the custom $(e)$.

In certain exceptional cases in which the wife has an adverse interest to the husband she is not incupable of contracting with him. Where a wife had instituted a suit for divorce, and she and her husband had agreed to refer the matters in dispute to arbitration, her next friend not being a party to the agreement, the House of Lords held that under the circumstances of the case she might be regarded as a feme sole, that the agreement was not invalid, and that the award was therefore binding $(f)$.

The real object of the reference and award in this case having been to fix the terms of a separation, it was later held that the Court would not refuse to enforce an agree ment to execute a deed of separation merely becallse it was made between the hushand and wife without the intervention of a trustee (y). In the simpler case of an agreement to live apart, with incidental provisions for maintenance, the agreement does not require the inter vention of a trustee, and the wife (apart from the Married Women's Property Act, which does not apply) can sue the husband for arrears of maintenance due

(c) Giudell v. Shlueu (17a1) I T. li. 3i;i.

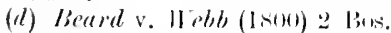
\& 1 . 93. Since the lot of 1852 the inly effect of the enstom, if atuy, secms to lee that at married woman tranling in the city of lonlon may be subject to greater frersonal liability than elsewhere.

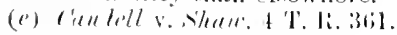

cintracts with Irusband as to separation, de., may be good. 
under it (h). It does not follow that in such transactions a married woman has all the powers of a feme sole. She has only those which the necessity of the case requires. She is apparently competent to compromise the suit with her husband $(i)$ : but she cannot, as a term of the compromise, bind her real estate (not being sottled to her separate use) without the acknowledgment required by the Fines and Recoveries Act $(k)$.

statutisy exceptions :

Julicial separations and protection orders.

Statutory exceptions other than Married Women's Property Act.

By the Act constituting the Court for Divorce and Matrimonial Causes, 20 \& 21 Vict. c. 85 , a wife judiclatly separated from her husband is to be considered whilst so separated as a feme sole for the purposes of (inter alia) contract, and suing and being sued in any civil proceeding (s. 26) (l); and a wife deserted by her husband who has obtained a protection order is in the same position while the desertion continues (s. 21). This section is so worded as when taken alone to countenance the supposition that the protection order relates back to the date of denertion. It has been decided, however, that it does not enable the wife to maintain an action commenced by her alone before the date of the urder $(m)$. Her powers of disposing and contracting apply only to property acquired after the decree for separation or the desertion (or protection order?) as

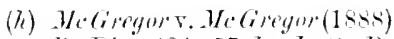
21 Q. B. Div. 424. 37 1. J. 1. 13. ist.

(i) Rincley r. Rincley (18bii)

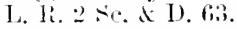

(li) rabill v. Guthill (1883) \& Ali. (a. 420 .

(7) The same consernenees follow a fortiori on a diswolution of marriage, though there is no exprese enactment that they shall : Wilkin. son r. Gitison (186i) L. R. $+\mathrm{E}_{\mathrm{q}}$. 162. 36 L. J. (h. 646: see also, as to the diroreed wife's rights. Hell.: v. Mulhu (186:2) 31 Beav. 48, 31 I. .J. Ch. 344: Fitzgerald v. Chap. man (15.5) 1 Ch. D. 563, t5) L. .J. ('h. 로 : burton y. sturgeon (1876) 2 (h. Ifiv. 3ls. t5 L. J. Ch. 633. (iii) Midland Ry. (o. v. Pye (1stil) 10 ('. 1: . . S. 179, 30 L. J. ('. H. 314 . 
the case may be $(n)$. These provisions are extended by an amending Act in certain particulars not material to be noticed here $(21 \& 22$ Vict. c. 108 , ss. $6-9)$; and third parties are indemnified as to payments to the wife, and acts done by her with their permission, under an order or decree which is afterwards discharged or reversed (s. 10). The words as to "suing and being sued" in this section are not confined by the context to matters of property and contract, but are to be liberally construed: a married woman who has obtained a protection order may sue in her own name for a libel $(o)$.

\section{Equitable doctrine of separate estate.}

In the eighteenth century, if not earline, the court of Chancery recognized and sinctioned the practice of settling property upon married women to be enjoyed by them for their separate use and free of the husband's interference or control. To this was added, towarits the end of that century, the curious and amomalous device of settling property in trust for a married woman "without power of anticipatim," so that she camnoti deal in any way with the income mutil it is actually payable. During the nineteenth eentury a ductrine was elaborated, not without difficulty and hesitation, under which a married woman having separate property at her disposal (not subject to the peculiar restraint just mentioned) might lind that property, though not herself personally, by transactions in the nature of $(\mathrm{com}-$

(n) Waite $v$ Morland (188s) 34 Ch. Div. 135, 57 L..J. Ch. 655: /lill v. (60) L. J. Q. B. 42:3, C. A. As to the combined effect of this Aet and s. 1 of the Married Womens's l'roperty Act, 1852, in making pro. perty subject to a married woman's disprosing power assets for thi: 1:tyment of hes dethts. seo lie llughles.
[189) ] 1 Ch. 529, 67 L. J. ('h. 27!, (C. A.

(o) Ramsdon v. Brearley (1875) L. R. 10 Q. 1., 147,44 I. J. Q. I?. 46. She tan give a valid receipt for a legacy mot reluced into pesssession lefore lle date of the order:

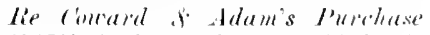

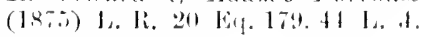
(h. 3ikt. 
tract $(p)$. Some account of this doctrine is given for reference in the Appendix, as being useful, if not necessary, for the full understanding of the modern law.

It should be observed that restraint on anticipation, being allowed only for the purpose of protecting the fund as capital, does not apply to income of the fund when it reaches the married woman's hands, or the hands of some person from whom she can immediately demand it. The income so paid or payable is ordinary separate property, and therefore on principle not exempt from the subsequent claims, equitable or statutory, of the married woman's creditors $(q)$; but it cannot be made liable to a previous judgment $(r)$.

\section{The Married Women's Property Act.}

4.. 4 is vict. The provisions of the Married Women's Property Act, c. 75 . 1882, extended by an amending Act of 1893, are so much wider that they may be described as a new body of law, consolidating and superseding the results of many cases in equity as well as the previous Acts of 1870 and 187t, which this Aet repealed. The law, as now declared, is to this affect:

Separate property is

(i) Property acouired by any married woman after January 1, 1883, including earning $(s)$ :

( $p$ ) Before the Act of 1se?, where a matried womant ebtainerl eredit by talsely remesenting helself as a wiluw, and a fuml was sectled on her for her staplate nus for life, witl a general power of aplointment by will. the creditor was held, in the administration of her estate. to have a gool claim on that fund as against appointers: Jaughan v. Jamderstegan (1554) 2 Drew. 363. 40s, 10u li. H. 173, 199.

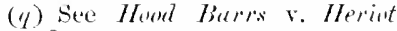
[1896] A. ('. 174, 6i) L. I. Q. IP. 352; H7iteley v. Lidwarls [1s!ni] 2 Q. B. 4s, is L. J. 1) B. 15i, C. A. ; this prinetple sexms to have beest overlookial by the ('. A. in construing the let of 1849 in liarmett r. Htomard [I!t)o] 2 Q. B. iิI, 18! I. J. Q. B. 955. which however has leeten followed: Broun v. Jimblely $[1904]$ l K. H. 25 , 7:) I..I. K. B. 3., (. A. See Mr. T. Cyprian Williams remarks in l. Q. R. xvii. 4.

( $)$ For the cffect of this would be to make the restraint on anticipation inoperative: Bolitho v. Gidley [letii] A. C. 9s. it I. J. K. B. 4:31, approving Illiteley $\mathrm{r}$. Eiluard. note (y) absice.

(s) Sis. 5, 2\%. Property falling into possession since the Aet uncler a title acquired before it is not inclucted: Reid r. Reid (Is86) 31 Ch. lyis. 412. is L. .l. ('h. 2:11. 
(ii) Property belonging at the time of marriage to a woman marrying after January $1,1883(t)$.

Special trusts created in favour of a married woman by will, settlement or otherwise, are not affected by the Act $(u)$.

Sulbject to any settlement $(r)$, a married woman citl bind herself by contract "in respect of and to the extent of her separite property," and cinn sue and be sued alone $(w)$.

Damages and costs, if recovered hy her, become her separate property; if against her, are patyable out of her separate property and not otherwise $(x)$. A married woman trading alone can be made bankirupt in respect of her separate property $(y)$.

A contract made by a married woman otherwise than as agent $(z)$

(i) Is deemed to be mitle with respect to and to bind

(t) S. 2 .

(u) $\rightarrow$. 19, which "provents the previous enaetment from interfering with any settlement which would have beim l the property if the Act had not passed" : ('otion

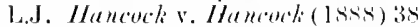

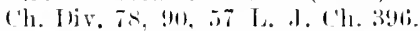
This provision covers buth s. 2and

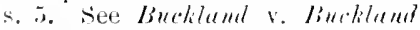
[19011] 2 ch. 534, ti9 h. .l. ( h. 64s.

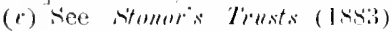
21 ('h. 1). 195, 52 1, . . ('h. 776.

(u) As lo the retroseretive

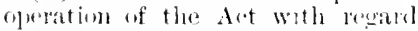
to powel to sue on a ratuse imblepentent of contrate sec 11 pldent. II inslome (lskt) I3 Q. D. Jiv. 7st, 5.3 6. J. Q. li. 5.2. As to liability on canses indepenulant al" contrat.

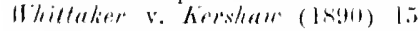

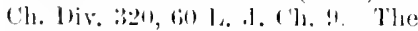
general workls of s. 1 (1) do mol give any greater power of disposal

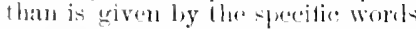

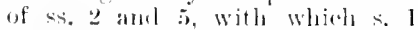

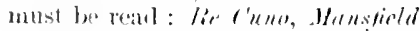

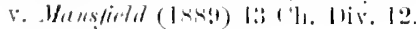

1i2 I. T. 1\%.

(.r) ) 1,1, sub-s, 2.

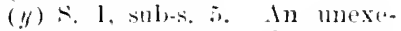
rutrol seneral bower of alymutment is mol "seluate polperty.' amd a married woman rammot les (4) for the benutit of her creditors: Liv

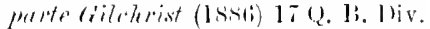

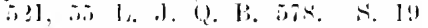
dues not prevent poperty to which she is mothed mirlel a selthement, without restmant on anticipation. from passing to the trustee in

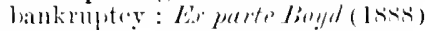
21 1). 13. Hiv, 26il, it L. J. U. li. isis.

(:) llese worrds do nut alloot tlec autlority of a marlied iwoman living with her lowsand to plodere his conlit. on the presumption that she deals on his credit alome:

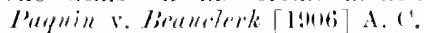

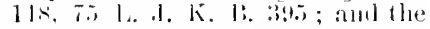
wher party's knowlealge is immotterial il there is no misceperentattion: il. The II. I. svas equatly alivilert. 
her separate property (a), and, if made since 5 Dec., 1893, whether or not she has any separate property at the date of the contract $(b)$ :

(ii) If so made and binding, binds her after-acquired separate property $(c)$, provided as to contracts of earlier date than 5 Dee., 1893, that there was some separate property at the date of the contract $(d)$.

A married woman's separate property is liable for her ante-nuptial debts and obligations $(e)$. She is also liable at common law for such debts, and judgment may go against her personally $(f)$. She cannot aroid this liability by settling the property on herself without power of anticipation $(g)$. As to women married before January 1, 188:, such liability applies only to separate property acquired by them under the Act $(h)$.

The Act contains other provisions as to the effect of the execution of general porer's by will by married women $(i)$, the title to stocks and other investments registered in a married woman's name either solely or jointly $(j)$, the effecting of life assurances by a married woman, or by aither hushand or wife for the benefit of the fanily $(k)$, procedure for the protection of separate property $(l)$, and other matters which belong more to the law of Property than to the law of Contract.

It is not expressly stated by the principal Aet whether

(a) Formerly there was nos such presumption unless she was living aprot from hes husband. Sete Aplentix. Sote C.

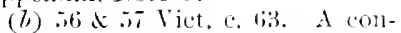
tract male before the Act cimant be blomglat within it lysubsupuent acknowledgment : lie Jleceler

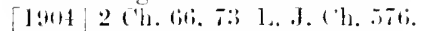

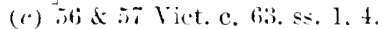

(i) Stogdon v. Le? [1,4!1] I (?. l?.

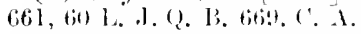

(c) $\mathrm{s}$. l:3. Whis hiability is at least choublful in cases not under the Act: sce Nite C. As to the Aet it lsin. Areford v. Fiend (1ssy) 2.2 Q. li. Dir. 231.

( $f$ ) liwhinsmn. King fo (i) v.

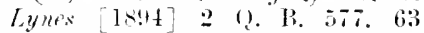
L. I. 1). 13. 75.1.

(d) $\rightarrow 1:$.

(ii) see note (il).

(i) Re Findluir\% [1909] I ('h. I.

is I..J. ('h. 1.3. t'. A.

(.j) Ss. i-Iu.

(i.) $>11$.

(l) 5.12 . 
on the termination of the coverture by the death of the husband, or by divorce, a married woman's debts contracted during the coverture with respect to her separate property do or not become her personal debts; but it has been assumed that they do ( $m$ ), and the Act of 1893 expressly makes this the rule for contracts subsequent to its date $(n)$. If not, the only remedy would he against her separate property which existerl as such during the coverture, and was not subject to restraint on anticipation (o), so far as it could still bo identified and followed.

The Act does not remove the effects of a restraint on anticipation. A married woman's creditor is not enabled to have execution or any incidontal remedies against property subject to such restraint $(p)$; though this affects only the remerly, not the canse of action $(q)$. But the Act of 1893 gives power to order costs to be paid out of such property $(r)$ in any action or proceeding instituted by or on hehalf of a married woman $(s)$.

It was settled under the Act of 1882, after some difference of judicial opinions, that income of separate property subject to restraint on anticipation is, when paid or accrued due, "free money" and liable to satisfy a judgment not of prior date to the date of such income

(iii) I/arrisun v. Ha)rison (1888)

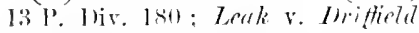
(1889) 24 (2. Ii. D. 98.

(u) itj d 57 lict. c. ti3, s. I (i) . (a) lintom Bros. v. Harrisom [16:11] 2 Q. B. 422,609 1. J. Q. B. $71,1 . \mathrm{A}$.

(p) Hrayrott v. Harrism (18xi) 17 \%. B. 1). 147. lint he may when the restraint is remored by the husband's death: Brriggs v. liyan [1599] 2 Ch. 717, (is l.t. ( h. (;6) B-at any rate a trustee in bankrupley may : il.

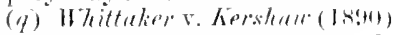
4) (th. lliv. 324, 327, fil 1, .1. Ch. 9 ,

(r) 56 \& 57 Viet. (. $6 ; 3$, s. 2. s. 1 does not make such property liable to satisfy a contract. See the proriso.

(s) Houd Harls v. ratheart [1891] 3) (h. 376,63 L. .J. Ch. 793, (‥ A., alproved, Momd Barrs v. Heviot 1897$]$ A. C. 177,66 L. . . Q. P. 356. This does not alply (1) motions, appeals. or other steps laken in a cause by a married Woman who is a defendant; but it does apply to a counterclaim by

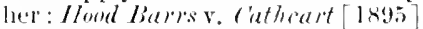
1 (2. 13. 873, 6.t L. .1. Q. 13. 520. The leurlen is on the married womentu to show why such an order shoukl not be made, but it is not a malter of course: I'artely r. Frewley [190is I Ch. 593, 74 I. J. (1). 31. 
becoming payable $(t)$. It is now held that $s .1$ of the Act of 1893 has the effect of ahrogating this rule, and protecting the income actually payable from separate property which was subject to restraint on anticipation at the date of the contract, even if the restraint on the capital has been removed hy the cessation of the coverture before the date of the judgment. The soundness of this decision appears exceedingly questionable $(u)$, and it is practically certain that the result is in any case foreign to the intention of the Act.

A married woman cannot free herself from a restraint on anticipation attached to any property held for hel separate use by any act of her own, whether in the nature of admission, estoppel, or otherwise $(r)$.

Where the surviving husband of a married woman takes her separate estate iure mariti, he is at once her "legal personal representutive" for the purposes of the Act, and liable to her creditors to the extent of that separate estate $(w)$.

On the other hand the Act does not exclude such equitable rights and remedies against a married woman's separate estute as were previously recognized. Where a married weman carries on a separate business, her hushand can sue her for advances made during the coverture for the purposes of that business $(x)$, on the general principle that in respect of her soparate estate she is treated as a feme sole. And it may still be possible in some cases not within the Act to enforce a

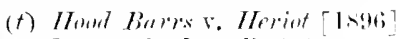
A. (1. 174.6.5 1. J. (). B. 3.8.

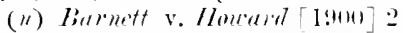
Q. [3. 784. 69 1..J. Q. 13. 955 : see p. 9o, above: followerl, bromen $\mathrm{v}$ l)imblely [1!04] l li. B, 28, 73 L. J. K. R. 35, C. A.

(r) Bateman v. Fabr\% [184s] 1 Ch. 14t. 67 L. J. Ch. I30, C. A. But she can bind her free separate property ly a coremant not to sue in respect of dealings with her reatrained property, and the measure of dimages in a counterclaim on her corenant may le the exact sum she would recorer on the frineipal elaim: Sprange v. Lee [19k] $]$ (h. 424. 77 L. J. Ch. 274. $(u)^{\circ} \mathrm{s} .23$ of the principal tet, as applial in sumban v. Ifhartom [1.91]1 Q. B. 191,60 L. J. Q. B. 233 . (a) Butler v. Butler (1885) 16 Q. B. Div. 374. 5.5 L. J. Q. B. 5.5. 
married woman's contract by means of the equitable doctrine of imperfect exercise of a power (y).

With regard to a husband's liahility for his wife's ante-nuptial debts, the Court of Appeal has recirter in a considered judgment that it is ristinct, and not meroly a joint liability with the wife's separate estate; but that, for the purposes of the Statute of Limitation, there is not a distinct canse of action accruing against the husband at the date of the marriage $(z)$.

\section{Lunatics and Druaken Persons.}

It will be convenient to consider these causes of disability together, since in our modorn law drunken men (so far as their capacity of contracting is affected at all) are on the same footing as lunatics.

The old law as to a lunatic's acts was that he could not be admitted to aroid them himself, though in certain cases the Crown, and in other cases his heir coutd (1). Even the fact of a defendant having heen found lunatic by inquisition was not conclusive as against a plaintiff who was not present at the inquisition (b). But a lunatic so found by inquisition camnot deal with his property by deed, oven in a lucid interval, while the inquisition is in fores (c). A lonatic not so found is capable of contracting (among other acts) during any lacict intervals $(d)$. The marriage of a lunatic is roid, and the same degree of sanity is required for marriage as for making a will or for any other purpose, though

(y) Siee per Fry L..J. E.r julte Gilchrist (1Ssi) 17 Q. 13. Div. at p. .332 .

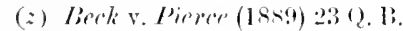
liv. 311, is L. J. Q. Li. ilti.

(r) See the jumlgment ol Fry I, .I.

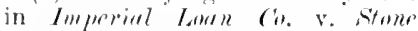
$[1 \times: 92] 1 \%$. [3. at $1 \%, 601$.

(b) Ilall v. Warren (1804) y Tes. (ion. gost. F li. li, at p. 30s.

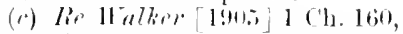

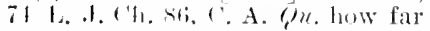
ilatl v. Ilarer"l is comsistent with llik.

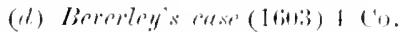
liep. 128b; Ifill r. Harren, note (i) aloove. 1)runkenness and Lunacy.

Iunaties by incuisition or otherwise. 
the burden of proof is on the party alleging insanity $(e)$. Marriage, however, is a peculiar transaction, and the exceptional treatment of it in our law, though perhaps historically due to the influence, in ecclesiastical Courts, of more general rules of civil or canon law, may well be justified on grounds of convenience.

Liability for necessaries. se.

It is equally settled that a lunatic or his estate may be liable quasi ex contractu for necessaries supplied to him in good faith $(f)$ : and this applies to all expenses necessarily incurred for the protection of his person or estate, such as the cost of the proceedings in lunacy $(g)$. A person who supplies necessaries to a lumatic or provides money to be expended in necessaries knowing him to be such can have an action against the lunatic if he incurred the expense with the intention, at the time, that it should be repaid. The circumstances must be such as to justify the Court in implying an obligation to repay; there is no doubt that such an obligation may exist in a proper case $(h)$. A husband is liable for necessaries supplied to his wife while he is lunatic ; for the wife's authority to pledge his credit for necessaries is not a mere agency, but springs from the relation of lusband and wife and is not revoked by the husband's insanity (i). In the same way drunkenness or lunacy would be no answer to an action for money had and received, or for the price of goods furnished to a drunken or insane man and kept by him after he had recorered his reason: in this last case, however,

(e) Huncerte v. Peat! (186i) L. Ri. 1 P. \& 1). 335. 341,36 L. J. Mat. 57: with which Durham r. Durham (1855) 10 P. 1). 80 does not conflict on this pint. The statute 15 Geo. 2. e. 30 , is rep. by the stat. Law lievision Act, $1 \times 73$.

(f) Brickuell v. Bulluck (1889) 22 Q. B. Div 5t; ; Batgter v. Earl of Purtsmouth (1826) 5 B.心 C. 170 . s. e. more fully, nom, Barter v.
Eirl P.. i D. \& R. 614. As to gookls sold and delivered, Sale of Goods Act, 1893, s. 2.

(g) Williams r. Wentworth (1542) 5 Beav. 325: Stedman v. Hart (185t) Kay. 607, 23 L. J. Ch. mos. lol R. R. Ftit.

(h) Re Rhwdes (Is90) 44 Ch. Div. $94,5 !$ L. J. Ch. 248.

(i) Read v. Legard (1851) $6 \mathrm{Ex}$. 636, 20 L. J. Ex, 309. 86 R. R. 418. 
his conduct in keeping the goods would be evidence of a new contract to pay for them $(k)$.

There is also express authority (which one would think hardly necessary) to show that contracts made by a man of sound mind who afterwards becomes lunatic are not invalidated by the lunacy $(l)$. It seems that an agency is determined by the principal becoming insane, except as to persons who deal in good faith with the agent in ignorance of the principal's insanity $(m)$.

The general rule as to the contract of a lunatic (at all events if not so found by inquisition) or drunken man who by reason of lunacy or drunkenness is not capable of understanding its terms or forming a rational judgment of its effect on his interests is that such a contract is voidable at his option, but only if his state is known to the other party. The defendant who sets up his own incapacity as a defence must prove not only that incapacity but the plaintiff's knowledge of it at the date of the contract $(n)$.

In Molton v. Camroux the action was brought hy Molteme. administrators to recover the money paid by the intestate to an assurance and annuity society as the priee of two annuities determinable with his life. The interstate was of unsound mind at the date of the purchase, but the transactions were fair and in the ordinary

(k) Gore v. Gibson (I8ti) $1: 3$

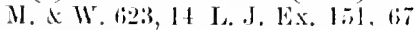
li. Ii. $76 ;.$

(l) Guen r. Daries, 1 les.str.s.2.

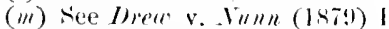

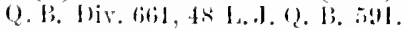

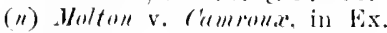
('h. $(1 \times 4 k) 2$ Ex. 1nt, + Ex. 17 , Is Is. J. Hx. 65. 3is; : Imperial

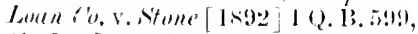
(i) I. J. Q. B. 14: C. A. The same principle hat lom belore been acterl upon in equity, but without deciding whedher there was a (enl)tract at law: Jiell r. Morley (1sil)

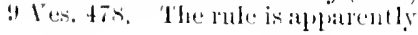

P. peruliar to the Common Law, amel is impugned by a learued eivilian als unjust to the lunatie: Prof. (iomly. " Contracts by Lunaties," L. Q. Ii. xvii. 147. See contru Mr. Rankine Wikon, "Lmacy in relation to contract, 'Jort, and crime," I. Q. li. xviii, 21. As to the riomanDutroll law of Nalal, Holymende v. Nital Land, die. (i). [1965)] A.C. 5is). lu liritish fueliat a persome of musommal mind is incalpable of comtracting: 1. (1. A. S.. 11), 11, 12 ;

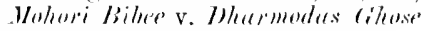
(1503) 1. li. 301. A. 114.
General rule : Contract voidalle if the Iunacy, de., known to other party. 
course of business, and his insanity was not known to the society. It was held that the money could not be recovered; the rule being laid down in the Exchequer Chamber in these terms: "The modern cases show that when that state of mind was unknown to the other contracting party, and no advantage was taken of the lunatic, the defence cannot prevail, especially where the contract is not merely executory but executed in the whole or in part, and the parties cannot be restored altogether to their original positions."

The context shows that the statement was considered equally applicable to lunacy and drunkenness, and the law thus stated involves though it does not expressly enounce the proposition that the contract of a lunatic or drunken man is not roid but at most roidable. The general rules as to the rescission of a voidable contract are then applicable, and among others the rule that it must be rescinded, if at all, before it has been executed, so that the former state of things camnot be restored: which is the point actually decided. The decision itself was fully accepted and acted on (o), though the merely voluntary acts of a lunatic, e.g., a voluntary disentailing deed (a class of acts with which we are not here con-

Development of the roctrine :

Mathews $r$. biaxter.

cerned) remain invalid $(p)$. The complete judicial interpretation of the result of Molton v. Camroux (q) was given in Matthews v. Baxter (r). The declaration was for breach of contract in not completing a purchase: plea, that at the time of making the alleged contract the defendant was so drunk as to be incapable of transacting business or knowing what he was about, as the plaintiff well knew: replication, that after the defen-

(11) Bearan v. W'Domell (1854)9 Ex. 309.23 L. J. Ex. 94 ; Price v. Berrington (15:0-1) 3 Mac. \& G. 1s6. t45, rerg. s. c. T IFa. 394. 87 li. R. 157 ; Elliwt v. Ince (185i)
7D. M. G. 475.488. 26 L. J. Ch. 821. (p) Elliot v. Ince, last note. (q) Note (n), last page. (r) (1873) L. R. 8 L. li. s Ex. 132, 42 L. J. Ex. 73. 
dant became sober and able to transact business he ratified and confirmed the contract. As a merely void agreement cannot be ratified, this matly raised the question whether the contract were void or only voidable: the Court held that it was only voidable, and the replication therefore good.

In Imperial Loan Co. v. Stone (s) a defendant sued on a promissory note set up the defence of insanity at the time of making the note. The jury found that he was insane when he signed the note, and could not agree whether the plaintiffs' agent, then present, knew of his insanity or not. It was held that this could not be taken as a verdict for the defendant, but there must be a new trial. The Court was unanimous, and the decision may be taken as finally settling the law if there was still any room for doubt. It also shows that a distinction formerly suggested between executed and executory contracts is not tenable.

The special doctrine of our Courts with regard to partnership (which is a continuing contract) is quite in accordance with this: it has long been established that the insanity of a partner does not of itself operate as a dissolution of the partnership, but is only a ground for dissolution by the Court.

It is to be noted that the existence of partial delusions does not necessarily amount to insanity for the purposes of this rule. The judge or jury, as the case may be, must in every case consider the practical question whether the party was incompetent to manage his own affairs in the matter in hand $(t)$.

(s) $[1 \times 92] 1$ Q. B. 599, (31 L. J. Q. B. HI9, C. A. It does not appear from the argument as reported how eounsel for the defendant deall with dolton y. C'umeroure, which was bincling on the tourt. (t) Jenkins v. Morrin (1880) 14 Ch. Div. fitt; commare remal of Branwell L.J. in Jrew r. Vunn (1579) 4 Q. B. Div, at p. 6699, 48 L.. J. Q. I. .591.
Imprerial

Loan Co. $r$. Stone.
I'artial delu sims compatible with calneity for contracting. 
IV. Convicts, etc.

Disability of conviets.

Alien enemies.

Extension of powers.

Agency.

At common law convicted felons (as also outlaws) conld not sue, but remained liable to be sued, on contracts made by them during outlawry or conviction $(u)$. since the Act to abolish forfeitures for treason and felony, convicts are incapable of suing or maling any contract, except while they are lawfully at large under any licence $(x)$.

Alien enemies, as we have seen above, are disabled from suing in an English Court even if the cause of action arose in time of peace $(y)$, but not from binding themselves by contract during war between their country and England, nor from enforcing such a contract after the war has ceased $(a)$.

\section{PAR'T II.}

We now come to the extensions by special institutions of the ordinary power of making contracts. And first of agency.

\section{Agency.}

We have not here to do with the relations created between principal and agent by agency regarded as a species of contract, but only with the mamner in which rights and chuties accrue to the principal through the dealings of the agent. We must also distinguish cases of real agency from those where the agency is apparent only, and we shall further notice, for the sake of completeness, the position of the true or apparent agent as regards third persons.

(i) Dicey on Parties, 4.

(x) 33 \& 34 Vict. c. 23 , ss. $8,30$.

(y) Le Bret v. Papillon (1804) 4 East, 502, 7 R. R. 618. (a) De llahl v. Braume (1856) I H. $\&$ N. 178,25 L. J. Ex. 343 : note $(z)$, ante. p. sti. 
A person who contracts or professes to contract on behalf of a principal may be in any one of the following positions :

1. Agent having authority (whether at the time or by subsequent ratification) to hind his principal.

(A) known to be an agent

(a) for a principal named;

( $\beta$ ) for a principal not named.

(B) not known to be an agent $(b)$.

2. Holding himself out as an agent, hut not having authority to bind his principal.

(A) where a principal is named

(a) who might be bound, but does not in fact anthorize or ratify the contract;

(3) who in law eamnot be bound.

(B) where the alleged principal is not named.

1. As a rule an agent may be appointed without any special formality; though an agent to expente a deed must himself be appointed by deed, and in certain calses the appointment is required by the Statute of Frauds to Authority of agent, its constitution and termination. he in writing. Revocation of an agent's authority takes place either by the principal's actual withdrawal of his will to be represented by the agent (which may be known either by express declaration or by conduct manifesting the same intention) or hy his dying or ceasing to be sui iuris, and thus becoming incapable of continuing it. In these last cases the authority is said to be revoked by the act of the law. "The termination of the authority of an agent does not, so far as regards the agent, take effect before it hecones known to him, or, so far as regards third persons, hefore it becomes

(b) Since the eases of rulder v. leobell, Fletet v. l/urtom, and Intchiusom r. Tatham (see following notes), it may perhajs be considered that the true leading distinetion is whether the : gent is known to be an agent of not, rather than whether the prineipal is namerl or not. 
known to them " $(c)$. It is held in England, but anomalously, that this rule does not apply to revocation by the leath of the principal $(d)$. It does apply in the case of the principal becoming insane, and it may perhaps yet be decided that in the case of death the principal's estate is liable to the other party for the actual loss incurred by the principal's representation--which, as regards him, was a continuing one at the date of the contract - that the agent was authorized (e).

Ratification must in every case be within a reasonable time, and where a time is expressly limited within which an act must be done, and an anthorized person purports to do it on behalf of the principal within that time, a ratification after the time has expired will not serve $(f)$.

Authority conferred by ratification relates back, as against the other party as well as the principal, to the date of the act done by the agent (a).

1. Agrent for existing principal.

In all cases where there is an authorized igent dealing on behalf of a real principal, the intention of the parties determines whether the agent, or the principal, or both, are to be liable on the contract and entitled to enforce it. The question is to whom credit was really given $(h)$.

(c) I. C. A. 208, cle. Stury on Agency, 5 to: Trupmutl t. Later (Isto) ] I A.\& E. 5.9, 52 R, R. 4i\}.

(d) Blades Free (1529) ? B.d ('. I67, 32 Ii. Ii. 6i2 1 . Cintra, I. C.. A. s. 208 (lllust. c.). Code Nap. 2018. 2009. and Gurman ('ivil code. ss. 1ti-lit ; and see Kent. Comm. 2. fifti. The sine rule was alphled to the dissulation of a company

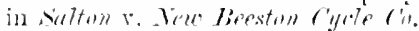

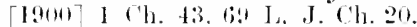
but the agent may be liable on an implicel warrauty of his authority. see p. 112. betory.

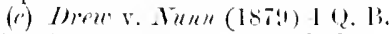
Iliv. fitil : see per Brett 1...I. at li. litik. (f) Diblins v. Dibbins [1890] 2 Ch. 348,65 L. J. Ch. 224.

(1) Bolton l'artners v. Lambert (Jses) 41 Ch. Div. 24 , is [. J. ('b. 425 (see. however, the note on this case in Fry on specific Performance. $3 \mathrm{rd}$ ed. and Fleming $\mathrm{r}$. Siank of low Zouland [1900] A. C'.

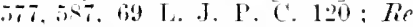
Titedmann [18!9] 2 (2. B. 66. 68 I. .J. Q. B. 852. As to ratification ly an mmliscloser princifral, see 1). It). lielow.

(il) itory on igency. \$\$ 279 st1. בss. Thamsan v. Dilenport

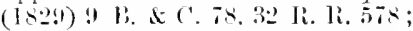
Gulder v. Thebell (18:I) T. R. l; ('. I'. 4.8. t1) T. J. I'. J. 221 . 
And the general rules laid down on the subject furnish only provisional answers, which may be displaced (subject to the rules as to admissibility of evidence) by proof of a contrary intention.

A. When the agent is known to he an agent, a A. know to contract is made, and knowingly made, by the other party with the principal, on which the principal is the proper person to sue and be sued.

And when the principal is named at the time, then there is prima facie no contract with the agent: but when the principal is not named, then prima facie the agent, though known to be an agent, does bind himself personally, the other party not being presumed to give credit exclusively to an unknown principal $(i)$.

But when the agent would not prima facie be a con tracting party in person he may become so in various ways. Thus he is personally liable if he expressly undertakes to be so $(k)$ : such an undertaking may be inferred from the general construction of a contract in writing, and is always inferred when the agent contracts in his own name without qualification $(l)$, though the principal is not the less also liable, whether named at the time or not $(m)$, or if he himself has an interest in the subject-matter of the contract, as in the case of an

(i) But one who dealt with an agent known to be such eannot set off arain-t the princiual's claim a debt the to him from the agent. If he has employed an agent on his own part, that agent's knowledge is for this purpose treated as the employer's own : and this even though the knowlelge was not accuiren in the entrse of the particular employment: Mresser v. Vimmol (Istii) Ex. ('h. 17 ('. B.

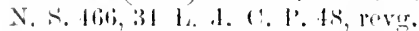
s. e. 14 ( . B. N. S . . 1, 32 h. J. ('. P. 201. C'ontmel. ('. A. S. 22!) (p). by design or ace istent?
(7) Story on Agrency, \$ 260 , Smith, Mere. Law, Iss.

(b) See Erairlir y. Fenton (1970) I. R. 5 Ex. 169, 39 L. .Г. Ex. 107:

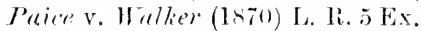
173, 39 L. J. Ex. 109. The latter ease, however, goes too far: see note (N). p. 10.5, below.

(III) Iligyins v. Somior (1511) \& M. \& W. si3t. is li.li. s.8t: the haw there lait down goes to superacil the liability of the agont, not to take away that of the principal:

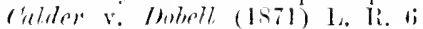
('. I'. ING, 10) L.J. ('. L'. 2.21. le an arrent : contract with principal ats initio.

a. Principal namel :

arent primis fiacie thes not contract in person.

ß. Princifal not namesl: agent mimile facie does contract in persen. Evilence of contrary intention $(\alpha)$. 
auctioneer $(n)$. And when the agent is dealing in goods for a merchant resident abroad, it is held on the ground of mercantile usage and convenience that without evidence of express authority to that effect the commission agent cannot pledge his foreign constituent's credit,

Technical rule as to decel of agent. and therefore contracts in person (o). When a deed is executed by an agent as such but purports to be the deed of the agent and not of the principal, then the principal cannot sue or be sued upon it at law, by reason of the technical rule that those persons only can sue or be sued upon an indenture who are named or described in it as parties $(p)$. And it is also held that a party who takes a deed under seal from an agent in the agent's own name elects to charge the agent alone $(q)$. A similar rule has been supposed to exist as to negotiable instruments: but modern decisions seem to show that when an agent is in a position to accept bills so as to hind his principal, the principal is liable though the agent signs not in the principal's name but in his own, or, it would appear, in any other name. It is the same as if the principal had signed a wrong name with his own hand $(r)$.

(i) 2 sin. I. 1 . Bi!?. A- to an auctioneer's prersonal liability fror nom-delivery to a purchaser of grums boucht at the amotion. Wimlfor $r$. Horne (1577) 2 (2. B. 1). 335. th

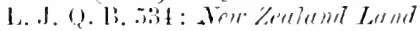
(ii. r. Jfitson (1+i-1) 7 Q. li. Jir. 37 , 301 1. I. Q. B. fï.s.

(ii) Armstimy v. Stolies (1-72)

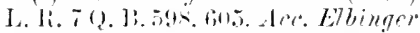

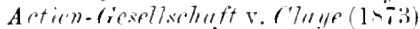
I. Ii. A ( . I) $313 .+1$ L. J. 1). I. 253 (aftirmed on another point. L. Ii. 9 2. P. 473,43 L. J. (?. B. 211). sbowing that the foreign principal cannot sue on the contrat: Iluttem v. Bulloch (1873) 1. 1., 8 Q. B. 331, aftirmed in Ex. Ch. I. li. y Q. B. Ti2. that he cannot be sued: Fou Zofuland Land ('o. v. 11 at.sun (1S81) 7 Q. B. Div. 374. 30
1. J. 9. 33. 433. In Haspums y Ilermand v. Vildied (1-83) 9 Q. B. Div. .30. 53 L. J. Q. B. 33 , the comrt of Apreal refuserl to extend this loctrine to a ca-e where the commi-oion agent as well as the principal was foreign: the decision was atfirmed in H. L., A Ap. Ca. -it. but this point not disenssed.

(j) Lord simthamptan v. Bromente

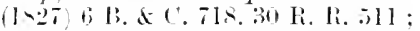

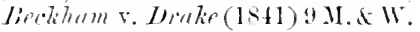
at p.95, attirmed sub nom. Wralie v. lifelleam. 1] ib. 315, 12 L. J. Ex. tsi, bill R. li. ti!l.

(1) Indiering: claim (18:1) I. li. 8 Ch. i2:

(r) Lindus r. Braduell (184s) 5 ('. B. .53. 17 L. J. C. I'. 123. .5 R. R. 7!s. (p. Edmunds s. Busleell( 186.5$)$ I. R. 1 Q. B. 97.35 L. J. Q. B. 20. 
Again, an agent who would otherwise be liable on the contract made hy him may exempt himself from Eridence of contrary liability by contracting in such a form as makes it appear on the face of the contract that he is contracting as agent only and not for himself as principal $($.$) : but$ even then he may be treated as a contracting party and personally bound as well as his principal hy the custom of the particular trade in which be is dealing $(t) . \quad 0$. he may limit his liability by special stipulations, e.!., when a charter-party is executed by an agent for an unnamed freighter, and the agent $x$ signature is mqualified, but the charter-party contains a clatse providing that the agent's responsibility whall cease as soon as the cargo is shipped (11).

It is also a rule that an agent for a gorernment is not personally a party to a contract made by him on behalf of that government by reason merely of having mals the contract in his own name $(x)$. In some catses the agent, though prima facie not a party to the contract as

(s) Words in the bouly of a diocument which amount to a lersonal contract by the acrent are not deprived of their effeet by a yualified signature: Lennurd i. Iholininson (1855) 5 E. \& B. 125, 24 L..J. Q.13. 275. I113 R. Ri. 4(12); IItroliesom v. Fitull (1884) 13 Q. B. Dir. 8til. see per lirett M.R. at $\mathrm{p} .865$ : and the description of him as agent in the budy of the doeument may under special circumstances not he enough lo malie him safe : P'rief v. Hinlker (3×70) L. R.5 Ex. 173, 39 L..J. Ex. 109! see the remarks on that case in Crudd v. llonghton (187ti) $1 \mathrm{Ex}$. loiv. 3is, 46 J..J. Ex. 71, which decirles that a contraet " wn account of " a namerl principal eonclusively rlischarges the agent. I'trict' v. IIalker is nearly but mot quite overrulerl: see Momgh v. Hanzuns (1879) + Ex. 1'. 1111. 18 L. J. Ex. 3\%8. Signature of a managing director, so describerl. following the eompany's name, does not linel him personally: (hupmen $\mathrm{v}$. simethmint [1509] \& k. IB, 923.

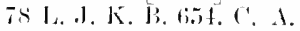

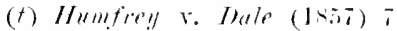
E. \& I. 266ti, E. I, d E. 10004. 2t;

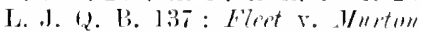
(1sil) L. R. 7 (2. 13. I I ti. 12! , 41 L. J. (1. 1. 4!); Hutrhinsol" r.

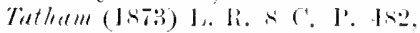

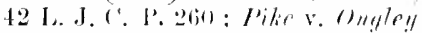

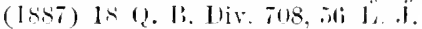
2. 13.373. On the enenelat quention of the constructions of contuate make by brokest for their principals, see simthrenll v. Burditoll (lsiti) I C. I'. Jiv. 3it. lis l. .J. (.. P. 374,630 .

(II) Ooplesty r. Yylesias (185s) E.

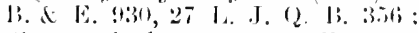

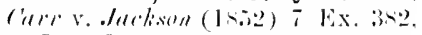
21 I. I. Ex. 1:37, sti li. R. 6ies.

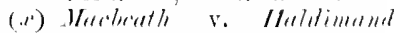

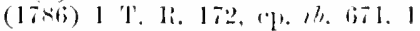

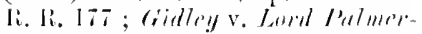
ston (1822) 3 Brod. \& B. 275, 21 li. R. ritis. 
B. Agent not known to be an agent.

Generally there is a contrate with the nudis. closed prin. cipal.

Hxceptions.

agent, can yet sue or be sued as principal on a contract which he has made as agent. These will be mentioned under another head of this subject $(y)$.

Where an undertaking is given in general terms, no promisee being named, to a person who obviously cannot be a principal in the matter, it may be inferred as a fact from the circumstances that some other person interested is the real unnamed principal, and that person may recover on the contract $(z)$.

B. When a party contracts with an agent whom he does not know to be an agent, the undisclosed principal is generally bound by the contract and entitled to enforce it, as well as the agent with whom the contract is made in the first instance (a).

It has been held that an undisclosed principal is as much liable as a known one for contracts made by the agent within the general apparent authority of agents in that business $(b)$.

But the limitations of this rule are important. In the first place, it does not apply where an agent for an undisclosed principal contracts in such terms as import that he is the real and only principal. There the principal cannot afterwards sue on the contract (c). Much less, of course, could he do so if the nature of the contract itself (for instance, partnership) were inconsistent with a principal unknown at the time taking the place of the apparent contracting party. Likewise, "if the principal represents the agent as principal he is bound by that representation. So if he stands by and allows

(y) Infia. p). 113-11.

(そ) Ileiduej v. Ileggett (1sib) ] ('. 1'. 1). 233 .

(a) The rule is not excluded b, the erintract leeing in writing (nim under seal) and signed by the acrent in hisown name: Brektam $\mathrm{r}$. make (1s+1) 9 M. \& W. at p. 91. (ii) R. R. p. 684. See p. 104. sиpro. (b) Huttean v. Fenwick [1893] 1 12. I. 3t6: sed qu.. see Lindley, l'artnership. lat n., and l. Q. i. ix. 111 .

(c) Mumbie v. Munter (1st8) 12 9. B. 310.17 L. J. Q. B. 3.20 .76 li. li. 291 . 
a third person innocently to treat with the agent as principal he cannot afterwards turn round and sue him in his own name" $(d)$.

It was long undecided whether an agent for an undisclosed principal must have authority at the time, or a man might adopt as principal an act not purporting at the time to be done on behalf of any principal, and not then authorized by him. A majority of the Court of Appeal held in a late case that such ratification was possible, but this was reversed by the House of Lords as contrary to such authority as there was (with one obscure exception) and to the general reluctance of the Common Law to give effect to alleged intentions which were not disclosed or recorded at the time when, if at all, they were material $(e)$.

Again, in the cases to which the rule does apply, the rights of both the undisclosed principal and the other contracting party are qualified as follows:

The principal "must take the contract subject to all equities in the same way as if the agent were the sole principal" $(f)$. Accordingly if the principal sues on the contract the other party may avail himself of any defence which would have been good against the agent $(g)$ : thus a purchaser of goods through a factor may set off a claim against the factor in an action by the factor's principal for the price of the goods $(h)$.

(d) Ferrand v. Bischoffisheim (1854) 4 (․ B. N. ․ $710.716,27$ I.. J. (:. 1'. 302.

(e) Durant v. Ioblerts if (i). [190()] 1 Q. B. 6.29, lig L. I. Q. B. 382, diss. А. 1. Smith T..J.. revil. nom. Keightey, Wursted of (ir. v. Duraut [1!01] A. C. 240, 70 I. J. K. B. lifiz.

(f) Sitory on Agency, \& T201:

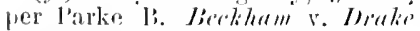
(1811) 9 M. \& W'. at p. as, tiu R. R. 1. 6is?. 1'. 101, supur.

(g) If the arent sucs in his owll name the rither farty eamot sot limitations of tle rule when it applies.

As to rights. of principal. off a debt due from the prineipal whom he lus in the meantime discovered, there being no matual debt within the statute of set-off; Isberg v. buwden (18.5i) $8 \mathrm{Ex}$. $8 \% 2,22$ 厅. J. Ex. 322. Under the Inlicature Acts, however, he can mike the principal a party to the action by counter-chaim and have the whole matter dispeseel of.

(h) lisorye v. (7aledt (1757) 7 T. li. 3is?, I li. li. 4132 ; tims v.

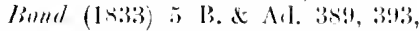

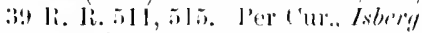
v. Bumlen, \& Fx. at J. S.5. If 
As tor gights of the other linty.
"Where a contract is made by an agent for an undisclosed principal, the principal may enforce performance of it, subject to this qualification, that the person who deals with the agent shall be put in the same position as if he had been dealing with the real principal, and consequently he is to have the same right of set-off which he would have had against the agent" (i). And his claim to be allowed such set-off is not effectually met by the reply that when he dealt with the agent he had the means of knowing that he was only an agent. The existence of means of knowlerge is not material except as evidence of actual knowledge $(k)$. On the other hand this equity against an undisclosed principal depends (so the House of Lords has held) on the third person's actual belief that he was dealing with a principal in that particular transation. Mere absence of knowledge or helief whether the agent is dealing as an agent or on his own account is not enough (l).

It has been said that conversely the right of the other contracting palty to hold the principal liable is subject to the qualification that the state of the account between the principal and the agent must not be altered to the prejudice of the principal. But this doctrine has been disapproved by the Court of Appeal as going too far. The principal is dischalged as against the other

leves not matter whether the factor is or is not actually authorized by lis puineipal to sell in his own name without diselosing the

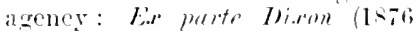
t ('h. I)iv. 133. ti' L. J. 15k. 21): nor what restrictions may as hetween himself and the principal. be imposed on him as to the price he is to sell all: sterens r. billor.

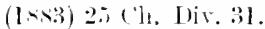

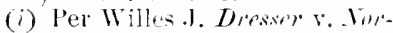

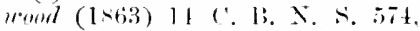
589,32 L. J. C. P. 201, 20.5. The revertal of this cave in the $\mathrm{Ex} . \mathrm{Ch}$.
17 A. I. X. S. thin, 3t L. J. C. I'. t.. lon-not affect this statement of the general law. The principle is not contined to the sale of goonl.

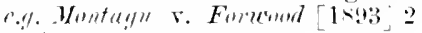
(2. 1. 3.311. C. A.

(i) Burrios r. Imperial Ottoman Bank (1+-3) L. Li, 9 C. 1'. 3s, +3 I. I. ('. I'. 3 .

(b) coulie ve Ekhelby (18si) 12 Alp. (a. 271, sti T. J. Q. 13. 50.5. 11 is weless to critieize the decision in Englanı: but see L. Q. R. iii. 35. 
party by payment to his own agent only if that party has by his conduct led the principal to believe that he has settled with the agent, or, perhaps, if the principal has in good faith paid the agent at a time when the other party still gave credit to the agent alone, and would naturally, from some peculiar character of the business or otherwise, be supposed by the principal to do so $(m)$.

Again, the other party may choose to give credit to the agent exclusively after discovering the principal, and in that case he cannot afterwards hold the principal liable; and statements or conduct of the party which lead the principal to believe that the agent only will be held liable, and on the faith of which the principal acts, will have the same result ( $n$ ). And though the party may elect to sue the principal, yet he must make such election within a reasonable time after discovering him $(o)$. When it is said that he has a right of election, this means that he may sue either the principal or the agent, or may commence proceedings against both, but may only sue one of them to judgment ; and a judgunent obtained against one, though unsatisfied, is a bar to an action against the other. Such is the rule as to principal and agent in general, and there is no exception in the case of a shipowner and freighter $(p)$.

The mere commencement of proceedings against the agent or his estate after the principal is discovered, although it may possibly be evidence of an election to

(m) Irrine v. II atsom (1880) ; Q. B. Jiv. 411,4 I. J. (). I1, 333, which seems on this point an redace

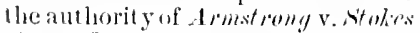
(1872) I. R. 7 (2. I?. 5) 5 , 11 L. I. (2. P. 313, to that of a decision on peculiar facts.

(1) Story on Agency, \$\$ 279, 2心s, 291 : Korsfall v. Fuxutloroy (15.30) 10 li. \& ('. 7.5. ; but the plimeipal is not discharged muless he has actmally dealt with the agent on the faith of the other party's antfluct in as to change his gusition: Iy yett v. Ilertford (181)2) :3 liast, $\mathrm{I} \mathrm{I} \%$

(a) Simethusest v. Witchell (1sit)

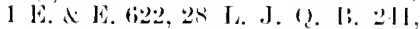
117 Ri. Ii. 371.

(1) Iriestley v. Fermie (186ij) 3 II. d ( . 977, 943, 31 J. .I. Ex. $173 ;$; (1. I. li. 6; C. I'. 19!. 
2. P'rofessed agent not having authority.

Principal named.

a. Who might be responsible.

Professed agent cannut sue on the contract. charge the agent only, does not amount to an election in point of law $(q)$.

2. We have now to point out the results which follow when a man professes to make a contract as agent, but is in truth not an agent, that is, has no responsib]e principal.

We may put out of consideration all cases in which the professed agent is on the face of the contract personally bound as well as his pretended principal: for his own contract camnot be the less valid because the contract he professed at the same time to make for another has no effect. But when the contract is not by its form or otherwise such as would of itself make the professed agent a party to it there are several distinctions to be observed.

First, let us take the cases where a principal is named. The other party prima facie enters into the contract on the faith of that principal's credit. But credit cannot be presumed to be given except to a party who is capable of being bound by the contract: hence it is material whether the alleged principal is one who might authorize or ratify the contract, but does not, or is one who could not possibly do so.

¿. The more frequent case is where the party named as principal is one who might be responsible.

It is settled law that there, subject to the qualifications which will appear, the pretended agent has not either the rights or the liabilities of a principal on the contract.

First, as to his rights. In Bickerton $r$. Burrell $(r)$ the plaintiff had signed a memorandum of purchase at an auction as agent for a named principal. Afterwards he
(,) (1.16) ว M. \& \$. 383. 
sued in his own name to recover the deposit then paid from the auctioneer, and offered evidence that he was really a principal in the trinsaction. But he was nonsuited at the trial, and this was upheld by the full Court, who laid down that "where a man assigns himself as agent to a person named, the law will not allow him to shift his position, declaring himself principal and the other a creature of straw. . . . A man who has dealt with another as agent $(s)$ is not at liberty to retract that character without notice and to turn round and sue in the character of principal. The plaintiff misled the defendant and was bound to mudeceive him before bringing an action." This leaves it doubtful what would have been the precise effect of the plaintiff giving notice of his real position before suing: but the modern cases seem to show that it would only have put the defendant to his election to treat the contract as a subsisting contract between himself and the plaintiff or to repudiate it at once $(t)$.

The doctrine under consideration was further defined in Rayner v. Grote $(y)$. There the plaintiff sued to Rayner $x$. Grote. recover a balance due upon the sale by him to the defendants of a quantity of soda ash according to a bought note in this form:- "I have this day bought for you the following goods from J. \& T. Johnson-50 tons soda ash, . . . . J. H. Rayner." It was provert that the plaintiff was the real owner of the goods, and 13 tons out of the 50 had been delivered to the defendants and accepted by them at a time when there was strong

(s) I.e. for a nanned and resumnsible principal.

(t) Felluncess r. Latrd Girygly (1826-9) I Sim. 63, 1 Russ. \& il. 83, 32 R. R. 14. in which Bicletrtone v. Burrell was not citerl, cin be supported, if at all, only on the groumil that the latets brought the (ase within the principle of $l$ arymer v. Girote (see next praragraph). The julgments eannot be regarleil as gond law, nor can any reason be formcl for a difference between common law and equity on the Inint.

(4) (1.46) 15 M. A IV. 354, 16 1..1. Ex. $7 !, 71$ Ii. li. 709 . 
evidence to show that they lnew the plaintiff to be the real principal. The law was stated as follows $(z)$ :--

"In many such cases [ $\mathrm{ri}$. where the contract is wholly mperformed] such as $\mathrm{t}, \mathrm{r}$ instance the case of contracts in which the skill or solvency of the perwon who is named as the princigal may reasonably be considered as a material ingredient in the contract. it is clear that the agent cannot then bow himself to be the real principal and sne in his own name : and lwhaly it may be fairly urged that this, in all executory contracts, if whully unperformed. or if partly performed without the knowledge of who is the real principal. may be the general rule."

But here part performance had been accepted by the defendants with full knowledge that the plaintiff was the real principal, and it was therefore considered that the plaintiff was entitled to recorer.

Nor can the luterestel agent be slied un the contract.

Implierl watranty of authority.

Next, as to the pretended agent's liability. It was at one time thought that an agent for a named prineipal who turned ont to have no atuthority might be sued as a principal on the contract $(a)$. But it has been determined that he is not liable on the contract itself $(b)$. He is liable, howerer, on an inplied warranty of his athority to bind his principal. This was decided in collen r. Wright (c), and is now finally established by the authority of the House of Lords $(d)$. In the rare

(:) l'ter (tir. 1; M. \& W. at 1. 3tis; and see the lematis on livelietule v. limiell. ad tim.

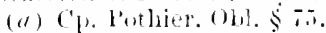

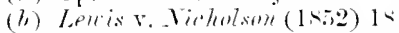
(). B. 5113. 21 1..J.12. 1. 311.

(i) $(18.7)$; E.d H. 301.26 J.J. G. 13. 147: in Ex. (h. \& E. \& l, 1it7. 27 L. J. (). B. 215; 1111 I. li. (bi):

(a) livelardson? r. Ililliatmsell (187l, L. R. (; Q. 1;. 27t, 4) I...1. 4. 13. 145: (7terry r. Colonial lianli uf Arotralasia (1stia) I. Ii. 313. C. 24, 31 : Ntarliey v. Bumb at England [1948] A. C. 114, 7: L. i. (h. for. Fut the reluesentation of the agent that he has anthority must be a representation of matter uf fact and not of law : Beuttie v. Lend Ebury (1siz) L. li. T Ch. T⿰氵, 7 H. L. 1112, 41 L.J. Ch. s0t, 44 it). 21): Weeks v. Propert (1873) L. R. \& C. l'. 427. 43\%, 42 I. J. C. P. 129. Anl the rule camot be al'lied to make a public servant actiug on behalf of the ('rown pressonally liable: Junn r. Mardonald [1597] I Q. B. $\pi 5,66$ L. J. Q. L. 420. C. A. As to the measme of damages Nimems v. Putelett (1857)

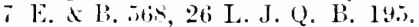
llu li. li. 730: Spediling v. Sevell (1stig) I. li. + C. 1'. 212. 38 L. I. (․ I'. 1333; Godurin v. Francis (1870) L. R. 5 C. P. 295, 39 L. J. ('. 1'. 121: Eir parte Pammure (1s83) 24 (h. 1)is. 3tit. The rule 
case of a person purporting to contract as agent for a named principal, and at the same time expressly disclaiming any present authority, the implied warranty is excluded, for the other party does not rely on the existence of authority and is not misled, but is content to take the chance of ratification for what it may be worth $(e)$. The pretended agent is also generally liable to an action in tort if he did not believe that he had authority $(f)$. The liability on implied warlanty is not affected by the supposed agent's good faith where he does so believe, and it is now decided that the rule applies even where a real authority has been determined, unknown to the agent, by the death or lunacy of the principal $(g)$.

$\beta$. The rules last stated are applicable only where the alleged principal was ascertained and existing at the time the contract was made, and might have been in fact principal.

Here the doctrine of ratification is important. When B. Alleged principal who could not be responsible : profes-cel agent treater a principal is named or described, but is not capable of as princinal.

in Collen v. Wriglet is not eon. fined to cases where the assumed authority is to enter into a contraet: Starkey v. Bank of Englund, in C. A. nom. Oliere r. Buale of Enyland [1902] I Ch. at p. (i2).

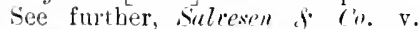
Mederi Aktiebulaget Nordstjernall [1905] A. (․ 302, 74 L.J. I'. ( . .96. where an attempt to extenc the rule to an agent's report to his own principal failed; an erroneous report as to the other farty's intentions may be a breach of cluty. but it is not a warranly.

(e) Ilalbut v, Lens [1:t01] I Ch. 34t. 70 I. J. ('h. 125.) It would seem arguable that in such a case there is mothing capalule of ratifieation.

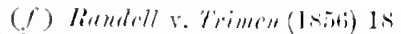

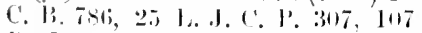
R. R. 5iti. The main object of establishing the liability er corte- treetle was to luave a remedy against executors.

For a somewhat similar loctrine applied to the contract to marry, see Willuerd v. Littlewend (15.5) ; Ex. 775, 20 L. J. Ex. 2, 82 Ii. L. sil, aul IIild v. Murvis (1849) 7 (. B. 994, Is L. J. C. P. 24\%, is R. li. sig. Here howerer there is not properly a warranty, for the promisor's unilertaking that he is legally capable of marrying the promisee is a term in the principal contract itself. ree Chap. III. below, at fill.

(a) Yompe r. Toumbet $[1910] 1$ K. 13. 215,79 1. J. K. T. 214, C.A. This overmos smout v. H/berly (1843) 10 II. A W. 1, ti2 li. Ti. Ilo. at any vate as a general atathority, and chler rases which followed it.

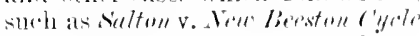
('i) [1900] I 1 h. 43.63: L... ( '11.20. 
authorizing the contract so as to be bound by it at the time, there can be no binding ratification: for "ratification must be by an existing person on whose behalf a contract might have been made at the time" $(h)$.

There fall under this head contracts entered into by professed agents on behalf of wholly fictitious persons, or uncertain persons or sets of persons with whom no contract can he made by the description given, persons in existence but incapable of contracting, and lastly (which is in practice the most important case) proposed companies which have not yet acquired a logal existence $(i)$. Now when a principal is named who might have authorized the contract, there is at the time of the contract a possibility of his being hound by subsequent ratification. But when the alleged principal could not have authorized the contract, then it is plain from the heginning that the contract can have no operation at all mless it binds the professed agent. It is construed accordingly ut res magis culeat quam pereat, and he is held to have contracted in person $(k)$.

This principle has been carried so far that in a case where certain persons, churchwardens and overseers of a parish, corenanted "for themselves and for their" successors, churchwardens and orerseers of the parish," and there was an express proviso that the corenant

(t) Per Willes J. and Byles .J. Kelner v. Buterter (181;i) L. H. 2 C. 1'. 174. 185.31 L. J. C. P. $44:$

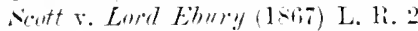
C. P. 25\%. 20\%. 3i; I. J. C. 1'. 161. When ratification is admittel. the original contract is imputed by a fiction of law to the person ratifying: and the fiction is not allowed to be cxtended berond the bounds (ff posibility.

(i) Kellep v. Buster (lstiti) I. H. 2 C. P. 17t. and autborities there referred to: Siont r. Lord Eburn!

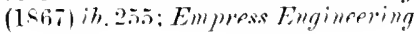

(a. (1880) 16 Ch. Div. 125. orerruling Silllerv. Paris skuting Rink G. (18is) i Ch. D.36s. Companies have been held in equits to be lound by the agrecments of their promoters but on grolinds in te. pendent of contract. Action upon such an agreement by the compans. under the mistaken belief that it is binding. cannot be treated as eri. dence of a new agreement: the Cinthamberland dirmue Hotel Co. (18ndi) 33 ('h. Div. li. 5t L. T. 77. (k) Kolner v. Barter (1866) L. R. 2 C. P. at pp. 183, 185. 
should not bind the covenantors personally, but was intended to bind the churchwardens and overseers of the parish for the time being as such churchwardens, sc., but not otherwise, it was held that since the funds of the parish conld not be bound by the instrment in the manner intended, the effect of the proviso was to make no one liable on the covenant at all, and therefore the proviso was repugnant and void, and the eovenanters were personally liable $(l)$.

Accordingly the proper course for the other contracting party is to sue the agent as principal on the contract itself, and he need not resort to the doctrine of implied warranty $(m)$. And as the agent can be sled, so it is apprehended that, in the absence of fraud, he might sue on the contract in his own name.

A slightly different case is where a man professes to contract as agent, but without naming his prineipal. He is then (as said above) prima facie personally liable in his character of agent. But even if the contract is so framed as to exclude that liability (and therefore any correlative right to sue), he is not precluded from showing that he himself is the principal and suing in that character. This was decided in Schmaltz r. Avery $(n)$. The action was on a charter-party. The

(l) Furmicall v. Commbes (184:3) 5) II. \& G il. 73i, 12 L. J. C. I'. 265, 63 R. R. 45.5. But the doetrine of this case will certainly never be extended (see II illiamix v. Mathareay (1857) 6 Ch. 1 . $5+4)$; and $q u$. Whether it would apply to an instrument not under seal. It is clearly competent to the parties to smeh an instrument to make its operation as a contract conditional on any erent they please: and in such a case as this why may they not agree that noborly whall be borind if the principal cannot be! In Kelner v. Burtor oral evidenee was offered that surh was the inten. tion, but was rejected as contrary to the terns of the writing sterl upoll.

(iii) Kolner v. Burter, note (k), last paue. Cp. Il'st Landon rom. merrial bunli v. hitson (Isrit) 12 Q. 13. D. 15i, where a biłl was accepted by directors on behalf of a company which had no power to actept bills; tle liability was put on the ground of deeeit in $1: 3$

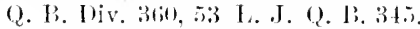
(11) (15.il) 16; (2. B. 65: the statement of the facts is taken from the jurlement of the comt. 1. (;.)8), 20) 1. J. (2. 13. 22, 8.3 li. 1R. 1i.is.
When profusserl agent nay le his own unuamed frimeipal. 
charter-party in terms stated that it was made by Schmaltz \& Co. (the plaintiffs) as agents for the freighters; it then stated the terms of the contract, and conchuded in these words: "This charter being concluded on behalf of another party, it is agreed that all responsibility on the part of (t. Sehmaltz \& Co. shall cease as soon as the cargo is shipped." This clause was not referred to in the declaration, nor was the character of the plaintiff as agent mentioned, but he was treated as principal in the contract. At the trial it was proved that the plaintiff was in point of fact the real freighter. Before the Court in banc the cases of Bickerton r. Burrell and Ruyner v. Grote (o) were relied on for the defence, hut it was pointed out that in those cases the agent named a principal on the faith of whose personal credit the other party might have meant to contract. Here "the names of the supposed freighters not being inserted, no inducement to enter into the contract from the supposed solvency of the freighters [could] be surmised. . . The plaintiff might contract as agent for the freighter, whoever the freighter might turn out to be, and might still adopt that chancter of freighter himself if he chose " $(p)$. And conversely, a man who has contracted in this form may nevertheless be sued on the contract as his own undisclosed principal, if the other party can show that he is in truth the principal, but not otherwise $(q)$. In the same mamner it is open to one of several persons with whom a contract was nominally made to show that he alone was the real principal, and to sue alone upon the contract accordingly $(r)$.

(o) See 11. 111-112, above.

(p) In a later ease in the Exchequer Chamber (Nhaman s. brandt (18.1) I. L. 6 Q. B. 7201, 41 L. J. Q. L., 312), there are some expressions not very consistent with this, but they were by $n 0$ means necessary for the deeision.
IIoreover Schmalt: $v$. Arery was not cited.

(q) (arr v. Jackson (18.52) $\mathrm{T} \mathrm{Ex}$. 342. 21 L. J. Ex. 137, 86 R. R. 699.

(r) smur v. Cass (1870) L. l. $\therefore$ (. B. 65ti, 3! L. J. Q. B. 24 ? 


\section{Artifinal Pernons.}

In a complex state of civilization, such as that of the suificial

Roman Empire, or still more of the modern Western lheirns: nations, it constantly happens that legal transactions have to be undertaken, rights acquired and exercised, and duties incurred by or on hehalf of persons who are for the time being charged with offices of a public nature involving the tenure and administration of property for public purposes, or interested in carrying out a common enterprise or object. This enterprise or object may or may not be of a kind likely to be worlied out within a definite time, and may or may not further involve purposes and interests of a public nature. The rights and duties thus created as against the worlel at large are wholly distinct from the rights and duties of the particular persons inmediately concerned in the transactions. Those persons deal with interests beyond their own, though in many cases including or involving them, and it is not to their personal responsibility that third parties dealing with them are accustomed to look.

This distinction (the substantial character of which it is important to bear in mind) is conveniently expressed in form by the Roman invention, adopted and largely developed in modern systems of law, of treating the collective persons who from time to time hold such a position - or, in some cases and according to some opinions, the property or office itsalf- as a single and continuous artificial person (s) or ideal subject of legal capacities and duties. It is possible to regard the artificial person as a kind of fietitions substaneer concedverl ats supporting legal attributes; and in fact this wals,

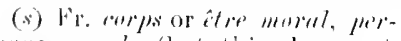
somer morale (but this does not necessarily import eapacily to sne or be sued in a corporate name) ;

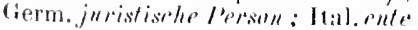
morale kent, comm. 2. 206, nises lheir nature. 
until lately, the prevailing theory of modern civilians on the Continent $(t)$. But it is equally possible, and it secms not only more philosophical but more businesslike, to hold that what we call the artificial identity of a corporation is within its own sphere and for its own purposes just as real as any other identity $(u)$. The corporation becomes, within the limits assigned to its existence, "a body chistinct from the members composing it, and having rights and obligations distinct from those of its members." This is often ealled a fiction: but it represents a class of facts not confined to legal usage or legal purposes. In the case of an ordinary partnership the firm is treated by mercantile usage as an artificial person, though not recognized as such by English law; and other voluntary and unincorporated associations are constantly treated as artificial persons in the language and transactions of everyday life. An eren more remarliable instance is furnished by the artificial personality which is ascribed to the public journals by literary custom or etiquette, and is so familiar in writing and conversation that its curiosity most commonly escapes attention. The existence of these artificial persons by mivate convention, if we may su call them, shows that, if indeed there be any fiction in the matter, it is not superfluous or arbitrary $(w)$.

$(t)$ see F. W. Maitland's Introduetion to Gierte's Political Theories of the Uirlile Age, Cambringe 1!no: further references there, at p. xxvi. Th" late-t expestion is

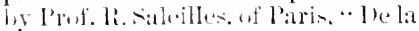

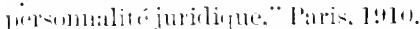

(1i) $\cdot A$ conpuration is a legal

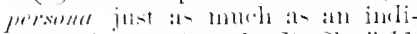

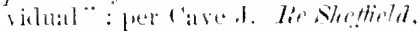

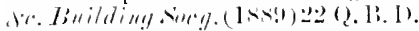
at p. tri. In the Inited states a corporation duly created by the laws of any state is treated as a person dwelling in. and therefore a citizen of. that state within the meaning of the constitutional pro. rition which enables the Ferleral courts to entertain suits between citizens of different states. See Mervoull v. Bultimore and onis liati: ('\%. (1853) 16 Howard. 314. lint it is not a citizen for all prurpores, nor entitled to all the const itutional immunities of indivinluals :

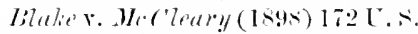

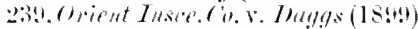

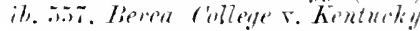
(1!H) 211 [. S. 45. In Germany the state as an wwner of properts. is specially personified as "the Fise." after lioman precelent and has not only the rights but the liabilities of ans private owner. see L. (1) F. xxiii. 13.

(ii) "The orthodox loctrine of 
In the Common Law no speculative opinion on the subject has been definitely adopted $(x)$, though it seems Corporations in the Comlikely that only Coke's incapacity for grasping any non Law. general theory, good or bad, saved us from what is now known as the "fiction theory" annong Continental publicists $(y)$.

In our authorities and practice the necessary marks of legal corporate existence are a recognized collective name (which however need not be expressly conferred at the outset), and capacity to sue, be sued, and do other acts in the law, in that name.

Perpetual succession, that is, the existence of a body independent of the natural life of any one or more members, and a common seal to authenticate the corporate acts, are consequences or incidents of incorporation rather than primary constituents. A corporation legally qualified to act as such can exist only with the sanction of the State, which may be expressed in England by a royal chirter $(z)$ or by statute. The statutory sanction may take the form -as in the familiar case of the Companies Acts-of anthorizing persons who are so minded to constitute themselves into corporations by fulfilling specified general conditions. In this class of cases, at any rate, it would seem that the operative registration, or other appointed formality, is not properly considered as involving fiction of any kind, but is the official recognition and regulation of substantial matters of fact. With us the official sanction is a matter

the common law, which reomenimes only individuals and corpulations as entities, mulomletedly lages fat behind the oglinary comceptions of laymen": Hayv. law hev. xv. $3 i 1$.

(a) Ilobbes gises an arluirable exposition of the purely indivitualist view in the lotle chapter of his leviathan, but ol combe withont regard to authority.

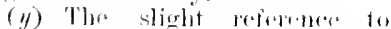
lioman law in the vinttuld s/aspilal

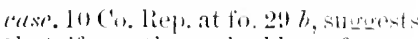
llat, it any theory hat been formol. lated, it would hitw been the then reaced ane of the eivilians.

(z) Tho want of this hat to lat supplied in some cases by the tiction of a lost grant : libekst. Gomm. i. 173 . Siee the whol. elapres (bomk 1, ch. ls) for a literary expesition of the (ommon law doctrone as it stome in the lattor part of the Isth contury.

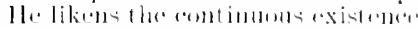


of procedure and pullic convenience. In the Roman law of the Empire it was an offence to form any kind of association without public authority; thus the early Christian churches were exposed to penalties by the mere fact of being collegia illicita. This principle has largely survived in the modern public law of the Continent; only the faintest signs of any attempt to imitate it occur in ours (a).

The holders of ecclesiastical benefices and dignities are said, by an analogy which is of no great antiquity, to be "corporations sole." Little or no useful result seems to be attained, for the alleged corporate character of a parson does not prevent the freehold of the church from being in abeyance when he dies, though a grant to an existing parson and his successors is effectual. By a still more doubtful extension of the analogy, the Crown is said to be a corporation sole (b) ; and the same description has been applied by statute to the holders of a certain number of public offices (c). It may be sufficient to observe, so far as the principle is concerned, that for many centuries the Vatican and its contentsto say nothing of the spiritual powers and other former temporal possessions of the Holy See-have been held under an absolutely unique system of succession, but it has never occurred to any one to call the Pope a corporation sole. At any rate, the persons whom we have to call corporations sole in England can do very little in their corporate capacity, and in particular cannot bind or "ren benefit their official successor's by contract,

uf a colpuration to that of the rivere Thames.

(a) It is salil to be an uffence to "assmule to act at a colponation," lut this is far shont of the limman wohibition.

(b) The theory of the King "burly politic" is given at some length in flowt. 213. It womld secm to have been a fashinmable novelty at the time. (c) See $\mathrm{F}$. WI. Matland. The Corprition sule. I. Q. R. xvi.335: The Crown as corporation, ib. xrii. 131. The notion of a corporation sole alpears to date only from the lith century. Is to the Pontmaster-General ste per Mathew L..J., bainbridgt r. P'stmuster-Ginforl [I906] l K. F. at 1. $1 ! 13$. 
except in one or two peculiar cases $(d)$. We therefore have nothing to learn in that quarter for the purposes of this work, and we may practically confine our atlention to corporations aggregate.

We have to ascertain what contracts corporate bodies can make, and how they are to be made. The second of these questions is reserved for the following chapter on the Form of Contracts. The first cannot be adequately treated except in comnection with a wider view of the capacities, powers, and liabilities of corporations in general.

The capacities of corporations are limited

(i) By natural possibility, i.e., by the fact that they are artificial and not natural persons:

(ii) By legal possibility, i.e., by the restrictions which the power creating a corporation may impose on Capracities and liabilities of ('orploriation as limiter? by the mature of an artificial perron. the legal existence and action of its creature.

First, of the limits set to the power's and liabilities of corporations by the mere fact that they are not natural persons. The requirement of a common seal (of which elsewhere) is sometimes said to spring from the artificial nature of a corporation. The fact that it is not known in Scotland is, however, enough to show that it is a mere positive rule of English law. The correct and comprehensive proposition is that a corporation can do no

(d) Generally "bishons, dwans, parous, vicars, and the like cammot take obligation to them and their suceessors, but it will go to the excentrin." linudel's ertse. IIol. (i) ; 20 L. IV. 2, pl. i; Homlry v. knight (18t!) 11 Q. 13.2. 2.10, 1! I... I. Q. B. 3. sol R. R. 26ie. "Regularly no chattel can go in surcessinn in at cate of a sole enrporation" : Cor. litt. Hill; it wats of herwise in the case of the hearl of a religions house, as he rould not make a will, ko. Abr. 1. 51. She the ollt authorities stumed up in bilackst.
C'omm. ii. 431-433. who attempts to timel reasoms. A curious recent rase where a fund of stock was vested in eertain reetors and their successins by a private Act is Pourer v. Bankis [1!01] 2 ch. 4s7, 70 1. I. ('h. 700. In truth, as l'pot. J. ('. Giay says (The Nature and Sundors of the Law, 1909, \$ 135), a corporation sole "is sinjuly a series of natural persons, some of whose rights are different and devolve in a different way from threent natumal pertons in general." 
executive act except by an agent; and a corporate seal is only one way of showing that the person entrusted with it is an anthorized agent of the corporate body. We say that executive acts of a corporation must be done by an agent. It does not seem necessary or plausible to extend the proposition to deliberative acts and resolutions. When, for example, the assembled Fellows of a College resolve to grant a lease of certain college land, their resolution, whether unanimous or by the statutable majority, would seem to he the act not of agents but of the College itself. For if the Fellows roting are agents, who authorized them, and when? But when they proceed to order the affixing of the College seal to the lease, then the officer of the College who is directed to affix it is an appointed agent, whether he is himself a member of the governing body or not. There seem also to be cases in which the permanent authority of the head or other acting member of a corporation is derived not from any authority specifieally conferred on him, but from the original constitution of the corporation. Here, however, the conception of an implied agency is convenient and fairly applicuble. Indeed, the Common Law doctrine of agency is so wide and flexible that we practically tend to regard all acts whaterer done in the name of a corporation as derived from some authority, general or special, vested in the natural persons by whom they are done. This may not be atrictly correct view, but it has largely sared us from the speculative questions which have rexed continental jurists ere since the thirteenth century, and prolably also from much more serious errors.

A corporation obviously camnot be subjected to death, corporal punishment, or imprisonment, though it can be fined or made to pay damages ats easily as a natural person. Further, it is understood that a corporation is incapable of committing the graver kinds of crime, such as treason, felony, perjury, or offences against the 
person (e), as well as of being punished for them. There can be no real authority to commit such acts. Any or all of the members or officers of a corporation who should commit acts of this kind (e.y., should levy war against the King) under cover of the corporate name and authority would be individually liable to the ordinary consequences. "Offences, certainly offences of commission, are the offences of individuals, not of corporations " $(f)$. Nor can a corporation undertake duties which, though it might be strictly possible for a corporation to perform them by its officer's or agents, are on the whole of a personal kind (g). On the other hand, it is subject to the same liabilities as any other employer for the acts, neglects, and defaults of its agents done in the course of their employment $(h)$; and conversely it may sue in its corporate capacity for a libel reflecting on the management of its business $(i)$. And the same principle is extended to make it generally subject to all liabilitirs

(e) Reg. v. (i. . Y. of Rinu. Riy. ('i). (1846) 9 Q. B. $315,326,14 \%$ L. . . II. C. 16,72 R. R. 2(i-) $n(1)$, it is said, ean it be exeommuncalted, for it has no soul: 10 Co. liep. 32: 1 : the ultimate authority for this was a decree of Imnocent $\mathbb{W}$. at the Couneil of Lyons in 1245: int otherwise as to interdict: (iierlis, Dentsehe Genossenschaftsrecht. iii. 313-9. So a corporation eannot do homage: (o. Litt. di $b$. Nirl cin it be subject to the jurindiction of a customary court whose process is exclusively fersonal: Lomdun. Joint

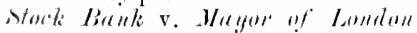

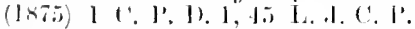

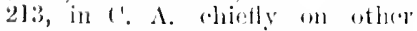

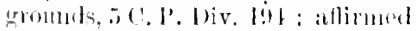
on this print in the llowse of larels, ti sper. (a. 3!13. Weare not aware that any linglish writer has thomght it neressary to state in terms that a colporat ion cannot bremaried or have any next of kin. The statr. ment is to be lomm in sarigny,

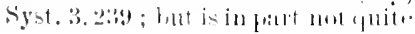

so odll as it looks, as in fimman law putria pestestes and all the family relations arising therefrom might be aceguired by aloption.

(f') Jramwell L.I. 5 Q. P. J. at

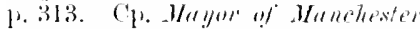
v. Hilliams [1891] I Q. B.94. 601 1. J. Q. B. 23 .

(4) Eir puste sicansed Friemally siecietty (1579) 11 ('h. 1). 768, ts L. I. (H.).77.

(h) Ditticult ies. formal and material. which nsed to be entertained on this head are now removed. Even maticious presecution is not now thomeht to be an exention :

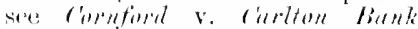
[16000] ] (1. 18. 2.2, dis L. I. 1). IS.

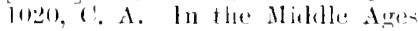
the posisilility of a corpmation committing a deliet wats clisputed ly the camonists but generally miantaned by the eivilians: (ijerke. op. cit. joz.

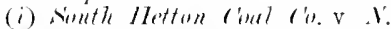

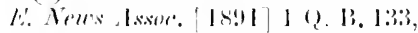

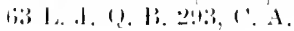

As to acts of agralts. 
incidental to its corporate existence and acts, though the remedy may be in form ex delicto or even criminal. Indictable Although it cannot commit a leal crime, "it may be in some cases. guilty as a body corporate of commanding acts to be done to the nuisance of the commumity at large," and may be indicted for a nuisance produced by the execution of its works or conduct of its business in an improper or unauthorized manner, as for obstructing a highway or navigable river $(k)$. A corporation may even he liable by prescription, or by having accepted such an obligation in its charter, to repair highways, \&c., and may be indictable for not doing it (l). A corporation carrying on business may likewise become liable to penalties imposed hy any statute regulating that husiness, unless a contrary intention appears from the language of the Act or the nature of the case $(\mathrm{m})$. A steamship company has heen held (on the terms of the particular statute, as it seems) to be not indictable under the Foreign Enlistment Act of Geo. 3, and therefore not entitled to refuse discovery which in the case of a natural person wonld have exposed him to penalties under the Act $(n)$. As to the difficulty of imputing fraudulent intention to a corpration, which has been thought to be peculiarly great, it may be remarked that no one has crel doubted that a corporation may be relieved against fraud to the same extent as a natural

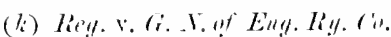
(1s16) 9 Q. 13. 315. per Cur. 1. 32ti.

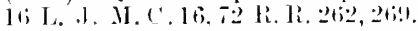

(l) see (ivaut on lorporations. 27\%, 203: Angell of Ames on Cor.

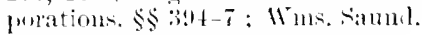
1. (i) 2. 473 .

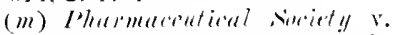

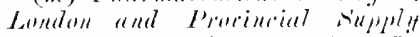

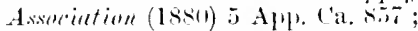
see per Lomd Blacklumn at p. s69:

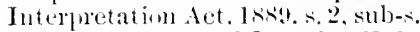

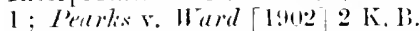
1, 3 I. J. K. R. li.ti. As to rentedy hy injunction. I.-li. r.

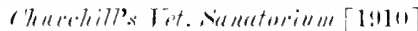
2 ('h. 101); but this does not extenu to making a corporation punishable as a rogue and ragabont, Havele v. E. Mnlten it (i) $[1 ! 0 ! 1] \geq$ K. R. 93. is I. J. K. 1. 6.33. 1 corporation camnot sale ils a common informer withont special statutory authority :

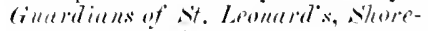
ditath r. Frumblin (185) 3 C. P. 1). $37 \%$

(i) king of The Nicilies $r$. Willeor (1s.,i) l sin. N. s. 335. 1!) L. I. ('h. tes. s! li. H. 104. 
person. There is exactly the same difficulty in supposing a corporation to be deceived as in supposing it to deceive, and it is equally necessary for the purpose of doing justice in both cases to inpute to the corporation a certain mental condition - of intention to produce a belief in the one case, of belief produced in the other-which in fact can exist only in the individual mind of the member or servant of the corporate body who acts in the transaction $(o)$. Lord Langdale found no difficulty in speaking of two raihay companies as " guilty of fraud and collusion," though not in an exact sense $(p)$. However, the members of a corporation cannot even by giving an express authority in the mame of the corporation make it responsible, or escape from being individually responsible themselves, for a wrongful act which though not a personal wrong is such that if lawful it could not have been a corporate act $(q)$. Such is a trespass in removing an obstruction of an alleged highway. For the right hy which the act has to be justified is the personal right to use the highway, ant a corporation as such camnot use a highway. Liliewise it is not competent to the governing body or the majority, or even to the whole of the members for the time being, of a corporation constituted hy a formal act and having defined purposes, to appropriate any part of the corporate funds to their private use in a manner not distinctly warranted by the constitution ; for it is not to be supposed that all the members of the corporation are equivalent to the corporation so that they cin do as they please with corporate poperty. A corporation

(i) See per Lrord blackburn, 3 App. Ca. 1264. A company may "feel aggrievel," (ompranjes Act. 1908 , s. 212, sub-s. i (re-enacting :1 provision of the former $A$ et if of 1880$)$.

(1) 12 Beav. 382, sis li. Ri, i29.

(q) Will v. Ilowher (Is74) L. R.
But cannot be boun's by aets of eren all its mem. bers when of a non-corlorate character.
9 Ex, 309, 3Is, 44 L. .J. Ex. 49: no julgment on this part of the case in Ex. ('h. I. Ii, fo Ex, 92. It might be. ly slatute, the right or doty of a colpuration to remove (obstrictious, and the real question hert' was whether a highway boaldel hat such a power or dity. 
does not exist merely for the sake of the members for the time being. Lord Langdale held on this principle that the original members of a society incorporated by charter, who had bought up the shares of the society by agreement among themselves, were bound to account to the society for the full value of them $(r)$. The fallacy of the assumption that a corporation las no rights as against its unanimous members is easily exposed by putting the extreme case of the members of a corporation being by accident reduced till there is only one left, who thereupon unanimously appropriates the whole corporate property to his own use (s).

Limitation of cori urate capacities by jositive rules.

The powers of a corporation are necessarily limited in some directions by the nature of things. There remains the question whether there are any general rules of law limiting them farther and otherwise. If our law had committed itself to the doctrine that the personality of a corporation is a mere fiction of the sovereign power, it might have been held as a natural consequence that a corporation could in no case have any powers except such as were conferred on it, expressly or by necessary implication, by the same act which created it. But this did not happen, and the judicial discussion of the subject has been eroked by the rapid growth of incorporated commercial and industrial societies in morlern times, and guided by reasons founded not in the nature of a corporation in itself, but in the need for safeguarding the interests partly of the individual members of companies, regarded as substantially partners in a joint undertaking, and

(r) Society of Pouctical hinurledige v. Ablutt (18ti) 2 Beav. 5is. 567.50 R. R. 205, 294. Cp, sar. syst. 3. 253. 33.5. But it may be otherwise if the corporation has nu definite constitution and no rules prescribing the application of its property. Such cases are some. times met with: Bromen r. Dule (1878) ! ( h. D. 78.

(.) Sav. syst. 3. 329 sqq. \$\$ 9719. The illuslration in our text is given at $1 \% 350$, note, with the remark, "Hier ist gewiss Einstimmigkeit rorhanden." 
partly of outside creditors dealing with companies, and looking to their corporate funds and credit, on the faith of apparently authorized acts and promises of their directors or agents. These two classes of interests are to some extent opposed, and the law has not reached the fairly settled condition in which it now stands without considerable fluctuations of opinion. On these, however, it is no longer needful to dwell at longth.

"At common law a corporation created by the King's charter has ... the power to do with its property all such acts as an ordinary person can do, and to bind itself to such contracts as an ordinary person can bind himself to" $(t)$, (subject to the corporate acts being sufficient in form, which we are not considering in this place). This rests on authority which, though it seems at times to have been forgotten, has never been disputed $(u)$.

But when a corporation is created directly by special statute, or indirectly by a statute authorizing the formation of a class of corporations on specified conditions, for purposes declared by the statute, or which the founders of the corporation are required to dleclare, then l'owers of statutory corporations determined by purposes (if incorporatim the question is different. As to power's expressly conferred on the corporation, or clearly authorized by general provisions, there can be no loubt; when farther powers are claimed, it must be considered what was the intention of the Legislature, and only such powers can be attributed to the corporation as are necessary or reasonably incident to the fulfilment of the purposes for which it is established. Member's of the company have the right to rely on those pruposes not being exceeded; the public can ascertain them, and have not

(f) Bowen I..J. in Raromess

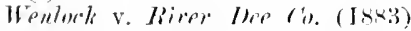
36 Ch. D. 675, ti8.5, "n. trmble this applied to chatered eompanies of the modern polition-commercial type: Britisle s. dfrica r'o. v. De

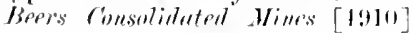

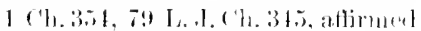
[1910] 2(1). 502. ( . 1.

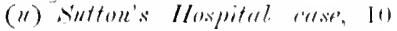
Co. lite., where it is said (at 1. 3t) b) that when a corproution is chly created, all other incichentio are tarite annexul. 
lieasons for the limitation lerived-

\section{From} partnership law.

Fights of dissenting partners.

any right to hold the company liable for undertakings outside them. On the whole, "where there is an Act of Parliament creating a corporation for a particular purpose, and giving it powers for that particular purpose, what it does not expressly or impliedly authorize is to be taken to be prohibited " $(x)$-prohibited in the sense not that penalties or disabilities follow on such an act if done, but that the attempt to do it can from the first have no kind of validity as a corporate act.

The reasons for this rule, as we have himted, are derived (1) from the law of partnership; (2) from principles of public policy.

1. In trading corporations the relation of the members or shareholders to one another is in fact a modified (y) contract of partnership, which in the view of courts of equity is governed by the ordinary rules of partnership law so fall as they are not excluded by the constitution of the company.

Now it is a well-wettled principle of partnership law that no majority of the partners can bind a dissenting minority, or even one dissenting partner, to engage the firm in transactions beyond its original scope. In the case, therefore, of a corporation whose members are as hetween themselves partners in the business carried on hy the corporation, any dissenting member is entitled to restrain the governing body or the majority of the company from attempting to involve the company in an

(x) Lord Blackburn in -t.-fr. v.

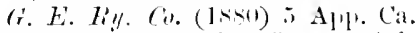
fi3, tisl, stating the effect of $A s k$. bury Ry. (arriage and Iron Co. . liveler (1875) L. R. 7 H. L. 16is, 44 L. J. Ex. 185. a leading case on the Companies Aet loti2, but not confinel to llue construction of that

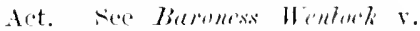

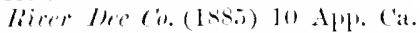
3it. 360, 5t L. I. Q. li. .7. A. As te railway companies unler speeial Acts. ree A.-(r. r. Jle'se'n Riy. ('e. [1907] A. C. 413, it L. i. Ch. 568.
$C_{1}$. as to the limited powers of a trale union, which is a peculiar kinul of statutory quasi-corporation. Amalqumated socy. uf Ry. Serronts v. O.torme [1910] A. C. 87. 7! L. J. ('li. $\therefore$.

(y) Namely ly provisions for transfer of shares limited liability of sharcholders, and other thing, which cannet (at least with convenience or completeness) be made incident to a partnershipat common law. 
undertaking which does not come within its purposes as defined by its original constitution. Courts of equity have been naturally called upon to look at the subject chiefly from this point of view, that is, as giving rise to questions between shareholders and dirrotors, or between minorities and majorities. Such questions do not require the conrt to decide whether an act which dissentients may prevent the agents of the company from doing in its name might not nevertheless, if so done by them with apparent authority, be binding on the corporate body. or a contract so marle be enforceable by the other party who had contracted in good faith. This distinction was not always kept in sight. But further, according to the law of partnership a partner can bind the firm only as its agent: his athority is prima facie an extensive one (z), but if it is specially restricted by agreement between the partners, and the restriction is known to the person dealing with him, he cannot bind the firm to anything beyond those special limits. Limits of this kind may be imposed on the directors or other officers of a company hy its constitution; and if that constitution is embodied in a special Act of Parliament, or in a deed of settlement or articles of association registered in a public office under the provisions of a general Act, it is considered that all persons dealing with the agents of the corporation must be deemed to have notice of the limits thus publicly set to their authority. The corporation is accordingly not bound by anything done by them in its name when the transaction is on tha face of it in excess of the power. thus defined. And it is important to remember that in this view the resolutions of meetings however numerous:

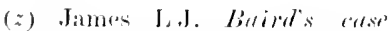
(1870) L. R. 5 ( ' h. 733 : story on Agency, $\$ \$ 124,125$, adopted $1, y$ the Iudicial committee in Bantif
Doctrine as limitel ageney.
In publit: compranies limit of directors authority presumed to be known. 
Assent of all the members will remove objections on this head.

and passed by however great a majority, have of themselves no more power than the proceedings of individual agents to bind the partnership against the will of any single member to transactions of a kind to which he did not by the contract of partnership agree that it might be bound.

Irregularities in the conduct of the internal affairs of the body corporate, even the omission of things which as between shareholders and directors are conditions precedent to the exercise of the directors' authority, will not, however, invalidate acts which on the face of them are regular and authorized: third parties dealing in good faith are entitled to assume that internal regulations (the observance of which it may be difficult or impossible for them to verify) have in fact been complied with.

But it is to be observed that in the ordinary law of partnership there is nothing to prevent the member's of a firm, if they are all so minded, from extending or changing its business without limit by their unanimous agreement. As a matter of pure corporation law, the nnanimity of the memhers is of little importance: it may supply the want of a formal act of the gorerning body in some cases ( 1 ), but it can in no case do more. As a matter of mixed corporation and partnership law this unanimity may be all-important as being a ratification by all the partner's of that which if any one of them dissented would not be the act of the firm: for although the corporate body of which they are members is in many respects different from any ordinary partnership, it is treated, and justly treated, as a partnership for this purpose. It appears, then, that the manimous assent of the members will remore all ohjections founded on the principles of partnership, and will so far leave the

(a) Even this is in strictuess hardly combintent with the principle that if $\mathrm{A}, \mathrm{B}, \mathrm{C}$. . . . sc.. are incorporated to them and their sucessors by the name of $\mathrm{X}$. then $\mathrm{A}+\mathrm{B}+\mathrm{C}+. . \mathrm{N}$. are nut $=\mathrm{X}$. 
corporation in full possession of its common law powers. There are nevertheless many transactions which even the unanimous will of all the members cannot make binding as corporate acts. For the reasons which determine this we must seek farther.

2. Most corporations established in modern times by special Acts of Parliament have been established expressly for special purposes the fulfilment of which is considered to be for the benefit of the public as well as of the proprietors of the undertaking, and for this reason they are armed with extraordinary powers and privileges. Whatever a corporation may be capable of doing at common law, there is no doubt that unusual powers given by the Legislature for a special purpose must be employed only for that purpose: if P'arliament empowers either natural persons or a corporation to take J. S.'s lands for a railway, J. S. is not bound to let them take it for a factory or to let them take an excessive quantity of land on purpose to re-sell it at a profit (b). If Parliament confers immunity for the obstruction of a navigable river by building a brirlge at a specified place, that will be no excuse for obstructing it in the

(b) Siee Giallowory r. Maymor of London (1866) L. R. I If. L. at 1. 43, 3.5 I. J. (h. 477: Lomel

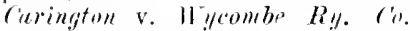
(186i8) L. R. 3 (h. 377. 381,37 L. f. Ch. 213. Nor may a eom. pany hold regattas or let out pleasure-boats to the inconvenience of the former owner on a piece if water aerjuired by them under their Act for a reservoir: Bostoel v. I. Staftordshire liy. ('o. (185ti) 3 sm. d (3. 243, 2!2. 25 L. .J. (h) 325. 90) R. R. 154. in (2. R. on a rase sent by Parker V.C. (1N,5) I E. A B. 79s. 9! h. li, 7... witl somb differenre of eprinion: 110 . alienate land sintiarly acepuired except for purposes anthorized by the Aret: Mullimer v. Midlumd Riy. (im. (1879) 11 (h) 1) 611, tie2, th L. J. ('h. 2.s. but a statutory corporation accuiring property takes it with all its rights and incidents as against strangers, subjeet only to the duty of exercising those riglits in good faith with a view to the objeets of incorporation: surinden Waterumlis Co.v. Writt.s

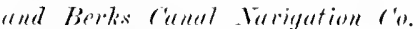
(1875) L. K. 7 H. I. $697,714,710$. 4.) L. J. Ch. 638 ; Banner v. Cr. II.

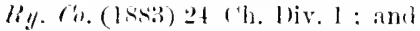
a roporation annot bind itsell wet to noe in the future spetial powers which have presmmably been conferred to la usesl for thr. public good: Ayr Ilarlume Tims-

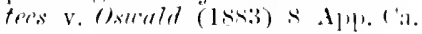
(i2).
2. I'ublic policy : powers must not be used to clefeat speeial purposes of incul poration. 
like manner elsewhere. Moreorer we cannot stop here. It is impossible to say that an incorporation for special objects and with special powers gives a restricted right of using those powers, but leaves the use of ordinary corporate powers without any restriction. The possession of extraordinary powers puts the corporation for almost all purposes and in almost all transactions in a wholly different poition from that which it would have held without them; and apart from the actual exercise of them it may do many things which it was otherwise legally compotent to do, but which without their existence it could practically never have done. Any substantial departure from the purposes contemplated by the Legislature, whether involving on the face of it a mirapplication of mecial powers or not, would defeat the expectations and ohjects with which those powers were given. When Parliament, in the public interest and in consideration of a presumed benefit to the public, confers extraordinary powers, it must be taken in the same interest to forbid the doing of that which will fend to defeat its policy in conferring them; and to forbid in the sense not only of attaching penal consequences to such acts when done, but of making them wholly roid if it is attempted to do them. Accordingly contracts of railnay companies and corporations of a like public nature which can be seen to import a substantial contravention of the policy of the incorporating Acts are held by the conits to be roid, and are often spoken of as mald prohilita. and illegal in the same sense that a contract of a natural person to do anything contrary to the prorisions of an Act of Parliament is illegal (c). Others prefer to say that the Legislature,

(a) Blackburn .I. in Taylor v. Chichester at Midlumst Ry. (b. (186ii) J. R. 2 Ex. at p. 379,39 L. J. Ex. 21\%: and (Brett and Grove JJ. concurring) in Rive $v$.

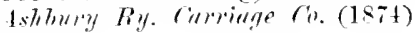

I. li. $9 \mathrm{Ex}$. at pp. $262.260,43$ L. J. Ex. 17i. Lord Hatherley. s. c. nom. Ashbury Ry. Carriage Go. Riche (18i5) L. R. ' T H. L. at p. 689 . 
acting indeed on motives of public policy, has simply disabled the corporation from doing acts of this clasts; "to regard the case as one of incapacity to contract rather than of illegality, and the corporation as if it were non-existent for the purpose of such contracts" $(d)$. This appears the sounder, and is now the more generally accepted view $(e)$.

There is another consideration of a somewhat similar kind which applies equally to what may be called public companies in a special sense-i.e., such as ale invested with special powers for carrying ont definesl objects of public interest and ordinary joint-stock (ompronies which have no such power's. The provisions for limited liability and for the easy transfer of shares in both sorts of companies must be considered, in their molern form and extent at least, as a statutory privilege. These provisions also invest the companies with a certain public character and interest apart from the nature of their particular objects in each case, but derived from the fact that they do professedly exist for particular ohjects. By far the greater part of their capital represents the money of shareholders who have bought shares in the market without any intention of taking an active part in the management of the concern, but on the faith that they know in what sort of adventure they are investing their money, and that the company's funds are not being

Tnterest of the public as investors. lingers of shares in market and persons giring credit to the compauy have a right to assume tl.at the company's professed ubjects are arbered to. (d) Arelinbald J., T. It. ! Ex. 293 ; Lord caims, L. Ti. 7 11. J. at p. fire: lomel Selbome, ito 6ilt. Anil Bramwell 1..l. rather strongly disapproved of ealling such act illegal, pointing wat that if they were properly so called there would have bren some means of restran. ing them in a court of commmon law at the instance of the Cowwn: A.-Gi. r. G. E. Ry. (i). (1880) II ('lu. Div. at $p \mathrm{p}$. Bai -3.

(a) The agreement of a thirel peron to promere a comprany to do something foreign to its preper purpues is plausibly called illegal:

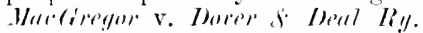

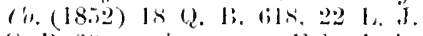
Q. B. big: and see per brle .1. in

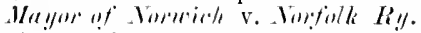

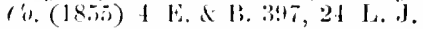
Q. B. 105,99 R. R. .1s ; hut it is really void as being the promise of "l freformanes impessible in law (1'h. V111.. behin). 
and will not be applied to other objects than those set forth in its constitution as declared by the act of incor. poration, memorandum of association, or the like. This is not a mere repetition of th: objections grounded on partnership law; the incoming shareholder may protect himself for the future, but the mischief may be done or doing at the time of the purchase: moreover persons other than shareholder's deal with the company on the faith of its adhering to its defined objects. They are entitled to "know that they are dealing with persons who can only devote their means to a given class of objects, and who are prohibited from devoting their means to any other purpose " ( $/)$. The assent of all those who are shareholder's at a given time will bind them individually, but it will not bind others $(h)$. If I buy shares in a company which professes to make railway plant in England I have a right to assume that its funds are not pledger to pay for making a railway in Spain or Belgium, and it is the same if dealing with it as a stranger I lend money or otherwise give credit to it. Accordingly the prorisions of the Companies Act, 1862, are to be considered as having been enacted in the interests of "in the first place, those who might become shareholders in succession to the persons who were shareholders for the time being; and secondly, the outside public, and more particularly those who might be creditors of companies of this kind " $(i)$. Accordingly it is settled that a company registered under the Companies Act is forbidden to enter, even with the unanimons assent of the shareholders for the time being, into a contract foreign to its objects as defined in the memorandum of association $(k)$.

(g) Lorl Hathertey, L. li. i H. L. at p. 684 .

(h) See L. Ii. ! Nx. $270,2 ! 1$.

(i) Lond cairns. L. R. 7 H. L. at p. ifis. (k) Ashbury Ry. ciarriaye dit Iran (i) v. Rirlee (185) L. R. T H. I. 6.5. 4t L. J. Ex. 185. See note $D$, in Appendix for some further account of the authorities by which 
It is not within our scope to discuss the particular contracts which particular corporate bodies have been held incapable of making. One class of contracts, however, is in a somewhat peculiar position in this respect, and requires a little separate consideration. We mean the contracts expressed in negotiable instruments and governed by the law merchant. As a general rule a corporation cannot bind itself by a negotiable instrument $(l)$. This is not because a corporation cannot be presumed to have power to do so, but, in the first place, because of the general rule of form that the contracts of a corporation must be made under its common seal $(m)$. It follows from this that a corporation camnot generally be bound by negotiable instruments in the ordinary form. The only comparatively arly authority which is really much to the point was argued and partly decided on this footing $(n)$. But the corporate seal may now take the place of signature in bills and notes $(o)$, and transferable debentures under a company's seal have been held to be negotiable $(p)$. Thus the objection of form does not seem of great importance in modern prac-

the rules were settled in the latter prart of the nineteenth century. It is harlly needful to arld that the consoliclating Aet of $190 \mathrm{~s}$ hats made no elange in the principles of the law.

(l) $A$ different rule prevails in the [rnited states, where it is held that a corporation not expressly prohibitel from so doing may gire negotiable promissory notes for atuy of the legitimate muposes of its incorporation. 'This aplears more convenient at the present lay.

(m) See nore as to this in tho following chapter.

(ii) Broughtorl v. Mamolestor II ateruorks ('). (ISI!I) 3 IS. A Alil. 1, 22 li. li. 278 . The wiel point was on the statutes wiving the Pank of Englatul rexclusion rights
Inability of corporations to malie negotiable iustruments of issuing notes, de., within certain limits. In Hura! v. E'. India Co. (1821) 5 B. \& Alil. 204. 24 R. R. 3.5. thestatutury anthority to issut bills was not disprited : a difliculty was raiser as to the noper remedy. but clisprosed of in the currse of argument: ; l3. \& All. 2[1), 2 t li. R. 330. Other cases at first sight like these relate to the authority of particular agents to binul a corprorate-or mincorpolatedassociation inrespective of the theory of corporate liabilities. Feenote $\left(\frac{j}{f}\right)$ next pagr.

(1) bills of Exclamee Act. 1882. s. 11 .

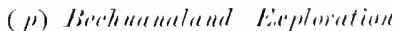

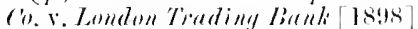
2 Q. I3. 65\%, 677 I. J. (). 13. 947,

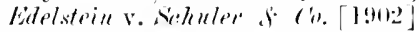

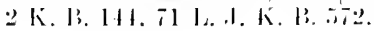


The ordinary rules of partnership ageney not applicable.
Ana partly in the peculiar character of the contract of exchange.

tice. The question of authority to bind the company in substance is more serious. It may be asked, why should not the agents who are anthorized to contract on behalf of a company in the ordinary course of its business be competent to bind the company by their acceptance or indorsement on its behatf, just as a member of an ordinary trading partnership can bind the firm? There is a twofold answer. First, the extensive implied authority of an ordinary partner to hinct his fellows cannot be applied to the care of a mumerous association, whether incorporated or not, whone members are personally wnknown to each other, and it has been often decided that the managers of such arocociations camnot bind the individual members or the corporate body, as the ase may be, hy giving negotiable instruments in the name of the concern, unlens the terms of their particular authority enable them to do so by express worts or necessary implication (q). In the catne of a corporation this authority must be sought in its constitution as set forth, in its special Act, articles of association, or the like. secondly, the power of even a trating corporation to contract without seal is limited to things incidental to the usual conduct of its businen. But as was pointed out by a judge who was certainly not dinposed to take a narrow view of corporate powers, a negotiable instrument is not merely eridence of a contract, but creates a new contrate and a distinct cause of action, and " it wouk be altogether contrary to the principles of the law

(4) A 1 (1) unincomprated juint stecte companien: Nowler. Yurton (152- + line. 14!9. 20! R. R. .i31:

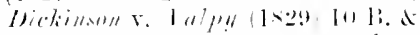

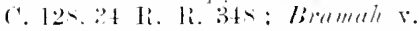

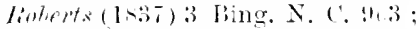
linlt b. J/orret (1-4ii) 1: A. d E

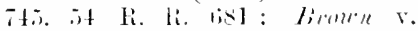
Byeis (1sti) 16 M. \& W. 20.2. 16 1.. .) Ex. 112. Al te in. corporated complanties: stele' r.

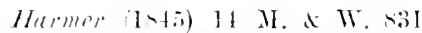
(in Ex. ('h. 4 Ex. 1, wut on this

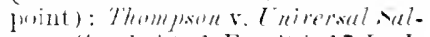
inge (i) (I-ti) 1 Ex. bi4. 17 I. I.

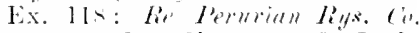
(186i) 1.. R. 2 Ch. 6iti. 3t; L. J. ch. sit : "u. E.r provte city bute

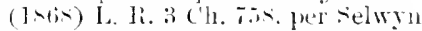
L.t. The two last cases go ratlier far in the Airection of implying - weh a power lom general words. 
which regulates such instruments that they should be valid or not according as the consideration between the original parties was good or ball; " and it would be most inconvenient if one had in the case of a corporation to inquire "whether the consideration in respect of which the acceptance is given is sufficiently connected with the purposes for which the acceptor's are incorporated" $(r)$.

The result seems to be that in England a corporation can be bound by negotiahle instruments only in the following cases:-

1. When the negotiation of bills and notes is itself one of the purposes for which the corporation exists"within the very seope and object of their incorporation" (s)-as with the Bank of England and the East India Company, and (it is presumed) financial companies generally, and perhaps even all companies whose business wholly or chiefly ennsists in buying and selling $(s)$.

2. When the instrument is accepted or made by an agent for the corporation whom its constitution empowers to accept bills, \&c., on its behalf, either by express words or by necessary implication.

The extent of these exceptions cannot be said to be very precisely defined, and in framing articles of association and similar instruments, it is therefore desirable to insert express and clear provisions on this head.

In the United States the Supreme Court hats decided that local anthorities having the ustal powers of adminAmerican istration and local taxation have not any implied power to issue negotiable secouties which will be indisputable

(a) Jier Eile ('..l. Buteman v.

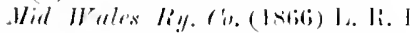

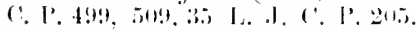
Railivay complotices are expre-sly. forbidten to isste nugotiable or assignable instruments without statulory authority. on pitin of forfeiting the uominal amomut of tlee seconrity : $T$ d s riet. 9 . sis. s. $1 !$.

(s) I'cr .Vomtangesmilh J. Is. Li.

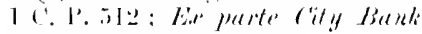

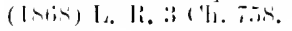


in the hands of a bona fude holder for value $(t)$, and has bren equally divided on the question whether municipal corporations have such power $(u)$. It seems, however that in American Courts a power to borrow money is held to arry with it as an incident the power of issuing negotiable securitis $(r)$, and it is held everywhere as settled law that in general a corporation may issue negotiable promissory notes for any of the legitimate purposes for which the company is incorporated $(x)$.

E-toprel and part verformance aplly tir copporations.

The common law doctrine of estoppel $(y)$, and the kindred equitable doctrine of part performance $(z)$, apply to corporations as well as to natural persons. Even when the corporate seal has been improperly affixed to a document by a person who has the custody of the seal for other purposes, the corporation may be bound by conduct on the part of its governing body which amounts to an estoppel or ratification, but it will not be bound by anything less (a). The principles applied in such cases are independent of contract, and

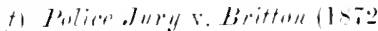
1.; Wallace, stis, in.

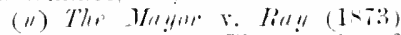
1!) Watlace thit. . The weight of authrits is against their having -nele prower" (l'ref. Williston"s note to thind American edition of this work, l906).

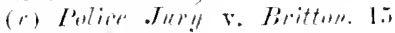
Wallace, sititi.

(.r) J'rof. Willistun's note, "ip. rit. at 1.144 .

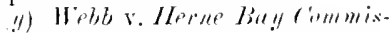

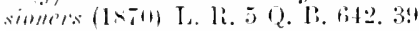
J., J. 1. P. .2.21.

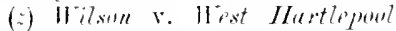
Riy. (i). (1-6t-5) 2 D. .J. S. 475, 493. per Tumer L.J. 34 L. J. Ch.

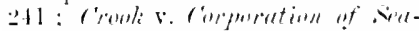
ford (1sil) L. li. it Ch. .isl :

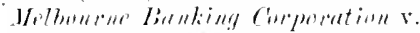

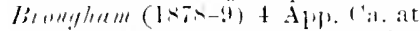
1. 16\%. An 1. J. I. I. I.2. Thi mu-t be contined however to cases where the corporation is " capable of being, bound by the written contract of its directors as an individaal is capable of being bound ly his own contract in writing: " ier Cinton L. J. Thut v. Wrimbledon

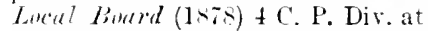
1. ti. to L. J. ('. 1'. 20 . see

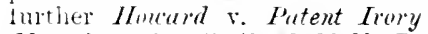

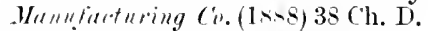
at HP. 162. 163. and cases collected in lindley on Companies, ith ed. i. $2-2.2$.

(a) Bunk of Ireland r. Eimns" Thurities (155) is H. L. C. 349. 101 Ii. IR. 21s: Werchants of the Stupler. Bunk of England (1Sis) 21 Q. B. Div. 160. 万I L. J. Y. B. the: Ruben r. Great Fingall tomsoliduted [lantio] A. C. 439. i: I. I. K. R. 4 .3. 
therefore no difficulty arises from the want of a contract under the corporate seal, or non-compliance with statutory forms. But it is conceived that no sort of estoppel, part performance, or ratification can hind a corporation to a transaction which the Legislature has in substance forbidden it to undertake, or made it incapable of undertaking. 


\section{CHAPTER III.}

Frorit of Contract.

\section{Formality in Early English Laue.}

Iorlem frinciples: form renpires only for special reatons.
Tus law of contract exists chiefly for the security of men in thej daily bu-ines. conducted in many different modes from hour to hour, and in whatever mode suits the circumstances, by word of mouth nowadays inchding tolephome), writton agrefment, letter, or telegraph. Hardly any linit can be set to the diversity of forms in which men bargain with one another; hut business, in the commercial sense, has this common feature in all it brancher, that it depends on bargain of some kind. Therefore the ('ommon Law does not, as a general rule, require any particular form in contracts, provided that there is a bargain intended to be binding, though in certain canes eridence in writing is required for special rearm- of precaution, or by mercantile custom embodied in the law, and in rome cases formalities are impo-ed for the protection of the revenue. Transactions of bounty, on the wher hand, are not in the ordinary way of business, and if a man wants to bind himself without bargain, or to dispense with proof of a bargain, he must do so with a certain amount of solemnity (reduced, howrere, to a matter of no great trouble or necesaly cont in modern practicejhy expressing his promise in a deed. Arcordingly agreements made for raluable consideration are subject to conditions of form only by way of exception in particular cases, but solemn form is necessaly to make a gratuitom 
promise binding. In some such words as the foregoing the broad principles of our molern law, and the reasoms which make us fairly content with it as it stands, may be stated with tolerable accuracy. But such a statement would be misleading if taken as implying the assertion that the law came to bo what it is by any such logical process. English law started from a gromudwork of archaic Germanic ideas not unlike those of the early Roman law, and quite umelated to the common sense of a modern man of business. Form and ceremony were everything, substance and intention were nothing or almost nothing. Only those transactions were recognized as having legal efficacy which fulfilled certain conditions of form, and could he established by one or other of certain rigidly defined modes of proof. The proof itself was formal and, when once duly made, conchusive. The history of this branch of our law, through the Middle Ages and even later, consists of the transition from the ancient to the motern way of thinking.

Taking English courts and the remodirs they administered as they were about the middle of the thirteenth century (for it is needless to go farther back for our present purpose) (a), we find that what we should call elaborate contracts or covenants, and of sufficiently varied kinds, can be ammexed to grants of land and interests in land, but there is very little independent law of contract, and, if by a law of contract we mean a law which enforce promises as such, it can hardly be said that there is any at all. Still lesis is theme any theory or system of the law. Those who aim at having one must go to the now rising continental seronee of

(a) There was primtinally un secular law of contract before the Torman Conquest. See lollock \& Maitland, IJist. Eng. Law, i. i7. 2nd ed.; " English Law before the

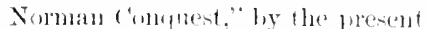
writer. 1. () H. xis. 241. $30 \%$. reprinted as appentix 10 "The Expansion of the ('ommon L.atw." Lonil. 1901. at \%. 15.5
Otherwise in earty law.
Nosystematic rules of contract. 
Roman law, and gather crumbs from the tables of the renowned glossators. Bracton, so far as he has a system, copies Azo of Bologna with variations due partly to misunderstanding and partly to the impossibility of contradicting the actual English practice $(b)$. But the only classification for which the practical English lawyer cares is a classification of forms of action, process, and remedies. Bracton was largely read and used, and was more or less closely followed by the unknown authors of the books called Britton and Fleta, but his Roman or Romanized arrangements of legal topics never acquired any anthority, and produced no effect whatever on the registers of writs or on the technical vocabulary of pleaders. English lawyers would not believe - and on the whole were right in not helievingthat an English charter had anything to do with the Roman rules about the rerbal contract by stipulation, or an appeal of felony with an action under the Lex Aquilia (c).

Archaic modes of jront.

The only moles of proof known to early Germanic law were oath and ordeal. The archaic oath is not a confirmation of testimony open to discussion, but a onesided oath of the party and his helpers. It may be preliminary, for the purpose of giring him a standing before the Court, or final and decisive. One regular form of deciding isones on the Continent, but not in England until it was introduced from Normandy, was trial by battle, not material in the history of this part of the law, but still theoretically possible in an action of debt as late as the time of Henry II. (d). Ordeal, abolished in the thirteenth century, was confined to criminal matters. Prosf hy rriting is ultimately of

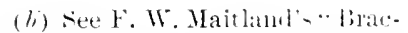
ton and $A z 0$. "selden society. 1695.

(י) "Actio legis Ápuilia de huninibus per feloniam occisis rel vulueratis ": Bracton. 10. $103 \mathrm{~h}$. (d) Cilans. x. 12. 
Roman origin, but was adopted by the Germanic nations of the Continent at an early time. Duel and writing are the two normal modes of proof in the King's Court in the twelfth century $(e)$. The charter or deed of medieval English law was not a continuation of the Anglo-Saxon "book," but a Norman importation, representing the Frankish branch of what we may call Roman conveyancing tradition $(f)$. Now the old Roman formal contract, the stipulation by question and answer, had been practically transformed into a written contract even before the legislation of Justinian ( $g$ ) ; and stipulatio or adstipulatio had long sinee, in Continental conveyancing, become a name for the signing or execution of a written instrument $(h)$.

Thus the charter came to us with all the historical dignity of the most solemn form of obligation linown to Roman law $(i)$; and if this was not enough, its authority was completed by the fact that all proof was formal in Germanic law, and was conclusive when once made in due form. "Proof was what satisfied the law, not what satisfied the Court" $(k)$. A deed was, and, subject to grounds of exception admitted only at a later time, still is binding, not hecause it records this or that kind of transaction, but by the form of the record itself. And, when a promise to pay money was recorded in a

(e) Glauv. x. 17 .

(f) The English charter of feoffment and memorantum of livery of seisin are really the curta and notitia familiar in Continental praetiee as early as the nintl century. As to the history of the wirlential value of writing see Prof. .J. Hl. Wignore in columbia Law liev. jv. 33 s.

(g) Brmmer, \%ar liechlogench. der rönischen mul germanischen Crkmole, 63; Moyle's Justinian. 2nd enl. 498.

(h) lirunner, hïm. «. Germ.
Crkunde, 200 *n\%. For an English example, see Kemble, C. D. No. 623 .

(i) The summary view of the koman classification of contracts formerly given in this chapter was written at a time when Englisl, text-books on lioman law were few and trustwonthy ones fower. It is mow, perhaps. needless, but is preserved in the Apmendix (Note E) in calse it maty be sometintes Use ful for inmediate reference.

(li) Salmond, Essays in Jurisprulence, sc.. p. 16. 
Remedies in I3th century.

Debt on covenant. letit on simple contract, retinue. se.

deed, the action which the promisee could bring was not an action on the promise.

The remedy to recorer money secured by deed was the action of debt, which retained, its essential form and characters through the whole history of common law procedure, so long as the forms of action were preserved at all. This was a writ of right for chattels, an action, not to enforce a promise, but to get something conceived as already belonging to the plaintiff: it was called an action of property as late as the Restoration (l), a conception which lingers even in some of Blackstone's language. A promise, where it was operative at all, operated not hy way of obligation, but as at grant of the sum expressed $(m)$. It was a good defence that the party's seal had been lost and affixerl by a stranger without his knowledge, at least if the owner had given public notice of the loss $(n)$ : but not if it had been misapplied by a person in whose custody it was; for then, it was sail, it was his own fault for not having it in better keeping. An arction of debt $(0)$ might also be brought, without proof by deed, for such things as money lent, or the price of goods sold and delivered, and an action of detinue (which was but a species of debt) for chattels bailed $(p)$, the cause of

(l) The action of ascumpsit was sail by Vaurhan (.l. to be "much inferior and ignobler than the action of debt, which by the hegister is an action of l'roperty " Lilfermb v. Dee. Vaugh. at p. lol.

(iii) Harv. Law her. vi. 349 . contracts of debt are recinrucal grants." Eilgroml) $\therefore$. Ihet. last note.

(ii) Glanvill (L. 10. c. 12) has not even this: Britton. 1, 16t. Ititi. an in the text. "l'ur ceo ge il ad conn le let estre socn en prartie, suir a varde pror le pleynt if: et se purvere autre foiz le defentaunt te meillow gardeyn." Cp. Fleta, 1. 6. с. 33. $\$ 2$; c. 34 . 4 . That the practice of publishing formal notice in casc of lis really exinted is shown by the example giren in Blount: Law lictionarr, s. v. Figillum. dated Is live. 11. In modern law such ques. tions. when they occur. come under the hear of estopnel.

(1) For fuller statement see P'ollock it Maitland, Hist. Eng. L.. ii. 210.

11) For the precise difference in the leveluged forms of plearling see per Maule J. 15 (. B. 303. The decision of the C.A. in Bryant r.

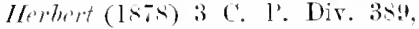
17 L.J. C. I'. 670, that an action fur wrongulul detention is " founded on tort "within the meaning of the Counts Court Acts is, and professes to be. beside the historical question, 
action being still not any promise by the defendant but his possession of the plaintiff's money (so it was conceived) or goods. 'The first thing needful to found the action of debt was, as it still is in jurisdictions where the old forms of action persist, that a certain sum of money should be payable by the defendant to the plaintiff. In debt and detinue the text-writer's could profess to recognize the Roman contractus innominati (do ut des, \&c.) which Bracton, carrying out the medieval notion that a promise to pay or deliver is a grant immediate in execution and only suspended in operation, put under the head, strange to us nowallays, of conditional grants $(q)$. In the course of the next two centuries we find it quite clear that an action of debt, provided the sum be liquidated, will lie (as we should now say) on any consideration executed, and also that on a contract for the sale of either gools or land an action may be maintained for the price before the goods are delivered or seisin given of the land $(r)$. In 1294 it was said that money paid as the price of land might be recovered back in debt if the seller would not enfeoff the buyer pursuant to his corenant $(s)$.

Other remedies applicable to contracts were of limited curenant. scope and utility. The action of covenant, of which we do not hear before the thirteenth century, was groundeci on agreement, comentio, both in form and in fact, but it was practically confined to agreements relating to interests in land. Attempts at extending it were cut

(q) Bracton 18, 1:1, Fleta 1.2. c. (ii). $\$ 23$. In Bractom fo. 19 an lines 14, 15, in ed. 1.569, si (the secontl). possunt and ut repeters pussim are corrupt. 'The true reatings, conjecturally restored long agiby (iiitirlbock, and in fact given ahuest irkentically by the beat Misi.. are sed... possum . . notl possim.

(i) Y. 13. 1: lial. 111, (livils at.) $5 \times 7[$ A.1). l:338]; Mich. 37 Jt. VI.
[A.1). 1159], \&. pl. 18, ly l'risut C.J., whare it is arfoed that in the case of gends sukl. though not of land, the buyer may take the goods: this follows from the theory of "reciprocal st:int."

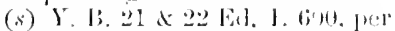
Metingham. The principal action was appatrently al quite regular antion of thet on covenant the

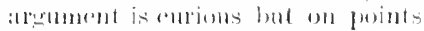
wateile the present subiject. 
short by the establishment, after some vacillation, of the rule that writing under seal was the only admissible proof; so that in the modern common law corenant is the proper name of a promise made by deed. The writ of covenant remained a solitary and barren form of action, without influence on the later development of the law $(t)$.

Account. The action of account (u) was a remedy of wider application (sometimes exclusively, sometimes concurrently with debt) to enforce claims of the kind which in modern times have been the subject of actions of assumpsit for money had and received or the like. It covered apparently all sorts of cases where money had been paid on condition or to be dealt with in some way prescribed by the person paying it $(x)$. One must not be misled by the statement that "no man shall be charged in account but as guardian in socage, bailiff or receiver" $(y)$ : for it is alco said "a man shall have a writ of account against one as bailiff or receirer where he was not his bailiff or receiver: for if a man receive money for my use I shall have an account against him as receiver; or if a man deliver money unto another to deliver over unto me, I shall have an account against him as my receiver " $(z)$. This action might be brought by one partner against another $(a)$. At common law it could not be brought by executors, except, it seems, in the case of merchants, nor against them unless at the suit of the Crown $(b)$ : but it was made applicable both for and against executors by rarious statutes to which

(t) See J'ollock it IIaitiand. ii. 216. Harv. Law her. vi. 39!-401. The statutmu Walline [A.L. I2st] is the most instrutire dienment. The suggestion in Blackstone. Comm. iii. IRs, that Assumpsit is an action on the case analogons to the writ of corenant, is quite unhistorical. though ingenious.

(ii) 32 Hen. Ill, (Ntat. Marlb.) c. 17. 13 Ed. I. (stat. Westm."2) c. 23.3. For more history and details see langlell in Harr. Law liev. ii. 243.251.

(r) Sue cares in 1 Rol. Abr. 116. (y) 11 Cu. Rep. s!!. Co. Litt. $172 a$.

(z) F. N. B. 116 Q.

(i) $17.117 \mathrm{D}$. Langlell disputes this. but Fitzherbert is clear and express on the point.

(7) Co. Litt. 90 b, and see Earl of Derondires ase. 11 Rep. s!. 
it is needless to refer particularly $(c)$. In modern times this action was obsolete except as between tenants in common $(d)$. Like the action of debt, it was in the nature of a writ of right, and founded not on a promise, but on the duty - in this case not of paying a sum certain but of rendering an account-attached by law to the defendant's receipt of the plaintiff's money.

On informal executory agreements there was in general no remedy in the King's Conrts (e). The' Ecclesiastical Courts, however, enforced them freely in suits pro laesione fidei, within (and sometimes, it would seem, not within) $(f)$ the limits set by the Constitutions of Clarendon, and defined later by the ordinance or socalled statute of Circumspecte agatis. Executory mercantile contracts were also recognized in the special courts which administered the law merchant. But we cannot here attempt to throw any light on that which Lord Blackburn found to be one of the obscurest pas-

Wien no remerly at conmon law. sages in the history of the English law (g). We read of exceptions by local custom in London and Bristol, but one may guess that the allegation of such customs was only a device to bring the rules of the law merchant within the jurisdiction of the King's Court $(h)$.

(c) The action is given against executors by $4 \mathrm{~d} ;$ Ann. c. 3 (liev. stat. 4 Ann. c. 16 in Riuffhead) s. 27.

(d) See Lindley on Partnership, 547 . note 0 .

(p) see further Anes, "larol Contracts prior to Assmmpsit." Jarv. Jaw Rev. viii. 252. repr. lissays in Inglu-Anuer. leenal History iii. 3011.

(f) Harv. Law liev. vi. to:3 : l'ollock \& Maitlaml, ll. E. I. ii. 200. Neither the authority nos the actual text of rimmonserte ayutis is certaits. Fee the remarlis of two jurlges in 5. P. Itt Jill. III.. ed. P'ike, 1906;: - - //illary: That is not a statute sealeal. il illow!hloy:
No, the Prelates mate it themselves."

(1) Blackbutn on the Contract of sake, 207-20s. In aclition to the quotation there from the Yeal Book of Erl. $1 T^{\prime}$. we Y. B. $21 \& 22$ El. I .. 1. 1.58. And see Master Macelonell's introbuetion to smoth's Mereantile latw, loth ed. Is!n: A. T. Carter, The Early llistory of the Laty Merchant in England, I. (2. Ii. xvii. 232. repr. in his History of Enolish I, eal Institu-

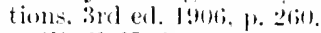

(h) F. N. I3. 146 a. Liber Albus

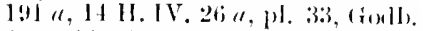

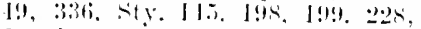
latch. I:34. I I (2). 2. I Jen. [11.5. 
Liter intrin. luction of assumpsit.

\section{The Action of Assumpsit.}

In the later mirlde ages a general remedy hecame indispensable; hut it was introduced from a different branch of the law, and by a device which at first was thought too bold to succeed. This was a new variety of action on the case, framerl, it seems, as often on the writ of deceit $(i)$ as on that of trespass, and it ultimately became the faniliar action of assumpsit and the ordinary way of enforcing simple contracts. Failure to perform one's agreements did not create a debt $(j)$, but it was found to be at wrong in the nature of deceit for which there must be a remedy in damages. The final prevalence of assmmpsit orel debt, like that of trover over detinue $(k)$, was much aided hy the defendant not being able to wage his law and hy the greater simplicity and latitude of the plearlings: but the reason of its original introduction was to supply a remedy where no other action would lie. This was not effected without dispute and dissent. In the first recorded case (l), the action was against a carpenter for having failed to build certain houses as he had contracted to do. The writ ran thus: "Quare cum idem [the defendant] ad quasdam domos ipsius Laurentii [the plaintiff] bene et fideliter infra certum tempus de novo construend' apud

(i) "The breach of promise is atlecred to be mixed with fraul and deceit to the suecial prejudice of the phaintiff. aul for that reasm it is called trespiass on the case" :

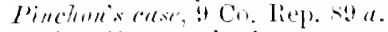

(.j) "No man hath property hy a bieath of flumine. but muni be reparierl in clamages" : Vaughan C.I. in Edgeomls ve. Dre, Vaughan al 1. 101.

(k) See per Martin B. Bur. reughes v. Payme (1seri) 5 H. \& X. at 1. 301, 29 L. J. Ex. 188.

(l) Mielı. 2 H. IV.. 3 h. 11. ؛. The full and careful historical his. cusion of the whole subject by the late Prof. Ames of Harvard in Har'v. Law lies. ii. 1. 33, supursedes all previons researches. Actions of trespasis on the case had previously heen allowed for malfeasance by the negligent performanee of contracts (tor winich it is still belel that there is an alternatire remedy in contract and in tort), but an attion for mere non-feasanee was a novelty. An excellent eontinu,u- narrative is now given by Dr. Holdsworth. Hist. Eng. Law, iii. $329-349$. 
Grimesby assumpsisset, praedictus tamen 'T'. domos ipsius L. infra tempus praedictum, \&c., construere non curavit ad dampnum ipsius Laurentii decem libr', \&c." The report proceeds to this effect:-

"Tirwit.-Sir, you see well that his count is on a covenant, and he shows no such thing: judgment.

Gascoigne.-Seeing that you answer nothing, we ask judgment and pray for our damages.

Tirwit.-This is covenant or nothing (eeo est merement un covenant).

Brenchesley J.-It is so: perhaps it would have boen otherwise had it been averred that the work was begun and then by negligence left unfinisherl.

(Hankford J. observed that an action on the Statute of Labourers might meet the case.)

Rickhill J.-For that you have counted on a covenant and show none, take nothing by your writ but be in mercy."

The word fideliter in the writ is significant. It seems to denote a deliberate competition with the jurisdiction of the Courts Christian in matters of fidci luesio. We will show you, the pleader says in effect, that the King's judges too know what belongs to good faith, and will not let breach of faith go without a romedy. It may also have been intended to show that there was a bargain and mutual trust $(m)$.

This adverse decision was followed by at least one like it $(n)$, but early in the reign of Henry VI. an action was brought against one Watkins for failure to build a mill within the time for which he had promised it, and two out of three judges (Babington C.J. and Cockaine .l.) were decidedly in liaverr of the action being maintainable and called on the defendantis

(iii) Morlent pleading would reguire, of comrse, a much more distinct averment of consicleralion: but the doctrine wats lont yod

\section{firmest.}

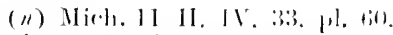
And sere diggelow L.e'. an Torts. ist. 
counsel to plead over to the merits (o). Martin J. dissented, insisting that an action of trespass would not lie for a mere non-feasance: a difficulty by no means frirolous in itself. "If this action is to be maintained on this matter"," he said, "one shall have an action of trespass on every agreement that is broken in the world." This, however, was the very thing songht, and so it came to pass in the two following reigns, when the general application of the action of assumpsit was well established. But only in 1596 was it conclusirely decided that assumpsit was atmissible at the plaintiff: choice where debt would al-o lie $(p)$. The fiction of the action being founded on a tort was abolished by the Common Law Procedure Act.

Meanwhile the relation between the parties which was assumed as the foundation of the duty riolated by the defendant, and which involved the plaintiff's having in some way changed his position for the worse on the faith of the defendant's undertaking $(q)$, was transformed into the modern doctrine of Consideration, coalescing on the way, in fact if not in strict theory, with the existing requirements of the actions of debt and account. Of this we shall speak separately.

Fivle that deeds may not be written on wood, se.

It is stated in sereral books of authority (e.g. Shepp. Touchst. 54) that a deed must be written on parchment or paper, not on rood, \&c. This seems to refer to the then common use of woorlen tallies as records of contracts. Fitzherbert in fact says $(r)$ that if such a tally

(1) Hil. 3 H. YT. 3i, pl. 38. There is some doubt as to the date uf this case, see 1. (?. R. xxiv. 384. Notwithstanding the favourable riew taken by several jutgen

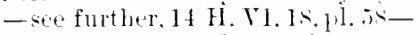
the puint remaines ofen for many rears. see $1: 4$ H. V1. H: pl. i.

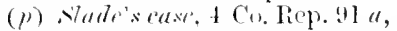
in Ex. Ch. It was still later before it was admitted that the sub-tantial cause of action in assump- sit was the contract. O. W. Holmes. The Commun Law. 2842x- For the earliel history see Ames. Harv. Law lier. ii. 16, and Holdsworth, ub. sup.

(1) ". In all these cases there is an unlertaking and matter of faet licyond that which sounds in eovenant " : Fewton in 14 H. VI. 1..

(r) F. N. F. 122 I. 
is sealed and delivered by the party it will not be a deed ; and the Year Books afford evidence of attempts to rely on sealed tallies as equivalent to deeds; and it appears that by the custom of London they were so $(s)$. These tallies were no doubt written upon as well as notched, so that nothing could be laid hold of to refuse them the description of deeds but the fact of their being wooden : the writing is expressly mentioned in one case $(t)$, and the Exchequer tallies used till within recent times were likewise written upon (u).

\section{Modern requirements of form.}

We have seen how in the ancient view no contract was good (as indeed no act in the law was) unless it brought itself within some favomed class by satisfying particular conditions of form, or of evilence, or hoth. The modern view to which the law of England has now long come round is the reverse, namely that no contract need be in any particular form unless it helongs to some class in which a particular form is specially required.

(x) "Tn taille r. rette enseale par usige de la citec est auxi fort come une obligarom" : Libe" Albus $191 a$.

(t) Trin. 12 11. 15. 23, p]. 3. The other eitations we hro heen able to verify are l'asch. 25 El. III. 83 (wrongly referred to as 40 in the last ease and in the marcin of Fitzh.). pl. 9, where the repriter notes it is said to be otherwise in london: and Trin. 44 E\&. H1. 21, 1). 23. For a rase where the ('omt was favourable to a merchant's tally see Mirllesex lter. 2:2 Ell. 1. 1., 8 .

(u) See acrount of them in l'enuy C'yelopaclia, s. v. Tally: IIall. Ant iquit ies of lose Exchequere, $118 . x / \%$. The French (art. 1333:3) ant llalian (art. l:3:3) ('ivil ('oles expresily achmit tallies as evielence between tratlers who keep their accomots in this way ; nor is lhe use of them mnknown at this al in Englaud. Iis the contesy of Mr. J. I, Mathews, of the Mirile Temple, formerly of Worcester, I lave a specimen of the taltics with whieh the hop-prickers in Herefordshire still keep' aceount of the yuantities pieked. They were neel in the Kentish hop country within living memony, and in ITampshire not very long ane and I am informel that they are still known in co. Galway. I have seen them. in a rongher form, in use in a village baker's shop in Normandy. Sipecimens of English tallies both aneient and revent may be seen in the melieval poun of ile: liritish Musenm, and at the

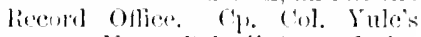
moteon Mareo l'olo, ii. 7s, 2maled. ; and sayings of Jaio-tial (tr. L. (ijles, "Wisdom of the East" s(ries), 1). 2!).
Reyuiremeints of firm now treated as the rxception. 
Contracts of Recort.
Contracts subject to speeial forms.
Before we say anything of these classes it must be mentioned that contracts under seal are not the only formal contracts known to English law. There are certain so-called "contracts of record" which are of a yet higher nature than contracts by deed. The judgment of a Court of Record is treated for some purposes as a contract: and a recognizance, i.e., "a writing obligatory acknowledged before a judge or other officer having anthority for that purpose and emrolled in a Court of Record," is strictly and properly a contract entered into with the Crown in its judicial capacity. The statutory forms of security known as statutes merchant, statutes staple, and recognizances in the nature of a statute staple, were likewise of recurl. but they have long since fallen out of use $(x)$.

The kinds of contract subject to restrictions of form are these:

(1). At common law, the contracts of corporations. The rule that such contracts must in general be under seal is earlier than the time when the modem doctrine of contracts was formed. Of late years great encroachments have been made upon it, which have hardly reached their final limits; the law is still mosettled on some points, and demands careful consideration. Both the historical and the practical reason lead us to give this topic the first place.

(2). Partly by the law merchant (now codified in many jurisdictions) and partly by statute, the peculiar enntracts expressed in negotiable instruments.

(a) As to cuntracts of Riecorrl, see Anson, 1. 6i2, 11th ed, and for

all acount of statutes merehant, Ne. $211 \mathrm{~ms}$. Fund. 216-222. 
(3). By statute only-

A. The various contracts within the statute of

Frauds. C'ertain sales and dispositions of property are regulated by other sitatutes, but mostly as transfers of ownership or of rights good against third persons rather tham as agrements between the partics.

B. Marine insurances.

C. Transfer of shares in companies (g+merally).

D. Acknowledgment of rehts barred by the Statute of Limitation of .tames $\mathrm{I}$.

E. Marriage: This, although we do not mean to enter on the subject of the Marriage Acts, must be mentioned here to complete the list.

1. As to contracts of corporations.

The doctrine of the common law was that corpurations could bind themselves only under their common seal, except in small matters of daily occurrence, as the appointment of household servants and the like (y). The principle of these exeeptions being, in the words of the Court of Exchequel" ('hamber, " "omvenience amounting almost to necessity " (z), the rast increato in the extent, importance, and rariety of corpmate dealings which has taken place in modern times has led to a corresponding increase of the exceptions. Before comsidering these, howerer, it is woll to cite an applored judicial statement of the rule, and of the passoms that may be given for it:-

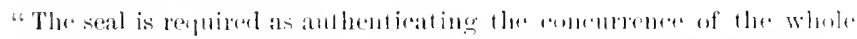

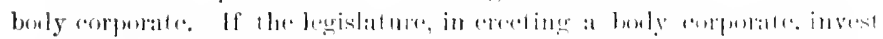

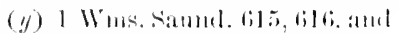
sees old atuthoritime endlectorl in

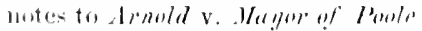
$(18+2)+11.8$ (ir. sito $121 . .1$.

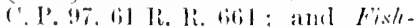

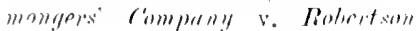

Cinporatims.

(1) let rule: Seal generally reguired.

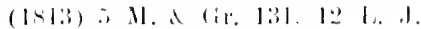

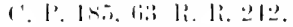

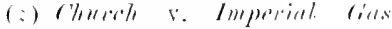

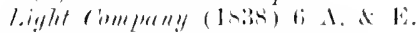

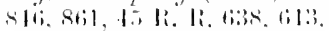


any member of it. either expressly or impliedly, with authority to bind the whole body by his mere signature or otherwise, then undonbtedly the adding a seal wonld be matter purely of form and not of substance. Everyon becoming a member of such a corporation knows that he is liable to be bound in his corporate character by such an act; and persons dealing with the enrontion know that by such an act the body will be hound. But in other eases the sual is the only anthentic evidence of what the enpuration has done or agreed to do. The resolution of a meeting. however munerously attemled, is, after all, not the act of the whole boly. Every member knows he is bound by what is done noder the comporate seal and by nothing else. It is a great mistake, therefore, to speak of the necessity for a seal as a relic of ignurant times. It is no such thing: either a seal or some snbstitute for a seal. which by law shall be taken as conclusively evinlencing the serse of a whole lonly eorporate, is a necessity inherent in the very nature of a corpuration "(o).

It is, no doubt, a matter of "inherent necessity " that when a natural person acts for a corporation, his authority must be shown in some way ; and the common seal in the agent's custoly, when an act in the law purports to be the act of the corporation itself, or his authority under seal, when it purports to be the act of an agent for the corporation, is in English law the recognized evidence for that purpose. But there is no reason in the nature of things why his authority should not he manifested in other ways: nor is the seal of itself conclusive, for an instrument to which it is in fact affixed without anthority is not binding on the corporation (b). On the other hand, although it is ustal and desirable for the deed of a corporation to be sealed with its proper corporate seal, it is lain down by high authorities that any seal will do (c). A company under the

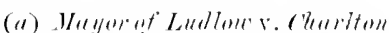

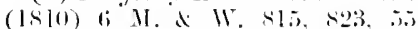
li. 1i. 794 arloptod hy lollock B. in Horner of Kidileminster r.

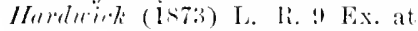
1. 21, 13 1. 1. kx. 4: ank see per Keating l. lustin v. (rumbdians of bethmel limen ( Ist t) I. Li.

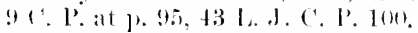

(b) Bamk of Ireland v. Eimms (learities (1855) \& H. I. r. 389. la1 R. li. 21s.

(r) 10 ro. Rep. 30 b. Nhepl'. Tonehst. 5i. Fet the rule is dombted, (irant on (onl). is, lout moly on the gromel al eomvenience and withont any anthority. The like rnle as to sealing ly an indiviclual is quite cloar and at least as old as Bractom: Non multum refert ntrum [carta] proprio vel alieno sigillosit sigmata, cum semel 
Companies Act, must have its name engraved in legible characters on its seal, and any director, sc., using as the seal of the company any seal on which the name is not so engraved is subject to a penalty of $50 l .(d)$ : but this would not, it is conceived, prerent instruments so executed from binding the company $(e)$. The seal of a building society incorporated under the Building Societies Act, 1847 (37 \& 38 Vict. c. 4.2, s. 16, sub-s. 10), "shall in all cases bear the registered name. thereof," "but no penalty or other consequence is annexed to the non-observance of this direction.

We now turn to the exceptions. According to the modern anthorities it is established that the " principle of convenience amounting almost to necessity" will cover all contracts which ean fairly be treated as necessary and incidental to the purposes for which the cor poration exists: and that in the case of a trading cor poration all contracts made in the orlinary course of its business or for purposes connected therewith fall within this description. The same or even a wider conclusion was much earlier arrived at in the United States. As long ago as 1813 the law was thus stated by tho Supreme Court:-

"It would seem to be a sombl rule of law that wherever a corporation is aeting within the scope of the legit imate purposes of its institution all parole contracts made by its aurhorized ayents are express promises of the corporation, and all duties impused on them by law, and all benetits

a tonatore coram tentihs ant line rocat is recognita et concessa fuerit, fo. 38 a. (\%) Britton. 1. 2.\%.

(d) Consolidation Act. I9ms, s. $63,(1) b,(3)=1862$, , s. 41,12 .

(c) Notwithstanding the statutory penalty. there is a reported instance of the private seal of at director being uxed when the company hat been so recently formod that there had been no time to make a proper seal, fromy r. Lomis

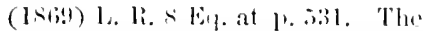
like direction and penalty are contained in the Industrial and Provident societies Act, 189:3, s. biti (repeating an earlier enatetnent). As we cecention of deedsabroul by companies muler the Aets of 1stiz and 1867 , sere the companies (com-

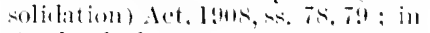
siontlant. the cinveyoureing (siont-

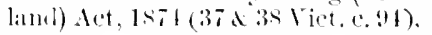
s. iit.
Volern exceptions. limin of columbia $r$. Patterson (sippreme (imut. V.s.). 
Distinctions in England.

Tratling entporations: Contracts in conrse of business do not want s.al.

$\therefore$ of Irehanel (inliery Co. $r$ Warlile.

conferrent at their rerpent. raise implien promises for the enforcement of which an action may well lie $"\left(f^{*}\right)$.

In England this rule camnot be so broadly laid down, as there is still a distinction hetween trading corporations and corporations created for any other purpose. As to the latter class there was at serions conflict of decisions until a few years ago.

As concerns trading corporations the law was settled by the unanimous decisions of the Court of Common Pleas and of the Exchequer ('hamber in South of Ireland Colliery Co. r. Wrddle (y). The action was brought by the company against an engineer for nondelivery of pumping machinery, there being no contract under seal. Bovill ('.l. said in the Cont below that it was imposibibe to reconcile all the decicions on the subject: hut the exceptions creater by the recent cases were too firmly establisher to be questioned by the earlier decisions, which if inconsistent with them must be held not to be law:-

-. These axceptioms aplly th all contrach hy trading corporations enteres into for the purpone for which they are incorporated. A comprany ean whly earry on busines by azents,-managers and others: and if the contracts mate by the persos are entraets which relate to

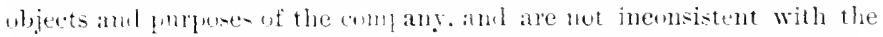

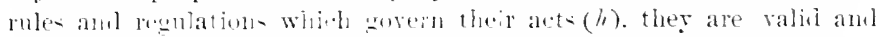

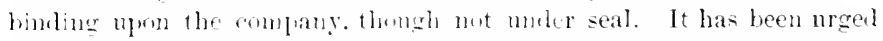
that the excenting to the cret eral rule are still limited to matters of frefuent accurrence and -mall impurtance. The authorities, however, to not instain the argument."

The decision was affirmed on appeal without hearing counsel for the plaintiffs, and Cockhurn C..J. said the

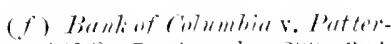

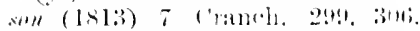
It is alon hell by thr. Anerie:aur antheritien that the alpwintencut hy a eorjuration of an agent.

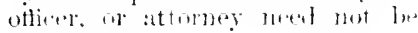
mmler seal.

(f) (Intis) I. IR. 3 ('. I'. 16is, in

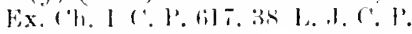

:33. Shent if mot all of the previons anthoritice are llere referreel to.

(h) Thi yualitication is itsell" subjed to the rule established by

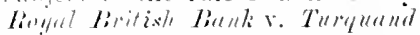

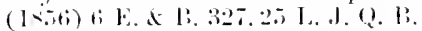
:it. lus Li. R. tiz, and similar cases. anl mentioned at f. lis above. For details see Sote D. in Appendix. 


\section{defendant was inviting the Count to reintroduce a relic of barbarouts antiquity $(i)$.}

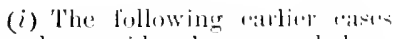
may be comsiclered ats oserruleat :East Lomdon It Iterworlis v. Builey (1827) 4 Bing. 28.3. Aetion for non-rlelivery if iron pipes ordereal for the comprany's worlis. 'The directors were anthorized by the incorporating Act of Parliament to make eontracts : but it was held that this only meint they might affix the seal without calling a meeting. Siee 1. R. 3 ('. l'. t75.

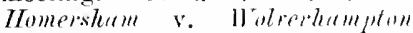
Waterworks ('u. (18.i1) ; ix. 1:37. 20 L. J. Ex. 193. Contract unler seal for erection of machinery: price of extra work dome witl approval of the eompany sengincer and aceepted, but not within the terms of the sealed contract, helkl not recoverable. Diggles. Lomdan \&. Blackwall liy. (\%). (1850) is lix. 442, J9 L. J. Ex. 308 . Work rloue on railway in alterations of permanent way ale. Finlaly v. liristol

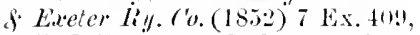
21 L.J. Ex. 117 , S61R. Ji. 701, where it was held that against a corporation temancy comlil in no ease be inferred from payment of rent so as to admit of an aletion for use and ocenpation witlont actual occupar. tion. London Dock C'o. v. Sinmott (18.77) \& E. \& B. $347,-17$ L. . I. Q. B. 129, II2 R. Li. 5!)?, where a contract for seavenging the antupany"s ducks for a year was helel to lequire the seal, as not heing of a mercantile natme nor with a castomer of the company, "ill now be of little or no authority beyoum its own special circumstances: see yer Bovill C... I. It. :3 ('. J. 171 .

'lie followinger atses are atlintued or not contrulieted. sime ol' them were rlecirler at the time on narrower or more particular grounds, and in anc or two the trading character of the corpen:ation secms immatcrial :- Brierley v. Limonln lios ('o. (1837) 6 A. A E. \$2!, 4.; R. Ji. 6i:li. Motim against the company for price of

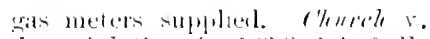

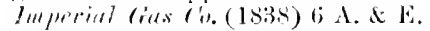
sti. 4i, li. li. 138 in lix. cli. Action by the company for breach of contract to accejt gras. A sulposel distinction between the liability of corporations on execonted and on executory contracts was exploted. Fapper Mine's at Emyland ง. Fox (1851) 16 (2. 13. 2.2!, 20i L.J. (?. 13. 17t. 8; K. li. 4.3!. Action (in effect) for nom-aceeptance of iron rails ordereal from the comspally. The comprany hat in fact for many years given "l, enpler mining imil trated in irom but this was not within the seople of its incorporation. Laner r. L. \& I. II. Ry. (․ (18.52) 1 R Q. R. 6.32, 21 L. J. Q. li. 361 . se Ji. R. 726 . The company was held liable in an aetion for use and oceuption when there hial been an actual occupation for corpolate purposes, party on the gromel that a parol contratet for the recupation was within the statutory powers of the directors and might be puresuned : cy. the next ease. Punlimy v. L. \& N. II. Ry. CH. (1,53) \& Ex. 867,23 L. J. Ex. 105,91 Ii. K. s07. sleepers supplied to an orter from the engineer's office and accepted : thele was no cloubt that the contract conld moler the companies Clauses Consulitation Act be male ly the directors withont seal, and it was hold that the aleceptames? and use were evirlence of an actual contract. Heudersom v. Llustraliat"

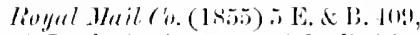

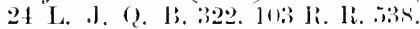
Action an ilereement to pay lor bringing lome whe of the commpany's ships trom syeluey. Ins-

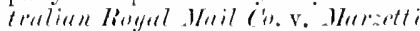
(15is) 1] lix. 228, 21 I. J. Wx. 273. Action by the emmbany on agreement to supply povisions lot its phosenger ships. litute'

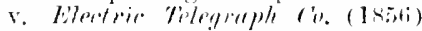

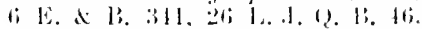
low li, li, liz: : where the chief 
Son-trating emporations. - Necessary ausl incisleintal " contracts.

\section{As concerns non-trading corporations, the modern} rule is "that where work is done or services rendered at the request of the corporation in respect of matters for the doing of which it was created, and the benefit of the work or services is accepted by the corporation, so that a contract to pay would be implied in the case of a private person, a similar implication should be made in the case of a corporation " $(k)$. So it has been laid down in the Court of Appeal, confirming earlier but not uncontradicted authority to the like effect $(l)$. There still does not seem to be any authority for holding a non-

wint was as to the ratification by the directors of a contract male originally with the chairman alone, who certainly had no anthority to make it. Ebbre Trale Compriny's arse (1srig) 1. Ii. \& Er. 14, decides that come who selk to a company grools of the kind useer in its business need not ascertain that the company means so to ne them, and is not prevented from enforcing the contract even if he had notice of an intention to nee them otherwise.

(h) Lamiond v. Lithericay Limral

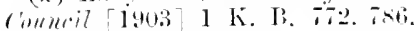
vel Hathew L...

(l) Sumders v. St. Wents Tuimull $(1+4 i)=12$. B. 810,$1 ;$ l. J. I. C. lit. 71 R. li. litis. lron gates for workhonse supplied to orier withont seal and accepted. Prim' v. strand Union (1sfii) o (2. 1). 32ti. 1.) I. J. II. C. 84. 71) I. I. . in. is really the same way. thongh at first sight conlow: the decision being on the groumel that making a plan for latimy parposes of alle merish within the unim was mot incilental to the purposes for which the suardians of the mirnt were incorporated: they hat nothing to lo with either inaking or collecting rates in the sereral parishes. nor had they power to aet as a corporation in matters contined to any fartionlar parish. rlurlae r. ruckitield l nion (15.52)
21 I. J. Q. B. 349,91 R. R. s!l (in the Bail Court, by Wightman J.). Builders work done in the workhouse. The former cases are reviewed. Huigh v. Sorth Bispley Inion (185\%) E. B. \& E. s. 3,28 L. J. Q. B. 62. An accountant employed to investiate the accounts of the union was lield entitler to recover for his work as "incidental and necessary to the prrposes for which the colporation was created." by Erle J., Cromptun J. loubting. Vichel.

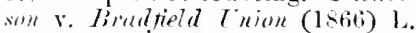
li. 1 Q. I. $420,3 . ;$ L. J. Q. B. 176 . In direct opposition to the foregoing was Lamprell v. Billericay I niun (1849) 3 Ex. 283.18 L. J. Ex. 282. Building contract nnder seal. proviling for extra works on written directions of the architect. Extra work done and accepter. but without such rirection. Held, action would not lie. This appears to be now orerruled. Ilunt $\mathrm{s}$. llimbledun Lenel Boum (1858) 4 C. P. Div. 4. to L. J. C. P. 207. Whether the preparation of plans for new ottices for an incorporated local board. which plans were not acterl on. is work incidental and necestary to the purposes of the boarl. yutfe. The actual decision was w the ground that contracts above the ralue of $50 l$. were imperatively required by statute to be under seal. 
trading corporation liable on a parol agreement not yet executed by the promisee.

With regard to municipal corporations (and it is presumed other corporations not created for definite public purposes) the ancient rule seems to be still in force to a great extent. An action will not lie for work done on local improvements $(m)$, or on an agreement for the purchase of tolls by auction $(n)$, or for the grant of a lease of corporate property $(o)$, without an agreement under seal. Where a municipal corporation owns a graving dock, a contract to let a ship have the use of it need not be under the corporate seal; but this was said to fall within the ancient exception of convenience resting on the frequency or urgency of the transaction. The admission of a ship into the rlock is a matter of frequent and ordinary oceurence and sometimes of urgency $(p)$.

There has also been little disposition to relax the rule in the case of appointments to offices, and it seems at present that such an appointment, if the office is of any importance, must be under the corporate seal to give the holder a right of action for his salary or other remuneration. This appears by the following instances :-

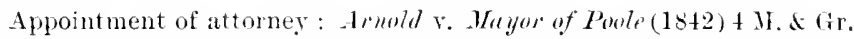
sive, 12 I. J. C. I. 97, ij L. I. vitit. It is true that the Corporation of Lundon appoints an attorney in conrt withont deerl, but that is becanse it is a matter of record: see 4 M. N (ir. $14.882,896$. But after an attorney has appeared and acted for a corpunt jon the corporation camnot, as aguinst the other party th the action, thisute his authority on this ground : Farioll

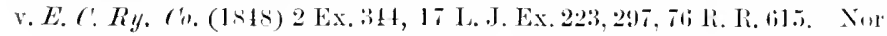
ean the otleer party dingute it after taking steps in the action: Thames

(Iii) Mayor of Lumlum r. Glureltom (1840) is 11. \& 11 . Als. si) li. R. Tit.

(1i) Mryor of Kiddtrminster $\mathrm{r}$.

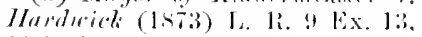
4:3 1. .1. . E. .9.

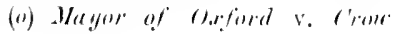

II unicipal

Corporations, de. Olil ruke in force, semble.
Appoint ments to offices by corporations.
[1.93] 3 Ch. 335, where the corporation songht to enforce the agreement.

(1) Wolls v. Kingston-upon-IIull (1875) L. L. 10 ('. I'. 4112. 4 L.. J. (1. 1.2.7. 


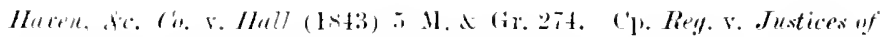

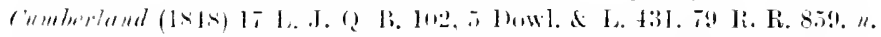

(ilant re militaly pen-ind by the East India Compray in its political

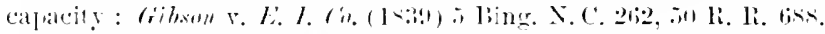

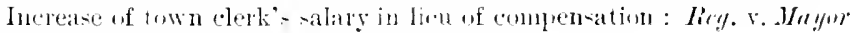

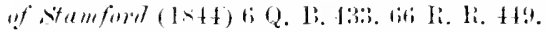

Othee with profit annexel (coal meter fatid by dues) though held at the pleasure of the corporation: Simith r. Corturight (1851) 6 Ex. 927, 20 L. J. Ex. 411. (The action was mot against the corporation. but against the person by whom the dues were alleged to be payable. The "lainu was alsi, wrong on anotler ground.)

Collector of poor rates: Simart s. West Hum Chim (185i) lo Ex. $86 \overline{7}$, 24 L. J. Ex. 201 ; but [rartly on the gronul that the guarlians harl not metertaken to fay at all. the salary buing charged on the rates : and wholly on that gromul in Ex. Ch.. 11 lix. atid. 25 I. J. Ex. 210.105 R. R. 834.

r'lerls to manter of worlshouse: Lustin v. Comardians of Bethnal Green

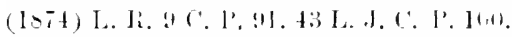

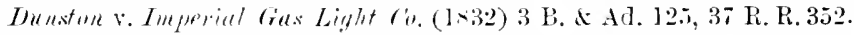
as to directors' fec- rotel by a meeting; but chiefly on the ground that the feen were nerer inteuded to be mire than a gratuity.

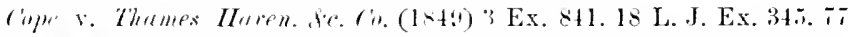
I. I!. 4.59: agent appointed for a special negotiation with another company not allowed to reeorel for hi- work. the contract not being under seal nor in the statutory form, rin, signel by thee directors in pursuance of at revolution. although by anther setion of tue special det the directors hat full power to .. alfoint atd displace. . . all such managers. officers, ngent, . . as they shall think proper." It seems difficult to supint the decion : this was not like an appointment to a continuing

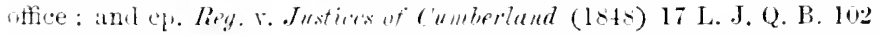
5 Lowl. \& 1. 431. Ft R. I. 8.59, ".. where under very similar enabling worls an appoiutment of an attorney by directors without seal was hell groul as against third partite.

To, pultity to enforce informal agreement acratint corlutatiun.

Right of corporations to $\rightarrow 1$ e on contracts exponted.

It has been decided (as indeed it is obrious in prin(iple) that inability to enforce an agreement with a corporation at law hy reason of its not being under the corporate seal does not create any jurisdiction to enforce it in equity $(q)$.

The rights of corporations to sue upon contracts are somewhat more extensive than their liabilities. When the corporation has performed its own part of the con-

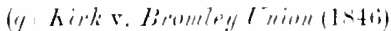

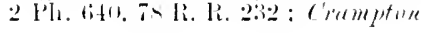

r. Jarme Ry. re. (1872) 1.. R. i Ch. 5ti2. tl h. J. ('h. 817 . 
tract so that the other party has had the benefit of it, the corporation may sue on the contract though not originally bound $(r)$. For this reason, if possession is given under a demise from a corporation which is invalid for want of the corporate seal, and rent Tenancy and occupation. paid and accepted, this will constitute a good yearly tenancy $(s)$ and will enable the corporation to enforce any term of the agreement which is applicable to such a tenancy $(t)$, and a tenant who has occupied and enjoyed corporate lands without any deed may be sued for use and oceupation (u). Conversely the presumption of a demise from year to year from payment and acceptance of rent is the same against a corporation as against an individual landlord: "where the corporation have acted as upon an executed contract, it is to be presumed against them that everything has been done that was necessary to make it a binding contract upon both parties, they having had all the advantage they would have had if the contract had been regularly made" $(x)$. And a person by whose permission a corporation has occupied lands may sue the corporation for use and occupation (y). In the case of a yearly tenancy the presumption is of an actual contract, but the liability for use and oceupation is rather quasi ex contractu $(z)$. It is settled that in general a callsc of action

Corporations liable on ruasicontracts generally.

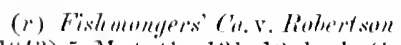
(1843) $5 \mathrm{MI}$. d ir. 131, 12 1... C. P. 185. The jutgment on this point is at $1 \%$. $192-6$; but the dictum contained in the passage " Evinn if . . . against themselves." 19. 192-3) (extending the right to sne withut limil.) is now overruled. See bleyou of hidderminster $\therefore$. Hardwirk (1873) L. R. !) Ex. 13, 21,13 L. J. Ex. 9.

(s) Houd v. Thite (1806i) 2 Bos. $\mathrm{d}$ P. N. R. 247, ! R. R. 615.

(t) Eichess. Commers. v. Jerral (1869) 1. R. I Ex. 162, 38 1... lex. 93. liy kelly o.f. lhis is correlative to the tonant s right to

P. enforce the agreement in equity on the grouns of part performance, sed qu.

(u) 11 aym of staftord v. Till $(1 \times 27)$ \& Bing. 75,29 R. R. 5ll. The like as to tolls. Mha!y" af (atrmarfle'te v. Lew is (1831) 6 C A P. bos, but see Sorj. Mamning's note, 2 M. A (ir. 2.19.

(.r) Dne d. Pénnington v. Taniere (1+4k) 12 Q. B. 998, 1013, 18 L. J. Q. B. 1? 7 6 li. R. 1.n.

(y) Lawe v. L. do N. H. Ry. G'o. (1852) 18 Q. R. 6332, 21 L. J. Q. B. 361,88 k. R. 726 .

(i) The liability existed at conumill lat, atud thestatnte 11 Gieo. 2 , 
Statutory forms of cuntract.

on a quasi-contract is as goor against a corporation as against a natural person. Thus a corporation may be sued in an action for money receired on the ground of strict necessity; "it cannot be expected that a corporation should put their seal to a promise to return moneys which they are wrongfully receiving " (a). It was held much edrlier that trover could be maintained aganist a corporation-a decision which, as pointer out in the case last cited, was analogous in principle though not in form (b). Sometimes it is stated as a general rule that corporations are liable on informal contracts of which they have in fact harl the benefit: but the extent and existence of the supposed rule are doubtful $(c)$.

Forms of contracting therwise than under seal are provided hy many special or general Acts of Parliament creating or regulating corporate companies, and contract duly made in those forms are of course valid. But a statute may, on the other hand, contain restrictive provisions as to the form of corporate contracts, and in that care they must be strictly followed. Enactments Jequiring contracts of local corporate authorities exceeding a certain value to be in writing and sealed with the corporate seit are held to be imperative, even if the agreement has been executed and the corporation has liad the full benefit of it (d). The gencral result seems to stand this: :-

c. 19. - . 1t, mate the remetly by action on the ca-ecterentensitewit that by actionof debt.ste (rit)sums

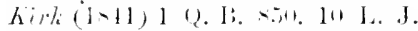
1. I\%. 2:1. Since the 1 . I. l'. Act the statute setmo in fact sinerHlutur.

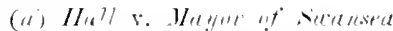

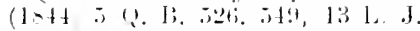
12. R. 111. tit R, li, stit. The like

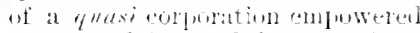
torse and be -led by an ufficer.

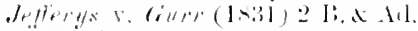
s.3. sii li, li. Tris.

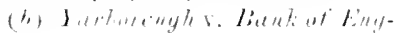

luen (1:12) lif East, if, It P. R. 2-2.2. Sere tarly case of tres]ass againt enporations cited by Lord Filendmough. 16 list, at $p 10$. 11 Ii. li. 2-2.5. 2iti.

(.) Ilunt v. ITimbleston Loral limel (I-T) + C. P. Divat 1 p. 53 . $\therefore 7$. ts L. J. ('. F'. 207.

(d) Fremd v. Derunet (1nis) 4 C B. N. S. 376.27 L. J. C. P. 31t: Ilunt 8 . Wimbledon Lowal Buard (18.-) 3 C. l'. 1). 2015, in C.A., 4 C. I'. IDir. 45. 48 L. J. C. F'. 207 :

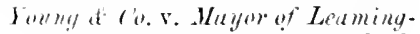

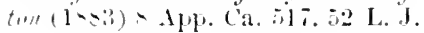


In the absence of enabling or restrictive statutory provisions, which when they exist must be carefully Summary of attended to-

A trading corporation may make without seal any contract incidental to the ordinaly conduct of its basiness; but it cannot bind itself by negotiable instruments unless the making of such instruments is a sul, stantive part of that business, or is provided for by its constitution $(e)$.

A non-trading corporation, so far as it is incorporated for special purposes, may make without seal any contract incidental to those purposes; but if it has no such purposes, or not any now practically subsisting, it apparently cannot contract without seal except in casess of immediate necessity, constant recurrence, or trifling importance.

In any case where an agreement has been completely executed on the part of a corporation, it becomes ic contract on which the corporation may sne.

The rights and obligations arising from the tenancy or occupation of land without an express contract apply to corporations both as landlords and as tenants or occupiers in the same manner $(f)$ and to the same extent as to natural persons.

A corporation is bound by an obligation implied in law whenever under the like circumstances it matural person would be so bound.

\section{Negotiuble instruments.}

The peculiar contracts undertaken liy the persoms Negotiable who issue or endorse negotiable instruments must by 
Statute of Frauds.

Promises by executor, de.

the nature of the case be in writing. Part of the definition of a bill of exchange is that it is an unconditional order in writing $(g)$. The acceptance of a bill of exchange, though it may be verbal as far as the law merchant is concerned, is required by statute to be in writing and signed $(h)$.

3. As to purly stututory forms.

A. Contracts within the Statute of Frands.

To write a commentary on the Statute of Frauds would be beyond the scope of this work. It may be convenient, however, to state as shortly as possible, so far as contracts are concerned, the contents of the statute and some of the leading points established on the construction of it.

The statute (29 Car. 2, c. 3) enacts that no action shall be brought on any of the contracts specified in the th section "unless the agreement upon which such action shall be brought or some memorandum or note thereof shall be in writing and signed by the party to be charged therewith or some other person thereunto by him lawfully authorized." The contracts comprised in this section are--

a. Any special promise (i) by an executor or administrator " to answer damages out of his own estate." No difficulty has arisen on the words of the statute, and the chief observation to be made is the almost self-evident one (which equally applies to the other cases within the statute) that the existence of a written and signed memorandum is made a necessary condition of the agreement heing enforceable, but will in no case make an agreement any better than it would have been apart

(g) Bills of Exchange Act, 1882 (45 $\mathrm{k}$ ti Viet. e. 61$), \mathrm{s} .3$. So of fromissory notes. s. 83 .

(h) 17, s. 17 .

(i) "special promice" meant. for the lawrers of the Restoration. special (is opposed to indebitatus) assumpsit. see l'rof. ('rawford 1).

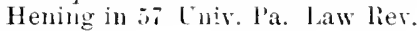
611. 
from the statute. A good consideration, a real consent of the parties to the same thing in the same sense, and all other things necessary to make a contract gool at common law are still required as much as before $(k)$.

$\beta$. "Any special promise to answer for the deht Guaranties. default or miscarriages of another person."

On this the principal points are as follows. A promise is not within the statute unless there is a dobt, \&e., of some other person for which that other is to rematin liable (though the liability need not be a present one): for there can be no contract of suretyship or guaranty unless and until there is an actual principal dobtor. "Take away the foundation of principal contract, the contract of suretyship would fail" (l). Where the liability, present or future, of a third person is assumed as the foundation of a contract, but does not in fact exist, then, independently of the statute, and on the principle of a class of cases to be explained elsewhere, there is no contract. On the other hand a promise to be primarily liable, or to be liable at all events, whether any third person is or shall become liable or not, is not within the statute and need not be in writing. It may be an indemnity, it is not a guaranty $(\mathrm{m})$. But if the promise is substantially dependent on a third person's default it is within the statute $(n)$. Whether particular spoken words, not in themselves ennelusive, c.q., "Go on and do the work and I will see you paid," amount to such a promise or only to a guaranty is a question of fact to be determined by the circumstances of the case $(0)$.

(k) As to these contracts of executors. 1 Wms. Exors. Pl. 2, Bk. 2, c. 2.

(1) Mountsteplien v. Latiemant (1871) K. R. 7 0. 13. 196. 202 (in Ex. (h.), 13 1. .1. Q. 13. Isis, per Willes .I. ; affil. L. li. 7 II. I. 17, nom. Lakeman v. Hountstephen
(1874).

(m) Guild f. ('o. v. Gonrad I894] 2 Q. В. $885,6.3$ I. .J. (2. B. 721.

(ii) Itorlourg India Rublier

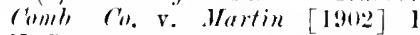
K. B. 778,71 1. I. K. R. 529 . C.A. (ii) Lelieman v. Monntstephen, Guild f. ('o. v. cimrad, suprer. 
Agreements upon con sideration of marriagre.

Nor is a promise within the statute unless it is made to the principal creditor: "The statute applies only to promises made to the person to whom another is answerable " $(p)$ or is to become so.

A mere promise of indemnity is not within the statute $(q)$, though any promise which is in substance within it cannot be taken out of it by being put in the form of an indemnity $(r)$. A promise to bear contingent losses in a transaction in which the promisor has an independent interest is a promise of indemnity and not a guaranty $(s)$.

A contract to give a guaranty at a future time is as much within the statute as the guaranty itself $(t)$.

$\gamma$. "Any agreement marle upon consideration of mar" riage." A promise to mary is not within these words, the consileration being not marriage, but the other party's reciprocal promise to mary. For further remarks on the effect of this clause see Chapter XIII. on Agrements of Imperfect Obligation, infra.

In the old books we frequently meet with another sort of difficulty fouching agreements of this kind; it was much doubted whether matrimony were not so purely spiritual a matter that all agreements concerning it must he dealt with only by the ecclesiastical courts: the type of these disputed contracts is a promise by A. to B. to pay B. 10l. if he will mary A.'s daughter. But this by the way (u).

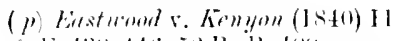

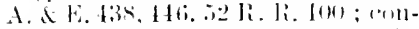
cess. (r)ps v. Hartnoll $(1 \times 63)+\mathrm{B}$.

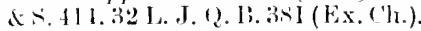
(if) rivpss. Haitnoll (last note): Hoildes y. Indlone (18-1) I. R. I! Eit. 19s. 14 L. J. ('h. 34t. So of an intennity by one partner to his co-partners in respect of a doubtful debt from a third person to the firm : lif $/ I^{\prime} y / l^{2}[1843]$ I Ch. st. (i2 1.. J. ('h. 152. ('. A.

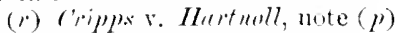
supret. (x) intton v. Girey [189t] I Q. B. 2.5. 63 L. .J. 9. B. 633.

(t) Mallot v. Hateman (I865) L. R. I C. P. 163 (Ex. (h.), 35 L. I. (. I'. 40. See further on this clause, I Wms. Saund. 229235. or 1 sm. L. C. 33t. note to Birkm!lr v. Darmell (1705). Cp. Waluce v. Gibson [1895] A. C. 354. on the Mercantile Law (scotland) Amenilment Act.

(u) Such promise may be sued on in the king's Court if by deed, 22 Ass. 101. pl. 70; olherwise if he 
$\delta$. "Any contract or sale of lands, tenements, or lnterests in hereditaments, or any interest in or concerning them." lans.

This clause is usmally and conveniently considered as belonging to the topic of Vendors and Purchasers of real estate; and the reater is referred to the well-known works which treat of that subject $(x)$. Questions have arisen, however, whether sales of growing crops and the like were sales of an interest in lands within the th section or of goods within the 17th $(y)$. A sale of tenant's fixtures, heing a sale only of the right to serel. the fixtures from the freehold during the term, is not within either section $(z)$.

By the 1st and 2nd sections of the statnte lases for more than three years, of reserving a rout less than

had promised lol. with his drengleter in marriage, then it should he in the court Christian. Trin. to Ed. 11I. 24, 1). 30; aetion gorol without speeialty where the malriage had taken place. Wich. 37 H. VI. S. pl. 18 ; cmentre (not with. out dissent). 'Trin. 17 Ed. IV. I, 1.l. 4 . In Bracton's time the exclusive jurislietion of the spiritual courts appears to have heen admitted: "arl formm seeulare trahi non debet per id yoor minus est et non principrale id quod prinsm et prineipale est in foro ecclesiastico, ut si ob cansam matrimonii perunia momittatur, licet vicleatur frima facie quod cognitio super eatallis et diebitis pertincal ael formu seculare. tanen propter id rund maius est ef dignius trahitur eognitio peculliae promissae et debitae al form ecelesiasticum, ef uhi [? ibi] lox'וum non habet prohibitio, cum rebitnm sit de festamento vel mat rimonio:" folio 175 a. It shonld be remembered that thromghout the Widulle Ages orlinary debts were indirectly enforeel in the spriritual courts by the imposition of penance: 2.4 .22 Ass. "hisup. The so-ralled statute

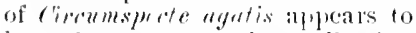
have been eonstrued at allowing this if the suiritual rourt dial not direetly order bayment of the delet.

(a) As toan agreenent colloterul fo a remise of land not heing within the statute, sew Mommon v. Griffitll (18il) L. R. (i Ex. 7 (1, to L. J. Ex. 46; brskine v. dewm (14-3) I. R. 8 Ch. 756, t2 I. J. Ch. 835: I meft v. Julie (1875) L. R. 13) (2. B. izt,

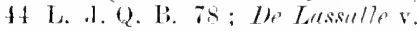
Guildfim [190] 2 K. B. 215,00 L. J. K. B. 533. C. A. A promise ly A. to P. that if B. buss Whiteacre $A$. will repray $b$. the price is not withins. t: Buston vo Boston [1!04] 1 K. B. 124. 33 I, J. K. B. 17, ( A. As to a more than doubtul extension of this clase of anthorities in Ontario, Herrier v.

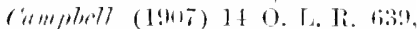
see l.12. li. xxvi. I!I. Mstotherlistinction between a temise and a mere licence or agreement for the nse of land without any ehange of

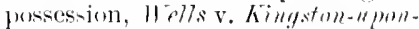
Hull (1875) I. It. I0 ('. I'. 412. It L. .I. ('. 1'. 2.5.

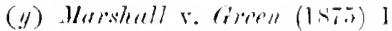
(1. P. 1). 3.), 45 J. J. (?. I'. 1.3. As to buildine materials to be ecrered from the soil, Lacery v. Pursoll (1885) 39 (\%. T). 508.57 1. . I. Ch. 570. And see I Whis. Siluml. 395.

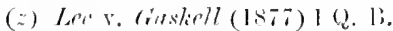
1). $7(119,151$ 1. .1. (). B. 510. 
Agreements not to be performer within a real.

As to s. 17 .

two-thirds of the improved value, must be in writing and signed by the parties or their agents authorized in writing, and now hy 8 \& 9 Vict. c. 106, s. 3 , they must be made by deed. But an informal lease, though roid as a lease, may he good as an agreement for a lease (a).

$\epsilon$. "Any agreement that is not to be performed within the space of one year from the making thereof."

"Is not to he," not " is not " or " may not be." This means an agreement that on the face of it cannot be performed within a year. An agreement capable of being performed within a year, and not showing any intention to put off the performance till after a year, is not within this clause $(b)$. Nor is an agreement within it which is completely performed by one party within a year $(c)$. It appear's to be now settled that an agreement depending on the life of a party or of some other person, or otherwise determinable on a contingency which may possibly happen within a year, though this be not expected or desired by the parties, is not within this branch of the statute $(d)$. An agreement for service for one year "from "the day next following is not within the statute $(e)$.

The seventeenth section of the statute (sixteenth in the Revised Statutes)( $f$ wa extended hy Lord Tenter-

(a) lort. Y. \& P. 1, 19s.

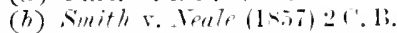
N. S. 67,26 L. J. F. P. 143, 109 R. R.b11. But see Rereve vo. Jrmillig:s [1!10] 2 K. B. . i2:2.

(c) rerry s. Heming (Iota) 4 Ex. 131. 19 I.. J. Ex. 63, s0 li. li. 733. See notes to Peter v. rom piton. $1 \mathrm{sm}$. L. C. $31 \mathrm{ti}$.

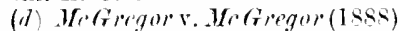
21 Q. B. Div, 424. 57 L. J. 1) B. 591, overruling Darey r. Stannen $(1 \times 79)+E x .1$ ). SI. and (it shoukl seem) Eley v. Pessitire Assumeres ('). (1576) l Fx. D. 20 (in C. A. it. 88. not on this point). 45 L. J. Ex. 451. The Englin deeisions appear to be receiver in Anerica: see IIarner. ․ Treres and Parifio Ry. (1S9t) Int C.. S. 41 r.

(e) Simith r. Goldt rinest and Ashenti Erploners $190037 \mathrm{~K}$. B. ysi, in C.A. it. 83s: for the last lay of the service will he the anniversary of the day on which the contract is made.

( $f$ ) The differenee arises from tbe preamble and the enacting part of $\therefore$. 13 bein! separately numbered as 13 and 14 in other editions. The seetion is commented on in detail in Blackburn on sale, Benjamin on Salo, and sir $M$. Chalmer- un the sale of Gools Act, 
den's Act, 9 Geo. 4, c. 14, s. 7, so ats to inclute all executory sales of goods of the value of $10 /$. and upwards, whether the goods be in existence or not at the time of the contract. In England these enactmonts are superceded and consolidated by the sale of crools Act, 1893 (9). We will here only refer very briefly to the question of what is a sufticient memorandum of a contract, as to which the decisions on the Statute of Frauds remain applicable.

There is a curious difference in the judicial interpretation of the "agreement" of which a memorandum or note is required hy $s .4$, and the "bargain " of which a note or memorandmon was required hy s. 17. The "agreement" of s. 4 inchules the consideration of the contract, so that a writing which omits to mention the consideration does not satisfy the words of that section: but the "bargain" of s. 17 includes the price of the goods as a material term only where it has heon specifically agreed upon $(h)$. So far as regards guarantios, however, this construction of $s$. $t$ haring been foumd inconvenient is excluded by the Mercantile Law Amendment Act, 1856, $19 \& 20$ Vict. c. 97, s. 3, which makes it no longer necessary that the consideration for a "special promise to answer for the debt default or miscarriage of another person " should appear in writing or hy necessary inference from a written document $(i)$.

The note or memorandum under the the as well as the 17th section (or Sale of (roods Act) must show what is the contract and who are the contracting partics $(l)$,

1893(71)(4t. 1910). A recent case of some importance on acceptance is tieylor v. Simill, (1. A. [1 $15 ! 3]$ 2 Q. 13.69, 61 1.. J. Q. 13. 333 . If a contract for sale within s. 17 is alses within s. I, acceptature atrel recojed withent writing will not make it arojomathe: l'rested llimers (i) v. Girmer [19[1)] 2 K. B. 76 i.

(g) 5 if $\mathrm{t}$ 57 Vict. c. $71, \mathrm{~s}, 1$. (h) Ilemally v. J/s Leine (183t)

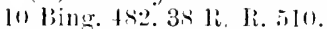

(i) See also an article by the late sir lames stephon and the present writur in the Law Quarterly Reviens. i. 1, and the notes to Birlimy v. Marmell (1705) and

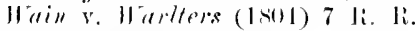
(i.li, in 2 sins. I. C. 26 (i.

(i) Hilliams v, Byrnes (186;i) 1
The "note or nemorandlum," 
but it need be signed only by the party to be charged, whether under the 4 th or the 17 th section, and indeed it need not be signed in the common meaning of the word, for the party's name inserted by his authority in the body $o r$ at the hear of the memorandum may suffice $(l)$. It is no answer to an action on a contract evidenced by the defendant's signature to say that the plaintiff has not signed and therefore could not be sued, and if a written and duly signed proposal is accepted by word of mouth the contract itself is completed by such acceptance and the writing is a sufficient memorandum of it $(m)$. It has also heen decided that an acknowledgment of a signature previonsly made by way of proposal, the document having been altered in the meantime and the party having assented to the alterations, is equivalent to an actual signature of the document as finally settled and as the record of the concluded contract. The signature contemplated by the statute is not the mere act of writing, but the writing coupled with the party's assent to it as a signature to the contract: and the effect of the parol evidence in such a case is not to alter an agreement made between the parties but to show what the condition of the document was

Mon. I'. C. N. S. 154: Temell r.

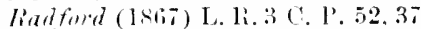
L. J. (. P. I : Williams s. Jordan (1575) 6 (h. 1). 517, 4t I. .1. Ch. isl : and as to sufficienry of de. scription otherwise than by name, Ressiter v. Willer (1s-s) 3 A ple. Ca. 1124. 48 1. J. Ch. 111; ('atling v. king (1876) 5 ('h. Div. 6eit. di 1.. J. Ch. 3st : Juriett r. Hunter, (1.886) 34 ('h. 1). 182; $6 \mathrm{cmm} / \mathrm{s}$ v. 11 ilkex [1s91] 3 Ch. 7т, il 1. J. Ch. $42:$ Filby v. Honksell [ I $89 i]$ 2 Ch. 737. 6.) L. J. Ch. \$52 (name of agent for undisclosed vendor suticient): ('arr v. Lynole [1900] 1 Ch. 613, 69 1. J. Ch. 345 (reference to payment marle by purchaser without name). As to what is sufficient description of the property sold under s, 4, Shathine v.
Cinterell (1851) 20 Cl. Div. 90, 51 L. J. Ch. 333 : Plant v. Bowrne [1897] 2 (h. 281,66 L. J. Ch. 613. C. A.

(l) Frans v. Houre [1892] 1 (1. I. $5 ! 13,6$ I 1. J. 1. B. 470. As to the authority of an anctioneer to sign as agent for a purchaser, and its luration. see Bell r. Balls [1897] 1 Ch. 663,66 L. J. Ch. 397. (iii) rimith v. Lifale (1857) 2 C. B.

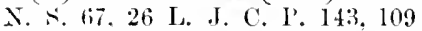
R. R. 611; Reuse v. Pieksley (1886) in Ex. Ch. L. R. 1 Ex. $342,3.5$ T. J. Ex. 218 . And where alternative offers are made by a signed writing, parol acceptance of one alternative has been held sufficient : Lerer v. Koftler [1901] 1 Cl. 543,70 L. .1. Ch. 395. 
when it became an agreement between them $(n)$. Moreover it matters not for what purpose the signature is added, since it is required only as evidence, not as belonging to the substance of the contract. It is enough that the signature attests the document as that which contains the terms of the contract $(o)$. Nor need the particulars required to make a complete memorandum be all contained in one document: the signed doeument may incorporate others by reference, hut the reference must appear from the writing itself and not have to be made out by oral evidence: for in that case there would be no record of a contract in writing, but only disjointed parts of a record pieced out with unwritten evidence $(p)$. The reference, however, nred not be in express ferms. It is enough if it appears on the documents that they are parts of the same agreement $(q)$. One who is the agent of one party only in the transaction may be also the agent of the other party for the purpose of signature $(r)$. The memorandum must exist at the time of action. hrought $(s)$.

It seems that the Statute of Frauds does not apply to deeds. Signature is unnecessary for the validity of a deed at common law, and it is not likely that the Legis-

Simlite, deeds not within the sitatute.

(ii) Stemart v. Eildomes (isil) I. IR. 9 C. I'. 311,43 I. J. (.. I'. 201.

(a) domes v. Jietoria Gimrill Hork ('). (18:7) 2 Q. 1). Hiv. 31 i, 323, 46 1. .1. (). B. 21!. It may be doubterl whether this view of the slatute does not tend to thrust contracis upon parties by surprise and contrary to their real intention.

(p) See l'fires v. (anf (1874) I. Ii.! Q. I3. 2I0, 13 I. J. U. IR. 52 ; Kronhaim v. Jolensom (1s77) 7 ('h. 1), 60, 17 1. J. Ch. 132; Leuther. rloth ris. v. IViermimus (1875) J. R, 10 (2. I, 110,41 I. .). (2. I?. i).

(4) Ntudds r. Ilatsoll (1881) 28
Ch. I. 305: Wylsom v. Dum (1887) 34 ('h. 1). sti!l ; Olirer v. Ilunting (1890) lt (ll. I). 205,59 T. .J. (h. 25, where the judgment states lhat the old rule was different; lenter's. Giarduer [18:17] I Q. P.

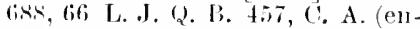
velupe and letier provel to liave been enelosed in it may he taken as mue document to irlentify arl(lressee).

(r) As to this, Wurnhy v. Buese (Isti) J. li. $10 \mathrm{Ex}, 126,4+\mathrm{L}$. I. lix. 10 .

(s) Lmeres v, Ji.eon (1889) 220 (). b. I)iv. 357, 5s I. J. (2. J. J61 (lofindant's attilavit on interlocutory proceedings in the action will not $(0)$. 
lature meant to require signature where the higher solemnity of sealing (as it is in a legal point of riew) is already present $(t)$. But as in practice deeds are always signed as well as sealerl, and distinctive seals are hardly ever used except by corporations, the absence of a signature would nowadiy's add considerably to the difficulty of supporting a deed impeached on any other ground.

Bille of Sale The law as to the sale and disposition of personal Acts. chattels is affecterl, in ardelition to the statute of Frauds, by the Bills of sate Acts, 1878 and 1882, with minol amending Acts of 1890 and 1891; but the subject is too special to be entered nn here.

Transfers of ships and copyright.

Sale of horses in market overt.

Transfers of British ships are required by the Merchant shipping Act, $189+(\therefore .2+s q q$.) to be in the form thereby prescribed. Assignments of copyright are directly or indirectly required hy the various statutes on that subject to be in writing (u), and in the case of sculpture hy deed attested by two witnesses (5t Geo. 3, c. 56, . 4). But an executory agreement for an assignment of copyright apparently need not be in writing. And informal executory agrements for the sale or mortgage of ships seem now to be valid as between the parties, though moler earlier Acts it was otherwise, and it is doubtful whether at common law a sale without writing would pass the property $(x)$.

There is "An Act to aroid Horse-stealing " of 31 Eliz. c. 12, which prescribes sundry forms and con-

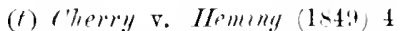
Ex. 6331. 19 L. J. Ex. 63. S11 I. R. 733. lilarkstone (ii. Buri. and see note in Strohen's Comm.. 1. 5lu. ith el.) assumet signature to be necessary.

(u) Leyluml v. Strment (ISTi) 4 Cl. D. 419,46 L. J. L L. 103 ; and as to atesigns. Jowitt v. Eikhardt (INT) 8 Ch. D. tot. The confusion of unr copryight statutes is st ill a rliserace to British legislation.

(r) Naucle and lolloek in Merchant shipping. the el. ply. 42. is, iii. And see the Merchant Shipfing Act. $1834,5.57$. 
ditions to be observed on sales of horses at fairs and markets: and "every sale gift exchange or other putting away of any horse mare gedling colt or filly, in fair or market not used in all points according to the true meaning aforesaid shall be void" $(y)$. The earlier Act on the same subject, 2 \& 3 Phil. \& Mary, c. 7, only deprives the buyer of the benefit of the peculiar rule of the common law touching sales in market overt. These Acts are not touched by the Sale of Goods Act, 1893: see s. 22.

B. Marine Insurances.

Marine

By the Marine Insurance Act, 1906, "a contract of insurance. marine insurance is inadmissible in evidence unless it is embodied in a marine policy in accordance with this Act;" it must specify prescribed particulars and be signed by or on behalf of the insurer (z); by the Stamp Act, 1891, which the Marine lnsurance Act does not affect (a), a contract for sea insurance (with a limited exception) is not valid unless expressed in a policy.

C. Transfer of Shares.

There is no general principle or provision applicable Transfer of shares. to the transfer of shares in all companias. But the general or special Acts of Parliament governing classes of companies or particular complanies always or almost always prescribe forms of transfer. An exfentory contract for the sale of shares need not as a rule be in writing.

1). Acknowledgment of barred debtis.

The operation of the statute of Limitation, 21 Jac. 1 , c. 16, in taking away the remedy for a debt may be

Promise to biay lebt birired by statute of Limitalion. (y) Moran v. L'itt (I873) 12 L.J. Q. B. 47.

(z) S8. $22-24$

(a) 51 \& 55 Viet. c. 39, s. 43, superseding 30 Virt. c. 23, s. $\pi$. which itself superseded earlier entactments: M. I. A. s.91. As to the recongition of the "slip" lor collateral purpuses, see 1). 7og, ('/1. Xll I., below. 
excluded by a subsequent promise to pay it, or an acknowledgment from which such promise can be implied. The promise or acknowledgment if express must be in writing and signed by the debtor (9 Geo. 4, c. 14, s. 1) or his agent duly authorized (19\& 20 Vict. c. 97, s. 13). We say more of this under the head of Agreements of Imperfect Obligation, Chap. XIII. below. 


\section{CHAP'TER IV.}

\section{Consideration.}

The following description of Consideration was given by the Exchequer Chamber in 1875: "A valuable conConsidera. tion what. sideration, in the sense of the law, may consist either in some right, interest, profit, or benefit accruing to the one party, or some forbearance, detriment, loss, or responsibility, given, suffered, or undertaken by the other" $(a)$.

The second branch of this judicial description is really the more important one. Consileration means not so much that one party is profited as that the other abandons some legal right in the present, or limits his legal freedom of action in the future, as an inducement for the promise of the first. It does not matter whether the party accepting the consideration has any apparent benefit thereby or not: it is enough that he accepts it, and that the party giving it does therehy undertale some burden, or lose something which in contemplation of law may be of value.

An act or forbearance of the one party, or the promise thereof, is the price for which the promise of the other is bought, and the promise thus given lor value is enforceable.

A consideration, properly speaking, can be given only

(a) C'uriev. Wha (1875) I. I. It) Ex. at 1. 162, 4. L. J. Ex. 94 ; per Cur. referring to ('om. Dig. Action on the Case, Assmmpsit 13. 1-15. ('p. Evans, Appendix to Pothier on Obligations. No.2; and Edyuare
Mighurey Bourd y. Marroue Gias (a). (1s74) L. R. 10 Q. B. 92, 95, 44 L. J. Q. B. 1 ; and for the historieal distinction between debt and assmmpsit in this respeet, Langlelt, summary, \$\$ (34, 65. 
for a promise. Where performance on both sides is simultaneous, there may be agreement in the wider sense, but there is no obligation and no contract. It may be amusing and not uminstructive to consider the distinctions to be observed in the legal analysis of such common dealings as being ferried across a river and paying on the other side, buying a newspaper on a railway platform, obtaining a box of matches from an automatic machine. The reader may multiply examples at his pleasure.

A consideration which is itself a promise is said to be executory. A consideration which consists in performance is said to be executed. It is important to remember that in the former case "it is the counterpromise and not the performance that makes the consideration $"(b)$.

Consideration is that which is actualiy given and accepted in return for the promise. Ulterior motives, purposes, or expectations nay be present, but in a legal point of riew they are indifferent. The party seeking to enforese a promise has to show the actual legal consideration for it, and he need not show anything beyond (c).

Gratuitom promines.

An informal promice made without a consideration, howerer strong may be the motires or eren the moral duty on which it is founded, is not enforced by English courts of justice at all. Even a formal promise, that is a promise made by deed, or in the proper technical language a corenant, is deprived, if gratuitous, of some of the most effectual remedies administered by them. A promisc to contribute money to charitable purposes is a good example of the class of promises which, though

(b) Hobart in Lemploigh $v$. Brotherut 1616 i) 1 sm. L. ('. 1 is.

(c) Themes v. Thom (1842) :Q. R. 851 . 91 R. R. :413. Finch sel.

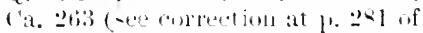

a bal clerical slip in the original report). In ('oles r. Pilkingtom (Irit) L. R. 19 Eq. 17t. tt L. J. (h. B. this case was strangely overtorked. 
they may be laudable and morally binding, are not contracts $(d)$.

The early history of the law of Consideration is still somewhat obscure, but some acquaintance with it is History of the doctrine. necessary for understanding the fluctuations on certain points which lasted well into the nineteenth century, and one or two anomalies which have survived.

The name of Consideration appears only about the beginning of the sixteenth century, and we do not know by what steps it became a settled term of art. The word seems to have gone through the following significations: first, contemplation in general ; then deliberate decision on a disputed question (hence the old form of judgments in the Common Law Courts, "It is considered ") (e); then the grounds as well as the act of deliberation; and lastly, in particular, that which induces a grant or promise. If we wish to for'm a probable opinion as to the origin or origins of this final modification, we must inquire how far anything like the thing signified was to be found in the old action of debt, or was involved in the necessary elements of the new action of assumpsit. We must also remember that the demand was for an extended remedy on business agreements, and, from the pleader's point of view, for an action which would enable him to rescue an increasing and lucrative branch of practice from the monopoly of ecclesiastical jurisdiction in matter's of breach of faith $(f)$, and at least to

(d) Cottuge street rhurelr v. Kendall (1877) 121 Mass. 528; Re II"dson, Creped v. Hemlersm (1885) if L. J. Ch. 811. A contract may arise, however, if the subscriber anthorizes a definite expenliture which is incurred in retiance on his making it goorl: see kidur Nath Bhattarhariji v. Cimie Mahomed (1886) I. L. R. 14 ('al. 6il; $q u$. if right on the far.ts.

(p) Altered to "adjuiged" by the Judicature Act for no obvious reason, muless it were that the word "adjudge" was equally unknown to the operative furms of common law and equity, though it was current with text-writers from the sixteenth century on waris.

(f) It is said that the ling's juilges had the remedy of prohibition in their hamels. No doubt the spiritual courts often might have been polihited, and sometines were: but one lats only to look at IIale's I'recolents and 
compete on equal terms with the Court of Chancery. Nobody wanted merely fanciful or gratuitous promises to be made binding without form, and there was no need for haste in defining exactly where the line should be drawn.

Quid pro quo in action of debt.

The action of debt assumed that the defendant had money or chattels $(g)$ which belonged to the plaintiff; either because the defendant had actually received so much from the plaintiff, or because he (or, in the later doctrine, a third person at the defendant's request $(h)$ had received from him something-it might be money, goods, or services - admitted to be equiralent to the money or goods claimed. As the buyer of goods had acquired property in the goods, so did a sum of his money measured by the agreed price become, in the merlieval view, the property of the seller. There was a change of property by "reciprocal grants" (i). Thus the debt could not be established without showing that the debtor had received some equivalent or "recompense." In the fifteenth century this equivalent was called Quid pro quo, a peculiarly English term $(k)$. The words bargain and contract, especially the latter, also came to be associated with the action of debt in the fifteenth and sixteenth centuries. In fact contract meant a "real contract," a transaction on which an action of deht might be brought (l). Mere one-sided

Ploceedings. representing a small patt of what went on all over the comntry, to see that in fact they got the business: and the repeated protest of Common Law julges show that the steular jurisiliction failed to eheck them : Holdsworth. H. E. L. ii. 252.

(y) Harv. Law lier. riii. 260.

(ii) Harr. Law Rer. viii. 262: Deet. \& it. ii. 24: "'after diver that be learned in the laws of the realm ... if he to whom the promise is made have a charge by reason of the promise. which he hat h also verformed. then in that ease be shall have an action for that thing that was promisel. though he that made the promise have no worldly profit by it." I agree with Prof, Vinogradoff, L. Q. R. xxir. 383, that this relates to lebt, not Assumpsit.

(i) Eigramh r. Dee, f. 14 . abore.

(i) It is not otherwise known to Di ('ange or his later elitors.

(l) see H. I. R. viii. 253 ; the 
speech could no more pass property in money than in goods.

The action of assumpsit was not to recover anything supposed to be the plaintiff's, or for restitution, but to recover damages for the breach of an active duty towards the plaintiff which had been expressly "assumed" by the defendant, or was attached by law to the exercise of his calling. If the defendant's "assumption" had not induced the plaintiff to incur risk or trouble in some way to his own detriment, there was no wrong done and no ground of action. Here again bare words of promise, as such, would create no duty; nor could mere disappointment be regarded as actionable damage. It was a considerible time before the fact that assumpsit was in substance an action to enforce contracts was in any way formally recognized; but this could not be much delayed when it was settled that the existence of a debt was a sufficient ground for an action in assumpsit $(m)$, the defendant not being allowed to admit the existence of a duty to pay the plaintiff and deny that he had undertaken to fulfil it.

Thus we have both in debt and in assumpsit the notion of some kind of value received as an element in the defendant's liahility ; in the later application of assumpsit concurrently with deht this element is identical with the quid pro quo of debt $(n)$; in the original assumpsit founded on an actual promise it is distinct.

Meanwhile the canonists of Europe, in opposition to the more technical views of the civilians, had been generalizing the Roman law of contract and breaking down its formalities. T'he cansa which made a pact actionable was no longer one of a limited set of circumstances or "vestments" applicable, according to their

Detriment to promisee in assumpsit. title of beht in the Abridgments; and even later, Termes le la Ley, s. $r$. Contract.

(m) This is "indebitatus" as distinet from "special" assumpsit. (n) Prof. Ames in Jary. Jaw Rev. ii. 18.
The canonist, expansion of crexue in Roman law : " consideration" in loctor and student. 
nature, to particular and limited classes of transactions ; it might be any reason for making a promise which appeared serious enough to be the foundation of a moral duty to fulfil the expectation created. Some English canonists, perhaps, used the word "consideration " with the same or nearly the same meaning as this extended sense of causa before it was familiar to the common lanyers. At any rate St. German, in his well - known Dialogue, first published in English in 1530 (o) puts this word in the mouth not of the Student but of the loctor. The Student in the laws of England, explaining "what is a nude contract or naked promise in the laws of England, and where an action may lie thereupon, and where not" $(p)$ speaks of recompense, of "a nude contract. . . . where a man maketh a bargain, or a sale of his goods or lands, without any recompense appointed for it," and of "a nude or naked promise . . . where a man promiseth another to give him cermoney such a day, or to build an house, or to do him such certain service, and nothing is assigned for the money, for the huilding, nor for the service; " in which cases no action lies $(q)$. It is the Doctor of Divinity who takes up the distinct question of what promises are binding in conscience, and distinguishes "promises made to a man upon a certain consideration .... as if A. promise to give $B$. xxl. because he hath made him

(1) The Latin cul. pr. (1:23, reprinted 152s) contained only the first Dialogue: and this also is amplitied in the English version. On the other hand the Latin text has a consilerable amount of seholastie authorities and discussion omitted in the Enghish: Vinogradoff, Reason and Conscience in sixteenth-century Jurisprudence, L. Q. li. xxiv. 373.

(di) Question put by the loctor, Dial. 2, c. 23, ad tin. The diseussion follows a c. 24.
(I) It is not manifest whether the author maans to alluce to the action of assumpsit or not. I think he was more likely to regard it as a remerly for a wrong indepenlent of contract, and not to have it before his mind at all in this place. The action on the case for negligence, which was one origin of as-umpsit. is recognized: * if I take [gooks to keep safely], and after they be lost or impraired through my negligent keeping, there an action lieth." 
such a house or hath lent him such a thing "-which is generally binding - from a promice which is "so naked that there is no manner of consideration why it should be made," and does not even create a moral obligation. Here the langlage is not technical, but is rather a literary explanation aldressed to the student, who is presumed not to know civil or canon law, and would not understand the Romanist term causu.

The word "consideration" had already been used in English Courts in discussing the validity not of promises but of uses; there is nothing to show any conncetion with the learning, civilian or canonist, of cansa, hut on the contrary "consideration" in this context is rather. analogous to the quid pro quo of dobt, though wider. On the whole the transitional view of the early axtesenth century seems to have been that a use was created by the will of the grantor, but his will could not be known by the Court without sufficient proof of his intent; and such proof might consist in the mutuality of the transaction (including the creation of a tenure as well as actual value received), or in the existence of a natural duty towards the cestui que use. Fither. kind of reason was called consideration. It is common learning that the mere solemnity of a deed was never held sufficient in this commexion $(r)$. (In the whole the Doctor, who represents the canonist half of St. German's extraordinary learning, appears to use "consideration" as a semi-popular word, which will dispense him from going into technical details, and be sufficiently accurate for his purpose. As the book rapidly became well known for its merits as an rxposition of the Common Law, it may well be that this very

(r) Y. R. 20 II. I'lI. 10, pl. 20 ; Bro. Ab. Feoffencents and Lses, 1). 40. (This is dated 1033, a litlle later than st. (ierman's book. but practically comtemuntiry.) Ju
Sharingtone v. Stroltan (listis), l'lowd. 302, the analogy of quid fro" qu" was reliet on in the unsucessful argument for the plitintilf. 
No probable commexion of caltsk with the common Law luctrine.

passage contributed to the current use of the word among the serjeants and apprentices at Westminster, and suggested its application to actions on promises, of which no earlier example has been found.

There is nothing to show that it was so applied by common lawyers with any conscious reference to either the civilian or the canonist interpretation of the Roman causa; nor had they any need to call in such notions. The quid pro quo which the defendant in debt must have received, and the damage which the plaintiff in assumpsit must have suffered by relying on the defendant's undertaking, were sufficient to form the notion of Consideration without any extraneous matter. In fact the Romanist conception could not have been fitted into the English legal categories. In its later canonical form it was too wide for the common lawyer's purposes (s), as in its ancient classical form it was too narrow $(t)$.

No one ever argued before an English temporal Court that deliberate bounty or charitable intention will support a formless promise; but such was undoubtedly the canonical riew, and is to this day, in theory, the rule of legal systems which bave followed the molern Roman law (u). There was no room within the common law

(s) Sitre in the point, unknown to English law, that a plaintiff suing on a promiar must show that its performance was of solme value

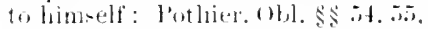
bi). (6ole xal, 1ll!9. It is saisl that a pomine by A. to B. to do somelhing neeful io Z., but sut to b.. is limbing in conseience ouly. 7. cantunt sue betanse be is not fanty to the contract, nur B. becanse he has un interest in its performance. so the nexlern evilians in. terpreted the rule altrin stipuluri neme potest and l"lpian's gless. ut alii detur nilhil interest mea, 1). 4.), 1. he v. 1. 34, $\$ 17$. Practon seems mot to have aceepted the Roman lextrine, see Mat land. Braeton and
Azo. 154-155. It is far froml rertolin that ceusu was really a current term in the early lart of the lith century amomg any canonists or civiliank from whom Englishmen were likely a borrow.

(t) Clyian in one place, [ . 14, s. de praceser. verbis. 15, gues near to a generalization when he says of the promise of a rewald for information of a lunaway slave: "Coun. ventio ista non esi nuda. ut quis dicat ex parto actionem non oriri, sed hahet in se negotium aligund."

(ii) Juthier. obl. \$ 42 ; sirey and dilbert on Code Nap. 1131: Denolumbe. Cours lu crale Nap. xxiv. 32!9 s4\%. : langdell, sel. Ca. (int. 169; so in lermany from 
scheme of actions for turning natural into legal obligation $(x)$.

We may now trace the characteristic points of the English doctrine. It was understood as early as the third quarter of the fifteenth century, with reference to the quid pro quo of Debt, that apparent benefit to the promisor is immaterial. In 1459 we have this case. Debt in the Common Pleas on an agreement between the plaintiff and defendant that plaintiff should marry one Alice, the defendant's daughter, on which marriage defendant would give plaintiff 100 marks. Averment that the marriage had taken place and the defendant refused to pay. Danvers J. said: "The defendant has quid pro quo: for he wiss charged with the marriage of his daughter and by the espousals he is discharged, so the plaintiff has done what was to be paid for. So if 1 tell a man, if he will carry twenty quarters of wheat of my master Prisot's to $G_{\text {. }}$, he shall have 40 s., and thereupon he carry them, he shall have his action of debt against me for the $40 \mathrm{~s}$; and yet the thing is not done for me, but only by my command: so here he shows

the 17 hl eentury onwards. with only theoretical differenees as to the reason of the rul*: sinufiert, Zur Giesch. der obligatorischen Vertı̈ige, !30 sty

(r) The view liele girnen is sul,stantially that of the late l'rol. Ames of llarvard (The llistory of Assumpsit, Hatv. Iaw Rev. ii. l. .33, now reprinted and revised in setect Essays in Anglo-Amer, legal II istory, iii. 25!1), who has put the whole subject on a new fouting. Mr. Instice Ilolmes's ingeninus attempt tomake the quid fmo quo of debt eover the whole gromml, and ernucet it with the functions of the serto in Anglo-Noman procelure. dhes mol senm aeceptable: see Pollork and Matithum, IJist. ling. Law. ii, elt. As to civilian intluences, it is improsible to prove
Benefit to promisor not. material. that there was none, but for the reasons in the text I think very little of it reached the minuls of practising tommon lawyers. Mr. Falumol's learued argument (Essays in. Jurispmdence and Legal Ilistory, No. iv.) fails to reemvert me to my own former opinion. One may almost say that, if there hart been any real borrowing, there must have been more misunter. standing. The repetition of the

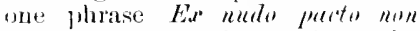
aritur actio, caught up from the eivilians, was, on the whole, harmless. As late as 1842 a despremate attempt was male by the late E. V. Williams J., when at the bar, to mix up the civilian couso with the doetrine of consitleration: Thumas v. Thomas, 1). 176, above. 
Adequacy of consideration not inquirel into

that he has performed the espousals, and so a good cause of action has accrued to him: otherwise if he had not performed them " $(y)$. Moyle J. : "If I tell a surgeon, if he will go to one .J. who is ill, and give him medicine and make him safe and sound, he shall have 100s.; there if the surgoon does cure. J. he shall have a good action of debt against me for the 100s., although the thing was done for another and not for the defendant himself; if there is not quid pro quo, there is what comes to the same" (y). Prisot (C.J. and Danby J. thonght such an action not maintainable except on a specialty (though Prisot was impressed by Danvers's and Moyle's instances), and an objection was also taken to the juristiction on the ground of marriage being a spiritual matter: the calse was adjourned and the result is not stated. But the point is quite clearly taken that what a man chooses to bargain for must be conchusively taken to be of some value to him.

It is really by a deduction from this that our Courts have in modern times laid it down as an "elementary principle that the law will not enter into an inquiry as to the adequacy of the consideration' $(z)$. The idea is characteristic not only in English positive law but in the English school of theoretical jurisprudence and politics. Iobbes says: "The value of all things contracted for" is measured by the appetite of the contractors, and therefore the just value is that which they be contented to give" $(a)$. And the legal rule is of long standing, and illustrated by many cases. "When a thing is to be done by the plaintiff, be it never so small, this is a sufficient consideration to ground an action" $(b)$. "A is possessed of Blackacre, to which B. has no manner of right, and $A$. desires $B$. to release him all his right to

(y) M. 37 H. VI. s. pl. 18.

(i) Wrotlake r. Adams (1855) i (. P. N. S. $24 \times .265,27$ L. J. C. P. 2il. jur liglest. (a) Leviathall, pt. 1, c. 15.

(b) sturlyn v. Albany, Cro. Eliz. (ij, and see Cro, ('ar. ii, and marginal references there. 
Blackacre, and promises him in consideration thereof to pay him so much money; surely this is a good consideration and a good promise, for it puts B. to the trouble of making a release" (c). The following are modern examples. If a man who owns two boilers allows another to weigh them, this is a good considleration for that other's promise to give them up after such weighing in as good condition as before. "The defendant," said Lord Denman, "had some reason for wishing to weigh the boilers, and he could do so only hy obtaining permission from the plaintiff, which he did obtain by promising to return them in good condition. We need not inquire what bomefit he expected to derive " $(d)$. If the owner of a newspaper offers to give advice on financial matters to any one who will send his inquiry to the city editor, writing to the city editor is good consideration for a promise to use reasonable care in giving the advice (e). So parting with the possession of a document, though it had not the value the parties supposed it to have $(f)$, and the execution of a deed (y), though invalid for want of statutory requisites $(h)$, have been held good considerations. In like mamner a licence by a patentee to use the patented invention is a good consideration though the patent should turn out to be invalid $(i)$. In the Supreme Court of the Inited states a release of a supposed right of dower, which the parties

(a) Holt C.J. 12 Mol. 4.5\%

(d) Buintsridlye v. Firmstome (I838) \& A. d E. 743, , .3 R., 1., 234.

(e) De la lisere v. Pearsime [1908] l k. B. $2 \times 0$. (.. A., 77 I. J. K. 1;. 380 , C. A. liut perhaps the ciuse of action iss better regardel as arising from default in the performance of it voluntary molertaking indepentent of contract.

(f) Hoigh v, Browks $(1 \times 3: 4-40)$ (2. B. and kx. ('h.), 11 A. \& E. $309,320,334,50$ li. R. 399, f07. 417. Or letting the promison retain posscession of a doeument to which the promisee is entitled: /lart v.

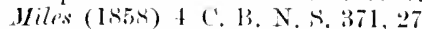
L. J. (. I'. 215 .

(g) (1). Jones v. Waite (1842) 9 Cl. it 10101.

(h) See note ( ) ) last page. The defemdant hat in fact hawl the full berefit of the consideration, the deed having been aeted on.

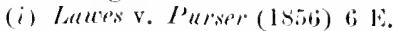
d 13. 934, 26 I. J. Q. L. 2.\% 114; ii. Ri. sitis. 
thought necessary to confirm a title, has been held a good consideration for a promissory note $(k)$. The modern theory of the obligation incurred by a bailee who has no reward is that the bailor's delivery of possession is the consideration for the bailee's promise to keep or carry safely. The bailor parts with the present Jegal control of the goods; and this is so far a detriment to him, though it may be no benefit to the bailee, and the bailee's tuking the goors is for the bailor's use and convenience (l). The determination of a legally indiffrepent option in a particular way, as roting for a particular candicate for a charity where there is not any duty of roting for the candidate judged fittest, is legal "detriment" enough to be a good consideration ( $m$ ). It has been held in equity, to the same effect, that a transfor of ratway shares on which nothing has been Same rule in paid is a good comsideration (n): and that if a person requity. indented to a testator"s estate pays the probate and legacy duty on the amount of the debt, this is a good consileration for a release of the debt by the residuary legateen (o): a strong case, for this riew was an afterthought to suppert a transaction which was in origin and intention certain!y gratuitous, and in substance an incomplete voluntary release; the payment was simply by way of inlemuity, it being thought not right that the dehtor should both take his deht out of the estate and leare the wate to pay duty on it. The consent of

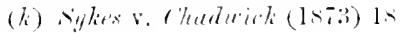
Watliane. $1+1$.

(7) (1) WI. Ilolnes. The Common Law, 2!t sty. Ilistorteally. the explanation is that the action sounderl in torl until grate mulem times. il. 1etti. The hallor parts with very little, for, if the bailment is at will, he as well ar the bailee can -ne a trespaser. The real ditheulty. howerrer is that in such eares. for the now part. the

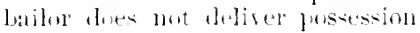

at the bailee serpuest, but reynests the Inilee to take it. One of the necesary elements is therefore lietitious. Cp. Langelell. ș rs.

(iii) Dultan v. Mulden (1si3) I. li. !' (1) R. . . ).

(11) Ghedle v. kemard (Jsis) 3 I) (i. . I. 27, 27 L. J. (Ch. 784. (a) Taylur s. Mannors (186.5) L. R. 1 (h. th, 3.5 L. J. ('h. 123. by Tuner L.J. dul. Knight Bruce $1 . .1$. 
liquidators in a voluntary winding-up to a transfer of shares is a good consideration for a guaranty by the transferor for the payment of the calls to become due from the transferee $(p)$. An agreement to continuei.e., not to determine immediately - an existing service terminable at will, is likewise a good consideration $(q)$. The principle of all these cases may be summed up in the statement made in so many words by the judges in more than one of them, that the promisor has got all that he bargained for'. 'The law will be satisfied that there was a real and lawful bargain, hut it leaves parties to measure their bargains for themselves. It has been suggested that on a similar principle the consileration Contingent consideration. for a promise maty lie contingent, that is, it may consist in the future doing of something ly the promisee which he need not do unless he chooses, but which being done by him, the contract is complete and the promise bind ing. But this cannot be. A consideration must be either a present act or forbearanee or a promise. If a tradesman agrees to supply on certain terms such goods as a customer may order during a future period, this is not a promise, but an offer. Ife cannot sue the customer for not ordering any goods, hut if, while the offer stands, the customer does order any, the condition of the offer is fultilled, and the offor being thus accepted, there is a complete contrat which the seller is bound to perform $(r)$.

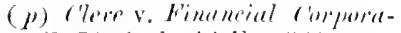
tion (1873) 1. Ii. 16 Er . :363, :375. $431 . .1 .(11.54$.

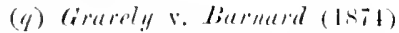

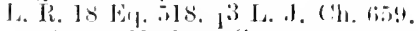
(i) (i. ) líl. (i) r. IJithem

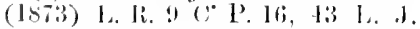

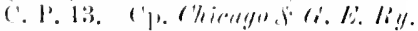
f'o. v. Juthe (1873) 4:3 N. Y. (1 llaml.) 2t1, where it wat lightly helet that a genemal assont to ati offer of this kimul (not mollentakings to order, ar ats in thr partionlat case tember to le carried, any detinite pluantity of gonels) alid not of itself constitute a contract. C.P. R. v. Demers $19(10)]$ A. t'. 1(13, 6!) 1. J. P. ('. 5) ; mulne lerench canalian law, but no difference. in principle is suggesteal. This serols to have been overhosed in

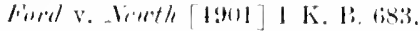
7) 1. I. K. li. lis. (lford r.

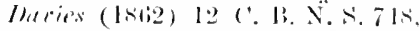
Finch, Sel. ('a. 37 , the catse of a glatratly, limitel totwelvommlls, 
Inadequacy as eritenee of fraud. sc.

Pillans $r$. Tan Nicrop.

Great inadequacy of consideration may, however, be material in cases of fraud and the like, though material as evidence only. This will be dealt with hereafter.

In the interesting eighteenth - century case of Pillans v. Van Mierop (s) the actual decision was on the principle that "any damage to another or suspension or forbearance of his right is a foundation for his undertaking, and will make it binding, though no actual benefit accrues to the party undertaking" $(t)$. But Lord Mansfield threw out the rerolutionary suggestion (which Wilmot J. showed himself inclined to follow, though not wholly committing himself to it) that there is no reason why agreements in writing, at all erents in commercial affairs, should not be good without any consideration. "A nudum pactum does not exist in the usage and law of merchant.. I take it that the ancient notion about the want of convideration was for the sake of evidence only . . . in commercial cases amongst merchants the want of consideration is not an objection " $(u)$. The anomalous character of this dictum was rightly seen at the time, and it has never been followed $(x)$. It was too late to set up a new class of Furmal Contracts, which was really the effect of Lord Mansfield's proposal. But if it had oceurred a century or two earlier to a julge of anything like Lord Mansfield's authority, the whole course of the English

of bills which the plaintiff might discrunt at the request of the defendants, involves the same frinciple; for the so-called guamanty. ar explained by the jutgment. was in truth only a stantung wffer.

(*) (17ib) 3 linut. lfitit. and Fineh sel. ('a. 2ris.

(t) Yer Yates J. at J. lizt.

(ii) 3 Burr. 1669 - 71 .

(x) In 1738 it was distinetly contradicted by the opinion of the judges delivered to the House of I_orils in titun v. Mnghes (17T-S) 7 T. R. 3.10, 11.: "All eontracts are. by the laws of England, distin. guisher intw agreements by specialty :tul agreements by parol; nor is there any such third elass, as come of the counsel have en(lea roured to maintain. as contracts in writing." Langdell ingenionsly arguted (summary $\$ \$ 49,50)$, that eontracts governed by the law merchant need on principle no eonsideration: in short, that a negitiable inst rument is a specialty. It might have been better so. In this cuntry one can only say dis aliter risum. 
law of contract might have been changed, and its principles might have been substantially assimilated to those of the modern civil law as adopted by the law of Scotland.

Another doctrine made current by Lord Mansfield and some of his colleagues with more success (y) was that the existence of a previous moral obligation constituted such a relation between the parties as would support an express promise. The Exchequer Chamber finally decided as late as 1840 , that "a mere moral obligation arising from a past benefit not conferred at the request of the defendant" is not a good consideration $(z)$. It is still not quite settled whether a past benefit is in any case a good consideration for a subsequent promise. On our modern principles it should not be $(a)$, and it is admitted that it generally is not (b). For the past service was either rendered without the promisor's consent at the time, or with his consent but without any intention of claiming a reward as of right, in neither of which cases is there any foundation for a contract $(c)$; or it was rendered with the promisor's consent and with an expectation known to him of reward as justly due, in which case there were at once all the elements of an agreement for reasonable reward. It is said, however, that services rendered on request, no definite promise of reward being made at the time, are a good consideration Supposed exceptions : Lampleigh $r$. for a subsequent express promise in which the reward is for the first time defined. But there is no satisfactory modern instance of this loctrine, and it would perhaps

(y) See the mote to Houmall v.

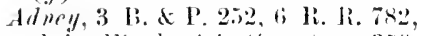
ancl in Finch sel. Ca. at p. 358, which is approved by Parke ls. in Earle volirer (18ts) 2 kx. 71 , at 1. 30, and has long been regarded as elassienl on the whole prest inn of past eonsideration.

(z) Edestroud r. Kingmu (1810) l'romises founded on moral duty.

Past con. sideration ineffectual.
11 A. \& E. $43 \times, 446,22$ li. R. 400 . (i) Cp. langlell, of cit. s!l. (b) Rosestala v. Thumas (1842) 3 Q. 13. 321, 6il 1i. R. 216, Finch sel. (a. 310.

(1) "It is not reasenahle that one man should de another a kindness, and thon charge him with a recompense." 1 Wms. Salinil.3sti. 
l'erformance of another's legal duty.
Ackinow leriguant of barred delotin.

now be held that the subsequent promise is only evidence of what the parties thought the service worth $(d)$. It is also said that the roluntary doing by one party of something which the other was legally hound to do is a good consideration for a subsequent promise of recompense. But the authority for this proposition is likewise found to be unsatisfactory. Not only is it scanty in quantity, but the decisions, so far as they did not proceed on the now exploded ground that moral obligation is a sufficient consideration, appear to rest on facts establishing an actual tacit contract indruendent of any subsequent promise.

Another exceptional or apparently exceptional case which certainly exists is that of a rlebt hared by the Statute of Limitation, on which the remedy may be restored by a new promise on the debtor's part. It is said that the legal remerly is lost but the debt is not destroyed, and the dobt subsinting in this dormant condition is a good consideration for a new promise to pay it. This is not logically satisfying, and in fact it belong to the now discredited riew of past consideration. There is no real equivalent for the new promise, and the only motive that can generally be assigned for it is the feeling that it would he morally wrong not to pay. It

(d) Latmpleigh v. Mratherrit (1filfi) Hob. los, an1 I sm. L. 1'.; sef per Erle C... 13 1'. I. X. S. at 1. itu. The J rish cas: of Bimdtom v. Romston (18.5) \& Ir, (‥ I. Rep. the, will. for Euglish lawyers at least, hardly out weigh this dictum : and the shetrine whuld seem to be open to examination in the $C . A$., see per Buwen L.J. strmut $\mathrm{r}$.

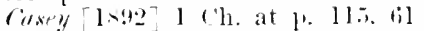
I.. .J. Ch. (B1. See Auson. M1. 111117 , ani ep. Clank Hare un (nontracts. 210-24!. At an earlier time it was hell that a pant consideration would not support an action of lebt, but was enough for asimplit. Mash ve Rainsford (15is) 2- Jem. 111 : Fidlmham $\mathrm{r}$. Hortiugtu" (1545) ih. 22t: Finch sel. Ca. 337: O. II. Holmes, The Common law, 2xt. 297. The theery was still that the breach of promise was an actionale wron: beranse of an existing relation between the parties which created a sinecial huty. not that an executury contract. as such. ereated an obligation : and on that theory there was no reasm why the promise and the consideration should be simultaneous. But Lord Mansfiekl cannot be supposed to have known anything of this. 
seems better at this day to say that the law of limitation does not belong to substantive law at all, but is a special rule of procedure made in favour of the debtor, who may waive its protection if he deliberately chooses to do so $(e)$.

The most characteristic rule in our law of consideration, and the most important for the business of life, is that mutual promises are sufficient consideration for one another. When the subject was still novel it would not have been difficult, one would think, to frame plausible arguments to the contrary. In fact there is no conclusive reason, other than the convenience of so holding $(f)$, for the rule that a promise and counterpromise will make one another binding: for neither of them, before it is known to be binding in law, is in itself any benefit to the promisee or burden to the promisor. If it be suggested that the mere utterance of words of promise is trouble enough to be a consideration, the answer is that such is not the nature of the business. Moving of the lips to speak or of the fingers to write is not what the promisor offers or the promisee accepts. However, there is very little trace of dissension in our books. As early as 1555 , the validity of reciprocal promises passed without question in a case reported on another point $(g)$. In 1615 it was disputed (we are not told on what grounds), and finally affirmod $(h)$. The promises must he exchanged for one another at the same time $(h)$, and each of them must, be binding

(e) See more on this juint in ('h. XIII.

( $f$ ) The only result of holiling otherwise would have been to impose a nominal executed consirleration. suel as delivery of a nut, a pin, or a farthing, on the formation of contracts by mutual promises ; this formality would have becone incxtricably confused with the archaic but not extinet
Mutual promises. 
on the face of it, that is, must not be unenforceable for any intrinsic reason. A promise which purports to be merely honorary, or which is invalidated by any rule of general policy or special provision of positive law, is no consideration $(i)$. It is true that the promise itself, not the obligation thereby created, is the consideration $(k)$; still, the value of a promise does not consist in the act of promising, any more than the value of a negotiable instrument consists in a piece of paper with writing on it, but in the assurance of the performance to which the promisor obliges himself, or, at worst, of damages for his default. A promise may be incapable of being sued on $(l)$, and therefore incapable of being a consideration for a counter-promise, for various reasons which we have examined or shall examine under their proper heads. Such reasons do not form part of the doctrine of Consideration, as is shown

to teliver the lefendant to his own use a cow, the lefemlant promised to deliver him tifty shillings: at julderl for the plaintiff in both Courts. that the plaintiff need not to aver the Jelively of the cow, because it is romise for promise. Note here the promines must be at one instant, for else they will be both mula pacta." Ste intermediate eases collected by l'rof. Ames in Harv. Law Rier. xiii. 32. n.

(i) Ilareindn s. Fage, 5 Mod. $4 \mathrm{Il}$; Langilell, "Mutual l'romises as a Consideration for each other," Harv. Law liev. xiv. 19li. 314. Some rery leamed persons atot the further condition that the performanee of the promise must be such as will or may impose a legal retriment upon the promisor : Prof. Willistun's note here in 3ril Amer. edn. Coutra. Isanglell. Harv. Law Rev. xiv. sos, with whom I agree.

(k) Anes. "lwo Themries of consideration." Harr. Law hev. xiii. 29. 32. But when Prof. Ames sugerests, at p. 34, that a promise which is and is known to be merely honorary nay be a good consideratiun, he seems to overlook the un. disputed authority of IIavismn v. Cuyp (last note). Certainly some men's honorary promises are in fact worth more than some meu's legal fromises, but the law cannot estinute or regard this. Mr. Justice (). W. Holnes. on the other hand, suggests that every legal promise so really in the alternative to perform or to pay damages: which can only he regarded as a brilliant pararlox. It is inconsistent not only with the existenee of equitable remerlies, but with the modern common law doctrine that premature refusal to perform may be treated at once as a breach. See li3 L. S. at 1. 600): Harriman, S.5.)

(l) ln many eases a promise may be aetionable thomgh not eapable, in fict or in law, of performance. 
by the fact that the same or similar reasons exist and are applied in the modern Roman law and national bodies of law derived from it, where the Common Law rules of Consideration are unknown $(\mathrm{m})$. In many cases a promisor has the option of avoiding his contract for some cause existing at the date of the promise. But in all such cases the contract is valid until rescinded, and the right to rescind it may be lost by erents beyond the promisor's control ; so there is no difficulty in treating his promise as a good consideration.

Since a promise which is to be a good consideration for a reciprocal promise must be such as can be Certainty required. enforced, it must be not only lawful but reasonably definite. Thus a promise by a son to his father to leave off making complaints of the father's conduct in family affairs is no good consideration to support an aceord and satisfaction, for it is too vague to be enforced $(n)$. And upon a conveyance of real estate without any pecuniary consideration a covenant by the grantee to build on the land granted such a dwelling-house as he or his heirs shall think proper is too rague to save the conreyance from being voluntary within 27 Eliz. c. $t(0)$.

Similarly, neither the promise to do a thing nor the actual doing of it will be a good consideration if it is a thing which the party is already bound to do either by the general law or by a subsisting contract with the other party $(p)$. It seems obvious that an express

Promises of a thing one is alreatly bound yenerally in to the promisec to ilo.
(III) Thus the question of the performance being possible is irrelevant here. In any case the language of 2 Wms. Samul. 43e and of the dicta there relied on is much tor wirle.

(11) Illite v. Inluott (J-.3.3) $2: 3$ L. I. Ex. 34, os R. It. I! 2 ; this -eems the ration defidtudi, thomerls of expremerl only by lauke li., who ankel in the course of argument, "Is an agreement by a father in

P. eonsirleration that his sun will not bore hin a binding contract ?"

(1) Rosher v. IItllium.s (1875)

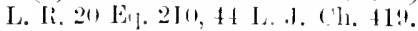
(11) Soe Leake, 431; ; ant besides authorities there given. Derforn v. Ciridle! (1851) I\% C. IR. 295. 24 L. I. (¿ I'. 17, 100 Ji. Li, 3.57; and the jutgment on the ith plat in

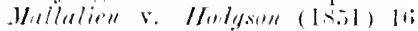
(2. В. 689,201 I. J. 12. 13. :339, 83 li. R. 679. 
promise by $A$. to $B$. to do something which B. can already call on him to do can in contemplation of law produce no fresh advantage to $B$. or detriment to $A .(q)$. But the doing or undertaking of anything beyond what one is already bound to do, though of the same kind and in the same transaction, is a good consideration. A promise of reward to a constable for rendering services beyond his ordinary duty in the discovery of an offender is binding $(r)$ : so is a promise of extra pay to a ship's crew for continuing a royage after the number of hands has been so reduced by accident as to make the royage unsafe, so that the crew are not bound to proceed under their original articles $(s)$. So, it is conceived, would be a promise in consideration of the promisee doing at a particular time, or in a particular way, something which otherwise he must do, but has the choice of doing in more than one way, or at any time within certain limits. Again, there will be consideration enough for the promise if an existing right is altered or increased remedies given. Thus an agreement to give a debtor time in con-ideration of his paying the same interest that the debt already carries is inoperative, but an agreement to give time or accept reduced interest in consideration of haring some new security would be good and binding. The common proviso in mortgages for reduction of interest on punctual payment-i.e. payment at the very time at which the mortgagor has covenanted to pay it-seems to be without any consideration, and it is conceived that if not under seal such a proviso could not be enforced $(t)$. Again,

(4) Fone Aneriean conth, however, hokl otherwine: Harriman (1) contracts. \$11\%.

(1) Enyland v. Duridsen (19411) 11 A. \& L. 8., 22 R, R, 322 .

(.) Hartley r. Poms+ndy (1s5i) i E. \& B. 8.2. 26 L. J. Q. B. 322.

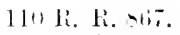

(t) This could be at once prorided against, however. if -0 desirel. by fixing the time fur "punctual parment " a single day earlier than those named in the mortgagrors corenant. 
the rule does not apply if the promise is in the nature of a compromise, that is, if a reasonable doubt exists at the time whether the thing promised be already otherwise due or not, though it should be afterwards ascertained that it wasso. We shall return to this when we speak of forbearance as a consideration.

Difficult questions arise when we have a promise made in consideration of the promisee doing or promising to do something which a subsisting contract with a third l'erformanee of sulsisting obligation to person has already hound him to do. Such cases are not frequent, and there has not yet been any full or satisfying judicial discussion of them. It would seem that, being infrequent and of no great importance in current affairs, they shonld be disposed of by the strict application of settled principtes, and that, even if such application should lead to apparently fine distinctions, the principles ought not to be tampered with merely to aroid that result. From this point of view, Andrew's performance of his binding promise to Peter does not appear capable of being a consideration for a new promise by John to Andrew; not hecause it camnot be beneficial to John, for this it may very well he, but because in contemplation of law the performance is no new detriment to Andrew, but on the contrary is benefieial to him, inasmuch as it discharges him of an existing obligation. Therefore the necessary element of detriment to the promisee is wanting (u). It seems therefore that if a promise is given in exchange merely for the performance of the promisee's duty under an existing contract with a third person, it in not binding. Anthority, however, is the other way so lat as it goes.

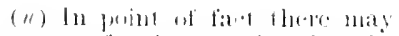
leseme, for it Jaty low that lie might have milted the performance with impunity. But this is like the cau of a merely homory lomise. The law is noule tor fit

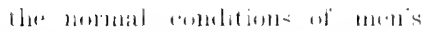
attairs. If ereey man's worl were a gand as his bourl, ne nobuly cared to enterce his rights, there would be mo place for any law of rontract at all. 
Performance of this kind appears to have been held a sufficient consideration in three English reported cases $(x)$, one from the early seventeenth and two from the middle part of the nineteenth century. In the first of these (y) the plaintiff and defendant were jointly liable as sureties on a bond, long before the modern equitable doctrine of contribution between cosurreties was established. In consirleration of the plaintiff paying the whole debt, the defendant promised to repay him half. The promise was held binding, but the real rifficulty does not appear to have been dealt with $(z)$. In the second case (a) the plaintiff, being engaged to be married, did (on the facts as assumed) proceed with the marriage on the faith of a promise by his uncle, the defendant's testator, to pay him an annuity during the prominor's life. The plaintiff succepled in an action for arears of the ammuity. To the majority of the Court it appeared sufficient to say that the marriage took place at the testator's request. But this (whether rightly saif or not) does not answer the question whether the simple fulfilment of a promise of marliage already binding on him could be any legal detriment to the promispe. The third case (b), in an

\footnotetext{
(r) The frimt might perhap have been considerel in .Jums $v$. Waite (1839. Int2) ; ling. X. C.

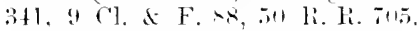
iri, lon the aroment and deciojon were on other gromuls. Sote that

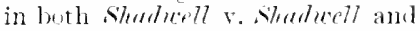
Siotsone r. Peyg it is by no meaneasy to be sure whother the Compt thought the considelation was performance or fromise. or whether the performance was exactls the performanet of an existing obligation. See hatrv Law Revorvil. (y) Butyle v. Nade (Itilb) 3 Bulst. 162. This derinim was a]parently forgotten until Prof. Ames lately called at tention to it.

(z) It i-certainly not toncherl by the statement, perfectly correet in
}

itself, of Dodleridge J.: * If the consileration puts the other to chares. though it be no ways at all frititable to him who mate the uromise, rei this shall be a gool "romileration to raise a promise."

(a) Sluaduell v. Shaduell (Is6o) 9 C. 1\%. N. .. 159. 30 L. J. C. P. 145. Brles 1. diss. chiefly on the groumi that there was really no animus controllendi, but only an act of bounty, cl. Lingdell, s 6s. If the re were any unimus contrullendi, an acceleration of the marriage at the testator's request would no donbt have male a gond consideration, but that was not averred.

(B) Soutson v. Pegg (Isti) $6 \mathrm{H}$. 太 N. 245. 30 L. J. Ex. 225. 
entirely different subject-matter, also goes on the ground of the performance being, in point of fact, both a benefit to the promisor and a detriment to the promisee. Here the defendant's promise was to nuload a cargo of coal at a certain rate in consirleration of the plaintiff delivering the coal to him, which the plaintiff was already bound to do under a prior contract with the shippers of the coal, from whom the defendant had bought it. There is a suggestion in the course of the argument that the performance requested by the defendant may have added new terms, as to time and manner of delivery, to that which the plaintiff was already bound to do, and it may be that the plaintiff was entitled to succeed on that point, if properly raised. But there is nothing of the kind in the judgments. It seems to be assumed that the rule must be the same whether the consideration relied upon is a performance alrearly due to a third party or a new promise thereof to the defendant. And so the Supreme Court of Massachusetts thought not very long ago (c). The validity of this assumption must, however, be examined.

Let us now take the case of a promise by John to Peter to do something whith he has already promised William to do. Such a promise may obviously create a moral obligation; for Peter may in many ways have a just and reasonable interest in boing assured that P'rominise to rerform nbligafion to, thind persin under subsisting Jolm will perform his contract, with William. Then is there any reason why it shonld not create a legal obligation, if supported by a sufficient consideration on Peter's part? The promise is a new and distince

(c) Hboft v. Dorem (Is,50) 163 Mass. 133: : mol see the jumbent of Wille li. in siontsoll v. Pergy. At first sight it lowlis imponsible, as at whe time it flid to myself, that a promise com be a goor comsirleration if performance of tho thing forminerl would not. liut the seening baralox vanishes when we hear in mind that the true test of consideration is mo benetit on the formisos bit dehinent to the peomise.e. As this was wholly ignoled in sertsunt ve f'tyt, the julgments in that case are moninstruetive. 
promise, creating, on the face of it, a new and distinct duty to a new party. Doties to sereral parties to perform thesame thing aresimultanemun ly crated in many fuite common forms of corenants. Why should they not he: craded by sucersicios and independent alets? Will any one deny that John's promise to Peter will be binding if given in exchange for a performance-say immediate payment of monte ly Peter? If it is not, this must be the lenult of some special rule of legal policy, for no other objection seems ponsible. But of any ancle rule of prolicy thele is no trace. If then the promise is hinding when given for a performance, why should it he less binding when it is given in exchange for Peter's promise? There is no roason in the nature of the cast for making any difference. If there were a poritive rule of law, fomended on reanons of policy, for not allowing John's promine to t'eter to perform his contract with William to be good, then Johnts promise would be no consideration; but only becaure, eren though supported hy sufficint consideration on the other side and satisfying all ordinary requisites, it was deprived of ralidity by the poritive rule, and therefore made incapable of having any ralue in contemplation of law. But again, no such positive rule can be produced. It has been said that John's promise is a good consideration only if it is hinding, and we have no right to assume that it is binding. The answer to this objection is that, if John's pronise can be binding, it is male so by the comnter-promise, and it is for the objector to show that it camnot be. The objection, in truth, if good for anything, is equally good to prevent mutual promises from ever heing a consideration for ach other; for in every such case neither promise, taken hy itself, is of any legal force or value (d).

(d) louf. Willi-ton, npholitines the objection ariginally rai-ed by
Fir Wr. Anson (now at p. lus of his lith ed.), perceived this. and pro- 
There is no objection, in any case, to a promise by John to Peter not to rescind a subsisting contract with William, or not to aceept a waives or release of it ; and a promise in that form would certainly he a good con sideration.

No direct decision has heen made in England on the validity of a promise to perform an existing contract with a thind person. A negative solution could not be given, it is apprehended, without overruling the cases in which, apparently, performance has been held sufficient; while a positive one, if the argument above submitted be sound, might be given for independent reasons. Not that I am at all desirous of upholding the authority of the cases in question. I venture to submit, on the contrary, that they were wrongly decided, or at any rate not on satisfactory grounds. What is here maintained is that a promise mate for raluablo consideration, and otherwise good as between the parties, is not the less valid because the performance will operate in discharge of an indepentent liability of the promisor to a third person under an independent contract already existing. This was the opinion of W. M. Leake (e), a most accurate lawyer, and of Prof. Langdell of Harvard $(f)$.

posed to meet the dithenlty by eunstructing an entirely new throry of mutual pronises: Harv. baw liev. viii. 27. Cp. 1)! 1!1-192, above.

(e) It may be worth while in cite the language of his tirst eftition, 1sit, 1. 321. "If a man lats alrealy contracted with another to ho a certain thing het rannot make the petformane of it a consideration for a now pomiso to the same individual ; but where there has been it promise to one person to tho a certain thing, it is ponsible to make a promisice to another to do the sime thiner. which may form a vali] onseleretion in a eont ratet with that othes."
In later elitions the worling is alterel and simplitied but the sub. stance is the same (5th ed. by A. E. liamlall, $\% 4.43)$. As to Hurtun v. BHrn (18:3) 7 A. \& H. 19, citol hy Jacke in sllymet, ser: L. Q. li. xxii. 32:3. Leakestrinion wats aseleokel throughont it lirolomered diecusion of lle puint some reatrs ilgu.

$\left(f^{\circ}\right)$ There has been txtlat. ordinary divergence of bentuert mpinions. Sir II. Anson and Prof. Williston (note (d) above) think neither performatme nor promice at gorol consideration in this class of gates. Prof. Ames (llare latw

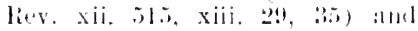


Rules as to comsileration extemled in the discharue of eontracts.

The doctrine of Consideration has been extended with not very hapjy results heyond its proper scope, which is to govern the formation of contracts, and has been made to regulate and restrain the discharge of contracts. For example, where there is a contract of hiring with a stipulation that the wages due shall be forfeited in the event of the servant being drunk, a promise not under seal to pay the wages notwithstanding a forfeiture is not binding without a new consideration $(g)$. It is the rule of English law (now referred to the same reason, though really older) ( $h$ ) that a deht of $100 l$. may be perfectly well discharger by the creditor's acceptance of a beaver hat or a peppercorn, or of a negotiable instrument for a less sum (i), at the same time and place at which the 10ol. are payable, or of ten shillings at an earlier day or at another place, but that nothing less than a release under seal will make his acceptance of 99l. in money at the same time and place a goorl discharge $(k)$ : although modern decisions have confined this absurdity within the narrowest possible limits $(l)$. A judgment creditor agreed in writing with

pof. Hontiman (Contracts. p. ti:) admit buth. leake (liat note). lancriell. summary. sto it. ot Harr. Law lier. xis. 4!ni, aml

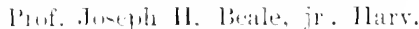

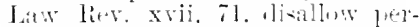
formance and allow pomies and with them. fol the letene given in the text. I aterea. lint if sach Gate were (ontmon there would 1e no great ham in allowing performance as well on the crmunt of comsenienes. In Amerieat the neestive chinion of sir W. Anesn and l'rof. Williton is sait to prevail.

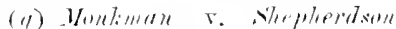
(liii) 11 A. A E. t]1, IZ R. R. $3:+11$.

(h) See Harv Law liev xii. i2l.

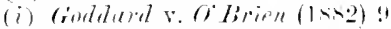
Q. B. 11. 37: Pidder r. Pridges (1) 'h. 300. Or a less sum in a diffelent currency : Cit" of Sull

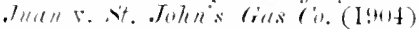
$19: 1$. . 510.

(i) Milluel's rase (I60) 5 (C). lity. 117. confirmes with reluctance by the House of Lorks in

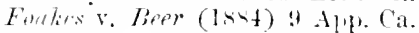
tilis, it I. I. Q. IS. 130, Loril likaliburn all but discenting. The Inclian (ontract det (s. 63. illust. b.) is accorlingly careful to express the contrary. The rule in Pinnels. arsp. it may be motel. though fraraloxical. is not anomalens. Its Humerical logic mas be archaic. but it in strictly logical. The Court doen not know judicially what a beaver hat may be worth, hut it mut know that 10 l, are not worth $20 \%$.

(l) See the nutes to ('umber $r$. llate (IIS) in $15 \mathrm{~m}$. I. C. 
the debtor to take no proceedings on the judgment in consideration of immediate payment of part of the debt and payment of the resiche by certain instalments; here there was no legal consideration for the creditor's promise, and he was entitled to claim interest on the debt though the whole of the principal was paid according to the agreement $(\mathrm{m})$. This rule does not touch the ordinary case of a composition between a debtor and several creditors; for every creditor undertakes to accept the composition in consideration of the like undertaking of the other creditors as well as of the debtor's promise to pay it (n).

If it is agreed between creditor and debtor that the duty shall be performed in some particular way different from that originally intended, this may well be binding: for the debtor's undertaking to do something different though only in detail from what he at first undertook to do, or even relinquishing an option of doing it in more ways than one, would be consideration enough, and the Court could not go into the question whether it gave any actual advantage to the creditor. But if the new agreement amounts to saying that the clebtor shall at his own option perform the duty as at first agreed upon or in some other way, it cannot be binding without a new consideration: as where an entire sum is due, and there is an agreement to accept payment by instalments, this would be good, it scems, if the debtor undertook not to tender the whole sum; but in the absence of anything to show stch an

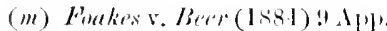

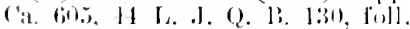

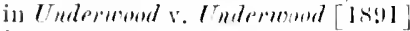
l'. 2114, 1i3 I. I. I'. 10!1. Ri1t where the solicitor of a defembant cutitlad to taxed costs acreptrel from thr: plaintilf's solicitor a

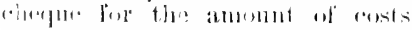

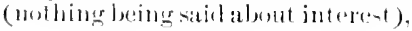

this was hell to be an acerrl and sitisfaction for ererything lue, aul the lefendant was not allower to issuce execution for the interest: birlder v. linidges (18st) 37 ('h. l)iv. fori, it t. J. (h. 300 .

(II) find v. ('hersman (18:31) 2

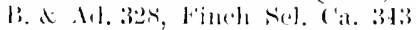
3i li. R. 5it.
The eonsideration for variation of eontrilets. 
Lenso er forlearance of rights as consilleration.
Fubearance ti) sle: 11 un-t le for detinite or ascertainaljlat time.

undertaking, the agreement is a mere voluntary indulgence, and the creditor remains no less at liberty to demand the whele sam than the debtore is to pay it (o).

The bosis abandonment of any right, or the forbearance to exercise it for a definite or ascertainable time, is for obrions reasons as good a consideration as actually doing something. In Mather r. Lord Maidstone $(p)$ the loss of collateral rights by the promisee supported a promine notwithotanding that the main part of the consideration failed. The action was on a bill of exchange. This hill was given and endorsed to the plaintiff as in renewal of another bill purporting to be accepted by the defendant and entorsed to the plaintiff. The plaintiff gare up the first bill to the defendant; thirty days afterwarls it was discovered that it was not really signed by the defendant: yet it was held that he was liable on the seennd bill, for the plaintiff had lost his remedy against the other parties to the first bill during the time for which he had parted with the possession of it, and that was comsideration enough.

As to forbearance, the commonest case of this kind of consideration is forbering to sue. Forbearance for a reaconable time is enough, on the principle of certum reddi potest: and terms in themselves vague, such as "forbearing to press for immediate payment," may be construed by help of the circumstances and context as meaning forbearance for a reasonable time. A promise to guarantee a debt if the creditor will give time to the principal debtor is in the first instance an offer: it hecomes a binding promise when the condition of giving the specified time, or a reasonable time, has been performed. It is a question of fact what is reasonable

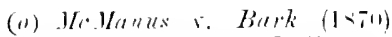
L. R. 5 Ex. (6.) 39 [. J. Ex. 6.). (1). Futhes B. Ber, note k), 1. 2(m. (p) (18.26i) 1s C. H. 273. 25 L. J. (‥ I'. 3]11, 167 R. R. 290 . 
time in a given case $(q)$. Forbearance of proceedings to enforce a "debt of hommo" hy purely conventional sanctions has more than onee been beld a good consideration $(r)$.

That which is forborne must also be tho axorcise ol: enforcement of some legal or equitable right which is honestly believed to exist. This is simply the converse of a rule already given. As a promise by A. to B. is naught if it is only a promise to do something $A$. is already bound, either absolutely or as against $B$., to do, so it is equally worthless if it is a promise not to do something which B. can alrouly, as a matter either of public or of private right, forbid A. to do. So far we assume the existing rights of the parties to be known: but as in practice they ofton are not known, but depend on questions of law of of fact, or looth, which conld not be settled without comsilferable trouble, common semses and convenience reguire that compromises of doubtful rights should be recognized as binding, and they constantly are so reangnized. " If an intending litigant bona fide forbears a right to litigate a question of law or fact which it is not vexations or frirolous to litigate, he does give up something of value $"(s)$; and such forbearance is good consideration for a promise eren

(q) Oldersletew v. King (18.5) (Ex. Ch.) 2 H. : N N. 517,27 L. I. Ex. 121), and see I Wus. Samd. 225. In Alliance Bumli v. Bromm

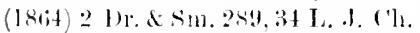
5ist. actual forbearance at the defendant's re puest, thomgh not for any sperilied time, was held ontli-

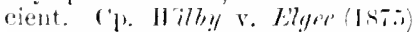
l. li. ('. P. $49 \bar{\gamma}$ ln ('mers s.

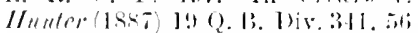

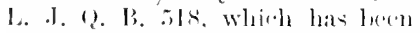
rriticizerl as ambignons, I. Q. li. iii. 4h4, it must be taken, with the heatl-note, that the consideration was artual forlearance. The londise boting in the lom of a prominuty mote. ir.. ese-entiall! uncourlitional, certainly makes a difficulty, for it would seem there was a complute promine before the consileration, viz. forbearing to sue fol a reasonable time, was or coulel be extented. On the prineiple see per bowen 1..J. in Miles. v. Vire Zimland Alford Extate ('i. (15.5-6) :32 Ch. Div. at p. 2s?

(r) E.r parte lartingal] [19014] 2 K. I. 133. 73 L. J.K. K. I11:

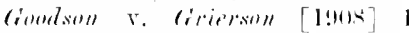

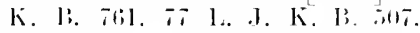
(.) 1 .

(s) Wiles vo lane Zinland llford

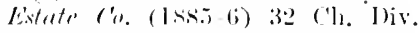

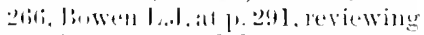
previons ratere and dicta.
There must be an actual $\circ r^{\circ}$ bitmle fide disputer] right.

Wiby contrjuninises are binuling. 
though the claim is not well founded, provided it is honestly believed in and the promisee does not conceal from the promisor any fact which to his knowledge would affect its validity $(t)$.

The real consideration and motive of a compromise, as well in our law as in the civil law and systems derived from it, is not the sacrifice of a right (of which the existence or non-existence is unknown until it has been judicially determined) but the abandonment of a claim $(u)$. The same rule applies in the case where the claim given up is on a disputed promise of marriage $(x)$. A partial compromise in which the undertaking is not simply to stay or not to commence legal proceedings, but to conduct them in some particular manner or limit them to some particular object, may well be good: but here again the forbearance must relate to something within the proper scope of such proceedings. A promise to conduct proceedings in bankruptcy so as to injure the debtor's credit as little as possible is no consideration, for it is in truth merely a promise not to abuse the process of the Court (y).

Fieaction of the general doctrine of consicleration on contracts under seal.

The main end and use of the doctrine of Consideration in our modern law is to furnish us with a comprehensive set of rules which can be applied to all informal contracts without distinction of their character or subject-matter. Formal contracts remain, strictly speaking, outside the scope of these rules, which were not made for them, and for whose help they had no need. But it was impossible that so general and so useful a legal conception as that of Consideration should not

(f) ruton L.J. 32 che Div. at 1.. 24 .

(u) Trigye v. Lacullée (1stit) 1: Mou. 1'. ('. 271, 292 (a case from Lower c'anada, then under olil Fr. law). Wilby v. Elgre (18.5)

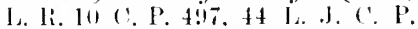
zit. The remark - of Manle .J. in
Martindale v. Fanlluer (1846) 2 (.. B. at p. 719 , 699 li. R. at 1. 611. are still profitable.

(r) Hiremu v. Handley (18tit):1). J. ‥ 28:3.

(g) Braremell s. Hilliams (186iti) I. H. 2 C'. I'. $19 \%$. 
make its way into the freatment of formal contracts, though with a different aspect. The ancient validity of formal contracts conld not be amplified, but it might be restrained: and in fact both the case-law and the legislation of modern times show a marked tendency to cut short if not to abolish their distinctive privileges, and to extend to them as much as possible the free and rational treatment of legal questions which has been developed in modern times by the full recognition of informal transactions.

This result is mainly clue to the action of the Court of Chancery. A merely gratuitous contract under seal is enforceable at common law (with some peculiar exceptions) unless it can be shown that behind the apparently gratuitous obligation there is in fact an unlawful or immoral consideration. Courts of equity did not, in the absence of any special ground of invalidity, interfere with the legal effect of formal instruments: but they would not extend their special protection and thrir special remedies to agreements, however formal, made without consideration. A voluntary covenant, though under seal, "in equity, where at least the covenantor is living $(z)$, or where specific performance of such a covenant is sought . . . stands scarcely, or not at all, on a better footing than if it were contained in an instrument unsealed" $(a)$. And this restriction is not affected by Nis slecific performance of voluntary agreement though by the union of legal and equitable juriseliction in the High Court of Justice. The rule that a court of equity will not grant specific performance of a gratuitous agreement is so well settled that it is ncedless to cite further authorities for it: and it is not to be overlooked that

(z) We shall see unler the head of undue influence that a system of presumptions has been extablisbed which makes it ditticult in many rases for persons elaining under it voluntary deed to upholit its valinlity if the domm, or even his remesenta. tives, chome within any reasmable 1 ime alterwarks to dispute it.

(ii) I'er Knight irnce I...I Geliewirls v. Wanning (1Nid) 1 ll. M. (i. I7ti, Iss, !l Ii. Ii, i3, 57.
Most conpienous in Equity. ileal. 
whereas the other mles that limit the application of this peculiar remedy are of a more or less discretionary kind, and founderl on motives of comvenience and the practical requirement of procedure rather than on legal principle, this is an unqualified substantive rule.

lint existure of comsideration may be shown aliundt.
Equity will not rive effect to imperfect gifts.

It is the practice of equity, howerer, at all events when the want of consideration is actively put forward as an objection (and the practice must be the same, it is conceived, when the objection is made by way of defence in an action for specific performance), to admit evidence of an agreement under seal being in fact founded on good consideration. where the deed expresses a nominal consideration (b) or $\mathrm{n} n$ consideration at all $(c)$, though (save in a case of fraud or illegality) a consideration actually inconsistent with that expressed in the reed could probably not he shown (b).

Closely connected with this in principle is the rule of equity that, althongh no consileration is required for the validity of a complete declaration of trust $(d)$, or a complete transfer of any legal or rquitable interest in property, yet an incomplete inluntary gift creates no right which can be enforced. Thus a voluntary parol gift of an equitab]e mortgages serarity is not enforceable; and, since bis interest in the deeds deporited with him, where the mortgage is hy deporit, is merely inciflental to his security, delivery of such deeds by the mortgagee to his donee makes no difference. and does not entitle the donee to retain them again the mortgagee's representatives (e). C'ertain modern decisions have indeed shown a tendency to infringe on this rule by

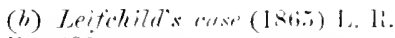
$1 \mathrm{Eq} .23 \mathrm{l}$.

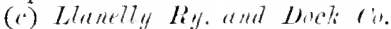

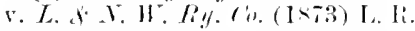
s ("i. : 4 \%?.

(d) Qul. whether this was originally right on frinciple.

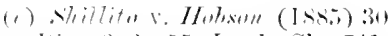
(h. Hiv, 3int is L, I. Ch. itl. The delisury over seems lo be a wholly miathorizal act dotermining the balment at common law. and therefore a trespas against the deprontor. 
construing the circumstances of an ineomplete act of hounty into a declaration of trust, notwithstanding that the real intention of the donor was evidently not to make himself a trustee, but to divest himself of all his interest $(f)$. But these have been disapprored in later. judgments which seem entitled to more weight (l)).

(f) Richards'ne v. Riolhardsome (1867) I. R. 3 Eq. 386, 36 I. J. Ch. 653; Murgun v. Mallesom (1870) I. R. 10 Eq. 47., 39 I. J. Ch. 680 .

(g) Warriner v. Rogers (I873) L R. It Eq. 340,42 L. .J. Ch. 581 ; Richards v. Delbridge (1874) L. F.
18 E1. 11, 43 I. J. Ch. 1.i!: : 1/0me v. Jowre (1871) I. R. 1s Eif. 174, 43 L. J. Ch. 6is: Iteartley v.

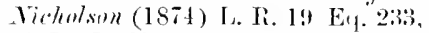
tt L. J. Ch. 277 . ('). Bireton v.

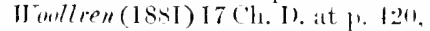
50) I. J. ('h. 3it:). 


\section{CHAPTER T. \\ Persons affecter hy Coxtr.act.}

Groneral Liules as to Partios. Original type THE original and simplest trpe of contract is an agree-
of contract. ment creating an obligation between certain persons. The persons are ascertained by their description as individuals, and not by their satisfying any general class description: or, more shortly, they are denoted by proper names and not hy class names (I). And the persons who become parties in the obligation createrl hy the agreement are the persons who actually conclute the agreement in the first instance and those only. The object of this chapter will be to point out the extent to which modern developments of the law of contract have altered this primary type either ly modifications co-extensive with the whole range of contract or by special clatsses of exceptions.

The fundamental notion from which we must take our departure is one that our own system of law has in common with the Roman srstem and the modern law of other cirilized countries derived therefrom. A wide statement of it may be giren in the shape of a maxim thus:

Legal effects confinerl to contrating parties.
The legal effects of a contract are confined to the contracting parties.

This, like most, if not all, legal maxims, is a generalization which an be nseful only as a compendions symbol of

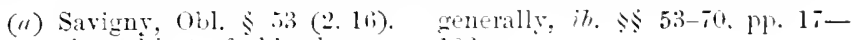
cp. on the subiget of this chapter 186. 
the particulars from which it is generatized and cammot be understoor except by reference to those particulars. The first step towards the necessary development may be given in a series of more definite lut still very general rules, which we shall now endeavour to state, emborlying at the same time those qualifications, whether of recent introduction or not, which admit of being stated in an equally general form.

It will be convenient to use certain terms in extended Detinitions. or special senses. A contract creates an oblination between the contracting parties, consisting of duties on the one part and the right to demaml the performance of them on the other.

Any party to a contract, so far als he becomes entitled to have anything performed under the contract, is called the creditor. So far as he becomes bound to perform anything under the contract he is called the debtor.

Representation, representatives, mean respectively succession and the person or persons succeeding to the general rights and habilities of any person in respect of contracts, whether by reason of the reath of that person or otherwise. A third person means any person other than one of the parties to the contract or his representatives (b).

Rules. 1. The original parties to a contract must be Rules. persons ascertained at the time when the contract is Parties. made.

2. The creditor can demand performance from the debtor or his representatives. He camnot demand nor can the debtor require him to accept performance from any third person: but the dehtor or his representatives may perform the duty by an agent.

(b) Contracts for the sisle of laud are enforesably in anty by aml against the heirs or alevigees of thet

P. Third persons not bound.

This maxim to be leveluind.

"Evelitor" and " lebtor."

- Representation."

\section{" Thind} person."

parties. But bere the obligation is torated as attached to the particular property. 
Thirel versont not entitled.

Assignnent.

Notice to lebtor.

E'puities.

Excertions : strictly perinal iluties.
3. A third person cannot become entitled by the contract itself to demand the performance of any duty under the contract.

This is subject to an cecretion as to provisions contained in a settlement made upon and in consideration of marriage for the benefit of children to be born of the marriage $(\cdot)$.

\section{Persons other than the crerlitor may become entitled} by representation, or by assignment if nothing remains to be done by the assignor under the contract (d) to stand in the creditor's place and to exercise his rights under the contract.

Errmanution 1. Title by assignment is not complete as against the debtor withont notice to the debtor, and a delitor who performs his contract to the original creditor withont notice of any assignment by the creditor is thereby discharged.

Erplunation 2. The debtor is entitled as against the representatives, and, unless a contrary intention appears by the original contract, as against the assignees of the creditor to the benetit of any defence which he might have had against the creditor himself.

The following exceptions given here in order to complete the general statement are connected in principle with the cases of a contract for personal services or the exercise of personal sill becoming impossible of performance by ineritable accident, of which we speal in Chapter VIII. below.

Eicution 1. If it appears to have been the intention of the parties that the debtor should perform any duty in person, he cannot perform it by an agent, nor can per-

(a) See 1. 221. below:

(d) Sie prel collin- M.K. in Tollenest r. Aswociated Portland rement Mamufacturess [1902] 2 K. B. thio, 60 . 71 L. J. K. L. (14!). 
formance of it be required from his representatives. Such an intention is presumed in the case of any duty which involves personal confidence between the parties, or the exercise of the debtor's personal skill.

Exception 2. If it appears to have been the intention of the parties that only the creditor in person should be Strictly personal riglits. entitled to have any duty performed, no one can becone entitled by representation or assignment to demand the performance of it, nor can such performance be required from the debtor's representatives.

Such an intention is presumed if the nature of the transaction involves personal conficlence between the parties, or is otherwise such that " personal considerations" are of the foundation of the contract (p).

Exception 3. The representatives of a deceased person cannot sue for a breach of contract in a case where the breach of contract was in itself a merely personal injury, unless special damage to the estate which they represent has resulted from the breach of contract. But where such damage has resulted the representatives may recover compensation for it, notwithstanding that the person whose estate they represent might in his lifetime have brought an action of tort for the personal injury resulting from the same act $(f)$.

These propositions are subject to several special qualitications and exceptions. Most of the exceptions are of

(p) ('). Indian ('ontracet Act.

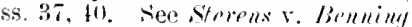
(I854) 1 K. d J. 165. 24 L. .I. Ch.

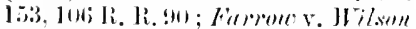
(1869) 1. R. 4 C. P. 744, 716, 38 I. J. (1. P. 3201; ; Rolinsoll v. Jallison (1871) I. IR. 6i Lix. 26i9, io I..J. Ex. 17:2 : Fimla! v. (hilm"y (IRSs) 2012. B. Div. 194, 37 T. .I. (2. 13. 2.7;

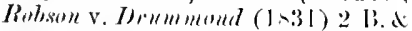

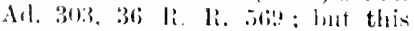
case goes very far : hitish IIlygum

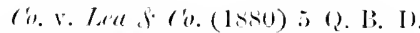
14!. 1.2, \&9 1. J. (). I;. 321. and will not be extended: l'hillips v.

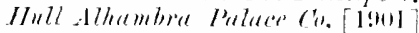
I Q. I;. 5!), 70 I. .J. 1). I3. 26 .

(f) See 1 Wms. Exems. 70!t, yth

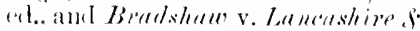

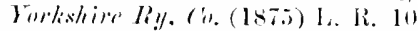

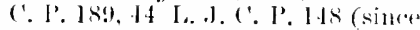
questionel in leggott v. (i. I. Ky.

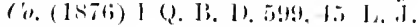
(2. 1?. .37 ). 
modern origin, and we shall see that since their establishment many attempts have heen made to extend them. Such attempts have in some departments been successful, while in other's exceptions which for some time were admitted have heen more recently disallowed.

We shall now go through the rules thus stated in order, pointing out under each the limits within which exceptions are admitted in the present state of the law. The decisions which linit the exceptions are (as commonly happens in on hooks) for the most part the chief anthorities to show the existence of the rules.

livle 1.

Parties

()ur first rule is that the miginal parties to a contract mast be persoms aseret cined at the time chen the contract is mall. It is obvious that there camnot be a contract withont at least one ascertained party to make it in the first instance; and it is also an elementary principle of law that a contracting party cannot bind himself by a floating olligation to a person unascertained. The rule has been thus expressed: "A party cannot have an agreement with the whole world: he must have some person with whom the contract is made "(g). There is no exception to this rule in such cases as those of promises or undertakings addressed to the public at large by advertisements or the like, and sales by auction. For, as we have already seen in Chap. I., the contract formed in any such case is former between two ascertained persons by one of then accepting a proposal made to him by the other, though possibly made to him in common with all other persons to whose knowledge it may come.

\section{Effints of Contract as to Third Persons.}

The affirmative part of our second rule, namely: The rertitor con demand performance from the debtor or his 
mpresentatices, is now and long has been, though it was not always elementary (h).

The negative part of it states that the rertitur summot kule 2. drmand, nor an the debtor require him to arecpt, performance fiom an!y third proson. This is subject to the explanation that the debtor or his representatives may perform the duty by an agent, which again is modified by the exception of strictly personal contricts as mentioned at the end of the rnles. On this we need not dwell at present.

It is obvious on principle that it is not competent to contracting parties to impose liabilities on other persons withont their consent.

Every person not subject to any legal incapacity may dispose freely of his actions and property within the limits allowed by the general law. Liability on a contract consists in further limitation of this disposing power by a voluntary act of the party which places some definite portion of that power at the command of the other party to the contract. So much of the debtor's

(h) As to the liability of personal representatives on the contracts of the testator or intestate see $1 \mathrm{Wms}$. situml. $241-2$. The old rule that an action of felyt on simple ennt ract wouln not lie against executorwhere the testator coukl liave waged his law (though it is salid the objection conld be taken only by demurer) seems to have been in truth an innovation. See the form of writ for or against executors. Fluta 1.2. li. 119.11 .1210 (the latter passager is muroms: il a man has enterenl

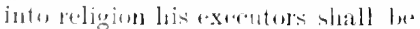
sucel for his debt. not the abot whe areptent him into religion:

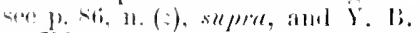
31 El. 1. 1. 233. It is savl, however, that "quia exeeutores non prossunt facere lecem por defuneto,
No liability imposed on third persons.

It: foundation in prineiple. peteus pobabit talliam suam, vel si habeat sectam secta debet examinari: et lore est verum sise sit mereator sive non": Y. li, 2.2 Ed. I. p. tinti). For the comtliet of opinion as to the remerly by a-sumpit. s'.

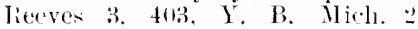
11. VIlI, 11, pl. 3 , the strange dictum ronten of Fitzherbert, 'Trin. 27 11. V1I1. 23, 1). 21. Who sajul there was mu remerly at all (al) prarently on the grommil that a canse of action in asmmplst was lor a tort. and therefore clied with the

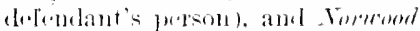
v. limed (15.5-s) in li. li., l'lews.

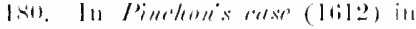

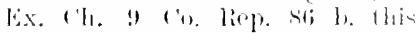
dietmm was overuled, antluritids leviowerl ame explajuel amel the (enmmon law settled in - Mlstances ac it mow is. 
Agency :

the exception only apparent.
When companies held in equity to promoters' agreements: not $e_{d} t^{\circ}$ "ontruet".

individual freedom is taken from bim and made over to the creditor (i). When there is an obligation independent of contract, a similar result is produced without regarl to the will of the party ; the liability is amexed by law to some wrongful act or default in the case of tort, and in the case of contracts "implied in law" to another class of events which may be roughly described as involving the accession of benefit through the involuntary loss of another person; but when an obligation is founded upon a real contract, the assent of a person to be bound is at the root of the matter and is indispensable $\left(l_{i}\right)$.

The ordinary doctrines of agency form no seal exception to this. For a contract made by an agent can bincl the principal only by force of a previous authority or sulsequent ratification; and that authority or ratification is nothing else than the assent of the principal to be bound, and the contract which binds him in his own contract. Ender certain conditions there may be a contract hinding on the agent also, as we have seen in Chap. II., hut with that we are not here concerned. Another less simple apparent exception occurs in the cases in which companies have been held bound by agreements or representations ( $l$ ) made by their promoter's before the companies had any legal existence. These cases, however, proceed partly on the ground of a distinct obligation having either been imposed on the company in its original constitution, or assumed by it after its formation $(m)$, partly on a ground independent

(i) Cu. sarimg. Ob). s. 2 .

(k) It is now inetled law that a strancer may he liable in tort for

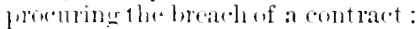

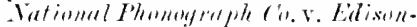

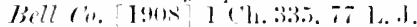
("h. 2) k, C.A. But thes is not an obligation under the contract, any more than when $A$. sells his land to
B. the dut $y$ of all men to respect the rights of $\dot{P}$. insteat of $A$., as owner of that land. is a duty under the contract of sale or the conveyance.

(l) Lir Metrop. ('al l'msumers'

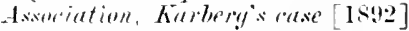
3 (h. 1.61 L. J. Ch. $7+1$, C. A. $14 !$ (m) Linulley on Companies. I 46 , 
of contract and analogous to estoppel, namely, that when any person has on certain terms assisted or abstained from hindering the promoters of a company in obtaining the constitution and the powers sought by them, the company when constituted must not exercise its powers to the prejudice of that person and in violation of those terms. The doctrine as now established probably goes as far as this, but certainly no farther $(n)$.

In one case of a suit in equity for specific performance of an award a third person interested in the subjectmatter was made a party, and was held to be hound by the award, thongh he had not heen a party to the Stranger helit boumel by ilwitul in entrity: sed in'. reference and had in no way assented to it, but simply knew of it and remained passive $(0)$. But it has been held by higher authority $(p)$ that in a suit for the specitic performance of a contract third persons claiming an interest in the subject-matter are not even proper parties: and even withont this it seems obvions that $A$, and $B$. have no business to submit C.'s rights to the arbitration of $\mathrm{D}$. It is apprehended accordingly that this exception nay be treated as non-existent.

Another branch of the same general doctrine is that Noration. the debtor camnot be allowed to substitute another person's liability for his own without the creditor"s assent. A contract cannot he male except with the person with whom one intends to contract $(q)$. When a creditor assents at the debtor's request to accept

(ii) Lintley un (ompanies, 152. Astoratifieation by compranies. see 1. I11, above.

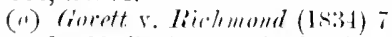
sim. I, lo R. R. sti. donbted in

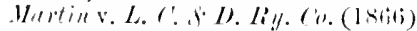

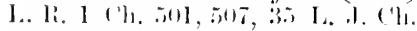

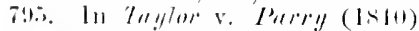

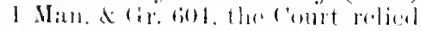
on pesitive acts of the parties ats howing that they aldopter the reference and were substantially parties to it.

(11) Tasker v. simall (1833) : $19 y$. c cr. 63, t. R. R. 2Iㄴ, followed in

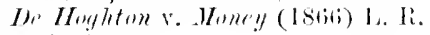
2 (tis. ilit.

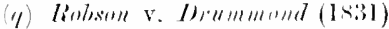

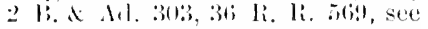

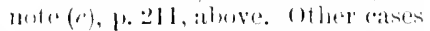
bearing wn the same point are consickerest for another purposse in ('). IX. betow, 
another person as his debtor in the place of the first, this is calleri a novation. Whether there has been a novation in any particular case is a question of fact, but assent to a novation is not to he inferred from conduct mnless there has been a distinct and unambiguous request $(r)$. Such questions are especially important in ascertaining who is liable for the partnership debts of a firm when there has heen a change in the members of the firm, or on contracts made in a business which has been handed over by one firm (whether carried on by a single person, a partnership, or a company) to another. A series of cases which were, or were supposed to be, of this lind arose about 1875 out of successive amalgamations of life insurance companies $(s)$.

The question may be resolved into two parts: Did the new firm assmme the debts and liabilities of the old: and dirl the creditor, knowing this, consent to accept the liability of the new firm and discharge the original debtor? (t). It would be heyond our scope to enter at large on this subject (n).

Rieal exceftions to come under liule l

There exist, howerer, exception n to the general rule. In certain eases a new liability may without novation he created in substitution for or in addition to an existing liability, but where the posibility exists of such an exceptional transfer of liabilities it is bound up with the correlated possilility of an exceptional transfer of rights, and eamnot be considered alone. For this reason the exceptions in question will cone naturally to our notice

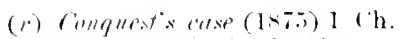

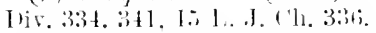

(s) It is dombthul whetler some of these were resilly eaces of miva-

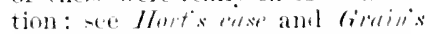

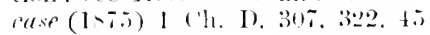
L. J. ( ' h. $32 \mathrm{~g}$ I.

$(t)$ see liolti, v. Flonere (1sti.j) I. F. 1 I. F. $2 \%$. H. 35 I. I. I'. r. 13 .
(11) See lindley on I'art nership. 216 * 99. aml as th the general

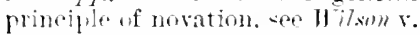
Lling (10-3) L. R. 16 Eq. 6il, it. I. I. I. C'h. 359 : for a later instance of erue novation, Meller.s fore (1sit) 3 Ch. Div. 391. The

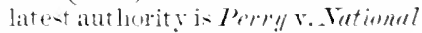
Pron. Bunk if lingland [1910]1 '1'. t6it. 
under Rule 4, when we deal with the peculiar morles in which rights arising ont of certain classes of contracts are transferred.

Apart from novation in the proper sense, the creditor may bind himself once for all hy the original contract to accept a substituted liability at the debtor"s option. Such an arrangement is in the nature of things milikely to occur in the ordinary dealings of privite persons among themselves. But it was decided in the winding-11p of the European Assirance Society that where the deerl of settlement of an insurance company contained a power to transfer the business and lialilities to another company, a transfer made under this power was hinding ou the policyholders and they had no claim against the original company $(x)$. In the case of a policy-holder there is indeed no subsisting debt $(x)$, but he is a creditor in the widler sense above defined (p. 209).

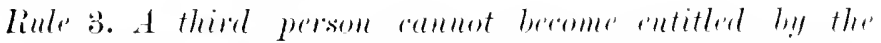
contract itself to demand the performances" of an!! dent!y under the contract.

Before we consider the possibility of creating arbitrary exceptions to this rule in any particular cases, there are some extensive classes of contracts and transactions thint persont. analogrons to contract which call for attention as offering real or apparent anomalies.

A. Contracts made by agents. Here the exception kxwprim.. is ouly apparent. The principal acquires rights muler a contract which he dicl not make in person. But the anly. agent is only his instrument to malie the contract within the limits of the anthority given to him, howerar extensive that anthority may les: and from the hegiming bo

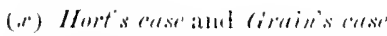
(1875) I (h. 1), 311\%, 1.; L.. I. ('ll. 321 ; Iturmun's rasp (1875) I ('h.

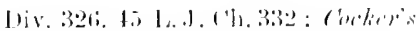

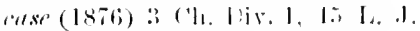
('h. $8 \times 2$. 
the end of the transaction the real contracting party is the principal.

Degrees of agency.

Agent

cont racting personally.

Fatification.
Consider the following series of steps from mere service to full discretionary powers:

1. A messenger is charged to convey a proposal, or the acceptance or refusal of one, to a specified person.

2. He is authorized to vary the terms of the proposal, or to endeavour to obtain a variation on the other party's proposal (i.e., to make the best bargain he can with the particular person), within certain limits.

3. He is not confined to one person, but is authorized to conclude the contract with any one of several specified persons, or generally with any one from whom he can get the liest terms.

t. He is not confined to one particular contract, but is authorized generally to make such contracts in a specified line of business or for specitied purposes as he may judge best for the principal's interest $(y)$.

The fact that in many cases an agent contracts for himself as well as for his principal, and the moditications which are introduced into the relations between the principal and the other party according as the agent is or is not known to be an agent at the time when the contract is mate, do not prevent the acts of the agent within his anthority from being for the purposes of the contract the acts of the principal, or the principal from being the real contracting party. Again when the agent is also a contracting party there are two alternative contracts with the agent and with the principal respectively.

As for the subsequent ratification of manthorized acts, there is no difference for our present purpose between a contract made with anthority and one made withont anthority and sulseyuently ratifier. The consent of the principal is referred hack to the date of the original act by a beneficent and necessary fiction.

(y) (p. Sarigny. Ohl. 2. 5i- tio. 
B. There are certain relations created by contract, of which that of creditor, principal del,tor, and surety may be taken as the type, in which the rights or duties of one party may be varied by a new contract hetween others. But when a surety is discharged by dealings between the creditor and the principal debtor, this is the result of a condition annexed by law to the surety's original contract. There is accordingly no real anomaly, though there is an apparent exception to the vagne maxim that the legal effects of a contract are confined to the contracting parties: and there is not even any rerbal inconsistency with any of the more definite rules we have stated. These cises are mentioned only because they have leen considered as real exceptions by writers of recognized anthority $(z)$.

Insolvency and bankruptey, again, have varions consequences which affect the rights of parties to contracts, but which the general principles of contract are inadequate to explaiu. We allude to them in this place only to observe that it is best to regard them not as derived from or incidental to contract, but as results of an overriding necessity and beyond the region of contract altogether $(t)$. Even those transactions in bankiruptey and insolvency which have some resemblance to contricts, such as statutory compositions with creditors, are really of a judicial or quasi-judicial character. It is obvious that if these transactions were merely contracts no dissenting creditor could be bound.

C. The case of trusts presents a real and important exception, if a trust is regarded as in its origin a contract between the anthor of the trust and the trustee. It is quite possible, and maty for some purposes be useful so to regard it. The Scottish institutional writers (who follow
Other relations : principal and surety ; terms annexed by law to original contraet.

Anomaluns effects of batikraptey and insolvency. (z) See Pothier, (1) s. s.?.

(a) A striking instance is furnished by the rule in IToring's corses (1815) 19 Ves. 31:, 13 R. li. ㄴ17;

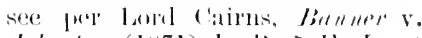

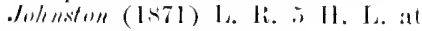
1. 181, f10 1., 1. (1). 330 . lrusts: a real exception, if trinst a conltract between anther of trust and trustee. 
So treated by the Roman arrangenent in the learning of Obligations seot tish and American witers: analogy hropesited in Enurlish bouks.

(ieneral analugy to contract. as elsewhere) consider trust as a species of real contract coming moler the head of depositation (b). Conversely deposits, haiments, and the contract implied by law which is the foundation of the action for money received, are spolien of in English books as analogons to trusts (c). A chapter on the duties of trustees forms part of the best known Anerican text-books on contracts, though no attempt is made, so far as we have ascertained, to explain the logical connection of this with the rest of the subject.

By the creation of a trust duties are imposed on and mulertaken by the trustee which persons not parties to the transaction, nor even not in existence at its date, may afterwarls enforce. Ant the relation of a trustee to his estrit que trust is closely analogons to that of a delotor to his creditor, in so far as it has the nature of a personal obligation and is governed by the general rules derived from the personal character of olligations. Thus the transfor of equitalle rights of any kind is subject, as regards the perfection of the transferee's title, to precisely the same conditions as the transfer of rights moler a contract. And the true way to understand the nature and incidents of equitalle ownership is to start with the notion not of a real ownelship which is protecter only in a conrt of equity. hut of a contract with the legal owner which (in the case of trusts properly so called) camnot be enforced at all, or (in the case of constructive trissts, such as that which arises on a contract for the sale of land) cammot be enforcer completely. except in a court of equity (a).

Howerer, although erely trust may he said to include at contract, it inchules so moneh more. and the purposes

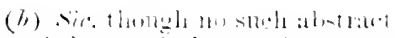
term is burown in lioman law. Sin Ewkine, In-t. Bls. 3. Tit. 1.s. 32. (r) Plackstome. romm. iii. 432. (d) Lieper Lord Westimy, Kmen"
V. tin (IATI 2) J., R. ; H. 1. at

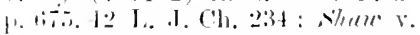
Fister (1,-2) L. H. 5 H. 1, at

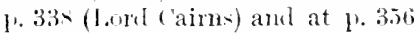
(Loril Hatherley): 42 I... . Ch. 4.4. 
for which the machinery of trusts is employed are of so different a linul, that trusts are distinct in a marked way not merely from every other species of contract, but from all other contrats as a genus. The complex relations involved in a trust cannot be reduced to the ordinary elements of contract.

D. Closely comnected with the anses corered by the doctrine of trusts, but extending beyond them, we have the rules of equity by which special farom is extended to provisions made by parents for their children. 'This exception has already leen noted in stating the general rule (e). In the ordinary case of a marriage settlement the children of the contemplated marriage itself are said to be "within the consideration of marriage" $(f)$ and may enforce any covenant for their benefit contained in the settlement. Where a settloment made on the marriage of a widow provides for her children by a former marriage, such chilkren, thongh in the technical language of equity rolunters, or persons having no part in the consideration, have been held entitled to enforce the provisions for their benefit; hut this extension has been doubted in the Court of Appeal (!)).

E. There is also a class of statutory exceptions (though of (lecreasing importance) in cases where companies and public bodies, though not incorporated, are empowered to sue and be sued by their pulblic ofticers or trustees.

Exception of cectain morvisions for chilutren.

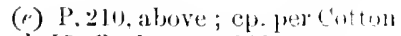
L. I. Is ch. D. at 1). 242 .

(f) It is even sitid that eonsideration move, or is asimmed to move, from them. Fint it mant not be inferred rrom thic that e: fuity regards "lat peinu de naitre" an a legal detriment.

(g) Giale v. Giale (1857) i ('h. I).

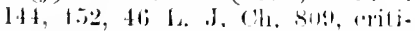
rizent jetr I.indley I..J. A.-(i. v.

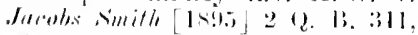

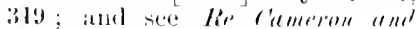

II ells (1.85) 37 (H. D. 32, 57 L. . . ' 'h. tig. The question how fas limitations in a marriage settlement to persons ot her than edi idien can br. suppurted by the eonsiderat tion ol marriace, se ats not to be

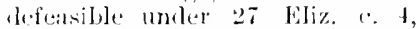

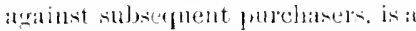
distimet and wider one. not falling within the seope of the present work. Sice tiald r. liald for referenteres to the antherities.
Statutoly exceptions: jower's to she by pullie vifticers, de. 
Corenants relating to real properts.

General apllieation of rule. iontract for benefit of third persom.

The trustees of Friendly Societies and Trade Unions are Jikewise empowered to sue, and may be sued, in their own names, in ases concerning the property of the society or union $(h)$.

By 8 \& 9 Vict. c. 106, s. 5 , a person who is not a party to an indenture may nevertheless take the benefit of a covenant in it relating to real property. This enactment has not, so far as we lnow, been the subject of any re. ported decision (i).

Having disposed of these special exceptions, we may now proceed to examine the rule in its ordinary application, which may be expressed thus:-The agreement of contracting parties cannot confer on a third person any right to enforce the contract.

There are two different classes of cases in which it may seem resirable, and in which accordingly it has been attempted to effect this: (1) where the object of the contract is the henefit of a third person: (2) where the parties are numerous and the persons really interested are liable to be changed from time to time.

It was for a long time not clear whether a contract between $A$. and $B$. that one of them shoukd do something

14) Frienlly focieties Act $1 \times 5$ (3. . 3!1 Vict. c. 180), s. 21 : Trade Enion Act, 1si) (3t a 35 Viet. r. 31), $\therefore$. 4. It is the same with buibling societies formet before the tet of list and nut incorporated moler it. A statute enabling a local authurity to recorter expenses. anul not specifying any remells. has been helu to make the local authority a quasi-corporation for the purpose of suing: Mills $v$. Siott (1N-3) I. K. \& 1 . B. 49h, 42 L. J. Q. B. 234. Aud the grant of a right by the Crown to a elass of persons may have the effect of incorprating them to enable them toexereise the right: Millingulev.
Yaitlam (1s6ti) L. R. 3 Eq. 103.36; L. I. Ch. tit, explained by Jessel M.li. in rhittun v. Comporicution of Lamdon (1sis) i Ch. D. at p. iti, 47 I. J. Ch. 433 .

(i) For an example of the inconrenience prorided against by it. see loird simthempton r. Brouch (Is.7) 6 l. A C. 7ls, 30 R. F. 511 , where the jerson who was really interesterl in the parment of rent on a demise male by trustees and with whom jointly with the trustees the corenant for layment of rent was expressed to be made, was held incapable of joining in an action on the coreunint. 
for the benefit of C. did or did not give C. a right of action on the contract $\left(k_{i}\right)$. And there was positive anthority that at all events a contract made for the benefit of a person nearly related to one or both of the contracting parties might be enforced by that person $(l)$. However, the rule is now settled that a third person cannot sue on a contract made by other's for his benefit even if the contracting parties have agreed that he may, and also that near relationship makes no difference as regards any common law right of action. The final decision was in Tuerllle v. Atkinson ( $m$ ). The following written agreement had been entered into:

"Memorandun of an agreement made this day between William Guy, se., of the one part, and John Tweddle of the other part. Whereas it is mntually agreed that the said William Guy shall and will lay the sum of $\mathfrak{E} 200$ to William Twedtle his son-in-law. railway inspector. residing in Thornton. in the eounty of Fife in seotland, and the said John Tweddle father to the aforesaid William 'Twedlle shall aud will pay the sum of 2100 to the said William Tweddle each and severally the said sums on or before the 21st day of August. 18.5; and it is hereby further agreed by the aforesid William Guy and the said John Tweddle that the said Willian Twerdle has full power to sue the said parties in any court of law or equity for the aforesaid sums hereby promived and speeified."

William Tweddle, the son of John Tweddle, brought an action against the executor of William Gny on this agreement, the declaration averring his relationship to the parties, and their intention to carry ont a verbal agreement made before the plaintiff's marriage to provide a marriage portion. The action was held not to be maintainable. The Court did not in terms overrule the older cases to the contrary, considering that their

(k) See Viner. Abr. Assumpsit, 7. (1.333-7) : per Eyre '.J. ('o. of

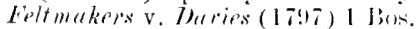
c. P. 98 : note to l'igot $v$. Thompsom (1R+12) 3 lios. \& l' 149.

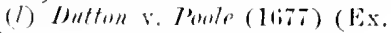
('b.) 2 I.ev. 213, Vent. 314, 32:2.
Aprovoved ly Lord Mansfieht ('ow?. H3. There appents to have been much differenee of opinion at the time.

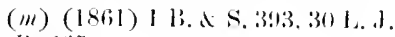
Q. H. . 265 .
Third person camnot sue at law. 
athority was already sufficiently disposed of by the effect of molern decisions and practice (n).

Auturitien in eluity atrainst right of third persoll.

Alparent excepotions. Gregory $r$. Williams (thind jersil co-plaintitf witl comtractet).

The doctrines of ennity are at first siglat not so free from doubt. 'There is clear and distinct anthority for these propositions: When two persons, for valuable consideration as between themselves, contract to do some aet for the benefit of another person not a party to the contract-

(i) That person camnot enforce the contract against either of the contracting parties, at all events if not nearly and legitimately related to one of them (i). Probably the only exception is that mentioned above, 1.1. 210, 221, in farour of children provided for by narriage settlenents.

(ii) But either contracting party may enforce it against the other although the person to be benefited had nothing to do with the consideration $(y)$.

On the other hand the case of Greyory $\mathrm{x}$. Williams (q) shows that a third person for whose benefit a contract is made may sometintes join as co-plaintiff" with one of the actual contracting parties against the other, and insist on the arrangement heing completely carried out. The facts of that case, so fin as now material, may be stated as follows; Parker was indehted to Williams and also to Gregory; Willians, heing informed by Parker that the deht to Gregory was ahout $900 l$., and that there were no

(11) See also Irice s. Firston

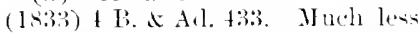
ran at stranger to a contract who hate suffered damage by the monperformance of it sue the defaulting party as on the cont ract: I'ley-

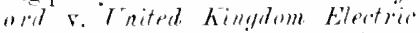

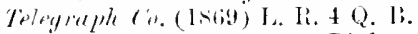

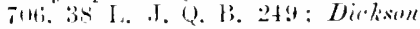
v. Reuter's Telegram (b. (1-io) 2

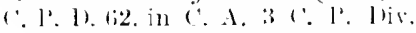
1,4 L. I. C'. l'. I. It is a distinet question whether these decisions rightly denied that there was any cinse of action at all. See the present writer's book on the Law of Turts. Sthe ed. 5. si sigl.

(o) Colyear v. Mulyrare (183ti) 2 keen. si. t4 R. R. 191 .

(p) Dacenport v. Bishopp (1843

2 Y. A C. $451,460,1$ Ph, $698,704$. (q) $(1 \leqslant 17) 3$ Mer. 5i2. 17 R. K. $13 i i$. 
other debts, undertook to satisfy the debt to Gregory on having an assignment of certain property of Parker's. Gregory was not a party to this arrangement, nor was it commumicated to him at the time. The property having been assigned to Williams accordingly, the Court held that Gregory, suing jointly with Parker, was entitled to call upon Williams to satisfy his debt to the extent of $900 l$. (but not farther, although the debt was in fact greater) out of the proceeds of the property. It was not at all suggested that he could have sued alone in equity any more than at law (r), and the true view of the case appears to be that the transactions between Williams and Parker amounted to a declaration of trust of the property assigned for the satisfaction of Gregory's claim to the specified extent $(s)$.

Another apparent exception is the case of Puge v. Cox $(t)$, where it was held that a provision in partnership articles that a partner's widow should be entitled to his share of the business might be enforced by the widow. But the decision was carefully put on the ground that the provision in the articles created a valid trust of the partnership property in the hands of the surviving partner. The result is that there is no real and allowed authority for holding that rights can in general be accuired by third parties under a contract, unless by the creation of a trust.

The general principle has been re-aftirmed of late years. "A mere agreement between A. and B. that B. shall pay C. (an agreement to which C. is not a party either directly or indirectly) will not prevent A. and B. from

(r) Fir an attempt of at thim person to sue at law under very similar circumstiunces, see Pripe v. Elastore (1833) + R. A Arl. 433, showing clearly that A. cannot sne on a promise by 13. to $C$ to pay C.'s debt to $\Lambda$. (s) Empress Enginepring (b).

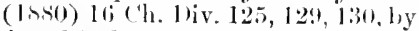
fersel M.li, and Jimes L.J.

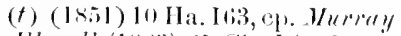
v. Flarell (184.3) 25 Ch. Div, 89,53 1. J. (1. 1.5.

P. 
coming to an agreement the next day releasing the old one" (II).

"An agreement between $A$. and B. that B. shall pay C. gives C. no right of action against B." $(x)$.

Different rules prevail in American jurisdictions, but, although none of them are so strict as the English rule, they vary greatly from one another $(y)$.

Thirl person empowered to sue for convenience of parties.

Contracting parties call enable one of themselves to sue on buhalf of himself and others:

We now come to the class of cases in which contracting parties have attempter for their own couvenience to vest the right of enforcing the contract in a third person. Except within the domain of the stricter rules applicable to parties to actions on deeds and negotiable instruments, there appears to be no oljection to several contracting parties agreeing that one of them shall have power to sue for the benefit of all except the party suer. Thus where partners create by agreement penalties to be paid by any partner who breaks a particular stipulation, they may empower one partner alone to sue for the penalty $(z)$. The application of the doctrines of agency may also lead to similar results ( 1 ). It seems doubtful whether a pro-

(11) Jessel 1l.h. Emmers Linginefrimg (a., li ('ll. bis. 12.), 12!.

(.r) Lindley 1..J. Re Rotherlherm

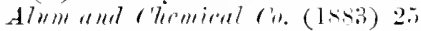
('h. Div. at 1). 111. These statements orerrule what is sail in

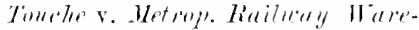

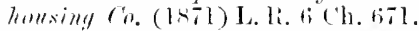
tir 7 . to L. J. Ch. tot (the decision may besupported on the grommel of trust. Lindley on Companies, 14s). Compare further Eley r. Masitir,

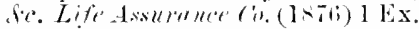
liv sis. t5 L. J. Ex. tis (a provision in articles of astociation that A. slatl be rolicitor to the company and transact all its leual husines is as regards $\mathrm{A}$. res inter aliws antu and gives him no right against the comprany); Mellodev. Pritus leym Ry. ('). (1874) L. R.9 C. P. 503, 43 L. J. C. P. 253 ,
(4) Harriman, 212 sty : Prof. Williston in Harr. Law Rev. xv. 767 : this article is in part embotien in an excursus to the third American exlition of this book. See further l'rof. Crawford D. Hening. "Hintory of the Beneficiary"s Action in Assmmpit," Essays in Anglo-American Legal History (194!) iii. 3394.

( ) Rudenturst $x$ Butro $(1826) 3$ Bing. 463. 470.28 R. R. 559 . of coure they must take care to make the penalty payable not to the whole tim. but to the members of the tirm minns the offending part. ner. Whether under the fresent kiules of Court the otlier partners could use the name of the firm to sue for the penalty. qurret.

(a) Smm v. Cass (1870) L. R. 5 Q. B. 656. 34 L. J. Q. B. 249. 
mise to several persons to malie a payment to one of then will of itself enable that one to sue alone $(b)$.

But it is quite clear that the most express agreement of contracting parties cannot confer any right of action on the contract on a person who is not a party. Tarious devices of this lind have been tried in order to evade the difficulties that stand in the way of umineorporated associations enforcing their rights, but have always failed when attention was called to them. This has happened in the case of actions brought by the chairman for the time being of the directors of a company (c), by the directors for the time being of a company $(d)$, hy the purser for the time being of a cost-book company $(e)$, and by the managers of a mutual marine insurance society $(f)$. It will not be necessary to dwell on any instance other than the last. In Cray v. Pearson the reasons against allowing the right of action are well given in the judgment of Willes .J. :-

- I am of opinion that this action eam not be maintained, and for the simple reason, - a reason not applicable merely to the procelure of this country, but one affeeting all somul procedure, - that the proper perion (1) bring an action is the person whose right has been violated. Though there are eertain exceptions to the general rule, for instance in the care

Julgment of Willes J. in Gray $r$. l'earson.

(b) (hunter. v. Lerse (18:39) + II. \& IV. 29.5, in Ex. Cin, 5 .I. \& W. 698 , i) IR. R. sist, where both courts inelined to think not, but gave no

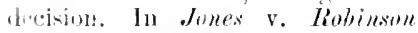
(1847) 1 Ex. 454, 17 L. J. Ex. 36, an alcion was bronght by one of two late fartners aganst the jurchaser of the lonsiness on a promise to pay the platutite what was due to hisi from the firm for arlvances, this was leclarenl on as a seprarate: promise in adrition to a general formise to the two partuers to pay the partuership clebts, and theomly prestion was whether there wais any separate comsinleration lor the promine sued om.

(i) Hall ve Barimleridge (1810) 1 Biall. \& (ir. 42.

(d) I7helps: v. Lyle (18399) $10 \mathrm{~A} . \mathrm{d}$
E. 113,50 R. R. 323 .

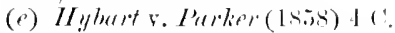
I. N. S. 209, 27 L. J. ('. I'. 1201), 111 R. R. liz: where Willes J. sluggester that it was trenching on the prerogatives of the ('rown to make a new species ol corporation sule for the purpose of bringing actions. (f) Crimly v. Prom (1870) l. li. $5(i$. P'. stix: in the arlite case of droly v. (ribsem (1sciti) L. R. 2('. 1'. 120, 36 1. J. (С. P'. 9!, a similar action succeeded, the question of the manager's right to sire mot lwing raised. In Scotland there seems to be mo similar ditliculty, at all events where the contran't is with in ollicial meresentative of a foreign government : see Vzynirid"

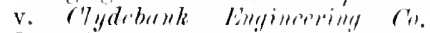

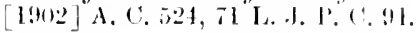

Q 2
Bint eannot enable a stranger. Attemits hy unineorporated collobanies to a)porint it nominal phaintiff. 
Fotes ant bills pilables to holiter of office. liule 4 . Transfer of right- unter eontrat.
Fight to - the on eontract not assign. able at cominom law:

of agents, anctimeers, or fartors, these exceptions are in truth more apluant than real. The persons who are suing here are mere agents, managers of an assulance association of which they are not members; aud they are suing for premiums alleged to have become payable by the lefendant in respect of policies effected by the plaintiffs for him, and for his share and eontributions to loses and lamages pairl by them to other members of the asuriation whone vessels have been lost or damaged. The bar. -tatement of the facts is emurh to show that the ation cannot fe maintainerl. . . It is in effect an attempt to substitute a person as a wominal blatintiff in lien of the persons whose rights have been violaterl."

At common law the payee of a negotiable instrument must, on the same principle, be a person who can be ascertainer at the time of accepting the bill or maling the note. But by the Bills of Exchange Act, 1882. s. 7, a lill (and it seems by ss. 73 and 89 also a cheque or a promissory note) may be mude payalle to the holder of an office for the time being:(1).

\section{Issigmment of Comtracts.}

Liule t. We now come to the fourth rule, which we have expressed thus:-

Persoms other than the restitor ma!y become entitled by repressentation or assifmment to stand in the creditors Hare and te experse his rights muler the comtract.

Tre need say nothing here about the right of personal representatives to enforee the contracts of the person they represent, except that it has been recognized from the earliest period of the history of our present system of law $(h)$. With regard to assignment, the benefit of a contract cannot be assigned (except by the Crown) at common law so as to enable the assignee to sue in his own

(y) (on the former law see $/ 1$ olmes v. Jutules (16ifi) L. R. 1 (3. B, 376, 3.) I. I. 12. I?. 131 .

(h) Subjeet to som" technical exceptions which have now disap- pearerl: see notes to IIthentley $r$. Laue 1667 ) 1 Wms. saund. $240 s q 7$. and for early instances of actions of debt bromght by exeeutors, Y. B. $20 \leqslant 21$ Ed. I. Pl\% 304, 37t. 
name (i). The origin of the rule was attributed by Colie to the "wistrom and policy of the founders of onr litw" in discouraging maintenance and litigation $(k)$ : but it is better explained as a logical conseguente of the archaic view of a contract as creating a strictly personal obligation between the creditor and the debtor (l). That sime rule is stated by Gaius as previliting in the Roman law (m). Anyhow it has been long estallished that the proper course at common law is for the assignee to sne in the name of the assignor. It appears from the Year Books that attempts were sometimes made to object to actions of this lind on the ground of maintenance, but without success.

In equity the right of the assignee was pretty soon recognised and protected, that is, if the assignor refused to empower the assignee to sne in his name at law. Where the assignee had an easy remedy by sumer in the name of the assignor, the Court of Chancery would not interfere ( $n$ ).

But equity also regarded the protection of the debtor; the modern law still does so, and therefore will not

In equity assignee may sue, if necesiary : (i) Termes de la Le'y, tit. C'lower in - drition.

(k) Lampertis cose (1613) 10 ('o. Rej. Is". For exposition of the rule in iletail, see liney on l'arties, 115.

(l) Spence, Eis. Jurisel. of ('hy. 2. 8.o.). An examination of the earlier anthorities has been foum to contirm this virw. The rnle is assumed as unyuestionable, and there is no trace of ('oke season for it. The objuction of maintenanee was set nup, not against the assignee suing in his own name, which was never attempted so lar as we ean tind, but against his suing in the nome of the assignor' : see Note $\mathrm{F}$ in Appentix.

(m) Gai. 2. 3\%, :9. Qum mihi ab aliquo debetmr, id si velim tibi deberi. mullo eormon molo suilms

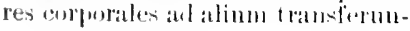

tur, id efticere postmm : sed opms est, utinberte me tu ab costipuleris: quaterseflicit ut a me liberetrat et incipiat tibit temrer fuas dicitur movationdigationis. Sine hav rero noratione non poteris tun nomine agere, sid flebes ex fiersma mea truas connitor ant pocurator mens experiri. In later tines the transforee of a debt was enalderl to sue ly atilis artio in his own mame. This seems to have been first int rochacel ouly for the lenetit of the purehaser of an inheritance: 1), 2. 14 de pactis. $16,12 \% 1$. 4. 39. de hererl. vel atet. vend, I, 2, t - i: and afferwards extenter to all

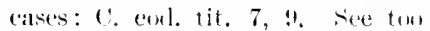
C. 1. 10. de (b) et act. 1, 2, 1'. 1. 15. ruando fisens, 5.

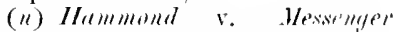

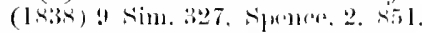
llarve latw lier. i. t; 7 . wobable origin of the rule. subject to debtor not being prejudiced. 
Legal right of assignee under Juticature Act. $18 \%$

In e juity more extensive: how far governed $i, y$ Statute of Frauls. qu.

enforce an assignment by which the debtor's burden is increased (a) or his remedies diminished $(p)$.

The Supreme Court of Judicature Act, 1873 (s. 25, sub-s. 6), creates a legal right to sue in the assignee's own name, but confined to cases where the assignment is alsolute (q), and by writing under the hand of the assignor, and express notice in writing has been given to the debtor.

There may still be more extensive equitable rights of this lind. By the Statute of Frauds (29 Car. 2, c. 3), s. 9, "all grants and assigmments of any trust or confidence" nust be in writing signed ly the assignor, and by sect. 7, equitable interests in land must be created loy writing. Sect.9 does not require writing for the creation in the first instance by the legal owner or creditor of an equitable interest in personal property or a chose in

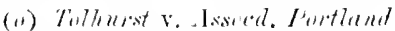

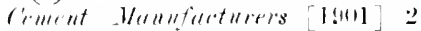
K. Is, sll, reverserl in ('. A. atul H. I... se. [19103] A.1'414. .2 L. .J. k. li. s:3t. but only on the groumd that the original contrat was still in firce and extented to asimSee per Lord Limbley [19033] A. C. at 1. le?.3.

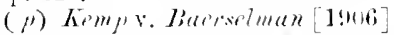

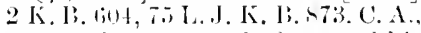
where the asimor has turned his busines into a limited comprany. and part of the original ensideration wh his sile was a promise by which the comprany eonhl not be bommel.

(1) Tamerel v. Itrlagon Pay and E. firira IR! Co. (185!) 23 Q. L. D. $23: 4$ is 1. J. Q. 13. 4.84. An alsohlue assigmment nay be subject tor a trust in respect of the moness receresed : Comfort r. Brtts [1s!i] 1 Q. I. 737. 6i L. I. (2. B. 65st, C.A. Whether the suls-section applies to an as-imment of part of an entire deht, quare: Durlum Bros. v. Robertam [1s!s] 1 \%. Is.

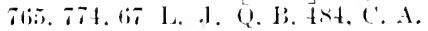
At : lll events :m molefined fout will not do: Jones r. Mumpleress [1902] l K. B. 11, .I L. J. K. H. 23. see further as to what amounts to an abolute assignment. Herratilo Bunk of Lombon v. Eeans [1s!n! 2 Q. B. 113, 65 L. J. Q. I. (121, (…;

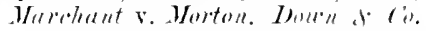
[1901]2 K. B. 829,70 L. J. K. B. S20: Hughese v. Pump Hous Hotel (o) 1902$] 2$ K. IB. 190,71 L. J. K. li. 630, C. A. The term " legral chuse in attion" in a corresponsting colonial det has been held to inelude a canse of action for negligence: King v. I ietwill Insuraner (o) [1.!14] A. C. 250 bis L. J. L. C. Bs: and see per farwell J.. bunchester Breurry ('o. . Combs [1901]? (h. 608, 619, - 6) L.... ('h. 814. It includes a claim to compensation muter s. ws of the Lamds Clatuses Act: Mnueson v. G. T. of rity Ry. (\%. [190i] I K. R. 2(10) it L. J. K. B. 1 ! 1 , I. A.: and the benetit of a contract for the furchane of a reversion: Torking-

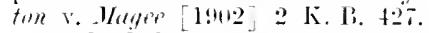
7l L. J. K. [3. il2, revil. in A'. A. on wher grounds [1:\%:3] $1 \mathrm{~K} . \mathrm{l}$. 64t, i2 L. . K. K. R. 336. 
action : and it may be argued perhaps that its operation is altogether confined to interests in land by the context in which it occurs. The writer is not aware of any decision upon it $(r)$.

It seems that to constitnte an equitable assignment there must be at least an order to pay out of a specified fund $(s)$.

As for the notice to the debtor, the rule of equity is that it must be express but need not be in writing $(t)$.

There remain, therefore, a great number of cases where the right is purely equitable, although the enlarged jurisdiction of every branch of the Supreme Court malies the distinction less material than formerly. The Judicature Act does not in any way impair the efticacy of a transaction which would have been a good equitable assignment before the Act (u).

In ordinary cases ( $e^{\prime}$ rights under a contract derived by assignment from the original creditor are subject, as already stated, to the following limitations:-

1st. Title by assignment is not complete as against the debtor withont notice to the debtor, and a debtor who performs his contract to the original creditor without notice of any assignment by the creditor is thereby discharged.

2nd. The debtor is entitled as against the representatives, and, unless a contrary intention appears by the original contract, as against the assignees of the creditor,

(r) Sian 1 Simders on lises, ith ed. $34: 3$.

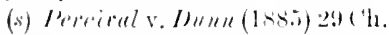
biv. 12s, it I. I. (1h. 5iz. An alventulous atcempt to extend the comerption of equitableatignment

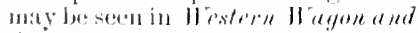

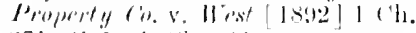

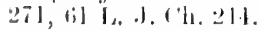
$31 \vec{i}$.

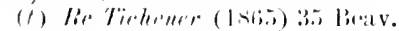

(u) Hilliam Brantt's Soms. f (i). v. Durelop Rubber ('o. [190.5]A.('. tist. Tt h. J. K. K. 89.

(.r) 11 does not setm uselul, at this das, to refer here to the varions

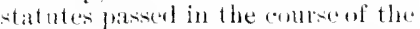
nincteonth century which mate varous kinds of seraritios and things in action specially trauslerable.
Limitation of assignte's rights. 
Bules of equitable assignment in general. Notice to delotor.

to the lenefit of any defence which he might have had against the creditor limself.

1. As to notice to the debtor. Notice is not necessary to complete the assignee's equitalle right as against the original creditor himself, or as against his representatives, including assignees in bankruptcy (y): but the claims of competing assignees or incumbrancers rank as between themselves not according to the order in date of the assignments, but according to the dates at which they have respectively given notice to the debtor. T'his was decided by the cases of Iecurle v. Hull and Loreridge v. Cooper (z), the principle of which was soon afterwards affirmed by the Honse of Lords (a). The same rule prevails in the modern civil law (b) and has heen adopted from it in the Scottish law (c): and the true reason of it, though not made very proninent in the decisions which establish the rule in England, is the protection of the debtor. He has a right to look to the person with whom he made his contract to accept performance of it, and to give him a discharge, unless and mitil he is distinctly informed that he is to look to some other person. According to the original strict conception of contract ("à ne considérer que lit subtilité du droit" as l'othier (d) expressed it), his creditor or his creditor's assignee cannot eren require him to do this, any more than in the converse but sub-

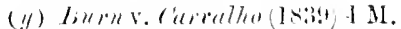

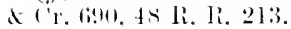

() $(1823-7) 3$ liuss. 1, 3\%, 4s, 27 1i. Ii. 1. 'The alplieation of the rule is mot nuolitied by consideration of the parties relative merits as to diligeruce in particular eases: lie Luke [1908] I li. I, 151, 7: L. J. K. li. 117. ('). (though not "puite in puri materia) Jared v.

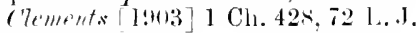
('h. 291 . C. A.

(a) Foster v. Corderell (1835) $3 \mathrm{Cl}$. A F. 4iti, 39 R. Ki. 24. It has only bately Jeen alecised that a secmul axignee who takes his as. signotent not from the leneticiars himself, but from his legal personal replesentative, may equally gain lriority by notice: Freshriell. Trusts (Isi!) 11 Ch. Jir. 198. The rule is eriticized, though allowed to be settled law. in Jlaid v. Imurombe [1893] A. C. 369, per Lord Macnaghten at pp. 391-3,62 I. .l. Ch. s.r.

(b) Sect" Puthier, Contrat de Vente, ș

(c) Erskinte Inst. Bk. B. Tit. 5.

(d) Contrat de Vente, sis. 
stantially different case a debtor can require his creditor to accept another person's liability, and his assent must be expressed by a novation (e). Such was in fact the old Roman law, as is shown by the passage already cited from Gaius. By the modern practice the novation is dispensed with, and the debtor becomes bound to the assignee of whom he has notice. But he camnot be bound by any other assignment, though prior in time, of which he knows nothing. He is free if he has fulfilled his obligation to the original creditor without notice of any assignment; he is equally free if he fulfils it to the assignee of whose right he is first informed, not linowing either of any prior assignment by the original creditor or of any subsequent assignment by the new creditor $(f)$. It is enough for the completion of the assignee's title " if notice be given to the person by whom payment of the assigned debt is to he made, whether that person is himself liable or is merely charged with the duty of making the payment" (y), c.y., as an agent entrusted with a particular fund. Notice not given by the assignee may be sufficient, if shown to be such as a reasonable man would act upon $(h)$. All this doctrine of notice has no application to interests in land (i): but, subject to that exception, it applies to rights created ly trust as well as to those created by contract; the beneficial interest being

(c) See p. 215, above.

(f') See per Willes J., L. R. :s 1.P. at p.594. l'er knight lirtee L.J. Sturks v. Im/sem (1858) । L. II. G. 11,102 li. Ii. $1,6,1 \%, 2,2$ 1. J. (th. 8st. Notice after a negotiable instrument has been given by the debtor is ton late even if the instrument is still heki by the original ereditor: Brome v. siteneman $[1898] 2$ ('h. 582, 67 L. J. Ch. Dl3, C. A.

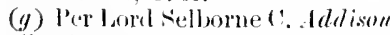

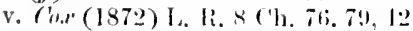
l. I. ('h. 2!)!. (h) Lloyd v. Rianks (18tis) T. Ii. 3 ('h. 4sis.

(i) Although the exception is fully establisherl its eavonablentess is doubtliul. Its effeet is that equitable interests in land stand on a different footing from personal rights: see this retied on as the ground of the exception, Joues r. .omes (1837-35) I Sim. t333, t2 li. R. 2f9. lint on the other hand their liability to he defeated by a murchase of the legal estate for value without notire show's that they fall short of real ownership.
This does not apply to interests in land; but does to all other equitable interests. 
treated for this purpose exactly as if it were a debt due from the trustee. In the case of trusts a difficulty may arise from a change of trustees: for it may happen that a fund is transferred to a new set of trustees without any notice of an assignment which has been duly notified to their predecessors, and that notice is griven to the new trustees of some other assignment. The first assignee prevails if he gave notice to all the trustees in existence at the date of lis assignment (li), but the new trustees cammot be malle personally liable for having acted on the secoun assignment (l). If, howerer, only one trustee has notice of A. is incumbrance, and dies, and after his death another incumbrancer $B$. grives notice io all the then existing trustex. 13. will be preferred (m).

The rules as to mutice apply to dealings with future or contingent as well as with present and liquidated claims. "An assurance office might lend momey upon a policy of insurance to a person who had insured his life, notwithstanding any previons assignment by him of the policy of which no notice harl been given to them " (II).

Arsignee takes subject tor puities : doublike lationing of the rube.

2. As to the debtor's rights against assignees. The rule latid down in the second explatnation is often expressed in the maxim " 'lhe assignee of an equity is hound by all the equities affecting it." This, howerer, includes another rule founded on a distinct principle, which is that no transaction purporting to give a beneficial interest apart from legal ownership can confer on the person who talies or is intended to take such an interest any hetter right than

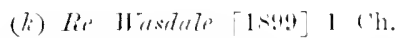
list, lis 1. I. Ch. 11 \%.

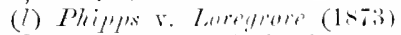

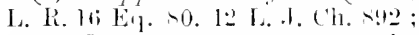

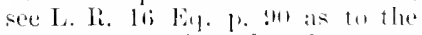
precautions tu he taken hy in asignee of an e fuitable interest who whes to le perfetty safe. The leath al une of two al mole trus- tees. beine the only une who has notice of an incumbince. does not deprive that incumblance of the wrinty it has gained: Ward $\mathrm{v}$.

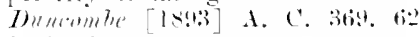
1.. .. (h. Wh. (III) Hhillips: Trusts $[19+13] 1$ ('h. IS3, i- L. I. ('h. 94. (il) L. L. Lit Eip. at p. s. 
belonged to the person professing to give it him. If $A$. contracts with B. to give B. something which he has already contracted to give C., then C.'s claim to have the thing must prevail over B.'s, whether B. knew of the prior contract with C. or not (o). And if B. makes over his right to 1), 1). will have no better right than B. had ( 1 ). And this applies not only to absolute but to partial interests (such as equitable charges on property) to the extent to which they may affect the property dealt with. Again, by a slightly different application of the same principle, a creditor of $\mathrm{A}$. who becomes entitled by operation of law to appropriate for the satisfaction of his debt any beneficial interest of A.'s (whether an equitable interest in property or a right of action) can claim nothing more than such iuterest as $\mathrm{A}$. actually had; and he can gain no priority by notice to A.'s trustee or dehtor even in cases where he might have gained it if $\mathrm{A}$. had made an express and unqualified assignment to him $(q)$. But we are not concerned here with the development of these doctrines, and we return to the other sense of the general maxim. In that sense it is used in such judicial expressions as the following:

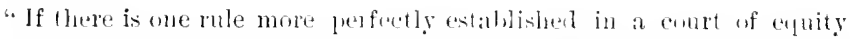
than another, it is this, that wheser takes an asignment of a chuse in action takes it subjeet to all the cyuties of the person who matle the assignment" (r).

"It is a rule: and principle of this court, ant of every cont. I believe, that where there is a chose in action. whether it is a debt, or an obligation, or a trust fund, and it is assigned, the person who holds the debt ar

(ii) This is of contse comsintent with lB. laving his remedy in danages. (') 1.. 33. above.

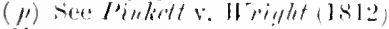
2 IIa. I20, allet. nem. Muraly v.

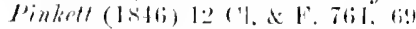

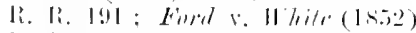

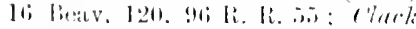

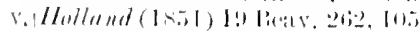
Ii. Ii, 1:it.

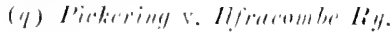

('). (1stis) I. R. 3 (C. P. 235. 37

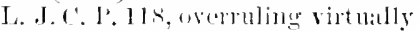

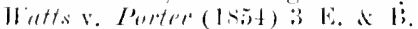

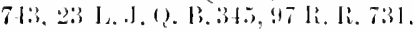

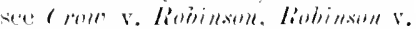

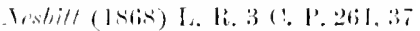

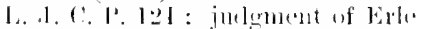
.1. (diss.) in ll alles v. Porter.

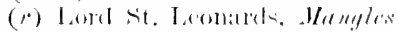
r. Nion (1852) :; HI. 1. (․ 70: הisl, sis li. li. 2!ni. :311. 
obligation, "1 has modertaken to holl the trust fund, has as against the asinnee exaetly the same cyuties that he woul have as against the assignor" $(*)$.

This is in fact the same principle which is applied by common law as well as equity jurisdictions for the protection of persons who contract with agents not known to them at the time to be agents $(t)$. What is meant by this special use of the ter"m "equities" will be best shown by illustration. A lebt is due from B. to A., but there is also a debt due from $\mathrm{A}$. to B. which B. might set off in an action by $\mathrm{A}$. In this state of things $\mathrm{A}$. assigns the first debt to $\mathrm{C}$. without telling him of the set off. B. is entitled to the set-off against C. (11). Again, B. has contracted to pay a sum of noney to $\mathrm{A}$., but the contract is voidable on the ground of frand or misrepresentation. A. assigns the contract to C.., who does not know the circumstances that render it voidal,le. B. may aroid the contract as against $C$. (c). Again, in a somewhat less simple case, there is a liquilated debt from $\mathrm{B}$. to $\mathrm{A}$. and a current accomnt between them on which the balance is against A. A. assigns the deht to C., who knows nothing of the account. B. may set off as against C. the balance which is due on the enrrent account when he receives notice of the assigmment, lut not any lalance which hecomes due afterwards $(r)$.

The rule may be exeluded by arreement of original eontracting parties.

But it is open to the contracting parties to exclude the operation of this rule if they think fit by making it a term of the original contract that the debtor shall not set up against an assignee of the contract any comnter-

(.s) James L.J. (-ittine as I...(')

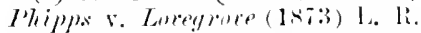

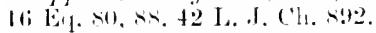

(t) See lp. 107. 111, athove.

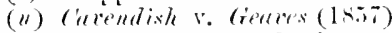
24 Beav. 163, 173, 27 L. .J. I'h. 31 t. where the doctrine is fully expounded. As to setwotf acciruing alter notice of assignment. Nitepleres.
צ. Linhlow (1862) 30 lieav. 625: Wotson v. Mid Wales Riy. Co. (1Nii) I.. I. 2 C. I'. 593, 3i I. J. ('. 1'. 28.5

(1) Graham v. Johensol (1869) I. li. \& Eq. 36. 3s L. J. Ch. 3it. (x) rarendiste r. Giveres. Dote (ii). 
claim which he may have against the original creditor. This is established by the lecision of the Court of Appeal in Chancery in Ex parte Asiatir Banling Corporation, the facts of which have already been stated for another aspect of the case (y).

Two alternative grounds were given for the decision in favour of the claim of the Asiatic Banking Corporation under the letter of credit. One, which we have already noticed, was that the letter was a general proposal, and that there was a complete contract with any one who accepted it by advancing money on the faith of it. The other was that, assuming the original contract to be only with Dickson, Tatham, \& Co. to whom the letter was given, yet the taker's of hills negotiated moler the letter were assignees of the contract, and it appeared to have been the intention of the original parties that the equities which might be available for the bank against Dickson, Tatham, \& Co. should not le available against assignees. Lord Cairns, then Lord Justice, thus stated the law :-

"Generally speaking a ehose in action assignable only in equity must he assigned subject to the exuities existiug het ween the original parties to the contract; but this is a rule which must yield when it appears from the nature or terms of the contract that it must have been intended to be assignable free from and unaffected hy such equities."

Where assignees of a chose in action are enabled ly statute to sue at law, similar consermences may be produced by way of estopuel $(z)$; which really comes to the same thing, the doctrine of estoplpel being a mere technical and definite expression of the same principle.

The principle thus laid down has heen follower ont in several later decisions on the effeet of transferable debentures issued by eompunies. The question whether the

Asiatic Banking Corporation's ease.

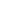


how far materia!.

holder of such a debenture takes it free from equities is to be determined by the original intention of the parties.

The form of thr instrument is of course material, but the general tenor is to le looked to rather than the words denoting to whom payment will be made; these cannot he relied on as a sole or conclusive test. Making a debenture payable to the holder or bearer does not necessarily mean more than that the issuing company will not require the holler who presents the instrument for jrament to prove his title, specially if the object of the delienture is on the face of it to secure a specific rebt (a). But an antecerlent agreement to give debentures in such a form is evidence that they were meant to be assignalile free from equities (h): and debentures payable to bearer without naming antrone as payee in the first instance are prima fure so assignable $(")$ and may be negotialble (d) : so again if the document resemlles a negotiable instrument rather than a common money bond or debenture in its general form $(\rho)$.

Even when there is nothing on the face of the instrument to show the special intention of the parties, the issuer cammot set up eqnities against the assignee if the instrument was issued for the purpose of raising money on it $\left(f^{*}\right)$. The general circumstances attending the original contract- $t . \%$ the issue of a number of debentures to a creditor instead of giring a single bond or

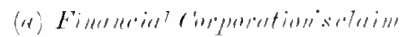

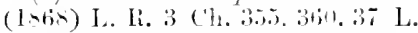
.J. ('h. $3+t^{2}$.

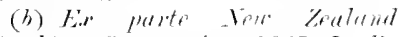

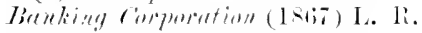
3 Ch. 1.t. 37 L.. J. Ch. 41 .

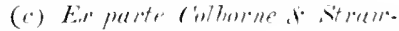
brilge (180-1) L. R. 11 E-1. 4T. f11 L. .J. ('h, .13, 313.

(d) Notwithstanding /'rom r.

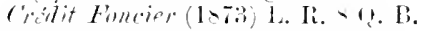
374. 38. 42 L. J. Q. B. 183 , see

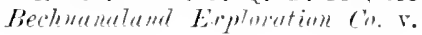

Landan Tionding Bank [1s!s 2 a.

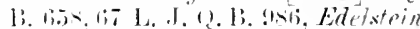

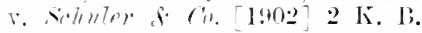
14. 1 1. J. K. B. .

(b) Kir puerter ('ity Bunk (1stia) L. I. 3 ch. 7 .

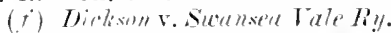
(i). (1-6) L. R. 4 (2. 1). 44. 3- L. J. Q. B. 17: Grahem r. Johnsom (1-ri!) I. L. - Eq. 36. 3' L. J. (h. Bit. seem: not consistent with this. 
covenant for the whole amount due-may likewise be important. Moreover, apart from any contract with the original creditor, the issuing company may be estopped from setting up equities against assignees by subseruent recognition of their title (!)).

The rule extends to an order for the rlelivery of goods as well as to debentures or other doements of litle to it debt payable in money (h).

On principle this doctrine seems inapplicable in a case where the original contract is not merely suljeet to a cross claim but voidable. For the agreement that the contract shall be assignable free from equities is itself part of the contract, and should thus have no greater validity than the rest. A collateral contrate for a distinct consideration might be another matter: but the notion of making it a term of the contract itself that one shall not exercise any right of reseinding it that may afterwards be discovered seems to involve the same kind of fallacy as a sovereign legislature assmming to make its own acts irrevocable. Nor does it make any difference, so long as we adhere to the general vules of contract, that the stipulation is in favour, not of the original creditor, but only of his assignees (i). However, the point has not been distinctly raised in any of the decided cases. In Groluam r. Johusom (k), where the contract was originally voidable (if not altogether void: the

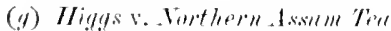
ro. (1869) 1. li. I H. 387,34 L. .I.

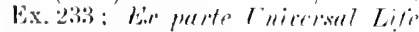

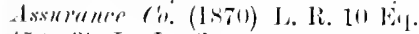
tis. 39 I. J. (h. seth (on same facts) ; Ex pate (horley (Is71) L. R. 11 Eq. $15 \pi$, to I. J. (H. 153:

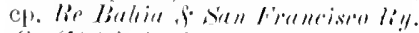

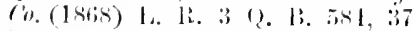
1.J.Q. B. I76. (1". cin Athemmm

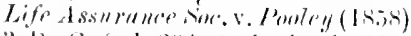
3 be (i.d.1.294, 2x 1. .1. (h. 119, be reconcilest with these cascs? It scems not : limuturiselaim (1sil)

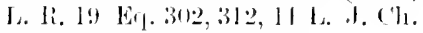
1.)(1).

(ii) Mereleant Banking ris af

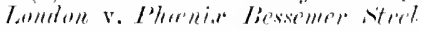
(i) $(1+76)$; ('). I) 205,46 L. I. ('l. $41 \%$.

(i) In principle it is tlos same as the case put in the bigen (.201. 17. de reg. iuris, 23) "non valerw "onvenerit, ne delus potestel tor."

(li) (1469) L. Li. 8 E. 36, 35 I. J. (1. 37.
(1). when the original contrait is voilable. 
plantiff had executed a bond under the impression that he was accepting or indorsing a bill of exchange) (l), an assignee of the bond as well as the obligee was restrained from enforcing the bond: but the decision was rested on the somewhat unsatisfactory ground that, although the instrument was given for the purpose of money being raised upon it, there was no intention expressed on the face of it that it should be assignable free from equities.

However, if the contract were not enforceable as between the original parties only by reason of their being in rari delicto, as not having complied with statutory requirements or the like, an assignee for value without notice of the original defect will, at all events, have a good title by estoppel $(m)$.

Negotiable instruments. Difficulties of assignec of ordinary contract.

We may now observe the difficulties which make the mere assigmment of a contract inadequate for the requirements of commerce, and to meet which negotiable instruments have been introduced.

The assignee of a contract is under two inconveniences $(n)$. The first is that he may be met with any defence which would have been good against his assignor. This, we have seen, may to a considerable extent if not altogether be obviated by the agreement of the original contracting parties.

The second is that he must prove his own title and that of the intermediate assignees, if any ; and for this purpose he must inquire into the title of his immediate assignor. This can be in part, but only in part, provided against by agreement of the parties. It is quite competent for them to stipulate that as between themselves payment to the holder of a particular document shall be a good discharge; but such a stipulation will neither affect the rights of

(l) The evidence was conflicting, but the Count took this view of the facts: see L. R. \& Eq. at p. 43 .

(im) see II thb v. He'rne Bay Com- misioners (1850) I., R. 5 Q. B. 142. 39 L. J. Q. B. 221 .

(n) Cp. Savigny, Obl. $\$ 62$. 
intermediate assignees nor enable the holder to compel payment withont proving his title. Parties camnot set mp a market overt for contractual rights.

The complete solution of the problem, for which the ordinary law of eontract is inadequate, is attained by the law merchant $(0)$ in the following mamner :-

(i.) The absolute benefit of the contract is attached to the ownership of the rlocment which according to ordinary rules woukd be only evidence of the contract.

(ii.) The proof of ownership is then facilitated ly prescribing a mode of transfer which makes the instrmment itself an anthentic record of the sncessive transfer's: this is the case with instruments transferable by indorsement.

(iii.) Finally this proof is dispensed with by presiming the bona fide possessor of the instrument to be the true owner: this is the case with instrments transferable by delivery, which are negotiable in the fullest sense of the word.

The result is that the contract is eompletely embodied ( $p$ ) for all practical purposes in the instrument which is the symbol of the contract: and both the right under the contract and the property in the instrmment are treated in Negotiable instruments. Peculiar and extensive rights of there a mamer quite at variance with the general principles of contract and ownership. We give references to a few passages where specimens will be foum of the positire terms in which the privilesess of luma find holders of negotiable instrmments have been repeatedly asserted hy the highest judicial authority (q).

(a) Extemalol to promissory notes by stante: 3. 4 Amm. es (in liex. Stat.) ss. 1 3. now supersederl and repealed by the bills of lixehange Act, Ixi2. As totlee eatliest formo of bills of exclatuge. sece Jules

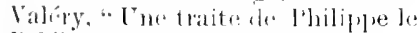

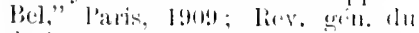
cloit, xxxii. Isis (190).

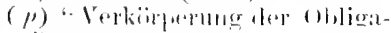
tion," sarigny.

$l^{\prime}$. liemerly by special rules of law merchant. (q) Sire frel liyles.J. Simun r. I. 15. Instralusinn (b. (186;3) in kx. (1). $211 . \&(!,[s t, 3]$ I. J. Ex.

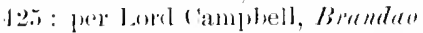

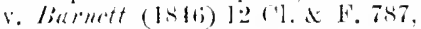
(i) K. Ii. 2011: opinion al simpeme

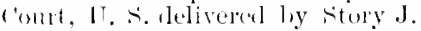
swift 8 Tysom (1842) 16 l'eters l, 15. The following refelences as fo the

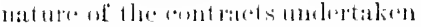
lig the partion to a bill of "xohatree" 
Qualities of negotiable instruments. Limiting rules in Croucle $e^{\circ}$ Crérlit Foncier.

The narrower doctrine which for a time prevailed, requiring a certain measure of cantion on the part of the holder, is now completely exploded. Nothing short of actual knowledge of the facts affecting his transferor's title or wilful and therefore dishonest aroidance of incuiry $(r)$ will defeat the holder's right $(s)$.

Horeover, there is no discrepance between common law and equity in this matter. Equity has interfered in certain cases of forgery and frand to restrain negotiation; but at law no title to sne on the instrument can be made through a forrery $(t)$; and "the cases of fraud where a lill has heen ordered to be given up are confined to those where the possession, but for the frand, would be that of the plaintiff in equity" ("I). The rights of lwom fide holders for value are as fully protected in equity as at common law, and against snch a holder equity will not interfere $(x)$.

The most freinent examples of negotiable instruments are bills of exchange (of which cheques are a species) $(y)$ and promissory notes. Their exceptional qualities are concisely stated in Cromelh v. Crélit Foncier (z).

" libll- of exchinge and promi-nory notes, whother payable to orter or t. Ixatrer, are by the l:LW merehant negotiable in both senses of the word. The fersul whe by a gemmine intorsement. or, where it is payable to

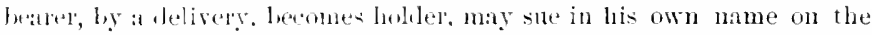

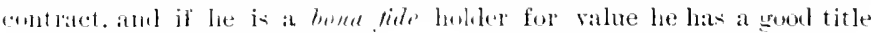

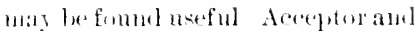

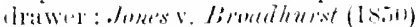

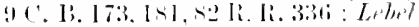

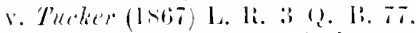
4. 37 1. J. 3. li. 4ti. Intorser:

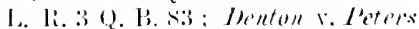

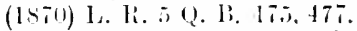

( ${ }^{\circ}$ Jard libekburn in doness.

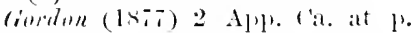
(i)!?.

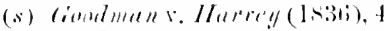

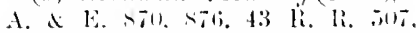

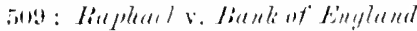

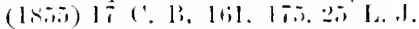

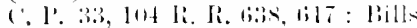
of Exehange Act, s. !11, and sir M.

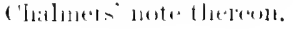

(t) 'The bun fidt holder of an in. -trument with a forger indorsement mity be axposerl to consinlerable hardship. Sice Bublett v. I'inkett (Initi) I Ex. 1) 36is. 35 L. J. Ex. i.i.

(ii) Jiness v. Lane (1838-9) :3 Y.

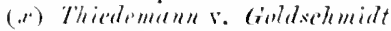
(1.5.1) I D. F. J. t.

(y) Bills of Exchange Act, 1st: (ti) 16 Vict. c. 61), s. i3. And they are equally negotiable: WLean r. Clydesdale Banking (i). $(1+3,3) ! 4$ Apl. (':a. 95.

() L. R. \& Q. R. 334. 4. L. J. Q. 1: 15:3. 
notwithstanding any defeet of title in the party (whether intorser or deliverer) from whom he took it."

It is doubtful at common law whether the seal of a corporation can be treated as equivalent to signature for the purpose of making a bill or note under it negotiable; in England the doult is removed by the Bills of Exchange Act $(a)$.

A negotiable instrument must be a contract to pay money or to deliver another negotiable security representing money $(b)$ : therefore a promise in writing to deliver 1,000 tons of iron to the bearer is not negrotiable and gives no right of action to the possessor $(c)$.

Mere private agreement or particular custom camnot be admitted as part of the law merchant so as to introduce new linds of negotiable instruments. but the fact that a uriversal mercantile usage is modern is no reason against its being judicially recognized as part of the law merchant. The notion that general usage is insufficient merely because it is not ancient is founded on the erroneous assumption that the law merchant is to be treated as fixed and invariable $(d)$. The negotiability of debentures issued by limited companies has now been recognized on the ground of general though modern mercantile custom ( $\left.\epsilon^{\prime}\right)$.

(a) lint the aulition of the sial will not prevent an instrment from being at gond bill ol mote if it is also signed by an agent or agents for the company so that it would be gond withont theseal; sere /lalford

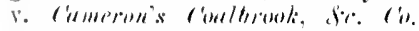
(18.) $11 ; 12.13 .142,20$ l. J. Q. 13, l60; Agys v. Vicholson (1sis(i) I II. a N. 16i2,251.J. Ex. 31s, 116 R. Ii.

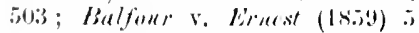
C. 1:. N. S. 6111, 2S I. J. C. 1'. 170,

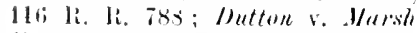
(18i1) 1. 1.. 1; 1. 13. 36il, 10 I. .1. Q. 1). 175. See now bills of lix. chatnge Act, 1sit: s. 91, stlb-s. 2.

(b) fouderin v. lintudts (1876) lix. (H., I. li, lo lix. 3:37, l A 111. Ca. Iiti, 15 1. 1. lix. J1s.
(1) llidell V. limill (lhiti) :

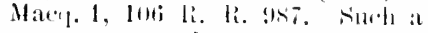
emblact may homaver be mate assignable free fom epmities:

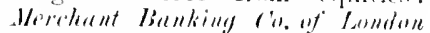

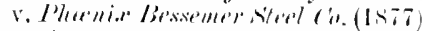

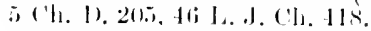

(d) Gionderin v. Leblatsts, note (b)

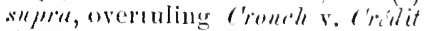
Fomrier on this point : limmlatl v. Hetropolitun Bank (1577) 21) 1: 1). 194, 16i L. . . (2. 13. 346.

(a) Siertenameland Eirplaration

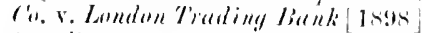

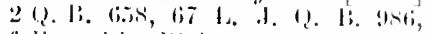
followed by lightam in lin lidstein

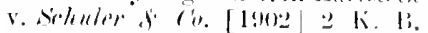
I11, 71 1..1. K. li, 572. It somes the come will new tahe julicial

li : 
The bonds of foreign governments issued abroad and treated in the Enghish market as negotiable instruments are recognized as such by law $\left(f^{\circ}\right)$. So is the provisional scrip issued in England by the agent of a foreign grovernment as preparatory to giving definite bonds $(q)$. Such bonds or scrip, and other foreign instruments negotiable by the law of the comntry where they are made, may be recognized as negotiable by our Courts though they do not satisfy all the conditions of an English negotiable instrument $(h)$.

Negotiability From what was said in rombin r. Rolnarts (i) in the by estolpiel.

Honse of Lords it seems that where the holder of an instrument purporting on the face of it to be negotiable, and in fact usually dealt with as such, intrusts it to a broker or agent who deals with it in the market where such usage prevails, he is estopped from denving its negotiable quality as against any one who in good faith aud for value takes it from the broker or agent. But where a person takes documents of value, negotiable or not, from one whom he knows to be an agent having limited authority, he must at his own peril ascertain what that anthority is and this whether his knowledge be derived from the principal or not $(k)$.

How instiuments maly ceiset to lie negotiable.

It is also to be observerl that an instrument which has leen negotiable may cease to be so in various ways, natnely-

untine that such instruments are negotiable. F'ronf of gencral usage and recontition in Englanel is enough; the original reann was that a jury. as "the comntry." "omld have no knowleilge of what was usual elsewhere.

(t) Gimier v. Wierille (1s24) 3 Ti.d ('. 4.), 27 li. R.,294. Negutiability in a foreign market is mot enougls: Pirlir" v. Lomdon and raunty banking (i). (185i) do

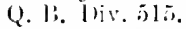

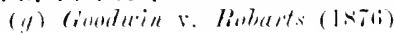
L. Li. I1) Ex. 7 i, :till. in Ex, Ih. ib. 33:. in if. L. 1 App. ('a. fït. 4.) L. .]. Ex. Tts.

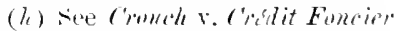
(1-73) I. li. \& Q. B. at p]). 3At-5: Gumluill v, loburts. 1 App. Ca. at 1). $4 ! 4-5$.

(i) 1 Apr. ('a lsc. 489, 493. 497.

(li) burl at silegtield v. Loudon Juint rtack Bank (1S心) 13 App. (a. 333. $\pi$ L. .J. Ch. 98t;. This "uphies only where there is actual knowlelge of the limited authority : Lamdon . Juint sterk liank r.

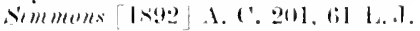
('h. 72.3 . 
Payment by the person ultimately liable (l).

Restrictive indorsement $(m)$.

Crossing with the words "not negotiable" $(n)$.

'To a certain extent, in the case of hills payable to orrler, indorsement when overdne, which makes the indorsee's rights subject to what are called equities attarhing to the bill itself, $\bullet . \%$, an agreement between the original parties to the bill that in certain events the acceptor shall not be held liable, but not to collateral equities such as setoff (o).

We have purposely left to the last the consideration of certain important classes of contracts which may he roughly described as involving the transfer of duties as well as of rights. This happens in the cases

(A) Of transferable shares in partnerships and companies.

(B) Of obligations (p) attached to ownership or intriests in property.

A. The contract of partnership generally involves personal confidence, and is therefore of a strictly personal character. But, "if partners choose to ayree that any of them shall be at liberty to introduce any other person into the partnership, there is no reason why they should not: nor why, having so agreer, they should not be bound by the agreement" $(q)$. At common law the number of persons engaged in a contract of partnership does not

Transfer of contratits where duties as well ats rights transferrel.
(A) Part. nerships: shares in omlinary partuersinjs and unincorjorated companies may be mate trans. ferible at common law.

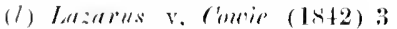
Q. l. lot. As to the positjility of sning on a bill after it has been paid by some of leerperson, see ('am)

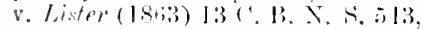
32 L. I. (1. I', 121.

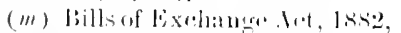
s., $35.36 \%$

(n) Billsof Fixhange Aot, I S4:

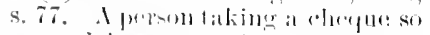
crossed has not and cannof erive a betten title than the person from

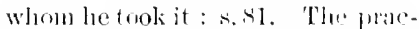
tice of crossing chenum is moknown in America.

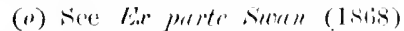
I. li. 6 E. 311, 359, whe the anthorities are alisenssent.

(y) 11 e whe the worl lace in its wide somse so at to demete the berefit or burlen of a contract, or looth. aecoleling to the mature of the ratise.

(4) Lindley on Partnership, 3188. 
But no uncertain contract and no real anomaly in this.

Practical rifheulties of unincorprated eompanies would

make any difference in the nature or validity of the contract: hence it follows that if in a partnership of two or three the share of a partner may be transferred on terms agreed on by the original partners, there is nothing at common law to prevent the same arrangement from heing made in the case of a larger partnership, howerer numerous the members may be; in others words, unincorporated companies with transferable shares are not mlawful at common law. But this, as Lord Lindley observes, is now only of historical interest $(r)$.

At first sight this may seem to involve the anomaly of a floating contract hetween all the members of the partnership, for the time being, who by the nature of the case are mascertainerl persons when we look to any future time $(s)$. But there is no neerl to assume any special exception from the ordinary rules of contract. It was pointed out by Lord Westbury that the transfer of a share in a partnership at common law is strictly not the transfer of the outgroing partner"s contract to the incoming partner, but the formation of a new contract. "By the ordinary law of partnership as it existed previously to" the Companies Acts "a partuer could not transfer to another person his share in the partnership. Even if he attempted to do so with the consent of the other partners, it would not be a transfer of his share, it would in effect be the creation of a new partnership" $(t)$. This therefore is to be adted to the cases in which we have already found apparent anomalies to ranish on closer examination.

Notwithstanding the theoretical legality of unincorporated companies, there does not appear to be any very satisfactory way of enforcing either the claims of such a

$13 i$

(*) Cp. per Ablott C.J. in

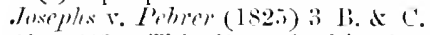
13:3. ti43. This line of objection however, does not appear to have been distinctly taken in any of the cases where the legality of jointstock companies was discusseil. (t) Wly v. Whittin (18\%2) L. R. 5 H. L. $711,727,42$ L. J. Ch. 161 . 
company against an individual member (11), or those of remain, even an individual member against the company $(x)$. But apart from under the modern law of companies questions of this kind have no practical importance in this country. In like manner the transfer of shares in companies as well as their original formation is almost entirely governed by modern statutes.

B. Obligations by or in the nature of enntract attached to ownership or interests in property are of several kinds. With regard to those attached to estates and interest in land, which alone offer any great matter for observation, the discussion of them in detail is usually and conveniently treated as belonging to the law of real property. There are however matters of general principle to he notel, and misunderstanding to be avoided, as to the respective methods of common law and equity in dealing with burdens imposed on the use of land by contract.

A preliminary statement in a summary form may be useful.

\section{OBLigations ATtACHED TO OWNERship AND INTERESTS IN Gieneral view PROPERTY. thereof.}

(B) Obligations attacherl to property.

I. Goods:

A contract cannot be annexerl lo gools su as to follow the property in the goods either at common law (l/) or in equity (i).

liy statute $18 \& 19$ Viet. c. 111 the imlorsement of a bill of liuing operates as a legal Iransfer of the eontraet, if and whenever by the law merehant it operates as a transier of the property in the goods.

(ii) We have seen $(. * n \mu \prime \prime, 1) \cdot 2 \cdot 27)$ that they eannot emprower ancilicer to sue on behate of the asisciation.

(r) See Lymu v. IHaymes (Isi:3) i M. E (ir. 5of. A partner can now sue or be sued by the part nership in the tim-name. See OH. XI,VIIIA. rr. $1,10$.

(y) Bril resolution in symerers ars. 1 Sm. 1. C. (ij); siplidt v. Bowles (1805) 10 Litst. 279, 10 li. li.
296. "In general contrincts do not by the law of England rum with groots": Blaekburn on sale,

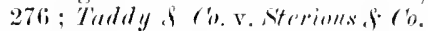

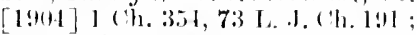
he tiruther v. Pitcher [1:001] 2 eh. 30t; 73 1. .t. ('h. 653, (1. 1. ; lietts-

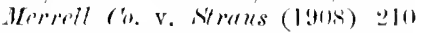
U. S. :3:3!.

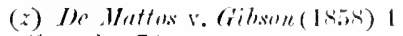
De G. d. I. 271,295 . 


\section{IAND $(a)$.}

a. Relations between landlorl and tenant on a demise.

\section{Burden :}

of lessce's corenants

of lessol's novenant.

Benerit :

of lessevisovenantis

As to an existing thing pareel of the demise. assignees are bomm whether namerl or not.

A. fusomething to be newly marle on the luemises, assignees are bound only if namisl (b).

mons with the recersion.

(32 Hen. VIII. c. :it.)

man with the reversion.

(32 Hen. V1I1. e. 34.)

The statute of Hen. IIII. alflies mly to demines umler seal (c), and

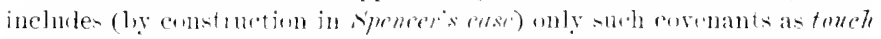
and romern the thin! demised (d). It applies only to the reversion whieh the corenantor hal at the time of entering into the covenant (

of lessor's covenants runs with the tenaney.

sce also 41 . $15 \mathrm{Vin}$. c. 11, ss. 10, 11, st.

A corenant gising the leste an option of purchasing the reversion at a fixed rate at any time duning the term is not within the statnte, as it. dnes not concem the tenaney of the damb ensidered as the subjectmatter of the lease $(f)$. A envenant with an underlessee to lerform a eovenant in the superion leave relating to premises not comprised in the mulerlease is collateral and does not bimd assignis $(g)$.

\section{Note.}

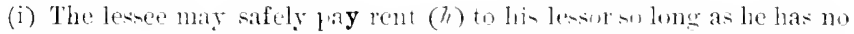
motice of any grant over of the reversiont : I 85 Anne c. 3 [in

(a) (In this generally se' l)art Y. A P. 2. slie squ. : Bri fieport of R. I'. Commisoion, liav. ('ons. 1. 122 (1the ed.): and above all the noten to spemerts ase in 1 sm. f. C.: and also as to eovenants in leasen the notes to Thurshy $r$. Plont, 1 Wms. Samme. 27s-2081, $294,30.5$.

(b) As to this alintinction, see 1 sin. L. C. $60.8 \mathrm{~g}$.

(c) e.g. smith v. Etygingtum (15it) L. R. : C. 1. 14. 4.8 i.. J. C. P. 140 .

(d) Fur the meaning of this see

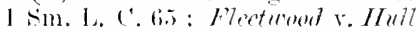

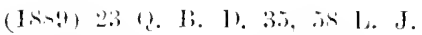
Q. 1i. : : 41 .

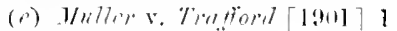

('h. 5t. in 1... . ('h. 72.

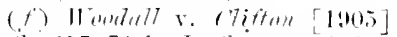

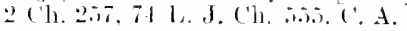

(a) Herear v. Gromblman [1!ng] 1 K. R.!1, 7. L. I.K. B. 16!, C. A.. [1909] A. (1. 72, - \& 1., . K. B. 209. Sie futher IJysull r. Forster [1909] A. 1. M, of L. I. K. I․ 246 ;

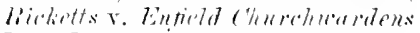
[190!1] l ch, 54t, 5.33, .s [.. J. ch. 291, L. Q. L. $\times x \times 117,2 \times 0$.

(h) In the case of the lessee's covenants other than for payment 
Rev. Stat.: al 4 Amo e 1ti], which is in lact a terelaration of

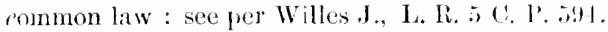

(ii) The lessee may still be suen on his expresis covenants (thomgh miter the old practice he coubl not be sned in drht for rent) after an assignment of the term (i).

(iii) The doetrine concerning a rewision in a term of pars is the same as eoneeming a freebuhl reversion $(k)$.

(iv) Where the statute of Ilonry VIII. llees not aly'ly, the asmignes of the reversion canmot sue an original leseet who has aswinned over all his estate, there being neither frivity of estate nor privity of contract (l).

B. Mortgage lelets.

The trinsfer of a mortuge security oprerates in rymity at a transer of the debt (m). Notice to the mortgagor is not neerled to make the assignment valid; but withont such not ine the assignce in bound by the state of the accounts bet ween mort gagor and mort gagee $(n)$.

$\gamma$. Rent-charges and anmuties imposedm liml imdepentently uf tenancy or eecupation (1).

An agreement to grant an annuty charged on lamel implies an argee. ment to give a personal eovenant for payment $(p)$ : lut l,y a somewhat eurinus distinction the burten of a corenant to pry a rent-charge does met run with the lamel enarged, nor does the berretit of it run with the rent $(q)$.

$\delta$. Other ecremants not between landlumel amel tenant, relatjug to lant and entered into with the owner of it.

The benefit runs with the covenantee's estate so that an asignee can sue at common law. The lessee for years of the covenante may enfirce

of reut, an assignee of the reforsion is not bonud to give notice of the assigmment to the lessee as a conrition precedent to enforcing his

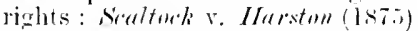
1 ('. P. 1). 106,15 L. J. C. P. 12.).

(i) $1 \mathrm{sm}, 1,1,24,1$ 11, Saumi, 2!s.

(k) $1 \mathrm{sm}, \mathrm{I}, 1+71,75$.

(l) H/looch y. Hom 9 (2. 1). Liv. Biti.

(iin) This is me of the canes in which the copitable tram-fer of a deht is not malle = a legal t lamsiep by the Juliuature Act, 1st3. In practioe an "xpless assignuncont of the debl is always allell: the old power of attormey however is mow superiluens.

(n) Jomes v. (iblumes (Isil) 9 Ves.
107, 111. 7 R. R. 217 ; Matthem v. Hallu!h (179s) + Ves. 11s. 12i;.

(1) These must le regarial as arisine from antract (we ro not sqeali of rents of servieses incirlent totrmur): thre treatment of rentchareres in Engrlish law as real rierlits or incorpureal hereditaments

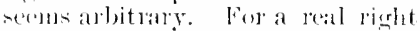
is the power of exerrising sme limiterl part of the rights of amereslip. and is quite distinet from the right to receive a lixerd payment without the ismorliate power of

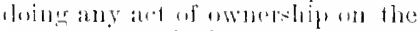
property on which the patyment is serellecil.

(1') Bumer r.timere (isiz): Ilat. 104. 11 j, .1. (1h. 287, 6.2 li. Ji. Itil.

(y) $111 \mathrm{nus}$. Fumbl. 30:3. 
the eorenant an an awign if asigns are named $(r)$. It is immaterial whether the eovenantor was the person who conreyed the land to the corenantee or a stranger (s). The usual ventor's covenants for title come under this hear. It is dimbtful whether a bona fide purchaser from a purchaser who thtained his eonveyance by fraud ean in any eireum. stances sue on the former rendor's evrenants for title $(t)$.

є. The like corenants enterel into ly the owner.

The burken of sueh eorenants alle ars on the whole mot to run with the lanl in any ease at common law (" ). Lut where a right or easement afferting land - a th as a right to get minerals free from the ordinary duts of nut letting lown the -urface- $\mathrm{i}$-granted subject to the ilut faying compenation for lamare done to the land by the exereise of the right, there theduly of paying compensation rums at law with the benetit of the grant. Here, however, the correct riew seems to be that the right itself is a qualitiel one-ris. to let duwn the surface, de. laying compensation. and not otherwise (,r).

The burlen is said to run with the land in equity (y) (subject to the limitation to be mentioned) in this sense, that a court of equity will enfure the curenant against assignees who have aetual or eon-truction (:) notice of it : aml whon the corenant is for the benefit of other land (as in practice is commonly the (ase) the benefit generally though not alwars rum with that other lant.

Lirplunation. Iet us call the land on the use of which a restrietion is impose by corenant the quesi-serrient tenement, and the land for whose benefit it in impored the quesidaminant tenement. Now restrictive covenants may be entered into.

(1) Iiy a rendor as to the use of wher land retained or simultaneously mhl, for the benetit of the land sold by him :

(.) Tuit, s. Gowling (1sia) 11

ch. 11. 273, ts L. J. ( 'h. $3: 7$.

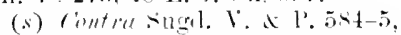
bat alone among molem writers. The case from the Year Books relied on ly Lorel st. Leonarils (I'akiphluamis rase. H. 42 E. 111.3.

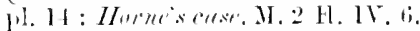
Hl. 2.) seem to show only that it was onee thought doubtful whether the asignee conld sue withont bein aloo heir of the oriminal eove. nantee. See also O. W. llolmes, The Conmon Law. 3:15, to4.

(t) Omend Building Niriety v. Simithann [18:3] 1 ch. 1. 15. 62 L. J. Ch. lis. C. A.

(i) Brd reprort of li. l'. Commis- sioners. in 1 Dav. Conr. Austerberry $\mathrm{r}$. (ompuration of Oldham (185.5) 29 Ch. biv. 750,55 L. J. Ch. 1333: Farwell J. in Rogers v. Howe gow $[19100] \div$ (h. 38s, 3\%5. 69 i. J. ('h. 28.

(, Aspelen v. Seddion (1siti) 1 lix. Div. 496, , 19, ti; L. J. Ex. :3is.

(y) The phrase is not free from objection, per Rigbr L.J. [1900] 2 Ch, at P. 401. See howerer lisbet i. Potts contr. [1940i] 1 Ch. 386 . 413.40 .5 .

(z) Ililsun v. Hart (1866) L. R. 1 Ch. 463: Patman r. Harland (1s+1) 17 Ch. D. 353, 50 L. J. ('h. (it2. 
In this ease the burden mns with the quasi-servient tenement and the benefit also runs with the quasi-dominant tenement.

(2) By a purchaser as to the use of the laud purchased by him, for the benefit of other land retained or simulanemsly sold by the vendor :

In this case the burden runs with the yuasi-servient tenement, and the benefit ma!l run with the yuasi-dominant tenenent when such is the intention of the parties, and espeeially when a portion of land is clivirled into several tenements and dealt with accorling to a preseribed plan or "building scheme" (a).

All these rights and liabilities being furcly expitable are like all other equitable rights and liabilitics subject to the rute that furehase for value without notice is an absolute defence. An asvign of a cosenantee may be entifled to the benetit of the envenant without having known of it at the date of his purehase: the puestion is whether he acsuired it as annexel to the land (b).

Further, this doetrine applies only to restrietive. nut to aflimative eovenants. Thus it does not apply to a covenant to repair. "Oaly such a eovenant as ean be complied with without expenditure of noney will be enforeed against the assignee on the ground of notice" (*). It does not apply to merely personal and collateral covenants $(d)$.

The only points which seem to call for more notice Further here are the doctrines as to bills of lading (I.) and restrictive covenants as to the use of land (II. $\epsilon$ ).

remarks : as to bills of lading.

As to (T.) it is to he borne in mind that bills of lading are not properly negotiable instruments, though they may be called so in a limited sense "as against stoppage in trausitu only" (e). Is far as the law merchant goes the bill of lading only represents the goods, and does

(a) Foutes v. Lyom. l. Ii. I ('il. 2Is, 3i 1. 1. Ch. 3.5. and other eases there comsidered ; / Harisouv. Goud (18.71) 1. R. I1 Ey. 33s, fo

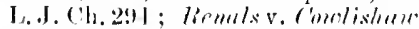
(18\%, ! (h. 1). 125. 11 ('h. I)iv.

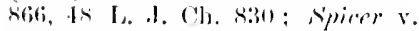

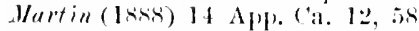
L. J. ('h. :30!9; Romeres v. /Iowegond

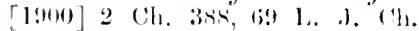
ti.s.2, (:A. As to the positum of a lessee of an owner lumml by a restrictive covenant, Mallaim!! Bros. v. I/ill [1502] ('h. til2, 71 L. J. ('h. Sis. (b) Ringers v. Iloxifgomd, last note.

(c) limulley J.ol. Ila!nmm v.

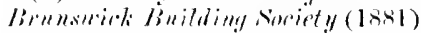

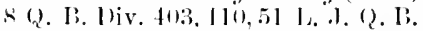
73; L. I. S. H. liy. ('o. v. (romm, 20 Ch. Jiv. iti2, it I. J. (h. 530 : lustrellereng v. Cimporation of Olalham, note (11), P. 250, above; llall v. Simin (1887) 37 (h. Iliv. 71,57 1..1. (.t. .95.

(d) $F(r m b y$ v. Burlire [19013] 2

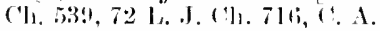

(e) l'el Willes J. Furntes v. Montis (1869) l. R. 3 (. I'. at 1. 276,38 L. J. C. I'. 95. 
not enable any one who gets it into his hands to give a hetter title than his own to a transferee; "the transfer of the symbol does not operate more than a transfer of what is representer " $\left(t^{\circ}\right)$. And the whole effect of the statute is to attach the rights and liabilities of the shipper's contract not to the simbol, but to the property in the goods themselves (!) : the right to sue on the contract contained in the bill of larling is made to "follow the property in the goods therein specified; that is to say, the legal title to the goods as against the indorser" (h).

As toburden of eovenants rumning with land difference between C. L. and Equity on this. Treatment of the question at C. I.

As to (II, $\epsilon$ ) the theory of the common law is to the following effect. The normal operation of a contract, as we have alrearly hat occasion to say, is to limit or cut short in some way the contracting party's control over his own actions. Among other limes of actions the exercise of rights of ownership over a particular portion of property may' be thus limiter. So far then an owner "may bind himself hy covenant to allow any right he pleases over his property" (i) or to deal with it in any way not unlitwful or against pullic policy $\left(k_{i}\right)$. But if it be songht to annex such an olnigation to the property itself, this is a manifest departure from the ordinary rules of contract. An obligation attached to property in this manner ceases to be only a burden on the freedom of the contracting party's individual action, and becomes practically a burden on the freedom of ownership. Now the extent to which the law will recognize such burdens

(f) Ginlley v. Brhiond (18.it) 3 E. A B. (i22, (i:31, 23 1. .T. 1) l?. 26ii, 97 R. H. 1 is 7 , 6i!s.

(y) Forr v. lott (1sili) bi H. \& N. 630, 1336,30 L. .I. Ex. 2.54; Simuthereite v. Willins (1si2) 11 ('. li. 5. . 842, s.41, 3I I. J. C. I'. 214 .

(h) The Freedom, 1. li. 3 l'. C.
594. 599. As to indorsement by way of pledge, see sempll v. Burdirk

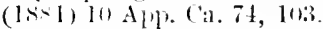

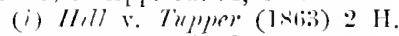
d $1.121,127,32$ L. J. Kx. 217.

(b) It is not unlawful for a landowner to let all his land lie waste: but a covenant to do so would probably be invalid. 
is already definer. Certain well-known kimils of permanent hurdens are imposed by law, or may be imposed by the act of the owner, on the use of land, for the permanent benefit of other land: these, and these only, are recognized as being necessary for the ordinary convenience of mankind, and new linds cannot be admitted. And this principle, it may be observed, is not peculiar to the law of England (l). Easements and other real rights in re alicnu cannot therefore be extended at the arbitrary discretion of private owners: "it is not competent for an owner of land to render it subject to a new species of burden at his fancy or caprice" (m). Still less is it allowahle to create new kinds of tenure or to attach to property incidents hitherto mknown to the law. But if it is not convenient or allowable that these things should be done directly in the form of easements, neither is it convenient or allowable that they should be done indirectly in the form of oblinations created by contract but amnexed to ownership. If the burden of restrictive covenants is to rom with land, people can practically create new easements and new kinds of tennre to an indefinite extent. Such alpears to be the view of legal policy on which the common law doctrine rests (n).

(f) ('p. Savigny, (1)), 1. 7 : and for a singular coine is lesece in dertail, b. s. 3. id serv praed rust is 1 .

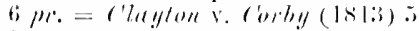

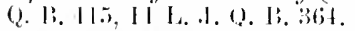

(iit) l'er Martin ls. Vuttull v.

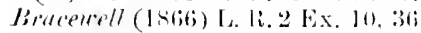
L. J. Ex. I ; for the (:. L. prineiples generally, see lokroyd v. rimith (1850) $10(\therefore .13 .164,19$ 1..1.1.1.31.5.

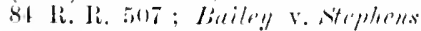
(1862) I2 \%. 1. N. S. 91, 31 1.. . C. I'. 2206, Nights of thic kind ale to be carelully distin zuished loum these created by grants in gross: sere

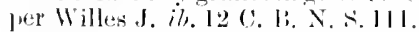
I'he Conals might have held thate new negative eatsemento might lue crated, hut mot pwitive ones, bul

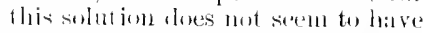
(aver been definitely lompred, although the modern dostrine of

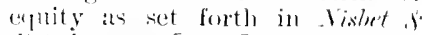

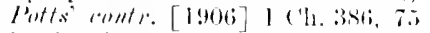
l. .I. Ch. 23s, (: A. comes very near it ; and the whole sulject iil megative easements is still ubeure, as is slown lis the wirlely different "prinions helit in Daltoli ve Inyms

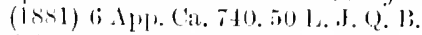
(i)

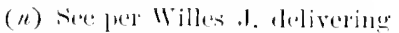
the julegument of the kx. ('/. in

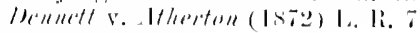

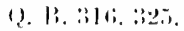


In erpity.

The history of the rloctrine in the Court of Chancery is somewhat curious. Lord Brougham, in an elaborate judgment which seems to have been intended to settle the question (o), treated what we have called the common law theory as fimal, and, ignoring the difference between positive and negative covenants, broadly laid down that where a covenant does not run with the land at law, an assignee cannot he affected by notice of it. But this judgment, though treated as an authority in courts of law ( $p$ ), has never been followed in courts of equity. After being disregarded in two reported cases $(q)$ it was overuled hy Lord Cottenham in T'ulk v. Moxhay (r), now the leading case on the subject. The most important of the subsequent cases are Kontes v. Lym (s) (where the anthorities are collected), Huy tool v. Brunswick Building Surcty $(t)$, which explicitly decided that the rule applies only to negative covenants, and Sottinghem Brick Co. v. Butler (n). Then a rendor sells land in building lots and takes restrictive covenants in identical terms from the sereral purchasers, not entering into any covenant himself, it is a question of fict whether these corenants are meant to operate for the protection of purchasers as between thenselres, or as against the rendor in his dealings with parcels retained by him $(x)$. Where such

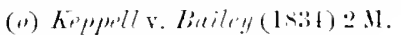

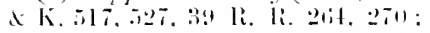
and : :ee the preface to that colume.

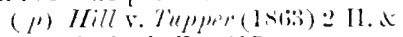
('. 121. 32 L. I. Ex. 217.

(q) 11 thetman v. Gibsom (1.835) !1 sim. 196,17 R. li. 211 : 11/un . stepleess (184ti) 15 sim. $37 \%$, it li. li. Jo!.

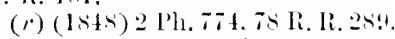

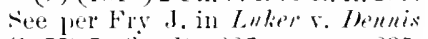

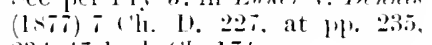
$236,+\vec{i}$ l. J. ('h. 17 t.

(s) (Istia) L. Ii. 4 ch. 214,38 [. I. ('b $35 \%$.

(t) $(15 \times 1)$ \& Q. 1. Div. 418, 51

L. I. Q. 1. .3.

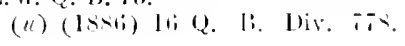

For the corresponding scottish denetrine, see Mislop v. Lerlice (18s1) 1i Aple (at seio.

(x) lie Birmingleam and Distrist

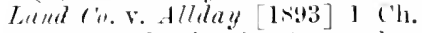
:3t.2. 1i2 L. I. ('h. 90. Is to what is sulticient evidence of a "building selente." Tincler v. loweles [1843] 1 ('h. 195,62 L. J. Ch. 172: Osbornt v. Bradle! $[1903] 2$ ch. 4 tio, is

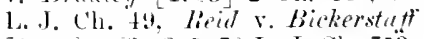

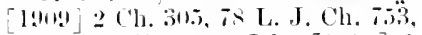
('. A. : Iilla v. st. Jolen [1!111] i ch. 32. 7! 1. J. ('h. 285. C.. A. The remurrs talsing restrietive covenants and not reserving any fart of the froperty is strong attimultive eviclentee" lout his 
is the intention, any purchaser can enforce the restriction against any other purchaser, or his assigns having notice, or the vendor as the case may lie, nor can the vendor release the covenant to any purchaser or his successors in title without the consent of all the rest $(y)$. An in. truder who acquires a statutory title by adverse possession is in no better position than a purchaser with notice (z).

The result of the equitalle doctrine is in practice to enable a great number and variety of restrictions to be imposed on the use of land for an indefinite time, subject The foundation of the equitable to the contingency of a purchase for value withont notice of the restriction (a). But equity does not profess to enforce a restrictive covenant on a purchaser with notice as being a constructive party to the covenant; it only restrains him from using the land in a manner which would be unconscientious as lepriving the covenantee of his effectual remedy $(h)$. So far as common law remedies go, covenants of this lind can be always or almost always evaded; if the equitable remedy by injunction were confined to the original covenantor, that also conld be evaded reservation of part is by no meths conelusive the other way.

(y) See sprop r. Hartin (Ists)

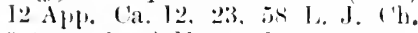
305 , per Lord Macnaghten approsing the statement of Hall V.C. in

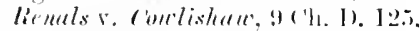
129 ; Ellistert v. Rearle [1908] :

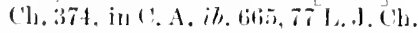
619, Ts L. J. ('h. s7. Note that the equitable obligation between lilferent purchasers is inclepentent of the dates of their respective porrchases. As to the effect of a purchaser of lots in a buihling entate under a restrietiveseheme forming a "sub-selueme" by re-selling purtions under new comlitions. see Knight vo rimmons [ Is:gi] 2 ' 1 l.

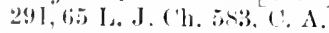

(z) Vistert and Potts rente.

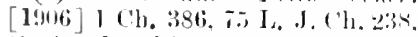
$\therefore$ A. In this case an equitable. restriction is cuforeded agatiost one who is in wo way party or privg to the transaction which created the original expity. amel thus as F. W'. Maitlame sati in one of the latest acllitions mate by himsell to his lertures, "a enrions class of negrative eas ment is here ereatrol": Maitland. Equity. ete. C'amb.. 1:0!9, p. 170. Sevortheless the leeision seems inevitable.

(a) Where there has once been

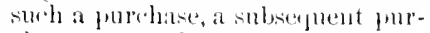
chatsen cammot be affected by notice. Ser prer Limbley L.J. I6 (2. I. I) Iy. at p. iss.

(b) "I cho not think any covenant mns with the lanel in equity. The eguitable duetrine is that a person who takes with notice of a covenant

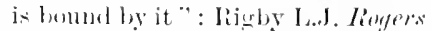

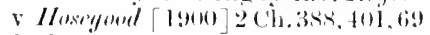

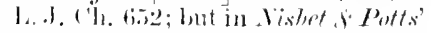
contr., note ( $)$ abrese it jesaid that at negative eovenant of this kind does

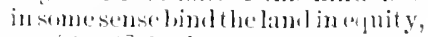

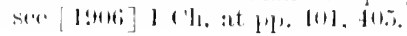


by a collusive assignment. On this principle however an assign cannot be and is not made answerable for the active performance of his predecessor's covenant: he can only he expected not to prevent its performance. Hence the decisions to that effect which have been cited (c). The jurisdiction is a strictly personal and restraining one. To rule of the law of contract is violated, for the assign with notice is not liable on the contract but on a distinct enuitable obligation in his own person. Lord Brougham fell into the mistake of supposing that the covenant must be operative in equity, if at all, by way of giving effect to an intention to impose permanent burdens unknown to the law. Equity does not trouble itself to assist intentions which have no legal merits, and any such action, Lord lirougham rightly saw, was beyond its proper province. The law laid down in Feppell r. Bailey (d) was erroneous on this point, not from any defect of reasoning in the judgment, but becanse the reasoning proceeded on an erroneons assumption.

Change of contlitions.

The true principle is further illustrated by the rule that even with notice an assign is not liable "where an altriation talies place throngh the acts or permission of the plaintiff or those mnder whom he claims, so that his enforcing his corenant hecones mireasonable" (ڤ). Were the liability really on the covenant, nothing short of release or estoppel frould aroid it.

(c) Seef a note in L. 6. R. ir. 11! (nut by the prencalt writer) on $/$ hall

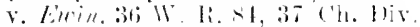

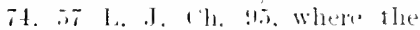
dectrine is well explained : ímell

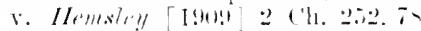
L. .I. ('I. Ftl, C. A.

(d) 2 I. A K. 57.39 li. R. 26 t. other rearons with which we are mot concerned here were given: the actual decison was perhap aloo right on the gromed that the corchant inquestion wats not merely

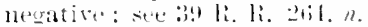

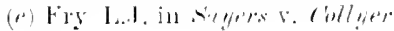

(ant) 28 (h. Div. 103, 109, i2 l. J. (h. Fo. explaining the limits of the rule as originally kail down in Dulie ut litelfind v. Trusteps of

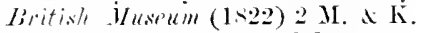
5.). 39 R. R. 2s: Ostorne r. Brudley 1903 2 ('h. 446.33 L... ('h. 4!. In New York this limitatien seems not to be recognized: Trustees

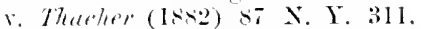
where, the residential amenity of a st leet having been lest royed by the tevatel railway the court refused iu thf ree a covennut against using the house for triwle. 


\section{CHAPTER V'I.}

\section{Duties under Contrict.}

\section{Interpretation stencrally.}

We have now gone through the general and necessary elements of a contract, and shall hereafter consider the Necessity of further canses which may amul or restrain its normal effect. This work does not profess to deal fully with the rules of law which govern the construction, performance, and discharge of contracts. But we cammot apply the principles by which disputes as to the vilidity of an agreement have to be determined withont first determining what the substance of the agreement is; and a dispute as to the original substance and force of a promise may often lie resolved into a conflict on the less fundamental question of what is a sufticient performance of a promise admitted to be linding. A smmmary view of the leading rules of interpretation may therefore be found useful at this stirge. We suppose an agreement formed with all the positive refuisites of a good contract; and we proceed to ascertain what are the specifie duties created by this agreement.

If there be not any special cause of exception, the promisor must fulfil the obligation which his ow act has promisor's created. He must perform his promise according to its terms. Here there are two distinct elements of which either or both may be more or less difticult to ascertain: first the terms in which the promise was mule, and then the tran sonse and aflect of those terms. The former 1 . 
Expectation of promisee.

lieasonable effect of promise on promisee. must be determined by proof or admission, the latter by interpretation, which, however, may have to take accomnt of specific facts other than those by which the promise it.relf is estallished. We assume the terms to be reduced to at form in which the Court can understand them, as for example by tramslation from any langnage of which the Cunt does not assume judicial knowledge, or by explanation of terms of art in sciences other than the law, which is really a lind of translation out of the language of specialists.

The nature of a promise is to create an expectation in the person to whom it is male. And, if the promise be a legally linding one, he is entitled to have that expectation fultilled hy the promisor. It has, therefore, to be consitered what the promisor ald entitle the promisee to expect from him. Every prestion which can arise on the interpretation of a contract may be bronght, in the last resort, miler this general form.

In order to ascertain what the promise had a right to expect, we rlo not look merely to the words used. We must look to the state of things as known to and affecting the praties at the time of the promise, including their information and competence with regard to the matter in hand, and then see what expectation the promisor's worls, as uttered in that state of things, wonld have created in the mind of a reasonahle man in the promisee s place and with the same means of judgment (a). 'he reasonable expectation thus determined gives us the legal effect of the promise.

Now this meisure of the contents of the promise will be found to coincide, in the usual dealings of men of grood faith and ordinary competence, both with the actual intention of the promisor and with the actual expectation of the promisee. But this is not a constant

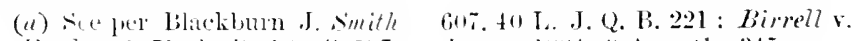

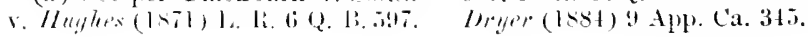


or a necessary coincidence. In exceptional cases a promisor may be bound to perform something which he did not intend to promise, or a promisee may not be entitled to require that performance which he milerstood to be promised to him. The problem has been dealt with by moralists as well as by lawyers. Paley's solution is well known, and has been quoted by textwriters and in court (l): "where the terms of promise admit of more senses than one, the promise is to be performed in that sense in which the promisor aplnehended at the time that the promisee received it." But this does not exactly lit the mark. Hetlection shows that without any supposition of fraur, Paley's rule might in peculiar cases (and only for such cases do we need a rule) give the promisee either too much or too little. And Archbishop Whately, a witer of great acuteness and precision within the limits he assigned to himself, perceived and corrected the defect: "Paley," he says, "is nearly lut not entirely right in the rule he has here laid down . . Every assertion, or promise, or declaration of whatever kind, is to he interpreted on the principle that the right meaning of any expression is that which may he fairly prosumed to bre understomd by it" (c). And such is the rule of judicial interpretation as haid down and used in our Courts. "In all deeds and instronments" - and not less, when occasion arises, in the case of spoken words - "the language used by one party is to be construed in the sense in which it would be reasomalny understood by the other" (d). All rules of construction

(b) L. Ii. (i) (1) Ii. tim). tilo.

(c) louley, Mloral l'hil. bk. : pt. 1, e. $\because:$ Ithately theress in notes tor ed. 18.5:). 1 :an intebted to any leamesl friend I/r. A. I. bicey for ealline my attention tis Whately's ancentment. Austin's altempt (Juri-prulence, i. list.

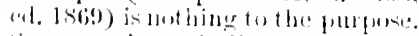
sime: molern civiliates hase said, with useless subtilty, that a prot minor whe hats by his own fatult

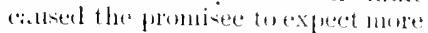
than was meant is lemmel " muln ex

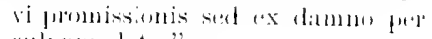
(cilpautu diato."

(d) Blackburn .I. in Finele's r.

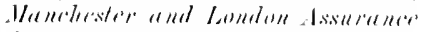

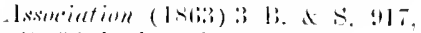

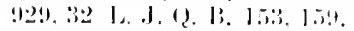


Agletenents eridenced by writing : rule against parol variations.

may be said to he more or less direct applications of this principle. Many rules of evilence involve it, and in particular its derelopment in one special direction, extended from words to conduct, constitutes the law of estoppel in pais, which under somewhat subtle and technical appearances is perhaps the most complete eximple of the power and flexibility of English jurisprudence.

We hare already seen that the terms of an offer or promise may be expressed in worls written or spolien, or conveyed partly in words and partly by acts, or signified wholly by acts without any use of words (r). For the purposes of eridence, the most important distinction is not between express and tacit significations of intention, but between writing and all other modes of manifesting one's intent. The purpose of reducing agreements to writing is to declare the intention of the parties in a convenient and permanent form, and to prechde subsequent disputes as to what the terms of the anreement were. It wonld he contrary to general convenience, and in the rreat majoritr of cases to the actual intention of the praties at the time, if oral evilence were admitted to contralict the terms of a contract as expressed in writing by the parties. Interpretation has to deal not with conjectured lut with manifest intent, and a supposed intent which the parties have not inchuled in their chosen and manifest furm of expression cannot. save for exceptional camses. be regarded. Onr law. therefore does not admit evidence of an agreement by word of mouth against a written agreement in the sume matter. The rule is not a technical one, and is quite independent of the peculiar qualities of a deed. "The law prohibits generally, if not miversally, the introduction of parol evidence to add to a written agreement, whether respectingr or not respecting 
land, or to vary it" $\left(f^{\prime}\right)$. " If A. and B. make a contract in writing, evidence is not admissible to show that $A$. meant something different from what is stated in the contract itself, and that B. at the time assenter to it. If that sort of evidence were admitted, every written document would be at the mercy of witnesses that unight be called to swear anything" (y).

Under normal conditions the same rule prevails in linten equity, and this in actions for specitie performance as well equity. as in other proceedings, and whether the alleged variation is made by a contemporaneons ( $h$ ) or a subsequent $(i)$ verbal agreement. "Variations verbally agreer npon . . . are not sufficient to prevent the execution of a written agreement, the situation of the parties in all other respects remaining unaltered" $(k)$.

Similarly, when a cuestion arises as to the construction of a written instrument as it stamds, parol evidence is not admissible (and was always inadmissible in equity as well as at law) to show what was the intention of the parties.

(f) Matin v. Pyoroft (1852) 2 1). Il. G. $75,5,795,22$ I. J. Ch. 94. 9. R. R. 321,330 Fol the earlier history see Wignore, in (c). Law liev.jv. 33s.

(a) Per lolluck ('.B. Nirlmol r. Goult.:(1854)10 Ex. 1!1, 1!11, 23 L...1. Ex.311. 102 li. li. .23. .206. see al-o

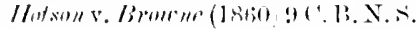

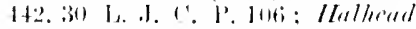

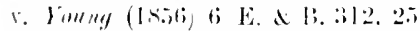

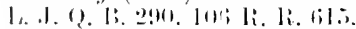

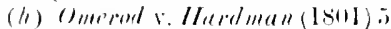

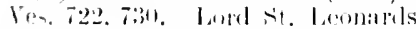

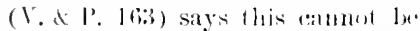
flecmed a ereneral rule: bul sce llill v. 11 itsm, l. H. s ('h. sisti: fer Hellish 1., J. at p. sisg, t2 l. . . ('). $\$ 17$.

(i) Jrires. IH, (1810) 17 l'os.

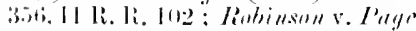
(142ti) 3 lills. $111,121,27$ li. K. 2i. liut a mbsegneme water by parol. if eomplete and monemelitimal, maty be a gorol defence; ib.: Coman v. Salisbury, I Vern.
210: and ep. \& Ves. 337̈. note. (1). if not atso at law, if the contraet be not mmler scill : sece bitrt

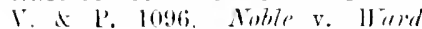
(1s6ii) 1. R. 2 Ex. l35, does not powe that a reabal waiver of a written agreement is no defenee at law, but only that a new rejbal

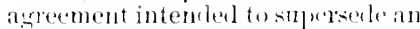
existing contract. but by reason of the statute of Elathls incapable wi

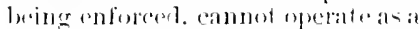

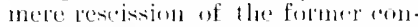
tract: the rround leeing that there is nothing ho show ans intentinn of the parties to reseiud the tirst conttract absolutely.

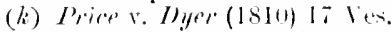

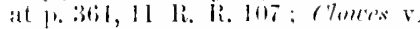
Migginson (Jisli) l les. d li, i2t, 1.2 R. li. 28t, where it wat hellt (1) thit evidence was not arluissible fo explation, contrartiot. om valy the writen atrerenent, but (2) that the witten agreenent was too ambiguous to be enforcer. 
Apparent exceptions at law anıl in equity.

A rembr's express contract to malie a good marketable title camnot he modified by parol evidence that the purchaser lnew there were restrictive covenants (l). It is otherwise where it is songht to rectify the instrument mmler the peculiar equitable juristiction which will be describer in a later chapter. And therefore the Court lias in the same suit refused to look at the same evidence for the one purpose and taken it into account for the other $(m)$.

It is no real exception to this rule that though " evidence to vary the terms of an agreement in writing is not artmisible," get "evilence to show that there is not an agreement at all is ahmissible," as where the operation of a witing as an agrement is conditional on the approval of a thirl person (II) or on something to be done by the other party (o). "A written contract not under seal is not the contract itself, but only evidence-the record of the c nutract. When the parties have recorded their contract, the lule is that they caunot alter or vary it by parol evidence. They put on paper what is to bind them, and somalie the written document conclusive evilence between them. But it is always open to the parties to show whether or not the written dociment is the binding record of the eontract " $(p)$.

"The rules including parol evidence have no place in any infuiry in which the Court has not got before it some ascertained paper heyond question binding and of full effect" (q). It may even be shown that what appears to

(7) ratu r. Thompsom (Isise)! Q. 1. Div. biti. In sach al are the trie intention maly well be that the venker shall remove the infeet.

(iii) liralford v. limmury (Istio)

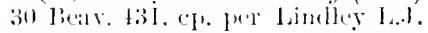
(1). I. lis. tien.

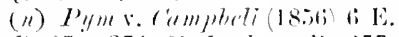

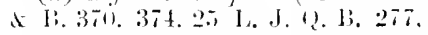
lewi li. li, ti3:- 6i3i.

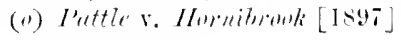

I ('h. 2.;. 6iti l. J. Ch. 14t. (1) Per Branwell D. Wake v.

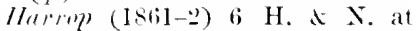

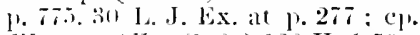
Hoerer, dthen (1888) 128 U.S.5? (q) Ginardhomser r. Bilackburn (1ntiti) L. It. 1 I'. d D. 109. 115,3. l. .l. l'. 116. And see per Page II ond Y.-C. in Druiff v. Lerd Parker (1\$is) I. R. 5 Eq. 131, 137,37 L. J. Ch. $2+1$. 
be a deed was delivered as an escrow, notwithstanding that a cleed once fully delivered is conclusive $(r)$. Still less does the rule apply to proof of the circumstances in which a document was signer which was not really part of the agreement at all, but only a memorandum marle at the same time or immediately after $(s)$.

So in Jemis v. Berrilge $(t)$ it was held that a document purporting to be a written trausfer of a contract for the purchase of lands "was . . not a contract valid and operative between the parties but omitting (designerly or otherwise) some particular term which had been verbally agreed upon, lut was a mere piece of machinery ... subsidiary to and for the purposes of the verbal and only real agrement." And since the object of the suit was not to enforce the verbal agreement, nor "any hylorict agreement compounded of the written instrument and some terms omitted therefrom," but only to prevent the defendant from using the written document in a mamner inconsistent with the real agreement, there was no difficulty raised by the Statute of Fraurls, "which does not make any signed instrument a valid contract by reason of the signature, if it is not such according to the good faith and real intention of the parties." If it appear's that a document signed by the parties, and apparently being the record of a contract, was not in fact intended to operate as a contract, then "whether the signature is or is not the result of a mistake is immaterial " (11).

Again it has been held, and that by Courts of common Collateral

(1.) See 11 athins r. Vish (18\%, L. R. 20 Fil. 2(i2; H7rlatl v. l'slimer (188s) 3!) ('h. D. fils, tis.) 57 I. J. ('h. TSI.

(s) Bank of frotralusin v.

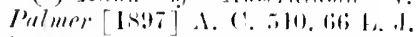
1'. ('. 10.5, 1. 1'.

(f) $(1873)$ L. Ii. s ( 'h. :3:1, 35!!,

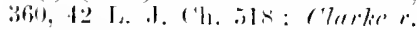

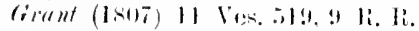
330 , aplears really to belong to this class.

(ii) lex bramwell 13. lingers v. Madley (18ti3) 2 H. \& (. 2.27, 2l!!, 3:3 1.. J. Ex. 211 . In this "ase there was "a real contrart not in writime and a paper prepares in arker to comply with some form, which was staterl at the time for contain a merely nominal plica."

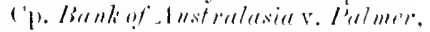
mote $(s)$, ilowe. 
parol agreements

Fridenes to explain particular tel'ms.

Not contradietory but auxiliary to the writing.

law not having equity jurisdiction, that eren where there is an agreement by deed a collateral agreement not inconsistent with the written terms may be shown. For such a collateral agreement, moreover, the promisee's execution of the principal writing or deed is consirleration enough $(x)$, in the same way as on a sale of goods no distinct cousileration is required for a simultaneous collateral warranty.

Another class of cases in which an apparent. or sometimes, perhaps, a real exception occurs, is that in which external evidence is admitted to explain the meaning in which particular terms in a contract were understood hy the parties, having regard to the language current in that neighbourhood or among persons dealing in that kind of lusiness. Witnesses have been allower, in this way, to prove that by local custom "a thonsand " of rabbits was 1,200 (i.r., ten long lumndreds of six score each, the old "Anglicus numerus" of Anglo-Norman surveys) (y); to show what was meant by "weelily accounts" among buililers $(\approx)$; to define "year," in a theatrical contract to lay a weekly salary for three vears, as meaning only the part of the year during which the theatre was open $(a)$; to identify the rool described as "your wool" in a contract to buy wool (b).

The theory is that such evilence is admitted "not to contradict a document, but to explain the words used in it, supply, as it were, the merentile dictionary in which you are to find the mercantile meaning of the words which

(x) Lrwkine $x$ Adrane (14i3)

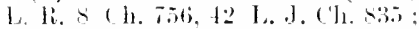
Jorgun v. Girifhth (18TI) I. K. ti Fx. 70. to L. J. Ex. tli (agreement by lessor to keep down rabbits): dugell v. Inthe (1si5) L. R. 10 Q. B. 17t (agreement to do rejairs and send in furniture) : see [194/] 2 K. P. at 1).223; Le Lecsulle v. Guildiond [1901] 2 K. B. 21. L. J. K. B. .33. ( A. A. (warranty of drains in gorel order)

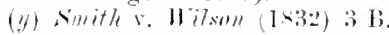
d A.t. 724. 37 R. R. 53t.

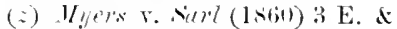
E. 3wi. 31 L. J. Q. B. \$? (a) Cirant r. Yudder (1s+6) I. M. A W. 737, Li L. J. Ex. 227. ఈ li. M. Sli.

(b) Wacdomald v. Lomelyottom, Ex. (h. 1s5:-60. 1 le. \& E. 97, 28

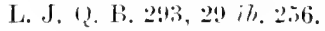


are used " $(c)$ (or other meaning received by persons in the condition of the parties, as the ease may be). The process may be regarded as an extension of the general rule that words shall have their primary meaning. For when words are used by persous accustomed to use them technically, the technical meaning is for those persons at any rate the primary meaning (d). It is a prestion not of adrling on altering, but of idenfifying the sulject-matter. "Suppose that I sell 'all my wool which I have on Dald Farm,' evidence must always be almissihle to show that the wool which was delicered was the wool on late Firm "('). 'The terms thus explained need nut be ambignous on their face $(f)$. Parol evidence is equally admissible to axplain worids in themselves ambindous or olscure aud to show, as in the case of "a thou and of rablits," that common words were used in a special sense. "l'he Inty of the ('ourt ... is to give effect to the intention of the parties. . . . It has always been held . . That where the terms in the particular contract have, besides their ordiusary and popular. sense, also a scientific or peculiar meaning, the parties who have drawn up the contrart with leference to that particular department of trade or lunsiness must fairly be taken to bave intender that the words should be used not in their ordinary but in thrir peculint sense" (y).

This kind of special interpretation must he kept distinct from the general power of the Court to arrive at the true construction of a eontract ly taking accomt of the material facts and circumstances prover or jurlially known. Thle words "warranted no St. Linwence" in a time policy of marine insurance have been deciled, by

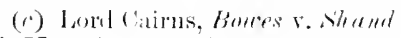
(1

(d) See Elphinstone, Norton and clark on luterpetation, fr, is: and sir Howard Elphinstome on "The limits of linkes of ('omstruclion," 1. Q. H. i. Hiti.

(o) Siled.in Hardom ld v, lam!lbottom (18.5)-60) 28 L.J. Q. B. at

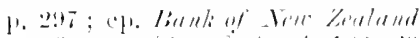

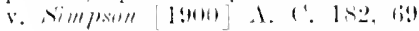

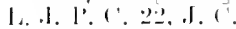

(i) rice the junlgment of liknokburlu o, in M!n alust.

(y) ('unburn (‥J. in Hy sarl (1stio) 301..1. (2. B. at 1. I2. 
reason of the known ficts of geography and the nature and risks of the navigation, to include the Gulf of St. Lawrence as well as the river, notwithstanding the failure of an attempt to prove that such was the customary meining (h). In another modern case the Court found no difficulty in holding that, in the circumstances of the transaction, a graranty for the price of goods to be supplied, definite as to the amount but otherwise loosely worled, must be real as a continuing guaranty and not as a guaranty confined to a single sale then about to be made $(i)$.

Incorporation of eustomaly terms by laril evirlence.

The Courts have talien yet a further step in this line of interpretation by reference to unexpressed matter. Not only particular terms may be explained, but whole new terms (provided they be not inconsistent with the terms actually expressed in writing) maty be added by proving those terms to be an accustomed part of such contracts, made between such persons, as the Court has before it. Custom, when the word is used in these cases, does not necessarily imply either antipuity or universality or any definite local range. It is merely a usage so general and well understood in fact, with reference to the business, place, and class of persons, that the parties are presumed to have made their contract with tacit reference to it, and to have intended to be groverned hy it in the same way and to the same extent as other like persons in like cases. The Court may act, it seems, on a proved change of usage within recent memory $\left(l_{i}\right)$. It might perhaps be better not to use in this comnexion the word "custom," which has a perfectly distinct meaning in the law of tenure and rights over land, or at least to speak by preference of

(i) Birrell v. IJryr (18:1) 9 Alp. ('a. 34. $1 \mathrm{n}$. Mheson r.

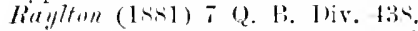
50 T. J. 1, B. 753. an implied warranty alleged to be cu-tomary was decided to be part of the general law.

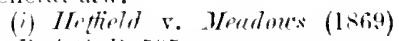
L. Ii. 4 ('. I'. ins.

(k) Siee per Channell J. in Holt v. Ifalliday [1<9s] l Q. B. at p. 130 . 
"usage," except where the phrase "custom of trade" has become too familiar to be eavily dropper. It would take us too far to enlarge upon this class of cases; it must suffice to indicate them and refer to a few leading authorities.

Rights allowed to agrienltural tentunts by the "custom rinstoms of of the country," such as to talie the away-going (rop) the comintry. after the expiration of the term, to receive compensation for particular kinds of innprovenent, and the like, have been held for more than a eentury $(l)$ not t be exchuled by anything short of actual contraliction in the terms expressed between the parties, and this even where the contraet is under seal. In modern cases of this class $(m)$ the question has generally leen whether something in the express terms was or was not so inconsistent with the usage as to exchule the presmmption that "the parties did not mean to express in writing the whole of the contract by which they intended to be bound, Jut to contract with reference to those lnown usages" ( $n$ ).

In the present century there have been a great number of trade. sc. of decisions arising ont of the usages current in trades and in various kinds of mercantile dealingss and public employments. One strong application of the principle now before us has been to make agents or brokers in certain trades and markets personally liable (unconditionally or in some particular event) notwithstanding that they contracted only as agents (o). This has been thought to go too far, as alding to the written contract

(l) The earlient cate eommmonly

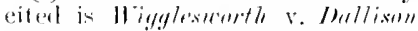

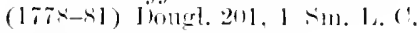
i2s. where sec the notes.

(m) As in t'melier ve limgre

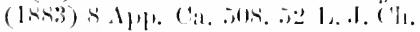
9l1. See per loml libeklmrn, \& Alp. ('it. at p. IIt.

(n) Pauke li., in I/uttun r.

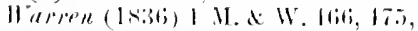
16 R. R. 36ix, 376. For a recent example not without difficulty, sec

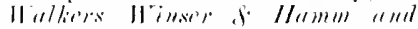

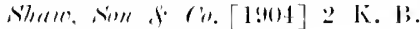
1.2, 33 1. J.K. 13.325.

(a) Ilumfir!l v. Dhle (1857) li. li. A lis. Ji) 4,26 I. J. (1) li. 1:3. followed in Fiold vo Lelente

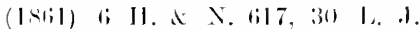
Lix. l6s. itself a pretty strong ("ise ; and other canes cited p. los, alluse. 
not merely a new term as betwen the same parties, but a new party. But the point is settled by an unbroken current of anthority (1). Som important groups of cases have turned on particular rubes and uriges of the Stock Exchange, with lorgal especially to the determination of the persons on whom they were binding withont inclividual astent or notice 19$)$.

As it is not always easy to say where the ordinary construction of the langritge used in affuirs ends, and explanation of suecial terms and renses by a "mercantile dietionary" as lond ('allus alled it (r). berins, so there is a move or lesin thetuating bomblay line, even now that the ha nerchant is pat of the general law. hetween the establishment. ly evirence of usage, of particula incidents of paticular mereantile contracts, and the general development of mercantile law by the judicial lecognition of nuiversal cuntome

Constructing proprer: pre. ference of generial intention to proticular terin-

Supposing the terme of the rontract, express or incorporated hy leference, to he tinstly establisherl, there remains the task of construction in the stricter sense; manely of clecirlins, whele the telms are capable of m lo than one meaning. Which meaning is to he preferver. On this head there ane few rules. if ans, which are confined to contracts. or are mon applicable to them than to instruments in witing genelally. The one miversal principle is that wefect is to ho riven to the intention of the parties collected from their expression of it as a whole. It must he collected from the whole: that is, particular terms ale to he constroul in that sense which is mont consistent with the goneral intention (s). It must also be collected from what is expressed, not from a mere conjecture of some intention which the parties mar have

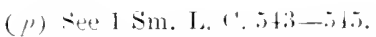

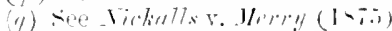

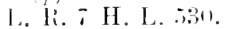

(i) Page 2ijt, ahore.

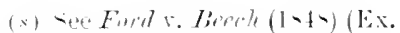

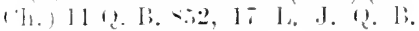
III. 
had in their minds, and would have expressed if they had been better adviserl ( 1 ). This caution, however, does not prevent the correction of mistakes which are obvious on the face of the document. In such cases the general intent, as expressed by the inmediate context, or collecter from the whole scope of the insurment, is clear: enough to overcome the difficulty arising from erroneons or defective expression in some part. Mere rerbal lolunders have always, in modern times at any rate, been corrected without difficulty by the ortinary jurisdiction even of courts of common law (a). Mala arammatica nom ritiat. chartam (e). In construing instruments of well-known types, such as family settlements, even omitted clinses have often been supplied by aid of the context $(y)$.

For the rest, our Courts are now much less disposerl to hold themselves bound hy canons of construction than they were even one or two grenerations ago. "They were Limits of rules of construetion. framed with a view to general results, but are sometimes productive of injustice by lealing to results contrary to the intention of the parties" $(z)$; and the recent tendeney is to pay less attention to any such rules and more to all admissible indications of what the intention actually wats

(t) Jessel MI. Ii. rimill I. Lurms

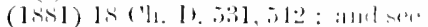
other anthoritise in Elphim-tors. Noltom and clatk an loterperelattiel1. 1). 37.

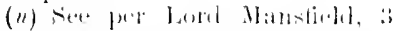

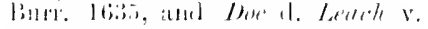

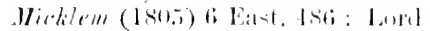

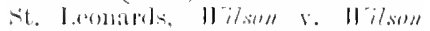
(1Sij) 5 11. I. (1. 411, liki, 2:3 1. . I.

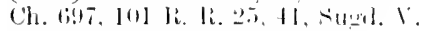
d'. 17].

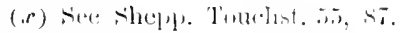
inis.

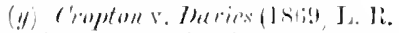

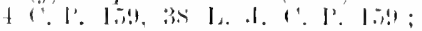

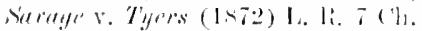

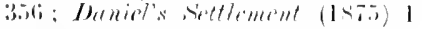
Cls. Iliv. :375. I.) I. I. I l. I11.;

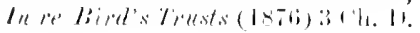

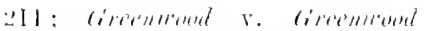

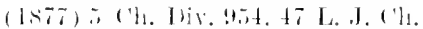

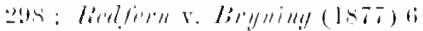

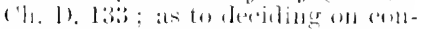
Hied in the termo of a lase liy

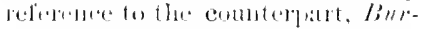

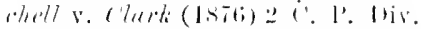

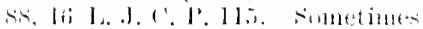
it is met atsy to decolele whether the"

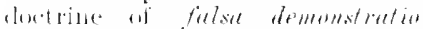
sulticus, or recouree numst be law to the ("putalue juristiction to rectily and instrument on the grmat

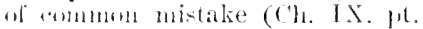

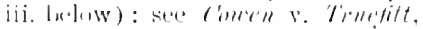

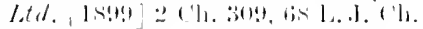
iti:i, i. 1 .

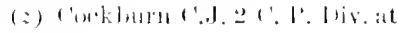
1. 19.8. 
in the case in hand, including the practical construction of the contract hy the conduct of the parties themselves $(a)$. It will he remembered that a rule which does not yie!d to sufficient evidence of contrary intention is not a rule of construction at all, but a rule of law (b). Again, many rules of construction are in truth more auxiliary than explanatory; their purpose is to supply the guidance required for dealing with events for which the parties have omitted to provide. In the langnage of Willes J. "disputes arise not as to the terms of the contract, but as to their application to unforeseen questions which arise incirlentally or accirlentally in the course of performance, and which the eontract does not answer in terms, yet which are within the sphere of the relation established therehy, and camnot he decided as between strangers" (c). The parties may really have taken no thought, and therefore has no intention at all with respect to those events, and ret something must be done. In such cases any ruk not inconsistent with justice is better than meertainty, and it matiers little whether the reasons originally assigned for an established rule he couvineing or not. Anong rules or maxims of construction some are nuch wealier than others, and are entitled, as it were, only to a casting rote. Such is that which says that works are to he talien, in ease of dould, anainst the person using them; a maxim to which Sir (i. Tessel denied even a subiliary value (l), but which is in sulstance classical ( $($ ) and seems reasonable, and on the whole stands approved on condition of heing ased to turn the scale where there is real doubt, not to force

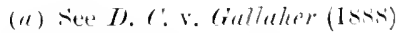
$12+12.505$.

(i) F. Y. Haw kins on the ('mstruction of Wills, l'reface.

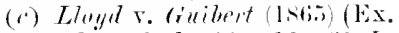
(h.) L. H. 1 Q. I. $11 \%, 120,35 \mathrm{~L}$. J. (). li. $7 t$.

(d) Truglor r. cionpuration of st.
Helens (18:-) i ('h. I)ir. $264,270$. (r) l'apinian in 1). 2. 1t. de pac$\mathrm{t}$ is, 39. Teteribus placet paetionem obscuram vel anliguam renditori. et pui locarit, nocere, in yuorum fuit putentate legem apertius conreriluere. 
a less natural meaning on words which have a more natural one $(f)$.

There are artificial rules of construction in particular cases which stand apart from the ordinary principles; they are derived chiefly, but not wholly, from the jurisdiction of the Court of Chancery, and in their origin did not profess to be consistent with the expressed intention of the parties. To some extent they went upon a presumed real intention, but the presumption was at least as much of what the Court thought the parties ought to have intended as of what it thought they did intend (!)). They were in truth rules of positive restriction, imposed by a policy whieh was then in the hands of the judges, but is now held to he in the exclusive competence of the Legislature, and for the prupose of maling the substance of the transaction conform to the requirements of fair dealing, as understood by the Court. Our Courts have long ceased to dictate to parties of full age and with the means of independent judgment on what terms they shall contract, but certain forms and terms have had an artificial meaning firmly impressed on them. 'The modern justification of such rules is that they are well known, and parties using the accustomed forms do in fact know and expect that their words will be construed in that sense which, by the standing practice of the Courts, has become a received and settled technical sense.

"If cases have laid down a rule that in certain events words are to have a particular meaning, and that has become a settled rule, it may be assmmed that persons in framing their agreements have had regard to settled law and may have purposely used words which, though on the face of them they may have a different meaning, they

(f) Elphinstone, Norton and

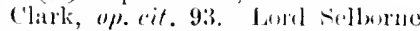
in teill v. Inker of Dermsthire

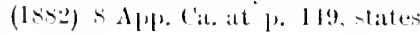

Artificial rules origrinally paramount to intention. 
know, by reason of the decided cases, must bear a particular or special meaning " $(h)$.

l'arties are now presumed to adopt tle artificial sense.
Order of pierformance in extentory contracts.

Policies of marine insurance are to this day made in a form which on the face of it is clumsy, imperfect, and obscule. But the effect of every clanse and almost every word has been settled by a series of decisions, and the common form really implies a whole body of judicial rules, "which originated either in decisions of the Courts upon the construction or on the mode of applying the policy, or in custums proved before the Courts so clearly or so often as to have been long recognized by the Courts without further proof. Since those decisions, and the recognition of those custonns. merchants and underwiters have for many rears contimued to enter into policies in the same form. According to ordinary principle, then, the later policies mnst be held to have been entered into upon the basis of those decisions and customs. If so, the rules dotermined by those decisions and customs are part of the contrict" (i).

The rules applied to restrain the effect of releases in general terms, of stipulations as to time, and of penal clanses, hat a different origin, but have been lrought round to rest on similar reasons. They ane now admitted tole rules of construction which the parties can supersede, if so minder. Wy the anlequate expression of a different intention. Sitll. they prestre traces of their history, and so lead np to the nethom he which equity jurisdiction has dealt, and still desils, with cases of real mistake in expessing and alderement: and in that connexion we shall find it useful to retum to them.

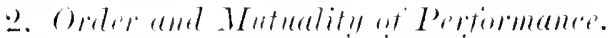

When a contrict consists in mutual promises which on one or both sides are not to be completely performed at

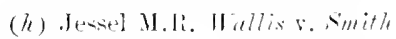

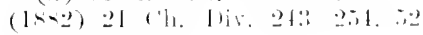
L. I. $(\%, 11 \%$. (i) r'ur: pere Brett 1..J. Lethre $\therefore$ lithisen (18-5) : Q B. Dir. isis, inte. 
one time, and a party who has not performed the whole of his own obligation complains of a failure on the other side, questions arise which may be of great difficulty. How far is the plaintiff bound to show performance of the contract on his own part, or readiness and willingness to perform? Or, to look at it from the other side, how far will a failure of one party to fulfil some part of his duties under the contract have the effect of discharging the other party from further performance or the offer thereof on his part? Such cases have heen of increasing frequency and importance in recent times, especially with regard to contracts for delivery and payment hy instalments. To a certain extent the difficulty is one of interpretation, for the morlern decisions at any rate endeavour to find a solution in accordance with the true intent of the parties, although the difficulty is much increased by the general want of any specific eridence of that intent. Most contracts are originally marle in good faith, and the parties do not necessarily, perhaps they do not usually, expect that all or any of the promises contained in the contract will be broken, or contemplate in any distinct way what will be the consequences of a breach.

From Lord Manstield's time to the present attempts have been made to lay down rules for determining, in the absence of express provisions or other clear indication of intent $(k)$, the relation of the one party's olligation to the other as regards the order of performance of mutual promises ard the extent to which either is bound to accept performance of part, notwithstanding failure to perform other part. In the earlier decisions the Conrts inclined to treat the several terms of a contract, mulesis expressed to be dependent on the other party's performance ( $l$ ), as separate and independent promises, paying little regard

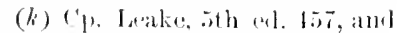
the chapter on "T'he Promise"

P.
The molern authorities look to intention of contract as a whole. 
to the effect which default in some or one of them might produce in defeating the purpose of the contract as a whole. At this day the tendency is the other way. The Court looks to the purpose and effect of the contract as a whole as a guide to the probable intentions of the parties ( $m$ ), and the presumption, if any there be, is that breach or defanlt in any material term of a contract between men of business amounts to default in the whole.

Ciunmon terms.

Certain terms which constantly recur in the authorities must be well understood and distinguished.

Promises or covenants are said to be iml'pml'nt when, although they be mutual, breach of any of them gives the other party a right of attion without showing performance on his own part $(n)$.

They are said to be demmlent where "the performance of one depends on the prior performance of another, and, therefore, till this prior condition is performed, the other party is not liable to an action on his covenant."

Where one party cannot sue for breach of the other"s promise without showing on his own part performance of some promise made by himself, or at least readiness and willingness to perform it, there, if the performance on his part was due before the other party's, it is said to be a comdition peredent to his right of action (o).

If the fulfilment of mutual promises is due at the same time, and so that the party suing must he at least ready and willing to perform his part, it may he said that these are commrment comditimns. "Neither is a condition precedent," but " the performance of each is conditional upon the other's heing performed at tie same time " $(p)$.

(iii) Bradfird v. 11 illiums (1+72)

1. li. T Ex. 2.5!" 41 L. .1. Ex. 2.i!. see julgument of Martin B.

(ii) Lord Inansfield in Kingston v. Preston (1773) cited in Jines v. brukley, Doug. 1899: Finch, Sel.
( il. 7isis.

(1) See biankentr. Bumers Istib) 1. R. 1 C. H. tat: Vimrington $\mathrm{r}$. Hright (1.5.5) 11 i [. . . 18:.

(i) Langdell. Sımmary, s 132. 
A contract which can be fultilled only as a whole, so that failure in any part is failure in the whole, is said to be entire. A contract of which the performance can be separated, so that failure in one part affects the parties' rights as to that part only, is said to be divisible.

It must always be understood that questions of this kind are possible only where a contract consists of mutual promises. For if performance itself is the consideration for a promise, there is no contract at all without performance. But when there is a contract made by nutual promises, we may have to enquire whether, in arldition to each promise or set of promises being the consirleration for the other, the performance thereof on the one side is not a condition, precedent or concurrent, of the right to claim performance on the other. There is no logical reason why it should not be so, or why express words should be required to manifest an intention that it should. Each party's promise is the consideration for the promise of the other, not for the performance which is dne by reason of the promise. What are the terms and conditions of the duty created by the promise is another matter. In an executory contract of sale the promise to deliver is the consideration for the promise to pay; but this need not he a promise to pay before or without relivery. However, the earlier line of decision was biassed by rules laid down in cases on promises by deed before the law of executory simple contracts was developed; and for a long time it was supposed that promises which were the consideration for each other must, as a matter of law, he inrlependent $(q)$. Late in the eighteenth century this view was abandoned, and it was held that "whother covenants be or be not independent of each other must depend on the good sense of the case, and on

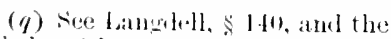
while title of "Depenlent and Indepentent Covenants and Pro- mises," and notes to Pmidager. rible, l Wms. Siauml, its?. 
Order of prexformance.
Total 11 partial default.

the order in which the several things are to be done," so that " if one party covenant to do one thing in consideration ( $r$ ) of the other party's doing another, each must be rearly to perform his part of the contract at the time he charges the other with non-performance" $(s)$.

(ienerally " the order in which the several things are to be done" is the test most readily applicable $(t)$; accordingly it is sail that "if a day be appointed for payment of money, or part of it, or for rloing any other act, and the day is to happen, or may happen, before the thing which is the consideration of the money (or other act) is to be performed, an action may be brought for the money (or for not roing such other act) before performance" (n). But this is really no more than a rule of interpretation; it "only professes to grive the resnlt of the intention of the parties " $(x)$; the reason given for it is that "it appears that the party relied npon his remedy, and did not intend to malie the performance a condition precedent." Therefore the rule, like all rnles of its kind, must yield to evidence of a different intention, and "where it is clear that the intention was to rely on the performance of the comdition and not on the remedy, the performance is a condition precertent" $(x)$.

Another test often applied is whether the term of the contrat in which default has been made "goes to the whole of the consideration," or only to part; in other words, whether the importance of that term with regard to the contract as a whole is or is not such that performance of the residne would be, not a defective performance

(r) The word " emsideration" is here used in an elliptical manner, and not quite aecurately. The fromises are the consideration, and the only eonsideration, for each other'. 'But if the substance of the promises is that performance shall be exchanged for performance, neither party can demand performance on any other terms.
(*) Wotan v. Lamb $(1797) 7$ T. li. $125,+$ li. li. 395 , per Lord lenyon ('.J and Grose J. 2,59 .

(f) Cp. ('lark Hare on Contrats.

(ii) $11 \mathrm{~ms}$. Saund. 5is ; Jervis C.J. in leoberts v. Brett (1sini) 18 C. B. 373.25 L. J. C. P. $280,286$.

(x) Jerris C.J. loc, cit. 
of that which was contracted for, but a total failure to perform it. Can it he said that the promisee gets what he hargained for, with some shortcoming for which damages will compensate him? or is the point of failure so vital that his expectation is in substance lefeated? The necessity of dealing with this question as a whole was perhaps obscured to some extent by the requirements of formal pleading (y), lout it has leen strongly asserted in all the recent authorities.

"Parties may think somr matter, apparently of very little importance, essential ; and if they sufficiently express an intention to make the literal fultilment of such a thing a condition preceelent, it will be one; or they maty think that the performance of some matter, apparently of essemtial importance and mima facie a condition precedent, is not really vital, and may be compensated for in dimnges, and if they sufficiently express such an intention, it will not be a condition precedent.

"And in the absence of such an express tectaration, we think that we are to look to the whole contratet, and applying the rule stated by Parke B. to be aclinowletged $(z)$, see whether the particular stipulation goes to the root of the matter, so that a failure to perform it wonld render the performance of the rest of the contract by the plaintiff a thing different in substance from what the defendant has stipulated for ; or whether it merely partially affects it and may be compensated for in damages. Accordingly, as it is one or the other, we think it must be taken to be or not to be intencled to be a condition precedent" (a).

The agreement sued on in the case where the principle

(y) It eannol be said that it was ovelonked: see llithers v. Mery-

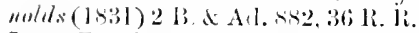
ise, Franklin v. Willor (1836) i A. A E. is: looth lome bedore the

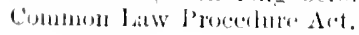

(z) In liveres v. Leg! (1sil)

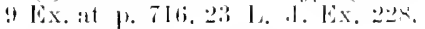
mi li. li. stioi.

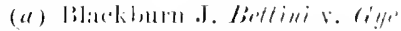

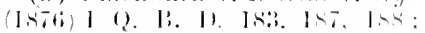

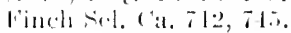


was thus declarerl was an opera singer's engagement. The singrer, who was plaintiff in the cause, was to $\operatorname{sing}$ in concerts as well as operas, and during a period of a year, begimning three months before the active duties of the engagement, he was not to sing out of the theatre in the Uniter Kingdom (in the opera season, or within fifty miles of London) without the defendant's permission. He was also to be in London for rehearsals six days before the commencement of the engagement. This last ter'm was not fulfilled, but it was held that, having regard to the whole scope of the agreement, it did not go to the root of the matter so as to justify the defendant in determining the engagement and refusing to employ the plaintiff. Matter of excuse was alleged by the plaintiff for his failure to arrive at the time stipulated, but nothing turned upon this. On the other hand wrongful dismissal of an employee is a total repudiation of the contract of service, and dischitres him not only from further service but from an undertaking restraining his right to carry on a similar business after the termination of the contract $(h)$.

Agreeluents are now presumed entire rather than divisible.
If, however, there be any presumption either way in the modern view of such cases, it is that, in mercantile contracts at any rate, all express terms are material. "Merchants are not in the habit of placing upon their contract stipulations to which they do not attach some vylue and importance $"(\cdot)$. In a case not mercantile, where the contract before the Court was held on its terms to be divisible, the late Lord Justice Mellish said :-

"I quite agree that as a general rule all agreements must he consiclered as entire. Generally speaking, the consideration for the performance of the whole and each part of an agreement by one party to it is the performance

(b) General billpesting (b. v. Athinsth [1!n!] A.C. 118. TR I..J. ('1. .7 . (i) Intel Caims in bimes $v$. shend $(1875) 2$ Alp. (at. 455. 463. 
of the whole of it by the other, and if the Court is not in a position to compel the plaintiff, who comes for specific performance, to perform the whole of it on his part, the Court will not compel the defendant to perform his part or any part of the agreement. As a general rule, therefore, an agreement is entire. I can also conceive that a court of equity might treat an agreement as entire even in cases where a court of law would say that the performance of one part is not a condition precedent to the performance of the other part, because the Court might see that those rules as to conditions precedent, which to a certain extent are technical, might not meet the real justice of the case. But, on the other hand, I do not find it laid down anywhere that it is impossible for the parties so to frame an agreement that there may be a specific performance of part" $(d)$.

The question to what extent, if at all, a party is bound to accept performance of less thim all that was promised him is to be distinguished from the question, not to be pursued here, of the duty incurred by one who does accept and in fact has some benefit from a partial performance. It may be the intention of a contract that the promise of one party shall be conditional on the actual performance of the other's promise, so that nothing less than complete performance shall fomd any clatim to payment. If such is really the parties' intention effect will be given to it; the condition, if they choose to make it, is good enough, and an imperfect performance, from whatever cause remaining imperfect, affords no ground of action. The express terms are not fulfilled, and a term or new contract to pay what the benefit received is reasonably worth cannot be introduced

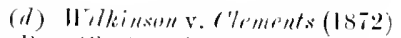
L. Ri. 8 (4). 96;, 110 .

(f) Where performance has been derective by the plaintiff's own fitut, the biurlen is on him to show a fresh contrat to pay for what he has actually done: see sumeter v. Iledgrs [1898] 1 Q. B. 6783, 67 L, d. (2. I. ili, C. A.
Entire consideration and quant um meruit. 
where the express terms exclude it $(e)$. In its results, though not in its form, such a case resembles that of a reward offered by advertisement to the first person who procures certain information. A person who brings the information, but is not the first to bring it, evidently has no claim on the advertiser, whaterer amount of trouble and expense he may have incurred, and although the delay may be due to inevitable accident $\left(f^{\prime}\right)$.

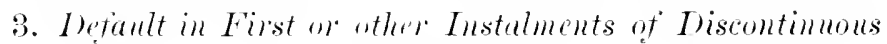
Perfirmance.

Questions on sales for delivery by instalinents.
Hoare $r$. Rennie.

Peculiarly troublesome questions have arisen upon contracts for the sale of groods to be delivered and paid for by instalments. It is not yet settled whether failure to deliver the first or any subsequent instahments is or is not presumed, in the ahsence of any special indication of the parties' intention, to go to the whole of the consideration and entitle the buyer to refuse acceptance of any further deliveries. It seems to be admitted that faibure on the huyer's part to pay according to the terms of the contract for the first or any particular instalment as delivered is not of itself a breach of the entire contract (a) : lut such defult or refusal may by the reason assigned for it, or because of other particular circumstances, manifest an intention to repudiate the contract as a whole, in which case the seller may justly refuse in lis turn to go on with the contract ( $h$ ).

In Howr r. Remnir (i), a case decided on pleadings, the contract appeared to have been to sell about 66 if tons of iron of a specified lind, to be shipped in .June, July,

(t) see ruter v. Ponell (17:15) iT. R. 3201. 3 R. li. 15. and notes thereto in 2 sim. L. C.

(1) Merse's Sterl and Iron limm-

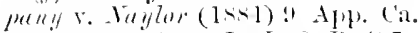
4:3. 4.34. 444, 53 L. J. Q. B. $4 ! 5$; Fithth r. Burr (1sit) 1. li.:t C. l'. 215. 43 L. .T. C. P. !1.

(i) Withers v. lirynolds (1831):- b. d Al. s. 36 R. R. Tis ; Freth จ. $3 \mu \%(18 i t)$ L. Li.9 ('. P'. 208. 43 L. J. C. I'. 91; and see per Lord liachlum, Mtrisey stent and

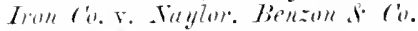
(1Bis)! Apl. Ca. at p. $4+2$.

(i) $(18.99)$; H. $\mathrm{H}$ ×. $19.29 \mathrm{I} . \mathrm{J}$. Ex. $:$ : 
August and September, in abont equal portions each month. The action was by the seller's for non-aceeptance, and for wrongful repudiation of the contract. 'The buyer's pleaded, in effect, that a June shipment of 21 tons only was offered hy the plaintiff's, who were never ready and willing to deliver a proper June shipment according to the contract, and that the defendants thereupon refused to receive the portion shipped and tendered, and gave notice that they would not receive the residue. The plaintiffs demurred, and the pleas were upheld, as showing that the plaintiffs had not been ready and willing to perfor'm the substance of their contract within the appointed time. In the judgments almost exclusive attention is paid to the question whether the defenclants were bound to accept the first shipment: in only one of them $\left(k_{i}\right)$ is it stated in general terms that the defendants were at liberty to rescind the contract, but the decision evidently involves this (l).

In simpson v. Criprin (m) the contract was to sulply about 6,000 to 8,000 tons of coal, to be relivered into the Simpson $\ell$. C'riplin. buyers" waggons, in "equal monthly quantities during the period of twelve months from the 1st of July next." During the first month of the contract the buyers, though pressed by the sellers to send waygons, took only 158 tons. The seller's therenpon gave notice to the buyers that they cancelled the contract. It was held that the breach did not justify rescission, and great doult was thrown upon Hoare v. Remire.

In Homeli v. Muller (n) the contract was to deliver 2,000 toms of iron, "November, 1s7!), or equally over

Honch $t$. Muller.

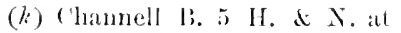
1. $2 ! !$.

(l) Inch of the language of the julgnents woukl restainly Jatve been more aplnongratle if the astion ham loeen for turn-atecept:ande ol the tirst shiputent mly. (f. 1., Q. Ii. ii. 201; and per Buwen l.o. in

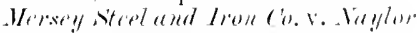

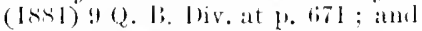
[er destel M.li, it. at pe bis. (III) (1.52) l. R. S Q. J. 14.

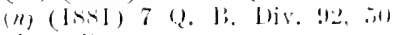
L. J. Q. L. .2.?. 
Norember, December, and January next, at 6d. per ton extra." The buyer failed to talie any of the iron in Norember, bat near the end of the month offered to "talie delivery of all in December and January" (o). On December 1 the seller cancelled the contract, and was held by the majority of the Court of Appeal to have been entitled to do so, eren on the supposition that in the ciremustances the hurer could and did elect to take delivery in three portions in the three months named. "I think," silid Bramwell L.J. "where no part of a contract has been performed. and one party to it refuses to perform the entirety to te performed by him, the other party has a right to refuse any part to be performed by hinn. I think if a man sells 2.000 tons of iron, he ought not to be bound to deliver $1.333 \frac{1}{3}$ only, if it can be avoided" ( $p)$.

Freethe. Meanwhile it had heen held in Freeth v. Burr (q) that Burr. refusal by a buyer to pry for a much delayed delivery of the first instilnent cuncler a mistaken claim to set off loss arising from any future defanlt in delivering the residue did not entitle the seller to rescind the contract. It was suggested that, " in cises of this sort, where the quention is whether the one party is set free by the action of the other. the real matter for consideration is whether the acts or conduct of the one do or do not anount to an intination of an intention to abandon and altogether to refure performance of the contract," or, in other words, "evince an intention no longer to be bound by the contract" (i).

(ii) See 7 4. B. liv. al 1) !4 (unt one-thind in becesulel and onte-thiad in . January an-sated in the hearl-note).

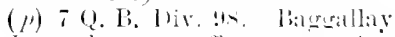
I...J. to the sime effert apluoving

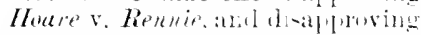
rimpsen r. criplnin. which liranwell l.t. emateavomerl to distingnish on the gromed that the con- tract hat in that care heen partly performet. lisett l... dinsented. thinking simpsenter. righin right. and Houre s. hempir wrong: ep. bis dissenting jurgment in firuter.

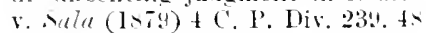
L. J. ('. 1'. $4 ! 2$.

(y) (1Nit) I. R. (c. I. 2018, 43 1.. I. ('. 1'. (t).

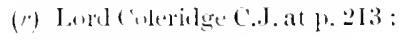


The later case of the Mrrsey Steel and Iron Commpany (s), where there was only a postponement of payment, in peculiar circumstances, under erroneous advice, Mersey steel and Iron Company $r$. confirms Frecth r. Burr, so far as it goes $(t)$. As a positive test, the rule of Freeth v. Bu\% is doubtless correct; that is, a party who, ly declaration or conduct, "evinces an intention no longer to be bound by the contract" entitles the other to rescind, and this whether he has or has not, apart from this, committed a loreach of the contract going to the whole of the consideration. But it seems donbtful whether the test will hold negatively. Can an intention to repudiate the contract be necessary as well as sufficient to constitute a total and irreparable breach? Can there not be, withont any such intent, a faihure in a vital part of the performance which destroys the benefit of the contract as a whole? Must it not depend on the nature of the contract and the order and apparent connection of its terms? All that the anthorities require of us is not to presmme delay in payment, as distinguished from delivery, to be in itself a total hreach. In other words, non-payment will not as a rule justify refusal to perform on the other side, mless there be something more in the circumstances by which it is shown to amount to repuliation, as in Withers v. Mapuolds (a), where there was a deliberate and wilful refusal to pay for the successive deliveries according to the terms of the contract.

In 1885 the Supreme Court of the United States ( $\left.1^{\prime}\right)$ had to deal with a case very like Innere romnir. The

Norrington $r$ Wright. contract was for 5,000 tons of iron lails to be shipped from

Ketting aml Denman .J.J. (ancurred in aftioming this principle.

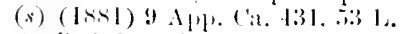
J. (Q. B. $1: 1 \%$. The Honse of Lants seems to have thought criticism of Ilocere v. lienuir not redevant.

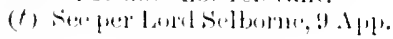

Gat at p. 43s, amb per Land Black. burn: at (1). 142-3.

(11) $(1+31) \geq 2 \mathrm{l}$. $\mathrm{d}$ Ad1. $882,36 \mathrm{li}$. li. 7ine, Finch sel. (4. TH9.

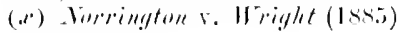
11.5 [. S. 1 s:. 
Europe "at the rate of about 1,000 tons per month, beginning February, 1880 : but whole contract to be shipped before Angust 1, 1880." The action was for non-acceptance. A few prassages from the judgment of the court will best show the view talien by them.

"In the contracts of merchants, time is of the essence $(y)$. The time of shipment is the usual and convenient means of fixing the probable time of arrival, with a view of providing funds to pay for the goods, or of fultilling contricts with thirel persons. .

"The contract snel on is a single contract for the sale and purchise of 5,000 toms of iron rails, shipped from a Enropean port or ports for Philadelphia. The subsidiary prorisions as to shipping in lifferent months, and as to pilynent for each shipment "pon its dehivery, do not split up the contratet into as many contracts als there shall be shipments or deliveries of so many distinet quantities of iron ...

"The seller is bound to deliver the ynantity stipulated, and has no right either to compel the buyer to aceept a less quantity, or to require him to select part out of a greater quantity ; and when the soods are to be shipped in certain proportions monthly. the seller's failure to ship the required 'plantity in the first month gives the buyer the sane right to resciud the whole contract that he would have had if it hat heen angeed that all the goods should be delivered at once.

" The plantiff, instead of shiplings abont 1.000 tons in February and about 1.000 tons in March, as stipulated in the eontract, shipped only 400 tons in February, and 885 tons in March. Mis fatilule to fulfil the contract on his part in respect of these first two instahments justified the defendants in rescinding the whole contract,

(1/) This had alleady been litil down in Fngland: lituter s. xiln $(108: 1)+C$ l'. Dir. 234 see per cotton 1..J. at 1), 249. \& L. I. C.

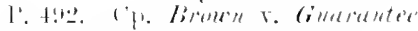

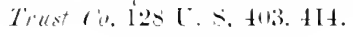


provided they distinctly and seasonably asserted the right of rescission."

The Court went on to review the Encrish cases, which did not in their opinion establish any rule inconsistent with the decision arrived at in the case at bar. All will agree with them that "a diversity in the law as administered on the two sides of the Atlantic, concerning the interpretation and effect of commercial contracts of this lind, is greatly to be deprecaterl" $(z)$. And althongh the decision is not anthoritative in this country. we nnay expect that an opinion of such weight, and so carefully and critically expressed, will receive full consideration whenever the point is again before the Court of Appeal or the Honse of Lords. It is a notable addition of force to the modern tendeney to eschew stiff and artificial canons of construction, and to hold parties who have made deliberate promises to the full and plain meaning of their terms.

The Sale of Goods Act, 1893, has now declared as sale of follows:-

Sect. 10.-(1.) Unless a different intention appears by the contract, stipulations as to time of payment are not deemed to be of the essence of a contract of sale. Whether any otler stipulation as to time is of the essence of the contract or not depends on the terms of the contract.

Sect. 31.-(1.) Enless otherwise agreed, the buyer of goorls is not bomm to accept delivery thereof by instalments.

(2.) Where there is a contract for the sale of goods to be delivered by stated instalnents, which are to be separately pail for, and the seller makes defective deliveries in respect of one or more instalments, it is a question in each case depending on the terms of the contract and the circumstances of the case, whether the lreach of 
contract is a repudiation of the whole contract or whether it is a severable breach giving rise to a claim for compensation but not to a right to treat the whole contract as repudiated.

The apparent intention and effect of these enactments is to put on record the existing state of the authorities without deciding any question that still remains fairly open. What is said as to repudiation is obviously derived from Frepth r. Bur (p. 282 above), but does not seem to amount to a legislative approval of everything that was said in that case: for the Act does not say "shows an intention to repuliate." lut " is a repuliation." Indeed, the opinion that the real question is not of intention but of result seems to be rather strengthened than otherwise ly this language. 


\section{CHAPTER VII.}

\section{Unlawful Agrements.}

We have already seen that an agreement is not in any case enforceable by law without satisfying sundry conditions: as, being made between eapable parties, being sufficiently certain, and the like. If it does satisfy these conditions, it is in general a contract which the law commands the parties to perform. But there are many things which the law positively commands people not to do. The reasons for issuing such commands, the weight of the sanctions by which they are enforced, and the degree of their apparent necessity or expediency, are exceedingly various, but for the present purpose mimportant. A murder, the obstruction of a highway, and the sale of a loaf otherwise than by weight, are all on the same footing in so far as they are all forbidden acts. If the subjectmatter of an agreement be such that the performance of it would either consist in doing a forbidden act or be so connected therewith as to he in substance part of the same transaction, the law cannot command the parties to perform that agreement. It will not always command them not to perform it, for there are many cases where the performance of the agreement is not in itself an offence, though the complete execution of the object of the agreement is: lut at all events it will grive no sort of assistance to such a transaction. Agreements of this lind are void as being illogal in the strict semse.

Again, there are certain things which the law (a) does

(a) I.r.the sommon kaw. But qu. whether the common law could take notice of anything as immoral which sulijectmatter or perfirmance a thing positively forbiditen, or part of a transaction which as a whole is forbilden (illegal). would not constitule an offence anainst ejther common or ecclesiastical latw. 
forbidden but not forbid in the sense of attaching penalties to them, but immoral.

which are violations of established rules of decency, morals, or good manners, and of whose mischievous nature in this respect the law so far takes notice that it will not recognize them as the ground of any legal rights. "A thing may be unlawful in the sense that the law will not aid it, and yet that the law will not immediately punish it "(h). Agreements whose subjeckmatter falls within this description are void as being immoral.

Not mositively Further, there are many transactions which cannot forlibilen. but arginst fairly be brought within either of the foregoing classes, publir pmliry. and yet camnot conveniently be admitted as the subjectmatter of ralid contracts. or can be so admitted only under special restrirtions. They seem in the main to fall into the following categories:

Matters gorerned by reasons ontside the regular scope of municipal law, and tonching the relations of the commonwealth to foreign states:

Matters touching the good government of the commonwealth and the administration of justice:

Matters affecting particular legal duties of individuals whose performance is of public importance:

Things lawful in themselves, but such that individual citizens could not withont general inconvenience he allowed to set bounds to their freedom of action with regard to those things in the same manner or to the same extent as they may with regard to other things $(c)$.

Agreements falling within this third description are void as being against mulie polien.

We have then in the main three sorts of agreements

(b) Bramwell B. Gowan v. Mitbum? (1stia) L. R. 2 Ex. at 1. 2236, 3 i L. J. Ex. 12t.

(c) We have alreary seen that the specific operation of contract is nome other than to set bounds to the party's freedom of action as regards the subject-matter of the cout ract. 
which are unlawful and roid, according as the matter or purpose of them is -

A. Contrary to positive law. (Ille!lll.)

B. Contrary to positive morality recognized as such by law. (Immor) al.)

C. Contrary to the common weal as tending

(a) To the prejudice of the State in external relations.

(b) To the prejudice of the State in internal relations.

(c) To improper or excessive interference with the lawful actions of individual citizens. (dyainst pullic policy.)

The distinction here made is in the reasons which determine the law to hold the agreement void, not in the nature or operation of the law itself : the nullity of the agreement itself is in erery case a matter of positive law. Bearing this in mind, it is a harmless abbreviation to speak of the agreement itself as contrary to positive law, to morality, or to public policy, as the case may be.

The arrangement here griven is believed to be on the whole the most convenient, and to r'present distinctions which are in fact recognized in the decisions that constitute the law on the sulject. But like all classifications it is only approximate: and where the field of judicial discretion is so wide as it is here (for nowhere is it wider) we must expect to find many cases which may nearly or quite as well be assigned to one place as to another. 'The authorities and dicta are too numerons to admit of any detailed review. Some positive rules for the construction of statutes have leen worked ont hy a regular serics of decisions. But with this exeeption we find that the aselaw on most of the branches of the subject presents itscif as a clustered group of andogies rather thim a linear chain of anthority. We have thera io select from these grouls a certain immber of the more centrat instances. 'The statement of the general a ules which apply

The ariance. nent only approximite.
Caution as to use of terms. 
to all classes of mlanful agreements indifferently will be reserved, so far as practicable, until we have gone through the several classes in the order above given.

Classes of unlawful agreenents. A. contrary to positive law.

1. Agreement to commit offence. voirl.

Sometimes doubtful if performance of agreement would be offence. Mayor of Nolwich $r$ Nolfolk liy. Co.

\section{A. Adrements contrany to pesitioe lau.}

1. The simplest case is an agreement to commit a erime or indictable offence:

"If one bind himself to kill a man, burn a house, maintain a suit, or the like, it is roid" $(d)$.

With very few exceptions, obviously criminal agreements do not occur in our own time and in civilized comntries, and at all erents no attempt is made to enforce them. In the eighteenth century a bill was filed on the Equity sicle of the Exchequer by a highwayman against his fellow for a partnership accomnt. The bill was reported to the Cont both scandalous and impertinent, and the plaintiff"s solicitors were fined and his counsel ordered to pay costs ("). The question may arise, homever, whether a particular thing anced to be done is or is not an offence, or whether a particular agreement is or is not on the true construction of it an agreement to commit an offence. In the singular case of Mayor of Nomich r. Norfolli Ii!l. C'. (i), the defendant company, being authorized to make a bridge orer a navigable river at one particular place, had found difficulties in executing the statutory plan, and had begmn to build the bridge at another place. The plaintiff corporation took steps to indict the company for a nuisance. The matter was compromised by an arrangement that the company should - not discontinne their works, but - complete them in a particular mamer, intended to make sure that no serions obstruction to the navigation should

(d) Shelp. Tullehst. 37 \%.

(") Lin ley on l'artuersip, 101. S. I. Q. Ii.ix. 195. for an aecount of the case (Lereet r. Millinmes) reritied from the originals in the lienerd Ottice.

(f) $(1 \times, i)+$ E.d T. $3 ! 17,2+\mathrm{L}$. J. Q. 1., 105, 49 R. R. 518. 
ensue: and an agreement was made by deed, in which the company covenanted to pay the corporation $\mathfrak{E} 1000$ if the worlis should not be completed within twelve months, whether an act of Parliament should within that time be obtained to anthorize them or not. The corporation sued on this covenant, and the company set up the defence that the works were a public nuisance, and therefore the covenant to complete them was illegal. The Court of Queen's Bench was divided on the construction and effect of the deed. Erke J. thonght it need not mean that the defendants were to go on with the works if they did not obtain the Act. "Where a contract is capable of two constructions, the one making it valid and the other void, it is clear law the first onght to be adopted." Here it should be taken that the works contracted for were worlis to be rendered lawful by Act of Parliament. Coleridge J. to the same effect: he thought the real olject was to secure by a penalty the speedy reduction of a nuisance to a nominal amount, which was quite lawful, the corporation not being bound to prosecute for a nominal nuisance. I ord Camplsell C.J. and Wightman J. held the agreement had, as being in fact an agreement to continue an existing unlawful state of things. The performance of it (without a new Act of Parliament) would have been an indictable offence, and the Court could not presume that an Act would have been obtained. Lord Campbell said :-_."In principle I do not see how the present case is to be distinguished from an action by A. against $\mathrm{B}$. to recorer $\mathfrak{\pm} 1000, \mathrm{~B}$. having covenanted with $A$. that within twelve calendar months he rould murder C., and that on failing to do so he would forfeit and pay to A. $\$ 1000$ as liquidated damages, the declaration alleging that although I3. did not murder C. within the twelve ealendar months he had not paid $A$. the $\mathfrak{\perp} 1000$ " (y).

(g) 1 L. S. 13. 14 . 
It seems impossible to draw any conclusion in point of law from such a division of opinion $(h)$. But the case gives this practical warning, that whenever it is desired to contract for the doing of something which is not certainly lawful at the time, or the lawfulness of which depends on some event not within the control of the parties. the terms of the contract should malie it clear that the thing is not to be done unless it becomes or is ascertained to be lawful.

When the ulterior ohject is an offene.

Moreorer a contract may be illegal becanse an offence is contemplated as its ulterior result, or because it invites to the commission of crime. For example, an agreement to pay money to A.'s executors if A. commits suicide would be roid (i); and although there is nothing unlanful in printing, no right of action can arise for work done in printing a criminal libel $\left(k_{i}\right)$. But this depends on the more general considerations which we reserve for the present.

2. Ascement fin civil wroug to third perons is rivil.

2. Again an agreement will generally be illegal, though the matter of it maly not he an indictable offence, and thongh the formation of it may not amount to the offence of conspiracy, if it contemplates (l) any civil injury to third persons. Thus an agreement to divide the profits of a fraudulent scheme, or to carry ont some ohject in itself not mulawful by means of an apparent trespass, breach of contract, or breach of trust is unlatful and roid $(m)$. A. applies to his friend B. to adrance

(7) Not only was the conrt exually clivicled. but a pernsal of the jullumert at laree will show that wo two nembers of it really lorked at the case in the sime way. The reporters (t E. \& B. 3:17) ardecis not without reason to the healnote: lit quepre inde.

(i) I'er Hramwell L.J. 5 C. P. 1). at 1. 3017.

(b) Poplett r. Stoukdule (15.s) F. \& M. 337,2 C. \& H. 198,31 R. R. 662 . (l) If A. contracts witl P. to do something which in fact. but not to B.'s knowlerlge, mould incolve a breach of contract or trust, $A$. cannot lawfully perform his promise, but ret may well be liable in dimages for the breach. Mitluard ऽ. Littlowed (1850) 5 Ex. 755. 20 I. J. Ex. 2. s.2 R. R. sil. , Tee further at ent of this chapter.

(ii) An agreement to commit a civil injury is a conspiracy in many, but it is still meertain precisely 
him the price of certain goods which he wants to buy of C. B. treats with C. for the sale, and pays a smu agreed upon between them as the price. It is secretly agreed between $A$. and $C$. that $A$. shall pay a further sum: this last agreement is roid as a fraud upon B., whose intention was to relieve $A$. from paying any part of the price $(n)$. Again, A. and B. are interested in common with other persons in a transaction the nature of which requires goorl faith on all hands, and a secret agreement is made hetween $A$. and $P$. to the prejulice of those other's' interest. Such are in fact the cases of agreements "in fraud of creditors": that is, where there is an arrangement between a lebtor and the general Acreement in fralut of creditirs body of the creditors, hut in order to procure the consent of some particular creditor, or for some other reason, the debtor or any person on his hehalf, or with his knowledge (o), secretly promises that creditor some adrantage over the rest. All such secret agreements are voil: securities given in purstrance of them may be set asile, and money paid under them ordered to be repaid ( 1 ).

in what, eases. Sue Mr. Craies article on Conpiracy in linerel. Laws of England, 2d ed. An agreement to commit a trespas sikely to leal to a breach of the luace,

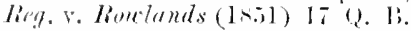

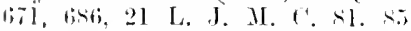
li. li. (i)i, or to commit a eivil wrong loy fraud and fatse piretences, ling. v. Warburtom (1sio)

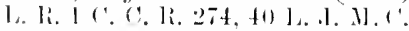

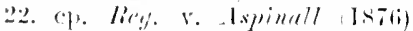

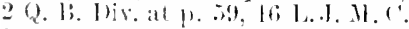

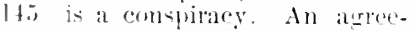
unest to commit a simple breaclo of rontiant is met a comsinaley. Sire on the whole subject. llugul viform.

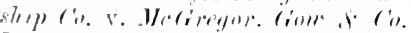

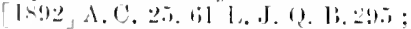

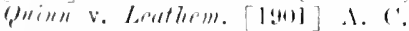

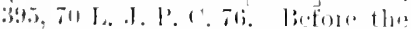
'. I. l'. Aet a conte of common law combl mer take notice of an

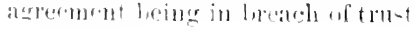

su as to hold it illegal: Hamirk

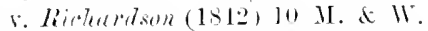
$2 \times 4,62$ li. li, wos. and arreements to indemify trmstee agamet formal lreaches of trust ale in practice comstantly asimuel to be valid in equity as well as law.

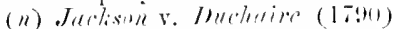

3 'T. R. . isl.

(i) E prality among the crediturs $i$ of the escence of the transil.tinn. Ally arreement to give a preforance, made with the debtor privity. strikins at the rent in the arial. It is immaterial whether the artallement is moler a statlat o or nut. and whether the pueforential partuent is to rome out of the

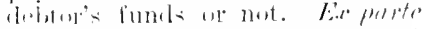

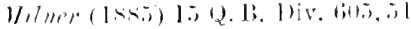
1. .1. 1. 1. 1.:.

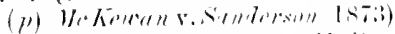

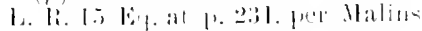
$1 . .4 .121 .1 .1$ h. 296. 
And ot her creeditor $<$ not monnt by the composition.

Noreover, the other creditors who know nothing of the frand and enter into the arrangement on the assumption "that they are contracting on terms of equality as to each and all" are under such circumstances not bound by any release they give $(q)$. And it will not do to say that the mulerhand bargain was in fact for the benefit of the creditor's generally, as where the preferred creditor becomes surety for the parment of the composition, and the real consideration for this is the debtor"s promise to pay his own debt in full: for the creditors ought to have the means of cxereising their own judgment $(r)$. But where one creditor is induced to become surety for an instalment of the composition hy an agreement of the principal debtor to indemnify him. and a pledge of part of the assets for that purpose, this is ralid: for a compounding debtor is master of the assets and may apply them as he will (s).

The principle of these rules was thus explained by Erle .J. in Mallation r. Horlyson $(t)$ :-

" Eirch crulitor comants to he part of his debt in consileration that

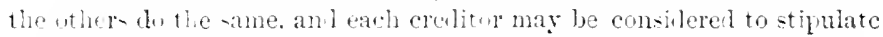
with the other for a releate from them to the lebtor in consideration of the relave by lim. Where any crelitur. in fram of the agreement to areept the comporition, stipulates for a lueference to himself, his stipukation is altrigether vill-not anly can he take no allvantage from it, but be is also to low the bentit of the mmpostinu (16). The requirement of wow fath among the crelitors and the preventing of gain lis acrements

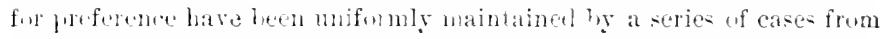

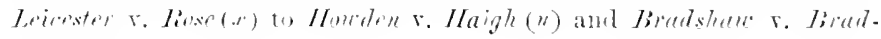
shen:" (y).

From the lant eited case (!) it seems probalile. though

(1) Jouglish r. Temurnt (1-iti) i. R. 2 12. 13. 4!1, it. 36 L. J. (1. I. 11'.

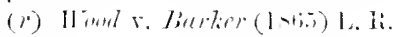

1 Eit. $13: 4$.

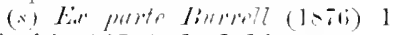

(h. l)ir. s3z. 4i) L. J. Hk. in.

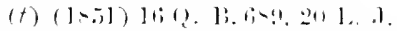

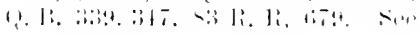

further Eir purte Olirer (1-49-il) t the (i. . ism. 35 t.

(ii) (1-111) 11 A. \& E. $11133 ;$;

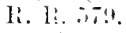

(r) (1N+3) + East. 372 : howing that the alrantage given to the lureferreal ereditu nea not be in montery

(1) $(1-11) \div 31$ \& $111,29$. 
it is not decided, that when a creditor is induced to join in a composition by haying an additional payment from a stranger withont the linowledge of either the other creditors or the debtor, the debtor on discorering this may refuse to pay him more than with such extra payment will make up his proper share under the composition, or may even recover back the excess if he has paid it involuntarily, e.\% to boma firle holders of bills given to the creditor nuder the composition.

A debtor who has given a framdulent preference can claim no benefit under the composition even as against the creditor to whom the preference has been given $(\approx)$.

A secret agreement by a creditor to withdraw his opposition to a bankirupt's discharge or to a composition is equally void, and it does not matter whether it is made with the debtor himself or with a stranger (a), nor whether the consideration offered to the crerlitor for such withdrawal is to come out of the debtor's assets or not (b); and this even if it is part of the agreement that the creditor shall not prove against the estate at all ( $\left.{ }^{\circ}\right)$. In like manner if a debtor executes an assigmment of his estate and effects for the benefit of all his creditors upon a secret agreement with the trustees that part of the assets is to be returned to him, this agreement is void $(l)$.

We have here at an early stage of the subject a good instance of the necessarily approximate character of our classification. We have placed these agreements in frand of creditors here als being in effect agreements to commit civil injuries. But a composition with creditor's is in most cases sonething more than an ordinary civil contract; it is in truth a quasi-judicial proceeding, and as such is to a certain extent assisted by the liw (4).

(z) Mignius v litt (1<19) + Ex.

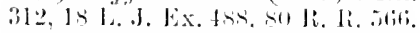
(a) Migyins v. I'ill, litht mote.

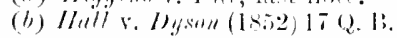

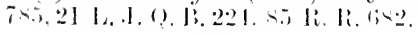

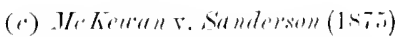

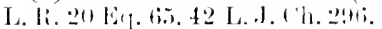

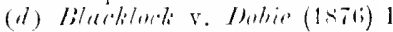

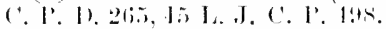

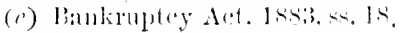


Fraul on thirel parties not to be pre. simed fiom mere prosilisitities.
3. Certain cases of malogous mature as involving "fraul on thind lersumin."
Public policy, therefore, as well as private right, requires that such a proceeding should be conducted with good faith and that no transaction which interferes with equal justice being done therein should be allowed to stand. The doctrine of frand on third parties, as it may be called, is howerer not to be extended to cases of mere suspicion or conjecture. A possibility that the performance of a contract may injure third persons is no ground for presuming that such was the intention, and on the strength of that presumed intention holding it invalid between the parties themselves.

"Whe an in-trument between two parties has been entered into for a purpere which may be comidered fraulnent as against some third lerkon, it may yet be binuling, accurling to the true construction of its Jancuace, a - betwen themselres.

Nor can a supposed fraudulent intention as to third persons (inferred from the general character and circumstances of a transaction) be allowed to determine what the true construction is $\left(f^{\circ}\right)$.

3. There are certain cases analogons enough to the foregoing to call for nlention here, though not for any full treatment. Their general type is this: There is a contract giving rise to a continuing relation to which certain duties are incident by law; and a special sanction is provided for those duties by loolding that transactions inconsistent with them aroid the original contract, or are themselves voidable at the option of the party whose rights are infringed. Te have results of this kind from

(a) Dealings between a principal debtor and creditor to the prejudice of a smrety :

(b) Dealings ly an agent in the business of the agency on his own account:

19. Since this det there is a motable increase of private compro sitim- independent of the Aet. (t) Vhate v. Jefier? (I860) 13 Noo. P. ( . 4.2. 4.5. 
(c) Voluntary settlements before marriage "in fraud of marital rights."

In the first case the improper transaction is as a rule valid in itself, hut aroids the contract of suretyship. In the second it is voidable as between the principal and the agent. In the third it is (or was) roidable at the suit of the liusband.

(a) "Any variance made without the surety"s consent in the terms of the contract between the principal debtor and the creditor discharges the surety as to transactions subsequent to the variance " (g), muless it is evident to the Court "that the alteration is musubstantial, or that it cannot be otherwise than beneficial to the surety" $(h)$. The surety is not the less discharger "even though the original agreement may notwithstanding such variance be substantially performed"(i). An important application of this rule is that "where there is a bond of suretyship for an officer, and by the act of the parties or by Act of Parliament the mature of the office is so elanged that the duties are materially altered, so as to affect the peril of the sureties, the bond is avoided" $\left(l_{i}\right)$. But when the guaranty is for the performance of several and distinct duties, and there is a change in one of them, or if an addition is made to the duties of the principal debtor by a distinct contract, the surety remains liable as to those which are maltered (l). The following rules rest on the same ground:

(g) Indian ('ontract . Ict, k. 133.

(ii) Ilulur v. lirmuxkill (lsia) :

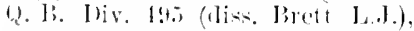
werruling on this punt sindereste

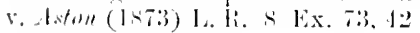
H. t. Lix. (il.

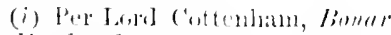

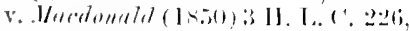
235. sie R. Ri, lis.

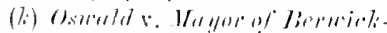

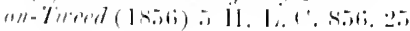

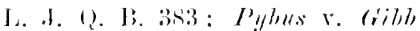

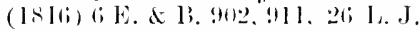

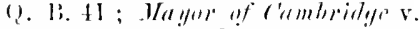
Dernis (J 1. .1. (2. 1). 174.

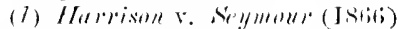
J. Ji. 1 ('. I', 5]s, 3. L. J. (․ I'.

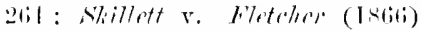

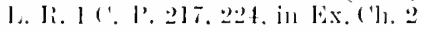
('. I'. 169. 34 I. I, ('. I'. 2011.
Dealings letween prin cipal cresitor and debtor to prejulice of surety. 
"The surety is discharged by any contract between the creditor and the principal debtor by which the principal debtor is released, or by any act or omission of the creditor the legal consequence of which is the discharge of the principal debtor " $(m)$.

"A contract between the creditor and the principal debtor, by which the creditor makes a composition with, or promises to grive time to or not to sue the principal delotur, discharges the surety, unless the surety assents to such contract" $(n)$, or unless in such contract the creditor reserves his rights against the surety $(o)$, in which case the surety's right to be indemnified by the principal debtor continues (1). One reported case constitutes an apparent exception to the general rule, but is really none, as there the nomina! giving of time had in substance the effect of accelerating the creditor's remedy $(q)$. The rule applies as against a creditor of two principal debtors of whom one has become primarily liable as between themselves, whether the creditor assents to the arrangement or not, provided he has notice of it $(r)$.

"If the creditor does any act which is inconsistent with the rights of the surety, or omits to do any act which his duty to the surety requires him to do, and the eventual remedy of the surety himself against the

(iii) I. C. A. s. 134. Kindeley v.

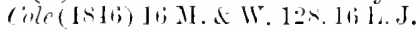

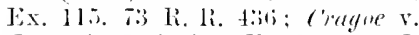

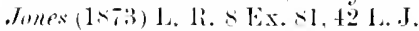
Ex. 6s. The tischarge extends to any secutity given by the surets:

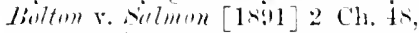
(b) L. J. Ch. 23:!.

(11) I. C. A. s. 13.5. Clukeley v.

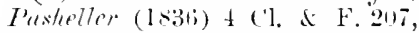
10 Bli. N.s. its. 12 li. IR. 1 : Oriental Finumial (arporations. Orerend, diurney of (\%. (1sit) L. R.7 H. L. 34: : cremen r. Hynn (18ia) L. R. 4 (h. 204, 3n l. J. ('h. 2-20); buteson ro Gosling

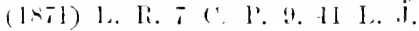

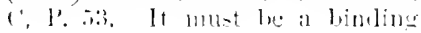

contract with the prineipal debtor: i'larlie r. Birley (1889) t1 ('h. D. 42.2. 434. 5s L. J. Ch. 616.

(o) Whether the surety knows of it or not: If $67, \mathrm{v}$. Hewitt (185i) 3 K. . J. 43s. 4t2. 112 R. li. 22t, 227 ; aml see per Loru Hatherley, ]. li. $7 \mathrm{Ch}, 150$.

(i) rlese v. Close (1853) 4 I) II. (i. 176, 18.).

(q) II lime v. (oles (1827) $2 \mathrm{xim.}$ 12. 29 Ri. li. 52 .

(r) Cakeley r. Pasheller (note (u) abore) as discussed and exphainel in liouse r. Bradford Bkg. (') [1s!4] ch. $32,63^{\circ}$ L. J. Ch. :37, $\because$ A. : attimed $[18: 4]$ A. C. inti. 6.3 L. J. Ch. 890 . 
principal debtor is thereby inpaired, the surety is discharged" (s).

"A surety is entitled to the benefit of every security which the creditor las against the principal debtor at the time when the contract of suretyship is entered into, whether the surety knows of the existence of such security or not; and if the creditor loses or without the consent of the surety parts with such security, the surety is discharged to the extent of the value of the security" $(t)$. Not only an absolute parting with the security, but any dealing with it, such that the surety cannot have the henefit of it in the same condition in which it existed in the creditor"s hands, will have this effect (n). For the same reason, if there be joint securities, and the debtor releases one, it is a release to all; otherwise if the sureties are several $(r)$.

(b) "If an agent deals on his own account in the business of the agency withont first obtaining the consent of his principal and acquainting him with all materiat ciremmstances which have come to his own hnowledge on the subject, the principal may repudiate the transaction " (y).

(s) I. C. A.s. 139 (= story, Er . Jur. \$ 825 nealy); Witson r. Allevick (I853) t H. M (i. 24:

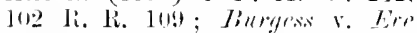
(1872) L. 1. 1:3 E. I.21. II L. I. Ch. ols: Phillips ve Fom (1sie)

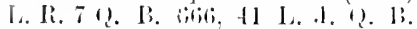

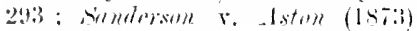
L. Ii. \& Ex. 73, t2 1.. . Ex. 6l.

(t) I. C. A. s. 1+1. Wty/lom r.

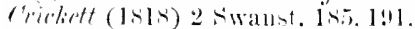
lit R. H. 57. 6il ; IIulf v. Jal (1872) 1. R. 7 Q. 1․ 75t. 762, 1]

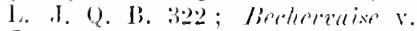

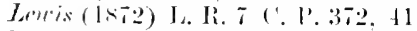
І. ј. ''. I'. libl; soratities now subsist mowithstanding payment of the lish for the benetit of at smety who has paid. Mlere. Law

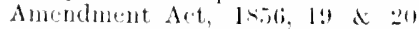
Vict. c. 97. s. 5. A right to distuatin for mot is mot at sereurity or semerly within thin suatuent:

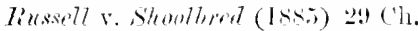
lhy. 2.51, 53 L. T. 36.5. During the enrrency of a bill of exchange an inderer is not a surety for the acceptor. But after nutice of dishonont he is ent itled in like mamer $a=$ if he were a sluet $y$ to the lenetit of all payments marle amd securities given by the acceptos to the bulder:

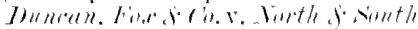

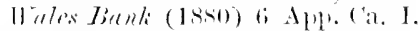
rove. ‥ in C. A. 11 ('l. Jiv. (i) 1. 1. ('l1, 355.

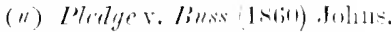
Giii.

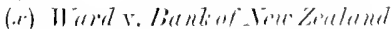

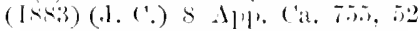
I. . I. I', (', 6.)

(y) I. ('. A.s. 2lis. The Indian Act goes on lo athl, "if the eated slow eitleer that any material linet

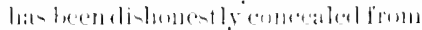
loin ley the arent, wh that the
Dealiugs by acent in the matter of the arency on his own aicount. 
"If an agent without the linowledge of his principal deals in the lusiness of the agency on his own account instead of on account of his principal, the principal is entitled to clain from the argent any benefit which may have resulted to him from the transaction " ( $(z)$.

These rules are well known and established and have been over and over again asserted in the most general terms. The commonest case is that of an agent for sale himself hecoming the purchaser, or conversely: "He who undertakes to act for another in any 1 natter shall not in the same matter act for himself. 'Therefore a trustee for sale shall not gain any arlvantage ly being himself the person to buy." "An agent to sell shall not convert himself into a purchaser unless he can make it perfectly clear that he furnished his employer with all the knowledge which he himself possessed "( (1). "It is an axiom of the law of principal and agent that a broker employed to sell cannot himself become the huyer, nor can a broker employed to buy become himself the seller, without distinct notice to the principal, so that the latter may object if he think proper" (h). Similarly an agent for sale or purchase must not act for the other party at the same time or take a secret commission from lim $(r)$. If the local usage of a particular trade or marliet contrarenes this axiom by " converting a broker employed to luy into a principal selling for himself," it cannot be treated as a custom so an

dealing- if the atrent liare been aiarintageous to him." but thene ylalifications are wor recosnized in

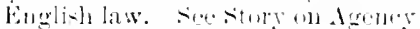

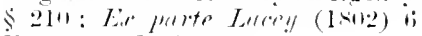
les. liza i li. li. !.

$\Leftrightarrow 1.1$. 1.2 .216 .

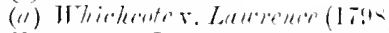
$\therefore$ Ves. 7to: Lmother r. Lurther (1>0+i) 13 Vec. 45. 103: and see

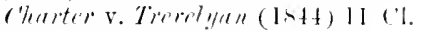
dF. Tl1. 732. ti.j li. Ji.30.5.

(i) $l^{2}+1$ Wille. I. in lollett $r$.

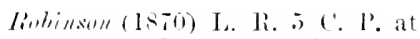

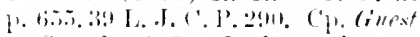

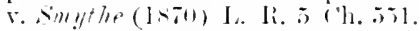

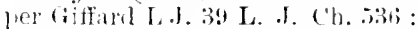

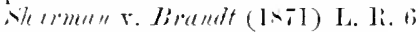
(2. 13. 720. 111 L. .1. Q. 13. 31:2.

(i) The latest ease, which, if anythint. increases the wholesome strictuess of the law. is Grant $v$.

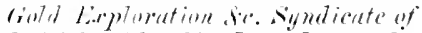
Britiste r alumbin [1900] I (2. P.

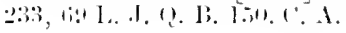


to bind a principal dealing in that trade or market through a broker, but himself ignorant of the usage $(l)$.

The rule is not arbitrary or technical, but rests on the principle that an agent cannot be allowed to put limself in a position in which his interest and his duty are in conflict, and the Court will not consider "whether the principal did or did not suffer any injury in fact by reason of the dealing of the agent; for the safuty of mankind requires that no agent shall be able to put his principtl to the danger of such an enquiry as that." It is a corollary from the main rule that so long as a contract for sale made by an agent remains executory he camnot re-purchase the property from his own purchaser except for the benefit of his principal('). A hilie rule applies to the case of an executor purchasing any part of the assets for himself. But it is put in this somewhat more stringent form, that the burden of proof is on the executor to show that the transaction is a fair one. This brings it very near to the doctrine of Undue Influence, of which in a later chapter. It makes no difference that the legatee from whom the puchase was made was also co-executor $\left(t^{\prime}\right)$. Another branch of the same principle is to be found in the rules against trustees and limited owners renewing leases or purchasing reversions for themselves $(a)$.

Again: "It may be laid down as a general principle

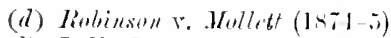
L. H. 7 H. L. St) 2 , \$3, \& L. I. C. P. $336^{2}$; and further as to alleced customs of this kiud /or liwsilli, $r$.

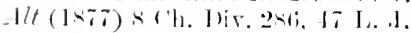
ch. :3o. For the rrecial application of the role to the dhety of directes's of compranies. I/ (I.55) L. li. lu ('h. 5.43. 41 I. .I.

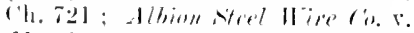

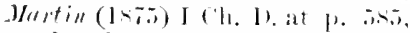
per lessel M.K. t5 I. J. I'h. I I:3;

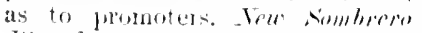
I'leospliate (6. V. Erlanyer (157\%)
5 Ch. Dir. 73, th; I. J. Ch. 42.;.

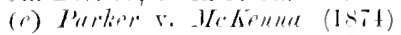

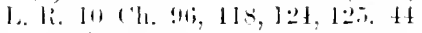
I.. J. ('h. 125.

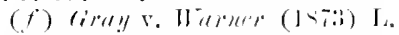

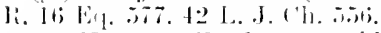

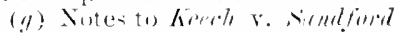
(172t) in 1 Wh. d T. I. '. 'The

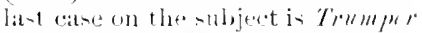
v. $7 \% m$ m $(1-73)$ L. H. II H. 245. s ch. sion. Iㄴ I. J. ('h. ditl. On the gencral rule ste alo Marisll

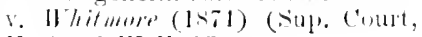
L. S.) 21 I 
that in all cases where a person is either actually or constructively an agent for other persons, all profits and advantages made by him in the husiness beyond his ordinary compensation are to be for the benefit of his employers" $(h)$. "If a person makes any profit by being employed contrary to his trust, the employer has a right to call back that profit" (i). And it is not enough for an agent who is himself interested in the matter of the agency to tell his principal that he has some interest: he must give full information of all material facts $\left(l_{i}\right)$.

Even this is not all: an agent, or at any rate a professional adviser, cannot lieep any benefit which may happen to result to him from his own ignorance or negligence in executing his duty. In such a case lie is considered a trustee for the persons who would be entitled to the lenefit if he had done his duty properly (l).

Niature of renelie: applitable.

In this class of cases the rule seems to be that the transaction improperlyentered into l,y the agent is roirable so far as the nature of the case admits. Where it cannot be aroided as against third parties, the principal can recover the profit from the agent. But where there are a principal, an agent, and a thirr party contracting with the principal and cognizant of the agent's employment, and there are dealings between the third party and the agent which give the agent an interest against his duty, there the principal on discovering this has the option of rescinding the contract altogether. Thus when company $A$. contracted to make a telegraph cable for

(1) Story on Algener, 211 anduted by the Cout in Warisons.

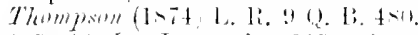
4-5. 43 L. J. Q. 1;. 215. where sereral ca-e are collected.

(i) Mus y r. Duries (179-1) ? Ve-.317, 321. 2 R. R.,21与.

(k) See authoritiesculected and olkervations of the cont thereon. Iunne v. limgliall (1-it) L. R. 1s Er. ,ol. 5it. The derthments of the principle in molern company law camnot be followed here. For a recent expostinon of its limits, see

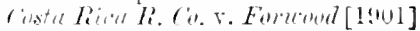
1 ("i. iti. .0 L. I. Ch. 3-i. C. A.

(l) liulkle! r. Wilfind (1.34) 2 ('l. A F. 112.8\% li, R. 39. (1). (arley r. Lord stafford (ls.5) l be (i. A . . 2.3. As to altematise renciles, sere (ribut's cuse. 1. Sun. alute. 
company B., and a term of the contract was that the work should be approved by $\mathrm{C}$., the engineer of company B., and C. took an undisclosed sub-contract from company A. for doing the same work; and further it appeared that this arangement was eontemplated when the contract was entered into ; it was held that company B. might rescind the contract $(m)$.

(c) The rule as to settlement "in fraud of marital right" was thus given by Lord Langdale ( 1 ) :-

Siettlements in framl of marital right.

"If a woman entitled to property enters into a treaty for marriage an l during the treaty represents to her in tended hustand that she is so entitled that upon her marriage he will become entitled juro muriti, and if during the same treaty she clandestinely conveys away the property in such manner as to defeat his marital right and scenre to herself the separate use of it, and the concealment continues till the marriage takes place, there can be no doubt but that a framl is thus practised on the hushand and he is entitled to relief " (o).

Moreover-"If both the property and the mode of its conveyance, pending the marriage treaty, were concealed from the intended lusband, as in the case of Goddard v. Sume $(p)$, there is still a framil practised on the husband. The non-aequisition of property of which he har no nutice is no disappointment, but still his legal right to property aetually existing is defeated" $(q)$.

The Married Women's Property Act, 1882, has made the subject obsolete in this country as regards all marriages contracted after its commencement, and there has been no reported decision for many years. It is now thought advisable to omit the details given in former editions.

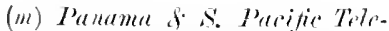

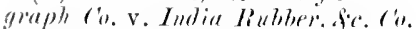

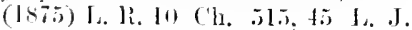
Ch. 1:1.

(ii) ('p. on this subject liav. Cons. vol. 3. pot, g. 7ir.

(ii) England v. Joures: (184ti) 2 lieav. 52: 52s, 50 li, 1i, 2tis, 272. 273.

(p) (IS24) I Rinss. 15., 25 Ji. R. 111. See the earlier anthorities there risensent. (q) Eumplend v. Dowens, 2 lieas.

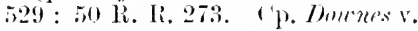
Jrmuings (18633) 32 Beav. 2991), 29)1. ree further st. Cintrge v. Mintie (1+31-3) I My. \& K. 610, (62-5, 3;

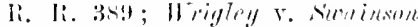
(1489) :3 1) (i. d sm. 4.8s: st

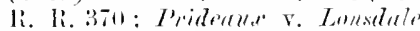
(1863) + (aiff. 159, on appeal. I 1). J. S. 43:3, 435, no decision on this patt uf the case : They/or r. I'nght (1812) l llate dors is li. R. 2ll. 
4. Marriage within prohivited degrees, ete.

t. Marriages within the prohibited degrees of lindred and affinity are another class of transactions contrary to positive law. For although no direct temporal penalties are attached to them, they have been made the subject of express and definite statutory prohibition (r). They formerly conld not be treated as void unless declared so loy an erclesiastical Court in the lifetime of the parties: but by a modern statute (5 \& 6 Wm. 4, c. 54 ) they are now absolutely roid for all purposes. An executory contract to marry within the prohibited degrees is of course absolutely void also (s), and would indeed have been so before the statute. These rules are not locil, like other rules of municipal law prescribing the solemnities of the marriage ceremony, requiring the consent of particular persons, or the like: the legislature has referred the prohibition to public grounds of a general nature (spealing of these marriages as "contraly to (rod"s law") $(t)$, and

(r) 32 H. s, c, 38, ant earlier repeated statntes of the same reign. It is the better supunted ofinion that is $86 \mathrm{Wm}$. 4, c. it. dow's not contain any new substantive prohibition. Siee Brome v. Bromli (1sti) (9) II. I., C. I93.

(s) It seems from Mulluad r.

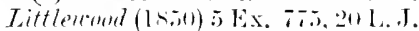
Ex. 2. . li. li. st, that in the barely jussible case of the relation. ship being linown to onls one of the parties, by whom it is framb. lently conecales from the other. the innocent party may sue as for a breach of eontract, thongh the performance of the agreement would be unlawful. Here the yromel of liability is eithere-toppel or. better, implies warranty of ability to perform the promise lawfully.

$(t)$ The she of these particular work seems of little infuritance. It would certainly alpear bolel to apply them to matriacres which are permissible by dispensation in the ('anon law, and allowet uncon- ditimally by the German civil corle. The true reason is shortly fut by tavjerns. sirt. s. 326: : "lie hier ein-chligenden diesetze. die anf sittliehen Rifeksichten beruher. haben eine streng positive Natur." savinges authority is perlape sullicient to deffend the doctrine of Browle $r$, Bromle against the canstic eriticism passed upun it by the (hitef Intiee of Massachneets in Commomuralth r. Lane (1-i3) 113 llass. at p. $433:-$

". The jutgment proceds monn the grouml that an set of l'arliament is not merely an ondinance of man but a conclusirederlaration of the law of fionl: and the result is that the law of Gol, as declare I ly Act of l'arliament. and expoumber by the Honse of Lurds. varjes aceneling to the time. place, length of lifeof parties. pecun iary interests of thind persons. pretitions t, hominn tribunals, and twehnieal rolles of statutory constuction and ju lichíl frocelure." 
it concerns not the form but the sulstance of the contract; it therefore applies to the marriages of domiciled British subjects, in whatever part of the wrorld the ceremony be performed, and whether the particular marriage is or is not of a kind allowed by the local law (11). A promise by a murried man whose wife is living to marry another roman after his wife's death is roid as being against public policy if the fact is known to the promisee $(x)$.

Where a marriage has been contractes in England between foreigner's domiciler abroad, English Courts will recognize disabilities, though not being inris yentium, imposed by the law of the domicil of hoth parties (y): but a marriage celebrated in England is not held invalid by English Courts on the ground that one of the parties is subject by the law of his or her domicil to a prohibition not recognized by English law, at all events where the other party's domicil is English (:).

5. Moreover a great variery of dealings of which contracts form part, or to which they are incident in the ordinary course of affairs, are for extremely various reasons forbidden or restricted by statute. In the

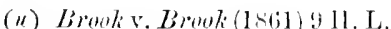
('. 193. See per Lord 'amplell at p. 220. He alsorinubted whethor a marriage allowed by the law of the place, liut contracted by Englibl subjects who had come there on purpose to evade the Fuglish law, would be reengnized even by the

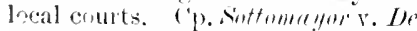
barros, infir.

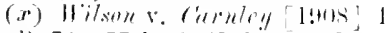

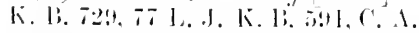
Acoopeling to carlio andhority which iv quite enssistent with this the promince has a right of aretjom if be believer the promitar to be lummaniell: Milluard r. Litflewomd, note (x). alurre.

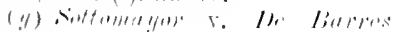

(1877) : I'. Iliv, 1, 17 L. .J. 1'. 23.

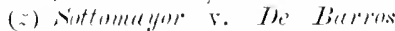
(15-8) ; l'. 1).94. aliwenting from some dieta in the previons jurlgment of the C. 1., which however went on a sulposel different state of the facts. see further, on this perplexel topie, sir Ifurarel lilphintunes.. Totes on the Enolish Latw of Marriare" in L. (2. li. v. 4l. the chalpter on Marriage in liecr." cintliet of Laws" : Chetti

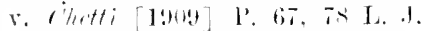
l'. 2:3. and Mr. Ilicey therenn in I. (2. Li. xxr. 202. As to the peetl-

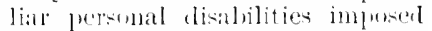
be the lingal Marriage Aet, see

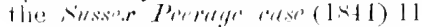

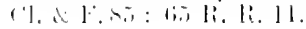

5. Agreements illecial by statute.

l'. 
eighteenth century, in particular, Acts of Parliament regulating the conduct of sundry trudes and occupations were strangely multiplied. Most of these are now repeated, but the decisions upon them established principles on which our Courts still act in dealing with statutes of this lind.

Con-truction of prohibitory statutes.
The question whether a particular transaction comes within the meaning of a prohibitory statute is manifestly one of construction. So far as we have to do with it here, we have in each case to ask, Does the Act mean to forlid this agreement or not? And in each case the language of the particular Act must be considered on its own footing. Jecisions on the same Act may afford direct anthoritr. Jint decisions on more or less similar enactments, and even on previous enactments on the same subject, camnot as a rule be regarded as giving more than analogies. Attempts have indeed been made at different times to lay down tixed rules, nominally of construction, but really amonnting to rules of law which would control rather than ascertain the expressed intention of the legislature. But in recent times on Courts have fully and explicitly disclaimed any such powers of interpretation.

." The only rule for the construction of Act of Parliament is that they should be comatres acouring to the intent of the larliament which

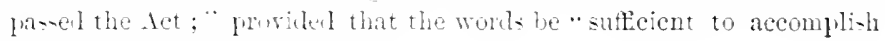
the manifent purione of the det " (11).

The effect of plain and unamliguous words is not to be limited ly judicial construction even though anomalous results shoull follow (l).

(11) Oprinim of the Jurges in the

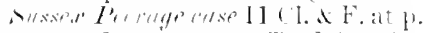

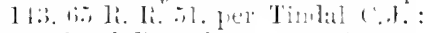

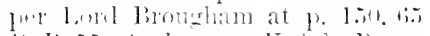

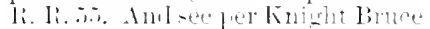

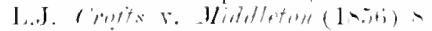
1). N. (i. at 11. 2li. 110 Ri. R. lati:

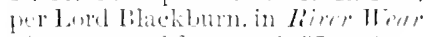
rommis. s. 1 d (a, at 3. 7ift. ti I., I. Q. B. 193.

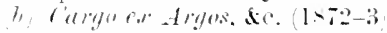

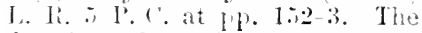
wectrine fomerly current in sleculative prinon on the continent). that statutes might be disceranded if the Comris thonght acondance with the frresiling 
On the other hand the general intention is to be re- rolicy of garded, and may if necessary prevail over particular expressions, no less than in the interpretation of private instruments. But it must also he in intention collected from what the legislature lias said, not arrived at by conjectures of what the legishature might or ought to have meant (c). A transaction not in itself immoral is not to be held unlawful on a conjectural view of the policy of a statute $(l)$. The true policy of a statute is for a court of justice neither more nor less than its true construction. 'The Courts no longer' undertalse either to cut short or to widen the effect of legislation according to their views of what ought to be the law. "Before we can make out that a contract is illegal under a statute, we must make out distinctly that the statute has provided that it shall be so "(e).

The cases in which acts of corporate bodies created for special purposes have been held void as "contrary to the policy of the legislature" and tending to defeat the objects of the incorporation have already been considered in Ch. II.

These principles, when applied to the more limited subject-matter of prohibitory statutes, give the following corollaries :

(a). When a transaction is forbidden, the gromeds of the prohibition are immaterial. Courts of justice cammot take note of any difference between mala mohilita (i.e. things which if not forbidden by positive law would not be imnoral) and mule in se (i.e. things which are so forbirden as being inmoral).

them contrary to reasun, rommon right, or liatural epuity (all symongmeme terms for this fintpose), las long been repuliaterl:

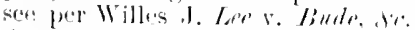
lig. fi. (1+7), l.. Ji, li t'. l'. iti. statutes. liules.

1. No differ. ence between malnm proliblitum and mulum in se.

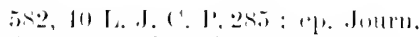

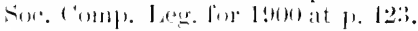

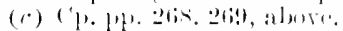

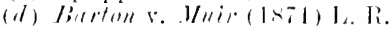
G I'. 1'. 1:3, H1 I., I. I', ('. 1!?

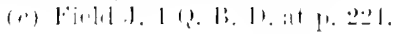


b. P'unalty mima facie imports prohibition. e. But absence of lemalty boes not alter exples prohibition.

(b). The imposition of a penalty ly the legislature on any specific act or omission is mima facir equivalent to an express prolilition.

These rules are established $b$ the case of Bensling Bimmole ( $\dot{ })$, which decided that a printer conld not recover for his work or materials when he had omitted to print his name on the work printed, as then required by statute (g). It was argued that his right under the contract was untoncled by the Act, which contained no specific prohibition, but only a direction sanctioned ly a penalty. But the Court held manimously that this was untenable, and a party could not be permitted to sue on a contract where the whole sulject-matter was "in direct riolation of the provitions of an tet of Parliament." And best J. said that the distinction between mula prohilitu and mula in se was long since exploded. The same doctrine has repeatedly been enounced in later cases.

Thuss. for example, by the Court of Exchequer:

"Whore the contraet which the plaintiff -eeks to enforce, be it express or implied. is express y or by implication forbiden by the common or statute law. no cont will lent its asintance to grive it effect. It is equaly clear that a contract is roit if prohibited by a statute though the statute inflets a penalty rmly. becase sueh a penalty implies a lonitition "(li).

It is needloss to discus the "policy of the law" when it is distinetly" enunciated by a statutory prohibition (i).

(c). Conversely, the absence of a penalty, or the failure of a penal clanse in the particular instance will not prevent the Court from giving effect to a substantive prohilition (li).

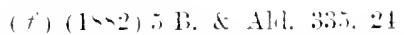
I. li. fol. I're-amably the def:ndant whln have sated in the enn. tract if he was not a prity to the transgresions.

(a) Fee now 32 d 33 Vict. c. 24.

(ii) rope v. Femlumts (1-36) $2 \mathrm{y}$.

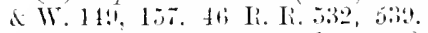

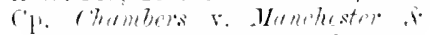

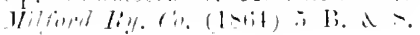

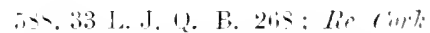
or Imaterl R.y. (o. (186:) L. R. 1 (h. It 7 .

(i) See ler Lord Cranworth, Ex

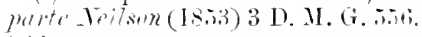
intiti.

(i) Nusser Peerage caso (1941)

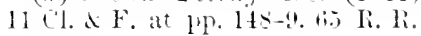
$\therefore 1.2$. 
(d). What the law forbids to be done directly cannot d. What may be made lawful by being done indirectly.

In Booth v. Banli of England (l) a joint-stock bank procured its manager to accept certain bills on the understanding that the bank would tind funds, these of Englant. bills being such as the bank itself could not have accepted without riolating the privileges of the Bank of England. It was held by the House of Lords, following the opinion of the judges, that this proceeding "must equally be a violation of the rights and privileges of the Bank of England, upon the principle that whatever is prohibited by law to be done directly cannot logally be effected by an indirect and cirenitous contrivince:" for" the acceptor was merely nominal, and the bills were in fact meant to circulate on the credit of the bank.

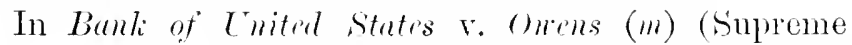
Court, U. S.) the charter of the bank forbate the taking liank of U.S. of a greater rate of interest than six per cent., lut did not say that a contract should be void in which such interest was taken. A note payable in gold was discomted ly a branch of the bank in a depreciated local paper curency at its nominal value, so that the real discount was much more than six per cent. The Court held this transaction void, though there was no express prohibition of an rgreemont to take higher interest, and though the charter spoke only of taling, not of resering interest. Parts of the judgment are as follows: "A fraud upon a statute is a violation of the statute." "It cannot be permitted ly law to stipulate for the reservation of that which it is not permitted to receive. In those instances in which Courts are called upon to inflict a penalty it is necessarily otherwise; for then the acturl receipt is generally necessary to consummate the offence. But when the restrictive policy

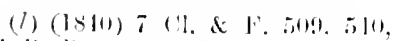
il li. Re. Bit, upholeling liank of

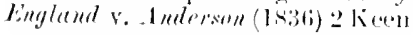

not be done directly must not be clone indirectly.

Booth $r$. Liank 
Where conditions pretscriberl for comlucet of particular trarle. dr.. mol-obseryance of theme. arrials aerwoment - if lote conditions are fin. general jublic: jomposes: t. nut if firl iucrely antmini-irative prapures.

Mhatration. of a law alone is in contemplation, we hold it to be an miversal rule that it is mlawful to eontract to do that which it is minlawful to do."

"There can be no civil right where there can be no legal remerly; and there can be no legal remedy for that which is itself illegal . . . . there is no distinction as to vitiating the contract hetween malum in se and malum mollilitum' (ii).

The cases are similar in principle in which transactions have been held roid as attempts to evade the bankiruptey law: thus, to take only one example, a stipulation that a security shall be increased in the event of the debtor's bankmptcy, or any provision designed for the like purpose and having the lilie effect, is roid (o).

When conditions are prescribed by statute for the conduct of any purticular husiness or profession, and such conditions are not observed, agreements made in the course of such husiness or profession-

e). are void if it appears lix the context that the object of the legislature in imposing the condition was the maintenance of public order or safety or the protection of the persons dealing with those on whom the condition is inlposed :

(f), alle valid if no specific penalty is attached to the specific transaction. and if it appears that the condition wis inposed for merely administrative purposes, e.\%. the convenient collection of the rerenne.

the following are instances illustrating this distinction:-

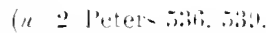

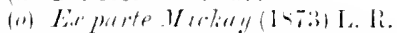

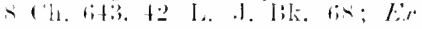

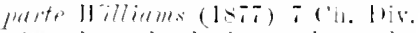
13- where the device u-ed wat the attomment of the debtor to his mortgagee at an excosize rent : Ko.

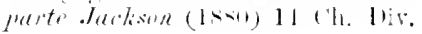

7.:. It mut ise shown, to vitiate atransat ion on this gromm. that the provision was inerted in contemplation of hankrupter and for the jurpue of defeating the bank.

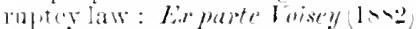
21 (i. Jiv, 442 . thil, 32 L. J. ch, $1: 1$. 


\section{Agrenient Void.}

Ritchie v. Smith (18ts) 6 C. 13. 4192, is L. J. C. P. 9, 77 R. R. 369. The owner of a licensed house molerlet part of it to another person, in order that he night there deal in liquor on his own aceount unler colour of his lessor's licence and without obtaining a separate liecnce. This agreement was voitl, its purpose being to enable one of the partics to infringe an Act passed for the protection of public morals: (the licensing Acts are of this nature, and not merely for the benefit of the revenne, for this reason, that licences are not to be had as a matter of right by paying for themr). For the same reason and also because there is a specific penalty for each offence against the licensing law, it scems that a sale of lifuor in in unlicensed house is void. Thumilton r. Ciraimger (1859) 5 H. \& N. 40.

Taylor v. Crowland Gus Co. (1sist) 11 Ex. 293,23 L. J. Ex. 25t, 102 I. R. 586. A penalty being improsed by statute on mulualified persons aeting as conveyaneers ( $\left(p^{\prime}\right)$, the court helel that the object was not merely the gain to the revenue from the anties on certificates, but the protection of the publie from unqualified pratitioners: an mualifies person was therefore not allowel to recover for work of this nature. (p. Leman r. Houseley (187t) L. R. 10 Q. L. 66, 41 L. J. Q. B. 22.

Fergusson v. Torman (1\$3*) is Bing. N. C. 7t, ,0 li. R. 6l3. When a pawnbroker lent money without complying with the recpuirements of the statute, the loan war voin and he had no lien on the pledge $(\not)$.

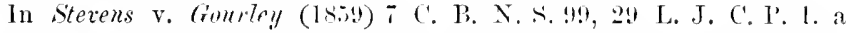
builder was not allowerl to recoser the price of putting up a worken shed contrary to the regulations imposed by the Metropolitan building Act, 18 \& 19 Vict. c. 122. The only question in the case was whether the strueture was a building within the Act. But note that here the prohibition was for a public purpose, namely, to guard against the risk of fire.

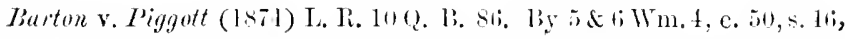
a penalty is imposel on any surveyr of highways who shall have an interest in any contract, or sell materiak, we. for work on any highway muler his care muless he first ohtain a licence from two justices. The effect of this is that an mulicensel contract by a survesor to jerform work or suphly materials for any highway under his care is absolutely illegal, and there is no discretion to allow payments in respect of it.

(p) Fow by 3:8 \& :31 Vict. e. 97 , s. 6io.

(q) The pesent Pawnholurs Ant

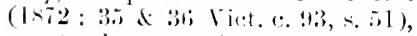
chacls that an offence algainst the
Ant by a pawbroker, not being an offence angaint any fortsion relating to licencess shaill not at vinl the contract or cleprive him of his licitr. 


\section{Contract not dronen.}

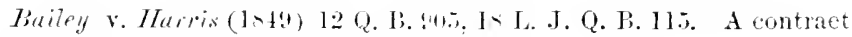
of sale is not whil merely beenue the gonds are liable to seizure and forfeiture to the crum unter the exciselaws.

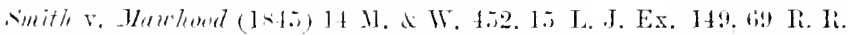
72t. The sale of an exci-cable article is not avoded by the seller having omittel to paint up his nane on the licensed premise- as required by if Geo. 4, c. s], s.2.5. l'robally this decision would govern the construetion of the very similar enactment in the Licen-ing Act, 15,2 (35 \& 36 Viet. c. (9. - . 11.)

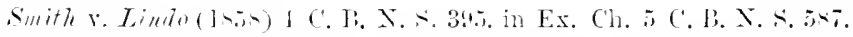

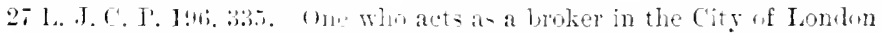

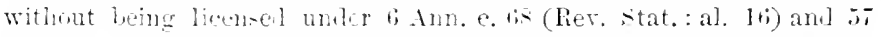

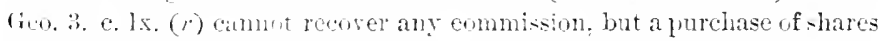
male by him in the marliet in mot woll and it he has to pay the purehasemon"y by the wiate of the market. he can recorer from hi-prineipa? the money so laikl.

And in general an agreenent which the law forbids to be made is void if marle. But an agreement forbidden by stutute may lie saved from being roid by the statute itself, and on the other hand an agreement marle roid or not enforceable by statute is not necessarily illegal. An agreenent may be forbidden withont being roid, or roid without being forlididen.

7. Arreement lot roil through finbililun, if statute exlre--ly so proviles.

(g). Where a statute forlids an agreement, but says that if made it shall not be void, then if made it is a contract which tlue Count mast enforce.

By 1 \& 2 Tict. c. 106, it is mlawful for a spiritual person to engage in trade, and the ecclesiastical Court may inflict penalties for it. But ly s. 31 a contract is not to be void by reason only of being entered into by a spiritual person contrary to the Act. It was contended without success in Lewis v. Bright (s) that this proviso

(1.) There Arte are repealed in to the power of the city enturt thake rules. Ace. blat not is to the nece. sity of broker- being ahnitted, $b$, the whewhat obemely fromed
Lambn brokers lieliuf Act lsio. 33 s 34 Vict. te 60.

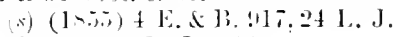
12. 1. Ka1. ?9 R. Ki. 
could not apply when the other party knew with whom he was dealing. But the Court held that the knowledge of the other party was immaterial ; the legislature meant to provide against the scandal of such a defence being sot up. And Erle J. said that one main purpose of the law was to make people perform their contracts, and in this case it fortmnately could be carried ont.

(h). Where no penalty is imposed, and the intention of the legislature appears to be simply that the agreement is not to be enforced, there neither the agreement itself nor the performance of it is to be treated as molawful for any other purpose $(t)$.

Modem legislation has produced some very curious results of this kind. In several cases the agreement cannot even be called roid, being good and recognizalle by the law for some purposes or for every purpose other than that of creating a right of action. These cases are reserved for a special chapter (II).

In the case of wagers the agreement is null and roid by 8 \& 9 Vict. c. 109 , s. 18, and money won upon a wager cannot be recovered either from the loser or from a stakeholder (with a saving as to subscriptions or contributions for prizes or money to be awarded "to the winner of any lawful game, sport, pastime, or exercise": the saving extends only to cases where there is a real competition between two or more persons $(x)$, and the

(f) Alopted by the supreme

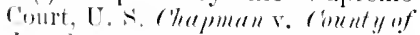

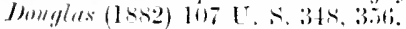

(11) See ('h, Xllt., On Algreements of Imperfect obligation. The elistinction between an enact. ment which impuses a penalty without making the transilet in voirl. and one which makes the for. bidfen transaction roid, is exprenced in licman law by the lewens minus: quam perforte lere and per-

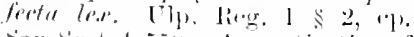

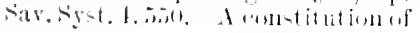

7. Agreement may be simply not cuforcentio, but not utberwise unlaw ful.
Wagers. Voide but n+t absolutely illegal. Fitchis. liness.
Theodosius and Valentinian (ciud. 1. 11. de leg. i) enjoined that all follibitory enactments were to be comstrued as avolime the trams. actions pohbibed by them that is. as beges prefertar whether it weres si experesied or not.

(.r) E.g. a wager that a huma will thot cojehtern miles in an hour is mot within it. at there can be no wintere in the true semse al the

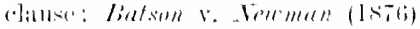
I ('. P. I)ir, ar:3. Xor a soreallici compretition where tlac erent is 
"subscription or contribution" is not money deposited with a stake-holler by way of warer) (y). Wagers were not as such unlawful or unenforceable at common law: and since the statute does not create any offence or impose any penalty, a man may still without violationg any law make a wager, and if he loses it pay the money or grive a note for the anrount (s). The consideration for a note so given is in print of law not an illegal consideration, lut merely no com-ideration at all. The difference is important to the subsequent holder of such a note. If the transaction between the original parties were fraudulent or in the proper sense illegal, the burden of proof would be on the holder to show that he was in fact a holder for value; but lere the ordinary presumption in favour of the holder of a negrotiable instrument is not excluded (1). It common law ". if a party loses a wager and reyuests anotler to pay it for him, he is liable to the party so paying it for money paid at his leefuest" (h); but the Craning Act, 1892, malies all such parments irrecoverable (r). ats also a loaln of money to be nsed for a wager; and to be repaid only if the borrower wins (d).

Attempts have leen lnate to erade the operation of the principal Act in ganbling transactions for . differ. ences" in stochis liy colourable provisions for the completion of purchase and delivery or receipt of the stocks.

Anemined by chancen by abover

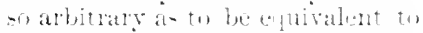

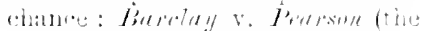

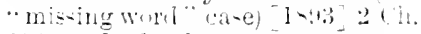

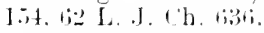

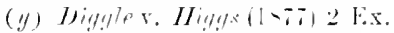

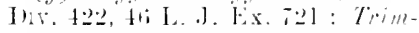

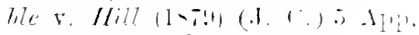

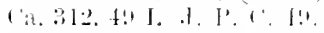

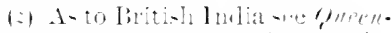

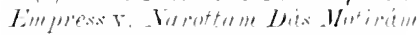
(l-!?) I, L. IR l:; lim. li-l. a curiou-care on the common Imbian

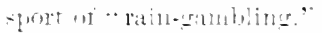

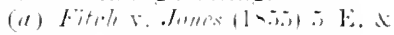

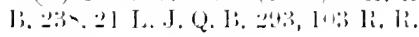

fir. we julument- of Lord camplbetl ( . J anil Eule J.

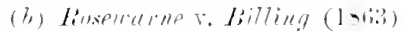

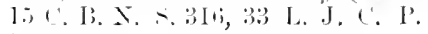
.5.

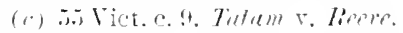

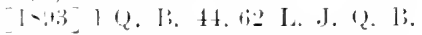
(3).

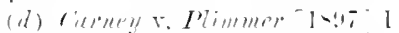

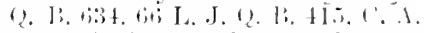
It a crubtful whether the Act affect- lown of money to be need in betting renembly of for proing

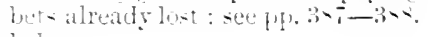
bus. 
Whether the intention of the parties was really to buy and sell, or to wager on the price of the stocks, is a que tion of fact on which the verdict of a jury will not be disturbed if on the agreement as a whole there is evidence of a gambling intention ('). Nor will provisions of this kind validate an agreenent which is otherwise a gambling agreement on the face of it $\left(f^{\prime}\right)$.

Under another modern statute (5 \& 6 Wm. 4, c. 41, s. 1) securities for money won at gaming or betting on games, or lent for gaming or hetting, are treated as given for an illegal consideration $(y)$.

Lotteries are forbidden hy penal statutes $(h)$.

It would be inappropriate to the general purpose of this work, as well as impracticable within its limits, to enter upon the contents or construction of the statutes which prohibit or affect various linds of contracts by regulating particular professions and occupations or otherwise (i).

(e) Tniversul Stock Eerlearys, Ltd. v. Strarlean [1s:6] A. C. 1i6. 6i. L. J. Q. B. 429.

(f) Re Gieve $[1899]$ I Q. P. 794. 68 J. J. Q. B. .419. ('. A.

(g) The statute cloes not affect a loan of money to pay a delet previonsty lost : Ein parte Pyke (1sis) sch. Liv. 754,47 L. J. IBk. 100.

It does not prevent forbcarance to sue on a security of this kinu, on to enforce it by conventional sanc. tions, from being a good consideration for a new promise: IIyams r. stuart king [194k] 2 K. B. 69t, 7 J. J. K. B. 6!9, C. A., dis.s. Fleteher. Joulton l..l. As the result stamis bookmaker's at any rate consirer. that a method has been discoveres of recovering by act ion money wom on a waser : sec l'uf. Dicer. K. I'. in J. 12. R. xxi. 7t; so. In the Cuited states it is genera]ly hele that wagering agreements are not only voinl but illenal : see Iroinv. llillin. (1853) $1101 \%$.. 19!, ה11,

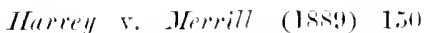
Jass. 1. As to recovering money deposited with a stakcholder or agent, see $1 \%$. 401 , below.

(h) $x$ \& 9 Vint. c. Tt, and several earlier Acts. Various innoeent aml not uneommon ways of raising money for charitable objects are frobably within the letter of these Aets.

(i) The list of such statutes formelly given in the appendix is not now reprinter, as it is not thought that it can be of practical use at this day. Fome of them are ton well known to the profesion to need enumeration ; sme are merely ineidental to criminal, reveme, or other public law; some are better fomml in monographs all the lines of business which they affect : some are neither needsary to be known in orelinary pratetice ros of any protit for the understanding of the law. 
Agreements in derogation of prirate Acts of Parliament not necessarily bad.
B. Contrary to positive morality. Practically this mears only sexual morality.
Influence of eeclesia-tical law.
The rules and principles of law which disallow agreements whose olject is to contravene or evade an Act of Parliament do not apply to private Acts, so far as these are in the nature of agreements between parties. If any of the persons interested make arrangements between themselves to waive or vary provisions in a private Act relating only to their own interests, it cannot be objected to such an agreement that it is in derogation of, or an attempt to repeal the Act $\left(l_{i}\right)$.

\section{B. Agrements contrary to morals or good manners.}

It is not every kind of immoral object or intention that will vitiate an argreement in a court of justice. When we call a thing immoral in a legal sense we mean not only that it is morally wrong, but that according to the common understanding of reasonable men it would lie a scandal for a court of justice to treat it as lawful or indifferent, though it may not come within any positive prohilition or penalty. What sort of things fall within this description is in a general way obvious enongh. And the law might well stand substantially as it is, according to modern decisions at any rate, upon this ground alone. Some complication has been introduced, howerer, by the influence of ecclesiastical law, which on certain points has been very marked, and which has certainly brought in a tendency to treat these eases in a peculiar manner, to mix up the principles of ordinary social morality with considerations of a different lind, and with the help of those considerations to push them sometimes to extreme conclusions. Having regard to the large powers formerly exercised by spiritual Courts in the control of opinions and conduct, and even now

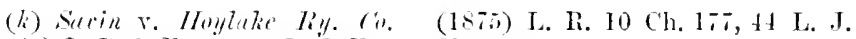
(1*6;) L. I. I Ex. 3. 3.5 L. J. Ex. 52. Cpre and dist. Shawe chuim ('ll. iin. 
technically not abolished, it seems certain that everything which om eivil Courts recognize as immoral is an offence against ecelesiastical law. Perhaps, indeed, the converse proposition is theoretically true, so far as the ecclesiastical law is not directly contrary to the common law $(l)$. But this last question may be left aside as merely curious.

As a matter of fact sexual immorality, which formerly was and in theory still is one of the chief subjects of ecclesiastical jurisdiction, is the only or almost the only kind of immorality of which the common law talies notice as such. Probably drunlienness would be on the same footing. It is conceived, for exanple, that a sale of intoxicating lipnor to a man who then and there arowed his intention of making himself or others drunk with it would be void at common law. The actual cases of sale of goods and the like for immoral purposes, on whose analogy this hypothetical one is put, depend on the prineiples applicable to mulawful transactions in general, and are accordingly reserved for the last part of this chapter. Putting apart for the present these cases of indirectly immoral agreements, as they may be called, we find that agreements are held directly immoral in the limited sense above mentioned, on one of two gromds; as providing for or tending to illicit colnabitation, or as tending to disturb or prejudice the status of lawful marriage " in derogation of the marriage contract," as it is sometimes expressed).

With regard to the first class, the main principle is this. The promise or expectation of future illicit colabitation is an mlawful consideration, and an agreement founded on it is roirl. l'ast cohalitation is not an mulawful consideration ; indeed, there may in some cireumstances be it

llicit cohabitation-if future, an illegal consileration : if past, mente sileration. 
Julirment of

L,oril

Selborne, Ayerst $r$. Jenkins.

moral obligation on the man to provide for the woman ; but the general rule applies ( $m$ ) that a past executed consideration, whether such as to give rise to a moral duty or not, is equivalent in law to no consideration at all. An agree. ment made on no other consideration than past cohabitation is therefore in the same plight as any other merely voluntary agreement. If under seal it is binding and can be enforced (11), otherwise not (o). The existence of an express agreement to discontinue the illicit cohabitation, which is idle both in fact (as an agreement which neither party conld break alone) and in law-or the fact of the defendant having previously seduced the plaintiff which "adds nothing but an executed consideration resting on moral grounds only, "-can make no difference in this respect ( $(1)$.

The manner in which these principles are applied has been thus stated by Lord Selborne:-

"Nost of the okker authorities on the subject of contracts foumled on immoral consileration are collecterl in the note to Benyon r. Yetflefold $(p)$. Their results may be thus stated: 1 . Bonds or corenants foumled on past culabitation. whether adulterous $(q)$, incestnons, or simply immoral, are ralis in law and not liable (unless there are cther elements in the case) to be set aride in equity. 2. Such bonds or covenants, if giren in consileration of future colabitation, are roik in law (r), and therefore of eurse also void in equity. 3. lielief cannot be given against any such bonk or corenants in equity if the

(in) But the rule is morlen (ch. IV. 1. 1s!. above), and the carlice cases on this subject belong to a time when a different doctrine prevailed; they therufore thens matters which in the molem view are simply irrelevant. e.\%. the previnus character of the fartics.

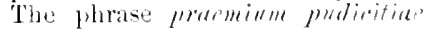
comesfrom this periml. T'ramiun fmdoris, howevel, was neel in al perfectly innecent sense in the whl law of fower : ( $\because$ l. lit. 3lal.

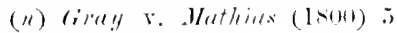
Ves. 2si, ; li. li. Is.

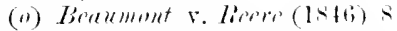
Q. 1․ 4s:3, 1: 1. I. 9. 1: 1 11. in
Ii. Ii. 5.52 .

(p) $(15.50) 3$ Jlac. \& $6.94,100$, si li. R. 25.

(q) Kuye r. Woore (1s2.2) I rim. itit. lit.

(1) Wulker v. Prokins (1764) 3 limer. 1.56is.

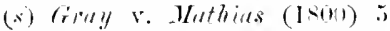

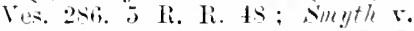
lrotinn (IO42, 13 sim, 245, 14 L. J. ('h. 2'? appears to be really nothing elet than an instance of the same mile. The rule is or was a general one: simpsoll r. Lord Howeden (1sio) 3 Mr. \& Cr. 97. 102. 45 li. li. 2.25. 22i;. 
illegal consideration appears on the face of the instrument $(x)$. + . If an illegal consideration does not aprear on the face of the instrument the objection of partireps eriminis will not prevail against a hill of discovery in equity in aid of the defence to an action at law (1), [ this is of no consequence in England since the Julicature Acts]. 5. Under some (but not under all) eircumstances when the consicleration is unlawful, anr does not appear on the face of the instrument, relicf may be wiven to a particeps criminis in equity "(

The exception alluded to in the last sentence is probably this: that "where a party to the illegal or' immoral purpose comes himself to be reliered from the obligation he has contracted in respect of it, he must state distinctly and exclusively such grounds of relief as the Court can legally attend to " $(x)$. He must not put his case on the ground of an immoral consideration having in fact failed, or complain that the instrument (loes not correctly express the terms of an immoral agreement (y).

Where a security is given on accomnt of past cohalitation, and the illicit connection is afterwards resumed, or even is never broken off, the court will not presume from that fact alone that the real consideration was future as well as past cohabitation, nor therefore treat the deed as invalid (z).

There existed a notion that in some cases the legal personal representative of a party to an immoral agreement might have it set aside, though no relief would have been given to the party himself in his lifetime: but this has been pronounced "erroneous and contrary to law" (a). An actual transfer of property, which is on the face of it "a completed roluntary gift, valid and irrevocable in

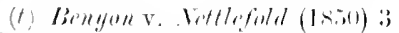
Mac. \& $1 ; .41$, sit hi. li. 25.

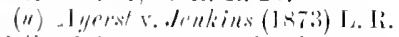

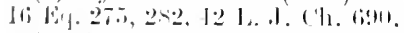

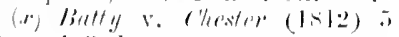
lieis. 103, 10!4.

(y) s'mble, lelief will lut be: given if it alprears that the immoral

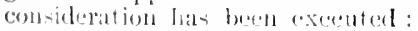

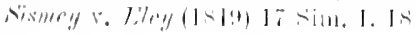

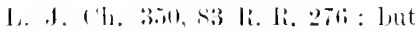
the case is homdly intelligible.

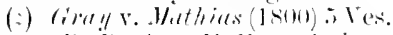

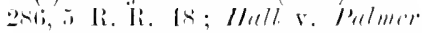

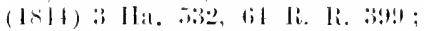

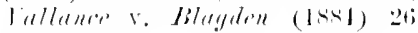
(11, 1). 35,3$)$

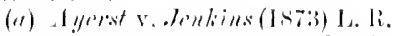

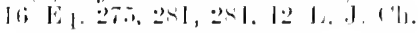
(i.). 
Proviso for reconcilia tion in qursi separation deed is roikl.

law" and confers an absolute beneficial interest, cannot be afterwards impeached either by the settlor or by his representatives, though in fact made on an immoral consideration (b). But it by no means follows that the Court will enforce the trusts. It may have to direct the trustees whom to pay, and will then disregard any disposition which is in fact founded on an immoral consideration (c). Thus a settlement in the form of an ordinary marriage settlement in contemplation of a marriage (as formerly with a deceased wife's sister) not allowed by English law is treated, as regards trusts for the so-called wife, as made on an immoral consideration, and the Court will pronomee such trusts invalid if applied to by the trustees for directions, though it rould not set aside the settlement at the instance of the settlor $(d)$.

Where parties who have been living together in illicit cohabitation separate, and the man corenants to pay an annuity to the roman, with a proviso that the annuity shall cease or the deed shall be void if the parties live together again, there the covenant is valid as a simple roluntary covenant to pay an annuity, but the proviso is wholly void. It makes no difference, if the parties, being within the prohibited degrees of aftinity, have gone through the form of marriage, and the deed is in the ordinary form of a separation deed between husband and wife $(c)$. Then the parties are really married such a proviso is usual but supertuous, for the deed is in any case aroided by the parties afterwards living together $(f)$. This brings us to the second branch of this topic, namely the validity of separation deeds and agreements for separation.

(b) Lyerst s. lemlins. last note.

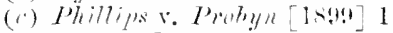
(h, sll, tis L..J. (H. ti) .

(d) Jhillips v. I'robyn. last niwte.

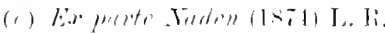

$\because(1,670.43$ L. .J. Bk. 121 .

(. $\left.{ }^{*}\right)$ Westmenth r. Salistum!n $\mathrm{Or}$ II stmeath (1820-1) 5 Bli. N. . 339,1 Dow it (1. 519, 35 li. R. it. 
The history of the sulject will be found in Lord Westbury's judgment in IIunt v. IImnt (g). From the canonical point of view marriage was a sacrament creating an indissoluble relation. The duties attaching to that relation were "of the highest possible religions obligation" and paramount to the will of the parties. In ecclesiastical Courts an agreement or provision for a voluntary separation present or future was simply an agreement to commit a continuing breach of chties with which no secular anthority could meddle, and therefore was illegal and roid.

For a long while all canses tonching marriage even collaterally were elaimed as within the exclusive juriscliction of those courts. The sweeping character and the gradual decay of stuch elaims have alreaty been illastrated by cases we have had occusion to cite from the Year Books in other places. In later times the ecclesiastical view of marriage was still uplueld, so far as the remaining ecclesiastical jurisdiction conld uphold it (h), and continned to have much influence on the opinions of civil Courts ; the amount of that influence is indeed somewhat understated in Lord Westhury's exposition. But the common law, when once its juriscliction in such matter's was settled, never aropted the ecclesiastical theory to the full extent. A contract porviding for and fixing the terms of an immerliate separation is treated like any other legial contract, only the ordinary rule that the wife eamnot eontract with her husband without the intervention of a trustee is dispensed with in these cases (i). being good and enforecable at law, the contract is also good and enforceable in equity, nor is there any reason for refusing to enforce it by any of the peculial remerlies

(f) (lktil 2) 11). F..J.221. Tho case was taken to the lanks of Jorks, but the proceredings ane to all end without any tecision by the death of the husband: see per Lomil sorborme, \& App. ('a. at p. 1:21.

(li) Sice 1 1). F. . 2.3.5-s.

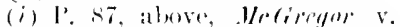
Mrelorgar (1856) 21 (2. R. 1)iv. 121, 57 1. J. (2. I). 26isi.
Separation

leerls in

general.

Hunt r. Ilunt.

P. 
IVilan $r$ IVilsm.

finsilena. tion for aricements for selatiation leeds.

of equity. In Hunt v. Hunt the husband was restrained from suing in the Dirorce Court for restitution of conjumal rights in violation of his covenant in a separation deed ( $i)$, on the anthority of the decision of the House of Lords $\left(l_{i}\right)$ which had already established that the Court may order specific performance of an agreement to execute a separation leed cortaining such a covenant. The case may be taken as having put the law on a consistent and intelligible footing, though not without overruling a great number of pretty strong dicta of varions jurkes in the Court of Chancery and even in the House of Lords ( $(7)$ : and it has been repeatedly followed ( $m$ ). but an agreenent i,y the wife not to oppose proceeding.s for a divorce pemding at the suit of the husband is void, heing not only in derogation of the marriage contract, hut a collusive agreement to evade the due adminisration of justice (11).

We have seen that when it is sought to obtain the specific performance of a contract the question of consilerition is always material. eren if the instrument is muter seal. Generally it is part of the arrangement in these cases that the trustees shall indemnify the hushand agraint the wife's delots, and this is an ample consideration for a promise on the husband's part to malie

(i) Thisowenant cullil not then lo plearled in the pirotes court. which lied it elf benme by the former ocoleciatinal prative to

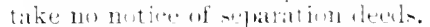

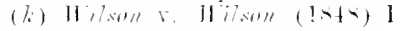
H. l. ('. sis. is R. li. lis

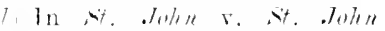

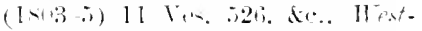

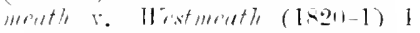

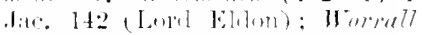

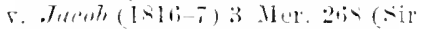

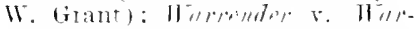

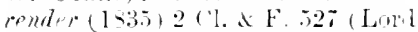
Bromgham), sil-2 (Lom Lendlunst) Most of these are to be fomm dited in the aromment in

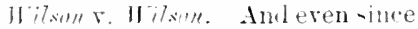

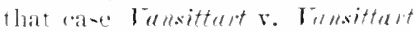

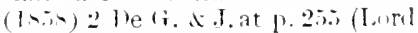
(helm-ford).

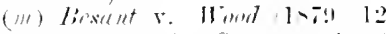

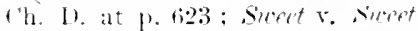
[ l-1., l Q. J. 12, it L. J. 1. B.

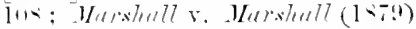
; 1'. 11.1!1.4 1..J. '?. 4!. A like covenant on the wife s lehalf $h \mathrm{~s}$ :

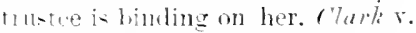
$17 \% 1 \%$. 10 P. Dir. 1es.

(11) Hepe r. Hope (18.5) \& 1 .

II 1․ $731,745,261$. J. Ch. 417. 
provision for the wife, and of course also for his undertaking to let her live apart from him, enjoy her property separately, \&c. (o). But this particular consideration is by no means necessary. 'The trustee's nudertaking to pay part of the costs of the agreement will do as well. But if the agreement is to execute a separation deed containing all ustal and proper clanses, this inchdes, it seems, the usual covenant for indemnifying the husband, so that the usual consideration is in fact present ( $/ 1)$. In the earlier cases, no doubt, it was supposed that the contract was made valid in substance as well as in form only by the distinct covenants between the husband and the trustee as to indemnity and payment, or rather that these were the only ralid parts of the contract. But since Wrilsom v. Wilsom (q) and Inut v. Hunt such a view is no longer tenable: in Lord Westbury's words "the theory of a leed of separation is that it is a contract between the husband and wife throngh the intervention of a third party, namely the trustees, and the hushand's contract for the benefit of the wife is supported by the contract of the trustees on her hehalf " $(r)$. A covenant not to sue for restitution of conjugal rights camnot be implied, and in the absence of such a covenant the institution of such a suit cloes not discharge the other party's obligations under the separation deed (s). Subsequent adultery does not of itself avoid a separation deed muless the other party's covenants are expressly qualifierl to that effect $(t)$. A covenant by the lussband to pay an anmuity to trustees for the wife so long as they shalt live apart--or, since the Married Women's Property

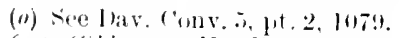
(1i) Gillss \&. Ilarding (1sio)

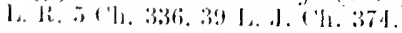
(1) On the cllect of that case see the remarks in the llouse of larels in a subserment appeal as to the

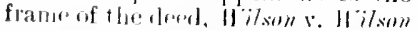
(1854) 5) H. L. ( . H11, 101 R. L., 25; and by Lord Westbury. I I . F. I. 231.

(i) 1 D. I'. I. 241".

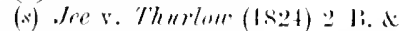
(. 517.26 R. R. 153.

(t) Il,.; Lirans: r. C'arrimgton.

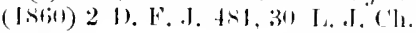
364.
Minor points as to separation decis. 
Act, to the wife herself-remains in force notwithstanding a substatuent dissolution of the marriage on the ground of the wife's adultery (II); but it seems it would be void if future arlultery were contemplated at the time $(r)$. The concenlment of past misconduct between the marriage and the separation may render the arrangement voidable, and so may sulsequent misconduct, if the circumstances show that the separation was fraudulently procured with the present intention of obtaining greater facilities for such misconduct (!)

A separation, or the terms of a separation, between hustand and wife camnot lawfully be the subject of an agreement for permiary consideration between the hushand and a third person. But in the case of . Tones r. Wrate (:) it was decided by the Exchequer Chamber and the IIonse of Lords that the hushand's execution of a sparation dext allealy drawn up is a good and lawful consisteration for a pomise ly a third person.

A separation deed, ats we have above said, is avoided by subserpent reconciliation and cohahitation (a). If it wore not so, but conld remain suspended in order to be pevived in the erent of a renewer separation, it might becone cquivalent to a contract providing for a contin-

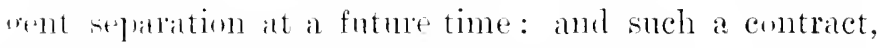
us will immerliately be seen, is not allowahle. However, a sulstantive and absolute declaration of trust by a

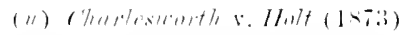

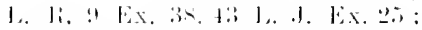

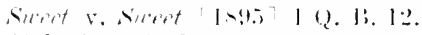
(i) 1. .1. ?. 1?. 10.

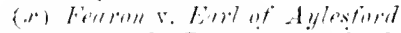

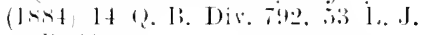
?. 1:. 410 .

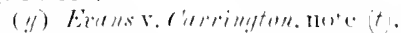
ami fere (intom L.el. It (2. L. 1). at 1. Tis.

(₹) (1-4:) l linge. X. ('. tisti. in Ex. ('h. 5 Hing. X. 1.3H1, in H. L. ! 1. A F. I11, , il H. H. 71., In the Fx. r h. luth label IJinger amel laml lemman dissented.

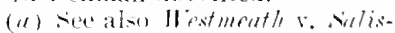
bur!l (1531) \% Bli. X. S. 3339. 3.5 li. R. it. Questions may arise whether particular terms are part of the arreement for separation. and therefore subject to be so avolited. or are of a premanemt and intependent nature: see $\mathrm{bic}$ r.

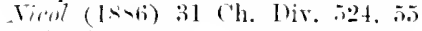
l. I. (1) 437. 
third person contained in a separation deed has been held not to be avoided by a reconciliation (b).

As to all agreements or provisions for a finture selatration, whether post-nuptial (c) or ante-nuptial (d) (e), and whether proceeding from the parties themselves or Agreements for future from another person ( $\mu)$, it remains the rule of law that they can have no effect. If a hushand and wife who have been separated are reconciled, and agree that in case of a future separation the provisions of a former separation deed shall be revived, this agreement is void $\left(f^{\prime}\right)$. But where a separition order has been marle on a wife's complaint, and she afterwards anrees to return to her husband on terms, a term that, in the event of fiture misconduct and another separation order, he shall pay her a fixed annuity is not against public policy $(g)$. A condition in a marriage settlement varying the disposition of the ineome in the event of a separation is void $(h)$. So is a limitation over (being in suls-tance a forfeiture of the wife's life interest) in the event of her living separate from her husbind through any fault of her own: thongh it might be good, it seems, if the event were limited to misconduct such as wonld he at gromud for divorce or judicial separation (i).

Likewise a reed purporting to jorovide for an inninediatr. separation is void if the separation does, not in fact talie plate: for this shows that an immediate separation was not intended, but the chnng was in truth a device to

(b) linllles v. Alstom (1sisi) l. li.

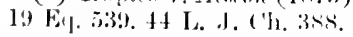

(1) Wartuis of Ifestmenth $\quad$.

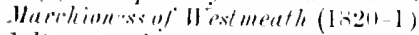

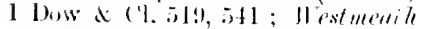
v. Sitlixlunty (18:31) ; lili. N. s. 3:3!!. 35 li. li. 51 .

(d) H. ․ II. (1 . 3x.2. 112 R. Ji. I!ti. Fome of the:

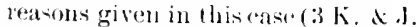

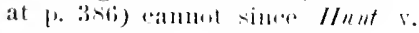

Ilunt be sulyorted.

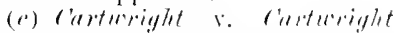
(1 ?lo. Sill, git li. li. fors: mote that this and the (atse last reited werte after Iltson v. II Ixon.

(f) Sice molte (r)

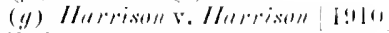

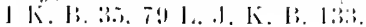

(/i) $\mathrm{xin}$ mint (a).

(i) $\mathrm{sin} \cdot 11011 \cdot($ d $)$.

separation verid. 
provide for a future separation $\left(l_{i}\right)$. Nor can such a deed he supported as a voluntary settlement $(l)$.

Reaton of the listinction.

lonumal pulylications:

lieing riminal wfleneces, llese are contrary to peritionlas.

The distinction rests on the following ground:-An anleement for an immediate separation is made to meet a state of things which, however undesirable in itself, has in fact become inevitable. Still that state of things is ahormal and not to be contemplated beforehand. "It is forbidden to provide for the possible dissolution of the marriage contract, which the policy of the law is to preserve intact and inviolate" $(m)$. Or in other words, to allow validity to provisions for a future separation would be to allow the parties in effect to make the contract of marriage determinable on conditions fixed beforehand by themselves (11).

It is a well established rule that no enforceable right cint be acyuired by a blisphemons, seditions, or indecent publication, whether in words or in writing, or by any contract in relation thereto(o); but it does not really belong to the present head. The ground on which the cases procesed is that the publieation is or would be a eriminal offence; not merely inmoral, but illegal in the striet sense. The criminal law prohibits it as menlum in se, and the eivil law takes if from the criminal law as molum funlibitum, and refuses to recognize it as the origin of any right ( 1 ). Then the decisions in equity profess simply to follow the law by refusing in a doubtful case to

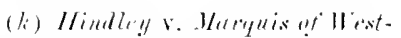

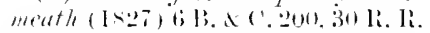
2!M : contimed by thestmeth v.

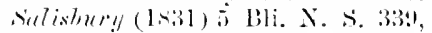
$34 \%-7,3$. R. R. it , is.

(l) Bimdley r. Mullowey (1569) L. li. . F. F. 343 .

(iil) 3 K. A J.382. 112 R. R. 196;.

(ii) Agre entent s between hm-bind and wifo contomplating a futme indicial separation (repatation le: ('nlw) are roble in French law: sirey di cilbert on Cinle Nap. art. 1 ! :3: no. . . . (a) I sumewhat amalogons questiom is raised by decentive trade marks and titles. A trate mark likely to deceive the public :ill not be registered: Emo v. Dunn (15961) 1.5 Alp. Ca. 252, 63 L. T. i. There is no copgright in a work of which the title or elecription is af fitul on the public: Mright $\mathrm{V}$.

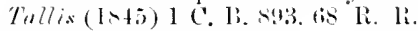
Si2.

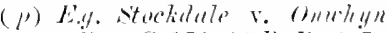

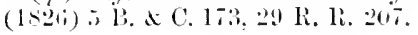


give the aid of equitable remedies to alleged legal rights mntil the existence of the legal right is ascertained $(q)$. It would perhaps be diffienlt to assert as an abstract proposition that a Court alministering civil justice miglit not conceivably pronounce a writing or discourse immoral which yet could not be the subject of eriminal proceedingss. But we do not know of such a jurisdiction having ever in fact been exercised; and considering the very wide scope of the criminal liaw in this behalf $(r)$, it seems unlikely that there should arise any occasion for it. Some expressions are to be found which look like claims on the part of purely civil Courts to exercise a general moral censorship apart from any reference to the criminal latw. But these are overruled by modern authority. At the present day it is not true that " the Court of Chancery has a superintendency over all books, and might in a summary way restrain the printing or publishing any that contained reflections on religion or morality," as was once laid down by Lord Mitcelesfield ; or that " the Lord Chancellor would grant an injunction against the exhibition of a libellous picture," as was laid down by Lord Ellenborongh (s). On the whole it seems that for all practical purposes the civil law is determined by and coextensive with the crininal law in these matters: the quastion in a given case is not simply whether the publicition be immoral, lut whether the criminal liw would punish it as inmoral.

\section{Agreements contraty to public policy.}

before we go through the different classes of agreements

(y) Sinthey v. Sthrevend (1817) 2 Mor. 135: Lamenter v. Simith (15:2) liac. 471.23 R. li. 1:3.3.

(1.) Ster lillsiell an ('rimes, lik.2, c. 21, atml stephents Digest of the (timinal law, ante !1-!), lil, 172.

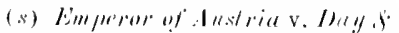
A

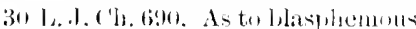

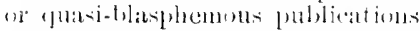
sombluing like theolier view seons

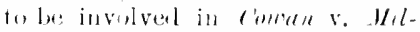

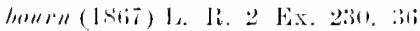
1.. J. lix. 1:2, but see contere the

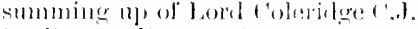

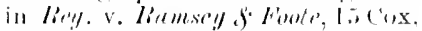
('. 1.2:3, 151, 15!). of the aloctrime of 
public policy which are void as being of mischievous tendency in some in general.

Its extension by anxiety of (ontsio diseomrage wagers, while wagers as surh were valid contracts.

one of certain different ways, something must be said on the more general yuestion of the julicial meaning of "public poliey." That question is, in effect, whether it is at the present time open to courts of justice to hold transactions or dispositions of property void simply because in the judgment of the Court it is against the public gool that they should be enforced, although the grounds of that judgment may be novel. The greneral tendency of morlern irleas is no donbt against the continuance of such a jurisdiction. On the other hamd there is a good deal of moder'n and even recent anthority which malies it difficult to deny its continued existence.

As a matter of history, there seems to be little doult that the doctrine of public policy, so far as regards its assertion in a gentral form in modern times, if not its actual origin, arose from watger's being allowed as the fommation of actions at common law. Theil validity was assmued withont discussion until the judges repented of it too late. Regretting that wagers conld be sued on at all it), they were forced to admit that wagering contricts ats sureh were not invalid, but set to work to diseonlage them so far ats they conle. This they did by becoming "astute eron to an extent hordering mon the ridieulous to find reasons for refusing to enforce them " in particulir cases (11).

Thus a wager on the future anomut of hop duty was letd void, betanse it might expose to all the world the anount of the pullic revenue, and Parliament was the only proper place for the discussion of such matters $(x)$.

(t) Giond v. Elliott (17\%+1) 3 T. li. 6:1:3. 1 li. R. sos, where liuller .J. proposerl (without sucerest) to hold voild all wagels on events in which the parties had no interest.

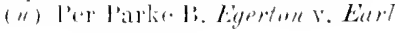

Bremelue (1553) + H. I. ( '. at l.

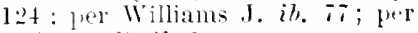
Alitelsoul 1) ib. list.

(r) Atherfild v. Bedrd (liss)? T. li. (il). I R. li. inti. 
Where one proprietor of carriages for hire in a town had made a bet with another that a particular person wonld go to the assembly rooms in his carriage, and not the other"s, it was thought that the het was void, as tending to abridge the freedom of one of the public in choosing his own conveyance, and to expose him to "the inconvenience of being importuned by rival coachmen" (y). A wager on the dmation of the life of Napoleon was void, because it gave the plaintiff an intelest in keeping the king's enemy alive, and also because it gave the defendant an interest in compassing his death by means other than lawful warfare (:). This was probably the extreme case, and has been remarked on as of doubtful authority $(a)$. But the Judicial Committee held in 1848, on an Indian appeal (the Act 8 \& 9 Vict. c. 109, not extending to British India), that a wager on the price of opimm at the next Government sale of opium, was not illegal (b). The common law was thus stated by Lord Camplyell in delivering the judgment:-

"I regret to say that we are bumd to combider the common law of England to be that an action mily be maintained on a wager, although

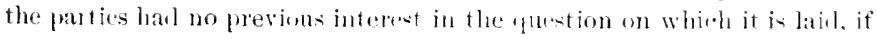
it be not ayainst the interests or leelinge of thim frersons, and does mot leal to indecent evidenee, and is not contrarg to publis policy. I lenk

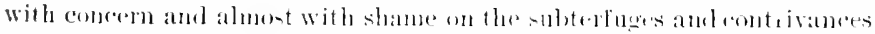

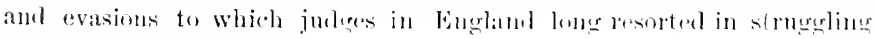
"igainst this rule " (r),

It may surely be thought doubtful whether decisions so produced and so reflected upon can in our own time he entitler to any regard at all. But it has heen said that

(y) Elthem v. Kimgrman (1sls)

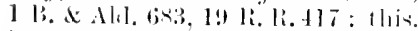
however, was not strictly needsary to the derision.

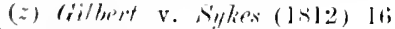
Fist, 1511. 14 R. R. 327.

(a) liy Alelerson B. in Eistertan v. Eial Bromelome I H. I. C. I1)!, and in the Privy ('ommeil in tlar raus next eited. if Mrus. I'. ('. 312. i!
I.ater remarlis in these decisions. (1). IInW lat now law. li. li. lil li.i.

(l) liy the Intian f'motract Act, s. 30, agrements hy way uf wayel are mow vold. whts an exceptim in farour of priz lor loose-racing of the value of lis son or mpwarels.

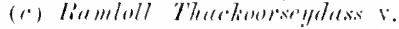

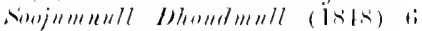

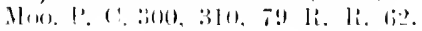
i.:. 
they establish a distinction of importance between cases where the parties "have a real interest in the matter, and an apparent right to deal with it "and where they "hirve no interest but what they themselves create by the contrite: " that in the former case the agreement is voil only if "directly opposed to public welfare," but in the latter "any tendency whatever to public mischief" will render it roid(d). It is difficult to accept this distinction, or at any rate to see to what class of contracts other than wagers it applies. In the case of a lease for lives (to take an instance often used) the parties "have no interest hu what they themselres create by the contract " in the lives nlamed in the lease: they have not any " "aplatent right to dral with" the length of the sorereign's or other illustrious persons" lives an a term of their contrict: ret it has nerel been doubted that the contrate is perfectly sood.

Eugertion $r$. biownliw.

'The most remitriathle modern case on the general doctrine of " public policy" is Égerten r. Eul Brounlon w. by the will of the serenth Earl of Bridgewater a series of life interests ( $f^{i}$ ) were limited, sulject to provisoes which were senterally called conditions, hu were really comblitonal linitations by way of shifting How 11 on the preceding estates (9). The effect of these Was that if the possensor for the time being of the estates did not arcunire the title of Marquis or Dulie of Bridgewater, or did aceept any inferior title, the estates were to go orer. The Horase of Lords held hy four to one $(h)$,

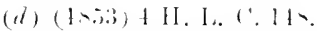

(e) 1 II. t. ( . 1-2.n. : 1 li. R. 1.

(f) Not entate of frecind with remaimler to first and other smo in tail in the nanal way but a chat tel

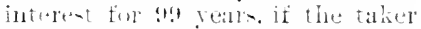
should at homg live. remain ler to the heirs male of his buly. see Lav. rons. 3. pt. 1. Bisl.

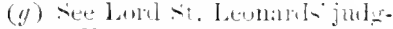
nent. 1 Il. L. 1'. at p.20.91 li. li. al $1, .2 .2$.

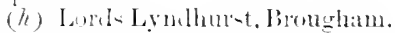
lruac. and sit. feonard- agamet lard framwonth. who had hearl the e:ate in the tirnt in-tance as cInancellor. 1 sim. X. S. 4tit. 4 li. Ii. I2. 4 . Lorl cratwolth could not sete his way to aroiding this will on the gronme of public fwelieg after the Thellusson will hat treall allower. 
in accordance with the opinion of two judges (i) against eight $(k)$, that the limitations were roid as being against public poliey. It was armitted that they were drawn with great slill and mimpeachable in form. But, according to the view which prevailed, they amounted in sulsstance to a gift of large peenniary means to be used in obtaining a peerage and retained only on condition of oltaining it, and a gift on such terms, even apart from any temptation to actual corruption, tended to the exercise of improper influence and the introduction of improper motives in the exereise of the Sovereign s discretion.

The fullest reasons on the sile of the actual decision are those of Pollock C.B. and Lord St. Leonarts. Their langnage is very general, and they go far in the direetion of climing an almost unlimited right of deciding cases according to the judges riew of public policy for the time being. Lord sit. Leonards mentioned the fluctuations of the decisions on agreements in restraint of trade as showing that pules of common law have been both ereated and moditied by notions of public policy (l). He also said that cach case was to he decided upon principle, luat alstract rules were not to be laid down (im). If this means only that the Comt is to be gavided ly recognized principles, Jut will not and cimmot lind itself by verlat definition, and in the application of constant principles must have due regand to any new or special facts, the proposition is correct and important, though by no moans confined to this topie; but if it means to say that the Court may lay down new principles of public policy without any warlant even of allalogy, it

(i) Pollowk (:.li, atud l'latt l:.

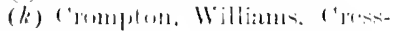
well. Talfouml. lohitrin:an. and

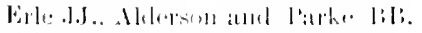

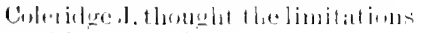
gand in part only. (l) Siere its to the variation of the "funlicy of the latw" in enenemal.

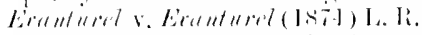

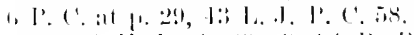
(Ii) + II. L. ('. 2?: !) ! R. li. Iil!. 
seems murranted and is not likely to be followed, as will be seen from the later anthorities. The practical value of the case is as a warning to draftsmen. If Lord St. Leonards had heen free to speak colloquially he might have said: "Yon have your name and arms clanse, which is well settled; but we do not mean to encomage any new-fangled shifting linitations, and experiments of that sort are at rour clients' peril ' $(n)$. The zeal of the Honse of Lords for liepling the fomtain of honom pure looks, to a converancer"s ere, ly no means mmixed with dislike to fancy conveyancings.

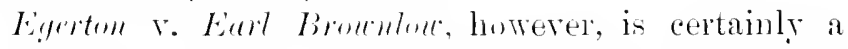
cartinal at thority for one rule which applies in ail cases of "public policy": namely that thr tendency of the transation at the time, not its actual result, must be looked to. It was niged in vain that the will of the seventh Earl of Brichewater land in fact heen in existence for thirty rears without producing any visible ill effects (o).

Later views: the rloctrine will not les extended.

The prevailing modern view is expressed ly the following lentralis of the late sir (i. . Jessel :-

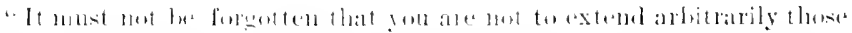

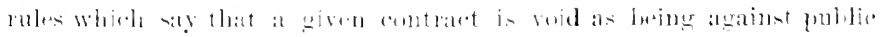

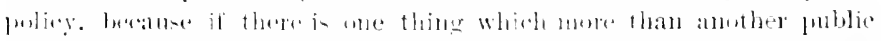

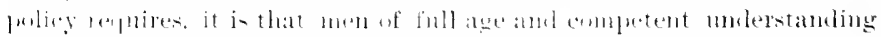

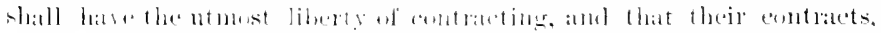

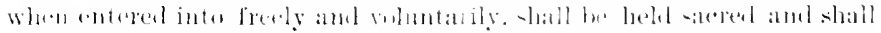

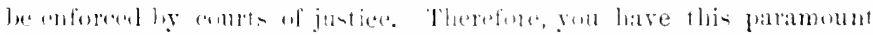
poblin policy to consider - that you are not lightly to interfere with this freeskm of contract" ( /").

(11) There was at prifeneinmal

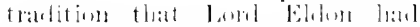
known of these disporitions amb expremed a private opiniom that

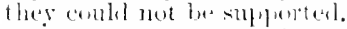

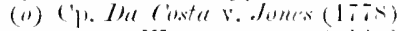

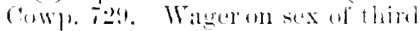
fersom roisl. ats attemeive to that

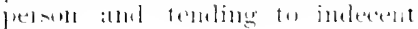

eridene: notwillstandiner it did unt alykan that the person has mate ally shjection, and the eamse han in lict heth tried withont any inderent trielence.

(1) Printing amb Sumerickl

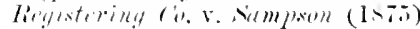
l. li. $1 !$ Ey. tiz. tt L. J. Cl. i11.i. 
In the House of Lords itself it has now been distinctly said that no Court cin invent a new head of public policy and that "pullic policy is always an unsafe and treacherous grom for legal decision," "a very unstable and dangerons foundation on which to build until mate safe by decision" (q). The may he pretty sure, therefore, that no further attempts in this direction will be made in our time $(r)$.

We now proceed to the several heads of the subject.

(a.) First, as to matters concerning the commonwealth in its relations with foreign powers.

"On the principles of the Enghish law it is not competent to any" domiciled British (s) "subject to enter" into a contract to do anything which mity be detimental to the interests of his own country" $(t)$.

An agreement may be void for reasons of this lind either when it is for the benefit of an enemy, or when the enforcement of it would be an affront to a friently State.

As to the first and more important branch of this rule: "It is now fully established that, the presumed Trading with enemy. object of war being as much to cripple the enemy's commerce as to capture his property, a declaration of war imports a prohihition of commercial intercourse and correspondence with the inhahitants of the enemy's

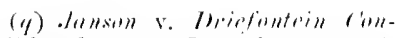

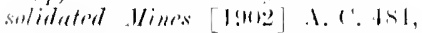

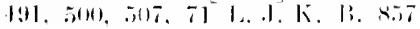

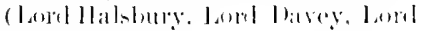
limbley).

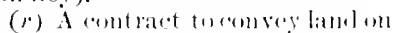
a contingency unt necenarily within the lintits of the me agrimet perpetuities is mot invaliol, lor 1he rule has nothine to , fo will merely beronal contracts: but it will unt be sperifically enforrerl. lor it rannot be recognized as ereationg any

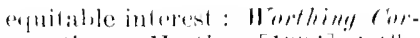

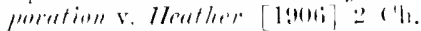

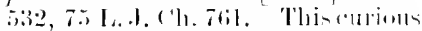
but correcel menlt follows low the strict application of porition rules and docesut depend on any dortrine of policy.

(*) 'lice rule iloes not alphy to british subjerds domiciled aboul:

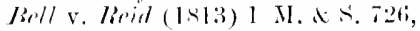
$11 \mathrm{li}$. Ji. is.

(t) T E. A R. T\&2. 1111 R. R. S2.
11. Public: policy ats touching external relations of the state. 
comtry, and that such intercourse, except with the licence of the Crown, is illegal "(11).

Potts r. Bell. The case of I'otts v. I'rll $(x)$, decided by the Exchequer Chamber in 1800 , is the leading anthority on this subject. The following points were there decided:

It is a principle of the common law (y) that trading with an enemy without licence from the Crown is illegal.

Purchase of goods in an enemy's country during the wal is tradling with the enemy, thongh it be not shown that they were actually purchased from an enemy : and an insurance of goods so purchased is roid.

As to insurinces originally effected in time of peace: "When a British mulject insmes against captures, the law infers that the contract contains an exception of captures male by the govermuent of his own comtry" (z). There is no rule of public policy to prevent insurance of a sulject of a foreign state against "arrests of all kings, princes, and peoples" from including seizure by that state before, thong shortly before, the outheak of war with (ireat Initain, where the policy is sued on after the wat is over (a).

biftect of war on subsisting contract-.

The effect of the outheali of war upon subsisting contricts between subjects of the hostile states varies according to the nature of the case. It may be that the contract can he lawfully performed by reason of the belligerent govermments or one of them having waired their strict rights: and in such case it remains valid. In ('lemontsom v. libessig (b) goods had been ordered of

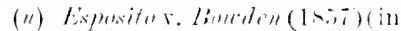
Ex. ('h.) i li. d I. 74.8. 779, 27

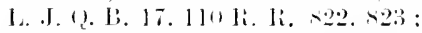

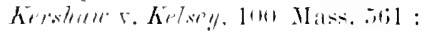
and see per Loril liarey 1902 A. ('. at [1. 1!1:4.

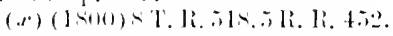
(1) In the Alminally it was alrealy beyond pluetion: are lhe series of preveldent-citel in Putts v. lioll.

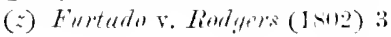

li. d I'. 1!1. 2014. (i li. li. 752:

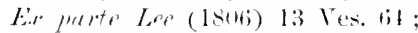

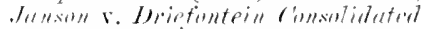
Hers $[1+112]$ A. ( $\therefore$ at 1 . t!!9.

(a) Intwoll v. Drigfuntein Gou-

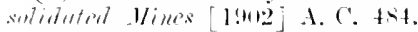
71 1..J. K. I: S.7.

(b) $(1,5,5) \quad 11 \mathrm{Ex}, 135: 105$ li. li. firl, and on the subject senerally see the reporters note, 1! Ex. itI-145, 105 R. F, 451.5 . 
the plaintiff in England by a firm at Ortessa before the declaration of war with Russia. By an Oreler in Comneil six weeks were given after the declarition of war for Russian merchant vessels to load and depart, and the plaintiff forwarted the goods for shipment in time to be lawfully shipped under this order: it wis held that the sale remained good.

If the contract camnot at once be lawfully performer, then it is suspended during hostilities (c) unless the nature or objects of the contract be incmsistent with at suspension, in which case "the effect is to dissolve the contract and to alsolve both parties from further prerformance of it" (d). The outhreals of a war dissolves at partnership previously existing between subjects of the two hostile comntries (c).

In Esposito v. Bonchen ( $f^{\prime}$ ), a nentral ship was chartered to proceed to Odess s, and there loat a cargo for an English freighter, and hefore the ship arrived there war harl broken out hetween England and Russial, and contimued till after the time when the loating should have talien place: here the contract could not be performed without trading with the enemy, and in such a ease it is convenient that it shonld be dissolverl at once, so that the

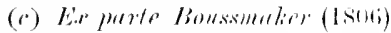
13) Yes. i], y R. IR. 112.

(d) Explatu v. Bumblen (1s.5) 7

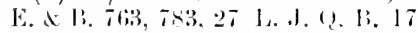
(in Hx. (h) revg. s. c. 1 lid $\mathrm{d}$ l. (143, 21 I. J. (2. H, 210, 110 li. Ii. 822 . 825. For a latel alplieation of the same? reaton of corrvenixuce, ell. Goipel s. stmith ( $1 \times 72)$ 1. R. 7 (1. B. 104,1$]$ 1. . I.

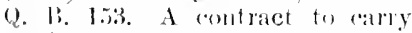

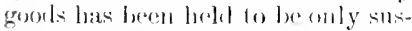
perted by a tomperary embareo,

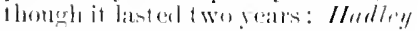

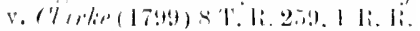
6il. sid qu. is not this virtually

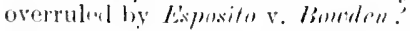

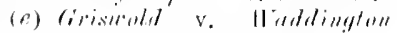
(1818) 15.10hus. (Niup. (1. N. Y.).7, in error 16 ib. 134. In Tom Jork

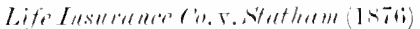
9:3 U. S. 2. I. a collous pluction arose at to the effect of the civil

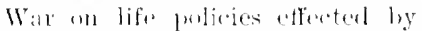
resialents in the sonthere sitates with a complatuy in the Nerth. It wan helet liy the majuety of thes foust that. Hhe preminme having been molatel doring the wat, the policies were arricleal: but that in the rifenm-talues the assured wele? entitled to the staremler value of

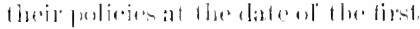

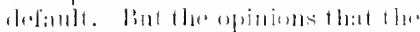

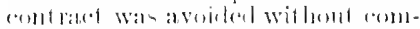

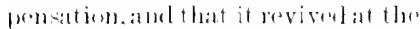

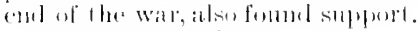

(f) siee note $(d)$. 
Bills of exchange between England and hostile country.
Irstilities atainst friently nation camot be subject of lawful con. tract.

parties need not wait indefinitely for the mere chance of the war coming to an end, or its otherwise becoming possible to perform the contract lawfully.

(Bnestions have arisen on the validity of bills of exchange drawn on England in a hostile comntry in time of war. Here the sulsstance of the transaction has to be lookerl at, not merely the nationality of the persons who are ultimately parties to an action on the bill. Where a hill was drawn on England he an English prisoner in a hostile comntry, this was held a lawful contract, being manle hetween English suljects; and by the necessity of the case an indorsement to an alien enemy was further held gool, so that he might well sue on it after the retmon of peace $\langle g\rangle$. But a bill drawn hy an alien enemy on a domieiler British sulject and indorsed to a British subject residing in the eneny's comntry, was held to give no right of action even aftel the end of the war: for this was a direct tratling with the enemy on the part of the aceeptor $(h)$. It seems proper to observe that these cases must be carefully distinguished from those which relate only to the personal disability of an alien enemy to sue in our Counts during the war (i).

On the other hand, an agreentent camot be enforced in Enstand which has for its olject the conduct of hostilities against a prower at peare with the English goremment, at all erents log rebellious sulgect of that power who are endearoming to establish their independence, but have not ret been reconnized as independent by England. Thlis was laid down in cases arising out of loans contracted in this country on behalf of sone of the South dmerican liepullies before they had been ofticially recognized.

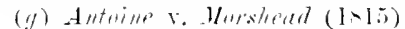

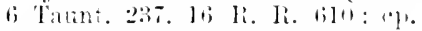

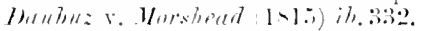
lit li. it. tiz:3.

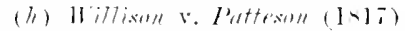
7 Tamet. 434. In R. R. i2s. The circum-tances of the inforsenent seem immaterial.

(i) Sitchare He commell v. Herters : li. \& l. 113. i li. R. $72 t$ :

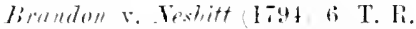
23. 3 R. li. lon. As to prisoners if wal here. Sparenlmagh v. Bamnatyne (1.97) I B. E P. I (63. + R. R. T-2. 
"It is contrary to the law of nations, which in all cases of international law is :rlopted into the muncipal corle of every civilized comtry, for persons in Eugland to enter into engagements to raise money to support the subjects of a government in anity with our own in hostilities against their govermment. and no right of action can arise ont of such a transaction" (k).

The Supreme c'ourt of the United States has held, however, that an assigmment of shares in a company originally formed for a purpose of this kind was so remotely connected with the original illegility of the loan as not to be invalid between the praties to it (l).

It is not a "municipal offence by the law of nations" for citizens of a nentral country to carry on trade with a blockader port - that is, the courts of their own conntry camot be expected to treat it as illegal (thongh of course it is done at the risk of seizure, of which seizure, if made, the neutral trader or his govermment cannot complain): and agreements having such trade for their object-e../. a joint adventure in blockade running--are accordingly valid and enforceable in the courts of the nentral state $(m)$.

There were decisions on this topic of aiding or trading with enemies in the Anerican Supreme Court in cases arising ont of the Ciril War (n).

It is admitted as a thing required by the comity of nations that an agreenent to contravene the laws of a foreign combtry wonld in general be nulawful. Bnt it is said that revenue laws (in practice the most inportant

Exceptional treatment of foreign reventue laws.

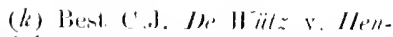
drirk: (1N24) 2 Bing. :314. 27 li. li.

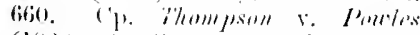
(1820) 2 sin. 191, where th. langnage secms unnoesesanty wirle. (i) Mebluir s. Ciblues (ISi) 17 Howaml. 2:3:.

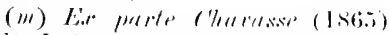

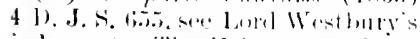

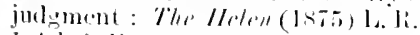

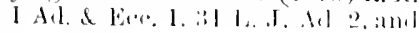

Anterion antlonities there enterl Kent, commo. 3.2015 .

(u) Sere Textes v. IIthite (Istis) 7 Watlane, 7on (where, lowwerer, the rluinf proints are of enustitutional law) : Ilamenter v. Intare (1870) 12 it. 3.2 symtt v. I. II:all. 1.it, gnes beyomel anything in one benks. and the discent at Findit.
Nentral trate with belligerents is at risk of capture only, not unlawful. 
cases) are excepted, and that "no comntry ever takes notice of the revenue laws of another" (o).

As a general proposition, however, this is disapproved by most modern writers as contrary to reason and justice (1). It should be noted that om Courts, so far as they have acted upon it, have done so to the prejudice of onr own revenne quite as much as to that of foreign states. Thun a complete sale of groods abroad by a foreign vendor is valid, and the price may be recovered in an English Conrt. though he knew of the buyer's intention to smuggle the goods into Englaud. "The subject of a foreign conntry is not bound to pay allegiance or respect to the revenue lans of this." (q). But it is arlmitted that an agreement to be performed in England in violation of English revenue laws would be void-as if. for example, the goods were to be smuggled hy the seller and so delivered in England. And a subject domiciled in the British dominions (thongh not in Fugland or within the operation of English revenue liws) cannot recover in an English Court the price of

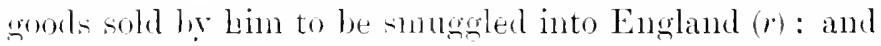
wrol a foreinn rendor cammot recover if he has himself actively contributed to the breach of English revenue laws, as lie packing the poods in a mamer suitalule and to his knowledge intemled for the purpose of sm110

The cases mpholding contracts of this lind, whether as against onl own or as against foreign laws, womld probably not be now extemed leyomed the points specitically

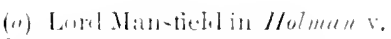

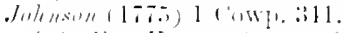

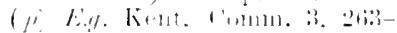

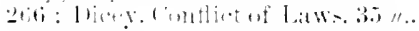

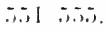

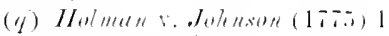

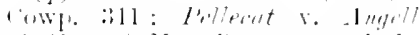

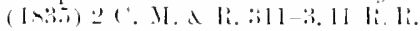

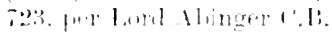

(r) rlugus x. Penuluma (1791)t 1. li. 4riti. 2- 1i. R. 4t2. It seem= but it is not quite certain. from this care. that mert knowledge of the buyer's intention womlit disentitle nim.

(*) Ilaymell v. lieed $(17: 4)$ i

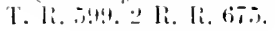


decided by throm, and perhaps not altogether upleeld (t). There is one moder'n case which looks at tirst sight like an anthoriy for saying that onr ('ourtis pay no regardel to foreign shipping registration laws: but it really goes upon a different principle, and, hesirles, the law of tho United states was not properly bromght before the Conrt (11).

As to instruments which cannot be nsed in their own country for want of a stamp, it is now settled that regald lineign will be paicl by the Courts of other States to the law which regulates them, and the only question is as to the real effect of that law. If it is a mere rule of locial procedure, requiring the stamp to malie the instrument admissible in evidence, a foreign Cont, not beingr homel by such rules of procedure, will not reject the instrument as evidence: it is otherwise if the local latw "malios at stamp necessary to the validity of the instrument," i.e., a condition precedent to its having any lesil effect at all $(x)$.

(b.) As to matters touching good govermment and the aduinistration of justice.

It is needless to produce anthorities to show that an agreenent whose olject is to intues any officen of the St te, whether juticial or executive, to act partially ar corruptly in his oftice, most in any civilized eomntry he

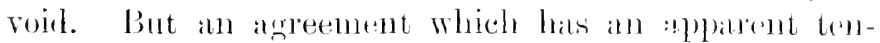
deney that way, thomgh an intention to dose molatiful meins be not atmitted, of even be montinally diaclatimed, will equally be hell vold. T'he calse of Etgreton v. Earl

(t) It must be [entembered 1] $1: 11$ the gremeral latw as lo sale of germl. de., whieh the sello.l knows will be

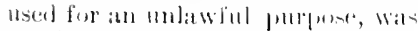

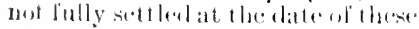
autburitics.

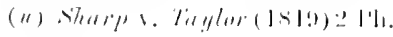

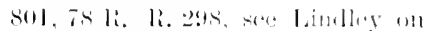

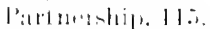

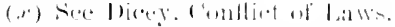

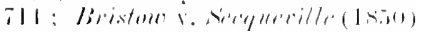

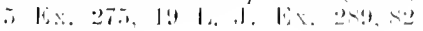
li. Ii, litil. b. Publi. policy as tollelinis internal (u) ('intil) w

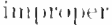
intluenerese polline oflicers (I) logislature. 
Marshall $r$. Baltinure. de. (i). (sup. court [....)
Irmenlon, of which an accomt has been given a few panes above, was decided on the principle that all transactions are void which create contingent interests of a mature to put the pressure of extraneous and inproper motives upon the coumsels of the Crown or the political conduct of legislitors.

A decision in the American siupreme Court which happens to be of nearly the same date shows that an agreement is voil which contemplates the use of underhand means to inflnence legislation. In Marshall $r$.

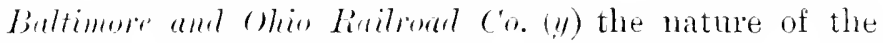
asreement sued on appeared ly a letter from the plaintiff to the president of the railway board, in which he propused a plan for olutaining a right of way through Virginia for the eompany and oftered himself as agent for the purpose. The letter pointed (though not in express terms) to the use of secret inflnence on particular menbers of the legrislature: and it referred to an accompanying document which explained the nature of the plan in 11 re detail. This document contained the following parsage:-“I contemplate the nse of no improper means or appliances in the attainment of your purpose. My scheme is to surround the legislatare with respectable agents, whose per.

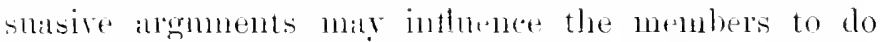
von a naker justice. This is all I reyuire-secrecy from motives of policy alone-because an open ageney would furnish ground of suspicion and mmerited inveetive, and might weaken the impression we seek to make." The arrangement was to be as secret as practicable: the company was to have but one ostensible agent, who was to choose such and so many sub-igents as he thought proper: and the parment was to be contingent on success. The actual contract was made hy a resolution 
of the directors, according to which agents were to be employed to "superinteml and further" the contemplated application to the legislature of Virginia " and to take all proper measures for that purpose;" and their right to any compensation was to be contingent on the passing of the law. The Supreme Court held, first, that it was sufficiently elear that the contrat was in fact made on the footing of the previous communications, and was to be carried ont in the manner there proposed: and secondly, that being so made it was against public policy and roid.

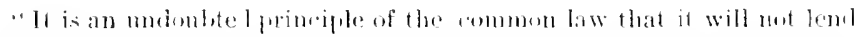

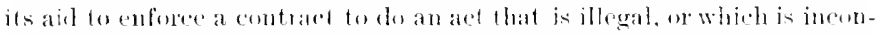

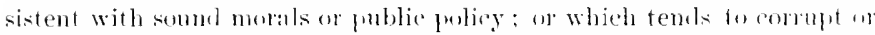
contaminate, hy improper influences, the integrity of on social or political

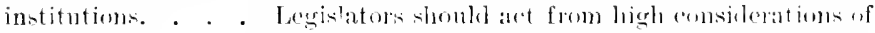

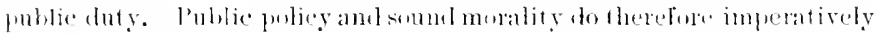

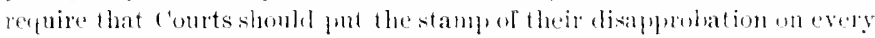

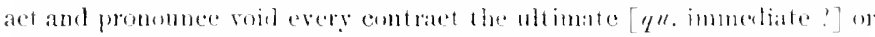

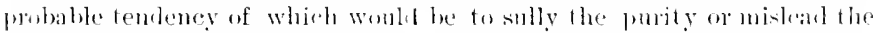
judgments of those to whom the high trust of legislation is confided." [The jurgment then puints out that fersons int resterl in the results of pemling legistation have a right to nrge their elaims ejther in person on by agents, but in the latter case the agency must he pren and acknowlertged.] "Any attempts to deceive persms intrusted with the high function of legintation by secret combinat ions, or to create or bring ints oferation undue influences of any kimb. have all the esflectsof a direct fraud on the public" $(z)$.

Ind the result of the previous anthorities wats stated to be--

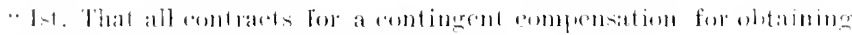

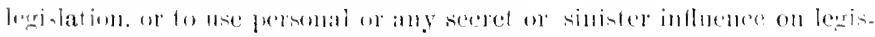
latersare (a) veril by the policy of the law.

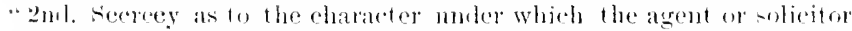
act-tende to deception and is immoral and fraudulnt, and where the

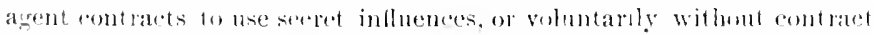
wilh his prineipal neses such means, loe eamont lave the assistamee of a

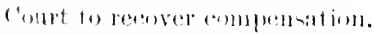

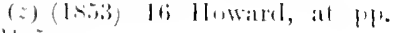
$331-i)$

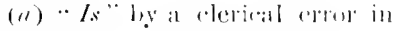
the report. 
*3rol. That what in the technical socabulary of priticians is termed "low-mlling" (b) in a mislemeanour at common law punishable by inlirotment" (, ).

So in a latel case (d) an agreement to prosecute a caim before comgress ly means of personal influence and solicitations of the hind lnown as "lobly service" lias leen hele roid.

Otherwise of contract loy person interested tor willolraw "l’hstion; Simponer. lomillowiten.

lint ats it is open to a landowner or other interested peram to defend his interest ly all lawful means against !nopused legistation from which he alprehends injury, so it is npen to him to witheraw or compromise his claims ant any terms he thinks fit. There is no reason andinst hatrains of this lind any more than against a compomise of disputed eivil rights in ordinary litigation. Amb the lawfulness of such an argreement is not altered if it so happens that the party is himself a member of the levislature. In the alsence of anything to show the contray, he is presumed to malie the agreement solely in his character of a person having a valuable interest of his own in the matter, and he is not to be deprived of his rights in that charater merely because he is also a lenishator (r). "A landowner eammot be restricted of his rightin hecance he hinplens to he a member of P'arliament. (f). This may seem anomalous: but it must be remembered that in practice there is little chance of a contlict between duty and interest. as the legislature generally infonms itself on these matter's by means of ammittes poceeding in a puasi-judieial mamner. Of comrse it would be improper for a member personally interented to sit on solch a committee.

(b) Arrangements butween menbere for the larter of rotes on private bilis.

(i) 1ti llowark :33ti.

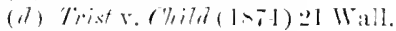

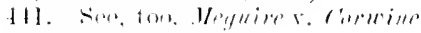
(1MB!) 101 U. S. dos. (r) Simpsoll r. Lord Howden $(1-3 ! 4-12) \geq$ H. K I. 714 . I0 A.S E. 7!3. ! ('l. \& F. 61. 50 R. R. 5.5.

( $f$ ) Kindersley V.-C. in Earl of

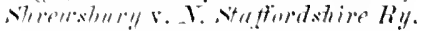
(1). (1sti.i) l. R. I Eq. .483. 6is. 35 1... (h. 1.tit. 
On similar grounds it is said that the sale of offices (which is forbidden by statutes extending to almost every case) is also void at common law (g). However, there may be a lawful partnership in the emoluments of offices, althongl a sale of the offices themselves or a complete assignment of the emoluments would be unlawful(h). The same principles are applied to other appointments which though not exactly public offices are concerned with matters of public interest. "Public policy requires that there shall be no money consideration for the appointment to an oftice in which the public are interested: the public will be hetter served hy having persons best qualitied to fill oflices appointed to them; but if money may be given to those who appoint, it may he a temptation to them to appoint improper persons." Therefore the practice which had grown up in the eighteenth century of purchasing commands of ships in the East India Company's service was held unlawful, no less on this ground than because it was against the Company's regulations (i).

In like mamner a secret agreement to hand over to another person the profits of a contract made for the public service, such as a Post Office contract for the conveyance of mails, is void $\left(l_{i}\right)$.

Nevertheless many particular offices, and notably subordinate offices in the courts of justice, were in fact saleable and the suljject of sale by custom or otherwise until quite modern times. But the commission of an officer in the army could not be the subject of a valid pledge even under the old system of purchase (l).

For like reasons certain assignments of salaries and

(a) Harington" v. IJ" chastel (1781) 2 Swatlst. 159, "1. ; Hopkins

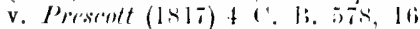

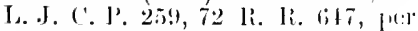
('oltman ,

(h) Sterry v. rliftom (18:0) !) (!. b, 110, 19 1, J, ('. 1'. 237, ,2 li. Ji.
$31 !$.

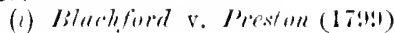

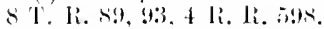

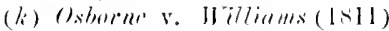
18 Ves. 379. 11 R. 1i. 218.

(l) G bllyer v. Finllon (1,23) T. a li. $4.9 . \%$ rale of

ollices, ice., at common law.
Assignments of salaries. 
pensions have been held roid, as tending to defeat the public objects for which the original grant was intended. Thus military pay and judicial salaries are not assignable. The rule is that " " pension for past serrices may be aliened, but a pension for supporting the grantee in the performance of future luties is inalienable" : and therefore a pension given not only as a reward for past services, but for the support of a dignity created at the same time and for the same reason, is inalienable $(m)$. But an assignment ly the holder of a public office of a smm efrivilent to a proportionate part of salary, and recured to his legal persomal rejresentatives on his death by the terms of his appointment, is not invalid. such a sum lieing simply a part of his personal estate like money securet hy life insurance (m). I clergrman having cure of sonts is not, as such, a public officer for the purpose of this rule (o). A mortgage by an officer of the Customs of his disposable share in the " Customs Ammuity and Benevolent Fund " created hy a special Act has been musncessfully disputed as contrary to the poliey of the $\operatorname{Act}(p)$.

Interference with course of justice. In eriminal pruceerlings. stilling proseculions." Wiiliams $r$. Bayley.

Agreements for the purpose of "stifling a criminal prosecution "ale void as tending to obstruct the course of public justice. An agleement male in consideration ostensilly of the giving up of certain 1romissory notes, the notes in fact having forged indorsements upon them, and the real consideration appeaning he the circumstances to be the forbearance of the other party to prosecute. was held roid an this ground in the House of Lords The principle of the law as there laid down by Lord

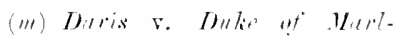

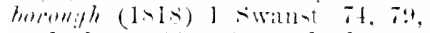

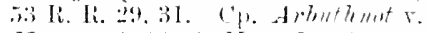

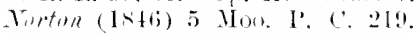
And see auth rities collecte in the notes to Ryull v. Romles (17t:t) in 2 Wh. . T. 1. C.

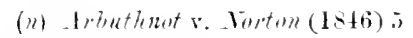
Y(n). l'. ('. 21!!.

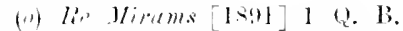
.3! t. (i) L. .I. Q. B. 397.

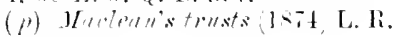
$1 ! 1 \mathrm{E}_{1}, 2 \mathrm{ZI}$ 
Westbury is "That you shall not make a trade of a felony" (q).

However the principal direct anthority must still be keir $r$. sought in the earlier case of Krir v. Lerman (r). The Lemm. Court of Queen's Benclr there said :-

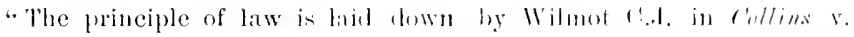
Blantern (s) that a contract to withdiaw a pessention for pering and consent to give no exilence agatinst the accused is folmed on an mulaw-

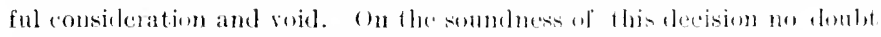

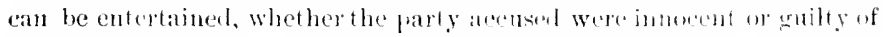

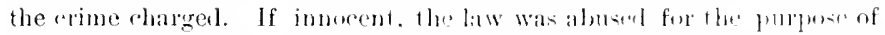

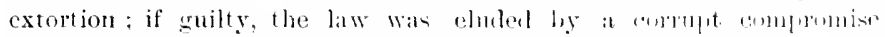
serecuing the eriminal for a bribe. [The easen atre then reviewel. We shall probably be safe in laying it clown that the kaw will permit a compromise of all offences. though mate the subject of crintinal perecution, for whieh offenees the ingured prity might sue ant reever damages in an action. It is often the only manner in whold lecen what restrese. But if the offence is of a public nature no angement ran be valid that is

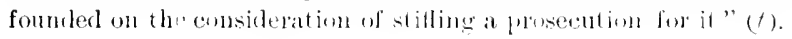

Accordingly the Court held that an indictment for offences inchuling riot and abstruction of a public officer in the execution of his duty cammot be legally the subject of a compromise. The jurgment of the Exehequer Chamber (11) affirmerl this, lnt showed some dissatisfatction even with the limiter right of compromise admitted in the Court below. The Conrt of Alpeal has since held that the compromise of any pullic misdemeanour, from whatever motive, is illegal (x), thom where there is a choice of a civil or crininal renerly a

(q) Ililliams v. Buylen ( Istidi) L. Ii. I II. T. $200,220,3.5$ 1. . I. Ch. 717 .

(r) $(1 \times 11) 6$ (2. Ii. 308, 1:3 L..I. Q. B. 2.5. 6i; R. li. 3!2. in kx. (1).

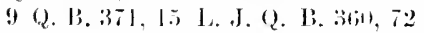
li. Ii. 293 .

(s) 1 sin. T. 1'. 36!), 342, (36!). $373,11 \mathrm{th}$ (el.).

(t) Ace. in $(7 n b l$ v. $/ / \| t+w n$

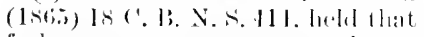
forbearanee to promerote a clatare of obtaining moncy by fake pire-

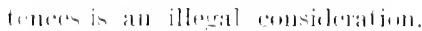
What if flere is 1mo leal gromol for

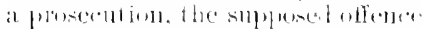
bring an and not rominally pumish-

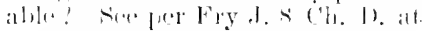
1. 17. I1 in smbunted that the

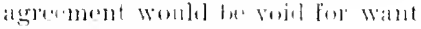
(1) rensiclerations.

(11) !) (2. I?. $: 11$ 1\%. :3:?2.

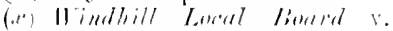
lint (lisen) lis ch. loiv. :isl, is I. .I. ('I. biss. 
compromise of criminal as well as civil proceedings may he lawful(y). It is even held that an agreement to compound an offence in a foreign comtry whose law does not forbici such agreements is not actionable here $(z)$.

There need not be an express agreement not to prosecute. An understanding to that effect, shown by the ciremustances to be part of the transaction, will be enough. And, since the defence of illegality in cases of this lime is allowed on public grounds, it must be allowed eren if the Court thinlis it discreditable to the party setting it up (a).

It is not compounding felony for a person whose name has been forged to a bill to adopt the forged signature and advance money to the forger to enable him to take up the hill. It is doubtful whether a security given by the forger for such advance is valid : lut he camnot himself actively clispute it (on the principle potion est conditio defondentis, of which afterwards), nor cam his trustee in bankruptey, who for this purpose is in no letter position than himself, as there is in any case no offence against the bankrupt laws $(h)$.

An agreement by an accused person with his bail to indemnify him against liability on his recognizances is illegal, as depriving the public of the security of the bail (c): and so is the lilie agreement of a third person (d). 18 Eliz. c. 5. The compounding of offences under penal statutes is expressly forbidien by 1is Eliz. c. 5, s. 5.

(y) Fisher if ('o. v. Ipmllimarix

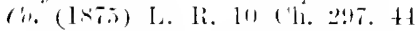
L. J. ('h. .j(t).

(:) hinuman v. Geroun [1!114] I K. 1. 5:1, 73 l. J. K. B. 3211. ('. A.. see L. Q. R. $x x, 227$. and p. to9, below.

(a) dones v. Herionethikire

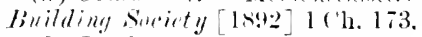
(i1 L. J. ('l. 133r, C. A.

(b) Otherwine where, after an act of bankinuter, the banking money has been paid for stitling a lmosecution : ther the trustee can

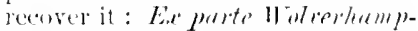
ton Banling (o. (188t) 1t Q. B. I). 32 ; Eir parte cialdecint ( $1<76$ ( ) ('li. I)iv. 150, 4i L. J. Bk. 14.

(c) Hermun r. Jeuclener (1xis) 1:U. B. Div. 561 . it L. J. Q. B. $340 . \quad$ It is an inclietable conspiracy : $l i$ v. Porter $[1910] 1$ K. l: 3ti9. 79 L. J. K. 1. $2+1$.

(d) Cinsoldiluted Explonetion and Fimeno ('o. r. Musquare [1900] 1 Ch. 3i, 6! L. J. Ch. 11. 
An election petition, though not a criminal proceeding, is a proceeding of a puhlic character and interest which may have penal consequences; and an agreement for pecuniary consideration not to proceed with an election petition is void at common law, as its effect would be to deprive the public of the lienefit which would result from the investigation (').

In like manner an angeement for the collusive conduct of a divorce snit is void (, $i$ ), and anceenents not to expose immoral conduct (g), and to conduct (riminal proceedings against a third person in such a way that the name of a party who was in fact involved in the transaction should not be mentioned $(h)$ lave been held void as against public policy. There is nothing illegal in an agreement between parties in a probitr action that costs shall come out of the estate whether the C'ourt so order or not ; and a party who malies such an agreenent jointly with an infant may be personally liable on it if, by the Court not sanctioning the agreement on the infant's part, it cannot be specifically performed (i).

A shareholder in a company which was in course of compulsory winding-11) agreed with other shareholders, who were also creditors, in consideration of being indennified by them against all future calls on his shares, that he would hely them to ret an expected call postponed and also support their chaim; it was held that "such an agreement amounts to an interference with the conrse of public justice ": for the clear intention of the Winding-up' Acts is that the proceedings shonlal he taken with reasonable speed so that the company's affiairs may be settled and the shareholders relieved; and therefore any secret agreement to delay proceedings to the prejudice of the

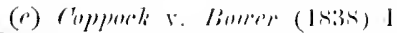

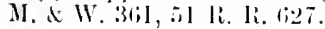

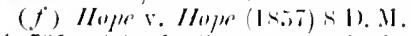
(i. 731, 261 1. J. ('h. 117. I1) R. li. 3011.

(g) Bromen v. Brime(185i) I lix.
Compromise of election petition.
Secret agreement as to eonluct of wincling-up' : Elliott $x$. Richarelson.
1). 5,151 1. J. Ex. 12!.

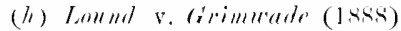
39 ('h. 1). 605, .57 L. I. ('h. 725.

(i) lovinter v. Hownth [190,i] 2 K. 1. 768,75 1. . . K. ., 92. 
Agreement fol reforence to altitration. how far valid at common taw.

Practically enforeeabie moler Arbitration Act.

other shareholders and creditor's is vold (k). This annes near to the cases of secret agreements with particula: creaitors in hankruptey or composition : and those cases (1) in fact rest partly on this gromed. But the direct frand on the other creditors is the chief element in them, and we have therefore spoken of them moler an earlier hearl (p. 29 !) $)$.

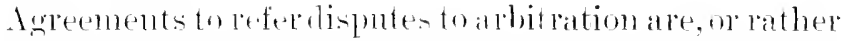
were, on at certain extent regarted as encroachnents on the preper anthority of courts of justice by the sulstitution of a " knnestic form " of the parties" own making.

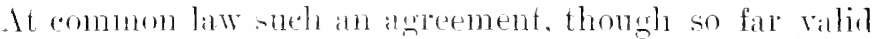
that an artion can be maintainel for a breach of it (h), does not "mut the ordinary jurisdiction of the Come" that is. cemmot be set np ats a batr to an action brought in the orilinary way to beternine the rery dispute which it was agreerl to refor. Jor conlle such an agreement he

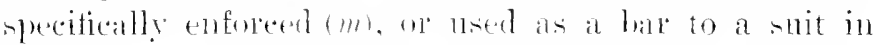
equity (m). It is sajel however " that a special eovenant not to she may make a difference" (11). And the law has not been divectly altered (1n): lnt the Common Law J'rocedure Act. 1s.st, now superseded by the Albitration A.t. 1ss! (5) is i: Viet. e. 4!). gave the Courts a discretion to stay proceseding in atclions or suits on the subject-matter of an algreement to refer, which amounts in pratice to mabling them to enfore the agreenent: and this discretion hat an a rule been exerciod by Courts both of law (o) and of equity (f) in the absence of special

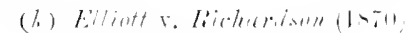

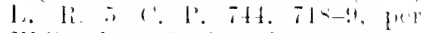

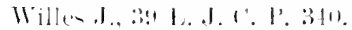

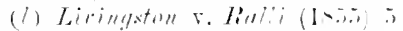

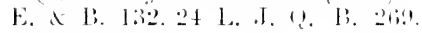
10:3 R. R. liti.

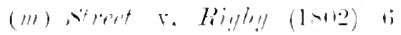

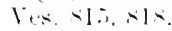

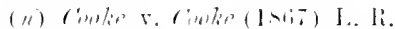
1 E. 7 . by soots law a reference exclutes the jurisdictin only if it is to

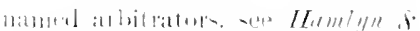

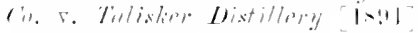
1. (1. 2011).

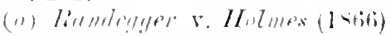

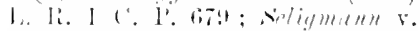
Le Liantillier Isibit ib. (i)l.

(1) 11 illestard $x$. II itsere $(1-73)$

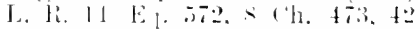
l. .l. ('h. 117: Plous v. Bubse

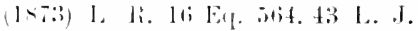
(1). 2!.3. A, to reference to the 
circumstances, such as a case where a charge of frand is made, and the party charged with it desires the inquiry to be public $(q)$, or where the defendant appeals to an arbitration clause not in good fairh, lout merely for the sake of rexation or delay ( $\%$, or is otherwise not really ready and willing to arbitrate (s). A question whether on the true construction of an arlitration clause the sulject-matter of a particular dispute falls within it is itself to be dealt with by the arlitrator, if it a plears from the nature of the case and the terms of the provisions for arbitration that such was the intention of the parties. Otherwise it must be decided lyy the Court (t).

And when the question is whether an arreement containing an arlitration clatuse is or is not determined, that question is not one for arlitration, sinee the arbitration clause itself must stand or fall with the whole agreement (II).

Certain statutory provisions for the reference to arlitration of internal disputes in friendly and building societies have been deciled (after some confliet) to be compulsory special statutory ablitratim and to exclude the ordinary jurisdiction of the Courts $(x)$.

devision of a lineign linut. we

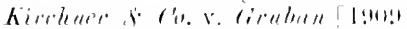
1 (11. 4l:3. 7s I. .1. (11. 117.

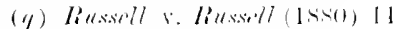

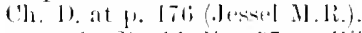

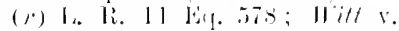

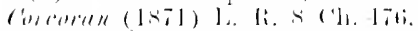

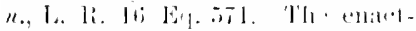
ment applies mly whege there is at the time of anotion bought atn exintiog agrecoment lor refereme

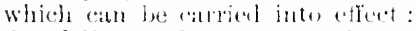

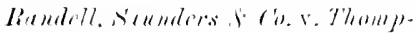
soll (lsiti) ] (2. li, Jiv. Tls, lis 1. J. 12. I: 7l3. Not where tha

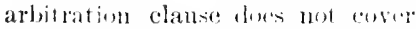
the wh lesubject-mbatter: Timmols

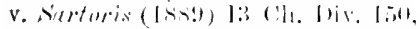
(j2) 1. T'. 20!9. Nor When the matter in etifference is a puostion

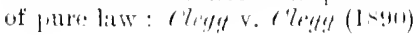

I ('h. I)

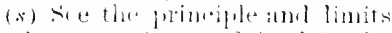

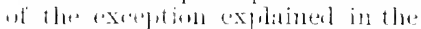

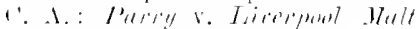
(i. $19401 \mid$ | 4. I:. 3:3!) ti! 1. I. () 1:. Jil.

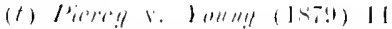

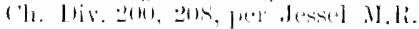

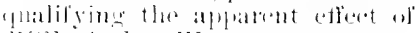

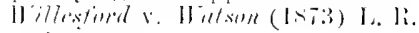
s ( h. I 13.

(11) l'o lanmeri L.J. in Llumbly

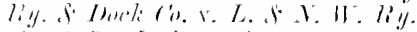
(i) (1873) L. li. s ('h. at p. bls.

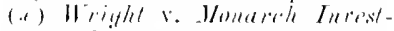

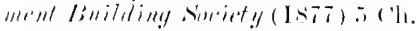

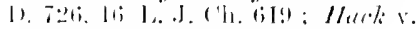

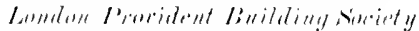

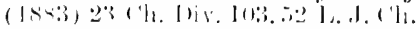

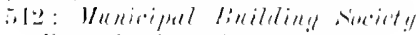

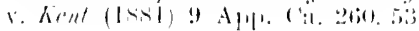


The Railway Companies Arlitration Act, 1859, is also ('ompulsory (!)

Agrexment of partice may make right of action couditional on arbitration.

Matintenance and chantperty.

Moreover parties may if they choose make arbitration a contition precedent to any right arising at all, and in that case the foregoing rules are inapplicable: as where the contract is to pay such an amount as shall be determined by arbitration or found due by the certificate of a particnlar person ( $\approx$ ). Whether this is in fact the contract, $o r$ it is an absolute contract to pay in the first instance, with a collateral provision for reference in case of difference as to the amount, is a question of construction on which there have been nore or less conflicting opinions (a).

Te now come to a class of transatctions which ale specially discombagerl, as temling to pervert the alue course of justice in civil suits.

These are the dealins which are held void as amounting to or being in the nature of champerty or maintenance. The principle of the haw on this head has been defined to be "that no encomiagement should be given (1) litigation by the introduction of parties to enforce

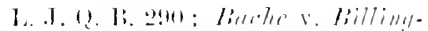
|a:111 | I

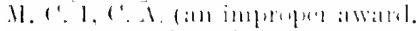
otherwise within the det. anmol lese dreatud ats il mere mullits).

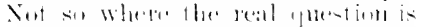

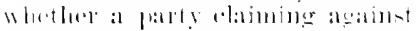

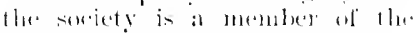

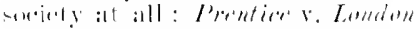

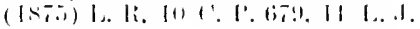

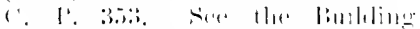

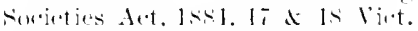

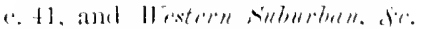

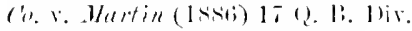

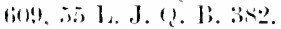

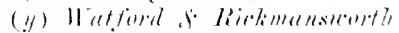
liy. (i) \&. l. I. I. II. Ry. li.

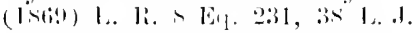
(h. 11:\% similar questions may arise moles special amel private

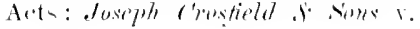

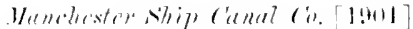

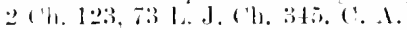

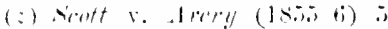
11. 1. (', s11. 25 T. .1. F. 301, li1 li. R. :382. which does not warlate the former general law wh the subject, see the juelgments

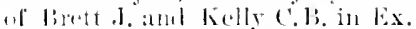

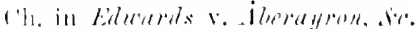

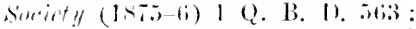

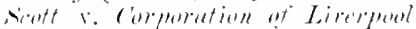

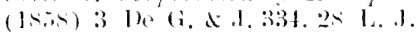

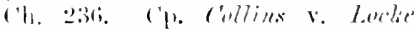

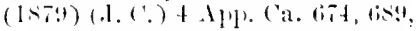
d. 1., 1. I'. ('. tis.

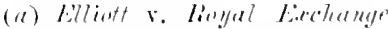

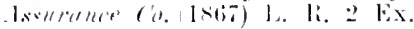

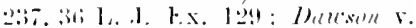
Fit:atemld (titi) I Ex. Div. 25T.

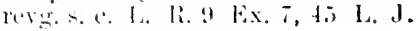
lis. 593. 
those rights which others an not disposed to enforce "( $(b)$. Maintenance is properly a general term of which champerty is a species. Their most nsual meanings (together' with certain alditions and distinctions now obsolete) are thus given by Coke :-

"First, to maintain to have part of the land or anything out of the land or part of the lebt, or any other thing in plea or suit; and this is called rambinartica [champart, ampi partitio], champertie."

The second is "when one maintaineth the one side withont having any part of the thing in plea or snit" (c). Champerty may accordingly be described as "maintenance iggravated by an agreenent to have a part of the thing in dispute" (d).

Agreements falling distinctly within these descriptions are punishable under certain statutes $\left({ }^{\circ}\right)$. It has always been considered, however, that champerty and maintenance are offences at common law, and that the statutes only declare the common law with additional penalties $(f)$.

Whether by way of abundant cantion or for other reasons, the law was in early times applied or at any rate asserted with extreme and almost absurd severity (!). It was even contended, as we had oceasion to see in the last chapter, that the alsolute heneticial assignment of a contract was bad for maintenance. T'le nodern cises, however, proceed not won the letter of the statntes or of the definitions giren by early writers, hut npon the real object and policy of the law, which is to repress that which Kinght Bronce L.J. spoke of as " the traftic of mer-

(b) by loord Abinged in l'rosser' v. Latmends (1835) I l. di 1 . lix. $451,4: 17,11$ li. R. 332: :3:3.

(c) (o. lit. 3tish. Every alamuperty is maiotenamee, 2 lie. .16 . 119 H.

(d) Bovill, ary. in s'morye ve l'orter

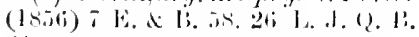
bis.

(e) 3 Eal. 1 (stal. Wesill. 1).
2.: : 1:3 lial. 1 (Ntat. Westm. 2). a. 1!: : 2, El. 1. - \&. 1, c. 11: Stat. he compliraturihss, temp. ineert:

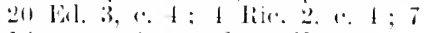

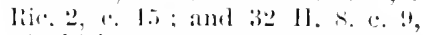
of which nure presently.

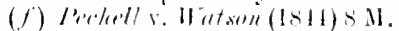

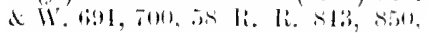
¿ lir. Al. $11+$ ll.

(y) Sice liaconis Alriblument, Maintentuce, $A .(5,251)$.
Relation of the statutes to the anmon law. and momern policy of the liaw. 
chandising in "purrets, of hurkstering in litigions discord," which decent perple hardly require legal knowledge to wath them from, and which makes the business and potit of "Ireterlbites, harretors, or comnsel whom no Inu will own, and solicitol's estranged from every roll" $(h)$. On the other land the courts have not deemed themselves homel to permit things clearly within the mischief aimed at any more than to forbid things clearly without it. They have in fact taken advantage of the doctrine that the statutes are only in affirmance of the common law to treat them as yiving indications rather than definitions: as hearing witness to the general "policy of the law " hut not exhansting or restricting it. It is not consideres necessiry to decide that a particular transaction anomints to the actual offence of champerty or maintenance in oreler to disallow it as a ground of eivil rights: it will le voil as "saroming of maintenance" if it clearly temels to the sime kind of mischief.

()f maintenance pure and simple. an important head in the ohl honks, there ale very fer modern examples (i); ahmont all the ilecisions illustrate the more special rule aginst champerty, namely that "a bargain wherehy the one palty is to shisist the other in recovering property, and is to shat w in the procests of the ation, is illegal " $\left(l_{i}\right)$.

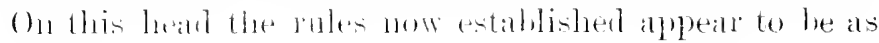
followis:

Liules as a 11 champerty.

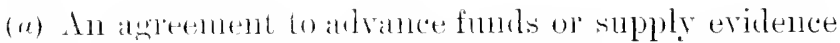
with or withont proferitonal als-istalle (or, it seems, professional atsistanke (m) ly) (h) for the recorery of property

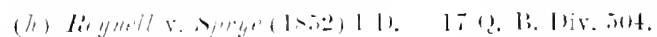

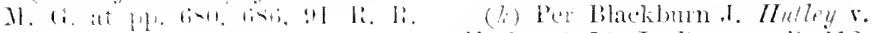
$\because 1,21 ! 9$

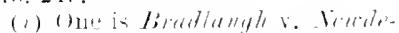

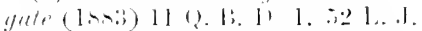

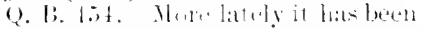

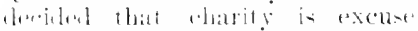

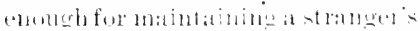

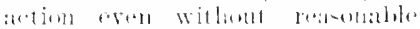

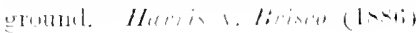

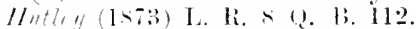
thanjurty is apt to becomplicated

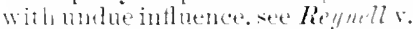

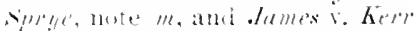
(ing! fl) ('h, l) 11 !?

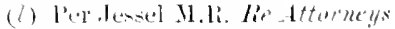
and soliciturs fot (Isid) 1 ('b. I). 
in consideration of a remmeration contingent on success and proportional to or be paid out of the property recorered is roid $(m)$.

(ß) A solicitor cannot purchace the subject-matter of a pending suit from his client in that suit (11); lut he may take a security upon it for andrances alreadr made and costs already due in the suit (1).

(ג) Except in the case hast mentioned, the purchase of property the title to which is disputed, or which is the subject of a pending suit, or an agreement for snch purchase, is not in itself unlawful ( $p$ : but such an anreement is molawful and void if the real olbjert of it is only to enable the purchaser to minintain the suit (q).

We proceed to deal shortly with these propositions in order.

a. This rule was laid down in rery elear terms by Tindal C.J. in stanliy v. Jomes (c), which seems to be the first of the modern cases at lan.

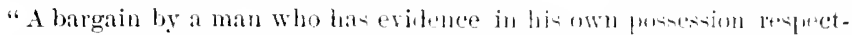

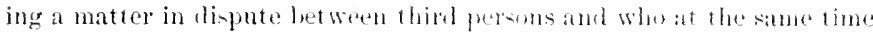

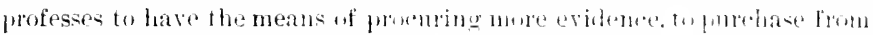
one of the conteming fratise, al the price of the evidence which he so

הi3, tt L. J. ch. ti, where llws agreement was to pay the soliceiture

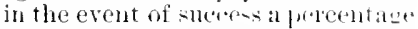
of the property rousered ; bnt fros bably the real meaning of it was that the soticitors slumbl tink the

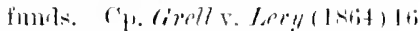

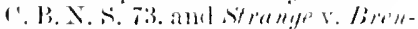

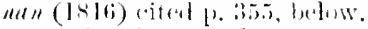

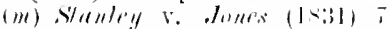

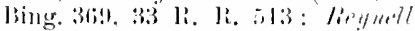

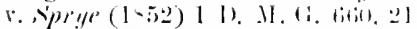

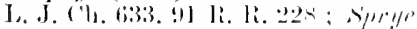

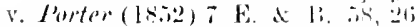
1.. J. Q. B. 1it, Il11 li. li. I!1:;

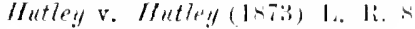
Q. H. 112.42 L. I. 4. H. 5.3.

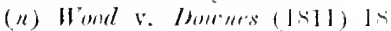

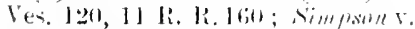

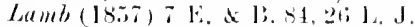
Q. B. J2l. Ilu li li, int.

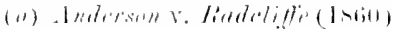

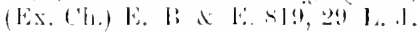

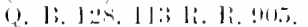

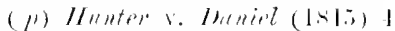
Ha. 12u, hit li. li. IJI: huight v.

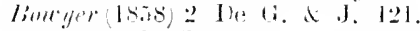

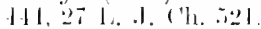

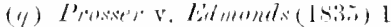
I. Iterrimflun v. Lema $(1633-1) \geq \mathrm{Mr}$.

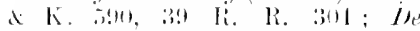

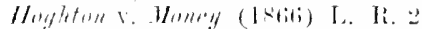

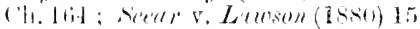

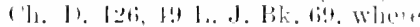
the preatie expent al the deretrine is trutand as lombteful: Gilly r.

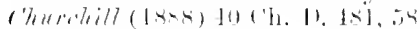
1. .1. (1).3.

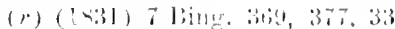
Ji. li. il3, i2t1.

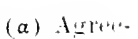
ment torlir. nish money or evislen. for litigatinn (III tirms il sharing porpelty

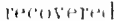
is vilit. 
Terbal erasions ineffectual.

possesses on can procure, a share of the sum of money which shall be recovered by means of the production of that very evidence, eannot be enforced in a court of law."

It is quite immaterial for this purpose whether any litigation is already pending or not, although the offence of maintenance is properly maintaining an existing suit, not procuring one to be commenced. It is obvious that the mischief is even greater in the case where a person is instigated by the promise of indemnity in the event of failure to undertake litigation which otherwise he would have not thonght of. If a person who is in actual possession of certain definite evidences of title proposes to deliver then to a person whose title they support on the terms of having a certain share of any property that mar he recorered hy means of these evidences, there being 110 snit depending, and 110 stipulation for the commencement of any, this is not mulawful ; for litigation is not necessarily contemplated at all, and in any case there is no provision for maintaining any litigation there may be (s). But it is in vilin to put the agreement in such a form if these terms are only colomable $(t)$, and the real agreement is to smpply evidence generally for the maintenance of an intended suit: the illegal intention may be shown, and the transaction will be held void(u). Still less can the law be evaled by slighter variations in the form or mannel of the transaction: for instance an agreenent letween solicitor and client that the solicitor shall adrance funds for carrying on a suit to recover possession of an estate, and in the erent of success shall receive a sum above his regular costs "according to the interest and benetit" atcquired lig the possession of the

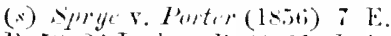
\& B. 58,26 L. J. Q. B. (it, 110 K. li. $49 \%$.

$(t) A s$ a matter of fact. it is difficult to sulpose that they coulc evere betherwise. (n) Sprye r. Fonter (1s50) i E.

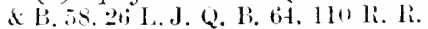

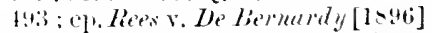
¿ ('h. 437. 6.5 L. J. ('h. 6.io, where these was a deliberate endearour tw conceal the real intention. 
estate, is as much void as a bargain for a specific part of the property $(x)$. So where a solicitor was to have a percentage of the fund recovered in a suit, it was held to he not the less champerty becanse he wats not himself (and in fact could not be) the solicitor in the suit, hut employed another $(y)$. A solicitor cammot refuse to aceomut to his client and submit to taxation of his eosts on the ground that the business for which lie was retained involved champerty or maintenance (:).

An agreement by a solicitor with a client simply to charge nothing for costs in al particular action is not champerty (i).

3. This rule came to be laid down in a somewhit

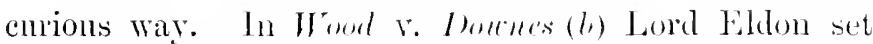
aside a purchase by a solicitor from his client of the res litigiose, partly on the gromed of maintenance. But it is to be noted as to this gromd that the agreement for sale was in substitution for a previous arreement which clearly amomted, and which the parties had discorered to amount, to maintenance: and the Court apleatr's to lave inferred ats a fact that it wats all one illeral transaction, and the sale merely colomiahle (r). The other ground, which alone would have been enomgh, was the presumption of undue influence in such a transaction, arising from the fidnciary relation of solicitor and elient (of which we shall speals in a subsequent ehapter). The

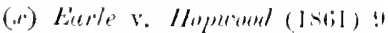

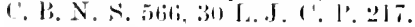

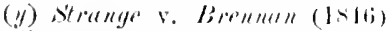

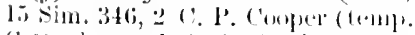

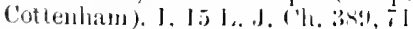
li. li. 9). 'The agreenent was malle with a soliceitor in I lolatul, nut being a solicitar of the lingliste

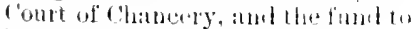
be recovereal was in lingtand.

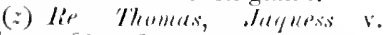
Thomas [1s:5] l Q. B. 717.

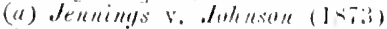
L. K. S 1.. 1'. t:. (b) (1, l1) lit Ves, 120. II li. li. I inil.

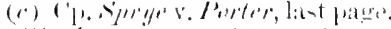

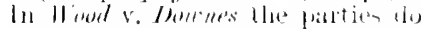
nut eeron to have erent kiph the miginal amb latal agreement ofl the late of the lransation in its

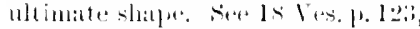
JI li. li. lize. It is to be regretted that llee reporter dial mot freserba the full statement of the fatets (is lis. 1. 122) with which the julement urened.
(,5) Suliceitur in stit eannut molhase - mbject matter of the slit trom his client. This rule atrumalous. 
Court of Queen's Bench, however, in Simpson v. Lamb (d) followed Woml v. Incues, as having laid down as a matter of the "policy of the law" the positive rule

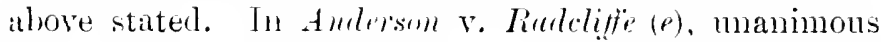
judgments in both the (). 3. and the Fx. Ch. added the qualification that a conveyance by way of security for past expenses is nevertheless good. The Court of Excherper Chmmler showed a decided opinion that rimpsom v. Lamb had gonte too far, but without positively disapproving it. In Krnight r. Butyer, again, Turner L.J. said: "I am aware of no rule of law which prevents an attorney from purchasing what any hody else is at liberty to purchase, sulject, of comse, if he purchases from a client, to the consentences of that relation" ( $i)$. But the case lefore the Cimrt wis not the purchase by a solicitor from his chient of the snbject-matter of a suit in uhirh he uas soliritu"; Simpsom v. Lamh, therefore, was only treated as distingushable $\left(f^{\prime}\right)$. The case must at present be considered a subsisting anthority, but anomalons, and not likely to be at all extended.

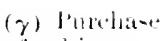
if sulijects. matlter of litivation mot in itself mulawful.
Bul is mulaw tul if the real intention isto acquire a $\gamma$. As to the purchitse of things in litigation in general, the atthorities cannot all be reconeiled in detail. But the distinction which runs throngh them all is to this effect. 'The prestion in arery case is whether the real object be to acquire an interest in property for the purchaser, or melely to speculate in litigation on the arcount either of the vendor and purchaser jointly or of the purchaser alone. It is not mulatul to purchase an interest in property though atverse clains exist which make litigation necessary for leatizing that interest: but it is unlawful to purchatse an interest merely for the purpose of litigation. In other worts, the sale of an interest to

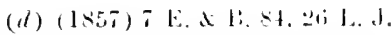

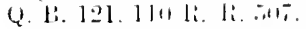

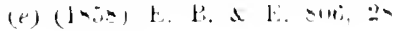

L. J. (1. 1. 32.29 it. 128. 113 R. L. $-4 ! 9$.

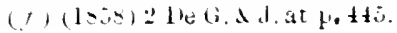


which a right to sue is incident is good $(y)$; lut the sale of a mere right to sue is bad $(h)$. A clain to compensamere right tion under s. 68 of the Lands Clanses Act is not a mere right of litigation hut an assinnable interest in property (i).

A man who has conveyed property hy a deed voirlable in equity retains an interest not only transmissible by descent or devise, but disposable inter riros, without such disposition being champerty. But "the right to complain of a fraud is not a marketable commodity," and an agreement whose real object is the acyuisition of such a right cammot be enforced (k). In like manner, a creditor. of a company may well assign his debt, hut he cannot sell as incident to it the right to proceed with a windingup petition (l).

The payment of the price lieing male contingent on the recovery of the property is probably under any cireumstances a sufticient, but is hy no means a neces. sary, condition of the Comt being satisfied that the real object is to traffic in litigation. If the purchase is made while a suit is actually penting, the circumstance of the purchaser indemnifying the vendor against costs may be material but is not alone enough to show that the lorwain is in truth for maintenance $(m$. But the only view

(a) Jiv7iuson v. Bumell (186iti)

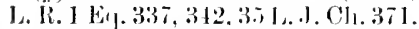

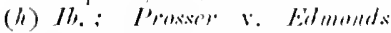

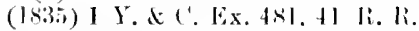

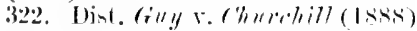

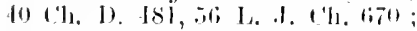
bankrupt's right of action assigneal by the rrustee to one rerelitor (in faet actiug for himself ant itliers). who was to keep flares-fumtho al the proceeds ; lield juntitiable as a bencticial arrangement for the cretitors.

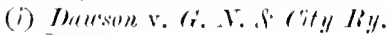
[190i] I K. B. $2(i 0,271$, I I I. I. li. I?. $190, \mathrm{C}, \mathrm{A}$.

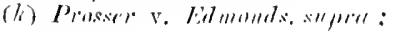

111 slle.

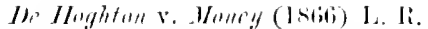

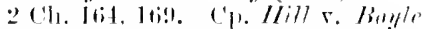

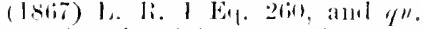
whether the right to ent down an

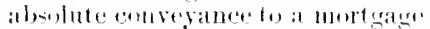

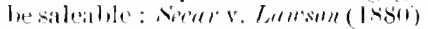

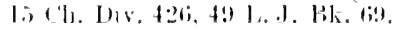

(l) lin Paris slatime lime $r$.

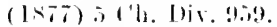

(III) Katrimgtan r. Lam! (1.833-4) 2 II. K K. inc, 39 li. li. 304, as corrected loy kimight v. Buwlyer, uste ( / ) p. 353, and see IInintor

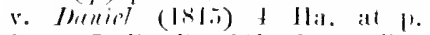
l:30, bit li. li. I21-12:2. liul the true gromml of lle trase serellos the same as in l'ossery r. 
Pulchare of slutres in cotulyally with inten. tion to ste

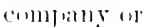
direvelus at

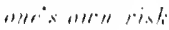
met main. terlat110.
$-1 a t .32$

H. IIII. c. ".

Nine shall

bur. sell. or laterail for any rierht in lands inles: the sellur. hath lreen in fresesiun of taken the juntits fur olle veal.

which on the whole seems tenalle is that it is a question of the real intention to he collected from the facts of each case. for arriving at which few or no positive rules can lie laid down.

There is no champerty in an agreement to enable the lwoma firle purthaser of an estate to recover for rent due or injuries done to it previonsly to the purchase (n).

It has heen decileci in sereral motern cases that the purehase of shates in a comprany for the purpose of instituting a suit at one sown risti to restrain the governing londy of the company from acts mwarranted ly its constitution cammot lee impeached as savouring of maintemance (1). It is not maintenance to talie an assignment of molispmed debts on the terms that the assignee shall realise them and pay orer the proceeds less cost to the respective assignors ( $(1)$. It was recognized as long ago as 21 Eil. III., that a purehase of property pending a suit affecting the title to it is not of itself champerty: "If pending a real aetion a stranger purchases the land of tenant in fue for good consideration and not to maintain the plea, this is no champerty" (

'Tlie statute $3: 2$ II. THl. (. !) "Agains maintenance and embranery lmying of titles. ise." after reciting the mineliefs of " maintelance embracery champerty suborllation of wituesines sinister labour buying of titles and petenserl riglts of persons not being in possession," and eonfirming all exinting statules against maintenance, enacts that:

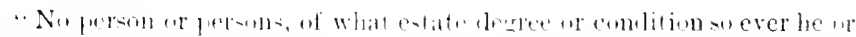

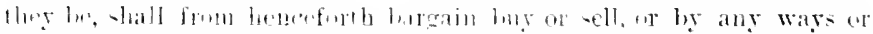

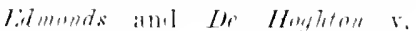

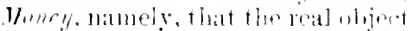
was to give the prochasel a linems stamli to set aside a dew for flaw

(11) Ier Cur. (Fx. (\%.) William:

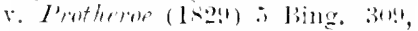
314. 311 li. Ri. firs, il:3.

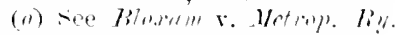

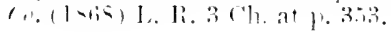

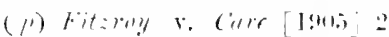

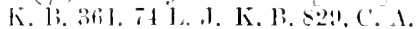
The arinnces nlterior mutives are immaterial.

(y) 2 lio. Ab. 113 13.; Y. B. 2: E. III.. ]1. pl. 33 [eited as $52 \mathrm{in}$ holle]: hut in in Ass. 323, pl. 3. the wencral opinion of the serjeants

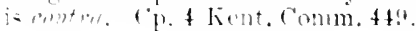


means obtain get or have, any pretensed rights or titles, or take promise grant or covenant to have any right or right of any person or persons in or to any manors land tenements or hereditaments, but if sueh person or persous which shall so bargain sell give grant eovenant or promise the same their antecessors or they by whom he or they elaim the same have been in possession of the same or of the reversion or remainder thereof, or taken the rents or protits therenf by the space of one whole year next before the sail bargain covenant grant or promise male."

The penalty is forfeiture of the whole ralue of the lands (s. 2), saving the right of persons in lawful possession to buy in adverse claims (s. 4). There is no express saving of grants or leases by persons in actual possession who have been so for less than a year: but either the condition as to time applies only to receipt of rent or profits without actual possession, or at all events the intention not to tonch the acts of owners in possession is obvious $(r)$.

This, like the other statutes against maintenance and champerty is said to be in atfirmance of the common law $(s)$. It "is formerl on the view that possession should remain undisturber. Dealings with property by a person out of possession teme to disturb the actual possession to the injury of the pullic at large " $(t)$. It is immaterial whether the rendor out of possession has in truth a good title or not (s). An agreement between two persons ont of possession of lands, and both claiming title in them, to recover and share the lands, is contrary to the policy of this statute, if not champerty at common law : therefore where co-plaintifts had in fact contlicting

(r) liy Inoutague C..l. Prortridye v. Strange, Flowd. 8s, eitol in Dere de Jillinems v. Lirems (1815) 1 (.. 1). 717,11 I. J. (. 1'. 237, lit'

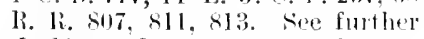

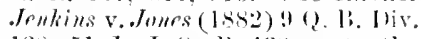
$128, ; 1$ 1.J. (2. 13. 43\%, as to the meaning of "pretenstul rights" and the limiterl aplolication of the statule at tlue present fime. A rigrht or litle which is grantable mirler

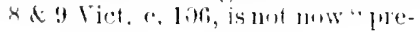

tencel "merely because the grantor" has nevol been in prosession. Th inforce a forfeiture unler the stat ute the plaintiff must show that the purchaser knew the title to be "pretensed": Kemuedy v. Lufell (1.5.5) $1:$ (2. B. D. 191, 53 L. T. Hiti.

(s) Sice last note.

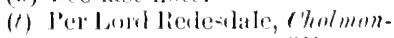

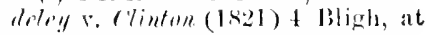
1. $7 .$.
Penalty and sariner.

Dealings held within the statute. Agreement to recover and divide property. 
Sale of term lis alminisirator mel of jerse-nion.

Sirus ale of 11011-liticinus expetaney.

interests, and it was sought to aroid the resulting diffi. culty as to the frome of the snit by stating an agreement to divide the property in suit between them, this derice (which now would in any case be disallowed on more general grounds) (u) was mavailing : for such an agreement, harl it realy existed, would have been unlawful, and would have suljecter the parties to the penalties of the statute $(. r)$.

Where after the death of a lessce a stranger har entered. and remained many years in possession. a sale of the term Jy the andmistrator of the lesee was held roid as contrary to the statute, althombly in terms it only forhids sales of pretended rights. d... umrler penalties, withont expressly making them roid (n). But the sale of a eontingent right or a mere expectamer, not being in the nature of a claim adverse to any existing posession, is not forbidren. The sale of a man in posible interent as the derisee of a livingr owner, on the terms that he shall return the purchasemoney if he does not becone the devisee, is not bad either at common law as creating an mulawful interest in the present owner"s death. or as a hargain for a pretended title muler the statuter(:).

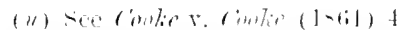

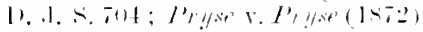

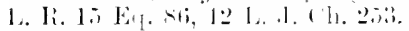

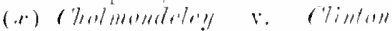

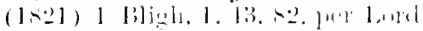
Holim and lond Realealale.

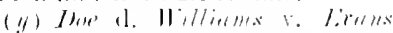

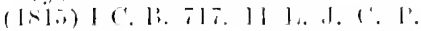

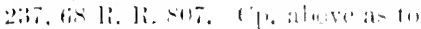

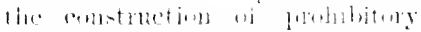

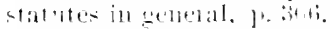

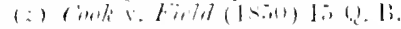

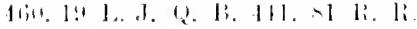
libu. by the eivil law. luwever, sueh contratets are resaleled as

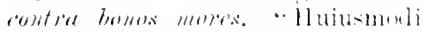
partiones antisate velentur et flelle tristiosmi et fericules rentus," we read in a recript al Instinian ron an agrement bet wers

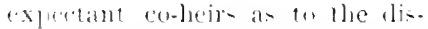

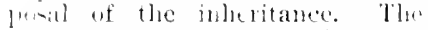

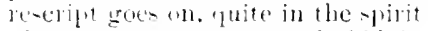

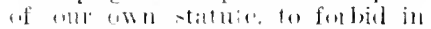
colreral terme all dralings " in alicum gethes entral demini volum.

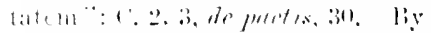

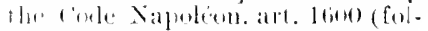
inwed by the Italian Ciril Come.

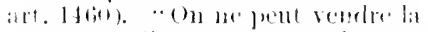

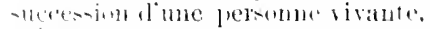

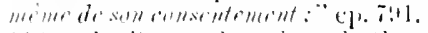
11:34. In Loman law the rule that the inheritance of a living perom condel not be sold is jot only on the terlnical gromul ". puia in rernm matua mon sit "fual renierit": 1 . 1. 4. de lereel. vel actione renalita, 1. and ree ferl tit. - 11 . 
Proceedings in lunacy seem not to be within the general rules as to champerty, as they are not analogous to ordinary litigation, and their object is the protection of the person and property of the lunatic, which is in itself to be encouraged; and "this object would in many cases be impeded rather than promoted by holding that all agreements relative to the costs of the proceedings or the ultimate division of the property were roid "(a).

As to maintenanee in general, maintenance in the strict and proper sense is understood to mean only the maintenance of an existing suit, not proenring the eommencement of a new onf. But the distinction is in practice immaterial eren in the rriminal law (b). It is of more importance that a transaction cannot he void for champerty or maintenance muless it he "something against good policy and justice, something tending to promote monecessary litigation, smothing that in a legal sense is immoral, and to the constitution of which a bad motive in the samo sense is necessary" (c). Therefore, for example, a transaction canmot be had for maintenance whose object is to enable a principal or other person really interested to assert his rights in his own name $(c)$. Nor is it maintenance for several

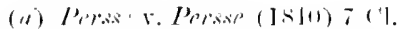

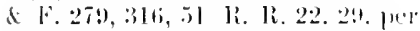
l.mil ('ottenlatm.

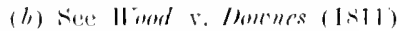

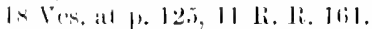

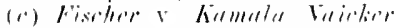

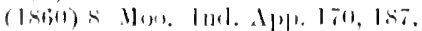

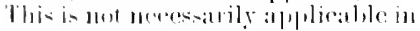

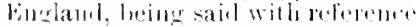
(1) the law of firitiols luliat. Where the English laws agaimet mainle. nance and rlamperty are not sle. citically in foree: see liom rimmor-

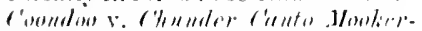

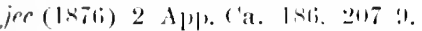
aml the later julgment ated lelow. lint il faily represents llo pritr. riples on which buelion inders
Froceedings in lunacy nol within the rules against champerty.

Maintenance in general. lave anded in the molem canes. "The English law of champerty in met in foree in Lulia. and decerments which set mo agreements 10 - hale the subject of litigation, il mencerer, in comsinteration of soly. plyber fumbls fo carrying it an, are

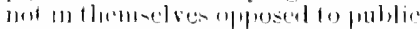

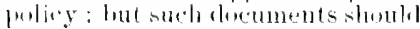
lu jealonsly seamed, and, when finum to be extortionale and nII(o)mseromalile, they are inequitable as agrain-t the party against when relief is someght, ankl elfect shoulhl mot be given lo then" : Kunmar

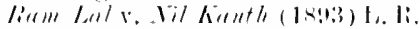
211 InI. Alp. 112, 11. 
I ertallh iustify main. tenance. hilt not rlin111beris. lctaling will

persons in agree to prosecute or defend a suit in the result of which they have, or reasonably believe they have, a common interest $(d)$. But a bargain to have a share of property to be recovered in a suit in consideration of maintaining the suit by the supply of money and evidence is not sared from being champerty by thr partis having a mere collateral interest in the result of the sult (e). Where a person sues for a statutory penalty as a common informer, it is maintenance to indemnify bim against costs $(f)$.

Lineal kinship in the first degree or apparent heirship, and to a certain extent, it seems, any degree of kindred or affinity, or the relation of master and serant, may justify acts which as between strangers would be maintenanco: hut blood relationship will not justify champerty $(g)$.

$\therefore$ luble (c.) A-to matters tonching legal (and posibibly moral) I")lice as to dution of individuals in the performance of which the intiviluat. public have an interest.

Certain kinds of agreements are or hate been considerer unlaw ful and void as providing for or tending to the rmi-nion of duties which are indeed duties towards incliviruals, butsuch that their performance is of public

Aereenents

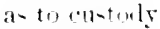
in colucationi if chilinen. importance. T'u this hat must be referred the rule of law that a father camont by contract deprive himself of the right, to the cu-tuly of his children $(h)$ or of his discetion as to their wheation. He "camnot bind himself ennclusively hy contract to exercise in all erents in

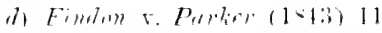

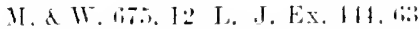
R. li. i22: Pletim (i. v. Far.

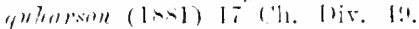
i1. 2 lio. Ab. 11.; (i.

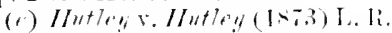

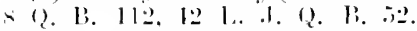
lint the interest of a bankmult -

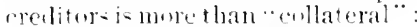

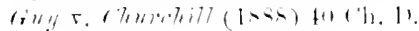

1. . . . L L. J. Ch. fiou.

(i) Brmblanile r. Vindelegute

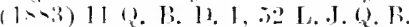
til.

(a) IIutloy v. IIutley. wupro. Siec 2 Rin. Ah. 11\%, 114.

(li) lir lut rers (1873) L. Ii, s

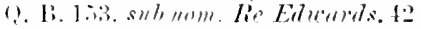
1. I. !. P. 9:4. and anthorities threnterent. 
a particular way rights which the law gives him for the benefit of his children and not for his own." And an agreement to that effect such as an agreement male before marriage hetween a hushand and wife of different religions that boys shall be elucated in the religion of the father, and girls in the religion of the mother-cannot be enforeerl as a contract (i).

After the father"s death the ('ourt has a certain dia cretion. The children are indeed to be brought up in his religion, mless it is distinctly shown by special cireumstances that it wemld be contrary to the infant $\mathrm{s}$ benefit $(k)$. When such circmomstances aro in question, however, the Court may inquire "whether the father" has so actad that he ought to be held to have waived or ahandoned his right to have his ehildren educated in his own religion" ; and in dedrmining this the exist ence of such an agreement as abore mentiones is material (l). The father"s comeluet in giving up the maintenance, control. w efueation of his children to others may net only forre the lourt feee to make aftere his death such provision as serms in itsolf best: it may prechole him even from asserting his rights in his lifotime (m).

Clauses in soparation deeds or agresments for separal- In separation tion, purporting to bind the father to givo up the general deeds. custody of his ehilderen ar some of them. hate for the

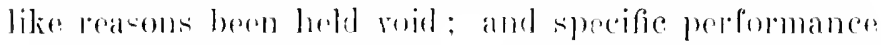

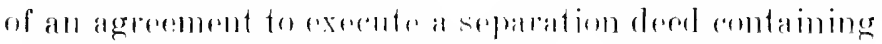
such clanses has brent rofused (11). In one rase, how-

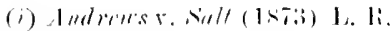
8 ch. 6i2: risti.

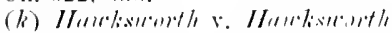

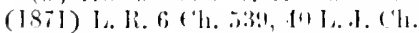
5.31 .

(l) Ambertes r. sirlt (187i) I. li. \& ('h. at 1'. $6: 3 \vec{i}$.

(iii) loymes r. Blonkin (19.21-1)

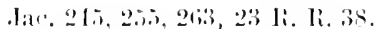

(11) Jumxitfurt r. Jansitfurt

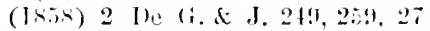
L. 1. (h. 22:2. As to the valiclity of portial restrietions of the hus-

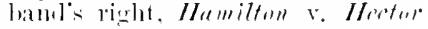

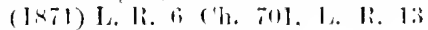

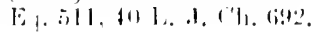


30 is 3 i lict. c. 12.5 .2 .

1) wher of illesitimate chilit.

(In thiserount. in falt. tlie het rines as in sepatition deetsin anerisl:

erer, such a contract can be enforced; namely, where there has been such misconduct on the father's part that the Court wonld have interfered to take the custody of the children from him in the exercise of the appropriate jurjoliction and on grounds independent of contract. The general rule is only that the custody of children cannot he marle a mere matter of hargain, not that the hushand can in no cirenmstances bind himself not to set up his paternal rights (o).

The law on this point is now modified by the Act $36 \& 37$ Vict. (2. 12, which enarts (s. 2) that

"Yo agreenent cuntainel in ant separalion deed between the father and mentler of an infant or infant shall be held to be incaliel by reason

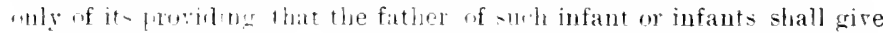

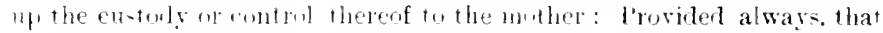
no lout tall enfores any sued agresurm if the court shall be of

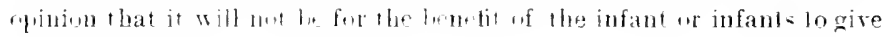
effeet thereto."

This Act does nut enahle a father to delegate his general rights and powers as regards his infant children ( $p$ ).

The mother of an illegitimate child has parental duties and rights lecognized hy the law $(q)$ and cannot deprive herself of them by comtract $(r)$.

Theobjections formerly entertained (as we have seen) fust against separation deerls in genemal, and afterwards down to quiter recent times against giving full effect to them in enurts of expluty. Wore hased in part upon the sillue sorte of grounds: and wr ale the reasons for which agreements providing for a future separation hare always been beld invalil. For not the parties alone,

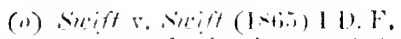
I. 710.714 .34 L. I. (h. 2013.3:4t. and see the lemarlis in I.. Li, if ('h.

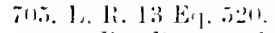

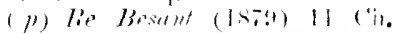

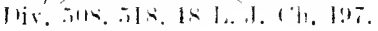

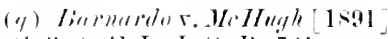

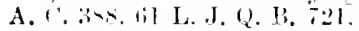

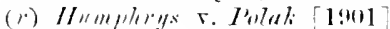
2 k. I. B. 60 L. I. K. I . $\therefore .1$. 
but society at large is interested in the observance of the duties incident to the mariage contract, as a matter of public example and general welfalle.

Considerations of the same kind enter into the policy of the law with respect to the sale of offices, also spoken anil as tor sale of oftices. of above. Such transactions clearly involve the abandomment or evasion of distinct legal tuties.

On similar grounds, again, seamen's wages, or any remuneration in lien of slach wages, cannot be the subject of insurance at common law $(s)$. The reason of this is said to be "that if the title to wages did not depend upon the earning of freight by the performance of the voyage, seamen would want one great stimulus to exertion in times of difficulty and danger " ( $t$ ). 'This reason, however, is removed in lingland by the Merchant Shipping Act, $189+$ (57 \& 58 Vict. e. 60, s. 157), which makes the right to wages independent of freight being earned. The question has not yet presented itself for decision whether the rule founded upon it is to be considered as removed also.

It has never been decided, but it seems highly probable, that agreements are voil which directly tend to discourage the performance of social and moral duties. such would be a covenant hy a landomer to let all his cultivable land lie waste, or a clause in a charter-pat'ty probibiting deviation even to save life (u).

(d.) As $\{0$ agratments moluly limiting the freedon of individual action.

There are certain points in which it is considered that the choice and free atedion of individuals should be as A greements against sicial duty. unfettered as possihle. As a lole a man may bind him self to do or onit, a procore another to do or onit, ally

husurance of seamen's wages. a. Public: policy as to ireedims of inclivilual action.

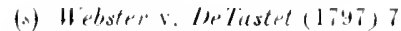

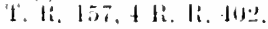

(t) Kint, t thutu, : $: 45$.

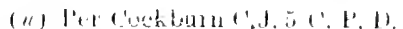
at is $3: 1.5$. 
thing which the law does not forbid to be lone or left undone. The matters as to which this power is specially himited on grommls of genelal convenience are:(a) Marriage.

(B) 'lestamentary dispositions.

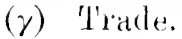

(. Mitriage.

(a) Marriags is a thing in itself encouraged hy thet law ; the marriage entratet is moreover that which of all other's should ba the result of full and free consent.

" Marriage brokage" awreements ride.

Agreement in general restraint ol marriage voill. Certain agreements are therefore treated as against public policy either for temding to impede this freedom of consent and introduce untit and extraneous motives into the contracting of partienlar marrages, or for tending to hinder marriage in genelal. The first class ane the agreements to procure or negotiate marriages for reward, which are known as marriage brokage contracts. All such agreements are roid $(x)$, whether for the procurement of marriage with a specified person or of mal'riage generally (y), and serviess rendered without request in procuring of lorwarding a marriage (at all "vents a clandestiuse or improper one) are not merely no consideration, hat an illegal conneideration, for a subsequent fromise of reward, which promise, even if muder seal, is therefore roid $(z)$. The law is said to be comparatively modern on this head: lout it has already ceaserl to bes of much practical importance (a).

We pass on to the second class', agleentents " in re straint of marriage" as they ares called. An agreement by a bathelor or spinster not to marry at all is

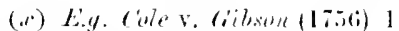

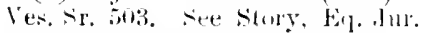
\$े 260 s sq.

(y) Hermann v. ('kurlesurith

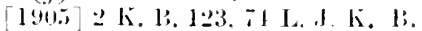
(iz), ( A.

(z) Ifilliamson s. Githon (150is) 2 sich. \& L. 3.7.

(a) In the Homan liw litese cus- trat - were gond apart from special legislation: ther were limited is 6 anount (though with an expression of genelal disapproval) by a constitution preserved only in as cireck epitome: C'. i. l. de spronsal. libu, se. 6. The Austrian ciule angees with our kaw (\$ 8.99 . 
clearly void $(b)$; so, it seems would be a bare agreement not to marry within a particular time (c). In Lowe v. Peers (d) a covenant not to marry any person other than the covenantee was held void. A promise to marry nobody but $A$. B. cimmot be construed as a promise to marry A. B. and is thus in mere restraint of marriage: and even if it could, it was thought doubtful whether an unilateral corenant to marry A. B. would be valid, A. B. not being bomd by any reciprocal promise (e). Lord Mansfield threw out the opinion (not without followers in our own time) ( $f$ ), that even the ordinary contract by mutalal promises of marriage is mot free from mischievons consequences. The decision was affirmed in the Exchequer Chamber, where it wats ob served that:-

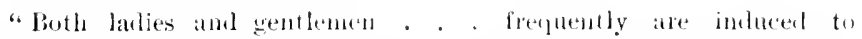
fromise not to marry any other persons bitt the objonts ol their present fassion; and if the law shonlul not rescind surle engagenents they wonlal become prisoners for life at the will w most inexurable jailn's die. "appointed lover's" (y).

A covenant not to reroke a will is not roid as being a covenant not to marry, though the party's subseduent marriage would revole the will by operation of law. As a eovenant not to revolio the will in any other way it is gool; but the party's marriage gives no grontud of action as for a breach (h).

In the absence of any linnern experess decision, it may be gathered from the analogy of the cases on conditions

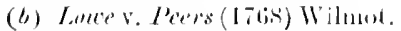
37 : Where it is silil that it is a contract to onat a moral derty, and "temels to depopulation. the greatest of all pulitical sins."

(a) Ilartley v. Liber (Inos) lo East, 2:, la R. Ii. 2.2s (a wager).

(d) $(176 x)+$ liurt 22.5 , in lix. Ch. Wilm. Bitil.

(e) but of thisqu. : for a restusal by A. B. lo marry onl rentest within a reatonable tome Womld smely

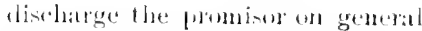

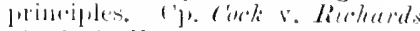

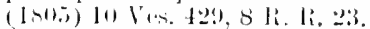

(.t) I lium. 22:30) pro Martin J'.

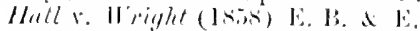

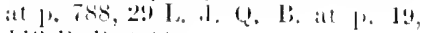
11:3 li. li. sits.

(y) Wilm. :3il.

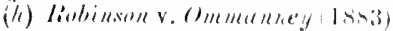

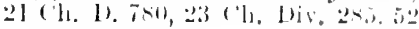
1., l. ('h. 410 .
(1) lo levoke will.

As 10 a.the ditions in restraint of mamiage. 
(B) Agreeinent $\mathrm{t} o$ influence testator.
( $\gamma$ ) Restraint of trate. General principle: Restrictive aureements allowed if reasonable in interest ol parties, and not injulions to public.

in restraint of marriage that a contract not to marry some particular person, or any person of some particular class, would be good unless the real intention appeared to be to restrain marriage altogether; and that a contract by a widow or widower not to mary at all wonld probably be good $(i)$.

(3) All agreement to use influence with a testator in favour of a particular person or object is roid $(k)$. (On the other hand, it is woll established that a man may validly bind himself or his estate by contract to make any particular disposition (if in itself lawful) by his own will (l). Siuch contracts were not recognized by Roman law $(m)$, and even a gift inter rivos of all the donor's after-atequired poperty would have been had as an evasion of the rule: but in the modern law of Germany, as with us, a contract of this sort (Erbrertrag) is good $(n)$.

\section{(v) Agreements in restraint of trade.}

This class of cases presents a singular exanple of the common law, withont aid from legislation and withont uny manifest discontinuity, having practically reversed its older doctrine in deference to the changed conditions of society and the reduirenents of modern commerce. The original principhe is that a man onght not to be allowed to restrain himself by contract from exereising any lawful eraft or business at his own diseretion and in his own way. It is still true that " all interference

(i) Ste lie Hhiting stotlomet [190: ] ('h. 6ti. it i. J. (1/1.:21\%, i. A. There is 111 , thistimotion between a will and a settlement lon this purpuse: itrid.

(k) Dobenkam is Ox (1ity) 1 Ves. sr. 2ati.

(i) Ihe Beil r. Themesten (1s+1 3 beav. 469, s. 1 . nom. Mlammersley v. Baron lo beil (1845) 1.2 (i) A b. 45, tie li. li. lis: bronkman's trusts (1s6iy) L. B. 5 (1). 18\%, 34 I. d. Ch. :34. A covenant to exercise at specital foweref testamentary appointment in a patticular way is bad, for sueh a power is of a fiduciary nature : lie Bradshat [1:402] i ('h. 430 . il 1. J ('h. 230.

(m) Stipulatio hoc mulo concepta : si heredem me mon feceris, tuntum dare spondes? imutilis est. fuia coltra bonos mores est haete stipulatio. H. 45. l. de s. 0.61.

(il) Sarigny, syst. 4, 142-5: ant now by German civil conte. s.227t sy\%. subject to requirements of form. 
with individual liberty of action in trading, and all restraints of trade of themselves, if there is nothing more, are contrary to public policy, and therefore void." So the rule is expressed by Lord Macnaghten in what is now the governing decision (o). "But," he continues, "there are exceptions: restraints of trade and interferonce with individual liberty of action may be justified by the special circumstances of a particular case." The exceptions were introluced with much hesitation, and were long supposed to be confined within inflexible limits. But the former attempts at strict definition have proved inapplicable. As the law is now laid down, "it is a sufficient justification, and indeed the only justification, if the restriction is reasonable-reasonable, that is, in reference to the interests of the parties concerned and reasonable in reference to the interests of the public, so framed and so guarded as to afford adequate protection to the party in whose favour it is imposed, while at the same time it is in no way injurious to the public."

No universal test can be assigned for ascertaining what is reasonable, not even the rule formerly accepted that the restraint contracted for must be limited in space, or in some sense not in "general restraint of trade." The precise object of the contract, and the nature and extent of the business interest to be protected, mut be considered in every case. The kinds of contracts involving restraint of trade which usually occur in modem practice are agreements by the seller of a business not to compete with the buyere by a palt ner or retiring partner not to compete with the firm, and by a servant or agent ( $p$ ) not to comperte with his master

(o) Vordenfelt ve luterim- Kindenfolt, \&o., (\%. [189t] A. ('. 535, 565.

(p) Note that wrongful dismissal. being a repulliation of the whole contract, cancels a stipulation of this kind: Cirmerel Bill-pusting

r.

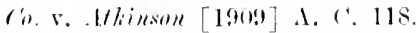

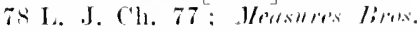
v. Vtorsm (h. 24s, not put on quite the sam. grotuml in $C$ '. 1 . 
Melicial

fetline:

The

('la:miner.

of Norwich.

$1: 3 ! 6-13: \cdots 1$.

The Tyer's (a), litis.

The Hlarke smitlis aise, $1 ; i-1,1+8$.

or employer after the termination of the service or employment. Obriously the measure of reasonable restrictions to protect the buyer, continuing partners, or employer in the case of a business with national or world-wide connections will be larges than in the case of a merely local trade or pretice. What is reasonable in the particular case is a question of law for the Court. Examples will he given presently. Neanwhile something must be sad of the ealy history and intermediate forms of the doctrine.

In the midrle ages thepe was a genceral feeling, apparenty popular and not derived from learned sources, against all agrenements which tembel to monopoly or

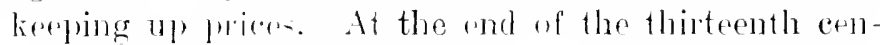
lary all the chatullens of Norwich were presented hy the

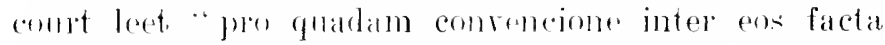
videdicet quod nullus erom remderet libram candele minus quam altere" (q).

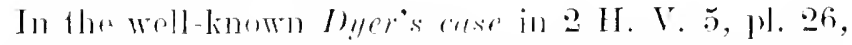
tha adion was debt an a homd comditioned that the defermbant shorld not use his craft of a dyer in the same

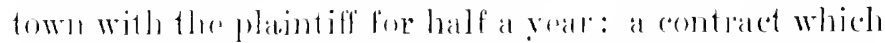
would now be eferly gond if made npon raluahle conmiderations. The defenee wate that the condition had

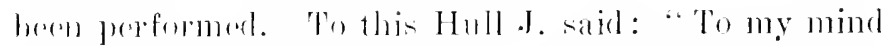
you might have demurrel to him that the obligation is roid. becaluse the condition is against the common law: and per Dien. if the plaintiff were here he should ge to prison till he hat marle fine to the kinger " $(r)$. This was not and entel not be moro than a dictum, and the parties procended to issue on the question whether the condition had in fact been performed or not. Hull's

(f) Leet Inriselietion of the (ity

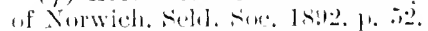

(r) This Ifill or Hull, Juetice of r. l'. in to le distinguibhed from Hnt. who -it in K. R. till 3 H. Y. llis expletive las been wrongly sillinal to be unique in the reporte. In the carlier lear bouks it is but luneommon. 
opinion, howerer, was approverl by all the Justices of the C. P. in a blacksmith's case in 29 Eliz, of which we have two reports (s). It loes not appear in rither rase what was the rad aceatsion or comsideration of the comtract. For alught the reports show it may have been the ordinary tramsaction of a sale of goolwill or tha like $(t)$.

It has heen plansibly suggested by a leamed Ameri. can writer that the medieval sloctrine is comnected with the rules and customs forhidding a man to exoreise any trade to which he had not been duly apprenticed and

Ilistorical (onnerelion of the roctrine with medieval regulation if trimle. admitted: so that if he eovenanted not to exeroise his own trade, ho practically corenanted to exercise none -in other words, note to eam his living at all (11). Indeed, hy the statute 5 litiz. a 4, which consolidited parlier Acts of tho same kind, not only the eommon labourer, but the antificer in any one of varions trates, was compellable to serve in his trate if 1 mmarried or moler the age of 30 years, and not a forty-shilling freeholder or eopyholder of " wortla of his ww gonds the clear value of ten pounds." An agreement by a person within the statute not to exereice his own trade might therefore he deemed, at any rate if mulimited, to amount to an agreement to om a legal duty. At the same time absolute freedom of trade is pritively assertol as the normal state of things always assmmed and mpheld by the common law. It was resolvol in the Ipsuich 'T'aitors' case $(x)$ that at the common law no man eonld be prolibited from working in an!l lawful trade: and it was said that

(*) Noore, 212, pl. :37!. fuller in 2 Leo. 210. Moore's remell matses the odd minlake of putting somb llimms in surrey.

(t) The explanitions wf ifered by lond Macelestield in lliteled $\therefore$. firymolds, I sm, I. ('. . al p. 3:94, am I

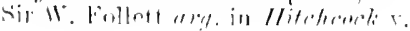

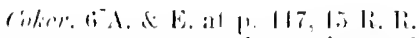
at p. ies, ale merely conjeetural attempts to find in the Year book a morlern point of view whinh is mit lliere.

(11) larsons on comtracts, 2. 2.is. (a) (llilis) 11 (1) line . is a, ith.
Absolume freedom of trade anerted hy coke as olil eommon law. 
"The statute of i Eliz. a. 1. which prohibits every person from using "I cxereing any "raft mytery or vecuption, uales he has been an alfrentiee $1, y$ the sprace of seren rears. was not enacted only to the intent that workmen sheth be silful, but alse that pouth should not be umrished in inlenes, but brought up and shated in lawful scichecantl trate- and thereby it aflears that without an aet of parliament (y) mone can he prohibite f from working in any law ful trate."

And certain ordinances, hy which the tailors of

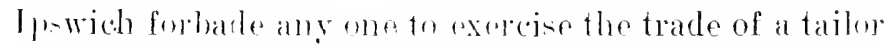
there motil he hat prenter himself to the master and wadens and satiofied them of his qualification, wele lueld roid, inamuch as

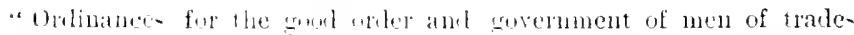

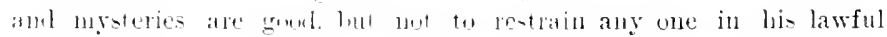
m11- tery."

Tolen iflplications lition $r$. Eikersley.

This principte is still in force as regards agreements and combinations among members of trades not made for the potection of purchatem for value, but by way of systematic denial of ealch contracting party's ordimaly discention in managing his affairs.

An agrement hetween serforl master manufacturers io regulate their wagen and hours of work, the suspending of work paltially altegetber, and the discipline and managment of their mablishments, by the decision of a majorily of thoig number, is in general restaint of trade a flepriving each one of them of the contol of his own businter, and is therefore not enforcoable $(z)$. It makes no difference that the object of the combination is alleged to be mutual defence against a similar combination of workmen. The case decides on the whole that neither an agreement for a stike nol an agrement for a lock ont is enforceable b?

(y) Sir again in the cate of Monupolies (1602) 11 (\%. Repr. st 7 .

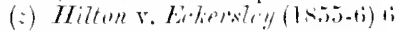
F.d B.ti, in Exeh. (h. it. fiti. 24

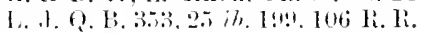
501. The dirtat therest fin at they sucrest that the arreewent would he a criminal offence at eommon law, are userruled by lorgul sterm.

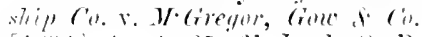
[1.42] A. C. 25.61 L. I. Q. 13. 29.5. 
law. The court of Exchequer ('hamber thas axpessed the general punciple in the couse of their julgment:

"Irrimat facie it is the privilege of a trater in a free country, in all natters not contrary to law, Io regulate his own mole of earrying it [ his

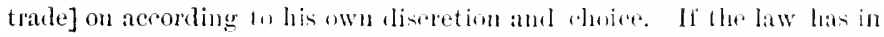
any matter regulated or restrained lis mone of dring this, the law mon-t

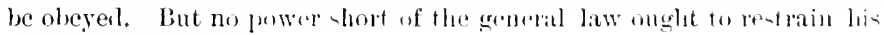
free rliscretion" (a).

On like grounds a restrictive agreement betwenthe members of a tradesociety as to the employment hy any one member of travellets and othere persons who had left the service of any other has been disallowed (b).

It is not an mulatul restraint of trate for seseral persons carrying on thesime business in the salme place to agree to divide the husiness anmeng themselves in such "way as to prevent competition, and porrisums rat sonahly necessary for this purpose are not invalid because they may operate in partial restraint of the parties' freedom to exereine their trade. But a provi sion that if other persons, strangers to the contract, do net employ in particular carses that onse of the eantracting parties to whom as hetween themselves the business is assignod by the agroement, then lumb of the other's will accept the amployment, is bate (c).

The reasons for the rule are sete forth at large in the

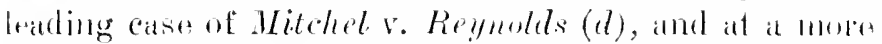

(a) i F. E B. at ly. 71-5, lok li. li. ize, iz:3. Ftrikes are unt mawful in themselves; ste for Fletrher Moulton, L..J., in Givinry v. Bristul Trade and Prorident

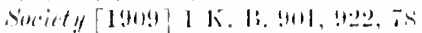

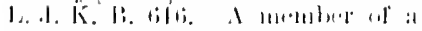

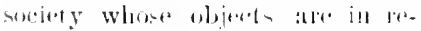

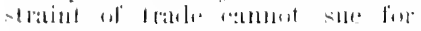
monry due lo him molele the rules:

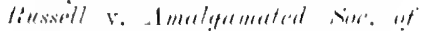

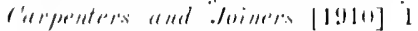
li. 1:.

(b) Minteal Ilatio liatlle, die.

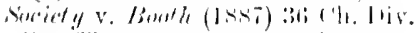

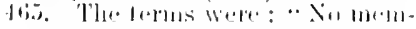

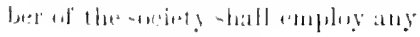

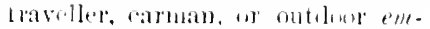
fleys. who las left the servied of another member, withont lhe consent in writing of his laterempleyer, until after the expiralion of iwn

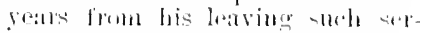
vir.t."

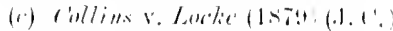

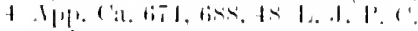

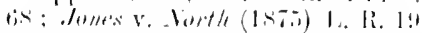

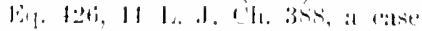

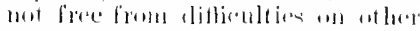
gromals. and apparenlly mol fully

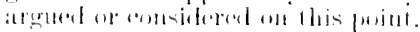

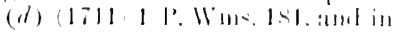
1 in1. 1..
Reasuns fill ont allowing nnqualifiel reatraint. 
recent date (1837) were put more concisely by the Supreme Court of Massachusetts, who held a bond roid which was conditioned that the obligor should never carry on or be concerned in iron fommling:-

. 1. Aublo contracts injure lle partire making them, hecause they dimini-h their suran of procuring livelitume amd a compeneney for their

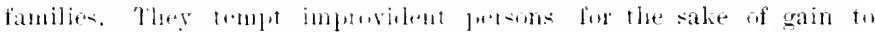

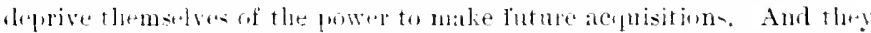

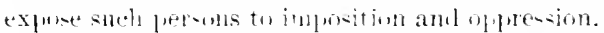

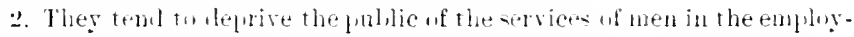

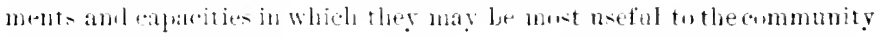
an well as tlems alves.

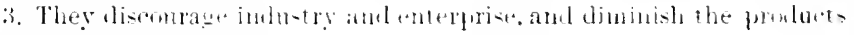
w' ingenuity and-kill.

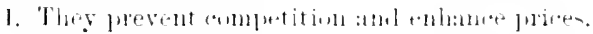

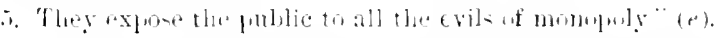

Fil all,wing particular restraint.
Mhoikinin al 1 te-tri, tifition aremants 1,11 sale of business in litherentury.

The qualified andmingom of restraints has been commonly spolien al ats an exception to the general policy of the law. But it serems bettor to regald it rather at another branch of it. Plublic policy retpuires on the me hamel that at man shath mot by contract deprive him- elf ol the state of his labour, skill ol talent; and on

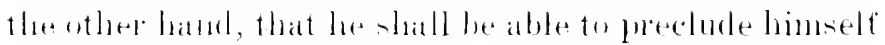
fom competing with palticulal perams so fall as necest saly to whtith the hest price for his husiness or know

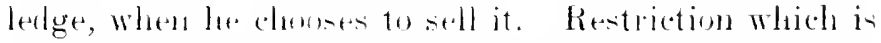
rearonable lon the protection of the parties in such at tatse is allowerl by the very salne policy that forbids ate strictions genelally, atud for the like reasoms $(f)$.

la the atrly patet of the sesenterenth antury the

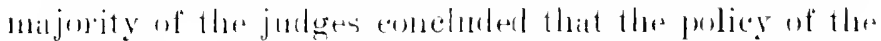

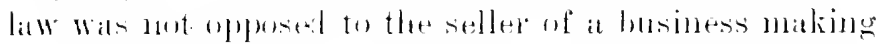
the sales rffectllal by andertaling not to compete with

(r) H/ger Y. Thather (1):37) $1 ! 1$

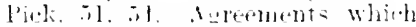

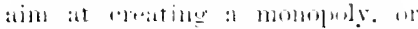

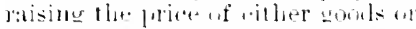

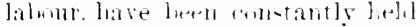

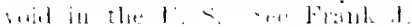

Gimblums, Trable Combinations at limmon law, lol. sei. Mnart, xii. 212.

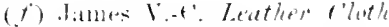

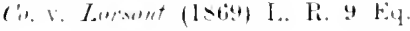
$\therefore 1 . i$, at $11.82,3$ 
the buyer. For that purpose, "for a time certain and in a place certain a man may he well bound and re. strained from using of his trate" (.l), provided that it is upon a valuable consideration (h). Restrictions extending to Newgate Market, in London, and the whol, of country towns, such as Basingstoke and Newpont (Iste of Wight), were allownd, hut it wats salil that suld a promise camnot be gond "if the restraint be genteral throughout England" (i). These anthorities were (onfirmed in 1711 by Mitchel r. Reynolds (k), the earliest ase usually referred to, and it wats settled that if a particular restrictive contrate on the circumstances brought before the conde, "appears to be a just and lonest contract," it will be mphede. At that time, how. ever, and long afterwards, it was taken for granted that such a contract could in 110 cate be reasonable unless limited, at any rate, in space. "Where tho" restraint is general, not to exercise a trade throughont the kingtom," it was thought that it must he bad ats matter of law. "What does it signify to a tradesman in London what another dous at Newciatle?" (l).

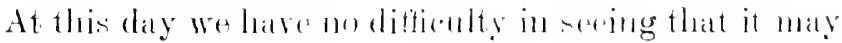
signily very much to a merehiant in Lendon what another is doing, not only at: Newratsle, hat at singal-

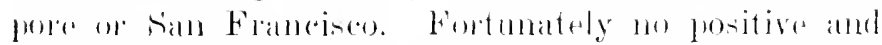
lixing ruln of linsits now lithl numlet. ab) monterio dired decision steme in the way of the law being antho-

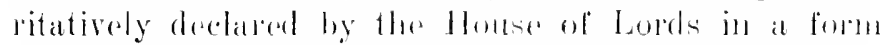

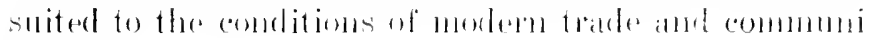
caltions.

before the midhe of the ninetenthe century it wats

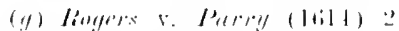

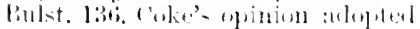
les the entme.

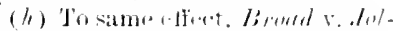

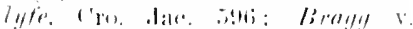

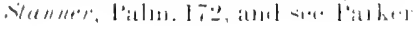

Mituluel $x$ liemolets: limit in slate thomert necesiary.

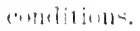

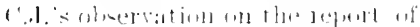

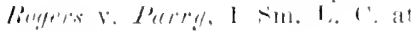
1.

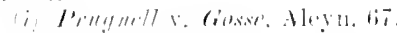

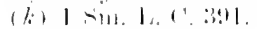

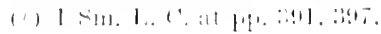


settled that, although a valuable and not merely colourable consideration there must be, even if the contract is under seal, the Court will not attempt to estimate the adequacy of the consideration in this more than in any other class of cases $(m)$.

Gradually the question whether the restriction imposed was on the whole commensurate, in point of law, with the benefit conferred, became the only question seriously discussed.

And now the dictat which apparently hound contracts of this kind within havd and fast rules must be taken not as general propositions of law, but as applieations of the general principle of rearonableness to conditions of fact which at the time might well seem to be permanent, but which lave pasned away.

In the leading case before the House of Lords, an inventor and manufacturer of guns and ammunition, doing business with militaly anthorities in rarious parts of the world, sold his bu-intes to a company, and covenanted not to compete with the company in that part of the buniness for twenty-fire rears: this was held not tor wide in the circum-tances, though a distinct covenant not to engage in any husiness competing with that for the time being carred on by the company was di-allowed $(n)$.

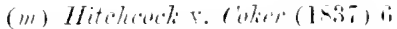

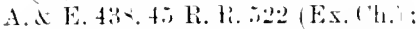

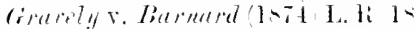
E. it was thonght it would secm from sonte expressions in the earlier cares that where the contract tralis deed the consideration must ajuear on the fare of the deted.

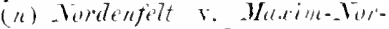

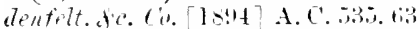
L. J. Cl. gus attiming $\therefore$. C. nom.

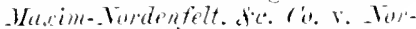

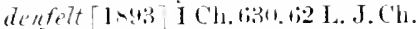
273 . In the $(\therefore$. A. Piowen I.J. endeavouma. in an dabrate juate- ment. to show that the common law rule in its old form was still in lines though the exceptions were "strinted. In the Hl. L. Low Herschell. thinking this historically wroet. concluder on the whole that the old rule had become * inaph hicable to the altered condition = which now weval," $154+$ A. C. at 1 . 5ts. Jurd Macnagbten thought fond Buwen's distinetions too retined. juslitied the decisions in ejuity which lort Bowen had criticized for distegarding the com. mom law rule. amilenied that there hat erer really been a haril and fast 
Meanwhile various relaxations of the supposed fixed rule as to limits had been sanctioned. These are now nothing else than special illustations of the broader principle; but as such they are still useful and instructive. A limit of time is not necessary to make an agreement in restraint of trade valid, and it is not of itsolf sufficient $(o)$. It has never been doubted that a dathture may bind himself absolutely not to eompete with the firm during the partnership: so may a servant in a trade bind himself absolutely not to eompete with the master during his time of service $(p)$. A contract mot to indulge a trade secret need not be qualified, and a man who enters into such a contlatet may to the samle. extent bind himself not to eary on a manufacture which would involve disclosure of the process intended to bre kept secret $(q)$. Indeed it has beren said that "salpes of secret processes are not within the principle or the mischief of restraints of trate at all " (1). An multer taking by a tradesman prorehasing gotkls from tha manufactures's not to sell them below specified prices. and not to sell to any retait trader without taking a similar agreement from him, is not in restraint of trads: for the manufacturese, not heing bound to make of sedl their goods at all, or to sell to this or that persom, alle entitled to sell on their own torms (s).

Whether the restrietion rontraced for in any parti

rule of law. flown to a resent time there was at itrong presumption in fiet against a restriction wilhout limit of spare being reasmably recuires for the proteetion of the monisee, but there was molecisinn or principle to make that presumption applicable to thr. hifferent stateof laces produced by the nature. of modern trate and tratlin. Inrol

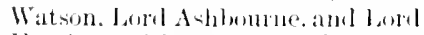
Jlorris, witlunt precisely conscurring in this, anpwar in have actered in sulfimes with l.tril
Detiderl examplen (formerly: ireated as sprecial (*xerpiniont) (in+1)+rial jeaturtable. Iterse ul
M:acnanghten.

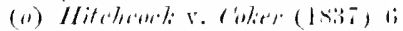

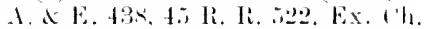

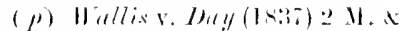
W. 273. J6 R. R. 6to?.

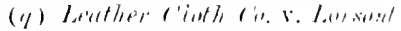

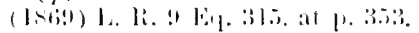

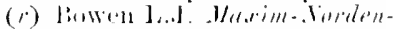

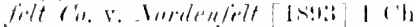

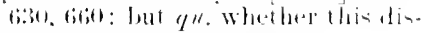
tinction be now necessary.

(*) Ellimath, Siths d it. S. Car-

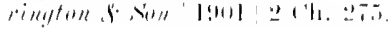


restriction in particular cases.

cular case be reasonable is a question not of fact but of law $(t)$, and evidence of persons in the trade as to what they think reasonable is not a lmissible (u). A covenant not to carry on "any business whatsoever," within however narow limits of time and space, is manifestly unreasonahle. Nor will the Court construe it as if limited to the particalar hasmesis which is really in question $(x)$. But a corrnant not to "deal or transact business" with custemers of the covenantees or of their succtssors maly be confinut hy the context to business of the same kind as that carried on by them at the date of the agreement (y). A corenant to retire, without exporesed limit in space or time, from a partnership, and "sn fall" as the law alluws, from the trade or husiness therent in all its branches," is batl for unreasonablenest if the words "so far as the law allows" arr surplusage, and bad for uncertainty if they are not; the parties cannot throw on the conct the task of sottling their agresment for them (z). A restriction clanse is not reatsonable if it has the effect of making the corenantere 1he sole judge whether a new husiness andertalien by the eorenanter enenpetes with his own or not (a). A restrictive coventant which eontains or may lie reald as entaining distinct molertaking: bonmber by different limits of space or time, or different in subject-matter, may he gowel as to part and ladel as to part (b). There is nut any solch rule as that a cosenant in lestraint of thate is peresmed to bet bad, and the

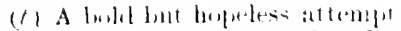
was mate torlispute this in lhorderle

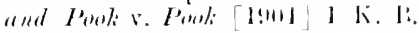
4.; $7: 3$ 1... K. K. BX, 1'. A.

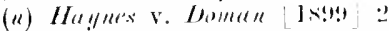
ch. l:3. tis L. .J. ('h. 41!, 1'. A.

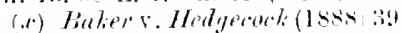

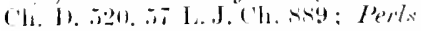

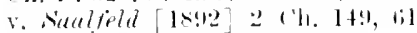
I. J. ('i. 1114. 1'. 1.

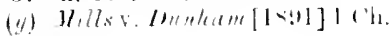

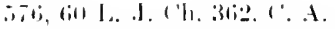

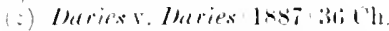
biv, :3i!, .t6 I. J. 1'h. !liz.

(a) l'els r. vialfeld [1s:2] :('h. 14!. 6) L. .I. ( h. t1!!, ('. A.

(b) Nee bainex v. lient"y (1657):3\%

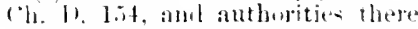

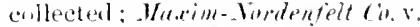

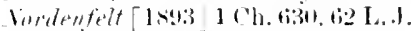

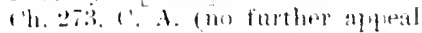
unthis futint). 
party relying on it must justify it. "You are to construe the contract and then see whether it is legal" $(c)$. As regards an employee's covenant, the measure of reasonableness is the protection of the rery trade in which he hats contrietod to sireve and in fact serves $(d)$.

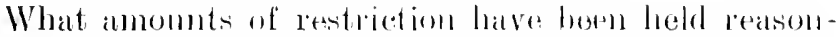
able or not for the circmmstances of different kinds of business is best seen in the labular statement of eases (down to 1854) subjoined to the resport of Avery $v$. Langford (e). It may lue comvenient to atd the later decisions in the same form.

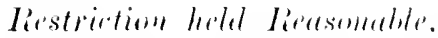

\begin{tabular}{|c|c|c|c|c|}
\hline $\begin{array}{c}\text { Name and bite of } \\
\text { Cast. }\end{array}$ & 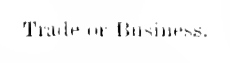 & $\begin{array}{l}\text { Extent ut lientrin. } \\
\text { liont in t'intr. }\end{array}$ & 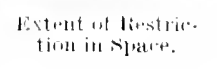 & $\begin{array}{l}\text { Tatile of andes } \\
\text { siace Avery } \\
\text { r. latheford. }\end{array}$ \\
\hline 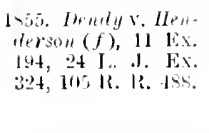 & Solicitur. & 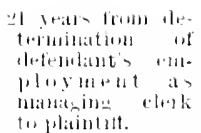 & 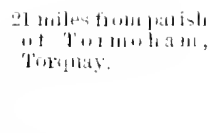 & \\
\hline 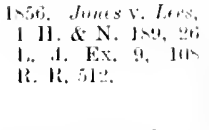 & 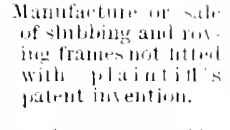 & 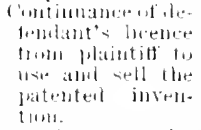 & 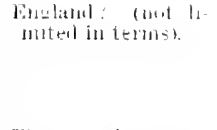 & \\
\hline 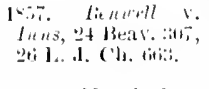 & 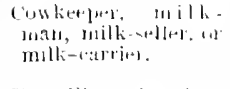 & 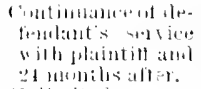 & 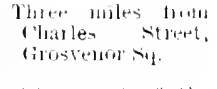 & \\
\hline 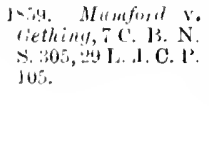 & 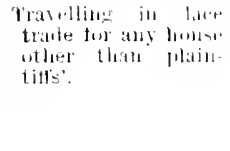 & lonlinifunt. & 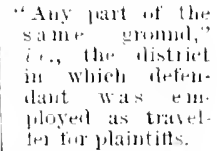 & \\
\hline
\end{tabular}

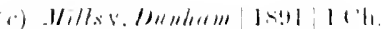

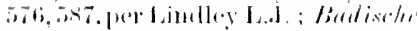

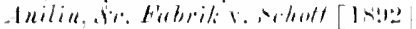

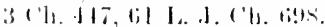

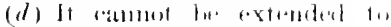

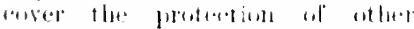
associated emploptels whom lie lia-

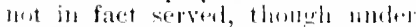

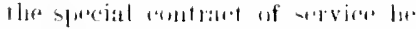

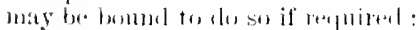

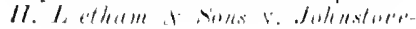

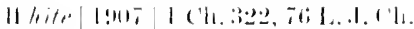

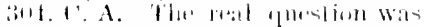

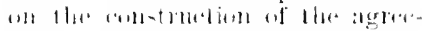
$1111 \cdot 11$.

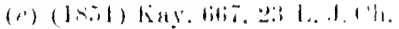
siz, li11 li. li. sinl.

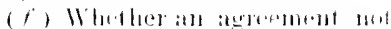
to ieside at at gibell platere ats well

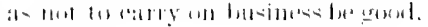
y"uritr. 
liestriction ledel Lieasonalie.

\begin{abstract}
Sante anul Ditte ut (ian.

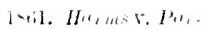
stit:, 32 Brav, 泣. 321. 3. Ch. 27 .

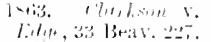

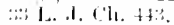
latit. lettl. Thele, l. Li. 4 Ch. piot is 1.. 3. the titi.

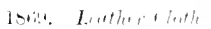

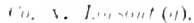

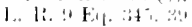
I.. .J. 1 भ. . +i

1-7id tiventid 8

tionelel. I. li. I

E. . is. 4 1.. I. (hi, in.

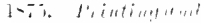

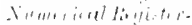

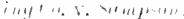
I.. R. 1! E E. the til. t. ( 1 , , th.

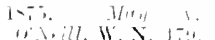
it I., I, I h , itit.
\end{abstract}

Trate of buanien.

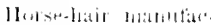
t(1) $1+1$ :

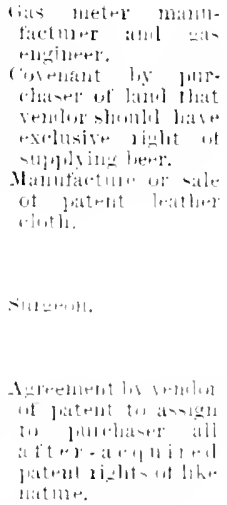

(mphetht ly bir. ('hitate of lianl that

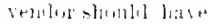

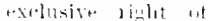

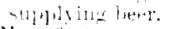

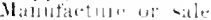
of bitmit lrittint intil.

\section{$\therefore \mid\{[\ldots,+\}$,}

A-drement lis bertin if fiatent fir athelgh (1) bourhater all

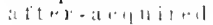

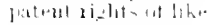
littintr.

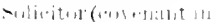

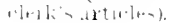

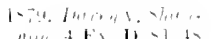
l. I. E t tid (m

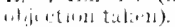

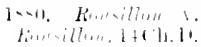

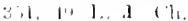
a.?.

1w1. Wilts b. I H w

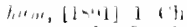

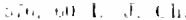
a. 1

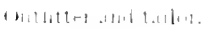

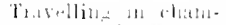

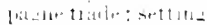

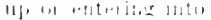

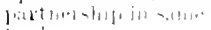
tikl.t.

Thathlute in tomes,

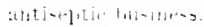
Extrit ol Restric-
tim in lintr.

Lulinitme.

TrII $1,: t !$

['ulinitm].

Eulinitul.

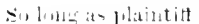
1.1. lils atsoizus - Humbl carty on biminings.

lifitinire of bellinis.

Lubuitat.

[nliniturl (takents i.) the fint its tiig juint listos it firintill :all ale. 1+miant)

161, betse atter

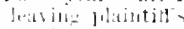
orvire ils te trat brlho: tren as th vealing an wh stewtint.

Uni,uit+il,
Evtrut of Restric. tion in slace.

290 willes from Bir. แ11.

211 hiles from Gisedt l'rter St., Wi-tmimater.

Aluy jublic lomer

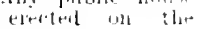
lan!.

Eilloge: lutt tir be collotruteil as as Grat Britain, or Unital Kingelun. Nuthle, see 1.. F. !lif. at p.öl (b).

Parials of Newirk anil toll milm lumul, exerpiting the town of laters. Enrol e (i).

Lumbur, Midilears itm.l Enstex ; ant unlimiterl an $t$, artion lor elimets ut plaintitt, thm. it any one whothed laneli aleh elielit dorims the trim of the alticles.

Five miles trum [erol]

[indiniteit.

[a]inita]

( Enclamel and

Wides क Jet liniley l.. d. [1-i,]] i ( h, , i).

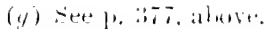

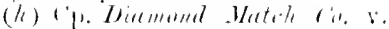

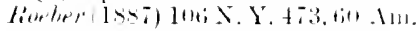

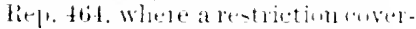
inn the whole territury of the

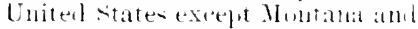
Sevala wa lete? lot tori wible.

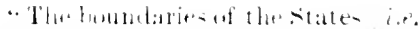

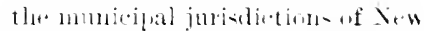

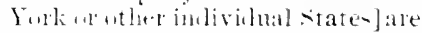

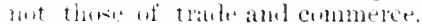
and hm-ines is retrainet within $110-13 \cdot 11$ limit."

(i) S+2 1:1 11140. 


\section{Restrietion held lieasonable.}

\begin{tabular}{|c|c|c|c|}
\hline $\begin{array}{l}\text { Name and Date of } \\
\text { Case. }\end{array}$ & Trate or 13 thinfess. & $\begin{array}{c}\text { Extent of Rentife- } \\
\text { timl in rime. }\end{array}$ & $\begin{array}{c}\text { Extent of Restrit:- } \\
\text { tion in Spare. }\end{array}$ \\
\hline 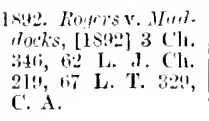 & $\begin{array}{l}\text { Travelling in lieer, } \\
\text { Se. }\end{array}$ & Twe yors. & $\begin{array}{l}\text { Jou nuiles fiom Car. } \\
\text { liff. }\end{array}$ \\
\hline 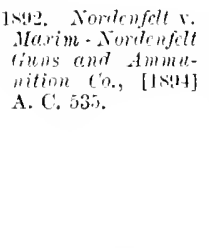 & 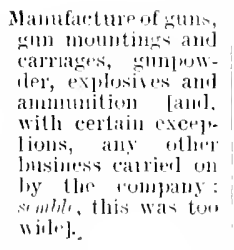 & 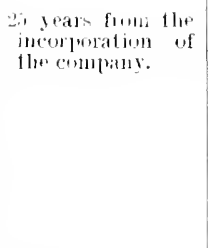 & 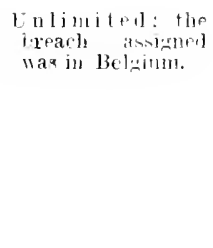 \\
\hline 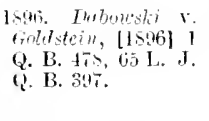 & lairyluen. & $\begin{array}{l}\text { Inletmute timo : } \\
\text { contmuance of } \\
\text { service ant "for. }\end{array}$ & $\begin{array}{l}\text { No defintion of } \\
\text { space, but heli } \\
\text { limited hy context } \\
\text { to actuil locality } \\
\text { of business. }\end{array}$ \\
\hline 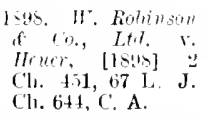 & $\begin{array}{l}\text { Enamelled lollow- } \\
\text { ware dralms. }\end{array}$ & 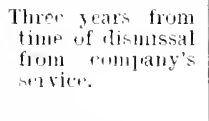 & $\begin{array}{l}\text { lig) miles foum } \\
\text { Wotrerhaniton. }\end{array}$ \\
\hline 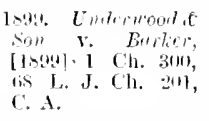 & $\begin{array}{l}\text { Hay and straw mer. } \\
\text { chants. }\end{array}$ & 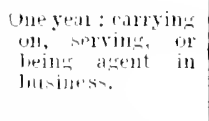 & 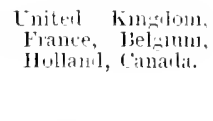 \\
\hline 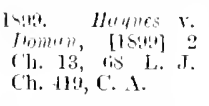 & $\begin{array}{l}\text { Hamluare manufac. } \\
\text { tures. }\end{array}$ & $\begin{array}{l}\text { Lulimaterl: work. } \\
\text { jus or serving in } \\
\text { some hemel of bust. } \\
\text { ness. }\end{array}$ & Roudun of 25 moloo. \\
\hline 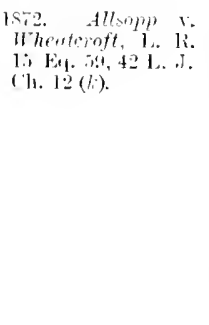 & 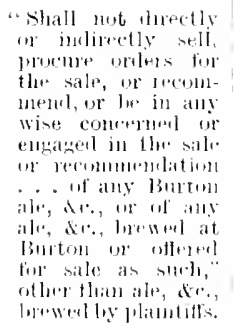 & 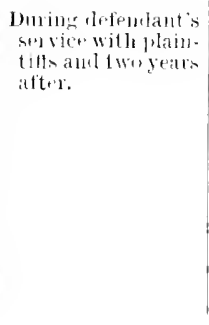 & Unlimiter. \\
\hline
\end{tabular}

(b) This appeass to la in direct "onflict wifl Rousillals limuillu". last pates, wlich sems in -tambl

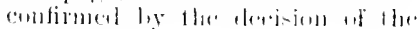

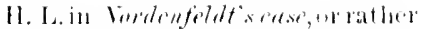
(the-11bject-matter bejug very different) by the reatoms given for it. 


\section{Listriation held Ineusumable.}

\begin{tabular}{|c|c|c|c|}
\hline $\begin{array}{l}\text { Name and late of } \\
\text { Cast. }\end{array}$ & Traile or Buines. & $\begin{array}{c}\text { Extent of Restric. } \\
\text { tin in tim. }\end{array}$ & $\begin{array}{l}\text { Extent of Pestric. } \\
\text { tion in sirace. }\end{array}$ \\
\hline 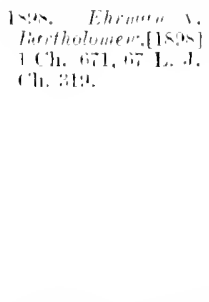 & 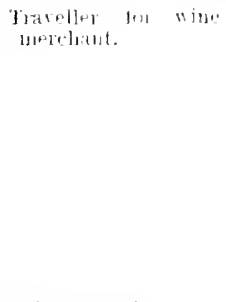 & 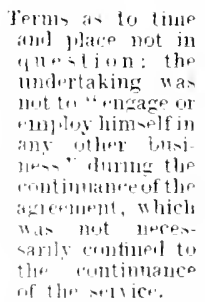 & \\
\hline 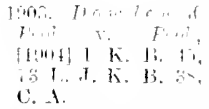 & 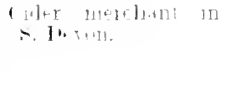 & Fin yars. & [nlemital. \\
\hline $\begin{array}{l}1: 09 . \quad 1 . \text { Inthem it } \\
\text { almie. }\end{array}$ & 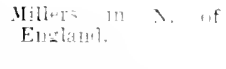 & Fir lod I & Fnited Kinglom (i) \\
\hline 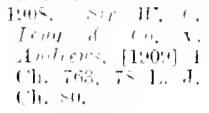 & 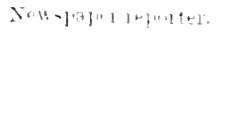 & Sinlmunt. & $\begin{array}{l}\text { harius of twenty } \\
\text { luiles from shot } \\
\text { lifil. }\end{array}$ \\
\hline
\end{tabular}

Meannement uf lisiances.

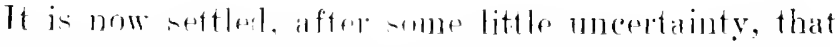
distancess specified in contlateds of this kind ate to be meansed as the corew tlies. i.e. in at straight line on the map, neglecting anvatule and inequalities of 511 face. This is mly a rule of comstruction, and the parties may prescribe another measurement if they think fit, stch as the neallet moter of access (m).

A cortain number of recent decisions are only on the

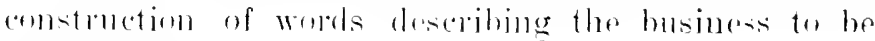
rentricterl (n).

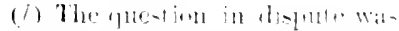
whether the - pecial comtlaset a.s.

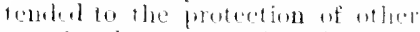
asociated concerdo whene busines the practically ewror the Inited ling(lom.

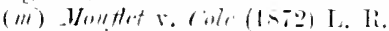
i Hx, 70 . in Ex. ('h. $\rightarrow \mathrm{Fx} .32,42$ l..J. Ex. $\therefore$ A $A$, what amollut

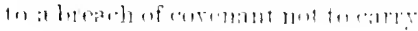

wh havines within certain limil-

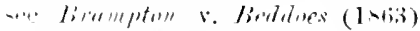
131.13. X. . .3.3.

(11) Such are suat s. Difluek (14:1) 1:3 ch. Wiv. 343, 5!4 L. .1.

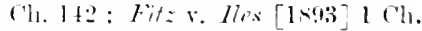

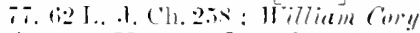
$\therefore$ isn r. I/(t) 酒 I..1.1\%, 111 ; and lusome extent

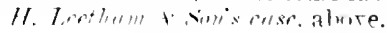


In British India the language of the Contract Aet (o) has been literally construed by the ('ourts so as to make the rule much more stringent than in England, and agreements not to eompete with former employers, or the like, have been disallowed, nofwithstanding that they would certainly have been mpheld at common law $(p)$. It seems very doubtful whether any such result was contemplated hy the framers of the Aet, and amendment seems desirible.

It is clear law that a emtrated to serere in a particular business for an indefinite time, ar "xen for life, is not roid as in restraint of trate or on any other gromul of public poliey $(q)$. It would not he rompetent to the parties, howerer, to attath servile inciclents to the conbaet, such as molimited rights of persenal control and correction, or orer the servant's porperty $(r)$. It is undisputerl that an agresement by $A$. to work for mohody

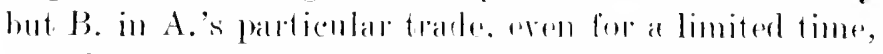

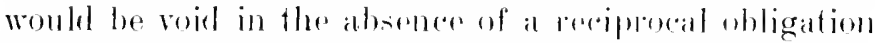
upon B. to employ A. (s). But a permine by B.

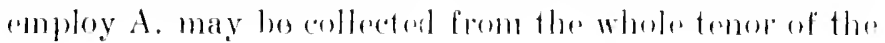

Indian

Contract A.t
I untract to -erve for Jife not inraliul. tiontract for exelusire service must be mutulit. (a) - Livery agreenent by which any one is rentrained foum excrojeing a lawful profession, latie. of lonsiness of any kinl is fo that ex-

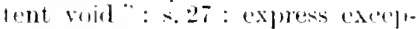
tions follow at $(1)$ ingrements on the sale of a gondwill and angere ments lefween partuers. This is whe of the ded's unfortunate borrowing from the [mole low

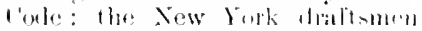
intemeter to matrow the haw.

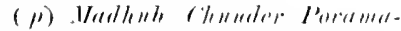

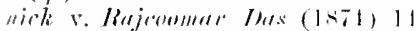

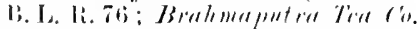

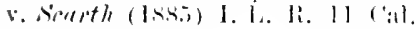
5iti.

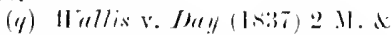

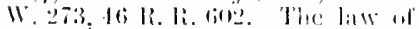

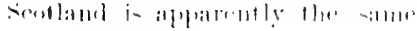

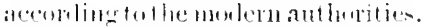
(I) Sece llatrates argament in

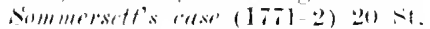
Tr. t:4, fiti. and bewen L.J. 3it 1 h. live at 1. 39:3. Jy the french law indefinite contlatet of serviee alre net allwwel: ('ml. ('iv. 17.80): On le pent ellyager ses service pll" a

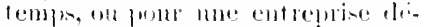

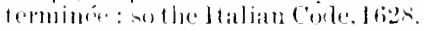

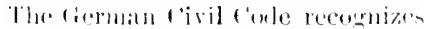

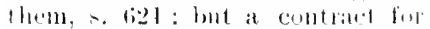
portstmat selvice for iny torm arer five years may after the first tive gears be eletermined by the am-

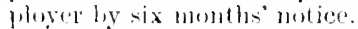

(x) See maxt mote, and ap the

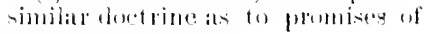
millitive, snfmet 
agrement between them, and so make the agreement good, without any express words to that effect $(t)$.

I). The judicinl treatment of mulawful agreements in general.

11. Rules ato treatment (if unlawful arreement - in general.
1. Intepen. dent promines.
sime lawful and some

Thus far of the variom specific grounds on which agreements are held unlawful. It remains for us to give as briefly as may be the rules which govern our Courts in dealing with them, and which are almost without exception independent of the particular ground of illegality. The general principle that an unlawful agreement cannot be enforced is not a sufficient guide. We still have to sittle more fully what is meant by an unlawful agreement. For an agreement is the complex result of distinct elements, and the illegality must attach to one or more of thoe elements in particular. It is material whethor it he found in the promise, the consideration, or the ultimate purpose. There are que-tions of eridenere and procedure for which anxiliary rules are nexded within the bounds of purely munieipal law. Morenver, when the jurisdictions within which gl contract is made, is to be performed, and is sued upon, do not coincide, it has to be ascertained by what local law the ralidity of the contract shall be detemined, or there may he a "conflict of laws in space" ": again, if the law he changed between the time of making the contract and the time of performance there may be " conflict of law in time."

This general division is a rough one, but will serve to guide the arrangement of the following statement.

Imluufulness of argement as determined by particulur clements.

1. A lawful momise made for a lawful consideration is not invalid hy reaton only of an mulawful promise

(t) Pilkington 5. Siontt (1Stit) 1 .i

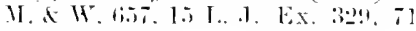

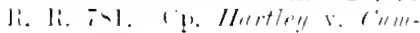

$\operatorname{ming.s}(1 \mathrm{~A} 4) ; C . \mathrm{B}, 247,17 \mathrm{~L}, \mathrm{~J}$.

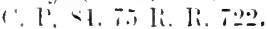


being made at the same time and for the same consideration.

In Pigot's case (u) it was resolved that if some of the covenants of an indenture or of the conditions indorsed upon a bond are against law, and some good and lawful, the covenants or conditions which are against law are void $a b$ initio and the others stand good. Accordingly "from Pigot's case $(x)$ to the latest authorities it has always been held that when there are contained in the same instrument distinct engagements by which a party binds himself to do certain acts, some of which are legal and some jllegal at common law, the performance of those which are legal may be enforcerl, though the performance of those which are illegal cannot" $(y)$. And where a transaction partly valid and partly not is deliberately separated by the parties into two agreements, one expressing the valid and the other the invalid part; there a party who is called upon to perform his part of that agreement which is on the face of it valid cannot be heard to say that the transaction as a whole is unlawful and void $(z)$.

It was formerly supposed that where a deed is roid in part by statute it is void altogether: but this is not so. "Where you cannot sever the illegal from the legal part of a covenant, the contract is altogether void; but where you can sever them, whether the illegality be created by statute or by the common law, you may reject the bad part and retain the good" $(a)$.

2. If any part of a single consideration for a promise

(u) (1615) 11 Co. Rep. 27 l,

(n) lieferred to in the report as ti Co. Rep. 2t; ; it is really in rol. di, el. 1826, which contains parts 1I, 12, and 13.

(y) Bunk of lustrallswin v. Brillat (1817) f 1100 . P. C. 152, 201, 7!) Ri. li. 24, sis.

(z) Odessa Tramualys $\quad$ (o. v. $\mathrm{P}$. unlawful ; the lawful ones can be enforcel. 
or part of consideration aroils the whole agreement.

3. Agreement is roid whose inmediate objeet is unlawful.
4. Where immediate object not unlaw farl, unlaw ful intention of both parties, or of une larty known to the other, makes agreement voill : unlawful intention of rine not known at time makes contract voinable at other's option. or set of promises is unlawful, the whole agreement is void.

This rule assumes the consideration not to be severable, and in such a case it is impossible to assign a lawful consideration to the promise or any of the promises induced by it $(b)$. In other words, where independent promises are in part lawful and in part unlawful, those which are lawful can be enforced; but where any part of an entire consideration is unlawful, all promises founded upon it are void.

3. When the immediate object of an agreement is unlawful the agreement is roid.

This is an elementary proposition, for which it is neverthelens rather difficult to find unexceptionable words. We mean it to cover only those cases where either the agreement could not be performed without doing some act unlawful in itself, or the performance is in itself lawful, but on grounds of public policy is not allowed to be made a matter of contract. The statement is material chiefly for the sake of the contrasted cliss of cases under the next rule.

4. When the immediate object or consideration of an agreement is not unlawful, but the intention of one or both parties in making it is unlawful, then--

If the unlawful intention is at the clate of the agreement common to both parties, or entertained by one party to the knowledge of the other, the agreement is roid.

If the unlawful intention of one party is not lnown to the other at the date of the agreement, there is a contract roidable at the option of the innocent party if he discovers that intention at any time before the contract is executed.

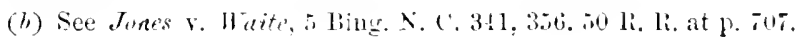


Here it is necessary to consiller what sort of connection of the subject-matter of the agreement with an unlawful plan or purpose is enough to show an unlawful intention that will vitiate the agreement itself. This is not always easy to determine. In the words of the Supreme Court of the United States:-

"Questions upon illegal contracts have arisen very often both in England and in this country; and no principle is better settled than that no action can be maintained on a contract the consideration of which is either wicked in itself or prohibited by law. How far this principle is to affect subsequent or collateral contracts, the direct and immediate consideration of which is not immoral or illegal, is a question of considerable intricacy" $(c)$.

We have in the first place a well-marked class of transactions where there is an agreement for the trans fer of property or possession for a lawful consideration, but for the purpose of an unlawful use being made of it. All agreements incident to such a transaction are roid; and it does not matter whether the unlawful purpose is in fact carried out or not $(d)$. The later authorities show that the agreement is roid, not merely if the unlawful use of the subject-matter is part of the bargain, but if the intention of the one party so to use it is known to the other at the time of the agreement $(e)$. Thus money lent to be used in an unlawful manner cannot be recorered $(f)$. It is true that money lent to pay bets could be recovered at common law (g), but

(c) $A$ rmstromet v. Tuter (1siti) 11 Wheat at 1. 2-i2.

(d) Gias Light and ralie? l'o. $\quad$. furner (1 S3:1) 5 bing. X. ('. ritili. ill Ex. ('h, i il, 324, ol h. Li. sts.

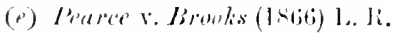

1 Ex. 213, 35 1. .J. Ex. 131.

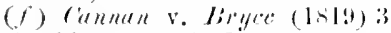

B. \& All. 179, 22 li. li. :342.

(g) See now the Ciaming Aet,
1892. It is hy nomeans clear that the frot extride beyond invalialating formines to reimbarse payments actually mate in respect of wagering agrements. 'There are mo womls which obvious!y hit the rase of (1) a loan to a preveon who to the lenter's knowleclge means 10 leet and to wice the money in jaying any bets he Joses, on even
What eromstitutes unlawful intention in such tases.
Intention to put property purchased, te., to mulawful use. 
that was because there is nothing unlawful in either making a bet or paying it if lost, though the payment cannot be enforced. If goods are sold by a vendor who knows that the purchaser means to apply them to an illegal or immoral purpose, he cannot recover the price: it is the same of letting goots on hire $(h)$. If a building is clemised in order to be used in a manner forbidden hy a Building Act, the lessor cannot recover on any covenant in the lease (i). And in like manner if the lessee of a house which to his linowledge is used by the occupiers for inmoral purposes assigns the lease, knowing that the assignee means to continue the same use, he cannot recorer on the assignee's corenant to indemnify him against the covenants of the original lease $(k)$. It does not matter whether the seller or lessor does or does not expect to be paid out of the fruits of the illegal use of the property $(l)$.

Option of party innocent in the first instance to aroil the contract on diseovering such intention.

But an executed transfer of jossession remains grood,

An owner of property who has contracted to sell or let it, but finds afterwards that the other party means to use it for an unlawful purpose, is entitled (if not bound) to rescind the contract; nor is he bound to give his reason at the time of refusing to perform it. He may justify the refusal afterwards by showing the unlawful purjose, though he originally gave no reason at all, or even a different reason $(m)$.

But a completely executed transfer of property or an interest in property, though made on an unlawful consideration, or, it is conceived, for an unlawful purpose known to both parties, is ralid, and cannot afterwards be set aside $(n)$. And an innocent party who discovers

$(\therefore)$ who to the lender's knowledge means to use the money in paring hats already lost. See A. V. lifeeg in $\mathrm{I}$. Q. I. $\mathrm{xx}$. 434 ; Anson on Contracts, 11 th ed. 211 .

(h) Perame r. Brooks (1stiti) L. R. 1 Lix. 213. 3. L. J. Ex. 134.

(i) Cias bightet and coke Co.v. Turner (1839) ¿ Bing. N. ('. 666, in Ex. ('h. if it. 324. 5t R. R. sos. (k) S Smith v. White (1866) R. R. 1 E.t. ti2ti. 35 L J. Ch. 454.

(l) See note $(h)$, ante.

(m) Gonean v. Wilbourn (1867)

L. Li, 2 Ex, 230,34 L. J. Ex. 124; see per Bramwell B. ad tin.

(ii) A yerst r. .Jenkins (1873) L. R. 16 Eq. 275. 42 L. J. Ch. 690. As 
the unlawful intention of the other after the contract has been executed is not entitled to treat the transaction as void and resume possession (o). As with contracts voidable on other gromols, this rule applies, it is conceived, only where an interest in possession has been given by conveyance or delivery. The vendor who has sold goods so as to pass the general property, but without delivery, or the lessor who has executed a demise to take effect at a future day, might rescind the contract and stand remitted to his original right of possession on learning the unlawful use of the property designed by the purchaser or lessee $(p)$.

On the same principle an insurance on a ship or goods is void if the royage covered by the insurance is to the knowledge of the owner unlawful (which may happen by the omission of the statutory requirenents enacted for the protection of seamen and passengers, as well as in the case of trading with enemies or the like). "Where the object of an Act of Parliament is to prohibit a royage, the illegality attaching to the illegal voyage attaches also to the policy covering the royage," if the illegality be known to the assured. But acts of the master or other persons not known to the owner do not vitiate the policy, though they may be such as to render the voyage illegal $(q)$.

to chattels, eontio per Martin B.in Pearer v. Brooks (1866) I. Ji. 1 Ex. 217 ; but this scems unsuphurted : see 1.. R. 4 Q. 13. 311, 315.

(a) feret v. Itill (1854) 15\% C. li. 207,23 L. J. C. I'. 18.;, 1001 Ii. Ii. 318 , where an interest in realty had passed and the re-entry was forcible; but semble, the lease was voilable in ermity.

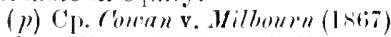
L. R. 2 Ex, 230, 36; l. J. Fx, 121.

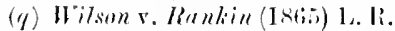
1 Q. J. I62. 35 I. J. Q. B. 203) (lix.

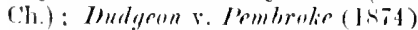

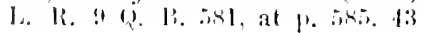

L. J. Q. B. 220, per Quain J. and authorities there referred to. ('I). further, on the general head of agreenents made with an unl:uwful

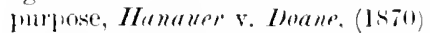
2 Wallace. 342. In surott r. $I$. S. (1s74) 20 il. 4.5!, it was liell that a buyer of cottom from the ('onfellerate (iovernment, knowing that the purchase-numey would be ap[tied in support of the rebelliom, comlal not be recognized by the I. S. Cuurts as owner of the coitton: diss. Field .I. wh the groumb (which seem right) that it was a yllestion not of coutract hut of wwership.
Insurance voil where royage illegal to knwwlerge of owner. 
Agreement eminected with but subse puent to an unlawful tran-action. silch agreement not void unles an integral part of unlawful design. Cares in supreme Count. I. .

Armstrong $r$. Toler, sc.
An agreement may be made roid by its connection with an unlawful purpose, though subsequent to the execution of it.

To have that effect, howerer, the connection must bo something more than a mere conjunction of circumstances into which the unlawful transaction enters so that without it there would have been no occasion for the agreement. It mut amount to a mity of design and purpose such that the agreement is really part and parcel of one entire unlawful scheme. This is well shown by some cases decided in the Supreme Court of the United States, and spreading orer a considerable time. They are the more worth special notice as they are unlike anything in our own books. In Armstrong r. Toler (r) the point, as put by the Court in a slightly simplified form, was this: "A. during a war contrives a plan for importing goots on his own account from the country of the enemy, and goods are sent to B. by the same ressel. A. at the request of $B$. becomes surety for the parment of the duties [in fact a commuted payment in lieu of confiscation of the goods themselves] which accrue on the goods of B., and is compelled to pay them: can he maintain an action on the promise of $B$. to return this money?" The answer is that he can, for the "contract made with the gorernment for the parment of duties is a substantive independent contract entirely distinct from the unlawful mportation." But it would be otherwise if the goods harl been imported on a joint adrenture by $A$. and $B$. In MeBlair r. Cibbes (s) an assignment of shares in a company was held grood as between the parties though the company had heen originally formed for the unlawful purpose of supporting the Mexicans against the and that in deciding on title tw
peromal property the dre tidot government existing at the time and flace of the transation mon-t

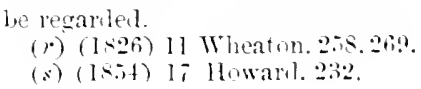


Spanish Government before the independence of Mexico was recognised by the United States. In Miltenberger $v$. Cooke $(t)$ the facts wero these. In 1866 a collector of United States revenue in Mississippi took bills in payment when he ought to have taken coin, his reason being that the state of the country made it still unsafo to have much coin in hand. In account with the government he charged himself and was charged with the amount as if paid in coin. Then he sued the acceptors on the bills, and it was held there was no such illegality as to prevent him from recovering. If the mode of payment was a breach of duty as against the Federal government, it was open to the government alone to take any objection to it.

We return to our own Courts for a case where on the other hand the close connection with an illegal design was established and the agreement held bad. In Fisher v. Bridges $(u)$ the plaintiff sued the defendant on a simple covenant to pay money. The defence was that the covenant was in fact given to secure payment of part of the purchase-money of certain leasehold property assigned by the plaintiff to the defendant in pursuance of an unlawful agreement that the land should be resold by lottery contrary to the statute $(x)$. The Court of Queen's Bench held unanimously that the covenant was good, as there was nothing wrong in paying the money, even if the unlawful purpose of the original agreement had in fact been exceuted: and the case was likened to a bond given in consideration of past cohabitation. But the Court of Exchequer C'hamber unanimously reversed this jurlgment, holding that the covenant was in substance part of an illegal transaction, whether actually given in pursuance of the first agree-

(t) (1873) 18 Wallace. 121.

(ii) $(18.3-4) \geq$ E. \& B. 11 s, 22

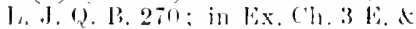

R. 642, 23) L. J. Q. B. 276,97 li. R. in).

(r) 12 tien $2, x, 2 s, 4.1$.
Fisher $r$ : Prillges in Ex, Cli. 
Principle of the jurlgment. ment or not. "It is clear that the covenant was given for payment of the purchase-money. It springs from and is a creature of the illegal agreement; and as the law would not enforce the original contract, so neither will it allow the parties to enforce a security for the purchase-money which by the original bargain was tainted with illegality." They further pointed out that the case of a bond given for past cohabitation was not analogous, inasmuch as past cohabitation is not an illegal consideration but no consideration at all. But "if an agreement had been made to pay a sum of money in consideration of future cohabitation, and after cohabitation, the money being unpaid, a hond had been given to secure that money, that would be the same case as this; and such a bond could not under such circumstances be enforced."

Some of the language used may have been "rague in itself and clangerous as a precedent" (y). The decision, however. does not appear to require anything wider than this-that where a claim for the payment of money as on a simple contract would be bad on the ground of illegality, a subsequent security for the same payment, whether given in pursuance of the original agreement or not, is likewise not enforceable: or, more shortly-

$\therefore$ Seeurity for payments under unlawful arreement is equally voirl with the original agreement,

5. Any security for the payment of money under an unlawful agreement is itself roid, even if the giring of the security was not part of the original agreement.

To this extent at least the principle of Fisher $r$. Bridges has been repeatedly acted on (z). In Gecre r. Mare (z) a policy of assurance was assigned by deed as a further security for the payment of a bill of ex-

(y) $1 \mathrm{sm}$. L. C. 391.

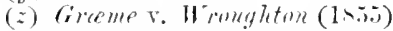
11 Ex. 146,24 L. J. Ex. 265.105
R. R. 4.in: Geove r. Ware (1863) 2

H. \& C. 339, 33 L. J. Ex. 50 ; rlay ร. Ray (186t) 17 C. B. N. S. 188. 
change. The bill itself was given to secure a payment by way of fraudulent preference to a particular creditor, and accepted not by the debtor himself but by a third person. It was held, both on principle and on the authority of Fisher v. Bridges, that the deed conld not be enforced. Again in Clay v. Ray (a) two promissory notes were secretly given by a compounding debtor to a creditor for a sum in excess of the amount of the composition. Judgment was obtained in an action on one of these notes. In consideration of proceedings being stayed and the notes given up a third person gave a guaranty to the creditor for the amount: it was held that on this guaranty no action could be maintained.

It seems doubtful whether this principle would apply to a security for money payable under an agreement of which the performance was not unlawful, thongh the agreement, on grounds of public policy, were not enforceable.

This is a convenient place to state a rule of a more special kind which has alrearly been assumed in the discussion of various instances of illegality, and the necessity of which is obvious: namely :-

$5 a$. If the condition of a bond is unlawful, the whole 5 . Bond bond is void $(b)$.

\section{Rules of Eridence and Procedure touching Unluwful Agreements.}

6. Extrinsic evidence is always admissible to show that the object or consideration of an agreement is in fact illegal.

(a) 17 C. P. N. S. ISA.

(b) Co. Lit. 2oti $b$, Shepp. Touch. 372 ; where it is said that if the matter of the rondition be only malum f"roh ibitum, the obligation is

alsolute (as if the comdition were merely impossible) : but this distinction is now clearly mot law: see Imergier v. Follemes (Ix:311) l11

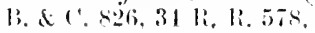

with

unlawful conclition is wholly void.

f. Illegality may always be shown by extrinsic exiklence. 
This is an elementary rule established by decisions both at law (c) and in equity $(d)$. Even a document which for want of a stamp would not be available to establish any right is arlmissible to prove the illegal nature of the transaction to which it belongs $(e)$.

But where the immediate olject of the agreement (in the sense explained above) is not unlawful, we have to bear in mind a qualifying rule which has been thus stated:

6a. Where inlawful inteution is alleger it mu-t be shown to have existed at date of agreement. Silbseruent comduct of parties may be eridemer of origrinal unlawful intention.

ida. "When it is sought to avoil an agreement not being in itself unlawful on the groum of its being meant as part of an unlawful seheme or to earry out an mlawful nhject, it must be shown that such was the intention of the partics at the time of making the agreement" $(f)$.

The fact that mulawftl means are used in performing an agreement which is prima facie lawful and capable of being lawfully performed does not of itself make the agrement mlawful (g). This or other subse. quent conduct of the prorties in the matter of the agreement may be evirlence, hut eridence only, that a riolation of the law was part of their original intention, and whether it was so is a pure question of fact $(h)$. The omission of statutory requisites in carrying on a partnership business is consistent with the contract of partner hip itself being lawful; but if it is shown as a fact that there was from the first a secret agreement to carry on the business in an illegal manner, the whole must he taken as one illegal transaction (i). Again,

(i) (iblins v. Blantern (17i7) I sin. I. ('.

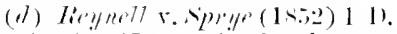

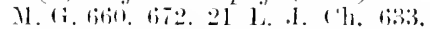

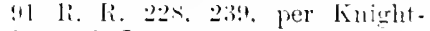
linuce $1 . . \mathrm{J}$

(r) ropporle v. Buner (18:35) 1 11. d W. Bill. j1 Ii. R. 1i27.

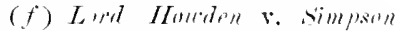

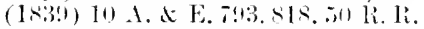
$\therefore \pi, 5 \pi 3$.

(a) A suhseguent agresmont to vary the perlormance if a comtlatet in a way that wonld make it unlawful is merely ino,erative, and leaves the niginal eontract in furce: rity of Hemplis v. brouen (1573) 2u Wallace (Nup. Ct. [. S.) 2xi!.

(li) Fruser v. Hill (1553) I M(4) 392.

(i) frmstrong v. Irmstrong (153t) 3 M. \& K. 4i. 6t, 13 L. . . ('h. 101, 41 li. 1i. 10): S. C. nmm. lrmotrong r. Lewis (1531) in Ex. ('h. 21 r. A M. $277.2 ! 17$. 
it is no answer to a claim for an account of purtnership profits that there was some collateral breach of the law in the particular transaction in which they were earned $(k)$. Where a duly enrolled deed inter rivos purported to create a rent-charge for charitable purposes, but the deed remained in the grantor's keeping, no payment was made during his lifetime, nor was tho existence of the deed communicated to the persons interested, and the conduct of the parties otherwise showed an understanding that the deed should not take effect till after the grantor's death, it was set aside as an evasion of the Mortmain Act (l). Again, an agreement is not unlawful merely because something remains to be done by one of the parties in order to make the performance of the agreement or of some part of it lawful, such as obtaining a licence from the Crown $(m)$. On the same principle it is not illegal for a highway board to give a licence to a gas company to open a highway within the board's juristiction, for it must be taken to mean that they are to do it so as not to create a nuisance $(n)$.

In Waugh v. Morris (o) it was agreed by charterparty that a ship then at Trouville should go thence with a cargo of hay to London, and all cargo was to be brought and taken from the ship alongside. Before the date of the charter-party an Order in Council had been made and published under the ('ontagions J)iseases (Animals) Act, 1869, prohibiting the landing of hay from France in this country. The parties did not

(i) Sharp v. Thylar (1845) 2 Ho. (6). 78 1. R. 2!s. still less where the illegal acts were dome by the frartnel against whom the acromt is sontert, without the sanction or knowledge of the other: Thuratos

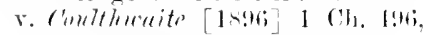

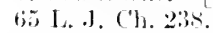

(C) Way v. Liast (185i3) 2 Hrew.

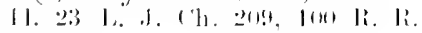
21.

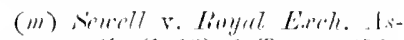

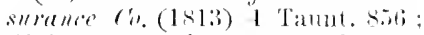
Maines s. linsk (1514) is it. i2l;

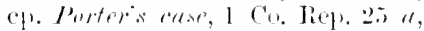
the like as to a combition in a hevise.

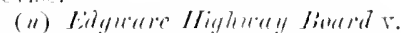

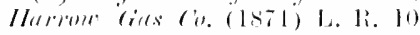

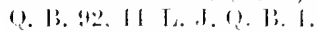

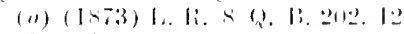
1.... U. li. .7.
Waugh $r$. Norris. Material on the ruestion of intention whethar the parties know the law. 
know of this, and the master learnt it for the first time on arriving in the Thames. In the result the charterer took the cargo from alongside the ship in the river into another vessel and exported it, as he lawfully might, but after considerable delay. The shipowner sued him for demurrage, and he contended that the contract was illegal (though it had in fact been lawfully performed), as the parties had intended it to be performed by means which at the time of the contract were unlawful, riz. landing the hay in the port of London. The Court howerer refused to take this view. It was true that the plaintiff contemplated and expected that the hay would be landed, as that would be the natural course of things. But the landing was no part of the contract, and if the plaintiff had had before him the possibility of the landing being forbidden, he would probably have expected the defendant not to break the law ; as in fact he did not, for no attempt was made to land the goods.

"We quite agree that where a contract is to do a thing which cannot be prerformed without a violation of the law it is void, whether the parties knew the law or not. But we think that in order to aroid a crintract which can be legally performerl on the ground that there was an intention to perform it in an illegal manner. it is necessary to show that there was the wicked intention to break the law: and if this be so, the knowledge of what the law is beemes of great importance" $(p)$.

Where

But on the other hand where an agreement is prima arreement primâ facio unlawful. not enough to show mere possibility of lawful performance. facie illegal, it lies on the party seeking to enforce it to show that the intention was not illegal. It is not enough to show a mere possibility of the agreement being lawfully performed in particular contingent events. "If there be on the face of the agreement an illegal intention, the burden lies on the party who uses expressions prima facie importing an illegal purpose to show that the intention was legal " $(q)$.

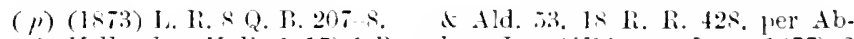

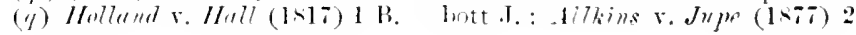


We now come to the rule, which we will first state provisionally in a general form, that money or property paid or delivered under an unlawful agreement cannot or property. be recovered back.

This rule (which is subject to exceptions to be presently stated) is the chief part, though not quite the whole, of what is meant by the maxim In pari delicto potior est condicio defendientis (r). To some extent it coincides with the more general rule that money voluntarily paid with full linowledge of all material facts cannot be recovered back. However, the principle proper to this class of cases is that persons who have entered into dealings forbidden by the law must not expect any assistance from the law, save so far as the simple refusal to enforce such an agreement is unavoidably beneficial to the party sued upon it. As it is sometimes expressed, the Court is neutral between the parties. The matter is thus put by Lord Mansfield :

"The objection, that a contract is immoril or illegal as bet ween plaintiff and defentant, sounds at all times very ill in the mouth of the defemlant. It is not for his sake, however, that the objection is ever allowed, but it is founded in general principles of policy, which defendant has the advantage of contrary to the real justice as between him and the plaintiff, by aeeident. if I may say so. The prineiple of publie policy is this: ex dolo mal" non uritur actio. No court will lend its aid to a man who founds his cause of action upon an immoral or an illegal act. If from the plaintift's own stating or otherwise the cause of action appears to arise ex turpi causu, or the transgression of a positive law of this eountry, there the Court says he has no right to be assisted. It is upon that ground the Court goes; not for the sake of the defendint, but hecause they will not lend their aid to such a plaintiff. So if the plaintiff and defendant were to chunge sides, and the defendant was to bring his aetion against the

(․ P. IJ. 375, 46; 1. .I. (. P. 82t. The same principle is expressed in a different form by l'aulus: "Item quod leges fieri prohibent, si perletuam eatusam servaturum esi, cessit obligatio. . . gluam 1ham ctiam si non sit perpetua causa ... Loril Manstield's explanation of the rule.

As to recovering back money (1) ilem dicemlum est. quia statim contra mores sit ": I). 4.5, I de v. $0.35 \$ 1$.

(1.) (1). 1). 5), 17, de reg. inris,

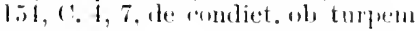
("allwill1, 2. 
plaintiff, the latter would then have the advantage of it : for where both are equally in fault, potior est ronditio defondent is" (s).

Ilaintiff canin it recover where his own unlawful consluct is part of his own ca-e.

The test for the application of the rule is whether the plaintiff can make out his case otherwise than "through the medium and by the act of an illegal transaction to which he was himself a party" $(t)$. In an action hrought to recover hack premiums paid on policies of life insurance alleged to be roid for want of insurable interest, it was held that, assuming them to be so, the position of the parties was equal even though the assured had relied on a mistaken statement of the law made in good faith by the insurance company's agent, and the premiums could not be recorered $(u)$. The rule is not confined to the case of actual money payments, though that is the most common. Where the plaintiff had deposited the half of a bank note with the defendant by way of pledge to secure the repayment of money due for wine and suppers supplied by the defendant in a brothel and disorderly house kept by the defendant for the purpose of being consumed there in a debanch, and for money lent for similar purposes, it was held that the plaintiff could not recorer, as it was necessary to his case 10 show the true character of the diposit $(x)$.

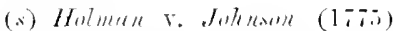
Cown. 341, 343.

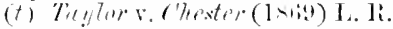
t Q. B. 31!1, 31t, is 1. J. Q. I. 2.25.

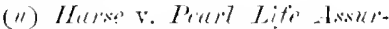

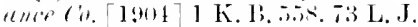

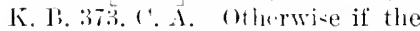
statement had been framlulent. see leer collins NH.R. [1:011] I K. B. at 1. isti3.

(x) This is apparent lin the courec of the pleatlings: the declaration was on a baibment of the larlf-note to be re-mlelivered on refuest, and in detinne. l'leas. in effect, that it was depowiter by way of pledge to secure moner due. liejlication, the immoral eharaeter of the lobt as alore. The Court inclined als, to think, lut alid not derible, that the plaintiff"s ease must fail on the more gemeral gromm that the delivery of the note was an executed eontract hy which a special property passed. and that snch froperty must remain. Compare Er parte Culdr-

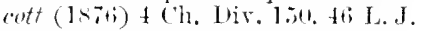
bk. 14. 1. 331. above: betbie 8

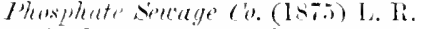
1! Q. L. 4!1], 500, affel. in C. A. 1 Q. P. liv. 30 ?. 
The rule is not even confined to causes of action $e x$ contractu. An action in tort cannot be maintained when the cause of action springs from an illegal transaction to which the plaintiff was a party, and that transaction is a necessary part of his case (y).

Independently of the special grounds of this rule, a completely executed transfer of property, though originally made upon an unlawful consideration or in pursuance of an unlawful agreement, is afterwards valid and irrevocable $(z)$.

The rule is not applicable in the following classes of cases, most of which, however, cannot properly be called exceptions.

An agent is not discharged from accounting to his principal by reason of past unlawful acts or intentions of the principal collateral to the matter of the agency. If A. pays money to B. for the use of C., B. cannot justify a refusal to pay over to $\mathrm{C}$. by showing that it was paid under an unlawful agreement between $A$. and C. (a). Again, if A. and B. make bets at a horserace on a joint account and $B$. receives the wimnings, A. can recover his share of the money or sue on a bill given to him by $\mathrm{B}$. for it: liere indeed there is no illagality in the proper sense (b). For the same reason

(y) Ficaz v. Nicholls (1846) 2 C. B. 501, 513, 15 L. J. ('. I. 125. 6y R. R. slt, a peculiar and apparently solitary eximple.

(i) dyerst v. Jenhins (1.78) L. li. $16 \mathrm{Eq} .275 .42 \mathrm{I}$. J. ("h. 690. Cp. . W. Chllun v. Hortimer (1812) (Ex. Ch.) 9 M. \& W. 636 .

(ii) Temolt y. Elliwtt (1795) I li. (1. P. 3. R. R. 7.5.

(b) Joll 11.

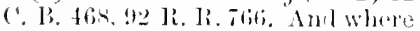
B. Wors moneys of his own and A.'s in betting. on the terms of divicling winninges in rertain proportions. A. can sue li, on a chepule riven for his share ol winnings: Bieston v. Berston (15ij) l lix, 11. 13, $15 \mathrm{l}$... 18x. 230. Ourre whether either of these cases is touched by the Gaming Ate 1s:2. ('p. anl dist. Minginsun v. Simpson (1877) 2 C. I'. 1) 76,$46 ; 1$. J. C. 1'. 192, where the transaction in question was hehl to be in substance a mere watger. A fine distinction lan lecen taken in two cases of purchate of lank shares thromeh brokers, where the contract mote omitted to sprecily the numbers of the sares as required by leceman's

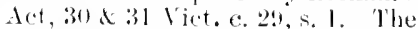
brokets, if they had mot completed the eontracts, might have boen herlatred defaulters and expelled from tha stuek Exelange. In
1) uty of agents and trustees to acconnt to principals notwithstancling collateral illegality. 
an agent employed to bet and collect winnings is bound to account to his principal for what he collects, though the losers could not have been compelled to pay $(c)$. But, by statute, such an agent cannot recover from his principal either any money paid by him in respect of losses or any reward ol commission for his services; nor can one who pays bets at the loser's request recover the money, whether he was employed in making the bets or not $(d)$. In like manner the right to an account of partnership profits is not lost by the particular transaction in which they were earned having involved a breach of the law (e). Nor can a trustee of property refuse to account to his cestui que trust on grounds of this kind: a trust was enforced where the persons interested were the members of an unincorporated trading association, though it was doubtful whether the association itself was not illegal $(f)$. So, if A. with B.'s consent effects a policy for his own benefit on the life and in the name of B., having himself no insurable interest, the policy and the value of it belong, as between them, to A. (g). If a man entrusts

Seymour v. Bridge (18s5) 14 Q. B, D. 460, Mathew J. hel I that the principal could not repuliate : in Perry v. Rarnett (1s-i) 1; Q. B. Div. 3st, 54 L. J. Q. P. 466. it was held that, if he did not know the usage of the sitock Exchange. he could.

(r) Bridger v. Sarage (18xt) 15 Q. P. Dir. 363. 54 L. J. Q. B. 464: the contract of agency is not a gaming or wagering contract. This does not seem to be affecterl by the Gaming Act, 1892. But he cannot be liable for failing to make bets or collect winuings, for the colleetion is precarious: Ghen v. Kittell (1889) 22 Q. B. 1). 681 , 58 L. J. Q. 1). 241 .

(d) The Gaming Act, 1892, ; Viet. c. 9 , amending $s$ s $y$ Vict. c. 109 , as interprcted ( $q u$. whether liuhtly) by Read F. Amderson (18st) 13 Q. B. Dir. 779.53 L. J. Q. B. 532 ; Tatum r. Reere [1893] 1 Q. B. 44. 62 L. J. Q. B. 30. Fomble the baintiff could not recover even if he did not know that the layments he made at the defenclaut s request were for bets. The Aet is not retrospective: Kniglet $r$. Lee $[1893]$ 1 Q. B. 41. 62 L. J. Q. B. 28.

(e) Sharp v. Taylor (1S49) 2 Ph. s01. Of course it is not so where the main ubject of the partnership is unawful: Thuaites r. Coul. thurate $1546 ;$ l Ch. $494 ; .65$ L. J. Ch. 238.

(f) sheppard s. Oxprefird (1855) 1 h. S J. 491, 103 R. H. 203.

(y) Winthimgton v. ("urtis (1575) 1 Ch. Dir. 419,45 L. J. Ch. 259. 
another as his agent with money to be paid for an unlawful purpose, he may recover it at any time before it is actually so paid; or even if the agent does pay it after having been warned not to do so $(h)$; the reason is that whether the intended paymont be lawful or not an authority may always be countermanded as between the principal and agent so long as it is not executed (i). It is the same where the agent is authorized to apply in an unlawful manner any part of the moneys to be received by him on account of the principal; he must account for so much of that part as he has not actually paid over $(i)$. The language of the statute $8 \& 9$ Vict. c. 109 , s. 18 , which says that no money can be recovered "which shall have been deposited in the hands of any person to abide the event upon which any wager shall have been marle" does not prevent either party from repudiating the wager at any time either before or after the event and before the money is actually paid over and recovering his own deposit from the stakeholder $(k)$. Also it does not apply to money or other" valuables deposited by way of sreurity or "cover" for performance of a wagering agreement ( $l$ ).

Where money has heen paid under an unlawful Money agreement, but nothing else done in performance of it, the money may be recorered hack. But in the decision which establishes this exception it is intimated that it recoverable back where agreement not excented. prohably would not be allowed if the agreement were

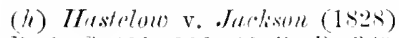
8 b. E ( . 221, 220, :32 li. li. 369, 373.

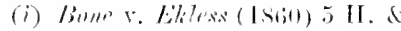
‥ $92 \div, 29$ 1. I. Ex. 133.

(h) Jigyle v. IVigys (]心i $2 \mathrm{Ex}$.

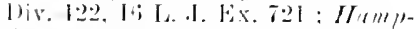

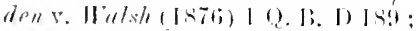

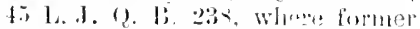
authorities are collectes and (a) sirderel: Trimble v. IJill (Isis) (.I. C.) on a colonial statute in the

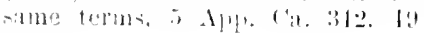

1 .
J. J. P. C. 4!9. ("). Perrele!n r.

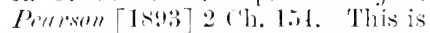
not afferes hy the Gaming Adet,

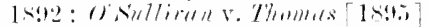

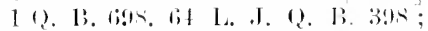

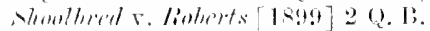

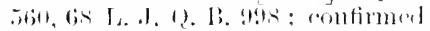
ly 1'. A. in Rinrye v. lahley amt

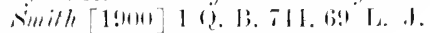
Q. B. .is?

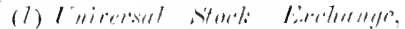

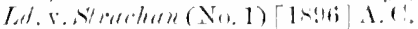

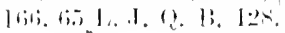


actually criminal or immoral (m). In general, "if money is paid or goods delivered for an illegal purpose, the person who has so paid the money or delivered the goods may recover them back before the illegal purpose" -or rather, before any material part of it-( $n)$ " is carried out; but if he waits till [some material part of] the illegal purpose is carried out, or if he seeks to enforce the illegal transaction, in neither case can he maintain an action" $(0)$. And the action cannot be maintained by a party who has not given previous notice that he repudiates the agreement and claims his money back $(p)$. In Tuylor v. Bouers (o) A. had delivered goods to $B$. under a fictitious assignment for the purpose of defrauding $A$.'s creditors. B. executed a bill of sale of the goods to $\mathrm{C}$., who was priry to the scheme, without A.'s assent. It was held that A. might repudiate the whole transaction and demand the return of the goods from C. In Symes v. Hughes $(q)$, a case somewhat of the same kind, the plaintiff had assigned certain leasehold property to a trustee with the intention of defeating his creditors; afterwards under an arrangement with his creditors he sued for the recovery of the property, having undertaken to pay them a composition in case of success. The Court held that, as the illegal purpose had not been executed, he was entitled to a reconveyance. It will be observed, however, that the plaintiff was in effect suing as a trustee for his creditors, so that the real question was whether the fraud upon the creditors should be continued against the better mind of the debtor himeelf. The cases abore mentioned as to recovering money from agents or stake-

(III) Tatpestenv. Rauntall (1801)

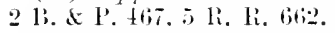

(ii) Kearley v. Thomsane (189ti) $2+$ (2. B. Dir. 7t2, 59 L. A. Q. B. 2xis: cl. Merman v. Jenthrer (1855) 15 2. B. Wiv. itil. it L. J. (2. B. 34 ').
(1) Pur Jlellish J.J. Tuylur v. bimers (1856) 1 Q. B. Div. $2: 1$, at 1. Bin.

(1) Palyart v. Lockie (1817) 6 II. \& $\therefore .29,1$ R. R. 3 SI. (7) $(1-7 i)$ L. R. 4 E $1.47,39$ L. I. (1). 301 . 
holders are also put partly on this ground, which, however, does not seem necessary to them $(r)$.

In certain cases the parties are said not to be $i n$ prri delicto, particularly where the unlawful agreement and the payment takes place under circumstances practically amounting to coercion. The chief instances of this kind in courts of law have been payments made by a debtor by way of fraudulent preference to purchase a particular creditor's assent to his discharge in bankruptey or to a composition. The leading molern case is Atkinson v. Denby (s). There the defendint, one of plaintiff's creditor's, refused to accept the composition, unless he had something more, and the plaintiff paid him 50l. before he executed the composition deed. It was held that this money could be recovered back. "It is true," said the Court of Exchequer Chamber, "that both are in delicto, because the act is a fraud upon the other creditors, but it is not par delictum, because the one has the power to dictate, the other no alternative but to submit." On the same ground money paid for compounding a penal action contrary to the statute of Elizabeth may he recovered back $(t)$. But where a bill is given by way of fraudulent proference to purchase a creditor's assent to a composition, and after the composition the lebtor chooses to pay the amount of the bill, this is a roluntary payment which cannot be recovered (u).

In equity the application of this doctrine has been the

l'arties not in pari delicts.

P'urchase of erelitor's assent to composition.

(i) Itustelow v. Jurlixou (1828) is

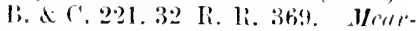

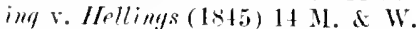
711. 15 L. I. Ex. lis. where that ease was dombted. deeides only this: A man cannot sue a stakcholiler for the whole of the sweepstakes he has won in a lottery. and then reply to the objection of illegality lhat it the whole thing is illegal he mont at all events recover his own slake. Allegans contuaria non ent andiendus,

(*) $(1860)$ i H. $\mathrm{A}$ x. $72 \mathrm{~s}, 30$ I. J. Ex, 361, in Ex. ('h, 7 H. N N. 931. 31 I. J. Ex. 3ti2: the chiof earlier ones are simith $\therefore$ Bromley (176ii) 2 Dour. 699); Simith v. r'uft

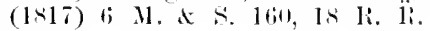
311.

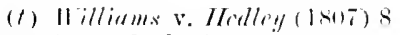
Lat, :37s, ! IR. Li. 173.

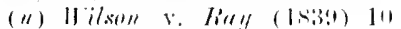
A. A k. S2, 50 li. li. 311.
Like rlectrine of equity. 
same in substance, thongh more raried in its circumstancer. The rule followed by courts of equity was thus described by Knight Bruce, L.J.: "Where the parties to a contract against public policy or illegal are not in pari delicto (and they are not always so) and where public policy is considered as advanced by allowing either, or at least the more excusable of the two, to sue for relief against the transaction, relief is given to him, as we know from various authorities, of which Osborne r. Trilliams [see below] is one " $(x)$.

Siecial ground: of relief.
On this principle relief was given and an account decreal in Osborne v. Williams (y), where the unlawful sale of the profits of an office was made by a son to his father after the son had obtained the office in succession to his father and upon his recommendation, so that he was wholly uncler his father's control in the matter. In Reynell v. Spryge $(z)$ an agreement bad for champerty was set aside at the suit of the party who had been induced to enter into it by the other's false representations that it was a usual and proper course among men of business to adrance costs and manage litigation on the terms of taking all the risk and sharing the property recovered. In a later case a mortgage to secure a loan of money which in fact was lent upon an immoral consideration was set acide at the suit of the borrower on the ground that the interest of others besides parties to the compt bargain was involved ( 1 ). A wider exception is male, as we have seen above, in the case of agreements of which the consideration is future illicit cohabitation between the parties. Apart from this particular claws of cases, it is submitted that the rule and its qualifications may be stated to this effect:

Statement

7. Noney paid or property delirered moler an un-

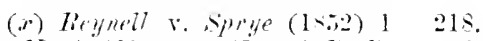

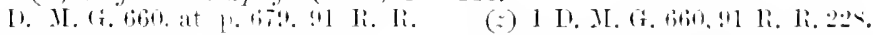
22.211.

(i) $(1911) 1 \div 10379.11 \mathrm{k}, \mathrm{li} . \quad \therefore 1$. 
lawful agreement camot be recovered back, nor thr of the me agreement set aside at the suit of either partyats quillitiel.

unless nothing has been done in the execution of the unlawful purpose beyond the payment or delivery itself (and the agreement is not positively criminal or inmoral?);

or unless the agreement was made under such circumstances as between the parties that if otherwise lawful it would be voidable at the option of the party seeking relief $(b)$;

or, in the case of an action to set aside the agreement, unless in the judgment of the Court the interests of third persons require that it shond be set aside.

8. Where a difference of local laws is in question, the lawfulness of a contract is to be determined by the law governing the substance of the contract (c).

Exception 1.--An agreement entered into by a citizen in violation of a prohibitory law of his own state cannot in any case be enforced in any court of that state.

Exception 2.-An agreement contrary to common principles of justice or morality, or to the interests of the state, cannot in any way be enforced.

(b) This form of explesinu seems justitied by IIare v. I'rarl.

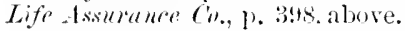

(r) Arcorling to our morlem authorities (see especially $I_{a}(\mathrm{ml} / \mathrm{\prime \prime}$ \&. (io. v. Talisker Distilli)y [1s!t] 1. (. 202) the question is rea]ly by what law the parties intencleal the contract to be governed : licey, conflict of laws. :17. The auxiliary roles for ascertaining that intellion, and so fixing the " proper Jaw of the contrate" which, hew ever, are plesumptions, and mot tixed rules of law, alle that $\cdots$ the

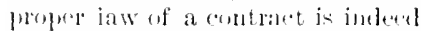
frimen fere ie the law of the contul ly where it js males (lexe lorei corth-

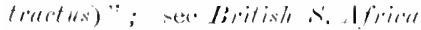

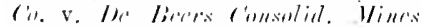

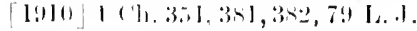

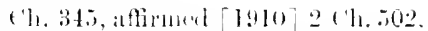
(: A.-." yet wlen a comtlact is makle in one comutry, but is wholly ar partially to be performed in another, then great weight will be grven to the Jitw of the plate of performanee (ler lori solutionis). as being pobalny the polner law of the contract, in regalel, at any rate, to acts to lee clolle there" Dices" op. rit. ativ. The framings "17 a contract in tedno (xelusively appongrate to a particular system of law is a stromg inclication of intention to makt that the eoverning law. For Anerian jullicial

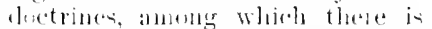

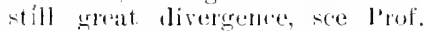
lescoh H. lieales articles in llav. law. liev. xxiii. 79, 191.
S. Cimtlict uf laws in space.

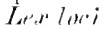
intratus pevails: miness excluter lig prohibitory inturicipal law of the fortum : ar andess the angeenunt is 
contrary to common justice or interests of the state. A- tois the first exception.

What we bere have to do with is in truth a fragment of a much larger subject, namely, the consideration of the local law governing obligations in general $(d)$.

The main proposition is well established, and it would be idle to attempt in this place any abridgment or restatement of what is said upon it by writers on Private International Law. The first exception is a simple one. The municipal laws of a particular state, especially laws of a prohibitory kind, are as a rule directed only to things done within its jurisdiction. But a particular law may positively forbid the subjects of the state to undertake some particular class of transactions in any part of the world: and where such a law exists, the courts of that state must give effect to it. A foreigner cannot sue in an English court on a contract made with a British suliject, and itself lawful at the place where it was made, if it is such that British subjects are forbidken by Act of Parliament to make it anywhere (e). It may be doubted whether such a contract would be recognized even by the courts of the state where jt was made, unless the prohibition were of so hostile or restrictive a character as between the two states as not to fall within the ordinary principles of comity (e.g., if the rulers of a people skilled in a particular industry should forbid them to exercise or teach that industry abroad). The anthorities already cited (pp. 30t, 305, ahove) ats to marriages within the prohibted degrees

(1) For the treat ment of it in this

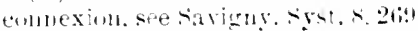

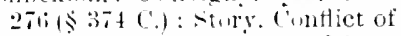

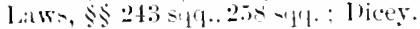
11. rit. chaps. 24. 25. Mr. We-tlike. lriv. Intern. Law. Bril ed. 25!?. 2tit). states the rules thus: IVhere a contract contemplated the violation of English law, it cannot be enforcel here, notwilhslanding that it may have heen valid by its proper law. Where a contlatet conflicts with what are deemed in England to be essential mablic ar moral interests, it cammot be nfured bere. notwithslanding that it may have been valid by it proper law.

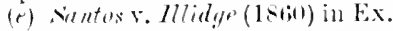
ch.. \& C. 1, X. s. at p. 8.4, 2! L. J. C. P' at 1. Bint, per Plack$\operatorname{limin} \mathrm{J}$. 
contracted abroad by British subjects may also be usefully consulted as illustrating this topic.

The second exception is by no means free from difficulties touching its real meaning and extent, $(f)$. There is no doubt that an agreement will not necessarily, though it will generally, be enforeed if lawful according to its proper local law. The reasons for which the court may nevertheless refuse to enforce it have been variously expressed by judges and text-writers, and sometimes in very wide language.

It may be taken for granted that the courts of a civilized state cannot give effect to rights alleged to be valid by some local law, but arising from a trunsaction plainly repugnant to the ius gentium in its proper sense-the principles of law and morality common to civilized nations. In other words a local law cannot be recognized, though otherwise it would be the proper law to look to, if it is in derogation of all civilized laws (g). This indeed seems a fundamental assumption in the administration of justice, in whatever forum and by whatever procedure. Likewise it is clear that no court can be bound to enforce rights arising under a system of law so different from its own, and so unlike anything it is accustomed to, that not only its administrative means, but the legal conceptions which are the foundation of its procedure, and its legal habit of mind $(h)$, so to speak, are wholly unfitted to deal with them. For this reason the English Divorce Court cannot entertain

$(f)$ "Whether an aetion can be snpported in England on a cont raet which is void by the litw of Eng. land, but valid by the law of the comntry where the matter is tratusacted, is a great question:" per Wilmot J. Roblinson v, Bland (176019) 2 Burr. 10\%3.

(I) It has betn litid dows that contracts to bribe or corruftly influence ofticers of a foreign government-even if not prohibited by the law of that government-will not be enforeed in the courts of the United States: Oscanyan v. Arms (o. 103 U. S. 261, 277; ant this not in the interest of the foreign govermment, hut for the sake of morality and the dignity of law at home.

(h) In German one might speals without any strangeness of the Re'eletshencusstsein of the Court.
As to the seconrl exception.
Transaetions contrary to eonmon prineiples of eivilized nations or founderl on a wholly foreign system of family relations, not recognized. 
a suit founded on a Mormon marriage. Apart from the question whether such marriages would be regarded by our courts as immoral iure gentium $(i)$, the matrimonial law of England is wholly inapplicable to polygamy, and the attempt to apply it rould lead to manifest absurdities $(k)$. Practically these difficulties can hardly arise except as to rights derived from family relations. One can hardly imagine them in the proper region of contracts.

But olvosi-

tion to minicipal principleof law nowt enough.

Contract for sale of slaves enfurced in sintus r. Illitive.

Again, judicial ob-ervations are to be found which go to the further extent of saying that no court will enforce anything contrary to the particular riews of justice, morality or policy whereon its own municipal jurisprudence is founder. And this doctrine is supported by the general acceptance of text-writers, which in this department of law must needs count for more than in any other, owing to its comparative porerty in decisive authorities. But a test question is to be found in the treatment of right: ari-ing out of slavery by the courts of a free country: and for England at least the decision of the Excheguer Chamber in Santos v. Illidge (l) has given such an answer to it as makes the prevailing opinion of the books untenable. Slavery is as repugnant to the principles of English law as anything can well be which has heen so far admitted by any other civilized system that iny serions question of the conflict of laws could arise upon it. There is no doubt that neither the status of slarery nor any personal right of the master or duty of the slare incirlent thereto can exist in England $(m)$, or within the protection of

(i) That in, amonge Werem nations. The rewention of $\mathrm{Hin}$ ln and Malmotan law in britiols

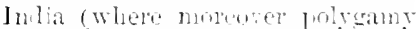
is in falct texcentional) -tands o is whily lifferent encound.

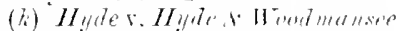

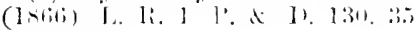

L. J. Mat. 5i.

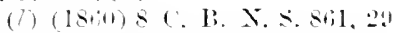
J. J. C. I' : its. reve. s. c. in court

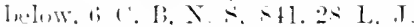
C. 1'.31\%.

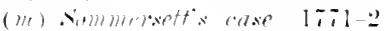
20 s. T. 1. 
English law $(n)$. But it long remained uncertain how an English comrt would deal with a contract roncerning slaves which was lawful in the country where it was made and to be performed. Passing over earlier and indecisive authorities $(o)$, we find Jord Mansfiekl assuming that a contract for the sale of a slave may be good here $(p)$. On the other hand, Best J. thought no action "founded upon a right arising out of slavery", would be maintainable in the municipal courts of this country $(q)$. In Santos v. Illidge $(q q)$ a Brazilian sued an English firm trading in Brazil for the non-delivery of slaves under a contract for the sale of them in that country, which was valid by Brazilian law. The only question discussed was whether the sale was or was not under the circumstances made illegal by the operation of the statutes against slave trading: and in the result the majority of the Exchequer Chamber held that it was not. It was not even contended that at common law the Court must regard a contract for the sale of slaves as so repugnant to English principles of justice that, wherever made, it could not be enforced in England. Nor can it be suggested that the point was overlooked, for it appears to have been marked for argument. But in Kaufman v. Gerson ( $r$ ) the Conrt of Appeal refused to enforce an agreement for compounding a criminal offence made in France between parties domiciled there, and valid by the law of France. The Court went on the ground that the agreement was

(11) Ti: on board an Englioh ship of war on the ligh neas or in lustile ocroupation of territorial

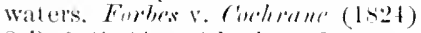

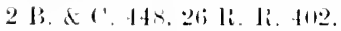

(in) They are collectal in llatgrase's argument in simmmersetto (ckisp.

(p) 24 st. 'T'r. 79.

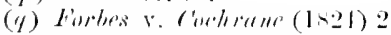

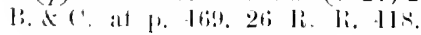

To same efïcet story, s.s:?, in spite of American anthitity beine adverse.

(qq) see mote (l) on p. Ios.

(i) 1901$]$ l k. 1: . .91, 7i: L. . .

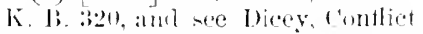
of law rez. "Arewe to believe

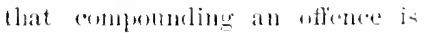
more obvionsly cost ratry to miversal ju-tiee than slave-tianling!.." 
obtained by duress, but on the facts as reported it is hard to see what duress there was beyond fear of the prosecution itself. Unless we may understand that the transaction was really mere blackmailing, it is not easy to reconcile the decision with Santos v. Illidge, which is of equal authority. However this may be, the earlier cases in which the dicta relied upon for the wider doctrine have occurred have in fact been almost always determined on considerations of local law, and in particular of the law of the place where the contract was to be performed.

Eartier cases eonsidered with reference to the general dinctrine.
'Thus in Robinson v. Bland ( $s$ ) the plaintiff sued (1) upon a bill of exchange drawn upon England to secure money won at play in France; (2) for money won at play in France; (3) for money lent for play at the same time and place. As to the bill, it was held to be an English bill; for the contract was to be performed by payment in England, and therefore to be governed by English law. For the money won, it could not have been recovered in a French court of justice $(t)$, and so could not in any case be sued for here; but as to the money lent, the loan was lawful in France and therefore recoverable here. Wilmot s. said that an action could be maintained in some countries by a courtesan for the price of her prostitution, but certainly would not be allowed in England, though the cause of action arose in one of those countries. Probably no such local law now exists. But if it did, and if it were attempted to enforce it in our courts, we could appeal, not to our own municipal notions of morality, but to the Roman law as expressing the common and continuous under231.

( $t$ ) Nor, under the eireumstances, in the marshal's court of honour which then existerl; but it seems the court would in any ease have deelinel to take notice of an extra. ordinary and extra-legal jurisdiction of that sort. 
standing of civilized nations. Such a bargain is immoral iure gentium.

In Quarrier v. Colston (u) it was held that money lent by one English subject to another for gaming in a foreign country where such gaming was not unlawful might be recovered in England. This, as well as the foregoing case, is not inconsistent with the rule that the law of the place of performance is to be followed. It must be taken, no doubt, that the parties contemplated payment in England. Then, what says the law of England? Money lent for an unlawful use camnot be recovered. Then, was this money lent for an unlawful use? That must be determined by the law existing at the time and place at which the money was to be used in play. That law not being shown to prohibit such a use of it, there was no unlawful purpose in the loan, and there was a good cause of action, not merely by the local law (which in fact was not before the Court $(x))$, but by the law of England. These cases do show, however, that the English law against gaming is not considered to be founded on such high and general principles of morality that it is to override all foreign laws, or that an English court is to presume gaming to be unlawful by a foreign law (y). Nevertheless it is now held that no action lies on an English cheque given in repayment of money lent for gaming in France, such

(u) (1842) l I'h. 147, ij li. li. 3il. Nuthing was saicl about the (iaming A(t) of $13: 35$.

(r) The liveal law might comceivably, without making graming unlawfiul, reduce delsts for money lent at play to the rank of raturail obligations or debits of homour not enfuceable by legal proess : if the view in the text be correct, the ('xistentex ol snch a law wombl make no difference in the binglish condet.

(y) Contra Savigny. who thinks laws relating to usury and ganting must be reckoned strictly compulsory (ron streng positiver. zwingemeler Natur)-i.e. must be afplied without regard to local law by every court within their allegianee, but are not to be regarded by any conte ontsicle it. Fyst, s. 27i. The old nsury laws were withont doubt supprined to "xpress the dictates of universal christian monlity. Some of the julgments in the recent buglish ('ases mentioned abure seem influenced by a view like Savigny's. 
gaming not boing unlawful there, and the consideration for the cherue being valid by French law. This appears to involve the doctrine that the Gaming Acts, so far as they invalidate securities giren in respect of gaming delots, apply to gaming in all parts of the world and without any reference to the local law. For otherwise it dloes not appear how anything in the English Acts was material in the case $(z)$. Still later the actual decision in Quarier $v$. Colston has been unanimously confirmed by a Court of Appeal differently constituted (a). The resulting state of our law, whaterer virtues it may have, has not that of simplicity.

In Hope v. Hope (b) an agreement marle between a hu-band and wifo, British sulijects domiciled in France, wovider for: two things which made the agreement roid in an Engli-h court: the collusive conduct of a dirorce suit in England, and the abandonment by the husband of the custoly of his children. It is worth noting that at the time of the suit the husband was resident in England, and it does not seem cloar that he had not recorered an English domicil. Knight Bruce L..J. put his julgment partly on the gromel that an important part at least of the provisions of the document was to be carried into effect in England. Turner L..J. did say in gonoral terms that a contract must be consistent

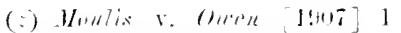

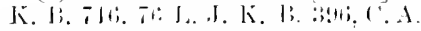
ste the disomenting jurlement of Fledeher Mroutull L. I. and Mr. Jicers meter in I. I. li. xxili.

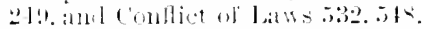

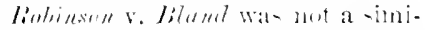

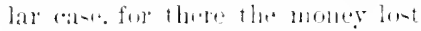
was distinetly stated lut in le

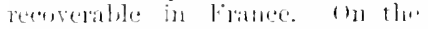
wher hasel the whly repert of $\mathrm{King}$

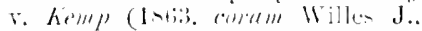

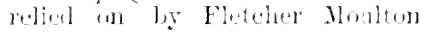

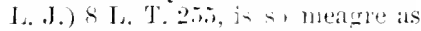

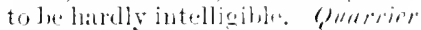

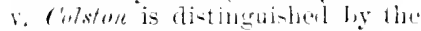

majorty of the ('mut (collins M.IR. asul (irgens-Ilandy I..J.) on the gloumbl loat there the alotion was mot on a recurity but on the mitrinal com-ioleralion; and tisis apluastote Fillore (nix) not:).

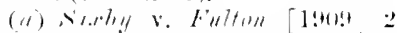

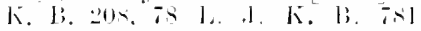
(Vanglam Williams. linckley am lienuen!y l...l.l.).

(b) $(\mathrm{j}, 35)-1) . \mathrm{H},(\mathrm{i}, 731, \mathrm{J11}$ li. li. . itu; ; per linierht Bunce l..l. - 1). Il. (i. at 1). Tfll; per Tumer I..J. at 1. T43. Jll li, li. 11, 31:? 311. 
with the laws and policy of the country where it is sought to be enforced, and he appears to have thought the provision as to the custody of the children was one that an English conrt must absolutely refuse to enforce, whether to be performed in England or not, and whether by a domieiled British subject or not. But this was not required by the decision and is not confirmed by. any later authority.

In Grell v. Levy (c) an agreement was made in France between an English attorney and a French subject that the attorney should recover a debt for the client in England and keep half of it. Our rules against champerty are not known to the French law: but here the agreement was to be performed in England by an officer of an English court (d). P'erhaps, indeed, the English law governing the relations and mutual rights of solicitor and client may be regarded as a law of English procedure; and in that character, of course, private arrangements cannot acquire any greater power to vary it by being made abroad (e).

As for agreements contrary to the public interests $A$ t. of the state in whose courts they are sued upon, it is obvious that the courts must refuse to enforce them without considering any foreign law. The the rule applies to the class of agreements in aid of hostilities against a friendly state of which we have already spoken. In practice, however, an agreement of this kind is more likely than not to be unlawful everywhere. Thus an agreement male in New York to raise a loan for insurgents in China would not be lawful in England; but it would also not be lawful in Now York, and for the samo reason. It might possibly happen, on the of her hand, that the United States should recognize such 
insurgents while they were not recognized by England; and in that case the courts of New York would regard the contract as lawful, but ours would not.

It should be borne in mind that the foregoing discussion has nothing to do with the formal validity of contracts, which is governed by other rules (expressed in a general way by the maxim locus regit actum); and also that all rules as to the conflict of laws depend on practical assmmptions as to the conduct to be expected at the hands of civilized legislatures and tribunals. It is in theory perfectly competent to the sovereign power in any particular state to impose any restrictions, however capricions and absurd, on the artion of its own municipal courts; and even to munieipal conts, in the absence of any paranount directions, to pay as much or as little regard as they please to any foreign opinion or anthority.

Conflict of laws in time. ?. Where jerformance beeomes unlawful. contract discolved.

9. Where the performance of a contract lawful in its inception is made mawful by any subsequent event, the contract is thereby dissolved $(f)$.

Explanation. - Where the performance is subsequently forbidden by a forcign law, it is deemed to have become not unlawful but impossible (y).

This rule does not call for any discussion. It is admitted as certain in Atkinson $r$. Ritchie $(f)$, and is sufficiently illustrated by the modern case of Esposito r. Bouden ( $f$, of which some account has already been given. It applies to negative as well as to affirmative promises. "It rould he absurd to suppose that an action should lie against parties for doing that which

(f) Athinson r. Ritrhie (1009) 10 East. 530,10 IR, R. 372, Espesitor. Bowden (1557) t E. \& B. 963. 24 L. J. Q. B. 210 ; in Ex. Ch. T E. d в. 763., 27 L. 1. 1. 1. 17. 11. 33:3. .3.34. $* n p \%$.
(4) Burtier v. Horlysem (181t) 3 i. d $\therefore$. 267.15 li. R. 485 ; Iromis v. Fredit Lyonnais (1884) 1.2 Q. 13. [iv. 584.53 L. J. Q. P. liti. 
the legislature has said they shall be obliged to do " $(k)$. To the qualification we shall have to retum in the following chapter on Impossibility.

10. Otherwise the validity of a contract is generally determined by the law as it existed at the date of the contract.

This is a wider rule than those we have already stated, as it applies to the form as well as to the substance of the contract, and not only to the question of legality but to the incidents of the contract generally $(l)$. It is needless to seek authority to show that an originally lawful contract cannot become in itself unlawful by a subsequent change in the law. It does not seem certain, however, that the converse proposition would always hold good. Perhaps the parties might be entitled to the benefit of a subsequent change in the law if their actual intention in making the contract was not unlawful.

The question may be put as follows on an imaginary case, which the facts of $\mathrm{Waugh} v$. Morris (m) show to be quite within the bounds of possibility. $A$. and $B$. make an agreement which by reason of a state of things not known to them at the time is not lawful. That state of things ceases to exist before it comes to tho knowledge of the parties, and before the agrement is performed, but A. refuses to perform the agreement on the ground that it was unlawful when made. Is this agreement a contract on which 3 . ean sue A.? Justice and reason seem to eall for an affirmative answer, and the analogy of $\mathrm{Iraugh}$ r. Morris (m), where the Court looked to the actual knowledge and intention of the parties at the time of the contract, is also in its farour.

(b) Iynu vo stropsthirr Inim

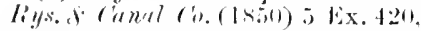
111).
10. Otherwise law at date of agreement governs.

ou. when agreement matle in ignorance of its illegality. and performanee afterwards becomes: lawful. (l) Six s. syst. \$ $392(\$ .135)$.

(ii) (1873) 1. 1. s o. 13. 2012. 12

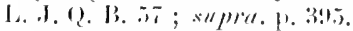


contract cons. Apart from this, a contract which provides for someditionit on performance becening lawful. thing known to the parties to be not lawful at the time heing done in the event, and only in the event, of its heing made lawful, is free from objection and valid as a conditional contract $(o)$ : unless, indeed, the thing were of such a kind that its becoming lawful could not be properly or seriously contemplated $(p)$.

Gencral result - an to knowledge of parties.

It may be useful to collect here in a separate form the results of the foregoing discussion, so far as they show in what circumstances and to what extent the knowledge of the parties is material on the question of illegality.

$\dot{a}$. If the immediate ohject of agreement he unlawful, the knowledge of either or both parties is immateriat $(q)$ : except, perhaps, where the agreement is made in good faith and in ignorance of a state of things making it unlawful: and in this case it is submitted for the reasons above giren that the agreement becomes ralid if that state of things ceases to exist in time for the agreement to be lawfully performed according to the original intention.

B. A. makes an agreement with $B$. the execution of which would involve an unlawful act on B.'s part (e.g., a breach of B.'s contract with C.).

If A. does not know this, there is generally a good

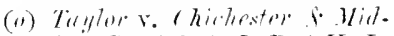
hurt Ri\%. (\%. (18Ri ) I. R. \& H. L. 1i2s, 6ito, 6it., 3:1 [. J. Ex. 217:

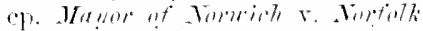

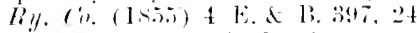

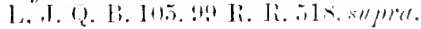
1.. $2 ! \cdots$.

(d) (1., D. 1s. 1. de cont, empt. at 2 (Taulan). Liberam homi. nem sientes emere non formmus: serl nee talis emptio ant -tipulatin admittenda et : r"lm strmes crit. quanvis lixerimus fut uras res emi fores : nee enim fia est eiromoli ar-11-cx+pectare. (y) A strong illustration of this will be found in lritlinsom $r$.

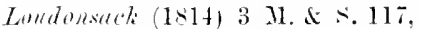
1.5 R. L. 438. In sinth Ifrican limentes r. King [189! $2 \mathrm{Ch}$.

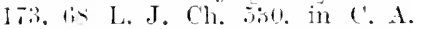
1:100) l Ch. 273.69 L. J. Ch. 17l, the parties were alvived that a clawe of their agreement wis. or might be helil. invalid by the loeal law. but executes the agreement containine that clanse for what it might be worth. Nothing decided in the case turned upon this rather curions -tafe of facts 
contract, and A. can sue B. for a breach of it, though B. cannot be compelled to perform it or may bo restrained $(r)$ from performing it. We may say (and must, it seems, where the illegality is such as to involve a personal incapacity on B.'s part to make such i contract) that B. is deemed to warrant that he can lawfully perform his promise.

The contract is voidable at A.'s option on the ground of fraud, if $B$. has falsely stated or actively concealed the facts; but not otherwise $(s)$.

If A. does know the facts, the agreem'nt is void.

$\gamma$. A. makes an agreement with $B$. who intends by means of the agreement or of something to be obtained or done under it to effect an unlawful or immoral purpose.

If A. does not know of this purpose, there is a contract voidable at his option when he discovers it.

If he does know of it, the agreement is void.

(r) Jones v. North (1855) L. R. be quite safe in drawing any 19 Eq. 426,44 L. J. Ch. 388. general conclusion from a decision

(*) Beachey v. Brown (1860) E. on the contract to marry. Anul B. \& L. 796, 29 L. J. Q. B. 105, ep. D. 1s. 1. de cont. empt. is \$3. 113 li. 1i. 592 ; but one can never 


\section{CHAPTER VHI.}

\section{Impossible Agreamexts.}

Performance of asreement may be imiosible in it st:lf (ligerically a lilysicaliy).

Dy law (incem-intent with leugal principle, dic.)

Ax agreement may be imposible of performance at the time when it is mate, and this in various ways.

It may be imposible in itrelf; that is, the agreement it elf may insolve a contradiction, as if it contains promises inconsi-tent with one another or with the date of the agreement. Or the thing contracted for may be contrary to the course of nature, "quod natura fieri non concedit" (a).

As if a man shoukd undertake to make a river rom up hill; to make two splieres of the same substance, but one twice the size of the other, of which the greater should fall twice as fast as the smaller when they were both dropped from a height; or to construct a perpetiral motion $(b)$.

It may be impossible by law, as being inconsistent with some legal prineiple or institution.

As in the catses already considered in Chap. V. of attempts to enable al stranger to a contract to sue upon it lyy agreement of the parties; or as if a man should gire a bond to secure a simple contract with a collateral agreement that the simple contract debt should not be merged (c) or should corenant to create a new manor. Again it is the general rule of law that a man

(a) 1). 45.1 de . . . . 35. 11.

(b) Of thene larticul:ar imposat liblities the secomel was sulpureal to be an elementary fitct before fialileo male the exirement; the last continues to be bow and then attenuted by lersons who linow merhanieal handicraft without meehanital principlen: we choose the examples as all the more instructive on that account.

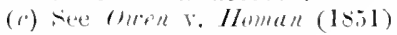

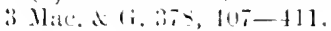


may contract for the sale of a specific thing which is not his own at the time. But if the thing be already the buyer's own, or cannot be the subject of private ownership at all (as the site of a public building, tho Crown jewels, a ship in the Royal Navy) $(d)$, the agreement is impossible in law.

It may be impossible in fact by reason of the existence of a particular state of things which makes the performance of the particular contract impossible. As where the contract is to go to a certain island and there load a full cargo of guano, but there is not enough guano there to make a cargo $(e)$ : or a lessee covenants to dig not less than 1,000 tons of a certain kind of clay on the land demised in every year of the term, but there is no such clay on the land $(f)$.

Moreover the performance of a contract which was possible in its inception may become impossible in either the second or third of these ways. The stiong and concurrent tendency of the modern authorities is to avoid laying down absolute rules in any case, and to give effect as far as possible to the real intention of the parties-in other words, to treat the subject as one to be governed by rules of construction rather than by rules of law. As evidence of intention in such matters is very seldom forthcoming, the Court has to fall back on its own view of what reasonable men would intend if they had thought of the contingency. Still actual intention will prevail if and so far as it can be ascertained. Before proceeding to details we may give an outline of the results.

1. An agreement is void if the performance of it is uither impossible in itself or inpossible by law.

(d) In lioman law "guorum commercium non sil, ut publica quate non in pecumia populi sed in publics u*II habeantur, ut est Campus Martius." II. 1r. I de: cont. cmpt. t; pr.

(a) I/lls v. simghme (1slii) 15

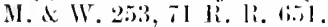

(f) ilifferd ve if ittls $(1,80)$

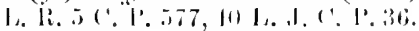

In fact (inconsis. tent witl particular state of facts existing at the times).

Or may lecende improsible in law or in fact. Acoriding to morlem authonities the rules are rules of constrution. 
When the performance of an agreement becomes impossible by law, the agreement becomes void.

2. An agreement is not roid merely by reason of the performance being impossible in fact, nor does it become roid by the performance becming impossible in fact without the default of either party, unless according to the true intention of the parties the agreement was conditional on its performance being or continuing possible in fact.

Such an intention is presumed where the performance depends on the existence of a specific thing, or on the presence or continuance of conditions contemplated by the parties as necessary for the fulfilment of the contract according to its true intention, or on the life or health of a party who undertakes personal services by the contract.

Sometimes this principle is applied even where the literal performance of the contract aceording to its terms remains possible $(g)$.

3 . If the performance of any promise becomes impossible in fact by the default of the promisee, the promisor is discharged, and the promisee is liable to him under the contract for any loss thereby resulting to him.

If it becomes impossible by the default of the promisor, the promisor is liable under the contract for the non-performance.

1. Agreement impossible in itself is vidu on the ground of impossibility, which the parties as reasonable
1. On the first and simplest rule-that an agreement impossible in itself is void-there is little or no direct authority, for the platin reason that such agreements do not occur in practice; but it is alwalys assumed to be so. Strictly this is not an absolute

(y) Sce the "coronation cases" cited below. These are really reculiar cases of contracts mate on an express or tacit condition, and might well have been derisled withont any attempt to bring them uncler a wisler wule. 
rule of law, but a rulo of interpretation; the impossible nature of the promise shows that there was no real intention of contracting and therefore no real agreement. Brett J. said in Clifford v. Watts $(h)$ : "I think it is not competent to a defendant to say that there is no binding contract, merely because ho has engaged to do something which is physically impossible. I think it will bo found in all the cases where that has been said, that the thing stipulater for was, according to the state of knowledge of the day, so absurd that the parties could not be supposec to have so contracted." The same view is also distinctly given in the Digest $(i)$. It seems to follow then that the question is not whether a thing is absolutely impossible (a question not always without difficulty), but whether it is such that reasonallo men in the position of the parties must treat it as impossible $(k)$.

On the other hand a thing is not to be deemed impossible merely because it has never yet been done, $\mathrm{Or}^{\circ}$ is not known to be possible. "Cases may be conceived," says Willes J. in Clifford v. Watts (h), "in which a man may undertake to do that which turns out to be impossible, and yet he may still be bound by. his agreement. I am not prepared to say that thero may not be cases in which a man may have con-

(h) $(1870)$ L. F. 5 C. P. p. js8.

(i) 1). 41. 7. de obl. et act. :31. Non selum stipulationes . . sed diane celeri pruxpe contraclus . . impossibili comblicione interlowitil alefue mullius momenti smot, sula in ea re, phae cx duormm plurinmve eonsensu agitur. omnium rolumbs spectetur ; yourum procoll dubio in luumsmorli ach talis cogritalio est, ut miluil agi exisliment alunsilat eai comlirime quam sciant erse inpossibilem.

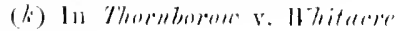

(1706) 2 Ld. Raym. 1161, a promixo to deliver two grains of rye certain Monday, and four, cirlut, sixjeen. de., mu alternate llmulays following for a year, was satil by llalt to be "only imposible with respect to the defemdant's ability," though it was urged for the defendaul that "all the rye in the worth wats nol so much," No juclentent was given, the case being settlent. The joing that the parties comlel mot hase been in eamest was mot made. men must be presumed to know, exchuling animus. rontrallendi.

A thinge is nut impossible becanse not lintenente be posibible. 
tracted to do something which in the present state of scientific linowledge may be utterly impossible, and yot he may have so contracted as to warrant the possibility of its performance by means of some new discovery, or be liable in damages for the non-performance, and cannot set up by way of defence that the thing was impossible." Indeed many things have become possible which were long supposed to be impossible; and this not only in the well-known instances of mechanical invention and the applications of sciontific discovery to the arts of life, but in the regions of pure science and mathematics. Formerly it seemed impossible that we should ever have direct evidence of the physical constitution of the sun and fixed stars: we now have much. In the rarlier editions of this hook the case of an agreement to malie a practicable flying machine was propounded with some diffidence. Now several persons are ready, and publicly offer, to sell and warrant such machines.

In testing the seriousnoss and validity of an agreement by the presumed intention of the parties, we must remember that they are also presumed to have the oldinary linowledge of reasonable men. Thus the Indian Contract Act ( $s$. 56, illust. a), says that an agreement to discover treasure by magic is roid: but it is notorions that in some regions of British India the partios might really helieve in the efficacy of magic for the purpose. If a promice believes in the possihility of the performance nominally promised, and the promisor does not, the case will generally he redueed to one of fraul.

- Practioal inl] w... sibilits, "i, . extreme cost or ditticults, not material.
If a man may hind himself to do something which is only not known to be impossible, much more can he hind himself to do something which is lnown to be possible, however expensive and troublesome. For some purposes practical imposibility may he treated 
as equivalent to absolute impossibility: a ship is said to be totally lost when it is in this sense practically impossible, though not physically impossible, to repair her $(l)$. But this does not apply to the matter now in hand $(m)$.

The other conceivable cases of absolute impossibility may be briefly dismissed. Inconsistent or, in the usual technical phrase, repugnant promises contained in the same instrument cannot of comrse be enforced: this however is rather a case of faihure of that certainty which, as we saw in the first chapter, is one of the primary conditions for the formation of a contract. There may also be a repugnancy as to date, as if a man promises to do a thing on a day already past. Practically, however, such a repug-

Jogitual imposibility. Riepugnant promises: rejugnancy between late :mul contents of instrumenit. In must ease's only apparent, ant deres not aroid the contract. nancy can haxdly be more than apparent. Either it is mere clerical or verhal error, in which case the Court may correct it by the context $(n)$, or it arises from the terms of the agreement being fixed before and with reference to a certain time but not reduced into writing and executed as a written contract till afterwards. In such a case it must be determined on the circumstances and construction of the contract whother the stipulation as to time is to be treated as having ceased to be part of the contract (in other words, as having been left in the statement of the contract by a common mistake), or as still capable of giving an independent right of action. At all events it cannot be treated as a condition precerlent

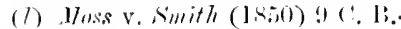

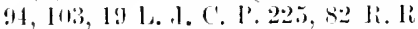
307.

(iii) See per Mellor I., I. I. G Q. 1. 123, jer Ilammen J. it. 127. These dicta acem to gon even heyomel what is siald in the text, l, al are pobably limited in the or true effect to what is here called impresibitity in fact. (n) Siee Fitall v. Jomes (1sis) is F. d I. 238, 24 I. J. (2. li. 2!3, 10.) fi. li. fis, where a loste payable two months after late, and macle in dammary, lsos, was dated by mislake 1sid, lout aconse it was written "due the th March, Is.s.," lihe court helel that this sullireiently corrected lhe mistake, and might bx: baken as a direction to real ifor 4. 
so as to prevent the rest of the contract from being cnforeed $(0)$.

Promisor It follows a fortiori from the principle laid down not exeused by relution by Willes J. (p. 421, above) that difficulty, inconimpossibility, renicnce, or impracticability arising out of circum i.r. not having the means of verformance. stances merely relative to the promisor will not excuse him. "Impossibility may consist either in the nature of the action in itself, or in the particular circumstances of the promisor. It is only the first or ohjective kind of impossibility that is recognized as such by law. The second, or subjective kind, cannot he relied on by the promisor for any purpose, and does not release him from the ordinary consequences of a wilful non-performance of his contract. On this last point the most obvious example is that of the dehtor who owes a sum certain, but has neither money nor credit. There is plenty of money in the worll, and it is a matter wholly personal to the

One may watrant acts of third fersons, wr natiral cerent in itself lossible. debtor if he cannot get the money he has bound him. self to pay" $(p)$. Therefore a man is not excused who chooses to make himself answerable for the acts or conduct of third persons, though beyond his control; or cren, it seems, for a contingent crent in itself possible and ordinary but beyond the control of man. It has heen said that a corenant that it shall rain to-morrow might be $\operatorname{good}(q)$, and that "if a man is bound 10 another in 20l. on condition quod pluvia deliet plucre cras, there si pluxia non pluit cras the obligor shall forfeit the lond, though there was no default on his part, for he knew not that it would not rain. In like manner if a man is hound

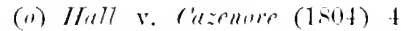
East. lit, 7 I. li. ill, where the comet agreed to this cxtent. but differel on the other anestion.

(p) Savigny. (01)1. 1. 38t.

(1) ligy Danke J. C'anham r.

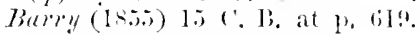

2f I. J. 1. T. at P. 16r. 101 li. R. at p. ils. ler cur. Baily v. Jo

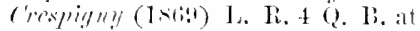
p. 1s.. Int qu. woukl not such a contract be a mere wager in almost any conceivable eircumstances? 
to me on condition that the Pope shall be here at Westminster to-morrow, then if the Pope comes not there is no default on the defendant's part, and yot he has forfeited the obligation" $(r)$. "Generally if a condition is to be performed by a stranger and he refuses, the bond is forfeit, for the obligor took $11 \mathrm{pm}$ himself that the stranger should to it" (s). "If the condition be that the obligor shall ride with I. S. to Dover such a day, and I. S. does not go thither that day; in this case it seems the condition is broken, and that he must procure I. S. to go thither and ride with him at his peril" $(t)$. Where the con. dition of a bond was to give such a release as hy the Court should be thought meet, it was held to be the obligor's duty to procure the judge to devise and direct it $(u)$. If a lessee agrees absolutely to assign his lease, the lease containing a covenant not to assign without licence, the contract is binding and he must procure the lessor's consent $(x)$. But on the sale of shares in a company, on the Stock Exchange at all events, the vendo $i$ is not bound to procure the directors' assent, though it may he required to complete the transfer (y), and it serms at least doubtful whether he is so bound in any case $(z)$.

Where an agreement is impossible by law there is no doubt that it is void: for example, a promise by a servant to discharge a deht due to his master is rojd, and therefore no consideration for a reciprocal

(r) Per Brian ('. I. Mich. 22 Hal. 11.20. The whole disemation there is rurious. and wedl worth perusal in the beoli at larere. Note lirian's changer of opinion ats to the plea in the case at bar, ad fl't.

(s) Ro. Ab. I. 152, I. ,1, ti.

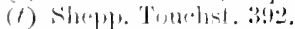

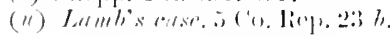

(r) Llund v. ('rispe (1813) $\mathrm{s}$ Tamit. 219, 14 li, Ji. 7H1; cp.

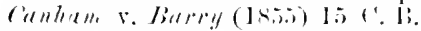

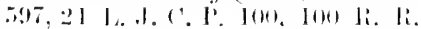
5.1):

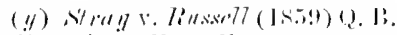

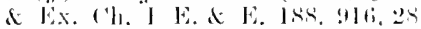

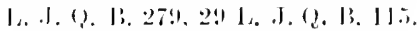

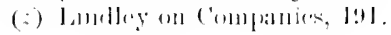

Agreenent impusible in law is roill. 
When prerformance lecomes imponible l, law 1' misis is sxemerle liaily r. le cresilgur.

promise (a); though, by the rule last stated, a promise to procure his master to discharge it would (in the absence of any fraudulent intention against the master) be good and binding. And when the performance of a contract becomes wholly or in part impossible by law, the contract is to that extent discharged. A good instance of this is Baily v. De Crespirm! (b). There a lessor covenanted with the lesere that neither he nor his heirs nor his assigns would allow any bulkling (with certain small exceptions) on a piece of land of the lessor"s fronting the demisul premices. Afterwards a railway enmpany purchased this piefes of land under the compulsory gowers of an Act of l'arliament, and built a station upon it. The beseres sued the lessor upon his covenant; but the Court liek that he was discharged hy the subsequent Act of Parliament, which put it out of his power to perform it. And this was agrecable to the true intention, for the railway company coming in under compulsory powers, "whom he the corenantor] could not bind by any stipulation, as he could an asignee chosen hy himself," was "a new lind of asign, such as was not in the contemplation of thr praties when the contract was entered into." Nor was it material that the company was only empowered liy Jarliament, not required, to build a station at that particular place (c). As the American phase concisely puts it, a covenant of walranty does not extend to the state in the exercise of its eminent domain (d). If a subserpuent Acet of Parliament making the performance of a contract impossible were a luivate Act obtained by the contrating party himself,

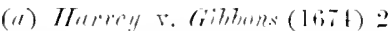
Jev. libl. It is alled an illogal ansoinleration. hut such verbal anfu-ions are custant in the early regurte. (h) (1.869) L. IR. 4 Q. P. 1811.39 I...1. (1. 13. 3..

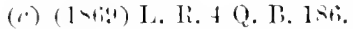

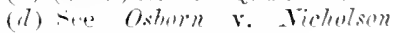
(I-il) 13 Wall, at p. firi. 
he might perhaps remain bound by his contract as if he had made the performance impossible by his own act (of which afterwards): but where the Act is a pullic one, its effect in discharging the contract cannot be altered by showing that it was passed at the instance of the party originally bound $(e)$.

The case of a man agrecing to buy that which is already his own is a peculiar one. IIere the performance is impossible in law; and the agreement may be regarded as roid not only for impossibility but for want of consideration. But this class of cases is by its nature strictly limited. No man will knowingly pay for what belongs to him already. If on the other hand the parties are in doult or at variance as to what their rights are, any settement which they come to in good faith, whatever its form, has the character of a compromise. There remain only the cases in which the parties act under a common mistake as to their respective rights. The presence of the mistaken assumption is the central point on which the whole transaction turns, and is decisive in fixing its true nature. Hence it is the most conspicuous element in practice, and these cases are treated as belonging not to the head of Impossibility but to that of Mistake. I'nder that head we recur to them in the next chapter. It is hardly needful to add that a contract for the sale of something which the seller has not at the time is perfeetly good if the thing is capatble of private owmorshipl. The effect of the contratet is that he hinds himself to acrguire a lawful title to it by the time alpuninted for completing the contract.

The gencral principles ahore considered are woll bronght together in the 1)igest, in a passage from

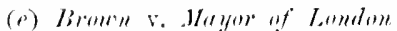
(Istil) ! ( . I:. N.

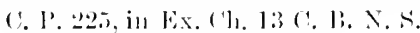

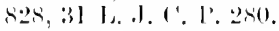

Buying (1)e's own foreperty.
Exposition of $\mathrm{s}, 11011 \mathrm{t}$ principles in Lim II: III ] 
a work of Venuleius ( $f$ ) on Stipulations. "Illud inspiciendum est, an qui centum dari promisit confestim teneatur, an rero cesset obligatio donec pecuniam conficere (g) possit. Quid ergo si neque domi habet neque inveniat creditorem? Sed haec recedunt ab impedimento naturali et respiciunt ad facultatem dandi $(h)$.

E.t generaliter causa difficultatis ad incommodum promissoris, non ad imperimentum stipulatoris pertinet [i.e. inconvenience short of impossibility is $n o$ answer]. . . . Si ab eo stipulatus sim, qui efficere non possit, cum alii possibile sit, iure factam obligationem Sabinus scribit." He goes on to say that a legal impossibility, $e . g$. the sale of a public building, is equiralent to a natural impossibility. "Nec ad rem pertinet quod ius mutari potest rot irl quod nune impossibile est postea possibile fieri; non enim secundum futuri temporis ius sed secundum praesentis aestimari debet stipulatio", (i): (as if it should be contended that a corenant to create a new manor is not a corenant for a legal impossibility, because peradrenture the statute of Quia emptores may be repealed.) All this is in exact accordance with English law.

2. $\mathrm{Per}-$ formance imporible in fact : no excines where contract is absolute.

2. We now come to the cases where the performance of an agreemont is not impossible in its own nature, but imposible in fact by reason of the particular circumstances. It is a rule admitted by all the authorities, and supported by positive decisions, that impossibility of this kind is in itself no excuse for the failure to perform an unconditional $(k)$ con-

(f) See Foby's Introuluction, $p$. elxxxiii.

(f) Hommsen's correretion for ruterer, which would mean "pay". or "contribite." nut "procure."

(h) For the explanation of a not very cleal illi-tration which follows here, and is omitterl in our text, see sar. ohl, 1. 38,

(i) 11. 2.7 1. le r.0. 137 . $\$ \$ t-1$.

(k) It may be shown, and not necessarily liy the presence of ex. jeress saving words, that the faet or erent was outsile the risks 
tract, whether it exists at the date of the contract, or arises from events which happen afterwards $(l)$. Thus an absolute contract to load a full cargo of guano at a certain island was not discharged by there not being enough guano there to make a cargo $(\mathrm{m})$ : and where a charter-pirty required a ship to be loaded with usuat despatch, it was held to be no answer to an action for delay in loading that a frost, had stopped the navigation of the canal by which the cargo would bave been brought to the ship in the ordinary course $(n)$. Still less will unexpected difficulty or inconvenience short of impossibility serve as an excuse. Where insured premises were damaged by fire and the insurance company, having an option to pay in money or reinstate the building, elected to reinstate, but before they had clone so the whole was pulled down by the authority of the Commissioners of Sewers as being in a dangerous condition; it was held that the company were bound by their election, and the performance of the contract as they had elected to perform it was not excused (o). So again if a man contracts to do work according to orders or specifications given or to be given by the other contracting party, he is bound by his contract,

undertaken by the fromisor: in other worts that the enntraet was not uncombitional.

(b) Athinson v. Ritchie (1809) 10 East, 530, 10 R. R. 372.

(mi) Hills v. Suglerue (1846) 15 M. \& W. 253, it li li, (ii). This catse turncel in part on the monsuat inciclent of the charter-party provilling that the cargo was to be fouml by the owner. "He is to receive freight at a high rate, anıl it looks very mueh like a contrat forsuply ying guatuo at that price:" larke 15, at $p, 261$. Whether it can be reconeiled with later aullurities or not (see A $A 1, \sin , 317$ ) it is tor prenoliar to be a siffe gruicle. (ii) Kearan v. Iearisen (Isisi) 7 H. A N. 38ti, 31 L. J. Ex. I. So where a given number of days is allowed to the charterer for unloakling, he is held to take the risk of any ordinary vicissitules which may cause delay : Thios v. Tiyers. (1576) I Q. B. D. 24t, 45 L. .. Q. 1..511.

(1) Broun v. Ringal Iusuranop (i) (1859) 1 L. de E. S.3, 25 L. I. Q. 13.27i, diss. Erle J, who thought such a reinstatement as was contemplated by the contratet (not being an entire reluniluling hamel become impossible ley the alet of the law.
A fintioni where only inconventient or iuluacticable. 
although it may turn out not to be practicable to do the work in the time or manner prescribed. In Jones v. St. John's College, Oxford $(p)$ the plaintiffs contracted to erect certain farm buildings according to plans and specifications furnished to them, together with any alterations or additions within specific limits which the defendants might prescribe, and subject to penalties if the work were not finished within a certain time. And they expressly agreed that alterations and additions were to be completed on the same conditions and in the same time as the works under the original contract, unless an extension of time were specially allowed. It was held that the plaintiffs, having contracted in such terms, could not aroid the penalties for non-completion by showing that the delay arose from alterations being ordered by the defendants which were so mixed up with the original work that it became impossible to complete the whole within the specified time $(q)$. In thorn r. Mayor of London (r) a contractor undertook to execute works accosting to specifications prepared by the angineer of the corporation. It turned out that an important part of the works could not be executed in the manner therein deseribed, and after fruitless attempts in which the plaintiff incurred much expense, that part had to be executed in a different way. It was held that no warranty could be inplied on the part of the corporation that the plans were such as to make the work in fact reasonably practicable, and that the plaintiff could not recover as on such a warranty the value of the work that had been

(p) (1);(1) J. R. \& Q. B. 11:124, to L. .I. (). H. 80.

(1) This case was arerned on denumrer. so that the agreement was almittel as plealed. Sich an arrement will not be implicel. or inferred from ambiguous terms: Intd $v$. (leurton [1897] Q. B. 5(i3, bit L. .J. Q. 1. 477, C. A.

(r) $(15,15)$ L. R. 9 Ex. 163. in Ex. ('h, lo Lx. 112, atil. in H. L.

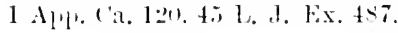


thrown away. The judgments in the House of Lords leave it an open question whether, assuming the extra work thus caused not to have been extra work of the kind contemplated by the contract itself and to bo paid for under it, the plaintiff might not have recovered for it as on a quantum meruit. In short, it is admitted law that generally where there is a positive contract to do a thing not in itself unlawful, the contractor must perform it, or pay damages for not doing it, although in consequence of unforeseen accidents the performance of his contract has become unexpectedly burdensome or even impossible $(s)$.

Where the performance of a contract becomes impracticable by reason of its being forbidten by a foreign law, it is deemed to have become impossible not in law but in fact. In Burker v. Hodyson. $(t)$ Prohilition by fincigne liw $=$ int josibibility intercourse with the port to which a ship was ehartered was prohibited on account of an epidemic prevailing there, so that the freighter was prevented from furnishing a cargo; but it was held that this did not dissolve his obligation. So if the goods are confiscated at a foreign port that is no answer to an action against the shipowner for not delivering them $(u)$. But where the effect of a foreign law is to prevent both parties from performing their respective parts of the contract, both are excused $(x)$.

(s) Taylor v. C'alduell (186i3) 3 B. \& s. $826,833,32$ L. J. Q. li. 164, 166. This rule does not extend. however, beyont expressis cont racts. An undertaking to be answerible for delay caused by ris maior, on ot ber eatuses beyond theeont ractors contret and a arat from any default on his patt, cannot be made part of an inplied contricet: Ford v. ('otesemer/h (1870) (kx. ('h.) L. li. 5) (2. 13. 54t, 39 L. J. Q. I?. IRs;

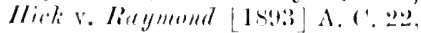

(i2 T., J. Q. T., 98.

(t) $(1 \& 14) 3$ M. \& Ji. li. 4si. ep. Jacols v. C'ridit Lyoumatio (1864) 12 Q. R. Div. 5.4. 5i) I. J. (. li. lot;, where the (2xpertation of the caren contracted for was forbidelen by loxal law.

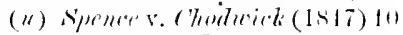

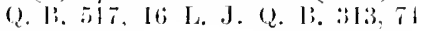
li. li. 117 .

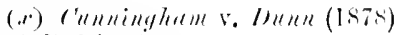
3 (.) I. liv. 113. 
()ligation of temaint to llay rint though demised pemises aceiclentally dentreged.

To impos. sibility here ;

Certain cases, of which Paradine v. Jane (y) is the leading one, are often referred to upon this head. The effect of them is that the accidental destruction of a leasehold building, or the tenant's occupation boing otherwise interrupted by inevitable accident, does not determine or suspend the obligation to pay rent $(z)$. In these cases, howerer, the performance of the contract does not really become impossible. There is obriously nothing impossible in the relation of landlord and tenant continuing with its regular incidents. We must be careful not to lose sight of the two distinct characters of a lease as a contract (or assemblage of contracts) and as a conveyance. There is a common misfortune depriving both parties to some extent of the benefit of their respective interests in the property; not of the benefit of the contract, for so far as it is a matter of contract, neither party is in a legal sense disabled from performing any material part of it. The expense of getting housed elsewhere, or the loss of profits from a business carried on upon the premises, may render it difficult or even impracticable for the tenant to go on paying rent. But it does not render the payment of his rent impossible in any other sense than it renders the payment of any other debt to any other creditor impossible (a). It is a personal and relative "causa difficultatis;" which, as we have seen, is irrelevant in a legal point of view. The lessee's special covenants, if such there be, to paint the walls at stated times or the like, do become impossible of performance by the destruction of their subjectmatter, and to that extent, no doubt, are discharged

(4) (1618) Aleyn 26.

() Lerds v. ihecthem $(182 \pi) 1$ sim. 146. 27 R. R. 1nl: Letit v.

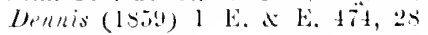

L. J. Q. 1. 16.8117 R. li. 292.

(a) Sie per Lord Blackburn, 2 Aln. Ca. 7 . 
or suspended as being within the rule in Ta!ylor $v$. Caldwell, which we shall immediately consider. Only to this limited extent is there any precise resemblance to the wider class of cases where the performance of a contract becomes in fact impossible. The true analogy is in the nature of the question which the rule of law has to decide: namely, whether the contract is in substance and effect as well as in torms unconditional and withont any implied exception of but a similar question, ria., whether the contract is really mencollditional. inevitable accident. We shall see that this is always the real question. The answer being berc determined by Paradine v. Jane (b), it was held in the later cases $(c)$ (about which difficulties are sometimes felt, but it is submitted without solid reason) that it is not affected by the landlord having protected himself by an insurance, which is a purely collateral contract of indemnity. There might indeed be a further collateral agreement between the landlord and tenant that the landlord should apply the insurance moneys to rebuilding the premises. Such an agreement would be good without any new consideration on the tenant's part beyond his acceptance of the lase, and probahly without being put into writing $(d)$. On the other hand it is often a term of the lease that tho tenant shall keep the premises insured and that in case of fire the insurance moneys shall be applied in reinstatement. There, if the landlord has insured separately without the knowledge of the tenant, so that the damage is apportioned between the two policies, and the amount received by the tenant is

(b) Aieyn 26 .

(i) Leeils v. (Whetham (1827) 1 Sim. Iff, 27 li. 1.. 181: Latft' $v$. Jomnis (1859) 1 E. \& E. 17t, 28 L. J. Q. 13. 168,117 IR. 1i. 2!).

(d) larol collatoral arterments have been held gool in lirshime v.

1 .
Adeane (1873) I. R. S Ch. 75ti. 42 I. .J. (h. 8.3.); M/myoll v. Gritlith

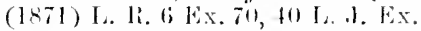
th: I lugfll v. Julie (1si5) 1. H.

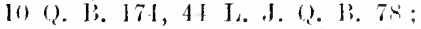

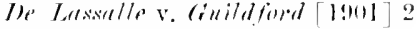

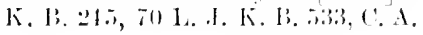


rimtion the civil law. diminisherl, the tenant is entitled to the benefit of the other policy also $(e)$.

The rule or presumption might have been the other way, as it is by the civil law, where it is an incident of the contract to pay rent that it is suspended by invitable accident destroying or making useless the thing demised. The particular event on which l'aradine $v$. Jane was decided, eviction by alien cnemies $(f)$, is expressly dealt with in this manner. The law of seotland follows the civil law $(g)$, and the lrish Landlord and Tenant Act of 1860 gives the tenant the option of surrendering on a dwellinghouse " $\mathrm{or}$ other building constituting the substantial matter of the demise" being by fire or other inevitable accident destroyed or made incapable of beneficial oceupation $(h)$. Either way the rule is subject to any special agrement of the parties; the only question of principle is which, in the absence of such agreement, is the better distribution of the hardship that must to some extent fall upon both. It is hard for a tenant, according to the English rule, to pay an occupation rent for a burnt out plot of ground. It is hard for a landlord, aceording to the Roman and Scottish rule, to lose the rent as well as (it may be) a material part of the value of the reversion. Either party may be insured; but that, as we have said, is not of itself relevint as hetween them.

bxeteptins inceltitin

So far the general rule. The nature of the excep-

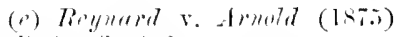
I. li. 111 in. 386 .

$\left(f^{\prime}\right)$ Si in 1:4. 2. lekesti comlucti, lis $\$ 2:$ :

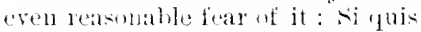
timoria eausal emierrasset . . responlit, si callsal fuisset enr pericham timeret, quam is prericulum vere nom fuisset. tamen nom lebere merectem: sed si cansa timoris justa nou fuistet, nihilominus debere. 13. end. tit. $27 \leq 1$.

(y) l'er lord Camplibell. Listit $\mathrm{x}$.

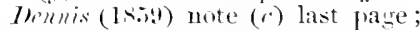
liell, l'rineiples, \$ 120s.

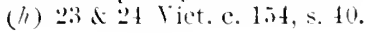


tions is thus set forth by the judgment of the Court in Baily v. De Crespigny:-

eases of subseruent impossibility.

"There ean be no doubt that a man may by an alssolute contract binl himself to perform things which subsequently become imprssible or to pay damages for the non-performance, and this construetion is to be put upon an unqualified mulertaking, where the event which causes the impossibility was or might have been anticipated and guarled against in the eontraet, or where the impossibility arises from the act or defanlt of the promisor.

"But where the event is of such a eharaeter that it cannot reasonibly be supposed to have been in the eontemplation of the contracting parties when the eontract was marle, they will not be heli bouml by general words which, though large enough to incluele, were not used with reference to the possibility of the particular contingency which afterwarls happens. It is on this principle that the act of Gorl is in some cases sail to exeuse the breach of a contract. This is in fact an inaccurate expression, because, where it is an answer to a complaint of an alleget breach of contraet that the thing done or left undone was so by the aet of ciol, what is meant is that it was not within the contract " (i).

This (as well as the following context, which is too long to quote) well shows the molern tendency to reduce all the rules on this subject to rules of construction. By the modern understanding of the Eveists noit within the eontenulation of the contract. law we are not bound to seek for a general definition of "the act of Crod" or vis maior $(k)$, but only to ascertain what kind of events were within the contrmplation of the parties, including in the trom event an existing but unascertained state of facts. This is yot more apparent if one attempts to frame any definition of the trom "act of Cind." It is said to be generally confined. to events which cannot be foresern, or which if they can be foresern cannot be gratrded against $(l)$. It does not inclurle every inevit-

(i) (1-6i3) I. li. + (2. B. at p. 15.5.

(h) lioth thest terme ald chasiral: "lis matur, guam limared

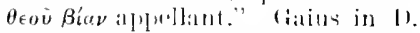
19. 2. Imati2. \$ li. Jis maim is somctimes the only appropriate ferm, at where the idlea is applien to actsuf a human sovereign power,

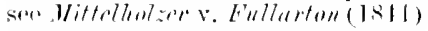
() (). 1:.98: 1015.

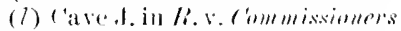

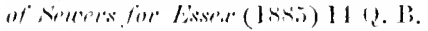
1). 5 (il,, $5 i 1$. 
ahle accillent; contrary winds, for example, are not within the meaning of the term in a charter-party. Nor is the reason far to seek; the risk of contrary winds, though inevitable, is one of the ordinary risks which the parties must be understood to have before them and to take upon them in making such a contract: therefore it is said that the event must be not merely accidental, but orerwhelming $(m)$. But on the other hand the term is not confined to unusual crents: death, for example, is an "act of God" as regards contracts of personal service, because in the particular case it is not calculable. Yet the fact that this very erent is not only certain to happen, but on a sufficiently large arerage is calculable, and therefore in one sense can be guarded against, is the foundation of the whole system of life annuities and life insurance $(n)$. Again, death is inevitable sooner or later, but may he largely prevented as to particular causes and occasions. The effects of tempest or of arthquake may be really ineritable by any precaution whaterer. But fire is not ineritable in that sense. l'recautions may he taken hoth against its breaking out and for extinguishing it when it does break out. We cannot arrive, then, at any more distinct conception than this: An erent which, as between the parties and for the purpose of the matter in hand, cannot be definitely forescen or controlled. In other words, we are thrown back upon the nature and construction of the particular contract $(o)$.

(iil) Per Martin 13. Oukley r. Jintsmouth is Ryde sterm Pacliet (a. (18.56) 11 Ex. 618. 22 L. J. Ex.

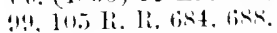

(II) As the medievil arkge puts it. " Nihil morte certius, nihil incertius hora mortis."

(i) As to what is such an "act of Civil" as will make an exception to a duty imposed not specially ly contract but by the general law, see Virkots r. Afarstand $(18-6)$ ? Ex. Div. 1. ti L. J. Ex. 17t:

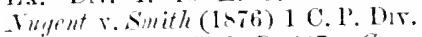
$423.444,45$ L. J. C. P. 6947 ; $\mathrm{Com-}$ missimenes af sincers r. Reg. (1886) 11 Apl. Cis. 4t!. 
We may now proceed to the specific classes of exceptional cases.

a. Where the performance of the contract depends on the existence of a specifie thing. The latw was settled on this head by Taylor v. Calduell (p), where the defendants agreed to let the plaintiffs haves the use $(p)$ of the surrey Gardens and Musie-hall on certain days for the purpose of giving entertainments. Before the first of those days the music-hall was destroyed by fire so that the entertainments could not be given, and without the fault of either party. The Court held that the defendants were excused, and laid down the following principle: "Where from the nature of the contract it appears that the parties must from the beginning have known that it conkl not be fulfilled unless, when the time for the fulfilment of the contract arrived, some particular specilied thing continued to exist, so that when entering into the contract they must have contemplated such continued existence as the foundation of what wass to be done; there in the absence of any express or implice $(q)$ warranty that the thing shall wist, the contract is not to be considered a positive contract, but subject to the implied condition that the parties shall be excused in case, before breach, performance becomes impossible from the perishing of the thing without default of the contractor." And the followImpitial (") nitition that further perform:ma. is excinsised: the thing perishies without the praty 5 own Helainll. ing authorities and analogies were relied upen:-

The civil law, which implies such an exception in all cases of obligation de certo corpore $(r)$.

(p) $(1863) 3$ 1. \& $5.826,32$ [..1. Q. R. 16t. There were words sullicient for an atetual demise. but the court held that the manilest general intention prevalad orer them.

(q) That is, understuml in ficcl batween the parties: the whole sople ol the palseige being loat it is not for he implient by law.

(r) 1). 15. 1. de v.0.23.33. 1 p.

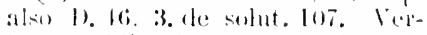

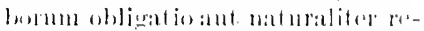

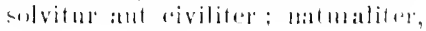

(a) Where the pir. formtance on $1.1 \mathrm{c}$ existemee of a specitic thing.

Taylore. I'aldwent. 
The cases of rights or duties created by a contract of a strictly personal nature which, though the contract is not expressly qualified, are by English law not transmissilste to executors.

The admitted rule of English law that where the property in specific chattels to be delivered at a future day has passed by bargain and sale, and the chattels perish meanwhile without the vendor's drianlt, he is excused from performing his contract to deliver ; and the similar rule as to bans of chattels and hathments. In all these cases, though the promise is in words positire, the exception is allowed "becallsen from the nature of the contract it is apparent that the parties contracted on the basis of the continued existence of the particular persom or chattel."

Allutely r. Myers.

In lpplely r. Myers $(s)$ the plaintiffs agreed with the defentant to edect an engine and other mathinery on his premises, at certain prices for the separate parts of the work, no time being fixed for payment. While the works were proceeding, and before any part was complete, the premises, together with the uncompleted works and materials nom them, wrete alecidentally destroyed by fire. In the Commen Pleas it was held that the plantiffe might recores the value of the work already done as on a term to that effect to be implies in the nature of the contract. In the lixchequer chamber the judgment of the common l'leats wats lerepredel. It was admitted that the work morter the contract conlel not be done unless the defendant's puenises continued in a fit state torecedve

veluti solutione, aut cun les in stipulationem ledmeta sine culpa pounissoris in relus humanic case lesiit. l'ollier. (11) \$1!1, il. l'art

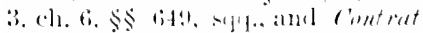
de lentes 30 s. se tramslated in

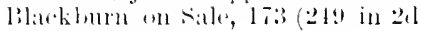
(e). lis (ilialı:1111).

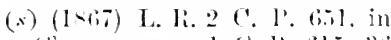

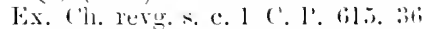
1. J. C. 1'. 331 : applied in a towate case where it was helul that the tues earned molhing when the vestel was aecilentally strambel lefore the end of the jommey: The Madias [1s!s] ]'. su. 
it. It was also admitted that if the defendant had by his own default rendered the premises unfit to receive the work, the plaintiffs might have recovered the value of the work alrealy done. But it was held that the Court below were wrong in thinking that there was an absolute pronise or warranty by the defendant that the premises should at all evonts continue so fit. "Where, as in the present care, the premises are destroyed without fault on either side, it is a misfortune equally affecting hoth parties, excusing both from further performance of the contract, but giving a cause of action to neither." Another argument for the plaintiffs was that the property in the work done had passed to the defendant and was therefore at his risk $(t)$. To this the Court answered that it was at least doubteul whether it had; and even if it had, the contract was still that nothing should be payable unless and until the whole work was completed. A contractor for work to be paid for in a lump sum can recover for part only if he has been prevented from completing the work by the other party's default, or if there is a new contract to pay for what has been clone (a).

The rule in Taylor v. Caldwell, as further defined by Appleby v. Myers, has now been extended to cases where, without the destruction of any materiat object, a state of things contemplated by the parties as

lixtension of the rule to fitilum of esiential comlitinns

(t) In the case citel in aroument from Dilloz, Jurisp. cién. Istil, ph.

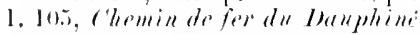
v. (It) (1siil) where railway works in contre: of enmstruction haul been spoilt by floosts, the court of Cassation retied on the distinetion that they werenot such as remainen! in the contractor's disposition dill the whele wat dinished, but "de

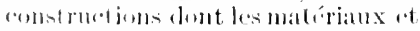
la main lienere cotomt lommis

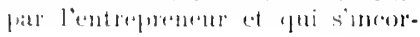

poraient an sol du proprifiale," at recluding the applicat ion of ar ineles

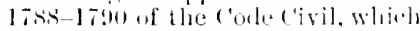
lay chwn a rule similar to that of the principal ase.

(11) Sice formall of ('o. v. Nhip

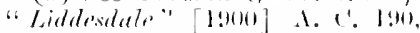

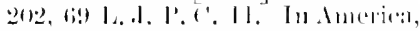
however, recovery for the work flone is eneneralliy allowerl: sous l'rult. Williston's note hare in the Ameriean extition. 
Jestruction of specitic things.

Cimpliact firl shipurent in 31 :111eal ship.

essential for performance according to their true intent fails to exist when the time for performance arrives, and this whether it is expressly mentioned in the terms of the contract or not $(x)$. Such is the result of the Court of Appeal's decisions in a group of cases arising out of the postponement, by reason of King Edward VII.'s illness, of the coronation procession appointed to take place in July, 1902. The contract is not avoided when the failure of the condition assumed as its foundation is ascertained, but all outstanding obligations under it, and those only, are discharged: that is, payments already made cannot he recorered back, and any payment actually acerued due is still recoresable (y). Only the House of Jords can review these decisions, but they are not universally approved in the profession $(z)$. In any case they are in aid of the presumed intention of the parties, and where the parties have contemplated and provided for the contingency no general rule is necessary or applicable, and there is nothing for the court to do but to construe the special contract on an ordinary business footing $(a)$.

Similarly, a contract for the delivery of cargo to be shippred at Alexandria in a named ship during a certain month was hedel to be discharged by an aceident to the ship which stranded her in the Baltic before the time for performance; in other words the contract was conditional on that ship continuing to

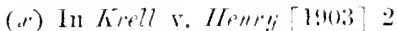

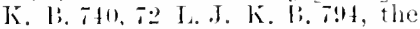
areerent was for the hire of rums. in fact to view the precession, but in terms it was nucun-

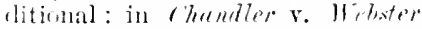
[1!n14] l K. li. $4 ! 13,7: 3]$, l. K. l?. f11, it was express]y "to view the filit coronation procesifon" : "iril sererer co-epereatire soriety $v$. limeral strum . Varigation ('o.

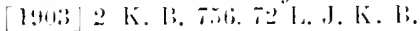

93:3. is an intermediate case.

(1) ler follins M.li. [1904] 1 K. 13. at 1\% 4!!!, per liomer h..l. il. at [1. 501 ; the rule is admitted to be to some extent arlitrary. and justitiable omly beeatne a perfect arliustment of rights is impracticable. It is not clear that a less abitrary one could not be levisel.

(:) Siee Ansom, 3isl.

(i) Elliout verintohley [1!nei] A. 1. . . I. I. K. I. 11\%. 
exist as a cargo-carrying ship available for the performance of the contract (b). But in a later case the Court of Appeal would not be persuaded that a ship chartered in the summer of 1902 for the purpose of conveying passengers to see the naval review intended to take place at spithead had failed to exist "as a review-visiting ship," and that the challterer was discharged on that ground. It was tho charterer's own venture and risk, and this was not altered by the nature of the intended voyage being specified $(c)$.

Where there is an entire contract for doing work upon specific property, as fitting a steamship with new machinery, for a certain price, but the price is payable by instalments, and the ship is lost hefore the machinery has been delivered, but after one or more of the instalments has been paid, the further performance of the contract is excused, but the money already paid, though on account not of a part, but of the entire contract, cannot be recovered back $(d)$.

The same doctrine has been applied where the subject-matter of the contract is a future siecifie product or some part of it. In March A. agreed to sell and B. to purchase 200 tons of potatoes glown on certain land belonging to A. In August the crop) failed by the potato blight, and $A$. was mable to deliver more than 80 tons: the Court held thit

(b) Virkoll i) Kinight v. Astetun,

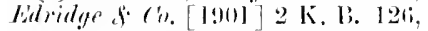
70 I. J. K. li. (6) ( I. A.

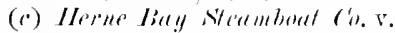

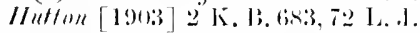
K. B. 379 . The purpose of a day's cruise romel the flect, which remained practicals]e, was alsen speciticel, and this hat some weight will the (omot, hat denes nont secen a necessary fiatel ol the reasons for ther derisions.

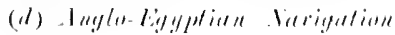

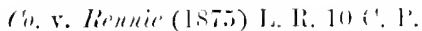
271 , 14 [..J. C. I'. 130. It wull. seem the sime on principle where the whole price is pail in atraner.

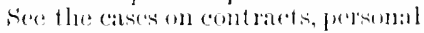
service. and apprentionlep cifter! farther on, 'The destruetion of at

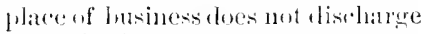
a continuing contrate to calry an the lusimese if it is alpables of beiner resumed clsewhere: Turmer v. linldsmith [ [s:1] 1 \%. li, ill. (i) $1 ., 1,12.1 \%, 217,1$ 1.
Saving as 10 instalusents of fiayment alriatily cimileal.
Contract for fut mere spereitic. pundurt. 
Aklition of slave statils.

Impkibility all ilite il contract from state of thinge not contemplated by patties. he was excused as to the rest. "The contract was for 200 tons of a particular crop in particular fields" "not 2010 tons of potatoes simply, but 200 tons off particular land" . . . "and therefore there was an implied term in the contract that each party should be free if the crop perished" (e).

The same principle is involved in the decision of the supreme Court of the Enited States that a warranty of title and quiet enjoyment given on the sale of a slate before the wat was discharged by the 'Thirteenth Anendment to the Constitution $(f)$.

These are all cares of the performance becoming imposible by erents which happen after the contract is made. But sometimes the same lind of imposibility results from the present existence of a state of things not contemplated by the parties, and the performance is excused to the same extent and for the same reasoms as if that state of things had supervened. Whate this impossibility consists in the absolute non-existence of the specific property or interest in property which is the subject-matter of the agreenent, it is erident that the agreement would not have been made unless the parties had contemplated the subject-matter as existing. Otherwise it would be reduced to a calse of absolute impossibility; for when a thing is once linown to be in the erents which have happened impossible, it is the same as if it had been in its own nature imporsible. Here, then, the agreement of the parties is induced ly a mistakedr assmmption on which they both proereed, at in the analogous cases noticed above under the head of imposibility in law. IIere, as there, it is a question whether imposilibity or mistake,

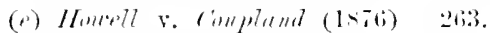

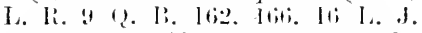
Q. B. 147 , affle in $(\therefore .1 .1 \%$ l:

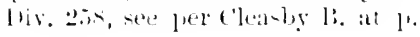

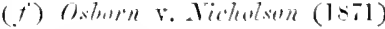
13 ilallace bist. 
or both, shall be assigned as the ground on which the agreement is void. And here likewise on anthorities rightly assign mistake as the preferable ground, for the material question is not whether performance is or remains possible, but what the parties assumed and contemplated as the foundation of their contract $(g)$. If it appears that they conceived and dealt with something non-existent as existing, the agreement breaks down for want of any real contents. Hence these cases may woll be freated as belonging to the head of Mistake; though there is no real need to talk of either impersibility or mistake except as part of the facts to be dealt with.

The historical explanation, however, is different. Accident, Frand, and Mistake were the accustomed descriptions of heads of equity moler which the Court of Chancery gave relief. The fiction of this relief being something extraordinary, and as it were supralegal, was kept up in form long after it had ceased to be either true or useful; and the terms Fraud and Mistake were extended far heyond any reasonable meaning in orter to support the jurisdiction of the Court in a great rariety of cases where the procedure and machinery of the common law Courts were inadequate to do justice. We shall now give one or two examples of cases lying on or near the line.

In Couturier r. Hastie (h), decided by the House Sial of alago of Lords in 1556, a bought note had been signed for a cargo of Indian corn described as "of far average quality when shipped from Salonica." Several days before the sale, but unlinown to the parties,

(y) Sice especially (onturier s.

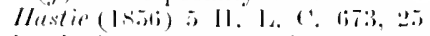
l. .l. lix. 2iriz, 101 li. li. 32!.

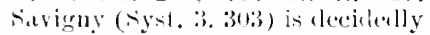

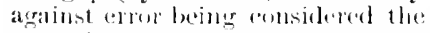
gromal al nullity in llese cases:

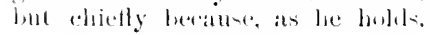

the knowlerlge or otlere state of mind of the parties malies mo ditlerencere It is at least doublind, as we slatl see later. whellure llis poition letatu in tonlish law.

(h) (1s,ti) is 11. 1. 11. 6i7:3, 101 li. Ii. .3:!. jurevinils lint. 
the cargo, then on the voyage, was found to be so much damaged from heating that the ressel put into Tunis, where the cargo was sold. The only question seriously disputed was what the parties really meant to deal with, a cargo supposed to exist as such, or a mere expectation of the arrival of a cargo, subject to whaterer might have happened since it was shipped. Lord Cranworth in the House of Lords, in accordance with the opinion of nearly all the judges, held that "what the parties contemplated, those who sold and those who bought, was that there was an existing something to be sold and bought." No such thing existing, there was no contract which could be enforced.

Civenants to work minus. or $1+1$ raise minimuth anomint.

Cliffill $t$. II:attis.

When a lessee under a mining lease covenants in monualified terms to paty a fixed minimum rent, he is hound to pay it $(i)$, though the mine may turn out to be not worth working or eren unworkable. But it is otherwise with a covenant to work the mine or to raise a minimum amount. Where a coal mine was found to be so interrupted by faults as to be not worth working, it was said that the lessor might be restrained from suing on the covenant to work it on the terms of the lesise paying royalty on the astimated quantity of coal which remained unworlied $(k)$. A similar question was fully dealt with in Clifford v. Watts (l). The demise was of all the mines, reins, ete., of elay on certain land. There was no covenant hy the lessee to pay any minimum rent, but there was a corenant to dig in every year of the term not less than 1,000 tons nor more than 2,yut tons of pipe or potter's clay. An action was brought by the lesior for breath of this corenant.

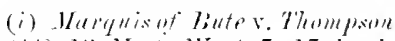

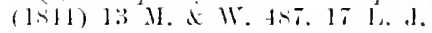

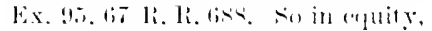

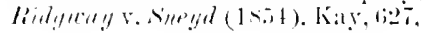

111) R. R. Titi.

(i) Ridyruly va sheyd last note. (l) (1sio) i.. li. jo ('. P. is. 41) H. .1. 1'. I'. : it. 
Plea $(m)$, to the effect that there was not at the time of the demise or since so much as 1,000 tons of such clay under the lands, that the performance of the covenant had always been impossible, and that at the date of the demise the defondant did not know and had no reasonable means of knowing the impossibility. The Court held that upon the natural construction of the deed the contract was that the lessee should work out whatever clay there might be under the land, and the corenant sued on was only a subsidiary provision fixing the rate at which it should be worker. The tenant could not be presumed to warrant that clay should be found: and "the result of a decision in favour of the plaintiff would be to give him a fixed minimum rent when he had not covenanted for it" $(n)$.

In certain kinds of contracts, notably charter-parties, it is usual to provide by express exceptions for the lind of events we have bean considering. It is not within our province to enter upon the questions of construction which arise in this manner, and which form important special topies of commercial law. However, when the exception of a cortain class of risks is once established, either as being implied by law from the nature of the transaction, or by the special agreement of the parties, the troatment is much the same in principle: and a few modern decisions may be mentioned as throwing light on the general law. Where the principal part of the contract becomes impossible of performance by an

(iii) It was plearled as an equitable plea undr. the $(\therefore$ I. l'. Act, but the count treaterl the defence as a legal onc.

(II) Per Montienue śnith J. I.. I.

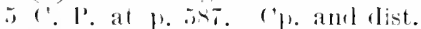

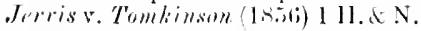

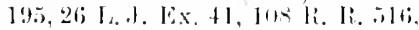
where the covenant was mot only to ret 2,000 toms of rock sialt per annum, but to pay bil. a tom for every ton short, and the lessees knew of the state of the mine when they exeentent the laise. Mills v. sughtere, 11. 11:4, 129, abore, was reciter on its peculiar follts. See

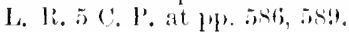

Analogous effect of express exceptions in commercial contracts. 
excepted risk, the parties are also discharged from performing any other part which remains possible, but is useless without that which has become impossible (o). It is a general principle that a contract is not to be treated as having hecome impossible of performance if by any reasonable construction it is still capable in substance of being performed $(p)$ : but on the other hand special exceptions are not to be latd hold of to keep it in force contrary to the real intention. Thus where the contract is to be performed " with all possible despatch," saving certain imperiments, the party for whose benefit the saring is introduced cannot force the other to accept performance after a delay unreasonahle in itself, though due to an excepted callse, if the manifest general intention of the parties is that the contract shall be performed within a reasonable time, if at all. The saring clause will protect him from liability to an action for the delay, but that is all: the other party cannot treat the contract as broken for the purpost of recorering damages, but he is not prevented from treating it as dissolved $(q)$.

( $\beta$ ) It here performance clepenuls on life or health of a person. Inplierl conIlition tliat the person shall remain alive and well enumin for the prirpunes of the contract.

3. Where the contract is for personal services of which the performance depends on the life or health of the party promising them. "All contracts for personal services which can be performed only during the lifetime of the party contracting are subject to the implied condition that he shall be alive to perform them: and should he die, his executor is not liable to an action for the breach of contract oceasioned by his death" $(r)$. Conversely, if the master

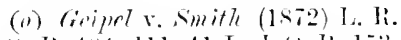

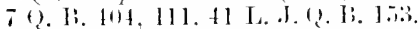
(li) The Trutonial (15-2) L. R. 1 P. C. 17I. IS., 41 l. .J. Ail. 5i.

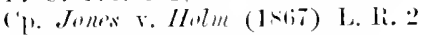
Ex. 33.

(q) Jatisun v. I nimn Murint In- suranor (o. (18-4) in Fx. Ch. L. R. 10 C. I'. 12.5. 144.8\% .. +1 L. J. C. I'. $2 \pi$.

(r) l'ollowek ('.li. in llall v. II right (1-So) E. B. de E. at p. Tas. 29 L. J. Q. R. at 1. 51. 113 R. IR. ( $! 1$. 
dies during the service, the servant is thereby discharged, and cannot treat the contract as in force against the master's personal representatives $(s)$. 'T'he passage now cited goes on to suggest the extension of this principle to the case of the party becoming, without his own default, incapable of fulfilling the contract in his lifetime: "A contract by an author to write a book, or by a painter to paint a picture within a reasonable time, would in my judgment ho deemed subject to the condition that if the author became insane, or the painter paralytic, and so incap)able of performing the contract hy the act of Ciod, he would not be liable personally in damages any more than his executors would be if he had been prevented by death." This riew, which obviously commends itself in point of reason and convenience, is strongly confirmed hy Taylor v. Caldwell (supra, p. 437), where indeed it was recognized as comect, and it has since been established by direct decisions. In Boast v. Firth $(t)$ a master sued the father of his apprentice on his corenant in the apprenticeship Ficast $r$. Firth. deed that the apprentice should serve him, the plaintiff, during all the term. The defence was that the apprentice was prevented from so doing by permanent illness arising after the making of the indenture. The Court held that "it must be taken to have been in the contemplation of the parties when they entered into this covenant that the prevention of performance by the act of Ged should be an excuse for non-performance" (u), and that the defence was a good one. In Robinson v. Intrison $(x)$ the deforndant's wile, an eminent pianoforte player, was

livinimith I:ivisun. (s) Furrome v. $11 \%$ ism $1186 ; 9) \mathrm{L}$. Ii.

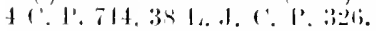

(t) (Jutis) 1, li. 4 (!. 1', 1, 3 1. I. 1'. I'. 1. (i) ler Montague Sinith .I. at 1). 7 .

(.i) (1sil) 1. li. if Jx. 26it, 11) 1., I. Vix. 17:. 
engaged to play at a concert. When the time cams she was disabled by illness. The giver of the entertainment sued for the loss he had incurred by putting off the concert, and had a verdict for a small sum under a direction to the effect that the performer's illness was an excuse, but that she was bound to give the plaintiff notice of it within a reasonable time. The sum recovered represented the excess of the plaintiff's expenses about giving notice of the postponement to the public and to persons who had taken tickets beyond what he would have had to pay if notice had been sent him by telegraph instead of hy letter. The Court of Exchequer upheld the direction on the main point. The reason was thus shortly put by Bramwell B. "This is a contract to perform a service which no deputy could perform, and which in case of death could not be performed by the executors of the deceased: and I am of opinion that by virtue of the terms of the original bargain incapacity either of body or mind in the performer, without default on his or her part, is an excuse The contract for non-performance" $(y)$. The same judge also becmes roik, observed, in effect, that the contract becomes not roidable at aption of fialty clisithled. simblenotice should be given to the wher party. voidable at the option of the party disabled from performance, but wholly roid. Here the player could not have insisted "on performing her engagement, however ineffectually that might have been," when she was really unfit to perform it. The other party's right to rescind has since been established by a direct decision $(z)$. No positive opinion was expressed on the other point as to the duty of giving notice. But it may be taken as correct that it is the duty of the party disabled to give the earliest notice that is reasonably practicable. Probably notice reasonable

(y) (18:1) L. l. 6 Ex. at p. 27.. (1876) 1 Q. B. D. 410, 45 L. J. Q. B.

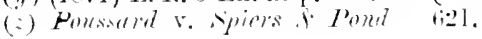


in itself could not be required, for the disaluling accident may be sudden and at the last moment, and the duty must be limited to cases where notice can be of some use $(a)$. It further appears from the case that the effect of an omission of this duty is that the contract remains in force for the purpose only of recovering such damage as is directly referable to the omission. The decision also shows, if express authority be required for it, that it matlers not whether the disability be permanent or trmporary, but only whother it is such as to prevent the fulfilment of the particular contract. In the event of the disabled party having suffered from the breach of contract or negligence of a third person, and being entitled to a remedy against that person, a question of subrogation might possibly arise, but this does not appear to have been judicially considered.

In the earlier and very peculiar case of Hall v. Hall $:$ Wright (b) the question of substance was thus stated: "Is it a term in an ordinary agreement to marry, that if a man from bodily disease cannot marry without danger to his life, and is unfit for marriage fiom the cause mentioned at the time appointed, he shall be excused marrying then?" $(c)$ or in other words: irright : decision on the contract to marry : illnces ine fitting for matliale no "Is the continuance of health, that is, of such a state of health as makes it not improper to marry," an implied condition of the contract? $(d)$. The Court of Exchequer Chamber decided by four to three that it is not, the Court of Queen's Bench having heen equally divided. The majority of the judges relied upon two reasons: that if the man could not marry

(a) Cp. the doctrine as to giving notice of abandomment to umlers' writers, lowelin v. lutter (15:2 3) L. R. 6 H. 1. $83,121,157,12$ I. J. (.. 1'. 169.

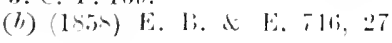
P.

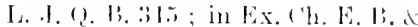
E. T6., 2!1 1. J. (2. B. $43,11: ; 1$ 1. 1i. sil, sil.

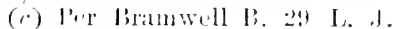
(a. 1). I.).

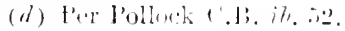


without danger to his life, that did not show the performance of the contract to be impossible, but at most highly imprudent; and that at any rate the contract could be so far performed as to give the woman the status and social position of a wife. It was not disputed that the contract was voidable at her option $(e)$. As to the first of these reasons, the question is not whether there is or not an absolute impossibility, but what is the true meaning of the contract; and in this case the contract is of such a kind that one might expect the conditions and exceptions implied in strictly personal contracts to be extended rather than excluded $(f)$. As to the second reason, it cannot be maintained, except against the common understanding of mankind and the general treatment of marriage by English law, that the acquisition of legal or social position by marriage is a principal or independent object of the contract. Unless it can be so considered, the reason cannot stand with the principle affirmed in Geipel $v$. Smith $(g)$, that when the main part of a contract has become impossible of performance by an excepted cause, it must be treated as having become impossible altogether. The decision itself can be reviewed only by a court of ultimate appeal; but it is so much against the tendency of the later cases that it is now

(d) "The man. though he may be in a basl state of health, may nevertheless jerform his contract to marly the woman, and so give her the benetit of social position so far as in his power, though he may be mable to fulfil all the ofligations of the marriage state; and it rests with the woman to say whether she will enforce or renomee the ent ract." The case is thus explained and dist inguished ly Montague Smith J. in Rimest $\mathrm{r}$. Firth (1stis) L. R. 4 C. I. S. $\left(f^{\prime}\right)$ It has long been settled that the contract to marry is so fotr personal that exceutors, in the absence of speeial clamage to the personal estate, canmot sne upm it : Chemberlain v. Williamsom (1814) 2 M. \& S. 408,15 R. R. 29.5. Anul it is now deeiderl that they ctmmot. except perhaps for special temporal damage, be sued: Finlay v. Chirney (18ss) 20 Q. B. biv. 4!t, 57 K. J. Q. B. 247.

(I) (187:) 1.. R. I Q. B. 404, 41 I. J. Q. B. 153. 
of little or no authority beyond the point actually decided $(h)$.

The rule now before us applies only to contracts for actual personal services. A contract of which the performance depends less directly on the promisor's health is not presumed to be conditional. If a man covenants to insure his life within a certain time, he is not discharged by his health becoming so bad before the end of that time as to make his life uninsurable $(i)$. It has never been supposed that the current contracts of a manufacturing firm are affected in law by the managing partner heing too ill to attend to business, though there are many kinds of business in which the proper execution of an order may depend on the supervision of a particular person. And in general terms it may be said that no contract which may be performed by an agent can be discharged by a cause of this kind, unless the parties have expressly so agreed.

As we saw in the case of contracts falling dircetly within the rule in Taylor v. Caldwell, so in the case of contracts for personal services the dissolution of the contract by subsequent impossibility does not affect any specific right already acquired under it. Where there is an entire contract of this lind for work to be paid for by instalments at certain times, any instalments which have breome due in the enntractor's lifetime remain due to his estate after the contract is put an end to by his death $(k)$. In like manner where a premium has been paid for aplorenticeship, and the master duly instructs the apprentice

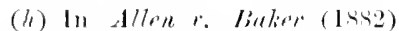

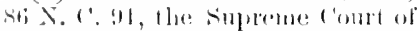
North ranolina expressly aleclined to follow thall v. II iright. Siee P'rof. Williston's note for other similar rulings. limitation of the rule to contracts for actual jersonal iervices. liights alrearly actuired under the contract remain. (i) Arfhur v. Wymm (1sson) 11

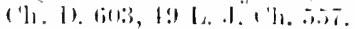

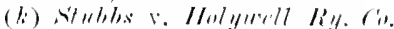

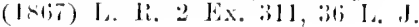
lix. liti. 
Subtituter entrat leceminger imposible of pelfurmance.

3. Impmosi. bility $\mathrm{b}$ defaiult of either liarty lefault uf loominer is blezell of eutlact.

Thefunlt of li) (1) intet

for a part of the term and then dies, his executors are not bound to return the premium or any part of it as on a failure of consideration $(l)$.

Where an existing contract is raried or superseded by a subsequent agreement, and the performance of that agreement becomes impossible (e.g., by the death of a person according to whose estimate a sum is to be assessed) so that the parties are no longer bound by it, they will be remitted to the original contract if their intention can thereby he substantially carried ont. At all events a party for whose benefit the contract was varied, and who but for his own delay might have performed it as varied before it became imposihle, camnot afterwards resist the cnforcement of the contract in its original form $(m)$.

3. We now come to the case of a contract becoming impossible of performance by the default of either party.

Where the promisor disables himself by his own default from performing his promise, not only is he not excused (for which indeed authority would be superfuous) but his conduct is equivalent to a breach of the contract, although the time for performance may not have arrived, and even though in contingent cireumstances it may again become possible to perform it $(n)$.

On the other hand, where the promisor is prevented

(7) Irhimenl v. IHughes (1-i1) L. IR, \& C. H. T, to I., J. C. I'. 10t. dissenting from the riew of the common law on which the deeision in Mir.st r. Thtson (155i)

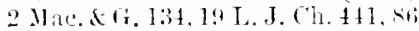
F. F. fi. jurported to be founded. Hirst r. Thlwh does not of course, establish any rule of enuit r.

(m) Firti v. Widlund" $I$. Co. (1-5) I. 1i. 20 E. 100, 44 L. J. (h. 313 .
(11) 1 Fo. Ab. 44s. B.. citing 21 E. IV. 5t, yl. 26 : . If you are bound to enfeoff me of the manor of $D$. before such a feast. and yon make a feoffment of that manor to another before the feast. you have furfeiled the bond notwithstanding that you lave the land lack before the feast, having once disabled rourself from making the said feoffment." per Choke J. 
from performing his contract or any part of it liy the default or refusal of the promisee, the performance is to that extent excused; and noreover default or refusal is a cause of action on which the promisor may recover any loss he has incurred thereby $(o)$, or he may rescind the contract and recover back any money he has already paid under it $(p)$. Default may consist either in active interruption or interference on the part of the promisee $(q)$, or in the mere omission of something without which the promisor cannot perform his part of the contract $(r)$.

The principle, in itself well settled, is illustrated by several modern cases. Where the failure of a building contractor to complete the works by the day specified is caused by the failure of the other. parties and their architect to supply plans and set out the lands necessary to enable him to commence the works, "the rule of law applies which exonerates one of the two contracting parties from the performance of a contract when the performance of it is prevented and rendered impossible by the wrongful act of the other contracting party " $(s)$, and the other party cannot take advantage of a provision in the contract making it determinable at their option in tho event of the contractor failing in the due per. formance of any part of his undertaking $(s)$. So where it is a term of the contract that the contractor shall pay penalties for any delay in the fulfiment of

(i) As in the fomiliar "ase of an action for nontareceptance of goods. for mot furmishing a cargs, de. : so wilh a special eontract, r.1.. Roblerts

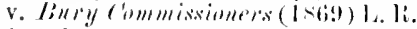

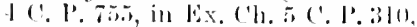

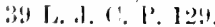

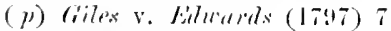

T. li, $1 \times 1,+1$ li, li. 11 I.

(y) I lin, $\lambda$, in, $\mathrm{N}$.

(r) Ithere a comdition an be diceharges 1untisor, and may be treated as breach, or makes contraet voidalle at his option.

Poberts $r$. Bury commissimers. se. performed onty in the ohliger's presence, his absence is an excove. I lio. Ab. 15. U. A coventant to make within a year smeb as-mance: as the corchantee's rommed shall devise is cliseharesed it the corermanteredes not temler an asiarame within the year, it. 1to. 1h. I:.

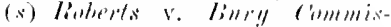

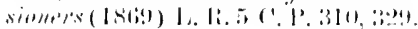


it, no penalty becomes due in respect of any delay caused by the refusal or interference of the other party $(t)$. Where a machine is ordered for doing certain work on the buyer's land, on the terms that it is to he accepted only if it answers a certain test; there, if the buyer fails to provide a fit place and occasion for trying the machine, and so deals with it as to prevent a fair test from being applied according to the contract, he is bound to accept and pay for the machine (u).

Cases af :1)penticehip.

In Raymond $v$. Minton $(x)$ it was pleaded to an action of coremant against a master for not teaching his apprentice that at the time of the alleged breach the apurentice would not be taught, and by his own wilful acts prevented the master from teaching him. This was held a good plea, for " it is evident that the master cannot be liahle for not teaching the allurentice if the alprentice will not be taught." An earlier and converse case is Ellen r. Topp (y), referred to by the reporters. There a master undertool: to teach an apprentice sereral trades; it was lorld that on his giving up one of them, and thus making the complete performance of his own part of the contract impossible, the apprentice was no longer bound to serve him in any. "If the master is not rarly to teach in the very trade which he has stipulated [promised] to teadeh, the apprentice is not hound to srrve." A calse of the same sort is put by Choke J. in the Year Book, 2.2 Eil. IV., 26, in a calse from which one passatg" has already been given.

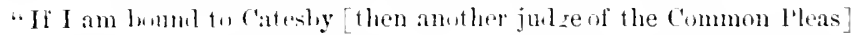

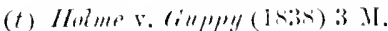

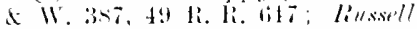

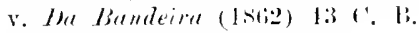
‥ ‥ 14!1,32 I. J. ('. I'. lix.

(ii) Marlacly v. Jick (Isind) in

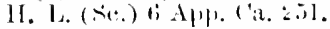

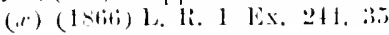

L. I. Lx. 1.33. So if a pawnbrokers apprentee is a babitual

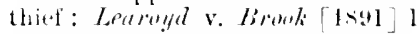

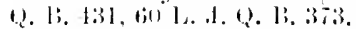

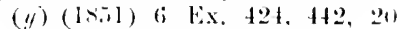
L. H. Lx. 241. sti R. li. 333. 
that my son shall serve him for seven years, and I eome with my son to Catesby, and offer my son to him, and he will not take him, there heeanse there is no default on my part I shill not forfeit the bonl. In like manner if he took my son and afterwarls within the term sent him away, it is unreasomable that this should be a forfeiture."

Where a contract is in the alternative to do one of two things at the promisor's option, and one of them is impossible, the promisor is bound to perform that which is possible $(z)$. We find the rule clearly stated in the Digest (a). Where one of two things contracted for in the altemative subsequently becomes impossible, it is a question of construction for which no positive rule can be laid down, whether according to the true intention of the parties the promisor must

Allermative contract. Whicre one thing inpossible, the possible one milust be perfinined. Where one becomes impressible, a question of eonstruction. perform the alternative which remains possible, or is altogether discharged (b). It was held, indeed, in Laughter's case (c) that where the condition of a bond is for either of two things to be done by the obligor, and one of them becomes impossible by the act of God, he is not bound to perform the other. But this is to be accounted for by the peculiar treatment of honds, of which we shall speak presently, the right of election being part of the benefit of the condition, of which the obligor is not to be deprived. And even as to bonds the general proposition has been denied $(b)$. In the absence of anything fo show the intention in the particular case, the presumption should surdy be the other way, namely, that the promisor should lose his election rather than the promisee lase the whole benefit of the contract. Whera either the promisor or the promisee, having the right mucler a contract to choose which of two things shall

(z) Ill ('os/ll v. Inaris (17-s) l

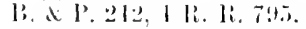

(a) Si ita stiputatus liucon; te

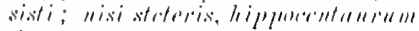

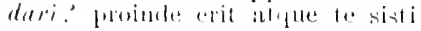

solumumolo stipulatus essom. I).

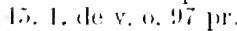

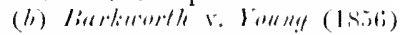

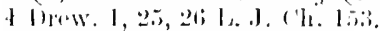

(c) ; ('c) lice. $21 \%$ \% 
Effecets of lefault.

Comblitional contract.

he done, chooses one which becomes impossible after the ehoice is determined, there (on authority as well ats principle) it is the same as if there had been from the first a single unconditional contract to do that thing (d). In Roman law the presumption seems distinctly in farour of the promisor remaining bound to do what is possible (e); otherwise it agrees with ours $(f)$. The exception as to mora in the extract giren in the note shows the application here of the general rule as to impossibility caused by acts of the purties. The case put is that the creditor has mate his election (to have Stichus, suppose) but has neglected or refucci to accept Stichus: now if sitichus dies he eamnot demand Pamphilus. It is the satne as if there had been a single promise, and the performance made impossible by the promisees default. The same lule is given in another passiage $(.9)$.

There is yet something to be said of the treatment of conditional contracts where the condition is or becomes imposibible. A condition may be defined for

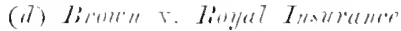

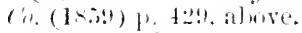

(1) Fince that in the rase of an altemative obligation to deliver speceitie abjects at the promison's election be still has an elecetion in solutirne as it is saidle iff. he may at hi-netien lay the value of that which hat peristed.

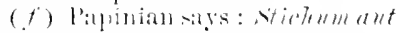

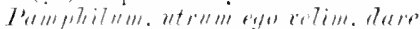
spmedes altero mortan. rani vivit sulus pertetur. uisi si mora fartal sit in ro mentmo. quem petitor eleyit ; tmor anim perinte solus ille qui

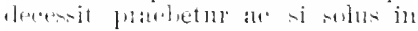
(1) digitionum dethetus fuimet.

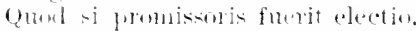

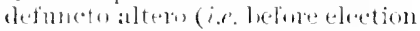

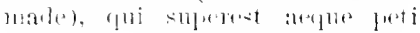

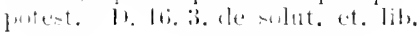

4 y. He proceeds to this cmions questim: Ithat if one dies by the debton s default $b_{\text {Hefore election }}$ mate. :m l afterwark the other vies whthout his default? Xo actinn e:an be mantained on the stipulatim, but there is a remedy by duli actiu.

(y) Stipulatus sum Ilamam aut Erotem -errum dari, c'mm Lamam dares, egu yuminns aceiferem in mora fui : unortmes est l lama : an putes me ex stipmlatu actionem halvere? Iiespomlit, secmulnm Masonri sabini chinionem puto te ex stipulatu agere nom pose; nam is recte existimabat. si per lebitwrem nora nom escet. quominns

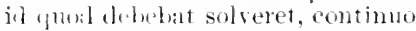

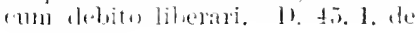
v. $0.10 \%$. 
the present purpose as an agreement or term of an agreement whereby the existence of a contract is made to depend on in future contingent event assigned by the will of the parties $(h)$.

The condition may be either that an event shall or that it shall not happen, and is cilled positive of negative accordingly. Now the event which is the subject-matter of the condition, instead of being really contingent, may be necessary or impossible, in itself $\mathrm{Or}^{\circ}$ in law. But the negation of a necessary event is impossible and the negation of an impossible event is necessary. It therefore depends further on the positive or negative character of the contingency whether the condition itself is necessary or impossible.

Thus we may have conditional promises with conditions of these kinds:

Necessary :

(a) By affirmation of a necessity. As a promise In what ways (o) maty lite mecescats 010 inponible. to pay 100l., "if the sun shall rise to-morrow."

( $\beta$ ) By negation of an impossibility: "If J. S. does not climb to the moon," or " if my executor does not sue for my debt to him."

Impossible:

$(\gamma)$ By affirmation of an impossibility: "If J. S. shall climb to the moon," or "if J. S'. shall create a new manor."

( $\delta$ ) By negation of a necessity: "If the sun shall not rise to-morrow," or "if my persunal estate shall not be liable to pay my debts" (i).

It is obvious that as a matter of logical con struction the forms (a) and ( $\beta$ ) are equivalent to unconditional promises, (y) and (o) to impossible or nugatory promises. And so we find it donlt with by

(h) Savigny, Śyct. 11 ti (3.1:1); liutue, Obl. 1 lin.

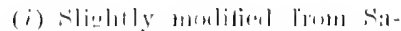

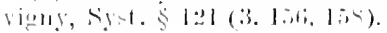


the Roman law $(k)$. It is equally obrious that (still as a matter of logical construction) there is nothing to prevent the condition from having its regular effect if the event is or becomes impossible in fact. Fur example, "if A. shall dig 1,000 tons of clay on B. 's land in every year for the next seven years:" here there may not be so much clay to be dug or A. may die in the first year. But a promise so conditioned is perfectly consistent and intelligible without importing any further qualification into it; and it is obriously more difficult to infer that some further qualification was intended than in the case of a direct and unconditional contract by $A$. himself to dig so mueh clay.

birect covenants or promises dependent on express conditions must be construted with reference to these general principles: beyond this no rule can be given except that effect is to be giren so far as possible to the real meaning of the parties $(l)$.

Treatment of conditions in Englislı law.

Practically the discussion in our books of conditions and their effect on the legal transactions into which they enter is limited to the following sorts of questions:

1. What contracts are really conditional, or in technical language, what imounts to a condition precedent $(l)$ :

$\therefore$. The effect of conditions and conditional limitations in conveyances at common law and under the Statute of Ises, which we hatre not now to consider:

3. The effect of conditions in bonds. This form of

(k) " $\mathrm{si}$ imposibilis comlicen, whligatim milns adiciat ur. nilitl valet stipulatio. Impussibilis autem comlie ite habetur. cui natura im. ledinento est ylan minus exi-tat. Soluti si yuis ita clixerit : Si ligitu carlumattigero, hate-jomber? At si ita stipuletur : Si digito caclnm rom attloter. dare spondes? fure facta obligatio intellegitur ileoque statim letere potest." I. 3. 19. le intut. -tipul. \$11.

(l) Sinpu, (h. VI., p. 2:-3. 
contract is now used only for certain special purposes, but was formerly of general application, insomuch that almost all the older learning on the construction and performance of contracts is to be found under the head of conditions. IIere there atre some peculiarities which call for our attention in this place.

So far as the form goes, a bond is a contract dependent on a negative condition. In the first instance the obligor professes to be bound to the obligee in a sum of a certain amount. Then follows the condition, showing that if a certain event happens (generally something to be done by the obligor) the linds. lifference between the technical form and the real meaning of the instrument. bond shall be void, but otherwise it shall remain in force. "The condition is subsequent to the legal obligation; if the condition be not fulfilled the obligation remains" $(m)$. This is in terms a promise, stated in a singularly involved way, to pay a sum of money if the event mentioned in the condition does not happen. But this, as everybody lnows, is not the true nature of the contract. The object is to secure the performance of the condition, and the real meaning of the parties is that the obligor contracts to perform it under the conventional sanction of a penal sum. This view is fully recognized hy the modern statutes regulating actions on bonds, by which the pemalty is treated as a mere security for the performance of the contract or the payment of damages in defantt $(n)$. On principle, therefore, a bond with an impossible condition, of a condition which becontes impossible, should be dealt with just as if it were a direct covenant to perform that which is or becomes inpossible. In the former catse the

(iil) Sir W. W. Follet1, ary, lirswick v. swindells ( IS3i) : A. de E. siis is li. li. 2011 .
(11) As to these, set Prostonte $v$.

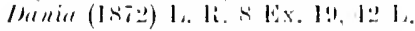
.I. Fx. $: 3: 3$. 
Wrene renulition immeriatedy imposible, ohtigation is abeolute, according to tise purely formal (4) silluction.
Biat sublsicplumit ins jorsithlity is a clistrutlgt.

bond should be void, in the latter the rule in Taylor v. Caldwell (o) would determine whether it were aroided or not. We lave seen that where the condition is illegal our Courts have found no difficulty in considering the bond as what in truth it is: an agreement to do the illegal act. But in the case of impossibility the law has stuck at the merely formal view of a bond as a contract to pay the penal sum, subject to be avoided by the performance of the condition; accordingly if the condition is impossible either in itself or in law the obligation remains alisolute.

"If a man be bound in an obligation, \&c., with condition that if the obligor do go from the church of St. Peter in Westminster to the church of St. l'oter in Rome within three hours, that then the obligation shall be void. The condition is roid and impossible and the obligation standeth good." So, again, if the condition is against a maxim or rule in law, as "if a man be bound with a condition to anfroff his wife, the condition is roid and against law, because it is against the maxim in law, and yet the hond is good.' $(p)$.

In the same way, "when the condition of an olligation is so insensible and incertain that the meaning cannot be known, there the condition only is roid and the obligation good" $(q)$.

On the point of subsequent impossibility, however, the strictly formal view is abandoned, and all opposite result arrived at, but still in an artificial way. 'Tho condition, it is said, is for the benefit of the

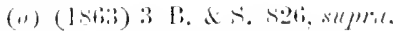
1. $13 \pi$.

(1) Co. Lit. 20t b (sone of the sce in in coke's text are mitted).

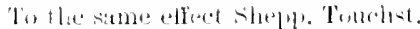
$3 i 2$. As to going to livine the wore usual phrase in the ohl book is thee thys: which is now inapplicable, the courec of post from lomblin (1) Rome being less than forty-einht hours.

(i) Shepl. Tuuchst. 373. 
obligor, and the performance thereof shall save the bond; therefore he shall not lose the benefit of it by the act of God $(r)$, and where the condition is possible at the date of the instrument, "and before the same can be performed the condition becomes impossible by the act of God, or of the law, or of the obligee, there the obligation is saved" $(s)$; or as another book has it, "the obligation and the condition both are become roid" $(t)$. "Generally if a condition that was possible when made is become impossible by the act of God, the obligation is diseharged" (u). As to the acts of the law and of the obligee this agrees with the doctrine of contracts in general: as to inevitable accident it establishes a different rule. The decision in Laughter's case (supra, p. 455), was an application of the same view, and it therefore appears that there should never have been any question of extending it to direct covenants or contracts.

The peculiar law thus laid down is distinctly recognized by modern authorities $(x)$. However, if a bond appears on the face of it to be given to secure the performance of an agreement which it recites, tho condition will take effect according to the true intention of the agreement rather than the technical construction resulting from the form of the instrument $(y)$.

Alternative conditions, at any rate as to immediate impossibility, and eonditions madr impossible by the default of the parties, or otherwine than by the "act

(r) This reastuing appears both

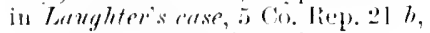
and Leembs suse, ith. $23 \mathrm{~h}$.

(s) (o. I,it. 2oin a.

(f) Shepp. l'omehst. 372.

(ii) liu. Ab. 1. 4 I?, (i, ,1. 1 ; repeater on $1.151,1,1 \% 1$. (.r) 1 Wins. Simull. 23s; pur Williams .I. Bromen v. Wayme of

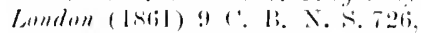

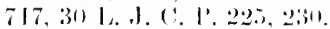

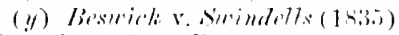
Ex. 'H. 3 A.d E. stis, in li, L. Joti.
Altemative comblitions, and le fandt of pration; same law as for ortinary contracts. 


\section{of Cod," are treated in the same way as direct promises.}

" When a conrlition beeomes impossible by the act of the obliger, such impossibility forms no answer to an action on the bond" $(\approx)$.

"When the condition of an obligation is to do two things by a day, and at the time of making the obligation both of them are possible, but after, and before the time when the same are to bedone. one of the things is beenue impossible by the act of Gorl, or by the sole act and laches of the obligee himself; in this case the obligor is not bound to do the other thing that is prisible. but is lischarged of the whole obligation. But if at the time of making of the obligation one of the things is and the other of the things is not possible to be done, he must perform that which is posible. And if in the firt case one of the things become impossible afterwark by the act of the obligor or a stranger, the obligor must see that he do the other thing at his peril." "If the condition be that A. shall marry li. by a day, and hefore the day the obligor himself doth marry her; in this case the condition is broken. But if the obligee marry her betore the day, the obligation is discharged " (a).

"If a man is bunnd to me in 201. an condition that he pay ne $10 /$., in that "ase if he temler me the money and I refuse he is altogether exeused from the obligation. because the default is on my part who am the obligee" (b).

Indian erse triact Aet.

The Indian Contract Act, s. 56, is so worded as to make the rule in Taylor v. Caldwell a rule independent of the parties' intention and applicable to every lind of contract. This is a wide and (it must be assumerl) a deliberate departure from the common law.

(2) Herc'ur. Bixulels v. Swindells

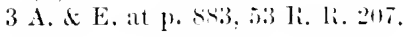

(a) Sheler. Touchst. 382, 39!2.

(li) liriall (. J. 22 E. IV. 26. 
CHAPTER IX.

Mistake.

Part I. OF Mistake in Ginkral.

Hithento we have heon dealing with perfectly general conditions for the formation or subsistence of a valid contract, and as a consequence of this the rules of law we have had occasion to explain are for the most part collateral or even paramount to the actual intention or belief of the parties. Apparent exceptions occur, but mostly in cases where the rules are found to be reducible to rules of construction. We now come to deal with cases in which the determining conditions are of a different kind, and the consent of the parties is the central point of the inquiry; the question heing how the legal validity of an agreement is affected when the consent or apparent consent is determined by certain causes.

The existence of consent is ascertained in the first instance by the rules and principles set forth in the first chapter. When the requirements there stated are satisfied by a proposal duly accepted, there is on the face of the matter a good agreement, and the mutual communications of the parties are taken as the expression of a valid consent. But we still require other conditions in order to make the consent binding on him who gives it, although their absence is in general not to be assumed, and tho party seeking to enforce an contrinct is not expected to
Comlitions afteeting reality or freeliom of consent. 
give affirmative proof that they have been satisfied. Not only must there be consent, but the consent must be true, full, and free.

The reality and completeness of consent may be affected (a) by ignorance, that is, by wrong belief (which may consist in $\mathrm{r}^{\circ}$ include oblivion of material facts) (b) or mere absence of information or belief as to some fact material to the agreement. Freedom of consent may be affected by fear or by the consunting party being, though not in bodily or immediate forr, yot so much under the other's power, or in dependence on him, as not to be in a position to rxercise his own deliherate choice. Now the results are different according as these states of mind are or are not due to the conduct of the other party (or, in certain cases, to a relation between the parties independent of the particular occasion). When they are so, the legal aspect of the case is altogether changed, and we look to that other party's conduct or position rather than to the state of mind induced by it. We speak not of Mistake induced by Fraud, but of Fraud simply, as a ground for avoiding contracts, though there can be no Fraud where there is no Mistake. We have then the following combinations:

Clansification anul legal cinseguences of llistake, Fraud, de.

A. Iynumaner.

A. Not eaused ly act $(r)$ of other party, is referred in law to the learl of Mistulie?. Catued by art (r) of other party

(11) It is guite wrong, as Savigny has shown, to say that a consent determined by mistake. fraul. or coereion is moconsent. Syst. s? 114 . If: (3. 9. $94 \%$ ). If it wereso the agletment would be abolutely rowl in all cases: a reduetion ad "hsurdum which is nu les complete for English than for lioman law. See per Lort Cranworth,

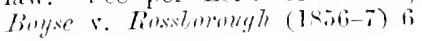

11. I. '. at p. 4t, Jos R. H. p. s, and per Lord Chelmsford, Oukes r. T"r. t"unde (1867) L. R., 2 HI. L. at 1. 349. (b) Howd of Aralon (Lady) $\mathrm{r}$. Jackinnen [1909] 1 Ch. tib. in L. J. Ch. :30it.

(r) It will be seen hereafter that omissiuns are equivalent to acts for this purpose in eertain speeial eases. 

B.
without wrongful intention.
Misreprisent ation.
c.
with wrongful intention.
Fraud.

B. Fear, or dependeners errluding firedum of action.

Not caused by acts of other party or rela-

tion between the parties.

(Immaterial.)

D. Cansed by such acts.

Inuess or courcion.

E. By such relation.

I'nlue intluenter.

The legal consequences of these states of things are exceedingly various.

A. Mistake does not of itself affect the validity of contracts at all $(d)$. But mistake may be such as to prevent any real agreement from bing formed; in which case the agreement is roid: or mistake may occur in the expression of a real agreement; in which case, subject to rules of evidence, the mistake can be rectified. There are also rules in the construction of certain species of contracts which are founded on the assumption that the expressions used do not correspond to the real intention (e).

в. Contracts induced by misrepresentation are not void. In many cases, and under conditions depending on the nature of the contract, they are voidable at the option of the party misled.

c. Contracts induced by fraud are not void, but roidable at the option of the party deceived.

D, E. Contracts entered into under coercion or undue influence are not void, but voidable at the option of the party on whom coercion or undue influence is exercised.

It is now seldom, if ever, necessary or useful to consider the former differences between the doctrines of the common law and those of equity.

These topics have now to be considered in order. And first of Mistake.

(d) Just as fear, merely as a state of mint in the party, is in itself immalerial. As liat is to

P.
Cocreion, so is Mistake to Frau.

Sitv. Sigt. 3.116.

(d) i'. 2il, atower. 
Mistilie: diflicultios ankl (onfistis) attemling thr. -ulliject.
A. (ienerial rule: Alistiklie "Es : inflerative:

The whote topic was formerly surommled with a great deal of confusion in our bonks, thongl on the whole of a verbal kind, and more cmbarasing to sturents than to practitioners. Exactly the same kind of confusion prevaled in the civil law (whence indeed some of it passer on to our own) until sarigny cleared it up in the masterly essay which forms the Aplentix to the thind volume of his system. The prineiples there entablinhed by him have been fuly adopted by later writers $(f)$, an l aplene to be in the main alplicable to the law of Fingland.

The difficultien which have arisen as well with us as in the civil law may be accounted for unler the following hears :

(1.) Cunfunin of proxinate with remute eauses of legal consequences: in other words, of cases where mistake has legal results of its own with cases where it determines the presence of sume other condition from which l'cral result- follow, or the absenee of some other condition from which lewal results would follow. or even where it is absolutely irrelevant.

(2.) The assution of phupurtions as general rules which ought to be takcin with reference only to particular effects of mistake in particular clasine of eanes. Such are the maxim lin ridentur qui srrant consentire amb other similar expresions. and to some extent the distinction between igmurane of fact amul of law (y).

(3.) Cmisoion to ansigu an exact meaning to the term "ignoranee of law" In thase canes where the dintinetion between ignonance of law and innorance of fact is material (the true rule. attirmed for the Roman law ly siavigny, and in a slightly different form for English law by Lord Westbury (h) being that "ignorance of law" means only ignoranet of a grmetel mbe of law, not ignorance of a right depending on questions of mixcl law and fact, wh on the true const raction of a particular instrment).

It is needless to foint out in detail how these intluences have operater

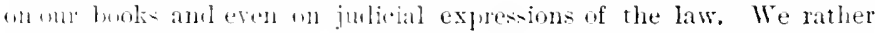

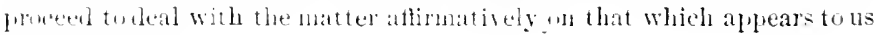
jts trite forting.

\section{A. Mistake in generas.}

The general rule of private law is that mistalie as such has no legal effects at all. This may be more definitely expressed as follows:

(f) Some of his conjectural dealins with specifir anomalies in the fiman texts are at least daring, but this dues not comern English stmlents. For the whl alticulties. 'p. cirotins Je lure li, ct l'. l. ii.

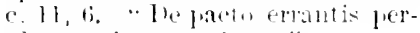
lexit ratis tratatio ent." (g) See Sarigny's Appendix, No. VII., VIII Syst, $3.342 .34 t$.

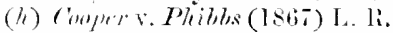
2 11. L. at 1 . 170: to which the dicta in the later case of Larl Berentump) r. II inn (1833) I. R. i 11. L. 22.93, really ath litte ur inthing. 
When an act is done under a mistake, the mistake does not either add anything to or take away anything from the legal consequences of that act either as regards any right of other persons or any liability of the person doing it, nor does it produce any special consequences of its own;

Unless knowlerge of something which the mistalie prevents from being known, or an intention necessarily depending on such knowledge, be from the nature of the particular act a condition precedent to the arising of some right or duty under it.

Special exceptions to the rule exist, but even these are founded on special reasons besile, though connected with, the mistake itself.

There are abundant examples to show the truth of this proposition in both its branches.

First, mistalie is in general inoperative as to the legal position or liability of the party doing an act. We must premise that a large class of cases is altogether outside this question, as appears by the qualification with which the rule has just been stated; those, namely, where a liability attaches not to the doing of an act in itself, but to the doing of it knowingly. There, if the act is done without know ledge, the offence or wrong is not committed, and no liability arises. It is not that ignorance is an excuse for the wrongful act, but that there is ne, wrongful act at all $(i)$.

It is certain that ignorance is as a rule no excuse as regards either the liabilities of a quasi-criminal

(i) 'The willer question how far ant unler what contition; ionosance of fact exclutes ariminal liability is beyomel the soope of this work, and tow impurtant to les disrussed incidentally. Sien llepeon excepit where by the special nature of the case knowlelge is a comlition precerlent of legal comientuences. As to the position uf the pristin acting muler milstales.

Wrongful acts : ignteratem in general 110 esellst.
Stophen's Digest of criminal haw

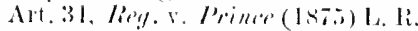

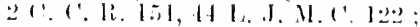
and comsult o. W. Holmes, Thu

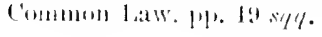


kind which arise under penal statutes $(j)$ or such as are purely civil. Thus ignorance of the true ownerst ip of property is no defence to an action for its recovery, except for carriers and a few other classes of persons exercising public employments of a like nature, who by the necessity of the case are specially privileged $(k)$. Again, railway companies and other employers have in many cases been held liabla for acts of their servants done as in the exercisc of their regular employment, and without any lawful intention, but in truth unlawful by reason of a mistake on the part of the servant: the act bring one which, if the state of circumstances sup)posed by hin did exist, would be within the scope of his lawful authority $(l)$. Of course the servant. himself is equally liable. Here, indeed, it looks at first sight as if the mistalie gave rise to the employer"s liability. For the act, if done with knowledge of the facts, and so merely wrongful in intention as well as in effect, would no more charge the employer than if done by a stranger. But it is not that mistake has any special effect, but that knowledge, where it exists, talies the thing done out of the class of anthorized acts. The servant who commits a wilful and gratuitous wrong, or goes out of his way to do somothing which if the facts were as he thought might be lawful or eren laudable, but which he has no charge to do, is no longer about his master's business.

Exections in jurlicial princes. but limiterl.

Real exceptions are the following:- An officer of a cont who has quasi-judicial duties to perform, such

(j) That ignorance cannot be plealed in discharge of statutory lenalties, see (arter v. MoLute'n

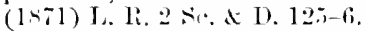

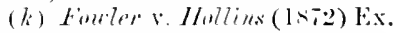
Cii., 1. li. 70 . R. tilli. affit. in 11. L. nom. Hollins r. Finelen $(1+\pi+5)$ L. R. T II. L. $75 \pi$.

(l) See Pollock on Torts. Sth ell. 8!-43. The latest reportet decision of this class is Hansoln v. Hielle's

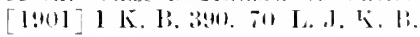
231. 
as those of a trustee in bankruptey, is not personally answerable for money paid by him under an excusable misapprehension of the law $(m)$. Also an officer who in a merely ministerial capacity executes a process apparently regular, and in some cases a person who pays money under compulsion of such process, not knowing the want of jurisdiction, is protected, as it is but reasonalle that he should be $(n)$. But this special exception is confined within narrow hounds. Mistake as to extraneous facts, such as the legal character of persons or the ownership of goods, is no excuse. It is "a well-established rule of law that if by process the sheriff is desired to seize the goods of A., and he takes those of B., he is liable to be sued in trover for them" $(o)$. A sheriff seized under a fi. fa. goods supposed to belong to the debtor by marital right. Afterwards the supposed wife discovered that when she went through the ceremony of marriage the man had another wife living: consequently she was still the sole owner of the gonds when they were seized. Therenpon she brought trover against the sheriff, and he was held liable, though possibly the plaintiff might have been estopped if she had asserted at the time that she was the wife of the person against whom the writ issured $(p)$. The powers of a Superior Court, under express rules or otherwise, to correct slips in its own proeeedings, is on a different footing: but it is not exercised indiscriminately $(q)$.

(m) Liar porte (lygle (1si3) I. Ii. s ('I. 万] I, I2 I. J. lik. 99.

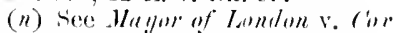
( Is6ii) I. Ii. 2 11. I. at 1. 269, 36; 1. I. lix. 2:25.

(a) loril Tenterilen ('..I. Kilaxs-

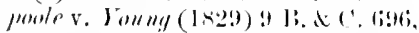

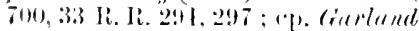

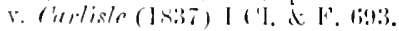

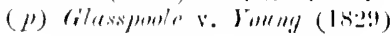

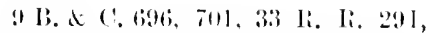
2915.

(y) Limsumeth v. II ilding [ Js:mi] 1 ch. 673, 6.i L. J. Ch. [3: ; aml

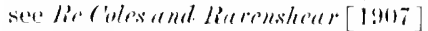
1 K. B. I, 76 L. J. K. I, 27, C. A., as to relieving a patty againsi his un' alviser's mistake in matter of procertule. 
Innorance in certain rases eorr. dition of ac priting rights: (j)ureliase for ralue without notice).

There are certain classes of cases in which it may he said that mistake, or at any rate ignorance, is the condition of acquiring legal or equitable rights. These are the exceptional cases in which an apparent owner having a defective title, or eren no title, can give to a purchaser a better right than he has himself, and which fall partly under the rules of law touching marliet overt and the transfer of negotiahle instruments, partly under the rule of equity that the purchase for valuable consideration without notice of any legal estate, right, or advantage is "an abso. Iute, unqualified, unanswerable defence" $(r)$ against any claim to restrict the exercise or enjoyment of the legal rights so acquired $(s)$. These rules depend on special reasons. The two former introduce a positive exception to the ordinary principles of legal ownership, for the protection of purchasers and the convenience of trade. It is natural and necessary that such anomalous privileges should be confered only on purchasers in good faith. Now good faith on the purchaser's part presupposes ignorance of the facts which negative the vendor's apparent title. It may be doubted on principle, indeed, whether this ignorance should not be free from negligence (in other words, accompanied with "good faith" in the sense of the Indian Codes), in order to entitle him. For some time this was so held in the case of negotiahle instruments, but is so no longer $(t)$. The rule of equity, though in some sort analogous to this, is

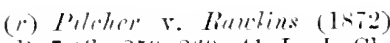
L. Li. 7 ("h. 2.59. 26!9. 41 I. .I. Ch.

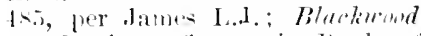
\&. Lometon chatered Bunl: at

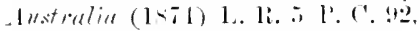
I11. 13 I. . J. I'. ('. 2.5.

(s) This applie- not unle topurely ergutable claims but to all purcly equitable remedies incialent to legil rights. But it does not apply to those rmedics for the enforcement of lecal rights which in a few ences have been administered by comrts of efuity coneurrently with courts of law. I'er Lord Westbury, Hhillips r. Plillips (1s61) + D. F. .1. 2015. 31 1\% J. (1). 321 .

(t) Sice Chap. I, 1. 2 tl. above. 
not precisely so. A. transfers legal ownership to 3., a prurchaser for value, by an act effectual for that purpose. If in A.'s hands the legal ownership is fettered by an equitable obligation restraining him wholly or partially from the beneficial enjoyment of it, this alono will not impose any restrietion upon B. For all equitable rights and duties are, in their origin and proper nature, not in rem. but in personam: they confer olstigationes not dominia. But if $B$. (hy himself or his agent) knows of the equitable liability, or if the ciremustances are such that with reasonable diligence he would know it, then loe makes himself, actively by knowledge, or passively hy negligent ignorance, a party to A.'s breach of duty $(u)$. In such case he cannot rely on the legil right derived from A., and disclaim the equitable liability which he knew or ought to have known to attach to it: and the equitable claim is no less enforceable against him than it formerly was against A. To be accurate, therefore, we should say not that an exception against equitable claims is introduced in favour of innocent purchasers, hut that the scope of equitable claims is extended against purchasers who are not innocent; not that ignorance is a condition of acquiring rights, but that knowledge ( 1 . means of knowledge treated as equivalent to actual knowledge) is a condition of being laden with duties which, as tho language of equity has it, affect the conscience of the party $(v)$.

Even here the force and generality of the main rulo is shown by the limits set to the exceptions. The

Ioinution if theserenterte tionat rights. (ii) Thus one who acegires property known bo be pant of at loukt extate from a vemblet known to he a truster, and comsering of lerwisu than water the anthority of the ("ourt itrelf. takes it subjeet to all tumbs and equities: Froham $r$ krmpter [1507] 1 (11. :373, 3411, iti 1. .1.1'h. 2.23.

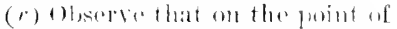

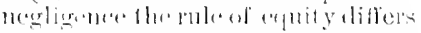

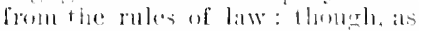
the suliject-malle' of the rales is

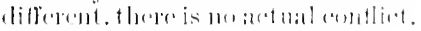


purchaser of any legal right for value and without noifee is to that extent absolutely protected. But the purchaser of an equitable interest, or of a supposed legal right which turns out to be only equitable, must yicld to all prior equitable rights $(x)$, howerer hlameless or even unavoidable his mistake may have heen. Again, no amount of negligence will vitiate the title of a bona fide holder of a negotiable instrument, lut not the most innocent mistake will enable him to make title through a forger indorsement. Where a hill was drawn payahle to the order of one II. Daris and indorsed by another H. Davis, it was held that a person who innocently discounted it on the faith of this indorsement had no title $(y)$. It might also he said that where tacit assent or acquiescence is in question, there ignorance is in like manner a condition of not losing one's rights. 3ut this is not properly so. For it is not that ignorance aroids the effect of acquiescence, but that there can be no acquisicence without linowledge. It is like the case where knowledge or intention must he present to constitute an offence. In this sense and for this purpoe "nulla roluntas errantis est. ${ }^{\prime}(\approx)$.

Apwication of the ceneral rule in cases if contract.

The same prineiples hold in cases more directly connected with the subject of this work. A railway company carries an infant above the age of three years without taking any fare, the clerk assuming

(.r) Ihimips v. Illitlips (1sici) t 1). F. . . 20 , 31 l. .1. (1. :321. A conrt of equity woulal rut deprive a furcharer for value without notice of anything he hasl actually gol. f.q prisension of title deels:

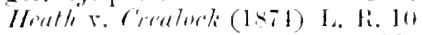
Ch. 2.2, 4 L. J. Ch. 1.5 : Itoldy v. Grey (1sis) L. li, $20 \mathrm{E}$. 238. 41 L. I. Ch. 394: bnt now that the court can aldninister both legill and equitable remedies in every cane this rule has lost its practieal impurtance: (im, r. r. lesey (1s82) 20 ch. Int till, ti32, il t. J. Ch. wiz. Similarly as to discorery: Ind. Cinpe it ro. ve Emmersont (1:57) $1: 2$ Alli. ('a. 300.

(y) Mfot y. Jomng (I790) 4

T. R. 2.s, 2. R. R. 314 .

( ) 1). 3:4. 3. de arpa plux. 20. 
him to be under that age, and there being no fraud on the part of the person in whose care he travels; the mistake does not exclude the usual duty on the company's part to carry him safely (a). A person who does not correctly know the nature of his interest in a fund disposes of it to a purchaser for value who has no greater knowledge and deals with him in good faith; if he afterwards discovers that his interest was in truth greater and more valuablo than he supposed it to be, he cannot claim to havo the transaction set aside on the ground of this mistake (b). This, however, is to be taken with caution, for it applies only to cases where the ral intention is to deal with the party's interest, whaterer it may be. The result would be quite different if the intention of both parties were to deal with it only on the implied condition that the state of things is not otherwise than it is supposed to be, as we shall find under the head of Fundamental E.rror.

So far, then, nistake as such does not improve the position of the party doing a mistaken act. Nuither does it as a rule make it any worse. A mistaken demand which produces no result does not affoct a plaintifl's right to make the proper demand afterwards. Where B. holds money as A.'s agent to pay it to C., and appropriates it to his own use, C. may recover from A. notwithstanding a previous mistalien

(a) dustin r. li. II: li. ('il.

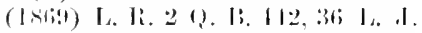
4. 18. 231. The mothere of the infant plaintiff tookonly one ticket for lerself : it secoms that the conllact operated in farome of buth

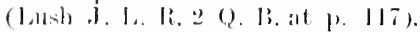
lint the anse is really alde of these. in the bereley-line if entratet and tort, where the breath is net so mach of a contratetual aluty as of

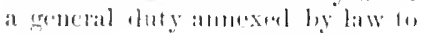

a particular business or mulerlakinge, streh ats was lhe erromml of the aletion of assmmpit in ils originat form. Sere jublgment of

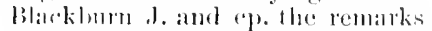

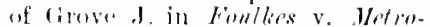

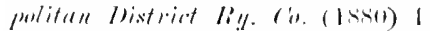
'. I'. I) at 1). 279. 4! 6. .I. ' '. I'. :icil, and the present witer"s" Iaw

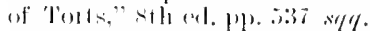

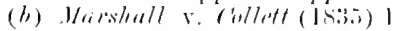

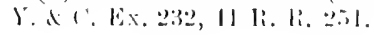


Iemand on 13. is estate, made on the assumption that b. would be treated as C.'s own agent $(c)$. Nor does a mistalien repudiation of ownership prevent the true owner of goods from recovering damages afterwards for injury done to them by the negligence of a bailee, whose duty it was to hold them for the true owner at all events $(d)$. This is independent of and quite consistent with the rule that a party who has wholly mistalien his remedy cannot be allowed to proceed hy way of amendment in the same action in an entirely different form and on questions of a different character $(e)$.

Antwexting Next, mistake does not in general alter existing rithtouf wher persins. rights. The presence of mistake will not make an act effectual which is otherwise ineffectual. Many cases which at first sight look like cases of relief against mistake belong in truth to this class, the act being such that for reacons independent of the mistake it is inoperative. Thus a trustee's payment orer of rents and profits to a wrong person, whether made wilfully and fraudulently, or ignorantly and in good faith, camot alter the character of the trustee's possission $(f)$. Where the carrier of goods after receiring notice from an unpaid vendor to stop them norertheless delivers them by mistake to the buyer, this does not defeat the rendor's rights: for the right of possession (y) revests in the rendor from the date of the notice, if given at such a time and

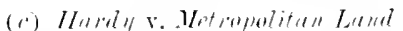

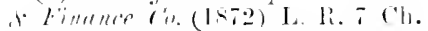
427. 1333.41 1. J. ('h. 25. th. Vancer w. Pand. 1. 11s.

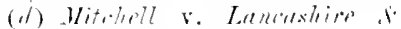

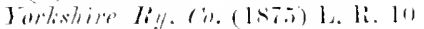

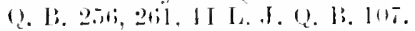

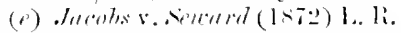
; II. L. Htit. 41 L. J. ('. l'. 2:21.

(f) Lister v. Prolition (1stis) 31

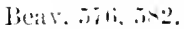

(a) The luok has propert! : but the word must here. as often, mean (nlly right to pussess. It is now weil understood that stoppage in transitu dues not rescind the contratel: Siale of roods Aet, 1593, $\therefore$ th: Limp r. Full, 7 App. Ca. at 1. . is 
under such circumstances that the delivery can and ought to be prevented $(h)$, and the subsequent mistaken delivery has not, ass an intentional wronglul delivery would not have, any power to alter it $(i)$. Again, by the rules of the French Post Office the sender of a letter can reclaim it after it is posted and before the despatch of the mail. C., a hanker at Lyons, posted a letter containing bills of exchange on England endorsed to D., an English correspondent. These were in return for a bill on Milan sent lyy D. to C. Before the despatch of the mail, learning from D.'s agent at Lyons that the hill on Milan would not be accepted and D. desired that no remit. tance should be made, $C$. sent to the post-office to stop the letter. It was put aside from the rest of the mail, but by a mistake of C.'s clerk in not completing the proper forms it was despatched in tho ordinary course. It was held that there was no effectual delivery of the bills to D., and that the property remained in C. The mistake of the clerk could not take "the effect of maling the property" in the bills pass contrary to the intention of both indorser and indorsee " $(k)$. Had not the revocation been at the indorsee's request, then indeed the argument would probably have been correct that it was a mere uncompleted intention on C.'s part: for as between $C$. and the post-office ererything had not heen done to put an end to the authority of tho post-office to forward thr letter in the regular eomsen of post.

Anderson's case (l) may possibly be supported on a

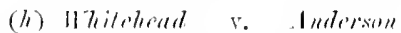

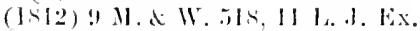

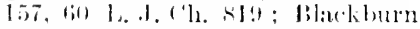

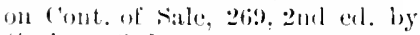
(iraham, 3:I.

(i) litt $\mathrm{r}$ (imle!l (18li) 7 †aunt. 169, IT R. 1․ 1\$2.

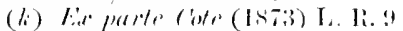

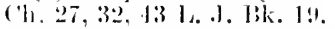

(l) (1869) 1. li. 8 by. sit. sind y". laprl Lindley. who was himself commsel in the case, ciles it (on 
Sillseguent collinlu?t of pialties firminley on mintaken ein-trictinn 1.lones 1100 t alter the cintratet : similar ground. It was there held that a transfer of shares sanctioned by the directors and registered in ignorance that calls wore due from the transferor might afterwards he cancelled, even by an officer of the company without authority from the directors, on the facts being discovered. It may be that the directors assent to the transfor is not irrerocable (aprart from the question of mistalie) until the parties have acted upon it.

Again, the legal effect of a transaction cannot be altered by the subseruent conduct of the parties: and it malies no thererence if that conduct is founded on a misalpmehension of the original legal effect. A man who acts on a wrong construction of his own duties under a contract he has entered into, does not throby entitle himself, though the acts so done be for the benefit of the other party, to have the contract performed by the other according to the same construction $(m)$. This decision was put to some extent upon the ground that relief cannot be giron against mistaliss of law. But it is submitted that this is not a case where the distinction is really material. Suppose the party hat not construed the contract wrongly, but acted on an erroneous recollection of its actual contents, the mistake would then have been one of fact, but it is obvious that the decision must have heen the same. Still less can a party to a contract resist the performance of it merely

(impanies, 2.9!) with the material unalifiention, $\cdot$ if 1 hir tran-feree hes not obiect." The case is remarkable for the dictum (which molit never to have been repurted) that "frand or mistake, either of them. is enough to vitiate an! tramsartioll."

(iil) lidland (i. II. Mil. of

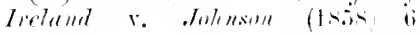

11. I. C. 79s, \$11, 111 li. li, 313. 31!. ver Jarrl chelunsfort. (On the wher hand, one who takes a wibley view of lijs rights uniler a contract than the other party will admit, is free to waive lhat dispute and enfore the contract to the extent which the other doesarmit:

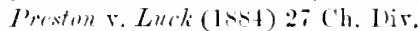
$1: 1 \%$. 
on the ground that he misunderstood its legal effect at the time $(n)$. Every party to an instrument has a right to assume that the others intend it to operate according to the proper sense of its actual expressions $(o)$.

It must be remembered, however, that where both parties have acted on a particular construction of an ambignous document, that construction, if in itself admissible, will be adopted by the Court $(p)$. To this extent its original effect, though it cannot be altered, may be explained by the conduct of the parties. And moreover, if both parties to a contract act on a common mistake as to the construction of it, this may amount to a variation of the contract by mutual consent $(q)$. And a mistake of one party induced, though innocently, by the other has the same effect as a common mistake $(r)$. This is in truth another illustration of the leading principle. Here the conduct of the parties in performing the contract with variations would show an intention to vary it if the true construction were present to their minds. It might be said that they cannot mean to vary their contract if they do not know what it really is. But the answer is that their true meaning is to perform the contract at all events according to

(ii) I'meell v. Smith (1872) I. R. 14 Eir. s.s, 11 T. J. Ch. 73l. The dietum in Wycombe liy. ('i. v. Jomninglon ILospital (1sibti) I. li. 1 Ch. 273, cammot be supported in any sense eontary to this.

(o) Per Kuight Bruee I.. J. bentley v. Marley $(1862)+$ D. F.J. 2n5. Cp. Ch. Vl., pp. 26ik, 26it, aliove.

(I) Forbes v. Hatt (1+72) I. R. 2 Fie. \& 1).211. Evirlenet of the construction put on an instrument by amme of the parties is of comrse

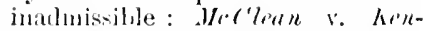

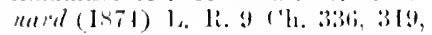

43 โ. . . 1 \%. 323. And a party who has acted on one of two pussible constructions of an olsenre agreement cammot afterwards enforce it acending to the othu' : Harshall v. Berridge (Iss') I9 ('H. Div. $233,241,51$ L.J. Ch. 329.

(q) 6 II. I. C. pl. st2-3. In the particnlar ease the apprellants were an incorporated complany, and therefore it was sainl eomlil not be thas bound : sed ya.

(r) IItdin! v. Samderson [15:7 ]

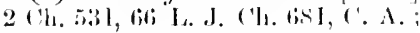
stomarl v. killuedy (No. :) (Is!a)

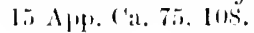

unless such that apratt from mistake it woruld amount to variation ly mutual consent. 
their present understanding of it, and thus the mistalie is immaterial. Practically such a mistake is likely to represent a real original intention incorrectly expressed in the contract: so that principle and convenience agree in the result.

Forfeiture isurared loy mistake.

Special cases where mistalke is of importance.

1. As exchuline true convent.

2 . In $(x-$ presing a lint ronserit.

3. Renum(ititiun of rivitit:.

4. T'ayment of mulley.
Again, mistake, in the sense of omission by pure forgetfulness to do something that ought to have been done, is not a ground for a court of equity in its discretion (assuming that it has jurisdiction) to relieve against forfeiture $(s)$.

What then are the special classes of cases in which mistake is of importance, and which have given rise to the language formerly current on the subject? They are believed to be as follows:

1. Where mistake is such as to exclude real consent, and so prevent the formation of any contract, there the seeming agreement is void. Of this wo shall presently speak at large (Part 2 of this chapter).

2 . Where a mistake occurs in expressing the terms of a real consent, the mistake may be remedied by the equitable jurisdiction of the Court. Of this also we shall speak separately (Part 3 ).

3. A renunciation of rights in general terms is understood not to include rights of whose actual or possible existence the party was not aware. This is in truth a particular case under No. 2.

All these exceptions may be considered as more apparent than real.

4. Money paid under a mistake of fact may be recovered back.

'This is a real exception, and the most important of all. Yet even here the legal foundation of the right is not so much the mistake in itself as the failure of the supposed consideration on which the money

(*) Barrou v. Isancs [189] 1 Q. 11. 417, 69 L. J. Q. B. 179, C. A. 
was paid; and the question is not of aroiding an existing obligation but of creating a new one.

\section{B. Mistake of F'act and of Law.}

Mere ignorance of law will not generally furnish r. Mistake any excuse or defence $(t)$. As has often bern said, if Law. the administration of justice would otherwise he intpossible. Practically the large judicial discretion which can be exercised in eriminal law may be trusted to prevent the rule from operating too harshly in particular cases. On the other hand it would lead to hardship and injustice not remediable by any judicial discretion if parties were always to be botmd in matters of private law by acts done in ignorance of their civil rights. There is an apparent conflict between these two principles which has given rise to much doubt and discussion $(u)$. But the conflict, if indeed it be not merely apparent, is much more limited in extent than has been supposed.

It is often said that relief is given against mistake of fact but not against mistake of law. But neither

IIow far the distinetion applie:alike.

(t) For a recent illustration sec Itremelle v. Korment (1!104) 197 U. S. 40, 55, 56. As to the enrent but inarourate form of statemont, sce per Maule .J.. Matimble v. Fulkner (1816) 2 C. 13. at 1). 719, 69 R. R. at p. 611 : "There is 110 presumption in this country that every person lnows the law: it woulel be contrary to common sense and reason if it were so. . . . The rule is that ignorance of the law shall not exeuse a man. or relieve him from the conserpences of a crime, of from liability a contract."

(u) Savigny, followed ly sevelal later writers, womld have it that mistake, to les a gromml of relief, must be free from nerligence. and igrmorance of law is prestimete thoush not ronolesively, to lis: megligent. lint this will mot lit
Englishlew as now settleal on the most important topic, viz.. reworering back moncy pail : for there. sis fome as the igmorance is of farel. negligence is mo bar: means of knowlerge are material moly as criblence of actual knowleifer: kill! v. Solari $(1 \times+1)$ ! M. \& 11 .

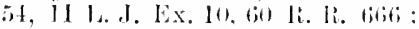

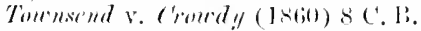
N. S. 177, 2! I. J. (. L. 3001 ; Imperial buth of C'umeda v. liank of Ilamiltm [1903] A. C. 19. 7.2 L..J. I'. C. 1. The only linutation is that the party secking to reconer must mot have waivel all inumiry :

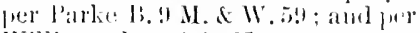
Williams .I. \& (!. H. N. Ś. I!)1. Sere

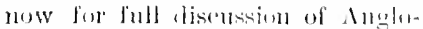

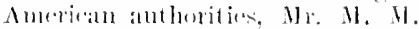

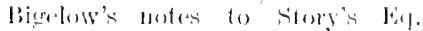

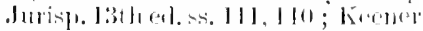

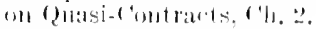


branch of the statement is true without a great deal of limitation and explanation. We have already seen that in most transactions mistake is altogether without effect. There such a distinction has no place. Again, there are the many cases where, as we have pointed out above, knowledge or notice is a condition precedent to some legal consequence. By the nature of these cases it generally if not always happens that the subject-matter of such knowledge, or of the ignorance which by excluding it excludes its legal consequences, is a matter of fact and not of law. The general presumption of linowledge of the law does so far apply, no doubt, that a person having notice of material faets cannot be heard to say that he did not know the legal effect of those facts. All these, how any correct sense.

Where

conslumoll mistalie exchirles real anteement, ienorance of private rightit at all vents = iesurituce of filct.

Then come the apparent exceptions to the general rule, which we have numbered 1,2 and 3 . As to No. (1) it is at least conceirable that a common mistake as to a question of law should go so completely to the root of the matter as to prevent any leal agreement from being formed. It is laid down by very high authority " that a mistake or ignorance of the law forms no ground of relief from contracts fairly entered into with a full knowledge of the facts $"(x)$ : but this does not touch the prior question whether there is a contract at all. On cases of this class English decisions go to this extent at all events, that ignorance of particular private rights is equi-

(r) bank of $t$. S. v. Dunifl (1s3s) (supt. ' 't. L. S.) l2 l'eters. 32. sti: but see Danirll r. Simelair (.). (') (18s1) b Apr. Ca. 181, 1!\%. the language of molern American authority persists in the old sharp distinetion : Ipton v. Tribilien
(1575) 91 l. S. 45, 50. Common mistake as to a collateral natler of law dhes nut of course aroid a contract : Eaglesticld v. Harruzis uf Lomdundery (1siti) + Ch. 1$)$. 6:13. 
valent to ignorance of fact $(w)$. As to No. (2) the principle appears to be the sante. A. and B. make an agreement and instruct C. to put it into legal form. C. does this so as not to express the real intention, either by misapprehension of the instructions or by ignorance of law. It is obvious that relief should be equally given in either case. In neither is there any reason for holding the parties to a contract they did not really make.

Authority seems to bear out what is here advanced $(x)$. A common mistake of parties as to the effect of a particular instrument is sufficient ground for varying a consent order founded on the mistaken opinion $(y)$. There is clear authority that on the other hand a court of equity will not reform an instrument by inserting in it a clause which the parties deliberately agreed to leave out (a), nor substitute for the form of security the parties have chosen another form which they deliberately considered and rejected $(x)$, athough their choice may have been determined by a mistake of law. The reason of these decisions is that in such cases the form of the instrument, by whatever considerations arrived at, is part of a real agreement. The parties have not been deprived by mistake or ignorance of the means of an effective choice of conrses, but have made an effective choice which some or one of them afterwards mislikes.

As to No. (3), there is quite sufficient authority to show that a renunciation of rights under a mis-

(ui) Bingleem v. Bingleam (1718) 1 Ves. Sr. 12t; : Broutgliton v. Bntt (15.8) 3 be (i.s .1.501: (beper v. Jhibls (186io) 1. R. 2 II. J. 149 , 170; of which eases a fuller aceosunt is given below.

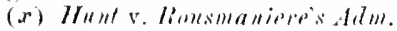

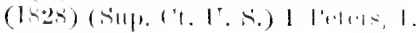

P.
Pectitication of instriments: relief given agains: mistake of draftiman though not against a deliberate choice of the pratties as to form or a)tents of instrunents.
Renunciation of rights: distinclion
13, If (amm a uniform conrse of later recisions in Anerica: see Prof. Williston's note).

(y) Hllard v. Walker [1896] 2

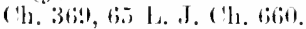

(a) Lard liwham vo Ghitd (1781)

1 Bir. (?.) (:.82. 
as to compromise or deliberate alsindinnent.

take as to particular applications of law is not conclusive, and some authority to show that it is the same even if the mistake is of a general rule of law. The deliberate renunciation or compromise of doubtful rights is of course binding; it would be absurd to set up ignorance of the law as an objection to the validity of a transaction entered into for the very reason that the law is not accurately known $(b)$. A compromise deliberately entered into under advice, the party's agents and advisers having the question fully before them, camnot be set aside on the ground that a particular point of law was mistaken or overlooked (c), though it may be otherwise if the advice has been misapprehended, or was in fact given without regard to the parties' legal rights $(d)$. Conduct equivalent to renunciation of a disputed right is equally binding, at least when the party has the question fairly before him. Thus in Stone r. Godfrey (e) the plaintiff had been advised on his title unfarourably indeed, but in such a way as to bring hefore him the nature of the question and give him a fair opportunity of considering whether he should raise it. Adopting, howerer, the opinion he lad whained, he acted upon it for a considerable time, and in a manner which amounted to representing to all persons interested that he had determined not to raise the question. It was held that although the mistake as to title might in the absence of such conduct well be a ground of relief, a subsequent discovery that the correctness of the former opinion was doubtful did not entitle him to set up his claim

(b) Cp. the remarks on eompromises in Ch. IV., p. 2013, above.

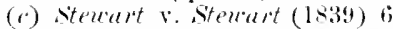
('l. A F. 911, 49 R. L. 26ii; sete the authorities reviewerl. ti ( 1 . $\mathrm{d} F$.

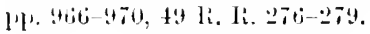

(d) Re Roberts [1905] $1 \mathrm{Ch}$. 714. it I. J. ('h. 483, C. A. (a peculiar ease of Welsh-speaking parties).

(e) (isit) 5 D. 11. (i. 76, 104 li. li. 32 . 
anew. In Rogers r. Inglam $(f)$ a fund had been divided between two legatees under advice, and the payment agreed to at the time. One of the legatees afterwards sued the executor and the other legateo for repayment, contending that the opinion they had acted upon was erroneous; it was held that the suit could not be maintained. Similarly where creditors accepted without question payments under a composition deed to which they had not assented, and which, as it was afterwards decided, was for a technical reason, not binding on non-assenting crectitor's, it was held that they could not afterwards treat the payments as made on account of the whole debt, and sue for the balance. They might have guarded themselves by accepting the payments conditionally, but not having done so they were bound (y). In Re Saxon Life Assurance Society $(h)$ it was held that a creditor of a company was not bound by a release given in consideration of having the substituted security of another company, which security was a mere nullity, being given in pursuanee of an invalid scheme of amalgamation. Here the mistalis was obviously not of a general rule of law; and perhaps the case is best put on the ground of total failure of consileration.

As to No. (t), the subject of recovering back sroney raid money paid hy mistake does not properly fall within our scope. It is here, however, that the distinction between mistalies of fact and of law does undoubtedly prevail. While no anount of mere negligence avoids the right to recover back money paid under a mistalie of fact (i), money paid under a mistake of law can-

(f) (1576) 3 ('h. I) liv. 3.1, 4i; L. J. ('h. 302.

(g) hitchin v. Hawkins (1stiti)

I. R. 2 (.. R. 2.2. (h) (1862) $2 \mathrm{~J} . \mathrm{N} \mathrm{H}$ H. 418, 112 (the Aluchor ctest).

(i) Nute ("), 1. 47!, supur. by mistake recoverable (mily whin the mistalie is of fact. 
not in any case be recovered $(k)$. Nor does anything like the qualification laid down by Lord Westhury in Croper v. Pliblss (l) appear to he admitted. Ignorance of particular rights, howerer excusable, is on the same footing as ignorance of the general law $(m)$.

An important decision of the American Supreme court appears to assume that giving a negotiable instrument is for this purpose equivalent to the payment of money, so that a party who gives it under a mistake of law has no legal or equitable defence $(n)$. But, according to later English doctrine, inasmuch as "want of consideration is altogether independent of knowledge either of the facts or of the law," the defence of failure of consideration is available as between the parties to a negotiable instrument, whether the instrument has been obtained by a misrepresentation of fact or of law $(o)$.

A covenant to pay a rebt for which the corenantor wongly supposes himsalf to be liable is ralid in law, nor will equity gire any relief against it if the party's ignorance of the facts negativing his liability is due to his own negligence $(p)$.

Alument rexpention in batiruptey:

The Court of Bankruptcy will order repayment of money paid to a trustee in bankruptey under a mis-

(li) lint as to re-opening aceountis in cupity, ste Janiell v. Sindair. (.l. ('.) (1sis) 6 Apte ('a. 1s'l.

(l) (listii) L.. li. 2 H. J. al 1). 170 .

(iil) Sice skyring v. Giremunoud

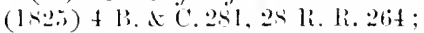
amd ('). Platt r. lirommer (155t) It 1. .1. Ex. 193, 111 li. li. 9133, where however the mistake was mot only a mistake of law, hut enllateral to the payment. the money leing really due: Aiken r. Shoit

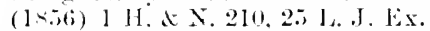
321 los li. R. Jodi. restson the same armuml. if the transaction in that case be lewaled as the lare bay-

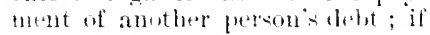

it be regarted as the purchase of a sex-arity, it is an apllidation of the lule carpat emptor, as to which ("p. clare v. Jamb (lisio) l. li. lo ('. I’. 334. 44 I. .I. C. I'. 17\%.

(ii) Junk of $l$. 5 . v. Doniel (1934) 12 l'eters, 32: lut this was not the only gromnd of the tecision.

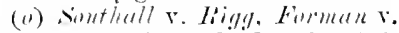
11 right (15.51) 11 C. P. 451. 4!92. 20 I. .i. ('. I'. 14.'. ST R. R. 73l : (imald v. Hughes (1855) l K. d. J. 443. 111: R. R. 172 .

(j) 1 lason r. Hareing (Isiz) 1; Puav.jol. Whether relief combl be griven in any case, unless there were framl on the other sile: ytertien. 
take of law: but this is no real exception, for it trustee is is not like an ordinary payment between party and party. The trustee is an officer of the Court and "is to hold money in his hands upon trust for its equitable distribution among the crelitors" $(q)$. In ollicer of (omit. Otherwise same rufes in exuluty general the rule that a voluntary payment made with full knowledge of the facts cannot be recovered back is no less an equitable than a legal one: "the law on the subject was exactly the same in the old Court of Chancery as in the old Courts of Common Law. There were no more equitios affecting the con science of the person receiving the money in the one Court than in the other Court, for the action for money had and received proceeded upon equitable considerations" $(r)$. Thus a party who has sulmitted to pay money under an award cannot afterwards impeach the award in equity on the ground of irregularities which were known to him when he so submitted $(s)$. It has also been laid down that in a common administration suit a legatee cannot be made to refund over-payments voluntarily made by an executor $(t)$ : but the context shows that this was said with reference to the frame of the suit and the reliof prayed for rather than to any general principle of law: moreover it was not the cxecutor, hut the persons beneficially interested, who sought to mike tho legatee liable. But in Bate v. Hooper (u) tho point arose distinctly: certin trustees were liable to make good to their testator's estate the loss of prin-

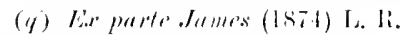

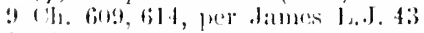
1. .1. 13k. 107. This holds even after the money paid by mistakes has been distributed, if the trustere still hats or maty have lumble alphlirables for payment of clividends:

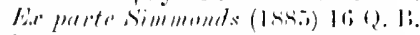

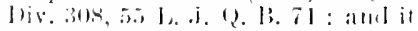
serems to rextend to all ollicers af the fourt and all brimches of the
Silpremo ( omit.

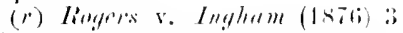

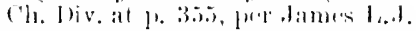

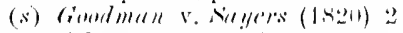
J:16. \& W. 219, 26i3, 22 R. R. 1+2.

(l) lev laml cotfoulatum, hich-

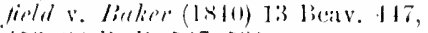

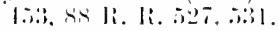

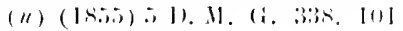
li. li. I11. 
('asestube dealt with in this sulfdivision.

Where no real common intention. each party meaniner different thingr. cipal incurred by their omission to convert a fund of Long Annuities: they contended that the tenant for life ought to recoup them the excess of income which she had received: but as she had not been a willing party to any orer-payment $(x)$, it was decided that she could not be called upon to refund the sums which the trustees roluntarily paid her.

\section{l'art II. Mistake as excluding true Consext.}

In the first chapter we saw that no contract can be formed when there is a rariance in terms between the proposal and the acceptance. In this case the question whether the parties really meant the same thing camnot arise, for they have not even said the same thing. A court of justice can ascertain a common intention of the parties only from some adequate expression of it, and the mutual communication of different intentions is no such expression.

We now have to deal with certain kinds of cases in which on the face of the transaction all the conditions of a concluded agreement are satisfied, and yet there is no real common intention and therefore no agreement.

First, it may happen that each party meant something, it may be a perfectly well understood and definite thing, hut not the same thing which the other meant. Thus their minds never met, as is not uncommonly said, and the forms they have gone through are inoperative. This is quite consistent, as wo shall see, with the normal and necessary rule (Ch. VI., pp. 258, 259 , above) that a promisor is hound by his promise in that meaning which his expression of it reasomably conveys.

$(x)$ the had in fact desired the tunstes tar convert the fumd: see 5 1). Il. G, 341, 101 li, Ii, I li : and compare ririte v. Grold (181i) 2 Narhl 11i3, 5.8 li. R. 33. 
Next, it may hippen that there does exist a common intention, which, however, is founded on an assumption made by hoth parties as to some matter of fact essential to the agrcement. In this case the common intention must stand or fall with the assumption on which it is founded. If that assumption is wrong, the intention of the parties is from the outset incalpable of taking effect. But for their common error it would never have been formed, and it is treated as non-existent. Here there is in some sense an agrenment: but it is nullified in its inception by the nullity of the thing agreed upon. The result is the same as if the parties had made an agrement expressly conditionil on the existence at the time of the supposed state of facts: which state of facts not existing, the agreement destroys itself. Indeed there is in most if not all cases of this class no difficulty in holding that the contract did include a tacit condition to this effect.

In the former class of cases either one party or hoth maly be in error: however, that which prevents any contract from being formed is not the existence of error but the want of true consent. "Two or more persons are said to consent when they agree "upon the same thing in the same sense:" this consent is essential to the ereation of a contract $(z)$, and if it is wanting, and the facts be not otherwise such as to preclude one party from denying that he agreed in the sense of the other (1), it matters not whether its absence is due to the crror of one party only or of both.

In the latter class of cases the error must be common to both parties. They do agree to the same

(a) Hannen J. in simith v. (a) IIamen I, l.r., Blackbum, .

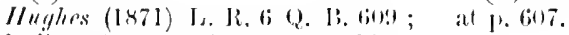

Indian contract Act, 1872, ․ 13.
Where there is a common intention but founded on a common crror. 
thing, and it would be in the same sense, but that the sense they intend, though possible as far as can be seen from the terms of the agreement, is in fact nugatory. As it is, their consent is idle; the senso in which they agree is, if one may so speak, insensible.

In both sets of cases we may say that the agreement is nullified by fundamental error; a term it maly be conveniont to use in order to mark the broad distinction in principle from those cases where mis. take appears as a ground of special relief.

Jivi-irns of fumblancutal curir.

As to nature of the transaction.

Thlol:minleroulin caste.

Wre proceed to examine the different linds of fundamental reror relating:

A. To the nature of the transaction.

B. To the person of the other party.

$C$. To the subject-matter of the agreement $(b)$.

A. Error as to the mature of the transaction.

(On this the principal early authority is Thoroughgrod's case $(c)$. In that case the plaintiff, who was a layman and unlettered, had a deed tendered to him which he was told was a release for arrears of rent only. The deed was not read to him. To this he said, "If it he no otherwise I an content"; and so delivered the deed. It was in fact a general relfase of all claims. Under these circumstances it was adjudged that the instrument so executed was not 1he plaintiff"s deed. The effect of this case is "that if an illiterate man have a deed falscly read orop to him, and he then seals and delivers the parch-

(b) The Gicman ('iril ('ud has takell a new and much -implitied curse on the whole matter. Any kinul of ". leclamation of intention" is voinlable om the gromml of fomta. mental erom. even if the mintalse is milateral: lut foidable omly, and subject to the dut of compensatin: auy larty fur lamage incured by relyin on the valinlity of the act: 1:. (i. I: ss. $11 !-122$.

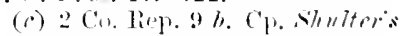
rase. 12 ('o. Ricp. 90 (deed falsely learl to a blind man). 
ment, it is nevertheless not his deed" $(d)$; it was also resolved that "it is all one in law to read it in other words, and to declare the effect thereof in other manner than is contained in the writing:" but that a party executing a decl without requiring it to be read or to have its effect explained wonlel bet hound $(e)$. Agreeably to this the latw is stated in Sheppard's Touchstone, 56. But at present the mere reading over of a deed without an explanation of the contents, to a person incapalile of reading it for himself, would hardly be thought sufficient to show that the person executing it understood what he was doing $(f)$.

The doctrine was expotunded and confirmed by tho luminous judgment of the Court of Common l'leas Fintine. Hackinmon. in Foster v. Mackinnon (y). The action was on a bill of exchange against the defendant as indorser. There was evidence that the acceptor had asked the defendant to put his name on the hill, telling lim it was a guaranty; the defentunt signed on the fath of this representation and without seeing the face of the bill. The court held that the signature was not binding, on the same principle that a blind

(d) Yer Cur. I. Ii. 4 ('. I', III It hanl been long before sain, in :-1 Hen. VII., that " if I desire a man to enfeoff me of an aere of laml in Thale, and he tell me to make a deerl for the atere with letter of at tormer. and I make the reed for I wo ateres and reat and dectare the teed to him ats for only one ace, and he seal the decel, this deed is ntterly buil whether the feoffor be let territ or not, becaluse he gave eledence on me and I teceivel him." (keilw. 70, l, (1.6): but q". whether this can be areepterl to the luble extent

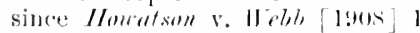

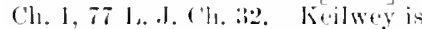
in lace only at commonplare besk, thongh it rems generally aremant.
Amb see the nhler anthorities referred to in mote (i), next page.

(e) I.e. to this extent, that lue conlif mot sily it wats not his deect, apart from any question of frand or the like.

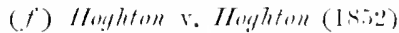

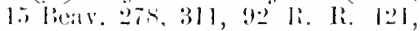
l:3.5. In the eare of a will the execution of it ly a testater of somml miml after havine hat it reat over to him is evidence. but

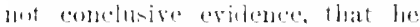

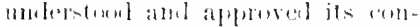

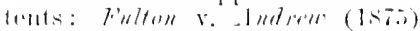
1. IR. 7 11. 1. 118, 160. $x_{7} \%$ 172, $141 . .1 .1 \% 17$.

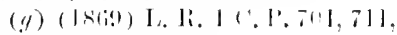
is 1.1. 1'. 1.310. 


\section{or illiterate man is not bound by his signature to a document whose nature is wholly misrepresented to him.}

\section{A signature so obtained}

"Is invalir not merely on the gromml of fraud. where frand exists, but on the grounl that the minl of the signer dicl not acomprany the signature; in other words, that he never intenderl to sign, and therefore in contemplation of law never dirl sign the eontract to whieh his name is a]premled (h). . . . The position that if a grantor or covenantor be leveived or minled as to the artual contrnts of the deed, the deed does not himb lim, is supwrted by many authorities: see Com. Dig. Fait (K. 2) (i), aml is recomizel by Bayley b, an! the court of Exchequer in the case of Edurards v. Brom $(k)$. Accordingly it has recently been deeided in the Exchequer 'hamber that if a deed be relivered, and a blank left therein be afterwards improperly filled un, (at least if that be done without the grantor's negligence). it is not the deed of the grantor: Sinan v. Sintle British Anstrulusiun Laud (i).(l). These eases apply to deeds: but the principle is equally applicable to ot her written cont racts."

(i) The same rule is lairl dorn, anil for the same reasm, in a rescrift of Dioeletian aml Maximian: Si falsum instrumentum emptionis culseriptum tibi. relut locationis ynam fieri mandaveras. subscribere te nim relecto sed finlem labentem sllasit. nentrum contractum, in utrupe alterutrius consensil detiriente, comstitise proul hubsu est. ('. I. 2.2. plus valere, $\therefore$.

(i) rited also by Willen.J. 2 C. I. X. S. 621 , and see 2 ho. Ab. 2ns: the eases there referred to (30 E. 111. 31 b: 10 H. V1. 5. 1, 10) show that the prineiple was recognizad in very warly times. (p. Fleta 1. i. c. 33 s.2. si autem rexatu.

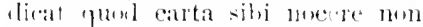
debart ... vel quiar jeer dolum arlenit, ut si cartam le feetfiamento sigillatam [qu. sigrillavit "r sigill:urerit cum soliptam de termino anmorum sigillare eresliclerit, vel ut si carta tieri debuit arl vitam. illam fieri feroit in fersluet hainsmuli, flum tamon niliil sit fuonel imperitia vel nerlierentine suae pusit imputari, at $[\mathrm{si}]$ sigillum suum senescallo trarliderit rel uxori, fuerl cautius lebut eas- todicisse. (More whether the oll authorities as to " non est faet um" are applieable to edueated and sceing versons, see Howretson r. Ib th, $[1 ! 0 x] 1$ ch. 1, 3, 4. But at all events it would be ra-h to divinte the authority of Fuster. Whelinnon.

(k) (IA31) \& C. S J. . $307,312,35$ R. R, 7.21, 725.

(7) (1863) 2 H. \& C $175,321, .1$. Ex. 273. And it was there doubted whether a man ean be estopped by mere negligence from showing that a lecel is not really his deed. sce ber livles J. 2 H. I C. 184.32 L.J. Ex. 2-s. and per Coekburn ('.J.

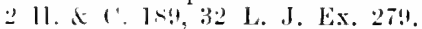
In llish L.J. in IIunter s. IIalters (18.1) I. L. 7 ('h. 75, 87. 41 L. J. ch. Iri. mentinned this ruestion as

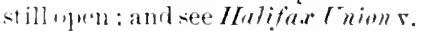
Hhemteright (IN-5) L. R. $10 \mathrm{Ex}$. 183. 152, t4 L. J. Ex. 121. The newatire answer seems to be the right one: ep. Omeard Buileding

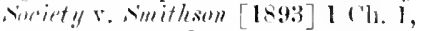
13, 1t, 6.2 1. J. (h. 133, ('A.; Lingmuan v. Broth Electria Tram"ays [l!n.5] $1 \mathrm{Ch} .616, i+$ L. .l. ch. 12i, C. A. 
The judgment proceeds to notice the qualification of the general rule in the case of negotiable instruments signed in blank, when the party signin! knows what he is about, i.e., that the paper is afterwards to be filled up as a negotiable instrument $(\mathrm{m})$. But here the defendant "never intended to molorse a bill of exchange at all, but intended to sign a contract of an entirely different nature." He was no more bound than if he had signed his name on a blank sheet of paper, and the signature had been afterwards fraudulently misapplied (u). This decision shows clearly that an instrument executed by a man who meant to execute not any such instrument hut something of a different kind is in itself a mere nullity, though the person so executing it may perhaps be estopped from disputing it if there be negligence on his part $(o)$; and that, notwithstanding the importance constantly attached by the law to the security of bona fide holders of negotiable instruments, no exception is in this case made in their favour.

The existence of a fundimental error of this sort, not merely as to particular's, but as to the nature and substance of the transactions, has seldom been

Silch ynestions in erpuity: gencratly (m) Whether this is a branch of the general principle of estopluel of a posit ive rule of the law merchant was mueh doubted in Swen v. Vurth British Australusian Lamd ("). (lsisis) in the tomt below, 7 II. \& N. (io), 31 L. J. Wx. 42., lis the present julment the Court of $c^{\prime}$. l'. scems lo incline to the latter riew.

(i) I. li. + C. L'. at 1). 712.

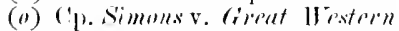
II\%. (\%. (18:7) 2 1: li. N. S. 620, log li. li. sori. where the praint iff was held not bomml by a palper ol special eomditions limitime the company's respousibility as arriers, whicle he hat signed withoul realing it, being in fact unable at the time to real it for want of his glasses, and beiner assured by the railway elerk tlat it was a nere form. "The whole ruestion was whether the platintiff signed the reeeipt knowing what he was abont"; fer ('incklmurn ('.J. at p). (i2t. The clerk's statement distinguishes this from the class of cases eitol at ply. 50. il, above. Where a pertom intending to execute his will has by mistake executed a woug commisut, that doemment anmot be amitfed to probate even if the leal intention would therely be partially carried ont : Inthr ionds

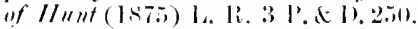
+4 1. I. I'. 13. 
complicaterl with rircom stances of fralut.

Inisingotion loetwrent tol:al

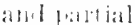
miniturne lie?l1-joll considered hy courts of equity except in connection with questions of frand from which it is not always practicable to disentangle the previous question whether there was any consenting mind at all: and a just zoal to restrain fraudulent practices has now and then led to the utterance of dicta not wholly acording to knowledge $(p)$. Evidently there cannot he such a thing as a peculiar doctrine of equity as to the passing of legal estates or the creation of lengal ohligations.

Rererent authorities do not deny that an instrument smay be wholly roid as against a party who hass rexented it under a total misapprehension of its nature, heing put off inquiry by fraud or other plansible cause $(q)$; but misapprehension of the effect or contents, when the party linows what he is dealing with, is not enough; and it seems that a man of ordinary education and competence, if he chooses to execute an instrument without informing himself of its ganeral purport and effort, does so at his peril ats regards innocent third persons, whaterer remedies he may have against any other party to the transatclion $(r)$.

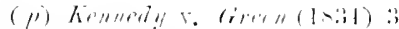

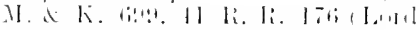

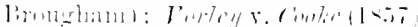

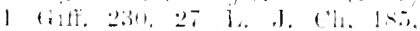
l11 Ji. li. tlis: Mtilitir r.

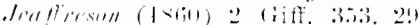

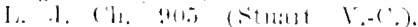

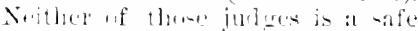
watrambl for - peculative extent-

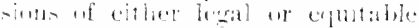

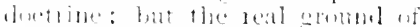

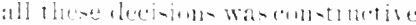
metire of the framl. Though in

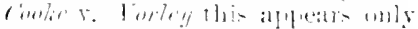

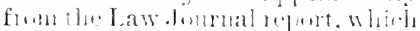

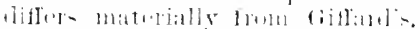

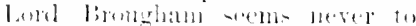

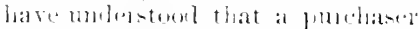
fug valuable combialuation without nutien ats wothing of a combl of epuity hut to leave him alome.

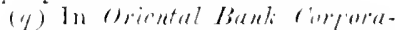

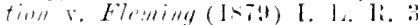
lim. 242, a compositions deed inclubing al releate which wat mot antborizel war executed on behalf of rechtors: time was puensinger and exantination of the deed was warted on the debtor's asturande that all was as atgreed : the lling cont aterecel that is was mot the deet of the plaintifis sis fat as it furported to uperate as a releate. Fratul was not alleged, but no right have ben andured l,y any thime party on the fath if the reclease.

(i) Henter s. Hielters (lsil)

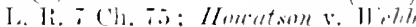

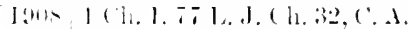


"When a man knows that he is eonveying or doing something with his estate. but does not ask what is the precise effect of the deen, because he is told it is a mere forn, and has such contidence in his suldeitur at to execute the deed in jgnorance, then a deed so executed, althomgh it may he voidable upon the grouml of fraud, is nut a void deed" (s).

Accordingly a man who executes a mortgage con taining the usnal covenants, and linows that he is transferring the property but assumes that it is an out and out conveyance, is liable on the covenant for payment of principal and interest to a transfore for value $(t)$.

A conveyance from A. to B., purporting to grant that which A. has already conveyed by deed, and being obtained by B.'s fraud, is not roid as a dered, and may create an estate by estoppel if it contains sufficiently elear averments $(u)$.

A contractor must stand by the words of his contract, and, if he will not read what he signs, he alone is responsible for his omission (c). And it maty be said generally that a man of business who exceutes "an instrument of a short and intelligible descrip" tion cannot be permitted to allege that he executed it in blind ignorance of its real character " (u).

(*) Hunter v. Hialters (19:1) L. R. 7 ('h. 75 : per Mellish I... at p. S8; "p. lat. Pror. Bitmk of Emgland v. Jurlisom (1886i) 33 ('h. Div. 1 : and Lloygl's liamk, Ltd. v.

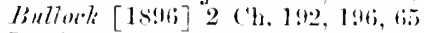

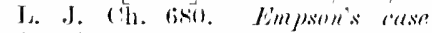
(1870) (J. R. 9 Eq. $5 ! 1 \%$, where 110 anthorities appear to have been cited) decided only that a fals: recital of a man being a member of a builling soriety will not make him a contributory in its winding-nu.

(t) Itowntson v. Ilobb) note (r) ahove. The 6. A. dist wot approve of a distinction between the effects of conveyance and coventunt in such rireumstances sngegestod by swinfen liady J. in lielget $\dot{x}$.

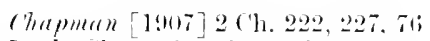
I. .J. ('h. i2s. Where the atrotial decision was on the groumb of total misrepresentation : see [1!m] 1 ('h. at 1 ln. $2,3:$ and qu. theseform

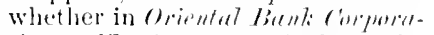
tim v. floming note (1) above. tha sutlicient alternative gromm of drcision, that the debtor's mistepersentation even if innoernt marl. the deed voldable, was not the sounder.

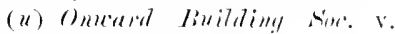

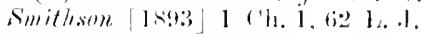
('h. 138, C. A.

(r) lyton v. Tribitrom (INis) 91 I. S. .5, 50.

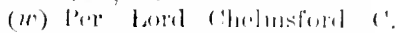

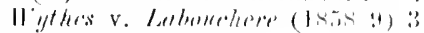

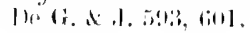


Strictly this may be an inference of fact rather than a rule of law; lut under such conditions the inference is irresistible. It may be observed, however, that a prudent man who has examined and approved the draft of a deed to which he is a party does not, as a rule, insist on verifying with his own eyes the exact correspondence of the engrossment with the draft; and it would surprise both branches of the profession in England if it were held to be negligence for a man to trust his solicitor to that extent $(x)$.

Error as tol leyal charicter if the transaction.

There may also be a fundamental error affecting not the whole substance of the transaction, but only its legal character. It is apprehended that on principle a case of this kind must be treated in the same way as those we have already considered; that is, if the two parties to a transaction contemplate wholly different legal effects, there is no agreement; but this will not prevent an act done by either party from having any other effect which it can have by itself and which it is intended to have by the party doing it.

Thus if $A$. gires money to $B$. as a gift, and B. takes it as a loan, B. does not thereby become A. 's debtor $(y)$, but the money is not the less effectually delirered to B. (z). So, if a balier who has ordered flour of $A$. is receives by a warehouseman's mistake flour of B.'s,

(.x) ('H. per Matins V.C. (whe knew the common course of business vely well, if his law was sometimes adrenturous) L. Ii. y E(1. at 1). 603.

(y) lint if B. communieates to A. his intention of treating the unmey as a ban, ant $A$. assents. then there is a good contract of loan. see Hill \&. Hilson (1si3) L. H. 8 Ch. s8s : per Mellish L..J. at $1 \% 896$; where it was heht that an advance at first intented to be a gift hal in this way been turned inte a loan, and was a groul con- sileration for a promissory note subsiguently given for the amount.

(i) Sarigny, syst. 3.269: Paulus, I. 4t. T. de. o. et a. $3 \$ 1$. Ton satis autem est dantis esse numos et fieri accipientis. ut obligatio naseatur, sed etian hoe animo dari et accipi ut obligatio constituatur. Itaque si quis peemiam suam donandi callsa derlerit mili, quamyuam et donant is fuerit, et mea fiat. tamen non obligaltor ei, quia non hoe inter nos actum ust. As to the transfer of the property being effectual (nntwithstanding Clpian's opinion in 
which is more valuable, and consumes it in good faith, he is not liable to $B$. for the true value (a).

We have seen however (p. 476), that mistake as to any particular effect of a contract depending on its true construction does not discharge the contracting party or entitle him to act upon his own erroncous construction.

\section{B. Error as to the person of the other party.}

Another kind of fundamental error is that which relates to the person with whom one is contracting. Where it is material for the one party to know who the other is, this prevents any real agreement from being formed $(b)$. Such knowledge is in fact not material in a great part of the daily transactions of life, as for instance when goods are sold for ready money, or when a railway traveller takes his ticket: and then a mere absence of knowledge caused by complete indifference as to the person of the other party cannot be considered as mistake, and there can be no question of this kind. In principle, however, the intention of a contracting party is to create an obligation between linself and another certain person, and if that intention fails to take its proper: offect, it cannot be allowed to take the different effect of involving him without his consent in a contract

1). 12. 1. de reb. ered. $18 \mathrm{pr}$.) cl. Julianns, 1). 41. 1. de aef. rer. dom. 36. The reason is that to that extent there is an intention free from error on the one part and an assent on the other. But a wholly mistaken handing over of money or goods passes no property: $k$. v. Middleton (1873) L. 1.. 2 C. C. Ti. $38,44,12$ I. I. M. C. 73 ; Kingsford v. Merry (185ti) (Ex. (H.) 1H. A N. 503, 26 L. J. Ex. \$3, IUs R. R. 691: and see ('hapman vo Cole (Is58) 12 Glaty (Mass.) 1+1 ; $R$. v. Asherell (1855) If Q. B. L. 190, 55 1.. J. H. C. 65is. (a) Ilill.s v. Suell (1s70) 104 Mass. 173; cp. the somewhat similar ease put by bramwell B. in R. v. Middleton (1873) L. R. '2 (1. (.) R. at 1). 56\%

(b) Savigny, Syst 3. 269; Pothier, Obl. \$ is, adopted by Fry a. in simith v. II heateroft (15\%8) 9 ('h. 1). at 1. 230,47 L. J. (h. 745 . If I take a kan from $A$. thinking he is $R$.'s agent to lend me the money when he is in truth C.'s there is no cont ract of han, though (' may get hark his monety by cendictie: 1) 12. 1. de reh. eredi. 3i.
Error in perisome. 
boullun $r$. Junes.

with some one else. In other words, an offer made to one man cannot be accepted by another.

In Boulton r. Jones (c) an order for goods had heen addressed by the defendants to a trader named Brocklehurst, who without their knowledge had transforred his business to the plaintiff Boulton. The phintiff supplied the goods without notifying the change, and after the goods harl been accepted sent an invoice in his own name, whereupon the defendants said they knew nothing of him. It was held that there was no contract, and that he conld not recorer the price of the goods. Possibly the person for whom the order was meant might have adopted the transaction if he had thought fit. But with the plaintiff there was no express contract, for the drefendint's offer was not addressed to him; nor yet an implied one, for the goods were accepted and usied by the defendants on the footing of an express contract with the person to whom their offer was l'edly addressed. The defendants might have had a set-off against the person with whom they intended to contract $(d)$.

I'ersmation.

Again, if A. means to sell goods to B., and C. olitains delivery of the goods by pretending to be

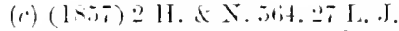

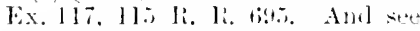

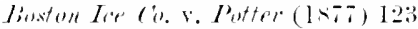
Misc. 2s, where limultun v. Jones was followel in its full extent. Kut might it not be contenled that accorling to general usage a properil andremest to a trader at his phace of buriness for the supply of grouls in the way of that business $i$. in the abience of anything showing suecial peisonal consileratimn, a fropusal to whrever in carrying on the same business eontinumsly at the same place and under the sature minne?

(d) Cp. Mlitulell v. Liepuge 1416

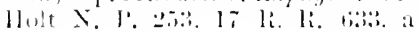

smewhat similar case, where the fuchiver, after notice. harl treated the contract as subsisting. Anal. ogons in some ways, but really having nothing to do with any rule specially relating to mistake, is the class of cases showing that a subsisting contract cannot be performel by a person with whom it wasnot made: Roblsun r. Drum. moml (1.831) 2 B. \& Al. 303. 3i li. R.sti9: Humble r. Hunter (18ts) I.) Q. 1). 3111.17 L. J. Q. B. 350, iti li. R. 2941. See further per collins M.R. in Tolluerst r. Assord. I'ortland ('ement Handirs. [1902] 2 k. li. titio dive it i. J. K. R. 91!?. 
B.'s agent to make the contract and receive the goods $(e)$, or if $\mathrm{C}$., who is a man of no means, obtains goods from $A$. hy writing for them in the name of B., a solvent merchant alrearly known to A., or one only colourably differing from it $(f)$, there is not a voidable contract between $A$. and (!., hut no contract at all; no property passes to $(\vdots .$, and ho can transfer none (save in market overt) 've'u to an innocent purchaser. The pretended sale fails for want of a real buyer. There is only an oifor on A.'s part to the person with whom alone he mrans to deal and thinks he is dealing.

Whether any analogous doctrine applies to derets is a question on which there does not seem to he any clear authority. It might be argued that these is no reason why the insertion of a wrong party, if material, shonld not have the same result as the insertion of wrong parcels; and that if a man exrcutes a conveyance of Whiteacre to $A$. as and for a conveyance of the same estate to $B$. it is equally not his deed. But the judgment in Hnnter v. IValters (!) is certainly adverse to such a view.

(e) Hardman v. Booth (186i3) 1 H. \& C. 803, 32 L, J. Ex. 105 ; cp. Kingsord v. Merry (18.ti) I H. N. 503,26 L. J. Ex. 83,106 li. li. 6.) ; Hollins: v. Fonder (1874-5) L. R. 7 H. I. 757, 7 (i3), 795.

(f) Limlstry v. ('und!l. ('mmly

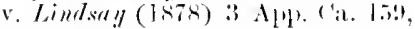
17 L. J. () J. 181 ; E.r mate Barlett (1876) :3 (1). 1). 123, 15 L. I. B.k. 120; Litmmlls v. 1/1\%.

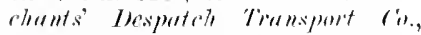
I35) Nass. 2.3, deeitles that if $A$. in person obtains gools by pretending to be $\mathrm{b}$., then, as $\Lambda$, is "identified by sight and bearing." property does palss. sed y". anl rf. Potlier, Obl. 19 . so, if a man is persuaded to join a new combany by fraudulently representing it to be identical with an older emmpony

P. of similar name, heshes not heome

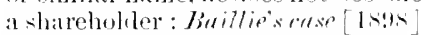
I Ch. JJo, 6i t. J. ("h. \&l.

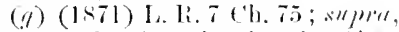
p. 493. Ont the other bant, "if $A$. personating $\mathrm{J}$. executes a leed in the name of B. purporting wan.

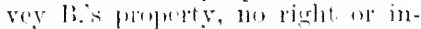
terest rin pussibly pass by mell an instrument. It is not a flecel. It makes mo difference in law that 1 . lial the sime name as li, il the false persenation is established; still the instrument is not a clesed, and that plea would be a complede ancwer loy li, or any one claiming thromgh him ": (inper vo Jesey

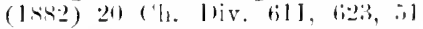
1. J. ('h. Stiz. (Kay . . : affil. in (… 20 (h. live (i27.)
Probably the prinoiple cannot 10 extented to deats. 
Siati-filetion liv a strander ti llie eontract.

Assigmment of coutracts.

It is on the same principle that a party to whom anything is due under a contract is not bound to accept satisfaction from any one except the other contracting party, in person where the nature of the contract requires it $(h)$, or otherwise by himself, his personal representatives, or his authorized agent: and it has even been thought that the acceptance of satisfation from a third person is not of itself a bar to a subsequent action upon the contract. It seems that the satisfaction must be made in the dubtor's name in the first instance and be capable of being ratified by him (i), and that if it is not made with his authority at the time there must be a subsequent ratification, which however need not be made before action $\left(k_{i}\right)$. But these refinements have not been recejved without doubt $(l)$ : and it is submitted that the law camnot depart in substance, especially now that merely technical objections are so little faroured, from the uld maxim "If I be satisfied it is not reason that I he again satisfied " $(m)$.

so far the rule of eommon law. The porrer of assigning contractual rights which has long been recognized in equity, and which since the Judicature Act, 1873 ( $\therefore .25$, sub-s. 6) is recognized as effectual in law, does not comstitute a direct exception. For

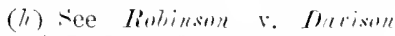

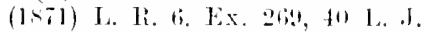
1‥ $17: 3$.

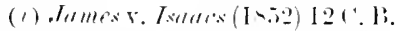

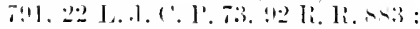

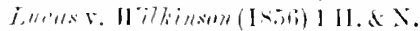

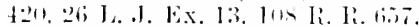

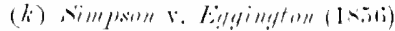
$111 \mathrm{kx}, 84.21 \mathrm{~J}, \mathrm{~J} . \mathrm{Ex}, 312.112$ li. li. stio (ratitication by plea of payment of at the trial may be [aini).

(1) see per Willen .J. in /impir.

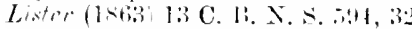
L. J. 1'. 1'. 1:3, who ansilered the doetrine bail down in .turess.

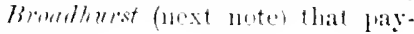

ment lya atranger is no layment till asent, as contrary to a wellknown principle of law: the eivil law leine the other way expesty. and mereantile law by analues : at the leas asent onche to be pre-

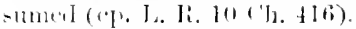

(m) Fit»h. Ab. tit. Fare, pl. 16ri, repreatedly citer in the motern eases where the doetrine is lliseunet. See in adelition to those alrearly referred to. Junes r. Rirad-

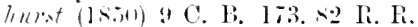

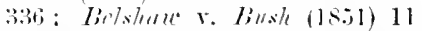
1'. 1., 1:1. 267\%, 22 I. J. ('. I'. 24. त7 li. li, iis!! 
wo are now concerned only to ascertain the existence or non-existence of a binding contract in the first instance. But on the other hand the limits sut to this power (which we have already considered under another aspect) ( $n$ ) may he again shortly referred to as illustrating the same principle.

Generally speaking, the liability on a contract cannot be transferred so as to discharge the person or estate of the original contractor, unless the croditor agrees to accept the liability of another person instearl of the first $(o)$.

The benefit of a contract can generally be transferred without the other party's consent, yet not so as to put the assignee in any better position than his assignor (oo). Hence the rule that the assignee is bound by all the equities affecting what is assigned. Hence also the "rule of general jurispludence, not confined to choses in action . . . that if a person enters into a contract, and without notice of any assignment fulfils it to the person with whom lye made the contract, he is discharged from his obligittion " $(p)$, and the various consequences of its application in the equitable cloctrines as to priority being gained by notice.

Again, rights arising out of a contract cammot he transferred if they are coupled with liabilities, or if they involve a relation of personal confidence such

(ii) ('h. V...smpma. p. 2.28, sqq.

(ii) Sice 1.215, aluve. 'T'lie ex(a)pitions to this are lut partial. Thus the asignor of leasehwlis remain: liablo on his express me11:uts. I Wmis. Sammil. 298. A stronger rave is the transer of shares in a company not fully pais up : but the speceial statutory law geverning these tromsactions has inet altegesther lost sight of the minciples of the general law: for (1) the trinserot is not immediately dischargen: (2) the com- pany is wot always loumel to regrister the transer.

(iii) Or the wher pate in at worse one than he was before:

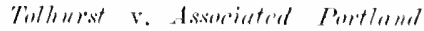
('oment Manufartmrers [1!(1)] 2 K. I, $811,71 \%$ L. I. K. I, 1033i (reversed on enromels mot attiocting the groneral prim.iple $[1,42] 2$

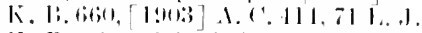

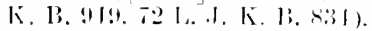

(1) Per Willes J. IJ Nichells v.

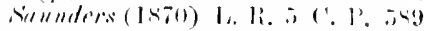

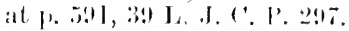

Rights

fommler on persinal iontislence caumet lee atsignent 
that the party whose agreement conferrerl those rights must have intended them to be exercised only by him in whom he actually confided $(q)$. Thus one partner cannot transfer his share so as to force a new partner on the other members of the firm without their consent: all he can give to an assignee is a right to receive what may be due to the assignor on the balance of the partnership accounts, and if thre partnorship is at will, the assignment dissolves it; if not, the other partners may treat it as a gromnd for dissolution. And a sub-partner has no rights against the principal firm.

"At the present day, no doubt, an agreement to pay money, or to deliver goods, may be assigned by the person to whom the money is to be paid or the gonds are to be delivered, if there is nothing in the terms of the contract, whether by requiring something to be afterwards done by him, or by some other stipulation, which manifests the intention of the parties that it shall not be assignable. But every one has a right to srlect and determine with whom he will contract, and cannot have another person thrust upon him without his consent" $(r)$.

In the same way a contract of apprenticeship is prima facie a strictly personal contract with the mastre; this construction may be excluded howerer hy the intrintion of the parties, $c . q$. if the master's rexentors aro expresty mamed $(s)$, or hy custom $(t)$.

Sio if an agent alpuints a sub-agent without authority, the sub-agent so appoints is not the agent of the principal and cannot be an accounting party

(1) Thin-tatement was aplerowal

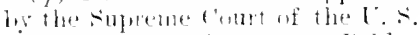

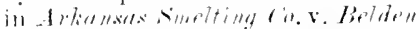

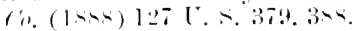

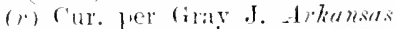

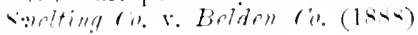

$127 . .379,8 \times 7$.

(x) (imper v. Nimmum (1-82) 7

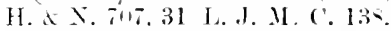

(t) Bac. Ahr. Master and servant. E. 
to him $(u)$. On the same principle it was held in Stevens v. Benning $(x)$ that a publisher's contract with an author was not assignable without the autlor's consent. The plaintiffs, who sought to restrain the publication of a new edition of a book claimed under. instruments of which the author knew nothing, and which purported to assign to them all the copyrights, \&c., therein mentioned (including the copyright of the book in question) and all the agreements with wuthors, \&c., in which the assignors, with whose firm the author had contracted, were interested. It was decided that the instrument relied on did not operate as an assigmment of the copyright, because on the true construction of the original agreement with the publishers the author had not parted with it: also that it did not operate as an assignment of the contract, because it was a personal contract, and it could not be indifferent to the author into whose hands his interests under such an engagement were entrusted. In the plaintiffs, however trustworthy, the author had not agreed or intended to place confidence: with the'm, however respectable, he had not intended to associate himself $(y)$. Similarly where persons contract to sell land as trustees, and it appears that their power to sell arises only on the death of a tenant for lifo who is still living, they cannot require the purchasel to take a conveyance from the tenant for life, from whom he never agreed to buy. This woukd be not merely adding a party to the conveyance, but forcing a wholly new contract on the purchaser $(z)$.

The law of agency, which we have already had

(a) Girtwright v. Muteloy (15!1)

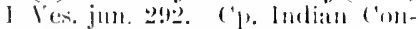
that A.t, 1si2, s. 19:3.

(r) $(1+5+5)$ । K. \& . I. I6s, i

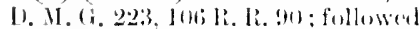
in /lole v. Bratlour!y (1579) 1:2 (1). 1). siti, numb applicel to itn incompolated complany, Girilith $r$.

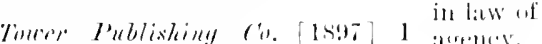
('h. 21, litil.... ('h. 12.

(y) See (; 1). M. (i. at 1). 2.2!), lot; li. Ii. !): !1.

(:) Bingut und Barnimblami

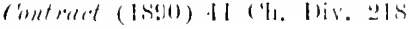
is) 1.. 1. ('h. liisi. 
occasion to consider (a), presents much more important and peculial exceptions. Here again we find that the limitations under which those exceptions are admitted show the influence of the general rule; thus a party dealing with an agent for an undisclosed prineipal is entitled as against the principal to the benefit of any defence he could have used against the agent.

It will be secn later that wilful concealment of a party's identity, even in a contract not as a rule of a strictly personal kind, may in particular circumstances amount to fraud $(b)$.

Errom as to subjiectmaller,

Kenmedy $r$. [':mistmit, di.. Mail ('illlint11.

\section{Error as to the subject-matter.}

'There may be fundamental erro: concerning:

A. The speecifie thing supposed to be the subject of the transaction.

1s. The kind or quantity by which the thing is described, or some quality which is a material part of the description of the thing, though the thing be specifically ascertained.

The question lowerey is in substance always the siane, and may be put in this form: It is armitted that the party intended to contract in this way for something; but is this thing that for which he intrutted to contract? The rule governing this whole class of cases is fully axplained in the judgment of the Court of Queen's Bench in the case of Kennedy v. Pamuma, de. Mall Company (c). There were eross actions, the one to recover instalments paid on shares in the company as money had and received, the other for a call on the sante shares. The contention on behalf of the shareholeler was " that the effect of the

(a) I'h. II., I. I(1), aluse

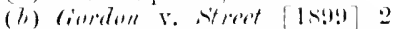

(a) (1867) L. R. 2 Q. B. 580.36

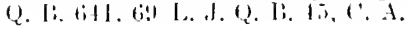

I. J. (i. I?. 2 (i). 
prospectus was to warrant to the intended shareholders that there really was such a contract as is there represented $(d)$, and not merely to represent that the company bona fide believed it, and that the difference in substance between shares in a company with such a contract and shares in a company whose supposed contract was not binding was a difference in substance in the nature of the thing; and that the shareholder was entitled to return the shares as soon as he discovered this, quite independently of fraud, on the ground that he harl applied for one thing and got another" (e).

The Court allowed it to be good law that if the shares applied for were really different in substance from those allotted, this contention would be right. But it is an important part of the doctrine $(f)$ that the difference in substance must be complete. In the case of a fraud, a fraululent representation of any fact material to the contract gives a right of rescission; but the misapprehension which prevents a valid contract from being formed must go to the ront of the matter. In this case the mirapprehension was not such as to make the shares obtained substantially different from the shares describer in the prospectus and applied for on the faith of that deseription (!)). It was at most like the purchase of a chattel with a collateral warranty, where a breach of the warranty

(d) A eontract with the pustmastrer-general of New Kealamil in behatf of the diovermment, which tumnerl out to be beyomt his amllurity.

(') P'er cur. I. R. 2 Q. li. at P. isti.

(f) In lioman law as well as in the common Latw, ihidl at p. ist.

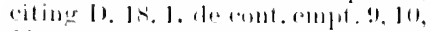
11. Liy a relereal enor the state-

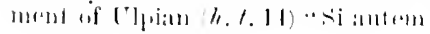

aes po amo reneat, non villet." is axcribed to l'anlus in the report.

(y) So, where new storek of a

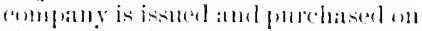
the supfersitum that it will hate at proference which in fact the combjany had no prower to give to it.

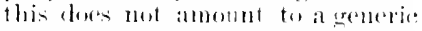

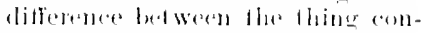

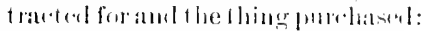

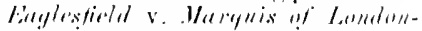

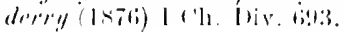


gives an independent right of action, but in the absence of fraud is no ground for rescinding the contract $(h)$.

In the particular case of taking shares in a comlany the contract is not in any case void, but only ruidable at the option of the shareholder if exercised within a reasonable time: this, although in strietness an anomaly, is required for the protection of the comprony's creeditors, who are entitled to rely on the register of shareholders (i).

We reserve for the present the question how the logal result is affected when the error is due to a representation made by the other party. The exposition of the general principle, howerer, is not the less valuable: and we now proceed to give instances of its application in the branches already mentioned.

Subdivision: Error in corpore. Anibigarian terms.

A. Error as to the specifie thing (in corpore). A singular modern case of this lind is Raffles $r$. Wichchaus $(j)$. The decharation arerred an agreement for the sale by the plaintiff to the defendants al certain gools, to wit, 1:5 bales of Surat cotton, (1) arrice ex "Peerless" from Bombay, and arrival of the goods by the said ship: Breach, non-aceeptance. I'lea, that the defendants meant a ship called the " P'ereless," which sailed from Bombay in October, and that the plaintiff offered to deliver, not any cotton which arrived by that ship, but cotton which arrived hy a different ship also called the "Peerless," and which sailed from Bombay in December. The plea wis hede good, for "The defendant only bought that cotion which was to arrive by a particular ship;" and to hold that he bought cotton to arrive in any

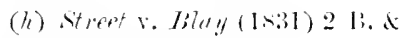

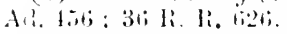

(i) See cesses citul H. in!? inf s't $^{\prime}$

(i) $(1+1,1) 2$ II. A C. 90i. 33 I. J. Ex. 1101. 
ship of that name would have been "imposing on the defendant a contract different from that which he entered into " $(k)$. Misunderstanding of an offer made by word of mouth might conceirably have a like effect, but obviously is, and ought to be, difficult to prove (l). Unconditional acecptance of an offer which in fitet is ambignous and has been misunderstood will not make the acceptor liable for not laving acted on the proposer's intention; nor can the acceptor hold the proposer liable on a construction which he did not intend $(m)$.

In Malins v. Freeman ( $n$ ) specifie performance was refused against a purchaser who had bid for and bought a lot different from that he intended to buy: but the defendant had acted with considerable nogligence, and the question was left open whether there was not a valid contract on which damages night be recovered. In a recent similar case of $\operatorname{Van}$ Prough v. Everidge (o) the Court of Appeal went on the ground that there was no signed memorandum of the contract, owing to a variance from the real date in the printed form which the auctioneer, on the defendant refusing to sign, purported to sign as his agent, but at least one menher of the Court thought thres was no real agreement. In Calrerley r. Irillioms (y) the description of an estate sold hy auction includerl

(k) P'er Pollock C.lB. and Martin 13.2 II. \& ('at 1).207. The further fluestions which might have arisen on the facts are of course not dealt wilh. Such a catse can axceur only where "the ordinary criblener" as to the prinaturyeanings of the words" usel ". shows that the woris may fras more than one meaning, witlont showing in which of those meanings either party used them,

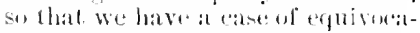
timn ": Sir I1. W. Elphinstence in I. 1). li. ii. 1lu.

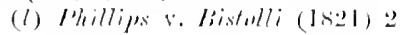

li. c C.511, 26; R. Ri. 433.

(iii) Fiblek v. 11 illiums [1!11m) A. ('. 176, 6.) 1. . J. 1'. ('. 17, a very peculiat case of a corle teleglan woungly anstruel.

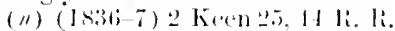

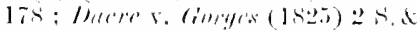

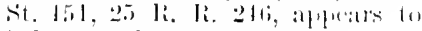
ledoly to the silme relasi.

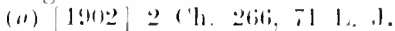

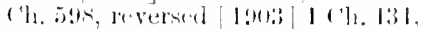
7.2 I. 1. (1), 2101).

( $\mu)(17 ! 41)$ l lis. jum. s]1, ] li. li. 11s. l'arets incluter th mistake. 
Harrio $c^{-}$ l'epperell, se.

a piece which appeared not to have been in the contrmplation of the parties, and the purchaser was held not to be entitled to a conveyance of this part. "It is impossible to say, one shall be forced to give that price for part only, which he intended to give for the wholr, or that the rother shall be obliged to sell the whole for what he intended to be the price of part only. The question is, does it appear to have bern the common purpose of both to have conveyed this part?" A mistake as to the contents of a lot put up for sale, arising from mere want of attention to the particulars and a plan therein referred to and cxhibited in the sale room, is no defence against an action for specific performance $(q)$. There remains a peculiar group of cases where the court has seen its way to a middle course. In Harris $r$. Pepperell (r) the ventor had actually executed a conveyance including a piece which he lad not intended to sell, but which the defendant maintained he had intended to buy: Lord Romilly, ateting in accordance with his wwn former decision in Garrard r. Frankel (s), gave the defendant an option "of having the whole contract annulled or else of taking it in the form which the plaintiff intended." The converse case occurred in Bloomer v. spittle $(t)$, where a reservation had been introduced by mistake. The Court, it seems, will not hold the plaintiff bound by the defendant's aceeptance of an offer which did not express the laintiff's real intention, and which the defendant conld not in the circumstances have reasonably supfosid to express it $(u)$; nor yet require the defendant

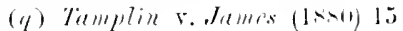

(H. Wiv. 2lis.

(r) (Istii) I. IR. ¿ Eq. 1 .

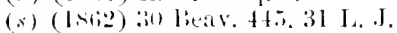
('li. iilt.

(t) $(1 \times 2,2)$ I.. li. l:i lit. $4: 2 .+1$ I.. I. 1 h. 364 (u) Ihis limitation is material:

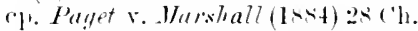

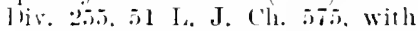
Tumplin v. Jumes (lscil) l:; ('h. lliv. 2li. Lord Romilly's julgments do nut, in terms at any ate. suthiciently atteml to the prineiple 
to accept the real offer which was never effectually communicated to him, and which he perhaps would not have consented to accept: hut will put the parties in the same position as if the original olfer were still open (i). The Court having come to the conclusion that the parties did not rightly mulerstand each other, "it is not possible without consent to make either take what the other has offered" $(w)$. This does not mean that a party who has accepted in good faith and in its natural sense a proposal made in explicit terms can be deprived of his right to rely on the contract merely beatuse the proposer failed to express his own intention. In such a ease the proposer is estopped from showing that his reasonably apparent meaning was not his real meaning $(x)$.

Similarly, "where the terms of the eontract are ambiguous, and where, by adopting the construction put mpon them by the plaintiff, they would have an Ambingums terms if contrat. effect not contemplated by the defendant, but would compel him to include in the conveyance property not intended or believed by him to eome within the terms of the contract," and the plaintilf refuses to have

enforced in Thmplin r. James. More lately it has been said that these derisions can be sulumpled only on the grommin of frame, wer

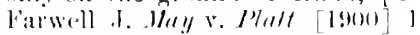
('h. 6i]ti, 6i!) 1. i. ('h. 3.57; Blommer v. Syithl has leen said by Neville .l. to be mintebligilhe as repouted, though mot exartly on this point:

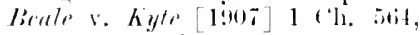

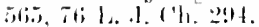

(r) liw the promeiple (whether it artually fustitien the pationlat

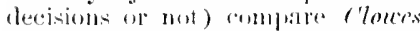
v. /liggimsm (next noto) aml logy-

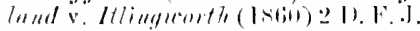

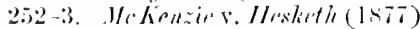
7 ('l. 1). 67\%, 17 1. J. ('h. 2:31, well shuws the alistinction between this elass of eases and lluse where a true antrate is arrieal 4 at with abatement or compensation. ln siott v. Littlemale (lsisis) so

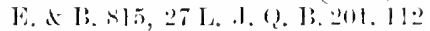
li. IR. 7!l] (a case on an e puitable

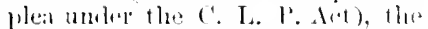

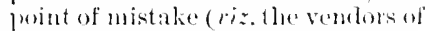
a specitie caroo slowing the jumchaser a sanple which in lact was of a different butls) (licl net gor to the essunce of the anthate : the armesondence of the butk to the sample was only a collatemal term which the purehaser might wative if be choser. The ventors, therefore, wereat all erents not rotitleal to reseime the contract unteme ditionally.

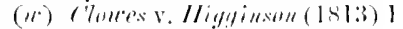

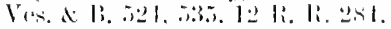

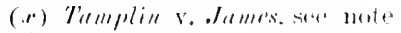
(di) liat joilure. 
the contract executed in the manner in which the defendant is willing to complete it, specific performance camnot be granted $(y)$.

When a purchaser, being naturally misled by the rendor's plan even after a view, supposes a portion of property to be included which is of no considerable quantity, but such as to enhance the value of tho: whole, this is a "mistake between the parties as to what the property purchased really consists of " so material that the contract will not be enforced $(z)$.

In this class of cases a simple misunderstanding on the buyer's part of the description of the property sold, if such as a reasonable and reasonably diligent man might fall into, may be enough to reliere him from specifically performing the contract, though not from liability in damages $(a)$. A rendor is in the same position if his agent has by ignorance or neglect included in a contract for sale property not intended to be sold (b). But, although the authorities admit the possibility that a mistake to which the rendor did not contribute, and which he could not be expected to perceive, may in circumstances of special hardship be a bar to specifie performance (c), it is certain that such cases are rare. One-sided mistake, we repeat only by way of abundant caution, will never of itself prevent the formation of a contract on which an action for damages will lie.

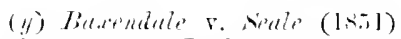

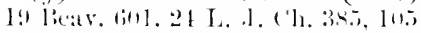

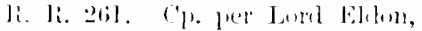
stomet r. Alliston (181.i) 1 Her. 24. :33. 15 li. li. 81 ; and per sir W.

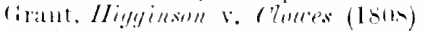

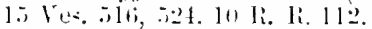

(:) Druny r. Hancolk (150) I. 1i. i; ('h. 1. 14. Note that here there wa- necrigent misrenmesentation going, in the opinim of the cinter, to the verge of framl. (a) Tamplin v. Jumes (1sso) I: ('h. J)iv. 2lis.

(i) Alronley v. Kinnuird (1nt!) 2 Mar. d (i. 1.s, st R. li. 1 ('). livitithe v. Jomes (1xi: L. L. li. E. 27 . +2 L. J. ('h. 4tis.

(c) Il ind v. siath (15,5) 2 K. .t. .33. 110 li. li. st. is the only anthority which apleas to

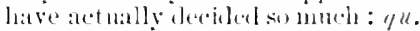
low far it womala now lae lollowerl. 
It was at one time (d) held that a material varianee as to slares: between the objects of a company as described in the prospectus and in the memorandum of associadion would entitle a person who had taken shares on the faith of the prospectus to say that the concern actually started was not that in which he agreed to become a partner, and to have his name remored from the register. But these decisions wre disapproved of in the IIouse of Lorts on the ground that "persons who have taken shares in a comprany are bound to make themselves acquainted with the memorandum of association, which is the basis upon which the company is established" $(e)$.

It has also been attempted to dispute the ralidity of a transfer of shares because the transferor had not the shares corresponding to the numbers expressed in the transfer, although he had a sufficient number of other shares in the company; but it was held that the transferee, who had in substance agreed to take fifty shares in the company, could not set up the mistake as against the company's creditors $(f)$. "The numbers of the shares are simply directory for the purposes (g) of enabling the title of particular persons to be traced; but one share, an incorporeal portion of the profits of the company, is the same as another, and share No, 1 is not distinguishable

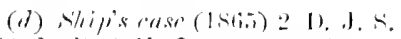

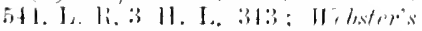

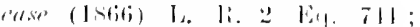

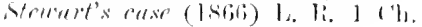
$\pi 1$.

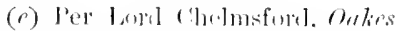

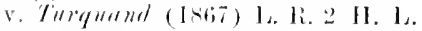

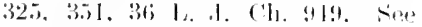

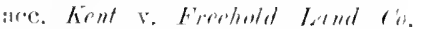

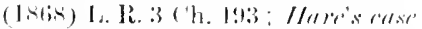

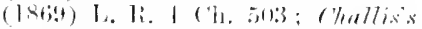

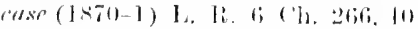
1... $(1,131$; all showing that the contract is in such catsen not voil, but only vollable at the option of

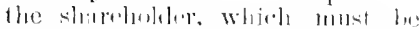

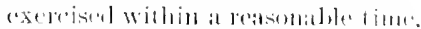
so. a forson who applies for shomes in a company not deseribus ats limited cannot afterwats be hearl to saty that he did not mean to take shares is an molimitul (ommlinty:

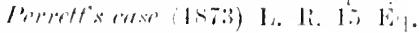
$2511,12[1.1 .1 \%, 3015$.

(f) Imd rese (1sig) J., li. 7

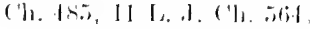

(g) Sir in the repurt.
Error in distingraishing numbers of shares not material. 
from share No. 2 in the same way as a grey horse is distinguishable from a black horse" $(h)$.

A compromise of an action has been avoided, where hy misapprehension of counsel it extended to matters which his client and he thought were not in dispute (i).

Error as to kint, de.

Genus: Thornton $r$. Kempiter.

B. Error as to kind, quantity, or quality of the thing.

A material error as to the kind, quantity, or quality of a subject-matter which is contracted for by a goneric description (whether alone or in addition to an individual description) way make the agreement void, either because there was never any real consent of the parties to the same thing, or because the thing or state of things to which they consented does not exist or cannot be realized.

In Thornton v. Kempster ( $j$ ) the common broker of both parties gave the defendant as buyer a sale note for Riga Rhine hemp, but to the plaintiff as seller a note for st. Petersbury clean hemp. The bought and sold notes were the only evidence of the terms of the sale. The Court held that "the contract must be on the one side to sell and on the other side to accept one and the same thing " : here the parties so far as appeared had never agreed that the one shomld buy and the other accept the same thing; consequently there was no agreement subsisting between them.

In a case of this lind howerer there is not even an agreement in terms between the offer and the acceptance.

(h) Or house No. 2 in a street from hurse Nu, $t$ in the same strest. though of the same rlecrintion and

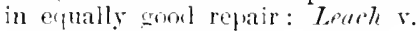
Jullett (is.t) 3 Car. \& P. 115, 33 Li. Ri. $65 \%$.

(i) Klirkman v. Berrus [1s!5] 2
Ch. 6i3s. 64 L. J. Ch. 285, C. A. ;

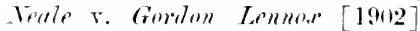
A. ('. 46.5.71 L. .J. K. B. 939, does not belung to this head.as it was decided (1) the groumd not of mistake but of want of authority fom the client. (j) STaunt. isti, 1,i R. R. 658 . 
A curious case of error in quantity happened in Quantity. Hentel v. Pape (k), where by the mistake of a telegraph clerk an orter intended to be for thren rifles only was transmitted as an order for fifty. The only point in dispute was whether the defondant was bound by the message so transmitted, and it was held that the clerk was his agent only to transmit the message in the terms in which it was delivered to him. The defendant had accepted three of the fifty rifles sent, and paid the price for them into Court: therefore the question whether he was hound to accept any did not arise in this case. It is settled however by former authority that when goots ordered are sent together with goods not ordered, the buyer may refuse to recept any, at all ovents "if there is any danger or trouble attending the severance of the two" $(l)$.

The principle of error in quantity preventing the Price. formation of a contract is applicable to an error as to the price of a thing sold or hired $(m)$. As there cannot be even the appearance of a contract when the acceptance disagrees on the face of it with the proposal, this question can arise only when there is an unqualified acceptance of an erroneously expressed or understood proposal. If the proposal is misunderstood by the acceptor, it is for him to show that the misunderstanding was reasonable. "Where there has been no misrepresentation, and where there is no

(i) $(1570)$ I. R. (i Ex. 7. 10 L. J. lix. 15 .

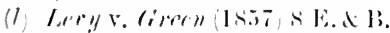
ing, 112 li. li. 69!9, in Ex. ('h. I

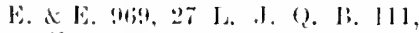
28 ib. 319 ; per byles J. 1 E. . E E.

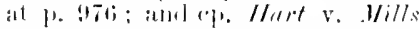
(18.46) 15 $11 . \&$ W. . .5, I.; 1. .J.

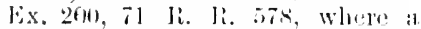
hew ronlaret was implied as tophort of the gerosts which was retainerl; but in that race lle puality as well as the promtity of the grienlo selst was not in conformity with the

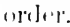

(III) J) 18.2. leati, 52, Siderem tilsi locen lumblum. to antem ris-

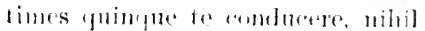
agitur. Serd et si end minoris me

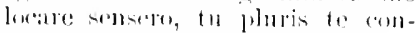

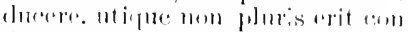

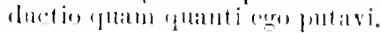


ambiguity in the terms of the contract, the defendant cannot be allowed to evale the performance of it hy the simple statement that he has made a mistake" (n). A. makes an offer to $B$. to take a lease of a named farm, specifying as its contents land amonnting to 2.50 acres; $B .{ }^{\circ}$ s agent, who meant to invite offers for only 200 acres, accepts A.'s offer withont exanining its particulars. Here there is a contract binding on $\mathrm{B}$., and $\mathrm{A}$. is entitled to specific performance to the extent of $B$.'s power to give it, with a proportionate rerluction of the rent $(0)$.

If, on the other hand, the proposal is by accident wrongly expressed, the proposer must show that the acceptor could not reasonably have supposed it in its actual form to convey the proposer's real intention. This occurred in Hebster $v$. Cecil $(p)$, where the defendant sent a written offer to sell property and wrote 1,100l. for 1,200l. by a mistake in a hurried addition of items performed on a separate piece of paper. This paper was hept hy him and produced to the Court. On receiving the acceptance he discorered the mistake and at once gave notice of it. It appeared that the plaintiff had reason to linow the real value of the property. Ender the circumstances specific performance was refused. The case is explained by James J.J. as one "where a person snapped at an offer which he must have perfectly well known to he mate by mistake $"(q)$.

Natringl attribute.

But sometimes, even when the thing which is the subject-matter of an agreement is specifically ascertained, the agreement may be aroided by material error as to some attribute of the thing. For some

(u) Timmulin v. Telmes (1-inl) 15 (h. Iriv. 215, 217 (Bascallay L..J.).

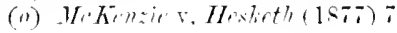

(h. I . 67. 4, 4. J. Ch. 231.

(v) (1s,il) 80 Beav. 62 . (q) $7 \mathrm{am} p$ tim v. Jumes (1s80) 15 Ch. I'. at !'. 221 . 
attribute which the thing in truth has not may be a material part of the description by which the thing was contracted for. If this is so, the thing as it really is, namely, without that quality, is not that to which the common intention of the parties was directed, and the agreement is void.

An error of this kind will not suffice to make the transaction void unless-

(1) It is such that according to the ordinary course of dealing and use of language the difference made by the absence of the quality wrongly supposed to exist amounts to a difference in kind $(r)$;

(2) and the error is also common to both parties.

Thus we read "Mensam argento coopertam mihi ignoranti pro solida vendidisti imprudens; nulla est emptio, pecuniaque eo nomine data condicetur" $(s)$. Again, "Si aes pro auro veneat, non valet" $(t)$. This, however, is not to be taken too largely. What does pro auro, as and for gold, imply as here used? It implies that the buyer thinks he is buying, and the seller that he is selling, a golden vessel: and further, that the object present to the minds of both parties as that in which they are trafficking -the object of their common intention-is not merely this specific vessel, but this specific vessel, being golden. Then, and not otherwise the sale is roid.

If the seller fraurlulently represents the ressel as golden, knowing that it is not, the sale is (as between them) not void but voidable at the option of the buyer. For if both parties have been in innocent and ergual error it would be mjust to let either gain any advantago: hut a party who has been grilty of

(r) Savigny, Syst. \$ $137(32 \times 3)$

- (s) 1). 18. 1. de cont. empt. 11 S. I.

(f) 1). codt. tit. 11, rited and

1.
Conditions necessary to a roid transaction on this ground. alopted by the conrt of 12. B. in

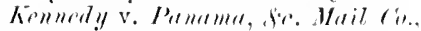
1. it). $x$. 
fraud has no right to complain of having been taken at his word; and it is conceivable that it might be for the interest of the buyer to affirm the transaction, as if the ressel supposed by the fraudulent seller to be of worthless base metal should turn out to be a precious antique bronze. Probably the results are the same if the buyer's belief is founded even on an innocent representation made by the seller. This seems to be assumed by the language of the Court in Kennedy v. Panama, de. Mail Company $(x)$. We shall recur to this point presently. Or in an ordinary case the buyer may choose to treat the seller's affirmation as a warranty, and so keep the thing and recover the difference in value.

Again, if the sale of the specific ressel is made in good faith with a warranty of its quality, the vendor must compensate the purchaser for breach of the warranty, but the sale is not eren roidable. For the existence of a separate warranty shows that the matter of the warranty is not a condition or essential part of the contract, but the intention of the parties was to transfer the property in the specific chattel at all events. Whether a particular affirmation as to the quality of a specific thing sold be only a warranty, or the sale be "conditional, and to be null if the affirmation is incorrect," is a question of fuct to be determined hy the circumstances of each case $(y)$.

(.) (18fit) L. H. 2 O. B. 280 ,

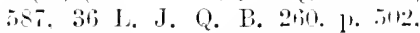
sillin.

(y) ree fer Wightman J. Gur-

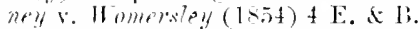
133. 142,24 L. . I. (2. R. 4li. !! li. R. 390.390 ; Jummerman v. White (1861 l11 C. P. X. S. 844 . 31 I. J. C. I. 2x. Finch sel. Ca.

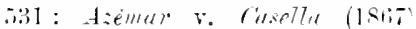
L. Ii. 2 C. I'. 131.67-, 26 L. J. C. l'. 124. The foman haw is the same as to a sale with warranty: D. 19 1 de act. empt. 21 \& 2 . expld. by sarigny, srst. 3. 2si. The whole of rarignys almirable exposition of so-called erwor in substantia in \$s 137. 138. (3. $276.4 q$.$) . deserves$ eareful study. Of course the conclusions in detail are not always the same as in our law: and the fundamental lifference in the rules as to the aetual transfer of property in gomls sold (as to which. see 
Accordingly, when the law is stated to be that "a party is not bound to accept and pay for chattels, unless they are really such as the vendor professed to sell, and the vendce intended to buy" $(z)$, tho condition is not alternative but strictly conjunctive. A sale is not void merely because the vendor professed to sell, or the vendee intended to buy, something of a different lind. It must be shown that the object was in fact neither such as the vendor professed to sell nor such as the vendee intended to buy.

And so in the case supposed the sale will not he invalidated by the mistake of the buyer alone, if loe thinks he is buying gold; not even if the seller believes him to think so, and does nothing to remore the mistake, provided his conduct does not go beyond passive acquiescence in the self-deception of the buyer. In a case (a) where the defendant bought a parcel of oats by sample, believing them to be old oats, smithr. and sought to reject them when he found they were new oats, it was held that "a belief on the part of the plaintiff that the defendant was making a contract to buy the oats of which he offered him a sample under a mistaken belief that they were old would not relieve the defendant from liability unless his mistaken belief was induced by some misrepresentation of the plaintiff or concealment by him of a fact which it became his duty to communicate. In order to

Blackbum on the cint late of siale, l'art 2. (6h. 3) numet not be overlookerl. But this does nut affect the wefuluess and importandes of the gencral antergirs.

(\%) ['er cur. Ilull vo rimder. (18.7) 21 13. X. . $22,11,24$

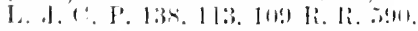
(i)

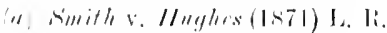

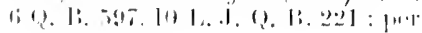

Error must be common. 
relieve the defendant it was necessary that the jury should find not merely that the plaintiff believed the defendant to believe that he was buying old oats, hut that he believed the defendant to believe that he, the plaintiff, was contracting to sell old oats." "There is no legal obligation on the vendor to inform the purchaser that he is under a mistake not induced by the act of the vendor" $(b)$; and therefore the question is whether we have to do merely with a motive operating on the buyer to induce him to buy, or with one of the essential conditions of the contract $(c)$. "Videamus, quid inter ementem et rendenten actum sit" $(d)$ : "the intention of the parties gorerns in the making and in the construction of all contracts " (e); this is the fundamental rule by which all questions, even the most refined, on the existence and nature of a contract must at last come to be decided.

$\operatorname{Cox} r$

Another curious case of this class is Cox r. Irentice. Prentice $(f)$. The declaration contained a count in assumpsit as on a warranty, and the common money counts. The nature of the material facts will suffciently appear by the following extract from the judgment of Bayley .].:-

"What did the plaintiffs bargain to bay and the defendants to sell! They buth understand [ sic that the one agreed to buy and the other to sell a bar containing -uch a quantity of silver as stoukl appar by the assay and the quantity is fixe l by the axay and paid for ; but thromgh some mistake in the assay the bar tums out not to contain the quantity represented hut a smaller quantity. The plaintiff therefore may rescind the contract and bring money harl and receired. haring offered to return the bar of silver."

(b) Per Blackinnru .J. L. R. i; Q. B. at p. 60 .

(c) Mtid.. per Cockburn, ('.J.

(d) Julianus in 1 1. 18. 1, de cont. empt. $41 \mathrm{pr}$. (c) Percur. Bunnerman r. White (1stil) 10 C. B. X. S. s14. 860, 31

L. J. C. P'. 2-, 32.

(f) (1-15) $3 \mathrm{M} . \mathrm{N} \div 3 \mathrm{H} .16 \mathrm{li}$. R. 20s. 
And by Dampier J.:-"The bargain was for a bar of silver of the quality ascertained hy the assaymaster, and it is not of that quality. It is a case of mutual error." These judgments went farther than was necessary to the decision $(g)$, for a verdict had been taken only for the difference in ralue. It would seem that the sale was good, and the mistake affected only the fixing of the price; the contract being to pay for the real quantity of silver, not for the quantity found by a particular assay.

It is important to distinguish from the cases above considered another class where persons who have contracted for the purchase of real property or interests therein have been held entitled at law $(h)$ as well as in equity (i) to rescind the contract on the ground of a misclescription of the thing sold in some particular materially affecting the title, quantity, or enjoyment of the estate. In some of these cases language is used which, taken alone, might lead one to suppose the agreement absolutely roid; and in one or two (e.g., Torrance v. Bolton) there is some real difficulty in drawing the line. But they properly belong to the head of Misrepresentation, or else (which may be the sounder view where applicable) $(j)$ are

(a) Arrl eertainly farther than the eivil law : see D. 18.1. de eont. empt. 14, where though a bracelet "quae aurea dieebatur " shomli be found "magna ex laste aonea," yut "venditionem esse eomstat ideo, quia anri alipnid habuit."

(le) Flight v. linoth (1831) 1 Biner. N. C. 370, fl li. li. s!ly : I'hillips v. C'aldelengh (Istis) L. L. 4 (2. 1). 1.39, 3. 1. J. 1). R. 63.

(i) Stanton v. Tattersall (185:3)

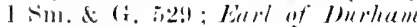

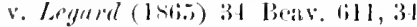

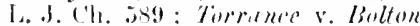
(1.i2) L. H. \& ('h, 11s, 4⿻ 1., J. ('h. 17\%. The atats of the subject belong to the law of Vemolors and l'urchasers.

(i) The differenee is purely theoretical: for if it be an actual breach of contsaet the furchaser can recurer only nominal damages : buill v. Futhergill (1573-4) 1. R. 7 H. 1.. $15 \%, 43$ L. .J. Ex. 243 , contiming threan v. Thornhill (1776) $2 \mathrm{~W}$. 13. lots. The analogry sugrested in the text should pel haph be contined to cases where the mistescription goes to matter of title. One camnot comprase a spectic sale of land to a nonsprecitic sale of grools: but the contract is not metely to sell specitic lanul, but to give a certain kinel of title.
Cases of mis. deseription on sales of real property distinguislied. 
cases where the contract is rather broken than dissolved. A man is not bound to take a house or land not corresponding to the description by which he bought it any more than he is bound to accept goods of a different denomination from what he ordered, or of a different quality from the sample. Mistake or no mistake, the vendor has failed to perform his contract. The purchaser may say: "You offered to sell me a freehold: that means an unincumbered freehold, and I am not bound to take a title subject to corenants" $(k)$ : or, "You offered to sell an absolute reversion in fee simple: I am not to be put off with an equity of redemption and two or three Chancery suits (l). I rescind the contract and claim back my deposit." Cases of this kind, therefore, are put. aside for the present.

Subjectmatter not in existence.
Illutratimu. a. A. agrees to sell to B. a specific cargo of goods supposed to be on its way from England to Bombay.

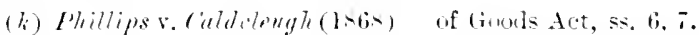

1.. li. + Q. B. 159. 3n L. I. (.) li. (is.

(1) Terranes r. Belton (1-i2)

L. Ii. o ('h. 11s: ste at 1. I2t.

(iil) Since 18.43 the common law is dectared in Eugland by the siale
(11) $\therefore$. 20: the rule is rather whlely statet: Where both the latties to an agreement are under a mistalie as to a matter of fact essential to the agreement. the agreement is roil. 
It turns out that, before the day of the bargain, the ship conveying the cargo had been cast away and the goods lost. Neither party was aware of these facts. The agreement is void.

This was assumed in the House of Lords and by all the judges in Couturicr v. Hastie (o), where the only question in dispute was on the effect of the special terms of the contract.

b. A. agrees to buy from B. a certain horse. It turns out that the horse was clead at the time of the bargain, though neither party was aware of the fact. The agreement is void $(p)$.

We may add a like example from the Digest. A. agrees with $B$. to buy a house belonging to $B$. The house has been burnt down, but neither A. nor B. knows it. Here there is not a contract for the sale of the land on which the house stood, with compensation or otherwise, but the sale is void $(q)$.

In like manner a sale of shares in a company will not be enforced if at the date of the sale a petition for winding-up has been presented of which neither ame principle applied to sale of the vendor nor the purchaser knew $(r)$. But the ignorance of the buyer only in similar circumstances does not of itself invalidate the sale. It seems however

(d) $(18,6)$.) H. L. C. 673, 25 L. ,I. Ex. 253, 101 R. R. 324. For a fuller accomnt of the case, and the relation of this class of cases to the doctrine of impossibility of verformance, see pp. 443.411 , above.

(p) Pothier, Contrat de Iinte, \$ 1, citel ; ll. L. C.67s, says: ". si fonc, igmonant que mon cheval est mort, je le vemlis a frodiu'un. il n'y aura yas un contiat re vonte, faute d'une chose qui en soit l'objet." ("p. Coule ('iv. 1601. "si au moment de la vente la chose rentue ctait prie en totaliti, la vente serait mulle" : and so Italian Code, ltiil. (y) Fanlus in 1). Is. 1. de cont. emplt. 57, pr. Lommon emi crm eam et ego ct venditor combustam iguoremus : Nerva, Subinus, Cassius, mihil venisse quamvis area maneat, pecuniangue solutan condici gosse aiunt. Cy. Papinian, eorl, tit. is. Arborilus puopue vento deiectis rel absumptis igne dictum est emptionem funcli non veleri exise contractam si contemplatione illal'um allorum, velutioliseti, fumlus emmparabatmr, wive sciente sive ignorante venditore.

(r) Emmersoris atese (186iti) I. R. l ('h. 433, cxplul. l. li.:3 c'l, :34t, per l'age IT cool I..J.
Couturier r. Hastic. 
that the sale would be roidable on the ground of fraud if the seller knew of the buyer's ignorance, but that such knowledge should be distinctly and completely alleged $(s)$. An agreement to take new shares in a company which the company has no power to issue is also roid, and money paid under it can be recorered back $(t)$.

To annuities and life interests.

c. A. being entitled to an estate for the life of B. agrees to sell it to C. B. was dead at the time of the agreement, but both parties were ignorant of the fact. The agreement is roid.

This was so held at law in Sitrickland $v$. Turner $(u)$. There, at the date when the sale of a life amnuity was completed, the life had dropped unknown to both rendor and purchaser; it was held that the purchase money might be recorered back as on a total failure of consideration. So in Hitchcock r. Giddings (v) a remainderman in fee expectant on an estate tail had sold his interest, a recovery having been already suffered unknown to the parties: a bond given to secure the purchase money was set aside. "Here is an estate which if no recovery had been suffered was a good one. Both parties, being equally ignorant that a lecorery had been suffered, agree for the sale and purchase of the estate, and the purchaser is content to abide the risk of a recorery being subsequently suffered. He conceives howerer he is purchasing something, that he is purchasing a

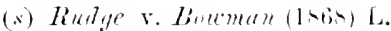
1. 3 Q. 13. 689. 69.7. The lioman lawern -eem to have treated the presumplion of dolus as almblute if the seller knew the facts. See the continuation of the pasige: abure rited.

(f) Bronk of Hinduston v. Blistn (15io) L. H. is (.. P. it. in Ex. Ch. it. 2.2. to 1. J. ( . l'. 1.117: L. joife disen (1sit) L. K. lis Eq.
344. \& Ch. 1. 24: E.r perte Compbell (1-i3) J. R. ] ] Eat 417, L. R. ! (h. 1.12.42 L. J. ('h. 酒.

(ii) (1<.2) 7 Ex. 208,20 I. J. Ex. 11\% -1 H. R. 619. The only yuention in dispute was when the rendur - interest was intended to ce:ale.

(r) $(1+1 i)+$ Pri. (Ex. in E(y.) 13.5. and wetter in Din. I. Is R. R. i:s. 
vested interest. $\mathrm{He}$ is not aware that such interest has already been defeated . . . [The defendant] has sold that which he had not-and shall the plaintiff be compelled to pay for that which the defendant had not to give?" $(x)$. More recently, in Cochrane v. Willis (y), an agreement had been made between a remainderman and the assignee of a tenant for life of a settled estate, founded on the assignee's supposed right to cut the timber. The tenant for life was in fact dear at the date of the agreement. The Court refused to enforce it, as having becn entered into on the supposition that the tenant for life was alive, and only intended to take effect on that assumption. So a life insurance cannot be revived by the payment of a premium within the time allowed for that purpose by the original contract, but after the life has dropped unknown to both insurers and assured, although it was in existence when the premium became due, and although the insurers have waived proof of the party's health, which by the terms of renewal they might have required: the waiver applies to the proof of health of a man assumed to be alive, not to the fact of his being alive ( $z$ ). An agreement to sell a policy on the life of a person supposed to be living, who is in fact dead, is not binding, and the subsequent execution of an assignment in pursuance of the agreement, the fact being still unknown to the vendor, makes no difference $(a)$.

The old case of Bingham r. Bingham (b), which

(r) Inan. at p. 7. Is R. R. 729 .

(y) (186ii) 1.. Li. 1 Ch. is, 3i, 1. .J. (h. Bti.

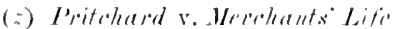

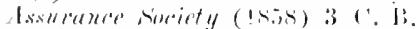
N. S. 6i22, 27 L. .J. ('. I'. 169. 111 li. R. 767. Fer the somewhat different treatment of the comtract of marine in-urance, where at the date of efferting the grolicy the risk has been determined wibust the knowledere of the parties, see

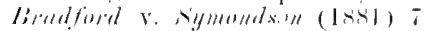

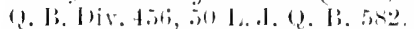

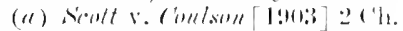

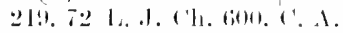

(b) (Izle) l les. Ar. I:4i, lielt's silu?. $7 !$. l'urchase of property 
alrealy one's was relied on in Cochrane v. Willis, helongs to this own.

lingham $r$. Bingham. the facts was that a purchaser was dealing with lis own property, not lnowing that it was his. There is therefore no ground for criticizing the decision as having given relief against a mere mistake of law $(c)$. It does not rest on mistake as a ground of special relief at all, but on total failure of the supposed subject-matter of the transaction. The one party could not buy what was his own already, nor could the other (in the words of the judgment as reported) be allowed "to run away with the money in consideration of the sale of an estate to which he had no right" $(d)$. So we find it treated in tho Roman law quite apart from any question of mistalie, except as to the right of recovering back money paid under the agreement. A stipulation to purchase one's own property is "naturali ratione inutilis" as much as if the thing was destroyed, or not capable of being private property $(e)$. Such an agreement is naught both at law and in equity, without reference to the belief or motive which determined it.

Agreement to pay rellt for one's own property Cooper $\bullet$. Phiblss.

Lord Westbury gave the correct rule in a case exactly similar in principle. In Cooper v. Phibbs $(f)$ $A$. agreed to take a lease of a fishery from B., on the assumption that $A$. had no estate and $B$. was tenant in fee. Both parties were mistaken at the time as to the effect of a previous settlement; and in truth $A$. was tenant for life and B. had no

(c) Story, E1, Juriup. \$124. took this objection.

(d) The ease ir considered. among other anthorities. am? nubele on the true ground, in stemart s. Stemert

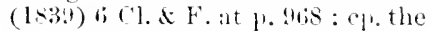
remarks of llall V.er. in Jomes $r$.

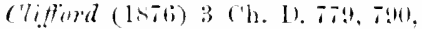
45 L. J. Ch. stot, anu of Limlley L.J. in Hudelessield bunking ci.

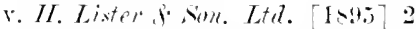
('h, $2-3,2-1$.

(c) raius in I. $4 t$. 7 . de obl et act. 15 lu. Sune rei emption $n$ valet, sive sciens, sire ignorans emi : serl si iguorans emi. yuml solvero repetere potero, quia nulla ohligatio fuit: Pomponiu-, D. 18. 1. de cont empt. Ir pr.

( $\left.f^{\circ}\right)(186 i i)$ L. R. 2 H. L. 149. 
estate at all. It was held that this agreement was invalid. Lord Westbury stated the ground of the decision as follows:- "The result therefore is that at the time of the agreement for the lease which it is the object of this petition $(g)$ to set aside, the parties dealt with one another under a mutual mistake as to their respective rights. The petitioner did not suppose that he was, what in truth he was, tenant for life of the fishery. The other parties acted under the impression given to them by their father that he (their father) was the owner of the fishery and that the fishery had descended to them. In such a state of things there can be no doubt of the rule of a court of equity with regard to the dealing with that agreement. It is said 'Ignorantia iuris haud excusat'; but in that maxim the word 'ius' is used in the sense of denoting general law, the ordinary law of the country. But when the word 'ius' is used in the sense of denoting a privato right, that maxim has no application. Private right of ownership is a matter of fact; it may be the result also of matter of law; but if parties contract under a mutual mistake and misapprehension as to their relative and respective rights, the result is that that agreement is liable to be set aside as having proceeded upon a common mistake. Now that was the case with these parties-the respondents believed themselves to be entitled to the property, the petitioner believed that he was a stranger to it, the mistake is discovered, and the agreement cannot stand " $(h)$.

The principle here laid down also covers Broughton v. Iutt $(i)$. There the heir-at-law of a shareholder Biroughton $r$. Hutt. in a company joined with several other shareholders in giving a deed of indemnity to the directors, believ-

Iord Westbury's explanation of igmorantiat iuris. (a) A ranse Pedition in the Irish court of Chancery. (h) I. L. 2 II. L. 170.

(i) $(1858) 3$ le (r. . J.501. 
ing that the shares had descended to him as real estate, whereas they were personal estate. The deed was held to be roid as against him in equity at all events, and probably at law. "The plaintiff never intended to be bound unless he was a shareholder, and the defendants never intended him to be bound unless he was so." Here the mistake was plainly one of fact within Lord Westbury's definition, namely as to the character of the shares by the constitution of the particular company. It is submitted, however, that an eroneous fundamental assumption made by both parties even as to a general rule of law might well prevent any ralid agreement from being formed.

Assignuent of leave for lives.
Results where only one party is
In the same way an agreement to assign a lease for lives would be inoperative if all the lives had dropped unknown to the parties. But the only thing which the parties can here be supposed, in the absence of expressed condition or warranty, to assume as esscntial is that the lease is subsisting, that is, that at least one of the lives is, not that they all are still in existence. Where the assignor of a lease for the lives of A., B., and C., expressly corenanted with the assignee that the lease was a subsisting lease for the lives of A., B., and C., and the survirors and survivor of them, this was held to he only a covenant that the lease was subsisting, and not that all the lives were in being at the date of the assignment $(k)$. That is, his contract was interpreted, according to the general practice and understanding of conveyancers, as a contract to transfer an existing lease for three lives, not necessarily a lease for three lives all existing.

If in any state of things otherwine resembling those just now discussed we find, instead of ignorance of

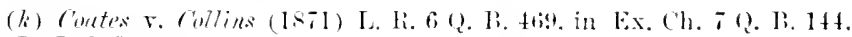
41 L. J. Q. B. !"!. 
the material fact on both sides, ignorance on the one side and linowledge on the other, then the matter has to be treated differently. Suppose A. and B. are the contracting parties; and let us denote by $\mathrm{X}$. a fact or state of facts materially connected with the subject-matter of the contract, which is supposed by A. to exist, but which in truth does not exist, and is known by $B$. not to exist. Then we have to ask these questions:-

1. Does A. intend to contract only on the supposition that $\mathrm{X}$. exists? which may be put in another way thus: If $A$.'s attention were called to the possibility of his belief in the existence of $\mathrm{X}$. being erroneous, would he require the contract to be made conditional on the existence of $\mathrm{X}$. ?

2. If so-Does $B$. know that $A$. supposes $X$. to exist?

3. If $B$. knows this-Does he also know that $A$. intends to contract only on that supposition?

If the answer to any one of these questions is in the negative, it seems there is a binding contract $(l)$. But it is to be observed that a negative answer to the second question will generally require strong evidence to establish it, and that if this question be answered in the affirmative, an affirmative answer to the third question will often follow by an almost irresistible inference. Thus if a purchaser of a reversionary interest subject to prior life interests knows that nne of these has ceased, and nothing is sairl abont it at the time of the contract, then the purchaser can hardly expect anybody to believe either that he himself orerlooked the material importance of the fact, or that he was not awille of the rendor's ignorance of it, or that he supposed that the vendor 
would not treat it as material $(m)$. So in the case already cited $(n)$ of the sale of shares after a petition for the winding up of the company had been presented, a distinct allegation in the pleadings that the seller knew of the buyer's ignorance of that fact, would, it seems, have been sufficient to constitute a charge of fraud.

If the questions above stated be all answered in the affirmative, either by positive proof or by probable and uncontradicted presumption from the circumstances, then it may be considered either that the case becomes one of fraud, or at least that the party who linew the true state of the facts, and also knew the other party's intention to contract only with reference to a supposed different state of facts, is precluded from denying that he understood the contract in the same sense as that other, namely, as conditional on the existence of the supposed state of facts.

Fundamentil On a similar principle (as we have already menerror producel by masepresen tation. tioned incidentally) it is certain that where fundamental error of one party is caused by a fraudulent misrepresentation, and probable that where it is caused by an innocent misrepresentation on the part of the other, that other is estopped from denying the validity of the transaction if the party who has been misled thinks fit to affirm it.

Does it follow that the contract is in its inception not roid, but roidable at the option of the party misled? Not so: for the fraud or negligence of the other must not put him in any worse position as regards third persons. These, if the transaction be simply roidable, are entitled to treat it as ralid

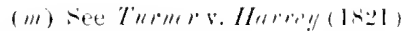
Jatr. 16:4, 23 R, R, 1 i (n) Reudye v. Bunlman (18rio)

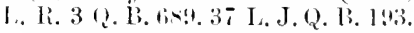


until rescinded, and may acquire indefeasible rights under it: if it be void they can acquire none, however blameless their own part in the matter may be $(o)$. Thus there is a real difference between a contract voidable at the option of one party and a void agreement whose nullity the other is estopped as against him from asserting. In the case of contracts to take shares in companies an anomaly is admitted, as we have seen, for reasons of special necessity, and the contract is treated as at most voidable. But even here there must be an original animus contrahendi to this extent, that the shareholder was minded to have shares in some company. An application for shares signed in absolute ignorance of its true nature and contents, like the bill in Foster v. Mackinnon (o), could not be the foundation of a binding contract to tako shares. An allotment in answer to such an application would be a mere proposal, and whether it were accepted or not would have to be determined by the ordinary rules of law in that behalf (see Ch. I.).

It appears from the authorities which have heen kights and adduced that a party to an apparent agreement which is roid by reason of fundamental error has more than one course open to him.

He may wait until the other party seeks to enforce the alleged agreement and then assert the nullity of the transaction by way of defence. If he think fit he may also take the opportunity of seeking by counterclaim to have the instrument sued on set aside $(p)$.

(ii) Fister v. Murlimmon (1s6:4)

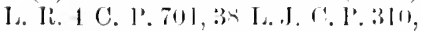
supier. p. ts.).

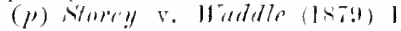

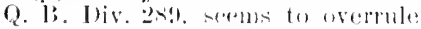
virtually the doxtrine astumed in
Hesty" v. Ilest lestyn (iml and

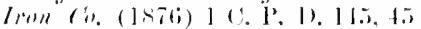
I...I. ('. I'. fol, that it is needful for thispourpose to whtain a to:msfor ofl the action to the chancery J)ivisiun. remedies of party to a void agreement. 
Or he may right himself, if he prefers it, by coming forward actively as plaintiff. When he has actually paid money as in performance of a supposed valid agreement, and in ignorance of the facts which exclude the reality of such agreement, he may recover back his money as having been paid without any consideration (the action "for money received" of the old practice). He paid on the supposition that he was discharging an obligation, whereas there was in truth no obligation to be discharged.

Moreover he may sue in the Chancery Division $(q)$, whother anything has been done under the supposed agreement or not, to have the transaction declared roid and to be reliered from any possible claims in respect thereof.

Election to adopt originally void agreement.
On the other hand, although he is entitled to treat the supposed agreement as void, and is not as a rule prejudiced by anything he may have done in ignorance of the true state of the facts, yet after that state of facts has come to his linowledge he may nevertheless elect to treat the agreement as subsisting: or, as it would be more correct to say, he may carry into execution by the light of correct knowledge the former intention which was frustrated by want of the clements necessary to the formation of any ralid agleement. It is not that he confirms the original transaction (except in a case where there is also misrepresentation, see p. 506), for there is nothing to confirm, but he enters into a new one.

It might be thought to follow that in cases within the Statute of Frauds or any other statute requiring certain forms to be observed, we must look not to the original roid and improperly so-called agreement, but to the subsequent election or confirmation in 
which the only real agreement is to be found, to see if the requirements of the statute have been complied with. No express authority has been met with on this point. But analogy is in favour of a deliberate adoption of the form already observed being held sufficient for the purpose of the new contract $(r)$.

A note on Bracton's treatment of the subject of fundamental error will be found in the Appendix (s).

Part III. Mistake in expressing true Consext.

This occurs when persons desiring to express an intention which when expressed carries with it legal consequences have by mistake used terms which do not accurately represent their real intention. As a rule it can occur only when the intention is expressed in writing. It is possible to imagine similar difficulties arising on verbal contracts, as for example if the discourse were carried on in a language imperfectly understood by one or both of the speakers. But we are not aware that anything of this lind has been the subject of judicial decision $(t)$. The general result of persons talking at cross purposes is that there is no real agreement at all. This class of cases has already been dealt with. We are now concerned with those where there does exist a real agreement between the parties, only wrongly expressed. Such mistakes as we are now about to consider were, even before the Judicature Acts, not wholly regarded by courts of law; but they are fully and adequately dealt with only by the jurisdiction which

(r) Stewart v. Eddowes (187t) Azo." 1. li. 9 C. I'. 311,43 L. J. C. R'. $204, * m, 171$.

(s) Note $(2$. This prosage is nut included in the portions editeel by Prof. Maithucl in "linaton and

P.

$(t)$ See however Jhilligs v. listolli (1821) 2 li. \& ('. 511, 26; li. R. 1:33, which comes near the supprosed case.

Mistake in expressing intention : generally oecurs in writing. 
was formerly peculiar to courts of equity. We shall see that this jurisdiction is exercised with much caution and within carefully defined limits.

C'lassification of cases according to the remeilies applicable: 1. General rules of construction.

2. Npecial equitable rules of construction. 3. - vecial equitable remcdies.

On the whole the cases of mistake in expressing intention fall into three classes:-

1. Those which are sufficiently remedied by the general rules of construction.

2. Those which are remedied by special rules of construction derived from the practice of courts of equity.

3. Those which require peculiar remedies administered by the Court in its equitable jurisdiction.

We proceed to take the classes of cases above mentioned in order.

\section{General Rules.}

Clerical errors, sce.

General intent prevails orer frarticular mistaken or repugnant expressions.

We have already seen that the more obrious forms of mistaken expression, mechanical errors as we may call them, can be dealt with in the ordinary course of interpretation $(x)$. A few more authorities may now be added.

In a case in the House of Lords the rule was laid down and acted upon that "both courts of law and of equity may correct an obrious mistake on the face of an instrument without the slightest difficulty " (y). Here a draft agreement for a separation deed had by mistake been copied so as to contain a stipulation that the husband should be indemnified against his own debts: but it was held that the context and the nature of the transaction clearly showed that the wife's debts were meant, and that in framing the deed to be executed under the direction of the Court in pursuance of the agreement the mistake must be corrected accordingly. So

(.e) Chap. V1.. p. 265. above.

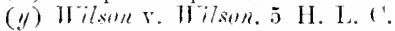
4it, tii, 101 Ii. R. 2.;, 42. per Lort it. Leonardis and see his note, Y. E P. lil. 
the Court may presume from the mere inspection of a settlement that words which, though they make sense, give a result which is unreasonable and repugnant to the general intention and to the usual frame of such instruments, were inserted by mistake $(z)$.

An agreement has even been set aside chiefly, if not entirely, on the ground that the unreasonable character of it was enough to satisfy the Court that neither party could have understood its true effect: such at least appears to be the meaning of Lord Eldon's phrase, "a surprise on both parties" (a). The agreement itself purported to bind the tenant of a leasehold renewable at arbitrary (and in fact always increasing) fines at intervals of seven years to grant an underlease at a fixed rent with a perpetual right of renewal. The lessor was in his last sickness, and there was evidence that he was not fit to attend to business. Charges of fraud were made, as usual in such cases, but not sustained: the decision might, however, have been put on the ground of undue influence, and was so to some extent by Lord Redesdale.

Again, there is legal as well as equitable jurisdiction to restrain the effect of general words if it sufficiently appears by the context that they were General words rest rained by context. not intended to convey their apparent unqualified meaning. It was held in Browning v. Wright (b) that a general covenant for title might be restrained by special covenants among which it occurred. And

(z) Re He la Tomethe's settlement (1870) L. R. $10 \mathrm{E}$. 5.59, tio:3, 40 l. J. ('h. 8.5; where however the mistaks was alsu establisher by evirlence.

(a) Hillan v. Hillan $(1809-10)$ If Ves. 72, 84; atlirmed in lom. Prom. 2 low, $275,27 x$, but the lacts were very peculiar, and the case has been seldom citel for a gencratinu or nore.

(b) $(1799) 2 \mathrm{H}$. \& P $, 13,26$, is R. R. 5.2l: bet it wals also thought the better construction to take the clanse in que-tion as being ar tually lart of a special covenamt, and so no general covenant at all. 
the same principle was again deliberately asserted shortly afterwards (in a case to the particular facts of which it was, howerer, held not to apply):-

"However general the worls of a covenant may be if standirg alone yet if from other covenants in the same deed it is plainly and irresistibly to be inferrel that the praty could not have intended to use the worls in the general sense whicil they import. the Court will limit the operation of the general worls." (c).

Similarly the effect of general words of conveyance is confined to property of the same kind with that which has been specifically described and conveyed $(d)$. When there is a specific description of a particular kind of property, followed by words which prima facie would be sufficient to include other property of the same kind, it has been held that those words do not include the property not specifically described, on the principle expressio unius est exclusio alterius $(e)$.

\section{Peculiar Rules of Construction in Equity.}

Such rules have been introduced by courts of equity in dealing with:

A. General words.

B. Stipulations as to time.

C. Penalties.

(c) Itrsis v. Sterenstu (18113) 3 B. d l' 56. 5i4.

(d) Rowke s. Lurd kensington (15.5i) 2 K. . . J. 753, 7/1, 25 L. I. ('h. 795,110 k. li, thti this. The same puinciple applies to general worls in the slatement of a company objeets in its memorandum of a cis ciation: Askbrry. di. Co. $v$.

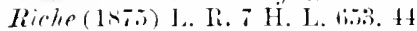
1.. J. Ex. 1s.

(b) Demn \&. Wilfurel (1826) \& lowl. \& Ry, 54!. The case was a curious cne. A fine had been levied of inter alia t welve messuages and twenty acres of land in Chelsea. The conusor had less than twenty aeres of land in Chelsea, but nineteen messuages. It was leeiled that although all the messuages would have passed under the general deseription of land if no les number of messuages had been mentioned. yet the mention of twelve messuages prevented any greater number from passing under the descrintion of land : and that parol evilence was admissible to show tir-t that there were in fact nimeteen messuages, this being no mure than was necessary to explain the nature and ehameter of the property : next (as a consequence of the construetion theseupon alopted by the Conrt) which twelve out of the nineteen messuages were intented. Anil see further the notes to Rue v. Tramurr (175s) 2 sm. L. C. 


\section{A. Restriction of General Words.}

We have seen that courts both of law and of equity have assumed a power to put a restricted construction on general words when it appears on the face of the instrument that it cannot have been the real intention of the parties that they should be taken in their apparent general sense.

Restrieted eonstruction of general worls carried farther than by common law: especially in releases.

Courts of equity went farther, and did the like if the same conviction could be arrived at by evidence external to the instrument. Thus general words of conveyance $(f)$ and an unqualified covenant for title $(g)$, though not accompanied as in Browning $\mathrm{r}$. Wright $(h)$ by other qualified covenants, have been restrained on proof that they were not meant to extend to the whole of their natural import.

This jurisdiction, in modern times a well established one, is exercised chiefly in dealing with releases. "The general words in a release aro limited always to that thing or those things which were specially in the contemplation of the parties at the time when the release was given " (i). This includes the proposition that in equity "a release shall not be construed as applying to something of which the party executing it was ignorant" $(j)$. There is at least much reason to think that it matters

(f) Thomas v. Daris (175\%) 1 l)ick. 301 .

(a) Coldent v. Mill, 1 ('h. Ca. 1., soll qu. for the ease looks rery like almiting contemporanerns con. verwation $t$ ") vary the effect of a solemn instrument. and that withcout any mistake or framl beingr mate ont, which is quite contrary to the modem rule.

(h) $(17949) \geq \mathrm{li}$. d l'. 13.; li. li. 5.2i, 1. .3.31, tht'.

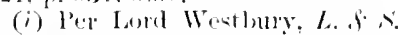

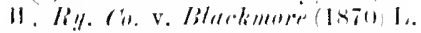

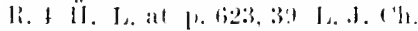

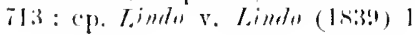

Beav. 496, 506. 4! R. R. 419, 425: Furmell r. (6) 2 Mer. 3.33; Dav. C'onv. is pt. 2. $62 \cdot 2-1$.

(j) Per Wille P. Lymll v. E⿰t-

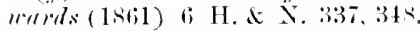
30 L. 1. Ex. 193, 1!17. This was a rase of e puitable jurisdiction under the ('. I. l'. Act, 1s.ts; but lefore that Act comrts of law would not allow a roleave to beset up if clearly satinfiel that a comot of erputy would set it aside: Millips $\therefore$.

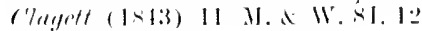
1. j. Wx. 20is. 
not whether such iguorance was caused by a mistake of fact or of law $(k)$.

In particular a release executed on the footing of accounts rendered by the other party, and assuming that they are correctly rendered, may be set aside if those accounts are discovered to contain serious errors, and this, in a grave case, even after many years $(l)$. It would be otherwise however if the party had examined the accounts himself and acted on his own judgment of their correctness. An important application of this doctrine is in the settlement of partnership affairs between the representatives of a deceased partner (especially when they are continuing partners) and the persons beneficially interested in his estate $(m)$.

A releasor, howerer, cannot obtain relief if he has in the meanwhile acted on the arrangement as it stands in such a way that the parties cannot be restored to their former position $(n)$.

Stipulations as to time.

B. Stipulations as to Time.

It is a familiar principle that in all cases where it is sought to enforce contracts consisting of reciprocal promises, and "where the plaintiff himself is to do an act to entitle himself to the action, he must either show the act done, or if it be not done, at least that he has performed everything that was in his power to do " $(0)$.

Accordingly, when by the terms of a contract one party is to do something at or before a specified time,

(h) Sce the cases cunsidered at l’. $\{$ \& 11, t81, above.

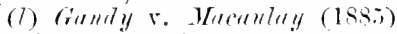
31 (h. Div. 1, where no accounts hat been renctered ot examined at all ; twenty years harl elapsel and the roleasee ivas deal.

(im) Millar v. rraig (1843) 6 Bear. 433, 63 R. R. 1:3!, I,inlley on l'artnership. 490.

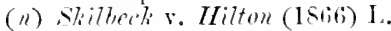
R. 2 Er. 5s : but qu. whether the principle was rightly applied in the particular case.

(1) Notes to Pefers r. Opie. 2 IIns. samml. $7+3$ : and see Ch. VI.. p. 274 , abore. 
and when he fails to do such thing within that time, he could not afterwards claim the performance of the contract if the stipulation as to time were construed according to its literal terms. The rule of the common law was that "time is always of the essence of the contract." When any time is fixed for the completion of it, the contract must be completed on the day specified, or an action will lie for the breach of it $(p)$.

The rule of equity, which now is the general rulo of English jurisprudence, is to look at the whole scope of the transaction to see whether the parties really meant the time named to be of the essence of the contract. And if it appears that, though they named a specific day for the act to be done, that which they really contemplated was only that it should be done within a reasonable time; then this view will be acted upon, and a party who according to the letter of the contract is in default and incompetent to enforce it will yet be allowed to enforce it in accordance with what the Court considers its true meaning.

"Courts of equity have eufureel contracts specitically, where noactim for damages conld be maintained ; for at law the party plaintiff must have strictly performed his part, and the inconvenienee of insisting upon that in all cases was sufticient to repuire the interference of conts of equity. They dispense with that which would make complianse with what the law requires oppressive, and in varioms cases of such enntrats they are in the eontant habit of relieving the man who has acted fairly, though negligently. 'Thus in the are of an estate sold hy ancetion, there: is a condition to forfeit the depresit if the purrhate be not completer within a certain time; yet the Cout is in the comstant habit of retieving against the lapere of time: and so in the race of mortgages, and in many instances relief is given against mere lapse of time where lapse of time is not essential to the substance of the centract."

So said Lord licdestale in a judgment which has

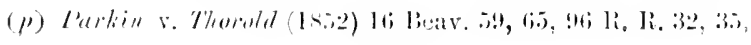


taken a classical rank on this subject $(q)$. Contracts between vendors and purchasers of land are however the chief if not the only class of cases to which the rule has been habitually applied $(r)$.

As to making time of the essence of the eontract.

It was once even supposed that parties could not make time of the essence of the contract by express agreement; but it is now perfectly settled that they can, the question being always what was their true intention $(s)$, or rather "what must be judicially assumed to have been their intention" $(t)$. "If the parties choose even arbitrarily, provided both of them intend to do so, to stipulate for a particular thing to be done at a particular time," such a stipulation is effectual. There is no equitable jurisdiction to make a new contract which the parties have not made $(u)$. The fact that time is not specified, or not so specified as to be of the essence of the contract, does not affect the general right of either party to require completion on the other part within a reasonable time, and give notice of his intention to rescind the contract if the default is continued $(r)$, as on the other hand conduct of the party entitled to insist on time as of the essence of the contract, such as continuing the negotiations without an express reserration after the time is past, may operate as an

(q) Lennon v. Tippler (1802) 2 Seh. \& L. 684, cited by Knight

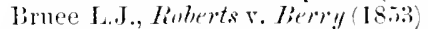
3 1). M. G. at 1. 289. 2.2 J. J. ('t. 398.98 R. R. 143 , and again adopted by the L.AJ. in Tilley r. Thamas (isti7) L. R. 3 ('h. 61.

(r) Sce per Cotton L.J. 4 C. P. D. at 1). $24 !$.

(s) Siton v. Slarle (1, so2) 7 Ves. 265, 275, 6 R. R. 124, and notes to that case in 2 Wh. \& T. I. C.; Ptrlin v. Thorold (1852) 16 Beav. 5.), !li R. R. 32.

$(t)$ Grove J.in Patriok v. Wilner (1877) 2 C. P, D. $342,348,46 \mathrm{~L}, \mathrm{~J}$.
C. I. 53\%.

(u) Per Aluterson B. Himeell s. Knight (183i) I Y. \& C. Ex. Eq. 41:. t1 R. T. 304. And see the observations of Kinlersley V.-C. to the same effeet in Ouladen $\mathrm{r}$. Pike (1865) $3+$ L. J. Ch. 620 .

(v) This is the true and only arlmissible meaning of the statement that time can be marle of the essence of a contraet by subiequent express notice. I'er Fry J. cireen v. Eerin (1859) 13 Ch. D. 589, 599: per Tumer L.J. Williams $\mathrm{s}$. Glentom (186ii) L. R. 1 Ch. 2610. 210. 
implied waiver of his right $(w)$. In mercantile contracts the presumption, if any, is that time where specified is an essential condition $(x)$. An express promise to do a thing "as soon as possible" binds the promisor to do it within a reasonable time, with an undertaking to do it in the shortest practicable time $(y)$. The principles of our jurisprudence on this head are well embodied by the language of the Indian Contract Act, s. 55:

When a party to a contract promises to do a certain thing at or before a specified time, or certain things at or before specitied times, and faits to do any such thing at or before the specified time, the contract, or so much of it as las not been performed, becomes voidable at the option of the promisee, if the intention of the parties was that time should be of the essence of the contract.

[The Court may infer from the nature of a contract, even though no time be specified for its completion, that time was intended to be of its essence to this extent, that the contracting party is bound to use the ntmost diligence to perform his part of the contract]. ( $*$ ).

If it was not the intention of the parties that time shouk be of the essence of the contract, the contract does not become voidable by the faiture to do such thing at or before the specified time : but the promisee is entitled to compensation from the promisor for any loss oceasioned to him by such failure.

If, in case of a contract roidable on account of the promisor's failure to perform his promise at the time agreed, the promisee accepts performance of such promise at any time other than that agreed, the promisee cannot claim compensation for any luss occasioned by the nonperformance of the promise at the time agreed, mlcss, at the time of such acceptance, he gives notice to the promisor of his intention to do so (a).

\section{Relief against Penalties.}

In like manner penal provisions inserted in instruments to secure the payment of money or the

Relief against penalties, especially as to mort gacres. (a) Webh r. IInghes (1870) L. R.

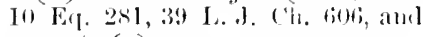
see note $(1)$.

(x) ler ('otton T..t. Rerlerv. Sala (1879) I ('. I'. Lliv. at !. 249, 48 L. J. C. I'. 492.

(y) Ilydranlir Enginepring (').

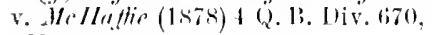
673.
Indian Con. tract Act thereon. (z) Mecturyle v. Wepties (IR.sfi) 22 liear. 333,111 R. R. 471 (eontract for a lease of working mines).

(a) "lt comstantly happens that an objection is waived by the condinct of the partice," prer James L.I. I puertom v. Nirtolsen (1s71) fi Ch. at $1.113,40$ I..J. ('h. 101. Autl see Dart, V. 5 I'. 121. 
performance of contracts will not be literally enforced, if the substantial performance of that which was really contemplated can be otherwise secured $(b)$. The most important application of this principle is to mortgages. A court of equity treats the contract as being in substance a security for the repayment of money adranced, and that portion of it which gives the estate to the mortgagee as mere form, "and accordingly, in direct violation of the [form of the] contract," it compels the mortgagee to reconvey on being repaid his principal, interest and costs $(c)$. Here again the original ground on which equity interfered was to carry out the true intention of the parties. But it cannot be said here, as in the case of other stipulations as to time, that everything depends on the intention. For the general rule "once a mortgage, and always a mortgage" cannot be superseded by any express agreement so as to make a mortgage absolutely irredeemable $(d)$. However, limited restrictions on the mutual remedies of the mortgagor and mortgagee, as by making the mortgage for a term certain, are allowed and are not uncommon in practice. Also there may be such a thing as an absolute sale with an option of repurchase on certain conditions; and if such is really the nature of the transaction, equity will give no

(I) In arblition to the authorities citch below. see the later ca-e of

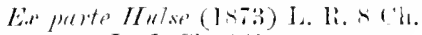
$1012-2.43$ I. I. Ch. 2101 .

(c) ler Romilly M.h. Mrkin v.

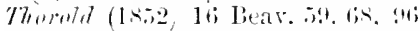
li. li. :32, 37 : ant see lowl lieterdakes julement in Lonum v. Vapper. p.i3s. snpre. As to the oll thenry of an "erpity of retemption" being not an estate but a merely lerstnal right, and its comse. quences. see bord blakbums remarks, ti An, Ca. al 11. 311 . (d) Mnward r. Mntris, I Vern.

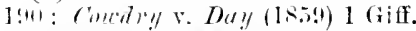
316 . se reporter's note at 1.323 ; 1 Ch. Ca. 1tl, 29 1.. J. Ch. 3!) 11 1 R. li. ftit. The C. A. was rivilerl, in a peculiar case. as to the applieation of this principle: Marryess of Korthameton v. Pollork (1s90) fi) (h. Liv. 190. 59 L. J. Th. 745: the opinion of the majority was whell in If. L. [18:12] A. C. 1 6i L. J. (ch. 4! ree now Vimkes c) ri. V. Rim $[1902]$ A. C. 24, 31 I. J. Ch. 139 . 
relief against the necessity of observing those conditions $(e)$.

"That this Court will treat a transaction as a mortgage, although it was made so as to bear the appearance of an absolute sale, if it appear that the parties intended it to be a mortgage, is no doubt true; $(f)$ but it is equally clear, that if the parties intended an absolute sale, a contemporaneorts agreement for a repurchase, not acted upon, will not of itself entitle the vendor to redeem " $(g)$.

The manner in which equity deals with mortgage Gencral rule transactions is only an example of a more general rule:-

"Where there is a debt actually dhe, and in renpect of that alebt a security is given, be it ly way of mortgage or he it by way of stipmliation that in ease of its not being paid at the time anpwinted a larger sum shall become payabje, and be prarl, in either of those cases Edfuity regards the security that has been given as a mer"s pledge for the debt, and it will not allow either a forfuiture of the property phedged. or any auguentation of the debt as a prenal provision, on the gromul that Expity romets the contemplated forfeiture which might take plare at lis with reference to the estate as in the nature of a penal provision, against which biruity will relieve when the object in view, namely, the secming of the luht, is attained, and regarling also the stipulation for the payment of a larger sum of money, if the sum be not paid at the time it is due as a penalty and a forfeiture against which Eipuity will relieve" (/).

This applies not only to securities for the payment of money but to all cases "where a penally is inserted merely to secure the enjoyment of a collateral object. (i). In all such cases the penal sum was originally recoverable in full in a court of

(c) Daris v. Thomes: (1830) 1

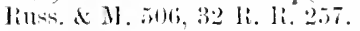

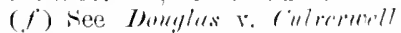
(Isti2) 3il L. .J. ('h. 51:3: and on also at conmon law, cirrdner $v$.

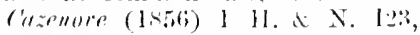
435, 135, 26; L. J. Wx. 17, 1 201,

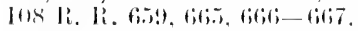

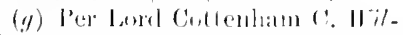

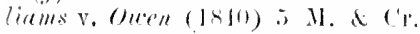

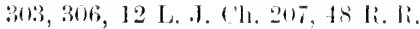
322.324 .

(ii) l'er lenrl llatherlicy (".

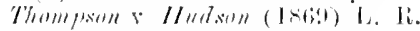
4 11. L. 1, 1., 3. L. . . ('). 1:31.

(i) Per losil Thurlow. Stomente $\mathrm{x}$.

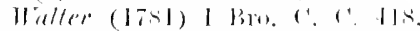

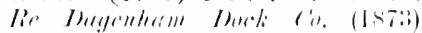

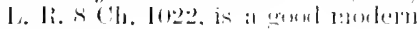
example. 
law, but actions brought to recover penalties stipulated for by bonds or other agreements, and land conveyed by way of mortgage, have for a long time been governed by statutes $(k)$.

It would lead us too far beyond our present object to discuss the cases in which the question, often a very nice one, has arisen, whether a sum agreed to be paid upon a breach of contract is a penalty or liquidated damages. It may be noted however in passing that "the words liquidated damayes or penalty are not conclusive as to the character of the sum stipulated to be paid." This must be determined from the matter of the agreement $(l)$.

\section{Peculiar Defences and Remedies derived from Eqnity.}

Defence against specific performance.

A. Defence against Specific Performance.

When by reason of a mistake (e.g., omitting some terms which were part of the intended agreement) a contract in writing fails to express the real meaning of the parties, the party interested in having the real and original agreement adhered to (e.\%. the one for

(k) Asto common money homis 4 \& Anne, e. li (3 in liev. Stat.) s. 13. As to other bonls and agreements s a 9 Will. III. c. 11. s. S. The statutes (some of which have been repealed hy rtatute Iaw Revision Acts) ire collected and revewed in Prextull r. Mullin (1872) L. I. S Ex. 1!. 4: I. J. Ex. 33. A mortgagee suing in ejectment, or on a bond grven as collateral seeutity, may be eompelled by rule of rourt to reconvey on payment of princilal, interest. and costs: 7 (ieo, Il. c. 20. ('. I. l'. Aet 1 s.i2 (15 \& 16 Vict. e. 76) s. 2I:1. Bonds of the kind last mentimed hardly neeur in molern practice.

(l) Per Bramwell 18, in Betts r.
Lureh (15.59) 4 H. \& X. 506. 511. 2S L.J. Ex. 267, 271. The later cases on this subject are- Mager $r$. Jalipll (IRT4) L. R. 9 C. 1'. 1i7, 43 I. J. ( . P. 131 (authorities diselrsed hy Jessel M.li.) : Lurd Elphimstone v. Monliland lion and Gial (\%. (Issti) 11 App. Ca. (śc.) 332: Mallix v. Smith (1882) 21 (h. 1)ir. 243,52 L. J. Ch. 145 ; Willson v. Lome [ ] 896] I Q. 11.626. (i.) L. I. (2. 18. 474. ('. A. CP. Jiston v. Hetrop. Asylum Inistrict (Ist2) ! ( . P. Div. 404, 5l I. J. 12. I3. 34! on the similar question of a perual rent. In the Indian contraet Aet the knot is cut hy abolishing the distinction altrgether: sees. it. 
whose benefit the omitted term was) is in the following position.

If the other party sues him for the specific performance of the contract as expressed in writing, it will be a good defence if he can show that the written contract does not represent the real agreement: and this whether the contract is of a kind required by law to be in writing or not. Thus specific performance has been refused where a clanse had been introduced by inadvertence into the contract $(m)$. It is sometimes said with reference to cases of this class that the remedy of specific performance is discretionary. But this means a judicial and regular, not an arbitrary discretion. The Court "must be satisfied that the agreement would not have been entered into if its true effect had been understood" $(n)$.

On the other hand a party camnot, at all events where the contract is required by law to be in writing, come forward as plaintiff to claim the performance of the real agreement which is not completely expressed by the written contract. Thus in the case of Townshend v. Stangroom (o) (referred to by Lord Hatherley when V.-C. as perhaps the best illusTownshend $r$. Stangroom. tration of the principle) $(p)$, there were cross suits $(q)$, one for the specific performance of a written agreement as varied by an oral agreement, the other for specific performance of the written agreement without variation; and the fact of the parol variations from the written agreement being established, both suits were dismissed. And the result of a plaintiff attempting to enforce an agreement with alleged parol varia-

(iii) Hetsone v. Warston (18.53) 4 1). M. (i. 230,102 R. 1i. 1001.

(ii) I hid. + L. If. (i. al p. 2lo, 102 R. R. los.

(i) (1s01) 6 Ves.32s, ; Ii. R. 312.
(1) 1 Fined v. Ficarth (15.5) $2 \mathrm{~K}$ d.J. 33, 42, $110 \mathrm{R}$. R. 8 s.

(q) Tuler the Julicature Acts there would be an action and counter-elaim. 
tions, if the defendant disprores the rariations and chooses to abide by the written agreement, may be a decree for the specific performance of the agreement as it stands at the plaintiff's cost $(r)$.

But it is open to a plaintiff to admit a parol addition or variation made for the defendant's benefit, and so enforce specific performance, which the defendant might have successfully resisted if it had been sought to enforce the written agreement simply. This was settled in Martin v. Pycroft $(s)$ : "The decision of the Court of Appeal proceeded on the ground that an agreement by parol to pay 200l. as a premium for . . . a lease [for which there was a complete agreement in writing not mentioning the premium] was no ground for refusing specific performance of the written agreement for the lease, where the plaintiff submitted by his bill to pay the 200l. That case introduced no new principle as to the admissibility of parol evidence" $(t)$.

lielation of this doctrine to statute of Frauls.

It is to be observed (though the observation is now familiar) that these doctrines are in principle independent of the Statute of Frauds $(u)$. What the fourth section of the Statute of Frauds says is that in respect of the matters comprised in it no agreement not in writing and duly signed shall be sued

(i) Siee Migginsun v. rlemess (1九us) $15 \mathrm{Ve} .516$, .2.) $10 \mathrm{li}$. R. 112; and such andears to be the real effect of Fifo v. Glayton (1001- 13

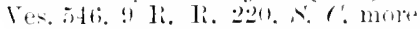
fully given, with the lecrees l C.. I'. Cooper (temp). Cottenham) 331. Ho this cave Lork Elfom hatel holet on the plaint iff: wffer in genteral tems to jurfurm the agreement as amounting to an offer to perform "what the Court. men hearing all the circumstances. should be of opinion wats the agrement." see the motes to the car-e in ! li, Ri. 2.20!. lit after a laintifi has failed to -mport his own construction of an agreement which the court llinks ambigmus, he eannot take adrantace of sueh an offer contained in his own plearlings " to talie mp the other comstruction which the defenclant was at one time willing to halve performed": Clowes v. Higginsen (1-13 1 Ves. \& B. i24. 335 , 12 Ri. li. $2 \times 4$.

(s) $($ I -52$) 2$ I). M. G. Ts, 2.2 L. 3. ('h. 94. 45 R. R. 324.

(t) Her Stuart V.-C. Pricer. Ley (I-tii) 4 (iiff. at p. 253 .

(11) Ste ler lurd Redestale in rlimum v. ( imke $(1-1) 2) 1$ sch. A I.ef. ?.). 33 -3!. ! H. H. 3. 7-11. 
upon. This in no way prevents either party from showing that the writing on which the other insists does not represent the real agreement; the statute interferes only when the real agreement eannot be proved by a writing which satisfies its requirements. Then there is nothing which can be enforeed at all. The writing cannot, because it is not the real agreement; nor yet the real agreement, because it is not in writing. A good instance of this state of things is Price v. Ley $(x)$. The suit was brought mainly to set aside the written agreement, and so far sueceeded. It appears not to have been seriously attempted to insist upon the real agreement which had not been put into writing.

B. Rectification of Instruments.

When the parties to an agreement have determined to embody their common intention in the appropriate and conclusive form, and the instrument meant to effeet this purpose is by mistake so framed as not to express the real intention which it ought to have expressed, it is possible in many cases to correct the mistake by means of a jurisdiction formerly peculiar to eourts of equity, and is still reserved, as a matter of proeedure, to the Chancery Division.

Courts of equity "assume a jurisdiction to reform instruments which, either by the fraud or mistake of the drawer, admit of a constiuction inconsistent with the true agreement of the parties (y). And of neeessity, in the exercise of this jurisdiction, a eourt of equity receives evidence of the true agreement in

(.r) (186i3) + (riff. 235, aftirmed

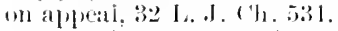

(y) The court need wot alecile the point of construction: it is curmeg that serions doubt exists whether the terms express the trone intention: Wrather v. L Imestrongy

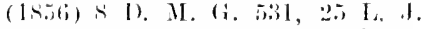

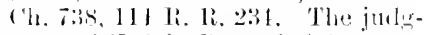
ment of Knight linuce L., is entertaining at well as profitable. 
contradiction of the written instrument." Relief will not be refused though the party seeking relief himself drew the instrument; for "every party who comes to be relieved against an agreement which he has signed, by whomsoever drawn, comes to be relieved against his own mistake" $(\boldsymbol{z})$. The jurisdiction is a substantive and independent one, so that it does not matter whether the party seeking relief would or would not be able to get the benefit of the true intention of the contract by any other form of remedy $(a)$. It would be neither practicable nor desirable to discuss in this place the numerous cases in which this jurisdiction has been exemplified. The most important thing to be known about a discretionary power of this kind is whether there is any settled rule by which its exercise is limited. In this case there are ample authorities to show that there is such a rule, and they expound it so fully that there is very little left to be added by way of comment.

Principles on which courts of equity will rectify instruments.

Precious agreement in writing not allowed to be varied.

The manner in which the Court proceeds is put in a very clear light by the opening of Lord Romilly's judgment in the case of Murray r. Parker (b):

. In matters of mistake, the Comt unloubtedly has jurisdiction, and though this jurisdiction is to be exercised with great eaution and eare. still it is to be excreised in ail cases where a deed, as executed, is not according to the real agreement between the parties. In all cases the real agreement must be established by evilence, whether larol or written; .... if these be a previous agleement in writing which is unambiguous, the deed will be reformed according] 5 ; if ambignous. parol eridente may be used to express it. in the same manner as in other eases where parol evilence is almitted to explain ambiguities in a written instrmment."

In the case of "a previous agreement in writing which is unambiguous" the Court cannot admit parol eridence to rectify the final instrument executed in

(z) Ball v. storie (1823) 1 sim. s. st. $210,219,2 \pm$ R. R. 170 .

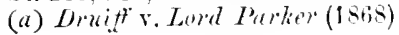

L. R. i) Eq. 131, 37 L. J. Ch. 241. (b) $(15,54) 19$ Beav. 305. 308, 105 R. R. 153. 154. 
accordance with such agreement any more than it could allow the party to maintain a suit, while the agreement was yet executory, first to rectify the agreement by parol evidence and then execute it as rectified-which, as we have seen, it will not dlo. For this would be to "reform [the instrument] by that evidence, which if [the instrument] rested in fieri, would be inadmissible to aid in carrying it into execution" (c).

If there be no previous agreement in writing, the modern rule is that a deed may be rectified on oral evidence of what was the real intention of the parties at the time, if clear and uncontradicted.

But if the alleged mistake is positively denied by any party to the instrument, parol evidence alone is inadmissible to prove it. The rule is contained in two judgments given by Lord St. Leonards in the Irish Court of Chancery.

He said in Alexander v. Crosbie $(d)$ :

"In all the eases, perhaps, in which the Court has reformed a settlement, there has been something beyond the parol evidence, such, for instance, as the instruetions for preparing the eonveyance or a note by the attorney, and the mistake properly acconnted for ; but the Court would, I think, aet where the mistake is elearly established by parol evidence, even though there is nothing in writing to which the parol evidence may attach."

What is here meant by "clearly established" is shown by his later statement in Mortimer v. Shortall (e), applying the general rule of equity practice that the Court will not act merely on "oath against oath": "There is no objection to correct a

(a) Per Iord st. Idemards Iheries v. Fittun (1812) 2 Ir. \& Wir. 22.5, 233. 90 K. K. 85.5. 889 : foll by Far-

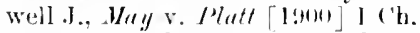
(i16, 69) I.... ('h, 3.5. These anthorities are criticized but arlmit ted to be binding by Neville J. in Tlemmpson

P. s. Hickman $[1907]$ I ('h. at p. $56 \mathrm{I}$. (d) (1835) b. d (i. teml). sug.

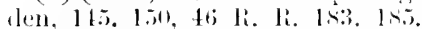
(1). Daries v. Fittoll (1+12) — Dr. \& War. 233, 610 R. 1. 889.

(e) $(1+2) 2$ Dr. d War. 363, 37., 59 R. K. 730.
Orat evidence of the real agreement admissible in the absence of any other if not con trablicterl. 
deed by parol evidence, when you have anything beyond the parol evidence to go by. But where there is nothing but the recollection of witnesses, and the defendant by his answer denies the case set $u p$ by the plaintiff, the plaintiff appears to be without a remedy. Here $I$ am not acting upon parol evictence alone; the documents in the cause, and the subsequent transactions, corroborate the parol evidence, and leave no doubt in my mind as to a mistake having been made."

Again, it was said in a case on the equity side of the Court of Exchequer, where the whole subject was considerably discussed:

"It seems that the Court onght not in any ease. where the mistake is

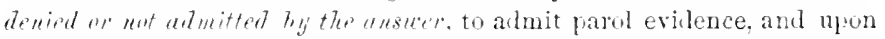
that eridence to reform an executory agreement " $(f)$.

On the other hand, when the mistake is admitted, or not positively denied, written instruments have repeatedly been reformed on parol evidence alone $(g)$.

What munt be proved: comulon intention of parties difforent from expresivel intention.

Thus far as to the nature of the evidence required; next lot us see what it must prove. It is indispensable that the eridence should amount to "proof of a mistake common to all the parties" $(h)$, i.e. a common intention different from the expressed intention and a common mistaken supposition that it is rightly expressed: it matters not, as we have seen,

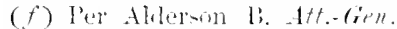

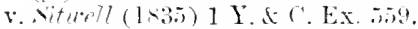
is3: Olley r. Floker (lanti) 34 Ch. I. 367 . 5i; L. J. Ch. 206s, seems to put this rule wholly on the starute of Frauls: but it has since been decidul that the statute dese not apply to an action for rectifieation of a marriage settlement: Jothesun r. Lira!gle [1!011] 1 ('l. 2., . I) L. J. (h. 4 !.

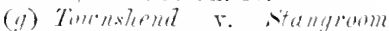
(1-ii]) t; Les. 320. 334, ; R. I. 312 : bull $x$ storie $(1-23) 1$ sim. d st. 210.2+ R. Ii. 170; Trmift v. Lard
Parlefe (loris) L. R. is Eu. 1:31. 3 i L. J. rin. 1+l: E.r purte Sitionel

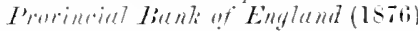
4 (a. I. 2tl. 4ti L. J. Bk. 11 ; Helman v. Helmen (1S80) $15 \mathrm{ch}$. 1). $30.4 !$ L. J. Ch. 736 , where a fower of revocation alpearing in the first draft hal been struck out in the instrument as it finally stool. and there was nothing to show how this had happened.

(7) l'er lord liomilly M.IR. Je'utley r. Mucluty (1sog) 31 Bear. at p. 1.il. 
by whom the actual oversight or error is made which causes the expression to be wrong. The leading principle of equity on the head of rectification,that there must be clear proof of a real agreement on both parties different from the expressed agreement, and that a different intention or mistake of one party alone is no ground to vary the agreement expressed in writing, - was distinctly laid down by Lord Hardwicke as long ago as $1749(i)$.

The same thing was explicitly asserted about a century later by the modern Court of Appeal:

"The power which the Court possesses of reforming written agreements where there has been an omission or insertion of stipulations contrary to the intention of the prarties and under a mutual mistake, is one whieh has been frequently and most usefully exereised. But it is also one which should be used with extreme eare and caution. To substitute a new agreement for one which the parties lave cleliberately subscribed onght only to be permitted upon evidenee of a different intention of the elearest and most satisfactory description. . . . It is elear that a person who seeks to reetify a deed upon the ground of mistake must be required to establish, in the clearest and most satisfactory manner, that the alleged intention to which he desires it to be made conformable eontinued eoneurrently in the minds of all parties down to the time of its exeeution, and also must be able tu show exactly and precisely the form to which the deed onght to be brought. For there is a material difference betwen setting aside an instrmuent and rectifying it on the ground of a mistake. In the latter case yon wan only act upon the nutual and concurlent intention of all parties for whom the Court is virtually making a new written agreement " $(k)$.

So it has been laid down by the American Supreme Court that Equity may compel parties to perform their agreement, but has no power to make agreements for parties, and then compel them to execute the same $(l)$; to the same effect in Rooke $r$. Lord Kensington $(m)$ by Lord Hatherley when V.-C.; and

(i) Ileukle v. liongul birell. Assere. (ir. 1 Ves. sr. 318.

(k) Fouler v. Fowler (1sid) 1

De G. \& J, 2.0, 21:4.

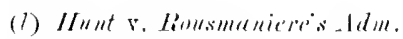
(1R.26) 1 Peter's, $1,14$.

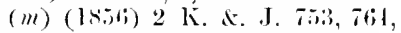
25 L. J. (h. 795,110 li. Li. $45 t i$.
Pooof of one party's intention will not do. 
nure recently by James L.J. when V.-C. in Mackenzie r. Coulson (n). On this principle, as we have already seen, the jurisdiction to rectify instruments does not extend beyond particular expressions. The Court cannot alter that form of instrument which the parties have deliberately chosen $(o)$.

The Court therefore cannot act on proof of what was intended by one party only $(p)$. And when an instrument contains a variety of provisions, and some of the clauses may have been passed over without attention, "the single fact of there being no discussion on a particular point will not justify the Court in saying that a mistake committed on one side must be taken to be mutual " $(q)$. The Court will not rectify an instrument when the result of doing so would be to affect interests already acquired by third parties on the faith of the instrument as it stood $(r)$.

Without derogation from the above general rules, a contract of insurance is liberally construed for the purpose of reforming the policy founded upon it in accordance with the true intention $(s)$.

Posible

There exists a rare class of cases (we know of exception where one party acts as other's agent. only two complete instances at present, and none in a Court of Appeal) in which the rule that a common mistake must be shown may admit of modification. This is where one party acts as another's agent in preparing an instrument which concerns them both-(in both the particular cases referred to an intended husband had the marriage settlement prepared in great haste and without any advice being

(11) (1869) L. R. \& Eq. 36, 37\%.

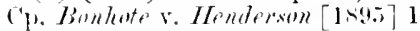
Ch. 742, tit L. J. Ch, 5its, affil. [18:5] 2 ('h. 202. C. A.

(a) See note (l), p. isti.

(1) Hills r. Ruellend (1853) + D. II. $($ i. 430,436 .
(4) Thompsons. Whitmore (1860) 1 J. A H. 248.276.

(i) Blackie r. Clark (1852) 15 Bear. 595. 92 R. R. 500.

(s) Equitulle Insuranse ('ompany v. Hetrme (18it) 20 Wallace (sup. ('t. C. s.) 4 (9t. 
taken on the wife's part) - and that other gives 110 definite instructions, but relies on the good faith and competence of the acting party to carry out the true intention. Here the acting party takes on himself the duty of framing a proper instrument-such an instrument, in fact, as would be sanctioned by the Court if the Court had to execute the agreement. And the instrument actually prepared, and executed by the other party on the assumption that it is properly framed, may be corrected accordingly $(t)$.

But cases of this lind would perhaps be better put on the ground that the acting party is estopped by his conduct, having talien on himself a fiduciary relation and duty, from denying that the intention of the other party was in fact the common intention of both. Compare p. 526, above.

The most frequent application of the juriscliction of equity to rectify instruments is in the case of marriage and other family settlements (u), when there is a discrepance between the preliminary memorandum or articles and the settlement as finally executed. As to marriage settlements, the distinction was formerly held that if both the articles and the settlement were ante-nuptial, the settlement should be taken in case of rariance as a new agreement superseding the articles, unless expressly mentioned to be made in pursuance of the articles; but that a post-nuptial settlement would always be reformed in accordance with ante-nuptial articles. The modern doctrine of the court has modified this

(t) rlark v. liidlumel (1877) 7 Ch. Dir. 9, 47 J... I. Ch. 116, on the antherity of rarley v. Lard stafford (Isii) i be (i. id d. 235. where hotwever there was no rectification : a bater and very similar ("alse is

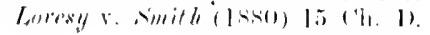

6is., la I. .J. ('h. Son. The l'ourt of Apreal dixes not seem likely to extend this juriscicotion. Siee

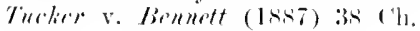

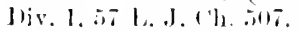

(11) Sien fortleer on this subjeret

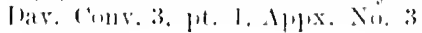

Pieformation of settlements according to previous articles. 
Speeial rules as to this.

as follows, so far as regards settlements executed after preliminary articles but before the marriage:

1. When the settlement purports to be in pursuance of articles previously entered into, and there is any variance, the variance will be presumed to have arisen from mistake.

2. When the settlement does not refer to the articles, it will not be presumed, but it may be proved, that the settlement was meant to be in conformity with the articles, and that any variance arose from a mistake.

In the first case the Court will act on the presumption, in the second on clear and satisfactory eridence of the mistake $(v)$.

A settlement may be rectified even against previous articles on the settlor:s incontradicted evilence of departure from the real intention, if no further evidence can be obtained $(x)$.

The fact that a provision inserted in a settlement (e.g. restraint on anticipation of the income of the wife's property) is in itself usual and is generally considered proper, is not a ground for the Court refusing to strike it out when its insertion is shown to have been contrary to the desire of the parties and to the instructions giren by them $(y)$. There is however a general presumption, in the absence of distinct or complete evidence of actual intention, that the parties intend a settlement to contain dispositions

(r) Buld v. Hutrhimsern (15.5i) i 1). MI. G, .5. 212. In reforming a set tement the intent rather than the literal worls of the articles will be followed: for a molern instance see rayan $r$.

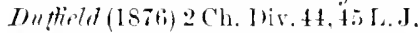
Ch.30T. As to the general principles on which conts of eijuity construe instruments creating executory

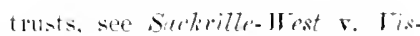
count Holmesdale (1870) I. R. 4 H. L. $543,555.565 .39$ L. J. Ch. 5).

(r) Simith v. Iliffe (1875) L. Ii. 20 Eq. Geto, tt L. J. (h. T.5: Irentry v. Itemron (18-9) $13 \mathrm{Cl}$. 1). 545 .

(y) Torre v. Torre (18.53) $1 \mathrm{sm}$. of (i. $) 18.90$ li. li. tit. 
and provisions of the kind usual under the circumstances $(z)$.

It is not necessary that a person claiming to have a settlement rectified should be or represent a party to the original contract, or be within the consideraAt whose suit rectification may tion of it $(a)$. But a deed which is wholly voluntary in its inception cannot be reformed if the grantor contests it, but must stand or fall in its original condition without alteration (b); the reason of this has been explained to be that an agreement between parties for the due execution of a voluntary deed is not a contract which the Court can interfere to enforce $(c)$. The Court has power, however, to set aside a voluntary deed in part only at the suit of the grantor if he is content that the rest should stand $(d)$.

The Court will exercise caution in rectifying a voluntary settlement at the instance of the settlor alone and on his own evidence $(e)$.

An agreement will not be cancelled at the suit of one party when he has rejected a proper offer to rectify it. It was agreed between $A$. and $B$. that Tiectifieation as alternative to cas A. should give $B$. the exclusive right of using a patent in certain districts: a document was executed which was only a licence from A. to B. Some time afterwards $B$. complatined that this did not carry out the intention, and A., admitting it, offered a rectification. B. refused this and sued for cancellation.

(z) See 1 , 530 . ahove.

(ai) Thompsomen. Whitume (Isfor)

1.J. \& H. 21:- 273.

(b) 18 roun v. kinnedy (186i3) 33

Beav, at 1.147.

(a) Lister v. Hordgsom (186ia) L. R.

4 Eq at p. 34.

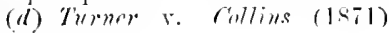

I. R, 7 ('h, 329), 342, 41 L.. I. ('h. 5is : and see per Turner $\mathrm{I}_{\text {..J. }}$.

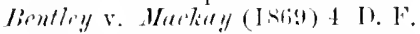
J. 2Qtiti.

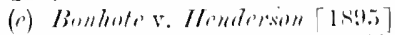
1 (h. 7l2.tit L. J. Ch. .isti, atlil. [1.59, 2 ('1., 20.2, (1. 1. 
Held that the relief prayed for could not be granted $(f)$.

In certain cases already mentioned for another purpose (g) the plaintiff sought to reform an instrument, and satisfied the Court that it did not represent what was his own intention at the time of execution, but failed to establish that the other party's intention was the same; and the Court gave the defendant his choice of "having the whole contract annulled, or clse of taking it in the form which the plaintiff intended" $(h)$. The anomalous character of these cases has already been pointed out.

Disentailing deeds.

Agreement exeruted by Count.

Mistake in wills.

Minor points of procedure.

The Court is not prevented by the Fines and Recoveries Act, ss. 40, 47, from exercising its ordinary jurisdiction to rectify the resettling part of a disentailing assurance $(i)$.

An agreement cannot be rectified after it has been adjudicated upon by a competent Court and performed under the direction of that Court $(k)$.

It is sometimes said, but inexactly, that in certain cases wills may be rectified on the ground of mistake $(l)$.

Actions for the rectification of instruments must be assigned to the Chancery Division; but where a statement of defence to an action brought in another Division is accompanied by a counterclaim for rectification, this is not a sufficient reason for transferring the action $(m)$.

When a conveyance is rectified the order of the

(f) Luter v. Dennett (1883) 109 L. 5.90.

(g) Simpre. 1'p. 5115-.507.

(h) Illlmis v. Pepperell (1867)

J. li. $5 \mathrm{E}$. 1, 5; Gumald r. Framliel (INiz) Bu Beav. 4tr, 3 I I. J. Ch. 604; Blumer' v. Spittle (1+72) I. R. 13 Eı. 427, 41 L. J. Ch. 36is. See .Ma!n v. Platt $[190(1)] 1 \mathrm{Ch}$. 616. (i9 L. J. i'h. 35i; Birale r. Kigte [196i] 1 ch. 564,76 L. J. Ch. 294. (i) Irall-Dare v. Hall-Tlare $(15,5) 31$ Ch. Div. 2.51 , 5j L, J. ('il. 1.it.

(k) Caird v. Moss (1s8ii) $33 \mathrm{Ch}$. Div. 22, 5.5 I. J. Ch. 8.54 .

(l) On this point, see the Ap pendix. Note H.

(m) Ntriey v. Iladdle (187!) t Q. B. I)iv. 2 s?. 
Court is sufficient without a new deed. A copy of the order is indorsed on the deed which is to be rectified $(n)$.

A consent order, being founded on agreement of the parties, may be set aside for mistake if the Consent irders. facts would justify setting aside an agreement on any of the grounds considered in the foregoing discussion (o). So where the mistake as to the effect of the order is on one side only, but induced, however innocently, by the act of the other $(p)$.

The Court may not only rectify but rescind unilateral acts, such as appointments under a settlement Tnilateral or will, which have been executed under a misapprehension of material facts $(q)$. But this is outside the field of contract.

(ii) II7ite v. White (1872) L. I. 15 Eq. 247,42 L. .J. Ch. 288 .

(ii) Hudderstield Bunking ('o. v. Lister \& Sim [1895] 2 Ch. 273,61 L. J. Ch. 523, C. A.
(1) Wilding v. Sumdersm [1897] 2 ('h. 534, 6it L. J. Ch, 68t. C. A.

(q) Iforrd uf Aralon (Lat!y) $\mathrm{r}$. Marlinmon [19091 1 Ch. 476,78 I. J. Ch. 300. 
CHAPTER X.

Misrepresentation and Fraud.

Part 1.-Generally.

Misrepresen. Tur: consent of one party to a contract may be tation hy fraul or caused by a misrepresentation made by the other of deceit. some matter, such that, if he had known the truth concerning it, he would not have entered into the contract. Putting off for a while the closer clefinition of the term, we see at once that there is a broad distinction between fraudulent and innocent misrepresentation. A statement may be made with linowledge of its falsehood and intent to mislead the other party, or with reckless ignorance as to its truth or falschood. In either of these cases the maling of such a statement is morally wrong and also wongful in a legal sense, and the conduct of the party making it is called Fraud or Deceit, and may be a substantive wrong giving rise to a claim for redless in damages, independent of any contract. The present writer has endervoured to discuss this aspect of it elsewhere (1).

Innocent On the other hand a man is generally safe, for the statement. purpose now being considered, in stating as true that which he believes to be true. Still more is he safo in giring his opinion, as an opinion, for what it may be worth. If he communicates at the same time the grounds on which he formed his opinion, or (a) In "The Iaw of Trits." (h, riii. 
reasonable means of access to those grounds, he has done all that an honest man can do.

Whenever consent to a contract is obtained by deceit, the contract is voidable at the option of the party deceived, subject to the conditions to be presently mentioned. The other party cannot take advantage of his own wrong. We shall see that the working of this rule involves caroful definition and distinction; but the substance of the law now rests on fairly broad and simple grounds. A man who makes positive statements to the intent that others should act upon them is bound, at least, to state only what he believes to be true $(b)$.

The combination of this principle with the still wider principle of responsibility for the acts and defaults of agents in the course of their employment gives rise to difficult questions, and in some cases to consequences of apparent hardship. A man who had no frandulent intention, or who has not even been personally negligent, may be liable as for fraul. The ground of liability in such cases is technically described as "constructive fraul," or, less aptly, "legal fraud" (c). The word "constructive" negatives actual fraud, but affirms that the actual conditions will have similar consequences. "Constructive possession " signifies, in the same way, that an owner out of possession has certain advantages originally given only to possessors; "constructive delivery" is a change of legal posression without change of physical custody; and wo speak of "construction

(b) The llone of Iorils deringel in Iterry v. Pephe (1846) 11 Alw. ('a. 3337,58 I. J. ('ll. sibl, that there is no general doty tomse any degree whatever of ililigence in aseertaining facts, as distinet from bare belief, in making presitive
Deecit in relation to contract.

Constructire or legal fraul. satements interuted for other peo beto aret on.

(c) At this dav we selifom iî crer hear of "legal frand," and " amstruetive fratul" is not of frepluest werclutremer. 
Former vanueness of jurlicial language.

Estopuel.

notice" where the existence of means of knowledge dispenses with the proof of actual knowledge.

It must he remembered that for a long time equity judges and text writers thought it necessary or prudent for the support of a beneficial jurisdiction to employ the term "Fraud" as nomen generalissimum (d). "Constructive fraud" was made to include almost every class of cases in which any transaction is disallowed, not only on grounds of fair dealing between the parties, but on grounds of public policy (e). This lax and ambiguous usage of the word was confusing in the books and not free from confusion in practice. Plaintiffs were too apt to make unfounded charges of frand in fact, while a defendant who could and did indignantly repel such charges might sometimes divert attention from the real measure of his duties. Cases in which there was actual fraud or culpable recklessness of truth were not sufficiently distinguished from cases in which there was only a failure to fulfil a special duty. But it seems needless at this day to pursue an obsolete verbal controversy.

Innocent representations are not necessarily harmless to the person making them. They may give rise to liability, or, as it is more exact to say, representations may give rise to liability without any need for determining whether they are innocent or otherwise (a matter sometimes far from easy to determine) $(f)$, in various ways. A statement made on quite reason-

(d) James L.J. L. Li. \& Ch. at 1. 124 .

(r) see story's Er . Jurisp. ch vii.

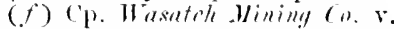

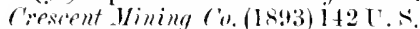
293. 248, per ('ur.:- - In equitable remedies giren for fraut, aecielent or mistake. it is the facts as fouml that give the right to relief, and it is often difficult to say, upon all. mitted facts. whether the error which is complained of was oceasioned by intentional fraud or by mere inatvertence or mistake. Indeel. upon the very same state of facts an intelligent man, acting deliberately, might well be regarded as guilty of fraud, and an ignorant and inexperienced person might be entitled to a more charitable riew. Yet the injury to the complainant woull be the same in either case." 
able grounds may nevertheless be defamatory and actionable; but this is remote from our subject. The rule of estoppel comes nearer to it. "Where one by his words or conduct wilfully causes another to believe the existence of a certain state of things and induces him to act on that belief, so as to alter his own previous position, the former is concluded from averring against the latter a different state of things as existing at the same time " $(g)$. And "whatever a man's real intention may be," he is deemed to act wilfully " if he so conducts himself that a reasonable man would take the representation to be true, and believe that it was meant that he should act upon it" $(h)$. The rule is not a rule of substantive law, in the sense that it does not declare any immediate right or claim. It is a rule of evidence, but capable of having the gravest effects on the substantive rights of parties.

Again, the existence of a certain state of facts, or the truth of a certain assertion, may be made a condition or term of a contract, apart from any question of good faith, so that if the fact be otherwise the proposed contract may never become binding, or else there may be a non-performance or breach of the contract, with the usual consequences. Such conditions or terms are in some important kinds of contracts implied by special rules of law.

It will be observed that these possible qualities of a representation are not mutually exclusive. One and the same statement may well be a deceit and a breach liability. of contract and capable of operating by estoppel $(i)$.

(y) Pickard v. Sious (18:37) di A. (t) E. 46.15 , 1. R. 538 .

(h) Fromen v. Cinke (1846) 2 lix. 15ist, 18 L. .J. Ex. 114. Finch siel. ('a. 483,76 li. R. 711 . See further the modem writers on Estoppel, Bigelow (1886), Ewart (1!001), a very learned and original work. (aspersz(calcutta, 1909). Thedates are those of the current editions.

(i) Sice per lord blackburn in Brounlie v. (iomploll (1880) is Ap. ('a. 425, 9.3. A hint of this was alrearly given by l'arke li, in Free. men r. combe, last note: see the end of the judgment.
Representation as term of contract.
Overlapping of clistinct gromucis of 
The exploded doctrine of "making representations gout."

Piefresentation of the future oremates as pomice if at all.
During a certain time some judges in the Court of Chancery seem to have thought that under certain conditions a representation which is not operative as part of a contract, or by way of estoppel, or as amounting to an actionable wrong, may still be binding on the person making it. But, when these three effects are duly considered, it appears that there is no other way in which it can be binding.

To say that a man is answerable for the truth of his statement is to say that it is his legal duty to see that it is borne out or to make compensation for its not being borne out. We need not here dwell on cases of deceit, or of estoppel independent of contract. Then, if the statement is of a fact, and made as an inducement to another person to enter into a contract, the substance of the duty can only be that the person making the statement undertakes that it is true. In that case must not his undertaking be a contract or a term in the contract? For if not, why should it bind him? It might peradventure work an estoppel also, but for all practical intents the estoppel is merged in the contract.

If, on the other hand, the statement is of something to be performed in the future, it must be a declaration of the party's intention unless it is a mere expression of opinion. But a declaration of intention made to another person in order to be acted on ly that person is a promise or nothing. And if the promise is binding, the obligation laid upon its utterer is an obligation by way of contract and nothing else: promises de futuro, if binding at all, must be binding as contracts $(j)$. There is no middle term possible. A statement of opinion or expectation creates, as such, no duty. If capable of creating any duty, it is a promise. If the promise is enforceable,

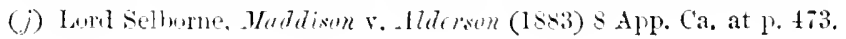


it is a contract. The description of promise or contract in a cumbrous and inexact manner will not create a new head of law. "There must be a contract in order to entitle the party to obtain any relief "' $(k)$.

\section{Part 2.-Misrepresentation and Non-Disclosure.}

So far nothing has been said of any affirmative duty No general to tell the whole truth in relation to the matter of a contract, as distinct from the negative duty of telling nothing but the truth, or at least what one honestly holds for truth. In general one is not bound in law to disclose in the treaty for a contract all known facts which may be material to the other party's judgment, nor even to remove a mistake not induced by one's own act $(l)$. Non-disclosure of a material fact which one was not specially bound to disclose is no defence to an action for specific performance $(m)$. And if one party asks a question which the other is not bound to answer, and it is not answered, he is not entitled to treat the other's silence as a representation $(n)$; that is, when there is really nothing beyond silence. A very slight departure from passive acquiescence might be enough to convert a lawful though scarcely laudable reserve into an actionable deceit. This must in every case be a question of fact.

There are several kinds of contracts, however, such that the one party must in the orlinary course of

(k) Per Cozens-Harely, I. lit

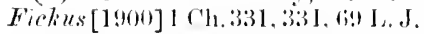
Ch. 161. Earlier authorities on the supposerl equitable dectrine of "making representations gerol "are rliseussed in the Appendix, Note l, which is now prescrved mot sumurh for any probable nose to pract it ioners as for the sake of students who positive duty of disclosme.
But such duties are implied in certain contract. may still be perplexed by some of these rases. No such dixctrine, J murterstand, has ever become enrrent in America.

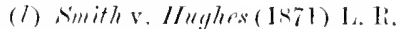
( Q. B. 597,40$)$ L. J. Q. B. 221 .

(iil) Titruer v. Gifen [1495] 2

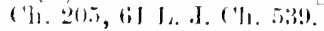

(n) Latellaw v. Organ (1S17) 2 
business take from the other, wholly or to a great extent, the description of the subject-matter of the contract. Now the parties may if they please make any part of that description a term or even a preliminary condition (o) of the contract. Whether they have done so is a question of construction $(p)$. But therein the nature of the contract, and the extent to which an erroneous description or material omission may deprive either party of the benefit to be reasonably expected, will justly count for much. More than this, fixed rules on this point have been established as to particular classes of contracts, and in some of these they go to the extent of a positive duty of disclosure; not only that all information given shall be true, but that all material information shall be fully as well as truly given. The character and stringency of the duties thus imposed varies according to the specific character and risks of the contract. It will be convenient to take a view of the classes of contracts thus treated before we examine in detail the universal rules as to Deceit. These classes are believed to be the following. It is by no means certain, however, that the same principle may not be applicable in other forms. The development of modern commerce may bring into prominence new linds of transactions in which the subject-matter of the contract, or a material part of it, is within the peculiar knowledge of one party, and the other

Wheat. 178: a sale of tobaceo: the buyer knew, and the seller did mot, that peace had been concluded between the U. S. ant England: the seller askel if there was any news affecting the market price: the buyer gare no answer. nor diul the seller insist on one. Hell that the buyer's silence was not fraululent. Cl. I. C.A.A. 17. illustration (d). (o) In such a case it las been said that there is not a conditional promise, but either an absolute fromise or no promiseat all : Lang. dell, s.s. But see Holmes. "The Common law," 304 .

(1) Behu v. Burmess (1863) Ex. ('h. 3 l. $\mathrm{d}$ ․ $751,3:$ L. J. Q. B. 204: Bannerman v. White (1861) 10 C. B. N. $\therefore .84,31$ L. J.C. P. 28, Finch sel. Ca. 473. 
has to rely, in the first instance at all events, on the correctness of the statements made by him.

(A) Insurance.

(B) Suretyship and guaranty (as to certain inci- specially dents only).

(C) Sales of land.

(D) Family settlements.

(E) The contract of partnership, and thence, by analogy, contracts to take shares in companies and contracts of promoters.

We proceed to follow out these topics in order. And first we shall say something in general of representations which amount to a condition or a warranty.

Representations amounting to Warranty or Condition.

The law on this subject is to be found chiefly in the decisions on the sale of goods; the principles howWarranty and condition. ever are of general importance, and not without analogies, as we shall presently see, in other doctrines formerly treated as peculiar to equity. We therefore mention the leading points in this place, though very briefly. In the first place a buyer has a right to expect a merchantable article answering the description in the contract $(q)$; but this is not on the ground of warranty, but because the seller does not fulfil the contract by giving him something different. "If a man offers to buy peas of another" and he sends him beans, he does not perform his contract; hut that is not a warranty; there is no warranty that he should sell him peas; the contract is to sell peas, and if lie sends him anything else in

(q) Iomess y. Iust (INtiv) L. It. : Q. I., 197, 204, 37 1. I. (2. I. 8!1:

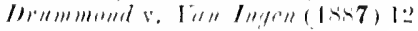

r.

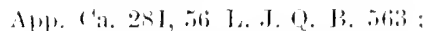

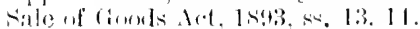


their stead it is a non-performance of it " $(r)$. So that, even if it be a special term of the contract that tho buyer shall not refuse to accept goods bought by sample on the score of the quality not being equal to sample, but shall take them with an allowance, he is not bound to accept goods of a different kind (s). It is open to the parties to add to the ordinary description of the thing contracted for any other term they please, so as to make that an essential part of the contract: a term so added is a condition. If it be not fulfilled, the buyer is not bound to accept the goods. "Condition" is purposely not defined by the Sale of Goods Act, though "warranty" is $(t)$. On a bargain and sale of specific goods with a warranty the buyer cannot reject them (u), but he may obtain compensation by way of deduction from the price, or by a cross action $(v)$.

No small confusion has been caused by the use of the word warranty where the thing meant in the first instance is really a condition. The proper mean. ing of warranty appears to be an agreement which refers to the subject-matter of a contract, but, not being an essential part of the contract either by the nature of the case or by the agreement of the

(r) Lord Alinger C.B. in Chanter v. Inpkins (1835) + I. $\mathrm{d} \mathrm{W}$. at l. 401 , il R. R. 6.5t, 655 ; "as sound an exposition of the law as can lie." ver llartin li. Límur v. C'asplle (latio) (Ex. Ch.) L. IR.

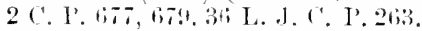
There is a elass of cases. however. in which it is eommonly. and relhap conveniently, salil that there is a morenty that the goods shall be merehantable besiles the ommdition that they shall an-wer the

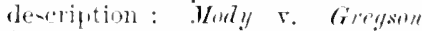
(1 - (is) L. L. + Ex. 49. 38 L. J. Ex. 12.

(v) Ascomer ve casella (186i) I. li. 2 C. P. 431 , in Ex. Ch. 67\%. :3i I. J. C. 1'. 121. 26i3. (t) Sect. 62. and see App. II. Nute (A), in Sir M. Chalmers edition of the Act.

(ii) Siale of Gools Act, s. 53 ; IIfymenth v. Ifutrhinson (186i) L. R. 2 Q. B. 477. 34 L. J. Q. B. 270 : but as to the application of the rule in the particnlar case see Benjamin. p. $4: \%$ and ep. Jarley v. Ithipl [1311]1 Q. P. 513,69 L.J. Q. B. 333.

(i) The reluction of the price can be only the actual loss of value: any further damages must be the subject of a counter-claim (under the old practice a separate action): Mondel v. Niten (1841) \& M. \& $\mathrm{I}^{+}$ S.5, s71, ]0 L. J. Ex. 426, 5s li. R. s.tu. 
parties, is "collateral to the main purpose of such contract" $(x)$. The so-called implied warranties of quality, fitness, and condition of goods sold are really conditions; if the goods tendered in performance of the contract do not satisfy those conditions, they may be rejected. But the buyer may, if he thinks fit, accept the goods and claim damages for the defect; in other words, he may treat the breach of condition as a breach of warranty. And after goods have been accepted, or the property in specific goods contracted for has passed to the buyer, "the breach of any condition to be fulfilled by the seller can only be treated as a breach of warranty, and not as a ground for rejecting the goods and treating the contract as repudiated, unless there be a term of the contract, express or implied, to that effect" (y). Conditions of this kind include a warranty from the first, and may be reduced to a warranty if the buyer does not take advantage of them in time. But a condition and a warranty are not therefore the same thing.

Similar questions have not unfrequently arisen on the construction of charter-parties. Thus in Behn v. Burness $(z)$ it was agreed that the plaintiff's ship' "now in the port of Amsterdam" should go to an English port and load a cargo of coals. The ship) did not in fact reach the port of Amsterdam till some days after the date of the contract. It was held that the description of her as in the port of Amsterdam was a condition, and that by its nonfulfiment the defendant was discharged from his obligation to loarl a cargo. It should be remembered

(r) See note $(t$ abrve.

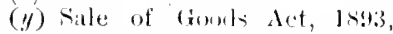
s. 11.

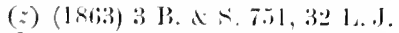
Q. B. 204. Was the charter-party

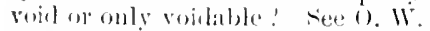
Hohnes. The Common latw, 328?.
I submit that it wan roid, lut the plaintiff woukl have been estoplued from showing that his own state. ment that his ship was in the port of lomsterdam was not trut: : " p.

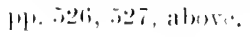


that the use of the word "warrant" or "warranty" is not conclusive, the question being what is the true intention of the contract as a whole $(a)$. We pass on to the contracts above mentioned as being under exceptional rules.

\section{A. Insurance.}

Concealment of material facts rill aroid a contract of insurance of any lind $(b)$.

Marine insurance : duty of disclosure.

As to marine insurance, not only misrepresentation but concealment $(c)$ of a material fact, "though made without any fraudulent intention, vitiates the policy" $(d)$, that is, makes it voidable at the under. writer"s election $(e)$.

For this purpose a material fact does not, on the one hand mean only such a fact as is "material to the risks considered in their own nature "; no: on the other hand does it include everything that might influence the underwiter's judgment: the rule is "that all should be disclosed which rould affect the judgment of a rational underwriter goreming himself by the principles and calculations on which underwriters do in practice act" $(f)$. The only ex-

(a) See Barmard v. Fither [1493] ] (2. B, 340. 62 L. J. 19. I. 159. C.A. "A stipulation may be a comlit ion. though called a warranty in the eintract": Sale of Gond" A $10.1,1893$, s. 11.

(b) Souton r. Meuth $[1899] 10$.

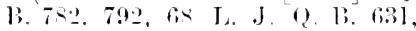
C. A. (revt. in 11. L. on fatetsonly,

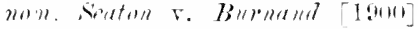

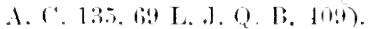

(a) Thi is the usual word, but nomedisclesmer would he more accurate.

(d) Tonides r. Pender (1sit) L. R. 9 १? B. 331.537 .43 L. J. Q. B. 227, $2 \mathrm{Wms}$. saund. i.s-9.

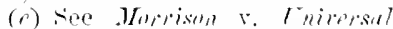

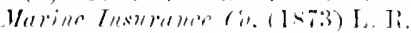

\& Ex. 197. 205, t2 L. J. Ex. 11. The settle l rules are now collitied in the Marine Insurance Act. 1:thi. $\therefore 17$ - 211.

(f) larsons on Insuranee. adoited lee cur. Lunines v. Pembor (1-it) L.. R., 9 Q. 13, at J. 589 . What falk within this description is a question of fact: stribley $r$.

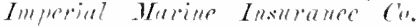
(18-6i) l Q. B. I). $207,45 \mathrm{~L}$. J. Q. B. 3:m. And the noliey will he vitiate l by concealnent of a fact material to gnide the umderwiter"s judement, though nut material t the risk in-ured against in itself :

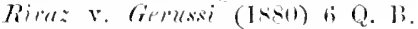

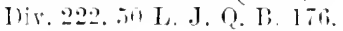


ception is that the insured is not bound to communicate anything which is such matter of general linowledge that he is entitled to assume the underwriter linows it already $(g)$ : and the obligation extends not only to facts actually within the knowledge of the assured, but to facts which in the ordinary course of business he ought to know, though by the fraud or negligence of his agent he does not know them $(h)$.

As regards life insurance, the assured is bound to disclose all material facts within his linowledge affectLife insurance. ing the life on which the insurance is made $(i)$. But where that life is not his own but some other person's, that person is not his agent, and if "the life" $O r^{\circ}$ his referees make false statements which are passed on in good faith by the assured, their falsehood will not of itself avoid the contract $(k)$.

Practically life policies are almost always framed with some sort of express reference to the statements made by the assured as to the health and circumstances of "the life." Not unfrequently it is provided that the declaration of the assured shall be the basis of the contract; and if the declaration thus

(a) Morrison v. Inirersal Marime Insurance (o. (1873) L. R. s Ex. to, 42 L. J. Ex. 115.

(h) Proudfout v. Mentefirre (186ii) L. 1..2 Q. B. 511, 3i; 1... Q. 13. 225. This applies only to the agent thromeh whom the insmance was actually effecter : Blacklourn v. Figars (18xi) 12

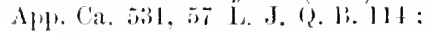
unless there is a continumur negrotiation by mome than one ateme :

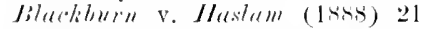
Q. L. 1). 141. 37 1. 1. Q. 1?. 179.

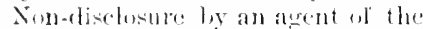
assureal. without inanchlent intentiom, has becen belel to avoid the juliey ondy to the extent of the Ioss or risk atising lrom the patrticular facts su withbeld: Stribley v. Impreral, for. ('o., suote $\left(f^{\circ}\right)$, sllin: but see per Lord Watoon, 12 Alp. ('a. at j) ito: ank $q u$. whether this exceptional rule is not abrogated by the Marine Insurance Act.

(i) Sicen authorities collected in

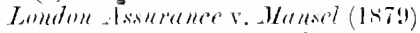
11 ('h. J). 3ii:) LS 1.. I. ('h. 333].

(b) Ilherltahe v. Hordisty (15.5)

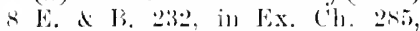

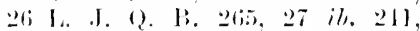
112 li. R. 233. The jutges allene to have been imelined to restret the virw taken bolore and

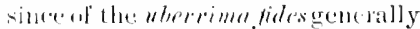
repuised in this contract, muless the diela (which in any arse tereble molbing) (an be taken as limited

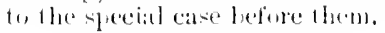


made part of the contract is not confined to the belief of the party, but is positive and unqualified, then the contract is aroided by any part of the statement being in fact untrue $(l)$, though not to the knowledge of the assured $(m)$, or by the concealment of any material fact $(n)$.

On the same ground the grant of a life innuity by the Commissioners for the Reduction of the National Debt was set aside at the suit of the Crown, the age of the life having been mis-stated; not so much on the ground of misrepresentation simply, as because, considering the statutory powers and duties of the eommissioners, "it was an essential part of the contract itself that the representation should be true" $(o)$.

The principles applicable to insurance against accidents are the same $(p)$.

Fire

insurance.

The contract of fire insurance is treated in somewhat the same way as that of marine insurance (which it resembles in being a contract of indemnity) $(q)$, though not to the same extent. The description of the insured premises annexed to a fire

(l) It need not be shown that the particular mis-statement wan material : Aluterson r. Fötogreald (1553) + H. L. C. 4s4. 9t li. li. 2(12). (p. Themson v. Ileems (1-8t) (sc.) 9 App. Ca. 6ĩ.

(iii) Macdonald r. Lath Enion Insuranee (i). (18:-1) L. Ii. ! Q. B. 32×. 13 L. I. Q. B. 131.

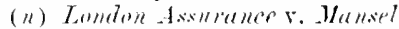
(1x79) 11 Ch. 1). 363. \&5 L. J. Ch. 331. I'sobably a material fact means for this forpose a faet such that its concealment makes the statement artually furmisher, though literally true so misleating as it stands as to be in effect motrue.

(d) A.-G. v. Ruy (1sit) L. I., ! Ch. 347, 407, 43 L. .1. Ch. 321 , 1,er
Jellish I.J. expressly comparing the care of a life policy where the repre-entations of the assured are made the basis of the contraet.

(1) Buriden v. Lomdon, Eminburyhe of citasgone Assce. (ó. [1892] 2 Q. B. 734,61 L. J. Q. B. 792 . C. A.. a curious example of the in-urers beine bound by their agent's knowledge. Cp. Bigqar r.

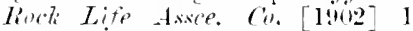
li. B. ilt. il L. J. K. IS. 79 where the applieant allowerl the compary's local agent to fill in a form for him and signel it without examination. and faleity in some of the statements so signeil was held to aroid the policy.

(4) Datrell f. Tiblitts (1880) ; Q. B. Liv. 5t0, 50 L. J. Q. B, 33. 
policy amounts to a warranty (or rather a condition) that at the date of the policy the premises correspond to the description, or at least have not been altered so as to increase the risk; and also that during the time specified in the policy the assured will not voluntarily make any alteration in them such as to increase the risk. The description must be the basis of the contract, for the terms of insurance can be calculated only on the supposition that the description in the policy shall remain substantially true while the risk is running $(r)$. Where an insurance is expressed to be "on same rate terms and identical interest" as other existing insurances on the same property, this is a condition of the contract $(s)$.

The principles applicable to insurance against miscellaneous rislis appear to be the same. Only those facts need be disclosed which are material to the risk actually undertaken $(t)$.

\section{B. Suretyship and Guaranty.}

The contract of suretyship "is one in which there is no universal obligation to make disclosure" $(u)$; but it has peculiar incidents after it is formed, which bring it within our present scope. A surety is released from his obligation by any misrepresentation, or concealment amounting to misrepresentation,

(r) Sillem v. Thorntom (185.t) 3 E. \& I3. 868,23 L. J. (2. 13. 362,97 R. R. sols; where it was held accordingly that the adklition of a third story to a house deseribed as leeing of two stories was of a material alteration, and dischargen the insurer: and see further, as to what amounts to material misclescription,

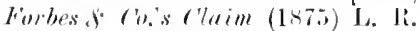
$191 \% .15 .5,11$ 1. J. (4. 301 .

(x) Anl the use of the worl "warranted" makes no difference:
Barmard v. Faber [1s93] I Q. B. 340,62 L. J. Q. B. 159, U.A.

(t) Thus an insurer of a surety's solvency is not entitled to be informed of all the cireumstances and conditions of the principal

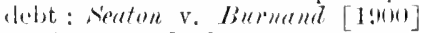
A. (1. 135, 69) L. J. Q. B. 1045.

(u) Railtum vo Mathoms (1st1) 10

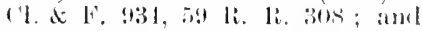
sece per liomer L.t. siruton $\mathrm{v}$. Heuth $[15999]$ I Q. 1., $752,74:$.
Miscellaneous instances.

Suret $y$ ship. Misrepresentation a voids contract. 
Surets is entitled to linow real nature of transaction.

of a material fact on the part of the creditor $(x)$. The language used in different cases is hardly consistent: the later decisions establish however that the rule is not parallel to that of marine insurance. The creditor is not bound to rolunteer information as to the general credit of the debtor or anything else which is not part of the transaction itself to which the suretyship relates: and on this point there is no difference between law and equity $(y)$. But the surety is entitled to know the real nature of the transaction he guarantees and of the liability he is undertaking: and he generally and naturally looks to the creditor for information on this point, although he usually is acting at the debtor's request and as his friend, and so relies on him for collateral information as to general credit and the like. In that case the creditor's description of the transaction amounts to, or is at least evidence of, a representation that there is nothing further that might not naturally be expected to take place between the parties to a transaction such as described. Whether a circumstance not disclosed is such that by implication it is represented not to exist depends on the nature of the transaction and is generally a question of fact $(z)$. Thus where the suretyship was for a cash credit opened with the principal debtor by a bank, and the cash credit was in fact applied to pay off an old debt to the bank, the House of Lords held that the bank was not bound to disclose this, no

(r) Fry J. Dhries v. London und

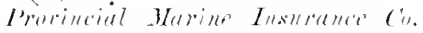
$(1+i)$ (h. L. at p. tis. ti L.J. ('h. 311 .

(y) Illedger r. Buss (1stion) Jolins titis; Wythes r. Lathumber

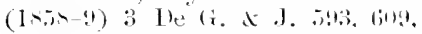

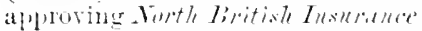

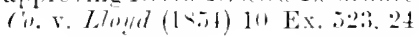

L. J. Ex, 1t, Fo: R. R. 686 .

(i) Lee r. Jones (18ti3) 14 C. B. X. S. 3-ti. in Ex. (h. 17 C. B. X.s. 4.2. 503.34 L. J. C. P. 131. 13-, which may be taken as a julicial commentary on the rule giren in Humiltun $r$. Watson (1-45) 12 cl. \& F. 109. 69 R. Ri. 28. 
actual agreement being alleged or shown that the money should be so applied, and the thing being one which the surety might naturally expect to happen (a). So the creditor is not bound to tell the surety that the proposed guaranty is to be substituted for a previous one given by another person $(b)$. But the surety is not liable if there is a secret agreement or arrangement which substantially varies the nature of the transaction or of the liability to be undertaken: as where the surety guarantees payment for goods to be sold to the principal debtor, but the real bargain, concealed from the surety, is that the debtor shall pay for the goods a nominal price, exceeding the market price, and the excess shall be applied in liquidation of an old debt $(c)$ : or where the loan to be guaranteed is obtained not in the ordinary way, but by an advance of trust funds of which the principal debtor himself is a trustee $(d)$. In Lec $\mathrm{r}$. Jones (e) there was a continuing guaranty of an agent's liabilities in account with his employers. He was in fact already indebted to them beyond the whole amount guaranteed by the surety's agreement, which was so worded as to cover existing as well as future liabilities. The surety was not informed of this, and the recitals in the agreement, though not positively false, were of a misleading and dissembling character. The majority of the Court of Exchequer Chamber held that there was evidence of "studied effort to conceal the truth" amounting to frand.

(a) Mtomilton v. Ilatsm (1sis)

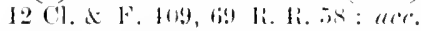
Iledge v. Busss (181;0) Juhns. biti:).

(b) Vorth Liritish Lesurenere (b. v. Lloyd (185t) 10 lix. 522.3.21 L. J. Ex. 14, log R. R. bisti. (p. Sereton v. Burmand, note (b). p. sitil, alove.

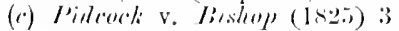
B. $2.605,27$ R. R. 4311 : I. C.A.
$\$ 1$ is, illust. $b$.

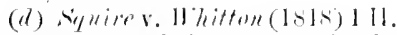
1. 1.333, deoded howerer chictly on the boater gromel that there camnet be a conteact of smetystip in blank, for no rrelitor was creel named or specitied to the surety.

(e) (186i3) 17 (\% 1\% N. S. 4 31 L.J. Ex. 131 . 
And on the whole it appears from this case and Railton v. Mathews $(f)$ that the concealment from the surety of previous defaults of the principal debtor, when there is a continuing guaranty of conduct or solvency, is in itself evidence of fraud. Where a person has become a surety on the faith of the creditor's representation that another will become co-surety, he is not bound if that other person does not join; and in equity it makes no difference that the guaranty was under seal $(g)$. Where a guaranty was given to certain judgment creditors in consideration of their postponing a sale under an execution already issued against the principal debtor, but in fact they did not stop the sale, being unable to do so without the consent of other persons interested, it was held that the guaranty was inoperative $(h)$; but perhaps this case is best accounted for as one of simple failure of consideration; for the consideration for the guaranty was not merely the credit given to the principal clebtor, but the immediate stopping of the sale.

Beyond this no positive duty to give infurmation.

The authorities, taken as a whole, establish that as between creditor and surety there is in point of law no positive duty to give information as to the relations between the creditor and the principal debtor, but the surety is discharged if there is actual mis. representation, and that silence may in a particular case be equivalent to an actual representation, whether it is so being a question of fact $(i)$. So far as

(f) $(1844) 10 \mathrm{Cl} \& \mathrm{~F} .934,59$ R. Ii. 30s.

(y) Ricerve Gurdon (Isti) 11 liear. 2tio, 83 R. Li. 1.33; Lians v. Bremridge (1-56) 2 K. N J.17t.81). M. (i. 100,25 L. J. Ch. 3.34 . The rule does not apply if the surty's remerlies are not leally diminished: ('orper v. Elans (186i) I., R. 4 Eq. 45, 36; L. J. Ch. 431, where the principal debtor had not executed the bond, but harl esecuted a separate ngree. ment under seal.

(li) Couper v. Joel (1859) I D. F. J. 240.

(i) CP. I. C. A.ss. $142-144$. S. 143: "Any guarantee which the creditor has ubtaned by means of keeping silence as to a material circumstance is invalid" is probably nut intended to go beyond the English law. 
these rules attach special duties to the creditor they. do not apply to a mere contract of indemnity $(k)$.

\section{Sales of Land.}

A misdescription materially affecting the value, title, or character of the property sold will mako the contract voidable at the purchaser's option, and

Sales of land: contraet voidable for material mis. description. this notwithstanding special conditions of sale providing that errors of description shafl be matter for compensation only. Flight r. Booth $(l)$ is a leading case on this subject. The contract was for the sale of leasehold property, and the lease imposed restrictions against carrying on several trades, of which the particulars of sale named only a few: it was held that the purchaser might rescind the contract and recover back his deposit. Tindal C.J. put the reason of the case on exactly the same grounds which, as we shall immediately see, have been relied on in like cases by courts of equity.

"Where the misdeseription, although not proceeling from fratu, is in a material and substantial point, so far affecting the subject-matter of the contract that it may reasonably be supposed that but for such misdescription the purchaser might never hive entered into the contract at all, in such ease the eontract is aroided altogether, and the purehaser is not bound to resort to the elanse of compensation. Under such a state of facts the purehaser may he considered as not having prehased the thing which was really the subjeet of the sale."

The rule so stated has been unanimously approved in the Court of Appeal $(m)$.

So in Phillips v. Caldcleugh $(n)$, where the con-

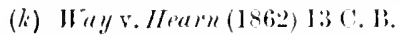
N. S. 292,32 L. J. C. R. R. ; but the point of that case is rather that there was mo mismeresenta-

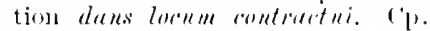
Seaton v. linruand $[19000]$ A. C'. 135,69 . L. J. (2. R. 409.

(l) (I831) I bing. ‥ C. 370,377,
41 R. R. 599, 601.

(iti) lie fractiont and Itolmes (Issig) $42 \mathrm{Ch}$. lyiv. 150, is l. J. Ch. T6i3. For a later example see

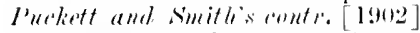
2 Ch. 25s, 71 L. . . Ch. titit, C. A. (11) (186x) 1.. L. I Q. B. 159, 161,38 L. J. Q. 1:. 68. 
tract was for the sale of "a freehold residence"which means free of all incumbrances (o)-and it appeared that the property was subject to restrictive corenants of some kind, the purchaser was held 'ntitled to rescind, though the corenants were in a deed prior to that fixed by the contract as the commencement of the title.

Specifie performance and compensation.
Where variance not ubstiutial contraet enforceable, but with compensation at suit of either party.

Questions of this kind arise chiefly in suits for specific performance between rendors and purchasers of real estate, when it is found that the actual tenure, quantity, or description of the property varies from that which was stated in the contract. The effect of the conditions of sale in the particular instance has almost always to be considered, and the result of the variance may be very different according to these, and according to the amount and importance of the discrepance between the description and the fact. A complete or nearly complete system of rules has been established by the decisions.

(i.) "If the failure is not substantial, equity will interfere" and enforce the contract at the instance of either party with proper compensation (o). The purchaser, "if he gets substantially that for which he bargains, must take a compensation for a deficiency in the value" $(p)$. Here the contract is valid and binding on both parties, and the case is analogous to a sale of specific goods with a collateral warranty.

Where

(ii.) There is a second class of case's in which the variance substantial and capable of pecuniary estimation. Iratty misled contract is roidable at the option of the purchaser, so that he cannot be forced to compete eren with compensation at the suit of the rendor, but may. elect either to be released from his bargain or to

(1) Hulsty r. Viront (logi) $1: 3$ Ves. $73,77,9$ L. I. $143,145$.

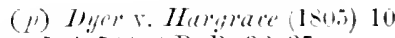
Ves, $506,50 s, s$ R. H. 36, 37. 
perform it with compensation. "Generally speaking, every purchaser has a right to take what he can get, with compensation for what he cannot get" $(q)$, even where he is not bound to accept what the other has to give him $(r)$.

However a purchaser's conduct may amount to an affirmation of the contract and so deprive him of the right to rescind, but without affecting the right to compensation $(s)$; again, special conditions may exclude the right to insist on compensation and leave only the right to rescind $(t)$.

Under this head fall cases of misdescription affecting the value of the property, such as a statement of the existence of tenancies, not showing that they are under leases for lives at a low rent $(u)$; or an unqualified statement of a recent occupation at a certain rent, the letting value of the property having been meanwhile ascertained to be less, and that occupation having been peculiar in its circum-

(q) Mmgles v. Jomes (186i1) 3 I), Н. .J. $307,315,3 \mathrm{I} \mathrm{I}$. .I. Ch. 83; Leyland v. Tllinguorth (1860) : D. 1. J. $248,252$.

(r) "If a person possessed of a term for loc years eontracts to sell the foe he eannot compel the purchaser to take. but the purchaser can compel him to comvey the term." l'er Ioril Ellon. ITirid v. Griflith (1sis) I Nwanst. at p. 51 , Is R. IR. 27 (thomgh in this ease nut with mompensation. sce next patge): anul see Jurthr v. Buller (1804) 111 V(es. 24:2, :215. 7 IR. IR. 117. Neltherpere V. Ilolgente (1S14; 1 coll. ('. C. 20:3 titi R. li. $4 i$.

(x) Ilughe'x r. Jomes. butr (g) above.

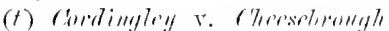

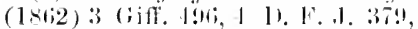
21 I. .1. ('h. filz. where tha jull-

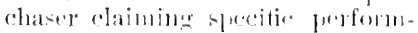

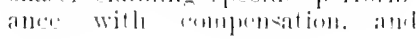

having rejeeter the rendor's offer to ammul the contract ams repay the purchaser his costs. was male to perform the contract unconditionally. See further as to the effect of comlitions of this kimul

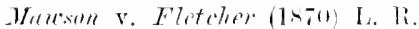
6 Ch. 91, for L. I. (h. 131 : I,

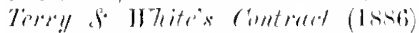

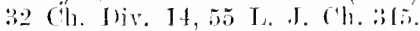
The authoritien were leviewer loy

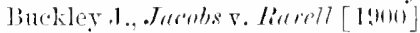
2 (h. sis, 69 1. . . (h. s79. The

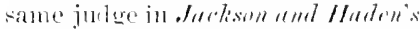

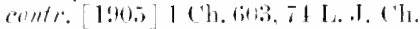
34.9, where there was a fotal fainume of title as to minerals, oleleres

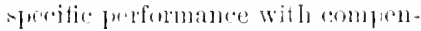
sation notwithstanding the unal combitim emponering the vemblor (1) leseiml if mable to remove a lefeet of title.

(u) Ilughes v. Jomes $(1863) 3]$.

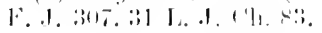

may reseind eontraet or enforce it with enmpensation. 
stances $(x)$; or the description of the rendor's interest in terms importing that it is free from incumbrances --such as "immediate absolute reversion in fee simple"-where it is in fact subject to undisclosed incumbrances $(y)$.

The treatment of this class of cases in equity is analogous to the rules applied at common law to the sale of goods not specifically ascertained by sample or with a warranty: see p. 561, above.

Exceptions. The doctrine that a rendor who has less than he undertook to sell is bound to give so much as he can give with an abatement of the price applies, it is to be understood, only where the vendor has contracted to give the purchaser something which he professed to be, and the purchaser thought him to be, capable of giving. Where a husband and wife had agreed to sell the wife's estate (her interest being correctly described and known to the purchaser), and the wife would not conves, the Court refused to compel the husband to convey his own interest alone for an abated price $(z)$.

Specific performance with compensation is granted only where the compensation is capable of assessment: for example, not where the defect consists of undisclosed restrictive corenants $(a)$. Also the Court will not order rendors who sell as trustees to perform their contract with compensation, on account

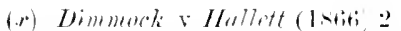
( h. 21. 3: I. .J. ( h. $11 \%$.

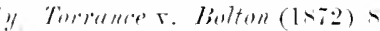
Ch. 118. 42 I. .J. Ch. 17\%. Of the p. culiat chatacter of the non-rlisclosure in that case presently. (" $)$

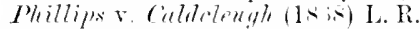
4 Q. B. 1.54, 1. .111.39 L. J. Q. B. 6 , above. $A=$ to the proper mule of assessing compensation in a cave of mintatemust of protita ses

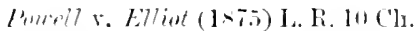
1.4 .

(:) fisther. Wilkinst)n (1.7(1) 5 ('h. 234.34 I. J. Ch. 843: in

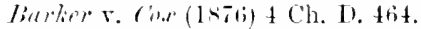
tii L. I. ( $\mathrm{n}$. 12 , the full purchasemoney hat been paid and the facts were otherwise peculiar.

(a) Dudd r. Lasipllex [1900? 1

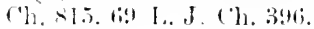


of the prejudice to the cestui que trust which might ensue $(b)$.

It is now settled (after many conflicting decisions and dicta) that a purchaser otherwise entitled to compensation can recover it after he has taken a conveyance and paid the purchase-money in full $(c)$.

(iii.) But lastly the variance may be so material (either in quantity, or as amounting to a variance in kind) as to avoid the sale altogether and to prevent not merely the general jurisdiction of the Court as to compensation, but even special provisions for that purpose, from having any application. "If a man sells freehold land, and it turns out to be copyhold, that is not a case for compensation $(d)$; so if it turns out to be long leasehold, that is not a case for compensation; so if one sells property to another who is particularly anxious to have the right of sporting over it, and it turns out that he cannot have the right of sporting because it belongs to somebody else . . . in all those cases the Court simply says it will avoid the contract, and will not allow either party to enforce it unless the person who is prejudiced by the error be willing to perform the

(b) White v. C'mddm (1s12) \& Cl. \& F. 766,54 R. R. 176 .

(c) Prilmer v. Johnson (1884) 13 Q. B. Ilir. 351, 53 L. J. Q. B. 348 . See the former wases there discussed.

(d) Specitic performance refused where the land was enfranchised copybolil and the minerals were reservel to the lort: Bifllamy v.

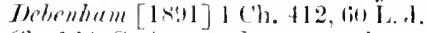
Ch. lifi, C.A. And converely, a man who buys an estate as copyhold is not bimml to accept it if it is in fact freedold. For "the motives amb fancies of mankind are infinite: and it is monecessing for a man who has contracted to purehase one thing to explain why he refuses to acecpt another": Ayles. v. $(1, r(18.2)$ lo Peav. 23. 9i li. li. 13. But on a sale of mixect frecholit and copyholil a rariance in the respeetive amomits loes not aroid the rontract : IIndstm v. ('mok (1872) L. R. 13 Eq. at 1. 420 . As to leaseholds, it is a settled though perliaps mot a reasumable rule that a contract tosell preprest betel umber a lease is mimil facie a contract to show tille to an original lease : $\left({ }^{\prime}(\mathrm{m}) \mathrm{h} \mathrm{e}^{2}\right.$ urell and so Lamdon Building

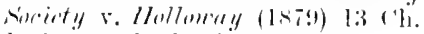
1). 35 i. 19 1.. . . (h. 3til.
Purchaser can recover compensation after completion.

Where variance not capable of estimation, option to rescind simply. 
contract without compensation" $(e)$. A failure of title as to a part of the property sold which, though small in quantity, is important for the enjoyment of the whole, may have the same effect $(f)$. This class of cases agrees with the last in the contract being roidable at the option of the party misled, but it differs from it in this, that if he elects to adopt the contract at all he must adopt it unconditionally, since compulsory performance with compensation would here work the same injustice to the one party that compulsory performance without compensation would work to the other. Such was the result in the case now cited of the real quantity of the property falling short by nearly one-half of what it had been supposed to be $(g)$. But in a later case where the vendors were found to be entitled only to an undivided moiety of the property which they had professed to sell as an entirety, the Court found no difficulty in ordering specific performance with an abatement of half the price at the suit of the purchaser, as no injustice would be done to the vendors, who would be fully

(c) Errl at Jumlum v. Leymrd (Isi.) 31 Teav. 6Il, 34 I. .J. Ch. $\therefore \rightarrow$ ?.

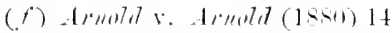
('h. Dir. 270. Where partientars of sale were mi-kating as to bonndaries anl frontage. the purchase? was liell cutilled to resciml uncon-

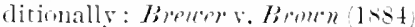
2ง ('h. D. 309, it I. J. C1. 60.).

(f) The price asked har been fixed by reforence to the rental alone. (f). hus the case womlel lave stoul rould a price proportional to the ares have been arrived at. Anu ree swatislund F. Diarstey (1)6il) $2 \vec{t}$ Beas. t3o (where it is left cloubtfur whether the purchaser coulil o: coul I not have enforced the contrat with compensation). CP. I. 1s. 1. de cont. cmpt. 22-24. enunciating precively the same urinciple as that applied by our comrts of equity. Hanc legem renditionis: si quid saeri rel reliflusi est. cils renit nihil. supervacham mon esse, sed ad modica loca pertinere: ceterum si omne reli. giosum. vel sacrum, rel publicum renierit. nullam essc emptionem: and see rom. tit. 18 . $40 \mathrm{~m}$. In Whittemore 8 . Ithittemore (1869) L. I. s $\mathrm{E}_{\text {r }}$. 603, a case of material deficiency in quantity, it was held that a condition of sale providing generally that errots of lescription shoull be only matter of compensation di.l apjly. but another excluiling compensation for errors in fuantity did not: so that on the whole line purchaser could not rescind. but was entitled to compensation. 
paid for all they really had to sell $(h)$. The real question is whether the deficiency is such as to be fairly capable of a money valuation $(i)$. It seems that where it is in the vendor's power to make good the description of the property, but not by way of money compensation, he can enforce the contract on condition of doing so, but not otherwise. A lot of building land (part of a larger estate intended to be sold together) was sold under restrictive conditions as to building, and in particular that no publichouse was to be built; the purchaser assumed from the plan and particulars of sale, and in the opinion of the Court with good reason, that the whole of the adjoining property would be subject to like restrictions. One small arjacent plot had in fact been reserved by the vendor out of the estate to be sold, so that it would be free from restrictive corenants; but this did not sufficiently appear from the plan. The vendor sued for specific performance. It was held that he was entitled to a decree only on the terms of entering into a restrictive covenant including the reserved plot $\left(l_{i}\right)$.

This third class of cases may be compared (though not exactly) to a sale of goods subject to a condition or "warranty in the nature of a condition," so

(h) Bailey v. Fiper (1,874) T. li. $18 \mathrm{Eq} .683$, 43 L. I. Ch. 704 ; ITorrocks v. Rriglyy (1878) 9 Ch. D. 180. 47 I... I. ('h. stor, where the moiety was st incumbered that the rendige in the result got nothing but an

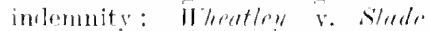
(1831) 1 sim. 126. 3:3 R. R. 101\%. is prartically overmaled by these "ases. Similarly" as to learehuld :

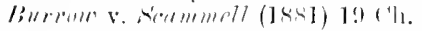

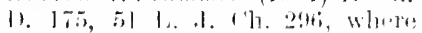

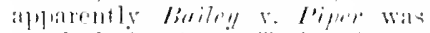

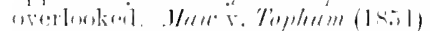
1!) Beav. soti, is distinguishable.
Where it is in venulor's power to make good his representations. as there the purchaser knew or ought to have known that a good title could not be marle to the while.

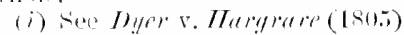

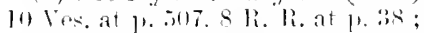
and on the distinction oll the

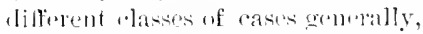

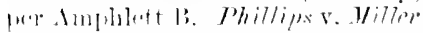
(IS7.5) 1.. If. 11) ('. I'. 1:27-4. 11 1...1. ('. . . . 26.5.

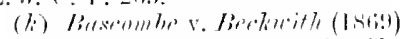

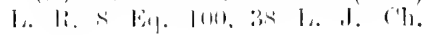
i3is. 
that the sale is "to be null if the affirmation is incorrect" $(l)$.

Deposit. Ac. recoverable in equity as well as at law.
General duly of rendor to grive correct description.

A purchaser who in a case falling under either of the last two heads exercises his option to rescind the contract may sue in the Chancery Division to have it set aside, and recover back in the same action any deposit and expenses already paid under the contract $(m)$. And it seems that there is an independent right to sue in equity for the return of the deposit and expenses, at all events if there are any accompanying circumstances to afford ground for equitable jurisdiction, such as securities haring been given of which the specific restitution is claimed $(n)$.

To return to the more general question, it is the duty of the vendor to give a fair and unambiguous description of his property and title. He is therefore bound to disclose any material defect in the title or the property which is within his exclusive nnowledge and not likely to be discovered by the purchaser with ordinary care (o). And, notwithstanding the current maxim about simplex commendatio, language of general commendation-such as a statement that the person in possession is a most desirable tenant-ais deemed to include the assertion that the rendor does not know of any fact inconsistent with it. A contract obtained by describing a tenant as "most deirahle" who had paid the last quarter"s rent in instalments and under pressure has been set aside at the suit of the purchaser $(p)$. If the rendor

(7) Bummermun $x$. IIthite (1865)

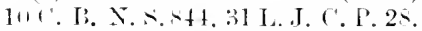

(m) E.t. Nountion r. Tottersall (14.33) 1 rm. d ( v. Bultun (18-2) L. R. \& ('h. 11R. 4.2 L. J. Ch. 17\%.

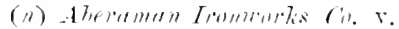

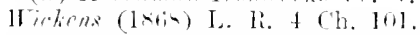
where the contract having ween rescinded by con-ent before the suit was hekt not to deprive the Court of jurisiletion.

(i) Such as the existence of an awand unler a Buikling tet which imposes a future liability on the

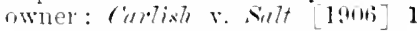

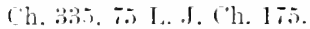

(1) Simith $v$. Lamd and $I I(1) / \mathrm{w}^{3}$

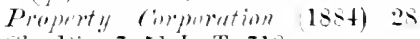
(h. Jir. T. il 1. T. 71 s. 
does not intend to offer for sale an unqualified estate, the qualifications should appear on the face of the particulars $(q)$. In Torrance v. Bolton $(r)$ an estate was offered for sale as an immediate reversion in fee simple. At the auction conditions of sale were read aloud from a manuscript, but no copy given to the persons who attended the sale. One of these conditions showed that the property was subject to three mortgages. The plaintiff in the suit had bid and become the purchaser at the sale, but without having, as he alleged, distinctly heard the conditions Concealment in particulars not exeuserl by correet statement in conditions only read out at the sale: Torrance $r$. Bolton, or understood their effect. The Court held that the particulars were misleading; that the mere reading out of the conditions of sale was not enough to remove their effect and to make it clear to the mind of the purchaser what he was really buying; and that he was entitled to have the contract rescinded and his deposit returned. Mere silence as to facts capable of influencing a buyer's judgment, but not such as the seller professes or undertakes to rommunicate, is not of itself any breach of duty $(s)$.

A misleading description may be treated as a mis. representation even if it is in terms accurate: for example, where property was described as "in the occupation of A." at a certain rental, and in truth A. held not under the rendor, but under another person's adverse possession $(t)$, or where immediate possession is material to the purchaser, and the tenant holds under an unexpired lease for years which is not disclosed ( 11 ). A misleading statement or omi-

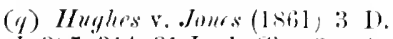
F. J. 307, 314, 31 I. J. Ch. .3. As to the duty of disedosing restrictive covenants: Ekswath and Tirly's

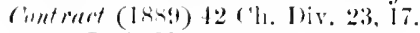
5l, ser I. I. Ch. biti.

(r) (1872) 1. R. H ('ll. 11<. 1:2

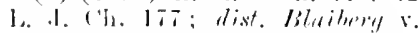

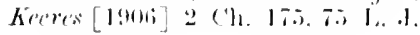

('h. lit, where a genuine fuestion of title was fairly disclosed.

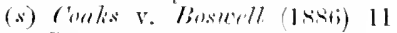

Apr. (a. $232-235$.

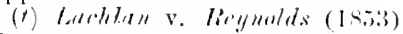

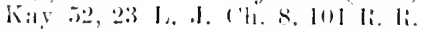
i2:3

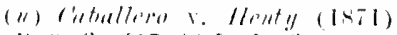

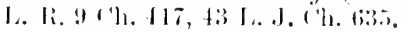


Ihuty of jurchaser in special cases.

sion made by mere heedlessness or accident may deprive a vendor of his right to specific performance, wen if such that a more careful buyer might not have been misled $(v)$.

All this proceeds on the supposition that the rendor's property and title are best known to himself, as almost always is the case. But the position of the parties may be reversed: a person who has hecome the owner of a property he knows very little about may sell it to a person well acquainted with it, and in that case a material misrepresentation by tho purchaser makes the contract, and even an "xtcuted convesance pursuant to it, roidable at the rendor's option $(x)$. So it is where the purchaser has done acts unknown to the rendor which alter their position and rights with reference to the property: as where there is a coal mine under the land and the purchaser has trespassed upon it and raised coal without the rendor's knowledge; for here the proposed purchase involves a buying up of rights against the purchaser of which the owner is not aware $(y)$.

On a sale under the direction of the Court a person offering to buy is not under any extraordinary duty of disclosure. It is not the law "that, because information on some material point or points is offered, nr is giren on request, by a purchaser from the conrt, it must therefore be giren on all others as to which it is neither offered nor requested, and con"erning which there is no implied representation, positive or negative, direct or indirect, in what is actually stated " (z).

(r) Jones r. Rimmer (18, 14

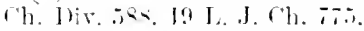

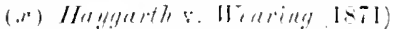
t. IR. I: Ei. : :2011: l11 L. J. ('h. 75. (p. the Indian Tran fer of
Property Act. Iss-2. s. 5i.

(i) Pllitlips r. Homion? (1N-1)

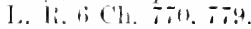

(i) Giaks r. Besuell (1-ib) 11 Npe. Ca. 232. 1411.55 L. J. Ch. 
Vendors of land may, and constantly do in practice, sell under conditions requiring the purchaser to Effect of special conassume particular states of fact and title. But such tions as conditions must not be misleading as to any matter within the vendor's knowledge $(a)$. "The vendor is not at liberty to require the purchaser to assume as the root of his title that which documents within his possession show not to be the fact, even though those documents may show a perfectly good title on another ground:" and if this is done even by a perfectly innocent oversight on the part of the rendor or his adviser's, specific performance will not be enforced $(b)$. A special condition limiting the time for which title is to be shown must be fair and explicit, and "give a perfectly fair description of the nature of that which is to form the root of title" $(c)$.

The House of Lords decided in Wilde v. Gibson (d) that the vendor's silence as to a right of way orer the property, of the existence of which he was not known to be aware, was no ground for setting aside the contract. This reversed the decision of Kuight Bruce V.-C. (e), who held that the silence of the particulars taken together with the condition of the property (for the way had been enclosed) amounted to an assertion that no right of way existed. In any view it seems

761, revg. s. c. 27 Ch. I)iv. 424, mainly on the facts.

(a) Itrywod v. Wallatien (16583) 25 ch. D. 357,53 I. .J. ( h. 192 (definite adverse elaims linown to at vendor must be diseloserl even if he thisks them unfommel).

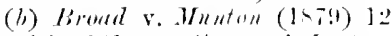
('h. Jiv. 1:31, peretom l..J. at 1 . 145, ts 1... (1h. 837: whether this woull be sutlieient gromid for reseimling the esmotrat, quere', pere Jessel II.li. 12 ('h. J)ir. at 1. 112 :

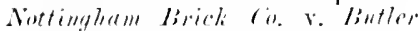

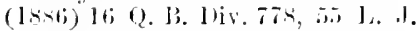
Q. 1;. 2-(1), where the renders solicitur amonembly alenied the existence of restrictive covenants contained in deeds prior to those whicl he had rean. Cf. L. (?. Li. ii. 414,41 .

(a) blark and Earl v. Giramilla (1 ('h. sl. whege the purehasel was

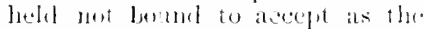

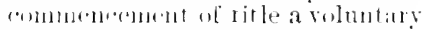
dreal rot sattel in the emtract to b. silati.

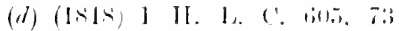

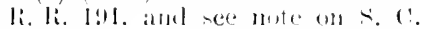

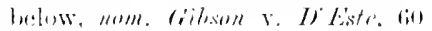
li. li. 20ii3.

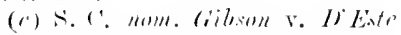

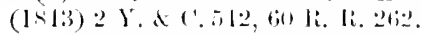

Non-rlisrlosine of lefect of title not actually known t, vendor : Wirle $r$. Gibsur. 
an extrandinary, not to say dangerons, doctrine to say that a vendor is not bound to know his own title, so far at least as with ordinary diligence he may know it: and the case was severely criticized by Lord St. Leonards $(f)$. The Irish case relied on by the Lords as a direct anthority may be distinguished on the ground that the representation there made by the lescor that there was no right of way was made not merely with an honest belief, but with a reasonable belief in its truth $(g)$.

The decision in Irilde v. Gibson was much influenced by the purchaser"s case having been rested in the pleadings to a certain extent upon charges of actual frand, which howerer were abandoned in argument: the doctrine of constructive notice, it was said, could not be applied in support of an imputation of direct personal fraud. Even so the result in modern practice would only be that the plaintiff would have to pay the costs occasioned by the unfounded charges: he would not lose any relief for which he otherwise showed sufficient grounds $(h)$. And on examining the plearlings it is difficult to find any imputation sufficient to justify the grave rebukes expressed in the judgments (i). It was also said by Lord Campbell that a court of equity will not set aside an executed conveyance on the ground of misrepresentation or concealment, but only for actual frand $(k)$ : this dictum has not been uniformly followed, but the latest anthority $(l)$ does follow it.

(f) Suget. law of l'roperts bilt, 637. Se.

(a) lumeed the Court seems to hare thought it ures the notwithstandine the alverse re-ult of an indictment for stophing the alleged publie way : Leggt' v. ("ruler (1s11)

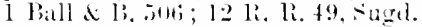
(p) cit. iist.

(h) Milliard r. Eifte (1sit) L. R.
7 H. I.. 34: see next chapter.

(i) The bill in Gibson v. I) Exte, which is to be found in the printed rases of 18tr. has the words "casefully concealed " in one pas. sage: " framlulently concealed " in another may mean. of course, framlulently in a technical sense.

(k) 1 H. I. C. . 332.

(l) Sidton v. Virth Eustern Sult 
There may also be a want of diligence on the purchaser's part which, although not such as to deprive him of the right of rescinding the contract betore completion, would preclude him from having the sale set aside after conveyance $(m)$.

As a general result of the authorities there seems General rule. to be no doubt that on sales of real property it is the duty of the party acquainted with the property to give substantially correct information at all events to the extent of his own actual knowledge $(n)$, of all facts material to the description or title of the estate offered for sale, but not of extraneous facts affecting its value: the seller, for example, is not bound to tell the buyer what price he himself gave for the property $(0)$.

The general rule seems not applicable as between lessor and lessee, where the letting is for an occupation by the lessee himself, and so far as concerns any physical fact which can be discovered by inspection; for in ordinary circumstances the landlord is entitled to assume that the tenant will go and look at the premises for himself, and therefore is not bound to tell him if they are in bad repair or even ruinous $(p)$.

(o. [1905] I Ch. 326, it 1..J. C'h. 199, and see per Cotton L.J. in Soper v. Aruold (1887) 37 (Yh. Div. $96,102,57$ L. .I. Ch. 145 ; IIa!garth v. Wearing (1871) L. R. 12 Eq. 320 , 40 L. J. Cll. 577 ; Murt v. Swaime (1877) 7 Ch. D. 42, 47 1. J. C'l. 5 , are contru.

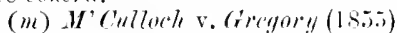
1 K. E J.286, 21 L. J. ( 1 . 216. 10\% li. li. si, where a will was misstater in the abstract so as to conceal a defeet of title, lut the purcluasel omitcel to examine the origrinals.

(n) Siec Joliffo v. Luther (18x:3) 11

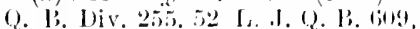
but that case is of litule authority, if any, on the guestion of contract ; see jer A. L. Smith J. in Palmer v. Johnson (Isis) 12 0. B. D. at p. 37 , explaining his own part in - Joliffr v. Batare. Neither veudors. nor their solicitors are bound to answer a gencral inquiry as to nona]prarent ineumbrances" lis for and Mill (1579) 10 ('h. Div. Biv.

(o) 3 App. (a. 1267.

(1) Krates v. birrl ribleyan

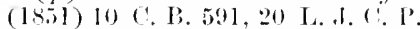
$76,81 \mathrm{l}, \mathrm{R}$. 715. The general lule does apply as to matters of title: Hostyll v. Itost Mestyn ('mel, de. ('i) (1876) I ('. L'. I). 115, 45) 1.. J. C. 1'. 101.
Exeeption as to occupation leases. 
Fimily settlinents: duly of full disiblinture.

Contracts 10 talie shates.

\section{1). Family Settlements.}

In the negotiations for fanily settlements and compromises it is the duty of the parties and their profesional agents not only to abstain from misrepresentations, but to communicate to the other parties all material facts within their knowledge affecting the rights to be dealt with. The omission to make such communication, even without any wrong motive, is a ground for setting aside the transaction. "Full and complete communication of all material circumstances is what the Court must insist on " $(q)$. "Without full disclosure honest intention is not sufficient," and it makes no difference if the non-diselosure is due to an honest but mistaken opinion as to the materiality or accuracy of the information withhele $(r)$. The operation of this rule is not affected hy the leaning of equity, as it is called, towards supporting re-settlements and similar arrangements for the sake of peace and quietness in families $(s)$.

\section{Iartues?ip. E. Partnership, Contracts to take Shares in Com- panies, and Contracts of Promoters.}

The contract of partnership is always described as one in which the utmost good faith is required. So far as this principle applies to the relations of partners after the partncrehip is formed, it belongs to the law of partnership as a special and distinct sulject; and in fact the principle is worked out in definite rules to such an extent that it is seldom appealed to in its general form. But it also applies

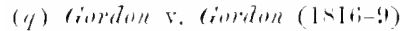
3 -w. f(1). 4-3. 1!1 R. li, $2+1,24 \div$.

(i) $17.47,1 ! 1$ R. li. 244 . 1Iuw

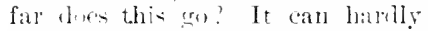
be a duty to anmmicate mere gusif on the chance of their leing something in it. l'roblaly the tent is (as in the case of mintine imurance. p. itit, above) whether the jurlyment of a reasonahle man wovild be affected. ('). Heryend

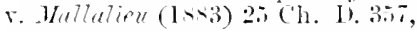
(i) I. .I. (h. the.

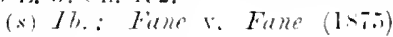
L. R. $20 \mathrm{E}$. 6 6.8. 
to the transactions preceding the formation of a partnership, or rather its full and apparent constitution. For example, an intending partner must not make a private profit out of a dealing undertaken by him on behalf of the future firm $(t)$. There is little or no direct authority to show that a person inviting another to enter into partnership with him is bound not only to abstain from mis-statement, but to disclose everything within his knowledge that is material to the prospects of the undertaking. But the existence of such a duty (the precise extent of which must be determined in each case by the relative position and means of knowledge of the parties) is postulated by the stringent rules which have been laid down as binding on the promoters of companies. These are expressed with the more strictness, inasmuch as the public to whom promoters address themselves are for the most part not rersed in the particular kind of business proposed, but are simply persons in search of an investment for their money, and with slight means at hand, if any, of rerifying the statements made to them.

"The public," it is said, "who are invited by a prospectus to join in any new adventure, ought to have the same opportunity of judging of everything which has a material bearing on its true character as the promoters themselves possess" $(u)$ : and those who issue a prospectus inviting people to take shares on the faith of the representations therein contained are bound "not only to abstain from stating as fact that which is not so, lut to omit no one fact within

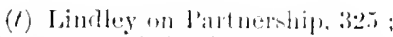

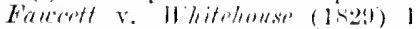

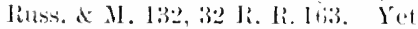
the duty is incident, met prederlent, to the enondact of partnership : for if there were not a complete enn- tract of partnershif there would he no) duty at all.

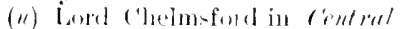

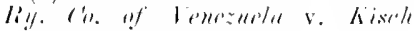

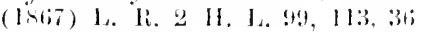
I. I. (11, \&1!?
Prospectus must be both positively and negatively correct. 
their knowledge the existence of which might in any degree affect the nature or extent or quality of the privileges and adrantages which the prospectus holds out as an inducement to take shares" $(x)$. Therefore if untrue or misleading representations are made as to the character and value of the property to be acquired by a company for the purposes of its operations $(y)$, the privileges and position secured to it, the amount of capital $(z)$, or the amount of shares already subscribed for $(a)$, a person who has agreed to talie shares on the faith of such representations, and afterwards discovers the truth, is entitled to rescind the contract and repuliate the shares, if he does so within at reasonable time and before a winding-up has given the company's creditors an indefeasible right to look to him as a contributory. For full information on this subject the reader is referred to Lord Lindley's treatise $(b)$.

Duty of promoter to company.

There is likewise a fiduciary relation between a promoter and the company in its corporate capacity, which imposes on the promoter the duty of full and fair disclosure in any transaction with the company, or even with persons provisionally representing the inchoate company before it is actually formed $(c)$.

(r) Kindersley V.C. . Vou Brunswirk. de. (o. v. Mugyeridy (1sGio) l Dr. d sm. 3ti3, 3ri. 311 L. I. Ch. 242, adopted by Lord Chelmsforl. l. $c$.

(y) Roses Rirer viller Mining (iv. v. smith (1869) L. R. + II. L. tit. 39 L. J. Ch. 849 affg. s. c. mom. simitlis Cilse (1S67) L. R. 2 Ch. 604.

() rentral Riy. I'i. of Tomenele 5. Kivel, suprele.

(i) Wright s r ros (1871) I. IR. i (h. 5., 41 L. J. Ch. I : Howe is Ite la Torres case (Ist) L. R. IN Er $.661,43$ L.. J. Ch. 7.s.

(b) Lindley on Companies. 72. 589, s.\%. Here eommunication to the company is not a sufficient re. puliation. The shareholder must do something to alter his status as a member: per Lindley L.J. lie scottinh Petroleum Co.(1\$83) 23 (b. Dir. 435. The critical date is that of the petition, not the ovder, in the winding-up: Intheley's case [1s!!) l ('h. 780,65 L. J. Ch. 365. (a) Vor simbere Plosphate Co. v. Erlanger (18\%) 5 Ch. Div. 73. y.r. James L.J. at p. 118,46 L. J. ch. 4.5: affol. in H. L. nom.

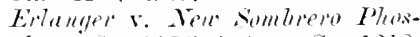
phate (a. (188) 3 App. Ca. 1218, 40 1..J.ch. 83 : Bugnall v. Curltone (1:7i) of ch. Dis. 3il, ti L. J. Ch. 31: and sce the whole subject (the 
Promoters who form a company for the purpose of buying their property are not entitled to deal with that company as a stranger $(d)$. They must either provide it with "a board of directors who can and do exercise an independent and intelligent judgment on the transaction" $(e)$ or give full notice that the directors are not independent; there may be cases in which all the original members of the company necessarily have such notice $(f)$. "The old familiar principles of the law of agency and of trusteeship have been extended and very properly extended to meet such cases" (g). A shareholder may be entitled to rescind his contract with the company on the ground of a material misrepresentation in a preliminary prospectus issued by promoters before the company was formed $(h)$.

The Companies (Consolidation) Act, 1908, repealing and superseding the Companies Act, 1900, enacts that every company prospectus "must state" a Companies Act, 1908, s. 81 , number of specified particulars. It would, therefore, seem that any mis-statement or omission, with knowledge of the facts $(i)$, of any of these particulars will be treated as fraudulent, and that all and every of them are conclusively declared to be material. Any liability under the general law is expressly saved $(k)$, so that the established case-law remains fully applicable. It would be useless to enter upon further details here; nor are we concerned with the question

details of which belong to comprany law) discussed in Laymuas Nit rute

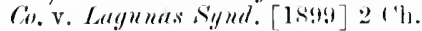
392, 68 L. J. Ch. 699. (. A. ; Leeds and Hanley Theutres of Tarieties. [1902] 2 (1). 809, 72 i...1. ('h. 1. C. $A$.

(d) Erlanger v. Seme sombrem Phospleate ('i. (1878) 3 App. ('a. at 1. $126 \times$.

(e) Ib. at $14 \cdot 1229,1236,1255$. (f) Lagmuas Nitrate ('o. v. Lagunas synd. [1899] 2 c'b. 392, 68 L. .J. Ch. 6999, C. A.

(y) siyduey, so. Co. v. Bird (18s6) 33 (h. Div. s.5, 94.

(h) lie Metropulitan Coul r'an-

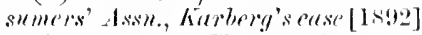
3 Ch. 1, (il T., J. Ch. 741, C.. A.

(i) Sice the exeeption in s. 81, sulb-s. 6 .

(k) Sub-s. 9. 
whether a right of action in tort is given by implication to persons who may suffer damage from the directions of the Act not being regarded.

The Companies (Consolidation) Act, 1908, s. 84 (l), imposes a special responsibility on directors and promoters for the accuracy, to the extent of their means of lnowledge, of statements made in prospectuses. This however is rather ex delicto than ex contractu.

contract tis mally.
Thus much of the classes of contracts to which special duties of this kind are incident. The absence of any such duty in other cases is strongly exemplified by the contract to marry. Here there is no obligation of disclosure, except so far as the woman's chastity is an implied condition. The non-disclosure of a previous and subsisting engagement to another person $(m)$, or of the party's owl previous insanity $(n)$, is no answer to an action on the promise. If promises to marly are to give a right of action, one would think the contract should be treated as one requiring the utnost good faitl: but such are the decisions.

Marriage itself is not arvided even by actual frand (o), hut the rearons for this are obriously of a different lind: nor is a marriage settlement rendered roidable by the wife non-disclosure of previous misconduct $(p)$.

(1) lieplacing the binectors Liability Aet. 1s.90 pased to mitigate the intidieg us ance puences of

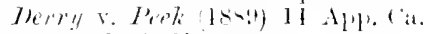

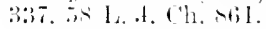

(iil) Braslery r. Bimen (1stio) E. I. \& E. 796, 29 L. J. Q. 1. 10.5. $11: 3$ li. li. .

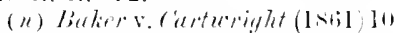

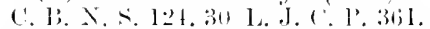

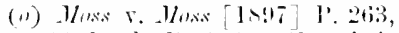

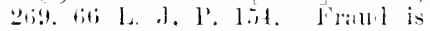
material conly when it is such as "procures the appearance withut the reality of consent." per sir F.H. Tenne. Fome of the language

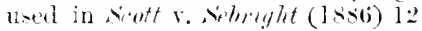
I'. 1). 21. 23. a tecesison on very peculiar facts hed to come within this hast-mentioned category. cannot be supporter.

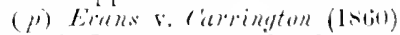
2 I. F. J. 4t1, 30 I. J. (h. 34 . It is there sais however that non. disclosure of adultery would be e'nough to a roid a separation deed. 
Some recent writers are of opinion that, according to the modern rule of equity, contracts of every lind are liable to be avoided by innocent misrepresenta. tion of any material fact, whether or not within the knowledge of the party making the representation more than of the other. With unfeigned respect for those learned authors, we have been unable to find any positive authority which goes that length $(q)$. It is conceived howerer that their wider form of statement would lead to very little difference in practical results.

As to voluntary gifts the rule is that a gift obtainerl by a misrepresentation of fact made, however innocently, by the donee, may be recovered back by the donor on the discovery of the mistake. Such gifts must be regarded as conditional on the truth of the representation $(r)$.

\section{Part 3.-Fraud or Deceit.}

Fraud generally includes misrepresentation. Its Fraul specific mark is the presence of a dishonest intention on the part of him hy whon the representation is made, or of recklessness equivalent to dishonesty. In this case we have a mistake of one party caused by a representation of the other, which representation is made by deliberate words or conduct with the intention of thereby procuring consent to the contract, and withont a belief in its truth.

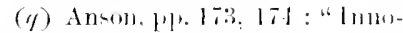
cent misceprerentation which briugs about a cont laset in $110 w$ a grouml for setting the comtract aside, and this rule applien to (6omtracts of every descoription," but we know of no reported ease in which sueb a rule has beren alphlied to a

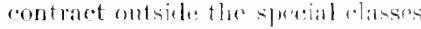
leatl with alose, and the dicta rited by sol W. Ansom mont be taken as qualitien by their suber.t. sinpuseal general rule of equity.

Vohuntary grifts.

generally includes mismeresentation. matter. Harriman. 1. 2.ie: $\cdot 1$ falce representation by che party in rearal to a material forct mate for the pompone of imlucing the

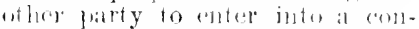
taact, alub actually indoremg the latter to enter into the contratet. molel's the contract roliable:" No antherity is givent

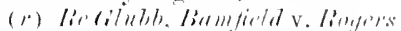

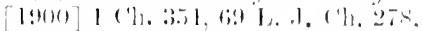
( $\therefore$. 1 . 
But not always: as when a contract is made with a collateral wrongful or unlawful purpose, or without intention of performing it.

There are some instances of fraud, however, in which one can hardly say there is a misrepresentation except by a forced use of language. It is framdulent to enter into a contract with the design of using it as an instrument of wrong or deceit against the other party. Thus a separation deed is fraudulent if the wife's real object in consenting or procuring the hushand's consent to it is to be the botter able to renew a former illicit intercourse which has been concealed from him. "None shall be permitted to take advantage of a deed which they have fraudulently induced another to execute that they may commit an injury against morality to the injury and loss of the party by whom the deed is executed " $(s)$. So it is fratud to obtain a contract for the transfer of property or possession by a representation that the property will be used for some lawful purpose when the real intention is to use it for an unlawful purpose $(t)$. It has been said that it is not fraud to make a contract without any intention of performing it, because peradventure the party may think better of it and perform it after all: but this was in a case where the question arose wholly on the form of the pleadings, and in a highly technical and now happily impossible manner $(u)$. And both before and since it has repeatedly been considered a fraud in law to buy goods with the intention of not paying for them $(x)$. Here it is obrious that

(di) Lians v. C'arrington (1sint) 2 D. E.J. 4sl. 501. 30 L. J. ("). 3fit: ep. Eratus v. Edmomts (15,3)

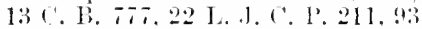
li. R. 332. where, howerer, expres representation was arered.

(f) Feret v. Mtill (1s.i4) 15 (.. B.

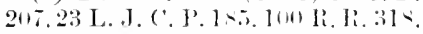
conceder this. deceding only that forseswon actually given mile' the contract cannot be treated as a mere trespas ly the party defrauded.

(ii) Heminguany v. Hamiltan (1538) + M. \& W. $115,51 \mathrm{R}, \mathrm{F}$. 497 . It is by no means clear that the Court really meant to go so far: see Pref. to 51 li. R.

(x) Froguson r. Farrington (IS29)

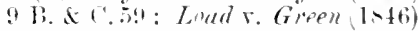
1: Y. . W. 216. 15 L. J. Ex. 113. $7 \mathrm{R}$. li. diat: White r. Garden (18.51) 10 (. B. $4194,923,20$ L. J. 
the party would not enter into the contract if he knew of the fraudulent intention: but the fraud is not so much in the concealment as in the character of the intention itself. It would be ridiculous to speak of a duty of disclosure in such cases. Still there is ignorance on the one hand and wrongful contrivance on the other, such as to bring these cases within the more general description of fraud given in Ch. IX. p. 464 , above.

The party defrauded is entitled, and in modern times has always been entitled at law as well as in equity, to rescind the contract. "Fraud in all courts Right of rescincling fraudulent and at all stages of the transaction has been held to vitiate all to which it attaches" $(y)$.

We shall now consider the elements of fraud separately: and first the false representation in itself. Elements of fraucl. It does not matter whether the representation is made by express words or by conduct, nor whether it consists in the positive assertion or suggestion of that which is false, or in the active concealment of something material to be known to the other party for the purpose of deciding whether he shall enter into the contract. These elementary rules are so completely established, and assumed so to be, in all decisions and discussions on the subject that it will suffice to give a few instances.

There may be a false statement of specific facts: Examples of this seldom occurs in a perfectly simple form. Canham v. Barry $(z)$ is a good example. There the tion.

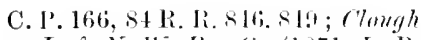
v. L. f. I. 11 . Iiy. (i) (18, L. Ji. 7 Ex. 26, 41 1....Ex. 17; E.t pate Whittuker (187.) I. R. I) ('h. 446 . 449, per Mellikh L.t. I1 1. .I. Bk.

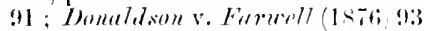
I. S. 6i3l. but it is not such a "falue representation or other frumel" as to constitute a mis. demeanor under s. 11, sub-s. 191 of the Jelotors Art. 184i9: E.r parte biett (18ii) 1 ('h. Iliv. 1is, 15 L. J. I3k. 17.

(b) ler Wilile d: Idell w. Ather. toll $(1 \leqslant 1 ; 1)$. H. d X. at 1). 181.30 1. J. Ex. $3: 3 \overrightarrow{\text {. }}$

( $)(1,5,5) 15(1.13 .597,24 \mathrm{~J} . \mathrm{J}$. C. 1'. 1001. 1010 li. li. 5083 . 
contract was for the sale of a leasehold. The rendor was under corenant with his lessor not to assign without licence, and had ascertained that licence would not be refused if he could find an eligible tenant. The agreement was made for the purpose of one M. becoming the occupier, and the purchaser and $M$. represented to the rendor that $\mathrm{M}$. was a respectable person and could give satisfactory references to the landlords, which was contrary to the fact. This was held to be a fraudulent misrepresentation of a material fact such as to aroid the contract. A more frequent case is where a person is induced to acquire or become a partner in a business by false accounts of its position and profits (a).

Or the representation may be of a general state of things: thus it is fraud to induce a person to enter into a particular arrangement by an incorrect and unwarrantable assertion that such is the usual mode of conducting the lind of business in hand $(b)$. How far it must be a representation of existing facts will be specially considered.

What is

framlulent cuncealment.

"Active concealment" seems to be the appropriate description for the following sorts of conduct: taking means appropriate to the nature of the case to prevent the other party from learning a material fact-. such as using contrivances to hide the defects of goods sold: or making a statement true in terms as far as it goes, but keeping silence as to other things which if discloserl would altre the whole effect of the statement, so that what is in fact told is a laalf truth equivalent to a falsehood (c): or allowing the

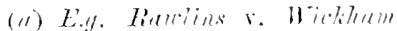

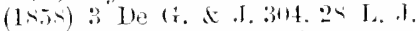
'h. lis. The ases where $\mathrm{c}$. tract- tis tatse shares have been h+lh voluble for mismeresentation in the proipectus are of the same kimi.

(b) Reynell v. Surye (18.52) l D. M G. at P. 620.21 L. A. Ch. 633. :11 li. li. $2+4$.

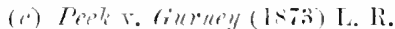
6 II. L. 3:2. 403, 43 L. J. Ch. 19: 
other party to proceed on an erroneons belief to which one's own acts have contributed (a.). It is sufficient if it appears that the one party knowingly assisted in inducing the other to enter into the contrat by leading him to believe that which was linown to be false $(e)$. Thus it is where one party has made an imocent misrepresentation, but on discorering the error does nothing to undeceive the other $(f)$. If, when he has better lnowledge, he does not remore the error to which he contributed in excusable ignorance, he is no longer excused. In effect he is continuing the representation with linuwledge of its falsity.

That which gives the character of fraud or deceit to a representation untrue in fact is that it is made without positive belief in its truth; not necessarily with positive knowledge of its falsehood. Where a false representation amomis to an actionable wrong, it is always in the party's choice, as an alternative remedy, to seek rescission of the contract, if any, which has been induced by the fraul: and it is settled that a false representation may be a substantive ground of action for damages though it is not shown that the person making the statement know it to be false. It is enough to show that le made it as being true within his own linowledge, with a view to secure some benefit to himself, or to deceive a third person, and without believing it to be true $(g)$.

Steurert v. Hyoming Runche (it. (188s) 128 C. S.. 383, 388.

(d) Hill v. (iraly (Isti) I stark. 434, 18 I. R. Ho. as explatuml in

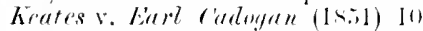

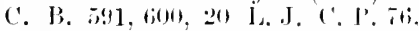
81 R. li. ils. ils: qu. if the explanalion deres not really overrole the particular derisin, per

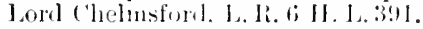

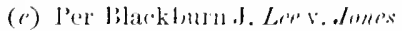
(1863) 17 ( . L. N. S. at 1. 318. 31 L. J. (C. I'. at p. 1 Ho.

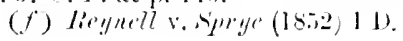

P.

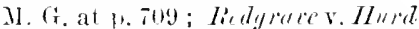

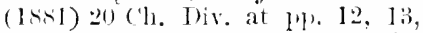
$\therefore$ l. J. (h. 11:3, but as to the ditficrence there assuned between efuity and common law see per

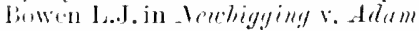

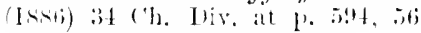
1. .) ('ll. 27.)

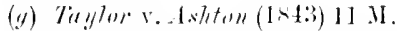

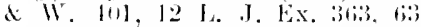
li. li. tiss; lerens ve Elmomes

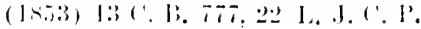
211. 9.8 1i, li. 73:2.
Representa tion made withont belief in its truth : actual knowledge of falsehoor not necessary.

Action of deceit. 
Eiffect of recklems innorance.

Nere ignorance as to the truth or falsehood of a material assertion which turns out to be untrue must be treated as equivalent to knowledge of its untruth. "If persons take upon themselves to make assertions as to which they are ignorant whether they are true or untrue, they must in a civil point of riew be held as responsible as if they had asserted that which they knew to be untrue " $(h)$. In other words, wilful ignorance may have the same consequences as fraud (i). So may ignorance which, though not wilful, is reckless: as when positive assertions of fact are made as if founded on the party ${ }^{\circ}$ own knowledge, whereas in truth they are merely adopted on trust from some other person. The proper course in such a case is to refer distinctly to the authority relied upon $(k)$.

Howerer it is now settled in England that the want of any reasonable grounds for belief in one's assertion

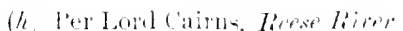

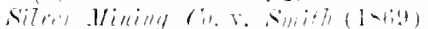

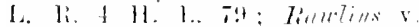

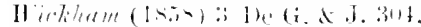

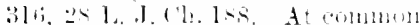
law the sane rule was given by

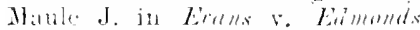

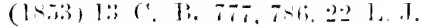

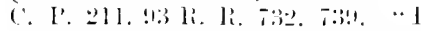

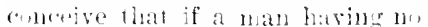

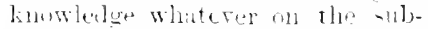
ject rakes upon himetif to reluesolit a rertain state of firste to axint, he doese so at his peril: amel if it lu drue eiller with a view to secur sine benefit to him-elf or to deceive a thimb person, le js revilty of a fian l, for he takenum himbelf to wanlant his own belice of the truth of that which he su assert.." In tophigh Zille "lud Irom ri. v. Iiamtind (1)!3)

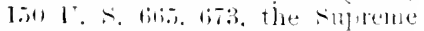
(inde of the Cnitul siater ayprovel a stitement uf the Court leklow which was. " in silintanee, that a perors who makes reureen- tations of material facts, assuming for intemline to corver the injures sion that he has aetual knowle lee uf the existueenf such faets. when hu jo romecious that lie has nusuch knowleder is as much responsible for the injurious censequances of smoth rel resentations to ote who buleres anl aets upon them as if

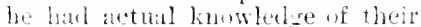
faloty: that deceit mas also be predicatterl of a vemelon or leseor whin make material untrue relreantilioms in respect to his own busimestr proverty for the purpuse of their being acted upon. and which ale in faet relied unom bs the prehaser or lessee, the truth of which representat ons the rendur ar lemor is bound and must le presuned to know.

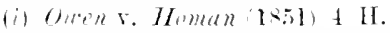
I. ( ${ }^{4}$. at 1 . 11135.

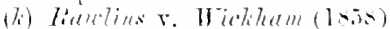
3 b (i. A J. at 1.313, cimith's cose (1-bia) 2 (h. at p. 61 l. 
is evidence, but only evidence, that it was uttered without any real belief $(l)$.

Silence is equivalent to misrepresentation for these purposes if "the withholding of that which is not stated makes that which is stated absolutely false," but not otherwise $(m)$.

If a man expects, however honestly, that a certain state of things will shortly exist, he is not therely justified in asserting by words or conduct that it does now exist, and any such assertion, if others have acted Luwarmated itatenent of mere expectation as loresent on the faith of it to their damage, ought to be a ground of action for deceit, and is of course ground for rescinding any contract obtained by its means. A stranger who accepts a bill as agent for the draweo on the chance of his ratifying the acceptance $(n)$ acts at his peril. But we have learnt from the House of Lords that directors of a tramway company may say they have statutory authority to use steam power when they only expect to obtain a consent which the statute requires $(l)$. Representations of this kind, which deliberately discount the future, seem to be of a different kind from statements honestly made on erroneous information of existing facts; for they are in their nature incompatible with belief in the truth of the assertion which is actually made. This distinction is not always clearly brought out in the anthorities.

The application of the doctrine of fraud to sales by auction is peculiar. The courts of law held the employment of a puffer to hid on behalf of the rendor to be evidence of fraud in the absence of any express condition fixing a reserve price or leserving a right of bidding; for such a practice is inconsistent with

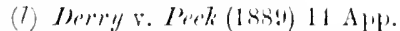

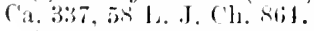
(m) Prok r. Gimrury (1973) I.R.

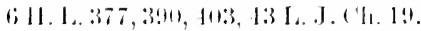

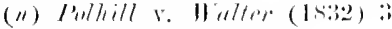
li. A N. 114, 37 R. li. 311. fict.

Sallub anction: cmpluyment of putfice. 
Frand in relation to marlage.

the terms on which a sale by auction is assumed to proceed, namely that the highest hidder is to be the purchaser, and is a device to put an artificial value on the thing offered for sale (o). There existed, or was supposed to exist (p), in conrts of equity the different rule that the employment of one puffer to perent a sale at an muderalue was justifiable $q$, with the extraordinary result that in this particular case a contract might be ralid in equity which a court of law would treat as voidable on the ground of fraud. The Sate of Land by Auction Act, 1867 (30) \& 31 Vict. (c. 45), asimilated the rule of equity to that of law. The Indian Contract Act (s. 123) adopts the rule of the common law $(r)$.

Marriage is to some extent an axception to the general rule: but marriage, though including a contract, is so much more than a contract that the exception is hardly a real one. The English rule is that "unless the party imposed upon las been de. ceived as to the person and thus has given no consent at all [or is otherwise incapable of giving an intelligent consent], there is no degree of deception which can arail to set aside a contract of marriage knowingly $(s)$ made $"(t)$. Still less is a marriage rendered invalid by the parties or one of them having practised

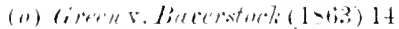

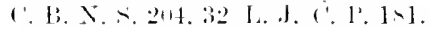
(l) loubt was thrown num it in Hortine r. bill (1stiis) L. Ri. 1

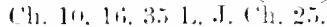

(q) Simith v. f'helle (1stli) 1:

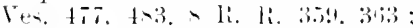

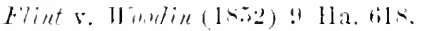
s.! li. li. fiol.?.

(r) "If at a sale hy an.tim th" seller makes use of pretented bilding to raist the frice. The sale is rinlable at the ontion of lhe buyer."

(x) A ceremony of marriage may be inonerative if the woman is triokel into it ly reprontations that it is not a marriage but a betrothal: though in this country sucil at case must obriously be rer. lare: Find r. stien [1sigi $P$. i. ii.i L. I. l'. 13. Here there is m, wheh howldad as is remired for leal cument.

(f) Niritt r. krill! (Is:35) 3 Knapl. 29i. 243. 411 i. R. 22. 1s:

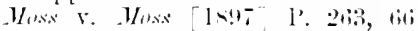
1..I. l'. 1.it, and as to the lifferent riews held in Ameriea and el-ewhere. we $[1-47]$ P. $273 \times 2$ ? 
a fraud on the persons who performed the ceremony or the authorities of the State in whose jurisdiction it was performed. Where a marriage had been celebrated in due form by Roman ecclesiastics at Rome between two Protestants, who had previously made a formal abjuration (the marriage not being otherwise possible by the law of the place as it then was), it was held immaterial whether the abjuration had been sincere or not, though as to the woman there was strong evidence to show that it was not (u).

We may observe in this place that when the consent of a third party is required to give complete effect to a transaction between others, that consent may Consent of third persons obtained be voidable if procured by fraud, and the same rules are applied, so far as applicable, which determino the like questions as between contracting parties. Thus where the approval of the directors is necessary for the transfer of shares in a company, a false deseription of the transferee's condition, such as naming him "gentleman" when he is a servant or messenger, or a false statement of a consideration paid by lim for the shares, when in truth he paid nothing or was paid to execute the transfer, is a fraud upon tho directors, the object being to mislead them by tho false suggestion of a real purchase of the shares by a man of independent position; and on a wind. ing-up the Conrt will replace the transferor's name on the register for the purpose of making him a contributory $(x)$.

(u) Simift $r$. killy (1+3is): Knaph, 2:i, lo R. R. 2.2.

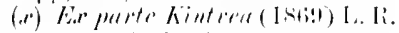

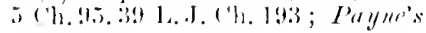

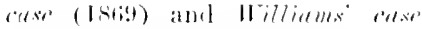

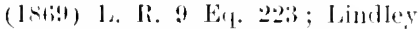
(n) ('mmpanies, 427 . 


\section{CHAP'TER XI.}

The Right of Rescissios.

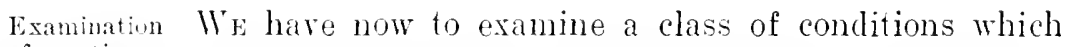
of pluestions (an lexcisici n of roidalie contracts.

apply indifferently, or very nearly so, to cases of simple misrepresentation (that is, where the truth of a representation is in any way of the essence of a contract) and cases of deceit. Some of them, indeed, extend to all contracts which are or have become roidable for any cause whatever.

Tha questions to be dealt with may be stated as follows:

What must be shown with regard to the representation itself to give a right to relief to the party misled?

What is the extent of that right, and within what bounds can it be exercised?

In 1888 the Supreme Court of the United States (a) thus summed up the points which a plaintiff in an action for the rescission of a contract must estab. lish :-

1. That the defendant has marle a representation in regard to a material fact:

2. That such representation is false;

3. That such representation was not actually believer by the defendant (b) to be true;

4. That it was marle with intent that it should bo acted upon;

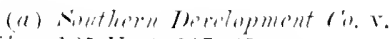

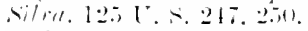

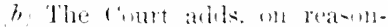

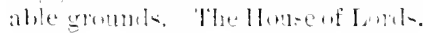

as we have seen (plp. 5!4. 59\%, abure), has dechded ntherwise for Englami. 
5. That it was aeted on by complainant to his damage;

6. That in so acting on it the complainant was ignorant of its falsity and reasonably believed it to be true.

1. As to the representation itself.

As to the

A. It must (except, it would seem, in a case of actual fraud) be a representation of fact, as distinguished on the one hand from matter of law, and on the other hand from a matter of mere opinion or intention.

As to the first branch of the distinction, there is authority at common law that a misrepresentation of the legal effect of an instrument by one of the parties to it does not enable the other to aroid it $(c)$. And in equity there is no reason to suppose that tho rule is otherwise, though the authorities only go to this extent, that no independent liability can ariso from a misrepresentation of what is purely matter of law $(d)$. But this probably does not apply to a deliberately fraudulent mis-statement of the law $(e)$. The circumstances and the position of the parties may well be such as to make it not imprudent or $\mathrm{un}$. reasonable for the person to whom the statement was made to rely on the knowledge of the person making it: and it would certainly work injustice if it were held necessary to apply to such a case the maxim that every one is presumed to know the law. The reason of the thing seems to be that in ortinary

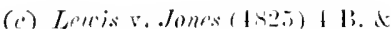

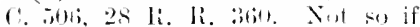
the actual contents or nature of the instrument are misrepresenterl, ats we saw in ('h. IX.

(d) Riskldall r. Ford (likbit)

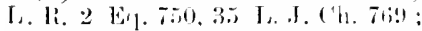

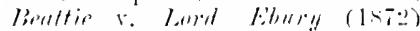

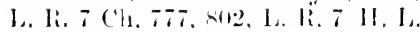

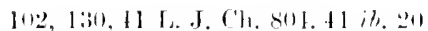
(the Holse of Litels held there wat ure mispoperentation at all).

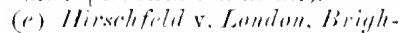

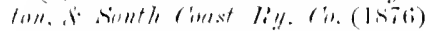
2 1. 1. 1). 1, ti 1. 1. 1) H. 1;

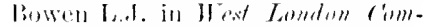

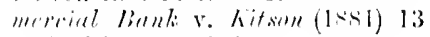
(1. H. Hiv. at p. 36;3. representa. tion relied on for rescincing a contraet. It must be of matter of fact, not of law (but qu as to ileliberate fraud). 
And not of were morive or intentinn.

cases the law is equally accessible to both parties, and statements about it are equally verifiable by both, or else are in the region of mere opinion. But there is no need to extend this to exceptional cases. At all erents the rule applies only to pure propositions of law. The existence and actual contents of $e . g$. a private Act of Parliament are as much matters of fact as any other concrete facts $(f)$.

As to the second branch, we may put aside the cases already mentioned in which the substance of tho fraud is not misrepresentation, but a wrongful intention going to the whole matter of the contract. Apart from these it appears to be the rule that a false representation of motive or intention, not amounting to or including an assertion of existing facts, is inoperative. "It is always necessary to distinguish, when an alleged ground of false representation is set up, between a representation of an existing fact which is untrue and a promise to do something in future " $(q)$. On this ground was put. the decision in remon r. Keys $(h)$, where the defendant hought a business on behalf of a partnership firm. The price wax fixed at 4,500 . on his statement that his protners would not give more: a statement afterwads shown to be false by the fact that he charged them in arcomnt with a. greater price and kopt the resulting difference in their shares of the purchane-money for himself. It was held that the rendor conld not maintain an action of deceit, as the statemont amounted only to giving a false reason for not offering a higher price. The case also illus-

(f) Hinwern L..J. mii snp.

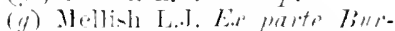

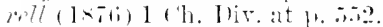

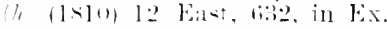
(h. 4 Tannt. firs, 11 li. Ji, 19!9. The language used in the Ex. (h. to the effect that the buyer's liberty must be co-extensive with the seller"s. which is to "tell every falsthom he can to induce a burer to purchise," in of course not to be literally accepted. 
trates the principle that collateral fraud practised by or against a third person does not avoid a contract. Here there was fraud, and of a gross kind, as between the buyer and his partners; but we must dismiss this from consideration in order to form a correct estimate of the decision as between the buyer and seller. It must be judged of as if the buyer had communicated the whole thing to his partners and charged them only with the price really given. Still the decision can hardly be supported unless on the ground of failure to prove damage. For the buycr was the agent of the firm, and in substance made a rilfully false statement as to the extent of his authority.

The Judicial Committee has held that it is clearly frauduient for $A$. and $B$. to combine to sell property in B.'s name, B. not being in truth the owner but only an intermediate agent, and the nominal price not being the real price to be paid to the owner $\mathrm{A}$., but including a commission to be retained by B. (i). And under particular conditions a statement of intention, such as the purpose to which a proposed loan is intended to be applied, may be a material statement of fact $(k)$. On principle A.'s existing intention seems to be as much a fact for B. as anything else.

It needs no authority to show that a statement of what is merely matter of opinion cannot bind the person making it as if he had warranted its correct.

Statements of ratter of opinion. (i) Limdiay litrolomm Fi. v.

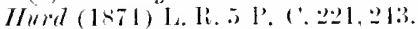
This no lombt amont actually overule the reasons given for the decision in linmon r. keys: for decisions of the ln licial committere throwgh they rarty great weight, are mot bimling in Emerish (onlts: sere

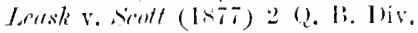

:37t. 4ti I. I. (2. B. 776 , where the ('. A. refused to follow the Judicial committee, also simith v. Bromen (1Sil) R. R. t; Q. B. at 1). 736,40 1. 1. (.). 1;. 211.

(b) Eilfington v. Fit:manriae

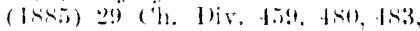
:i, 1. .1. ('h. (i.j). 
ness. And it is said that if a man makes assertions, as of matter of fact within his own knowledge, concerning that which is by its nature only matter of more or less probable repute and opinion, he is not legally answerable as for a deceit if the assertion turns out to be false $(l)$. But it seems doubtful if this could be upheld at the present day. For surely the affirmation of a thing as within my own lnowledge implies the affirmation that I have peculiar means of linowledge: and if I have not such means, then my statement is false and I shall justly be held answerable for it, unless indeed the special knowledge thus claimer is of a kind manifestly incredible.

Ambiguous statements.

The representation must incluce the contract. No relief to

Statements which in themselves are ambiguous cannot be treated as fraudulent merely because they are false in some one of their possible senses. In such a case the party who complains of having been misled must satisfy the Court that he understood and acted on the statement in the sense in which it was false $(m)$.

B. The representation must be such as to induce the contract (dans locum contractui) $(n)$.

Rolief cannot be given on the ground of fraud or

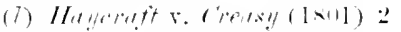

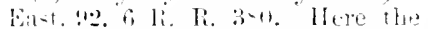
lefembant lual stated, as a fart within his awn knowlerge, that a person was solvent who apleared to have ample means, but turned out to be an imlontar. The natjurity of the comat seem to have thurght that the plaintitf must in the circom-tances bave known the chemlant to be expresing only an opinion fommel on that which appealed to all the world. So a statement of confident expectation of protits must be dietimemblel from an asertion as to protics actually unale: Rellairs v. Tinclier
(1-4) 131 \%. R. D. 54 .2.

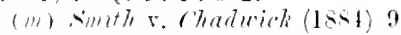
Alp. ra. 187. il I. J. Ch. 547, see eneroitly per Lorel Blackhurn at 1'1\% l:4-211. The language used in Hallars v. Fornie (lstis) L. H. 3 ch. at p. tri. -cems to go too far. Iord lilacklom leaves it as an wnettled quention what would halpuen if the defevalant coull in turn prove the falsehood or amhignity to be due to a mere bluniter.

(n) Jo:d Bongliam. Attwoul r.

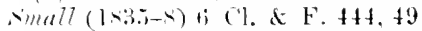
li. R. 137: 1,oml Wensleydale, smitle v. hay (ls.ou) i H. L. C. $77 j-7 i$. 
misrepresentation to a party who has in fact not acted on the statements of the other, but has taken steps of his own to verify them, and has acted on a part y who has acted on his own the judgment thus formed by himself $(o)$.

"The Court must be careful that in its anxiety to correct frands it does not enable persons who have joined with others in speculations to convert their speculations into certainties at the expense of those with whom they have joined" $(p)$.

It is not perfectly free from doubt whether in any, and if in any, in what cases the possession of means of knowledge which if used would lead to the dis. covery of the truth will bar the party of his remedy.

In the case of active misrepresentation it is no answer in proceedlings either for damages or for As to means of linowlewge: immaterial in case of active mirrepresetting aside the contract to say that the party complaining of the misrepresentation had the means of maling inquiries. "In the case of Dobell v. Stevens $(q)$. . . which was an action for deceit in falsely representing the amount of the business done in a public-house, the purchaser was held to bo entitled to recorer damages, although the books were in the house, and he might have had access to them if he had thought proper" $(r)$. The rule was the same in the Court of Chancery. It ras sairl of a purchaser to whom the state of the property ho bought was misrepresented:-." Admitting that he might by minute examination make that discorery, ho was not driren to that examination, the other party having taken upon him to make a representation. - . The purchaser is induced to make a less accurate examination by the representation, which

(11) See for a reeent example.

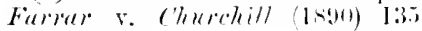
I... (305.

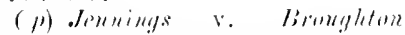
$(1853-1)$; 11. IJ. 18. 1:2i, 160. 22

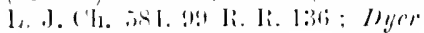

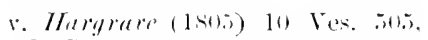
s li. Ri. 3 is.

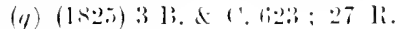
Ii. 111 .

(r) Per land chelmeford. h. h. 2 H. 1. 1.21. 
ho had a right to believe" $(s)$. The principle is that "No man can complain that another has too implicitly relied on the truth of what he has himself stated" $(t)$. And it is not enough to show that the party misled did make some examination on his own account; proof of cursory or ineffectual inquiries will not do $(u)$. In order to bar him of his remedy, it must be shown either that he knew the true state of the facts, or that he did not rely on the facts as represented $(x)$.

In 1867 the same principle was affirmed by Lord Chehmsford in the House of Lords $(y)$. The suit was instituted by a shareholder in a railway company to be relieved from his contract on the ground of misrepresentations contained in the prospectus. Here it was contended that the prospectus referred the intending shareholder to other documents, and offered means of further information: besides, the memorandum and articles of association (and of these at all events he was bound to take notice) sufficiently corrected the crors and onissions of the prospectus. But the objection is thus answered :-

"When once it is e-tablisher that there has been auy fratuhlent misreprementation or wilful concealment by which a person has been induced to enter into a eontract, it is no ancwer to his claim to be relieved from it to tell him that he might have limwn the truth by proper inquiry. He has a right to retort $n$ un his objector. "You at least, who have stated what in untrue, or have conceled the truth for the purpose of drawing me into a contract. camnot aceuse me of want of eantion hecause I relied implicitly "yon pour fairness and hone- $y$.

(s) Iy yer s. Haryater (lsus) in Ves. at p. 309, s li. li. at p. 39.

(t) Reynell v. sisngye (15.2) 1 I).

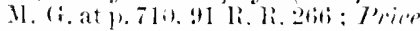
v. Mucumlay (15.52) 2 b. M. (i. 339, 316.95 R. R. 1294 134.

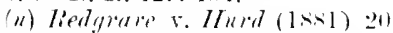
('b. lliv. 1. il L. .l. ch. 113.

(r) Riedyrate r. IIm, 1 1-s1) 24 ('h. liv, 1, 21 (.Jesuel MI.R.).

(4) Contral hy. (o. of Ienezurla ง. Kiscle (1Stio) L. li. 2 H. L. 99, 120. 31i I. J. ('h. S4!. As to the earlier and indecisive case of Attword r. s'mull (183.)-s) o Cl. \& F. 232. 4! 3. K. 115. see now Red.

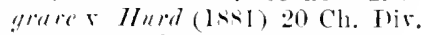
al J. 14.51 L. I. Ch. 113. 
This doctrine appears, also on Lord Chelmsford's authority, not to apply to the case of mere nondisclosure, without fraudulent intention, of a fact which ought to have been disclosed.

"When the fact is not misrepresented but con. cealed [or rather not communicated] $(z)$ and there is nothing done to induce the other party not to avail himself of the means of knowledge within his reach, if he neglects to do so he may have no right to complain, because his ignorance of the fact is attributable to his own negligence" (a).

It appears also not to apply to a mere assertion of title by a vendor of land (b).

In a case before Lord Iatherley, when V.-C., the double question arose of the one party's knowledge that his statement was untrue, and of the other's means of learning the truth. The suit was for specific performance of an agreement to take a leaso of a limestone quary. The plaintiff made a distinct representation as to the quality of the limestone which was in fact untrue: he did not believe it to be false, but he had taken no pains to ascertain, as he might easily have done, whether it was true or not. But then the defendant had not relied exclusively upon this statement, for he went to look at the stone; still he was not a limeburner by trade, and could not be supposed to have trusted merely to what he saw, being in fact not competent to judge of the quality of limestone. The result was that the Court refused specifie performance, declining to decide whether the contract was otherwise valid or not (c).

(z) See I. R. 2 II. I., 3339.

(a) Lino Brunsuleck, fir. I'i. v.

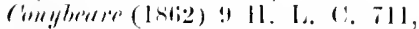
742,31 [... . ('h. 2:17.

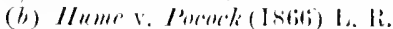
I (h. 379), 355, 35 I. J. (h. 731,
Otherwine in ease of mere non. diselosure, semlile.

Nere assertion of title. 
606

Atempt ti) dereeire in-peetion which pulith-er omitstu malie.

The case of Horsfall $r$ Thomas $(d)$ was decided on the same prineiple: there a contrirance was used to conceal a defect in a gun manufactured to a purchaser's order, but the purchaser took it without any inspection, and therefore, although the rendor intended to deceive him, had not been in fact deceived.

It might also be giren as a rule that the repre. sentation must be material. But to make this quite accurate it should be stated in the converse form, namely that a material representation may be presumed to have in fact induced the contract; for a man who has oltained a contract by false representations cannot afterwards be heard to say that those representations were not material. The excuse has often been put forward that for anything that appeared the other party might no less have given his consent if the truth had been made known to him, and the Court has always been swift to reject it. When a falsehood is proved, the Court does not require positive eridence that it was successul (e); it rather presumes that assent would not have been given if the facts had been linown (f). Those who have made falso statements cannot as the Court to speculate on the exact share they may have had in inducing the transaction $(g)$; or on what might have been the result if there had been a full communication of the truth $(h)$; it is enough that an untrue statement las been made which was likely to induce the party to enter into the contract, and that he has done so (i).

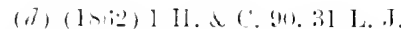

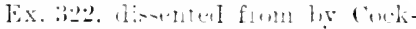

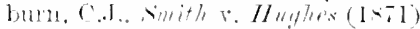

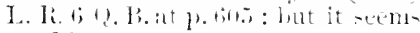
geurl litw.

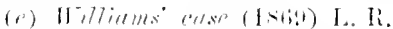
(4) E. 2.2.5.

(f) Ed perte kintere (15tia) 1 ..

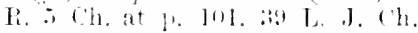
$10 \%$

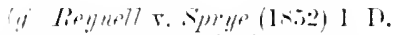

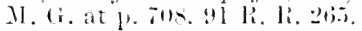

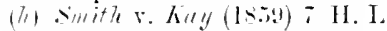
Cat p. T.s.

(i) l'er Lord Denman C..J. II ittson 5 Eurl of (\%orlemont (lsts) 12 Q. B. A.ti. stit. ] I.. J. (). B. (i.). To the like effect, Jerel II.K. in

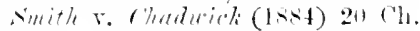
livat at 1 t sec howerer note (l) ,
} 
Special circumstances may make a representation material which in ordinary cases of the same lind of contract would not be. If a moneylender who has become notorious for harsh and oppressive deal. ing attracts a borrower by advertising in an assumed name, a jury may find that the contract was fraudu. lent $(k)$. An inference or presumption of this class is of fact, not of law, and is open to contradiction like.other inferences of fact $(l)$.

In like manner, if there has been an omission even without fraud to communicate something which ought to have been communicated, it is too late to discuss whether the communication of it would probably have made any difference $(m)$.

If it be asked in general terms what is a material fact, we may answer, by an extension of the language adopted by the Queen's Bench in a case of marine insurance $(n)$, that it is anything which would affect the judgment of a reasonable man governing himself by the principles on which men in practice act in the kind of business in hand.

There is an exception, but only an apparent one, to the rule that the representation must be the cause of the other party's contracting. A contract arising directly out of a previous transaction between the same parties which was voidable on the ground of fraud is itself in like manner voidable. A. makes a contract with $B$., with the fraudulent intention of maling it impossible by a secret scheme for B. to perform the contract. B. ultimately agrees to pay and does pay to A. a sum of money to be released from the contract: if he afterwards discovers the

(k) Gordon v. Sitront [18!9!?] 20.

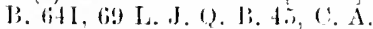

(l) Lomb lalackburn, simith v.

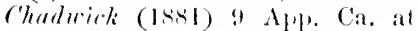
1. 196 ,
And contract incidental to fraululent transaction is itself treated as framilulent. (iii) Traill s. Ratring (Istit) + I). J. S. at 1 . 3330 .

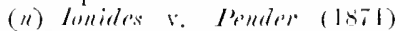
I. Ii. 9 Q. I. $531,4: 3$ I. .J. Q. li. 227, s"1 
scheme B. can rescind this last agreement and recover the money back $(o)$.

"If the promoter of a complany procures a eomprany to be formed by improper and framlulent means. and for the purpose of seeuring a profit to himself, which. if the company was succenful. it would be unjust and inecuitable toallow him foretain [in the particular case a secret pament to the promoter out of purchase-money], and the company proves abortive and is ordered to be wound up without doing any business. the promoter eamot be allowed to prove against the comprany in the windingup, either in repect of his services in forming the eompany or in respect of his servicen as an officer of the compang after the company was registered " $\left(l^{\prime}\right)$.

So it is where the parties really interested, though not the nominal parties, are the same. Thus where it sale of goods is procured by fraud, and the rendors forward the goods by railway to the purchaser"s agent, and afterwards reclaim them, indemnifying the railway company, these facts constitute a good defence to an action by the purchaser's agent against the railway company, though the re-delivery to the vendors was before the discovery of the fraud and arose out of an unsuccessful attempit to stop the goods in transitu $(q)$.

Must be made by a party to the contract.

C. The representation must be made by a party to the contract. This rule in its simple form is elementary. It is obvious that $A$. cannot be allowed to rescind his contract with $B$. because he has been induced to enter into it by some fraud of $C$. to

(d) Barry v. C'reskey (1861) 2 J. s H. 1 .

(p) ler Cur. Herefond is s. Wales Waggon of Enginering ra. (1876) 2 (h. Inir, 6;21,626, 45) 1. J. ('h. f6i. It must not be assumed that the company would be liable even in the ahsence of framl. see

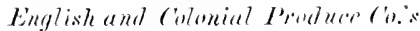
rase $[1906] 2$ ch. 435, ;is l. J. ' 'h.
-31. 9. L. T. .58. C. A.

(q) rlongh v. L. \& . Y. H. li!. F\%. (15.1) (Ex. (h.) 1. li. 7 Ex, 26, t1 L. I. Ex. 17, an exceedingty instruetive case: as to the misconceived act being justified by reference to the true gromul of reseission afterisants discovered. ep. Wright is

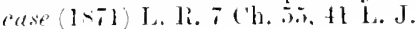
('h. 1. 
which B. is no party $(r)$. Thus in Sturge v. Starr $(s)$ a woman joined with her supposed husband in dealing with her interest in a fund. The marriage was in fact void, the man having concealed from her a previous marriage. It was held that this did not affect the rights of the purchaser.

When we come to deal with contracts made by agents the question arises to what extent the representations of the agent are to be considered as the representations of the principal for the purposes of this rule. And this question, though now practically set at rest by recent decisions, is one which has given rise to some difficulty. A false statement made by an agent with his principal's express authority, the principal linowing it to bo false, is obviously equivalent to a falsehood told by the principal himself; nor can it make any difference as against the principal whether the agent knows the statement to be false or not. But we may also have the following cases. The statement may be not expressly authorised by the principal, nor known to be untrue by him, but known to be untrue by the agent; or conversely, the statement may be not linown to the agent to be untrue, and not expressly authorised by the principal, the true state of the facts being, however, known to the principal. There is no doubt that in the first case the principal is answerable, subject only to the limitation to be presently stated $(t)$. In the second case there is every reason to believe that the same rule holds good, notwithstanding a much canvassed decision to the contrary ( $u$ ), which,

$(r)$ see per Land Caims, Smith's

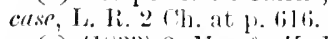

(s) (183:3) 2 Hy. \& K. 19 ; ; cl. llierlton v. Mardisty (18.7) \& lit. B. 232,24 L. I. Q. 13. $26.5,27$ ib. $241.112 \mathrm{k}, \mathrm{R} . \mathrm{si35}$

( $t$ ) The rule applies to an agent

P.
As to representations made by agents. 
The only question is whether the representation was within the agent's authority. Barwiek $r$ scope of the agent's authority. And it is now English Juint accepted as the law that this is the only question
stock Bank. IIackay $c$. Commercial Bank of New Brunswick.

These distinctions have to be considered only when there is a question of fraud in the strict sense, and then ehiefly when it is sought to make the principal liable in damages. Where a non-fraudulent misrepresentation suffices to aroid the contract, there it is clear that the only thing to be ascertained is whether the representation was in fact within the even in a case of fraud. It was laid down by a considered judgment of the Exchequer Chamber $(y)$,

if not overruled by the remarks since made upon it $(x)$, has been cut down to a decision on a point of pleading which perhaps cannot, and certainly need not, ever arise again. fully approved by later decisions of the Judicial Committee $(z)$, that "the master is answerable for every such wrong," including fraud, "of the servant or agent as is committed in the course of the service and for the master's benefit, though no express command or privity of the master be proved." Although the master may not have authorizer the particular act, yet if "he has put the agent in his place to do that class of acts," he must be answerable for the agent's conduct. It makes no difference whether the principal is a natural person or a corporation (a). In two of the cases just referred to, a banking corporation was held to be liable for a false representa-

(r) 2 sim. I. C. s1, sf: anl see especially per Willes J. in burwick

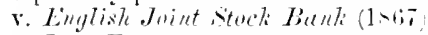
L. Ji. $2 \mathrm{Ex}, 262$.

(y) Buruick v. English Joint

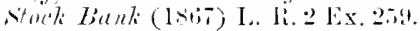
$3 i$ L. J. Ex. 147 .

(z) Harkay r. Gommerial Pank

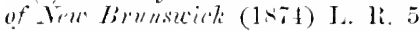
i. C. 344, +11, t3 L. J. H. ('.31; swire v. Fruncis (1-ia) 3 Ape. C'a.
101,47 L. J. I'. C. 18.

(a) I. Ii. is P. C. +13-5. disienting from the dieta on this point in II sistere Bumk of seotlend v. Addie (1siti) L. R. 1 sc. ct D. 14.) which. though alparently intenled to be decine, have not been followed. Switt v. Jewslury (1sit) (Ex. Ch.) I. Ii. 9 Q. B. at 1 . 312, per Lord Coleridge C.J. C1. I. C. A. \$ 238 . 
tion made by one of its officers in the course of the business usually conducted by him on behalf of the bank; and this involves the proposition that the party misled is entitled to rescind the contract induced by such representation.

The directors and other officers of companies, acting within the functions of their offices, are for this Directors and purpose agents, and the companies are bound by their acts and conduct. Conversely, where directors employ an agent for the purposes of the company, and that agent commits a fraud in the course of his employment without the personal knowledge or sanction of the directors, the remedy of persons injured by the fraud is not against the directors, who are themselves only agents, but against the company as ultimate principal (b): and one director is not liable for fraud committed by another director without his authority or concurrence $(c)$. Reports made in the first instance to a company by its directors, if afterwards adopted by a meeting and "industriously circulated," must be treated as the representations of the company to the public, and as such will bind it $(d)$. Statements in a prospectus issued by promoters before the company is in existence cannot indeed be said with accuracy to be made by agents for the company: for one cannot be an agent even by subsequent ratification for a principal not in

(b) Hirir v. liarnatt (1877) :3 Ex. 1). 32, affel. in C. A. mom. Ileir v. Jiell (1575) itr. 2:35, 17 L. J. Ex. 704. But a director who polited by the fraul after knowledge of it womkl frobibly be liable: see julgments of Coekburn (..J. and IBrett I,.J. And dueeters whorlele. gaterl their oflice without anthority, so that their delegate diil not become the comprany sagent, would be liable: see the dissenting juclerjuent of cotton L.J., whe touk this view of the facts.

(a) l'argill v. Bimere (1878) 10 (1). 1). 50. 47 I. J. Ch. 6l!.

(d) l'er horel lVestloury: wiew

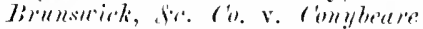
(181;2) ! II. I. (․ 711, 725, 31 I. J. (h. 2:97. Sice further, as to what must be shown to bint a company in respect of misrepresentations imblucing a person to take slatues, Lifude v. Ingla. It alian Ilemp, Yyin-

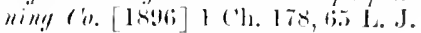
('li. 96 ;. 
existence and capable of ratifying at the time $(e)$. But such statements also, if afterwards expressly or tacitly adopted, become the statements of the company: It is a principle of general application, by no means confined to these cases, that if $A$. makes an assertion to B., and B. repeats it to C. in an unqualified manner, intending him to act upon it, and C. does act upon it, B. makes that assertion his own and is answerable for its consequences. If he would guard himself, it is easy for him to say: "This is what A. tells me, and on his authority I repeat it; for my own part I believe it, but if you want any further assurance it is to him you must look " $(f)$.

Agent always liable for his own personal fraud.

The representation must be in the same transaction.

It is to be borne in mind that in a case of actual fraud on the part of an agent the responsibility of the principal does not in any way exclude the responsibility of the agent. "All persons directly concerned in the commission of a fraud are to be treated as principals"; and in this sense it is true that an agent or servant cannot be authorized to commit a fraud. He cannot excuse himself on the ground that he acted only as agent or servant $(g)$.

D. The representation must be made as part of the same transaction.

It is believed that the statement of the rule in this form, though at first sight vague, is really more accurate than that which presents itself as an alternative, but is in fact included in this-namely, that the representation must be made to the other party or with a view to his acting upon it. The effect of the rule is that the untruth of a representation made

(f) P. 114, abore.

(f $f^{\prime}$ S'mitl's case (186i) L. R, 2 ('h. 604, 611, p. 586 , above.

(g) Per Lord Westbury. C'ullens.
Themsens Trustees and herr (1862) 4 Hacu. 424. 432: Sirift v. Winter. bothem $(1 \times 3)$ L. L. \& Q. B. 244, $254,4 \div$ L. J. 4. B. 111. 
to a third person, or even to the party himself on some former occasion, in the course of a different transaction and for a different purpose, cannot be relied on as a ground either for rescinding a contract or for maintaining an action of deceit. Thus in Western Bank of Scotland v. Addie (h) the direetors of the bank had made a series of flourishing but untrue reports on the condition of its affairs, in Western Bank of Scotland which bad debts were counted as good assets. The shareholder who sought relief in the action had taken additional shares on the faith, as he said, of these reports. But it was not shown that they were issued or circulated for the purpose of inducing existing shareholders to take more shares, or that tho local agent of the bank who effected this particular sale of shares used them or was authorized to use them for that purpose. Thus the case rested only on the purchaser having acted under an impression derived from these reports at some former time; and that was not such a direct connexion between the false representation and the conduct induced by it as must be shown in order to rescind a contract. This, however, was not the only ground of the decision; its main principle, as explained in a later case in the House of Lords, being that a person who remains a shareholder, either by having affirmed his contract with the company or by being too late to rescind it, cannot have a remedy in damages against the corporate body for representations on the fatith of which his shares were taken $(i)$.

In Peek v. Grurney $(k)$ the important point is de- Peek $x$ cided that the sole office of a prospectus is to invite ciurney.

(h) (1857) J. R. 1 sic de D. 14 .

(i) IIouldsurosth v. City of Gills:-

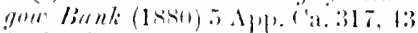
1. J. ('h. 1!?. (li) (1473) I. R. 6 HI. L. 377 395 : and see the eave gut by tord Carme as an illustration at p. 111 . 
the public to take shares in the company in the first instance. Those who take shares in reliance on the prospectus are entitled to their remedy if the statements in it are false. But those statements cannot be taken as addressed to all persons who may hereafter become purchasers of shares in the market; and such persons cannot claim any relief on the ground of having been deceived by the prospectus unless they can show that it was specially communicated to them by some further act on the part of the company or the directors. Some former decisions the other way $(l)$ are expressly everruled. The proceeding there in hand was in the nature of an action of deceit, but the doctrine must equally apply to the rescission of a contract. It is otherwise, however, if the prospectus is in fact used afterwarks, at any rate in conjunction with other fraudulent statements, to induce people to buy shares in the marliet $(m)$.

Way $v$. Hearn.

In $H^{r} a y$ r. Hearn $(n)$ the action was on a promise by the defendant to indemnify the plaintiff against half of the loss he might sustain by having accepted a bill drawn by one R. Shortly before this, in the course of an investigation of $R . \therefore$ affairs in which the defendant took part, $R$. had at the plaintiff's request concealed from the accountant employed in the matter the fact that he ored a large sum to the plaintiff; the plaintiff said his reason for this was that he did not wish his wife to know he had lent so much money upon had security. At this time the bill which was the subject of the indemnity was not thought of; it

(7) Bralfard v. Bayshate (15:5) t H. \& ×. 538.29 1. J. Fx. 69 :

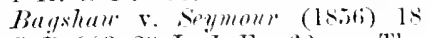
C. B. 903.24 L. J. Ex. 60. "1. The authority of Gomurd r. Butes (1853) 2 E. A R. 4iti. 22 T...1.12.1. $360.95 \mathrm{R}$. R. 6\%5 is sared by a rather fine distinction; L. R. 6 II. I. $3 ! 19$.

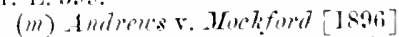
1 Q. B. 372.65 L. J. Q. 13. 302. $\therefore$.

(ii) (1482) 13 (․ B. . . . 242,32 I. I. C. P. 34 . 
was in fact given to get rid of an execution afterwards put in by another creditor. Here a misrepresentation as to R.'s solvency was made by $R$. in concert with the plaintiff, and communicated to the defendant; but it was in a transaction unconnecter with the subsequent contract between the plaintiff and the defendant, and the defendant was therefore not entitled to dispute that contract on the ground of fraud.

2. As to the right of the party misled. This right is one which requires, and in several modern cases of importance has received, an exact limitation and definition. It may be thus described:

The party who has been induced to enter into a contract by fraud, or by concealment or misrepresentation in any matter such that the truth of the representation made, or the disclosure of the fact, is by law or by special agreement of the parties of the essence of the contract, may affirm the contract, and insist, if that is possible, on being put in the same position as if the representation had been true:

$\mathrm{Or}_{\mathrm{r}}$ he may at his option rescind the contract, and claim to be restored, so far as may be, to his former position within a reasonable time (o) after discovering the misrepresentation, unless it has become impossible to restore the parties to the position in which they would have been if the contract had not been made, or unless any third person has in good faith and for value acquired any interest under the contract.

It will be necessary to dwell separately on the several points involved in this. And it is to bo observed that the principles here considered are not confined to any particular ground of rescission, but

(a) But $q u$. whether time is in itself material: see L. R. 7 Ex. 35, $8 \mathrm{Ex}, 2(15$. 
apply generally when a contract is voidable, either for fraud or on any other ground, at the option of one of the parties; on a sale of land, for example, it is constantly made a condition that the vendor may rescind if the purchaser takes any objection to the title which the vendor is unable to remove; and then these rules apply so far as the nature of the case admits.

Of aflirmation and reseission in general.

Election to avoin or aftirm.

A. As to the nature of the right in general, and what is an affirmation or rescission of the contract.

"A contract induced by fraud is not void, but voidable only at the option of the party defrauded;" in other words, valid until rescinded $(p)$.

Where the nature of the case admits of it, the party misled may affirm the contract and insist on having the representation made good. If the owner of an estate sells it as unincumbered, concealing from the purchaser the existence of incumbrances, the purchaser may if he thinks fit call on him to perform his contract and redeem the incumbrances $(q)$. If promoters of a partnership undertaling induce persons to take part in it by untruly representing that a certain amount of capital has been already subscribed for, they will themselves be put on the list of contributories for that amount $(r)$.

It is to be remembered that the right of election, and the possibility of having the contract performed with compensation, does not exclude the option of having the contract wholly set aside. "It is for the party defrauded to elect whether he will be bound " $(s)$. But if he does affirm the contract, he

(p) Oulies r. Turquemd (1867)

L. R. 2 II. I. $346,37.376$.

(a) Per Romilly Ml.R. in Pulsford v. Rirluards (1563) 17 Beav. 91i. 2.2 I. J. ('h. 5.54. 49 R. R. 54. ('p. Frugley v. Fingley (1sit) 5 Ch, Vir.s87, $46 \mathrm{~L}, \mathrm{~J}, \mathrm{ch}, \mathrm{s} 5 \mathrm{t}$, (r) Woere and De la Tinrers arse (1s7t) L. R. 18 Eq. 661, 43 I. J. Ch. 7.51 .

(x) Rawhins v. Wieliham (18.33) 3 De (i. \& J. 304, 322. 2.8 I.J. Ch. 1ss. 
must affirm it in all its terms. Thus a vendor who has been induced by fraud to sell goods on credit cannot sue on the contract for the price of the goods before the expiration of the credit: the proper course is to rescind the contract and sue in trover $(t)$. When the contract is once affirmed, the election is completely determined; and for this purpose it is not necessary that the affirmation should be express. Any acts or conduct which unequivocally treat the contract as subsisting, after the facts giving the right to rescind have come to the knowledge of the party, will have the same effect $(u)$. Taling steps to enforce the contract is a conclusive election not to rescind on account of anything linown at the time $(x)$. A shareholder cannot repudiate his share on the ground of misrepresentations in the prospectus if he has paid a call without protest or received a dividend after he has had in his hands a report showing to a reader of ordinary intelligence that the statements of the prospectus were not true $(y)$, or if after discovering the true state of things he has taken an active part in the affairs of the company $(z)$, or has affirmed his ownership of the shares by taking steps to sell them $(a)$; and in general a party who voluntarily acts upon a contract which is voidable at his option, having knowledge of all the facts, cannot afterwards repudiate it if it turns out to his disadvan-

(t) Frymuson r. G'arrington (1s2!9) 9 B. \& ( $)$. Th. The form or formal cause of action is now immaterial in most jurislictions, but the measure of damages may be different.

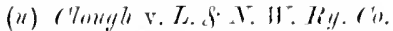
(1sil) (Fx. (b.) I. Li. 7 lix. at 1). 31 .

(a) Graly v. Fowlor (1S73) (Fx.

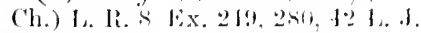
lix, $16 i 1$. (y) Noluley v. rintral li!l. ro.

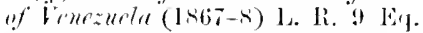
ibii, 11 .

(i) sharpley v. Lanth and Liest firtst li!. fo. (1876) 2 (h. Div. 6633. 16 1. .1. (']1. 2.5.9.

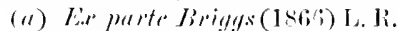

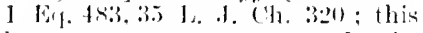
howevel was a case not of misstateal farts. but of material depatere from the objects of the? company ats stated in the prospectus.
What shall determine election. 
tage $(b)$. And when the right of repudiation has once been waived by acting upon the contract as subsisting with linowledge of facts establishing a cas $\theta$ of fraud, the subsequent discovery of further acts constituting "a new incident in the fraud" cannot revive it $(c)$. The exercise of acts of ownership orer property acquired under the contract precludes a subsequent repudiation, but not so much because it is evidence of an affirmative election as because it makes it impossible to replace the parties in their former position; a point to which we shall come presently.

When the acts done are of this kind it seems on principle immaterial whether there is linowledge of the true state of affairs or not, unless there were a continuing active concealment or misrepresentation practised with a view to prevent the party defrauded from discorering the truth and to induce him to act upon the contract; for then the affirmation itself would be as open to repuliation as the original transaction. Something like this occurs not unfrequently in cases of undue influence, as we shall see in the next chapter.

Omission to repudiate within a reasonable time is eridence, and may be conclusive evidence, of an election to affirm the contract; and this is in truth the only effect of lapse of time. Still it will be more convenient to consider this point separately afterwards.

Election to rescind must be communicaterl to other party.

If on the other hand the party elects to rescind, he is to manifest that election by distinctly communi. cating to the other party his intention to reject the

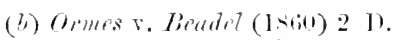
F. .I. 332. 331, 3* L. I. ('h. 1. (c) riemplell v. Fleming (15.34) 1 A. E E. 40. 53 R. R, 1:4. This does not apply where a new and distint cause of rescission arises: (rimy r. Fineler (1si3) L. L. \& Ex. $2+4,42$ L. J. Ex, 161. 
contract and claim no interest under it. One way of doing this is to institute proceedings to have the contract judicially set aside, and in that case the judicial rescission, when obtained, relates back to the date of the commencement of such proceedings $(d)$. Or if the other party is the first to sue on the contract, the rescission may be set up as a defence, and this is itself a sufficient act of rescission without any prior declaration of an intention to rescind $(e)$. For the purposes of pleading the allegation that a contract was procured by fraud has been held to import the allegation that the party on discovering it disaffirmed the contract $(f)$. Where the rescission is not declared in judicial proceedings, no further rule can be laid down than that there should be "prompt repudiation and restitution as far as possible" $(g)$. The communication need not be formal, provided it is a distinct and positive rejection of the contract, not a mere request or inquiry, which is not enough $(h)$. But it seems that if notwithstanding an express repudiation the other party persists in treating the contract as in force, then judicial steps should be taken in order to make the rescission complete as against rights of third persons which may subsequently intervene. Especially this is the case as to repudiating shares in a company. The creditors of a company are entitled to rely on the register of shareholders for the time being, and therefore it is not enough for a shareholker to give notice to the

(d) Reese River silles Mining (io. v. Simith (INti9) L. IR. 4 Jl. I. 73-5, 39 L. J. (1. 819. As to shares in companies, see below.

(i) rlomgh v. L. i. I. II. Iiy. ro. (187I) (Ex. ('h.) J. R. I Lx. 3ti. 4] I.. J. Ex. 17 .

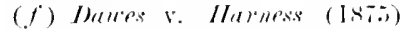
L. R. I0 ('. P. 166;, 11 L. . I. ('. I'. 1!14. The earlier cases there citel, eqpecially ingusit Liff lswaramer

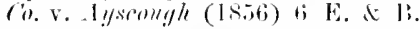

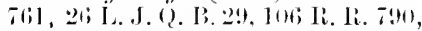
are not wholly comsistent.

(a) Pur liramwell Ii, Juldh-y.

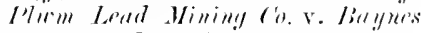
(1sii) I. R. 2 Ex. 326, 3i I\% J. E.x. I S.?.

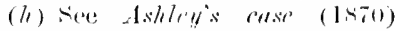
L. Li.9 Lit. 263,39 L. J. ('1. 3.it.
What connmunication sutficient. 
company that he claims to repudiate. A stricter rule is applied than would follow from the ordinary rules of contract (i.). "The rule is that the repudiating shareholder must not only repudiate, but also get his name removed, or commence proceedings to have it removed, before the winding-up $(k)$; but this rule is subject to the qualification that if one re. pudiating shareholder takes proceedings the others will have the benefit of them if, but only if, there is an agreement between them and the company that they shall stand or fall by the result of those procecdings, but not otherwise" (l). Where the original contract was made with an agent for the other party, communication of the rescission to that agent is sufficient, at all erents before the principal is disclosed $(\mathrm{m})$. And where good grounds for rescission exist, and the contract is rescinded by mutual consent on other grounds, those grounds not being such as to gire a right of rescission, and the agent's consent being in ercess of his authority, yet the rescission stands good. There is nothing more that the party ean do, and when he discovers the facts on which he might have sought rescission as a matter of right he is entitled to use them in support of what is already done. In Wright's case $(n)$ the prospectus of a company contained material misrepresentations.

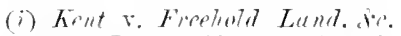

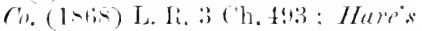
chese (latig) L. R. t ('h. $203 ;$ Re

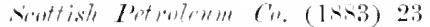
('h. L)iv. 113. But if there are several repuliating sharehollers in a like poition. proceeding taken by one of them and treated by agrement with the company as representative will enmre for the

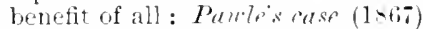
L. R. 4 Ch. 497 . 35 L. J. ' 'h. 31s:

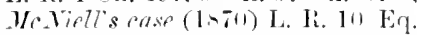
5013,39 1. J. (h. A22. aluarently rests only on this ground: sie review of cases per Baggallay I..J. 23 (h. D. at 1.433.

(k) I.p. before the presentation of a winding-up petition on which an orler is made: Whiteley's case [1:89] 1 Ch. 770.68 L. J. Ch. $3+i 5$.

(i) Lindley L.J. 23 Ch. D. at p. $4: 37$.

(m) Maynard v. Laton (18it) I. R. \% Ch. 414,43 L. J. Ch. 641 .

(n) $(18.1)$ L. R. 7 Ch. 35.41 T.. .J Ch. 1 : ep. clomgh v. L. i. I. H. Ry. со., sitpra, p. fors. 
The directors had at a shareholder's request, and on other grounds, professed to cancel the allotment of his shares, which they had no power to do, though they had power to accept a surrender. Afterwards the company was wound up, and then only was the misrepresentation made known to him. But it was held that as there was in fact a sufficient reason for annulling the contract, which the directors knew at the time though he did not, the contract was effectually annulled, and he could not be made a contributory even as a past nember $(o)$.

Inasmuch as the right of rescinding a voidable contract is alternative and co-extensive with the right of affirming it, it follows that a voidable contract may be avoided by or against the personal representatives of the contracting parties $(p)$. And further, as a contract for the sale of land is enforceable in equity by or against the heirs or devisees of the parties, so it may be avoided by or against them where grounds of avoidance exist $(q)$.

A party exercising his option to rescind is entitled to be restored so far as possible to his former position. This includes a right to be indemnified against obligations incurred under the contract, and in cases of fraud, but in such cases only $(r)$, the right may extend to liabilities which are natural consequences

(1) But Wiekens V.-C. thought otherwise in the court below ( $\mathrm{L}$. L. $12 \mathrm{E}$. . 331) and the correctues of the reversil is dombted by Loril lindley (on tompanies, 77 ).

(p) Including assignees in bank. ruptey : Lead v. Cimen (1816) 15 11. d IV. 216,15 L. J. Lx. 113 ; Itomaldsion v. Furwell (187ii) 913 I. S. 6.83 .

(4) Ciresley vo Mlenstey (IstiI) 1 le G. \& J. is ; and sec eases wited
Right of reveission exereivable by and against reprecentatives. in next chapter, ad fin., and (hurtes. v. Treeplyen (1844) 11 ('l. . E F. 714 , where the parties on both sides were nltimately representatives, and as to the defemdints through nore than one suceession.

(r) Blhittington vo somle-Hoyne (Ismi) 42 [.. 'I'. 4!, per Farwell .J. atlopting buwen L.J.'s (ninion in

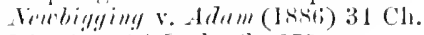
live sige, 5ti L. I. ' 'h, 275. 
of the contract though not created by the contract itself.

Yo rescision unless parties can be restored to former position.

Where the prarty in fault has acted on the faith of the contract.

Common deralings with subject. mater of contract.

B. The contract cannot be rescinded after the position of the parties has been changed so that the former state of things cannot be restored.

This may happen in various ways. The party who made the misrepresentation in the first instance may have acted on the faith of the contract being ralid in such a manner that a subsequent rescission would work irreparable injury to him. And here the rule applies, but with the important limitation, it seems, that he must have so acted to the linowledge of the party misled and without protest from him, so that his conduct may be said to be induced by the other's delay in repudiating the contract. Thus where a policy of marine insurance is roidable for the nondisclosure of a material fact, but the delay of the underwriters in repudiating the insurance after they know the fact induces the assured to believe that they do not intend to dispute it, and he consequently abstains from effecting any other insurance, it would probably be held that it is then too late for the underwriters to rescind $(s)$. Or the interest taken under the contract by the party misled may have been so dealt with that he cannot give back the same thing he received. On this principle a shareholder cannot repuliate his shares if the character and constitution of the company have in the meantime been altered. This was the case in Clarke r. Dickson $(t)$, where the plaintiff had taken shares in a cost-book mining company. The company was afterwards registered under the Joint Stock Companies Act then in force,

(s) Fer Cur. Morristn v. C'mirer.

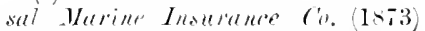
(Ex. (h.) 1. li. \& Ex. at p. $20 \%$; ch. ('lough r. L. A I. H. Iiy. Co. (1nil) (Ex. Ch.) L. H. I F.x. at 1. 35.

(t) $(150$ (1) E. B. \& E. 148,27 L. J. Q. B. 223,113 R. R. 583 . 
apparently for the sole purpose of being wound up. In the course of the winding-up the plaintiff discovered that fraudulent misrepresentations had been made by the directors. But it was by this time impossible for him to return what he had got; for instead of shares in a going concern on the costbook principle he had shares in a limited liability company which was being wound up $(u)$. It was held that it was too late to repudiate the shares, and his only remedy was by an action of deceit against the director's personally responsible for the false statements $(x)$. As Crompton J. put it, "You cannot both eat your cake and return your cake" (y). A similar case on this point is Western Bank of Scot. land v. Addia $(z)$. There the company was an unincorporated joint stock banking company when the respondent took his shares in it. As in Clarke v. Dickson, it was afterwards incorporated and regis. tered for the purpose of a voluntary winding-up. It was held as a probable opinion by Lord Chelmsford, and more positively by Lord Cranworth, that the change in the condition of the company and of its shares was such as to make restitution impossible, and therefore the contract could not be rescinded $(a)$. There is some reason to think that where goods or securities have been delivered under a contract void-

(11) The fact of the wimling-up having begun before the repulliation of the shares is of itself teeisive according to the cases muler the later Companies Acts; but here the point was harlly male.

(x) Which course was aceordingly taken with sllecess: (1/arlip

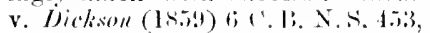
28 L. . . C. l'. 22.5. These prin. eiples do not apply where a sharebohler, lasving haul his shares forfeited for non-prayment of catls, and thereby ceased in be a menter of the coninany, is sued for the calls in arrear and defents on the ground of fraul. After he is remitted to the position of a mere debtor of the company he is mot bound to take any active steps: Iarou's lients v. Thiss $[1596]$ A.C. 273,65 L. J. l'. (1.54.

(y) E. H. \& E. at 1, 152. 113 Ii. Ii. isis.

(:) 1. 1. 1 se. d I). 11.).

(ii) It would seem, but it lases not elearly appear, that in this case also the mispepresentations were mot discosered till after the coms. mencement of the winling-up. 
able by the buyer on the ground of fraud, and before the repudiation their value has materially fallen through some cause unconnected with the fraud, this is such a change in the condition of the thing contracted for as to make restitution impossible in conduct of law $(b)$. The case is simpler where the party misled party misled. has himself chosen to deal with the subject-matter of the contract, by exercising acts of ownership or the like, in such a manner as to make restitution impossible; and it is still plainer if he goes on doing this with knowledge of all the facts; if the lessee of mines, for example, goes on working out the mines after he has full information of the cir. cumstances on which he relies as entitling him to set aside the lease $(c)$. So a settlement of partnership accounts or a release contained in a deed of dissolution $(d)$ cannot be disputed by one of the parties if in the meantime the concern has been completely wound up and he has taken possession of and sold the partnership assets made orer to him under the arrangement $(c)$; and an arrangement between a company and one of its directors which has been acted upon by the company so as to change the director"s position cannot afterwards be repudiated by the company $(f)$. So a purchaser cannot after taking possession maintain an action to recover back his deposit $(g)$.

The right to recover back money paid under an agreement on the ground of mistake, failure of con-

(b) Waddell r. Blocliey (1-ia) 4

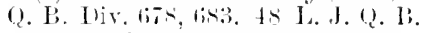
517, per The siger l...j.

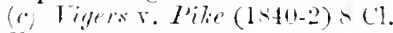

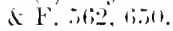

(d) Iryphart r. Marpherson (1858) 3 A ur. Ca. 831.

(e) skilbeck r. Hilton (1sibi) L. H. $2 \mathrm{Eq} .58 \pi$. (f) Shethitd Virkel Co. r. Tmuin (186) 2 Q. B. D. 214,46 L.J. 2. B. 2949

(a) Bldedilurn r. Smith (15ts)

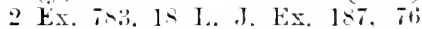
h. li. is: but it was also held that ajart from this the objection came too late under the conditions of sale in the particular case. 
sideration, or default of the other party is also subject to the same rule. Thus a lessee who has entered into possession cannot recover back the premium paid by him on the ground of the lessor's default in execut. ing the lease and doing repairs to be done by him under the agreement $(h)$ : nor can a party recover back an excessive payment after his own dealings have made it impossible to ascertain what was really due $(i)$.

C. The contract camnot be rescinded after third tro rescission persons have acquired rights under it for value.

The present rule is altogether, as the last one is to some extent, a corollary from the main principle that a contract induced by fraud or misrepresentation is as such not void but only roidable. The result is that when third persons have acquired rights under the transaction in good faith and for value, those rights are indefeasible. The rule is also stated to be an application of the principle of convenience "that where one of two innocent parties must suffer from the fraud of a third, the loss should fall on the one who enabled the third party to commit the fraud" $(k)$.

Thus when a sale of goods is procured by fraud, the property in the goods is transferred by the conFrawlulent sales. tract (l), subject as between the seller and the buyur to be revested by the seller exercising his option to rescind when he discovers the fraud. A purchaser in good faith from the fraudulent buyer acquires an

(h) IHunt v, ville (1501) : Last 419. 7 R. R. 73!1.

(i) Frerman v. Jeffries (1869) L. R. 1 Ex. 189, 197, 38 I. J. Ifx. $11 \%$.

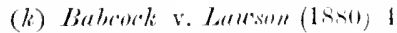
Q. H. W. at 1. fin.

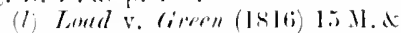
W. 2li, 1; I. J. Rix. 113. I li. R.
627. where it was held that a fraudulent buyer becoming bankrupt had not the goots in his order and disposition with the consent of the true owner: for the veurlor became the true owners only when they elected to reseinil and demanderl the goods from the asignees. 
Distinction where there is no con. tract, but goods are merely obtained by fraudulent pretences.

indefeasible title $(m)$ now confirmed by the Sale of Goods Act, 1893, which abolished a statutory exception $(n)$. And a person who takes with notice of the fraud is a lawful possessor as against third persons, and as such is entitled to sue them for all injuries to the property, unless and until the party defrauded exercises his right of rescission $(0)$.

The same rule holds good as to possession or other partial interests in property. A. sells goods to B., but resumes the possession, by arrangement with B., as a security for the price. Afterwards B. induces A. to re-deliver possession of the goods to him by a fraudulent misrepresentation, and thereupon pledges the goods to C., who advances money upon them in good faith and in ignorance of the fraud. This pledge is valid, and $C$. is entitled to the possession of the goods as against $\mathrm{A} .(p)$.

It must be carefully observed that a fraudulent possessor cannot give a better title than he has himself, even to an innocent purchaser, if the possession has not been obtained under a contract with the true owner, but by mere false pretences as to some matter of fact concerning the true owner's contract with a third person. To put a simple ease, A. sells goods to B. and desires B. to send for them. C. obtains

(III) IItite v. Gurden (18.5I) 10 C'. Ii. 919, 20 L. J. C. I'. ltiti. st li. li. stei: Steremsom ve Nirlenteem (1.53) (Ex. (h.) 1:3 C. R. 295, 303, 22 L. J. (C. I'. 110, 115,93 I. li. 3:32, st2 : cp. 12 Apr. Ca.at p. 483.

(ii) $24 \& 25$ Vict. e. 96. s. 100, extended the re-resting of molerty in the true owner unom the thicf's conviction to caves of obtaining goods by criminal fraud not amounting to larceny : Bentley $\mathrm{s}$. Tilmont (1sis) I2 App. Ca. 471, it L. J. Q. B. 1s, overmling Mloyse v.

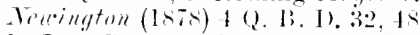
L. J. 1. B. I25; the sale of rouls
Act, s. 24, restores the older law.

(i) Stecenson v. Tewnham, see note $(m)$.

(p) Perse v. Glouhere (186ti) L. R. I P. (C. 219.35 L. J. P. C. 66. The clealings were in fact with the bill of lading : but as this completely represented the gools for the purposes of the ease the statement in the text is simplitied in order to bring ont the general principle more elearly. A later case of the same lind is Babork ง. Laxesen (1880) 5 Q. R. Dir, 24t. 4! L. J. Q. B. 40. 
the goods from A. by falsely representing himself as B.'s servant: now C. acquires neither property nor' lawful possession, and cannot make any sale or pledge of the goods which will be valid against $A$., though the person advancing his money have no notice of the fraud. The result is the same if $A$. means to sell goods to B. \& Co., and C. gets goods from $A$. by falsely representing himself as a member of the firm and authorized to act for them $(q)$, or if B., a person of no credit, gets goods from A. by trading under a name and address closely resembling those of $\mathrm{C}$., who is known to $\mathrm{A}$. as a respectable trader $(r)$. It is also the same in the less simple case of a third person obtaining delivery of the goods by falsely representing himself as a sub-purchaser; for here there is no contract between him and the seller which the seller can affirm or disaffirm; what the seller does is to act on the mistaken notion that the property is already his by transfer from the original buyer. This was in effect the decision of the Exchequer Chamber in Kingsford v. Merry (s), though the case was a little complicated by the special consideration of the effect of delivery orders or warrants as "indicia of title."

The decision of the House of Lords in Oakes $v$. shareholder Turquand $(t)$, which settled that a shareholder in a company cannot repudiate his shares after the com-

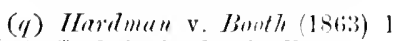
H. \& C. 8013, 32 1. .1. Fx. 105: Hollins v. Fimeler (1S7I-i) I. R. i H. I. 757,795 .

(r) Cumb!y v. Limdsu!! (1sis) 3

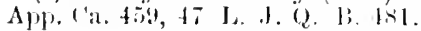
Otherwise where the fraud stop short of personation, and is only a false representation of the party's condition and means: Attrubstomigh

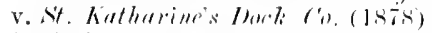

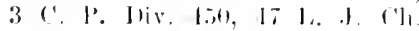

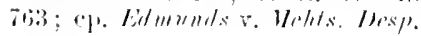

Tronsy. ('0. J35 Mass. 24.3, which goes farther.

(s) $(1$ S.;6) 1 II. A N. 503,$26 ;$...J. lix.s.3 (see pro Erle $J$ at p. sis), los R. li. 6944, revg. s. c. in court lekw, 1 ] kx. $577,25 \mathrm{I}_{0} \mathrm{~J}$. Ex. 166. (t) $(1567)$ 1. 16.,2 II, J. 325,$36 ;$ l. .t. (th. 9l?. This principle applies to a roluntary as well as at rompulsory winding-11p: Stome v.

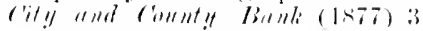

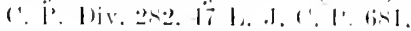

cant repudialte after winding.np: Oake: $r$. 'T'uluatul.

$$
x+2
$$


mencement of a winding-up, proceeded to a considerablc extent upon the language of the Companies Act, 1862 , in the sections defining who shall be contributories. But the broad principles of the decision, or if we prefer to say so, of the Act as interpreted by it, are these. The rights of the company's creditors and of the shareholders are fixed at the date of the winding-up and are not to be afterwards varied. The creditors are entitled to look for payment in the first instance to all persons who are actually members of the company at the date of the winding-up. And this class includes shareholders who were entitled as against the company to repudiate their shares on the ground of fraud but have not yet done so. For their obligations under their contracts with the company, including the duty to contribute in the winding-up, were valid until rescinded, and the creditors in the winding-up must be considered as being, to the extent of their claims, purchasers for value of the company's rights against its members. They are not entitled to any different or greater rights: no share. holder can be called upon to do more than perform his contract with the company $(u)$.

It is now settled law that the same rule applies to joint-stock companies not under the Companies Acts. And the date after which it is too late to repudiate shares may be earlier than the commencement of the winding-up. Probably the actual insolvency of the company fixes this date: at all events a shareholder cannot repudiate after the directors have convened an extraordinary meeting to consider whether the

(u) Waterhousse v. Jamieson (1580) L. F. 2 sce. II I. 29. In Jall r. Old Thlargerh Lesd Mining Co. (INiti) 3 Ch. D. 74!. 4; L. J. (h. 7.5, an action for rescission and indemnity commenced by a shareholder after a resolution for winding-up but in ignorance of it was allowed to proceed. Here however relief was chaimed against the directors personally as well as the company. 
company shall be wound up. For thus, "by holding out to the body of creditors the prospect of a voluntary winding-up," the directors, who are the shareholder's agents as long as he remains a shareholder, stay the hands of the creditors from compulsory proceedings $(x)$. And the rule holds even if there are no unpaid creditors. "The doctrine is, that after the company is wound up it ceases to cxist, and rescission is impossible" $(y)$.

On the other hand, persons who have taken any gratuitous benefit under a fraululent transaction, though themselves ignorant of the fraud, are in no better position than the original contriver of it. Thus where a creditor was induced to give a release to a surety by a fraud practised on him by the principal debtor, of which the surety was ignorant, and the surety gave no consideration for the release, it was held that this release might be disaffirmed by the creditor on discovering the fraud. But third persons who on the faith of the release being ralid had advanced money to the surety to meet other liabilities would be entitled to assert a paramount claim (z).

D. The contract must be rescinded within a reasonable time, that is, before the lapse of a time after the true state of things is linown, so long that under the circumstances of the particular case the other party may fairly infer that the right of rescission is waived.

It is believed that the statement of the rule in some such form as this will reconcile the substance

(x) Trunent r. r'ity of Gilesigoum

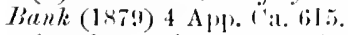

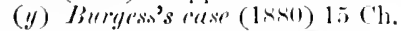
1). 507,5199, 19 h. J. Ch, 5l1 (Jessel M.R.).

(z) Shlutefiold v. Trmpler (1859) Johns. 155, 165, 4 De (i. \& J. H29,
28 1..J. (h. 452. The cont behw endeavourel to provile for the payment of the third persons in guestion (Johns. 171), but the court of Apeal varied the decre by making it simply without prejulice to their rights: I le (i. I. I. A35.
Rescission must be within reasonable time.

Explanation of this: the importance of time 
is not perse: and language of all the leading authorities. On the bit as eridence of acquiescence. Authorities in equity. cne hand it is often said that the election must be macie within a reasonable time, while on the other hand it has several times been explained that lapse of time as such has no positive effect of its own. The Court is specially cautions in entertaining charges of fraud or misrepresentation brought forward after a long interval of time; it will anxiously weigh the circumstances, and consider what evidence may have been lost in consequence of the time that has elapsed $(a)$. But time alone is no bar to the right of rescinding a roidable transaction; and the House of Lords in one case set aside a purchase of a principal's estate by his agent in another name after the lapse of more than half a century, the facts having remained mnlinown to the principal and his representatives for thirty-seren years (b). In a later case the Lord Justice Turner stated expressly that "the two propositions of a bar by length of time and by acquiescence are not distinct propositions." Length of time is eridence of acquiescence, but only if there is linowledge of the facts, for a man cannot be said to have acquiesced in what he did not know (c). Lord Campbell slightly qualified this by adding, that although it is for the party relying on acquiescence to prove the facts from which consent is to be inferred, "it is easy to conceive cases in which, from great lapse of time, such facts might and ought to be presumed " $(d)$.

(ii) Clr. Briglet v. Leyerton $(1-61)$ 21). F. J. 6016. +17.

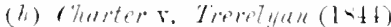

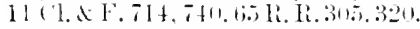
(c) Lifi Associntion of Sortland

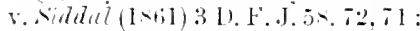
on the point that there cannot be accule-ence without lnowledge:

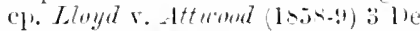
G. \& J. 614. 6.91, 29 L. J. Ch. 97 ; per Allerson B. Land r. Girepn

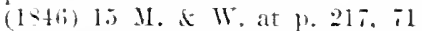
li. Ii. 628: "A man cannot permit who does not know that he has a right to refuse:" and per Jessel M.R. 1 ('h. 1). I.2s.

(d) 3 I. F. J.at 1, 77. The case wa-one not of rescinding a cont raet but of a breach of trinst: but the principles are the same. 
The rule has been laid down and acted upon by the Judicial Committee in this form: "In order that the remedy should be lost by laches or delay, it is, if not universally, at all events ordinarily . . . necessary that there should be sufficient knowledge of the facts constituting the title to relief " $(e)$.

To the same effect it has been said in the Supreme Court of the United States: "Acquiescence and waiver are always questions of fact. There can be neither without knowledge." And the knowledge must be actual, not merely possible or potential: "the wrongdoer cannot make extreme vigilance and promptitude conditions of rescission " $(f)$.

Acquiescence need not be manifested by any positive act; the question is, whether there is sufficient evidence either from lapse of time or from other circumstances of "a fixed, deliberate and unbiassed determination that the transaction should not be impeached " $(g)$. In estimating the weight to be given to length of time as evidence of acquiescence the nature of the property concerned is material $(h)$. And other special circumstances may prevent lapse of time even after everything is known from being evidence of acquiescence; as when nothing is done for some years because the other party's affairs are in such a condition that proceedings against him would be fruitless $(i)$. "In questions of this lind

(e) Lindsay Petroteum ri. v. Hurd (1874) L. R, 5 P. C. 241.

(f) Penere v. Langdon (1878) 99 U. s. at p. sst.

(g) Per Turner I..J. Hright v. landerplank (15is) \& 1). iI. (i. 133, 1.7, 25 L. J. ('ll. 73:3, 114 k. li. 60. The epithets, however, are more specially appropriate to the part ienular gromed of rescission (undue intluence) then before the Court. Nore generally, the only proper meaning of acquiescence is quiescence under such eircumstances that assent may be reasonably inferred from it: per ('ur. in fle Busselle v. Alt (1s7a) 8 (h. Div at 1. 314,47 L.J. Ch. $3+6 ;$.

(h) \& I). H. (4. at 1) 150.

(i) Siblelefinld v. Te'mplte (185:) 4 le (. d J. 429, 25 L. J. Cli. 452. 
special obligation of diligence in case of shareholders.

it is not only time but the conduct of the parties which has to be considered" $(k)$.

If a party entitled to avoid a transaction has precluded himself by his own acts or acquiescence from disputing it in his lifetime, his representatives cannot come forward to dispute it afterwards $(l)$.

It is said that holders of shares in companies are under a special obligation of diligence as to making their election, but the dicta relate chiefly if not wholly to objections apparent on the face of the memorandum or articles of association. With the contents of these a shareholder is bound to make himself acquainted, and must be deemed to become acquainted, when his shares are allotted $(m)$. But objections which can be taken upon these must proceed on the ground, not of fraud or misrepresentation as such, but of the undertaking in which shares are allotted being substantially a different thing from that which the prospectus described and in which the applicant offered to talie shares. Nor are we aware of any case in which the rule has been applied to a repudiation of shares declared before a winding-up and on the ground of fraud or misrepresentation not apparent on the articles. Still it seems quite reasonable to hold that in the case of a shareholder's contract lapse of time without repudiation is of greater importance as evidence of assent than in most other cases.

Same general The authorities thus far cited have been from courts rule at law, per cur. in Ex. Ch. of equity. The same general principle was laid down in the Exchequer chamber in 1871. "We think the party defranded may lieep the question open so long

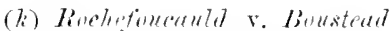
[1:97] l ch. l!n;, 211, C. A., per c'ur.

(l) Strottmere yilliams: (1stil) 3 L. F. J. .335. 541 . (m) rentral Riy. of Tenesuelar. kivele (1stit) L. li. 2 H. L. at 1. 125: Goties v. Iurquand (1stit) il. at 1 . 3.2, and see Ch. IX.. 1. 514, above. 
as he does nothing to affirm the contract . . In such cases the question is, has the person on whom the fraud was practised, having notice of the fraud, elected not to avoid the contract? or has he elected to avoid it? or has he made no election? We think that so long as he has made no election he retains the right to determine it either way, subject to this, that if in the interval whilst he is deliberating an innocent third party has acquired an interest in the property, or if in consequence of his delay the position even of the wrongdoer is affected, it will preclude him from exercising his right to rescind. And lapse of time without rescinding will furnish evidence that he has determined to affirm the contract, and when the lapse of time is great it probably would in practice be treated as conclusive evidence to show that he has so determined" $(n)$.

The French law treats the right of having a contract judicially set aside for fraud, \&e, as a substantive right of action, and limits a fixed period of ten years, rumning from the discovery of the truth, within which it must be exercised $(o)$. There are provisions of similar effect in the procedure codes of many of the United States.

One or two points remain to be mentioned, which we have reserved to the last as being matter of pro. cedure, but which depend upon gencral principles. Courts of justice are anxious to discover and dis-

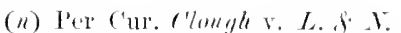

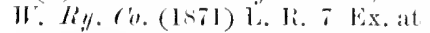
1. 3t, repeated in Morismll v.

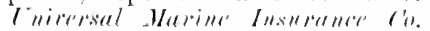

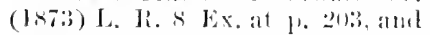
cited by Lord liackburn in lir.

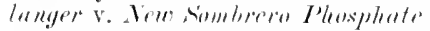
(a. (1878):3 Apr. ('a. at 1). 1277. see the remarks on weliay and acquiscence in the several julgments in that case. Note that the jutgment of the Ex. Ch. in rlomghth v. L. if I. II. Ríy. l'o. was pie. bared thom not delivered by biackburn o. as stated by him later when at lord of Alpeal,

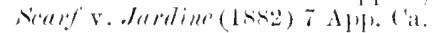
at 11. 38,0 .

(iv) Coder civ. 1301. The Inliam Limitation det (XY. of Ist. Sish. 2 , No. 1II) lixes a prering of three years.
Fixel

period of limitation by French law.

Cufounded charges of framil discouraged: jratties making them most prity conts. 
courage fraud in every shape, but they are no less anxious to discomrage and rebuke loose or unfounded charges of fraud and personal misconduct. The facts relied on as establishing a case of fraud must be distinctly alleged and proved $(p)$. Where such charges are made and not proved, this will not prevent the party making them from having any relief to which ho may otherwise appear to be entitled, but he must pay the costs occasioned by the unfounded charges (q). And in one case, where the plaintiff made voluminous and elaborate charges of fraud and conspiracy, which proved to be unfounded, the Court of Appeal not only made him pay the costs of that part of the case, but refused to allow him the costs even of the part on which he succeeded. It was held that he had so mixed up unfounded and reckless aspersions upon character with the rest of the suit as to forfeit his title to the costs which he otherwise would have been entitled to receive $(r)$.

Independent juriscliction of equity to cancel instruments for frand, sc.

The special jurisdiction of courts of equity to order the cancellation of an instrument obtained by fraud or misrepresentation is not affected by the probability or practical certainty that the plaintiff in equity would have a good defence to an action on the instrument, nor is it the less to be exercised even if the instrument is already in his possession. $\mathrm{He}$ is entitled not only not to have the contract

(p) Thus mder the old system of equity plealing a charge of framl in greneral terms would not supprort a bill on demurer: crilbert ․ Levis (1862) 1 1). J. S. at H. 49, 32 I. J. Ch. 347, per Lord Westbury : cp. Lateranee v. Vineres. (1890) 15 Apl). ('a. 210,59 L. J. ('h. (is'1, as to allegations of concealud fraud within the statute of Limita. tions.

(q) Ililliard v. Eiffe (18it) L. R.
7 H. L. 39, 51, 52; London Chartered Bank of Australia v. Lemprieve (1s-3) L. R. 4 P. C. at 1). 597 ; rlinch \&. Finumial Corpuration (1868) L. R. 5 Eq. at p. 4 $43.3 \mathrm{~s}$ L. J. C'h. 1; per Lord ('airns, Thompsom v. Eustelood (187T) $2 \mathrm{App}$. (a. at p. 243 .

(r) Parker v. Mikenna (187t) I. R. 10 Ch. $96,123,125,44$ L. J. (1). 425 . 
enforced against him, but to have it judicially annulled $(s)$.

(s) London s' Prorincial Insur. ance ('o. v. Seymour (1873) I. R. $17 \mathrm{Eq} .85,43 \mathrm{~L}$. J. (h. 120; and see Hoare v. Bremridlye (1872) L. R. 8 Ch. 22 , 42 L. J. Ch. 1. there explained and distinguished. Therefore a defendant sued on an instru. ment which he alleges to be voidable may properly add to his defence a counter-elaim for the cancellation of the instrument. It may also be proper to ask for a transfer to the ('hancery bivision if the action is in the King's Rench Division, but this is not a matter of eourse. See storey v. Waddle $(1879)+$ Q. 13. liv. 2s:. Where, eonversely, a purchaser snes for the retmon of his deposit, and the vendor comberelaims for specific performance, a transfer to the Ch. W. will generally be ordered: Latudan Lamd ro. v. Hamis (1884) 13 Q. B. D. 540, 53 L. J. Q. 1. 531 . 


\section{6}

\section{CHAPTER XII. \\ Duress axd Txdue Ixfluexce.}

Coutraet voidable if convent not free.

The common law doctrine of Dures:.

Ir the consent of one party to a contract is obtained by the other under such circumstances that the consent is not free, the contract is voidable at the option of the party whose consent is so obtained. It is quite clear that it is not merely roid so long as there is consent in fact $(a)$. The transaction might indeed be void if the party were under actual physical constraint, as if his hand were forcibly guided to sign his name; but this wonld be not because his consent was not free, but because there was no consent at all.

What then are the circumstances which are held by English courts to exclude freedom of consent? The treatment of this question has at common law hecn singularly narrow and in equity singularly comprehensive.

\section{Duress at Common Law.}

At common law the coercion which will be a suffcient cause for aroiding a contract may consist in cluress or menace; that is, either in actual compulsion or in the threat of it. In modern books the term duress is nsed to include both species. It is

(a) Co. ㄴ Inst. 402. and 2mal

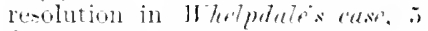
Co. Riefr. 119. In two nodern calses a marriage has been ammulled on the ground that cuerein, or a mixture of ecercion and frani, hat gone to the point of excluding any real eonsent on the womans part:

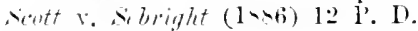
21, in 1. I. I'. 11: Fird r. Nitier. 1.6."i] I'. 1. ti: L. J. l'. 13. The facts of lorth these ense were most exceptional. 
said that there must be some threatening of life or member, or of imprisonment, or some imprisonment or beating itself. Threatening to destroy or detain, or actually detaining property, does not amount to duress (b). And this applies to agreements not under seal as well as to deeds $(c)$. The reason appears to be that the detainer is a wrong of itself, for which there is an appropriate remedy. Should the party choose to make terms instead of pursuing his rights (at all events when there is nothing to prevent him from so doing), he cannot afterwards turn round and complain that the terms were forced upon him $(d)$. "It must be a threatening, beating, or imprisonment of the party himself that doth make the deed, or his wife" (b) or (it seems) parent or child (e). And a threat of imprisomment is not duress unless the imprisonment would be unlawful. This is illustrated by two rather curious modern cases, in both of which the party's consent was determined by the fear of confinement in a lunatic asylum. In Cumming $\mathrm{r}$. Ince $(f)$ the plaintiff had been taken to a lunatic asylum and deprived of the title deeds of certain property claimed by her. Proceedings were commenced under a commission of lunacy, but stayed on the terms of an arrangement signed by counsel on both sides, under which the deeds were to be deposited in certain custody. The plaintiff afterwards repuliated this arrangement and brought detinue for the rleeds. On an issue directed to try the right to the posses sion of the deeds as between herself and the other parties the Court held that in any view the defen-

(b) Shepp. Touch. (it.

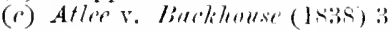
MI. \& W. 6333: sterute v. Pirule (1840) 11 A. \& R. !143, .2 R. R. 554.

(d) See Sillimun v. Inited states
(1879) 101 U. S. 465.

(1) Lio. Al. 1. 685, 11. o; Hace

Ab. Huresis (B).

(f) $(1817-4) 11$ Q. B. 112, 17 L. . . Q. R. 105. 75 R. R. 29\%.
In a case of menace the threat must be of something unlawful. 
dants were wrong. For if their own proceedings under the commission were justified, they could not say the plaintiff was competent to bind herself, and if not, the agreement was obtained by the fear of a merely unlawful imprisonment and therefore voidable on the ground of duress. And it made no difference that the plaintiff's counsel was party to the arrangement. His assent must be considered as enforced by the same duress: for as her agent he might well have feared for her the same evils that she feared for herself. In Biffin v. Bignell $(h)$, on the other hand, the defendant was sued for neces. saries supplied to his wife. She had been in a lunatic asylum under treatment for delirium tremens, and on her discharge the husband promised her $12 \mathrm{~s}$. a week to live apart from him, adding that if she would not he would send her to another asylum. The wife was accordingly living apart from the husband under this agreement. It was held that her consent to it was not obtained by duress, for under these circumstances " the threat, if any, was not of anything contrary to law, at least not so to be understood": consequently the presumption of authority to pledge the husband's credit was effectually excluded, and the plaintiff could not recover $(i)$.

Mones paid under circum stances of compulsion recoverable back.

The narrowness of the common law doctrines above stated is considerably mitigated in practice, for when money has been paid under circumstances of practical compulsion, though not amounting to duress, it can generally be recovered back. This is so when the payment is made to obtain the possession of property wrongfully detained $(k)$; and the property need not

(h) 18627 H. \& .477 .31 L. J. Ex. 1 199.

(i) , whether in any case he conhlhave recovered without showing that the wife hat repuliated the arrangement.

(h) Wieletield 8 . Terben (184t) (i) (1. 1. 27ti. 290, 13 L. J. Q. B. 258 ; Cireen 8 Durkett (1883) 11 Q. B. 1). $27, .52$ L. J. Q. B. 435. 
be goods for which the owner has an immediate pressing necessity, nor need the claim of the party detaining them be manifestly groundless, to make the payment for this purpose involuntary in contemplation of law $(l)$. So it is where excessive fees are taken under colour of office, though it be usual to pay them $(\mathrm{m})$; or where an excessive charge for the performance of a duty is paid under protest $(n)$. The person who actually receives the money may properly be sued, though he receive it only as an agent $(o)$. The case of one creditor exacting a fraudulent preference from a debtor as the price of his assent to a composition $(p)$ is to a certain extent analogous. But in all these cases the foundation of the right to recover back the money is not the involuntary character of the payment in itself, but the fact that the party receiving it did no more than he was bound to do already, or something for which it was unlaw. ful to take money if he chose to do it, though he had his choice in the first instance. Such payments are thus regarded as made without consideration. The legal effect of their being practically involuntary, though important, comes in the second place; the circumstances explain and excuse the conduct of the party making the payment. Similarly in the kindred case of a payment under mistake the actual founda. tion of the right is a failure of consideration, and ignorance of material facts accounts for the payment having been made. The common principle is that if

(l) Shluw v. 11 ind B. d C. 73,31 R. Li. 158.

(m) Jow v. I't wom (Isla) 2 l. \& All. intiz, 21 li. li. lul : steeler.

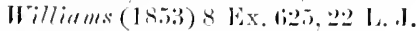
Ex. 225.

(n) l'urlier v. (i. If. Ml/. (\%.

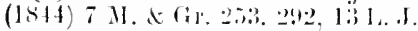
C. L'. 105, And seeother anthoritim
Iint on the gromnd not of cuercion in itself but of failure of consideration. mollected in wotes to Murvint $r$. Ilalliptoll (17!li) 2 sin. J. ('. $1: 21$.

(a) Sterler. Il illiams, note (iil).

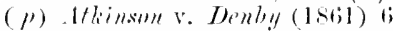
11. d N.77x. 30 L. J. Wx. 3til. in

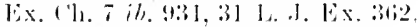

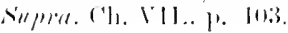


a man chooses to give away his money, or to take his chance whether he is giring it away or not, he cannot afterwards change his mind; but it is open to him to show that he supposed the facts to be otherwise or that he really had no choice. The difference between the right to recover money back under circumstances of this kind and the right to rescind a contract on the ground of coercion is further shown by this, that an excessive payment is not the less recoverable if both parties honestly supposed it to be the proper payment $(q)$. We therefore dwell no farther on this topic, but proceed to consider the more extensive doctrines of equity.

\section{The equitable doctrine of Undue Influence.}

The equitable doctrine of Endue Influence.

renerality of the principle.

In equity there is no rule defining inflexibly what lind or amount of compulsion shall be sufficient ground for aroiding a transaction, whether hy way of agreement or by way of gift. The question to be decided in each case is whether the party was a free and roluntary agent $(r)$.

Any influence brought to bear upon a person entering into an agreement, or consenting to a disposal of property, which, having regard to the age and capacity of the party, the nature of the transaction, and all the circumstances of the case, appears to have been such as to preclude the exercise of free and deliberate judgment, is considered by courts of equity to be undue influence, and is a ground for setting aside the act procured by its employment.

"The principle applies to every case where influence is acquired and abused, where confidence is

(q) Dew v. Pupsums 1819) 2 B. ( Ald. i62. 2I R. R. 404 .

(i) Williems v. Bayley (1stivi)
I. R. 1 H. L. $200,210,35$ L. J. Ch. $71 \%$ 
reposed and betrayed" $(s)$. Such cases are thus classified by Cotton L.J. "First, where the Court has been satisfied that the gift was the result of influence expressly used by the donee for the purpose; second, where the relations between the donor and donee have at or shortly before the execution of the gift been such as to raise a presumption that the donee had influence over the donor. In such it case the Court sets aside the voluntary gift, unless it is proved that in fact the gift was the spontaneous act of the donor acting under circumstances which enabled him to exercise an independent will and which justifies the Court in holding that the gift was the result of a free exercise of the donor's will. The first class of cases may be considered as depending on the principle that no one shall be allowed to retain any benefit arising from his own fraud or wrongful act. In the second class of cases the Court interferes, not on the ground that any wrongful act has in fact been committed by the donee, but on the ground of public policy, and to prevent the relations which existed between the parties and the influence arising therefrom being abused" $(t)$. Yet in many cases of the second class the circumstances might, if they could be fully brought out, amount to proof of actual compulsion or fraud $(u)$; so that it may perhaps $b^{\prime}$ said that undue influence means an influence in the nature of compulsion or fraud, the exercise of which in the particular instance to determine the will of the one party to the advantige of the other is not specifically proved, but is inferred from an existing relation of dominion on the one part and submission

(s) Per Lord Kingstawn, Simith ง. Kay (1809) 7 II. I. C. at 1. 779. (t) flleard r. Nkinmer (18xi) Bir ('l. Hiv. 14i, 171, 56 1.. 1. 11.

?.
10.52.

(ii) ('p. per Linaley [.,I. Bit c h. loiv. al p. 18:?. 
Gieneral intluenee presumed from certain relations.

on the other $(x)$. Given a position of general and habitual influence, its exercise in the particular case is presumed.

But again, this habitual influence may itself be presumed to exist as a natural consequence of the condition of the parties, though it be not actually proved that the one habitually acted as if under the domination of the other. There are many relations of common occurrence in life from which "the Court presumes confidence put" in the general course of affairs "and influence exerted" in the particular transaction complained of $(y)$.

Persons may therefore not only be proved by direct evidence of conduct, but presumed by reason of standing in any of these suspected relations, as they may be called, to be in a position of commanding influence wer those from whom they take a benefit. In either case they are called upon to rebut the presumption that the particular benefit was procured by the exertion of that influence, and was not given with due freedom and deliberation. They must "take upon themselves the whole proof that the thing is righteous $"(z)$. A stringent rule of evidence is imposed as a safeguat against evasions of the substantive law.

"Wherever two persons stand in such a relation that, while it contimues, confidence is necessirily repused by one, and the influence which naturally grows out of that eonfilence is possessed by the other, and this

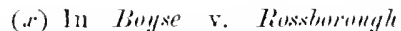
$(18.5-7) 6$ H. L. C. at p. 4s. los li. R. 11. it is sajd that taking the words in a wide sense, all undue intluence may be resolved into enereion and fraul: but the ease there eonsirlered is that of a will, in which undue influence has a more restricled meaning than in transactions inter riros: - ree mote (i), p. titii, infiute.
(1) l'er Lord Kingslown, simith v. Kily (18.5!) 7 H. L. C. 750, 77!.

(z) Grilstll v. Jeyes (I801) 6 Ves. 26it. 27i. ; R. R. 20.5, 303. The like burlen of proof is cast upon those who take any benefit nnder a will which they have themselves been instrumental in preparing or

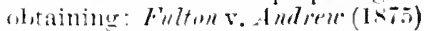
Ł. li. 7 II. L. Ifr. 172. 4t l. J. l'. 17 . 
confidenee is alused, or the influence is exerted to obtain an advantage at the expense of the confiding party, the party so availing himself of his position will not be permitted to retain the alvantage, although the transaction eould not have been impeacher if no sueb eonfidential relation had existed" $(a)$.

"Nothing can be more important to maintain than the jurisdiction, long asserted and uphelel by the Court, in watching over and protecting those who are placed in a situation to require protection as against acts of those who have influence over them, by which acts the person having such influence obtains any benefit to himself. In such cases the Court has always regarded the transaction with jealousy" (b) -a jealousy almost invincible, in Lord Eldon's words $(c)$.

"In equity, persons standing in eertain relations to one another, such as parent and ehile $(d)$ [man and wife] $(e)$, doctor and patient $\left(f^{\circ}\right)$. attorney and client $(g)$, confessor and penitent, guardian and warl (li), are subjeet to eertain presumptions when transactions between then are brought in question; and if a gift or contract male in favour of him who lolds the position of influence is impeached by lim who is subject to that influenee, the courts of equity east upon the former the buthen of proving that the transaction was fairly eonducted as if between strangers, that the weaker was not unduly impressed by the natural influence of the stronger, or the inexperiencel overreached by him of more mature intelligence" (i).

(a) Per Lord Chelmsford, Thit v. II illiemson (I866) L. R. 2 Ch. 55, (il.

(b) Lord Hatherley, Turuer v. C'ollins (I87J) 1. R. 7('h. 329, 333.

(a) Ilatch v. Matele ? les. at 1). 296,7 R. R. 197.

(d) Archer v. Hulsol (1stt) 7 Beav. 551, l3 L.J. (1., 380, tit li. li. l.i2 ; Turner v. (ollins (1871) L. li. 7 ('h. 329, +l I. J. ('h. 5.s.

(r) There does not appear to be any real anthority for this : the relation of husband and wile is not within the rule: Howes v. Bishon [1909] 2 k. li, 3!90, $7 \times$ L. .l. K. li. 7!ni, C. A., sce esperially per latrwell l..d. It seems no longer nise- fut to cite the earlier and indecisive anthorities there considered.

(f') Dent v. Beunett (I 8339$)+$ II d ('r. 269, 48 R. R. 94; Jlurarme v. Iloygen (1s+t) Iru. 310; s. v. Blarkir v. ('lark (1852) la beav. at P. 6413, 92 li. R. .7.5.

(g) (ribson v. Jeyges (Isod) ti Ves.

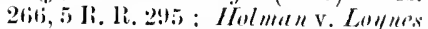
(1451) 4 W. M. (i. 270,23 1. ... th. 529, 1112 li. R. 127; Ciresley v.

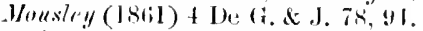

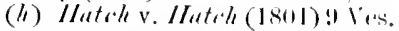

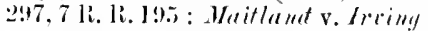
(IsI6) I5 sim. 437, al li. Ii. I1\%.

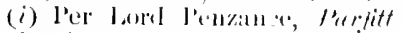

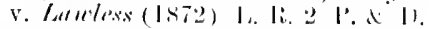
Iti2, Alis, II I. I. I'. Gix. II is to 
This and all similar specifications are merely illustrative.-"As no Court has ever attempted to define fraud, so no Court has ever attempted to define undue influence, which includes one of its many varieties" $(k)$. The cases in which this jurisdiction has been actually exercised are considered as merely instances of the application of a principle "applying to all the variety of relations in which dominion may be exercised by one person over another" $(l)$. As to certain well-known relations, indeed, the Court is now bound by authority to presume influence. As to any other relation which the Court judges to be of a confidential kind it is free to presume that an influence founded on the confidence exists, or to require such proof thereof as it may think fit.

It has even been said $(m)$ that in every case where "one person obtains, by roluntary donation, a large

he moted that this does net anply to wills, as to which mulue intluence

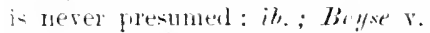

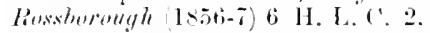
4!1, followed by Ind. Comm. Ban-

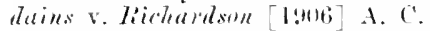

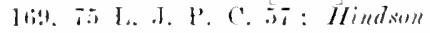
․ Heatherill (lsit) is D. M. (:. 311. :311, 813; though a dispusition ly will may le set aside at well as an act inter riras when umber intlutace is aretualiy proved: but then. it seens, the intluence must be such as to "ovelpower" the woltion. without convincing the julgment" : I1all v. IIall (15tis) L. K. 1 I'. \& D. 4.2. 37 L. J. I'. 40. See Waller v. Simith (1861) 24 beas. 34t. where between the same barties gifts by will were suplorted and a gift inter rires set aride. Lord Penzance adrled to the list of suspected relations that of promotors of a company to the comlany which is their creature: Evlanger r. Iew Sombrere Thosphate ('a. (1877) 3 All'. Ca. at 1. 1230. But is not pessunal contirlence esential to make the present duetrine applicable? And has any case gune the length of casting on a promoter the burlen of proving in the first instance that a contriet letween him and the company was a fair one? Cp. Eden v. Ridsidale's Rableay Lamp and Lighting ('). (185!!) 23 Q. I. Div. 3is, is I. J. Q. B. Sis. where theduty is put on the ground of agency.

(k) Linuley L.J. in All"urd r. skinker (185i) 36 Ch. Dis. at 1. 183.

(l) Sirs. Romilly, ary. IInguètu

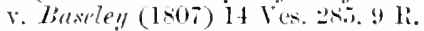
Ii. 283: arlopted by Loml Cottenham. Thent v. Brwnett (1-3:4) t Hy. \& Cr. $269,2 \pi$, tí Ji. li. 14, 1112: Billage v. Sunthee (15.2) 9 Ha. 534. 540, s! H. R. sit. C'p. D'Agnesseau (Eurles. 1. .949) "farceque la raison del'ordonnance est générale, et qu'elle comprend également tous ceux qui peuvent avoir quelque empire sur lesprit des donatenrs, vos arrêts en ont étendu la disposition aux maitres, aux médecins, aux confesseurs." So l'othiel, 'Tr. des domations entre-rifs, vol. vii. 1. $t+1$, in (Eurres, ed. Dupin. 152.).

(in) liy lowd limully in finker. Lumbete $(1-i 1)$ lis litar. 234.240. 
pecuniary henefit from another," the person taling the benefit is bound to show "that the donor voluntarily and deliberately performed the act, linowing its nature and effect;" that for this purpose a voluntary donation means any transaction in which orr. person confers a large pecuniary benefit on another, though it may bo in form a contract $(n)$; and that such is the rule whether there is any confidential relation or not. But these dicta are not law. There is no general presumption against the valiclity of gifts as such (o). Where grounds of unfavourable presumption exist, it is easier to set aside a mere gift than a transaction from which the plaintifl has derived some benefit, though not adequate to what was given for it; and attempts to disguise a gift as a dealing for value are almost always fatal $(p)$. Beyond this, it is conceived, the law does not go.

In the absence of any special relation from which influence is presumed, the burden of proof is on the person impeaching the transaction $(q)$, and he must show affirmatively that pressure or undue influence was employerl.

Having thus stated the fundamental rules, we may proceed to say something more of -

(1.) The auxiliary rules applied hy courts of equity to voluntary gifts in general:

2) I. .I. Ch. 371,92 li. IR. 397.402 ;

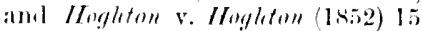
liear. 278,$295 ; 0$ li. Ii. 121, 430); cp. per Lord Hatherley in Phillips v. Mullings (1.51) J. K. 7 (h. 21 1. $216,+1$ H. . ( ) 1 . 211.

(n) E.\%. Coulde v. Letmolle (185i) 15 Beav. 23I, 21 I. I. ('ll. 37I, 92 R. Ii. 397: Mrent v. Benuett

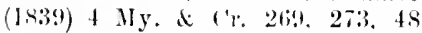
Ii. Ii. $94,99$.

(i) If there wore, the chaborate discension which trok place, r.g. in

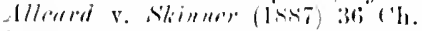
liv. 145, womld have been superlluolls ; and see /lomry v. Armest rom!
(1881) 19 ('h, 1). 6igs, which, llomeh a decision of omle a cordinateanhority with Lond liomilly's, experseces the clear scume of the Eryily bar ever since the present writer can remember it.

(1) Also any innoceut misrepesentation by the donee wherely a voluntary gift is obtained is grominl in couity for aroirling the vift :

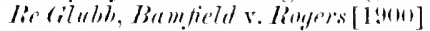

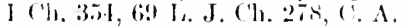
(1) Blarkir v. rlark (1852) lis

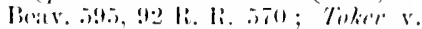

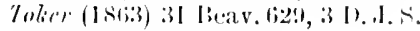
187,32 i. J, (h, 322.
Bimelen of wouf where ju special relation.

Anxiliary livles and loctrines on special points. 
(2.) The like as to the influence presumed from special relations, and the evidence required in order to rehut such presumption:

(3.) What are the continuing relations between the parties from which influence has heen presumed:

(t.) From what circumstances, apart from any continuing relation, undue influence has been inferred: and herein of the doctrine of equity as to sales at an undervalue and " catching bargains" :

(5.) The limit of the right of rescission.

Voluntary dieporitions generatly.

1. As to roluntary dispositions in general. (CP. Dar. Cons. 3, pt. 1. Appx. No. 4.)

A roluntary settlement which deprives the settlor of the immediate control of the property dealt with, though it he made not for the benefit of any particular donee, but for the benefit of the settlor's children or family generally, and free from any suspicion of unfail motive, is not in a much better position than an absolute and immediate gift. It seems indeed dembtful whether the court does not consider it improvident to make in general indefinite contemplation of marriage the same kind of settlement which in contemplation and consirleration of a definitely intended marriage it is thought improvident not to make $(r)$.

It is conceived that the ground on which such dis. positions are readily set asicle at the instance of the sottlor seresentatives is not the imprudence of the thing alons, but an inference from that, coupled with other circumstances-such as the age, sex, and capacity of the settlor-that the effect of the act was not really considered and understond at the time when

(1) Everitt s. Eirerith (18T(1) I. R. 10 lis. 405. 39 L. J. ('h. 737 ; but here some of the usmal provisions were omitled. 
it was done $(s)$. A voluntary settlement in favour of a parent is eminently open to suspicion unless the donor is of mature age and experience $(t)$.

The absence of a power of revocation has often been insisted upon as a mark of improvidence in a voluntary settlement; and it has heen even held to be in itself an almost fatal objection: but the doctrine now settled by the Court of Appeal is that it is not conclusive, but is only to be taken into account as matter. of evidence, and is of more or less weight according to the other circumstances of each case $(u)$.

2. Auxiliary rules as to the influence presumed from special relations.

The principle on which the Court acts in such cases is not affected either by the age or capacity of the person conferring the benefit, or by the nature of the benefit conferred $(x)$.

"Where a relation of confidence is once established, either some positive act or some complete case of abandonment must be shown in order to determine it:" it will not be considered as determined whilst the influence derived from it can reasonably be supposed to remain $(x)$.

Where the influence has its inception in the legal authority of a parent or guardian, it is presumed to continue for some time after the termination of the legal authority, until there is what may be called a

(s) Ib.: Pridereud v. Lomesdale (1863) 1 5.J.s. 433: this grouml is strongly taken ly Jescel M.R. in Intfon v. Thompsom (1848) 23

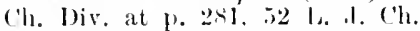
(ifil : Jamers v. Gourlemum (1855) 2 !) (h. 1). 212, it I. .J. ('h. Sisk so common iguorance or mistalie of both parties as to the efferet of an instrument may sometimes be inferreel on the face of it from it. unreasonable or unuswal character :
As to fower of revocation.
Sperial relations.

Age, fie, not material.
Influence presumed to continue. see 1. 5:31, sum r.

(t) l'mell v. Powell [1!104] I Ch. 213, tig 1. . I. Ch. I6it.

(ii) Ilatl v. Ilall (1883) L. R. . ('h. 430, 42 L. J. Ch. HH, wher the former eases are reviewcr ; and see lourell v. Pruerll. last note.

(.r) Per Turner. L..l. Rhodes v.

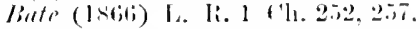

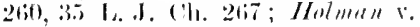

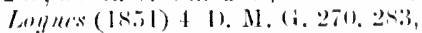

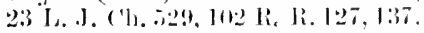


Frinlente reguirel to rebut presumption af influence.

Father ancl sont.

Sulicitor anrl client.

complete emancipation, so that a free and unfettered judgment may be formed, independent of any sort of control $(y)$. It is ohvious that without this extension the rule would be practically meaningless. It is said that as a general rule a year should elapse from the tormination of the authority before the judgment can be supposed to be wholly emancipated: this of course does not exclurle actual proof of undue influence at any subsequent time $(z)$. With regard to the evidence to be adduced to rebut the presumption in a transaction between a father and a son who has recently attained majority, the father is bound "to show at all events that the son was rally a free agent, that he had adequate independent advice. . . that he perfretly understood the nature and extent of the sacrifice he was making, and that he was desirous of making it."

"So again. where a solicitor purehases or ubtains a benefit from a client,

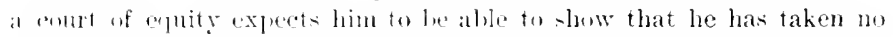

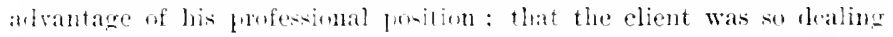
with him an to he free fom the intluence which a solicitor must necesiatrily

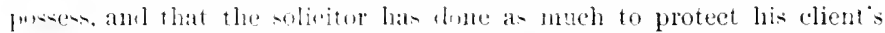
interest as he wold have dne in the cant of the elient dealing with a stranger" ("i).

IIe must give all the reasonable alvice against himself that he would have given against a third person (b). And he must not deal with his client on his own account as an undisclosed principal. "From

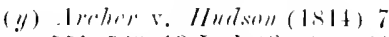

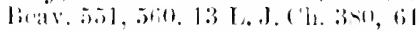

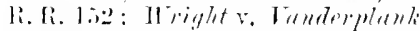
(15:5) \& 1). H. (i. 133, 1:37, 1 16, 25 I.. I. Ch. 7233,114 K. Ii. lio, iit:

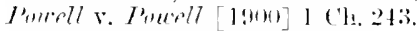
ti!) 1. .J. Cih, lit.

(z) Sice per Lond ('ranworth, i 11. 1. ('. at 1). 772 .

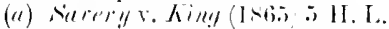

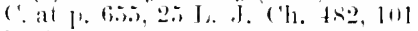

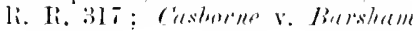

(1539) 2 Rear. 7i. in li. li. 116i, secm- nut puite comsistent with this: but there the plaintiff was not the elient himself, but his ascignee in insolveney. and the client: own evilenee was ratluer favomable to the solicitor.

(b) Githam v. Jeyes (1801) (i Ves. 264t, 2-t, 5 R. R. 295. 306. As to solicitor's charges, see Lyddoll v. J 
the very nature of things, where the duty exists that he should give his elient advice, it should be disinterested advice; he cannot properly give that advice when he is purchasing himself without telling his client that he is purchasing" (c). If the cliont becomes bankrupt, his trustee is entitled to the benefit of this special duty $(d)$.

The result of the decisions has been thus smmmol up by the Judicial Committe of the Priry conncil. "The Court does not hold that an attornoy is ingapable of purchasing from his client; but watches such a transaction with jealousy, and throws on the attorney the onus of showing that the bargain is, speaking generally, as good as any that could have been obtained by due diligence from any other 141 . chaser" $(e)$. He is not absolntely bound to insist on the intervention of another professional adviser. But if he does not, he must not he surprised at the transaction being disputed, and may have to pay his own costs even if in the result it is upheld. As to gilts, the rule is that the client must have competent independent advice $(f)$, and the C'oult must be satisfied that the influence has in fact ceased (y). The result seems to be that it is all but imposisible in law for a gift from client to solicitor to be unimpeachable.

\section{Generally-}

Fiduciary relations gencrally.

"The broad prineiple on which the cont acts in cases of this

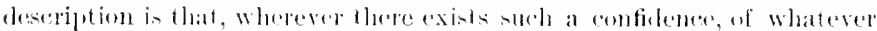

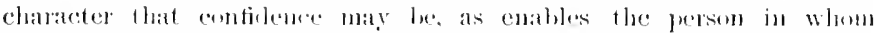

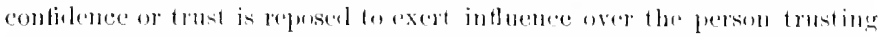

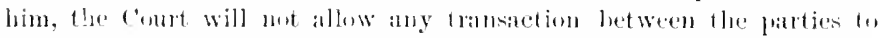
stand unless there hat been the follew amb fairest explanation and

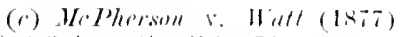

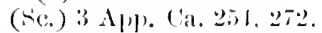

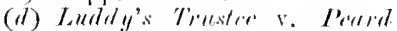
(1886) :38) ('l. I). 500.

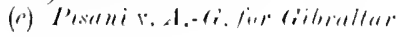

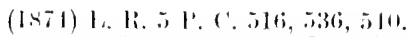

(f) Liles v. Torry [1s:5] 2

Q. 1. 679, 651, .1, (1. 1., 31, (1.1. (g) Hright $v$. Titefor [1:00:3] ।

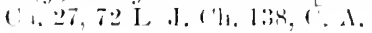


communication of every particular resting in the breast of the one who seeks to establish a contract with the person so trusting him "(h).

In other words, every contract entered into by persons standing in such a relation is treated as being uberrimae fidei, and may be vitiated by silence as to matters which one of two independent parties maling a similar contract would be in no way bound to communicate to the other; nor does it matter whether the omission is deliberate, or proceeds from mere error of judgment or inadrertence $(i)$. The rule extends not only to beneficial transactions with the confidential adviser, but to such as confer a benefit on any one closely connected with him (j).

Thus a medical attendant who makes with his patient a contract in any way depending on the length of the patient's life is hound not to lieep to himself any knowledge he may have professionally acquired, whether by forming his own opinion or by consulting with other practitioners, as to the probable duration of the life $(k)$. Perhaps the only safe way, and certainly the best, is to avoid such contracts altogether.

In Groscenor $r$. Sherratt $(l)$, where a mining lease had been granted by a young lady to her brother-in-law (the son of her father's executor) and uncle, at the inducement of the said executor, "in whom she placed the greatest confidence," it was held that it was not enough for the lessees to show that the terms of the lease were fair; they ought to have shown that no

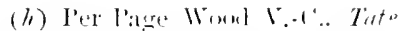
r. Hillimmsim (1Nfiti) L. Li. 1 E`l. at 1. . i3ti.

(i) Volon!y r. Kerman (Ist2) 2 Dr. \& 11 . at 11.3!.

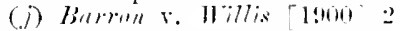
(1. 121, 19 1.. .J. ('l. N32, C. A. : which alsw shows (if authority lese neederf that it mere suggestion of independent arlvice, not followed up, will not valulate such a tram- action. This decision was aftirmed in 11. I. [1!12] A. ('.271. II L. I. ('h. bis!. on the broaler ground that the nature of the transaction was not understuod.

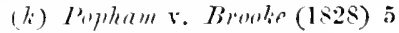
litise s. is li. R. hitl.

(l) (15601) 2s Beas. 6.59, 6633. This is an extreme case: but there wits some evidence of indepentent offers being diseouraged. 
better terms could possibly have been obtained; and as they failed to do this, the lease was set aside.

This comes very near to the case of an agent dealing on his own account with his principal, when "it must be proved that full information has been imparted, and that the agreement his been entered into with perfect good faith." Nor is the agent's duty altered though the proposal originally came from the principal and the principal shows himself anxions to complete the transaction as it stands $(m)$. The same rules apply to an executor who himself becomes the purchaser of part of his testator's estate $(n)$. But this obligation of agents and trustees for sale appears (as we have alrealy considered it, 11$) .299-300$, alove) to be incidental to the special nature of their employment, and to be a duty founded on contract rather than one imposed by any lule of law which guards the freedom of contracting parties in general.

The duty cast upon a solicitor, or other person in a like position of confidence, who deals on his own account with his client, of disclosing all material circumstances within his linowledge, does not howevel bind him to communicate a "speculative and consequential" possibility which may affect the future value of the subject-matter of the transaction, but which is not more in his own knowledge thin in the client's $(o)$.

It must not be forgotten that the suspicion with which dealings between parents and children presumably still under parental influence are regarded by courts of equity is to a certain extent counteracted hy

Family arrangements exceptionally faromed. (m) Ilally r. Homlam (186i3) $: 33$ licav. 1:it.

(ii) Betker v. Rroul (15isl) IS beav. 3!Is; affil. 3 W. Li. 81 , Jod i. h. 181: where however relief was refused on the grouml of seventwen years' delay.

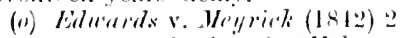
Ha. 100. 74. 62 li. Li. 23: IIolman v. Latym's (155) । II. M. (1. at 1. $2 \times 0,10^{2}$ li. li. al p. 13.3. 
the favour with which dispositions of the kind known as family arrangements are treated. In many cases a balance has to be struck between these partly conflicting presumptions. "Transactions between parent and child may proceed upon arrangements between them for the settlement of property, or of their rights in property in which they are interested. In such cases this Court regards the transactions with farour. It does not minutely weigh the considerations on one sicle or the other. Eren ignorance of rights, if equal on both sides, may not avail to impeach the trans. action $(p)$. On the other hand, the transaction may be one of bounty from the child to the parent, soon after the child has attained twenty-one. In such casces this Court views the transaction with jealousy, and anxiously interposes its protection to guard the child from the exercise of parental influence" $(q)$.

It must he ohserved that the rules concerning gifts, or transactions in the form of contract which are sub. stantially gifts, from a son to a father, do not "lply to the converse case of a gift from an ancestor to a frscendint: there is no presumption against the validity of such a gift, for it may be made in discharge of the necessary duty of providing for descendants $(r)$.

( $\left.f^{\prime}\right)$ lerhap it is safer to say that the "almost invincihle jealini-y" of the tomet is reluees to : a reasumble legree of jealum-y" :

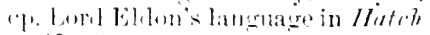

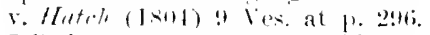

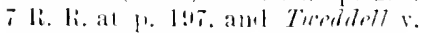
Tudall (1,2-3) Turn. \& li. at p. li.

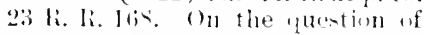

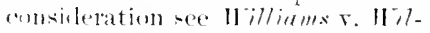

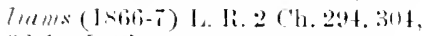
36) I. I. (1). 2 (l).

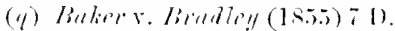
M. (i. I!) , 6201, I119 Ri. R. 245. 25!.

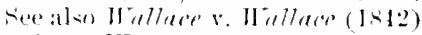

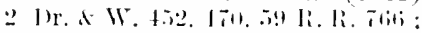

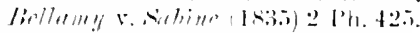

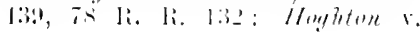

Morhtmm (15.52) 1.5 Reav. 278,30m. 92 Ii. ii. 121. 431 : and on the doctrine of fauly arrangement not applyiur when a sin withont consideration grives 11 valuable rights to his faller: surery r. Kirng (Is.si) is II. 1. ('. at p. 6.57. 10I Ri. Ri.318. A sale hy a nephew to has [ireat] incle of his reversionary interest in an estate of which the mncle is tenant for bife is not a finmily arrange-

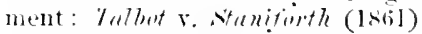
1.J. \& 11. 484.501. As to $1 \mathrm{~h}$ amomnt of notice that will affect a fulchaser : Baimbrig!te v. Broune

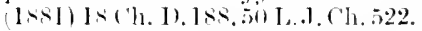

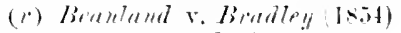
2 sul. d (i. 339.97 li. li. 22x. 
3. Relations between the parties from which in- Relations fluence has been presumed.

It would be useless to attempt an exact classification presumel. of that which the Court refuses on principle to define or classify: but it may be convenient to follow an order of approximate analogy to the cases of wellknown relations in which the presmmption is fully established.

A. Relations in which there is a power analogots to that of parent or guardian.

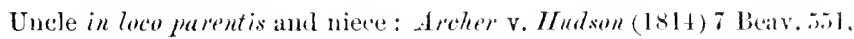
13 L. J. Ch. 380, tit li, R. 152 ; Maitland v. Irring (184ti) his Sim. 137, it R. R. 115. Step-father in low purentis and step-langhter: K'mpsinn $r$ Ashbee (1874) L. R. 10 ('h. 15, 44 L. J. ('b. 195; Espey r. Lake (1.5.2) 10 Ha. 260, 90 R. R. 362. Executor of a will (apparently in a like position) and the testator's daughter: Growner v. Sherratt (1 stio) 28 Peav. 16.9.

Husband of a minor's sister with whom the minor hat hived for some time before be came of age: Griftin v. Derenille (1751) 3 P. Wms. 131." . But the mere fact of a miuor living with a relative of full age dues not raise a presumption of intluence: ur the presumption. if any, is rebuted by proof of business-like habits and capacity on the fonor s part: Taylun. v. Johnston (1882) 19 ('b. 1). tio3. 51 L. J. (11. 859.

'Two sisters living together, of whom me was in all reipeets the hear of the lunse, and might be considered as in loco purentis towards the other,

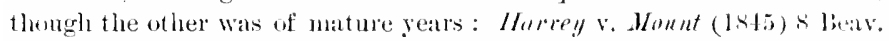
439, 6is R. K. 14ti. Brother and sister, where the sister at the ane of lif exceuted a veluntary setflement umler the brother's advice and for his benefit : sharp v. Leorlh (1.862) 31 beav. $4: 91$.

llusband and wife on the one part, and aged and inlirm and of the

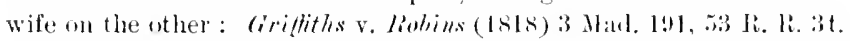

Distant relationship, by marriage: the donor old, intirn, and his

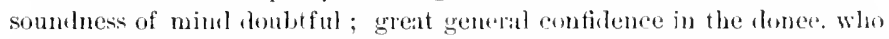
was treated by him as a sonl : sterd v. ('alley (1836t) I kee, 1200. This rather than the domoris insunity seens the true gromm of the case: see l', 644.

Keeper of lonatio: asylum and reowererl patient: Hright v. Promd

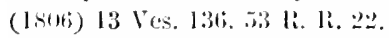

There are also cases of general control obtained by one person over

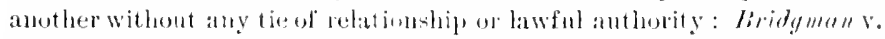

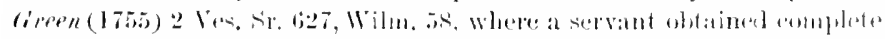

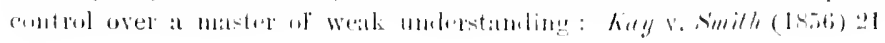


Cases analogous to solicitor and client.

Beav, 522, aftirmed nom. Simith v. Kuy (1859) 7 H. L. C. 750, where an older man living with a minor in a joint conrse of extravagance induced him inmediately on his eoming of age to execute securities for bills previously accepted by him to meet the joint expenses.

In Lloyd v. Clark (1\$43) (i Reav, 309, 63 R. R. 85, the influence of an whicer wer his junior in the same regiment was taken into account as increasing the weight of other suspicions circumstances: but there is nothing in the ease to warrant including the position of a superior officer in the general category uf "suspected relations."

\section{B. Positions analogous to that of solicitor.}

Certificated conveyancer acting as professional adviser : Rhodes v. Bute (18iii) 1. R. 1 Ch. 252. 35 L. J. Ch. 265. Counsel and confictential adviser : Broun v. Kennedy (1863) 33 Reav. 133, 148, 4 D. J. S. 21 T.

Confidential agent substituted for solicitors in general management of

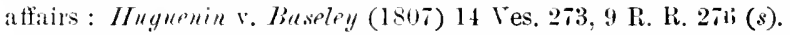

A person leputed hy an elder relation, to whom a young man applied for advee and assistance in pecuniary difficulties, to ascertain the state of his affairs and alvise on relieving him from his debts : Tute v. Williamson (1siti) 1. R. 1 Eq. 526, 2 (b. is.

The relation of a medical attendant and his patient is treated as a confidential relation analogous to that letween solieitor and elient: Dent v. Bennett (1839) 4 My. A Cr. 269, 48 K. R. 94; Billuge v. Southee (1852)

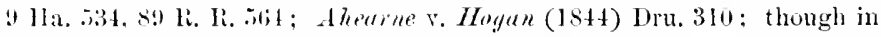
H7ukie v. (lurk (1852) lis lieav, 595, 6013,92 R. R. 570, less weight appears to he attached to it. It dues not appear in the last case whether the existence of "inything like undue persuasion or coercion" (p.604) was merely min prored or pustively disprored: on the supposition that it was dispromed there would be no inconsisteney with the other authorities. For another unsucessful attempt to set aside a gift to a medic.l attendant,

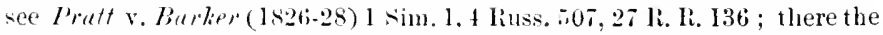
Jomon was alvised by his own solicitor. who gave positive evilence that the act was free and deliberate.

(s) A fortiori, where characters of stewird and attorney are combined : Harris vo Tirementerenter (1sis) lis les. 3t, lo R. R. is. A flagrant ease is bullo' v. Loade'

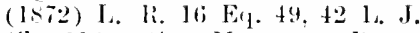

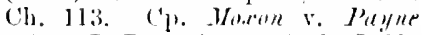
(1873) I. R. s ('h. 881,43 l. J.Ch. 240. where however the faets are unt given in any detail. As to a land agent funchasing of taking a latae from his princijal, sees also
Molony v. Kerman (1842) 2 Dr. E W. 31: Lord siplsey 5 Rhoudes (1+24-2i) 2 sim. os st. 4 l, 1 Bli. I, 2: R. R. 1:0, 30 R. R. 1. In lissiter v. Ilalsh (1843) + Dr. \& W. 45.5 : 65 R. R. 74.5 , where the transaction was between an agent and a sub-agent of the same prineipals, the case was put by the bill ( 4 Dr. (iV. p. 4si), but not deeiled on the ground of filueiary relation. sie 1.650, alove. 


\section{c. Spiritual influence.}

It is sail that influence would be presumed as between a elergyman or any person in the habit of imparting religions instruction and another person placing confidenee in him: Dent v. Bennett (1835) 7 sim. at p. 546 , 48 R. R. p. 97. There have been two remarkable moderu eases of spiritual influence in whieh there were claims to spiritual power and extraordinary faeulties on the one sirle, and implieit belief in such claims on the other: it was not neeessary to rely merely on the presumption of inlluence resulting therefrom, for the evislence which proved the relation of spiritual eonfidence also went far to prove as a fitet in each case that a general influenee and control did aetually result: Noftidlfe v. Priner (1860) 2 Giff. 246, 29 L. J. Ch. 857 ; $L y o n$ v. IIome (1868) L. R. 6 Eq. 655, 37 L. J. Ch. $67 t(t)$. In the former ease at all events there was gross imposture, but the spiritual dominion alone wonld have been sufticient ground to set aside the gift : for the Comt considered the intluence of a minister of religion over a person under his direct spiritual charge to be stronger than that arising from any other relation (11). There seems to have been also in Norton v. Relly (1764) 2 Eden, 286, the earliest reported ease of this elass, a considerable admixture of actual frand and imposition.

A peeuliar ease is Alleard v. Nkimer (1887) 36 Ch. Div. I45, if L. J. Ch. 1052. The plaintiff, a lady of full age, had joinerl a religions sisterhood, apparently of her own mere motion and free will. Its rules, known to her before she applied for admission. re fuired the members to abandon all their individual property; not necessarily to the sisterhood, but the conmon practice was to give it to the superior for the purposes of the sisterhood. Other rules required striet obelience to the superior, restrained communication with "externs" about the affairs of the eonvent, and forbade members to "seek advice of any extern without the superior"s leave." At varions times after entering the sisterhorl the plaintiff made transfers of considerable sums of money and stock to the superior, in fact "gave away practieally all she could." After some years she left the sisterhood, and after nearly six years more she elaimed the return of the funds remaining in the superior's hatmls. It was hell that, having regard to the position of the plaintiff as a member of the sisterhood, and to the rules she had undertaken to obey, especially the rnles against communication with "externs," she was not a free agent at the time of making the gifts. But the majority of the court held that her subseruent comduct amounted to eonfirmation.

A still later case where a weak rich man became a mere pulpet in the

(t) In Lyon v. Home there wats some evichence that the crifts in thestion wore not asked for by the defemdant but pessied on him by the platintill; but, given the cir-
Spiritual

influenee: mixed claraeter of the eases. 
Lindue

intluence without filuciatry relation. Securities obtained by pressure; Williams $e$. IRayley.

hauds of an anateur spiritual director, who used his ascendency for the most grossly seltish ends, is burloy r. Lumglentn [I893] 1 Ch. 73ti, 62 I. J. C'h. ili.

The authority of IIuguenin v. Buseley (1507) 14 Ves. 273, 9 R. R. 276. as to this particular kind of influence, is to be found not in the jurlgment, which proceeds on the gromul of confidential agency but in sir $\therefore$. limilly argument in reply, to which repeated judicial approval has given a weight scarely if at all inferior to that of the decision itself.

4. Circumstances held to amount to proof of undue influence, apart from any continuing relation.

In a case where a father gave security for the amount of certain notes believed to have been forged by his son, the holders giving him to understand that otherwise the son would be prosecuted for the felony, the agreement was set aside, as well on the ground that the father acted under undue pressure and was not a free and voluntary agent, as because the agreement was in itself illegal, as being substantially an agreement to stifle a criminal prosecution $(x)$.

In Ellis v. Barker (y) the plaintiff's interest under a will was practically dependent as to part of its value on his being accepted as tenant of a farm the testator had occupied as yearly tenant. One of the trustees was the landlord's steward, and in order to induce the plaintiff to carry out the testator's supposed intentions of providing for the rest of the family he persuaded the landlord not to accept the plaintiff as his tenant unless he would make such an arrangement with the rest of the family as the trustees thought right. Under this pressure the arrangement was executed: it was practically a gift, as there was $n$ real question as to the rights of the parties. Afterwards the deeds by which it was made were set aside at the suit of the plaintiff, and the trustees (having

(a) Hilliams v. Paule! (ls6ri)

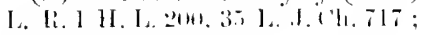
cp. 1. 34.5. aluse. (ii) (15i) L. R. 7 ('l. 104. 41 L. I. ('h. ift. 
thus unjustifiably made themselves partisans as between their cestuis que trust) had to pay the costs.

These are the most distinct cases we have met with of a transaction being set aside on the ground of undue influence specifically proved to have been used to procure the party's consent to that particular trans. action $(z)$.

In Smith v. Kay (a) a young man completely under smith r, Kay, the influence and control of another person and acting under that influence had been induced to exreute securities for bills which he had accepted during his minority without any independent legal advice; and the securities were set aside. There was in this cass evidence of actual fraud; hut it was distinctly affirmed that the decision would have been the same without it, it being incumbent on persons claiming under the securities to give satisfactory evidence of fair dealing $(b)$.

This comes very near to the peculiar class of cases on "catching bargains" with which we shall deal presently.

Undue influence may be inferred when the benefit is such as the taker has no right to demand [i.e. no natural or moral chim] and the grantor no rational motive to give $(c)$.

Inadequacy of the consideration, though in itself not decisive, may be an important element in tho conclusion arrived at by a court of equity with respect to a contract of sale.

The general rule of equity in this matter has been

(z) Cp. Ormes v. Beadel (1860) 2 Giff. 16i;. 30 L. J. Ch. 1, revil. 2 b. F. J. 33:3, on the erromnt that the agreement had afterwark been voluntarily acted mpon with a bnowledire of all the facts. (a) (1859) 7 H. 1. (. 750 .

P. (b) P. 76il, 770. The securities siven were for an amount vely mulh exceeting the whole of the sums really alvancel and the interest apon them: $1 \% .78$.

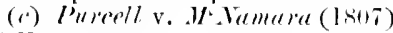
11 Ves. !1, 115.
Other circum. stances from which undue influence inferrel.

As to mulervalue.

General rnle; inelervalue has of itself no elfert. 
But compled with etlier circum-tances may be material as evirlence that consent, $\mathrm{Or}^{\circ}$ freedom of consent. was wanting.

thus stated by Lord Westhury: "It is true that there is an equity which may be founded upon gross inadequacy of consideration. But it can only be where the inadequacy is such as to involve the conclusion that the party either did not understand what he was ahout or was the rictim of some imposition" $(d)$.

The establisher doctrine is that mere inadequacy of price is in itself of no more weight in equity than at law (c). It is evidence of fraud, but, standing alone, hy no means conchusive eridence $(f)$. Eren when coupled with an incorrect statement of the consideration it will not alone he enough to vitiate a sale in the absence of any fiduciary relation between the parties (g).

But if there are other circumstances tending to show that the rendor was not a free and reasonable agent, the fact of the sale having been at an undervalue may he a material element in determining the Court to set it aside. Thus it is when one member of a testator family convey his interest in the estate to others for an inardequate consideration, and it is doubtful if he fully understood the extent of lis rights $\mathrm{ol}^{*}$ the effect of his act $(h)$. If property is bought at an inarloquate price from an uneducated

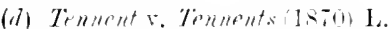
R. 2 s.e. I. T. ti. ?. For a molern instance of such a conclusion being actually drawn ly the Court from a sale at a grose unlervalum. see

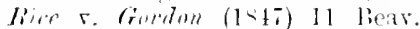

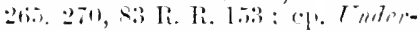
hill r. Hormond (1801) 1") Ve. at 1. 2II! ; inmmets re cirithths (1 Reiti) 35 Batr. 27. 33. and the earlier dictum there referred to of Lord Thurlow in Gimgne v. Heutum $(1-5) 1$ IBro. C : 1. ?, that * to set asibe a conveyance there mont be an inepuality so strong. grow. and manifest that it must he im. po-ible to state it to a man of commun whe without prohucing an exclamation at the inequality of it."

(1.) If iond v. Almey (1819) 3 . Varl. H7. 423.18 li. R. 26it.26s: Parmek r. Ermms (180!) 16 Ves. 512. ili, 1o li. Ii, 21s. 222: stilluell v.

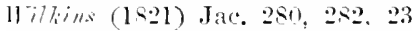
li. li. sti.

(f) ristell v. Tuylor (1851) 15 Bur. 1113. 115,21 L. J. Ch. 515, 492 Ii. Ji. 322. 336 .

(g) IIturvinn v. Guest (1855) on

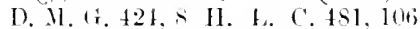
R. li. 129 .

(h) stumge vo stumpe (18t!) 1? bear. 2:2:. 1: L. .J. (h. 17, 85 li. R.

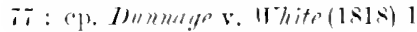

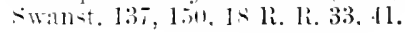


man of weak mind (i) or in his last illness ( $k$ ), who is not protected by independent advice, the burden of proof is on the purchaser to show that the vendor made the bargain deliberately and with knowledge of all the circumstances. Nay, more, when the vendor is infirm and illiterate and employs no separate solicitor, "it lies on the purchaser to show affirmatively that the price he has given is the value," and if he cannot do this the sale will be set aside at the suit of the vendor $(l)$. In 1871 a case in the Court of Appeal was decided on the ground that "if a solicitor and mortgagee . . obtains a conveyance [of the mortgaged property] from the mortgagor, and the mortgagor is a man in humble circumstances, without any legal advice, then the onus of justifying the transaction, and showing that it was a right and fair transaction, is thrown upon the mortgagee" $(\mathrm{m})$. Still more lately the poverty and ignorance of the seller of a reversionary interest have been held enough, without infirmity of body or mind, to throw the burden of proof on the buyer $(n)$.

Similarly if a purchase is marle at an inadequate price from vendors in great distress, and without any professional assistance but that of the purchaser"; solicitor, "these circumstances are evidence that in this purchase arlvantage was taken of the distress of the vendors," and the conveyance will be set aside (o).

It has even been said that to sustain a contract of sale in equity "a reasonable degree of equality

(i) Lemgmater v. Ledger (1 \&6ii) 2 (iiff. 157, 163 (aflirmed on appeal, see I I. F. .J. +402).

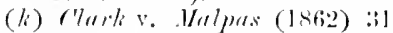
Beav. sol, I 1). l.. J. .10!.

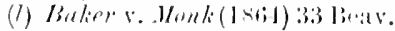
11!, 1 1). J. . $2.345,3: 91$.

(iii) lord llatherley ('. I'rons v. colie (1570-1) L. li. fi Ch, bits, fils: though in general there is no rula against a mortgagee luying from his mortgagor : Kmight s. Marjuri-

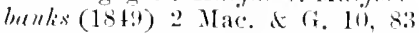
li. Ri. Jitit; and see Ford v. Jlden

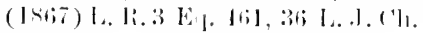
(ii).

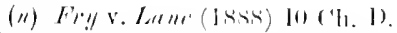
312, is 1. .1. ('h. 11:3.

(i) Iroml v. Alerey (1818) 3 Mat. 117, 121, Is R. R. 26il, 26!9.
- Eiquality between the contractintr partics." 
between the contracting parties" is required $(p)$. But such a dictum can be accepted only to this extent: that when there is a very marked inequality between the parties in social position or intelligence, or the transaction arises out of the necessities of one of them and is of such a nature as to put him to some extent in thr power of the other, the Court will be inclined to gire much more weight to any suspicious circumstances attending the formation of the contract, and will be much more exacting in its demands for a satisfartory explanation of them, than when the parties are on such a footing as to be presumably of equal competence to understand and protect their respective interests in the matter in hand. The true doctrine is well expressed in the Indian Contract Act, s. 25, expl. 2. "An agreement to which the consent of the promisor is freely given is not roid merely because the consideration is inadequate; but the inadequacy of the consideration may be taken into account by the Court in determining the question whethor the consent of the promisor was freely given." A sale marle by a person of inferior station, and for an inadequate price, was upheld by the Court of Appeal in Chancery, and ultimately by the House of Lords, when it appeared by the evidence that the vendor had entered into the transaction deliberately, and had deliberately closen not to take independent professional advice $(q)$.

(ii) Lamgumate v. leftyer (1860i)

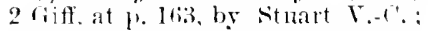
cr. the same judge's remarks in Biarent v. Ilurtley (1866) L. R. 2 Eq. at f. 794. We have alreary seen something of the leamed Vice. Chancellor's alventurats doctrines about $M$ istake. See the more correct statement in 11 rond $x .4$ lorey. 3 1larl. at 1. 423,18 R. li. p. 268 . "A court of equity will inquire whether the parties really did meet on ecpual terms: and if it he foreme. that the rentor was in distressed circumstances, and that adrantage uas talien of that distress, it will avoisl the contract."

(4) Harriwon v. Guest (15.5i) $6 \mathrm{D}$. MI. (i. 424.8 H. L. C. 481,106 R. R. 129! : cp. Rosher v. Williams (1875) I. li. 20 Eq. 210,44 I. J. Ch. 419. 
It was long doubtful whether a degree of inade-sipecific quacy of consideration which does not amount to performance evidence of fraud may not yet be a sufficient ground the gromin of for refusing specific performance. The general rule alme. as to granting specific performance, so far as it bears on this point, is that the Court has a discretion not to direct a specific performance in cases where it would be highly unreasonable to do so: it is also said that one cannot define beforehand what shall be considered unreasonable $(r)$. On principle it seems doubtful whether it should ever be considered unreasonable to make a man perform that which he has the present means of performing, and which with his eyes open he has bound himself to perform by it contract valid in law. And it is said in Iratson $r$. Marston ( $r$ ) that the Court "must be satisfied that tho agreement would not have been entered into if its true effect had been understood." Perhaps this may be considered to overrule those earlier decisions which furnish authority for refusing a specific performance simply on the ground of the apparent hardship of the contract. As to the immediate question whether inadequacy of consideration, not being such as to make the validity of the contract doubtful (s), is regarded as making the performance of it highly unreasonable within the maning of the above rule, it is now settled by general consent in the negative.

(r) See Hatson v. Harston (1 S5:3) 4 I). M. G. $230,239,240,102$ Li. li. 100,107 , and diclat there referred to.

(s) Dombe as to the validity of the eont rack sluth of the comelusion that it is not valiel, hats always been held a sultieient grouml for refusing specilic performance. l'robably this arese from the habit or etigliette by which comets of epuity, down to resent limes, meverdecileal a tegal point when they combl helpit. Now loat legal and equitable juristietion ate anited, the conrt will consider the question of dumages if an atch for specitic presformance is bromght in :1 c:ase such that muler the cihl watedies the bill would have ben disumissed withont prejullice to: an

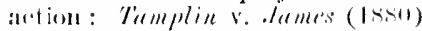
i.i ('h. l)iv. 2lis. 
Tho opinions of Lord Eldon and Lord St. Leonards were clear.

"Unless the inadequacy of price is such as shocks the conscience, and amounts in itself to conclusive and decisive evilence of fraud in the transaction, it is not itself a sufficient ground for refusing a spreific l'rermance" $(t)$.

"The undervalue must be such as to shock the conscience" [i.e. as to be sufficient evidence of fraud: ('p). Lord Eldon's dictum, supra! (u).

Sir Edwarl Fry alrearly consirlered this to be "the well establisher principle of the Court" in the first xlition of his well known treatise on specific Perfomance published in 1558, and this is substantially repeated in the subsequent editions $(x)$. There is just one modern case to the contrary, which is now left aside as an aberation. In that case there was something heyond mere inalequacy: the agreement was for a purchase at a raluation, and there was no valuation hy a competent person. V.-C. Kindersley however expressed a distinct opinion that specific performance onght to be refused on the ground of inadequacy alone $(y)$.

Sir Edward Fry's hook or the earlier editions of the present work may be consulted, if desired, for a view of the older conflicting authorities, most of which ware indecisive.

A brief notice of the French law on the head of crptation (partly corresponding to our Undue Influence) will be found in the Appendix $(z)$.

(t) Coless ve Trecothick (1sut) !) res. 234.24ti. i li. R. 167. 175, per lomb Elion.

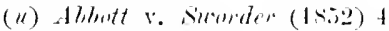
lee ri. 1 sim. 4t8. thil: per Lord st. Leonard. (,x) 4th ell, 1903, by W. D. liawlins, K.C., p. 1!!;.

(y) Fialcher $r$ Grals $1854+$ 1) ii. li. 493.

(i) Note $\mathrm{k}$. 
We have still to deal with an important exceptional class of cases. That which may have been a discretionary inference when the discretion of courts of equity was larger than it now is has in these cases become a settled presumption, so that fraud, or rather undue influence, is "presumed from the circumstances and condition of the parties contracting" $(a)$. The term "fraud" is indeed of common occurrence both in the earlier (a) and in the later authorities: but "fraud does not here mean deceit or circumvention; it means an unconscientious use of the power arising out of these circumstances and conditions" $(b)$ : and this does not come within the proper meaning of fraud, which is a misrepresentation (whether by untrue assertion, suppression of truth or conduct) made with the intent of creating a particular wrong beliof in the mind of the party defrauded. Perhaps the best word to use would be "imposition" as a sort of middle term between fraul, to which it comes nearer in popular language, and compulsion, which it suggests by its etymology.

The class of persons in dealing with whose contracts the Court of Chancery went beyond its general principles are those who stand, in the words of Sir George Jessel, "in that peculiar position of reversioner or remainderman which is oddly enough described as an expectant heir. 'This phrase is used, not in its literal meaning, but as including every one who has either a vested remainder or a contingent remainder in a family property, including a remainder

(a) Loml IJardwicke in (hosterfirld v. Jatuston (1750-1).2 Ves. sis. at p. 125, classifies this in gemeral terms as "a thind kiml of framl:" he procecels (at 1. 157) to malie a separate head of catching Jargatss, as "mixel eases compmommled of all or several species of frand: "but the
Exceptional cases of expectant heirs anil reversioner's. 
in a portion as well as a remainder in an estate, and every one who has the hope of succession to the property of an ancestor-either by reason of his being the heir apparent or presumptive, or by reason merely of the expectation of a derise or bequest on account of the supposed or presumed affection of his ancestor or relative. More than this, the doctrine as to expectunt heirs has been extended to all reversioners and remaindermen, as appears from Tottenhrm v. Eimmet $(c)$ and Earl of Aylesford r. Morris (d). So that the doctrine not only includes the class I have mentioned, who in some popular sense might be called expectant heirs, but also all remaindermen and reversioners" $"(e)$.

Motices for exceptional treatment :

1. Presumption of fraud.

2. Public policy ats to welfare of families.

The Act 31 Vict. c. + modified the practice of the Court of chancery which now continues in the (hancery Division) less than might be supposed: it is threfore necessary to give in the first place a connected view of the whole doctrine as it formerly stood. It was considered that persons raising money on their expectancies were at such a disadrantage as to be peculiarly exposed to imposition and fraud, and to reguir an extraordinary degree of protection $(f)$ : and it was also thought right to discourage such dealings on a general ground of public policy, as tending to the ruin of families (a) and in most cases involving "a sort of indirect fraud upon the heads of families from whom these transactions are conceraled " $(h)$.

(c) (1,atio) 11 W. li. :3.

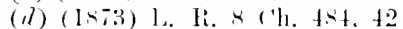

L. J. ('h. itti.

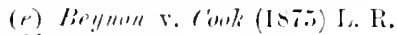
11) ('h. 3il. ".

$(f)$ "A degree of protection approaching nearly to an incaparity to bine themseren by any contract": sir W. Grant in íturels

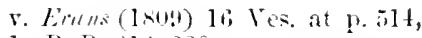
11 R. R. 21: 200.

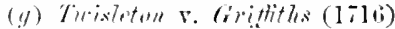
1 i. Wms. at p. 312 : Cole r. (rildorns. 3 l'. Wms. at 1. 293 : (besterfield $\therefore$. Jausken (1750-1) 2 Ves sir. at p. lis.

(b) l'er Joml Selbome. Liarl of

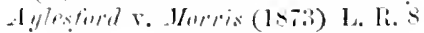


Moreover laws against usury were in force at the 3. Evasion of time when courts of equity began to give relief against usury laws. these "catching bargains" as they are called $(i)$; any transactions which looked like an evasion of those laws were very narrowly watched, and it may be surmised that when they could not be brought within the scope of the statutes the Courts felt justified in being astute to defeat them on any other grounds that could be discovered $(k)$.

The doctrine which was at first introduced for the protection of expectant heirs was in course of timo Extension of extended to all dealings whatever with reversionary interests. In its finally developed form it had two branches:-

1. As to reversionary interests, whether the reversioner were also an expectant heir or not:

A. The rule of law that the vendor might aroid the sale for undervalue alone;

B. The rule of evidence that the burden of proof was on the purchaser to show that he gave the full value.

It is this part of the doctrine that is changed by the Act 31 Vict. e. 4 .

2. As to "catching bargains" with expectant heirs

('h. 4k1, 4!) 42 I. J. ('h. 5ti ;

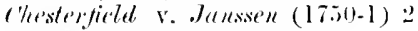
V(x. sir. 121, 157.

(i) In 11 isemente ve. Beake, 2 Vorm. $12 \mathrm{l}$, it appears from the statement of the lacts that twenty years or thereabouts after the Riestomation this juristiction was regardel at a movelly: for the defemdand's tentater. "nullersamling that the

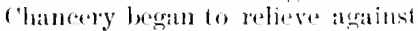
such bargans." touk certain steps to maks: himself safe, but withoul sureess, the Comet promonareing them "a contrivanee only to domble:

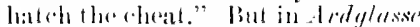

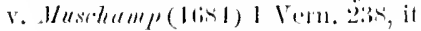

is sail that many precelents from land lincous, Jomet Ellesmere's ank Juril coventry's times were promlueal.

(li) The repurts of the cases on this heat anlerior to chesterfield v. .Jussertl are nufortunately so meatere llat it is ditficult to ascertain whether thry proceeleal on any unilinm priseiple. lint the molives abovo alleged set'un an the whole lo have beton those which detemined the policy at the ('mut. (In the enalual extension of the remerly abe the remarlis al Burmelt.

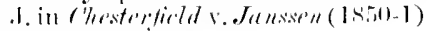
2 Ves. sir. at p. I1\%. 
Forner doctrine as to saltes of reverwionary interentis.

and remaindermen or reversioners in similar circumstances, i.e. bargains made in substance on the credit of their expectations, whether the property in expectancy or reversion be ostensibly the subject-matter of the transaction or not (l):

The rule of evidence that the burden of proof lies on the other contracting party to show that the transaction was a fair one. We use the present tense, for neither the last-mentioned Act nor the repeal of the usury laws, as we shall see presently, has made any change in this respet

The part of the doctrine which is abrogated was intimately connected both in prineiple and in practice with that whith remains; and though it seems no longer necessiry to go through the authorities in detail, it may still be adrisuble to give some account of the manner in which it was applied $(\mathrm{m})$.

The general rule established by the cases was that the purchaser was bound to give the fair market price, and to presere abundant eridence of the price haring heen adequate, however difficult it might be to ascertain what the true value was. It was applied to reversionary interest of every kind, and the rendor was none the less entitled to the benefit of it if he had acted with full deliberation. The presumption originally thought to arise from transactions of this lind had in fact become transformed into an inflexible rule of law, which, consistently carried out, made it wellnigh impossible to deal with reversionary interests at all. The morlern cases almost look as if the Court, finding it too late to shake off the doctrine, had sought to call the attention of the legislature to its inennrenience by extreme instances. Sales were set aside

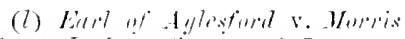

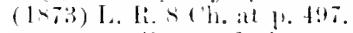

(III) A digent of the "astes wate given in the firs two clitions

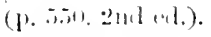


after the lapse of such a length of time as 19 years, and even 40 years $(n)$. A sub-purchaser who bought at a considerably advanced price was held by this alone to have notice of the first sale laving been at an undervalue $(o)$. In one case where the price prid was 200l, and the true value as estimater by the Court 238l, the sale was set aside on the ground of this undervalue, though the question was only incidentally raised and the plaintifl's case failed on all other points $(p)$.

Finally Parliament found it necessary to interfere, Art to ament and in 1867 , by the "Art to amend the law relating to sales of reversions," 31 Vict. c. $t$, it was enacted (s. 1) that no purchase (defined by s. 2 to inelude every contract, se., by which a benefiecial interest in property may be acquired), made bonc fide and without fraud or unfair dealing of any reversionary interest in real or personal estate, should after danuary 1 , 1868 (s. 3), be opened or set aside merely on the ground of undervalue. The Act is carefully limited to its special object of putting an end to the arbitraly rule of equity which was an impediment to fair and reasonable as well as to unconscionable bargains. It leaves undervalue still a material element in cases in which it is not the sole equitable ground for relief $(q)$.

It had already been decided $(r)$ that the repeal of the usury laws $(s)$ did not alter the general rules of the Court of Chancery as to dealings with expectant

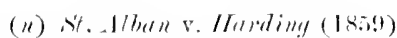
27 lieav. 11 ; Salter v. Biradshum (1Sis) 2 i lieav. lil.

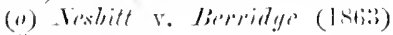
3.2 lieav. 2ail).

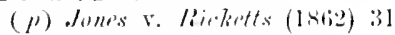
ineav. 130, :31 1.. . 1. ('h. 7533.

(i) Litrl af Iylestord v. Murris

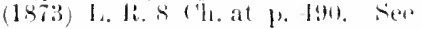

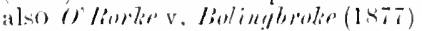
$2 \mathrm{~A} \mu$ (

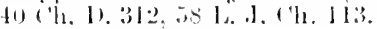

(r) (rout v. Giraham (1 siii3) 2 1). I. S. 15.

(.) 17 \& 15 Viet. (a) 90. But befure this complete repeal txeplions hat lern marle from the usury laws in farom of cerlatio lifls of exchange and leans axceesling 10/. mot seculerl on lithd:

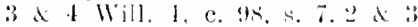
Vire. e. 3it. s. 1, atml commments

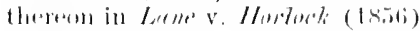
$\therefore 11.1 .11,580,251 . .1 .111,253$. the law relat ing to sitles of reversions. :il Virt. 1.1 .

ficueral rules ol copity as (1) " catcising bargaims" mustlectert. 
('omblitions thowinger burkele if fimeif (1) lenkir.

heirs. This decision was followed in Miller $r$. Cook $(t)$, and adhered to in Tyler v. Yates $(u)$, and lastly in Earl of Aylesford v. Morris $(x)$ and Beynon $r$ Cook (y), and in the two latter cases it has been clearly laid down that the rules are in like manner unaffected by the change in the law concerning sales of reversions. And this was confirmed by all the opinions delivered in O'Rorke v. Bolinglroke $(z)$ in the House of Lords, though the particular transaction in dispute was upheld.

The effect of these rules is not to lay down any proposition of substantive law, but to make an exception from the ordinary rules of evidence by throwing upon the party claiming under a contract the hurden of proving not merely that the essential requisites of a contract, including the other party's consent, existed, but also that the consent was perfectly free. The question is therefore, what are "the eonditions which throw the burden of justifying the righteousness of the bargain upon the party who claims the benefit of it "(a). Now these conditions have nerer been fixel by any positive wuthority. We hare seen that the court of chancery has refused to define frand, or to limit by any enumeration the

(f) $(15811)$ L. L. 111 E1 641. 40 L. I. ('h. Il.

(11) (1Ril) L. R. 11 Eip. 29is.

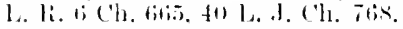

(.e) L. li. \& ' 'h. till: this nay now be regarderl as the lealing "ase on the snbject. It should be (1) served that in Figles s. Fates a principal and surety marte themselses liable for a bill which the primeigat had accepted during his minurity, without knwwing that there was an existing legal liability (n) the bill, and all the subse puent tran-actions were houml up with this: and the "ase was rested on this gromnl in the ('ont of Alputal (p. tiil). (p. on this point (incurd

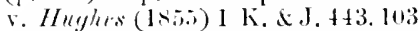
li. li. 17. where a widow whoduring her hustand's life hat joined as sarety in his pounisory note executed a new note muler the implession that she was liable on the chl one, and withont any new considerafion. and the note was set asile; see sintluall s. Rig!n (15.)1) and For. manv. Itright (1

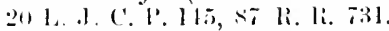

(y) (1 5 is) L. li. lo ('h. 38!!.

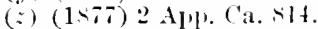

(ii) Eirel of tylesford r. Merris (1si:i) L. R. 's che at p. $4: 2$. 
standing relations from which influence will be presumed. In like manner there is no definition to bo found of what is to be molerstood by a "catching bargain." This being so we can only observe the conditions which have in fact heen generally present in the bargains against which relief has been given in the exercise of this juristiction. These are:-

1. A loan in which the borrower is a person having little or no property immediately available, and is trusted in substance on the credit of his expectations.

Ols. It is immaterial whether there is or not any actual dealing with the estate in remainder or expression of the eontingency on which the fund for payment of the principal antranced substantially depends. Erol of Aylesford v. Morris (1873) L. R. S ('h. at p.4!). It is also immaterial whether any particular property is koked to for ultimate parment. A general expeetation deriver from the prition in socicty of the borrower. family, the lender intending to trate on their probable fear of exposure. may have the same effect. Sirill v. Shelling (1881) lis (h. D. 679, 702, 49 L. J. Ch. 777 (1)enman J.).

2. Terms prima facie oppressive and extortionato (i.e. such that a man of ordinary sense and judgment cannot be supposed likely to give his free consent to them).

07s. An excessive rate of interest is in itself nothing more than a rlisproportionately large considuration given by the borrower for the han : and it is not suffieien', stanting alone, to invalidate a contract in erpity : Wrbster v. Coole (1867) I. I. 2 rh. 542, where a loan at fio per cent. per annum was upheft. Stuat V.-C. Risapproved of the ease in Tyter. $\mathrm{s}$. Yates (1871) L. R. 11 Eq. at P. 276, lut on anther proint. Ant see

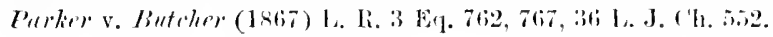

3. A considerable excess in the nominal amount of the sums advanced over the amount actually recoived by the borrower.

Ols. 'This appears in all the modern cases in which relinf has been given: dedurtions being mate on every arlvanee, acoroling to th. common practice of professed money-lenters, umler the name of discomnt, commission, and the tike. The result is that the rate of interest appearing to 
be taken does not show anything like the terms on which the loan is in truth marle: aud this may he consi.lered evilence of fraul so far as it argues a desire on the part of the lender to gloze over the real terms of the bargain. A jury eudul, perhaps, not be thrected so to consider it in a trial where fraud was distinctly in issue: though no loubt such circum. stances, or crell an cxorbitant rate of interest, woukl be made matter of obervation.

4. The absence of any real bargaining between the pruties, or of any inquiry by the lender into the exact nature or value of the borrower's expectations.

1/h. These arcumstinces are relied on in Earl of Aylesford r. Morris (1873) L. li. s Ch. at 1. 49H, as increasing the difficulty of upholding the

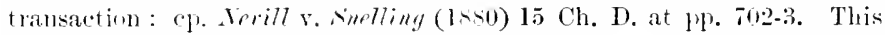
agrain is the usual practice of the moner-lenters who do this kind of business. Their terms are calculated to enver the risk of there being no security at all: morenver the borrower often wishes the lender not to make any inyuiries which might end in the matter coming to the knowlulge of the ancestor or other person from whom the expectations are derivel. The concealment of the transaction from the ancestor was beld

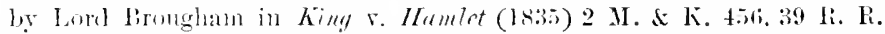
21, 237, to be an indinpensable condition of equitable relief : but this

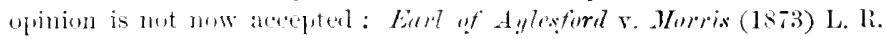
$s$ ('h. at 1. 491. The fecision in King r. Mnmlot (athimed in the Honse of [cords, hut without giving any reasons, 3 Cl. \& F. 218. 39 li. k. 24) can be suphorted on the groum that the party seeking relief hat himself acter on the contrat he impeached so as to make restitution imposible.

It seems safe to assert that in any case where these conditions concur the burden of proof is thrown on the lender to show that the transaction was a farir one: it scems equally unsafe to assert that they must all concur, or that any one of them (except perhaps the first) is indispensable.

(') if $]$ eneler sis situatel can in practice erer exunerate himself.
It may then be asked, By what sort of evidence is the lender to satisfy the Court that the borrower was not imposed on? As there is no reported case in which it was considered that the burden of proof lay upon the lender, and yet be did so satisfy the Court, it is impossible to give any certain answer to this question. It is evidently most improbable that in any 
case where the above-mentioned conditions are present, any satisfactory evidence should be forthcoming to justify the lender (b). P'ractically the question is whether in the opinion of the Court the transaction was a hard hargain $(c)$ - that is, not merely a bargain in which the consideration is inadequate, but an mconscionable bargain where one party takes an unfair advantage of the other $(d)$. This jurisdiction is of considerable importance in British India, and especially in the United (formerly North-West) Provinces, which have furnished an interesting line of cases $(e)$.

An account stated for the purpose of a contract of this description is of no more validity than the contract itself, and a recital of it in the security does not preclude the borrower from re-opening the account even as against purchasers or sub-mortgagees of the original lender who have notice of the general character of the transaction. For such notice is equivalent to notice of all the legal consequences $(f)$.

The borrower who seeks relief against a contract of this description must of course repay whatever sums have been actually advanced, with reasonahle interest (according to the usual practice of the Court, 5 per

Terms on which retief is givent. (b) "No attempt has been marle to show by any independent eviprenee (if surle a thiml romld lie comerifed posible) that the terms thus imposed on the plaintiff were fail aut reasonable," I. R. \& Cli. 196.

(i) See the juelerment of the M. li. Beymom ․ (bok (187i) L. li. 10 ('h. 341, "1., and livill v.

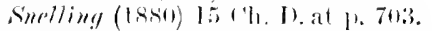

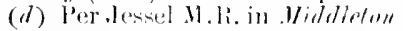
v. Rromen (1sis) 17 1. I. (1). 111, ('A.: levill v. smellimg (I Ke(1) 1 i) ('h. 1). 679, 4! l, .J. ('h. 777. where the lemer systematically took alvantage of a mistakei over-payment of interest by the horrower.

(o) Siee finmmor liam lal v.

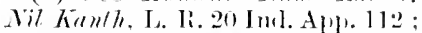
liajal, Wobluam single v. linjall linl simgh, it, 127, and cp. note $(r)$, 1. 361, above. the pesent writer's Iaw of Fraud, de.. in British India. (Tagole Jaw leetures 1s!l3-1), H. $77-79$, and I. C. A. $5.11 ;(3)$ and notes the reon in ed. loblock ancl Mulla.

(f) Toltemlerm v. Giente (1:8i3) as I. J. ('h. 201 : a case deriules muler the old role ats to dealines with reversionary interests. bat the principles seem applicable in all ares whore the burlen of proot is still on the lenter. 
As to the

lenrler suing on the contract.

cent.), and the relief is granted only on those terms. Moreover it is held not mnjust that he should obtain it at his own expense, since he calls in the assistance of the Court to undo the consequences of his own folly $(g)$ : and accordingly the general rule is to gire no costs on either side $(h)$.

The rule of eridence cisting a special burden of proof on the lender being peculiar to equity, there Was generally no defence at law to an action bronght by him to enforce a contract of this kind. But since the rule of eridence established in equity now prevails in every branch of the High Court, it seems that when a lender of money (not being a money-lender within the Act to be presently mentioned) sues on a special contract, whether the contract be embodied in a negotiable instrument or not, and the borrower proves facts which bring the contract within the description of a "catching bargain" as understood by courts of equity, the lender must prove the reasonableness of the hargain; and if he fails to do so, he cannot recover on the special contract, but can recover his principal and reasonable interest as on a common count for money lent. This, however, is now of but little practical importince: and the importance of this class of cases is also diminished by the Infants

(g) Earl of Aylesforl v. Yorris (IR.3) I. R. \& Ch. at p. 499.

(b) In the cases of silus rif rever. sions under the former law wh that hearl the practice was for some time to treat the suit as a relemption suit. and gire the prurehaser his costs as a mortgagee : but the later rule was to give no costs on either side, except that the plaintiff harl to bear such as were oncasioned hy any unfounder charese of an+tial fraud : Edwards v. Burt (1-5.2) 2 J) II. G. at p. 65. 95 R. K. 17: Brmmley r. smith (1854) 26 Bear. at $\mathrm{l}$. hiti. and costs might be given against the defendant as to any transaction in which thare had been misconduct on his part : Tottenham v. Grepn (1sti3) 32 L. J. ('h. 201, 20 h. In Jerill v. Shelling (1880). note (d) last page. the plaintiff having offered before action brought to repay the sums aetually adranced with interest at sper cent., the defenlant was orlered to pay the costs: 1.5 (h. I) at p. i0.5, cp. Beyrenl v. Chok (185.5) L. P. $10 \mathrm{Ch}$. at $\mathrm{p} .393$. in judgment of Jessel II.I. 
Relief Act, 187t, which makes loans of money to infants absolutely void and forbids any action to be brought on a promise to pay debts contracted during infancy. See p. 63, supra.

The Money-lender's Act, 1900 (63\& 6t Vict. c. 51), imposes special burdens on professional money- lembirs Act, lenders $(i)$ by way of registration and ofluerwise, and enabless the Court to set aside any terms which it considers "harsh and unconscionable" without being bound by the former practice of eomts of equity $(k)$. Excessive interest alone may be a sufficient ground for relief $(l)$. An umregistered money-lender camnot recover at all $(m)$, and a borrower from such a lender who does not seek any special equitable relief is entitled to an unconditional declaration that any security he may have given is void $(n)$; but the lender, even an unregistered one, will not be ordered to give up the borrower's securities except on the terms of the actual arlvances being repaid, according to the practice of the Court in dealing with asmions loans under the old law $(o)$.

The same equitable principles apply, so far as they are applicable to a transuction of sale as distinguished from loan, to the sale of reversionary interests hy persons who are not in an independent position, as

(i) As to the persons within this description, Litchfield v. IJrenfirs [1906i] I K. B.535, 75 L. J. K. li. 447. So far as any test can be assigned, it is readiness to lent money in a general way of business : occasional loans inciclental to another business. or to ganuine persomal acfuaintance, to not inake a man a money-lemder.

(k) lie a Dobtur [1!n3] $1 \mathrm{~K}$. B. 705,72 L. J. K. B. 3\$2, (C. A.; siamuel v. Newbold [1906] A. C. 161, 75 L. . I. ('1. 70. .

(l) Samuel v. Sirebold, last note.

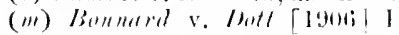

P. (h. 740, 7., 1... J. (H. 44li, C. A. As to the natne to be registered, see stirling v. Silburn o Pyman [19!1]

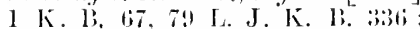
IIhiteman v. sudler. [1!10] A. G.

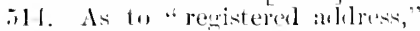

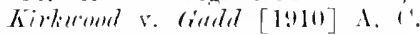
f22: details must be somelit in setecial rentumentaries on the $\mathrm{A}$.

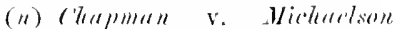

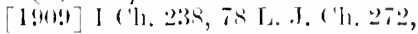
( $A$.

(11) Lanlye v. Virtiomul l'mion

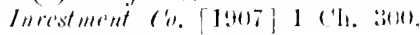
i(i 1..I. ('H. 1si.
Aprliention of principles to sales of reversionilry interests liy persons in dependent position. 
when the sale is made by a man only just of age in pursuance of terms settled while he was still an infint. Here the burden is on the purchaser to show the fairness of the transaction. He is not bound to show that the price given was absolutely adequate; but he is bound, notwithstanding the Act of 1867 (:31 Vict. c. t, p. 664, above), to show that it was such as, upon the facts lnown to him at the time, he might have reasonably thought adequate. Moreover he ought to see, where practicable, that the seller has independent legal adrice. These rules seem to be established by ORorke $v$. Bolingbroke $(p)$, which is remarkable as an almost singular instance of an impeached transaction with an "expectant heir" being upheld. There a father and son negotiated with a purchaser for the sale of the son's reversionary interest expectant on the death of the father. The sule was completed three weeks after the son came of age. The price was agreed to after some bargaining; it was founded on a statement of value furnished by a third person, and would have been adequate if the father"s life had been a good one. The purchaser did not know and had no reason to beliere anything to the contrary, but it was in fact a bad life. The young man took no independent advice, being " penniless, and except for his father friendless" $(q)$. The father died within three months after the sale. Four yars later the son sued to have the whole transaction set aside, but failed in the House of Lords after succeeding in the court of Appeal in Ireland. The majority of the Lords $(r)$ held that the burden of

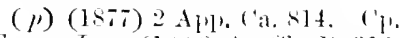

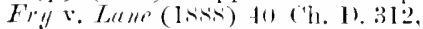
so h.o. C'h. 113. whore the seller was froor and ignorant, and the same sulicitor purporled to and for buth parties.
(1) Lord Blackburn. 2 App. Ca. at $1, \times 37$.

(v) Lurl Blackburn. Lord $0^{\circ} \mathrm{Ha}$ -

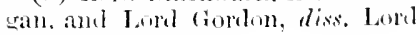
Hatherley. 
proof was indeed on the buyer, but that he had satisfied it. In some cases unconscionable bargatins of this kind are complicated with champerty. Where this is so the transaction cannot, of course, he upheld $(s)$.

Another alleged ground of equitable relief against contracts founded on the notion of an inequality between the contrating parties has been "surprise," or "surprise and improvidence." But this seems to be only a way of describing eridence of fratud or of a relation of dependence between the parties.

The case of Evans v. Llewellin $(t)$ may be taken as the typical instance. The plaintiff was a person Evans $r$. of inferior station and education who acquired by descent a title in fee simple to a share in land in which the defendant had a limited interest. Ilis title was first communicated to him by the defendant, who represented to him (as the fact appears to have been) that the circumstances of the family created a moral obligation in the plaintiff not to insist on his strict rights, and offered to purchase his interest for a substantial though not adequate consideration. The defendant suggested to the plaintifl to consult his friends in the matter, which however he did not do. Three days intervened between the first interview and the conclusion of the business by the acceptance of the defondant's offer. It was considered that the plaintiff was under the cireumstances not a free agent and not equal to protecting himself, and was taken by surprise, and the sale was set aside $(u)$. The ease seens somewhat anomalous, but, according to very

(s) Lipes v. Ite liremedty [184ti] 2 ('h. 137. 65: L. . . C'h. 6ist).

(l) see following note.

(11) (1787) ะ firo. ('. ('. 1:11, 1 Cox. $3: 3$ (! Ii. Ii. 1!1). : lallew report. whice. is here followerl ; the

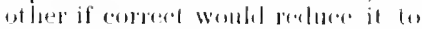
a plain case oll l'rand or al all events miscepresentation. In $/$ ta!! $/$ arth

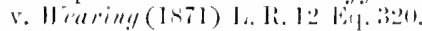

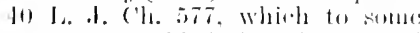
exterst lesembleal this. the gromont of the decision wats a pustise misrepresentation as to the value of the property.
"Sinpurise and " inbuvilinues" malter of evirlence only. 
high atuthority, it might still be followed in setting aside a contract as "improvident and lastily carried inte execution" $(x)$, and it has been distinctly approved in the Court of Appeal in Chancery $(y)$. But no judicial authority can make "surprise" or "improvidence" a word of art, or bind lawyers to affirm as a general proposition that haste or imprudence can of itself be a sufficient cause for setting aside a contract, or even that there is any particular degree of haste or imprudence from which fundamental error, fraud, or undue influence, will be in. variably presumed. "The Court will not measure the degrees of understanding" $(z)$. "Surprise" and "improvidence" are matters from which it may be inferred, as a fact in particular cases, that there was no true consent, or that the consent was not free. What is recorded in such a case as Exans r. Llemellin (a) is not an enunciation of law, but an inference of fact which mal be useful in the way of

() Jinions rit jullets in liall of liath am1 Nontilgruts case. analegy but is not binding as an authority. To this offeet, indeed, were the observations of the judges in the Earl of Bath and Montayne's case as long ago as $1693(b)$. In that case Baron Powel said (3 Ch. Ca. at 1.56$)$ :

"It is said, Thi is a Deed that was obtaned ly surprize and riremvention. Now I pereeive this word surprize is of a very large and general lixtent. . . I harlly knw any surprize that should be sntficient to set anide a beed after a Verdiet, unless it be mixed with Fraud, and that expressly proved." [I.e. the verdict in favour of the deed precludes the party from asserting in equity that he did not know what he was abont: for he should have set up that ease at haw on the plea of non ext fartum.]

(r) Lome St. Ieonards in ('urwom

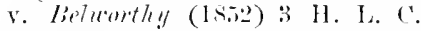
7t2. so Ri. li, 3194 ; there the allee? lant reliod on express charges of framl. whicin were not made out: bat Lool sit. Leonards thought he might posithly have strecerted if he hat rested lis ciatse (1) the ground suggested.

(y) Per Turner I..J. in Raker r. Momk (1stit) + 1). J. s. at p. 392.

(2) Bridyman $\mathrm{r}$. (ireen $(175 \mathrm{~s})$ Witmot, sis.til.

(a) (17is) 1 cox. 333. I R. R. 49. (b) 3 ('h. (a) s. (1) Situry. E1. Juris]. \$25l. 
"It must be admitted that there was Deliberation, and Comsilemtion and Intention enough proved to make it a grenl Dees at Inaw, otherwire there woula not have been a Verlict for it": per 1. (. J. Treby; il. at p. 74 .

The judgment of the Lord Keeper Somers is rven moro decided, and points out clearly the dillerence between an instrument which is void both at law and in equity, and one which is voidable in equity (p. 108):-

"It is true, it is charged in the bill that this leed was ohinined by Frand and surprize. . . But whonever reals over the Depenitims will see that the End they aimed at was to attack the Deeds themselves as false Deels and not truly executed : but that being tried at Law, anul the Will and Deeds verified by a verdict, the Counsel have attempted to make use of the same Evilence, and real it all, or at least the greatest Part of it, as Evidence of Surprize an! ('iremmention. . . . . . .

"Now, for this word (surprize) it is a Word of a general signification, so general and so uncertain, that it is impossible to tix it ; a Man is surprizil in every rash and indiwereet Action, or whatsocrer is not done witl. so much Julgment and Cousideration as it ought to be : Rut l sulpuwe the Gentlemen who use that Worl in this Case mean such surplize as is attended and aceompanied with Fraul and Cirenmvention; such a surprize incleed may be a good groum to set aside a lleed so obtain's in Equity and hath been so in all times: but any other suprize never wis. and I hope nerer will be, hecanse it will introduce such a wilk Luen. tainty in the Decrees and bulyments of the court, as will be of greater ('onsequence than the lielief in any ('ise will answer for."

Moreover the doctrine thus stated is exactly analogous to the undoubted law conceming inadequacy of consideration. The value of the subject-matter of a contract, and therefore the adequacy of the considia. tion, which drpends on it, is in most cases easior to measure than the degree of delibaration or prudenew with which the contract was entered into.

5. Limits of the right of reseission.

The right of setting aside a contract or transfere of The rimht of property voldable on the glound of undue influenee is analogous to the right of rescinding a transadetion rex.i-ion in like thitl in catersen 
framd. ce. and roidahle on any other ground, and follows the same sane rules. rules with some slight modifications in detail.

What is said in the last chapter of rescinding contracts for fraud or misrepresentation may be taken as generally applicable here. We proceed to give some examples of the special application of the principles.

Examyles. The right to set aside a gift or heneficial contract voidable for undue influence may he exercised by the donor is representatives or successors in title (c) as well as by himself, and against not only the donee hut persons claming through him $(d)$ otherwise than as purchasers for value withont notice $(e)$. But the jurisliction is not exercised at the suit of third persoms. The Court will not refuse, for example, to pay a fund, at the request of a petitioner entitled thereto, to the trustees of a deed of gift previously executed by the petitioner, because third parties suggest that the gift was not freely made $(f)$.

Jurisdiction not comtinent to influence of aretual barty to the contract.

()n the other hand it is not necessary to the support of a claim to sot aside a contract on the ground of undue influence to show that the influence was directly employed by another contracting party. It is enough to shew that it was employed hy some one who expected to derive benefit from the transaction, and with the knowledge of the other party or under circumstances sufficient to give him notiee of it. The most frequent case is that of an ancestor or other person in loco parentis inducing a descendant, ete., to give security for a deht of the ancestor. But if the other

(a) Lis. Exerntur : Inuter v. Athins (18.32-t) 3 M. \& K. 113,41

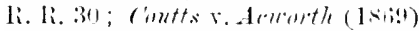
I. R. \& E. sis. Astignee in bankinptey : Find r. Olden (1siz)

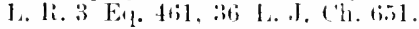

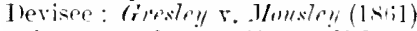

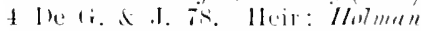

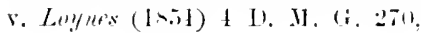

23 1.. J. (h. 529. 102 li. li. 127. (d) Inguenin v. Buseley (1807) 11 Ves. 273. 2s!. 9 li. R. 27i, 28 . (1.. Mrlony r. kerman (1842) $2 \mathrm{Tr}$. .til. $31,411$.

(e) Collbett r. Browk (18.5in) $\geq 0$

Jiar.

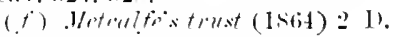
J. 122,33 i. J. ('h. 308 . 
party does all he reasonably can to guard against undue influence being exerted (as by insisting on the person in a dependent position having independent professional advice), and the precautions he demands are satisfied in a manner he camnot object to at the time, the contract cannot as against him be impeached $(g)$.

It appears to be at least doubtul whether a contract can be set aside on the ground of influence exerted on one of the parties by a stranger to the contract who did not expect to derive any benefit from it $(h)$ : except where the contract is an arrangomont between cestuis que trust claiming under the same disposition, and the trustee puts pressure on one of the parties to make concessions; the ground in this case being the breach of a trustee's special duty to act impartially $(i)$.

The right to set aside a contract or gift originally voidable on the ground of undue influence may he lost by express confirmation $(k)$ or by delay amounting to proof of acquiescence $(l)$. But any subsequent confirmation will be inoperative if made in the same absence of independent alvice and assistance which vitiated the transaction in the begimning $(m)$. 'This

(g) Compare Cubluett v. Birrel: (1855) 20 Beav. .i21, lig li. li. i2:3.

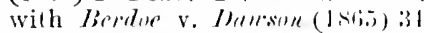
Beav. (jo):. As to what anominte to

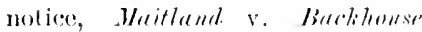

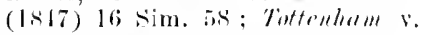

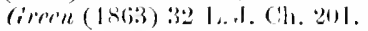

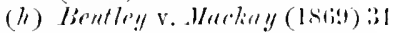
beas. 143. 151. On principle the answer should clearly be in the

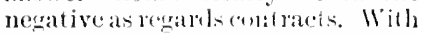
gifts pure and simple, as lo which thele may be somb: tombt, we are nol nuw concerned.

(i) Ellis v. liallore(1.6i) I. li. 7(1. 101. 11 1... (1). 1il.

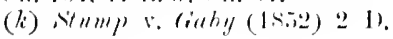

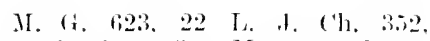

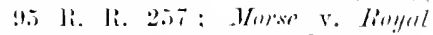
(1816\%) 12 ves. 35.s st li. Ii. 3338.

(l) 11 right v. Famderylumle

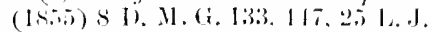
('h. 753, 114 li. Ii. (i) ; Thrmer. ('mlins (1kT) I. li. 7 ( h, :320, 11

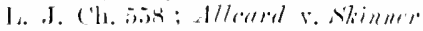

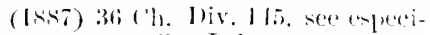

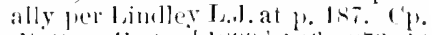

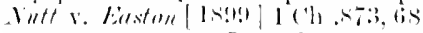

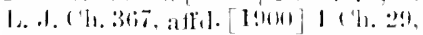
bit l.o.t. ('h. li. Where the phantiol's

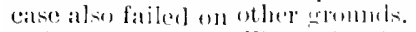

(iii) Siterly v. Kimg (1-isi) i

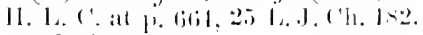
(1)] Ii. Ii. :32:3. ('ontirmation anclachuteseence. 
has been strongly stated in the judgment of the Lords Justices in Moxon r. Payne (n): "Frauds or impositions of the kind practised in this case cannot be contoned; the right to property acquired by such mrans cannot be confirmed in this Court unless there be full knowledge of all the facts, full knowledge of the rquitable rights arising out of those facts, and an ahsolute release from the undue influence by means of which the frauds were practised. To make a confirmation or compromise of any ralue in this Court the parties must he at arm's length, on equal terms, with equal knowledge, and with sufficient advice and protretion." And delay which can be accounted for as not unreasonable in all the circumstances is no bar to relief $(o)$. In short, an act "the effect of which is to ratify that which in justice ought never to have taken place " nught to stand only upon the clarest evirlence $(p)$. The affect of delay on the part of the person seceing relief is also subject to a special limitation. In a case hetween solicitor and client, or parties standing in any other confidential relation, less woight is given to the lapse of time than is due to it when no such relation subsists $(q)$, and it is of special importance that the confirming party should not only be fully acquainted with his or her rights but have indrendent advice $(r)$.

In the ease of a deliberate confirmation after the

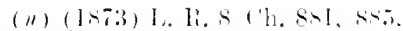
13 1. .l. ('h. 211). Amb a confirmiltion will not the helped by the perence of an imblentent silvieer of the fialty confinting. if. in (comserpence of the continuing inthence of the wher party his aivice is in fact discegarded : it.

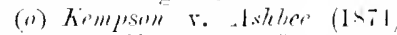
J. li. 11 Ch. I. II I. I. Ch. $19 \%$.

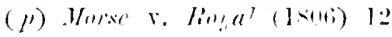

Ven at p. 3izl. S li. R. at 1. 311 .

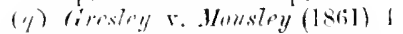
leci.d.J. I. !ti. But event in at (ate between solicitor and client a delay of eighteen rears has been h.lil fatal: Champion r. likghy (183i) I liuk of II. 539,31 K. li. $10 \%$.

(r) linrom r. Hillis [1900] 2 ('h. 1:21, 1:3. 69 L. I. Ch. 532. 1. A. in 11. I. on loroater grounds

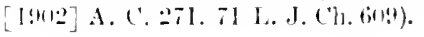


relation of influence has ceased to exist, it neod not be shown that the donor lnew the gift to be voidable $(s)$ : otherwise where the alleged confirmation is connected with the original transaction and talies place under similar circumstances $(t)$.

An adoption of the instrument impeached for a par ticular purpose (as by the exercise of a fower (on tained in it) may operate as an absolute confirmation of the whole $(u)$.

It seems that the presumption of influence arising from confidential relations is not to be extended to cases where a merely trifling benefit is conferred $(x)$. This is more than a simple application of the maxim De minimis non curat lex, for the transaction brouglut in question might he in itself of great magnitude and importance, though the advantage gained by one party over the other were not large. Inderd the case to which this principle seems most likely to be applicallw. is that of a transaction not of a commercial nature, and on such a seale that the proties, doaling fairly and deliberately, might choose not to be curious in weighing a comparatively small balance of profit or loss.

(s) Jitrhell v. Homfledy (1sis])

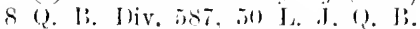
4(i). In Tomson v. .Julg (ls.s. 3

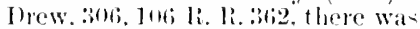
not inderendent alvice, and thepe Was an affemple to conceal the real

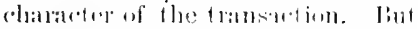

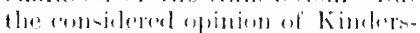
ley V.-C'. on the genemal primeiple is dould lesis a wejerty one.

(f) sice note (1) in ] d disil.

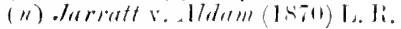

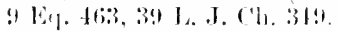

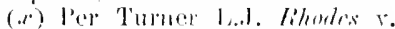
Iinta (lstiti) 1. [i. I ('h. al l. 2ast,

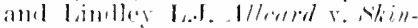

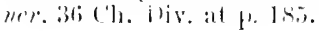

Simblite, 111 plestimptioll of molue influenw. where tle gain is trilling. 


\section{CHAPTER XIIT.}

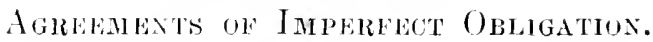

Niture uf imperfect ubligations.

How Henincert.

Uxpler this hear we propose to deal with topics of a miscollaneous lind as regards their subject-matter, and forming anomalies in the general law of contract, but presenting in those anomalies some remarkable uniformities and analogies of their own.

Brotween contracts which can be actively enforced hy the persons entitled to the benefit of them, and agreements or promises which are not recognized as having any legal effect at all, there is another class of agreoments which though they confer no right of action are recognised by the law for other purposes. 'These may be called agrements of imperfect ohligation. Some writors (as Pothier) speak of imperfect obligations in the sense of purely moral duties which are wholly without the scope of law: and what we here call Imperfect Obligations are in the civil law called Natural Obligations. But this term, the use of which in Roman law is intimately connected with the distinction between ius cirile and ius gentium. (a), would he inaprepriate in English (b).

Where there is a perfect ohligation, there is a right compled with a remedy, i.e., an appropriate process of law hy which the authority of a competent court can be sot in motion to enforce the right.

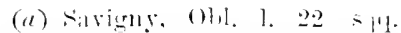
Fur a smmmaty statement of the effects of a natural chligation in

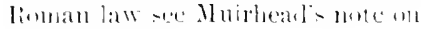
(iai. :3. 11 ise. (b) The term " covenant en ley de nature" was applied by kishop stillington. (.. to a parol agreement lut to slle: 9 EA. W. 41 . 1.l. 24 . 
Where there is an imperfect obligation, there is a right withont a remedy. This is an abnormal state of things, making an oxception whenerer it occurs to the general law expressed in the maxim Ubi ius ili remedium. And it can be produced only by the opera tion of some special rule of positive law. Such rules may operate in the following ways to produce an imperfect obligation :

1. By way of condition subsequent, taking away a remedy which once existed.

2. By imposing special conditions as precedont to tho existence of the remedy.

3. By excluding any remedy altogether.

Wo shall now endeavour to show what are the effects of an imperlect obligation in these three classes of cases.

1. Under the first head we have to notice the operation of the Statutes of Limitation, so fal as it illustrates the present suliject $(c)$. The Statute of 1. Riemerly wsiatutes of Limitation of Jimes I. (21 Jite. 1, c. 16, s. 3) enatcts that the actions therein anmerated-which, with ath exception since repealed, comprise all actions on simple contracts $(d)$ - "slith be commeneed and surd " within six years after the catuse of action, and not after. By the modern statute $3 \& 4$ Will. 4, c. 42 , s. $3(e)$, following the presumption of satisfaction

(a) Debts contraeted by an infint are often combared 10 ilehts batred by the statuten of limilat tion: and the comparison is just to this extent, that at common law they might be ronderes enformable. in mueh the same manmer, and practically the antlurities ante interchangeable on this point. line an infint's contract is in its inerption not of imperlect obligation, but sintply roiditble. (d) Is to the extent to whinh the statute applies to procerelings

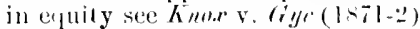
I. Ii. 5 I. L. 65ti, 12 L. J. Cls. 231 .

(a) This sertion is not affereter by the real l'roperty Limitation Act, Int except that promentings to reenver rent or money chitrined on lame now have to be talien within 12 years: 37 . 3 : 34 lict a $\therefore \pi, s .1, \therefore$. 
The right nut ane.

after the lapse of twenty years which already obtained in practice $(f)$, it is enacted that (inter alia) all actions of corenant or debt upon any bond or other speciality "shall be commenced and sued" within twenty years of the cause of action. We need not stop to consirler the exceptions for disability, or the rules as to the time from which the statutes begin to run: for the object throughout this chapter will not he to define to what cases and under what conditions the laws under consideration aply, when that is abundantly done in other treatises, but to observe the general results which follow when they do apply.

Now there is nothing in these statutes to extinguish an obligation once created. The party who neglects to enforee his right by action cannot insist upon so anforcing it after a certain time. But the right itsolf is not gone. It is not correct even to say without qualification that thore is no right to sue, for the protection given by the statutes is of no avail to a defendant unless he expressly claims it. Serjeant Williams, after noticing the earlier conflicts of opinion on this point, and some unsatisfactory reasons giren at different times for the rule which has prevailed, conchudes the true reason to be that "the Statute of Limitations armits the cause or consideration of the action still existing, and merely discharges the defendant from the remedy" (g). This alone shows that an imperfect obligation subsists between the parties after the time of limitation has rum out. In the case of unliquidated demands that obligation is practically inoperative, since an unliquidated demand cannot be rendered certain except by action or an express

(f) Roddum r. Worley (1Sini-i)

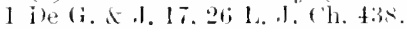

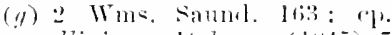

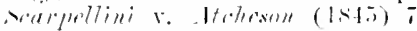

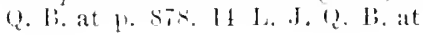

1.: :3:s. on the technical effect of a lilea of the statute. The rule contimues muler the Judicature Acts. Orier XIX. 1. 15 [No.211]. 
agreement founded on the relinquishment of an existing remedy. But in the case of a liquidated debt the continued existence of the debt after the loss of the remedy by action may have other important effects. Although the creditor cannot enforce payment by direct process of law, he is not the less entitled to use any other means of obtaining it which he might lawfully have used before. Thus if he has a lien on goods of the debtor for a general account, he mily hold the goods for a debt barred by the statute $(h)$. And any lien or express security he may have for the particular debt remains valid $(i)$. If the debtor pays money to him without directing appropriation of it to any particular debt, he may appropriate it to satisfy a debt of this lind $(k)$ : much more is he entitled to keep the money if the debtor pays it on account of the particular debt, but not linowing, whether by ignorance of fact or of law, that the creditor has lost his remedy. So an executor may retain out of a legacy a barred deht owing from the legatee to the testator $(l)$. He may also retain out of the estate such a debt due from the testator to himself: and he may pay the testator's barred debts to other persons $(m)$, though not any particular debt which has been judicially declared to be not recoverable from the estate $(n)$ : and this even if the personal estate is insufficient (o). But though a ereditor

(h) Spruts v. ITartl! (1806) 3 Lisp. sl, if li, R. 814 .

(i) Miggins v. Siott (1831) 2 l:.

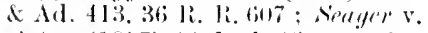

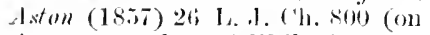
the statute of 3 \& 4 Will. 4$)$.

(le) Wills v. Fomples (In39) 5

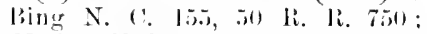

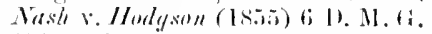
471, 25 L. .l. ('h. 161;. 106; li. li. 1:57.

(b) cimerfona! v. II illiams. (1s+1) 3 IIa.539, 1:36, .1.6 h, 161, 1:51..1.1'h.

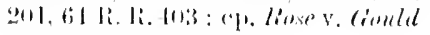

(18.52) 1.5 Beav. 189), 92 Li. Li. 37s.

(m) Mill v. Il allier (1s.as) I K. d. I. loti: Strelelsolumint v. Lett

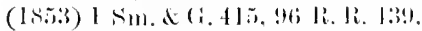
(1i) Midgle'y v. Midyle! [18:13]

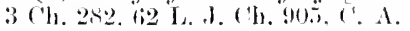

(a) Lomis v. Rummery (Istii) I. li. I kip. 4.3l. This is a peculiar rule. It is otherwise as to clams not mulurceable by reasin of the Statule of Frandis: lie Rommeron

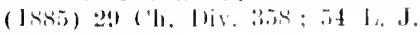
(11. 6511$)$ liesulis. Incielental rights of creelitor preserved. 
Aclinumled ninit by debtur. may retain a barred debt if he can, he may not resist another claim of the debtor against him by a set-off of the barred deht: for the right of set-off is statutory, and introduced merely to prevent cross actions, so that a claim pleaded by way of set-off is subject to be defeated in any way in which it could be teferated if made by action $(p)$. This reason applies equally to all other cases of imperfect obligations. Herein our law differs from the Roman, in which compensatio did not depend on any positive enactment, but was an equitable right derived from the $i$ us gentium.

Again, the creditor's lost remedy may be revired by the act of the debtor. The decisions on the statute of James I. have established that a renewed promise to pay, or an acknowledgment from which a promise can be inferred, excludes the operation of the statute. It was formerly held that the statute rested wholly on a presumption of payment, and therefore that any acknowledgment of the deht being unpaid, even thongh (roupled with a refunal to pay, was sufficient. But this opinion has long since been overruled $(q)$. Again, it has been said that although the original remedy is gone, the original consideration remains as a sufficiont foundation for a subsequent promise. But this explanation is not satisfying, since the consideration for the new promise is wholly past, and therefore insufficient according to modern doctrine $(r)$. The only theory tenable on principle seems to be that the statute is a law merely of procedure, giring the debtor a defence which he may waive if he think fit. Nevertheless it is held that the acknowledgment operates as evidence of a new promise, and therefore it is not effectual unless made before action brought $(s)$.

\footnotetext{
(p) The refence if set-oft must lo specially met by replying the statute of limitation. see I II ins. siatiul. 431 .
}

(q) $2 \mathrm{Wms}$ saund. 183. $1 \mathrm{~s}$.

(r) Siee p. 1s9. alove.

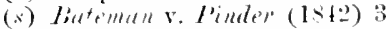
U. 1., 34,11 1. J. U. B., 2-1. 
The modern law was eoncisely stated by Mellish L.J. "There must be one of three things to take the case out of the statute. Either there must be an acknowledgment of the debt, from which a promise to pay is to be implied; or secondly, there must be an unconditional promise to pary the debt; or thirdly, there must be a conditional promise to pay the debt, and evidence that the condition has been performed" $(t)$. The promise must be to pay the debt as ex debito iustitiae; a promise to pay as a debt of honour is insufficient, as it excludes the admission of legal liability $(u)$. When the promise is implied, it must be as an inference of fact, not of law; the payment of interest under compulsion of law does not imply any promise to pay the principal $(x)$.

The acknowledgment or promise, if express, must be in writing and signed by the debtor (9 Cieo. $t$, c. 14 , s. 1) or his agent duly authorized (Mercantile Law Amendment Act, 1856,19 \& 20 Vict. c. 97, s. 13). But an acknowledgment may still be implied from the payment of interest or of part of the principal on account of the whole, without any admission in writing $(y)$.

The more recent statute which limits the time for suing on contracts by specialty contains an express
What in sutlicient ackinowletsnent.

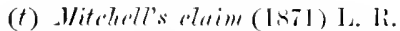

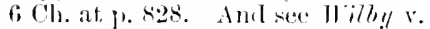

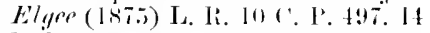

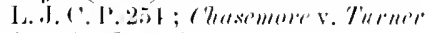
(187.) (Ex. (\%.) 1. R. II) (2. Ii. 501. 506, 510. 520. 1.5 L. . I. 2. IS.

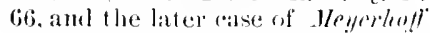

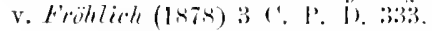
in C. A.. + ('. I. Iliv. Ai3. IS I., J. ('. I. 43. which also show how moeh difficulty there may be in dedemining in a particular cake whether there hats been an ancon-

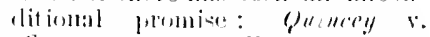
Sterrepe (1S7ti) I Ex. 1), T2. 15

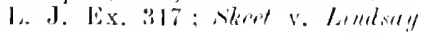

(IN7) 2 Ex, 1). 314. 46 L. J. Ex.

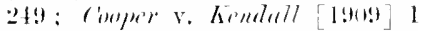

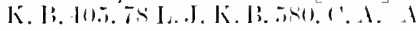
pomise to faly what may be lomml lue on takingan anomot is enongh:

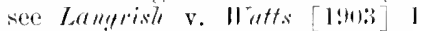

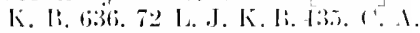

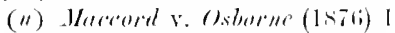

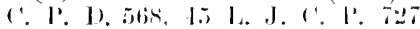
(onl loril T'enterilen's Ael).

(.r) Mtorgan v. limelamds (1-72) I. Ii. 7 Q. L. I!I, I!S. II 1. J. (2. 1: 1si.

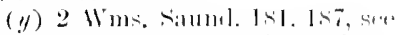

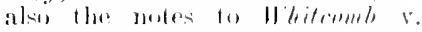
Il biling (1781) I sm. I. ".
Statutory provision for 
aknowledg- proviso as to acknowledgment and part payment mont of sperialty debts.

Stat. of

Jimitation as tor real pro. perty : right ats well as remedy taken iway.

Enolish statutes of linitation antl

analogons foreign laws affecting the remely only. treated as piart of ledeleri.

(3\& 4 Will. 4, c. 42, s. 5) (z). The cases as to aclinowledgment, \&c. under the statute of James, and Lord Tenterden's Act, are not applicable to this proviso. Here the operation of the acknowledgment is independent of any new promise to pay, and the action in which the acknowledgment is to be operative must be founded on the original obligation alone $(a)$.

The Act for the Limitation of Actions and Suits relating to Real Property (3\& 4 Will. 4, c. 27 , s. 34 ) does not only har the remedy, but extinguishes the right at the end of the period of limitation. It is therefore uncomected with our present subject.

We have seen that by the operation of the statutes of limitation applicable to contracts the right itself is not destroyed, but only the conditions of enforcing it are affected. The law of limitation is a law reluting not to the substance of the cause of action, but to procedure. Hence it follows that these enactments belong to the lex fori, not to the lex contractus, and are binding on all persons who seek their remedy in the courts of this country $(b)$. A suitor in an English conrt must sue within the time limited by the English statute, though the cause of action may have arisen in a country where a longer time is allowed $(c)$. ConFicle B.C. versely, an action brought in an English court within tet. the English period of limitation is maintainable although a shorter period limited by the law of the

(:) See Prals v. Latiug (1sil) I. Ii. 12. E11. 41. 41 I. .J. Ch. 22:5.

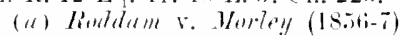
1 be (i. .t J. 1. 2ti L. J. ('h. t38. opinion of Willians and Crowder .J. at 1. 15.

(7) This principle was approved and applied. after full dixcussion and very long leliberation. by the

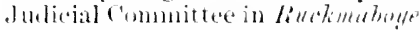

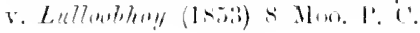

4. 9 r R. R. 1. The only point that gave any real trouble was whether its application to Hindus at Bomha was compatible with the terms in which the personal law of Asiatic suitors wats saved br the ('harter of the supreme Court then in force.

(1) british Linen ('o. r. Imum.

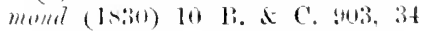
li. li. 54.5 . 
place where the contract was made has elapsed, won if a competent court of that place has given judgment in favour of the defendant on the ground of that period having expired $(d)$. And for this purpose a document under seal has been treated by an Fug lish court as creating a specialty deht, though made in a country where our distinction between simplo contract and specialty dehts does not exist, and more than six years before attion bronght $(e)$.

The House of Lords, as a seots court of alpeal, hals had to decide a similar question as between the law of Scotland and the law of France. It was held that the Scottish law of prescription applied to an action brought in Scotland on a bill of exchange drawn and accepted in France, the right of action on which in France had been saved by judicial proceedings there $(f)$. In the case where the shorter of the two periods of limitation is that allowed by the foreign law governing the substance of the contract, and that period has elapsed, it is of course necessary to aseertain that the foreign law is analogous to our own in its operation, and merely takes away the remerly without maling the contract roid at the end of the time of prescription. But it is considered that an actual destruction of the right would be so inconvenient and unreasonable that it may almost be pro-

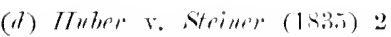

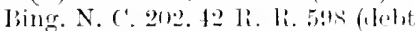
harred liy french law): Ihroise. gmine (1stig) L. R. I \%. L. 6i,3,

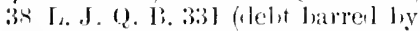
Manx law): in the latter case cockburn ('.). expressed some domb as to the principle achmittine however thiat the rule was set llacl by aubority : Sarigny tom (syst. . $273)$ is for applying that law which governs the sulistimere of the contract.

(a) Alliener bients of simle $\therefore$

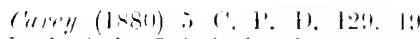

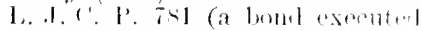

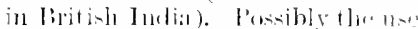
ly liritinh subjets of an Engliois form, unmeanines at the plate of execution, may justafy the infer. ence that they at that time intember the areunent to olerate as an Enclish abed. Otherwise the

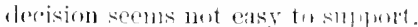

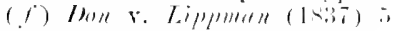

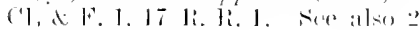
Wm: situml. 3!!!?. 
2. Complitions precerent to renterly.

1 Sitalitu of Fiatuls. $\therefore 1$.

sumed that such is not the operation of the law of any civilized state; and the English courts would not put such a construction on the foreign law unless compelled so to do by very strong evidence $(g)$.

We shall presently see that analogous questions concrining the lex fori may arise in other cases of imperfect obligations.

2. Inder the second head fall the cases of particular classes of contracts where the law requires particular acts to be done by the parties or one of them (in respect of the form of the contract or otherwisc) as conditions precedent to the contract being recognized as enforceable.

A. The most important of the enactments thus imposing special conditions on contract is the fourth section of the Statute of Frauds (29 Car. 2, c. 3).

The fourth section enacts that after the date there mentioned

" no action shall be brought wherely to ehirge any exeentor or alministratur mon any special promine tuanswer dimages out of his own estate : 1.' wherehy to charge the defomlant upon any special promise to answer fur the tebt. defunlt, or miscarriages of ansther person ; or to charge any furson upun any agreement mate upon consideration of marriage; (n) upul any contract or sule of lands, tenements, w hereditaments, or any

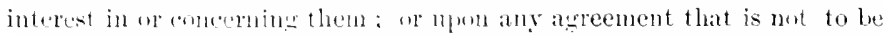
lerformed within the space of one year from the making therenf ; unles: the aycement nipm which such acting shall be brought or some menorandum or note therenf shall be in writing. and signed by the party to be chitran therewith or sme other persm theremto by him lawfully :110therized,",

The terms of the 1 tih section (now superseded in Fingland by s. $t$ of the Sale of Goods Act, 1893) wre different, and raised a question whether they did not wholly avoid agreements not satisfying its conditions; yet the better opinion was that the 17th

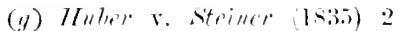

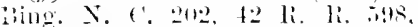
where it was in vain attempted to show that by the French law of prearention the right was absolutely extinguished. 
section, like the the was only a law of procedure $(h)$; and the Sale of Goods Act has so settled it for the future by using the words "shall not be enforceable by action." And it seems that the statute does not prevent property from passing on an informal sale (i). The cases of part acceptance of the gonds or pirt payment of the price are expressly provided for, either of these having the same effect as a chuly made memorandum in writing.

We now return to the fourth section. For the salie of brevity we shall use the term "informal agrosment" to signify any agreement which comes within this section and does not comply with its requirements.

For some time it was not fully settled what was the effect of this enactment on informal agreements. There was some authority for saying it made them void. It was never held necessary in the courts of law for a defendant sued on an informal agreement to plead the statute specially, as in the case of thr. statutes of limitation: and it has been held (bofore the C. L. P. Act) that a special plea was not anly unnecessary but had as an "argumentative denial". of the contract declared upon (j). Moreover an actiom cannot he maintained when, although it is not brought

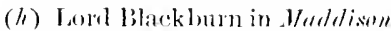
v. Aldersom (1883) \& A A H. (at. at

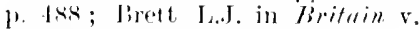
liossitue (1879) 11 (). I3. 1). at 1. 127. 48 I. .J. Jx. 3102.

(i) Tillar v. li. L. Iill. ri.

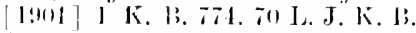
$19 ! 9$.

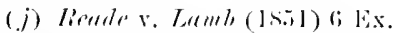
1:30, 20) 1. .1. Ex. 1til. Sine tla" Jurloature defs the deferee of the slatule must always bo distimelly raised on the pleadiness (Oreling XIX. r, li, ell. r. 20. The defendant need not spereify on whirels section he reties, but if he does, he cammot alter it hy ameminmmi:

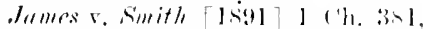

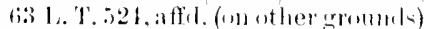
(is) I. T. ill. As to tle lemmer

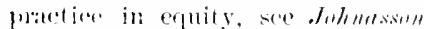

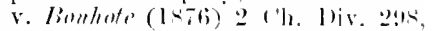

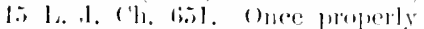
rased the defence is amilabile withemt further repetition at any suberpuent slage of the prorededings: ib. Conversely, a paty who omise for mase it may be astopleed from doing sil in latere

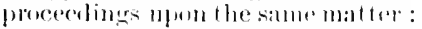

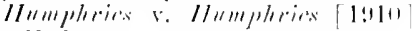
? K. 1: .31, \&...
Eiffert of s. 4 for sime time nut settlert. 
to enforee any right ex contractu, the right which is the foundation of the plaintiff's claim depends on an informal agleement. In Carrington. v. Roots $(k)$ the plaintiff sued in trespass for seizing his horse and cart: the dofendant pleaded that they wore incumbering and doing damage on his ground: the plaintiff reptied a verbal agrement that the defonflant shonld sell the cop) and grass growing there to the plaintiff, and that the plaintiff might enter with his horse and cart to take them. It was held that this agreoment was for the sale of an interest in land withins. 4, and that the plaintiff could not set it up, though it might have been arailable as a licence only, in answer to an action for trespass ( $l$ ). Both here and in the later case of Rende v. Lamb above cited the julges said distinctly enough that informal agreements wre not only not enforceable but roid. And so Sir Wr. Grant appears to have thought in Randall v. Morgan $(m)$. These dicta are not consistent with the decisions to he presently mentioned in which the existence of an imperfect obligation is implied. And there had ation been judicial expressions of opinion the other way. But it is not necessary to notice these, for the point was expressly

lesision in laroux $r$. liriwn: arrewinent init vinil. bint only not enfurceable. decirled by the Court of Common Pleas in Leroux $\mathrm{r}$. Brown (n), where the earlier dicta are also considered. The action was on a contract not to be performed within one yoar, and made in Franco, where by the French law the plaintiff might have sued on it. For the plaintiff it was alegud that s. $t$ of the Statute of Fratudis applied to the substance of the contract, and therefore, on general principles of private inter-

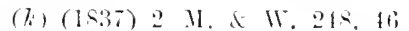
Ti. Ti, is?.

(l) Cl\% ropsly r. Wadsurmeth

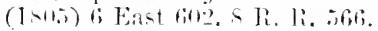

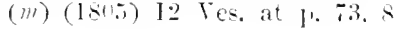

li. li. 21 ?. 293.

(u) $(1-52)$ I2 C. B. s01. 22 L. J. '. P. 1. 92 R. R. ssot and see per Juril lilackburn in Madnison $v$. dhlowen. note (h), last page. 
national law, did not affect contracts which were mate out of England, and which as to thrie sulstance were to be governed by the law of the place where they were made. But for the defendant it was answered that this enactment, like the statute of Limitation, only allected the remedy, and was therofore a haw of the procedure of the English courts, and as such bind ing on all suitors who might seek to enforce their rights in those courts: the agreement might be gond enough for any other purpose, but the plaintiff could not sue on it in England. And this view was adopted by the Court. Jervis C... said: "The statute in this part of it does not say that unless those requisites are complied with the contract shall be void, hut merely that no action shull be brought upon it. . . . The fourth section relates only to the procedure and not to the right and validity of the contract itsolf." It will be observed that the plaintiff was here in the curious position of contending, in order to sulpurt his right to recover on a contract made in France, that it would have leen absolutely roid if made in England $(0)$. If this decision and the reasons givon for it are correct, it would seem to follow that a foreign or colonial court onght to enforce an English agreement, motwithstanding that it was informal moler s. \pm of the statute of Frauds, if it had the general requisites of a valid contract in English law, and was not informal according to the local law of promcerlure.

It has even beren alrgued that the worels " no action shall be beneght" eomfine the operation of the statute to civil pocess, so that an informal agreemont for

(d) Leroute v. lirourn. latet mole, was doulded by Willess .I. in

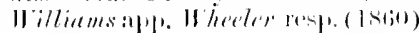

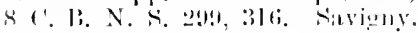

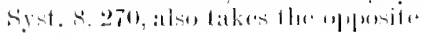

view. The rase also rouk (abiler) a elistiaction betweren s. 1 allal s. 17, whinde was mot eromerally

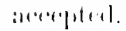


riesults of imprerlect (1) ligation mutel 1 of statule of Flinds.

As $=10$ montey lial.

service not to he performed within a year might be onforced by eriminal process under the Master and Servant Act, 1s67. But the Court held that such at construction would be tom unreasonable, and the statute must mean that informal agreements are not to be enforeecl in any way $(p)$.

It being established that the informal agreements we are considering are not roid, it follows that they give rise to imperfect ohligations. We will now indicate the results. We have seen that neither the (b)ligation itself, nor any right immediately founded an it, can be directly enforced. But it is recognized for the purpose of explaining anything actually done in purstance of $j$, and anything so done may in many eans be a gond consideration for a new obligation on a subsequent and distinct contract, or a sufficient lonndation for a new obligation quesi ex contractu.

A. Money paid moner an informal agreement cannot be recorered bate merely an the ground of the agresenunt not being enforceable. Thus if a responsibility lias been assumed and executed under a rerbal glatranty, the guarantor cannot recover back the money paid by him (q). So a purchaser cannot re corter a deproit paid on an informal agreement lor the sale of land, the rendor remaining realy and willing to complete $(r)$. And not only can the one party liens money actually paid to him by the other, hat if money is paid by $A$. to B. in order to be paid wer to ('. in pursuanee of an informal agreement

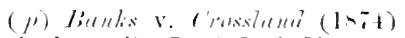

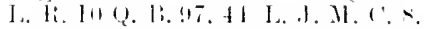

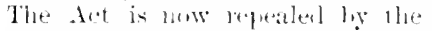

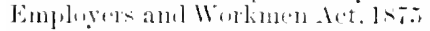

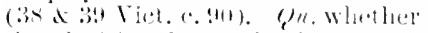
the decision be applicable to the malicious breaclese of contract in

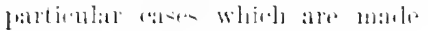
sublantib oflences ly the cin- spiracy and lrotection of linperty

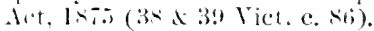

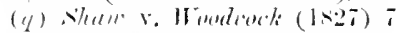

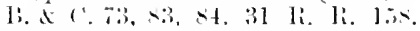

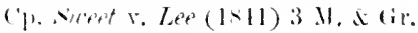
fie. liol R. Ri. itti.

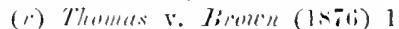

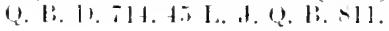


between A. and C. which C. has executed, then C. can recover it as money receivel to his use. In Griffith v. Young $(s)$ the plaintiff was the defendant's landlord. The defendant wished to assign to one P'., which he could not do without the plaintilf's consent. It was verbally agreed that $l^{\prime}$. should pay the defendant 100l. for goodwill, out of which the defendiant was to pay 40l. to the plaintilf for his eonsent to the assignment. P. knowing of this agreement paid the 100l. to the defendant: it was held that the defendant was liable to the plaintiff for 40l. in an action for money received to his use. Lord Ellenborough said: "If one agree to receive money for the use of another upon consideration executed, howerer frivolous or void the consideration might hare been in respect of the person paying the money, if indeed it were not absolutely immoral or illegal, the person so receiving it camnot be permitted to gainsaly his having received it for the use of thit, other."

On the same principle, if on the faith of an in formal agreement money has been paid in advance to a party who afterwards refuses or fails to perform his part of it, or has been expended on his aecount, it is conceived that proof of the agreement may he admithed to show what was in fact the consideration which hats failed $(t)$.

But an executor may not pay or retain a deht which by reason of the statute of Fratuds the creditor cammot enforce $(u)$.

B. The execution of an informal agreement may be shown as at fact, and the pally whe has hat seme henefit from such execution, so as in fiact to get what he batgained for, eammot treat the bargatin ats a nullity.

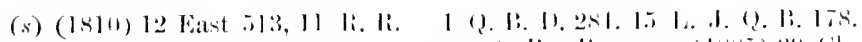
tix.

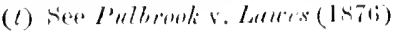

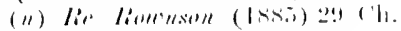

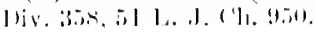

As 10 agreensent cxeruteds. 
Thus the drivery of possession under an informal agrement for the sale of land is a good consideration for a lromissory note for the balance of the purchase-money $(x)$. It was held in the case cited that the bargain was for a future conveyance, and that the Infomlant, who did not deny the plaintiffs' allegation that they were willing to convey, had got all he batrgilinerl for.

The same holds of an account stated. In Cocking 5. Ward (y) there was an oral agreement by an incoming tenant from year to year to pay 100l. to the outgoing tenant: it was held that the agreement was within s. 1 of the statute, and the outgoing tenant crukl not recorer the 100l. on the agreement itself, but that on an aceount it ited he could.

Again, money due sinply under an informal agreement from the plantilf to the defendant camnot of coutse be set ofl ; but the performance of an informal agreenent hy the defendant may he good as an accord and satisfaction. In Lacery r. Turley $(z)$ the plaintilf sted for goods sold, de.: the defendant pleaded an equitalle plea showing that in pursuance of an agreenent between the parties (which turned out to be rerbal) the defendant lad given up to the plaintilf fustesion of a house and premices in satisfaction of thr causes of action sued ujents. The plea was held gond, and it seems it was good emough at law (per Jiranwell and (hamnell Bib.). Pollock C.B3. said: "It is pleaded ats a fact that the defendant performed the agreement and the plaintilf accepted such performance in satisfation. The objection that the agreement wats not in writing is got rid of. The fourth section of the statute of Frauds does not

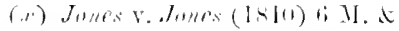
IV. Al, is li. li. .i2l.

(?. P. 21., 6. R., R. S31.

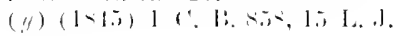

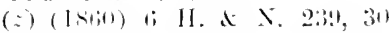
1... H. H. 19.
} 
exchude unwritten proof in the case of executed contracts" (a). This of course does not mean that the agreement itself can in any case be sued upon $(a)$.

It is admitted that if $A$. agrees informally with $X$. to sell land to him, and alterwards aglees in writing to sell the same land to $Z$., and then eonveys to $X$. in pursuance of the first agreement, $Z$. hats no eypity as against $\mathrm{X} .(b)$.

c. It is a well-known doetrine of equity that one $\Lambda$ s to fiat who has partly performed an informal agreement for perfminance the purchase or hiring of land $(c)$ is entitled to and can sue for a specific performance at the hands of the other party, if the acts of part performance hale been done on the faith of an existing agreement, and have been of such a kind that the parties cammot he? restored to their original position, and if the existener of an agreement is reasonably to be inferred from the acts themselves, or they are "unequirocally referable? to the contract" $(d)$. This srens to be the real moining of the distinctions as to what is or is not at sufficient part performance. P'ayment of money is in itself an equivocal act, and therefore the part payment of purchase-money is not a sufficient part per. formance $(e)$. But payment of increased rent by a yearly tenant holding orer has been held a sufficiont part performance of an agreement for a lease $(f)$.

(a) $\mathrm{Cp}$. Simele v. sitmentridge

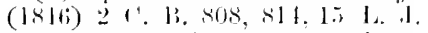
(1. P. 170, ij! li. li. lili, and lemalls on the dictum thepr in

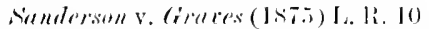

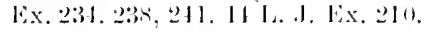

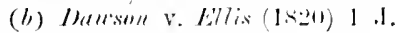
(t II. 521, 21 li. li. 2207.

(1.) 'Jle aloctline is not rextromeles to rother transations. libitaill v. liossiler (1RT!) 11 12. IR. Jiv. 12:3, 131, 1. 1. .1. Hx. 362. Sce, how-

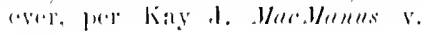

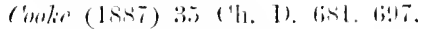
ini 1. J. ('h. (iti2.

(d) Dhaldisure v. Aldersom (I-Sha)

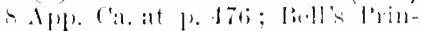
(iples, 179. rited by lomes sollume. ib. at p. $17 \%$.

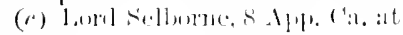
1). $17 !$.

(f) Iunt v. Fibliall (listia)

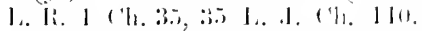
fere explatuation of that ane lis

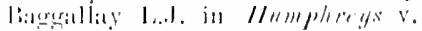

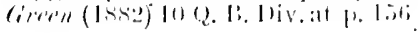


Here the part performance consists not in the payment itself, but in a possession which, though continuous in time with the old possession of the plaintiff as yearly tenant, is shown to be in fact referable to some new agreement (y). This doctrine of part performance is not in direct contradiction of the statute of Frauds. It would be erroneous to say that a court of equity accepts proof of an oral agreement and part performance of a substitute for the evidence required hy the statute. The plaintiff's right in the first instance rests not on contract but on a principle akin to astoppel; the defendiant's conduct being equivalent to a continuing statement to some such effect as this: It is true that our agreement is not binding in law, hut you are salfe as far as I am concerned in acting as if it were. A man camnot be allowed to set up the legal invalidity of an agreement on the faith of which he has induced or allowed the other party to alter his fusition $(h)$. In the law of scotland such tacts are said to "raise a personal exception" $(i)$. The same principle of equity is carried out in cases of repersentation independent of contract (see pp. 701, 70:2, below) and wen of mere acquiescence. In equity

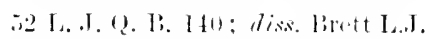

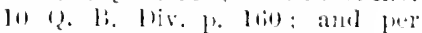

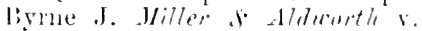

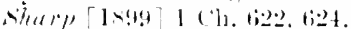

(11) In the genteral theory of poression as comatitutinge part pertormance see per .Jessel II.li.

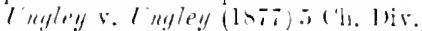
at p.s?t): "The reasom is that peneston by a stranger is evilenece that there was some contract. and is stleh eongent eridence as focompel the comrt to almit evinlence of the torms of the entract in onder that juitice may le done between the parties" : to same effect cutton

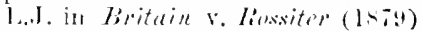

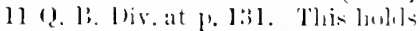
resen where the pustesien wats talien before the agreenent was conelndeal: Hodxun v. Mrulaut 1s!ti] $2($ 'h. 426,65 L. J. Ch. $\pi$. (h) ratone v. C'atene (Istis) L. li. 1 the at p. 14t, 3.i l. I. Ch. 2!2: Monphett $\because$ Junes (1S1s) 1 Swanst.

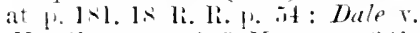
Haniltun (1sti) : Ma. at ]) 331, il Ii. li. 13i : accorelingly the cases on estoplec at law are compared by Lord cranworth in Jorden $v$.

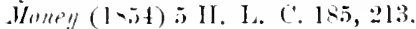
23 L.. J. ('h. 86.5, lol Ji. li. 116. 130); aml by lord (amplell in Prighott v. stratton (15:54) I L. F.J. 33. 4!, 29 1. J. ('h. 1. It must be almilled, however, that the recon anthorities do not exhibit a vely delinite or settled theory.

(i) lin.ll, ciled l,y larn selborne, 8 ipt. Ci. tii. 
an owner may be estopped by acquiescence from asserting his rights, although there has not been any agreement at all $(k)$. This also explains why the plaintiff must show part performance on his own side, and part performance by the defendant would be inmaterial $(l)$. When the Court is satisfied that the plaintiff has altered his position on the faith of an agreement, and that the defendant camnot he heard to deny the existence of that agreement, it proceeds to ascertain by the ordinary means what the terms of the agreement were. The proof of this is strictly collateral to the main issue, though the practical result is that the agresment is enforced.

D. The case of an agreement in comsideration of marriage presents special difficulties, and has to be treated in an exeeptional manner. This subject is fully discussed in the late $\mathrm{Mr}$. Davidson's volume on settlements (I)av. Conv. vol. 3, part 1, appendix No. 1, to which place the reader is referced for details). It is thoroughly settled that the marriage itself does not constitute such a part performance as to make the agreement binding in equity in the manner just mentioned, though other acts may have that effect $(m)$.

Then, what is the aflect of a post-nuptial "noter or memorandum" satisfying the requisites of the statute on ante-nuptial informal agreement? This is a rather complicated matter. It is not the statute of Frauds alone that has to be considered in these cases, but also the statute of $13 \mathrm{Eli}$. c. 5, and the extrnsive mpplication of it by julicial construction to voluntary dispositions of property. L'wo distinct questions aro

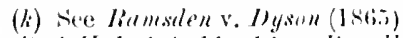
I. Ii. I II. L. 129, $1111,16 \mathrm{~s}$; l'merll

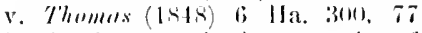
li. Ii. 116; and the remantis of

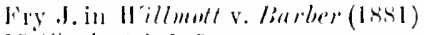
15 (1). 1). !). 10.5.

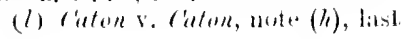

Ante-nuptial agreenents.

Etreet of conthirmation ley fuistniintial writing.

\section{page.}

(iii) See Lasse'tse r. Tierme'y

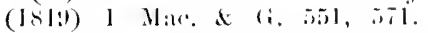

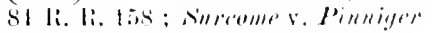

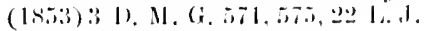
(1. 119. !) R. R. 22!9, 23:2. 
Fiond as agatinst fromisor: Parkworth r. Younge.

Pat ats argainst sittlins rereditors: Wardente. hones.

in fact raised: namely whether an informal antenuptial ingreement can after the marriage be rendered valid as against the promisor, and whether a postnupitial settlement can be made to relate back to such an agreement so as to be deemed a settlement made for valuable consideration and thus be rendered ralid as ayninst creditors. The first question is answered in the affirmative by the deeision in Barkworth $r$. Joung $(n)$. The case was decided on demurrer, and the facts assumed by the Court on the case made by the plaintiff's bill were to this effect. The testator against whose estate the suit was brought had orally promised his daughter's husband before and in consideration of the marriage that at his death she should have an equal share of his property with his other children. After the marriage the testator made an affidavit in the course of a litigation unconnected with this agreement, in which he incidentally admitted it. It was held that the affidavit was a sufficient note or memorandum of the agreement within the Statute of Frauds, and that as such, although subsequent to the marriage, it rendered the agreement binding on the testator.

The second question is answered in the negative by the almost contemporaneous decision in Farden $r$. Jones (o). That was a creditor's suit to set aside a post-muptial settlement. It was attempted to support the settlement as having been made pursuant to an oral ante-nuptial agreement. This agreement was not referred to in the settlement by any recital $(p)$ or otherwise. It was held both by Romilly M.R., and

(11) $(15,6 i)+$ I rew, 1, 20; I. .J. (h. 1.3. 113 li. li. $2 ! 9$.

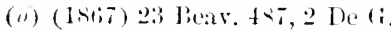

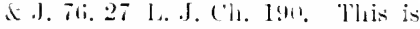
mot inconsistent with biaknorth

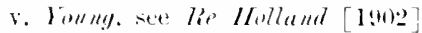
2 ("ls. stii), il L. I. ('h. ils. eque- cially per stirling L.I. The huselamils trustee in bankruptey has 11." better right than the husbanel himself : ill.

(l) As to the effoet of reciting a previons agreement, see lie Mollind. last note. 
by Lord Cranworth C. on appeal, that the settlement could not he supported: and Iord Cranworth inclined to think $(q)$ that if the settlement had experssty inferred to the agrement it would have matre no difference.

On the whole even if the imperfect obligation arising from an informal ante-nuptial agrement ran be made perfect and hinding as botwern the partios by a post-nuptial note or memorandum, it appears that the marriage consideration cannot in this way he im. ported into a post-nuptial settlement made in pursuance of the agreement so as to protect it from being treated as a voluntary settlement and subject to the consequent danger of heing set aside at the suit of the settlor's creditors. There seems to be no ground in either case for drawing any distinction hetween promises made by one of the persons to be married and promises made by a third person to either of them. These doctrines appear to he hoth reasonable in themselves and not inconsistent with one anothere, as the Court of Appeal has now declared them not to be $(r)$. There is nothing mexampled in a transaction being valid as regards the parties to it and invalid as regards the rights of other persons.

1. It is doubtful how far an informal agrement varying a perfect one can be relied on as a defenee to an action brought on the original agreement. On principle it womld seem that an agreement which will not support an action ought not to support a de fence $(s)$, and there is good authority to that effect $(t)$, but none of recent date.

There is yet another class of cases, not resting on

(1) Notwithstanding Jumdas v. lutens (17!n) l Ves. jun. 194. I Ri..li. 112.

(i) Site (il) above.

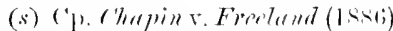
112 Mass. 393.

(t) Vible'v. Hard (1siti ) I. IR. : Ex. I3\%, Ex, $\mathrm{C}^{+} \mathrm{h}$.
Infirmal agreement as defener. 
estoplent listinguished.

contract or agreement at all, in which courts of equity have compelled persons to make good the representations concorning existing facts $(x)$ on the faith of which they have induced others to act. The distinction is pointed ont by Romilly M.R. in Marden $v$. Jones (y): and the extension of the toctrine to marred women shows very forcibly that it has nothing to do with contract or capacity for contracting: for a maried woman's interest in property, though not sottlod to her separate use, has repeatedly been held to be bound hy this lind of equitable estoppel $(z)$.

H. . Slip, ${ }^{\circ}$ in matrine insulance Aits repuiring stiminted polic:s.

3. Another curious and important instance of an imperfect obligation arising out of special conditions imposed on the formation of a complete contract is to be found in the case of marine insmrance. In practice the agreement is concluded between the parties by a memorandmm called a slip, containing the terms of the projosed insurance and initialled by the underwritors (1). It is the practice of some insurers always to date the policy as of the date of the slip (b). At common law the slip would constitute a hinding eontract. This howrer is not allower by the revenue laws. By the Stamp Act, 1891 (5+\& 5̆ Vict. c. 39), $\therefore 93(c), " A$ contract for sea insurance (other than

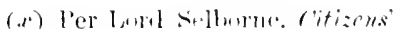

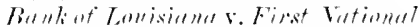

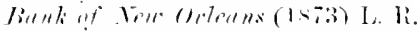

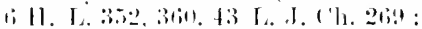

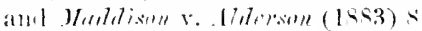
Alp. (a. at p. 1.3.

(y) (15.) 23 lows at p. 4043 : cu. Fommens r. Willikms (1865) 1. H. I E1. 1-1. 18R. 3.5 [. I. Ch. 2×3: and ses: Dar. Conv. 3 . litu-bitti.

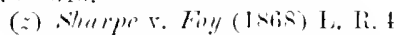

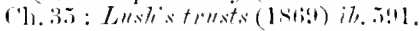
(a) For the form of this, see

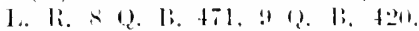
In the are of tile insurance, there being no statutory repuirement, there is nothing to prevent a slip from forming a complete contraet of insuranee; the burden of prow is an the underwriter to show a contrary intention: and there is not any implied condirion that a policy shall be put forward for ignature within a reasonable time: Thamlusen r. Atams (18s!) 23 Q. B. 1). 361 .

(b) See I. R. \& Ex. 199.

(c) 1 is 10 stamping and produetion in evidence (which thes not affect on present subiect). ree $\therefore$ s. $45-97$ : there is a special 
such insurance as is referred to in the 55 th sectim of the Merchant Shipping Act Amentment Act, $1862(d)$ ) [i.e. against the owner's liability for aceidents of the kinds mentioned in s. 5t of that Act] shall be void unless the same is expressed in a policy of sea insurance."

Earlier statutes on the matter now hefore us wore differently worded, and made every contract of insurance "null and void to all intents and purposes" which was not written on duly stamped paper or dit not contain the prescribed particulars. (35 Cieo. 3, c. 63 , ss. 11,$14 ; 5+$ Geo. 3, c. $14 t$, s. 3 : the latter statute was expressly pointed, as appears by the preamble, against the pratice "of using mstamped slips of paper for contracts or memorandums of insurance, previously to the insurance being marle by regular stamped policies.") It was settled on these statutes that the preliminary slip could not be regarded as having any effect beyond that of a more proposal $(e)$ : and it was even held that the slip) could not be looked at by a court of justice for any purpose whatever $(f)$. The change in the language of the modern statute law, which dates from 1867 (a), has given the Courts the opportunity of adopting a more liberal construction without actually overruling any former authorities.

It has now for many years been judicially recog. nized that the slip is in practice and according to the understanding of those engaged in marine in-

Minlern reangnition the the lip. penalty of $\mid(x) /$. insteac of the usual 10\%. for stamping in l'ont. This Act is not alferefed by the Marine Insmranee Art, log6.

(d) Now Merchant shipping Ad, 1894, s. $504 \%$.

(o) Stee per Willes .l. in Joms v.

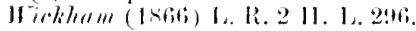
314,36 1. .1. (1. 12.33:3; simitls

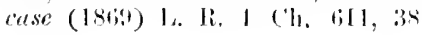

\section{I. .J. I'h. 6.8.}

(f) See per Blacklourn it. in

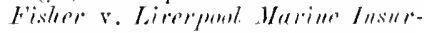
"mere ri. (1873) T. R. \& Q. H. 16\%. 171. 13 T. J. (1. 1. 114.

(g) 30. 31 Viet c. 23. menealed. "xopt lwo seetims not here retevant. and on this promt suldatan-

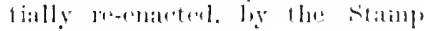
Ac1, 15!11. 
Twe train intrition of biaties.

Tin fix true late of culltritit. (i)llittelat ingrimestif the alutrine.

surance the complete and final contract between the partios, fixing the terms of the insurance and the frominn, and noither party can without the assent of the other deviate from the terms thus agreed on without a breach of faith. Accorlingly, though the contract expressed in the slip is not valid, that is, not mforceable, it may be given in evidence wherever: it is, though not ralid, material $(h)$. In the case rerreed to the slip was admitted to show whether the incention of the parties was to insure goods by a particular namer ship only, or by that in which they might he actually shipper, whatever her name might he. A still more important application of the same principle was made in Cory r. Patton $(i)$, where it was held that the time when the contract is concluded and the risk accepted is the date of the slip, at which time the underwriter becomes hound in honour, though not in law, to execute a formal policy; that the Court, when a duly stamped policy is once before it, may look to the slip to ascertain the real date of the contract; and therefore that if a material fact comes to the knowledge of the assured after the date of the slip and before the execution of the policy, it is not his duty either in hononr or in law to disclose it, and the non-disclosure of it does not vitiate the policy. This holds though after the completion of the contract by the slip a new term be added for the benefit of the muderwiters $(k)$. The same doetrine has beren comsidered, and allowerl, though not directly applienl, in other cascs. In Fisher r. Liverpond Marine Insurance $C_{\text {on. }}$ (l) the slip had been initialled

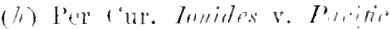

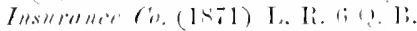

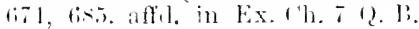
$\therefore 17$, H 1. I. 12. 1․ 33. 194.

(i) $(1<i 2)$ I. R. i 1) P. 314t sne further s. e. 9 0. H. 57.9 .13 L.J. 1). 1., Inl. (i) Tosham r. Kinthern Mari-

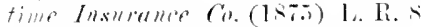
('. 1'. 2lli, attirmed in Ex. (h. 10) C. P. 17:. 44 L. J. C. P. 185.

(1) $(18$ - $)$ L. R. \& Q. B. thy (Blackinm I. dis.s.) aff l. in Ex. (h. :1) R. 418,43 L. J. Q. B. I1t. 
but the insurance company had executed no policy. In the case of an insurance with private underwriters it is the duty of the broker of the assured to prepare a properly stamped policy and present it for execution. But in the case of a company the policy is prepared by the company, executed in the emmpany's office, and handed over to the assured or his agent on applications: It was held that there was no under. taking by the company, distinguishable from the contract of insurance itself, to do that which it would bo the duty of a broker to do in the case of private underwriters; that the only agreement of the company with the assured was one entire agreement male by the initialling of the slip, and that as this was an agreement for sea insurance, the statute applied and made it impossible to maintain any action for a breach of duty with regard to the preparation and execution of a policy. In Morrison v. Universal Marine Insurance $\mathrm{Co} .(\mathrm{m})$, the question arose of the effect of delivering without protest a stamper policy pursuant to the ship after the insurers had discovered that at the date of the slip a material fact had been concealed. It was held in the Exchequer Chamber, reversing the judgment of the Court below, that the delivery of the policy did not prechude the insurers from relying on the concealment, but that it was a question properly left to the jury whether they had or had not elected to abide by the contract. This implies not only that the rights of the parties are determined at the date of the slip, but that the execution of the stamped policy afterwards has little or no other signifieance than that of a necessary formality $(n)$. In the case of a mutual marine insuranee association, a letter by

Application in wintling up insurance complaties. (mi) (1.873) I\% Ii, \& Lx. Ho, in Ex. (h. il. 197, 12 L. J. Ex. 11\%.

(11) Siee the jutgrnent of cleatshy
I. in the Court below, L. Li, is kx. at 1. 6io. 
Stamp rluties in gencral.

Variation by subseruent unstamped agreemeut.

which the assured undertook to become members of the association was admitted as part of one agreement with the stamped policy, to show that the assured were contributories in the winding-up of the association $(o)$. In the winding-up of another such association a member has been admitted as a creditor for the amount due on his policy, though unstamped, when the liability was admitted by entries in the minute books of the association, which seem to have been considered equivalent to an account stated $(p)$.

It has already been observed that the general revenue laws as to stamp duties are on a different footing. However their effects may in one or two cases resemble to some extent those which under the present head we have attempted to exhibit. Thus, if an unstamped document combines two characters (as, for instance, if it purports to show both an account stated and a receipt), and if in one of those characters it requires a stamp, and in the other not, it may be given in evidence in the second character for any purpose unconnected with the first $(q)$.

In a case where the parties to an agreement in writing had afterwards raried its terms by a memorandum in writing, and the memorandum was not stamped, the plaintiff joined in his action a count on the agreement in its original form and another on the agreement as varied: and when it appeared by his own evidence that the memorandum did materially alter the first agreement, but was unavailable for want of a stamp, it was held that he could not fall back on the agreement as it originally stood $(r)$. Neither this decision, nor the earlier authorities on which it

(i) $B l y t h$ of $($ in's rease $(1,-i 2)$ L. R. 13 Eq. 529 .

(p) Murtinis rluim (1<i2) I. H. 14 E. J 48,41 L. J. ('h. 6is.
(4) Matheson r. Risis (1849) 2

H. L. C. 286.81 R. R. 153.

(i) Reet v. Defere $(1827) 7$ B. . (. 261.31 k. R. 190 . 
rested, were referred to in Noble v. Mard(s). In that case there was a substituted agreement which was unenforceable under sect. 17 of the Statute of Frauds $(t)$ : and it was held that as the parties hal no intention of simply rescinding the former agreoment, that former agreement remained in force. Tho two cases, if they can stand together, must do so hy reason of the distinction between a contract the reeord of which is unavailable for want of a stamp, and an agreement which camnot be sued on at all if the defendant pleads the statute.

In a much litigated case of Evans v. Prothero ( $u)$, the question arose whether a document purporting to be a receipt for purchase-money on a sale of land, but insufficiently stamped for that purpose, can be admitted as evidence to prove the existence of an agreement for sale. In a series of motions for new trials, Lord Cottenham and Lord St. Leonards took different views. The judges before whom the applications came in the Court of Chancery in the first instance, and those before whom the issues were tried at Cardiff Assizes, were also divided in opinion. The opinion of Lord St. I,eonards, who held the document admissible, has now been recognized as authoritative $(x)$.

C. There are also many statutes which impose special conditions on the exercise of particular pro-

(s) $(18+i z)$ I. R. 1 Ex. $11 \pi$, in Lx. (h. 2 Ex. 135; but otherwise where the substituted agrecmest has been executed in part ; for this shows that the oll one is gone:

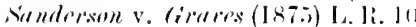
Ex. 234. It I. J. Ex. 2ll. There has ben a tentency in some renent eases (unt regularly reported) to depart from vible v. If urd. Whet her correct or not in law, smoli a dectrine has nothing to recommend it in point of substantial justice, see Mr. Ermest G. ('.
Fith is article in L. Q. L. ix, :Biti.

(t) Now repualed aml substantially re-nacted by the sale of (a)mis .et. Is!13. s. it

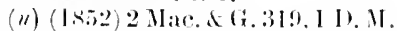
(i.572, 21 H..J. ( h. 772, 91 R. R. 175.

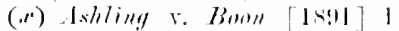

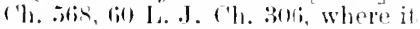
was helel that an insullieiently tamperl pomissury note enalel not be arlunit ted as a receight for the connsideration meney, this being "of the rery essence of the promissory note itsell."
Attempt to 11se 1111 stamper decument in a itifferent character.
('. Statutory romlitions affect inger professions, de. 
fessions and occupations and the sale of particular kinds of goods. Most of these, however, are so framed, or have been so construed, as to have an absolutely prohibitory effect, that is, not merely to take away or suspend the remedy by action, but to render any transaction in which their provisions are disregarded illegal and roid. The principles applicable to such cases have been considered under the hrad of Unlawful Agreements. In a few cases, howwer, there is not anything to prevent a right from bring acquired, or to extinguish it when acquired, but only a condition on which the remedy depends. () $f$ this kind are the provisions of the Act $6 \& 7$ Vict. c. 73 , with respect to attorneys and solicitors, and of the Merlical Act, 1858 (21 \& 2.2 Vict. c. 90), with respect to medical practitioners.

Attorneysant -olieitus. (ints of unrertificated solicitor. how far allowed.

By the $6 \& 7$ Vict. c. $73, s .26$, extented by $37 \& 38$ rict. c. 68 , it is enacted in substance that an attorney or solicitor practising in any court without having a stamped certificate then in force (as provided for by ss. 22-25, and now 23 \& 24 Vict. c. 127 , ss. 18_-23) shall not be capable of recorering his fees for any business so done by him while uncertificated. This, however, does not make it unlawful for the client to pay such fees if he thinks fit, nor for the solicitor to take and keep them. It has heen helel that a defeated party in an action who has to pay his adrersary's costs is bound by any such payment which has been actually made, and cannot claim to have it disallowed after taxation (y). But, since the Act of $187 t$ at all erents, a successful party whose solicitor was uncertificated cannot recorer costs if the objection is made on taxation $(z)$. This appears to

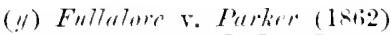
1.2 i. B. .. S. 246,31 L. J. C. I'. 239. 214 .
( ) Finder r. Yonmenthshire limal Fo. (1859) + Q. 1). D. 334 , As L. I. U. I. 4.5 . 
leave untouched an earlier case (a) where it was decided that items for business done by a solicitur while uncertificated must be allowed as against the client in a taxation on the client's own application; for the client submits to pay what shall be found due, not only what the solicitor might have sued for, and the debt is not destroyed. Proceedings taken by a solicitor who has not renewed his certificate cannot be on that account set aside as irregular $(b)$. It has been said that an attorney can have no lien for business done by him while uncertificated $(c)$. But the case cited for this $(d)$ was on the earlier Attorney's Act, 37 Geo. 3, c. 90, by which the admission of an attorney neglecting to obtain his certificate as thereby directed was in express terms made void (s. 31): it was held that under the special circumstances of the case (which it is mnecessary to mention) there had been a neglect within the meaning of the statute so that the attorney's admission was roid, and that he must be regarded as having been off the roll of attorneys. He was therefore, as a neeessary consequence, incalpable of aequiring any right whatever as an attorney while thus disqualified. It is submitted that under the modern Act there is no reason for depriving an uncertificated solicitor of his lien, at any rate in the absence of any wrong motive or personal default in the omission to take out the certificate.

Apart from this, a solicitor cannot in any case sue for costs till a month after the bill has been delivered (6 \& 7 Vict. e. 73, s. 37), unless authorized by a As to time of sting fin: ants. judge to sue sooner on one of certain grounds now

(a) Ris dones (1869) L. Li. 9 Fin, 633,39 I. J. (\%). 33.

(b) syarling v. limpetanl (1.66it) I. R. 2 Eq. 61, 3.5 h. I. ('h. 461. (a) Chity's Arehbold's l'r. 19!. el. 1sititi.

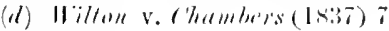
A. d E. E.21. 
much enlarged by the Legal Practitioners Act, 1875 (35 \& 39 Vict. c. 79) (e).

Mertical prace titioners. rimmon latw as to phy is cians.

lrorinions of Henlir:al A.t. Jxis:

The rights of medical practitioners now depend on the Medical Acts, 1858 and 1886, and (in England only) the Aprthecaries Act, 55 Geo. 3, c. $19 \pm(f)$. Before the Medical Act the state of the law, so far as concerned physicians (but not surgeons or apothe. caries) was this: It was presumed, in accordance with the general usage and understanding, that the services of a physician were honorary, and were not intended to create any legal obligation: hence no contract to pay for them could be implied from his rondring them at the request either of the patient or of a third person. But this was a presumption only, and there was nothing contrary to law in an express contract to pay a physician for his services, which contract would effectually exclude the presumption $(g)$.

The Medical Act, 1886 ( 49 \& 50 Vict. c. 48), s. 6, 'nables every registered medical practitioner to recoret his expenses, charges, and fees, unless restrained by a prohibitory by-law of a college of physicians of which he is a fellow $(h)$. Accordingly there is no longer any presumption of honorary employment $(i)$. It remains competent however for a medical man to attend a patient on the understanding that his attend-

(b) As to mpecial agrements fretween suldotor and client, see 1. 71 is, lelew.

(f) This is still in fore sulijeet to ertain andmolments mate in

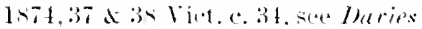

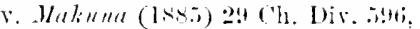
it I. J. ( 'h. 11 ts.

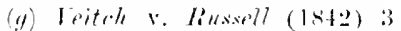
Q. H. 12. 12 I. .) 1. I, 13. No such frestumption exints in the Unitul states: aml qu. how far, il at all, it exists in leritish hominions beyomd seas.

(li) Such by-laws have been male by the lioyal college of Plomicians in Lomkin, and though afjiarenty without emmulsory furce umler the Act) the linsal college of surgeons of Englami.

(i) Giblum ve buld (ls(iii) $2 \mathrm{ll}$. d ('. 92. 32 L. J. Ex. 1 \&2 (on the similar pruvision of the Act of lass. which is repealed thy the $A \cdot \cdot$ of

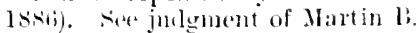


ance shall be gratuitous, and whether such an understanding exists or not in a disputed case is a question of fact for a jury $(k)$.

By the Act 55 Geo. 3, c. 194 , s. 21, an apothecary cannot recover his charges without having a certiApotheraries ficate from the Apothecaries' Society: and this is not repealed by the Medical Acts $(l)$.

It seems that a practitioner must have been registered at the time of rendering the services sued for, not merely at the time of suing $(m)$, decisively and at all events as to apothecaries: for an unrepealed section of the Apothecaries Act (55 Geo. 3, c. 19t, s. 20) expressly forbids unqualified persons to practise: and in the clear opinion of the Court on the construction and intention of the Medieal Act also.

A qualified practitioner cannot recover for services rendered by an unqualified assistant who in fact acter without his specific direction or advice $(n)$.

Similarly an agreement by a qualified practitioner to assist an unqualified one is bad, though perhaps an unqualified person might lawfully carry on merlical business through qualified assistants if he did not act as a practitioner himself $(o)$.

3. We now come to the cases in which some posi-

(k) Giblon v. Budd, last note.

(l) Sice rlecisions on this det collecterl l Wms. Saluml. is:3-4. $\therefore$. 31 of the Medical Aet of Is.i. enabler a pratitioner to sue only "arecortling to his enalitication," and a quatitication in whe capacity chist not entitle bom for ste leor services remelered in ancther: Lemon

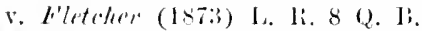
319, 12 1.. J. 9. 1., 214. lint these worde do mot arear in the Aret of lssti, which on the other hand requiles all partitionsers to be gencerally atalition.

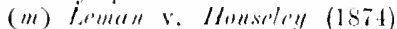
1. . Ii. 111 1). B. liti, \&1 L., J. (1. B.
Aet, $\sin (i e n, 3$.
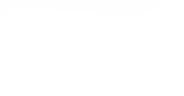
Arloitrators.

tive rule of law or statutory enactment takes anray the remedy altogether.

The only cases known to the writer in which there is a rule of law to this effect independent of any statute ale those of the remuneration of barristers engaged as advocates in litigation, and (to at limiter extent) of arbitrators.

With regard to arbitrators the better opinion appears to be that they are in the same condition as physicians were at common law. It is said that an arbitrator cannot recover on any implied contract for his remuneration, but this is by no means certain. There is no doubt that he can sue on an express contract $(p)$.

binmi-ters.

The position of a harrister is different.

It was formerly a current opinion that in the case of comnsel, as in that of a physician, there was a presumption of purely honorary employment, derived from the custom of the profesion, but that this presimpition would be excluted by proof of an express contract $(q)$.

No remely atrainst elient in respeet of litigrious busines.

But the decision of the Coust of Common Pleas in Kennedy r. Bromn (r) extablished the unqualified doctrine that "the relation of counsel and client. lenters the parties mutually incapable of making any legal contract of hiring and service concerning adrocatey in litigation." The request and promises of the client, even if there he express promises, and the services of the counsel, "create neither an obligation

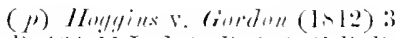

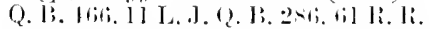

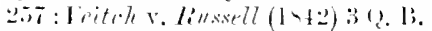

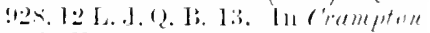

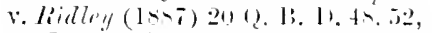
A. I. Snith , t tholght that in mercantile arbitrations a fromise to pay for the arbitrator"s services might well be implieel. When a case is referred by the court, the referefes of arbitrator's lemmeratim is determinable by the court:
Arbitration Act, 18s?. S. 1.).

(a) So Lord Demman secms to have been inclined to think in

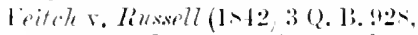
12 L. .l. Q. B. 1:3: anil a monlern lrish cane of Hobart $v$ Butlere (1-ist) ! Ir. C. L. 1.5, thungh it dirl not decile the point. preceded ti) sime extent on the sime as-muption.

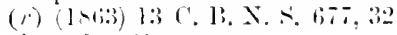
1..1.1'.1. 1:3. 
nor an inception of obligation, nor any inchoate right whatever capable of being completed and made into a contract by any subsequent promise."

On the other hand there is apparently no reason to doubt the validity of an express contract to remunerate a barrister for services which, though to some extent of a professional kind, and involving the exercise of professional knowledge, do not involve any relation of counsel and client between the contracting parties: as when a barrister acts as arbitrator or returning officer $(s)$. The want of attending to this distinction has led to such cases being cited as authorities for the general proposition that a barrister can recover fees on an express contract.

Moreover, it has been argued that an express contract even between counsel and client may still he good as to non-litigious luusiness. A claim of this sort made against an estate under administration was disposed of by Giffard L.J. on the ground, which was sufficient for the particular decision, that at all events a solicitor has no general authority to bind his elient by such a contract: but he also observed that such applications had never been successful, and expresised a hope that they never would be $(t)$. And it must be pemembered that although the rule laid down in Kennedy v. Broun is in its terms confined to litiga tion, and the word advocate, not counsel, is studiously

(s) Irmgyins v. Cormon (1842) :3 Q. B. 466, I1 I6, J. (2. Li, 286 , (i) li. R. 2.57; Eyan v. Cinamlimns of kimsingtull Inion (1S11) 312. 1). (3), 11.

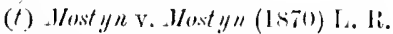
5 (1. 457, 459, 39) 1. . . ('h. 751. The cases there referded fo in argnment in livome of the eommsel's chaim seem, wilh the sole exreption of Ilobert v. Butles (1805!) ! Ir. C. 1. 157, irrelevanl. Fir instance,

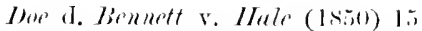
Q. J. 17I, 18 L. J. (2. I. :3:3, s1 li. R. ilo, shows only that there is mo alsolute rule of law that in :L eivil canse a barrister may not $x^{2}$ instructed directly by the client. ame throws no light whatever on

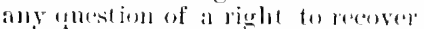

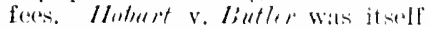
really a deceision agatinst a similar

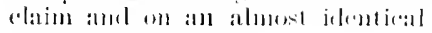
puint.
Distinction when barrister atots as arbitratur, die.

Express contract with client as 10 mon-litigions business: ¿n. 
liiglatis if batiotel as anginst sulicitur ; qu.

used throughout the judgment, yet the rule is founded not on any technical distinction between one sort of business and another, nor on any mere presumption; but on a principle of general convenience supported ly unbroken custom. No doubt it may be said that some of the reasons given for the policy of the law do not apply in their full extent to non-litigious business (u); and it is doubtful whether they apply even to those English colonies where the common law is in force $(x)$. But there is no reason to suppose that English courts of justice are likely to narrow the scope of a decision called by the late Lord Justice Giffard "a landmark of the law on this subject" (y).

There is no express anthority to show whether a barrinter can or camnot contract with his client's solicitor for payment of his fees any more effectually than with the client himself. It is apprehended that, inasmuch as counsel's services are given not to the solicitor but to the client, there would be no consideration to support such a contract unless the solicitor had actually received the fees from the client. In that case it is difficult to see on what ground of principle or policy the barrister should not be legally entitled to them as money receired by the solicitor for his use. A barrister has in fact been admitted to prove in bankruptey against the estate of a firm of solicitors for fees (apparently for conveyancing, not litigious husiness) which had been actually paid by clients to

(ii) In aldition to kinuedly v.

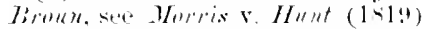
1 chitty. itt, int. sint, where the rule is fint on the gromul that the remuneration of the counsel ought to be indegendent of the result of the canse. and therefore counsel should rely on prepayment alone. This reasion would however bo

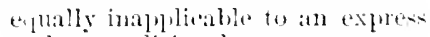
and uncomelitional contrace to pay fees for atroeacy, if matle before the commencement of the litigation.

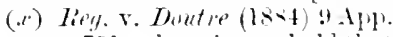
Ca. at p. Fil. where it was hehl that the case at bar was governed by the law of the l'rowinee of Quebec : in that law there is nothing to prevent an alvocate from suing for pror fe-sional services.

(y) Howtyn r. Wostyn. note $(t)$, l:at liage. 
the bankrupts before the bankruptcy $(z)$. If this be right, it is also difficult to see why an express promise by the solicitor to pay such fees, or an account stated between the solicitor and the counsel in respect of them, should not he binding. On the other himd the Court of Common Pleas has refused to exercise a summary jurisdiction, on the motion of the client, to compel an attorney to pay to counsel fees atleged to have been paid by the client, or else to return them to the client $(a)$. The case, however, was a peculiar one and goes but a very little way towards answering the general question.

It is hardly necessary to add that although counsel's fees cannot be recovered in any way by action, except possibly in some of the cases which have been mentioned as still doubtful, the propriety of paying such fees is judicially recognized by the constant practice of the courts in the taxation of costs: and the solicitor needs no authority from the client beyond his general retainer to enable him to retain and pay counsel and charge the fees to his client $(b)$. The payment of comsel's fees may in this manner be indirectly enforced either against the client himself or against an unsuccessful adversary who is liable for the taxed costs. Notwithstanding the strong expressions used by the Court in Kennedy v. Broun (c), the judicial notice thus taken of the obligation of a client to pay his counsel seems to show that it is in the nature of a legal duty, though not a perfect one, and is on a different footing from a mere moral obligation.

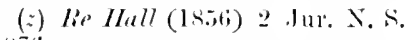
1076.

(a) The lugell (1861) 29 L. . I. ('.

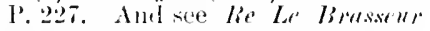

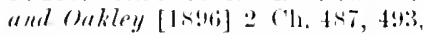
4!5: * I dumbe whether anything short of a bonal would enable comnel to sue a solichitor for litis cus," lindley L. I. at p. 1!12. liut a comnel's voncher for fees ropuires at receint stamp: (írneral f'rumeil

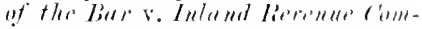

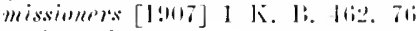
L. I. K. I:. $21: 2$.

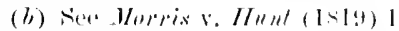
(hitty, sll.

(a) (1.663) 1:3 ( . B. N. A. 67. . : : 1.. I. (‥1‥ 137 .
Recrunition of coimusel's leets in taxation of costs. 
Solicitors Remmeration Act, 1881 .

Sipecial angerements leetween solicoitor and rlient under Aet of Is.11.

Toidable contracts of infants aflirmed at finll are.

The Solicitors' Remuneration Act, 1881 (d), establishes complete freedom of contract between solicitor and client as to conveyancing and other non-contentious business, and to that extent expressly supersedes the earlier Act of 1870.

By the Attorneys and Solicitors Act, 1870 (33 \& $3 t$ Vict. c. 28), special agreements for remuneration between solicitor and client were made lawful (s. t) and in a qualified manner enforceable. Agreements under this Act cannot be sued upon as ordinary contracts, but the procedure is by motion or petition, when the Court may enforce the agreement if it appears to be in all respects fair and reasonable, or otherwise set it aside. In the last case the Court may direct the costs of the business included in the agreement to be taxed in the regular way (ss. 8, 9). Where there is an agreement to employ a solicitor on certain terms at a future time, this does not prevent the solicitor from suing the client in a court of law if the client refuses to let him transact the business at all. The Act applies only to that part of an agreement which fixes the mode of payment for work done $(e)$.

since the Infants Relief Act, 187 , any contract of an infant voidable at common law and affirmed by him on attaining his majority must be reckoned as an imperfect obligation of this class, riz. on which there has not been and cannot be any remedy. The special features of this subject have been already considered (f), and there is nothing to add except that the general principles set forth in the present chapter secm to be applicable to these, so far as they still

(d) $44 \mathrm{~d}$ tis Viet. c. 44 .

(r) Liess v. Hilliams (1sis) I. R. 11) Ex. 2011. tt 1.. J. Ex, l16. liy the terms of the Aet the anteement must he in writing. ant it seems it must he signed by both part ies: El purte Munio (18i6) 1 Q. R. D, i24. 4.) L. J. Q. 1B. S1 li.

(f) In ('hap. Il.. above. 
exist, as well as to other agreements of imperfect obligation.

There are sundry other cases of a less important kind in which the remedy naturally attached to a contract is taken away by statute, without the contract itself being forbidden or avoided.

By the Act 24 Geo. 2, c. 40, s. 12, commonly known as the Tippling Act, no debt can be recovered for spirituous liquors supplied in quantities of less than twenty shillings' worth at one time $(q)$. The County Courts Act, 1888, s. $182(h)$, similarly enacts that no action shall be brought in any court for the price of beer or other specified hiquors ejusdem gencris consumed on the premises. The Act of Geo. 2 applies whether the person to whom the liquor is supplied be the consumer or not $(i)$. As these enactments do not make the sale illegal, money which has been paid for spirits supplied in small quantities cannot be recovered back $(k)$. A debt for such supplies was once held to be an illegal consideration for a bill of $\mathrm{ex}$ change $(l)$ : but this decision seems dictated by an excess of zeal to carry out the policy of the Act, and is possibly questionable. In a later case at Nisi Prius $(m)$ Lord T'enterden held that where an account consisted partly of items for spirituous liquors within the T'ippling Act, and partly of other items, and payments had been made generally in reduction of the account, the rendor was at liberty to appropriate these payments to the items for liquor, so as to leave

(a) By 25 at 26; Vict. c. 34. an exception is marle in favour of sales of spirituous lifuor not to be consumed on the premises, and theliveres at the purchaser's residene in quantities of not less than a reputerl quart.

(1) Superseding a similar enact ment in the c'ounty c'ourts fot, Istit.
Other canes where ents. triact nost. illegal, lint remerly taken awily by

stalute. simall debts for spirits by 'lippling Act, 24 (ice). 2 ; for beer, de. hy county cimets det, 1858.

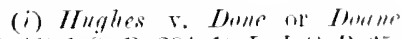
(1311) 1 Q. B. 291, 10 L.J.Q2. I, ti.), $\therefore$ R. R. 2.53.

(k) Phitpott v. Jomes (18.31) 21 . d E. 41,11 li. R. 371 .

(l) Srott v. Grillmore (1810) 3 Taunt. 226, 12 H. R. 6ill.

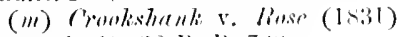

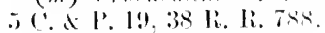


a good cause of action for the balance; thus treating these debts, like debts barred by the Statute of Limitation of James I., as existing though not recoverable.

The writer is not aware of any decision on the modern enactment as to beer, sc., in the County C'ourts Act.

Trate nuion acreements murler l'sale lnim Act, 157.
Casesif if analowy to imperfect

By the Trade Union Act, 1871 (3t \& 35 Vict. c. 31), s. 4, certain agreements therein enumerated and relating to the management and operations of trade mions cannot be sued upon, but it is expressly provided that they are not on that account to be deemed unlawful. In this enumeration are included agreements to pay subscriptions. It has also been decided that a member of a trade union who complains of having been wrongfully expelled cannot be reinstated hy the Court, though this may be done in the case of a club or other voluntary association holding property for purposes lawful at common law, on the ground of the expelled member being deprived of a right of property $(n)$. Practically trade union subseriptions are thus placed on the same footing as subseriptions to any club which is not proprietary $(o)$. Not that, so far as we are aware, there is anything in rinciple against the payment of subscriptions to a cluh being legally enforced: the practical difficulty lirs in ascertaining who are the proper persons to sue. The same difficulty exists in the case of any numerous mincorpurated association. But this belongs to another division of our subject $(p)$.

The present place seems on the whole the most appropriate one for mentioning a singular case which

(ii) lighby s. (ammol (18xio) 14 (h. I). 4-2. 49 1. J. ('h. 32 : : cp. Intfe r. Wutthen (1,882) 21 ('h. 1). 1: J, 51 L. J. Ch. 833 .

(o) In the case of a pmorictary club the proprictor can sue: see
Raggett v. Bishop (1826) 2 C. \& P. 343.31 P. R. 660 : Raggetf r. .MHsgrave (1125) 2 C. \& P. 5sti. The practical sanction is the power of excluding a member in default .

(l') Sce 1'l. 227. 246, 247. supra. 
may be regarded as the converse of those we have been dealing with. A valuable consideration is given in the course of a transaction which as the law stands at the time is wholly illegal and confers no right of action on either party. Afterwards the law which made the transaction illegil is repealed. Is the consideration so received a good foundation for a new express promise on the part of the receiver? The question came before the Court of Exchequry in 1863, some years after the repeal of the usury laws. The plaintiff sued on bills of exchange drawn and accepted after that repeal, but in renewal of other bills giren before the repeal in respect of adrances made on terms which under the old law were usurious. The former bills were unquestionably roid: but it was held by the majority of the Court that the original advance was a good consideration for the new bills. The question was thus stated in the julgment of the majority:-" Whether an advance of money under such circumstances as to create no legal obligation at the time to repay it can constitute a good consideration for an express promise to do so." And the answer was given thus:- "The consideration which would have been sufficient to support the promise if the law had not forbidden the promise to be marlo originally does not cease to be sufficient when the legal restriction is abrogated. . . . A man by express promise may render himself liable to pay back money which he has received as a loan, though somo positive rule of law or statute intervened at the time to prevent the transaction from constituting a legal debt" $(q)$. The debt, therefore, which was originally void by the usury laws, seems to have been put in

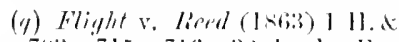
(. 706, 715. $716.321, .1 .5 x$. 26is. 265. Langdell (simmary. $\$ 7$ ii) sulnuts the are on the ohligations.

Effect of repeal of usury laws as to advances matc beftue. 
Treatment of equitable. (t) ligations at common law.
Summary of results. the same position by their repeal as if it had been a deht once enforceable but barred by the Statute of Limitation. But the decision seems wrong, for the consideration was wholly past at the time of the pomise. The consideration for accepting a renewed hill of exchange is not the value received which was the eonsideration of the original hill, but the abandonment of the right of action thereon.

There is one rther analogy to which it is worth while to advert, although it was never of much practical importance, and what little it had has in England heen taken awa by the Judicature Acts. Purely equitable liabilities have to a certain extent been treated by common law courts as imperfect obligations. The mere existence of a liquidated claim on a trust against the trustee confers no legal remedy. But the trustee may make himself legally liable in respect of such a claim by an account stated $(r)$, or by a simple admission that he holds as trustee a certain sum due to the cestui que trust $(s)$. A court of law has also held that a payment made by a dehtor without appopriation may be appropriated by the creditor to an equitable debt $(t)$.

It may he useful to sum up in a more general form the results which have heen ohtained in this chapter.

An imperfect obligation is an existing obligation which is not directly enforceable.

This state of thing; results form exceptional rules of positive law, and repecially from laws limiting the right to enforee contracts by special conditions precorlent or subsequent.

When an agreement of imperfect obligation is executory a right of possession immediately founded on

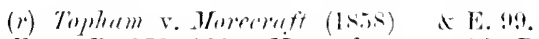

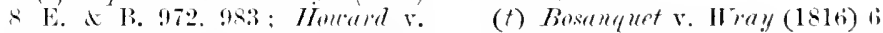
Bromuthill (15.3) 23 T. .Ј. Q. I3. 23.

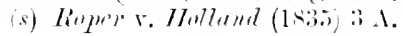

Taunt. S! 
the obligation can be no more enforced than the obligation itself.

Acts done in fulfilment of an imperfect obligation are valid, and may be the foundation of new rights and liabilities, by way of consideration for a new. contract or otherwise.

A party who has a liquidated and unconditional claim under an imperfect obligation naty obtain satisfaction thereof by any means other than direct process of law which he might have lawfully employed to obtain it if the obligation had not been imperfect.

The laws which give rise to imperfect obligations by imposing special conditions on the enforcement of rights are generally treated as part of the law of procedure of the forum where they prevail $(u)$, and as part of the lex fori they are applicable to a contract sued upon in that forum without regard to the law governing the substance of the contract $(x)$; but on the other hand they are not regarded in any other foruin. 273.

(x) This (it is conceiverl) does not apply to revenue laws, anl enactments which are merely ancillary to revenue laws, snch as the provisions relating to marine insurances ( 1.702 , above). 



\title{
APPENDIX.
}

\author{
$\longrightarrow$ \\ Note A. \\ Terminology and Fundamental Conceptions of Contract.
}

In the first two editions I made use of Savigny's definition of Vertrag (which can only be translated by Agreement, but in a wider sense than is known to any English writer). It now seems to me out of place in a special treatise on Contract. In the third volume of his System Savigny deals in the most general way with the events capable of producing changes in rights and duties in the field of private law. Such events he calls juristische T'hatsachen; an expression to which our own accustomed "acts in the law" seems well fitted to correspond. (Acts in the law must be carefully distinguished from acts of the law, which are really neither acts nor events, but legal consequences of events. But the terms are not common enough for uny serious risk of confusion to arise.) To speak, as some writers do, of "juridical facts," is to use language which is so firr from being English that it becomes intelligible only" by a mental re-translation into German. We are free to coin the term "event in the law" for juristische Tlutsurhe in its widest sense; but, as law has nothing to do with events except so fiur as they can have legal consequences, this may be superfluous. It seems better for English purposes, at any rate, to reserve " act in the law" for the species which Savigny proceeds to mark off from the genus, namely, freie Iloullung, or better, perhaps, for the further specified kind of voluntary acts which manifest an intention to bring about particular legal consequences. Such an act is callecl by Savigny Willenserlilüruny. Specifying yet more, we distinguish the acts in which the will of only one party is expressed from those in which the wills of two or more concur. This last species gives the conception of Vertray. Savigny defines it as the concurrence of two or more persons in the expression of a common intention, whereby mutual rights and duties of those persons are determined. "Vertrag ist die Vereinigung Mehrerer zu einer ibereinstinmenden 
Willenserklärung, wodurch ihre Rechtsverhältnisse bestimmt werden." (Syst. 3. 309.) This covers a much wider field than that of contract in any proper sense. Every transaction answering this description includes an agreement, but many transactions answer to it which include far more: conveyances of property, for example, including dispositions inter viros by way of trust and even gifts, and marriage. A still further specification is needful to arrive at the notion of Contract. A contract, in Savigny's way of approaching it, is an agreement which produces or is meant to produce an obligation (obligatorischer lertray). It is thus defined in his Obligationeurecht $\$ 52$ (vol. ii. p. s): "Vereinigung Nehrerer zu einer übereinstimmenden Willenserklärung, wodurch unter ihnen eine Obligation entstehen soll." Now the nse of the more general notion of Vertray, as Savigny himself explains, is not to clear up anything in the learning of contracts. It is to bring out the truth that other transactions which are not contracts, or which are more than contracts, have in conmon with them the character of consent being an essential ingredient. Moreover we shonld have to consider, before adopting this terminology, the wider question whether the retention of (obligations as a leading division in a modern system of law, and especially English law, be necessary or desirable. On the other hand, this definition leaves aside the somewhat important question whether and in what cases a binding obligation can be produced by a merely unilateral declaration.

The distinction between the illeas denoted by dominimm and mhigatio is certainly as fundamental in England as anywhere else; and the habit of using "obligation" as a synonym of "duty," though respectable authority may be found for it, is in my opinion to be deprecated. But to apply the Roman terminolngy to the Common Law would be as violent a proceeding, in any case, as to igure it in Roman Law.

For these reasons Savigny's detinition, admirable as it is for its own purposes and in its own context, and iustructive as his work is almost everywhere as an example of scientific method, is now reserved for this note.

\section{Note B. (p. 39).}

Autherities on contract by cenrespondence.

The first case of any importance is Allems v. Limelsell, 1 B. \& Ald. $6 \$ 1$ (1sls), Finch sel. (a. 102, 19 R. R. 41j. Defendants wrote to plaintiffs, "We now offer you son tods of wether Heeces, de." 
(specifying price and mode of delivery and payment), "receiving your answer in course of post." Here, therefore, the mode and time for acceptance were preseribed. This letter was misdireeted, and so arrived late. On receiving it, the plaintiffs wrote and sent by post a letter accepting the proposal, but the defendants, not receiving an answer when they should have received it if their proposal had not been delayed, had in the meantime (between the despatch and tho arrival of the reply) sold the wool to another buyer. The jury were directed at the trial that as the delay was occasioned by the necrlect of the defendants, they must take it that the answer did come bick by course of post. On the argument of a rule for a new trial, it was contended that there was no contract till the answer was received. To this the Court replied :-

"If that were so, no contraet could ever be completed by the post. For if the defendants were not bound by their offer when accepted by the plaintiffs till the answer was received, then the plaintiffs ought not to be bound till after they had received the notification that the defendants had received their answer and assented to it; and so it might go on arl infinitum. The defendants must be considered in law as making, during every instant of the time their letter was travelling, the same identical offer to the plaintiffs, and then the contract is completed by the acceptance of it by the latter. Then as to the delay in notifying the acceptance, that arises entirely from the mistake of the defendants, and it therefore must be taken as against them that the plaintiff's' answer was received in course of post."

As far as the case goes, it secms to amount to this: An acceptance by letter is complete as against the proposer from the date of posting the acceptance if it arrives within the prescribed time, if any, or otherwice within a reasomable time; but if the communication of the proposal is delayed by the fiult of the proposer, and the comn. munication of the acceptance is consequently delayed, such delay is not to be reckoned against the acceptor.

In the Scotch ease of Immmore v. Alerander, 9 shaw \& Dunlop, 109 , and Finch Sel. ('a. 120 (18:30), the defendant wrote to a friend desiring her to engage a servant on terms which, that friend had

Dunmore $r$. Alexamler (sic.). already informed the writer, would be agreeable to the servant. $A$ letter revoking this was written the next day ; ultimately they were both posted and delivered to the servant at the same tine. It was held that no contract was conchuled, but it is not elear whether the majority of the Cont meant to docido that an accoptance sent through the post is neutralized by a revocation arriving at the same time though posted later, or that the first letter was only a proposil. 
Potter $x$ Sambers.

Dinloper. liverims.

Heblis case and lieidpath's case.

British and American Telerraph Co. i. Colson.
Neither is it clear how far and for what purposes they regarded the intermediate person as an agent for either or both of the parties. No distinction was taken between postal and other communications. The French Court of Cassation had held in 1813 that when an acceptance and the revocation of it arrive together there is no contract. Merlin, Répertoire, Vente, $\$ 1$, Art. 3, No. 11 bis, Langdell Sel. Ca. Cont. 155.

In Potter v. Samlers (1846) 6 Ha. 1, 77 R.R. 1, the posting of a letter of acceptance is said to be an act which "unless interrupted in its progress" concludes the contract as from the date of the posting. 'This seems to imply that a letter not received at all would not bind the proposer.

Then comes Imnloy r. Iliggins (1848) 1 H. L. C. 381, 73 R. R.98, Finch Sel. Ca. I0s, a Scotch appeal decided by Lord Cottenham. Here the proposal did not prescribe any time, but the nature of it (an offer to sell iron) implied that the answer must be speedy. The acceptance was posterl, not by the earliest possible post, but in business hours on the same day when the proposal was received. The post was then delayed by the state of the roads, so that the acceptance was received at 2 p.m. instead of 8 a.m., the hour at which that post should have arrived. The decision was that the contract was binding on the proposer; and it might well have been put on the ground that the acceptance in fact reached him within a reasonable time. Lord Cottenham, however, certainly seems to have thought the contract was absolutely concluded by the posting of the acceptance (within the prescribed or a reasonable time), and that it mattered not what became of the letter afterwards. It appears to have been so understood in Duncan v. Topham (1849) S C. B. 225, is I. J. C. P. 310, 79 R. R. 470, where, however, the decision was on other grounds.

The latter cases arose out of applications for shares in companies being male and answered by letter. Itebl's case, (1867) L. R. 4 Eq. 9, decides only that an allotment of shares not duly despatehed will not make a man a shareholler; for the letter of allotment was sent to the company's local agent, who did not deliver it to the applicant till after he had withdrawn bis application. But the same judge (Lord Romilly) held in Reirlyatl's case (1870) L. R. 11 Eq. 86 , $40 \mathrm{~L}$. J. Ch. 39, that the applicant was not bound if he nerer received the letter.

In British and Amerian Telegraple company v. Colson (18i1) I. R. 6 Ex. 10s, 40 L. J. Ex. 97, it was found as a fact that the letter of allotment was never received. The Court (Kelly C. B., Pigott B., and Bramwell B.) held that the defendant was not 
bound, and endeavoured to restrict the effect of Unnlop v. Higgins.

In Toursent's case (1871) I. R. 13 Eq. 148, 41 T. J. Ch. 19s, the letter of allotment miscarried, and was delayed some days by the applicant's own fault in giving a defective address. By a simple application of Adans v. Limdsell (expressly so treated in the judg. ment, L. R. 13 Eq., p. 15t) it was held that the applicant was bound, and that a withdrawal of his application, posted (and it seems delivered, 1. 151) before he actually received the letter of allotment, was too late.

In Harris' case, L. R. 7 Ch. 587 , the letter of allotment was duly Harris' case. received, but in the meantime the applicant had written a letter withdrawing his application on the ground of the delay (ten days) in answering it. These letters crossed. The Lords Justices (James and Mellish) held that the applicant was hound, on the authority of Dunlop v. Higgins, with which they thought it difficult to reconcile British and Amer. T'elegraph ('n. v. Colson (1). On this, however, no positive opinion was given, "because although the contract is complete at the time when the letter accepting the offer is poster, set it may be subject to a condition subsequent that if the letter does not arrive in due comrse of post, then the parties may act on the assumption that the offer has not been accejted" (per Mellish L.J. at p. 597 ). In Wall's case (1872) L. R. 15 Eq. 18, 42 L. J. Ch. 372, Malins Wall's case. V.-C. held that as a fact the letter had been received, inclining, however, to think Harris' case an authority for the more stringent construction of Dunlop, r. Iligyins-ize, that the contract is absolute and unconditional by the mere posting. This construction was held by the Court of Appeal in IIonsetwhl Fire Insurance (\%) v. Grant (1579) 4 Ex. 5. 216,48 T. J. Ex. 577, p. 37, abeve, to be the correct one.

'The American case of Taylor v. Merchants' Fire Insurance Co., !) How S. C. $390(1550)$, is of less importance to English readers than it formerly was, the gromul being now fully covered by our own decisions. The insurance company's agent wrote to the plaintilf offering to insure his house on certain terms. The plaintiff wrote and posted a letter accopting these terms, which was duly received. The day after it was posted, but before it was lelivered, the houso was burnt. The objection was made, among others, that there was no complete contrat before the receipt of the letter, an assent of the company after the acceptance of the proposed terms being

(a) It seems not to litve been disputerl that the letterof allotiment

was in fact sent within a leasomable tine.

'Townsend's cise. Taylue's case. 
essential. But the Court held that such a doctrine would be contrary to mereantile usage and understanding, and defeat the real intent of the parties. 'This decides that a contract is complete as against the proposer by posting a letter which is duly delivered. It may still be useful to cite part of the judgment:-

"The fallacy of the argument, in our judgment, consists in the assumption that the contract cannot be consummated without a knowledge on the part of the company that the offer has been accepted. This is the point of the objection. But a little reflection will show that in all cases of contracts entered into between parties at a distance by correspondence it is impossible that both should have a knowledge of it the moment it becomes complete. This can only exist where both parties are present. . . It is obviously impossible ever to perfect a contract by correspondence, if a knowledge of both parties at the moment they become bound is an essential element in making out the obligation. . . It seems to us more consistent with the acts and declarations of the parties to consider it complete on the transmission of the acceptance of the offer in the way they themselves contemplated, instead of post. poning its completion till notice of such acceptance has been received and assented to by the company.

"For why make the offer, unless intended that an assent to its terms should bind them: And why recuire any further assent on their part after an unconditional acceptance by the party to whom it is addressed:" (Pp. 400, 401.)

Place of contract where it is made by correspondence.
There seems to be a fair consensus of authority, such as there is, for holding that the plare to which a contract made by correspondence should be referred is that whence the acceptance is despatehed: Sariguy, Syst. S. 253, 25i; Newcomb v. Le Roos (1859) 2 E. \& E. 270,29 L. J. Q. 13. 4. Conversely, where an offer to buy goods is made by a letter posted in the City of London, and accepted by sending the goods to the writers' place of business in the City, the whole cause of action arises in the City: Taylor v. Jones (15i5) 1 C. P. 1). $\$ \bar{i}, 45$ I. J. C. P. 110 . So in criminal law a false pretence contained in a letter sent by post is made at the place where the letter is posted : lief. v. IHelnes (1\$s3) 122 Q. B. D. 23, 53 L. J. M. C. 37. So of a notice of dismissal: Hellamel v. Benuett [190:2] 1 K. B. s6i, C.A. But a solicitor's letter of demand sent by post is, for the purpose of a restrictive covenant binding the writer not to prietise within certain limits, an act of demand at the place of

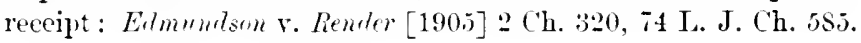




\author{
Note C. (p. 92). \\ History of the Equitable Hoctrine of Separate Estate.
}

When the practice of settling property to the separate use of married women first became common, it seems probalis that neither the persons interested nor the conveyancers had any purpose in their minds beyond excluding the husband's marital right so as to secure an independent income to the wife. The varions forms of circumlocution employed in old-fashioned settlements to express what is now sufficiently expressed by the words "for her separate use" will at once suggest themvelves as confirming this. In course of time, however, it was found that by recognizing this separate use the Court of Chancery had in effeet created a new kind of equitable ownership, to which it was impossible to hold that the ordinary incidents of ownership did not attach. Powers of disposition were accordingly admitted inclurling alienation by way of mortgage or specific charge as well as absolutely; and we find it laid down in general terms in the latter part of the eighteenth century that a feme corert acting with respect to her separate property is competent to act as a feme sole (r). Nevertheless the equitable owner hip of real extate by neans of the separate use, carrying as incilents the same full right of disposition by deed or will that a feme sole would have, was fully recognized only by much later decisions $(l)$. From a mortgage or specific charge on separate property to a formal contract under seal, such as if made by a person sni imris would even then have bound real estate in the hands of his heir, we may suppose that the transition did not seem violent; and instruments expressing such a contract to be entered into by a married woman came to be regarded as in some way binding on any separate property she might have. In what way they were binding was not settled for a good while, for reasons best stated in the words of V.-C. Kindersley's judgment in Jaulylane v. Fanderstryen (r).

"The Courts at first ventured so far as to hold that if "a married woman "made a contract for payment of momey by a written instrument with a certain degree of formality and solemnity, as by

Separate estate : Power of alicnation.

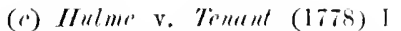
Wh. \& 'T. I., ('. In Frarorli v. Honk (17501) 2 Ves. Su. 190, Ilere referred to liy Iord Thumber no such general rule is expressed. As to the recognition of seplatate foroferty by (inuts of Common lasw, see Duncan v. ('akhin (1875) I. Ii.
10 ('. I'. 5.5t, +1 I. J. ('. I'. 3968.

(d) Thylar v. Weads (1s(ij) + 1). J. .. $5 ! 17,31$ I. .]. (h. $203 ;$ I'rid,

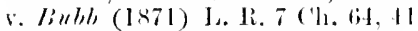
I. I. I'I. Jos.

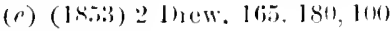
Ii. li. (ii, TI.
Power lo bind the separite estate loy formal instruments: historicial view given l) $1 .-1$. linulemisy. 
a bond under her hand and seal, in that case the property settled to her separate use should be made liable to the pasment of it ; and this principle (if principle it could be ealled) was subsequently extended to instruments of a less formal eharacter, as a bill of exchange or promissory note, and ultimately to any written instru. ment. But still the Courts refused to extend it to a rerbal agreement or other assumpit, and even as to those more formal engagements which they did hold to be payable out of the separate estate, they struggled against the notion of their being regarded $a s$ whts, and for that purpose they invented reasons to justify the application of the separate estate to their pasment without recognizing them as debts or letting verbal contracts. One sugrestion was that the act of disposing of or eharging separate estate by a maried woman was in reality the execution of a power of appointment $(f)$, and that a formal and solemn instrument in writing would operate as an execution of a power, which a mere assumpsit would not do. . . . Another reason suggested was that as a married woman has the right and eapacity specifically to charge her separate estate, the execution by her of a formal written instrument must be held to indicate an intention to create such special charge, because otherwise it could not have any operation,"

Earlier doctrines now untenable.

Both these sugrestions are on the later authorities untenable, as indeed V.-C. Kindersley then (1553) judged them to be $(g)$; the theory of specific charge was revived in the later ease of shattork $v$. shattork (h), but this must be considered as overruled (i). It had really been discarded by Lord Eldon as long ago as 1803 in a case which seenss to have been orerlooked $(k)$. One or two other suggestions-such as that a married woman should have only such power of dealing with her separate estate as might be expressly given her by the instrument creating the separate use-were thrown out about the begiming of the nineteenth century (l), during a periorl of reaction in which the doctrine was thought to have gone too far, but they diul not find acceptance; and the dangers which

(f) kig. Inke of Bultom v. IITlimms (179:3) 2 Ves. Jr. at l. 119.

(a) $11 . .1 / 4$ raly $\because$. liallee $(1-31)$ 3 il. it $k$. 209, where the arguments show the history of the doctrine: Ouens v. Itirlieresun (1\$40) 1 Cr. \& Ph. 4s, 53, it Ii. Ii. at p. 198, where the notions of power and charge are both dismisect as inapplicable by Lol't cottenham.

(h) (1stit) l., R. 2 E1. 1s:-143.

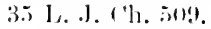

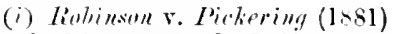
Jich. Div. 660, 50 L. J. (h. 527.

(k) Vuntes v. Corrock, 9 Ves. 182 , 7 Ii. Li. 1.86.

(l) sice fones v. Ifarris (1801) " Ves. $186,497,7$ R. R. 282,285 ; larks v. White (1sut-5) Il les. $2019,220 \times 1 \%$; and collection of cases 5 Ves. 17. note. 
gave rise to these suggestions were and still are provided against in another way by the curious device of the restraint on anticipation $(m)$.

The modern locus classirus on the subject is the jurlgment of Turner T.J. in Johnson v. Gallayher (n), which had the full approval of the Judicial Committee (o) and of the Court of Apreal in Chancery $(p)$. The general result was to this effect:

"Not only the bonds, bills, and promissory notes of married women, but also their general engagements, may affect thcir separate estates" (3 I). F. J. 514 ) ; and property scttled to a marred woman's separate use for her life, with power to dispose of it by deed or will, is for this purpose her separate estate (y).

These "general engagements" are suliject to the forns injored by the Statute of Frauds or otherwise on the contracts marle in pari materia by persons competent to contract generally, but not to any other form: there is $n o$ general rule that they must be in writing.

A "general engagement" is not binding on the separate estate unless it appear " that the engagement was marle with reference to and upon the faith or crerlit of that estate" ( 3 D. F. J. 515).

Whether it was so made is a question of fact to be detemined on all the ciremustances of the care: it is enongh "tu show that the married woman intender to contract so as to make herself-that is to say, her seprarate property-the debtor" (L. R. 4 P. C. 597).

Such intention is presumed in the ease of debts contracted by a married woman living apart from hes husband (3 D. F. J. j21). (This tallies with the anle of common law, which in this cine exeludes even as to necessaries the orlinary presumption of authority to pledge the husband's eredit: see notes to Maulny v. Srott in $2 \mathrm{Sm}$. I. C.)

The like intention is inferred where the transaction would he otherwise ummeaning, as where a married woman gives a guaranty

(m) Sice ford collentam's jurly-

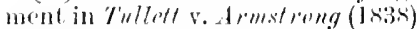

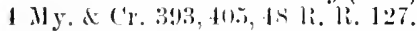
liestraint on anticipation ean exist only as incirlental to a trust for separate use. Such a trust camot be supplicel in orker to give effect to a restraint: stoghlom. v. Lee

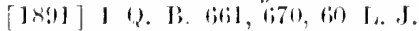
ใ. [i. 1699. A. A.

(11) $(1 \leq 61)$ 3 1) F. . 1. 191, 5099
Judgment of 'Tumer L.J. in Jolnson $x$. Gallagher.

" General engagements" may bimel separate estate withont special form, but with proved a presumed intention: rules as to this.

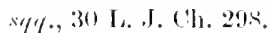

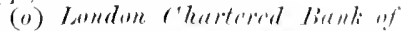
Alustralire v. Lempriem (1sai) L. R. \& I'. (1.572, 42 I. J. H. U. 1!). (11) I'irum v. Mine (Isti!) I. R. i) Ch. 271.

(y) Mloyd v. Fibld (1876) :3 (1/.

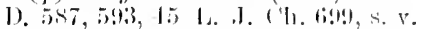

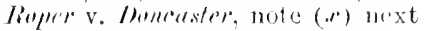
parge. 
for her huband s debt $(r)$ or joins him in making a promissory note $(s)$.

The "engagement" of a married woman differs from a contract, inasmuch as it gires rise to no personal remedy against the married woman, but only to a remedy against her separate property $(t)$. But it creates no specific charge, and therefore the remedy may be lust by her alienation of such property before suit ( 3 D. F. J. 515, $513,52()-2)(11)$. On the same principle the exercise by a married woman of a general testamentary power of appointment does not make the appointer fund liable to her engagements, for it is never her separate property $(r)$.

In cases where specific perfomance would be granted as between parties smi imis, a married woman may enforce specific performance of a contract made with her where the consideration on her part was an engagement biuling on her separate estate according to the above rules; and the other party may in like manner enforce specific performance against her separate extate $(y)$.

A maried woman: engagement relating to her separate property will have the same effect as the true contract of an owner sui inris in creating an obligation which will be binding on the property in the hands of an assignee with notice $(z)$.

Effect of cesciation of eoverture.

If a married woman becomes sir inris by the death of the husband, judicial sefaration or otherwise, what becomes of the debts of her

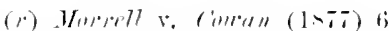

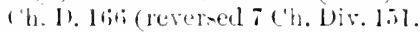
17 L. J. ' 'h. 32 . but only on the coustruction of the Jocument). where $n 0$ attempt was marle to ai-pute that the guaranty, thengh not expresty leferring to the separate estaice was effectnal to bint it.

(*) Inries v. Jomkims (1sii) d; ('h. 1). I.2)

(f) Hence hefore the bet of $1 \times 2$. the married woman, mit leing a real tebor. Was mot subject to the bankraptey law in resinet of her separale solate: Eor porte foness (1s) 12 Ch. Dir. ARt. A L. J. Bk. $10 ! 9$

(11) Ace. Roblimson v. Pigliering

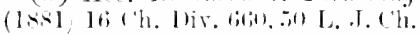
.i2- which leceiderl that a creditior of a married woman on the fath of leer separate extate is not thereby entitled tor a charden her separate preperty. or to an injunction to restrain her from dealing with it.

(r) Ruper v. Doncuster (1sis) 39 ch. U. 482, is L. J. Ch. 31 : q". bow far consistent with luyd r. Field. note (q) last page. As to the effect of $\mathrm{s}$. 4 of the Married Womens Property Act. 1sis. sec

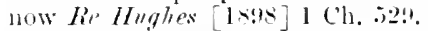
6) [.. I. ' 'h. 27!t.C. A. ; Re Hordgsan Juta ] Ch. 6titi. tis L. J. Ch. 313: Lif Finduicle [1909] $1 \mathrm{ch}$. 1. 1 ..A.

(y) The eases cited in sige. I. di. 2ilf, sn far as inconsintent with the molerr: anthorities (see Jireerl v. Hine (1869) L. R. 5 C'tr. 27. where the form of deeree arainst the separate estate is giren, Pride $\because$. Bubb (1\&71) I. R. i (h. 64. +1 L. J. (h. 105), must be com-inlered as overruled.

$\Leftrightarrow$ l'er dessel M.R. Harne s. liontlodge (1sit) L. R. lo Eq. 5ou, 43 L. .I. (1). 1904. 
separate estate? It appears that they do not become legal debts : for this would be to create a new right and liability quite different from those originally created by the parties ; but that the creditor's right is to follow in the hands of the owner or her rerresentatives the separate estate held by her at the time of contracting the engagement, and still held by her when she became sui imris, but not any other property. Property subject to a restraint on anticipation cannot in any case be bound $(a)$.

On principle it should seem that a married woman's engagement with respect to her separate estate, while not bound by any peculiar forms, is on the other hand bound in every case by the ordinary forms of contract; in other words, that no instrument or transaction can take effect as an engagement binding separate estate which could not take effect as a contract if the party were sui inris. That is to say, the creditor must first produce evidence appropriate to the nature of the transaction which would establish a legal debt against a party sui iuris, and then he must show, by proof of presumption as explained above, an intention to make the separate estate the debtor. There is, however, a decision the other way. In McHenry v. Laites (b), a married woman, or rather her separate estate, was sued in equity on a bill of exchange indorsed by her in Paris. It was contended for the defence, among other things, that the bill was a French bill and informal according to French law. Tord Romilly held that this was immaterial, for all the Court had to be satisfied of was the general intention to make the separate estate liable, of which there was no doubt. This reasoning is quite intelligible on the assumption that engagements bind separate estate only as specific charges; the fact that the instrument creating the charge simulated more or less successfully a bill of exchange woull then be a mere accident $(c)$. The judgment bears obvious marks of this theory; we have seen indeed that it was expressly adopted by the same judge in an earlier case $(d)$, and we have also seen that it is no longer tenable. In Johnson v. Gullaglier.

(a) Pike v. Fitzyibzon (1581) 17 Ch. Div. 45t, 50 L. J. Ch. 394. Earlier cases are indecisive. For the view taken in the comt below in . Mhuson v. Ciallagher, where the bill was tiled after the death of the husband, see 3 II. F. J. 445, and the decree appealed from at $\%, t 97$. The Act of $18 \times 2$ (norlitied only ats to payment of costs by the $\Lambda$ ci of $1 \times 93$ ) gives 110 pow re to touch surd lonerty, see p. $9: 3$, abuve.
How far is a marriel woman's "engagement" bound by the orrinary forms of contract?

lletenry r. Davies: quere. (b) (1870) L. R. $10 \mathrm{Eq} .88$.

(c) Note, however, that in the ease of parties sui inris a bill of exchange cannot be treated as an equitable assignment: Shund v. Ilu Buissm (187t) Lo R. Is E⿰. 253,43 I. J. (h. 50s. Nor a cherpe: Hoplkinson v. Foster (18i]) L. li. 19 Eq. 74 .

(d) Sthattock vo sthatterl: (I Sriti) I. li, $2 \mathrm{H} \%$. 182, 35 1. J. ('h, 504, sterta, 1. 7301. 
siatute of Limitation.

Can the seprarate estate be marle liable on a quasicontract?

Tenteney of modern authority and legislation.

it is assumed that a married woman's engagements concerning her separate interest in real estate must satisfy the eonditions of the Statute of Frands $(e)$. An engagement which if she were sui iuris would owe its validity as a eontract to the law merchant must surely in like manner satisfy the forms and conditions of the law merehant. It is submitted, therefore, that McHenry v. Davies $(f)$ is not law on this point.

It is now held that the Statute of Limitation, or rather its analogy, applies to claims against the separate estate $(g)$.

It is said that a married woman's separate estate cannot be made liable as on an obligation implied in law, as, for instance, to the repayment of money paid by mistake or on a consideration which has wholly failed $(h)$. But the decisions to this effect belong (with one exception) to what we have called the period of reaction, and are distinctly grounded on the exploded notion that a "general engagement," even if express, is not binding on the separate estate.

The exception is the modern case of Hright $\mathrm{v}$. Clarel (i), where V.-C. Kindersley held that a married woman's separate estate was not liable to refund rents whieh had been received by her as her separate property, but to which she was not in fact entitled. But the language of the judgment reluces it to this, that in the still transitional state of the doctrine, and in the absence of any precedent for making the separate estate liable in any case without writing (this was in 1859 , Jolenson v. (iallagher not till 1861), the V.-C. thought it too much for a court of first instance to take the new step of making it liable "in the absence of all contract" ; and he almitted that " the modern tendeney has been to establish the principle that if you put a married woman in the position of a feme sule in respect of her sejurate estate, that position must be carried to the full extent, short of making her personally liable." The test of liability would seem on principle to be whether the transae. tion ont of which the demand arises had reference to or was for the benefit of the separate estate.

'The spirit of the modern authorities is, on the whole, in the direction of holding that a married woman's "engagement" differs from an ordinary contract only in the remedy being limited to her selarate property. Her creditor is in a position like that of a

(e) (1861) :3 D. F. J. at p. 514.

(f) $(18 \pi 0)$ L. R. $10 \mathrm{E} 1.88$.

(4) Le Lady Hastings (1sis) 35

Ch. Dir. !4.

(h) 3 1I. F. J. 512, 514, referring to Duke of Bulton vo Milliams (1793) 2 Ves. Jr. liss; domes $v$
Harris: (1s0t) 9 Ves. 486. 493. 7 R. R. 2s: and Aguilur s. Aguilar (1N20) i Madd. 414.

(i) (1859) + Drew. 673, 685. 29 L. J. Ch. 82: on appeal. I D. F.J. .157, $113 \mathrm{R}$. R. . 511. but not on this lnint. 
crerlitor of trustees for a society, or the like, who has agreed to look only to a specified fund for payment. And on this view the Married Women's Property Act of 1582 is framed, though it might be wished that the principle had been carried ont more thoronghly.

Note D. (1. 134 above).

Limitution of Comporate Powers by loctrines of Partnership aml Alyency.

A case in which this reason appears most clearly is Simpson r. Application Denison (1852) 10 Ha. 51, 90 R. R. 276. The suit was instituted by dissentient shareholder's to restrain the carrying out of an agreement between their company (the Great Northern) and another railway company, by which the Great Northern was to take over the whole of that eompany's traffic, and also to restrain the application of the funds of the Great Northern Company for obtaining an Act of Parliament to ratify such agreement. The V.-C. Turner treated it as a pure question of partnership: " How would this case have stood," he says in the first paragraph of the judgment, "if it had been the ease of an ordinary limited partnership?" The Railways Clauses Consolidation Act became in this view a statutory form of partnership articles, to which every shareholder must be taken to have assented; and tho general ground of the decision was that " no majority can authorize an application of partnership funds to a pripose not warranted by the partnership contract." For the purposes of the case before the Court this analogy was perfectly legitimate; and the dissent expressed by Parke B. (in Sonth Fonkshive, ar. ('o. v. G. N. R. 'o. (1N53) 9 Ex. 8s, 22 L. J. Ex. 315,94 R. R. 575) must be considered only as a warning against an unqualified extension of it to questions between the corporate body and strangers. In I'icliering v. Stephenson (1572) L. R. 14 Eq. 322, 340, 41 I. J. Ch. 493, the same rule is thus set forth by Wickens V.-C. - "The principle of jurisprudence which I am asked here to apply is that the governing body of a corporation that is in faet a trading of partnership law: simpson $v$. Denison. partuership cannot in gencral use the funds of the community for any purpose other than those for which they were contributed. By the governing body I do not of course mean exclusively eithor directurs or a general council $(j)$, but tho ultimate authority within the society itself, which would ordinarily be a majority at a

Sitatement of the principle in l'ickering $\therefore$ ittephensin.

(i) Roferring to the peculiar enstitution of the company then in question. 
Rights of dismenting shareholiters.

I'arties to action. general meeting. According to the principle in question the special powers given either to the directors or to a majority by the statutes or other constituent documents of the association, however absolute in terms, are always to be construed as subject to a paramount and inherent restriction that they are to be exercised in subjection to the special purposes of the original bond of association." Nothing is said here on the extent to which a corporation may be bound by the "nanimous assent of its members.

Any dissenting shareholder may call for the assistance of the Court to restrain unconstitutional acts of the governing body, but he must do so in his proper capacity and interest as a shareholder and partner. If the Court can see that in fact he represents some other interest, and has no real interest of his own in the action, it will not listen to him; as when the proceedings are taken by the direction of a rival comprany in whose hands the nominal plaintiff is a mere puppet, and which indemnifies him against costs : Forrest v.

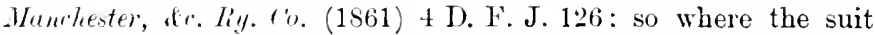
was in fact instituted by the plaintiff's solicitor on grounds of personal hostility, liokion v. Ilobls (1s69) I. R. \& Eq. 301, 38 L. J. Ch. 6ti. But if he has any real interest and is proceeding at his own risk, he is not disqualified from suing by the fact that he has collateral notives, or is acting on the suggestion of strangers or enemies to the company, or even has acquired his interest for the purpose of instituting the suit: Colman v. K. C. liy. ('o. (18+6) 10 beav. 1, 16 L. J. Ch. 73, 76 R. R. 7s ; teaton v. Grant (1S6T) L. R. 2 C'h. 459, 36 I. J. Ch. 6:38; Blorum v. Metrop. Ry. Co. (1s68) L. R. 3 Ch. 337. For full collection of cases, see Lindley on Companies, 597. As a rule the plaintiff in actions of this kind sues on behalf of himself and all other shareholders whose interests are identical with his own ; but there seems to be no reason why he should not sue alone in those cases where the act complained of cannot be ratified at all, or can be ratified only by the unanimous assent of the shareholders: Hoole v. G. Ir. liy. (o. (186i) L. R. 3 Ch. 262. There is another class of cases in which abuse of corporate power's or authorities is complained of, but the particular act is within the competence of, and may be affirmed or disaffirmed by, "the ultimate authority within the societs itself" (in the words of Wickens V..C. just now cited), and therefore the corporation itself is prima farie the proper plaintiff. See Iindles on Companies, 574 sq4. ; Gray v. Lewis (1569) L. R. S Ch. 1035, 1051; Macdougall v. Gardiner (1575) L. R. 10 Ch. 606, 1 Ch. I). 13, 21 ; Russell v. Wrelefield Itutereorlis (" $"(1575)$ I. R. 20 Eq. 474,44 L. J. Ch. 496. "The majority are the unly persons who can complain that a thing 
which they are entitled to do has been done irregularly" (li). The exception is when a majority have got the government of the corporation into their own hands, and are using the corporate name and powers to make a profit for themselves at the exponse of the minority; then an action is rightly brought by a shareholder on behalf of himself and others, making the company a defendant: Menier v. Hooper's Telegraph Worles (1sid) L. R. 9 Ch. 350, 43 L. J. Ch. 330; Mason v. Iarris (1879) 11 Ch. Div. 97, 4S I. J. Ch. 589. We mention these cases only to distinguish then from those with which we are now concerned.

With regard to the doctrine of limited agency, and its peculiar importance in the case of companies constituted by public documents, all persons dealing with them being considered to know the Limites agency of director's, de. contents of those documents and the limits set to the agent's authority by them, it may be useful to give Lord Hatherley's concise statement of the law (when V.-C.) in Fouruture v. Curmarthen Ry. Co. (1S68) L. R. 5 Eq. 316, 322, 37 T. J. Ch. 429.

"In the case of a registered joint stock company, all the workl of course have notice of the general Act of Parliament and of the special deed which has been registered pursuant to the provisions of the Act, and if there be anything to be done which can only be done by the directors nuder certain limited powers, the person who deals with the directors must see that those limited powers are not being exceeded. If, on the other hand, as in the case of Royal British Bamle v. Trumuand (l), the directors have power and authority to bind the company, but certain preliminaries are required to be gone through on the part of the company before that power can be duly exercised, then the person contracting with the directors is not bound to see that all these preliminaries have been observed. He is entitled to presume that the directors are acting lawfully in what they do. That is the result of Lord Campbell's judgment in Royal British Bank v. T'urquand." For fuller exposition see Lindley on Companies, $166 \mathrm{sqq}$.

The contrast of the two classes of cases is well shown in linyal

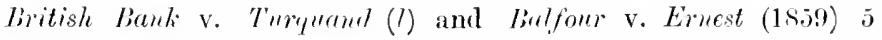
C. B. N. S. 601, 2S L. J. C. P. 170. In the former case there was

Iinyal Pritish Bank $r$. T'urpuant, se. (k) Mellish L.J. 1 Ch. D. at p. 25. As to a shareholder's right to nse the company's name ats plaintiff, sce Pruder v. Lushington (1877) 6 Ch. D. 70. 16 L. J. ('h. 317 ; Juckett v. Cimere (1877) ti ('h. I). 82, 16 I..J. (h. 107 ; silbe.

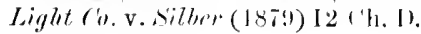

P.
717. 48 L. .J. Ch. 385 ; Murben v. Jhillips (1882-3) 23 Ch. D. 14, 2!!, 3s: Burland v. Earle [1902] A.C. 8.3, 7I L. .I. I'. C. 1.

(l) i) E. \& B. 2 Is, fi ibid, 237,21 L. . . 2. B. 327 25 ibid. 327. 10:3 li. li. [ili. 
power for the directors to borrow money if authorized by resolution : and it was held that a creditor taking a bond from the directors under the company's seal was not bound to inquire whether there had been a resolution. Jervis C.J. said in the Exehequer Chamber (the rest of the Court concurring):-

"We may now take for granted that the dealings with these companies are not like dealings with other partnerships, and that the parties dealing with them are bound to read the statute and the deed of settlement. But they are not bound to do more. And the party here on reading the deed of settlement would find not a prohibition from borrowing, but a permission to do so on eertain conditions."

The same principle has been followed in many later cases (Ex farte Eagle Insurance Co. (185s) + K. \& J. 549, 27 L. J. Ch. 829 ; C'ampluell's case der. (1s:3) L. R. 9 Ch. 1, 24, 43 L. J. Ch. 1 ; Totterdell v. Fareleem brick (1). (18s6) L. R. 1 C. P. 67t, 35 L. J. C. P. 278 ; Re Comnty Life Assre. '" (1870) L. R. 5 Ch. 288,39 L. J. Ch. ti1, a very strong case, for the persons who issued the policy were assuming to carry on business as directors of the company without any authority at all; Romford Caual Co. (1883) 24 Ch. D. 85, 52 L. J. (h. 729), and it was decisively affirmed by the Honse of Lords in Mahomy v. East Holyford Mining Co. (1875) L. R. $7 \mathrm{H} \mathrm{L.}$ 869. In that case a bank had honoured cheques drawn by persons acting as directors of the company, but who had never been properly appointer ; and these payments were held to be good as agrainst the liquidator, the dealings having been on the face of them regular, and with de futto officers of the company. Share. holders who allow persoms to assume office and conduct the company's business are, as against innocent third persons, no less bound by the acts of these re furto officers than if they had been duly appointed. It is for the sharcholders to see that manthorized persons do not usurp office, and that the business is properly done $(m)$. Similarly where the proper quomm of directors fixed by internal regulations of the company was not prerent: ('ounty of Giloucester liank v. Rudry Mertleyr, (r. Cn. [1890] 1 Ch. 629, 64 L. J. Ch. 451. Creditor are cutitled to rely on the anthority of a managing director purporting to exercise powers which under the articles he might have: Biggerstaff v. Rouratt's Whatf [1896] 2 Ch. 93, 102, 65 L. J. Ch. 536.

In Balfour v. Errest the action was on a bill given by directors of an insurance company for a claim under a policy of another

(m) Opinion of julges L. R. 7 1I. L... at p. sso ; per Lord Hatherley, at Pp. siti-s. 
company, the two companies having arranged an amalgamation; this attempted amalgamation, however, had been judicially determined to be void: Ernest v. Nicholls, 6 H. L. C. 401, 108 R. R. 175, revg. S. C. nom. Purt of Lumdon Co.'s cuse (1854) 5 D. M. G. 465. The directors had power by the deed of settlement to borrow money for the objects and business of the company and to pay claims on policies granted by the company, and they had a power to make and aceept bills, \&c. which was not restricted in terms as to the objects for which it might be exercised. It was held that, taking this with the other provisions of the deed, they eonld bind the company by bills of exchange only for its ordinary purposes, and not in pursuance of a void seheme of amalgamation, that the plaintiffs must be taken to have known of their want of authority, which might have been ascertained from the deed, and that they therefore could not recover. "This bill is drawn by procuration," said Willes J., "and muless there was authority to draw it the company are not liable $(u)$. . . this is the bare case of one taking a bill from Company A. in respect of a debt due from Company B., there being nothing in the deed (which must be taken to have been known to the plaintiffs) to confer upon the directors authority to make it."

The connection with ordinary partnership law is brought out in the introductory part of Lord Wensleydale's remaks in Ernest v. Nicholls (18.5) 6 H. L. C. $401,417,108$ R. R. 175, 182.

"The law in ordinary partnerships, so far as relates to the powers of one partner to bind the others, is a branch of the law of principal and agent. Each member of a complete partnership is liable for himself, and, as agent for the rest, binds them upon all contracts made in the course of the ordinary scope of the partnership business. - . . Any restrictions upon the authority of each partuer, imposed by mutual agreement amongst themselves, could not affret third persons, unless such persons had notice of them; then they could take nothing by contract [sc. as against the firm] which those restrictions forbade. [The law in this form, i.e., the presumption of every partner being the agent of the firm, being obviously inapplicable to joint-stock companies]. The legislature then devised tho plan of incorporating these companies in a mamner unknown to the common law, with special powers of management and liabilities, providing at the same time that all the world should have notice who were the persons authorized to bind all the shareholders by

(11) In form it was a bill drawn by two directors on the company's cashice, and seated with the compitly's seal. 
requiring the copartnership deed to be registered . . . and made accessible to all." The continuation of the passage, however, goes too far; in fact, it disregards the distinction established by Roynl Irritish Bronli v. Fwrinaml, and the Courts have distinctly declined to adopt it: Atyar $v$. Athenemm Life Assee. Soc. (185s) 3 C. B. N. S. 725, 27 L. J. C. P. 95, 111 R. R. 817 ; l'rince of Wales Assce. Co. v. IIarting (185i) E. B. \& L. 183, 27 L. J. Q. B. 297, 113 R. R. 594.

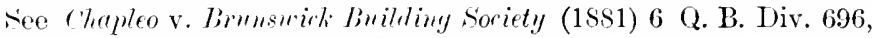
50 L. J. Q. J3. 372, for an example of the society not being bound by a loan contracted beyond its borrowing powers : the directors, having held themselves out as authorized, were found personally liable.

Fatification of irregular transactions by asent of ail the shareholiters.

Siackman $r$. Evans. de. considererl.

Transactions in the conluct of a company's affairs which in their inception were invalid as against any dissenting shareholder may nevertheless be made hinding on the partnership and decisive of its collective rights, as between the company and its own past or lrevent members, by the subsequent ansent of all the shareholders, though suchassent be informal and shown only br acquiescence. The leading examples on this head are given hy the well-known cases in the Iloure of Lords which arose in the winding-up of the Agriculturists' Cattle Insurance Company.

It is to be observel that these cases turned on the internal con-titution and affairs of the company, and there was no occasion to conider to what extent or in what transactions the assent of shareholders was capable of binding the company as against strangers. Ther therefore stand apart from the question of positive statutory limitations of corporate powers as between the company and outsiders. Moreover, the irregular act which was ratified was unauthorized as to the manner and form of it, but belonged to an authorized class (o). The general nature of the facts was thus: At a meeting of the company an arrangement was agreed to, afterwards called the Chippenham arrangement, by which shareholders who elected to do so within a certain time might retire from the company on specified terms by a nominal forfeiture of their shares. The deed of settlement contained provisions for forfeiture of shares, but not such as to warrant this arrangement. It was held-

In Errens v. Smallombe (1868) L. R. 3 H. L. 249, that the Chippenham arrangement could be supported (as having become part of the internal regulations of the company) only by the assent of all the shareholders, but that in fact there was knowledge and

(1) See per Lord Romilly (L. R. 3 H. L. 214-5). See also the juulg. ment of Archibald J. in tribe $v$.
Ashbury Railuay Corriage Co. (1855) L. 1i. 9 Ex. 289. 43 L. J. Ex. $17 \%$. 
acquiescence sufficiently proving such assent. A shareholder who had retired on the terms of the Chippenham arrangement was therefore not liable to be put on the list of contributories. (Cp. Brotherhood's case (1862) + D. F. J. 566, an earlier and similar decision in the same winding-ıp.)

In Spackman v. Eians (186s) T. R. 3 II. L. 171, 34 I. J. C'h. 321, that a later and distinet eompromise made with a smaller number of dissentient shareholders had not in fact been eommunicated to all the shareholders as distinet from the Chippenhan arrangement, and could not be deemed to have been ratified by that aecuiescence which ratified the Chippenhan arrangement; and that a shareholder who had retired under this later compromise was therefore rightly made a contributory.

In Houldsworth v. Evuns (1S6s) I. R. 3 H. L. 263, that time was of the essence of the Chippenham arrangement, so that when a shareholder was allowed to retire on the terms of the Chipjenham arrangement after the date fixed for member's to make their election, this, in fact, anomnted to a distinet and special compromise, which ought to have been speeially communicated to all the shareholders: this case therefore followed Symatiman v. Liens (1). ('1). Stemert's case (1866) I. R. 1 Ch. j11.

The question of the shareholder's knowled gre or assent in each case involved delicate and difficult inferences of fact, and on these the opinions of the Lords who took part in the decisions were serionsly divided. It may perhaps also be almitted that on some inferences of mixed fact and law there was a real difference; but it may sufely be affirmed that on any pme (question of law there was none (q). 'These eases appear to establish in substance the following propositions: (1.) For the purpose of binding a company as against its own shareholders, irregular transactions of an anthorized class may be ratified by the assent of all the iudividual shareholders. (2.) Such assent must be proved as a fact. Acquiescence with knowledge or full means of knowledge may anomnt to proof of assent, and lajse of time, though not eonclusive, is material. The eonverse proposition that the assent of a partienlar shareholder will bind him to an irregulat transaction as against the company is likewise well established, but does not fiall within our present scope. Soe r'cmplell's rese dic. (1573) I. R. 9 Ch. 1, 43 T. J. Ch. 1.

The later case of Ihosplate of lime Co. v. Green (1sil) T. Ti. Phorphate 7 C. P. 43, was of much the same kind though in a different form.

(p) (1k68). Siee also L. R. T (y) sere per Willes J.. L. R. T

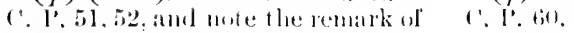
(i) lime Co. r. fireent.

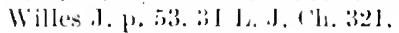


The action was by the company against past shareholders for a debt, and the defence rested on an accord and satisfaction which had been effected by an irregular forfeiture of the defendant's shares, and which in the result was upheld on the ground of the shareholder's acquiescence. It was not necessary to consider the distinction between irregular acts which can be ratified and acts contrary to the constitution of the compauy which cannot be ratified in any way, nor was it brought to the attention of the Court $(r)$.

Statutory frolibition : Companies Act. $18+i 2$.

With regard to cases in which ratification is impossible by reason of the corporation being absulutely disabled from undertaking the transaction, the existence of such cases has been recognized ahnost from the beginning of nodern corporation law. "A company incorforated by Act of Parlianent for a special purpose cannot derote any part of its funts to objects manthorized by the terms of its incorporation, however devirable such an application may appear to be" (s). The apllication of this principle to companies under the Companies Act, 1862 (the most important class of cases in practice), was fixed by the Ifoure of Torts in $1875 \mathrm{in}$ Ashbury, dor. Co. v. livlle, I'). 13:-134, above. The Honse decided that, by the frome and intention of the Act as a whole, the memorandum of association is the fundamental constitution of the company, and the company in incompetent to mulertake anything outside its objects as thereby defined. As a consequence of this, any provision in the articles for applying the company's capital to a purpose not warranted by the mesnorandun is itself invalid: Gimimess r. Lamd corporation of lielund (1882) 202 Ch. Div. 349. For sume time past it has been the practice of company draftinen to frame the memorandum in the most comprehensive terns, in order to prevent questions of this kind from arising; but the decisions remain in full force, and the practice and forms in use cammot he adequately understood without reference to then. As to when the Attomey-General is entitled to interfere, see A.-C. v. (i. E. Ry. ('o. (1sso) 11 C'h. Div. $449 ; 49$ I. J. Ch. 545; A.-(i. v. Loudon C'unenty Council [1902] A. C. 165, 71 T. J. Ch. 268 : this case also decides that a county council under the Local Government Act, $18 \mathrm{~s}$, is a jurely statutory body and has not the general power's of a corporation at common law ; $A$.- $(i$. v. Wersey Ry. (". [1907] 1 Ch. s1, C. A. (revd. on the point of sulstance in II. I. $[1907]$ A. C. 415,76 I. J. Ch. 568$)$.

(r) See further on the suljeet of ratification by companies. Lindley

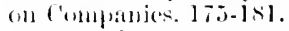

(*) Su laid down as well settled doctrine by Lord l'rasworth in E. (: Ry. Ca. v. Hawkes (185i) is H. 1. (1.331. 21 L. J. ('l. (iol, 101 li. li. 183 . 


\section{Note E. \\ Classification of Contracts in Roman and Medieval Law.}

Formal contracts (legitimae conventiones) gave a right of action irrespective of their subject-matter. In Justinian's time the only kind of formal contract in use was the Stipulation $(t)$, or verbal contract by question and answer, the question being put by the creditor and answered by the debtor (as Dari spondes sonder: Promittis? promittu: Facies? faciam). The origin of the Stipulation is believed to have been religious (u), though the precise manner of its adoption into the civil law remains uncertain. In onr authorities it appears as a formal contract capable of being applied to any kind of subject-matter at the pleasure of the parties. Its application was in course of time extended by the following steps. 1. The question and answer were not required to be in Latin ( $r)$. 2. An exact verbal correspondence between them was not necessary $(y)$. 3. An instrument in writing purporting to be the record of a Stipulation was treated as strong evidence of the Stipulation having actually taken place (z), and it might be presumed that the form of question and answer had been duly observed even without express words to that effect $(a)$. Hence the medieval development of operative writings.

Informal agreements (pacta) dicl not give any right of action without the presence of something nore than the mere fact of the agreement. This something more was called atusa. Practically Tudum pactum and culusus. the term covers a somewhat wider ground than our modern " consideration executed": but it has no general notion corresponding. to it, at least none co-extensive with the notion of contract; it is simply the mark, whatever that may be in the particular case, which

(t) The litterarum obligutio (ciai. 3. 128) was obsolete. What appear's unler that title in the Institutes (3.21) is a general rule of evilence meonnectel with the ancient usage: see Doyle's Justinian, Exc. riii.

(ii) Savigny's derivation of the sijpulation from the $\|P \cdot x\| m$ is abandoned, so far as I know. by all reeent writers. It seens quitio possible that the earliest ty po of contrate is to le sought in wovenants made between inclopembent tribes or lamilies. CT. Ciai. 3. 14 on the llses of the word sponder in treaties. If this wereso, one would
The verbal contratet. expect the eovenant to becontinum by an onth, of which Muinheal (on (iai. 3. 92) tiuds a trace on other grounds in the form promit/is.' jromilto.

(.r) (rai.8. 9.3. I. 3. 15, de v. o. \$1.

(y) (. 8. 3s. le eunt. et eomm. stipul. 10.

\&) C. s. 38. de ennt. et comm. sipul. 14, I. 3. 19. de innt. stipul. \$12. Probably Greek and provincial nise of writen agreenents lawl momels to des with this.

(a) laul. Sent, $1,7, \$ 2, \mathrm{Fol}^{\circ}$

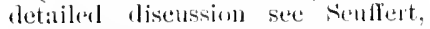
\%ur (ieschichte aler ublignturiseben Verriages \$3. 
What informal contracts enfurcealle.

distingnishes any particular class of agreements from the common herd of partu and makes them actionable. Informal agreements not coming within any of the privileged classes were called nuta partu and cuuld not be sued on $(b)$. The term malum pactum is sometimes uned, howerer, with a special and rather different meaning, to express the rule that a contract without delivery will not pars property (r).

The further alplication of thi- netaphor by speaking of the rausa when it exists as the clothing or vesture of the ayreement is without clasical anthmity but very common; it is adopted to the full extent l,y our own early writer: $(\lambda)$.

The privileged informal contracts were the following: 1. Real contracts, where the ans consisted in the delivery of money or

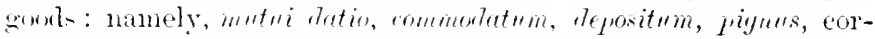
re-ponding to our bailments. This clas was expanded within hi-torical times to corer the s-r-alled inmominate contracts denoted

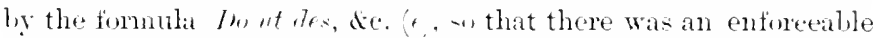
olligation it contrerte wherever, at we should say, there was a comsirteration excented : yet the procedure in the different clases of (a)e was l, no nean- mifom $\left(t^{\prime}\right)$.

‥ Consensulel contracto, leing contracts of constant occurrence in dialy life in which numse was required beyond the nature of the tran-action iteelf. Four such contracts were recognized, the fir-t three of then at all crent- (y), from the earliest times of which we knw any thing, nanely, Sale, Hire, Iartner hip, and Mandate.

(1.) They gave rive however t.

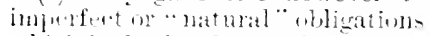
which had ither lexal etfect-

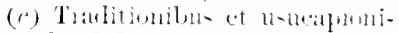
bus dominia rerum. non nudis pactis. tran-fermutur. curt. 2..3. de pactis. 21). Lint the context is mot presersed and the partichlar pore tum in questidn may have leeen

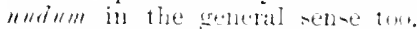
The contraty rule of the Commons Law ha- not in far been traced to an earlier time than the secomel guater of the fifferenth century :

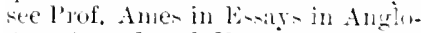
American Legal Ilist, iii. 312. 313.

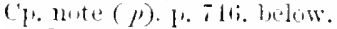

(d) - l'actmin nulum est ron restitum stipulatione vel re ret litteris vel consensu vel contractus cohaerentia": Azu. Sinnma in Cixl. aj. Senffert "1) cit. 41 : Maitland.

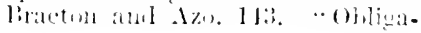

tio yuatuor species habet quilus contrabitur et flura restimenta." liracton. "sa. "Obligacioun deit entre ventue de vo mancers de garmisem.ustz." liritton 1. liti. Austin (burispradence. 2. 1146.3rd

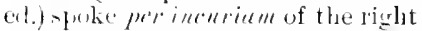
of action itself. instearl of that which given the right. as being the ". elinhing."

(P) Alut enim do tibi ut des aut to ut facias. ant facio ut les. aut facio ut facian: in quibusquaeritur quae bligatio nasedtur. 1). 19. $\therefore$. de furaecte verbis. i pr. Blackstone (comm. ii. 441) took this formula fur a classitication of all valuable considerations. and his blumber was copied without reflection by later writers.

(f ) lig. 1.c. $\$ \$ 1-4$.

(i) See lluirbead on Gai, 3. 2l6. 
(Emptio Venditio, Locatio Conductio, Societas, Mandatum.) To this class great additions were made in later times. Subsidiary contracts (pacta adiecta) entered into at the same time and in con. nexion with contracts of an already enforceableclass beeame likewise enforeeable: and divers kinds of informal contracts were specially made actionable by the Edict and by inperial constitutions, the most material of these being the "omstitutum, covering the English heads of arconnt stated and guarauty. Jnstinian added the partum donationis, it seems with a special view to gifts to pions nes (li). Even after all these extensions, however, matters stood thus: "The Stipulation, as the only formal agreement existing in Justinian's time, gave a right of action. Certain particular classes of agreements also gave a right of action even if informally made. All other informal agreements (mula parta) gave none. This last proposition, that nula parta gave no right of action, may be regarded as the most characteristic principle of the Roman law of Contract" (i). It is desirable to bear in mind that in Roman, and therefore also in early English law-texts, mulum futum does not mean an agreement made without consideration. Many mule partu, according to the elassical Roman law, would be quite good in English law, as being nade on sufficient consideration; while in many cases obligations recognized by Roman law as fully binding (e.r. from mandate or neyotiorm gestio) would he mentorceable, as being without comsideration, in the Common Law.

When the Roman theory came to be adopted or revived in Modem Western Christendom, the natural ohligation admitted to arise civi] law. from an informal agreement was, under the influence of the eanonists, gradually raiced to full validity, and the difference between partum and legitima contentio ceased to exist (li). The proeess, however, was not completed until English lin had already struck out its uwn line.

The identification of stipulation with formal writing, complete on Continent not later than the ath century (l), was adopted by our

(h) C. 854 , de donat. $35,55$. 'The estalnishment of empliyteusis as a listinet species of contract is of minor importance for our present julpose.

(i) Sav. (0), 2, 23]. Muimhearl, on Gati. 3. 131, says that * amomest peregrins a mulum purtum was cleative of actinn: "which secolns to be a slip. J'rovincial usage, se, fall as kutwn. Was lesis atratued than lioman; thus the contract of sile was (as in (icolnanic custom) real and not consensual: (iilsins. letude du droit romain compane aux autres clowits le lantiguite (1859) 1 . 217.

(li) seullent ap. cit. cp. Hatr.

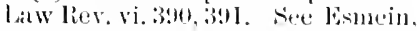
Et unles sur les contrats dius le tres

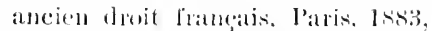
for the earlier meslieval history.

(b) Details ant authontices in

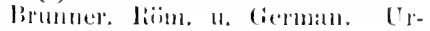
kinucle.
The deral in English metieval law. 
medieval authors. In Glanvill we find that a man's seal is conclusive against him $(m)$. Bracton, after setting forth almost in the rery words of the Institutes how "Terlis contrahitur obligatio per" stipulationem," \&e. adds: "Et quod per scripturam fieri possit stipulatio et obligatio videtur, quia si scriptum fuerit in instrumento alipuem promisise, perinde habetur ac si interrogatione praecedente responsum sit" (n). There is no doult that he means only a witing under seal, though it is not so expressed: Fleta does say in so many worls that a witing unsealed will not do (o). The equiralent for the Roman Stipulation being thus fixed, the classes of Real and Consensual contracts are recognized, in the terms of Roman law so far as the recognition goes: the Consensual contract: are but meagrely handled for form's sake, as the Roman rules could not be reconciled with English practice $(1)$. We hear of nothing corre-ponding to the later Ronan extensions of the validity of informal agreements. Such agreenents in general give noright of action: in Glanvill it is expres-sy said: "Privatas conventiones nun solet curia domini regis tueri" (4); the context makes it dumtful whther eren agreenents under seal were then recognized by the King's Comt unless they hal been made before the Comt itself. In bracton too, notwithstanting his elaborate copving of Thman sonces, we read: "Indicialis autem esse poterit stipulatio, vel conventionalis: indicialis, quae inssu iudicis fit rel praetoris. Conventionalis puae ex conventione utrinsque partis concipitur, nec in-su indicis rel praetoris, et quarmu totidem sunt genera quot paene (r) rermu contrahendarun, de quilus omnilus omrino curia regis se uon intronittit nisi aliqum do de gratia" (fo. 100a).

(m) L., x, $\because, 12$.

(11) $y 96$. lox) I. Latel students of lionan law seem to have bech disisatisfied ; at any rite the follow. ing turious marerinal note oecurs in an earty $1+t h$ centuly lls. of linten in the cambriale Eniversity Libraly (14l. 7. li): Differt bactum a conventionte quia lactum solum consistit in sermunibus. ut in stipnlationibns. conventis tam in sermolle quam in opele. nt cum in script is redisitur.

(a) Lib. 2. c. 60. \$ 2.) Non sobun sutliciet seriptura nisi sigrill monimine stipulantis (see $1 \%$. 14 . above) roboletur com testinmono tide dignormm pratestutium.

(y) Bractun's law of sale. like Gilanvill's. is the uld fiermanie law in which the contrael is not ronsensmal but real: fo, il b.. Ciitel- lock. 1\% 113. Mandate is still unknown to the Common Law.

(q) Lib. x, e. 1s, and more fully ib. c. s. "Curta domini regis" is significant. for the ecelesiastical courts. and it seems. beal and private courts, clial take comizance of breaches of informal agreements as being against good ernscience. ib. c. 12: 1;lacksone. Comm. 1. 52 . and authorities thert cited: Arehdeacon llale's series of Freedents and l'roctedings. where several instances will be fonnd : Hars, Litw. Rev vi. 402.

(r) This is evidently the trme reading: the printed book has pertute. stemingly a mele printer's misteading of pene. which is giren by the best Ilsi. Bracton was copsing the language of 1.3. 18. s. 


\section{Note F. (p. 229). \\ Early Authorities on Assignments of Choses in Action.}

In Mich. 3 Hen. IV. 8 , pl. 34, is a case where a grantee of an 1. c'ases annuity from the king sned on it in his own nane. No question seems to have been raised of his right to do so.

In Hil. 37 Hen. VI. 13, pl. 3, it appear's that by the opinion of where a direct assignment ouly is all the justices an assignment of debts (not being by way of satisfaction for an existing debt) was no consideration ( $q$ uil pro quo) for a bond, forasmuch as no duty was thereby vested in the asignee: and the Count of Chancery acted on that opinion by decreeing the bond to be delivered 1 . . The case is otherwise interesting, as it shows pretty fully the relations then existing between the Court of Chancery and the Courts of Common Iaw, and the cardinal doctrine that the jurisdiction of equity is wholly personal is stated with emphatic clearness.

In Hil. $21 \mathrm{Ed}$. IV. 84, pl. 38, the question was raised whether an annuity for life granted without naming assigns could be granted over ; and the dictum occurs that the right of action, whether on a bond or on a simple contract, cannot be granted over.

Mich. $39 \mathrm{Hen}$. VI. 26, pl. 36. If the king grant a chty due to him from anothor, the grantee shall have an action in his own name: "et issint ne prit mul autre faire."

So. Mich. 2 Hen. VII. 8, pl. 25. "Le Roy poit granter sa arrion on chose qui gist en acrion ; t issint ne poit nul anter persun."

In Roll Abr. Action sm Cise, 1. 20, 11. 12, this case is stated to have been decicled in I3. R., 42 Eliz, between Mowse and Ehney, per curiam: A. is indebted to B. by bill (i.e., the now obsolete form of bond called a single bill), and B. to C. 13. assigns A.'s bill to C. Forbearance on ( $\because$ s part for a certain time is no consideration for a promise by $\mathrm{A}$. to pay $\mathrm{C}$. at the end of that time (s. ". contro, ib. 29, pl. (60); for notwithstanding the assigmment of the bill, the property of the debt remains in the assignms.

In none of these cases is there a word abont maintenance or public policy. On the contrary, it appears to be assumed throughout that the imposibility of effectually assigning a chose in action is inherent in the legal nature of things. Finally, in termes de la Ley, tit. Chose in Artion, the rule is briefly and positively stated to this effect: Things in artion which are certain the king nay grant, and the grantre have an action for them in his own uane; but a common person can make no grant of a thing in action, nor the king hinself of such as are uncertain. No reason is given. 
The exception in favour of the Crown may perhaps be derived from the universal succession accruing to the Crown un forfeitures. This would naturally include rights of action, and it is easy to understand how the practice of assigning over such rights might spling up without much examination of its congruity with the legal principles governing transactions between subjects.

liefore the expulsion of the Jews unter Edward I. they were treated as a lind of serfs of the Crown (ipsi lutaei et monia sua regis sunt, Psendo-L. Edw. Conf. c. 25 ; tayllables an lioy come les soens seifs th a mul autre: Statutes of Jewry, temp. incert., dated by l'rune, : Ell. I.), and the king accordingly claimed and exercised an arbitrary power of confiscating, releasing, asigning, or licensing then to assign, the debts due to them. Cp. charter of Frederick II. l'et. de Vineis Epist. lib. 6, no. 12: "omnes et singuli Iurlaei legenter ubique per teras nostrae iurisclictioni subiectas Christianae legis et Inperii praerogativa senvi sunt nostrae Camerae rpeciales." And see on this subject Y. 13. 33 Ed. I. 1p. xli. 355 , and l'ryne's "short l lemurer to the Jews," \&c. (Iond. 1656, a violent polenic against their re-almi-sion to England), passim.

2. Cases where the right of an assigneet to sue in the name of the atsignen was itt question.
In Ilil. 9 IJen. V1. 64, pl. 17, Thomas Rothewel sues J. Pewer for maintaining. $\mathrm{W}$. H. in an action of detiune against him, lothewel, for " "l" lo,t ore charters th muiments." Defence that W. II. hat grunted to Pewer a rentcharge, to which the mumiments in quention related, and har also granted to l'ewer the box and the deeds, then being in the puression of Rothewel to the use of $\mathrm{I}$. H., wherefore l'ewer maintained W. Hl, as he well might. To this lantmu, whe of the julges, mate a curions objection by way of dilemma. It was not avered that W. II. was the owner of the deted, but only that hotherel had them to his use; and so the fuoperty of them might have been in a stranger: "et issint con fuit chase " arrion t issint tout wid." The precise meaning of these work in not rery clear, but the seneral drift is that, for anything that alleared, IV. II. had no asignable interest whatever: and it lowk as if the strong expresion tout con was meant to take a higher ground, distingui-hing between a transaction impeachable for maintenance and one wholly ineffectual from the leginning. It may have been supposed that an as-igmnent by a person ont of poscensun tould have no effect. Lut if $\mathrm{W}$. H. Was the true owner, l'anton continued, then the whole punerty of the deeds, de. lasicel to I'twer, who ought to have brought detinue in his own nane (s). balington ('.J. and Martyn J., the other julges

(x) Amotluer argument fut by the flatiotitl's commoct. themgh not vely material. is two guaint to be passed oler: Whaterer interest l'ewer 
present, were of a contrary opinion, holding that any real interest in the matter made it lawful to maintain the suit. The attempt to assign a chose in action is here compared by the counsel for the plaintiff to the grant of a reversion without attormment; showing that the personal character of the relation was considered the ground of the rule in both cases.

In Mich. 34 Hen. VI. 30, pl. 15, Robert Horn sued Stephen Foster for maintaining the administrators of one Francis in an action against him, R. IIoru : the cireumstances being that Iforn was indebted to Francis by bond, and Francis being indelsted to Stephen in an equal sum assigned the deht and delivered the boud to him, anthorizing him, if necessary, to sne on it in his (Francis') name, to which Horn agreed; and now Francis had died intestate, and Stephen was suing on the bond in the name of the administrators with their consent. And this being pleaded for the defendant, was held good. Prisot, in giving julgment, compared the case of the cestui que use of lands, whether originally or claiming by purchane through him to whose use the feoffment was originally marle, taking part in any wuit tombing the lands. On this Fitzherbert remarks (Mayntenams, 14) "Nota in"y que per reo il stmble que un duite muit estre assigne yum satisfartion." So it is sail in Hil. 15 Hen. VII. 2, pl. 3, that if one is indebted to me, and deliver to me an obligation in satisfaction of the del,t, wherein another is bound to him, I shall sne in my rlebtor's name, and pay my comnel and all things incident to the suit; and so may do he to whom the obligation was made, for each of us may lawfully interfere in the matter.

Brooke, Abr. 140 b, observes, referring to the last-mentioned case: "Et sir vide que chuse in accion poet estre assigne onstre $\mathrm{m}$, loyal carse, come inst det, me: nemy mur maintenance." This form of expression is worth noting, as showing that assignment of a chose in action meant to the writer nothing else than enpowering the assignee to sue in the asignor's name. He was at no pains to explain that he did not mean to say the asignee could sue in lin own name; for he did not think any one conld suppose he meant to assert such a plainly impossible proposition.

It was long supposed (as is implied in Fitzherbert's and bronke's language-aur see the case in $37 \mathrm{Hen}$. VI., cited $\mathrm{p}$. 747 above) that the assignment of a debt by way of sale, as opposed to sati-faetion

might have latil by the grant of the rent and the deeds relating to it, yet he had none in the box, and therefore in respect of the bux. at all events, there was unlawful maintenance on his part. 
of an existing liability, was maintenance. Even under the Restora. tion the Court of Chancery would not protect the assignment of any chose in action unless in satisfaction of some debt due to the assignee: Freem. C. C. $145, \mathrm{pl}$. 115 , see Prof. Ames in Harv. Law Rev. i. 6, note; and further on the whole matter, the same learned writer in Essays in Anglo-American Legal History, iii. 580 sqq.

\section{Note G. (p. 529). \\ Bracton on Fumlamental Error.}

In arquireml" remm dominio, fo. $15 b, 16$ : "Item non valet lonatio, nisi tam dantis quam aceipientis concurrat mutuus consensus et roluntas, seilicet ruod donator habeat animum donandi et donatarius animum recipiencli. Nuda enim donatio $(t)$ et nuda pactio non obligant aliquem nec faciant aliquem debitorem; ut si dicam, Do tibi talem rem, et non habeam ( 1 ) animum donandi nec tradendi nee a traditione ineipiam, non ralet, ut si dicam, Do tibi istam rem, et illam nolim $(x)$ tradere vel $(x)$ sustinere quod illam tecum feras vel arborem datam suceidas, non valet donatio quia donator plene non consentit. Item oportet quod non sit error in re data, quia $x$ i donator senserit de ma re et donatarius de alia, non ralet donatio propter dissensum : et idem erit si dissentio fiat in renere, mumero et quantitate. . . . [Then follow instances.] Et in fine notanclum quod $\mathrm{si}$ in corpus quod traditur sit consensum, non nocet, quanvis circa causam danti atque recipiendi sit dissentio: ut si pecuniam numeratam tibi tradam, rel quid tale, et tn cam quasi ereditam (y) aceipias, constat ad te proprietatem transire."

(f) rotin lls. Hobhouse, Lincoln's lnu.

(ii) hathuen Ms. Hobh.

(r) MIS. Hobl. : edll. nolni, at.

(y) Tinditum el. litis?. followed without remark by Sir T. T'wiss, 1878 , who also gives by a misprint. and translates, tali for tale immediately abore. (Nee on the general character of this edition $\therefore$ The Text of Bracton." by Prof. Paul Vinograrloff. I. Q. R. i. 189.)
But "reditam is the reading of a majority of good MSS. (Lincoln's Inn. Camb. Cnir., Brit. Mlus., Bibl. Nat. Paris) and is evident ly required by the sense. Bracton is quoting from the bigest, 41.1 . de acq. rer. dom. 36 ; ep. Guiterbock. Henr. de Bracton, p. 85. who assumed, with. out cause. as the MSs. now show. that Bracton misumlerstood the passage. The eorruption, however, is an easy and carly one. 


\section{Note H. (p. 552).}

\section{Mistalie in Wills.}

Properly speaking, there is no jurisdiction in any eourt to rectify a will on the ground of mistake. The Court of Probate may reject words of which the testator is proved to have been ignorant, whether inserted by the fraud or by the mistake of the person who prepared the will $(z)$. But it has no power to insert words (a) or otherwise remerly a mistake "by modifying the language used by the draughtsman and adopted by the testator so as to make it express the supposed intention of the testator. . . . Such a mode of dealing with wills would lead to the most dlangerous consequences, for it would convert the Court of Probate into a court of construction of a very peculiar kind, whose duty it would be to shape the will into conformity with the supposed intentions of the testator" (b). Exactly the same rule has been laid down in equity (c).

The cases in which it is said that the Court will interfere to correct mistakes in wills may be classified thus:

1. Cases purely of construction according to the general intention collected from the will itself $(l)$.

2. Cases of equivocal description, of words used in a speeial habitual sense, or of a wrongly given name whieh may be corrected by a sufficient description $(\rho)$.

3. Cases of dispositious made on what is called a false cause $(f)$, i.e., on the mistaken assumption of a particular state of facts existing, except on which assumption the disposition would not have been marle. These are analogous to the cases of eontract governed by Couturier v. Hustie (.1); and just as in those cases, the expressed intention is treated as having been dependent on a condition which has failed.

But the true view of all these cases appear's to be not that the

(z) E.\%. Norrell v. Worrell, 7 I'. U. 68 , I I I. J. I'. 49, following Fillon v. Andrew (Isti) l. R. 7 II. I. 448,44 I. .J. l'. 17 : Bristo v. Buillie-Ifamilton [1902] I', 234, 7 I 1. J. I'. 1:21

(a) In the gouds of selunt $[1901]$ I'. 190,70 L..J. I'. 16.

(b) Hartor s. Hartor (1873) L. li. 3 1'. \& I. 11, 21, 44 I.. J. I'. 1, following Guathouse v, Blackburn (186it) I., R. 1 1'. \& H. 109. 3.) I. J. P. 116.

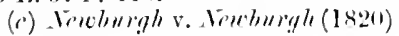

j Miul, 364, 21 li, li. 310.
(1) See Ilawkins on Constructirn of lills, Introduetion.

(r) Not ouly an efuivocal name may he explained, but a nime which applies to only one person may he corrected by a description sufliciently showing that another person is intenterl: (horter v. Chartor" (187t) L. Li. 7 H. L. 364 .

(f) Cimpliell v. French (1797) 3 Ves. 321. 4 Ii. li. 5 .

(g) (18.;i) 5 H. L. C . 6i73, 2.) I. J. Ex. 253, 101 R. li. 329. supre, !1. $443,51 !$. 
words are corrected, but that the intention when elearly ascertained is carried out notwithstanding the apparent difficulty caused by the particular words.

Note I. (p. 559).

On the s"lposal equituble doctrine of "making representations goorl."

Original statement in Hammersley $i$ l le lieil.

This once frequently alleged head of equity, in so far as it purports to establish any rule or principle apart from the ordinary rules as to the formation of contracts on the one hand, and the principle of estoppel by assertion as to existing facts on the other, is now known to be imaginary. In the principal class of cases the "representation "is of an intention to make a prorision by will for persons about to marry, in reliance on which representation the marriage takes place. The leading authority is IIammersley $r$. De Biel (h), decided by the Ifonse of Lords in 1845 on appeal from the Court of ('hancery. In the Conrt helow (i) Lord Cottenham had laid down the proposition that "a representation made by one party for the purpose of influencing the conduet of the other party, and acted on by him, will in general be sufficient to entitle him to the assistance of the Court for the purpose of realizing such representation." This appears to he the source of all the similar statements which have since been made $(k)$. Taken with its context, however, it need not mean more than that an exchange of proposals and statements by which the conduct of parties is determined may, as containing all the requisites of a good agreement, amount to a contract, though not to a formal contract. To Mr. Justice Stephen Lord Cottenham's words appeared " to mean only that contracts of this nature may be made like other contracts by informal documents, or partly by documents and partly by conduct" (l). And in this sense the rule secms to have heen understood in the Honse of Lords both in the same and in subseruent cases. Iord Brougham and Lord Campbell speak of the transaction in plain terms as a contract. In the Rolls Court it had also been dealt with on that footing $(m)$. still more pointed is the remark made by Lord St. Leonards in 1854:-

(h) $(1845) 12$ ('l. \& F. 4.'. 6! R. H. 18.

(i) 12 Cl. \& F. at p. 62.

(k) The turn of langnage is in itself not novel. It seems to be modelled on that which had long before been usel in cases of a different class and for a different purpose. See Erans v. Bicknell (1811) 6 Ves, 174,5 R. R. 245.

(l) Alderson v. Maddison (1880) $\therefore$ Ex. D. 293, 299. 50 L. J. Q. B. thit.

(iii) Nom. De Beil r. Thomson (1841) 3 bear. 469. 
" Was it merely a representation in Hammersley v. De Birl? IVas it not a proposal with a condition which, being accepted, was equivalent to a contract?" ( 1 ). In the terms of the Indian Contraet Aet, it was the case of a proposal accepted by the performance of the cenditions. The statement "I will leave you 10,(0)0/. by my will, if you marry A.," if made and acted on as a promise, becomes a binding. contraet (the manriage undertaken on the faith of that promise being the eonsideration), and so does a statement in less plain language which amounts to the same thing. On the other hand the statenent "If yon marry $A$. I think, as at present advisel, I shall leave you 10,000l.," is not a promise and cannot beeome a contrat: neither ean it act as an estoppel, for it camnot matter to the other party's interest whether the statement of an intention which maly be revoked at any time is at the moment true or false. And the same is true of any less explieit statement which is held on its fair construction to amount to this and no more. Such was the result of the ease where Lord st. Leonarls put the question just eiter (1). And in that ease the true doctrine was again distinetly affirmed by Lord ('ranworth $(\mu)$.

"By what words are you to define whether a party has entered into an engagement as distinct from a eontract, but which becomes a eontract by another perwon acting upon it? Wherea man engages to do a particular thing, he nust do it; that is a eontraet; but where there are no direct words of eontruct, the question must be, what has he done? He has made a eontract, or he has not; in the former case he must fulfil his eontraet; in the latter there is nothing that he is bound to fulfil." Again: "There is no middle term, no tertium quid between a representation so male as to be effective for such a purpose, and being effective for it, and a contract, they are identical."

He proceeded to comment on Hammersley v. Ire Liel, and to express a decided opinion that the language there used by Lord Cottenham was not meant to suplort, and diel not support, the notion that words or conduct not amounting to a true contraet may create an equitable olligation which has the same effect. "The only distinction I molerstand is this, that some words which would not amonut to a eontract in one transietion may possibly be hold to do so in another." In the case of Jorden v. Money (y), which

(1i) Maunsell v. Iletlges (1851) 4 H. L. C. at p. 105i, 91 Ri. L. 5.39,

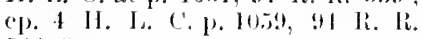
$5,4.5$.

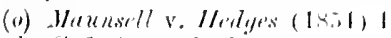
H. L. C. 11339, 11 li. Ii. 53:?.

P.
Subseruent explanations in IIonse of Lords. 
liasen in

(iint of

C'han ely.

Opinion of

-tuat Y.:

came betore the Howe ol Lords sone months later, it was held, first, that the -tatement there relied on as linding could not work an e-tolpel, becance it was a statenent not of fact but of intention; secondly, that on the erinlence it dirl not amomit to a promice, and therefore conk not be hineling as a contrat. Lord st. Leonards dis-ented both on the evirlence and on the law. His opinion seems: on the whole to eome to this: "MY inference from all the facts is that this statenu+ut was a lwnise; but if not, I say it is availables

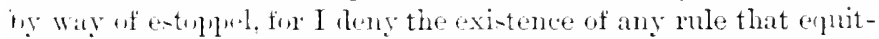
alde entonder can be by -tatement of fact only and not of intention." On thi- print, howerer, the onimine of the majority (Lord cran worth and Lend bromghan) i- conelusive $(r)$. A promise de futuro cannot be an extolyel $(x)$.

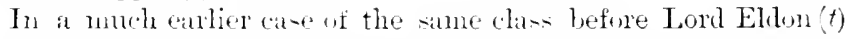
the langhage nerl is indeci-ive: "arrangenent" and "engargenent" reen preferred to " apreenent." In two laterones deeiled by sir John Stmant ( ${ }^{\prime}$, an intumal statenent or promise as to a

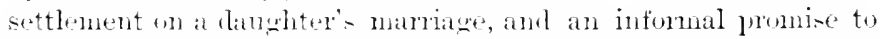
loave lonelty hy will to an attendant as recompense for servees, were held to lwe enforealle. The Vice-chancellor certainly seens t. have arlonterl the opinion that a "representation" short of contract had somehww a limbling form. He aplears further to have helel that, inammeh as there were not polerly eares of enotract, it ma- inmaterial to consider whether the statrite of Frands applied to thens, and to hase thomght that the oninion of Lord Cranworth in Jorden v. Money was incom-iotent with the deeision in Mam-

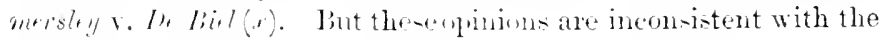

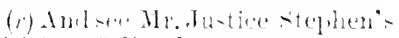
(ritivion. $=\mathrm{kx}$. 1) alt 1, 2013.

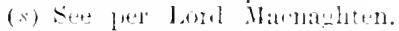

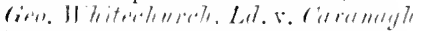

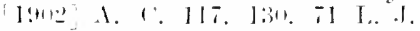

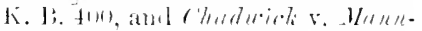

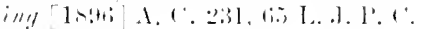
I:. J.1.

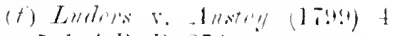
Ver. הit. + R, R., 27is.

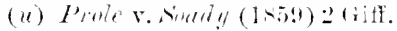

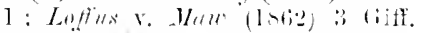
5.92 (186,2). In Leffins r. Mure there is a mogerention that the "re. fresentation atfects the puecitic froperty an an copluitable (do:trece similar notiors aceus in sine of

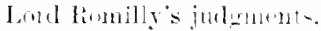

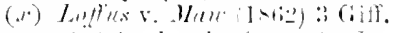

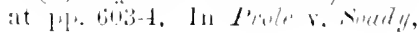

a trange and entangled eave. no print wa maje on the statute of Frank. but there it appeas to lave been cotablished as a fact that the wif $\therefore$ father represented to the intemlet humbul, an linglisuan, that a eertain tumet dieposition of senteh land in the lloper scottish form was irrevocalle. This was. as regards the feron to whom it was mide. a repuratution of foreign law. and therefore efuiralent to a represertation of firct. And thus the decisim may hate been right on the gromel of enteplet. But it is far foun cary to di-cover on what grumur it really proceder. The met went wh the Alyeal romt, but wa-complomi-al: -ee L. Ri. 1 ch. 
true meaning and effect of the cases in the IIouse of Icorls which have already been eited: and one of them is now expresily overruled (y). Other judicial expressions are to he fund loth earlie and later, which in some degree comntenance them; hut these have been, without exception, unnecessary for the decision of the case. in which they occurred. It is remarkable that the authoritative explanation of Hammersley v. De Biel(\%) given in Mamusell v. Hedyes (a) was commonly left umoticed.

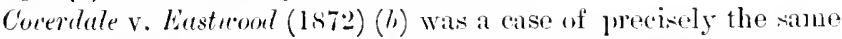
type as Hammersley v. He Biel. Bacon V.-C. decided it on the Later calses of sallue rlass. ground that the transaction anounted to a contract, and so it was expressed in the decree. But he also thought that there existed, and was applicable to the case in hand, " this larger principle, that where a man makes a representation to another, in consequence of which that other person contracts engagenents, or alters his position, or is induced to do any other act which either is permitted ly or sanctioned by the person making the representation, the latter cannot withdraw from the representation, lut is bound hy it conclusively." Later, in Iotheroul v. Jerm:gn (c) (1879), which was another marriage case, he held that the connexion hetween the statement relied on as a promise and the marriage alleged to have taken place on the faith of it was not sufficiently made ont. He stated the general rule thns:- "If a man makes a representation on the faith of which another man alters his position, enter's into a deed, incurs an obligation, the man making it is bound to perform that representation, no mattor what it is, whether it is for present payment or for the entinuance of the payment of ammity, or to make a provision by will. 'That in the eye of a Court of Equity is a contract, an engagement which the mian making it is bound to perform." This appears to qualify to some extent the dictal of the

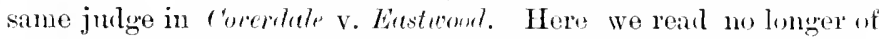
two distinct kinds of obligation, ly contract and ly "representation," but of one kind of obligation, and that a contractual one, arising from the reperentations made by one party with the intent

115. The still later case of sirl-

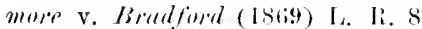
Eit. I31, deeided by the same judge was merely a case of contract.

(y) Lo!fin v. Waw (Isti2) is clearly disaphoved Jy Lord hel. borne and Lordo'Itagan in Maddison v. Alderson (1.8.3) \& Alu. ('a.

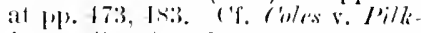

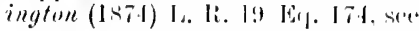
at 1. I7s, 11 l., J. ('l. 3SI ; it is now enomeh to say that it was decinled by Milins V.-A. on the anthority of Lo!fus v. Haw: which, if possible. it execeds in andarity.

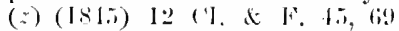
li. li. lis.

(a) $($ ISisl) + H. I. C. 10:39, 91 li. li. 3332 .

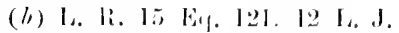
('h. IIs.

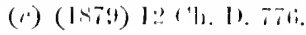

3 c 2 
Cases of c.jllateral "represerltations $"$ int ducing contracts.

that they should he acted upon, and the conduct of the other who does act upon them. If the learned judge thought that the same fact might anomit to a contract in equity and not at law, he was clearly mistaken. In Alderson r. Mudlison (1sso) (d) there was an agreement to leave property by will as a reward for services. Here Stephen . . set forth the view that it must be a contract or nothing ; and he held that a contract was proved by the facts of the case. The decisinn was reversed $1, y$ the Comt of Appeal on the gromd that, the care being within the statute of Frauls, there was no sufficient part perfomance: and the same view was taken by the House of Lorils. No encouragement whatever, to say the least, was given to the doctrine of " representation." Finally, in lie Fickus $(e)$, where a faint attempt was made to revive it, Cozens-IIardy J. summarily disposed of it with a reference to the decisions in the Honse of Lords.

$\rightarrow$ far the authorities as to direct enforcement of "representations." We do not connt among them Piygntt r. Strutton $\left(f^{\prime}\right)$, decided by the court of Apleal in 1559, in which Lord Campbell incidentally touk a minimizing view of the effect of Jorder v. Morey (\%). Thit cise, so far as it did not proceed on express covenant, was une of equitable estoplet. Mills r. $F_{0, r}(1587)(h)$ was also decided expresly w the eromd of estrpel by representation of fact. The representation was not of intention at all, but that a certain state of fucts with its leyal conseyuences existed and would continue to exist. But another class of decisions now calls for mention. These lay down, or seem to lay down, a rule to the effect that where a contract has been entered into upon the representations of one party that he will do something material to the other party's interest under it, and he does not nake good that representation, he cannot enforce specific lerformance of the contract : and in one case the contract has even been set aside at the suit of the party misled. It is difficult in the-e cares to see why the so-called representation does not amount to a collateral acreement, or even to a term in the principal contract it:elf. In the first set of cases, where specific performance was refused, a vendor or lesior had represented that he would do some. thing for the purchaser's or lessee's benefit, either in the way of repair or improvement on the property itself (i), or by executing

(d) $; \mathrm{Ex} .11 .293 .7$ Q. R. Lir. 174. 8 Alp. Ca 467,50 L. J. Q. B. 46 it.

(e) $[19106] 1$ ('h. 331. 334, 69 L. J. Ch. 1 til.

(i) 1 1). F. J. 33.29 L. J. Ch. 1.

(4) At p..il. Piut Lond selborne stems to athint the opinion of Lord
Cranworth to its full extent in C'itizens" Bank of Lemeisiana v. First Mational Banke of lew Orlenm: (1873) L. R. 6 H. L. at p. 360,43 L. J. Ch. 269.

(li) 37 Ch. D. 1.i3. . is L. J. Ch. iti.

(i) Lamaine v. Jixon (1873) L. H. i H. L. 414, 43 I. J. ('h, 2013. 


\section{"REPRESENTATIONS."}

works on adjoining property as part of a general plau (k). In these cases it has been thought immaterial, since the remerly of rpecific performance is " not matter of absolute right," to consiler whether the collateral " independent engagement" could or could not have been sued on as a contract or warranty $(l)$. In the one case which goes farther the contract was a partial re-insmance effected by one insurance society (A.) with another (B.) for one-third of the original risk, the secretary of society $A$. stating, when he proposed the reinsurance, that on-third was to be re-insured in like manner with another office $\mathrm{C}$., and the remaining one-third retained by $\mathrm{A}$., the first insurers. This last one-third was afterwarls re-insured by $A$. with $\mathrm{C}$. without communication with $\mathrm{B}$. It was held that society B. was entitled to set aside the policy of re-insurance given by it on the faith that society $A$. would retain part of the liability And it was said to make no difference that such an intention was really entertained at the time: for the change of intention ought to have been communicated. "If a person makes a representation by which he induces another to take a particular course, and the circumstances are afterwards altered to the knowledge of the party making the representation, but not to the knowledge of the party to whom the representation is made, and are so altered that the alteration of the circumstances may affect the course of couluct which nay be pursued by the party to whom the representation is made, it is the imperative duty of the party who has made the representation to communicate to the party to whom the representation has been made the alteration of those circumstances" ( $m$ ).

This case, decirled by the Jords Justices in 1864, is that which gives rise to most difficulty. No reason appears why the retaining of the specified part of the risk by the re-insuring office should not have been deemed a term or condition of the contraet ("). Indeed it seems to have been an integral part of the proposal, and evilence was offered that by the constant usage of insurance offices it was so understood. The jurlgments, however, certainly do not proceed on that footing. Possibly it might be sail that the representation in this case, being of something to he done not in a more or less ristant future, but at the same time with and as part of the proposed trins. action, was in the nature of a representation of fact. It might be

(b) Beammont r. Inlies (1822) Jac. 122, 23 li. R. 110: J/yers v. 11 atsom (15.51) 1 sim. N. ‥ 523, 89 li. R. 173 .

(l) Jord (tanwouth, I Sim. N. S. 5eg ; Lond c'amus, I. Ii. if II. I. $1: 25$. (m) Traill v. Burimg (1sil) I D. J. ง.. 318, 32!, per ']uner 1..J. approver by liy I..J. Norting

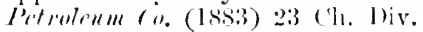
at 1). l:3s.

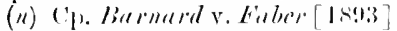

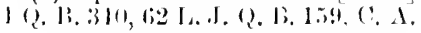


put thus: "We are re-insuring one-third with C.; one-third of the risk we keep; will you, B., take the other third:" And thus put, it might be regarded as an alternative case of contract or estoppel, in which (for some reason not evident from the report) the Court preferred the less simple course.

In the other cases it is by no means clear that the existence of a true collateral agreement or warranty is excluded; in at least one sinilar case (o) the question is treated as one of agreement entirely. In Lanure $v$. Diron $\left(l^{\prime}\right)$, which came before the House of Lords in $1 s ; 3$, the principal agreement was for a lease of eellars to be used as wine vaults. Inuring the negotiations the Iessor assured the lessce either that he had already taken, or that he would forthwith take, sufficient measures to keep the cellars dry and fit for a wine merchant's use. It seems most natural to regard this as a warranty: still, so far as it related to antrthing already done, it might be regarded as a positive statement of fact. "You will find the cellars dry," or any speech to that effect, might mean either: "I undertake to make the eellars dry," or "That has been done which is known by competent experience to be sufficient to ensure dryness." The line between warranty and estoppel is here a fine one, and perhaps not worth drawing, but still it is possible to draw it: and when Lord Cairns said "I quite agree that this representation is not a gruarantie." he may have meant that he preferred to regard it as a statement of fact operative by way of estoppel. There certainly does run through these cases. however, the ilea that specifie performance is so far a di-cretionary remedy that it may be refused to a party sceking it on grounds which do not affect his legal rights under the contract. But it seems a tenable position that equity judges have taken a needlessly narrow riew of what is a binding agreement on the principles of the common law ( $)$. In fact agreements eollateral to leases, and not in writing. have of late years been enforced withont doubt $(r)$. In all these eases the facts appear undistinguishable in their character from those which were treated in the

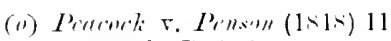

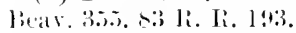

(1) 1. li. 6 HI. I. 414. 4; L. J. (1..2) 2113.

(q) It wonlal be curions to know in what proportion of cases muler the ald practiee a party left by the Cinurt of Chancery, as the phrase was. to make what he comld of it at law. rerivel substantial or any punfit from that liberty.

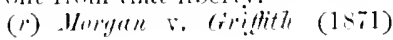

L. R. i Ex. 70, 40 L. J. Ex. 46 ;

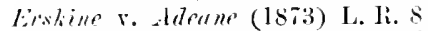
('h. 7.tit. +2 J. I. Ch. 835; Angell v. Intie (185) 1.. R. 10 Q. B. iTt. it L. J. Q. B. is: De Lassalle r. Guild ard $[190]$ ] 2 5. R. 215.70 I. J. K. B. 533. C. A. (warrant $y$ of drains being in good orler). The ground taken as to the statute of. Frauls is that the collateral agreement is mot a * contract or sale of lands." se.: the cffeet of the 
Court of Chancery as establishing a right to relief on the ground of "representation."

There remains a class of cases in equity in which it has been held that a statement marle to a person intended to act upon it by one who knows it to be false, or is recklessly ignorant whether it is true or false, may create in the person who acts on it to his injury a substantive right to compensation. Here the statement is a wrong, and the remedy is precisely analogous to, and before the Judicature Aets was concurrent with, that which was given at law hy the action of deceit, or action on the case in the nature of an action of $\operatorname{deccit}(s)$.

It is worth remark that not unfrequently a difficulty occurs in drawing the line between contract or warranty and fraul, as we have already seen that there does hetween eontract and estorpel. "Most of the cases. . . when looked at, if they do not absolutely amount to contract, come uncommonly near it. . . . If yon choose to say, and say without inquiry, 'I warrant that,' that is a contract. If you say, 'I know it,' and if you say that in orler to save the trouble of inquiring, that is a false representation-you are saying what is false to induce them to act upon it" $(t)$. Thus cases are possible, as has been mentioned in the text, in which the legal effect of the facts may equally he considered as warranty, cstoppel, or duty er delicto. And since equity judges, dealing with facts and law together, were not bonnd to distinguish with precision, and often did not distinguish, on which of two or nore possible grounds they rested their decisions, it is not smprising that a good deal of ambiguity has gathered round the subjects discussed in this note.

\section{Note K. (1). 662$)$.

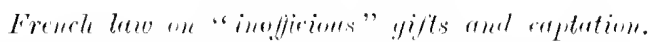

French jurispudenee lass sometimes ben eited in our Courts as affording useful analogien in cases where it was solught to set aside gifts on the gromm of nulue influence, expecially spiritual influcuce. (Wuvres l'Aguessean, 1. 2si, 5. 514, ed. 1819; Lyon ".

Fiench authoritions before levoslal jonl. Home, J. R. 6 Eq.jil.) Without druying the instructiveness of

Cases where filse representation gives, as wrong, a substantive right of action.
Statute being as it were exhaustel by the principal contact; with which the collateral une must of comse be comsistent.

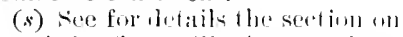
beceit in ('hap. viii, of my wark on the Jatw of Tints.

(f) lonol likeklum in liomentie? v. (ampletl (1s80) (sic) is App.

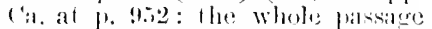
shoull be sturiel. 
the comparison, it may be pointerl out that these French cases procected on rather different grounds. Charitable bequests in general were unfarourably looked on as being "inofficions" towards the natural successors. This principle is strongly brought out by D'Agnesseau in the case of the Religienses dn Saint-Sacrement (Euvres, rol. 1, p. 295 ) :-

"Ces dispositions universelles, contraires aux droits du sang et de la nature, qui tendent a frustrer les héritiers d'une succession légitime, sont en elles-mêmes peu favorables; non que ce sevil moyen soit peut-étre suffisant pour anéantir un tel legs; mais lorsqüil est sontenu par les circonstances du fait . . lorsque la donation est immense, qu'clle est excesive, quelle renferme toute la succesion . . . dans toutes ces circonstances la justice $\therefore$ sot toujours déée contre ces actes odieux; elle a pris les héritiers sous sa protection ; elle a carvé ces donations inofficieuses, exces. sives et contraires à l'utilité publique."

Monlen law

In modern French practice a will may be set aside for captation of cuptutimn. or suyys stim. But, as with ns, the burden of poof is on the ob. jector to show that the testator: will was not free, and something amounting to fraudulent practice must be proved. "La suggestion ne saurait étre séparée," sars Troplong, " d'un dol subversif de la libre rolonté du testateur ... On a toujours été très difficile en France a adurettre la preuve de la suggestion et de la captation." (I)roit ciril expliqué. Des donations entre-rifs et des testaments, art. 492.$)$

On the otler hand the Corle Civil (art. 907, 909-911) contains express and severe restrictions on dispositions by wards in favour of their wuardians, and by persons in their last illness in favour of their medical or spiriturl advisers. These apply alike to wills and to wifts inter rimes. 


\section{INDEX.}

\section{AC'EETANCE:}

by act, when complete, 26 .

by post, though never delivered, effectual, 3., 38.

when complete, 35 .

certainty, necessity of, 17 .

communication of, 31 .

cannot be constructive, $11, n$.

means of communication, 3.).

correspondence, aceptance of contract marke ly, $3 i, s / \%$.

English cases, theories in, 37.

date of proposal, acecptance will not relate bick to, 11 .

double, of same proposal, 33 .

cxpress or tacit, 11 .

insufficient, examples of, $43-41$.

of proposal, general but not universal form of agreenent, 5,6 . eflect of, where proposal misunderstood, snl507.

lerformance of conditions of proposal, 14, 15.

special comlitions, acceptance by receiving document with, jo.

sufficient, examiples of, 14-15.

when implied, 5.2.

taeit, must be unambiguous, jo.

unqualified, must be, 42 .

when in time, 29.

witl immaterial or ambiguous addilion, 14, 1. .

ACC1DENT: destroying subjeet-matter of conituat, effect of, 129 , $432,437$.

NC'OLNT: action of, $11 \%$.

AC(O)ENT S'LATED : with infant, not void but voilable, 62.

ACKNOWLEJAMENT of debt barred by Slatute of Limitation, 19n, 686. And see himitution.

ACQULESCENCE :

estoppel hy, 698, 699.

knowledge essential to, 172. 
ACQUHESENCE-contimued.

lape of time as evilune of. (390.

pasive, in self-rleception of other prary. ils.

revision of contract, acpuieseme as hal to, fi30.

undue influence, acquiescence in cases of. tirg.

"AC'T OF GOD": meaning of: no general definitiou posoible, 13 t.

MCT1ON:

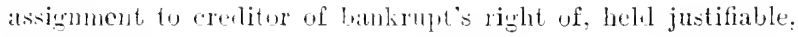
$3 \pi \pi, n$.

forms of, carly clatifitation of, 112.

\section{ADERTISEMENT :}

contract by, 15, 2.2, sq\%.

surh contracts not eximpt from situte of Frauls, 25.

\section{AGENT:}

apprintment of repuires no sperial formality; 60].

authority. impliel warranty of, 112.

of, its constitution ant ent. 101.

lorofesed acent without, 10-ition of, 110 .

revocation of. 1 lil.

anthurized agent known to bo such. contract with, lo3.

not known to be such, contract with, lors.

hill of exhange, aceptance hy ayent, prineipal bound though

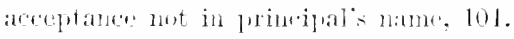

contract of. is contrat of pincipal. $211,217$.

contraets mate lye 102. s/q.

corloration can generally only act l,y 122.

liable for womgs of, 128.

death of prineipal, wfinet of, on sulserfuent contracts of agent lefore notice. Jo2.

election to sne primeipal or agnest. 109.

fram of liability of corporation for $121,611$.

ferwmal, agent always lialle for. ble.

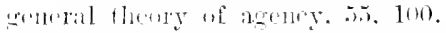

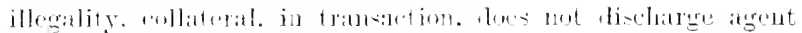

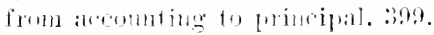

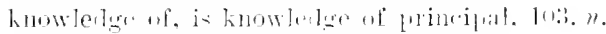

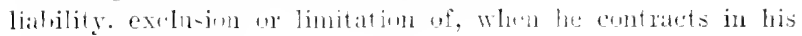
own name, 10.5.

negligene, agent may not prohit ly his own. 302.

personal liahility of, 103.

professed agent: when he may liwtowe himself as roal principal, $11 \%$.

witumt authority. p-itim of. where responsilile pin inal nitumel, 110. 


\section{AGENT-contimued.}

professed agent: withont anthority, position of, where responsible principal not naned, 115 .

representation of, when principal liahle for, tilo.

revoeation of authority: methods of withdrawal, 101 .

rights of other contraeting party, 108 .

sale to or purehase from himself, 300 .

secret commissions, agent for sale or purelase must mot aceph, from oflier party, 300 .

dealings by, on his own account in matter of agency, $299-302$.

sub-agent not agent of priuripal, son.

undiselosed principal, rights of, 108.

wrong, agent always liable for his own, fil2.

\section{AGREEMENT :}

analysis of, as aecepted proposal. fi.

certainty of terms, neessity of, 17.

collateral, evidence of, $26 \mathrm{f}$.

consent, apparent, but not real and no contrat. Isti.

condition affeeting valility of, I63. Ind see MIstalit. how expressed, 5.

detinerl, 2, 3 .

definition of, Savigny's, 723 .

election to adopt originally voil agreement, s.2.

evislence to explain partienlar terms in agrement, ötit.

whether a document is or is nut record of, 2012.

illusory promise, ellect of, 18.

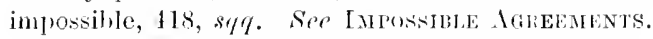

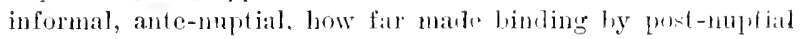
settlement, 699 .

effect of part performance, 697 .

execution of, may be good consileration or aceord ancl satisfartion, 6915.

lumatic agrecment of, not voirl hut voilalile, 97-99.

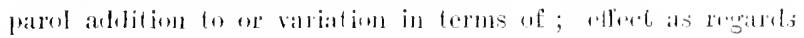

specitic performanee, 511, 512.

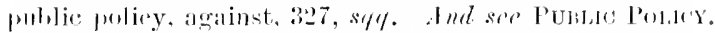

thirel person, agrecurent with, als subject of promise, in).

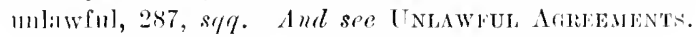

void and roidalie, distinetion butween, 3,9 .

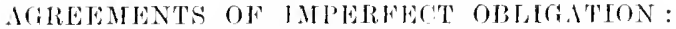

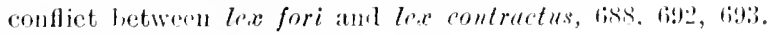

gencral results as to, 729.

their nature and ellects, 682. 
ILIEN :

enemies, lisabled from suing here but wot from eontracting. 100.

wife of, when she can contract as feme sole, 86 .

ANNUITY : agreement to give. charged on land, implies personal corenant for repayment, 219.

APOTHECARIES : cannot recover charges unless properly qualitied at time of services, 711 .

\section{ARBITRATION :}

agrecments for reference, now practically enforcealse, $3 \mathrm{ls}$. arlitrator, can reegrer remumeration on express coutract, 712. award, whether stranger ean be bound by, 215 .

right of action may lie conditional on awarl, 351).

statutory provisions for reference to in disputes of friendly and buililing societis, 349 .

DHTHELLAL PERSON :

nature of, 117.

newspapers and journals, artiticial personality a-cribed to, 11.8 . frartnerships and other holies treated as, by custom though not ly law, 118.

term not synonymous with "tictitious:" $11 \overline{\boldsymbol{i}}, n$.

And sen Conporation.

ASSIRINENT :

assignee: rights of, umber contract, 22s, sq\%.

takes subject to enuities, 234 .

rule may be exeluded ly agreement, 235 .

attempts to oppose on ground of maintenance, $2: 29$.

equitable, hill of exchange is not an, $733, n$.

of debt, 231 .

not affeeted by Judicature ict, 231 .

not enforeed where debtor's burden increased, 229,234 . notice to debtor. 210, 231,232 .

of contract (uhich see), 228, sq\%., 498.

uf copyright, 1i2.

of pensions, de. void, 314.

title $1, y, 210$.

to ereditor of lankrupt s right of action, 3.5, $n$.

\section{ASSLMPSIT :}

action of, its introrluction, 118 .

implied detriment to plaintiff, 179.

AUCTION :

sale by : contract on, formation of, 1 if. depuit, recovery of, $57 s$. 
AUCTION-continued.

sale by : misdescription; general duty of vendor to give correct description, 578, 583.

mistake as to contents of lot, effect of, 506.

puffer, cmployment of, 595 .

title, effect of special conditions as to, 581 .

without reserve, 18 .

AUCTIONEER : liability of, to purehaser, 10t, $n$.

AWARD. See Aritration.

\section{BAILMENT :}

deposit of goods at railway station, $\tilde{5}$.

without reward, consideration for, 186.

\section{BANKRUPTCY :}

anomalous effects of, on contractual rights, 219.

bankrupt's right of action, assignment to creditor of, held justifiable, $357, n$.

infant, loan obtained by, unler pretence of full age, provable in, 82 .

laws, attempts to evade, 310 .

payment to trustee under mistake of law, 484, 485.

secret agreements with particular creditors voil, 298.

\section{BARRISTER :}

arbitrator, if acting as, may recover fees, 713. colonies, whether English rules apply in, 714 .

fecs of, for alvocacy, not recoverable from client, 712. for non-litigious bnsincss, qu., $7 \mathrm{I3}$.

judicial notice of counsel's fees in taxing costs, 715 .

paid by clicut to solicitor, whether recoverable by counsel, 714 .

returning officer, may recover remnneration for acting as, 713.

BATTLE: trial by, in action of debt, 136.

BENEFICE : holder of, is a corporation sole, 120.

BIL., OF EXCHANGE :

acceptance of, by agent in his own name, 10 t.

must be in writing and signed, 161.

checulue is a, 212 .

drawn in hostile country in time of war, 336 .

equitable assignment, bill is not an, $733, n$.

forged inlorsement, confers no title on bonâ ficle holdrer, 1i2. indoreer not a surely during curren'y of, 294, $n$. 
BILL OF EXCIIANGE-continued.

infant's, not roid but voilable, 62 .

negligence does not aflect title of bonâ fide holder, $4 i 2$.

seal of company, whether equivalent to signature, 135, 243.

unconditional order in writing, bill is an, 164.

wager, promissory note given for, treated as withont consideration, 314 .

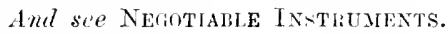

BILI, OF LADING:

intorsement of, transfer of contrant 1,y, 217, 2:2.

is not propexly negotialle, 251 .

BILL OF SALE, 172.

BOND :

condition, where impossible at time. obligation is absolute, 459,460 .

but suhsequent impossilility is a discharge, 460.

alternative conlitions, where one imposible, 461.

foreign govermment, bonds of, truatel as negotiable instruments by English law, 244.

statutes as to, $5+0, n$.

BRACTON: his theory of fundamental error, Note G., 750.

BROKERS: unlicensen, in city of Lombon, eannot recorer commission, 312 .

\section{BUJLDING SOCIETY :}

arbitration, referenee to, of dipputes with members, 349 .

infoul may be minber of, $6 i$.

but le nay not borrow money from socjety on mortgage, 67.

cannot claim and lohe land purehased witle soojety's money frie from charge for money altrancel, 69.

CANCELLATION of instruments by enuts of equity. $133 \mathrm{t}$.

CARGO: sale of, when previonsly lost, 143.

"CATCIING BARG.AINS" :

on what terms borrower relievel, bis.

rules of equity as to, $667,66 \mathrm{~s}$.

what are marlis of, 668 .

\section{CAOSA :}

"consideration" not analogous to, 1's, 1s".

in Roman law of contract, 179, 1si.

what the term covers, of 3. 


\section{CHAMPERTY :}

agreements made abroal, whether rules against rhamperty apply to, 413.

bargains to find means for litigation and share property recovered, 351.

definition of, 351 .

kinship does not justify, 362 .

lunacy, proceedings in, exceptional, 361.

purchase of sulojet-matter of litigation, not in itself mlawful, 356 .

solicitor eannot purelase subject-matter of suit from elient, 355.

statute of IIen. VIIT, against, 35s.

what amounts to, 35.2, siqq.

CHARTER. See DEED.

CHARTER-PARTY :

conditions in, $56 t, n$.

express exceptions in, t4i.

\section{CHEQUE :}

effect of crossing witl works " not negotialule," "2t5.

is a bill of exchange, 212.

\section{CIILLDTEN :}

enstody of, agreements as to, $3102,112, \$ 13$.

right of, to enforee provicions for their lenefit in settlements, $210,221$.

And see INF.n'T.

\section{CIIOSE IN ACTION :}

early anthorities on assignment of, Note F., iti.

why formerly not assigmalla, 2.2!).

\section{CIVIL DEATH :}

meaning of, $86, n$.

wife of person civilly dear ean sne alone, si.

\section{COERCION :}

contracts entred into umler, voilal,e in equity, 465.

money paid unter, recoverable, though transaction of herwise mlawful, 103.

and thongh cirrumstimees do not amount to duress, 6:38.

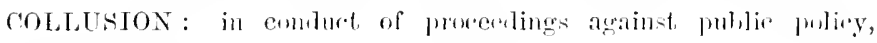
$317,412$.

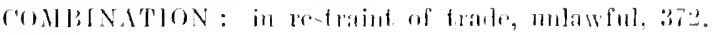


COMPANIES ACT, 1862: company under. cannot bind itself by contract for purposes foreign to the memorandum of association, 131,712 .

COMPANIES (CONSOLIDATIUN) ACT, 1908: provisions of, as to prospectuses, 587 .

\section{COMPANY :}

bills and notes may now be uniler seal of, 13.j.

Companies (Consolidation) Act, 1908...587.

contract, executed, liability of company on, 160, 161.

implied, 163.

statutory forms of, 162 .

summary of law as to, 163 .

tending to defeat purposes of incorporation, 132.

debentures, transferable, negotiable if under seal of, 135, 237, 238.

form of, 238 .

whether holder of, takes free from equiti.s, 237, 238.

directors, acts of, not invalilated by mere irregularity, 130 .

duty of, to state facts truly in prospectus, $585, s q q$.

powers of, linited by constitution of company, 129 .

and by principles of partnership, 1:s.

registration of company, how far notice

of limitation to third persons, 129.

right of dissenting shareholders to restrain acts of, 736.

statements of, when company bound by, 611.

estoppel, doctrine of, applicable to, 138 .

executed contract, right of company to sue on, though not originally bound, $160,161$.

fraud, of agent, liability for, 611.

maintenance, purchase of shares in order to sue company or directors at one's own risk, is not, 358.

majority of shareholders, powers of, 130, 131, 736, 737 .

negotiable instruments, may now be under company's seal, 13;

when company bound by, 135,137 .

ol.jeets of, as defined in memorandum of association mnit be strictly adhered to, $13 \mathrm{t}$.

partnership rules, relation of, to law of, 128, 136.

And see Corporation.

powers of, limited by special purposes of incorporation, 127, 131. promoter, duty of, to company, 586 .

promoters' agreements, when company bound by. 203.

proppertus, company"s A.t, toms, ats to, 587, 585.

duty of diredors to statu facts trujy in, iss. 
COMPANY-continued.

prospectus, statements of, ahliressed only to original sharelolders, 614.

variance between memmrandum antl. 509.

public, interest of, as investors, 133.

ratifieation of irregular transaction by assent of shareholders,

130,740 .

seal of, contracts formerly required to be wnder. 1.53.

improper use of, 138.

trading contrats, seal not necessary in, 1.st.

transferable dehentures under, negotiable, lis..

whether equivalent to signature in cate of bills and notes, 13.5, 243.

shareholders canmot sinction acts outsile scope of powers, 130, 134,736 .

dissenting, riglits of, 130, 131, 73t.

majority, powers of, 130,131 .

manimity of, when necessary, 1:30, 1:31.

shares, contract to take, not roid, lut only roidable on ground of error, $509, n$.

distinguishing numbers of, crror in, not material, 509.

repudiation of, when too late. 509. 617, n., 622, 623, 627,628 .

rescission of contract to take: misstatments in prospeetus, 509.

sale of, aroided by pedition for winding-up unknown to partics, 519 .

trinsfer of, $173,246$.

invalid, where directors' consent ubtainerl

by fraud, 597 .

statutory powers, arts in excese of, 126-12s. 131, 132.

unincorporated, power of, to sue by public oflicer, 2.21.

transfer of shares in, 216.

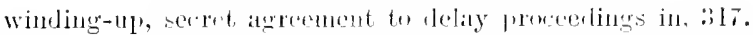

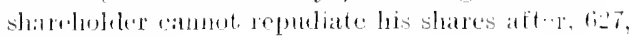

ises.

Amd ser colitoration.

CUMPENATTLON:

for misteseription on sale of lauml, nta.

purchaser can reorer alter completion, 57.,

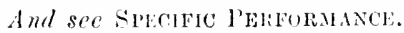

\section{COMPOSITION :}

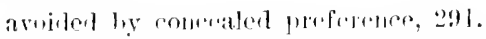

with revilure, (9)

P. 
(UMTROMISE :

consideration for, 2013.

mistake, of counsel, compromise arrangel ly. 510.

mistake or oversight as to partirular points of law, compromise cannot be set arite for 18:

of criminal proceerlings, when bawful. $345,346$.

of election petition, voir, 317 .

(UNIITIONS :

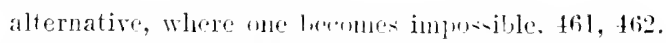

impossible combtions in bomls. treatment of. t59, t60.

wepentations anounting to. thrir nature and eflect. 5hl-5it. restraint of marriage. $360 \%$

shecial, on tieket. how far hindiug on person to whom it is issued, i1.

stranger, conditions to be performet hy. nust be performed at obligor's peril, 121. 425.

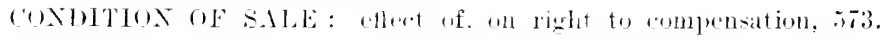

1ONFIRALATION: of infant's mariage sutlement, 61.

And see ACQuiecentr.

\section{GNFLICT OF LAWS :}

as to existence of remedy, tins. 1993.

lawfulness of agrement, $10 ., s q \%$.

dhange of law; effect of. 11\%.

domicil, efferet of law of. on vali lity uf niarriage, 30.).

foreign law. low far admi-ible to dow ide law fulness of agreement made alioul, 105.

led loci: ly what lowal law the lawfuhes of an arrecencent is detrrmined, 10.5.

marriage of drmiriled Briti-le subjects. wherever celeteated. gerement lig Enerlish law, 30.5.

repuirement of stanp. liow treated in foreign court. 339 .

\section{(ONSENT :}

Irouf of, $\pi$.

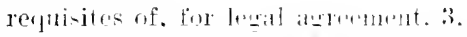

to contrat, que-tions allecting valitily of. Iha.

ways of declaring, $\therefore$.

(ONSIDERATION :

abauloument of rights as. 201.

aderuacy not material, 181. 3ir.

assumpsit, idea uf consilcration in artion of, t79.

loilment, gratuitous. andilumtion for. 1sti.

crusa, "eonsideration" not analogeus to. lis . 
CONSIDERATION-continued.

cohabitation, illicit, if future, an unlurful consirleration ; if past, no consideration, $317,318$.

contingent, doubt as to, 187.

debt, action of, consideration in, 178, 179.

deed, voluntary, no specific performance of, in equity, 20.5.

but evidenee of eonsideration may be anmited, ?of.

discharge of contraets, how fur consideration refuirew for, 2uo.

"Doctor and Student," consideration in, 180 .

equity, doetrine in, application to contracts under seal, 201, 20(15.

will not enforec incomplete gifts, 206.

evidenee, external, of, 206.

evolution of the word, 177 .

execution of informal agreement ats, 701 .

failure of, the true ground for recovering batek compulsory payments, 639 .

forbearance to sue as, 202.

must be definite and of really disputed right, : 213 .

gaming and money lent for betting, an illegal, 315.

general character of, $10,175$.

gift, imperfect, equity will not enforee, 2 m.

history of the doctrine of, $177, s q \%$.

immoral, where gift complete and irrevorable. 319, 320.

settlement on marriage with dereased wile's sisler treated as made on an, 320 .

inadequate, as evilence of fraud, $18 \mathrm{~s}$, 6i57, fins.

past, ineffeetual, 189.

promise must be definite, 193.

to perform existing duty, how far consileration, $193, s q q$.

quid pro quo, consideration analogous to. 1si.

restraint of trade, partial, musideration necessaly for atgreement in, 376 .

separation deel, consinleration for agreenent for 3228.

unlawful, makes whole agreenent roirl, 38.5, 38ti.

variation of contratet, how far consideration respired for, :old.

voluntary agrenent, no sperific performance of, 205.

even though muler seal, 200.

wager, note given for, treaterl as beilug without, 311.

\section{(1) NSTRUCTION :}

of contract, mot altered by mistalie of partins. Iiti.

peculiar rules of in equity, 2271, .3:2, stq

rules of, gincral intent provals, 266x, 273), 271 .

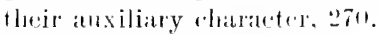

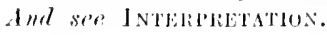


CoNTLis'T:

acceptance of, tacit, 50 .

advertisement, leral theory of contract by. 1.s.

performance of conditions of ofler made by, 15, $s q q$.

Statute of Frauls, chect of, on coutract by, 25.5 . arreenent to conmit breach of. void, 292,293 .

ambiguous, 501 .

assignment of, 228, 498.

difficulties of asimese of ordinary contract. 240.

equitable: notire to debtor, 232 .

free from eiputies. $237,238$.

subject to equitis. meaning of, 234 .

litl of la ling. intorsement of. transfers contract, $217,251,252$. capacity of parties to, Jt. sqq.

conclusion of, may be postponth until execution of formal instrument, 45 .

condition, impliel, of life and lieatth in contract for personal service, 416.

conditional on performanen heing or remaining possible,

137, sqq.

consideration for lischarge or variation of. 200. 201.

correspondence. contract by. 3., siq .

definition of, 2.8 .

dissolution of, by subseruent inuposibility. docs not affect acquired rights, t51.

carly use of word. 178.

entire of divisible. 275. 27s.

forlididen. contraet may be lut not roid. 312.

furm of, in early Engli-h law, 111.

modern prineiples, 110 .

110 srotematie rules in early law, 111.

forme special, contracts sulpect to, 152 .

general nature of. 1.

imposille in Jaw, voil, 1:31.

intention. reprewhition of, not anumenting to contract. has 110

eflect, 558 .

interpretation of, rules for. f5.

letter. contraet $1, y$, when conchulel, $35.8 \% \%$.

malum prohibitum and malum in se, הas.

marriage. agrements in restraint of. 3 hth.

mistake in, $463, \mathrm{~s} q \mathrm{q}$.

property included liy, 505.

negotialle instruments, gualit ics of. 212 .

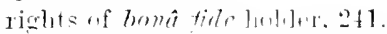

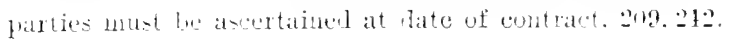




\section{CONTRACT-contimued.}

partnership, contract of, 245 .

personal, cannot be assigned, 499.

personal services, contract for, $44 i$, sqq.

persons affected by, 208, sqq.

procedure upon, in metlixval Engli-h law, 1 th.

proof, archaic modes of, 142 .

quasi-contract, distinguisher from tacit hut roal eoutract. 12.

fictitions contracts in English law. 11.

in I. C. A., how lealt with, 11.

term now generally recognizer, 14 .

record, contracts of, 152 .

restraint of trate, agreements in, 368 , syq.

lioman law, influence of, on maly English law of contract,

$142, s q q$.

satisfaction by stranger to, 199 .

shares in partnerships and unineorporated companios, transfor of, $245,246$.

special eonditions, acceptane of, when implieil, 5l, 5.2.

stamp duties on, 706 .

variation of stamperl agreement hy subernent unstamper

document, 706 .

stranger cannot sue for damage for nom-performaner, 221, $n$.

tacit, distinct from quasi-contract, 12 .

third persons, authorities in equity, 221.

cannot sue at law on contract mate for his benefit, 223 .

not bound, 209, 213.

not entitled by contract itself to drmand performance, 210,2217 .

promise to make contract with, 50.

to marry, 149.

transfer of, where duties as well as rights transforrol, 215.

unconditional, not exeniod ly performanes lwing in fart impossible, 420 .

mulawful, 287, sıq.

voidable, when, 3,9.

will, agreement to make disposition by, sos.

CONVICTs: disabilities of, as to coutracting. 100 .

COPYHOLD :

infant copylohler must pay tine, tiz. lis.

sale of, as focetholi, voinlatilie, sis.

ropvinght :

assignments of, 172.

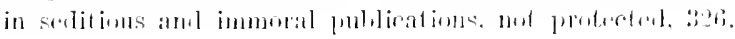




\section{CORPOR.ATION:}

appointments to othices by, must he under seal, $159,160$. agent, corporation can only act hy, l22.

this rule does int apply to deliberative acts and resolutions, 122.

corporation liable ex delicto for acts of, 124 .

artificial person. treatmunt of rorjoration as, $117,118$.

eapacity. limitation of, ly po-itive mbes, 128.

rharter, corporation ereatud hy. common law powers of, 127.

common law has no theory of, 119.

montract, executed, lialiblity of corporation on, loo, 161.

implier, $\mathbf{1 6 3 .}$

statutory forms of 162.

summary of law as to, 163.

copporation sole: Crown sail to le a, 120.

corlenstiral lemefiec. holder of. is a, 120

Poipe not a. 1:00.

rrime corporation cantot muntit, l:21.

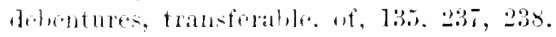

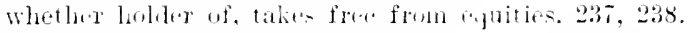

dectit, lablility of corpmation for, l:-5.

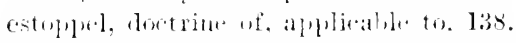

execuled contraets. risht of anpriation to sue on, thongh not

ariginally lomml, lob, 161.

form of corporate contrat., summary of law as to, lis.

frame, liability for. 121, 61\%. till.

inflictale for a nuisance, 124 .

legal corforate exi-tence, necenary marks of, 119.

libel. corpunation may sue for. 123.

malivins provecntim, corporation liable for. 123, $n$.

memlers, existing, comsepterese of the distinction of enpora-

tion from, 126.

members, unaninity of, 13 !.

money received. action for. lies against, 162.

mulieipal contracts of, 1.59.

negliguce. corporation lialle for. 123.

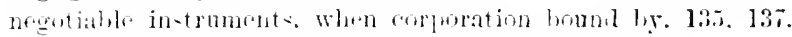
may now le moler sal, 135.

nuisane, corporation may lee indirted for. 121 .

chliver: powes of, to bini corpwition by apparently regular acts. $737,73 s$.

official sanetion matter of proculure and convenience. 119. 120. part performance, equitahle hot rine of applieatile to. 138.

fenaltios impused liy statute regulatiug pantioular lusiness. lialility for, 12t.

porsonal liabilitios comporation cannot inenr strietly. 12. 


\section{CORPORATION-continued.}

powers, limited, of statutory rorporation, 127.

must not be nsed to defeat purposes of incorporation, 131.

of, modern authorities on, Notr. D., 735 .

public, interests of, as investors, 133.

ratification of irregular transaction ly assent of all members,

$7+0$.

rogue and vagabond, corporation not pmislable as, $121, n$.

Roman law, would not allow formation of, without anthority, 120.

seal, corporate, contraets formerly lepuired to he umler, lö:. improper use of, 13ऽ.

requirment of, a mere positjo rule of English law, 121.

trading contrarts, cxerptim of, 1;,6.

transferable debentures unler, nogutiable, 1:5, 237,238 .

whether equivalent to signature in hills and notes, 135, 213.

shareholders, dissenting, rights of, to restrain acts of gorerning body, 736 .

statutory, arts of, void ontsite of statutory powers, 126-12s,

131, 132 .

trespass, liability of corporation for. l:2t.

And see Company.

\section{CORRESPONDENCE :}

authorities on, Note B., 72t.

complete ly posting acerptaner. 3i-3s.

contract by, $3 i, s q q$.

Costs :

agreement with elient as to, 716 .

fraud, unfounded rharges of, visited witls, 5s:2, 63:3, 6.31.

Solicitors' lienumeration sot as 10, 7lf.

And see solicizor.

COUNSEL, See Balimister.

COVENANT :

power, envenaut, to exereise by will, whether gooul, $36 s, n$.

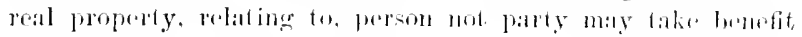
of, 22:2.

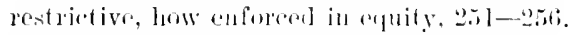

when rovenants rmu with laml, $218, s / 4$.

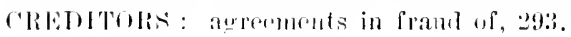


CROWX : sajel to lie a corporation sole, 120 .

CUSTOTY OF CIIICHREN : agrements as to, how far ralid, 362, $412,413$.

CUSTODY OF TNFANTS ACT, 1ST: 364.

ETSTOM :

Lombut. chstom of : as to infant apprentier, 7 .

as in married women trarling alone. s6.

mororn. may ald to tho law mohant, 211.

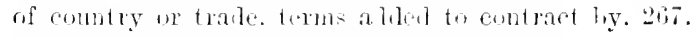

some contrats of infants binling lyy, ir.

DMMArES: distinguithel from ponalty. 5li.

JIE.ITII :

civit, sit, $n$.

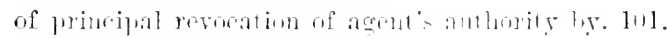

revaration of [urbaral Jy. 11.

DEBENTIRTS :

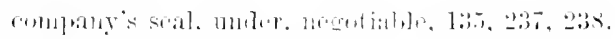

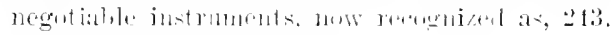

tranterable, form of, :3s.

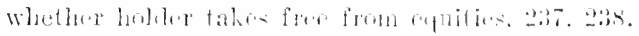

\section{IIETT :}

action of, 111. 115.

comsineration in. 17s. 179.

frial ly lattlo in. 11:.

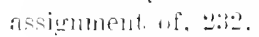

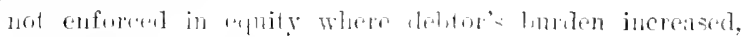
$209,230$.

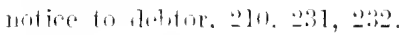

THECTT, ACTHON OF:

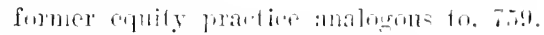

may lie against moplutation, l:5.

what is gromm for, ig:?.

DTED :

artion on, is on deal itsulf. not on promiar. 118. 111.

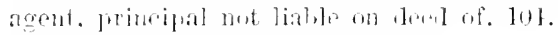

combet be writton an waml. 190.

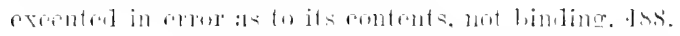

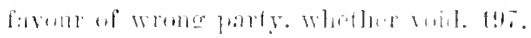




\section{DEED-continued.}

Frauds, Statute of, does not apply to, 171.

medieval, in England, of Norman origin, 143.

promises made by, peculiarity of, 7,52 .

DEPOSIT : recovery of. See MONEY PAID.

DETINUE : action of, 14 .

\section{DIRECTORS :}

how far third persons are bomm to know whother partieular acts are authorized, 737 .

of public companies, extent of their anthority presment to be known, 129.

statements of, when company bomm by, 6ill.

And see COMPANY.

\section{DISCLOSURE :}

no general positive duty of, 559 .

but duty implied in sperial cases, 559, 560 .

DISENTAIJING DEED: may be rectilied hy the Comt, s5:

DOCTOR AND STUDENT: "considertion" in, lsz.

DOMICIL: eflect of law of, on valibity of marriage, 805 .

\section{DRUNKENNESS :}

contract of drunken man voilable, not void, $97,9 s$.

effect of, on capacity of contracting, same as of insanity, 54,95 .

\section{DIRTESS :}

recovery of money pail miter compulsion, 638.

threats, whin it comsists in, the thruat most be of something molawfinl, 6:37.

what is, at common law, 633 .

EASEMENTS: new linds cannot the created, 253.

ECCISSIASTICAL LAIV: inthence of, on lewal view of morality, $316,317$.

\section{EITECTON :}

to adopt agrement voirl for mistake, 528.

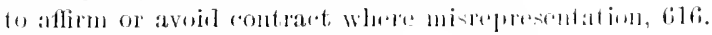

how elaet ion shown, tili.

to a woil contract male in infancy, b2. tia.

16 whroe principal or agent, los.

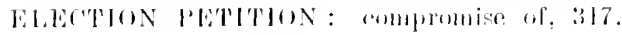


"ENGighatent." See Sepirate Estite.

\section{EQUITY :}

acquiescence, estoplel by, 698, 699 .

loss of remedies by, 630 .

agent's contract, undiselosed principal must take subject to equities, 107.

assigument of contrat in. 209. s\%y.

assignee may sue, 2.29 .

takes subject to equities, 231 .

unless rule excludel hy speeial agreement, 236,237 .

assignment which increases itebtor's burlen not enforeed, $2: 29,230$.

notice to debtor reypired. 2931. 23:2.

anetion, sales by, former differemee lwetween law and equity,

$595,596$.

award, whether stranger bound ly. 2015.

cancellation of instruments. juristietion of equity as to. 634 .

"atelhing tartains," gules as to, titit, this.

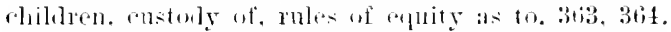

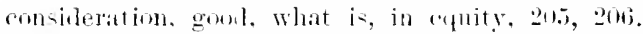

enpyriglat, of seditions or inmoral pullirations. equity will not

protect. 326 .

covenants rmung with land, doctrine of eyuity as to, 2it.

deceit, suits andogruls to antions of, in equity, $594, n$.

doctrine of, as to mnlawhul agrements where parties not in pari delicto, 103.

"equality" lwetween contracting partins. 659, 6 tio.

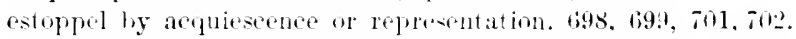
evidence, parol, equity leses not admit on questions of construction, 261 .

expectant heir's, special protection of. 663.

frand, contrarts voilable on gromd of, $465.5 \%$.

grifts, imperfect, treatment of, in equity. enti.

infant: liability ju equity on false representation of full age,

79.

marriage settlement treatment of, 61 .

infant's contract, no speeitie perfurmaner of, $16.2,65$.

lunatie, erpity adopts rule of law as to arts of. $97, n$.

"making representations goml." suppowel former loctrine of, 558.

mistake, payment made ly. recorery hack, agreament with law, 48.

pmrehise of party's own property ty, ize.

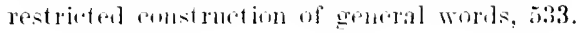




\section{ININEX.}

\section{EQUITY-continued.}

negotiable instrmments, equity agrees with common law as to, 242.

equity restrains negotiation in eases of frand, 24:.

obligations, equitable, treatuent of, at common law, 720. part performance in equity, 697 .

penalties, relief against in, 539 .

purelase for value without notier, rule of equity as to, tro471.

equity will not deprive pmrehaser of anything he has already got, $172, n$.

reetification of instrmments in. 543, s/q.

representation, estoppel hy. $701,702$.

sales of land, where parecls incluled by mistake, decisons in equity, 505.

speeific performance and eompensation on sales of lame, $572, s q q$.

refusal of, on gromul of undervalue. fitil.

surety, agrement betwere law and refuity as to combitor's duty

to, 570 .

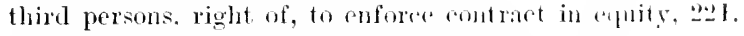

time, when of essenee of contract in, 536 .

undue influence, eifuitable doctrine of, tito. sitq.

voluntary covenants, treatment of. in, 205.

settlements generally, bts, bti.

how set aside, bti-bit.

ESCROW : writing teliveret as, $20 i_{2}^{2}, 263$.

\section{ESTOPPEL :}

acquiescence, estopped by, $698,699$.

agent, one party arting as, to otlue party in preparing instrument concerning botl, s/8.

corporations homd hy, 138.

misrepresentation, estopmel of party who has indmend fumblamental error by, 526.

negligenee, estoppel by, whether applieable to derels, lan, $n$. of holder of instrument dealing with it as metrotiable, ylt.

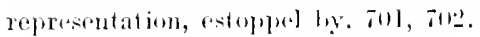

statemonts binding ley way of, jojli.

\section{EVII)ENCE:}

extrinsir. abways atmissiblo to show ildegality of agroment, :393.

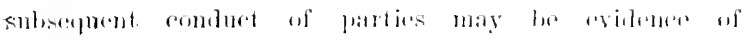
original mulawfol iutution. :391. 
EVIDEXCE-continued.

extrinsie, always admissible-continued.

to explain particular terms in agreement, 261 .

of document being agreement or not, admissible. 262.

parol, not almitted to vary witten eontract, 260 .

of oral variation, admitted as defence to specific performance of witten agreement, $5+1$.

l.nt not to ohtain performance of agreement as raried, $5+1$.

inalmissile to roctify instrmment where there is prerions agreement in writing. 544.

lut arimisible, if uncontralicted, where no written agrement, 5.5.

\section{EXECTTORS :}

lialility and right of. enencally. on contracts of testator, $213, n ., 228, n$.

persinal serviee. contrats of. "xecutors eannot sue and be shed $o n, 211,436,4 t s$.

or on contract to marry. $1511, n$.

EXPETTANCY : salo of : not mlawful, 360.

EXIECTANT IIEIJis : protertion of, by omts of conity. 6e3.

FAMTLY ARRIXGEMEXTS : exoptional tratment of. 65l. 652.

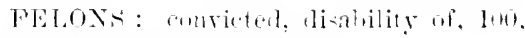

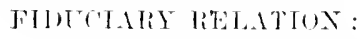

between contlacting parties, etfort of bit.

instances of, its-tijl.

Ald see LNTLE TNTLENe.

FORBE.LRANIE TO STl: a ansibration for promise, 202.

FoliETIIN LAW :

agrements lawful lig. hut not hy law of formm, treatment of, 405.

sulsequent poubition by foreign law: performanee decmed impossible, tit.

but contract rentreel imposilile of performance lyy. not hischargel, t:31.

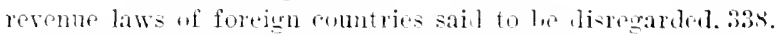

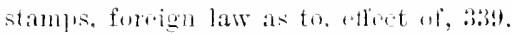

molne inthenes: French law ut captution. Note K., 759.

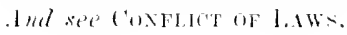


FURFLITURE : relief against, in cquity, 538, 539.

\section{FORMAL CONTRAC'IS :}

cases where form specially required, 11s, st\%.

charter, English medieval, of Norman urigin, 113.

contracts of record, 152 .

importance of, in ancient law, 111.

modern requirements of form, 151.

Roman law, position of, in, $112,143$.

transition from formal to informal prowe in linglish law, 11 .

And sec Contorations; Frauds (Statere of).

\section{FRALD AND MLREPRESENLATUN:}

acyuiescence, passive, in sclf-deception of other pally is not fraud, 515.

agent, lability of corporation for fraud of. 121, till, (ill.

auction, sales by, special doctrine as to, 595.

company, contract to take shoues in; misstatements in prospectus, $3 \times 5-58 i$.

provisions of the Companies Act. $1908 \ldots 587$

concealment, fraululent, whit is, 592.

consideration, inadequate, as evidence of fraud, $188,657,65$. "constructive fratud." what is. 5.5.

contract incidental to a fraul is itself fraududent. int.

corporation, liability for fraul of agent, fis), fill.

costs, unfounded charges of fratul visited with, 552, 6933, 631.

creditors, framl on, in compositions. 2!93.

error, fundamental, prolued by misepresentation. allect of:

$512, s q \%$.

estoppel, relation of fratud te. niti.

false representation: when an andinathe wrong. nis.

falsedrod, when sileme expivilent to, 592, 595.

fanily settements, misrepresentation in. ist.

generally. 5.51, sty.

sifte, winutary, ist.

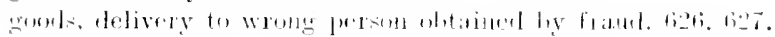

insmane, special rules ats to miscepresentation in contrato

of, 561, s.t.

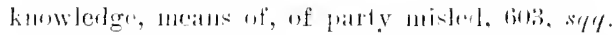

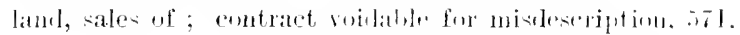

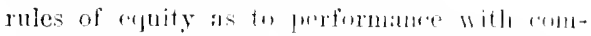
jensation, 57:2.

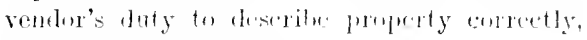
i) 78 .

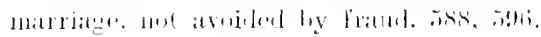


FRIUD AND MISREPRSENTATION-continned.

misceresentation. non-fraudulent. when affecting validity of contract, 55f. 559 .

hew fraud distinguished from, 590 .

mistake distinguisher from frand, 464.465.

negrigent ignorane. expivalent to fraul. 591.

non-direlosme, mispepresentation distinguished from, 59.

lartnership, contract of, misepresentation in negotiation of. 58t. 585.

reckless assertions. 594 .

representation. fraululout. What is. 593.

rights of party misled. 6is.

settlements in fraud of marital right. 313.

silence, when equivalent to falsehoml. 593, 595.

suretyship: miscrepesentation aroid contract. 5it.

third person. consent of, olitained hy freud. 59 .

fraul on. maker agreine 11 roid. $292,296$.

warranty, relation of fratul to. in.

And gee Revising.

FUALIS, FTATITE OF :

as to agreements not to he perfonmen within a gear. 1his, 692. contracts hy adrertiement not exempt from. 2.).

deris, whether statute applicalle to. 171.

effect of. whore writing thes not represent the real agreement, jt: its.

exwentor. spetial pronis by lit.

guaranties, 16.s.

informal agrements within $\therefore$. 1. elfect of. tiat. sy\%. not voils, fig:?

lante interents in, contlants als to, 167 .

leares. 16it.

marriage. atrement- in con-ileration of, lin.

note or mellniantum. Iha.

edfect of note signed hy one larty only. lit.

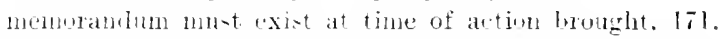

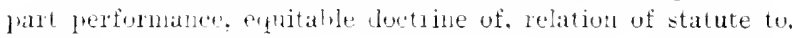
(6.5.).

sale of garnts. 169.

settlement. ante-nuptial agreculent for. confirued by postnut, ial writing. 699.

tru-t, assignment of, 230 .

FRACDELEXT PREFEREXCE : aglenents with fartientar creditors ly way of. $293-295$.

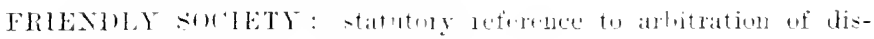
lutes with members. 319. 


\section{GAMING :}

securities for money won at, 315.

treatment of ganing debts contracted abroal and not unlawful by local law, $110-112$.

And see Wages.

GAVELKIND : eonveyance by infant tenant in, 77.

GENERAL WORDS : restrained ly context or by intention appearing from external evitlence, 533.

GERMANIC LAW: prouf in, 112.

\section{GIFT :}

aceeptince of, as loan, effect of, 191.

from elient to solicitor. how far valid, 619, 680.

imperfeet, not aided in eruity, ?o6.

And see lNoue INFlence.

GOODS :

contract cannot run with, 217 .

delivery of order for may he assignable lree from eptuities, but camnot lie negotiable, $243, n$.

to wrong person by mistake or frand does not pass property, 626, 627 .

And see SALE OF GoODS.

\section{GUARANTY :}

voilable for misrepresentation or dissimulation to surety, ifi, 568 .

within Statute of Frauds, 165.

IIORSES: sale of, in market overt, 172, 173.

IIUSBAND AND WIFE: doetrine of mulue influence does nut apply t1, 613.

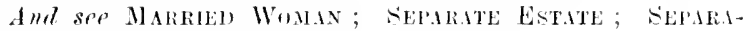
THON DEED ; C'USTUDY OF C'HILUREN.

\section{MINORINCLE:}

does not in general exclude envil lialdility, 167, lois.

of law, may he material as exchuling specilie unlawful intention, 396, 115.

thut is generally no defene to action in contract. 179.

reckless or negligent, carries respmeililities of knowledere, 59t. where it is a comdition of atequiring rights, 170 .

Sere also Mlstaki. 
IGXORATA II lits : meaning of, explained by Lord Westbury, 523 .

\section{IMAORA, AGREEMENTS:}

agreencut inmmal iur grotim caunot be justified by any Iocal law, 107.

roid: what are such. and what is immoral consideration. 315. 317.

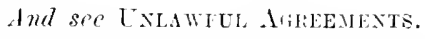

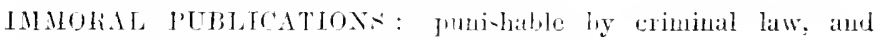
therefore no gromed of civil rirghts, 320 .

\section{IALOSSHBLE ARREEMENTS :}

accidents not contemplaterl hy contrat, exception of, 13., sy\%. suberuent to contract. affect of : analogy of contract

to bay rent, where premises destroyed by fire, 132. abretment imponile in itself voit. 420.

$$
\text { law roid. 42.5. }
$$

lout imposihility ly law exeuses promisor. 42 ti. impresibility at late of. from state of things not contemplated by parties, 42 .

in fart: no exruse in alısolute con†ract. 428 .

alternative combitions in honds. where one impossible, thi.

contrats, where one thing in or becomes impussible.

455.

bourl, where condition inmoilhte. Whigation is alsolute, fise. 460 .

otherwise where conditim sulwajunty beromes inpossible, 460.

cargo lost at date of contract. sile of. 113.

commerejal contracts. expese exerptions in. 14.

contitional contrants whe the cundition is or becones impossible, $45 n, 157$.

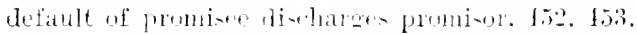

promisur. impere ihility hy. chuivalent to breath of contlart. 15:2.

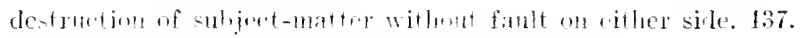

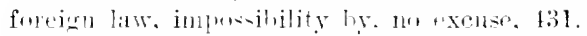

Indian Contract fet on impsible agrements. Ho.

law a: to. general statement of. 119,400 .

marriage, contract of, annmatoms treatment of, 449 .

mining leases. covenants iu. cmotruction of, 44 .

perfomance repenting wn wistene of sperific thing. 437 .

life or heath of promisor: implier] enmition that life or health slall continue. 146. 


\section{IMPOSSIBLE AGREEMEN'S'-continued.}

performance, means of, promisor not having, is not impossibility, 422 .

"practical impossibility" not equivalent to actual impossibility, 422.

relative impossibility, 424 .

repugnant promises, 423.

warranty of contingent acts or crints. 12t.

\section{INDIAN CONTRACT ACT :}

acceptance must be unqualified unler, 42.

performance of condition as, 15.

agent, knowledge of, as knowledge of primipal, 112, 11 .

consideration, iualequacy of, 660 .

discharge of contracts, $200, n$.

impossible agrcements, 462.

insanity as ground for revocation umltr, t2.

penalty and liquilated damages, distindim letween, abolishol by, $540, n$.

quasi-contracts dealt with separately in, 11 .

restraint of trade, 383 .

sales by auction, employment of putfir at. iati.

time, when of essence of contract, 5:37.

wagers void under, 329, $n$.

\section{INFANT :}

account stated, liability on, 62.

age, representation as $t o, 79,81,82$.

apprenticeslip, contract of, 69,77 .

by enstom of Tondon, $7 z$.

lankrupt, infant cannot be make in absence of ficles reprosentation as to age, 82 .

bulding society, infant may he memler of, 67.

but may not borrow money from socicty on mortgage, 6 .

cannot elaim to hold lanel purchased with roridy's muny

free from charge for money alvancel, 6\%.

contract, avoidance of, time for, 62 .

beneficial, 69 .

generally cannot bind himself hy, 56.

implied in law, 79 .

of service, $58,69,70,77$.

of, voidable at conmm law : no anthority for holdin!"

it in any case voill, 5s.

custody or chlncation of, agrements lutwern parmits as to, 315.

ruthm, what contr:tuta infint and matle ley. ir. 
TNFANT-contimued.

equity, liatle in, for representing himself as of full age, $\mathbf{7 9}$.

l,ut not to rrejudice of sulisequent ralid contract, 82 .

false reprenentations, liability for. $57,79,82$.

larceny by as bailee. 66.

leas's ly, good if beneficial. 5!.

granted molir statute. $7 \pi$.

10. voiliatste. (i!).

Joans to, $5 \mathrm{i}$.

marriage of, 61 .

settlements, til, 7it. 7i.

mistake. common, aroiling agrement, j1s, s19.

money latil umber awilded contract, recorery of, ti3.

beresaries, lial,ility for, $5 i$. 71 .

lialility in simple contract only, 76.

dewl given to secure reprayment of money advanced for, 7 ti, 7 .

negotialue iu-trument given for. 36.

what are. 72.75.

negotialle instrunents, 1:- iti.

jartnership, 60.

Jmmise to mary. 61.

Joperty, obligations incilint to. liability on. 6i.

sale of grools to. $\pi$.

or jurrehase of land. til. 7 .

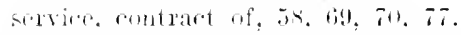

shatehohler, liahility for ealls on shares, bit, 68.

sperithe jerformanee, infant ranmet hawe, 62, 65.

statute. What contracts infant = can make ly, 7 .

tranling contrate, 5s.

wong. liahility for, when combertur with contrart. is.

TNFANT' RELILF ACT. 1ST :

effect of section 1...tits.

since the Act. of afhming agroment roibate at common law. ilit.

makes certain agreements of infants roill 63.

exception of eontracts for necessaries, bi.

ratilication not wholly inoperative mule $1,63$.

TXSAXITY. See Lusate.

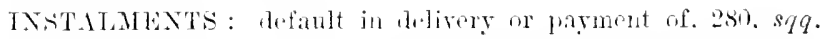

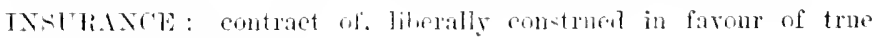
intention, sts. 
INSURANCE (FIRE) :

contract of iusurers to reiustate is unconditional after election made, 429.

effect of, as between landlord and tenant, 432 .

implies condition that property is correctly deseribed, 566, 567.

\section{INSURANCE (LIFL) :}

duty of diselosure by assured, 56:5.

recovery of premiums where policy voil for want of insurable interest, 398 .

INSURANCE (MARINE) :

Marine Insurance Act, $1906 \ldots 173$.

misrepresentation or non-disclosure, material, renters policy voidable, 561 .

policy, common form, result of stries of decisions and of long recognized customs, 272 .

delivery of, by underwiters, 705.

insuranee must be expresied in, 173.

stanped, lequired ly statute, 702, 703.

seamen's wages not insurable at common law, 365.

"slip" recognized for collateral purposes, 70:3, 701.

rights of parties determined at date of. 701, 70).

voyage illegal to knowledge of owner: insurane voill, :389.

\section{INTERPRETATION :}

ambiguous terms construed hy conduct of parties, 477 .

general intention prevails over particular terms, $26 x, 273$.

mutual promises: interpretation as regards order of proformance, 275,276 .

necessity of, 257 .

of contracts, rules for, t5.

promise in general, 258.

terms nsed in special sense, 261.

\section{KNOWLEDGE :}

how far material on question of unlawfulness of agreement, 436 .

means of, as affecting right to restind contrart for misepresentation, 6003.

I.AND :

Frands, Statute of, as to sale of interest in, 167.

what povenants ran with, 2ls, sqy.

And serestat: ar Lats. 
L.ANDLORD AND TENANT :

covenant: 10 action on. Whre premises leased for unlawful purpose, 368.

covenants rmming with tomany on reversion, $248,249$.

fire, premises destroyed by, 132 .

Frauds, Statute of, as to lease, 167, J68.

infant, lease of, at common law, voidable, 59.

statutory powers to make and renew leases, 77.

lease for lives, effect of contraet for sale of. 524 .

Frands. Statute of, as to. J6i, 168.

of premises for unlawful purpose, no action on covenants, 388 .

lessor not bound to inform of state of premises. 583 .

possession. whether lessur can resume on discovering unlawfui purpose of lissee. 389.

he may rescind contract whre poscosion has not been delivered, semble, 3ss.

rent payable tlongh purmizes areilentally destroped. 432.

reacision of contract for latio whe possession not actually delivered, $3 \triangleleft 9$.

\section{LAII MEILCILAN :}

not. invarialile, $2 \$ 3$.

peculiarities of, as 10 newoliahle in-trmmente, 241 .

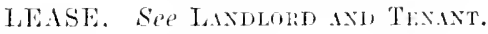

IALSEIOLDS :

non-disclosure of restrictire covenants on sales of, 571.

sale of as freeluhl, voilable. $5 \pi$.

I.FTTER: contract by: :3i, syq.

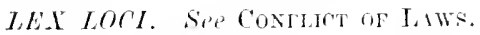

IICENSED PREMISES: effect of muision to paint seller's name on, 312 .

I.ICWNSING LCTS: attempts to cram. 311.

IIMITATION, STATUTES OF :

acknowletgment of harred letets, 19n. 6so.

operates as new promise muler statute of James I., 68ti.

otherwise if specialty delet moler statute of Will. IY.. $68 \mathrm{si}$, tss.

revises right of actien, list.

applind accosting to le rori wot lew contractus, 688 . 
LIMITATION, STATUTES OF-contimu'd.

debts not extinguished, 684 .

executor may pay barred debt of testator, 68.5.

married woman, promise or aknowlelgment by. cannot revive barred debt, 85 .

statute applies to claims against separate sitale. $7: 31$.

payment by debtor without particular directions: anpropliation te satisfy barred debt, 68.5.

Real Property Limitation Let bars right as well ats remedy, 688.

set-ofl, barred debt cannot le, 685.

but statute must be plearled in reply to defenes of, $686, n$. specialty debt, acknowledgnumi ot, muter : \& I Will. IV. must be founded on original ohligation alone, fise.

LIQUDDATED DAMAGES: distinguished from penally, „In.

\section{LONDON :}

custom of, as to infant apprentice, 77 .

as to married women trading alone. 86.

\section{LUNATIC :}

chanperty, rules as to, procedings in lunacy nut within, 3til. contracts in lucid intervals goul. 95.

of, in general voilalke, not vill, $97-99$.

knowledge of other party to contriwet.97.

prior to lunacy, 97.

delusions, partial, compatible with calpalcity for contrating, 99. equity, adopts rule of law as to acts of, $97, n$. marriage of, void, 95 .

necessaries, liability for, 96 .

partner: ground for dissolution 111 ly. $: 99$. revocation of contract by insinity, 12 .

\section{MAITENANGE :}

definition of, 351.

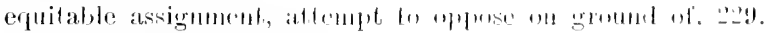
includes ehamperty, 35.9 .

kinship or affinity will justify, $3+2.2$.

shares, purchase of, in oribr to sur rompluy at me's own risk is not, 3.28 .

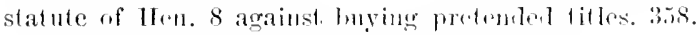

what dealings are within the stathte, 359.

mutawful intention essintial lo, :3til.

what anounts to, 3.53. 35i, 36it. 
MAJORITY : abuse of corporate powers by, 737.

WALUM PROHIBITE, $V$ and malum in se, 307, 326.

MARITAL RIGHT: settlements in fraud of, 303.

MARliET: market overt, sale of horses in, 172, 173.

\section{MARRTAGE :}

agrements in convideration of, 16, .2.21.

conditions in restraint of, 367,368 .

contract to marry not uberrime fidei, iss.

to procure for reward void, 3 hit.

domicil. effect of law of. on validity of, 30.5 .

fraul, marriage not avoiled by, osk, 596.

illness unfitting for, does not avoil contract to marry, 149 .

infants, of, 61 .

promise of marriage. infant may sue but is not lialble on, 61 .

informal agreements in moniteration of. how far made ralid l.y post-nuptial settlement. 699.

invalid by law of party's domicil. Whether valid in England. 30.

Junatics, marriage of, voill. 95.

polygamous, not recontized by English lliveree Court, 107. tos. frohibited degrees. matriage within. voinl. 301.

pronise to mary, whother resinded ly illnes untitting party for marriage. 4.19 .

l,y married man. after wife's deatl. void, if fact known to fronisee, 305 .

restraint of, agreements in. 3 tit.

conditions in. 367. 36s.

Roval Marriage Aet. 305. $n$.

settlencent in framk of marital right. $3 \circ 3$.

not affected ly wifes non-disclosure of previous misconrluct, iss.

post-nuptial, 699 .

\section{MAlilen) IIUMAN :}

chore in action, arofuicition of. 81 .

contract ly, roile at commen law, s.

debt. larred. remewed promior by marred woman cannot rerive. 8.5 .

debti. ante-nuptial, husband's liahlility for, 95.

equital,le enforement of contracts in cases not within Act. 94. estoplel. interests of marriel women may be bomm $\mathrm{by}, 7 \mathrm{TH}$. 
MARRELD WUMAN-rontinued. ineapacity, exceptions to : contracts with husbancl as to separaltion, 87 .

Quern fonsule 8is.

trader, custom of 1 inmlon, sit. effect of let of 18s: thereon, $87, n$.

wife of alion mot reitent in Luited

Kingtom. 86. person civilly deal, 85.

statutory execplions. sis. sefq.

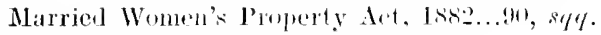

restraint on anticipation, !13. 91.

separate estate, equitatsle doctrine of, s!\%.

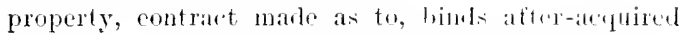
property, 92.

is liable for ante-nuptial debts. !?.

married woman may contrast and he nade bankrupt in respert of, 91.

what is, by let of 1sis...90.

settlement of, in frant of marital right, 303.

And see separate Estate.

\section{MASTER AND SERVANT:}

exclusive service, eontract for, nut he mutual. 383 .

iufant's contract of service, is, 69, 7 .

life, eontract to serve fur, gook. if mutual, 38.3.

wrongful dismissal of servant diwharges both strvice and restrictive agreement against futnre competition, 278 .

\section{MIXIMS :}

expressio unins est, exelu-io alterius, .i3:.

ignorantia iuris haud expusat, 523.

in pari delicto potior est condirio defendentis. 397 .

loeus regit aetun, 114.

non videntur qui criant consentire, Hofi.

nulla voluntas creantis est, 172 .

ut res magris valuat quam pereat. 111.

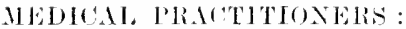

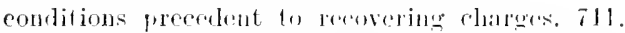

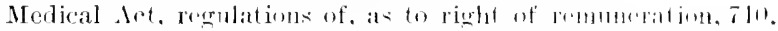
presumption of influchere in gifts, de. from pattintes, fisl.

MHNEs: enstruction of murualitiod covenatuts to work, 111.

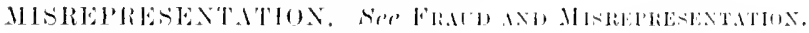




\section{MISTLE:}

ambignous terms of coutract. 507 .

assignment of econtrats, mistak" ats atfecting, 199-501.

hankruptey, money paid to tru-tee in. replayment of. 181. 18.

luyer. error of, not induced by seller. inoperative, 515.

compromise of action arranged hy. 510 .

disputed rights, 182.

andition of title, whon: purehate for value without notice, 170.

muent order, mistake in, jo.3.

true, mistake in expersing. 17s, 529 , sq4.

mistake as exilubling. fisti.

constraction. mistake in, hy farties, deres not alter eontract, 17 it.

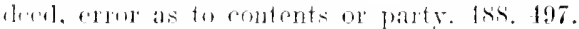

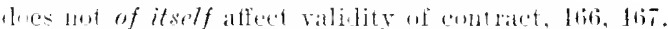

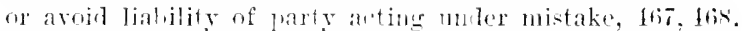

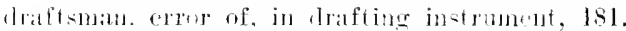

alection, to alopt voil agreenimt. izs.

cror as to existence of subject-matter, 518.

nature of transaction. Ass.

its legal cliaractir. 491

gerson of other party. 195.

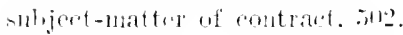

funlamental, 188.

Bratelons treatment of Note ti.. Fin.

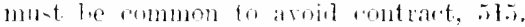

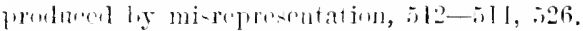

exiting rights, mistahe bles mot as a rule alter. 171.

firct, mistake of, t79.

infeiture indured ly. 178 .

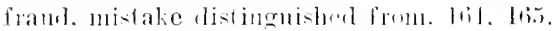

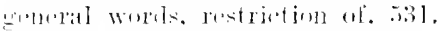

ctmuls, mistelivery of, tit.

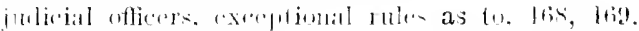

kind, crorer a to, sio.

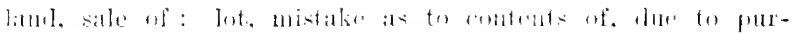
rhaser"s want of attention to partionlars and plan, int.

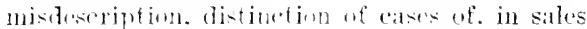
of land. 517 .

parels inclutenl ly mistake, ins.

latw, mistake of lig.

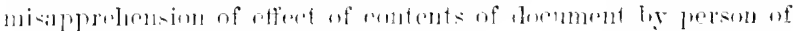
ordinary competence not suflicient to alvoid instrunent. 1!!2. 
MISTAKL-continued.

misrepresentation, fundanmial eror proluced by, 513, 511, 526.

money pairl hy, recovery bick of, 183.

obvious, correetion of, by ordinary construetion, 269.

payment to wrong person, 17 .

under mistake of fact, 178.

person of other party, error as 10, 195.

price, error as to, 511.

purehase of property really une's own, rizl, siz.

quantity, error as to, 511.

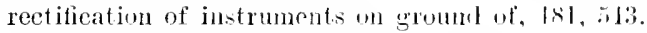

And sec Rectification.

remedies, of party to voil agreement, 527.

rights. renunciation of, $478,481,4 \$ 2$.

settlements, rectification of mistakes in, ila.

shares, purchase of, through fratulutent miscepesentation at to identity of company, $497, n$.

error as to nature and ohjects of company, sol?.

specitic performance, mistake in expression of contract a bar to, 511 .

wills, mistake in, $\tilde{5})_{2}$, , 7.I.

MONEY-LENDERS AC:T, 1900...673.

grounds of relief against contlated with registered moneylender, 673.

unregistered money-lenter cammot recover, 673.

\section{MONEY PAID :}

bankruptey, money paid to trutere in, unker mistalse of law $481,485$.

compulsion, money pait umler, recoserahlo, fiss.

deposit, monry pait as, on purehase of hant, when recorerable. 578,621 .

infant, money pait by, unler voilahle contrate 633.

informal atreenent within sest. I of statute of fiatus, money paid unter, not recoverable. 691.

lease, premium paicl for, when recolerathe ly lesisen, 62.5.

mistake, money paid by, when rexorerable bitek, 483.

promiums on life puliey, renorery where insurane soil for want of interest, 398.

Tippling Act, money foid for lobts within, nut recuverable, 717.

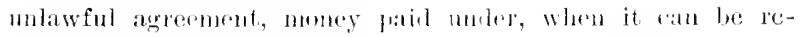
coverol brak, $29 \pi$, syg.

weng person. payment t1, 17 i. 
MONEY RECELED: action for. lies arainst corporation, 162.

\section{MURTGilit:}

the court will treat nominal sale as. if such is true intention, 539 .

treatment of, in eifuity, $538,539$.

\section{NECESSARIES :}

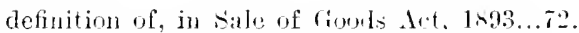

infunt, applarent means of buyer not material, $i t$.

liability for. 7 , s sqq.

is on simple contract only; 76.

supply from other sourese 73.

what are, continul to goorls, is, if.

question of mixed fact and law, i2.

Iunatic, lialility for, 9 s. $^{\circ}$

NEGLTGENCE:

agent must not profit ly his own, 3ir.

of, corporation answerable for as well as natural person. 123.

estoppel by, extent of, $191, n$.

misrepresentation, negligence des not exelule right to resciud for. 593 .

\section{NEGOTIABEL INSTRCMENT :}

agent. aceeptance ly: principal bunnd thugh not in principal's name, I0t.

bonk, foreign govermment, treated as negotiable by English law, 244 .

corporation. when houml by. 135, 13i.

debentures are. 243.

estoppul. negotiahility ly. 214.

how instruments enase to he negntiable. 214. 2t.5.

indorement, forger, holdre enmot make title through, tia.

in errer as to nature of instrunent not binding: $189-491$.

infintst. willillic, iiz.

met lie in writing. 163. 161.

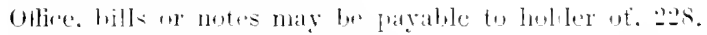

peculiar qualitirs of, 2 t1.

promisory note given for watre treated as without consileration, 314 .

serip, foreign gosermment. i*suml in Englant, i.s. ㄴtt.

seal of corporation. whether equivalent to sirnature. 135, 243. what can he a mittul as, 243 .

ind ser BHLL of Exisiste. 


\section{NO'TICE :}

assignee of marred wonan's repalate property with, hound by engagenent affecting it, 732 .

assignment of contrict, notier to dehtor, 210, 231, 232.

purchase for value without, 25, 256. 170.

\section{NOYATION :}

assent to, not presimed mless there be distinet repuest by debtor, 2 Iti.

its nature explatined, 20\%.

VUDUM PACTUM :

ehange in the neaning of the term in Englisls use, its.

in "Doctor and student," 180.

\section{UFFENCE :}

agreement to commit, sojil, 290 .

compounding of, $3+1-3+t$.

ofFER. See Proposal.

\section{OFFICE :}

appointments to. lyy corporation must be mider seal, 159. bills or notes may he payable to holder of, 228. public, sale of, unlawful, 313 .

\section{PAR DELICTUM :}

doetrine of, 397 .

qualifications of and exceptions to it, $397-399,103$.

PARCELS: mistake as to, in sales of lant, 50.5.

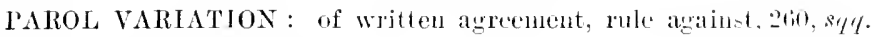

\section{PART PERFORMANCE :}

applicable to corporations, 138.

equitable doctrine of, 697 .

\section{PARTIES :}

to action, on contract marte by atgent. Hor, sty.

to contract, rules ats to, 2018, stry.

\section{PARTNERSIII :}

company law, rules of, analugous to law of, les.

contract of sharcholders a molitied contrant of, 128.

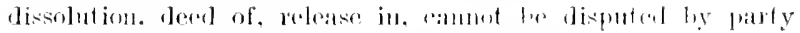
after concern completely wotmel we. tizl. 
PARTNERSIIP-continued.

infant partuer, position of, 60.

insanity of partner, 99.

misrepresentation in negotiation of. $281,58.5$.

shares in, transferable at conmon law, 215.

P'A MENT :

bankrupteg payment to trustee unter mistake of law, 181, 18.5. to wrong persoll, 17 .

umler mistake of fiut, 178. 1s3.

or law, 183, 181 .

PLNALIY :

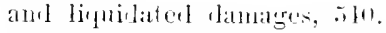

imporitim of, hy statute. inplise pohibition, 318.

relief in equity agams. 335 .

IENBION : assigument of. 311 .

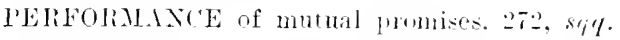

LERSONAL (ONTRACTS :

implied comlition in. ats to life or health of party continuing. 416 .

not assignable, 199. inn.

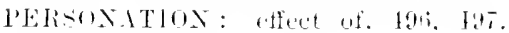

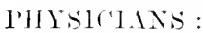

rights of. as to payment for sorried at common law, 710. unler Medical Act, iI!.

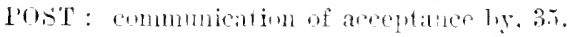

POST OFFlle: whenher ammon atent of parties in correspendenee by letter. 3x. 175.

l'HA'L: : errur as to, ill.

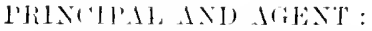

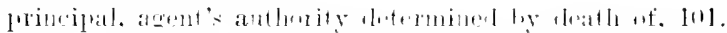

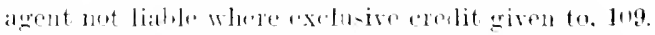
liatrility on contlatets nale by agent. 106, sqr. representations of agent. when an-werable for, 609 . right to contermanl unexecute 1 at hority. fol. undiselosed, rights of. $10 \pi$.

profeswel ageut: when he may leclare himself as real principal, 115.

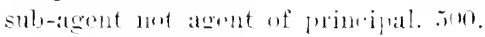

And ses AlEvit. 
PRINCIPAL AND SURETY. See SUIETS.

PROHIBITION : implied, where penalty impused by statute, 308.

\section{PROMISE :}

as consideration, 176 .

by advertisement, nature and limits of, 15 .

by deed, binding without arceptance in English law. $\pi$.

definition of, 2,7 .

effect and interpretation of, $25 \pi$, sty.

express, tacit, implied, 11.

founded on moral dnty, not binuling witlonut valunble ronsideration, 189 .

illusory, 48.

inferred in fact or implied by law, 12.

must be eertain, 193 .

mutual, 191.

past serviees renderen on request, promise to pay for. 189.

tacit and fictitions, distinction letwen, 12.

to perform existing duty, 193, sqq.

several, whether one can sue on, 22ti.

See Acceptance; Agremment.

\section{PROMISES :}

dependent and indejrendent, 27.

in same instrument, where some lawful and some not, 3st, 35. mutual, order of proformance. $272,273$.

PROMISSORY NOTE. See Bilm of Eximuras; Negotinte ThSTRUMENT.

\section{PROMOTERS :}

agreements of, when linding on company, 211 .

fidueiary position of, as regntels empany, 5sti, 611, $n$.

speeial responsibility of, mur Companios Are, $1906 . .585$.

statements of, may become statments of rompany. fill.

\section{PROOF :}

archaic modes of, 112 .

transition from formal to informal moles in Engliali law, 111. writing, proof by, origin of, $112,113$.

\section{PROPOSAL :}

anceptance will not relate luack to date of. 11.

alliessed to all to whon it eumes, li.

comditions of, as to time, \&r., 29.

express or tacil, 11.

generally wement of eontract, 1 , 5. 


\section{PROPOSAL-continued.}

revocation of, ly death of proposer before acceptance (under

I.C... only if known to other party). $41,42$. must be eommunieated, 30 .

wheu it may be made, 27 .

PROSECLTION: agreements to stifle, 344.

PIITLC UFFICE. See OFFICE.

I'LALIC POLLCY :

agreements contrary to. $32 \overline{2}, s \%$.

aiding lostilities against friemlly nations. 836 .

arbitration, agreements for reference to, $31 \mathrm{~s}$.

company : corporate powers must not be used to lefeat purposes of incorporation, I31.

compounding offences, $3 t t, s q 4$.

corrupt or inproper influence, agreements for, 339.

custody of chilhen, agreenents as to, 362.

Egerton r. Eurl Brounlou, opinions in and etfect of, $33 \%$. syq. election petition, compromise of, 347 .

foreign levenne laws as to, 33i-339.

indivilual action, agreements limiting freedom of. 36.5.

maintenance and champerty. 350, $36 \mathrm{I}$.

marriage, agreenents in restraint of, 360 .

promise by married man to marry another woman after wife's death. void, if fact known to promisee, 305.

salaries, assigmment of, 343,34 .

sale of oflices, 343 .

State, agrements against interests of, vold, 333.

and where sued upen, camot be supurted hy any local law, $405-40 s$.

"stilliug prosecution," 3 tt.

testatur, agreements to influence. 368 .

trale, restraint of (which see), 3ts', sty.

trating with enemies, 333 .

wagers, doctrine extended in order to disconrage, 32s.

winding-up, secret agreenent as to comluet of, $3 \pm 7$.

PUBLICATIONS: immoral, de., cannot he ground of civil rights, 326.

PLBLISIIER : contract of, with author, not assignable, 50I.

\section{QUASI-CONTRACT:}

distinguished from tacit hut real contract, 12.

fetitions contract in Engli-h law, 13, I1.

in Indian cuntract Aet, dealt with separately. 14.

term now generally renguized, 1 t. 
QUII) PRO QUO :

"consideration" analogous to, 181.

in action of debt: apparent benefit to promisor mot material, 183.

medieval use of term, 178 .

RAILWAY COMPANY : liability of, as to eorrertness of timetable, 17.

\section{RATIFICATION :}

must be within reasonable time, 102 .

and by one who might have been originally bount, 111.

of aet of unauthorized person after expiration of time limited,

102.

agent's acts, relates back, 102.

infant's contract : effect of Infants' Relief Act, (6i3, 105.

irregular acts by assent of sharetolders, 130, 710.

RECORD : contracts of, 152 .

\section{RECTIFICATION OF INSTRUMENTS :}

actions for, procedure in, 552 .

common intention of parties different from expressed intention must be shown, 516 .

proof of one party's intention will not do, $\check{5}+7$.

possible exception where one party acts as other's agent, 548.

conveyance, new, not required, 55:, 553.

disentailing deeds, 552 .

draftsman, mistake of, 481 .

jurisdiction of the Court in, 543, $s q q$.

option to rectify or set aside in certain cases, 551.

oral evidence, how far almissille, 515 .

settlements, at whose suit rectitieation grantod, jol.

reformation of, according to previons articles, 519 . special rules as to this, 550 .

voluntary, when rectification sought ly settlor alone, 551 .

wills, no jurisiliction in equity to rectify, 55:, 751 .

RELLASE :

in deed of dissolulion, cannot be disputed by frarty after con-

cern completely wound up, 62 1 .

restricted construction of, in equity, 5333.

REPRESENTATION :

agent: representation of, when principal lisble for, tome. representation of antlonity mut he of matter of fact. $11 \%$. 
REPRESENTATION-continued. ambiguous statemints, 602 . as term of contract, $5 \tilde{5} \pi$. fraudulent, examples of, 592 . or innocent. 55 .

future, representation of the, operates as eontract, if at all, 558.

induring contract. 60:, sqq.

infant: representation of full age. 79-82.

must be shown to have misled other parte. 81. jnnocent, not necessarily harmless to person making it, 5iti.

"making representations goon." supposel equitahle dootrine of, 555 .

married woman: representation of discoverture ly: 83. meaning of the word, ang.

must be made by party to cuntract, 608. anl as part of same transation. 612. opinion, statements of matter of. $101,602$. recision of contract : conditions which plaintiff must satisfy in action fur. 598 .

representation must generally he of matter of fact, 5.99.

not of mere motive or intention. 600.

must have, in fact, induced the contract, bos.

silence, when equivalent to, 542, 795 .

warranty and condition. repuntations amounting to. 361.

TREPDIATION OF SHAliLs, Ser SHAREHOLIER.

\section{Rissclssion:}

acts treating contract as subsisting, 617 .

conduet of party mislel, tigt.

election to athirm or recind, how determined. 617 .

rescind must be communicaterl, 618 , b19.

what communication sutlicient, 619.

fraul, option to afhim or rescinl contract for, 615 .

misceprentation, resision of contract for, $59 s, s y q$.

representation must generally be of fact, 599 .

not of mere motive or intentisn, 600 .

must have, in fact, induced the contract, 602 .

and must be male as part of same transaction, 612 .

ownership. acts of, negativing right to revind, bizt.

position of parties, change in: 10 reseision where former

pusition cannot he restorel, 622.

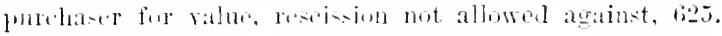

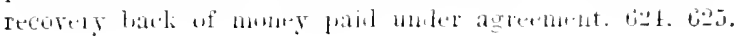




\section{RESCISSION-continued.}

representatives, right of resciseion exprisealip ly and against, $62 \mathrm{I}$.

right of, on disovering mula ful purpose of other contracting party, $38 s$.

but a completely executed transer of property cannot be rescinded, 388.

shares, contract to take: shareholde cammot rewinl after winding-np. 620 , $62 \mathrm{~s}$.

time, reasonable, reseision must l, williu, liog.

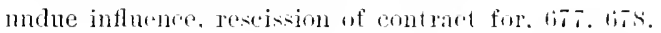

\section{RESTRAINT OF MLARILARE. Se' MARTARE.}

\section{RESTRAINT OF TRADE:}

combination in restraint of trade, mulawful. :3:-2.

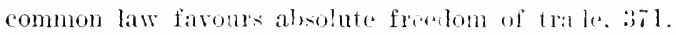

competition, covenant making covenauter she julge of. void, 378.

consideration, a lentuacy of not enpuires into, siti.

customers, covenant nut to diat witl, 3is.

distances, how mrasurerl, 35:.

exchisive service, contract for, must be munal. 3xs?.

general principles, 368 .

Indian Contract Aet onl. 383 .

life, contract to serve for, good, if mutual, 3\$3.

limited restraints almitted. 33t, 335.

medieval doctrine on restraint of trade, 370-372.

monopoly, agreements tending to. feeling against in mildh ages, 370.

held roid in Lnited states, 37.

presumption of hadness of covenant: no rule as to, 378 .

price, specilied, mulertaking not to sell goods below, valiu, 377. puble policy. restrant in gerneral opposed to. 369.

reasonahlo, cases where restriction has been hell, 379. sty.

restriction must be, 369 .

What is, must be decided on merits of each case, 369.

and is a question not of fact, hut uf law, :3is.

restriction partly goml and partly had, 378.

serbant, wronglal dismissal of, liseharges both servie and restrietire agrenent agamet future competition. 2as.

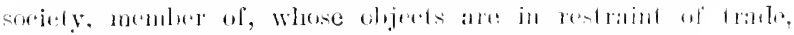

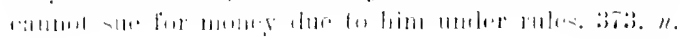

$r$. 
RESTRAINT OF TRADE-continued.

space, limit of, olit common law rule as to, now modified, $375, \operatorname{siq}$.

time, limit of, not necessary to validity, 377.

trade seedet, contrat not to diselose. may be unqualified. 37. nnqualified restraints voil, $373,374$.

unreasonali, cases where restriction held to be, 382 .

REVENUE LAIIS : fweign. tratment of, 337-389.

And see stanirs.

HEVERSION :

sale of: whon rent or covenants run with, 218.

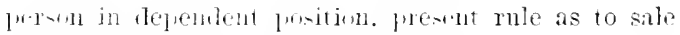
by, 673 .

undervalne, voilalste for, under old law, 66 t.

development of the loctrine, 66.5.

its abrogation by 31 Vit. e. 4 ...66i.

FETOCITION:

comminication of, 30 .

leath of poposer, revocation liy, 41.

im-anity as ground for, 42 .

of general otfer. 21. 23.

of proposal, when in timp. $27, x " y$.

tacit, 32.

ROMIN I.AW:

ctusu in, 17a, 181.

clacsificatim of contracts in. Note F.. Tls.

corporalions, treatment of, in, l:3.

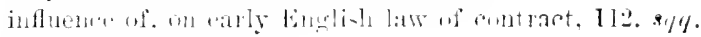

stipulation in, 113.

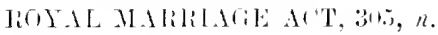

S.ST.T: :

of future suceilic probnt, eontract discharged ly failure of produce, $4+1$.

of mere cxpectang. valid ly Engli-h law, wherwise by ciril law, 360 .

SALE DI ALETION. See AUETION.

SALE OF GOODS :

delisery oltained by fale pretenes withont ans contract, (i一ti, $1 ; 27$.

Frank, fialute of, as to, lis. 


\section{SALE OF GOODS-contimued.}

fraudulent, effect of, 617,625 .

horses, sale of, iu market overt, 172, 173.

infant, sale of goods to, not necessaries, voil by Infants' Relief Act, 63 .

instalments, default in delivery of, $280, s q q$.

mistake, how sale affected by, $496,510,511$.

price not recoverable where gooms soll for mawful purpose, 388.

purchase liy one not meaning to pay is frant, 5.4.

warranty or eondition upon, $51 \mathrm{t}$.

dangenow 2 , $15 \cdot x^{2}, 141$

SALE OF GOODS ACT, 1893 :

as to liability of infant for necessaries, $71, s \eta \%$.

as to note or memorandum, 169 .

\section{SALE OF LAND :}

auction, sale by, employment of puffer, 595.

Frauds, Statute of, as to, 167.

infant, sale by, voidable, 60 .

lot, mistake as to contents of, due to purchaser's want of attention to particulars and plan, 506.

misdescription of thing sold distinguishul from fundumental error, 517.

on, effect of, 571 .

option of, or agreement for re-purchase, 538.

parcels, mistake as to, 505 .

price, mistake as to, 511.

purchase of property already one's own, 522.

purchaser, duty to give information in special cases. 5sot.

speefic performance with eompensation where misteseription proved, 572.

title, etrect of speeial conritions as to, 581. non-diselosure of latent defeet in, 581 .

vendor's duty to give eorrect description, ars.

And see Specific l'ErFurmanoe.

SALE OF REVERSION. See REVERSTN.

SATISEACTION: ly stranger, whether a har to suberment artion on contriet, $19 s$.

SEAT :

building soeiety, seal of, must boar registeriel name of somint 155.

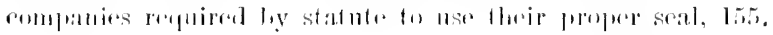


SEAL-contimed.

corpurate, epuivalent to signature in bills and notes, 135. 243. transferalble detentures muder. negotiable. 135. uecesinty of. in contracts by corporations, 153, sqq. director, private seal of, use of, on behalf of company, 155, $n$. misapplication of, corporate, 138.

$$
\text { private, } 14 .
$$

SEAMEX : wages of, not insuralle at common law, 36.5.

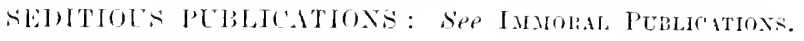

SlPLARATE ESTATE:

cessation of cowerture etfect of, 332 .

debts contracted lefore marriage. lialility for, 92 .

"engagement." how far bound hy ordinars rules of eontract, 733.

engagamouts. general, rules as to. 731 .

expitable dortrine of, $\$ 9$.

Linitation, statute of, analogy of. Whether applicable to elaims agaims, 8.5, 734 .

origiu of separate $11 \times 0,729$.

lower of hinding stparat. estate earlier doctrines as to, 7.29, sit.

quari-contracts, whether liable m. 331.

spereifie performanee against, 332.

SEPARATIOA: judicial ; effect on wife's caparity of contracting. ss.

SEPARATION DEED :

adultery. subserpuent. Woes not of itself aroid deed. 323 .

muline contemplated at time. 322 .

agreements for, between hushand and wife alone. si.

com-ideration fur. 32.2.

dilitren, custody of provisions for, 363.

covernat for payment to wife in event of future separation order, 325.

effect of, on special points, 323 .

future scparation, arreement for, vois, 325 .

reonciliation. deed avoided hy. 320, 32t.

proviso for, roid when partice not lawfully marrierl, $3: 0$.

ralility of, 321 .

SERTICE : infant's contract of, $38.69 .7 \%$

SETTEFMENT :

deeated wifts sioter, settlement in contemplation of marriage

witl, bill. 320. 
SETTLEMENT-eontinued.

diselosure, dnty of, in negotiations, 581.

infant, settlement by, 61, 76, 77 .

"in frand of marital right," 303.

not affected by wife's non-disclosure of previuns misconduct, 588.

post-nuptial, how far supported hy informal ante-nuplial agreement, 699 .

reformation of, according to previons articles. 519.

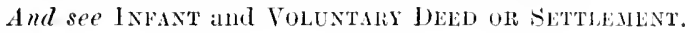

\section{SHARELHOLDER :}

infant may be, 60 .

and is liable for calls if slares not disclatined, bis.

prospectus, only original shareholders cutitlen to rely on, 611. ratification by assent of, 130.

repudiation of shares by, 509, 617, 622, $623,627,624$.

cannot repudiate after aets of ownership, 617.

or after ehange in eonstitution of company. 62.

or after winding-up, 627,628 .

diligence of shareholder essential, 632.

rescission of contract by, on ground of misrepresentation, sst. right of, to restrain eompany from acts not warranted by its constitution, 131.

And see Comp.iny.

\section{SIIARES :}

numbers, error in, not material, ing.

repudiation of, 509, 617, $622,623,627,628$.

sale of, after winding-up, not enforceable, jly.

transfer of, 173, 216.

invalid when directors' consent obtained by hratud, 597.

And see Company.

SHH, transfer of, $17 \%$.

SLAVERY: contract for sale of slares in slave country not woid in England, tos.

"slap":

in marine insurance, effect of, 173, 7112.

recognized for eollateral purposes, 701.

statutory enactments relatimg to, 703 .

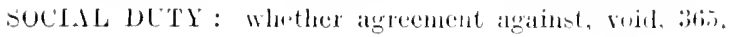




\section{SOLICITOK :}

agrenents with elient: chanperty. 353.

client, presumption of influence in contracts with, 619 .

costs. speeial agreenent with client as to, 716 .

purchase by, from client, 648 .

of subject-matter of suit by, $3 \pi \%$.

Sulicitors' Remuneration Aet, 1881...716.

uncertificated, costs of, not recoverable, 7118.

lien, position as to, 709 .

SULATTURS' REMLNERITION AOT, ]S81: as to agreenents between solicitor and client, 716 .

\section{SLEC'LIO PLRFORMANCE :}

anliguos terms of contrat, specitic performance refused in cases of. 5itr.

(n) Hateral "l'presentations" inducing enutract : non-fulfilment of, 751 .

empensation with specific performane on sale of land, 5i2. contract not expressing real arreement of parties, 510 . defruce against, 506.510.

description of property. when vendur ean substatiate his uwn, $\therefore 7$.

infant, specifie performance wot granted at suit of. 62.

110r, since Infants lielief Act, of any contract made during. infaney, 65 .

matried woman, solatate estate. specific performance agaiust, 732.

misleseription: slecitic rerformanee at suit of either party where variance not sulstantial, 5i2.

at purelaser's eption where substantial and eapable of estimation, $5 \% 2,573$.

where subtantial and not capable of estimiltion, option only to reseind or to aftirm unconditionally, 575.

farm athlitin to or variation in terms of agreement, 511.

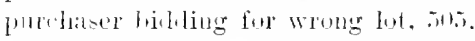

undervalue, whether specitic lerfurnanec can be refused for, alone, 658.

\section{SHLITUAL INFLERENE:}

its relation to undue influcice, 6.5 .5$.

treatment of, by French law, Nute K., 75.

\section{STAML's :}

fureign laws as tu. etlect of. 339 . 
S'TAMPS-contimued.

promissory note, bearing insufficient stamp, not antuissible as receipt, $707, n$.

stamp duties in gencral, 706.

unstamped document, when arlmissible as evidence, 706 .

variation of contract by subsequent unstanped agreenent, 706 .

STATUTE OF FRAUDS. Se Frauds, StTtuTE or.

STATUTE OF LIMITATION. See Linitation, STritutis or.

\section{STATUTES :}

prohibitury, construetion of, 306 . policy of, 307 .

"STIFLING PROSECUTION," 314.

STIPULATION : in Roman law, $11 \%$.

\section{STRANGER :}

liability in tort for procuring brach of cunlrat. $211, n$. satisfaction of contract hy, whether it bar's action, I9s.

to contract, cannot sue on it, 223 .

SURETY :

discharge of: hy subsernent dealings between creditur and debtor, 297 .

by misrepresentation ar concealment on pant of ereditor, 567.

entilfed to benefit of secmities, 299.

information as to real nature of transadinn, 56s.

but creditor not bound to voluntece informattion, 570 .

"SURPRISE": whether at ground of relief against contracts, tio.

TALLIES: use of, 150, 151.

TELEGRAPII : communination of acceptance by. :3:

TESTATOR: agreement to influene, void, 368.

\section{TIIIRD PARTIES :}

cannot sue on contratet, 223.

apparent exceptions to this rule, 2.21 , $3 y \%$

consent of, oltained by fraurl, 597 .

fraul on, vitiates contract, 292,296 .

not presumed, 296.

instrument not reetified against, inferests of, als.

promice to make ontract with, 50. 
"THHRL L'ERSON": meaning of, 2019.

TIILE :

when of esence of contract in equity, 535 .

may be marle so by express agreenent, $535,537$.

THME TABLE: ellect of statement in, 17.

TIPPLIXt: AC'T : small debts for spirits male not recorerable by. 717 .

TOSiT :

"founder on contract." infant not liable for, て-

liability of corporations in, $123,124$.

ThAUl: :

agrements in rectraint of. See Restinst of Trubs.

contrats of corporations in contes of. neel not be under seal.

15.5.

THADE LXIONS :

agremont for strike not enfurcealole. 372. 373.

Lut not a riminal wfence by the enmon law. 37.

certain acreements of, lawen hut not enforcoable. 71 s.

TH.HUM(: WTII FXEMIES :

hill of exhange hetween England and hostile comotry: posi-

tion of, 335 .

contracts disolved or stepented by war. 831 .

nentral trabe with belligente wot unlawful, 337.

withont livence from crown, illegal. 333, 33 t.

ThESLAS:

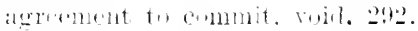

liability of corpuration for. 1:3.

TRLST:

agrement to eommit breach of, roil, 2h-

assigment of . 230 .

low far in the nathere of contract, 214.

trustee: must account to exstuis que trust notwithetanding collateral illegality. Ino.

le impartial as betwen cestuis que trust, 6.j6, $65 \pi$.

notice of assignment to, 231 .

LNDEHTALE :

does not itself aroil contrat, but may he evilence of fraud, sc., 6.5.

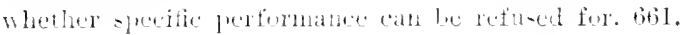




\section{UNDUE INFLUENCE :}

aequiescence in eases of, 679 .

age of person conferriug henefit not material, 617 .

captation, doetrine of, in French law, Note K., ing.

"catching bargains," rules of equity as to, bi67, bis.

confirmation in cases of, 679 .

delay in cases of, 679 .

equitable doctrine of, $640, s q q$.

expectant heirs, protection of, 66:3, sq\%.

family arrangenents, 10 presumption against. 6.51. 65:.

father and son, transactions between, presumption of influener, 648 .

fiduciary relation, duty of persons in, 619 .

undue influence apart from, 6.50 .

gifts, voluntary, 645 .

husband and wife, doetrine does not apply to, (it3.

medieal attendant and patient, doctrine applies to, fiist.

parent and ehild, relation analogons to, 658.

presumption of influence, evidenee repuired to retut, bis.

from certain relations, 612 .

proof, burden of, 612,645 .

rescission of contract for. 677,678 .

reversionary interests, sale of, hy persons in dependent posi-

tion, 673 .

reversioners, protection of, 663 .

settlements, voluntary, when set aside, 616 .

in favour of parent, 647 .

solieitor and client, relations analogons to. 651 .

purehase by, from elient, 6 ts.

spiritual influence, 655.

stranger to contract, whether undue infuenee material if exerted by, 679.

"surprise" as evidence of, 675.

undervalue, how far material. 65i, sq\%.

voluntary scttlements, when set aside, 616 .

in favour of parent, 617 .

wills, presumption does not extend to, 643, 611, $\mu$.

\section{UNLAWFUL AGREEMENTS :}

agent must account to principal notwithstanding collateral illegality, 399 .

clissitication of, 289.

conflict of laws as to lawfulness, what local law goverus, fo5.

in time, contract disisulved by performane lecoming mulawful, 11 t.

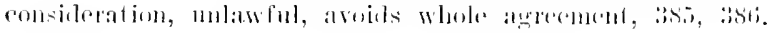




\section{TNLAWFTI AGREEMENTS-continued.}

erelitors, agreement in frand of, 293, sqq., 403.

evilenee. extrinsic, illegality may always be shown by, 393 . ignurance of law, low far material, where immediate object not unlawful, 395 .

immediate object, where unlawful aroids whole agreement, 386 . insurance roil where royge illegal to knowle lge of owner, 389. intented milawful use of sulijet-matter of contract, 387 .

innocent party may rocind on liscovering such intention, 388.

intention, nnlawful. must be shown to have existed at date of agreement where immeliate object not unlawful, 394 . marriage within prolibited degrees, contract for, 304 . morals, agreements contrary to, 316 . offence, agreement to commit, 290 . payments under, when recoverable. $39 \pi$.

can always be recorered when agreement not exeentel, tol. unless agreement criminal or immoral, to1. 402.

presumption of unlawful intention where agreement illegal, 396.

promises. where independent, lawful ones enforcealle, $384,385$. public policy. agreement contrary to, $32 i, s_{1 q}$.

publication, inmoral. agreement relating to, vois, $2: 26$. restraint of trale. agreements in. $348 . s / q$.

seamen's wages, policy of insurance of, void, 365 . security given for payments under unlawful agrement, roir, 392.

separation, future, agrecment for, roil, 325. immediate, agreement for, gool, :::21.

settliments in fram of marital righte :303.

slaves, contrate for sale of. made and to be performol in slitre state. recognized in English Courts, 10s, 409. statute, agrements illegal $\mathrm{by} .305, s_{1}$. surety, contracts between principal debtor and creslifor to prejulice of, 297 .

testatur: agreement to influence. $36 s$. wagers, void, but not illegal, 313 .

wrong, civil, to thiri person, agrment to commit, 292 .

\section{CSLRY LAWS :}

eflect of repenl on subsisting loans, $\mathbf{7 1 9}$.

repeal of, has not altered loctrine of " ratehing hargains." "ati.

YAlidTION : oral, of written contract, arailalle for dofonciant but

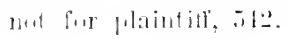


VENDOR AND PURCIASER. See Sale of LaNd ; SPerthe PerForMaNCE.

VIS MAJOR : meaning of, 135.

VOID AND VOIDABLE :

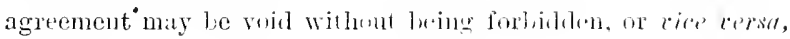
312.

confusion and distinetion letwen these tems, 9, 5s.

contract depenting on personal skill mate voil, mol veidahle, by subsequent disalility, 148 .

deed roid in part by statute, not necessnrily voin altogetles, 385 .

infants' contract voilable, not void, $5 \vec{i}, 58$.

lunatic: contracts of, when voil or voilahle, $95-97,99$.

TOLUNTARY COVENAN'T: sperifie performance of, not granted, 205.

\section{VOLUNTARY DEED OR SETTLEMENT :}

at whose suit set asicle: old rule in equity, 616 .

deed not rectified against grantor, 50 l.

impeachment of : burden of proof, 615 .

readily set aside, 616 .

revocation, power of, mot neessary to valiclity 617 .

undue influence, presumption of, tilti.

And see UNDUe Infuenct.

\section{WAGERS :}

authorities as to, 711 .

"cover," money or semplitios depositer as lecovery lack of, 401.

deposit, recovery of, from stakeholiter, 401.

former treatment of them at common law, 328 .

loan to be used for anl to abide result of, not recoveralile. :311. money paid for, on recliest, not recoverable, 311.

promissory note given for, treated as withont consileration, 314.

void by statute, but met illogal, 313 .

\section{WARRANTY :}

elfect of, as distinguisher from condition. nit, ifie.

express, on sales of goods, nie.

friud, relation of, to, 557 .

implied, of agent's anthority, 11:.

in contract fo mary, ll:3, $n$.

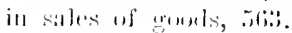


WILI. :

contract to make di-position ly, lawful. 368 .

covenant wht to roke. not bruken by subsequent marriage, $36 \pi$.

mi-take: canot w rectified. but general intention may take eflect against particular words, 552, Note H., 751 . exteution of wrong locment wholly inoperative. $191, n$.

te-tator, agrement to influener. voind, 3 ths.

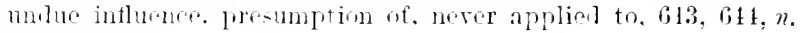

WTADTAG-LP:

of insurane mompane, applieation of prohibitory stamp laws to policies, 70.5. rom.

right to proced with crolitor's petition for, not saleable, 35i. secret agrecencht for conduet of. voil, 347.

shares rabmot he repuliatel after. 627, 62s.

WRITING:

agremints in. mot varied ly garol evidence. 260.

lout may he romtrued ly wilence of special meaning of terms, 261.

or supplemented by eu-tomary terms. 266.

contracts in, nut a precial class in Euglish law, $183 . n$. 
THE KING'S BENCH SERIES now publishing.

THE

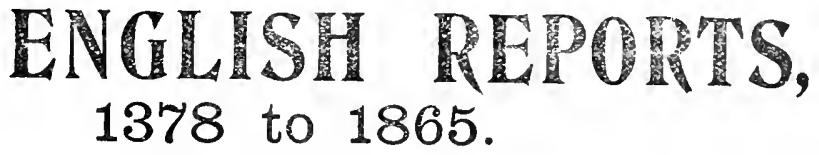

FULL VERBATIM REPRINT ANNOTATED.

CONSULTATIVE COMMITTEE :

The Right Hon. The Earl of Halsbery, lately Lord High Cha The Right Hon. Lond Alverstone, G.C.M.G., Lord Chief Justice of England ; The Right Hon. Lond Colness, a Lord of Appeal in Ordinary;

The Right Hon. Sir R. B. Frniay, G.C.MI.G., K.C.

Folnownsa on the complete re-issue in 71 volumes of the House of Lords, Prirs Couneil, Chaneery, Rolls Court aud Viee-Chancellor Reports, the KING'S BENCH SERIES is now in course of publication, and may be subscribed for separately.

This series is perhaps the most important of all the reports prior to 1565 . A complete set of the originats from Bellewe, 1378-1100, down to and inchnding Best and Smith, 1861-1866, with all the collaterul reporters, extends to no fewer than 250 volumes of all sizes and styles of printing. These atre very costly, ind wonld almost require a separate roon for their accommodation. Subscribers will have the privilege of possessing a complete annotated reprint of all of these invaluable reports in about 40 uniform volnmes in a nodern and much more legible style of type, at a cost of 30 s. per volume.

The reports will be reprinted in strictly chronological order, and as the original pagination and machinery of reference will be maintained, references fron text-books and digests will be found even more easily than in the originals.

\section{NOW ISSUED.}

HOUSE OF LORDS (I694 to 1866), complete in 11 vols. royal 8 vo. Price net, half bound, E22. PRIVY COUNCIL (including Indian Appeals) (1809 to 1872 ), complete in $y$ vols. Price net, half bound, $\$ 13: 10 \mathrm{~s}$. CHANCERY (including Collateral Reports) (155T to 1866), complete in 27 vols. Frice net, balf bound, $£ 40: 10$ s. ROLLS COURT (1829 to 1866), complete in 8 vols. Price net, hall bound, \&12.

VICE-CHANCELLORS (1815 to 1865), complete in 16 vols. Price net, half bound,

$£ 24$.

SOW NOW FUISHING.

KING'S BENCH and QUEEN'S BENCH (1378 to 1865), including Collateral Reports, complete in about 50 vols. (Vols. 1 to 40 ready). Price per volume net, half bound, 30 s.

The Volumez are not sold separately.

Full particulars sent on applicetion to-

Stevens \& SONS, Ld., 119 \& 120, Chancery Lane, London. 
Chalmers' Digest of the Law of Bills of Exchange. - Senenth Entituit. By Sir M. D. CHAL.MER:, K.C.B., C.S.I., Draughtsman of the Bills of Fxchange Acts. IJm!l sio. 1909 . jrice 20 s. cloth.

Spencer's Agricultural Holdings Act, 1908, with the Xew Inules and Forms issned by the Board of Agriculture. Fourth Edition, Re-Issue. By ITBREY J. SIENCER, Barrister-at-Law. Itimy Sto. 1509. Price fs. cloth.

Spencer's Small Holdings and Allotments Act, 1908, with lixplauatory Notes and Forms. together with the small Holdings Act. 1910.-By

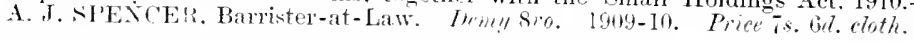

Disney's Law of Carriage by Railway.-. Second Edition. By HExpY W. HINES. Barrister-at-Law. Hemy seo. 1909. Price is. 6d.cloth.

Ro

$\mathrm{Pe}$

\section{UNIVERSITY OF CALIFORNIA LIBRARY}

Los Angeles

This book is DUE on the last date stamped below.

La

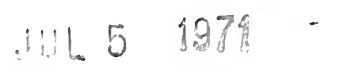

Bra

Arr

Pol

Pol

Mas

Bur

Wri

Stri

Form L9-Series 4939 
Wigram's Justice's Note-Book. - Contannmy a shor't accoun of the Jurisliction and Duties of Justices, and an Epitome of Crininal Law. Winth

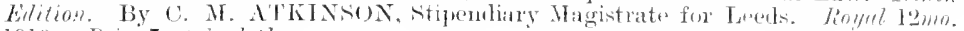
1910. Price 7s. bre cluth.

Archbold's Pleading, Evidence and Practice in Criminal

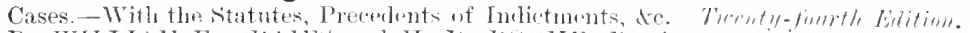

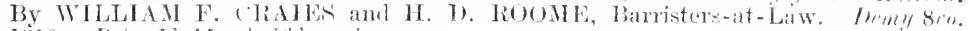
1910. Irice I/. lis. herlth lumell.

King's Costs on the High Court Scale-Bing Appen-

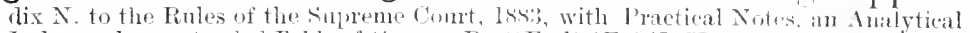

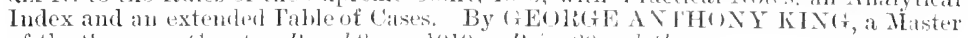

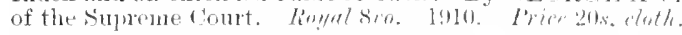

Benest's Alphabetical Guide to the Law of Costs, as regulated by the Riules of the surrem. Court. - By JOIIN L. MI. IBEXEST, Solicitor. lemy sero. 1910. l'rice lis. clolth.

Carson's Real Property Statutes.-Being the Elecenth

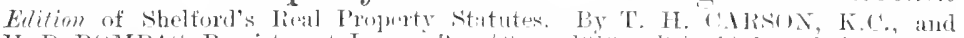

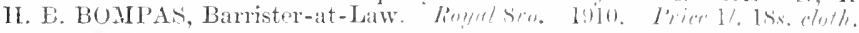

Watts' Assurance Companies Act, 1909.-Annotated,

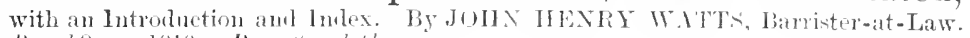

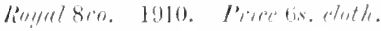

Bowen-Rowlands on Criminal Proceedings on Indict-

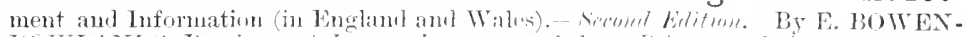

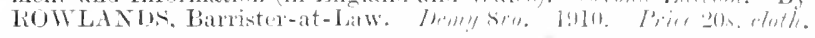

Russell's Treatise on Crimes and Misdemeanors.-- terenth Edition. Iy WILLIAM E. ('RAIES and L. W. KEIitHAW, Barristers-at-Law.

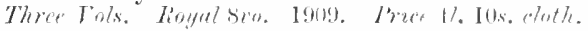

Carver's Treatise on the Law relating to the Carriage of

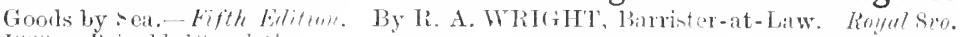
I:909. Hiree 12. 18s, cloth.

Lush on the Law of Husband and Wife within the Juristiction of the King's Bench and "hancery bivisions. Ky C. MONTAGUE

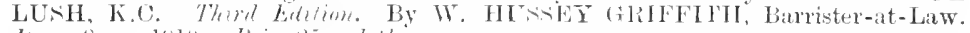

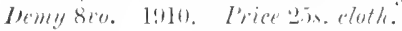

Blackburn on Contract of Sale.--A 'Treatise on the Effect of the Contract of sinle on the Lapal lights of l'roperty and Possosion in Goorls,

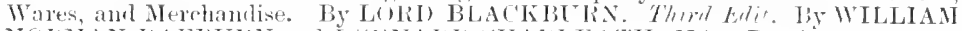

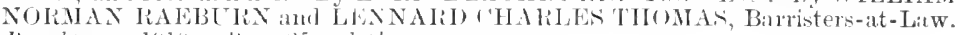

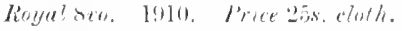

Farleigh's IManual of Commercial Law.-By li. IUs'rin

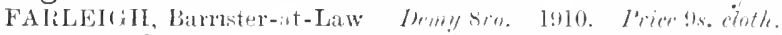

Theobald's Concise Treatise on the Law of Wills. - s'epenth

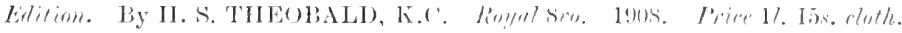

Farrer's Precedents ố Conditions of Sale of Real Estate,

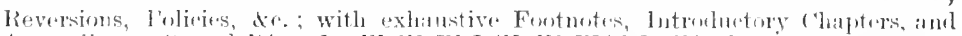

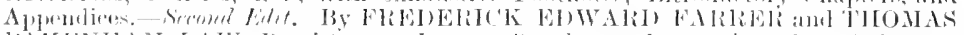

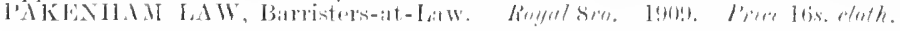

Hood and Challis' Conveyancing, Settled Land and

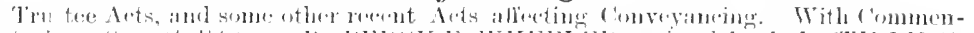

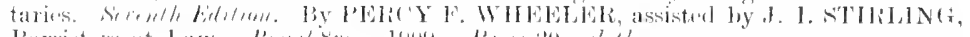

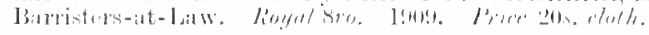

Leake's Elementary Digest of the Law of Property in

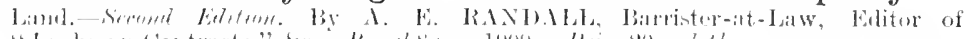
"Lrake on contraxts,"

Leake's Principles of the Law of Contracts. - Fiftl Eflit. 
